CIHM Microfiche Series (Monographs)
ICMH

Collection de microfiches (monographies)

Canadian Institute for Historical Microredroductions/Institut canadien de micr oreproductions hisloriques
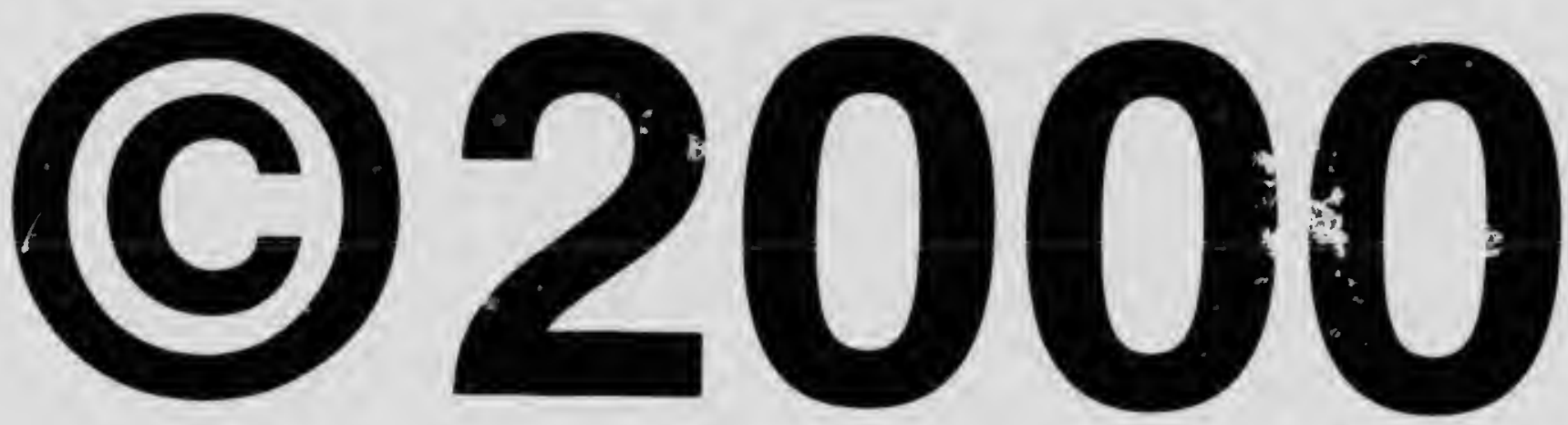


\section{Technical and Bibliographic Notes / Notes techniques et bibliographiques}

The Institute has attempted to obtain the best original copy available for filming. Features of this copy which may be bibliographically unique, which may alter any of the images in the reproduction, or which may significantly change the usual method of filming are checked below.

\section{Coloured covers I \\ Couverture de couleur}

Covers damaged /

Couverture endommagée

Covers restored and/or laminated /

Couverture restaurée etou pelliculée

Cover title missing / Le titre de couverture manque

Coloured maps / Cartes géographiques en couleur

Coloured ink (i.e. Other than blue or black) /

Encre de couleur (i.e. autre que bleve ou noire)

Coloured plates and/or illustrations /

Planches etou illustrations en couleur

Bound with other material /

Relié avec d'autres documents

Only edition available /

Seule édition disponible

Tight binding may cause shadows or distortion along interior margin / La reliure serrée peut causer de l'ombre ou de la distorsion le long de la marge intérieure.

Blank leaves added during restorations may appear within the text. Whenever possible, these have been omitted from filming / II se peut que certaines pages blanches ajoutées lors d'une restauration apparaissent dans le texte, mais, lorsque cela était possible, ces pages n'ont pas été filmées.

Additional comments /

Commentaires supplémentaires:
L'Institut a microfilmé le meilleur exemplaire qu'il lui a été possible de se procurer. Les détails de cet exemplaire qui sont peut-être uniques du point de vue bibliographique, qui peuvent modifier une image reproduite, ou qui peuvent exiger une modification dans la méthode normale de filmage sont indiqués ci-dessous.

Coloured pages / Pages de couleur

Pages damaged / Pages endommagées

Pages restored and/or laminated /

Pages restaurées etou pelliculées

Pages discoloured, stained or foxed/

Pages décolorées, tachetées ou piquées

Pages detached / Pages détachées

Showthrough / Transparence

Quality of print varies /

Qualité inégale de l'impression

Includes supplementary material /

Comprend du matériel suppléınentaire

Pages wholly or partially obscured by errata slips, tissues, etc., have been refilmed to ensure the best possible image / Les pages totalement ou partiellement obscurcies par un feuillet d'errata, une pelure, etc., ont été filmées à nouveau de façon à obtenir la meilleure image possible.

Opposing pages with varying colouration or discolourations are filmed twice to ensure the best possible image / Les pages s'opposant ayant des colorations variables ou des décolorations sont filmées deux fois afin d'obtenir la meilleure image possible.

This item is filmed at the reduction ratio checked below /

Ce document est filmé au taux de réduction indiqué ci-dessous.

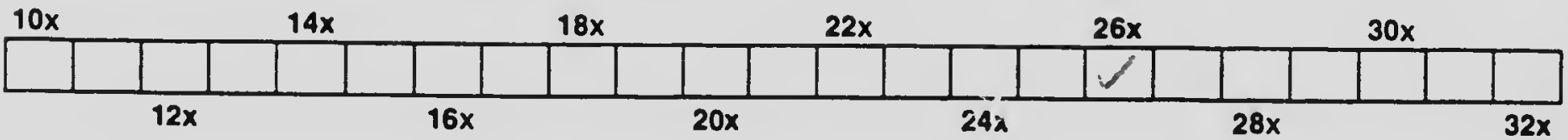


The copy filmed here has been reproduced thanks to the generosity of:

Mational Library of Canada

The images appeering here are the best quelity possible considering the condition and legibility of the original copy and in keoping with the filming contrect specificetions.

Originel copies in printed poper covere ore fllmed beginning with the front cover and ending on the lest poge with a printed or illustreted impres. sion. or the beck cover when appropriote. All other originel copies ere filmed beginning on the flrst poes with a printed of illustreted impres. sion. and ending on the lest pege with - printed or illustreted impression.

The lest recorded frame on each microfiche shall consain the symbol $\longrightarrow$ Imesning "CON. TINUED". or the symbol $\nabla$ (meaning "END"). whichover applies.

Meps, plates, charts. etc., mey be filmed at different reduction ratios. Those too lerpe to be entirely included in one exposure sre filmed beginning in the upper lete hend corner, lote to right and top to botrom, as many fremes as required. The following diegrams illustrate the method:
L'exemplaire filmo fut reproduit grâce a la gondrosite de:

\author{
Bibliothèque nationale du Canada
}

Les images suiventes ont det reproduites avec te plus grand soin. compte tenu de la condition et de le notrets de l'exemplaire filmb, ot en conformits evec les conditions du contipt de filmoge.

Les exempleires originaux dont la couverture en papier est imprimbe sont filmés on commencant per le premier plet et en terminant soit par la dernidre page qui comporte une empreinte d'Impression ou d'illustration. soit pap le second pler, selon le ces. Tous les eutres exemplaires originoux sont filmds en commençant par la promidre pege qui comporte une empreinte d'impression ou d'illustration ot en terminant par le dernidre pege qui compone une telle empreinte

Un des symboles suivants apparaitra sup la derniore image de chaque microfiche. selon le cas: le symbole signifie "A SUIVRE". le symbole $\nabla$ sionifie "FIN".

Les certes. planches, tableaux, etc.. peuvent etre filmós des taux de róduction diffórents. Lorsque le document est trop grand pour etre reproduit on un seul clicho. il est filmb à partir de l'angle supérieur gauche. de gauche à droire. ot de haut on bos. en prenant le nombre d'imeges ndcessaire. Les diagrammes suivants illustrent la mothode.
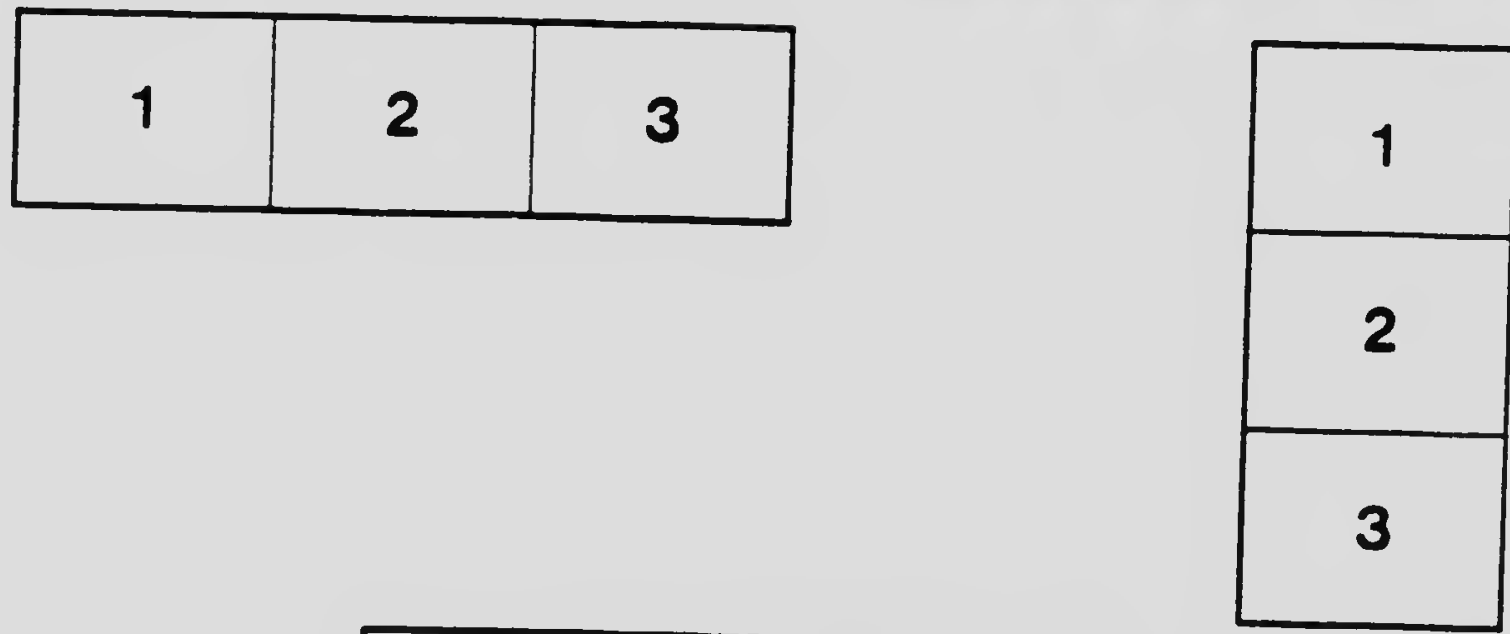

\begin{tabular}{|l|l|l|}
\hline 1 & 2 & 3 \\
\hline 4 & 5 & 6 \\
\hline
\end{tabular}


MICROCOPY RESOLUTION TEST CHART

ANSI and ISO TEST CHART Pto 2
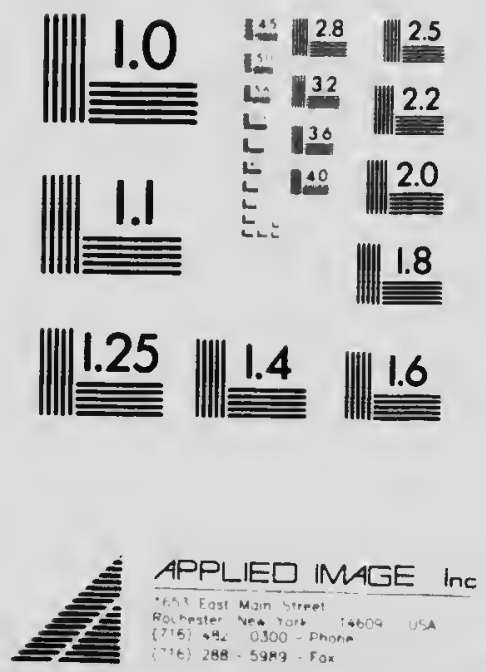


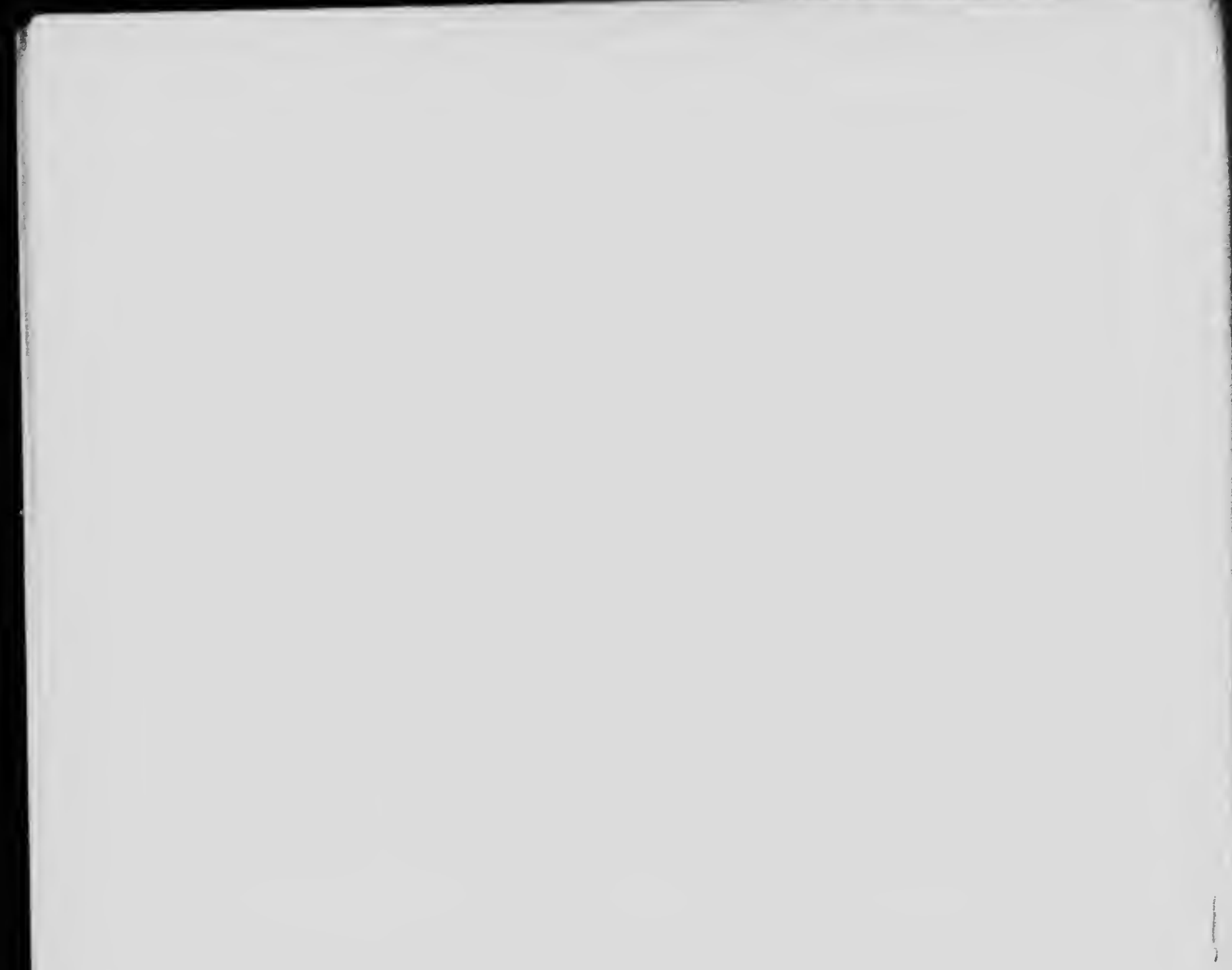


MODERN HORSE MANAGEMENT 


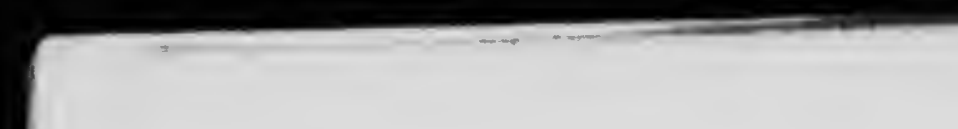





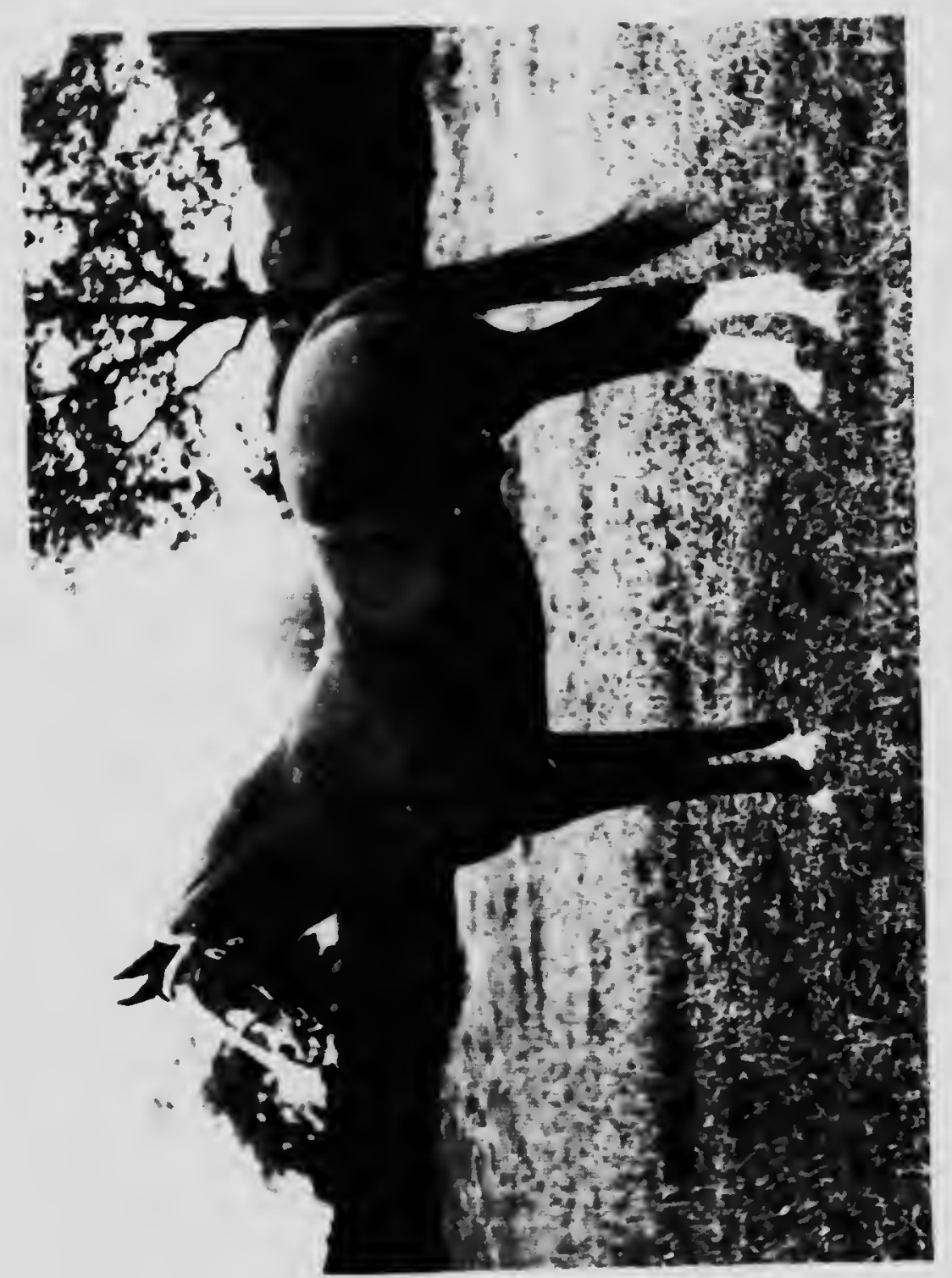

等 


\title{
MODERN \\ HORSE MANAGEMENT
}

BY

\author{
REGINALD S. TIMMIS \\ notal canadian dachoons (regulak monczs)

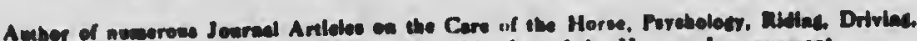

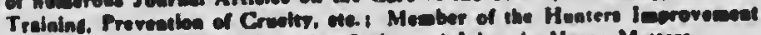

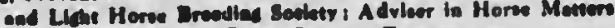 \\ is the S.P.C.A. Otuwe. Tormeto, me.
}

Introduction by

Major-General F. L. LESSARD, C.B.

Preface by

The late Prof. ALFRED SAVIGEAR

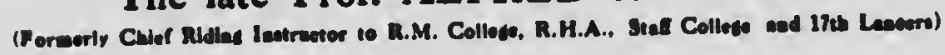

466 PHOTOGRAPHS, PLANS AND DRAWINGS

CASSELL AND COMPANY, LTD

London, New York, Toronto and Melbourne 


$$
\begin{aligned}
& =5 \\
& 1=5 \\
& 11 \cdots \\
& \therefore !
\end{aligned}
$$




\title{
5025
}

\author{
THIS BOOK IS MOST RESPECTFULLY \\ DE DICATED \\ my
}

THE AUTHOR

ro

\section{General H.R.H. PRINCE CHRISTIAN OF SCHLESWIG.HOLSTEIN \\ K.G. G.C.V.O., A.D.C., eto.}

FORMERLY PRESIDENT OF THE HUNTERS IMPROVEMENT SOCIETY

(Who was so lartely repponsible for the food work done by that Society) 


\section{PREFACE}

\section{BY PROFESSOR ALFRED SAVIGEAR}

Is placing this book beforc the public the author is placing much information of grcat value to the horseman and horsc owner, and is very greatly helping the lot of our friend the horse. It is for this latter reason that the author has compiled the work.

I am extremely pleased to find that an old pupil of mine has given up the time and study necessary to produce such a book.

Chapters III., IV., V., and VII. are of particular interest to me. So is Chapter XIII. ; in fact, it was the subject in this chapter that brought the author and myself together. I thoroughly endorse every word he says in the chapters on cruelty.

I strongly advise riders to read the author's notes on riding. Were it not for his ability and practical and calm methods adopted in riding young horses I would never have allowed him to ride so many of my young horses and to assist me in other ways in my school at Earl's Court. When under my tuition he was always looking for advice. May I emphasise the three important qualifications that a horseman should possess, and which fact the author strongly impresses upon his readers -good hands, good seat, and a perfect control of temper when working with horses?

The Press has rightly acknowledged the author as an authority on horse matters, and I was delighted to read that he had lectured with such success in many large cities, including H.R.H. the Duke of Connaught among his hearers. His remarks on training are mostly common-sense ones, and the result of minute study and practical experience.

My advice to conceited riders : clear your mind of conceit-dismiss the idea that you excel everyone else. Practice on sound principles makes perfect; but on false principles confirms mischievous habits.

To the student who has studied until the type has almost melted before his eyes, regardless of the lamentable state of his health, I strongly advise that he take the prescription of the old family physician-healthy horse exercise. But, as in everything else, riding must be taught by one who can ride, and who can teach. The average groom who teaches riding knows little about it. Do not despise the school, 
I have had fifty-six years' experience in it and across country. Why do the French, Belgian, and Russian horsemen beat us at Olympia? Because they study the subject and make use of the school, whilst we are apt to think that we have nothing to learn.

Money spent on horses is well spent, and is always better than half the money spent on a doctor's bill. There is no finer health-giving excrcise in the world. No one who has the opportunity to take it can ever say, "Oh, what can I do to-day ?"

\section{ALFRED SAVIGEAR.}

EARL'S COURT, S.W. 


\title{
CONTENTS
}

\author{
CHAPTER I
}

Pas

\section{AUTHOR'S INTRODUCTION}

Aims and Scope of the Work-Acknowiedgments

\section{CHAPTER II}

\section{HISTORY OF THE HORSE}

Earliest Knowledge of the Horse-Biblical References-Classical References-The Horsn at the Time of the Roman Invasion-At the Time of the Conquest-In More Modern Times-Various Breeds Considered-The Horse in Geology-Etymoiogy of the Horse-Geological Position of the HorseThe Equine Machine Described.

\section{CHAPTER III}

\section{PSYCHOLOGY OF THE HORSE}

The Horse's Mind-The Horse's Memory-Outward Signs-Superiorlty of Man-Obedience-Reactions-Caresses-Associations-Punishment-Fear-Principies of Training-Circus HorsesCrueity of Horse Dealers.

\section{CHAPTER IV}

\section{FOODS AND FEEDING-EXERCISE AND TRANSPORT}

Introductory-The Digestive Organs-Composition and Values of Foods-Appetite-Watering-Conditioning Horses-Conditioning Foods and Powders-Exercise-Lending Horses-Horses in Camp-Transport-Swimming Horses

\section{CHAPTER V \\ GROOMING AND STABLE MANAGEMENT}

Theory of Grooming the Skin-Hair-Exfoliation of Skin and Hair-Winter Care of Horse-Testing Proper Grooming-Grooming Requisites-Care of Legs-Clothing-Bedding-Sanitation in the Stabie-Care of Feet-Foot Dressing-Clipping-When to Trim Horses-Banging and Thinning the Tall-Hogging-Regrowing Manes-Pialting Manes and Tails-Mane and Tail Diseases and their Treatment-Causes of Rubbing Tails 


\section{CHAPTER VI}

\section{DRIVING AND HARNESS}

Draught: Theory and Practice-Whime Trees-Poies-Loads-Ovcrloading-Driving-Whips-Reins - Hints on Tandem and Four-In-Hand Driving-Runaways - Notes on Treatment of PullersTeaching Horse to allow Rein to be placed under Tail-Types of Harmless Horses-Types of Vehicies-Anatomy of Shoulders-Coliars-Sore Shoulders-Harness-Cruppers-Harnessingup-Harness Injuries-Bridles-Blinkers-Bits-Halters-Tralning Gear-Care of Harness .

\section{CHAPTER VII \\ RIDING AND SADDLES}

Anatomy of Horse's Back-Backs-Pressure-Saddling-Saddles-Fitting Saddlery-Saddle BlanketGirths-Saddling-up-Sore Backs : Prevention and Cure-Cure of Galls-Seats-Hands-Treatment of Refusers-Spurs-On Ladies Riding Astride-Paces-Conformation of Saddle HorseCurb Bits-Port-Curb Chains-Martingales-Cold Bits

\section{CHAPTER VIII}

\section{STABLE CONSTRUCTION AND THE CIRCULATORY SYSTEM}

Circuiatory System-Respiratory System-Ventllators-Stable Impurities-Horse Urine-LightRoos-Walis-Doors and Windows-Coach-houses-Drainage-Damp-Sanitation-HeatingPrecautions against Firc-Improvements to Oid Stables-Stalis and Boxes-Mangers-Water Troughs-The Loft-Tying up Horses-Sllings . . . . . . . . .

\section{CHAPTER IX}

\section{SURGICAL DISEASES, LAMENESS, TEETH AND CONFORMATION}

Lameness-Structure of Bone-Histology of Bone-Sprains-External Applications for Spralns-External Counter-irritants-Blistering-Firing-Massaging-Diet when Suffering from SpralnsThrowing a Horse for Operation-Detection of Lameness-Surgical Ailments : Spralns of Ligaments, Joints and Tendons, and their Symptoms and Treatment-Splint-Bone Spavin-Ringbone -Sidebone-Sore Shins-Navicuiar Disease-Quittor-Bog Spavin-Thoroughpin-Eniargements caused by Serous Eflusion-Capped Hock-Capped Elbow-Contusions and BruisesBrushing-Speedy Cut-Over-reach-Broken Knees-Open Joints-Fistulous Withers-BurnsFrost Bites-Snake Bites and Stings-Lightning and Electric Shocks-Fractures-Dislocations -Stable Vices-The Jorsi's Teeth-How to Examine Teeth-Table of Incisors-Age of HorsesPhotograpining Horses-... mformation of the Horse-Structural Examination-Coiour-Natural Marks

\section{CHAPTER $\mathrm{X}$}

\section{PHARMACOPGIA AND USES OF MEDICINES}

The Theory of Medicine-Notes on the Use of Drugs-Methods of Administering Drugs-Hypodermic Injections-Use of Trocar and Cannula-Passing the Catheter-Poultices-Dosage-Pharmacopela-Strength of Drugs-Useful Compounds to keep In Stock-Incompatabllity of DrugsPoisons and their Antidotes-Apparatus Kept in a Veterinary Pharmacy-Use of PurgativesTabie of Weights and Measures-Giossary and Therapeutical Classffication of Drugs . . . 12 
GENERAL DISEASES: ORGANIC, FUNCTIONAL AND CONTAGIOUS

Temperature, Pulse and Respiration-The Membrana Nictitan\&-Tracheotomy-Diseases of the Alimentary Canal-Liver, Spleen and Peritoneum-Heart-Blood Veasels-Blood-Eye-SleinResplratory Tract-Genital Organs-Notes on Parturition

\section{CHAPTER XII}

\section{ANATOYY AND USE OF THE HORSE'S TAIL}

Anatomy of the Coccygeal Reglon-The Panniculus Carnosus-Flies-Mosquitoes-Spread of Disease by Flies-Other Uses of the Tail-Fly Nets-Fly Whisks-Fly Papers-Nicking Tall-Dividing Depressor Muscles-Stralghtening "KInked" Talls

\section{CHAPTER XIII}

THE CRIME OF DOCKING HORSES' TALS

The Uss of the Tall-Operation of Docking-After-Effects of Docking-Cruelty of Doclding-Excuses for Docking-Cleanliness Excuse-Excuse that Docking Strengthens Hindquarters-Safety in Driving Excuso-Four Important Points-Smartness Excuso-Neatness Excuso-The Hackney -Prevention-Summary

\section{CHAPTER XIV}

\section{OPINIONS OF EMINENT MEN, BOOKS AND THE PRESS ON DOCKING}

Rarity of Docking in Rusda-Cruelty of Docking-Docling Unnecessary-The Indecency of Docking Mares-Defencelessness of a Docked Horse against Flies . . . . . . 178

\section{CHAPTER XV \\ BUMANE EDUCATION-THE LAW}

The Law-The Law in other Countries-Decrepit Horse Traffa-The Penal Code of California-Legislation in Great Britain

\section{CHAPTER XVI}

\section{ON ANESTHETICS AND ANASTHESLA-HUMANE DESTRUCTION}

The Nervous System-Description of Nervous Tissue-History of Ansesthetics-Use of AnestheticsChoice of Anesthetics-Use of Morphine-Anresthetising Dogs-The Animal Anæesthetics ActLocal Anzsthetics-Local Anesthesia by Freezing - Use of Ether Spray-Anasthesia by Local Injections-Humane Destruction

\section{CHAPTER XVII}

\section{BACTERIOLOGY, ANTISEPTICS AND THE THEORY OF DISEASE}

Theory and Prevention of Disense-Contagious Diseases-Bacteria-Methods of Admission into the b

System-How Pathogenic Microbes produce Disease-How the System fights against Microbes- 
Immunity trom Disease-Bacterial Vacelnes-Other Means of Destroying Disease MlerobesAntiseptics and how used-Aseptic Treatment of Wounds-Aseptic Surgery-Notes on the

Prevention of Human Disease

\section{CHAPTER XVIII}

\section{ON SHOEING AND CARE OF THE FEET}

Structure of the Foot-Mechanism of the Foot-Princtples of Shoeing-Rasping-Paring-Conformation of the Foot-Nalls-Clips-Removing Shoes-Calkins-Tips-Feathering-Roughing-C mmon Faults in Shoeing-Pricks-Presses or Binds-Forge and Shoeing Tools-Faulty Feet-Diseases of the Hool

\section{CHAPTER XIX}

\section{THE USE AND ABUSE OF BEARING-REINS}

Arrerican Overhead Check-rein-Side Bearing-reln-Good Work of the London Anti-Bearing-rein Association-The Hame Rein-Mechanics of the Bearing-rein-Opinions of Experts and the Press on the Bearing-rein 


\section{LIST OF PLATES}

\section{"Gallinule" . . . . .}

PLA.

1. Landseer's "Favourites": "Les deux amis," "The Mourners" . .

2. The Arab In Art: "A Battle on the Desert," "A Halt in the Oasts""

3. Napoleon and Washington on thelr Chargers

4. The Arab : "Horses Frightened by Lightning," "Somo Sierra, 30th November, 1808 "

5. Meissonier's "1814" .

6. Hunter, "Walnut." Couching Stallion, "Beaston Prince" . . .

7. English Thoroughbreds: "Dlamond Jubllee," "Cyilene" .

8. Thoroughbred, "Sysonby." "An Arabian Outpost" . . . . .

8. "Dan Patch," Worid's Record Pacer. "Lou Dillon," Trotter at Speed .

10. Jackson and Lee on their Chargers. "An Arab," by Schreyer . . .

11. The Horse in Art: "The Meet," "The Imperial Courier" . . . .

12. Hunter, "Partridge II." " Pretty Polly "

13. "Gulinule" and "Admiration," "Pretty Pully's" Parents.

14. The Duke of Connaught in Sleigh. Standard-bred Stallion, "Stephen L." Thoroughbred, "Taslett" .

15. English Thoroughbreds : "Bend Or," "Spearmint" . . . .

16. Thoroughbred Horses: "Berrill," " RightIul"

17. Hunter Sire, "Spook." Hunter Mare, "Goid Leat", Spook." Hunter Mare,

18. Standard-bred Stallion, "Bird Peter." Arab Stallion, "Shahwan" . .

19. Standard-breds : "Cecilian Jay," "Lord Bryson," "Joe Patchen," "Majestic." Thoroughbreds : "Josn of Arc," "Per. simmon"

\section{Frontispiece}

PAOX

4

5

8

9

12

Matr.

20. Thoroughbred Stallion, "Veronese." Standard-bred Stallion, "The Moidng" .

raar

21. Polo Ponles: "Grey Light," "White Wings "

22. Thigh-straps for Bianket; Keeping Mome Dressed; Methods of Brushlng the Mane and Tail ; Putting on Hayes' Bandages ; Yorkshlre Boot

23. The King at Marlborough House. Types of Loincloths, Blankets and Sheets

24. Curry Combs. Lolncloth and Robe. Bandaging Tall . . . .

25. Thoroughbred, "Cicero." Trotting Mare, "Bergamot." Patent Fy-net Attachment

26. Types of Tall-plaiting : Light Horses .

27. Types of Tail-plaiting: Heavy Horses and Hunters

28. Types of Banged Tails: Duke of Connaught's Carriage and Four.

29. Types of Banged Tails (i.e. Undocked) 60

30. Types of Tail-plaiting : Heavy Horses . 61

31. Diagrams of Shoulder (Anatomy); Collars ; Halters; PIcketing

32. Diagrams of 64

33. Driving Bits. Methorls of Holding Reins for Single, Pal:, Tandem or Four-in-hand

34. Types of Modern Tandem and Four-Inhand.

36. Driving and Harnessing to the Vehicle $\quad 67$

37. A Modern Carriage and Pair . 68

38. Types of Harness. Six-in-hand Driving. Pacing Mare, "Ruby R." . . . 68

39. Types of Canadian Vehicles . . . 68

40. U.S. President's Four-in-hand. World's Ice Record Holder, "The Eel" . . 68

41. American Trotters: "Peter the Great," "Ed. Finter". . . 70

12. Types of Harness, with Names of Parts . 71 
ILATE

43. The Horse In Action: Mr. Winan's " Bonny Vlew," "Majestlc"

44. Trotung Horses : " Gipsy B.," "Princel!," "Lake Erie"

45. Canadlan Carriages and Palrs

46. Cleveland Bays: "Josephlne," "Hawthorr. Beauty

47. Types of Heavy Carriage Horses

48. Canadlan-bred Carriage Horses. Hackney Stallion, "Peter Shales ".

49. Commercial Horses, Canadian Bred 7

50. Types of Commercial Horses . . 7

51. London Van Horses; Types of Tallplaiting . . .

52. Canadlan-bred Van Horses: Greys . 76

53. Commercial Trap Horses . . . 76

54. British Isle Ponles . . . . 76

55. Toronto Fire Brigade Horses $\quad$. 78

56. Toronto Fire Brigade Horses. . . 78

57. Types of Commercial Horses . . . 78

58. Equestrian Statue of "Cailgula," showing the Natural Seat .

59. Ofticers' Chargers .

60. American Cavairy Horses

61. Sleigh and Pair. Polo Pony, "Maystar"

62. Modern Polo Ponies. "Energy" .

63. The Lady's Seat : Astride Saddle .

64. Hunters

65. A Study in Horses by Mr. Harry Payne

66. The Lady's Seat: Side Saddle

67. Champion Hunters: "Forensic," "Barometer"

68. Champion Hunters: "Monarch," "Busby"

69. Anatomy of the Bisk and Limbs .

70. Diagrams Illustrating tr Theory of Saddie Fltting

71. The Circulatory System. Bitting Diagrams. 72. Riding Bits. Methods of Holding the
Reins

73. Jumping. Swinming Horses. The Side Saddle .

74. Types of Saddies and Saddie Horses.

75. Tracks of Horses' Feet at Different Paces.

76. Ladies' Hunters

77. Huntcrs, "Grey Mall "

78. King George V. and his Favourite Charger. The Outer Layer of Muscles of the Horse.

79. Canadlan-bred Army Horses . sed

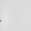

r.4.

80. Cavaluy Horses

81. Champlon Grey Percherons

82. The Estemal 92

33. Earl Harrington on Polo Pony. Grey Percherons .. . $^{\circ} .94$

84. Design for Modern Thirty-two-hore Stable 95

85. Design for an Outdoor Summer Stable for Permament Camps

86. Designs for Manger, Stalls, Wall and Stabie Fittings

87. Designs for Ventlating Arrangement, Drainage and Shlp Sling .

88. Interlor of a Modern Stable . . . 86

89. Stables. Palace Horse Car . . . 98

90. Types of Canadlan-bred Horses . 99

91. Jumping a Stone Wall. A Good Type of Van Horse.

92. English-bred Arabs

93. Types of Arabs. KIng Edward VII.'s "Persimmon". . . .

94. The English Coach Horse: "Rlllington Sensation," "Woodland Briar" . .

95. Conformation of the Hock, Curbs, Spavins, Capped Hocks, Windgalis

96. Conformation of the Cannon and Foot, Spilnt, RIng-bone and SIdebones.

97. Conformation of the Limbs . . . 108

98. Conformation of the Fore-limbs and Back 108

99. Conformation of the Hock and Hind-limbs

100. Diagrams of the Correct Conformation of the Horse. The Suspensory Ligament.

101. The Tendon and Ligaments of the Four Limbs .

102. How to Teli the Age of a Horse by the Incisor Teeth

103. How to Tell the Age by the Angle of Incidence. Cross-section through Molar Jaw

104. Flies and Fiy-protection Hackneys: "King's Proctor," "Hopwood Clematis," "Roan's Queen." Shire, "Midl.nds Squire" . . . . 160

106. The Anatomy of the Tail . $\quad$. 161

107. "How Would He Like It $\eta "$ a Plcture Parable by Phllip R. Goodwin a Plcture

108. Life Sketches, showing the Beauty of the Undocked Tail . 109. The Art of the "Docking Advocate,"
with Suggestions . 110. Three Famolis Hackneys : Docked and
Undocked

\section{6} 16
9

9

0

2

3

104

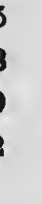




\section{LIST OF PLATES}

VUAT

III. Examples of Docked and Undocked Horses

112. Champion Saddle Horse, "Korosko." Hackney, "Admirabie Crichton".

113. Hackneys : "Beckingham Lady Grace," "Lady Beckingham". . . . 170

114. The Folly of Tall-docking . . . 171

115. Shire, "Rlekford Coming KIng." Hack. ney, "Hawsker Rosina." Standard-bred, "Peter the Great"

116. Some Beautiful Toronto Carriages and Pairs . . P

117. Long Talls and Plaited Talis

118. "Docking " Polnts. "Talke Whanre" . 175

119. Four-In-band Driving. The Length of the Natural Dock

120. Four-in-hand Driving. Re-docking

121. "The Rein Excuse." Four-In-hand and Tandem

122. Mr. Walter Winan's Horses. Major Brooke's "Betty" . . . 181

123. Percheron Stallion, "Frank J." Clydesdale Stallion, "Bonnle Buchlyvle" " 184

124. Work of the S.P.C.A. . . . . 185

125. Examples of Humane Education . . 188

126. Champlon Percherons : "Marquls" . 189

127. Champlon Suffolks : "Sudbourne Lassie," "Sudbourne Redeup"
กละ

128. Champlon Suffolk: "Sudbourne Lord," "Sudbourne Beaumondo"

129. Champlon Suffolks: "Satum," ," bourne Arabl" . . . . . 190

130. Champlon Clydesdale, "Royal Guest." Champlon Percheron, "Thor" . . 107

131. World-Champlon Clydesdale, "Baron O'Buchlyvie." Suffolk Punch, "Easton Duke " . . . . . . 200

132. Types of Heavy Draught Horses . . 201

133. Percheron-bred Hones . . . . 204

134. Heavy Draught Horses . . . . 205

135. Suffolk Stallion, "Sudbourne Peter." Farming in Scotiand . . . . 208

136. Heavy Draught Teams . . . . 209

137. The Nerves of the LImbs. Jugular Vein. Submaxillary Artery. The Braln . . 212

138. Points of Injection for Hypodermic Needle. How to Shoot a Horse. Positlon of Jugular Vein. A Sound Poot. Winter Shoe. . 213

139. Diagrams of the Foot, Shoes and Nalls . 216

140. Percheron, "Marjorle." The Unbeaten Clydesdale, "The Dunure" . 217

141. The Bearing-rein, Mechanics of . . 220

142. Bearing-reins. The Free Neck . . 221

143. The Hame Reln . . . . . 224

144. 1 i nroughbred, "Wuldowler." King ige V. and the Duke of Connaught sing in Hyde Park . . . . 225 


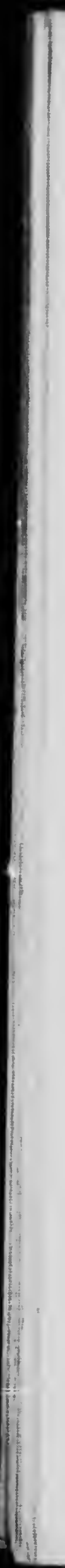




\section{INTRODUCTION}

I HAve read with a great deal of interest the proof sheets of "Modern Horse Management," which have been sent to me before printing.

I sincerely congratulate the author upon the perseverance and hard work which enabled him to compile this book. It must be a great source of pleasure for him to know that the book will be useful, not only to his brother officers, but also to all those wl. " irn or care for horses.

I am very .roud indeed to see that an officer of my old regiment has established the fact that with study and persistent work one can acquire that knowledge in horsemanship and horsemastership that the author has shown himself to possess in writing this book.

F. L. LESSARD, Major-Generar, Comocandang 2ND Diviston Toronto. (late commanding Royal Canadian Dragoons). 


\title{
MODERN HORSE MANAGEMENT
}

\author{
CHAPTER I
}

\section{AUTHOR'S INTRODUGTION}

1. In placing this book before the horse-loving public, I take the liberty of hoping that the horse, so long called the friend of man, will benefit. For more than five years I have been asked by many of my friends and others who have been good cnough to read my articles in farm, horse and other periodicals, and who have attended my lectures on the horse, to publish a book. For a long time I hesitated to do this, though I had accumulated copious notes, both mentally and in writing, of the habits of the horse and the right and wrong ways of caring for lim and teaching him.

It is from these notes that I have compiled many of my chapters. All through I have aimed at brevity; particularly have $I$ done so in Chapters IX., X. and XI.

$I$ have at the last moment tried to bring everything as much up to date as possible, but, on account of my limited time, I feel that there is even yet much left out.

I have compiled Chapter II. from several histories, the classics and various articles. I am indebted to Mr. Basil Tozer (autloor of "The Horse in History") for much valuable informa. tion. Chapter III. has been compiled from notes taken while actually training horses during the past ten years. Most of the points brought out are purely common-sense ones, but, unfortunately for the horse, too many horsemen possess so little horse sense, and, what is more, they never take advico-never hear someone else's opinion and compare it with their own. A horseman is one who is always open to advice and who is always learning. It is a very regrettable fact that so many Englishmen are such poor horsemen. The cause of this is our conceit, our unwillingness to learn. We ride more than any other nation; but mere riding does not signify any knowledge of horsemanship. The exhibitions of bad riding and the large number of untrained horses in the hunting fleld are sufficient to prove this. I have laid down no theory that I have nut proved to be correct with all classes and ages of horses. But where the $\mathbf{B}$ average horseman fails is in not having perfect patience and complete control over his own temper while handling horses. I have dealt with the correct principles of feeding and watering in Chapter $: V$., showing how absurd some of the old ideas really are. I have purposely gone into the physiological reasons, because unless one knows why such and such a thing should be done it often w:ll not be done.

In Chapter V. I have gone into physiology for the same reason. I have discussed at some length the subject of tail plaiting, for which I have plotographed a large number of plaited tails.

In Chapters VI. and VII. I have pointed out many of the common faults practised by rorsemen to-day, giving in each case practical reasons, considering them always from the horse's point of view.

I owe very much to my late riding-master, Professor Alfred Savigear, who, it must be remembered, entered the British army in 1855 , and was the prime promoter of what is now the Royal Naval and Military Tournament. He was one of those who revised Baucher's system of horse training, using his many good points, but eliminating his radicuily wrong ones. I am also indebted to my late instructor, Sergt.-Major Broadley (1st D.G.), whn as the British army champion in ns.unted sports some six years ago. I show numerous types of horses and vehicles.

In Chapter IX. I deal with anatomical diseases, in Chapter XI. diseases of organs, and in Chapter XVIII. diseases of the foot. These chapters have been compiled from my notes taken while studying at the Ontario Veterinary College and Toronto University and while practising in Western Canada. They have been made as up to date as possible by studying the latest veterinary journals. In most cases I give the treatment that I have found to be the most successful; but, as I advise in these chapters, it is dangerous for an amateur to play with a sick horse or with drugs.

I feel that the condensed pharmacopoia, giving the uses and doses of drugs, with tables 
of autidotes and weights and meacures, will be useful to many horse owners. Chapter $\mathbf{X}$. is con. cluded with an extensive glossary of terms for the benefit of those who are not familiar with them. In Chapter XII. I have dealt in detail will the use of the horse's tail. I have considered the subject of flies and mosquitoes, listing the names of many of these pests. The cliapter is concluded with notes on minor operations.

2. In Chapters Xill. and XIX. I have de' in detail with the commonest furms of cruelty to animals. One might ask why it is necessary to write at such length on such a subject in such an enlightened age. The reasons, I think. are clearly set forth in Cliapters XIII. and XIX. The fashion of docking loorses is one that, thank God, is receiving much attention now. I commenced writing on this subject in the English and American Press nine years ago, at the tine Prin'e Christian spoke so strongly.

The Times truly said not long since: "The long tail is now considered preferable." To any real lover of Nature I believe it always was; but until a short while ago the cowardly "horsedoper" had it all his own way. Inexprienced owners purchased sucn horses because they knew no better. Now that liorse shows are setting the example of humanity (except in the case of the Hackney, Shire and clyde), we seo a wonderful change. The modern horse show was inaugurated to encourage horsemanship and this it should really do, while steadily discountenancing all brutality.

In Canada and the States the type of delivery horse is rapidly improving, as shown in many of the plates, and is ofter much ahead of many of the English horses; but the private carriage horse in Canada is far behind the times. VVe see few of the goorl type of carriage liorse, of which examples are illustrated, and it has only been during the past few years that we have seen these better liorses in New York. The proprietors of "Reducine," in an excel-
lent little pamphlet on the horse, show a striking picture of a "swell," with eyeglass, etc., driving a tightly checked horse, with tail stuck up like a hat-peg, in a high dog-cart. Below it are the words, "Which has the most brains?"

Cruelty is becoming more and more suppressed. Ignorant cruelty is checkerl by the law, but the law at present has very little hold over wanton cruelty and needs much amending. It is clear, from the numerous letters I have received from noted liorsemen and others on both sides of the Atlantic, that the general opinion is strongly against crue! fashions.

The Times, in a leading article on cruelty, discussed at length the public sentiment that is growing against cruelty on the stage. A recent music-hall "turn" was removed by public
request. It says: "An animal on the stage is to some extent a personality on the stage, and the moderu sentiment that condemns its treatment as an ingenious but somewhat fatuous automa. ton is not without justification." As it rightly argued, people now realise that a dumb animal should not be treated in a way that is unnatural
to it.

3. Then another change is taking place. The Times continues: "The notion of what constitutes a smart appearance is undergoing a change. Animals are becoming more and more emancipated from the fetters of human, often feminine, fastidiousness. The important fact is more such a change implies the adoption of a more rational attitude towards animals in general ; a preference for what is natural over
what is artificial."

The Times concludes: "It is only now that we are beginning to look upon humbler animals in a new light." But, I add, how much there is

Since writing Chapter XIII. serious steps have been taken by that famous horseman, Mr. Valter Winans. May his good work be re. warded! Although he may have some enemies, as most reforniers have, his many friends must be ever increasing. But what does it matter if ing has no triends in the world: is he not standing up for a dumb creature of God's creation that has no say in the matter?

The veterinary profession of late has done much to help the gnod cause, but it is very necessary that this p.-fession be closely allied to sll humane societies. These must work hand feel hreatly produce really permanent results. I College and indebted to the Royal Veterinary of Otlawa, the late Rutherford and Torrens, Directors-General of and present Veterinary

The subject of the Dominion.

is dealt with is dealt with in Ghapter XV., in which I have lso quoted from different writers.

In Chapter XIY and the latter part of Chapter XIX. I have quoted from the opinions of various ing.reins, etc.

Well knowing how shocking it is that little use is made of anasthetics by those who have to operate on dumb animals, I have dealt with the subject rathcs in detail in Chapter XVI., much of it being compiled from my notes while

In Chapter XVII., for the beneft of the scientific mind, I have gone rather deaply into bacteriology, as the subject is replete with interest and imnortance. Most of the chapter subject under subject under Professor Amyot,, of Toronto
University.

I have felt it my duty to add some notes on the prevention of human risease.

In Chapter XiIII. : have pointed out in detail 
the terrible blunders the modern farrier makes in the forge, giving the reasons and the correct methods, and a brief description of the anatomy of the foot.

4. My illustrations, I feel, will appeal to the true lover of the horse. They are conspicuous for the absence of the mutilated type, except in a few instances. I feel that a study of them will cause most, people to appreciate the beauty of the horse as Nature made him.

I have gone to enormous expense and trouble in procuring many of these photographs. I am extremely indebted to many horse lovers for the help they have given me, without which it would have been impossible to procure many of my photographs.

5. I beg to offer my sincerest thanks to MajorGeneral Lessard, C.B., and my squadron commandar, Major D. D. Young, for much help ; to Captain J. A. Campbell, C.A.V.C., Toronto, for so kindly revising Chapters IX. and XI., and for some valuable additions; to Dr. T. C. Evans, of Ottawa, for furnishing me with some valuable bacteriological information. I also wish 'o thank most sincerely the following for kind assistance: Lieut.-Colonel Wm. Hendrie, Major Joseph Kilgour, Major-General Sir Wm. Otter, Mr. Walter Winans, Earl Grey (former GovernorGeneral of Canada), Sir Henry Pellatt, Senator Kirchhoffer, Colonel H. T. Allen (U.S. Cavalry), Mr. N. J. Holmes, D.V.S., the Hon. Geo. Saville, Mr. Darrach, the Hon. S. N. Parent, Major Eaton, R.C.H.A., Thos. Tilling, Limited, Sir Edmund Osler, Lieut.-Colonel Hall, Mr. W. U. Pitfield,
Captain A. McMillan, D.S.O., R.C.D., Squadron Sergt.-Major James, R.C.D., Mr. F. Bernard, Mr. P. C. L. Harris, Mr. G. A. Parsons, the Proprietors of the Toronto Sunday World, Buffalo Horse World, New York Spur, Cavalry Journal, Sporting and Dramatic News, The Graphic, Canadian Farm, Irish Field, Farm Life, Our Dumb Animals, Sphere and Tatler, Sketch, and my sister and twin brother. I also thank Messrs. André and Sleigh for the extra trouble taken in the production of most of these cuts.

Hearty thanks are due to the many friends ...10 kindly sent me photographs and allowed their horses to be photographed, as acknowledged under each plate. I nm also much indebted to Farrier-Sergt. Hogan, R.C.D., for assistance in taking many of the photographs; to $\mathrm{Mr}$. Bailey, of the Galbraith Photo Company, Toronto, for taking such pains in finishing several hundred photographs at very short notice; to Mr. Redpath, of Chas. Potter, Limiled, and Messrs. Pringle and Booth, Toronto, for special pains taken with many of my photographs; and to the Misses Swanton and Carr for working so hard in preparing my manuscript for the printers.

Since writing the above I have learnt of the sad death of my sincere friend and riding-master, Alfred Savigear. The horse has lost a great friend.

R. S. T.

STANLEY BARAACKS, TORONTO. 


\section{CHAPTER II}

\section{HISTORY OF THE HORSE}

6. BEFORE entering upon the subject of the horse's character and habits, it will be as well to give a brief history of the horse as far back as it can be traced. The native country of the horse is not certainly known.

Some writers are of the opinion that horses were used in chariols 3,000 years before Christ, but no reliable information can be obtained on this point.

The gravestones of the Mycenean period show sculpture reliefs of pair horses and chariots, the approximate date of some of these being 1500 B.c. According to Basil Tozer, the Libyan women of Asia Minor rode horses astride as early as 1800 B.C., and pairs were also driven in chariots.

7. About the year 1740 B.c. horses were probably first used in Egypt. The Book of Genesis states that wagons (probably drawn jy horses) were used at the time famine devastated Canaan, but that horses were not then common enough to be used as pack animals, because the corn was laden on asses. Soon after this, however, horses became common, and cavalry formed a considerable portion of the Egyptian army. The Bible tells us that, aboul 1650 B.c., the horse was commonly used by the Esyptians: horsemen and chariots existed at this time. One hundred and fifty years after this, as we learn from the Book of Exodus, the horsemen were the principal strength of the Egyptian army. Horse races and chariot races were instituter in the Olympic Games in 1450 B.C.

8. Virgil mentions that King Erichthonius, some time before the year 1400 B.c.., was the first to drive a four-in-hand. It is clear from the accounts in the Bible that the first animals to be domesticated were the ox, the sheep, the goat and the ass, and that the horse was not domesticated until later.

In 1000 B.c. dark bay horses were used by the Libyans in Asia Minor, and later many of this colour were imported into Asia Minor. From Homer we also gather that biunze bits were used 1000 years B.c.; previous to this bone, horn and copper bits had been used. Ancient reliefs show us that men rode at times without saddle or bit. Homer tells us many facts of interest about four-in-hand chariots and expert riding in 900 B.c. in the "Iliad." Horsemanship lad evidently become quite an art in Homer's time.

9. Abuut 900 B.c. horse cloths were used by the Assyriaus to sit on, but not until 400 years later did t're Greeks and Macedonials use cloths for this purpose. Herodotus says that about 600 B.c. the Greeks learned much from the Libyans, that st this time the Libyans rode astride, and drove pairs as well as four abreast. He also tells us that wh: te horses existed in those days. About 650 B.c. riding horses were raced; at this time cavalry were not much used in.war. About 400 B.c. the Celts had berome good riders and possessed a good cavalry. The reason cavalry were not used in the early days was partly due to the fact that the warrior, wli . on horseback, was unable to carry his tieavy shield. Herodotus tells us that the horses of 'his period were to a great extent small and possessed a long shaggy coat; 300 to 400 B.C. the Gauls of Northern Italy were a race of good horsemen.

10. Xenophon tells us, more than 350 years before Christ, that jointed bits were used, and that as early as 600 B.c. the art of bitting had reacher an advanced stage. Several centuries before Christ horses were taught to dance to music. Home: asserts that Thracian horsea were of the finest for riding and chariot work, although riding was not resorted to much in those days. The horses around this date wer mostly dappled or of a golden colour, and Achilles' steeds (so history tells us) had very heavy manes.

11. Greek scholars will remember the interesting story Plutarch relates of young Alexander the Great, about 330 B.c., when he displayed before his father, King Philip of Macedonia, his extraordinary knowledge of horses and his common sense. He had, no doubt, studied the writings of the famous horseman, Xenophon, who probably wrote his work on horses about 350 B.c. but he was a born horseman and one of the first natural horsemen that history tells us of King Philip had a young, nervous horse brought before liim, but on account of its apparently ferocious behaviour ordered it to $b$ sent away as unmanageable. Thereupon young Alexander stood out before the mass and declared that he could ride the horse. He was laughed at for his behaviour and severely reprimanded by the 

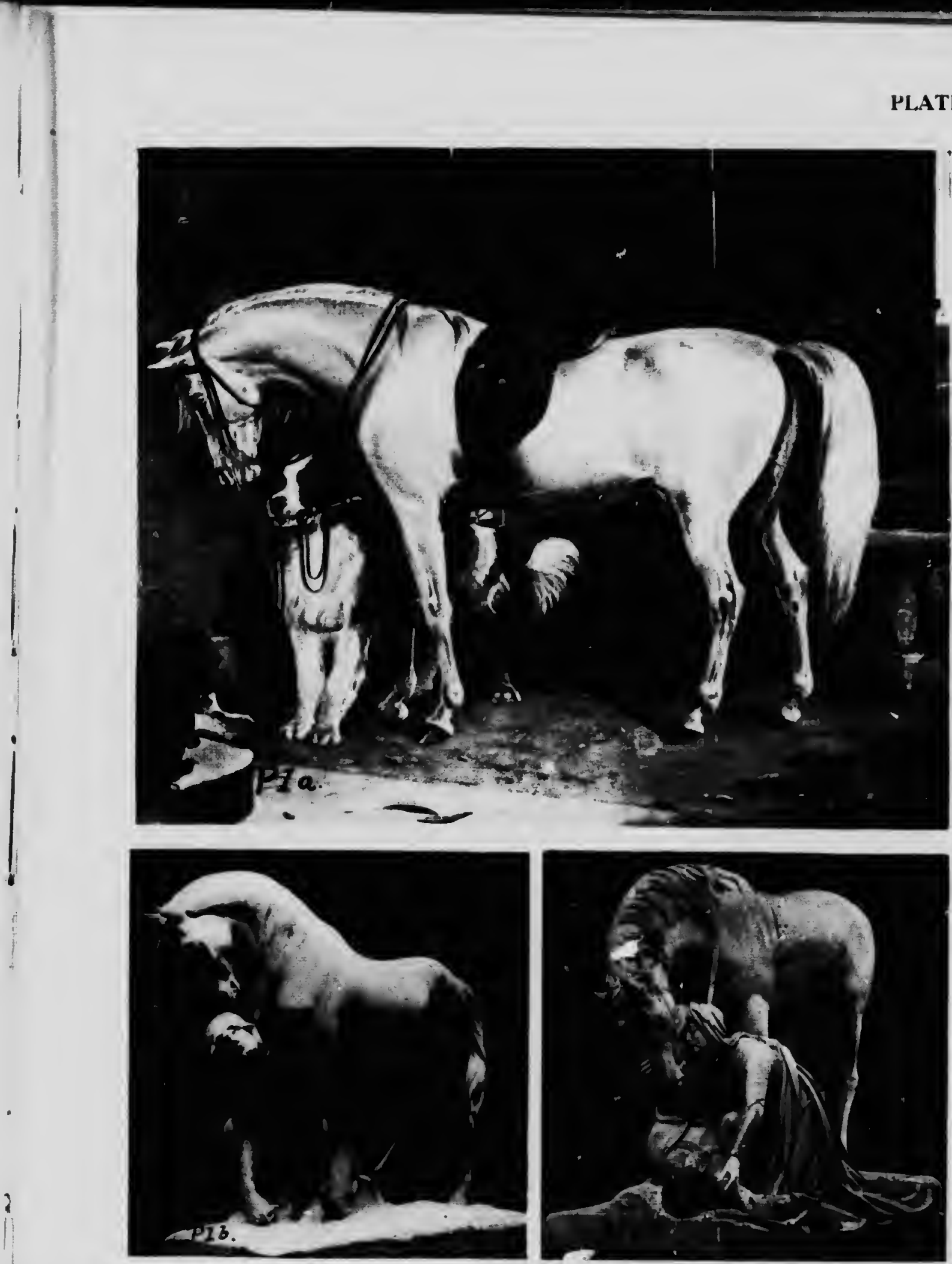

THE HORSE IN ART

a, Landseer's "Favourites." b, "Les deux amis." c, "The Mlourners." 
PI.ATI: 2
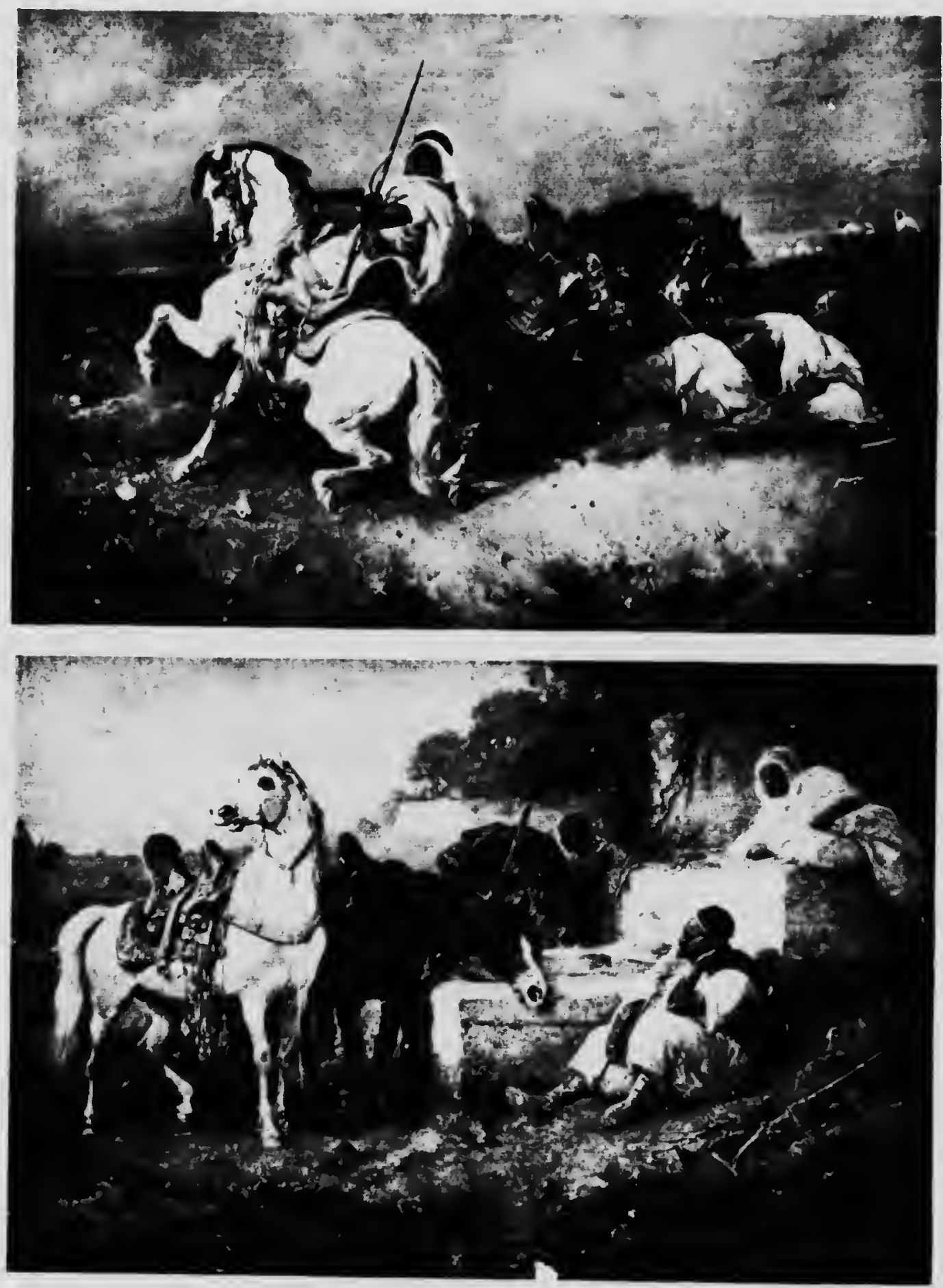

THE ARAB IN ART

a, "A Battle on the Desert." $b, " \Lambda H_{a} l t$ in the Oasis." By Schreyer 
King. But after repeated appeals he was allowed to try, the penalty for failure being forfeiture of a large sum of money. Alexander had noticed that the horse (like so many modern so-called vicious horses) was so frightened that he even shied at his own shadow, and was not vicious. The yout', lurned the horse facing the sun, so that lie could not see his own shadow, and after caressing the horse for several minutes drew himself upon his back, and after several minutes of patience was able to make the horse walk and finally trot in tront of his amazed audiunce. Plutarch tells us that King Pliilip was so overcome by his son's wonderful horsemanship that he wept, and stood up and said that his whole kingdom was not too much for such a lad. This horse was given to Alexander, and was called Bucephalus. Alaxander could do anything with the horse, but his groom could not. The horse carried the great warrior through countless battles, and eventually was killed in action.

From inscriptions on vases lately discovered in the ancient tombs of the Scythians, who lived on the steppes of Southern Russia, it is ev: ient that in those days (400-300 B.c.) both men and women rode astride on saddle cloths, without saddles or stirrups. The horses were small (about 14 hands) and well made. Spurs were not used. A single rein bridle was used, with a bit something like a bridoon.

12. About fifty years later, Thucydides tells us that the horses in war became lame through not being shod. At this period, and until the Christian era, horses were represented on coins. It is clear that prolessional horse trainers and horse doctors existed three or four centuries B.C. Xenophon gives us a great deal of valuable information throughout his works; much good could be gained by the modern horseman if he were to read Xenophon's words on the horse. Tozer reminds us that Xenophon understood the horse, and was certainly not an advocate of shortening the horse's tail and of cutting off its mane. This great Grecian horseman explains the uses of these appendages. Docking horses was probably not heard of in his time. Up to that date proper saddles and stirrups were not used; riders mounted from either side by springing on to the horse's back.

13. Xenophon instructed young Greek horsemen in riding about 400 B.C. The Romar.s possessed a fair number of cavalry, mounted on beautiful horses, in 280 B.C. when they fought the Persians. At this time the horrible practice of offering live horses for sacriflce to the gods was not uncommon. We cannot obtain much informatiun about the horse during the three hundred and fifty years lollowing the death of Xenophon, which took place in 359 B.C., though Virgil furnishes some details concerning the animal. About 250 B.c. the lamous Buddhist
Emperor of India, Asoks, founded probably the first animal hospital in the world. He was a great humanitarian, and gave vast sums of money lowards bettering the lreatment of horses and other animals. His hospital was free. A writer not long ago compared the work of Asoka to the humane work of to-day, and concluded by remarking that, when one considered the cruelty that the modern horse show (and some dog shows, too) is in great part responsible for, the progress made in the last 2,000 years has not been notable.

14. It is clear that the Greeks used spurs; these spurs had no rowels, but possessed a sharp spike. Xenophon and Horace both remind us of the importance of a horse's possessing good hoofs. The Romans at the time of Casar did not use shoes, but covered the feet with a leather sock which had a metal base. In the British Museum is a statue of Caligula on horseback (about A.D. 37) which shows him sitting bareback with a correct seat, like the best of hunting seats to-day. (See P. 58.)

In 55 B.C., when Julius Casar invaded Britain for the first time, cavalry were becoming more common. Cæsar was also met in battle by a great number of mounted knights, showing that horses were ridden for war purposes in Britain at this period. At the time of the invasion by Julius Cesar, history tells us that the English breed of horse must have been extremely powerful and active, and that many were taken back to the Roman Empire, where they were highly valued. At that period the English breeds were crossed with the horses brought in by the Romans Irom Italy, Gaul and Spain.

15. Just prior to the commencement of the Christian era we read of white and of black horses in chariots, with long and curly manes and tails; the black horses were probably of Spanish or Gaulish blood. Cæesar, a few years B.C., and Tacitus, about A.D. 50 , both refer to the race of Iceni, who practised chariot racing and lived in the central parts of Fingland. The first riding race on record in England probably took place about 200 years after this.

Afterwards English mares were crossed with Arabian stallions. It is doubtful whether the modern thoroughbred comes from the Darley Arabian or the Godolphin Arabian. Queen Boadicea, who led the Iceni against the Romans, was a claver horsewoman and was devoted to her horses. Pliny is supposed to have written a bcok on the horse, but this book is said to have been destroyed in the eruption of Vesuvius, A.D. 79, when the rity of Pompeii was buried.

16. In the first century A.D. Calpurnius and Columella mention the horse. In the third century A.D. Oppian and Nem_ian speak of the horse, and in the following sentury Apsyrtus, Pelagonius and Palladicea sive us information of interest. 
Towards the end of the fourth century the Romaus commenced to use saddles. This was about the time that the lionan soldiers returned to their own couniry from Britain (A.D. 110 ) Record is marle that the Roman horses sultered from sore backs the to these chair-shated sadtles. In A.D. 400 son Captaducian horses were sent by the Iloman Emplerur as the most acceptable present he could offer a powerful Prince of Arabia, showing that horses were not common in Arabia; and as late as A.n. Ton thousands of camels and sleep were nentioned amongst bits of phunder, but no mention was made of horses. When Mahomet attacked Koreish, malr Mecca, he hal but two horses. Previous to this ancient history inentions that presents of horses were sent from Esypt to Arabia. It is clear, therefore, that the horses of Arabia, and probably of ihe south-eastern parts of Eilrope. were derived from Egypt, but whether they were brel in Eaypt or brought there from the south-We stern ragions of Asia, or from the interior or northern coasts of Africa, cannot be clearly determined.

17. It is interesting to note that ancient sculptures, such as those on the ruins of Persepolis, show that the horse was driven in chiriots and used probably for pack work before he was ridden. This is strange, as one would think that the tendency would be to sit astritle a horse before going to the task of makir a wheeled
vehicle.

Reliefs in museums show that when the loorse was first ridden no sadllle was used, and that the horsemen rode with a seat very similar to the modern hunting-seat-that is, with the knee
bent. (See P. 58.)

Berenger tells us that the first record of proper horse shoeing dates about A.D. 460 , at the time of Childeric. Within a century of this horse-shoeing had become quite conmon. About then the Swedles had become fine horsemen and possessed beautiful horses. About this time the Arabs are supposed to have commenced horse bretding in a sistenatic way. About A.D. 610 Mahomet encouraged horse breelling. At this time stirrups became common. About A.D. 630 the English are said to have commenced using saddles. In the eighth century saddle horses became common. Horse racing was popular in France for running horses (falloping) in the
ninth century A.D.

18. It is interesting to note that even in those days the frauls met amongst horse breeders and hiremen were only too common, and many instances are recorded of brutality practised on horses. The methods of recording such brutalito the sufferings how liltle attention was paid Chapter XIV.)

We now reach the periorl of the krorman Conquest (1066). At this time the general development of the horse in many countries was ellcouraged, and into England a number of fine stallious were imported from Spain. Previous to this we find that the English breed receivert another cross about the time of Alfred the Great (A.D. 871-901), when German running horses were importel.

A great inmprovement in our cross breeds followed the Conquest of IVilliam $\mathbf{I}$. He brought with ilim Nurman cavalry horses of the best type. Fine Spanish horses were also introduced.

Subsequently Crusaders brought many useful horses from the Eastern countries. In later history we find that King John (1190-1210) importel a huudred stallions of fine breed from Flanders. These were agricultural horses.

Edwart II. (1307-1327) imported war horses from Lombardy. Horse-breeding was again given encouragement when Henry III. (1216$1272)$ came to the throne, and this King was rery fond of horses; he took much interest in proper breeding.

19. Edward III. (1327-1377) encouraged horse breeding. At this period quite an interest was being taken in the turf and also in the chase (hunt). Edward III. purchased a great number of foreign horses, which he brought to England. IIistory, nevertheless, tells us that during his reign, at the battle of Crecy (1346), there was a great shortage of horses for the British troops.

Richard II. (1377-1390) was a horseman and encoltraged horse-breeding. One of his horses in particular he is said to have loved like a sun: this was Roan Barbary, to which Shakespeare refers in Richard II. Horse-racing is supposed to have commenced properly during this reign.

Edward III. imported many fine Spanish horses. He was devoted to turi sports, and probably kept racehorses of his own. Richard II. is recorded as having done much to improve the breed of the English horse.

Henry VII. (1485-1509) and Henry VIII. (1509-1547) also, so history tells us, did much to improve the breeding of the English horse. Cardinal Wolsey, in the reigns of Henry VII. and Henry VIII., who was a fine horseman and horsemaster, did much to encolirage horsebreeding and horsemanship. When Henry VIII. commenced his long reign another great impulse was given to horse-breeding in England. Henry was a keen sportsman, and spent his money freely upon the bettering of the horses of the country. He owned many famous Barbs and other racehorses, and was also a lover of the chase.

20. Queen Elizabeth was a lover of the turf and was very fond of horses; she was a good horsewoman and rode considerably. During her reign a great advance was made in turf-racing, and consequently in hreeding thoro!ighbred
stock; many new races were run.

James I. (160s-1625), who is supposed to have 
founded Newmarket, also encouraged horseracing and Jreeding. At the close of James's ruign horse-racing had become so generally popular that it was denounced by public speakers and clergymen as being the beginning of the ruination of the country. It is strange that a great many of the fast turf horses first bred at Newmarket were bred from some of the Spanish Armada horses. About 1640 liorsemanship in England was greatly benefted by the Duke of Newcastle, who was a high authority on riding and horsemastership. Soon after this dale he published a valuable book on equitation. (See P. 74c.) The Duke was called a fearless and a finished lorseman.

21. It was not until the close of the reign of James I. that horse-racing was run on definite lines under fixed rules. Charles I. was an ardent lover of turf sports; Charles 1I. followed no less keenly. Up till the end of Queen Anne the Arabian had not received much notice, but at this time Mr. Darley, fighting against much prejudice, introduced the Arabian into England, and gradually the unequalled beauty, speed and strength of the Arabian (sometimes known in those days as the Darley Arabian) became recognised.

During the reign of the two Charleses (Charles I., 1625-1649, Charles II., 1660-1685) horses increased in value. Charles II. was an exceptionally good horseman, and is said to have been most humane in the manner in which he treated his horses.

While writing I have before me some of Van Dyck's and Landseer's paintings of the horses of the period of the Charleses and Jameses, and cannot but think, when I compare these superblooking creatures of Nature's handiwork with some of the disfigured animals we see at times on the road and in the show ring, that the advancement of civilisation has caused a deterioration in the methods in which our equine friend is treated.

About that period stage coaches were intro. duced and became commonly used. This caused an increase in the breeding of heavy coach horses, as the coaches were very heavy and the roads very bad.

22. During the eleven years of the Commonwealth of Oliver Cromwell (16:19-1660) the turf and hunting suffered a trem,-jous setback, for although Cromwell, great cavalry leader as he was, encouraged the breeding of the magnificent cliargers ridden in those days, he forbade the continuance of either horse-racing or hunting.

Following this came the accession of Charles II., and horse-racing was resumed. Horsemanship in general was encouraged by the King, who was alı accomplished horseman.

George III. (1760-1820) was a keen horseman, and encouraged driving and other forms of equine sport. It was George III. who so openly condemned the practice of cropping horses' ears and of docking thair tails, "unbecoming the ignorance and cruelty of savage.s." The King forbade all the horses in his arniy trom being thus disflgured and ill-treated, and various steps were taken to abolish these practices by law; but the ultra-fashionable horse-dealer got his way, and although, thank God, the former practice has become extinct, the latter is quile common still, as a peep into the modern Hackney or Shire horse show will convince us.

It is truly said that the introduction into England of the Arabian horse has been respons. ible not only for the beautiful English thoroughbred, but also for the present strength, endurance and activity of our roadster, coach horse and hunter.

The horse is not a native of prairie land or plains, but comes from the forest.

23. The American horses are mostly either from the French or from the English. The Canadian breed is found chiefly in Canada and the Northern States, and is supposed to be of French descent. Many of the celebrated American trotters come from this breed. The Conestoga breed, from Pennsylvania, is a longlegged, light-bodied horse, used chiefly for light carriage work. The Virginian and Kentucky breeds originate from the English breed. The Percheron is a most excellent breed of draught horse, and, except for his small feet, is far superior to many other breeds.

English and Scotch breeds are very numerous in number, such as the Suffolk, Cleveland Bay, Shire, Clydesdale, Hunter, the old Northamptonshire, Hackney, Dartmoor, Shetland, Exmoor and the New Forest, and the Irish, Highland, Galloway and Welsh pony breeds.

24. Troops of wild horses were found on the plains of Great Tartary and in several parts of South America, but these were very unlikely of an original race. They were probably descendants of those who had escaped from the slavery of men, who had brought them into those countries. The Tartary horses were supposed to be descended from those that were turned loose at the siege of Azoph in 1657 for want of forage.

The manner in which these wild herds protect themselves is interesting. They move about and live in huge troops of as many as 10,000 horses. All the mares and foals are kept in the centre. There is one leader, whom all the others implicitly obey and trust. He is the first to face all danger in case of attack. Travellers found that it was dangerous to approach on horseback, because some of the troop would advance close to the saddle horse and try their utmost to call him to join them. In many instances the saddled horse would succeed in ridding itself of its master and saddle, and with a 
wild yell would join the broop-tree for ever. In some instances the horses of Tartary were not so Iriendly to domesticated horses; they would even attack them with their teeth and kill them. These Tartary horses, when captured by man, were found to be most docile.

At the beginning of the last century troops of wild horses were found in the central parts of Africa, in the Island of San Dumingo, in the deserts of Arabia and in otler parts of the world, but these horses did not equal domesticated horses in form, strength or even speed.

25. When we consider that Egypt is a country that is not favourable to horse-breeding, we cannot help wonderng whether the liorses which the Hible and ancient history tell us came from Egypt were actually bred there. It is only reasonable to suppose, as stated above, that they originally came from the interior or northern coasts of Africa. At any rate, there is 110 doubt tlat Africa was the first continent to produce the horse.

The head of all tlie African horses is the Barb, from Barbary, Morocco, Fez and Tripoli; remarkable for his fne and graceful uction, his height seldom exceeding 14.1 hands. The most celebrated racehorses trace their descent from African Barb mares. The Arab is inferior in form to the Barb, but has better spirit, speer and countenance. The Spanish loorse is mostly descended from the Barb.

The kingdom of Dongola and the neighbouring districts between Egypt and Abyssinia produce another breed known as the Doncola; he is a much larger horse, 16 hands or more in height, with a much shorter body tlian either the Arabian or our modern thoroughbred. They were imported into Europe early in the nineteenth century, but were of little value.

26. Going farther East, we come to the Arabian. About seventy years ago wild horses were still seen in the deserts of Arabia. These horses were extremely swift, and some of them were hunted by the Bedouins for food. Although in the seventh century Arabia had no liorses of value, the horses which it had-as the Cappadocian and others-were so carefully cared for and bred that in 600 years (i.e. the thirteenth century) they had produced one of the finest horses in the world-the true Arab. This horse is divided into three breeds: the Attechi, an inferior breed; the Kadischi, a half-breed; and the Kochlani, whose genealogy in some cases, it is claimed, could be traced back for 2,000 years. In fact, people kept the tables of these wonderful steeds with greater care than they kept the tables of their ow $n$ relations. The Bedouin Arabs had been chiefly responsible for the breed. ing of the Kochlani Arab horse. It has always been with great difflulty that an Arab mare has been purchased, but exported Arab stallions have been quite common. The female was always the better aninial, and genealogits were always reckoned on the female side.

27. Tlie fluest part of the $A$ rab liurse, witlout doubt, is lis head, and he is always well-balanced in aplearance, because he has a magnificent tail, which lie carries extrentely well. The broad, square forehead, short, fine muzzle, small ears and proininent, briglit eyes are the characteristics of an Arab's head. His shoulders are ideal, althougl he is a little narrow in the chest, but there is ample lung space behind the shoulders. The Arab seldom exceeds 14.2 hands. The leg is small, flat and wiry, and he is capable of performing marvellous feats. His temper and docility are his characteristics, no lass than his speed and his courage. Bishop Heber, in his "Journeys Through the Upper Provinces of India," states that "he is not the flery, das: : 5 animal I had supposed, but has almost as much attachment and coaxing ways as a dog." This is due to the manner in which these horses wero brought up from their birth-as one of the children-so different from the harsh way tho majority of so-called horsemen of to-day bring up their young horses.

28. Still pursuing our way Eastwarl, wo come to the Indian liorses. There are several Inclian breeds, the most important being the Toorky, originally from Persia, a beautiful and docile animal, with splendil spirit and action. The other breeds are: the Iranee, the patient and strong Cozahee, the speedy and beautiful Mojinniss, and, lastly, the Tazsee, a breed not beautiful in form, but extremely comfortable to ride. Going still farther East, we come to tho Chinese horse; this animal is small and weedy, ill-formed, and without much spirit.

Returning Westward, we come back to the Persian horse, which is said to be very like the Arab, but lias less power of endurance. This breed is micl older than that of the Arab. Alexander the Great is said to have considered no gift finer than that of a Persian horse. Their height is about equal to that of an Arab.

29. The Turkoman breed that comes from South Tartary (north-east of the Caspian Sea) constitutes a pure and valuable breed. For service they excel the Persian. Th'y stand from 15 to 16 hands, and are swift and inexhaustible. However, their head is usually too large, legs inclined to be long, and barrel small. The horses from the other parts of Tartary (i.e. the plains of Central Asia and European Russia) are small and badly made, but have the extra. ordinary power of travelling tremendous and rapid journeys on comparatively little food.

The Turkish horses are descended chiefly from the Arab. They have assisted in improving, in the past, English breeds. Their body is inclined to be lcng.

30. The Italian liurse las sadly degenerated from what it was several centuries ago. Tho 
CHAP.

PI.ATE: 3

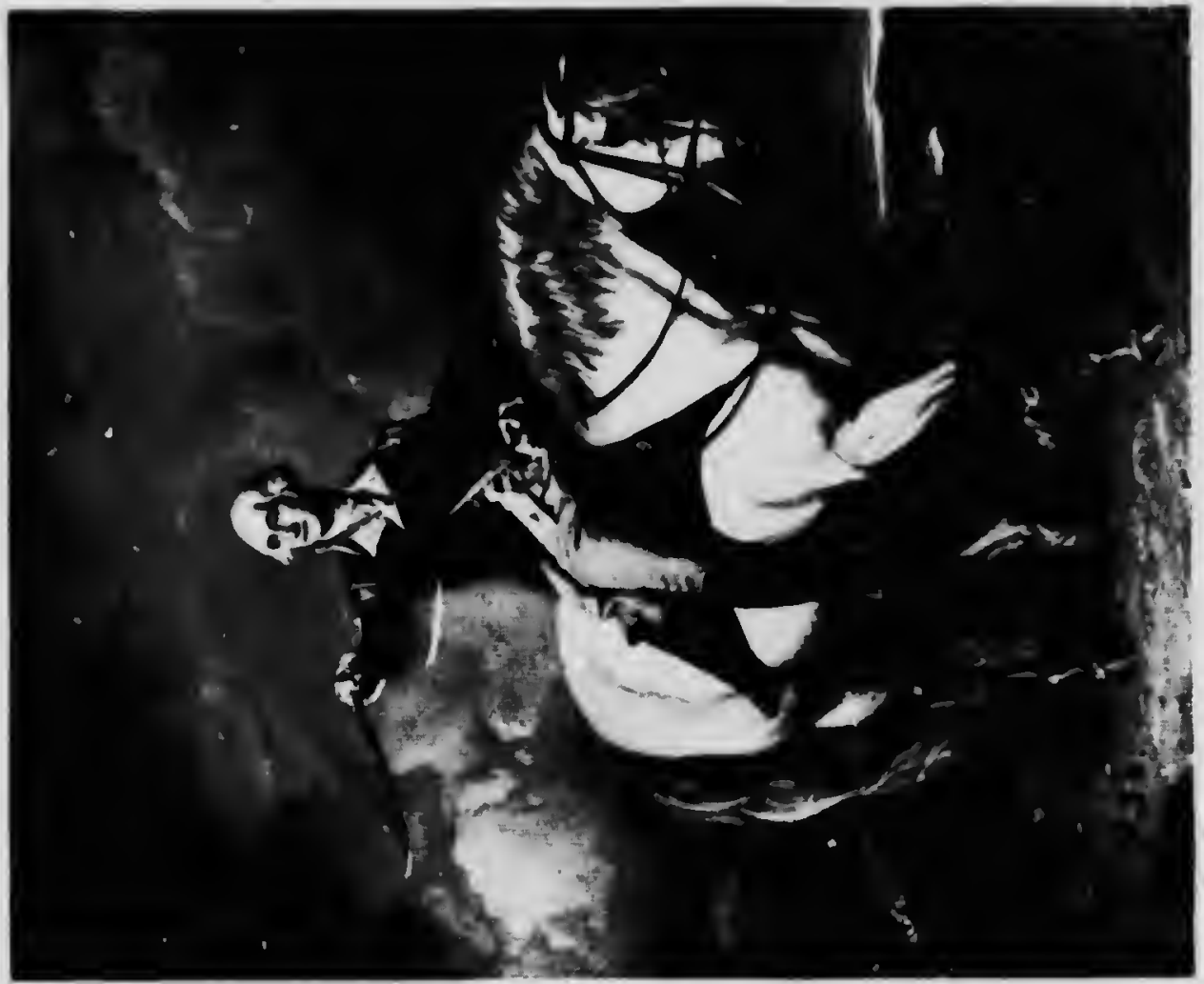

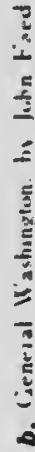

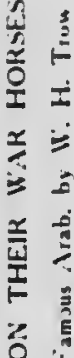

ithout

lanced

it tail

1 ears

cteris-

ideal,

t, but

ilders.

per-

and

in his

in hi:

$\therefore$

much

Thi:

the

y the

bring

1. we

veral

5 the

ction.

atient

utiful

d not

ole to

0 the

eedly,

o the

e the

This

Arab.

dered

Their

from

Sea)

For

from

tible.

legs

The

xtra.

and

iefly

orov-

dy is

rated

The

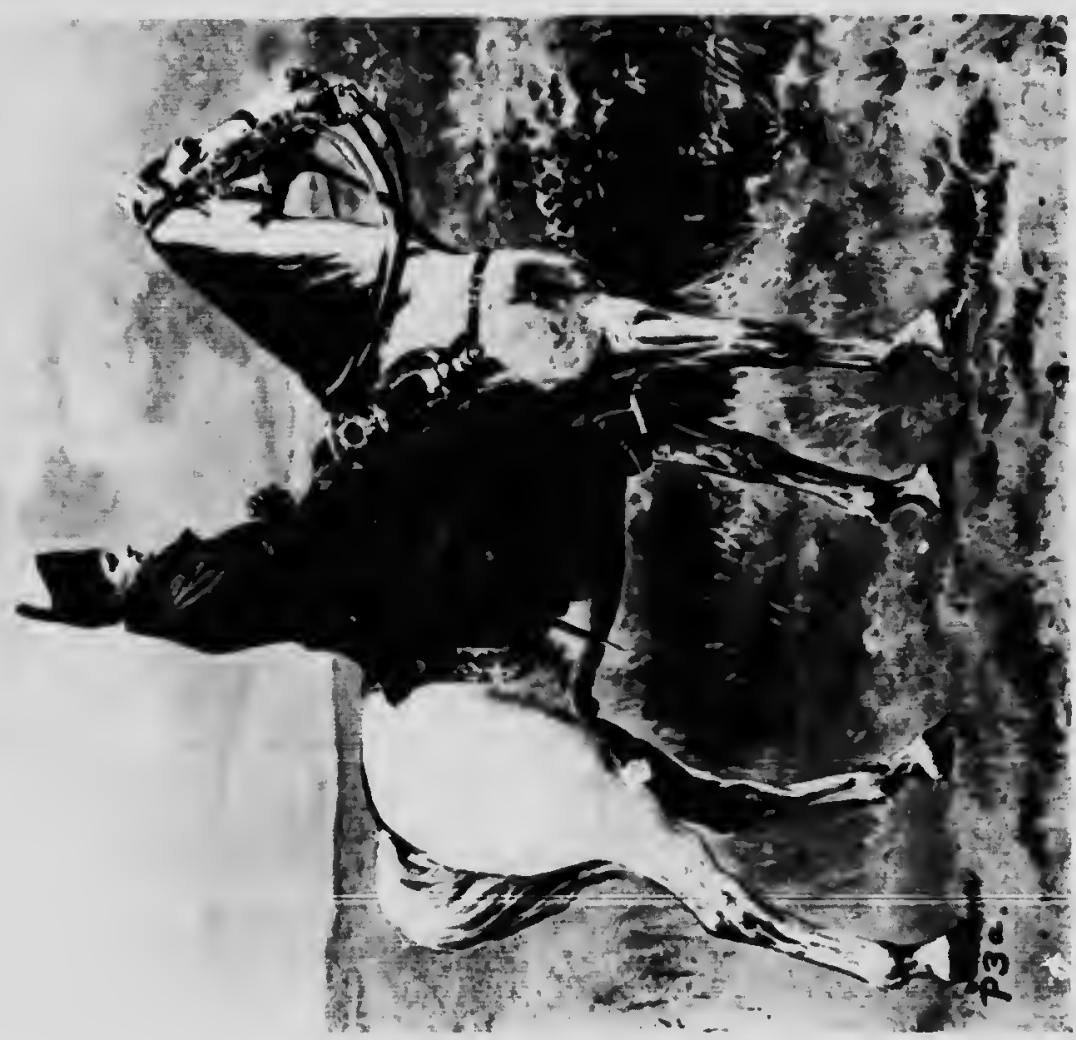

ช

닝

는

ก

$3 x$

$\because \frac{5}{2}$

is

잉

E 
PIATI: +
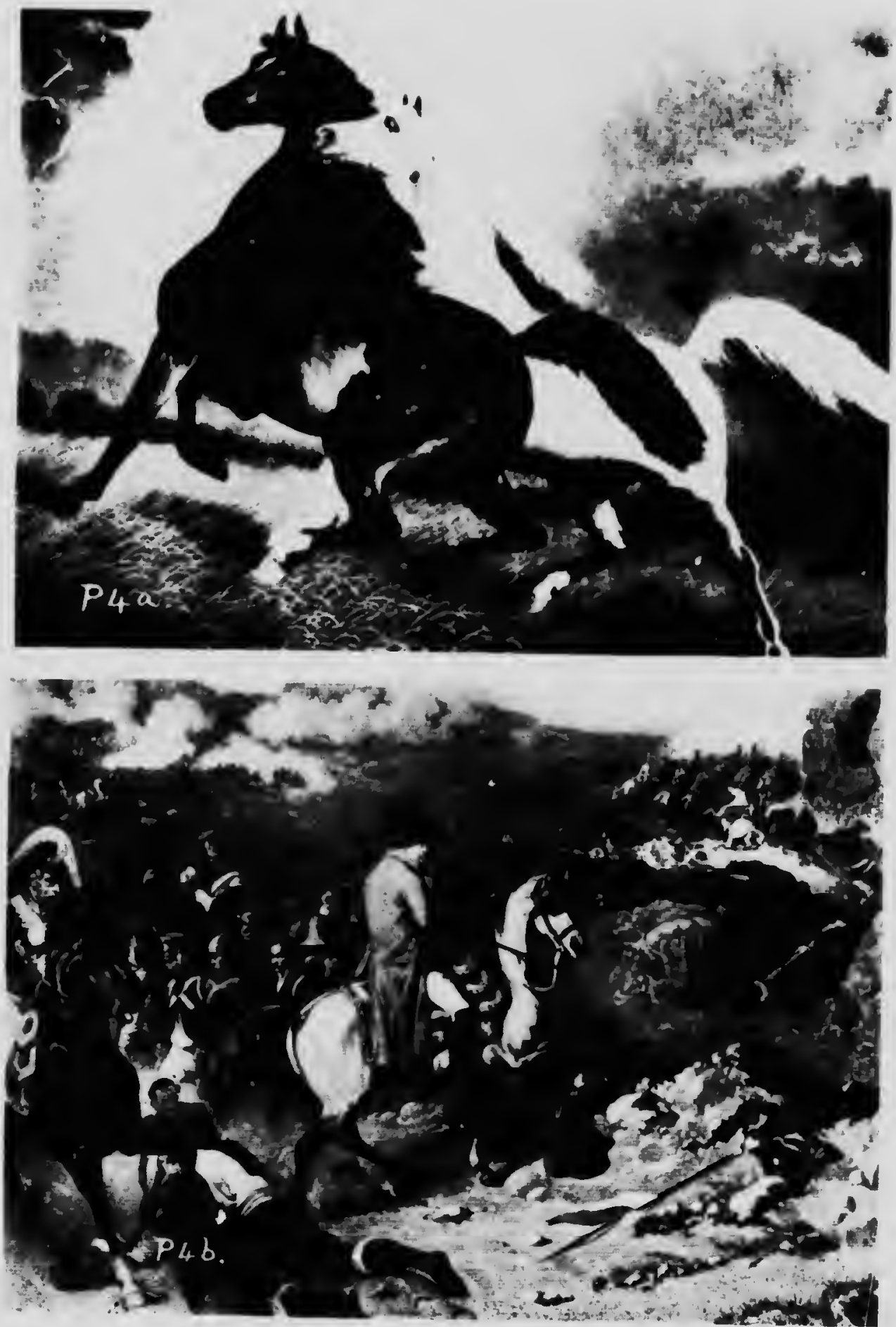

THF. WORLD ADWHRED IR.IU HORSE

a, "Horses Frighiened by Lighıning." hind permissum Taber-Prang Ar Co., Springfield, Mass. b, "Somo-Sieria, 30th Nivember. Iros" 
old breed, known as the Neapolitan, was particularly suitable for carriage work on account of its size and stateliness.

The Spanish liorse has always been of the best, and owes it excellence to the Barbary blood brought over by the Moors.

The Germian horse is large, heavy and slow. Many of the modern Gerinan horses have origiuated Irom Holstein.

The Erench horsa is of vurious breeds. The best are those from Limousin and Normandy, but the modern French horse is much crossed with English breeds.

Flemisli and Dutch horses form a great part of the ancestors of our draught horses, their breeds being strong, large and beautifully formed.

The Swedish and Norwegian horses are small, speedy, high-spirited and well-formed. Finland breeds are even smaller.

The Iceland horse is small, strong and swift, and is very probably descended from the Norwegian.

31. It is a regrethable fact that the climate of the North American continent is not suited to produce fine horses for any length of time. Before European horses were imported into Canada and the United States, the horses of these countries were small and often of a weedy type, although, centuries ago, derived from the finest breeds of large and well-formed horses.

Horse-breeding in these countries is only successful with a certain admixture of European blood every now and then. On the other hand, the English climate is absolutely ideal for horsebreeding. The cobby breed of horse (see P. 29) could be produced for ever without introducing other blood.

It will be remembered how soon the Canadian and the United Stites hursty collapsed in the South African war. Very lew of the Canadian horses exrorted to England are of the same build and stamina as the English horse.

The Argentine horses, that had been fed on alfalfa (sainfoin) previous to leaving their native land, collapsed at once when fed on oats in South Africa. The best horses that were sent to South Africa were the London 'bus horse and the Kirghiz pony (from South Russia). The former (similar to those in P. 20d, e, f) were in the best of condition, and very readily adapted themselves to their new country, the latter lasting equally as well.

\section{The Horse in Geology}

32. The earliest trace of the ancestors of the horse shows us a small animal of about 16 in. in height. He is known as the Palæotherium, and had a hoot on each aide of the main one, nearly as big as the latter. All three of the hoofs touch the ground. The next tribe was the Pala- photherium, which had amaller hoofs on each side of the centre one. Nexl was the Anchitherium, which had much smaller hoofs on each side.

Then came the Hipparion, whose side hoofs were hidden in the leg close to the main hoof. Lastly came the horse. Ilow great a time elapsed between these various ancestors it is impossible to state. Sufilce it to say that the Hipparion was probably the several millionth great-grandfather to the horse. The Hipparion was found in the Plioce:1e and Miocene periods of geological time. The inost recent period is tho Post-pliocene, whict. is subdivided into the Glacial and tl.6 nower recent epochs. To give an idea of the age of the Ilipparion (so geology tells us), to say nothiug of its three ancestors mentioned above and others previous to these, it must be noted that the whole of the written history, from early Egyptian, Babylonian and other Bible records to the present day, for.ns a small part of the latter half of the recent epoch.

Prot. J. Cossar Ewart, speaking at the Victoria and Albert Museum (British museum) a few years ago, said that it wes impossible to $f x$ the ancestors of the horse. He believed that the horse descended trom many lines. The Paleontological Bection of the New York Museum hns six stages of the evolution of the horse, all of which were collected from the rock bids of the State of Montana (West U.S.A.) by Frofessor Wortmann.

\section{Etymology of the Hore}

33. The horse is supposed to have derived its name equus, in the Latin tongue, or hippos, in the Greek tongue, from its swiftness, equrus meaning swift.

\section{Zoological Position of the Horse}

84. The position that the horse holds in the universe is worthy of note.

The horse belongs to the animal kingdom, the Chordata Phylum (form), the Vertebrata SubPhylum, and to the Craniata division of this Phylum.

He belongs to the Mammalia class, the Theria sub-class, and the Eutheria division of this sub. class; and to the Ungulata order (hoofed or nailed), the Perissodactyla sub-order (odd number of digits, the Equidæ family, the Equus genus, and the Caballus species. Varieties of the species are very numerous.

\section{The i, uine Machine}

s. "et us first consider what the equine machine is. It is a complicated mass of powerful and less powerful muscles which connect to bony levers (limbs, etc.), and have the power of 
moving these levers, which in turn are counected to a powerfill framework of bone. Now these muscles must receive vitality, or else they (or, rather, the cells of which they are composed) will die. This vitality is supplied oy various organs; these are placed witinin and protected by this framework, which forms an origin for most of the main muscles. Hence the framework (knowil as the careass) has a twofold function. All the cells in the bonrs, as well as those in the muscles, have to be smpplied with vitalıty, i.e. foot. In fact, all the tendons, ligaments ind other tissues have to be similarly supplied. This cell food is pat of the blood, or, rather, is carriel by the blood and thistributed throughout the machine. The blood receives its fool by means of various organs that abstract certain cliemical poolucts from various animal, vectable and mineribl conpounds, which constitute what we call food.

These organs receive this foot, grind it $11 p$, convert it cliemically into other chemical compominds, and pass it on to the blood and lympli, which flow in the arteries and lymph-vessels respectively. The solids not required are passed out. The liquids in the blood not required are collected by the kidneys and passed out.

Some of the liquids and solids required are collected from the hlood by the liver and stored up; the remainder is distributed by the blood to the cells of the machine.

36. Another necessary food is oxygen. This is collected by the lungs from the air and carried by the blood ant distributel to the various cells of the boty. The whole of this machine lias to be regulated. This is done by a marvellons telegraphic system, known as the nervous system, partly involuntary and partly voluntary in action. The involuntary part regulates the vital meclianism. These telegraplic circuits are connected to sub-offlees, known as the spinal cord. The whole of these sub-offices are, again, controlled by a central station known as the brain.

Besides its mechanical movements, this machine is given senses, controlled directly by the brain. The central office is strong!y protected in a bony case. The wnole franie ard all the levers are surrounded by a fatty cushion (unless the animal is very thin), and outside this by connective tissue, and fina'ly by a thick shin, from which grows a ilairy coat.

So we may realise that the horse consists of a living machine controlled by a brain-a mind ; and we must always bear in our own milld that the horse's mind (like our own) requires to be, and, in fact, must be, if any success is demanded, developed before it will be able to command the machine over which it rules. (See Chaptrr III.)

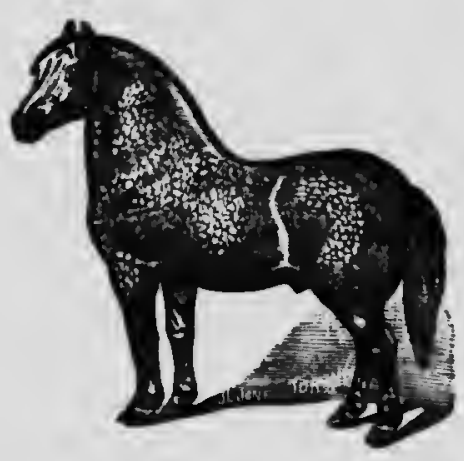




\section{CHAPTER III}

\section{PSYCHOLOGY OF THE HORSE}

\section{The Horse': Mind}

37. Re/ ising fully illat the horse's mind is the first pa $t$ of the horst to which our attention must b directed if we wish to train him to any degree, 1 is consid.l a few points on this subject.

Anatomically, the horse's brain is proportionately very much smaller than ours, whilst his spinal cord is proportionately much larger. This fact is made quite clear when we see what little effect an overdose of alcohol has on the horse's brain (especially a horse of less than normal intelligence), and what a strong effect it has on the spinal cord, stimulating all the motor neive centres of the animal. The most developed portion of the nervous system is always acted upon by alcohol.

38. The horse is born, as we are, ignorant, and therefore has to be educated; but he has a natural gift of instinct of which we have very little. In wild horses (i.e. horses born and brought up away from civilisation) this natural instinct is very well developed, whilst in the highest-bred horse it is comparatively slightly developed. The horse possesses similar senses of hearing, smell and taste to those of men, those of hearing, smelling and tasting being particularly well developed. Unfortunately, the sense of sceing is often far from good in the horse, but this is usually due to his being kept in a dark stable. I think that the infant foal prohably has, in most cases, good sight. The sense of feeling is, of course, well developed, but not as well as ours; particularly is this not the case on the surface of the body, as our skin is far more fully supplied per unit area with sensory nerves. It must be remembered, however, that the horse varies a great deal in the manner in which he shows evidence of pain, as well as in the extent to which he actually feels it; some horses will bear an enormous amount of excruciating pain. Intense fear is probably responsible for the absence of motion or reaction.

39. The sense of hearing is very acute in almost every horse-in fact, so ecute in some horses that shouting or other loud noises are responsible for strange actions, which actions are usually put down to the horse's stupidity or high spirits, and the poor snimal is punished for that which he cannot help. The firing of guns and rifles has a most disturbing effect on some horses, which is supposed to produce a painful feeling in the ear or brain. The remedy for this is to place cotton wool in the ears. The same effect, in a milder degree, is responsible for many loorses becoming what is commonly known as "gun shy."

The senses of smelling and tasting are very acute (particularly in wild horses), as it is these senses that guide the horse in choosing food and water and also in determining whether he knows an object and whether certain objects cause him fear or not. I might remark here that the horse's muzzle is to him what our fingers are to us, the soft pad at the end of the muzzle being fully supplied with tactile hairs and nerves. For this reason the horse apparently smells all new objects; although he smells most of them as well, the chief reason for placing his muzzle so near to them is generally to feel them.

40. The mind of the horse varies in quality very considerably, and while I fully realise that the poorer-bred, badly educated horse more resembles the ass, I refer in this chapter, in considering his character, to the better-bred horse the horse whose mental power is considerably developed.

The horse has an extraordinary memory, a great imagination, and a limited amount of intelligence. This last, of course, does not in any horse reach the high development that it has reached in the more intelligent dog. James Fillis, who was looked upon as the greatest horse-trainer of the last decade, stated that he believed the horse was not intelligent, and in his writings gives a few examples to prove his theory. I do not agree with Fillis, and I do not think his examples are clear enough to convince one of his theory. I think that before man can really understand the horse's intelligence he has to possess an exceptional sympathy with the horse, which sympathy I do not think Fillis possessed, judging from the manner in which he lays down his views in more than one place.

41. It is quite clear to me that the horse possesses intalligence. It $i$ by his intelligence that he studies the means of opposing what he is asked to do; that he awaits his opportunity to attack the person whom he dislikes the moment this person's eye is directed elsewhere; 
that he respects his trainer when kind to him, and reasons that if he obeys his trainer lie is not punished; that if he hurries home at meal hour he will get his meal quicker; that he can free himself of pain by throwing the rider who is abusing him; that by coming over backwards, when lie is in anger, he can injure his rider. It is also by his intelligence that he knows when his rider is afraid on approacling a difficult jump, and, in consequence, hesitates himself to take the jump. When lie is uneducated, his intelligence is very slight, but it increases as he becomes educated.

If a horse who baulks is tied for several hours alone at the spot where he baulks, the next time he is driven past this spot he has sufficient intelligence to go past, because he anticipates the consequences. That clever lorseman, Count Martinengo Cæasaresco, tells us of how a baulk. ing horse will move forward the moment straw placed beneath him is lighted, if he has had previous experience with fire that had not been underneath him. This is due to intelligence. Cæsaresco says: "The more intelligence and memory a horse possesses the better he will be able to learn, remember and execute what he is

Fillis also declares that a horse has no love for man, and gives examples. I have had several horses that I claim lave had a love for me irrespective of feeding, because I have experimented by not feeding them myself nor giving them anj tit-bits. I think it is clear that the majority of horses have no love for man, except the kind of love towards the man that feeds them. I remerner a two-year-old colt that appeared always to be very fond of me, and yet I never fed him. I left him for several months, and upon quietly entering the stable one day, not at his feeding lour, he took no notice of the sound until he saw who it was, when he whinnied and made quite a fuss until I went

42. A great many of the liorse's actions are caused through his instincts of fear and selfpreservation ithe latter being well developed in wild lorses) and his instincts of his own needs

As stated above, the horse has an extraordinary imagination-he magnifles everything fear: but causes him to be very susceptible to fear: but this has its advantages, as it is one of the reasons of our being able to train him. He is extremely observant of minute details, and our minds would make little impression on our minds will perhaps make a great impression upon his, so that it is often difficult to discover what has caused a horse fear.

43. Another most peculiar characteristic of the horse is his intense excitability to motion upon the slightest provocation. His excitability
to motion is the chief reason of his being the valuable animal that he is; it is the casis on which lis training is founded, and on which we are able to make him imagine that we are superior in strength to him. A writer decl" -ed that a horse cared for him only because he fed him. I do not think that this man had any true syınpathy for the horse, and the horse knew it. On the other hand, a dog will often muke a great friend of anyone who feeds it ; in fact, few dogs will refuse food, whilst I have owned and known of several horses that would not feed at all from a stranger. I knew of one horso that would not eat his feed if it had been placed in the manger until he had been assured by his master that the food was all right. I expect he would have eaten it, however, if ho had been left for any length of time. A horse, no doubt, likes to see his groom come in at feedhour, and shows pleasure by giving a neigh, but a horse that is really fond of his master will utter a little whinny whenever it sees him. I have foind this to be the case with a number of intelligent horses. True affection between man and horse is rare.

44. The character of the horse depends, as in human beings, greatly on his parents, but it is also influenced to a marked degree by his trainei. I claim that the intelligent horse develops the character and habits of his master. in some cases to a marked dfgree, and there is absolutely no doubt that one can, by careful observation, judge the type of man that has been attending or training a certain horse. The horse acquires the kind or cruel ways of his master; he acquires his master's temper and his character in genera!. This, of course, will be more marked in the case of an intelligent horse and an exceptionally sympathetic and intelligent mas $3 r$. In this latter case the horse has a strong love for his master. Instances in the past have been evident: masters have been injured, and their horses have refused to leave them; a drunken master has fallen of his horse, and the latter has stood by him for hours, without food, watching over him. Instances are not uncommon of horses behaving in a most marvellous manner when their masters have been in peril; and how soon the young horse realises he is not going to be hurt when first handled by a modern and intelligent horse-trainer $\rightarrow$ "wild " horse may give in within five minutes of being caught. The ordinary horse-breaker has quite a different bethod causes the horse to become frightened; hence his powers of educattemporary.

45. Casaresco evidently conslders that horses are naturally vicious. I do not believe that they are naturally vicious, but that they may have a predisposition to become so through having parents that have been made vicious, and the.?
they may easily succumb to this habit. Almost 
PIATE 5

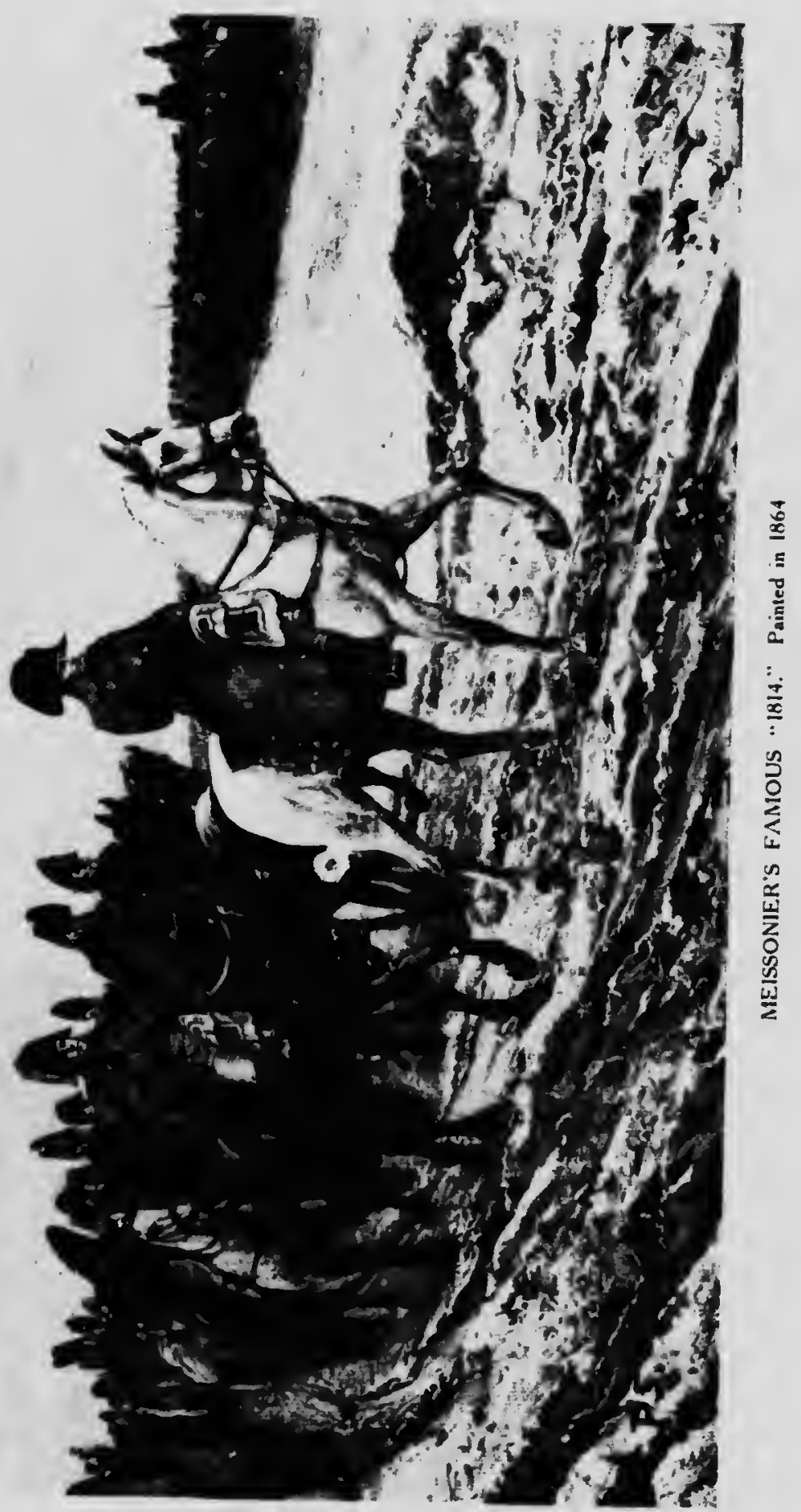


II.ATE: 6
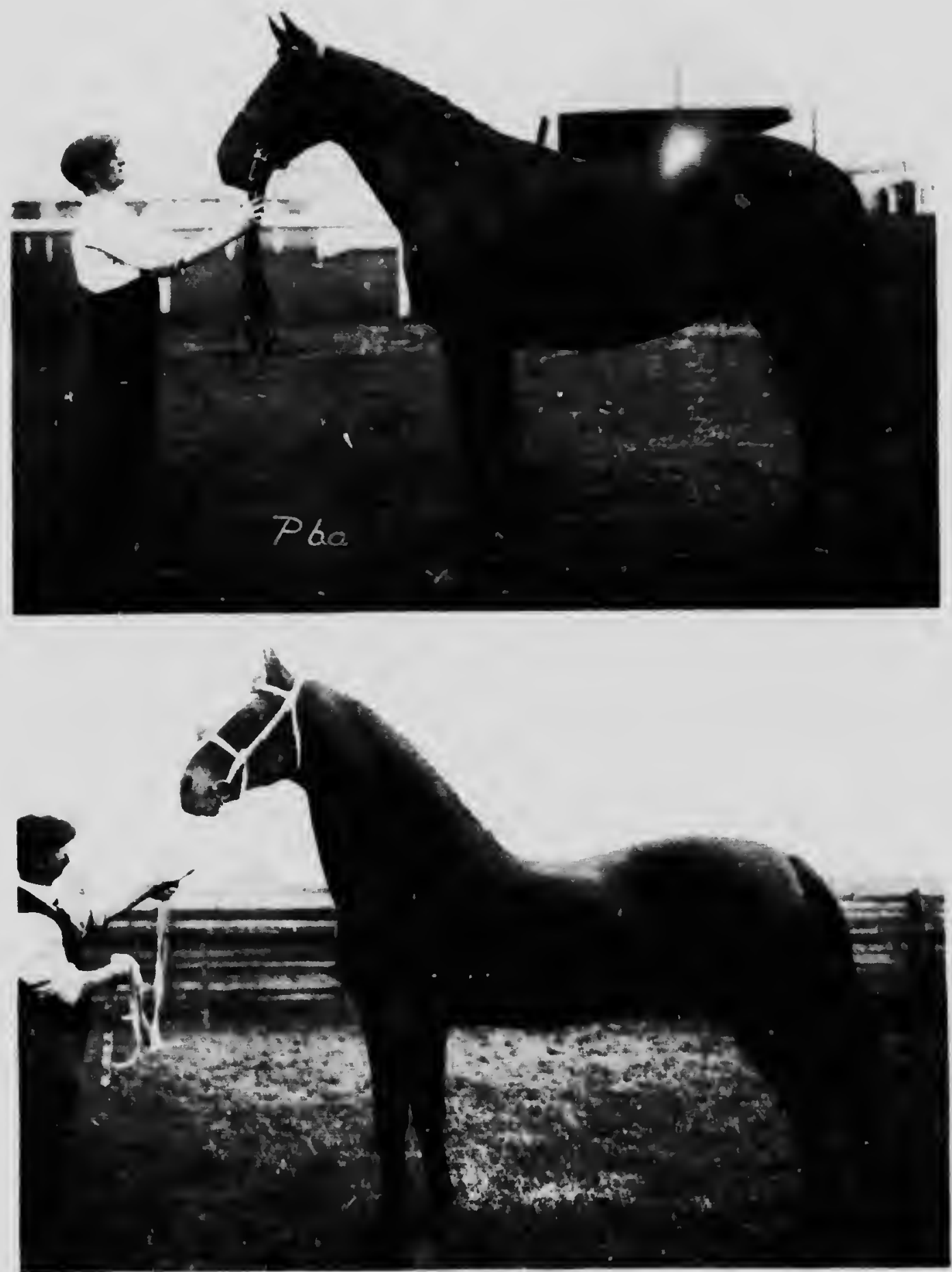

a, Hunter "Walnut," First, Koyal Shriw, 1912. b, Coaching Stallion " Heaston Prince," Noted Champion for Breed. I'hotos: C. H. Parsins. Alsager, Cheshire 
any horse may be made vicious if an ignorant person is in charge of him. Mere teasing may make a horse vicious. A wild horse is not vicious, although he sometimes atlacks man; this is done merely from fear-in self-preservation. With the worst type of Australian or Western American "outlaw" there has never been any proof of viciousness, but ample proof of intense fear; and, as we shall see later on, fear will cause a horse to behave in a very strange way. I have seen many so-called vicious horses, and have had the pleasure of riding some of them in the great North-West, but nothing was more evident to my mind than the intense fear exhibited by these horses. This is only natural when, from the moment they see human life, they are shouted at, h.t, roped, spurred, and everything else is done to them calculated to frighten them. I think these socalled horse-breakers are most unreasonabie if they honestly think that a horse so treated will be anything but intensely frightened.

46. The horse notices things in minute detail, and on account of his extraordinary memory he is able to remember them on future occasions. If these things have pleasant associations connected with them he will, the next time he sees them, expect pleasant things to happen to him again. If, on the other hand, when he first saw them he was punished or in any other way hurt, he would associate the pain or fear produced with the object, and the next time he saw the object he would expect a similar treatment; consequently, the sight of the object would cause fear, and might cause him to refuse to go
near it.

For this reason one of the fundamental reasons of successful horse-training is that the young horse must never be punished because he shies at an object or shows fear. The punishment will leave a bad association connected with that object, and the next time he sees that object he will behave worse instead of better.

47. The horse usually pays attention to one thing at a time, and therefore much can be done if the trainer keeps his eye on the horse's eye and prevents the animal from looking about for other objects. It has been said that a horse takes no notice of our facial expressions, but only watches our hand and leg movements. I cannot agree on this point, because I have experimented on many occasions. I remember a thoroughbred that understood by my face whether I was angry or pleased, and by smiling I could make a distinct impression upon her, which, unless she was feeling particularly high-spirited, told her that I was pleased with what she had just done.

A horse is always looking for its own pleasure-for things that will cause it pleasure, and therefore it likes everything that is associated with pleasure, Unlike man, it is not always looking for work. A horse does not work for the sake of working; he seeks pleasure instinctively. He does not understand our looks to the same extent as does an intelligent dog that watches our face all the time. But an angry horse is calmed by our gaze, whilst an angry dog is usually made worse. Horses act differently in certain ways; some horses act very strangely and inconsistently on some days. This is due to a brain affection, to excessive high spirits, or to great fear.

48. The horse takes great notice of our voice; he can understand a most extraordinary amount by our speech. He can detect the difference in tones, but not in words, because different words expressed in the same tone produce the same effect. When we say different things to a horse we use different tones of speech, and these tones he rapidly commits to memory. A sharp tone is used when we are angry, a slow, soft tone when we are pleased, etc. A horse's sense of detecting sounds, as already mentioned, is very acute, and therefore he should always be spoken to quietly. I can always do more with a young horse that has never been handled by the average groom, who shouts as if the horse were deaf, because it can understand me better when I talk as if I were talking to a friend in a quiet room. A horse can hear one's voice when one talks in a quiet whisper, and one should get into this way of talking to horses, as it shows greater know. ledge of horsemanship. The voice should not be used too much with a trained horse. I will explain later on how aids and indications are taught to him in conjunction with words, and how the voice will eventually be dispensed with, except in case of fear, when the voice is of the utmost value. The horse then loves to hear one's voice, unless his fear is extremely great.

In training, however, as will be explained later, the voice is of the utmost use. The degree to which a horse will understand the voice will, of course, depend on his intelligence. The better he is bred the better will be his intelligence.

A wicked horsc that is well-bred is a very dangerous aninnal, as he will be clever enough to know when to get us off our guard and how to cause us harm; our voice, our indications and our punishments may not have the slightest effect upon him. Of course, a bad- or highspirited horse, when first brought in from the pasture, has lost a great deal of his bad qualities or spirits, as the case may be, so allowance must be made for this.

49. I remember reading of a striking example of intclligence recorded in the Winnipeg Free Press. Mr. Begley, of Glendale, Manitoba, has a mare that goes to the pump and flls the trough with the greatest of ease, using her lips to work the handle of the pump up and down. When the valve of the pump lias "cauzht," she uses her teeth to compete with the extra weight of 
the water. The Press stated: "As fast as sle pumped, the cattle around would drink up tlie water; but she would continue until every one had had enough, when sle would fill the trough, have her Irink, and go away contented. When we arrived on the scene slie stopped and pawed at the ground and looked at us as if to say, 'Please to this for me.' There have been a number of examples of horse-sense, but this is the most impressive that we have come across."

\section{The Horse's Memory}

50. The liorse's memory is most extraordinary, and it is upon this faculty that we base his education. In no way is the existence of his extraordinary memory so clearly evident as in the manner in which he notices fresh objects. I have taken a horse along a certain street for the first time; the horse, knowing it to be a strange street, has not shied at anything, yet in taking lim along the same street two rionths afterwarts he has shied and shown fear at a house, anc. evell a box placed on the side of the street which was not there before. There were similar boxes in other places on the first day, but he took no notice ci them.

Again, I took a horse along a road and around a bend where there was a heap of old machinery, at which the horse shied. Two months afterwards, on going along the same road, when this horse approached this corrier, he hesitated and held up his head and prepared to shy-but the machinery was gone.

However far you take an intelligent horse through various streets of a strange city, he will always know, saving ir exceptional cases, when he turns nis head towards home. If one take a horse over miles of strange prairie land, making turning after turning, and let him loose, he will find his way back to his home. This is due to a peculiar natural instinct for direction and his wonderful memory.

51. If a horse has once been cruelly illtreated by a man, he will never forget that man. I know of a stallion which was shamefully mutilated by a man; flve years later he met this man when he was at liberty, and, but for a stuning blow on the horse's head from an assistant, this man would have been killed-and would have got his deserts. As it was, he was badly mauled.

If a horse has experienced fear, or has been hurt by an object, he remembers it and seeks to escape from it the next time he sees it. If this fear is great, and he is afterwards forced to approach the object, his fear is only in. creased; if, however, he is taken slowly up to it by gentle encouragement, day after day, his growing familiarity with the sensation produced will diminish his objection,

52. The faculty of horses being able to realise which side they are on in war is an example of the wonderful instinct the horse possesses. I believe this is also due to his memory and to a certain power of reasoning. History tells us of various instances where the horse has refused to allow onc of the enemy to mount him, and where lie has returned riderless to his own lines after having been lost and liaving passed through a number of the enemy's lines. The following is an excellent example of this faculty: A Scotsman, Major MacDonald, having killed an English officer in battle (1745), took possession of his horse. The horse, in spite of the efforts of his ricler, galloped back to the English lines and reached the head of his own regiment, to the place in which he had been accustomed to moving. Macdonald was then captured.

53. The horse is generally sociable, like most men, and this trait can be turned to good account, for he will follow another horse into the water, approach near to a motor-car if another horse is between him and the car. In some liorses the affection for man is greater than that for the horse, and the presence of a man in front will produce a wonderful effect. Some horses hate all other horses, and try to kick and bite at them whenever they get an opportunity.

I remember one horse that showed its affection very strongly. For some weeks it was turned out in the pasture-fleld, and on several occasions while I was walking and talking near the field the horse would recognise my voice and come over to the fence and put its head over. I never fed this horse in the fleld.

Some horses are very proud and like to attract attention. It is a well-known fact that many horses will never make a good performance unless before a large audience. A horse neighs to attract attention; he likes being noticed and being made much of. He shows envy if another horse is fed or made much of while he is neglected. This may cause him to feel hatred towards the other horse. Jealousy in all entire horse is generally more marked.

54. Some horses are obstinate, tut as a rule this obstinacy is due to bad early training and to excessive exuberance of spirits. Obstinacy is less common amongst well-bred horses generally.

A horse is usually courageous unless he has been ruined by bad training; cases are known where horses have fought wild beasts, such as lions and tigers, in self-defence.

There is no reason why the entire horse should not be as docile as a mare or gelding, provided he is brought up with suitable surroundings. The Arab entire that is brought up almost as one of the family is perfectly locile, and usually constitutes the Arab's saddle horse.

The horse has a disposition to copy what he seps. For instance, an idea comes tu lim to gallop when he sees other horses galloping, or 
to roll when he sees other horses rolling, etc. This is of much use in training young horses.

The horse becomes irritated, and perhaps angry, if we do not please him, so we must always ain at pleasing him whilst keeping him obedient to our desires.

The horse's character varies to a great extent, and although much can be learnt about a horse by an external examilation of his conformation and qualities, we must ride him and know him for some days before we can judge his character.

lie may be good, bold, subject to fear, or bad. The various factors that constitute his character might be summed up as follows: the degree of sensibility, as of fear, obstinacy; willingness to surrender to man; viciousness; the sensition of tucll, as tickling by the spurs; the quality of his will; the sensitiveness of his mouth to the rein and his flanks to the leg; and the degree of excitability to motion.

\section{Outward Signa}

55. Having considered the inward character of the horse, let us briefly consider how his various characteristics are made evident to the observant onlooker by outward signs.

The ears are a faithful index to the man. The horse pricks his ears forward when he is looking at an object intently, and when he is afraid of something, and generally immediately before jumping an object, etc. He depresses his ears backwards when he is feeling in a bad temper, when approached by another horse or by a man to whom he objects, and when something is causing a tickling sensation, etc. He turns them backwards, or turns one back only, to receive sounds, as the voice of his rider or driver. For this reason a highly strung horse will often go along with one ear forward and the other back, or he may continually move his ears to and fro, in expectation of sounds.

56. A quiet eye shows that the horse is quiet, and a lively eye shows the opn,site. A restless eye indicates that the horse is uncertain, and is looking out for his opportunity to resist, so we must beware of such a horse. These horses, as a rule, by continually looking to one side, show an abnormal amount of the white of the eye. Turbid eyes show that the horse is afraid.

A horse neighs when he is alone and sees company in the distance, or when left alone by other horses. A mare sometimes neighs when alone merely because she feels high-spirited. A horse may neigh at seeing its stable, its groom, its feed, or its master. A horse grunts or groans from pain; he may grunt from fear. He snorts from fear or from anger, o: when smelling an objectionable odour. He raises his upper lip and nose when he objects to an odour or a taste.

57. Swishing the tail is common with some mares who are of an irritable disposition. This is generally brought on and then encouraged by bad riders continually using their legs or by bad drivers continually jerking the reins or chirruping with their mouths. A bad driver with bad "hands" is often responsible for a horse trying to relieve its sore mouth by attempting to grab the reins with its tail. (For the cure of such trouble, see Chapter VI.) Swishing the tail may be the result of excitement, obstinacy, bladder trouble or temper.

A tail held high is generally the sign of good breeding, but a horse may carry it exceptionally high when excited or when in fear. He dopresses his tuil sometimes when in fear-particularly when he is expecting the whip, and instinctively at all times to protect his quarters. A depressed tail may be a sign of sluggishness or of poor breeding, or it may mean that the horse is fatigued or cold.

A staring coat means ill-health or excessive cold. Trembling, as a rule, means great fear, and is really distinct from shiveriug, which may be the result of cold or of the action of certain drugs, as eserine.

\section{Superiority of Man}

58. The horse does not instinctively believe man to be superior. In the first place he probably thinks nothing about it; but, if he does consider the matter, he thinks that he himself is superior, and tries to resist man. If our opposition fails, he learns his superiority; therefore, if we are trying to stop him from doing an act and discover that we cannot stop him, we must let him do it, and by this let him think that we are not trying to stop him. Our superior power is only imaginary, and it is due to the horse's great imagination that we are able to deceive him as to which of us is superior in strength. No one should suggest for one moment that we can control the horse by pure strength; we could not stop a runaway horse by pulling with a leather rein if he knew that he was superior to man in strength.

If a horse starts to run back, it would be foolish to try to hold him by the rein, and therefore we must allow him to run back; he will thus think that we want him to do so. If, however, we tried to stop him, he would discover that he could oppose our efforts, and thus learn his superiority of strength. If we cause him to run farther back after he has stopped, we shall make a better impression on him and make him dislike running back.

Our first object is, therefore, to show the horse our apparent superiority, and to do this we use our superior intelligence against his inferior. Our principle is to prevent him doing what he wants to do and to make him do what we want him to do, little by little, caressing him whenever he obeys, and punishing him 
slightly whenever he disobry's. As in a clild, nearly all disobedient acts are those done through the child being able to do what he was asked not to do; so in the horse, this is the chief cause of disobedience. Therefore, we must be most careful to sce he does not do what lie wants to do and what we do not want him to do.

59. Want of exelcise, and therefore excessive exuberance of spirits, may cause him to become refractory, and may allow linı to lliuk that he is superior to man. A horse may learn his superiority over man by being badly used by a groom, when he may be driven to act in self. defence. A timid liorse will not act in selfdefence; this is the type of horse that the coward chooses to abuse. A spirited horse detests the very sight of a coward: this is the type of man that is responsible for so many bad horses; he is always a bully. A horse, when he acts in this manner in self-defence, will finul that the cowardly groom ceases to abuse him; in fact, he will find that, by attacking, he becomes the victor-hence the knowledse of his superiority is gained.

\section{Obedience}

60. A horse should not be allowed to do an act that shows disobedience. Fortunately, ho readily acknowledges obedience. A well-trained horse is next to a well-trained dog; the latter is the most obedient animal we have. Love must bo gained before obedience is taught; without the former-affection for its trainer-the horse will never be made really obedient. The stronger the horse physically, and the better his feeding, the greater must be his obedience. To obtain a high degree of obedience, the horse must have a good disposition. Such a horse likes obedience; it pleases him to please us, because it is one of his instincts to seek pleasure, and by pleasing us he receives caresses and titbits which associate pleasure in his mind.

61. We obtain obedience from the horse by means of love and fear. By means of love alone he would be tempted to obey his own impulses; by both we persuade him to obey us. Physical force may be adopted to cause physical obedience, but it really only increases fear, producing obedience as long as the physical force exists and perhaps for a very short time afterwards. This method of training a horse would be a sure way of spoiling him.

The whole secret of imparting love and fear in the right proportions to a horse is a knowledge of how to do it, which. I claim, is an acquisition gained by few. The knowledge of successful horse-training is a very rare gift, and the inspiration of obtaining obedience from the equine pupil is the most difficult duty of the master. It is useless to try to obtain obedience until we have obtained love and the horse's con- fidence, because before we can obtain confidence we shal' have to resort to a certain amount of punishment in order to inspire fear. If we inflict punishment before we have gained his confldence, we shall cause him to hate us, to try to flee from us; he will misunderstand the punishment, and think we are doing him harm. In extreme cases punishment may have to be given before confldence is gained, but only a trainer of wide experience will know when this is necessary.

All acts that make the hors do what we want him to do and prevent him trom doing what we do not want him to do tend to teach him obedience. If a horse wants to turn down one road, and we prevent him, we teach him our superiority; but if we are unable to, and he goes on, ho learns that he can satisfy his wants by disobeying us, and thus learns his superiority of strength. As was said before, it will be better to let him go than to try to resist but erentually to give in.

62. Obedience may be temporarily oblained by his greater power of self-preservation, which is an instinct, but even this will be uncommon in well-trained horses.

It must always be borne in mind that physical pain may cause a horse to be disobedient, or it may even compel him to bo obedient. For example, I was teaching a horse the "reining-back" lesson. I lad taught him this on foot for several days, and he obeyed well, but whenever I mounted him he refused to step back, however much I collected him. I dismounted and examined his hocks, and found a painful curb on his near hock; this was the cause of his apparent disobedience. My extra weight had so increased the pain that he refused to perform the act that I wanted him to do.

The only successful way to teach obedience is to be helped by an assistant, and to resort to the use of the cavesson and a strong leadingrein ; the trainer himself must be on foot. The horse will be led about and coaxed to do certain things, and punished slightly at first for distinct acts of disobedience. It must always be quite plain before punishing that the horse understands exactiy what you require of him. Most apparent disobedience is caused through the trainer asking him to do something that he (the horse) does not understand.

63. The horse very quickly picks up what we teach him if he is taught the right way. In many cases he is considered slow at learning, when the cause of this apparent slowness is in reality due to the master not knowing the correct methods of teaching.

Lessons must be short, and repeated often, in order not to strain or tire the muscles, etc. Training must never be hurried, as hurrying may cause serious physical harm, besides probably spoiling the liorse's disposition. 
PIATI: 7
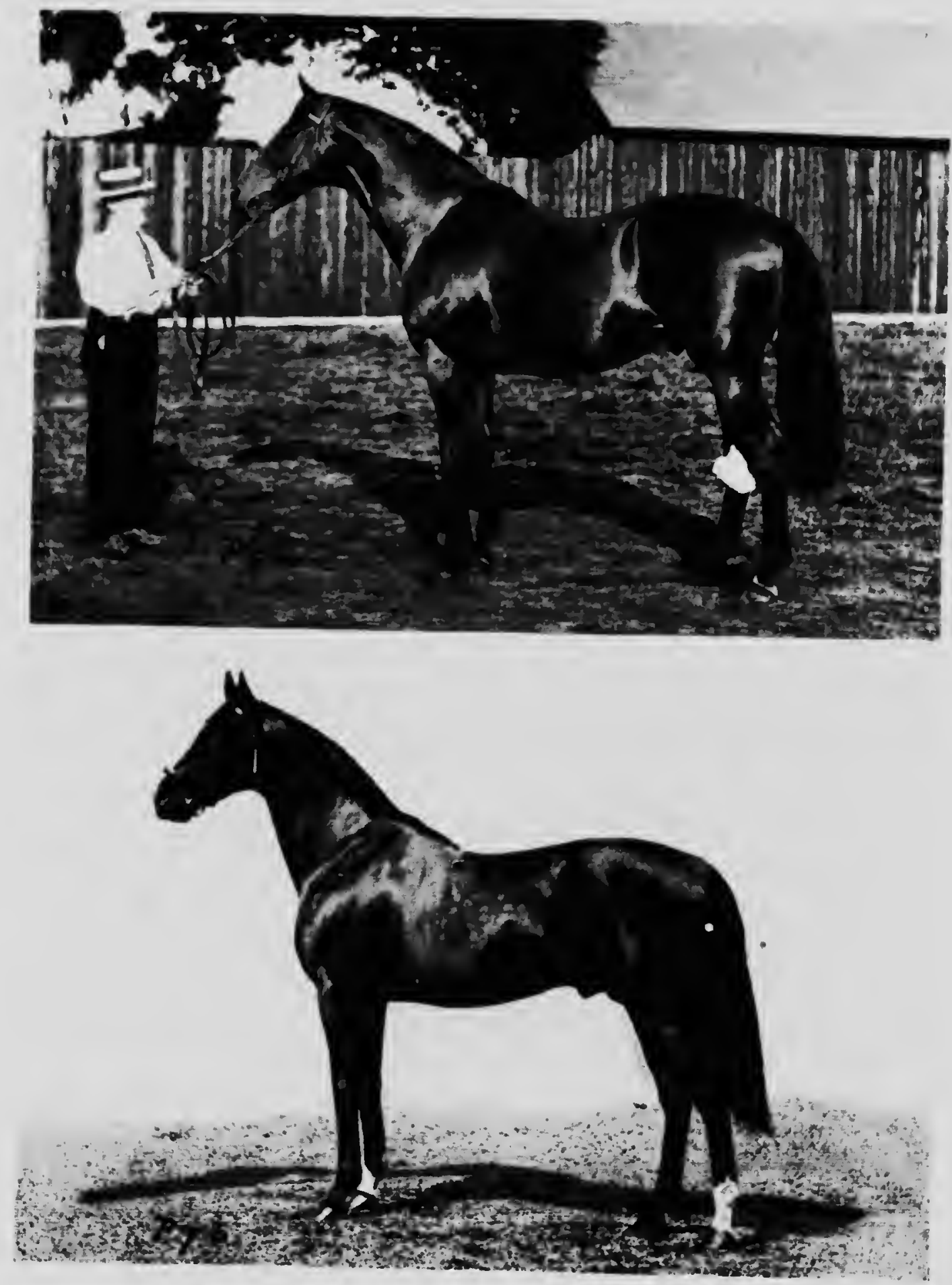

ENGLISH THOROUGHRREDS

a, "Diamond Jubilee," Derby Winner. 1900. b. "Cyllene." Photos: G. H. Parsons 
PITI:
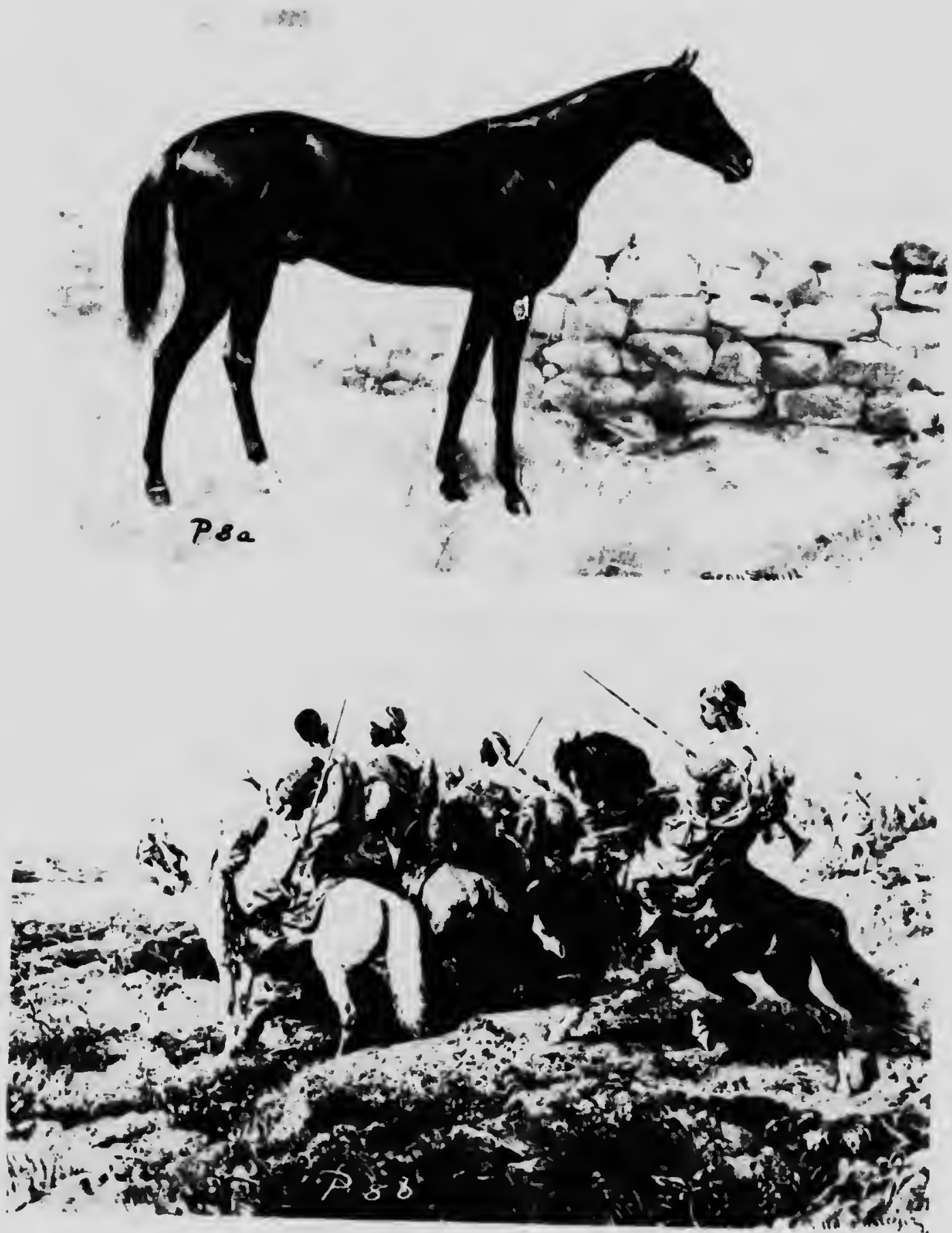

THE HORSE IN IRT

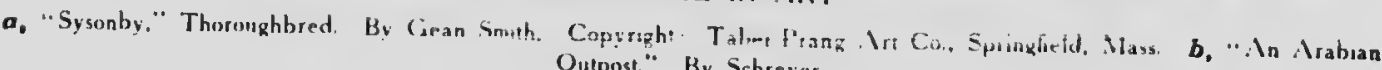




\section{Reactions}

64. When a horse is tisobedient lie makes a reaction. Now, we can physically prevent a horse making many reactions by placing his body in a position in which he cannot make the preparatory mution. But to stop a lorse attacking his rider or his groum is far more diffleult, as the liorse knows lis superiority. In the first instance he probably attacked the man, and found that the man becarr. Traid and also, perhaps, ceased to ill-treat him, lence the horse continued to attack to avoid ill-treatment. This attacking soon becomes a habit; the horse is very susceptible to acquiring habits. Later he probably atlacks without any reason.

The cure of this fault or habit (if it has become one) requires kindness and no punishment; then the horse will learn that he is not going to be ill-treated. He must also be placed in a position in which he cannot attack, he will then learn man's superiority. If he attacks we must show him that his attacks do not harm us ; he must also be shown that we are appar. ently superior to him in other ways. Many reactions are caused by the horse doing something to try to avoid pain or irritation; for example, a rider may be hurting a horse's mouth, the horse bucks or perhaps throw's the rider, the latter ceases to hurt the horse; the next time his mouth is hurt he does the same, because he associates this behaviour with relief from the pain, and this reaction becomes a vice. Again, a horse may attempt to refuse to do something asked of him, and through the ignorance or the weak methods of the trainer, the horse succeeds; he then learns that he need not do this act, and reacts next time.

If a horse on being whipped or spurred is able to raise his croup or to rear up and the rider ceases to abuse him, the horse learns that he can do these things, and that by doing them he causes the pain to cease. Hence reactions are very often due to the horse not being taught proper obedience. A kicker may be produced through the same method. A horse kicks through fear, we will suppose, of his cruel groom; the groom ceases to ill-treat him, so he kicks next time he is ill-treated.

65. A timid rider may also cause reactions in a horse; he applies certain aids with the leg, and the horse objects and reacts; the rider not being capable of preventing the horse from reacting ceases to apply the aids; he thus gives way to the horse and causes him to react the next time these aids are applied.

Other reasons for causing reactions in a horse are using too much and too severe punishment, thereby causing him to look upon you as his enemy, against whom he will instinctively fight; excessive exuberance of spirits, which may cause him to discbey your requests; advancing his education too rapidly, and thereby asking him to

do what he cannot do physically, on account of his body not being suficiently prepared. We cannot expect the man who has only been in a gymnasium for a week to perform a long-arm balance on the bars, nor can wo expect a recruit after ont week in the riding-school to vault into the saddle of a galloping horse; then wlyy on earth do so-called horse-trainers expect to develop the equin 'rame and muscles in a week when it lakes montis? If the horse is not prepared, he evinces pain and therefore re: r.ts. Hence we see tha our ignorance is really responsible for all reactions in a horse.

68. The time required to make a horse give up bad habits depends on the length of time that those habits have existed and upon the horse's character. It must be remembered that punish. ment, saving in exceptional cases, will make matters worse ; he must be prevented by physical means from doing tliese things and be caressed, so that he will see that by not trying he is caressed. If a horse has acquired a habit, such as that of shying, which shows no viciousness, then physically to force him to approach the object at which he has shied and belore which he was probably beaten or spurred, would make him much worse. He should be placed under the same circumstances again and caressed; this must be repeated until he learns to lake no apparent notice of the object.

Every young colt when first brought into the school must be treated with great kindness, and for a considerable time little reactions should be overlooked; our principle being, as stated belore, first to gain the animal's confidence, and this will never be gained if we commence by punishing him and making him think that we are his enemy. A thoroughbred horse requires much more careful handling than a commonbred horse.

\section{Caresses}

67. Kind treatment causes a horse to do well, because thereby he expects to be well trealed. In countries like Arabia the horse is looked up to by everybody, because they love the horse. The horse is of greater value to its owner if he is a friend to him, therefore at all times the owner should treat his horse with the utmost justice.

The horse is particularly susceptible to receiving and appreciating caresses unless he is very frightened or in a bad temper. The best place to pat a horse is on his neck; the patting must not be done hard enough to hurt the horse and yet not soft enough to tickle him. The horse likes being stroked or rubbed better than being patted, as this more resembles the way his mother licked him on the neck and around the head when he was a foal. The best place to rub a horse is on the top of the head, unless he has been damaged in this part; some horses 
seem to prefer being rubbeal just above the eyes.

If a horse does not show pleasuro at boing caressed it means that he is either frightened or in a bad temper, and he nust therefore not be trusted for a wliile. Curessing is a most valu. able aid to uur being ablo to gain a horse's will anil affection: therefore in training lim its full use must never be forgctten. It inust also be remenibired that it can be orerilone, and that a lorse can easily be spuilenl. He should bo treated likı a chilil-kindls but striclly.

\section{Associations}

68. The hoose associates oljocts that he sees. and acts that he performs, with either pleasant or unpleasint things. Iitmambering the horse's wonderful menury, our aim must be to try to associate objecls and actions witl pluasat sensations. This is lle secret of suceessful horse. training.

A horse in passing a motur-car shows a little fear and is whipped or spurred ; he associates this pail with the car, and not with the fool belnind limn, and the next time he prasses a car he expects the pain and shirs worse than before. In such a case he slould have been caressed and shown that only pleasint things could arise from the prosence of the motor.

- a horse, while jumping, is jerked in the mouth, he associates this yain with the junıp and not with the bad rider on his back; lie thus is made to dislike jumping, aud will try to refuse noxt time. Similarly, if he is slouted at or whipped when doing his best he will be encour. aged next lime not to do his best. Associations of pain may cause fear as well as hatred, as was explained in the case of the molor-car.

69. A horse that is being made a kicker by ill-treatment associates being left alone with his kicking. I remember a liorse of the lioyal llorse Guards which had a red ribbon tied in its tail; he was supposed to be very savage, and no one except his groom ever went up to him. The siglit of the riblon caused everyone who passed to keep at a distance. This liurse soon learnt that everyone was afraid of him, that he was superior to then: and whenever anjone approached near to him he would kick. He disliked all men except the one who fed him. In his early days he had associated his kicking with being left alone by man, eventually he hated all men, and the more he saw them avoid lim the more he thought he was conqueror of man. One day I walked right up to this horse without taking any notice of him, and stood behind him and smacked him casually on the croup: the groom thought that I was nad, as the red ribbon was apparent enough. But the horse thought that I was his superior, he saw that I was not afraid of him; I touk hin by surprise and ho allowid ne to do angthing. Had I been foolish onough to approach him slowly as if he were a inall-euting liou and sliown him my fear of course he would have kicked me, and I shoulit have deserved il. The realer will notice that in this eitse I approached right up) to the horse's lucks before halting, beeause had he kicked at une his hocks would have unly lifted me; on the oliner hand, had I stood a few feet away the unetal-slivil euds of his legs, which act like levers, would have cauglit me and frobably tone consillerable dainage. Whenever a hurse kicks at a mall standing behind him, the latter should ap. proinch quile elose to him muless he wishes to feel the horse's shoes. In this instance this horse should have: been put into a stall and so held that he could not kick, and carrssed by all the mon of his stable until he becane friendly with them. The ribbon, which was the callse of most of the trouble, coull then have been dispensed with.

70. $A$ horse will associate things entirely foreigll; for instance, I was bridling a well-bred horse one day in a low-roufed stable; I lifted niy hand carelessly in front of his eyes and he threw up his liead suddenly from feir. Ilis forehead lit the roof and gol quite a bad cut. For werks afterwards it took ne ten minutes to bridle that horse; he associated the intense pain with the brilling. I could not convince hin that ho laal himself caused the pain by throwing up his head.

In brilling and larnessing horses, especially in putting on the crupper, care must be taken not to ubuse the liorse in any way, because if he is abused he will only be more troublesome next time. Ife will associate recciving the bit into his moutl or the crupper under his tail with the pain, and will object next time to open his mouth, or will depress his tail tightly. Abuse will never do good; extreme patience and kindness are required from llee first.

\section{Punishment}

71. Santa Paulina, three centuries agn when speaking of horses, said, "Irevention is belter than cure"; this is a golden rule that horsetrainers must never furget. It must not be forgutten either that trust must be obtained before punishment (unless inevitable) is given. Above all things, a horse nust never be punishel while its trainer is in a bad temper. The trainer hat far better put the horse in the stable for an hour and have a quiet smoke himself. A threat should be given before real punishment is resurted to, and then the punishment should be given mildly at first. The best method of punishing a liorse is to stand at his shoulder and not to be in the saddle ; and to use a riding-whip on his back, if saddled, behind the saddlo, The trainer must never stand in front of a horse while punishing 
him, and never hit a horse on the shoulder while rilling liim if he is required to advance; ho should be whipped behind the girth.

I deal witl whips and spurs in Chapter VII.

Impunity is an inducement to crime, so a wilful crime must never be let nass. It is a difficult matter to determine al ames whether the liorse does not understand our request or whether he is wilfully disobeying ; the former is the more common. Horses vary very much as to the degree of punishment that should be given them. A high-spiriterl liorse has often to he punished early, sometimes almost from the becimning of his schooling, whilst a timid llorse is entirely discouraged by punishment.

72. The theory of punishment is that, if a horse refuses to do a thing he has to do, he is punisliel, anl thus lenrns to avoid the pain produced by loing what he is asked to do; and still more, he is caressed for loing it. Further, the association of pleasure or of displeasure must immediately follow the action that is, or is not, asked of him. A late punishment will be taken as an ill-treatment and will spoil him. If a horse cannot be punished on 1"e spot he must not be punished afterwards, as lie will not be able to associate this punishment with his misconduct. A horse should also be caressed a short time after he has been punished, because an impression must not be left on his mind that we aro at enmity with him; he must therefore never be nageed at, nbove all things. So a tew minutes should only be allowed to pass between a punishment and a caress to show him that we are his best triend.

In some cases the punishment should be inflicter while the disobedient act is being com. mitted, for example, while the horse's hind quarters are in the air when he is in the act of kicking; in which case he should be struck underneath with the whip. He learns then that he is whipped if he kicks. At other times he should never be whipped underneath, particularly between the thighs.

73. Punishment should be as rare as possible. The horse will soon understand that he is caressed whenever he obeys; bearing this in mind, the rare infliction of punishment is of great value. A previously ill-treated horse may behave badly; he should not be punished, but allowed to see that he will not be hurt, that we are his friend. Punishment in such a case, until he thoroughly understands us, will make him worse.

A horse must never be punished when in fear, because punishment increases tear, it can never diminish it. The horse regards anything associated with a punishment as the cause of the punishment; therefore he shies when he sees an object that he shied at betore and was punished, thinking that he will experience pain again by approaching the njject.
When a horse is doing his best he must never be punished, although it is not uncommon to 800 livery- and cab-drivers thrashing their horses when they are doing their best; this is enough to cause a horse to lose heart, because he might well associate the punishment with the work he is doing. So, when a baulking horse starts he must never be punished, or else he may think he is being punished for starting.

74. The horse's skin varies in thickness, so that certain parts teel pain more readily than other parts. The skin on his legs, for instance, is quite thick, in order to protect them while coing through thorn bushes. He is very sensitive inside the thighs, on the flanks, beneath the abdomen, and belind the shoulders.

Bearing in mind that punishment increases fear, it must be remembered that the existence of tear of punishment is responsible for our being able to make a horse obedient.

\section{Fear}

75. Fear in horses is contagious, and is very peculiar in its degree and causes. It will cause a horse to do very strange things. The horse is very susceptible to feer, which is inconvenient; although, as stated above, its existence is the secrel of our being able to master him. Fear causes a horse to be careful not to fall down, to be careful not to place his foot into a rabbit hole, not to go into puddles and so on, and therefore increases his usefulness and safety. Fear naturally causes a horse to understand the whip actions.

The horse being very prone to fear, it is better if he has never been ill-treated. Foar repeated increases in intensity, therefore at all times we must aim at preventing fear as much as possible. Ordinary horses are more dangerous when in fear than thoroughbred ones, but a very timid horse is most dangerous, because he may fall down or take his rider into great danger; such a horse is better dismounted and led. The presence of a rider upon a horse's back tends materially to diminish fear, especially if he knows his rider and has affection for him.

Fear is really a beliet of danger, and varies with the momentary state o: the horse's mind. Mares are generally more prone to fear. Defective sight, which is not uncommon, due to dark stables, causes much fear, especially when a horse is flrst brought out into the light. The horse shies at new objects because they frighten him. He fears noises, smells, and being touched suddenly. He should be able to see the object that he is afraid of, and for this reason blinkers olten increase fear.

76. A horse is more susceptible to fear when at speed; fear causes a horse often to run away, and when at speed the fear increases, hence it is so ciflleult lo stop the runaway horse. A run- 
away, when lie does stop and realises that he is abaildo:ied, feels great fear. All horses when in fear like company, and sell the voice of a master will cause nurli comfort. A horse when in fear should not be worked, and kind treatnent alone should be resorted to. Fear may be so great as to cause trenlbling, and sometimes a rider can feel the lieart pulsations from lis seat in the sadite when the liorse is in great fear. Horse dealeró who are up to almost auy trick in order to get a good price for a horse, frighten the horse in order to make him go well and show liimself of and perliaps forget any little pain causing lamelless.

Practically in all cases of fear there will be a preliminary sign given by the horse, which sign shoulit be letected by all good horsemen, so that they will know that the horse is becoming frightened.

77. The signs of fear are: intently looking or listening in a certain direction, slown by the horse holdiug his head high, ears pricked, and by his standing, as it were, upon his toes; moring his ears to and fro or bending lis head and neck in the direction of the object; shying from the object; stopying or reducing the pace, and, perhaps, rearing. An object advancing towards him in front might cause him to rear. Other signs are grunting, snorting, depressing the tail, raising the tail high, and, if intense, trembling.

Bofore we can prevent fear in a horse we must gain his confidence and then his obedience. Two young horses should not be driven togetler, because the fear of one increases that of the other. In the first place, the horse should be taught in an enclosed school, where his attention can bo held, then led around streets, and finally riditen. During the leading, the cavesson is used with the help of one or two assistants.

78. The means of preventing fear are: caressing the horse and placing oneself between it and the object causing the fear; patience; obedience : the company of another horse; and the use of voice-sounds. The presence of another horse is of great value in causing a frightened horse to folluw tl:rough a gate, to go into wuter, etc.

\section{Principles of Training}

79. I do not intend giving here in detail the methods of training the horse, but merely to give a few words on the principles that should be strictly adhered to in training this noble animal, more with the idea of saving him fres the terrible abuse to which he is generally subjected. In the past many wonderful horse-breakers, using the term in its 'ruest sense, have given performances before the public; these so-called horse-trainers have based their principles upon the idea of subduing their pupils by brute force, by exhaustion, and by fear. A horse that has been broken by being subaued will never be the same animal as one that has been educated and trained on modern liues. Their object was to break the horse's will and to overcome his physical power; these two qualifications are absolutely essential in the horse; but when these are not present the horse's value is incalculably decreased,

80. The principles of modern horse-training are to retain all the fine qualities that the horse possesses and to educate him, and to control, govern, direct and manage him by skill, knowledge, tact, patience and self-control. There are fow men in the wor!d who are competent to handle and educate a horse, because so few make any effort to know the horse as he should be known. A horse-tainer should know his own weak points, because any display of weakness of character will quickly be picked up by the equine pupil. He muit have perfict control over himself and have wonderful patience; he must rave pluck, and be quiet and gentle yet firm. Fie must also know l:ow to display his apparen; superiority of strength before the horses by not asking that horse to do anything that he cannot prevent him from reacting against. He must know just how to combat the horse's strength, without resorting to any cruelty. It must also be remembered that no two horses are alike, therefore it is foolish and brutal to punish one horse because he does not learn his work as quickly as another. Gentleness must always exist. Because we have the power of brutally ill-treating a horse, it is all the more necessary that we should take every precaution to educate him by humane methods only. Humane methods are really the only permanent and successful ones, because our principle is to gain confidence and obedience, to dissipate fear, and then to train the horse mentally and physically.

81. "Wild" horses require nuch kindnoss to commence with in order to gain love and respect and to lose fear. A very little slip while training a "wild" horse may cause loss of confldence. The whole secret of gaining success in training horses to any really permanent and advanced degree is to understand the horse's nature, to remember that he is not naturally vicious or wild. In training the so-called wild horse, i.e. one that has been born and bred away from human life, as on tie prairie, the above fact must be borne in mind all the more. It was not until Professors McGillivray and Skuthorp and a few others showed their wonderful methods to the public that horse-owners would believe that these horses could be trained by absolute kindness from the very first.

Rarey, Sample, Hyland, Leightwark and Galvayn, great as they were in their horse-break. ing methods, resorted to the principle of subduing the horse first of all; hence their success never reached the stage to which that of McGillivray and Skuthorp reached. These modern 
PLATE 9

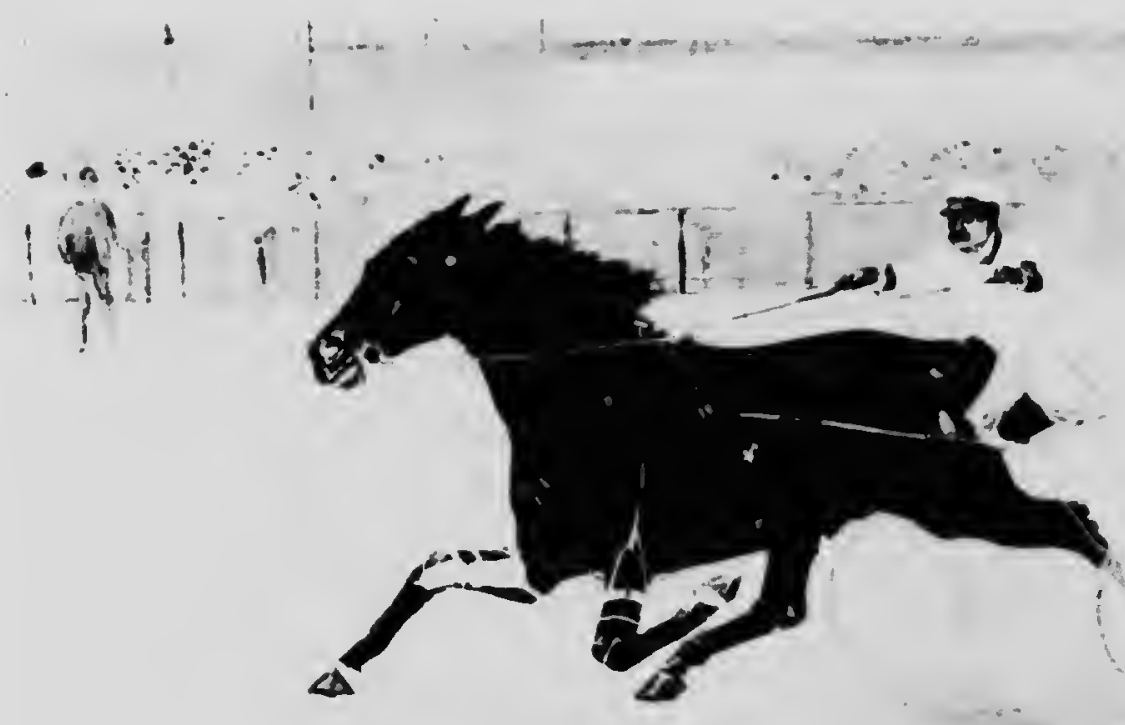

$P q a$

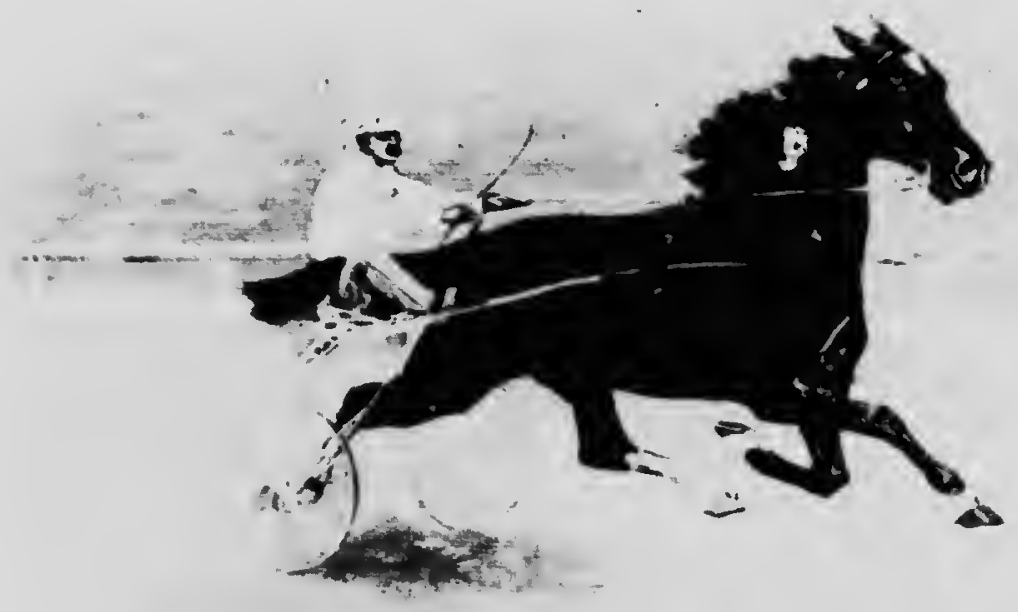

Pq

THE HARNESS HORSE

a, The Pacer. "Dan Paich," the Holder of the World's Record, I mile in I min. 56 secs. Copyright: Taber.Prang Ar: Co. Springfield, Mass. Courtesy: International Stock Fond Co., Minneapolis, Minn., the Owners of "Dan Patch." Panted by Ciean Smith. b. The Trotter. "Lou Dilton," At Speed. Panted by Gean Smith. Conpyright: Taher-Prang Art Co. 

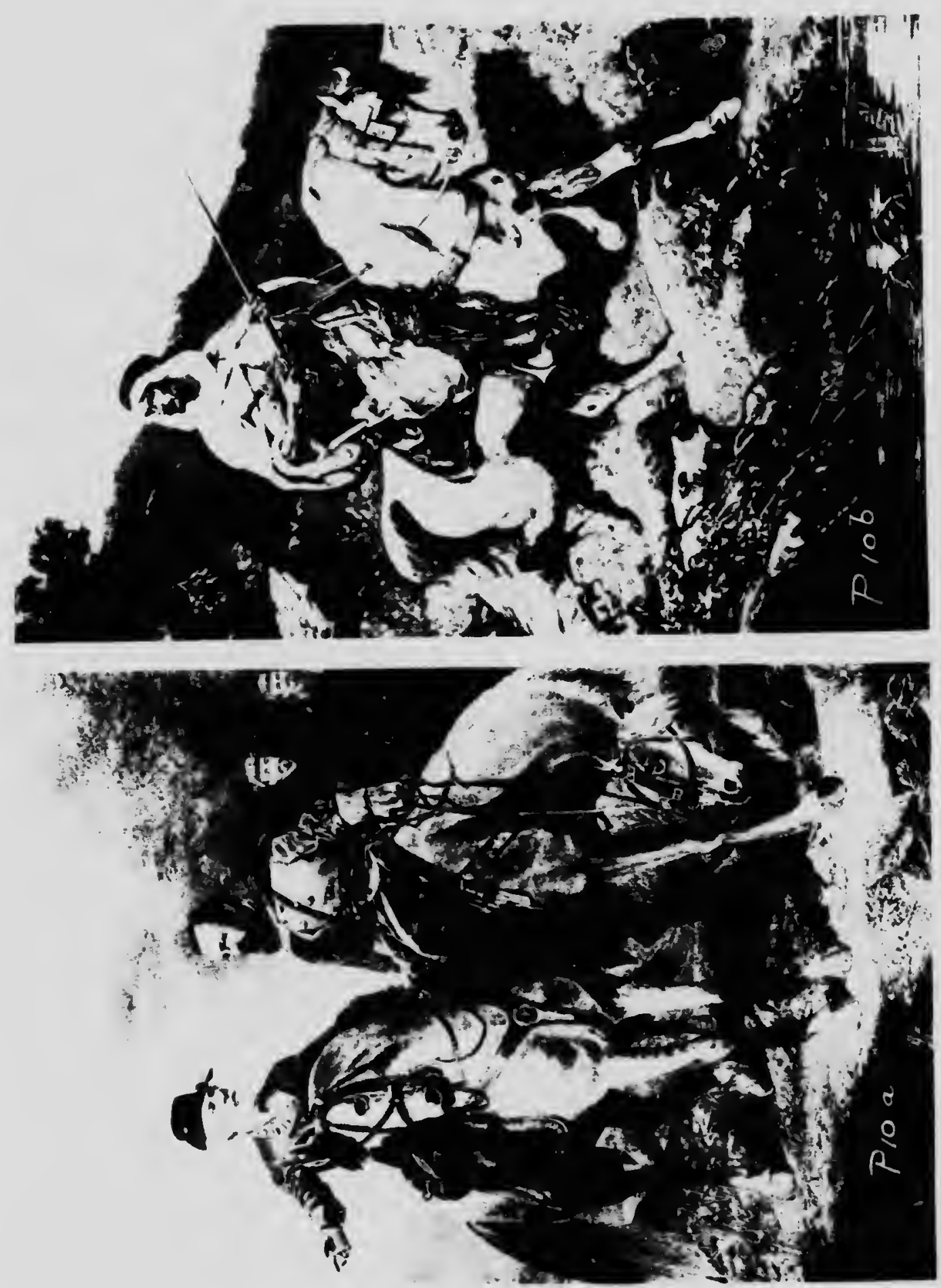
methods are now adopted by all successful horsetrainers who live in the parts where these "wild" horses still exist. Professor Beery, under whose valuable instruction I was for some time, has shown marvellous skill in the manner in which he has trained so-called vicious horses, basing his principles upon those of kindness from the first. (See story of Alexander the Great, Sec. 11.)

Unfortunately for the horse, many cruel liorse-breakers have shown apparent success in the past, and thus cruel methods have been followed by others. We should remember the old saying: "There is none so cruel as the coward who has attained success." It is to abolish this brutal method of horse-training that I have devoted part of this book to the humane training of our four-footed friends. Everyone who has had much experience with Western Canadian horses knows well how soon a subdued horse gives in when put to a test afterwards; and how the horse that has been trained by kindness will never give in until physically obliged to. Why is this? Because the former's heart has been once broken, and a horse's heart if once broken is always broken. Such a horse is quite a different animal from his brother that has been scientifically and humanely trained. These remarks do not so much apply to the better-bred horse, or to the horse born and bred amidst civilisation, although the principle of using gentleness from the first is seldom adopted by the avr-age horse-breaker.

82. While a horse is being trained he must be given good food and his rations must be in. creased. The old idea of keeping a horse quiet and free from reaction is wrong, it does not tend to assist in educating our horse ; we must please him and associate his training with nice things. A fill stomach tends to make a horse contented; i'. prevents him from always thinking about the next meal, and thus allows us to hold his attention. If the horse is high-spirited he must be exercised, unmounted, before the daily training is commenced.

The best method of exercising a horse is to lunge him with the cavesson and lunging-rein, using a lunging-whip to keep him in his place; the whip should be used as an indicator, and not as a means of punishment, for we must gain his love and confidence before we resort to any form of punishment. Little reactions at first should therefore be overlooked. Idleness is the root of all evil. Want of exercise causes an overstock of energy that irritates horses; this will :end to cause reactions, tend to cause him to wish to kick, buck, rear, bite, and eventually to convince him of his superiority over man. Thus it is of the utmost importance not to attempt to ask an untrained horse to be obedient if he is in high spirits.

83. The lunging-rein and cavesson are of the utmost use in teacling a horse, because with them we control the horse's head, which is the centre of his mechanism, and our object is to start at his head. It is also practically im. possible to react when being lunged around in a circle, because he cannot go out, he cannot stop or turn in, because he will be shown the whip; therefore he must go forward, and he soon learns his first lesson of obedience, and associates going forward with caresses whilst he associales reacticuns with the sight of the whip. With some horses that are not at all timid and that show a little obstinacy, it will be necessary to use the whip if they react while being lunged; merely showing the whip will probably have no effect. With such horses there is little risk of losing their love and confidence if we adopt the above methor. Want of exercise induces a horse to take more notice of things which cause a little fear, and thus we are unable to get his proper attention.

So we must gain the pur'l's attention and have his confluence and obedience before we can commence physically to train him. In asking him to do any act, associations of pleasure must immediately follow his obedience, and associstions of displeasure must immediately follow his disobedience. But before asking him to perform any act we must be quite sure that he is physically able to perform the act. Thus our whole system of training must be to develop, stage by stage, his various muscles, etc., and thus prepare his body so that he feels no inconvenience in performing these acts, because if he were to he would probably offer opposition. Absence of gradation causes opposition.

84. After the horse has done a good deed he should be rested as well as caressed, because it eases his mind. Lessons must be short and repeated to avoid any risks of tiring muscles and ligaments, and also of upsetting his temper. The school is of the greatest use in training young horses; but a horse that has been trained only in a school becomes cramped in his actions. Hence a young horse requires to be taken across country before his education can be considered complete. His freedom of action may also be hampered if his training is done at the halt instead of while moving forward. We inust at all cost prevent him from performing acts which are disobedient ; for instance, we must not ask him to stand still if we are not able to make him do so, nor must we ask him to lead by the halter if we are not able to make him follow us by means of encouragement from behind, and so on. In the former case if he had his own way he would discover that he could walk about wherever and whenever he liked; in the latter case, that he need not be led, and might even object to being tied up in his stall by the halter. So our method would be to use the cavesson and leading-reins, with an assistant, and a whip to 
cause him to follow. We must never tie him up with a rope that he can break. If he discovers that he cannot break the rope when he first tries he will probably not try again, unless he is tcrribly frightencd. Horses of different dispositions require modifications in thcir methods of training. A horse that has a good will and a good disposition is easy to train; whilst a timid horse will not have sufficient spirit. Horses vary so much in their dispositions that a great deal of common sense and tact is necessary for success in horse-training.

85. The early portion of a lorse's training should be done disniounted, because when the trainer is by the horse's head he is able to control him more readily, to dissipate fear and to caress him more easily. A timid horse should not be mounted nearly as soon as a horse of good will. The horse shoulıl always be aione, as the presence of other horses will distract his attention. $\mathrm{By}$ being on foot the trainer is able to prcient reactions which lie would be unable to prevent if he were in the saddle, providing the horse is untrained. As a horse is very susceptible to being excited by motion, the trainer, if in the saddle, may perhaps cause his mount to run away by feeling too heavily on the rein or leg and thus upsetting the horse. In teaching the horse to perform any act, our principle is to give rise to ideas we desire in him. We can do this by setting an example, e.g. asking him to follow another horse or a man, to jump after another horse, to follow another horse into the water, etc. The idea of doing these things is given to him and he does them. Or we may let him see objects, see our movements, or feel certain aids which will call forth these required ideas in him. At the same time we must prevent ideas arising in him that would cause him to do things against our wish; for instance, if he passes a motor-car and shies at it, "ie gets the idea that he need not pass close to it, and the next time he passes a car he tries to keep away from it.

In teaching a horse to perform actions we must give him indications that he can understand, things suited to give rise to the actions we require. He will thus associate certain indications or aids with certain movements, and in time, on account of marvellous memory, we shall have only to give the slightest inclication of what we require and he will perform the act. Thus there is a rreat difference between riding a trained horse and riding an llntrained horse; the former knows exactly what is required the moment we commence to apply an aid, however padly we may apply it; in fact, he probably knows what we arc going to ask by our subconscious preliminary movements. Thus we see a well-trained horse performing acts before an indifferent rider has really annlied any indications.
86. The same associations should always be used to indicate the same actions; and the horse's body must never be asked to do what it has not been prepared for. Hence the great importance of gradation in training a horse. The voice is of great use in training, and will be used in conjunction with aids and indications from the very beginning. The horse will thus associate different sounds with different movements. The same word (i.e. sound) is always used with the same action. The word "Whoa" is to be used when the horse is required to stop, and in time he can be made to stop upon this word being used. "Whoa" should never be used wheil quietening a horse or approaching him in his stall, as he is already standing still; but some other sound should be used. If he is already standing and he is told to stop, what can he be expected to do? With ordinary saddle and harness horses, after the horse is fairly well traincd, the voice is dispensed witl and aids and indications only used; this is also done with high-school horses, but with circus horses the voics is often used afterwards alone, and in this way the so-called "talking" horse is produced. As a matter of fact, the horse does not understand words, but only tones. A circus horse associates by long practice a certain sound with a certain action, and upon hearing this sound he performs the action because thereby he knows he will be caressed. The voice should always be used in a soothing manner when a horse is friglitened, and if the horse is very timid the rider should dismount and go to his head. The leading of another horse between the object that the horse is afraid of and himself is a good way to accustom him to the object; a man wlom he knows well and whom he is fond of will often serve the same purpose.

87. Music can be used to assist in training horses with wonderful effect. Horses love music as a rule, but some are afraid nintil they become used to it, as they fear it will cause them harm. Horses' ears are very acute, and they generally like soft music better than noisy drums. Horses are taught to trot, canter or gallop to various tunes, and upon hearing these tunes afterwards they will often break into the step suited for that particular tune. I remember the colonel of a cavalry regiment objecting to having any more remounts take part in musical rides, because whenever many of his horses heard the sounds of "Bonnie Dundee" thcy would break into a slow canter in spite of the riders' attempts to prevent them.

The horse must not be expected to do things that are against his nature. Thus, if he will not stand alone he must not be punished; no horse will stand still alone for any length of time. In teaching him to stand alone we should try for a quarter of an hour a day for scveral days, by having his head held by assistants with ropes 
attached to the cavesson; and later by replacing the rope with strong black thread which he will not be able to see very easily. The trainer will move farther and farther away, but will ad. vance and check him the moment he attempts to move. He sliould be caressed whenever he stands for a few minutes. Punishment should not be resorterl to until this training has been tried for a week and the horse still reacts.

88. Whatever we ask the horse to do we must first cause an idea to be produced in him by means of an aid or indication that will suggest this action; on performing the action we must caress the animal and thus show our approval of what he has done, and he will then associate our aid or indication with the act he performs. In giving a drench to a horse he must not be tied up by the head and have his throat pinched and face smacked, as is often done, because he will associate the sight of a drenching bottle with unpleasant things. If he is treated kindly and given a tit-bit afterwards he will like the sight of a drenching bottle and take the drench readily, knowing that something nice is to follow. The same principle is to be followed in picking up a horse's foot; if he is shouted at or kicked because he will not readily lift the foot, or because he will not keep it still, he will be worse next time. He will associate any lift of his foot witl the bad treatment, and naturally object to having it lifted. Had he been spoken to quietly in the first place he would probably not object to lift his foot. I find by this method that a horse of ordinary intelligence can be taught in two or three days to pick up all his four feet in turn by merely rubbing the hand lightly down the near fore; his memory lelling him to raise them in the right order. I remember one horse that I had trained refusing to pick up one of her hind feet to a fresh groom until he had attended to the fore feet.

89. It is a good thing to use soft padded bandages on the forelegs of the young horse in order to save the flexor tendons and to minimise the risk of producing splints. After the horse has been given the same indications day after day and performed respectively the same actions he becomes almost a machine, which requires only the slightest indication to start it in performing these actions. Thus in asking him to canter on a slight circle in his earlier training we feel both reins, the outer the stronger, and close both legs, shifting our weight slightly inwards; stronger feeling is made with the outer leg in order to make him strike off with the inner leg. It may be necessary to turn his head momentarily outwards to make him strike off correctly, immediately afterwards turning it in the direction he is going. He thus learns that he is to lead with the inward leg. After a while, however, we can make him do this by merely shifting our weight and closing our legs. If the lorse is taught various acts one after the other, always in the same order, he will remember them, and upon being given the indication for the first act he will go through the whole of the performance. It is upon this principle that the circus horse performs his acts.

If a lorse refuses to take the bit into his mouth, his mouth must be partly opened by placing one's fingers in between the bars of the mouth; and he must be caressed upon opening his mouth. On no account must the bit be forced into his mouth, because he will associate being bitted with pain-but many grooms cannot understand this. I have spent many weeks in making a bit-shy horse take the bit nicely, but it is always worth the pains taken. A horse will open his mouth for the bit as willingly as a child for sweetmeats once he has learnt that he will not be hurt.

In catching a loose horse, chasing after him will only excite him to motion, so we must remain quiet and approach him only when his attention is attracted elsewhere, remaining still directly his attention is directed on us. If a horse is running away he should not be cliased, but be cut off if possible by making a detour around and thus getting ahead of lim. This, as a rule, cannot be done on foot.

80. A horse which has become bad through ill-treatment requires to be very carefully handled for a long time; he must never be teased. Teasing ruins any horse. A horse that has once been spoilt will be suspicious of further ill-treatment; he must be shown that no one will harm him and that we are his friend. Such a horse will have to be very sparingly punished until his affection and confidence are gained. Some writers say that it is not worth while training a bad horse; they say that we do not take criminals and educate them into high positions. True, but this is scarcely analogous to the horse. A bad liorse, unless he has been ill-used for a long time, can be made into a good one if taken over by a competent horse-trainer.

It has often been stated that the most successful horse-trainers have a hypnotic influence over their subjects. I do not believe this, nor that they have a mesmeric effect over horses. I do believe, though, that the most successful horse-trainers fascinate their pupils very considerably; the horse is not able to concentrate its mind sufficiently to be mesmerised or hypnotised. I was fortunate in having a long conversation on this subject with the hypnotist, Professor McEwen. He told me that he had experimented on horses without result.

\section{Circus Horses}

91. A few words on the general princip::3 adopted in training circus horses and on the cruel methods sometimes used to make stage 
horses perform will be of use here. A few examples will suffice to show the cruel methods that are sometimes adopted. Any fool can make a horse do certain acts by the means mentioued bolow, so there is no credit due either to the man or to the horse. In many cases the man deserves to be treated in a similar manner. My motto in training horses, or in cuing anything else with them, is "Never do to your horse what you would not have done to yourself." If all horse-owners went on these lines good horsemen would be more common. These performances, which require no cleverness on the part of the trainer, and no study by the horse, but which astonish and amuse the public, because they are ignorant of the means employed, a re not so commonly witnessed as they have been in the past; this is due to the work of the S.P.C.A. and other humane organisations and to the police; it is also due to the horse being better understood by certain trainers, who are therefore able to educate the horse and thus make him perform the same things in an intelligent manner without ill-using him.

The cruel methods adopted are such as these: A noble rider comes home in distress at meeting misfortune, and his horse is supposed to share his master's grief. When offered oats he puts his muzzle into the basket, but withdraws it with a negative shake of the head, much to the astonishment of the audience, who are not aware that the poor horse has run his muzzle against a number of pins in the bottom of the basket.

A horse who loses his master in one of the acts refuses to eat during the rest of the performance. He is supposed to be mourning, but in reality the food offered him is soaked in a drug that possesses a disagreeable odour. Similar means are used by the mountebank to cause his horse to go through its daily performance. Too often the mountebank is a charlatan, because far greater skill than that which he possesses is required to train a horse. He usually poses as superior to school riders and has the gift of talking much; he thus makes the audience believe what he says. Ho is clever at one thing, and that is in deceiving the public.

92. We will now consider briefly the properly educaled performing horse, known as "the horse at liberty." In the past, during many centuries, a certain number of horse-trainers existed who were able to educate the horse to an advanced degree, and until about two centuries ago these trainers were considered as magicians or sorcerers. Stories are told of these trainers being burnt alive or otherwise punished, on account of the public becoming afraid of their apparent power over the horse.

A Neapolitan, named Pietro, had a little horse called Mauraco, whose naturally good disposition he turned to account; this little animal would perform some very clever tricks that his master taught him. After some years when passing through Arles he caused such astonishment that he was taken for a sorcerer. Pietro and Mauraco were both burnt alive in the public market-place. A liorse mentioned by Shakespeare, called Morocco, that was owned by a trainer named Bankes, was also burnt because of superstition. The principles of training laid down in the earlier portion of this chapter should be carefully adhered to in training a horse for public performances, i.e. to perform at liberty in the circus and, finally, perhaps, on the open stage. In teaching a horse the numerous little tricks we must watch him very carefully to see whether he really understands our wishes, whether he is becoming wearied, and whether he is physically able to do what we ask of him. When he refuses to obey, our difficulty lies in being able to discover whether he does so from obstinacy, from ill-temper, or from ignorance of our wishes; in the last case, of course, it would be our own fault. An enclosed circus is the best place in which to teach a "horse at liberty"; the man is near to the horse, and can easily correct his faults. The horse should have had several weeks with the cavesson previous to this, in order that the trainer may gain his confidence and love, and to teach the horse obedience. Once the horse has become thus thoroughly obedient he can be taken into the circus ring. He will now be free of the cavesson and lunge, but the circus boards will keep him in the circle; the radius of this circle should be the same length as the lunging-rein. We keep him near the boards by the same means as we kept the lunging-rein taut.

Later he will be taught to turn in and to come up to the trainer; at first the lunging-rein and the voice will be used for this, which can afterwards be replaced by a thick black thread that he will not easily be able to see. He will be given a til-bit upon coming up to the trainer. Thus lie will associate our voice-sound with turning in towards us and receiving a piece of sugar. After he has been taught a few little tricks like the above, he may be made to trot, walk and canter with a roller and side-reins on. Each time he is made to trot, the word "Trot" must be said slowly and the whip raised to a certain position. Another sound and position of the whin will be used when he is made to canter. The whip will be held in the hand away from the direction in which the horse is moving, so that he cannot see it very readily. He will thus associate these sounds and movements of the trainer's hand with the various actions, and after a while will perform these acts merely upon the sound being used with the movement, and later by the movement alone, or by the sound alone. He can thus be taught many other acts, such as halting, turning right-about, left-about, elc. Great patience is required and incessant kind 

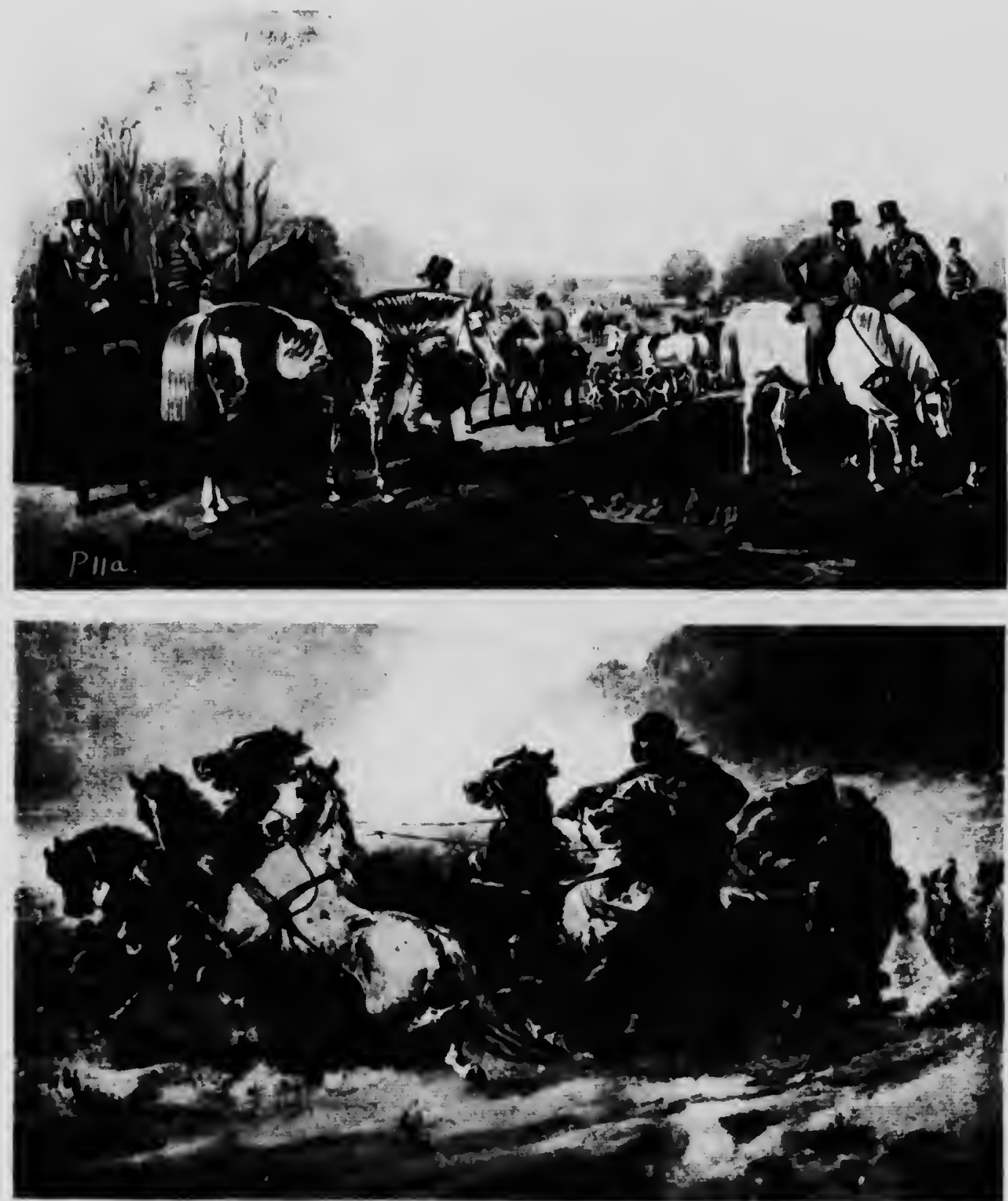

a, "The Mleet." The English Hunting Field in the Early Victorian Era. b. "The Imperial Courier," by Schreyer 
PI.ATE 12
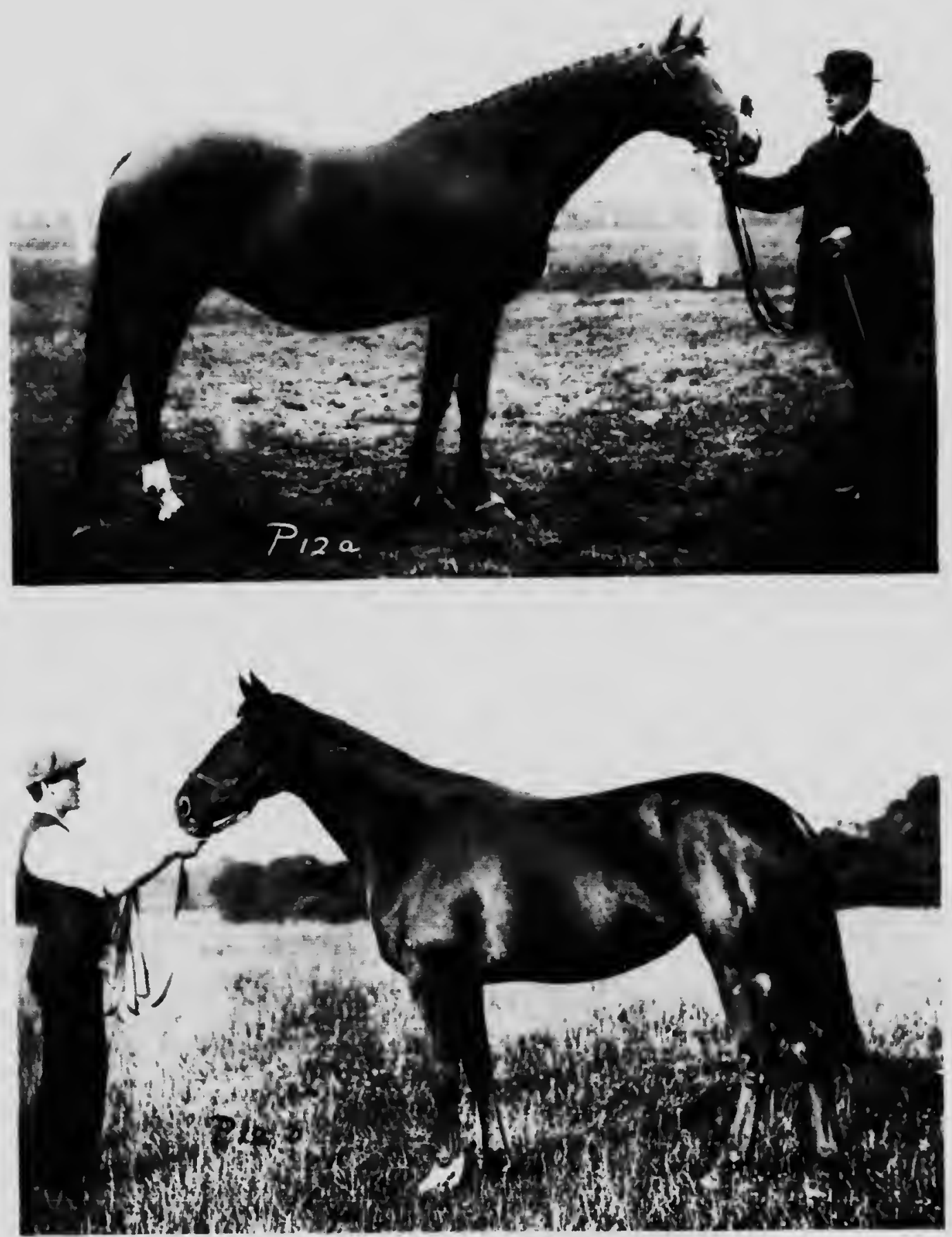

a, Hunter Mare "Partridge 11." First, Royal Show, 1912, b, "Pretty Polly," the Famous Winner ol the Oaks, etc Photor. C. H Parsons 
treatment. If the horse has been made obedient in the first place there will be little fear of reaction, so there will be little need of punishment; a little may have to be used at times when he becomes lazy or disinterested, to remind him who is master. But he must never be nagged at, and, as we have said, should always be caressed a short time after the punishment.

83. In the earlier stages of all these performances the horse's education is assisted by the trainer going through the same action with his own body and limbs; e.g. when the horse is asked to walk the trainer should walk, when asked to trot the trainer should run, when asked to turn about the trainer should do the same, and so on. The horse always watches the movements of his trainer very intently.

It is absolutely necessary that the circus should be enclosed to prevent the horse's attention being distracted, as his whole attention must be concentrated upon his trainer. He will thus notice slight movements made by the trainer; therefore the trainer must be most careful not to make movements that the horse may read as signals, unless they are meant as such. The horse's eye is so keen in observing his master's signals that, when his training is well advanced, the trainer can signal to the horse to perform all kinds of acts by signals that the audience will be unable to detect. It must be remembered that careful gradation is necessary in training the mind as well as the body. A lesson should never be allowed to weary a horse and make him thus dislike his work. If he is too fresh at the beginning of the lesson, he must be exercised before the losson is continued. It is very easy to spoil a horse by asking him to obey one's signals when he is too fresh.

94. The principle of training a horse to hold, and afterwards to pick up, a handkerchief is simple: A white handkerchief soaked in sugar solution, or whatever the horse is fond of, is offered to him. A finger is passed into his mouth to cause him to open it and the handkerchief is placed inside; the thumb and forefinger are then used to keep the lips closed; should he drop it he will be spoken to severely and made to take hold of it again. Upon tasting the sugar the horse will probably like to keep hold of the handkerchiel; every time the horse drops the handkerchief he will be spoken to severely, but caressed whenever he holds it for any length of time. While teaching these actions words of command will also be used, so that eventually the horse will take hold of the handkerchief upon being told to. Similarly signs will be given. The tricks which can be taught to a horse upon these principles, i.e. giving signals with the body, hands or whip, and at the same time uttering commands, are very many, and are particularly pleasing to the public, because they think the horse understands the words. The horse $\mathbf{E}$ pays more attention to the trainer's movements than he does to the voice. Thus a horse is taught to pick up blocks of wood, to stop, to paw the ground, to nod his head affrmatively or negatively, to count, etc., upon certain signals from his trainer. In this way he answers "yes" or "no" to questions, counts the time by pawing the ground, stops at a certain letter block and picks it up, thus spelling words, etc.

95. After a while the horse will learn to carry on the various actions consecutively in the right order, because he will every day be asked to perform them in the same order. A horse that will stop at a given signal can thus be told to point out the lady in the black hat in the front row, and so on. The best method to teach the horse to stop as above is to use a black strong thread attached to a bridle, and when it is desired to stop him to pull on to the thread, to say "Whoa!" and to make a certain slight movement with the arm and whip, say, towards his forelegs; later the thread will be dispensed with, and then the voice, the act being performed merely by the signal. A thread will also be used in leading the horse to a row of letters when teaching him to spell. Whenever he obeys he will be caressed and shown that he has done right; he will thus associate the act with the caresses and tit-bils.

86. In days of old it was thought that peculiar-smelling oil had a peculiar effect upon horses, and that horse-trainers could do wonderful things with horses by the use of these strongsmelling oils. There is no doubt that good rosults were never obtained from the use of these oils.

The things we see circus horses perform appear marvellous to those who do not understand how they are done; and circus-horse owners have kept up this idea of marvellous power by keeping their methods secret. I have gone into the methods of training circus horses rather fully in order to show that a horse can be educated only by kindness; that the methods adopted by all modern horse-trainers are humane ones, punishment being resorted to only when wilful disobedience is quite evident. The training of the horse is very like that of a child, except that, as stated before, the uneducated horse has very little intelligence, but an ample amount of instinct, whilst the uneducated child has very little instinct but a certain amount of intelligence.

97. Before leaving this subject I must remind animal lovers that the means adopted in training other performing animals are often very cruel, and I have been surprised and disgusted to see that some dogs have been trained by cruel methods. Such dogs, however, perform in a different manner from those trained by kind methods, and observant animal trainers can easily detect these animals on the stage. The 
inferior trainer uses at limes cruel methods that the good trainer has no need to use. With the horse, no cruel methods will bring results worth speaking of; punishment in the right place, given while the trainer's temper is under perfect control, is not cruelty. The trainer on the stage who adopts cruel methods, or who has animals which sliow signs of cruel treatment, gives hintself away as being an incapable man in his profession. (SeC Secs, 2 and 3.)

\section{Cruelty of Horse Dealers}

88. This subject is discussed in Chapters $\mathrm{X} 111$. and XV. Lntil our laws are very much improved, so long will horse dealers continue to torture and drut horses in order to deceive the public and to beneflt their own pockets. I am most thankful to say that many of these wretched human parasites liave had their businesses ruined through the advent of the motor-they may be trying their tricks upon the phlic with motor-cars, but even if they are, they will not be torturing dumb animals which have no defence.
Some horse dealers will do almost anything to a horse to prevent him from showing signs of lamelless, or from showing bad tricks, or to make him appear high-spirited. Drugs are used to case pain and to make a horse feel fresh; over-fetding on soft feed and want of exercise are resurted to to keep the horse fat and to make him feel fresh. Nirves are cut to hide lanieness, and, worst of all, a sound foot may be injured in order to make the horse go apparently sound on the unsound foot, i.e. by having both legs injured he cannot lavour one leg.

I think the greatest enemy that the hors' has is the horse dealer. Wlat horse dealer will not mutilate the horse to any degree merely to suit a prevailing fashion or the foolish fancies of an ignoramus who wishes to buy a horse? All horst dealers' stables should be open to public inspection by the police and humane socicties at all times; so slioull most large stables. For the horse's sake, the quicker the motor takes his place for commercial and showy purposes the belter.

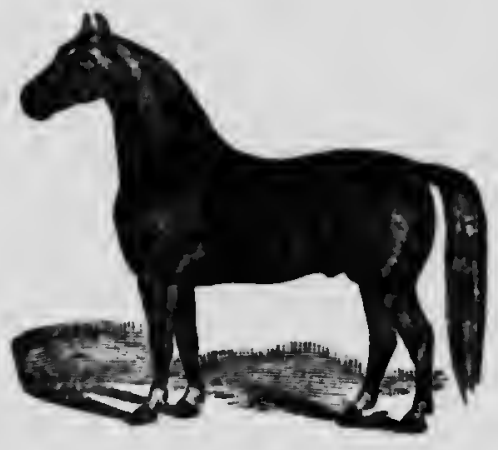




\section{CHAPTER IV}

\section{FOODS AND FEEDING-EXERCISE AND TRANSPORT}

99. EvEny owner of a horse has quite a responsibility upon his shoulders-that of seeing that the animal is properly fed and cared for. The modern law has a considerable check upon owners of horses, but very often, through want of knowledge rather than through cruelty, the horse that works so hard for us is put to much inconvenience and even suffering. For this reason I wish to point out to the ordinary horse owner the ways of feeding and caring for the horse in the stable and on the road. The crrrect regulation of the feeding of the horse is far more difficult to control than is commonly thought. As a rule the feed is thrown into the horse's manger day after day without any consideration being taken as to whether the horse is being over-fed, under-fed, or wrongly fed. The horse was created for motion, and he requires it; and the amount of motion he gets will proportionately affect the amount of food he should receive as well as the kind of food.

100. After good food and rest, a deficiency of exercise brings the horse to a state of nervousness, a state which varies according to his disposition. This nervousness, which is usually shown in the form of excitement, is due to excessive exuberance of spirits. This excitability may even be intense when the horse is lame. A lame horse, who has been fed well while standing idle for a week, if taken out for gentle exercise, may apparently forget his lameness and prance about, causirig himself much injury. Hence, a horse must be given various quantities and qualities of food according to the work he does. During the sixteenth century the common way of causing fractious horses to become subdued was to slarve them. We read that Henry VII. ordered a horse he was to ride in a public procession to be starved for twenty-four hours previously, because, as he was a bad horseman, he was afraid to ride the horse otherwise. Of course, no civilised person would think of doing this now; soft food and hay alune would be sufficient to produce the required effect.

101. All horses in one stable should be fed at the same time, because unfed horses are liable to become restive and to learn objectionable habits, as pawing, biting at the manger, etc. The horse should be fed at regular hours, if possible. Irregular feeding causes the horse to look unfit. When anyone approaches the horse in its stall he should speak to the horse, or otherwise a nervous animal is liable to kick upon being suddenly surprised. He should say, "Steady, boy!" or something similar to this, but not "Whoa!" because the horse is already standing still. On no account must the horse be shouled at, unless he is preparing to kick, and then a sharp word will generally stop him. In using the pitchfork in the stall, care should be taken to let the horse know what is being done, else, on suddenly seeing the fork under its hind legs, it may kick out, and perhaps injuro itself on the prongs.

102. I strongly object to overhead mangers, because with these the dust and seeds get into the horse's eyes, mane and ears. It is far safer to put the hay into the manger with the hands, and not with the fork ; if the fork is used, great care must be exercised. Care should be taken never to throw anything up in front of the horse's head-as one's hand, for example. Grooms should immediately report to their master should they accidentally injure their horses-by pricking them with a fork, for instance. By hiding such things serious trouble may result, instances of which are not uncommon. If, however, an accident is reported at once, nothing serious will ensue, and the master will be able to trust his groom in the future. It is dishonest to hide anything like this, and a dishonest man is not fit to look after a horse. Laziness is responsible for a great number of neglected horses; the common excuse, "It has al ways been done," should never be accepted. A good horsemaster is one who would not have done to his horse what he would not have dore to himself.

\section{The Digeative Organs}

108. Before entering into the subject of what is the best food and what are the best methods of using the food, we will briefly consider what the animal frame is composed of, what foods are composed of, and the manner in which the animal system obtains its nourishment from these foodstufts.

Health is the ordinary condition of the body, 
i.e. the body with all its organs working normally-a very rare state of affairs. Disense i.s an abnormal state. The horse in its wild state is lesa liable to disease than the one that is brought into unuatural surroundings ; liculw, it is llecessary for us to allow the horse to live $I 1$ as natural a state as possible. Of course, befort the horse was domesticatid he was the victim of disease, and Nature's law always has been "the survival of the fittest." In zoology we learu that this law exists in every state of animal life. Nature has no pity on the weakling.

A horse, on account of its love of company, genirally keeps better if in a stable with other horses.

104. The animal borly consists of water. nitrorenous natter, carbo-liydrates, fat, and certain acids and minetil matter. These comvounds are formel from various chemical clentents, the commonest of which are oxygen, hydrogen, nitrogen, carbon, calcium, phos. phort" sodium, potassium and sulphur; other less common chemicals found in the animal body are chlorine, silicon, iron, magnesium, iodine, lithium, fluorine, and occasionally cupper, manganese and lead. Watrr forms about thrce. fifths of the entire weight of the animal body. This varies under different conditions and decreases as age increases. The mineral sub. stances, which are formed of salts and acids, consist of about one-twentieth of the weight of the body, and are chiefly found in the bones; a little is found in the muscles and blood. The water, salts and inorganic acids (as hydrochloric) are known as inorganic substances. The remainder are known as organic, and are divided iuto nitrogenous, which consist of protein, albuminoids and simple nitrogenous bodies; ami non-nitrogenous, which consist of fats, carbo-hydrates and simple organic bodies, as acids, lactic acid being the commonest.

The most important organic substances are protein, carbo-hydrates and lat. Now, the whole animal system (which includes every living creature in the animal kingdom) is composed of minute cells. These cells vary approximately in size from $1-300$ th to $1-3,000$ th of an inch in diameter. The cell consists of protoplasm, a nucless and a centrosoine. Animal matter grows by the continned duplication of cells, i.e. each cell splits into two, and then each of these grows to the orixinal sizc of the cell before it is split, and so on. The centrosome is the portion of the cell that is responsible for this dividing. The nucleus controls the division and also the supply of food to the cell. The protoplasm forms the greater part of the cell, and consists of protein (or proteid) and water. Thus we see that protein is the most important substance in the animal body; none of the phenomena of life occurs without its presence. Protein is a very complex material, consisting of carlwn, liyilrue, $n$, ingen, nitrogen, sulphur, phosphorus, ste thers are several kinds of protelu. which varz consiuerably in their com. position. Plants are made of cells which aro very similar to the animal cell. (See Chapter Xill.)

In ordec to mantaiu vital existence in the aninal bolly we nust keep the cells alive, and this is done by supplying them with fomd this food is the blood. The blood and lymph collect the good portions of foud lying in the intestines, this heing dune by uprocess known as osmosis, i.c. the tement passing directly through the cells of the intestunes iuto the blood and ly mph vessels. This foal is carried all over the sysw. Impurities are again collected by the blood from the system and deposited in the kilneys, which aro flters. Some of the food carried by the blood is left in the liver in the form of glycogen. which is given out again whenever the bodt requires extra nourighment.

105. We must ruw consider what process the food that the hors eats goes through from the tine it enters the mouth until the time it lies in the intestines เพwatiug absorption into the blood. The alimensary canal consists of a long tubc of musc!es, lined with mucous membrane, extending from the lips to the extremity. It consists of the mouth, pharynx, cesophagus (guliet), stomach. small intestines, cacum (three feet), large intestine or colon (twelve feet), floating colon (ten feet), and rectum (two f(ct). The small intestines consist of the duodenum (two feet), jejunum (thirty feet), and ileum (forty feet). Various glands pour juices into this canal that digest the food. These glands are partly large olles, as the salivary fiands, liver and paucreas, and partly small ones, as those situated in the walls of the stomach and intestines. The large ones secrete ptyalin and other salivary juices, bile, pancreatin, etc., whilst the small ones secrete mucus, hydrochloric acid, pepsin, elc. Food, on being taken into the munth by the lorse (known as prehension), which he does by means of his lips, is passed on by the tongue, and masticated by the teeth. During the process of mastication the fluid from the sub-maxillary glands causes a chemical change to take place in the composition of the food, whilst the fluid from the parotid gland (which is affected in strangles, or mumps) inoistens the food. All this is necessary before the food is swallowed. The chief chemical change is the formation of sugars from the starches. Hence the importance of a thorough inspection of the horse's teeth every six months to ensure perfect masticalion. (See Chapter IX.) The process of mixing the food with the saliva is known as insalivation. Next comes deglutition (swallowing). The gullet is kept oiled by the mucous glands, which allow the food to pass down easily. The food is then mixed with the 
PI. ATI: 1.3
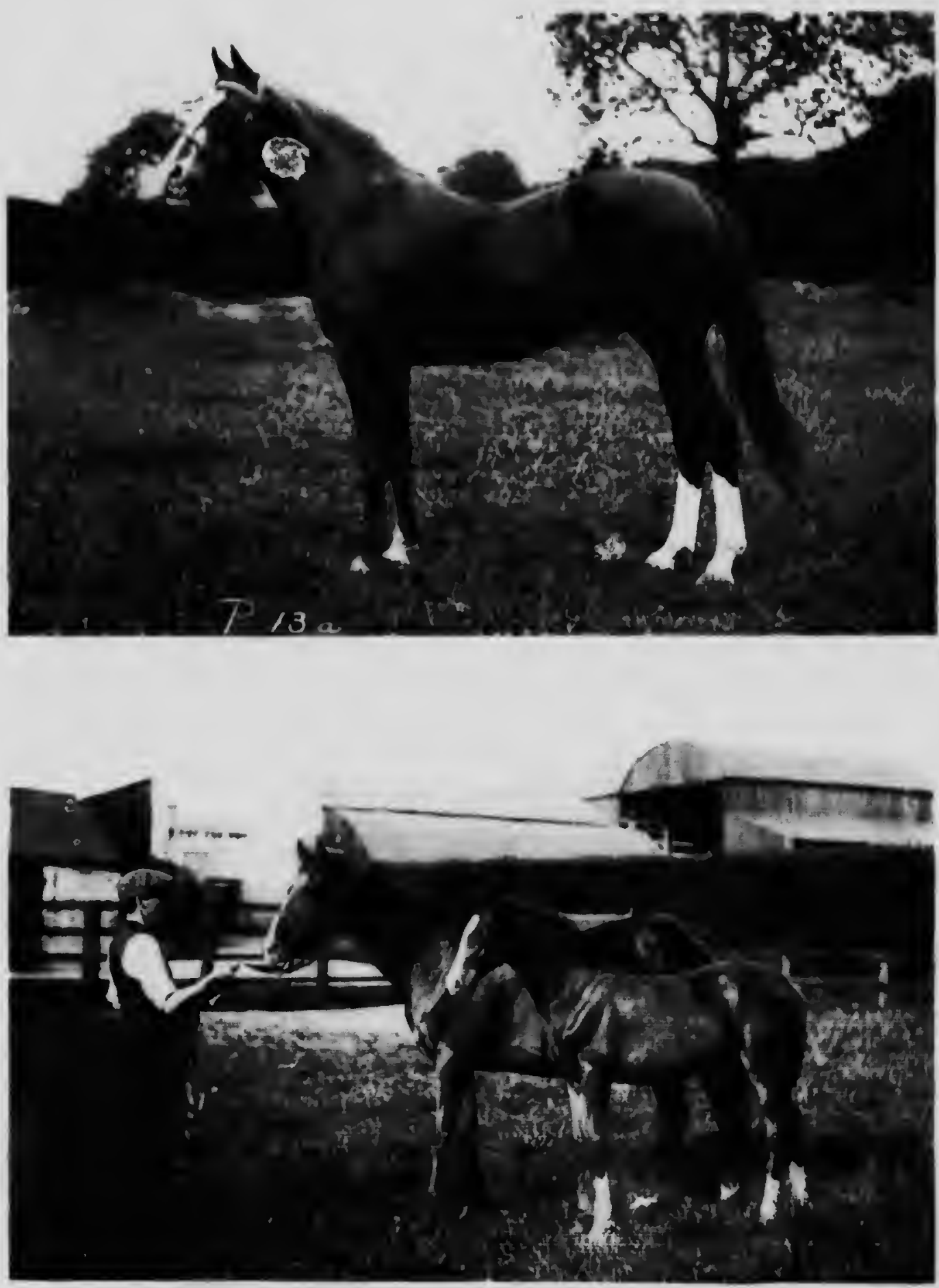

PRETTY POLLY'S PARENTS

a. "Ciallinule," Sire. b, "Admiration" (and Fnal). Dam. Photos: G. H. Parsons. Alsager. Cheshire 
PI.ATE: It
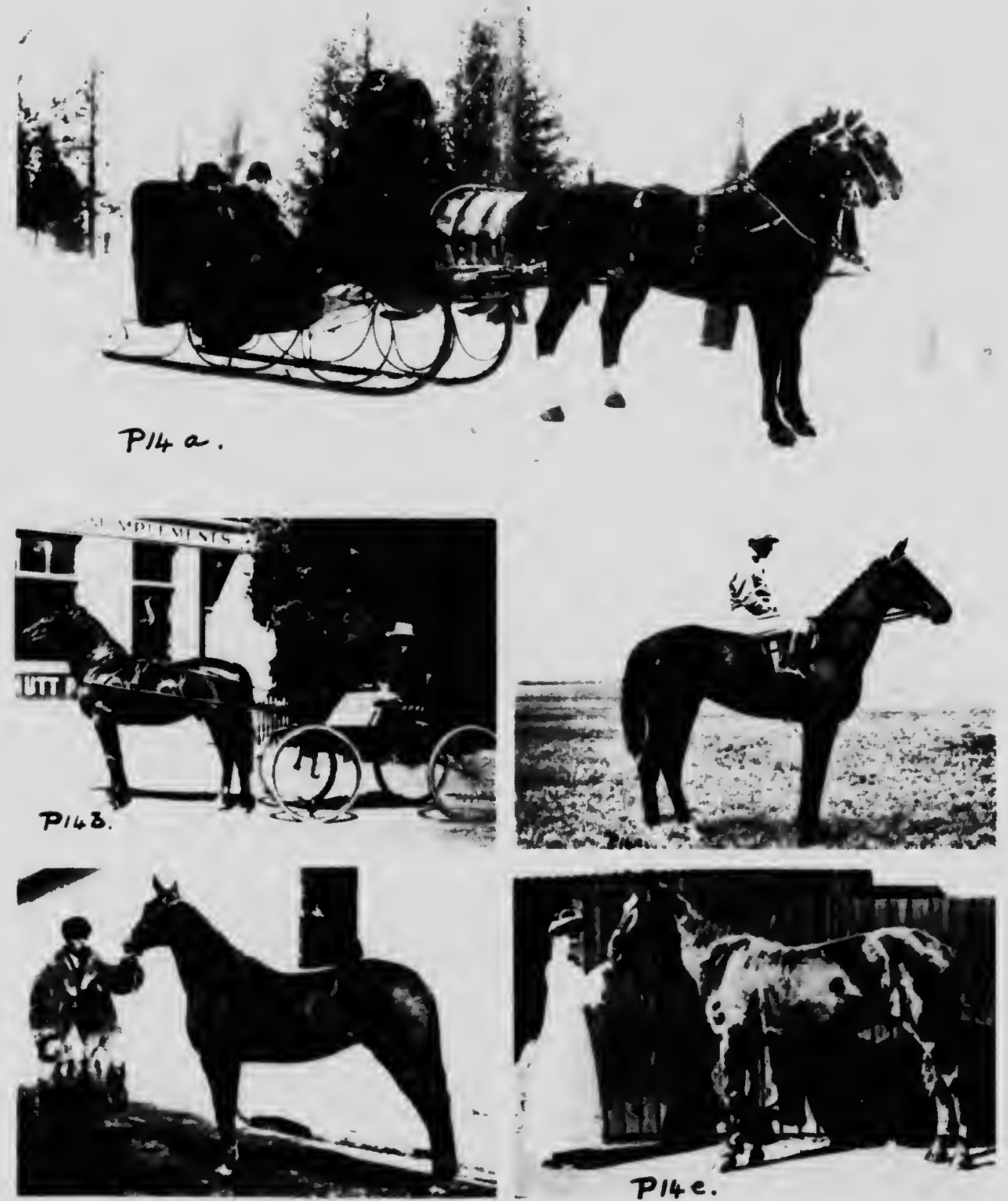

Pl4e.

a. HR.it. the Dute of Comnaught (Covernor.General al Canadal in the Cirounds ol Rudeau Hall. Orawa.

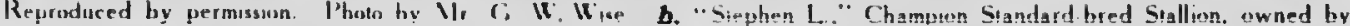

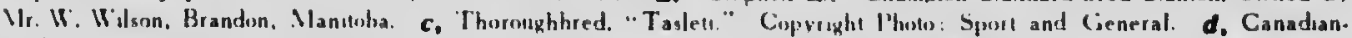
bred Buggy Horse. e, F.nglish Carrage Ilorse. Cuurlesy: Res. (i. Perkes. L.mpstield. Surrey. I'hutus, b. d, e, by the Suthos 
gastric juices in the stomach, forming chyme (known as chymification). Then it is passed on to the small intestines, where it is mixed with the intestinal juices, forming chyle (known as chylification). Then absorption takes place, and, finally, we arrive at the defacation of the unabsorbed portions of the food.

\section{Composition of Food}

108. A healthy and suitable food must possess the following properties: (1) The proper amount and proportion of the various proximate principles; (2) those adapted to climate, age of animal, and work done by him: (3) the proximate principles must be contained in a digestible form. For instance, beans and peas contain a higher percentage of protein than meat, but are not so suitable for human use, as they are less digestible, much passing of unused. The nutritive value of a diet depends chiefly upon the amount of carbon and nitrogen that it contains.

During exercise an enormous amount of carbon is secreted by the lungs in the form of carbon dioxide; a certain portion of nitrogen is also secreted in the form of urea in the urine. Oth - impurities are secreted by the perspiratory glands of the skin. It has been found that the carbon secreted in one day is ten times greater th. ' the nitrogen, therefore we must feed the ai al in these proportions. Protein contains three and a half times as much carbon as nitrogen, so the extra carbon required will be derived from the fats and carbo-hydrates. As a rule, vegetable food contains an excess of carbohydrates (as sugar and starch).

107. With human tood, cooking serves very many important purposes, so with horses cooking some of the food has its advantages. Cooking vegetable foods destroys parasites and breaks up the starch grains, bursting the cellulose, and allowing the digestive juices to come in contact more readily with the granulose and thus form the sugars. Vegetable foodstuffs contain water, nitrogenous matter, soluble carbo-hydrates, fat, wood flbre and ash.

The various elements of the different foods are classed as follows: flesh-making, fat-heatmaking (starch, sugar, and fat), bone-making. wood fibre, and water.

The chief soluble carbo-hydrates consist of ordinary starch $\left(\mathrm{C}_{6} \mathrm{H}_{2}, \mathrm{O}_{8}\right)$, grape sugar $\left(\mathrm{C}_{6} \mathrm{H}_{1}, \mathrm{O}_{6}\right)$, and cane sugar $\left(\mathrm{C}_{12} \mathrm{H}_{22} \mathrm{O}_{11}\right)$. When saliva is mixed with starch, as already stated, sugar is formed; the chemical reaction is:

$$
\begin{aligned}
& \text { Starch }+ \text { Soliva }=\text { Grape sugar } \\
& \mathrm{C}_{4} \mathrm{H}_{10} \mathrm{O}_{5}+\mathrm{H}_{2} \mathrm{O}=\mathrm{C}_{4} \mathrm{H}_{18} \mathrm{O}_{6}
\end{aligned}
$$

The saliva gives up its water and causes it to combine with the starch.
The following table gives the percentage composition of the grains, roots, hay and grasses

\begin{tabular}{|c|c|c|c|c|c|c|}
\hline & \multirow{2}{*}{ 赵 } & \multicolumn{2}{|c|}{$\begin{array}{l}\text { Fal-heat- } \\
\text { producing }\end{array}$} & \multirow{2}{*}{ 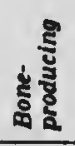 } & \multirow{2}{*}{ 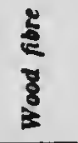 } & \multirow{2}{*}{$\begin{array}{l}\text { है } \\
\text { है }\end{array}$} \\
\hline & & $\begin{array}{c}\text { Starch } \\
\text { \& Sugar }\end{array}$ & Fat & & & \\
\hline Oats & $11 \cdot 3$ & $57 \cdot 3$ & $5 \cdot 4$ & $3 \cdot 0$ & $10 \cdot 0$ & $13 \cdot 0$ \\
\hline Maize & $10 \cdot 3$ & $70 \cdot 4$ & $5 \cdot 0$ & 1.5 & $2 \cdot 2$ & $10 \cdot 6$ \\
\hline Barley & $10 \cdot 6$ & $65 \cdot 5$ & $2 \cdot 1$ & $2 \cdot 5$ & $5 \cdot 0$ & $14 \cdot 3$ \\
\hline Rye & 11.5 & 69.5 & $1 \cdot 7$ & $2 \cdot 0$ & 1.9 & $13 \cdot 4$ \\
\hline Wheat & 11.7 & $69 \cdot 3$ & $2 \cdot 0$ & 1.8 & 1.8 & 13.4 \\
\hline Beans & $25 \cdot 4$ & $48 \cdot 5$ & 1.5 & $3 \cdot 2$ & $7 \cdot 1$ & $14 \cdot 3$ \\
\hline Peas & $22 \cdot 5$ & $53 \cdot 7$ & 1.6 & $2 \cdot 8$ & 5.4 & $14 \cdot 0$ \\
\hline Linseed & $20 \cdot 5$ & $19 \cdot 6$ & $37 \cdot 0$ & $3 \cdot 4$ & $7 \cdot 2$ & $12 \cdot 3$ \\
\hline Bran & $14 \cdot 1$ & $56 \cdot 0$ & $3 \cdot 7$ & $5 \cdot 8$ & $7 \cdot 2$ & $13 \cdot 2$ \\
\hline Carrots & $1 \cdot 2$ & $9 \cdot 3$ & 0.2 & 1.0 & $1 \cdot 3$ & 87.0 \\
\hline Potatoes & $2 \cdot 1$ & 20.7 & 0.2 & 0.9 & $1 \cdot 1$ & $75 \cdot 0$ \\
\hline Rlce & $7 \cdot 3$ & $78 \cdot 3$ & 0.6 & 0.6 & 0.4 & $12 \cdot 8$ \\
\hline Clover hay. & $13 \cdot 6$ & $36 \cdot 2$ & $2 \cdot 6$ & $6 \cdot 3$ & $25 \cdot 0$ & $16 \cdot 3$ \\
\hline Meadow hay & $9 \cdot 2$ & $42 \cdot 9$ & $2 \cdot 5$ & 6.5 & $25 \cdot 2$ & $13 \cdot 7$ \\
\hline Lucerne & & & & & & \\
\hline (Alfalfa) & 4.5 & 9.2 & 0.8 & $2 \cdot 0$ & 9.5 & $\mathbf{7 4} \cdot 0$ \\
\hline Green grass & 4.0 & $11 \cdot 5$ & 0.9 & $2 \cdot 4$ & $5 \cdot 9$ & $75 \cdot 3$ \\
\hline Wheat straw & $3 \cdot 3$ & $39 \cdot 4$ & 1.3 & $5 \cdot 3$ & $37 \cdot 1$ & $13 \cdot 6$ \\
\hline Oat straw .. & 4.0 & $37 \cdot 0$ & $2 \cdot 0$ & $5 \cdot 7$ & $36 \cdot 8$ & $14 \cdot 5$ \\
\hline Barley stran & 3.5 & 39.1 & 1.5 & $5 \cdot 7$ & $36 \cdot 0$ & $14 \cdot 2$ \\
\hline Bean straw. & $12 \cdot 0$ & $31 \cdot 6$ & $1 \cdot 3$ & $6 \cdot 3$ & $30 \cdot 6$ & 18.0 \\
\hline Pea straw.. & $7 \cdot 5$ & $29 \cdot 3$ & $2 \cdot 1$ & $4 \cdot 1$ & $42 \cdot 4$ & $14 \cdot 6$ \\
\hline
\end{tabular}
most commonly used :

108. The digestibility of some of the above foods is approximately as follows:

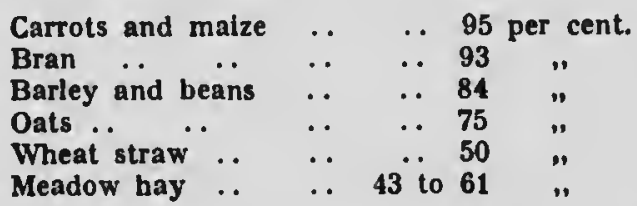

It is interesting to note that the parotid salivary gland of the horse is very large, and probably has become so since he has been domesti. cated and fed on dry oats.

The suitability of food cannot be conveniently measured chemically, so we must find out its value by observing the effects upon the horse. A wholesome food is not necessarily a suitable one. The state of the freces is a valuable guide. Fortunately in health the horse's dung is not con. stipated like that of a dog, nor fiuid like that of horned cattle ; it is moderately soft, fairly well formed and brittle, light in colour (never dark), moderately damp and free from odour and slime. If loose and unformed it indicates that the food is unsuitable, that it has produced either irrita. tion or a purgative effect. Other foods will cause a slow action of bowels or greater absorption of fluid, and thus cause the faces to become hard. The longer the waste matter is left in the 
intestines the greater will be the chance of the poisonous portions being absorbed into the system. Meat is a valuable food in that it is the most concentrated and most easily assimilable of nitrogenous foods. Horses are not generally fed on meat, although they have been in the past, as during the siege of Metz, when it was rolled with bran. 1 remember a horse in the Britisl cavalry that would eat liot meat and vegetables without any hesitation.

109. Oats.-Oats have been found to be the most suitable for working horses; they contain a higlier percentage of woody fibre and not too much starch and sugar. The wholesomeness of a horse food consists chiefly in its correct percentage of wood fibre and nitrogenous material. Woorly fibre, although indigestible in itself, aids in the digestion of the nutritive parts of the food. By not containing too much nitrogen it has a less poisonous effect than highly nitrogenous food. Thit greatest amount of nourishment can be obtained by horses from oals with the least chance of upsel'ing the digestive system.

The Characteristics of Oats.-As oats are so commonly used and as it is so important that horse owners should know good from bad oats, it is advisable to give in detail their characteristics. Good oats are plump, short, round, hard, dry, floury if bitten, without odour, with colour either pale yellow, or almost white or black; a deep yellow indicates kiln-dried aats. Good oats should smell slightly sweet and should rattle if shaken in one's hand. The kernels sliould bulge slightly through the husks. The fatter the kernel is the heavier will be the weight of a bushel; rood oats should be of uniform size. They are beardless or nearly so; beards decrease the weight of oats. New aats are soft, and horses deteriorate if fed on them. New oats are also heavier because they contain more water, so they may be sold by dishonest dealers as good old oats. Oats of the previous year are the best.

Oats vary in weight from 25 to 50 pounds per bushel. An average weight is from 32 to 40 pounds. In weighing oats the measure should be flled from a sack, and the surplus immediately "struck" from the top with a round stick; no shaking is to be allowed. The measure should be placed on the scales before it is filled. Goorl oats should be cleaned; therefore they should be shaken to determine if there is any dust in them. White oats are more nutritious, as they have less husk than black oats. English oats are generally the best from the point of view of nutriment.

110. Defects in Oats.-The worst oats are longer, thinner, more irregular in shape, heavily bearded, darker in colour, stronger in odour. If squeezed in the liand they will feel soft and spongy, chiefly due to the beards. Oats that have become damp (through the leaky hold of a ship) become heated and sometimes commence to steam. They will have a darker colour and a peculiar acrid smell; these are called foxy oats. In order to hide this they are sometimes kilndried, which gets rid of the foxy odour, restores hardness, but turns the colour still darker (almost brown). To get rid of this dark colour they are sometimes bleached with sulphur; in wlicll case the sulphur can be tasted if the aats are cruslied in the mouth. Kiln.drying good aats that liave only become a little damp does no harm and saves them.

Inferior oats with long beards are sometimes "clipped" by passing them through a machine. Mustilless and mouldiness, due to damp harvest or dainp stowage, is generally detected by a musty smell; if mouldy, the mould will probably be detectable upon close examination. Oats that have commenced to sprout are of no value for feeding purposes. Rats may taint oats to such an extent that horses will not eat them. If a horse will not eat his oats, grcat care must be taken that some good aats are given to it before it is treated for sickness, as it may not be sick.

111. Feeding Oats.-The daily ration of oats for a horse about fifteen and a half hands high is about ten pounds, which should be increased to twelve or fifteen with hard work. The cavalry allowance is insufficient if horses are doing very hard work. Horses at rest require only from four to six pounds a day, if at rest for any length of time perhaps as little as two pounds a day. These last should, of course, be fed on bran mashes, with a small amount of oats added. Unless crushed, oats should never be fed alone to c horse, but should be given mixed with cut-up hay (chaff) or bran. Chaff is cheap, as the ordinary hay can be cut up daily by a chaficutting machine, which can be purchased for about three pounds (fifteen dollars). Its cost, if treble this, would soon repay itself. Cutting up hay is the best way to prevent the horse from wasting it. Three or four gallon measures of chaff with each feed of oats are not too much. At any rate, one gallon should be added to every gallon of oats. Chaff improves if kept in bulk for some time, and is better if damped before it is fed, because the dust affects the nostrils. Heavy draught horses doing hard work are given as much as forty pounds of oats a day. This shows that oals can be fed in large quantities to hard-working horses without any harm, at the same time keeping them in hard condition.

112. Crushed Oats.-With any horse crushed oats are an advantage over uncrushed oats, but with old horses, and those that feed hurriedly, through greed or fear of their neighbour robbing them, crushed oats are of the utmost value. Normally a horse can grind up oats very well witl its molar teeth; but, of course, if onts are already crusher the juices will have greater access to the kernels, and therefore digestion will be more perfect. Oals should not be crushed 
flat, but the kernels merely split; too much crushing will lose some of the flour. Crushing is more essential with hard, small, foreign aats than with the English and Canadian oats, which are the best oats we get. Oats can also be steamed or boiled.

Every horse should have a hot feed in the form of boiled oats or a mash on Saturday night, or on the night previous to his day of rest or his easiest day.

113. Measuring Oals.-Oats as a rule are sold in small quantities by the bishel; in large, by the quarter or by the locd. A bushel is taken at a fixed weight; thirty-five pounds in some countries, forty in others, and so on. The total weight of oats is oblained, then, if this weight is divided by the thirty-five or the forty, as the case may be, the quotient gives the number of bushels that the purchaser has to pay for. Thus if the oats are lighter than thirty-five to the bushel the purchaser will really get more bushels than he pays for.

Dry measure (by which oats are measuren,

$\begin{array}{ll}4 \text { gills } & =1 \text { pint } \\ 2 \text { pints } & =1 \text { quart } \\ 4 \text { quarts } & =1 \text { gallon } \\ 2 \text { gallons } & =1 \text { peck } \\ 4 \text { pecks or } 8 \text { gals. } & =1 \text { bushel } \\ 4 \text { bushels } & =1 \text { sack } \\ 8 \text { bushels or } 2 \text { sacks } & =1 \text { quarter } \\ 5 \text { quarters } & =1 \text { load or wey } \\ 2 \text { weys } & =1 \text { last. }\end{array}$

The grain bushel must be "struck" so that its top is level with the sides of the measure. The standard bushel contains 2,218.192 cubic inches (or nearly 2,218 ). It measures $19 \%$ inches in diameter, and $8 t$ inches in depth.

114. Maize.-Maize is called corn on the American continent and mealies in South Africs. It is unsuitable for young stock on account of its high percentage of minerals, but it is an excellent food for hard-working horses. Maize should be dry, bright in colour, hard, free from dirt, have a sweet taste if crushed in the teeth, and have no distinct odour. Maize is bought by the quarter, and weighs sixty pounds to the bushel. The best variety of maize is the North American corn, which is almost triangular in shape, large and rather flat. It is eaten enormously by human beings. It soon deteriorates if kept in bulk, and if allowed to become at all damp is very liable to become heated. When heated, maize is darker, softer, and has a peculiar pungent odour. It may also become musty or mouldy.

Maize as a rule is fed mixed with other grains. If fed alone it should be mixed with chaf ; it is sometimes fed on the cob. It is more important to crush maize than oats, as the former is much harder. As maize lakna : long time to digest. water must not be given in any quantity for nearly two hours after foeding it. Maize may be soaked for several hours, which will assist greedy horses, or horses with bad teeth. The daily ration of maize if fed alone is the same as that of oats.

The daily ration of the London Road Car Company, for their omnibus horses, was : Maize, $16 \mathrm{lb}$. ; oats, 1 lb. ; peas, 1 lb. ; hay (chopped), $12 \mathrm{lb}$., making a total weight of $31 \mathrm{lb}$. of food per diem.

115. Barley.-Barley is not generally fed in England, but is fed a great deal in some countries. It should be plump, short, hard, with a thin wrinkled husk, of a pale golden colour and without a distinct odour. It is sold by the quarter, at fifty-four pounds to the lushel. On account of the indigestibility of the husk, barley should be fed crushed, parched or boiled. It requires far more power to crush barley than oats. Barley is parched by throwing a little together with a little sand (heated to almost red heat) and stirring until it is seen that the husks are split. The sand is then sifted off with a fine mesh sieve. This sand, of course, can be reheated and used again.

116. Rye.-Rye is a poor food for horses, and is therefore unsuitable if fed alone. It is fed in some countries coarsely ground and cooked. It rapidly ferments after cooking. Small quantities may even cause diarrhoa. Ergot fungus is very often found amongst rye.

117. Wheal. - Wheat is a useful food if nothing better can be obtained. It can be fed crushed, or parched, or mixed with other grain or chafi. It is not easily mastica!ed if fed whole alone. It must be dry to be easily digested. It has been fed whole up to seven pounds per day with good results. The flour of whest is often fed with splendid results.

118. Beans.-Beans and peas are the most nutritious form of grain fed to horses, as they contain a very high percentage of flesh-producing elements. They are therefore very "heating," and can only be used when horses are doing hard work or being exposed to severe cold, and then four pounds a day can be given quite safely. Horses turned out to pasture in winter can be fed six to eight pounds a day. Under ordinary conditions on!y one pound should be given to horses.

Beans should be hard and dry, light brown in colour and sweet to the taste. They are sold at sixty-four pounds to the bushel. English beans are the best, and are smaller, rounder, plumper, and thinner skinned. Beans less than a year old are indigestible, and if very old become deteriorated and dark in colour. Heavy horses doing hard work should not be fed over five pounds a day. Beans should be split on account of their tough husks. Good beans nuust be free from weevil.

Peas.-The same remarkis apply to peas as to 
beans, conceruing the feeding of then. Peas must be light in colour, liard and sound. They are liable to become wet at harvest, wliereupon they become darker in colour.

119. Linsecd.-Linseed is one of the most valuable conditioning foods we lave; it contains a ligh percentage of fat-producing elements. Linseed cake is excellent for horses; it is made of residue linseed from which the oil has been expressed. Linseed grains must be plump and we!l filled, free from dirt and bright in colour. The extremely tougl husk of linseed prevents it from being fed whole; it is therefure ground or boiled. Even when groind, very little of the husk is digested.

Boiled linseed is made by boiling the whole grain slowly for six to twelve luours, with repeated stirring; or the whole grain may be soaked in cold water for twenty-four hours. In both cases a jelly will be formed which horses readily eat, end which is an excellent food for fattening purposes. Half a pound a day is suffcient for an ordinary-sized horse. Linseed cake may be given broken up in the manger, about half a pound a day.

120. Linseed mash is made by boiling one and a half pounds of linseed in water for eiglit hours, not very thick in consistenc: : two pounds of bran and one ounce of commun salt are then added and stirred in. The whole is covered and allrwed to cool sufficiently so that it can be taten. Linseed oil, given two ounces a day in the food, is an excellent substitute for linseed.

Linseed tea is particularly good for soothing mucous membranes and the urinary organs. It is made by boiling one pound of linseed in one gallon of water and allowing it to simmer for twelve hours. About a teacupful she.id be poured on the food at night.

121. Bran.-Bran, wlich is the husk of wheat after the kernel has been ground to flour, owes its nutritive value to the amount of flour left with it. Therefore bran from modirn mills has not much nourishment; it is, however, useful, as it increases bulk and regulates the action of the bowels and prevents horses from bolting their food. It is an excellent food if given in the form of a hot mash to a sick horse. Bran is also advantageously used when mixed with heating foods, such as boans and pers. With most horses dry bran tends to cause slight constipation, whilst bran mashes are laxative in their action.

A bran mash is made by scalding two or three pounds of bran in a bucket of water, adrling one ounce of common salt, covering and allowing it to stand until cool enough to eat. A mash must be stirred with a clean stick, and not with one's hand ; cleanliness is of the utmust importance in feeding as in all other stable duties. Bran must be quite dry (moisture will immeriately make it sour and lumpy), sweet, flaky, free from lumps and of a yellowish-red colour; the colour varies considerably according to the wheat. The hand, if plunged in and drawn out, should be covered considerably with flour; and if the bran is chewed it should not feel gritty nor taste sour. Sand nay have been added to increase its weight; to test for this some of the bran should be thruwll into a glass jug of water-any sand present will sink to the bottom.

122. Carrols.-Both red and white carrols are liked by all horses, and should be fed, especially in the spring; about one to two pounds a day in lieu of some roots. Carrots should be mashed or cut lengthways, ncver crossways, as they may cause choking.

Other Rools.-Potatoes are used nsiderably in Ireland. They should be cooked lore use, as raw potatoes are indigestible. If used to them, horses can do hard work on boiled potatoes.

Turnips and other roots can be boiled into a masl or chopped up into small pieces and mixed with the rest of the feed. These pieces must never be more than an inch in diameter. Turnip mashes are commonly used in England on farms.

128. Rice.-Unhusked rice is fed considerably in India, but the husks are very indigestible to animals who are not accustomed to them. If crushed or boiled it makes a fairly good food; it should be fed in larger quantities than oats. Without the husk rice is unsuitable to horspa, becalise it does not contain any woody flbre.

124. Sugar.-Until lately the value of sugar has not been sufflciently realised, but now sugar is very commonly used in England with excellent results, under the name of molassine, which is composed of refuse sugar and peat moss. Molasses is also fed with good results in South Africa and India. Some of the horses in the long-distance rides in Europe have been fol entirely on molasses. Raw sugar should not be fed except as an occasional tit-bit, because it upsets the system. But a considerable amount of sugar-cane or treacle can be added to the food. Sugar is sustaining and fattening, and especially suitable during exposure to hardship or cold.

125. Oatmeal.-Oatmeal gruel is an excellent food to give a horse after a good day's work. Gruels may be made of other meals, such as maize or bean meal, and should be quite liquid in consistency. Warm gruel is made by pouring warm water on a little oatmeal in a bucket, stirring, covering and allowing to cool sufficiently. Then one unce of common salt should be added. A cold gruel can be made by stirring a few handfuls of the meal into a bucket of water.

Compressed rations are issued in active service and consist of various mixtures. They should be well broken up and damped before use. Grain is often steamed, which generally means being soaked for an hour or so in hot water : this is good for sick horses or those that are of their feed.

126. Rock Salt.-it' horee's food containg 

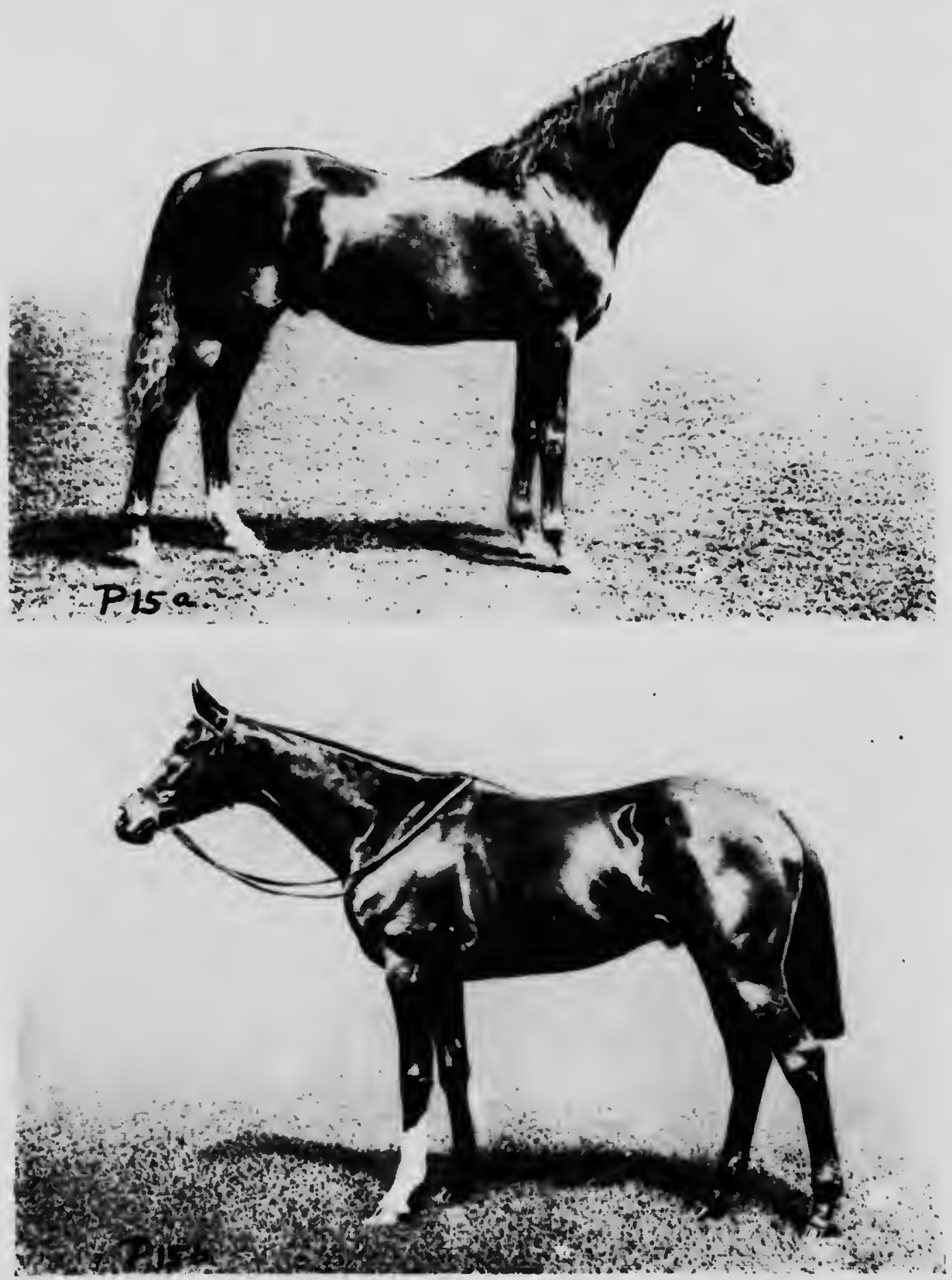

THE ENGLISH THOROUGHBRED

a, "Bend Or." b, "Spearmint." Copyright Photon: W'. A. Rouch, Strand, London 


\section{PI. IT1: 16}
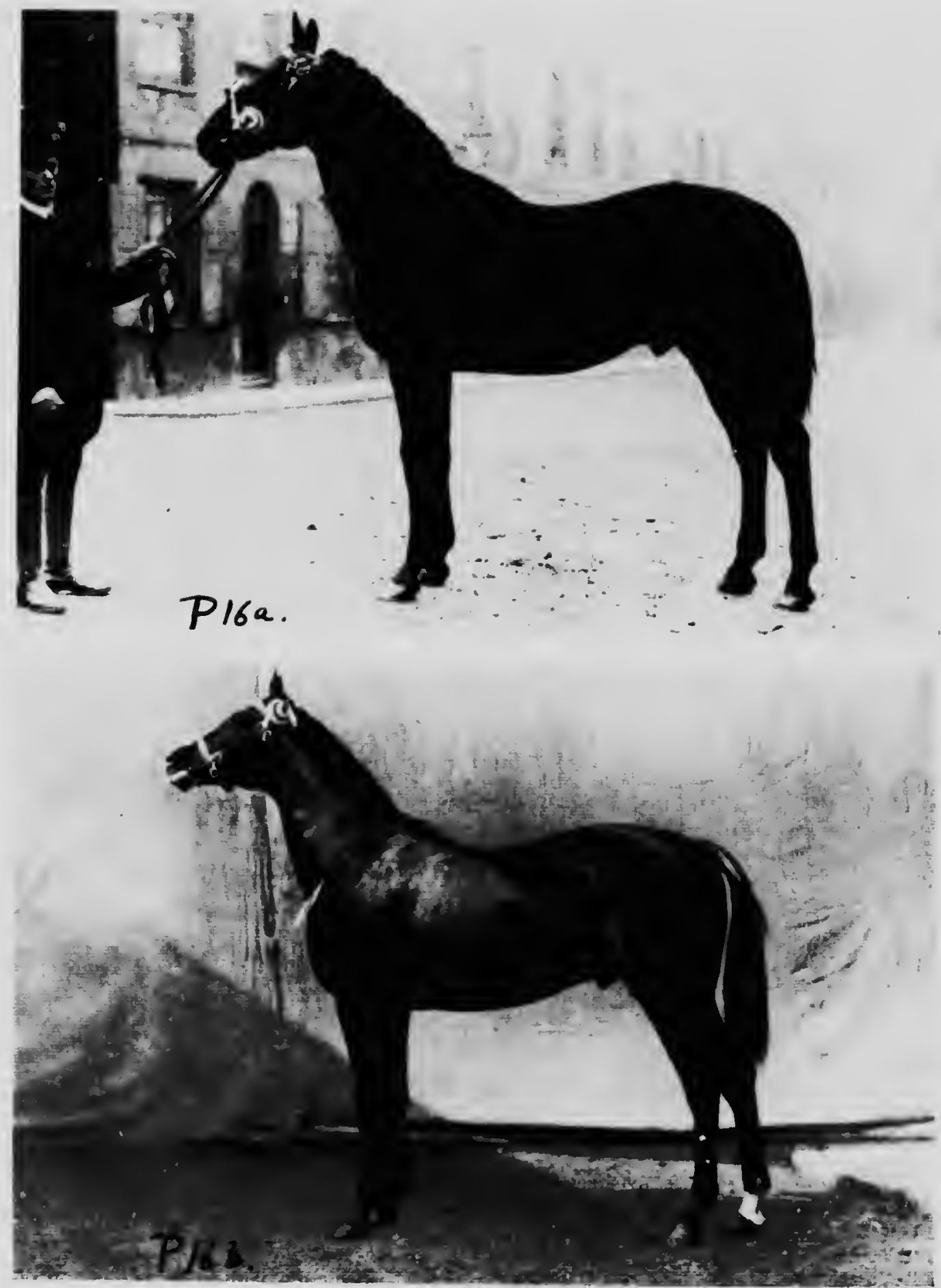

THOKOUGHISKED HORSES

a, "Befrill." b. "Rightful." Owned by Mr W. Li ison. Coppright thotos: Sport and Cieneral, Essex Street, Strand, I.nndon 
already a great annount of salt, so that without extra salt some horses keep in excellent condi. tion. But the addition of salt or the use of rock salt placed in lumps in the manger certainly in. creases the horse's thirst and adds generally to his tone. All horses are fond of salt, and its use increases the power of the blood to resist disease, salt being an antiseptic. Rock salt should be stored in small lumps in perfectly dry places ; a cold place will do no harm as long as it is dry. A damp and warm place will cause it to crumble. Salt (sodium chloride) of any kind assists digestion and lends to get rid of worms.

Crushed oats, bran and other foods are often mixed together and called "chop." Cliop is very useful for feeding from the nosebag, but it should not be bought ready mixed, as it is a very common practice for dishonest dealers to add inferior foods.

127. Cleaning Grain.-Grain, especially oats, has very often to be cleaned by being screened, to rid it from dust, small stones, nail heads (froni ships' holds), etc. Screening machines can be bought at reasonable prices.

128. Green Food.-The addition of a certain amount of green food to the daily ration is of $g$ reat value to the horse in spring and summer. It must not be given in large quantities suddenly, nor in large quantities to a hard-working horse. A few pounds partly mixed with the hay and partly chopped with the feed are excellent, and horses like it. Green food is laxative, and if fed in large quantities will make the horse too soft in condition. It may produce diarrhœea or even colic. Great care must be taken in using it. A horse should never be given grass that has been cut from a damp field, until it has been allowed to dry. A horse fed entirely on green food should have about forty pounds a day. Ten pounds is sufficient for an ordinary working horse, which should be given in lieu of some of the hay and oats. Horses must never be allowed to gorge themselves on green food; they will try to do so if they are given the opportunity.

129. Grazing.-Grazing is most beneficial to any horse, but especially is it so for the hardworking horse that is fed so much on hard grain. Horses enjoy it immensely, and derive the utmost benefit from even a few minutes' grazing a day. No opportunity should ever be lost by riders or drivers to allow their horses to nibble at the grass along the side of the road. Such opportunities occur almost hourly to the soldier in the field, and cavalrymen are always taught to graze their horses at every opportunity. A few mouth. fuls quench a horse's thirst and perhaps appetite for a while, and will never do any harm unless the horse is very heated and the grass is covered with frost, when it is dangerous. Horses that are heated or that have just been doing hard work should not be allowed to graze on wet grass.
This may not harm some horses, but there is a risk of fatulent colic or even enteritis setting in. Grazing in the same way as feeding green fodder keeps the horse's bowels in good condition and assists in maintaining good health. Well-caredfor horses should get half an hour's grazing every day in the spring.

130. Pasture.-All horses should, if possible, be turned out to pasture for two weeks every year. The summer is the best time for this, but I do not recommend that a bobtail horse should be turned out during the fly season. Pasture is also most necessary for horses with sore feet, or for those who are recovering from a splint, spavin or other injury (see Chapter 1X.). Great care must be taken that there is a plentiful supply of water in the fleld; also that there is no barbed wire in reach of the horses. The state of tha pasture must be given careful consideration. Horses are too often put into scanty pastures; besides this being cruel, the horse does not benefit, but probably comes in worse than when he went out. Weeds and rushes and bad grasses, however plentiful, are worse than useless. Horses, while at pasture for only a fow weeks, and if taken from hard work and put back to hard work afterwards, can be kept in fair condition by being fed on four to six pounds of oats a day, half in the morning and half at night. The heating effect of the grain is counteracted by the grass. If pasture is not good, oats must be fed at least once a day.

131. Hay.-Hay varies so greatly in its quality that it is necessary that horse owners should have considerable knowledge of what is bad, indifferent or good hay. The value and quality of hay vary according to the grasses and herbage that it is composed of, the time of year it was cut, the manner in which it was saved, and the soil on which it was grown; the last is the most important factor that affects the value and quality of hay. Hay is composed of dry grasses and herbage, etc., that have been allowed to mature in a stack. Herbage consists of the plants that are not true grasses. Since the introduction of modern farm drainage and irrigation, practically all hay is "meadow hay," i.e. that grown on land suitably drained or irrigated, as the case may be, and used for hay, year after year. Grass that is gathered from very damp districts is distinguished by the presence of water grasses, rushes and sedges, forming what is known as water-meadow hay; all the grasses in it are coarse, as a rule.

Hay that is grown from seed sown as a rota. tion crop is spoken of as "ley" hay, and may be cut for two or three years in succession, after which the land will be used again for grain, roots, etc. Ley hay is known as artiflcial, hard or seed hay. Hay that is largely composed of clover is called clover hay. Meadow hay is distinguished by its fineness and by the large variety 
of grasses, and by the pleasant aroma. It is grbener, because it is usually more quickly saved, for it is composed of finer grasses which take less tine to dry. Seed hay is harder and contains a small variety of grasses, which are larger; it often contains much clover and other herbage.

Good hay, whatever kind it may be, is of a greenish-brown colour, not yellow or dark brown. If cut when wet it looks bleached and becomes mow-burnt. It should be moderatoly hard, well saved, alld about one year old. The odour slould be sweet, flowering heads should be abundant, and the grasses should lie flat and nol confused.

Horses doing hard work do not require much luerbage, but a little is a good lling. Good hay is crisp to the feel and sweet to the taste; each specimen of grass should be good. The quality of the hay for feedinz purposes greally depends on the kinds of grass which yield it.

132. Hay should be composed of mostly good grasses, few indifferent, and no bal or useless grasses. Old hay is from six io eighteen months old; before and after this hay is not good. Now hay, which, in the trade, is that sold before September 20 (Michatmas Day), strictly speaking, is that which is sold witlin six months of its being cut. It is softer, less crisp, has more colour, tastes sweeter and smells stronger. It is more bulky and heavier, because it contains more moisture. The flower-heads of new hay are not faded, and the herbage and weeds are not blackened as in old hay. New hay does not cut up so solidly into trusses as does old hay. The hand plunged leeply into new hay detects a warm feeling. One-jear-old hay should preserve most of its colour.

$$
\begin{aligned}
\text { One truss new (young) hay } & =60 \text { pounds } \\
\text { One truss old hay } & =56 \text { pounds. }
\end{aligned}
$$

The hay should be cut when it is flowering: if cut before, nutriment is in the stalk ; if cut afterwards, nutriment 's in the seed. If the farmer, however, wishes to help his land he may allow some of the seed to fall before cutting, but, of course, the hay will be of less value. This is distinguishable by the absence of flower-heads and seed. As soon as the seed has fallen the stems become woody.

133. Great care should be taken in saving the hay, by which is meant the manner in which it is dried, carried and stacked. The usual way is to rake it into windrows by horserakes, and then to put it into cocks. In Alberta the hay is stacked on the same day that $i$ is cut, but in England it generally lies untouched for a day, in rows for another day, and then if there is no rain may be cocked and carted the third day. This greatly depends on the dryness of the season and on the amount of sun and wind. The quicker it can be got in the belter it will be.
Rain destroys hay by washing out much of its nutriment, which is shown by the colour being washed out. A laige number of trees in a field decreases the value of hay on account of the increased amount of leaves that will be in the hay, and also by the amount of nourishment that will be taken up by the trees from the soil. Cleaned ground will contain less weeds.

Dust is always plentiful in old hay ; but it will be much increased if the hay is of great age, if the hay was weathered while being made, or if the soil on which it was grown was very dusty. Over-exposure to sun will increase the amount of dust. If hay is stacked too soon, i.e. before the juicy stems of the grasses are sufficiently dried, fermentation (heating) sets in and the stack may become mow-burnt or even fired. If it is only slightly mow-burnt it can be fed to horses with. out danger-in fact, they like it; if, however, it is niucl mow-burnt it will tend to cause diabetes mellitus, while some horses will refuse it. On the other hand, hay that is internally dry, but that has become wet through rain or dew, if stacked when damp may become musty or even mouldy. Musty hay is an inferior food; some horses, however, will eat it. It may be dark brown or a bright yellow, with a bitter taste and an umpleasant odour. If mouldy, white patches will be visible; such is unfit for fodder. A good truss may become mouldy if exposed to damp.

134. The sweet smell which lasts for several months in hay, and which is known as its "nose," is chiefly due to the odour of sweet vernal, which is the chief aromatic grass in hay. To examine hay it should be carefully looked at to ensure uniformity of colour. It should be noted whether it is free from dust and weeds, and whether it is much mow-burnt. Several trusses should be opened right through. Canadian baled hay is sold a great deal on English and other markets. It generally contains a great deal of timothy, but is always very dusty. Exposure to air will destroy the musty odour. It should be wel: shaken and sprinkled with water, or, better still, with brine or lime-vater, before being fed.

135. Hay Grasses.-The chief grasses and plants are divided into useful and useless grasses. The useful grasses are rye grass, meadow and tall fescue, foxtail, timothy (catstail), crested dogstail, cocksfoot, sweet vernal, rough- and smooth-stalk meadow grass and yellow-oat grass. Meadow soft grass is as good as a tonic.

The useless grasses are barren fescue, the bents, false oat, wavy mountain hair-grass, field brome, sheep's fescue, slender foxtail, darnel, tufted hair-grass, ribbon grass, quaking grass, rib plantain, reed sweet-grass, couch grass, harren hrome, rattle and wall barley (squirreltail).

Some common weeds are blackhead, coltsfoot, 
silver weed, sedges and rushes, dandelions, buttercups, margueriles, nettles, etc.

Herbage consists of clover, trefoil, vetch, sainfoin and alfalla, or lucerne.

186. Clover hay makes excellent food for horses that are not doing very hard work. It is a change, and horses like it. Any hay containing a fair amount of clover is increased in value. There are several varieties of clover. At present farmers are unable to grow clover in Western Canada, but the Experimental Farms have got a special hardened variety, and it is hoped that in a few years they will be able to put it on the market. This variety withstands the severe winters of Manitoba and Saskatchewan.

187. Lucerne (called alfalfa in North America) is a most valuable green food; it is most nutritious, and several crops can be cut of the same roots in the same season. It is practically perennial, and is a tall, green plant with a small purple flower. It roots deeply, and can, therefore, be grown on dry soils, such as those in India. It does best in countries with hot summers. It is brittle, and consequently dusty, which is a drawback.

Sainfoin makes an excellent hay. The plant is large, course-stemmed, thin-leaved, with a pinkish flower. It is specially suitable for heavy horses. Its coarseness of stalk does not lower its value unless the stalk is tough. It is very nutritious and is liked by horses. Two crops a year may be cut, but the plant is only biennial. It is usually cut for hay before it flowers.

\section{Appetite}

138. The appetite is a fairly good indicator of the kind and amount of food required by the system. The reliability of this indicator is much increased when the horse is at hard work. In nature the horse is not idle, nor does he eat threshed oats, so that for this reason the appetite of a hard-working horse, fed on such palatable foods, will over-indicate the amount of food required. When the system requires nourishment, which means an emply stomach and small intestinal tract, it excites the nervous system and produces a sensation of hunger (appetite). Experiment has shown that this sensation ceases if food is artificially introduced into these empty organs through the rectum, or through an artiflcial opening which may have to be made in certain diseases of the throat, etc. This sensa. tion is also produced by external impressions, e.g. by the sense of smoll, taste, feeling, seeing and hearing. The stimulus, whatever it may be, excites the whole digestive apparatus and prepares it for the reception of lood.

When a horse is sick or much fatigued, it would do no good, but considerable harm, to stimulate this sensation by showing him oats or other palatable foods, as his system will require alI its energy to throw of the illness without exerting itself in this other direction. Hence, a very easily digestible mash or gruel should be given, which would not excite the appetite too much. Severe work lowers the activity of the appetito and digestion, and is seen in racehorses that are over-trained.

To force a horse which is ofl its feed to eat and to give it stimulants will do harm. He should be given plenty of water and a little green feed or a mash. Only a very little at a time should be given, and repeated when necessary; the digestive organs will thus be able to recuperate.

189. As the appetite under the conditions of civilisation will over-indicate the amount of lood required, we must make horses eat slowly. When a horse is hungry he eats, but to eat as long as he is hungry will probably mean to over-eat, because it takes time for the stomach and intestines, when sufficiently supplied, to communicate this fact to the nervous system, and thence to the nerves that cause the sensation of appetite. Thus, when he thinks he has had enough, he has really had too much, and every particle taken in excess will do no good, but harm; this risk will be lessened if the animal eats slowly. The same principle applies to ourselves.

140. Cleaning Mangers.-Oreat care must be taken before every meal to see that the manger is absolutely clean and that it contains no sour odour. Before a horse is taken out it should be ascertained whether he has finished his last meal. The crevices and comers of the manger are usually neglected by grooms, and soon become sour, causing a dainty horse to lose its appetite. A dirty manger is a sure sign of bad horsekeeping.

141. A horse requires bulk. However high may be the nutrient properties of concentrated loods, without bulk they will never cause a horse to be in good condition. A horse of the stamp of the cavalry troop horse, doing moderate work, requires twenty-five to thirty pounds of food day. About half of this should be oats, the remainder hay; two pounds of the hay should be cut up into chafi, and mixed with the oats. The digestive system can scarcely consume too many onts a day if the horse is working hard, but if oats are given alone, i.e. without being mixed with chaff or bran, it will not be able to consume sufficient, as a great deal of the oats will pass unconsumed. Hence the importance of adding bulk to the asts ration. A heavy draught horse should have as much as three times the above quantity of oats and nearly double the hay.

The best method of feeding horses is to give only a handful of hay in the morring, with about one-third of the oats; to repeat this amount 
of oats at noon, with a large armful of liay ; to give the same amount of hay at night, with the renuainder of the oats, and to give the rentainler of the hay last thing at night. This allows th: horse tlee whole night to inunch his hay quietly. If the oat ration is very large, four feeds shoulid be givell a day, i.e. one lute at miclit. Heavy draught liorses usually get three feeds a day of vile and il half gallons, which is over half a bushel a day.

12. 'The principle adopted in feeding horses is to water before feeding, and not for at least an lour ifter feeding uats or two hours after rice. Gruil or wet green fom must not be fed when the horse is exhausted or overheated. The horse should be ferl often and in small quantitits. He nust not be worked hari or fast for an hour after feeding grain. l'ery fnst work, as racing, should not be alluwed for two hours after feeding grain. We nust feed a horse on such food, in such a manner, and in such a quantity as will keep him in health and flness for the work required of him. No opportunity should be lost for grazing a horse or allowing him to pick at suituble food.

In comnercial stibles hay is often chopped up with the grain, forming "chop." which is fed almost continuously throughout the day, no long hay being given. This is done with London cab horses. If we study the very small stomach of the horse, and the fact that his digestive fluids flow continuously (he liss no gall bladder as we have), and take into account his natural methods of feeding, we shall realise fully that this method of feeding continually is the right one for horses, but not for ourselves. The horse has been known to graze for twentytwo out of twenty-four hours when undisturbed. The horse is better if his stomach is always partly filled, because, as stated above, his digestion is continuous, so I must emphasise strongly the importance of horses being ferl frequently and in small quantities. The system of putting large rations before a horse is most wasteful, but the horse will seldom waste small rations. Overhead hay racks are most objectionable. Hay should be put into the rack by hand, and not with the pitchfork. Four pounds of oats, with a couple of handfuls of chaff, is the maximum that a horse about 15.2 hands should be given at one feed. Oats weighing thirty-two pounds to a bushel would weigh four pounds to the gallon: good oats, of course, would weigh a little more than this. If the stomach is overloaded, it will become distended, the food will ferment, and gases will be given off. Gastritis, or even rupture of the stomach, may result. With thin horses it is even more important to give small feeds, repeaterl often.

143. The reason hard or fast work should not be allowed for an hour or two after : meal, according to the meal and form of work, is because the stontach and bowels will bo dis. tended with food and gases. These will proses against tlie diaphragm and lungs, and hinder the free action of the latter, and nay cause them to become clioked with blood; or, vice versa, the expansion of the lungs may rupture the stomach or intestines.

With increased work increased grain niust bo given. A lewty horse doing slow work can be given at la rge amount of bulky food, as its lungs are not so wuch required, and he may ", worked half au hour after being feo. Racehorses only gut about seven pounds of hay a day, and get as niuch as fifteen to twenty pounds of oats. Dealers feed their horses well on hay and bran to keep them fat-fatness covers up a multitude of ovils. Hay can always be fed to a hot or tired horse, unless he is very fatigued, when a hot mash or gruel should be given, with a little salt added.

144. Exhausting work has a weakening effect on the digestive system, hence wo must not allow the hurse to eat grain when exhausted or heated, because the blood is at the surface of the body or in the tired muscles away from the stomach and intestines. A horse must never be hurried over its feeding. If he has not time to finish his usual feed, he must be given less, and fed the remainder when he has time. If he misses one meal, he must not be given double at the next meal on any account, but be given an extra meal late at night.

Horses are usually allowed one hour for meals, but one hour and a half should be allowed for the midday meal. While he is eating his hay he can be rubbed down, but while feeding oats he should be left alone.

While digestion is going on rapidly a large supply of blood is in the blood-vessels of the viscera, and therefore we should not call upon any muscles to do work : in order to work they require an extra blood supply.

The greatest care must be exercised in feeding horses. The theory of feeding must be understood, and this must be combined with the closest observation. In no equine matter is there more ignorance displayed than in that of feeding. Hot feeds and hot drinks should be given on the horse's idle days, and always one night a week. Hot gruel should be given after a hard day's work, and the legs massaged and bandaged.

145. Special Cases of Feeding.-If the addition of bran or chaff will not prevent a horse from bolting food, a large manger may be used, with the feed thinly spread all over it; large, smooth stones may be put in the manger; the manger may be divided into partitions by crossbars, or, belter still, the manger may be cast with a series of cups in the bottom about five inches in diameter and two inches in depth, each cup approximately fitting the horse's mouth. Whole grain in the manure is a sure sign of 
PI.ATE 17
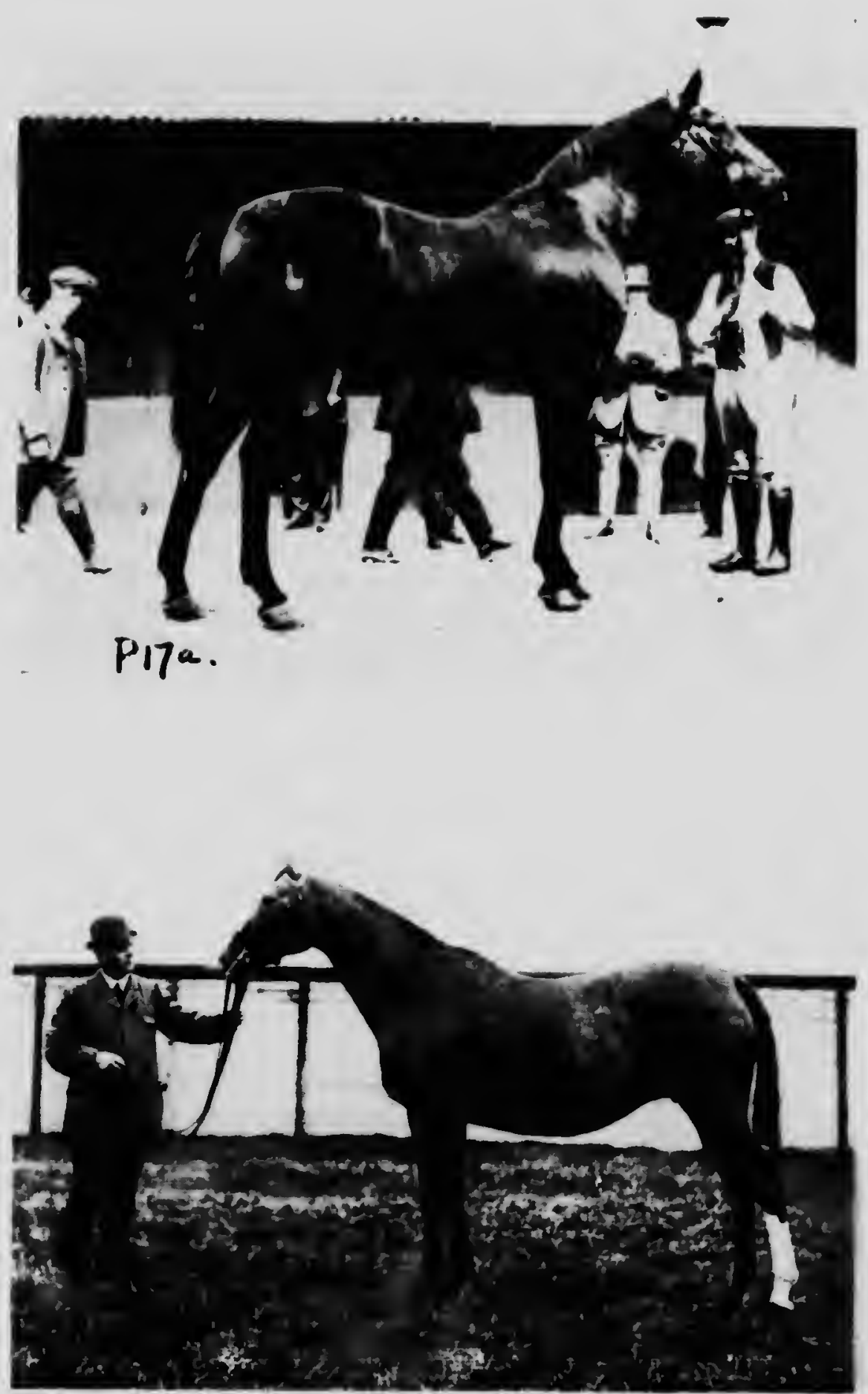

a, Cold Medal Hunter Sire "Spook." Courtesy: "Weekly Irish Times," b. Champion Hunter Broo I Mare "Gold Leal." Pholo: G. H. Parsona, Aleager, Cheshire 
PI.ATI: IX
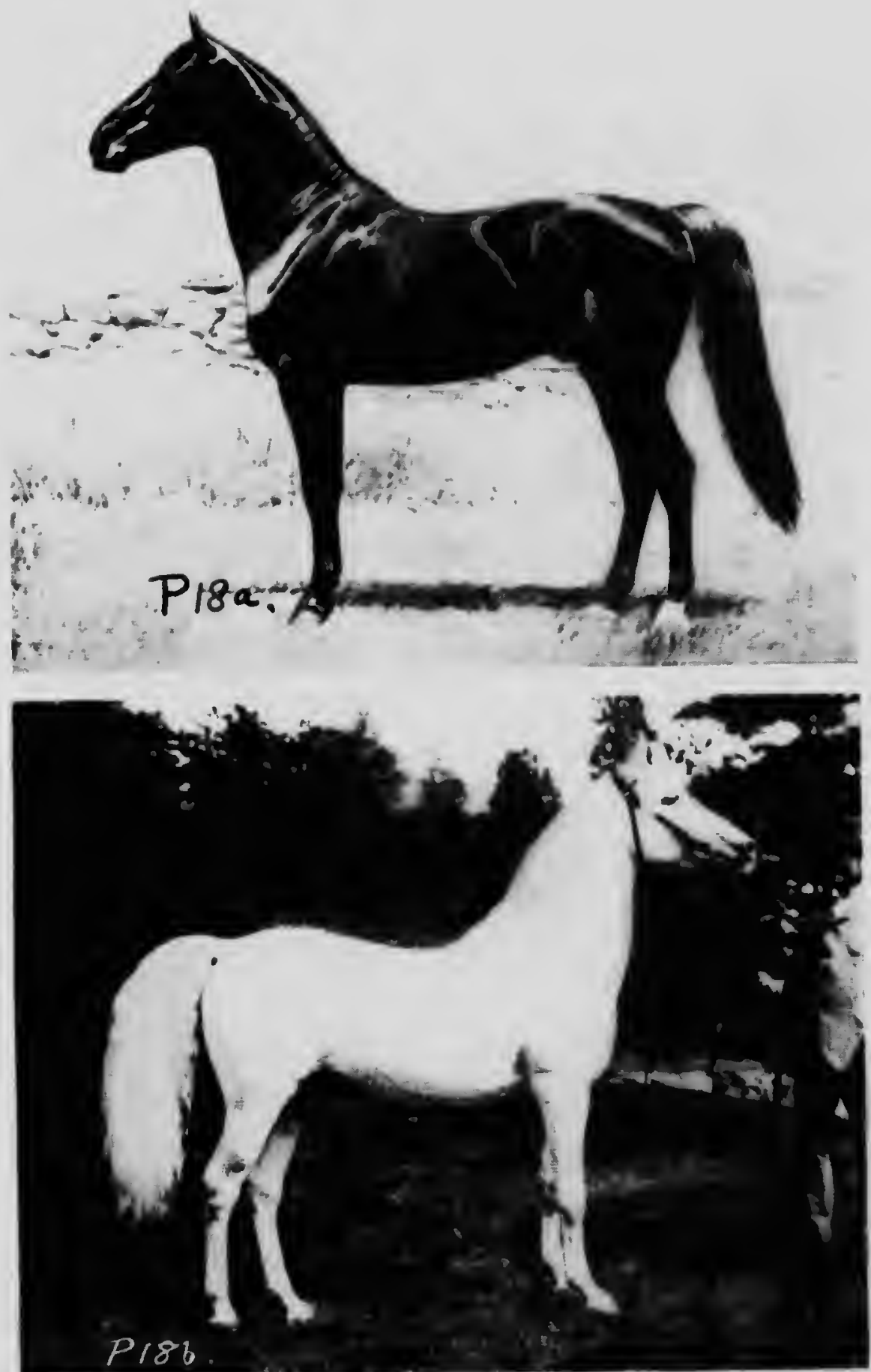

a, Standard-bred Stallion "Burd Peter" (58275). Son of "Peter the Great" b, Arah Stallion "Shahwan." imported from Arabia. Courtesy of Owner. Both owned by Mr. J. A. P. Ramsdell, Newburg, N.Y 
greply ferling or bad leeth. Horses that suffer fruil lon:mess or dliarrlioe while at work are not generally affected by cliauglug the food. The ciuse is a nervous affection gonerally, the result of the absurbing power of the intestines hecom. ing temporarily paralyserl, or, at ally rate, chicked, allowing the fluil to pass into the rextum. This affection is chiefly in the floating colin!.

Horses that have been troubled witlı fever in the feet, probably due to over-feeding arul want of exercise, must be rigularly exerciseil and care. fully fed, with unly a snall ration of grain; benns aud peas must unt be ferl, th they are too heating. Hurses with broken wind should liave their lasy wetted with line-water or brine, and should be given food tree from dust. They must not be worked for a long period ifter ferdiug.

146. Fecding aller Foaling.-After foaling. the mare has to tal sufficient food to feed herself und her oflspring. This must, therefore, be borne in mind. For several weeks after foaling. the feed should consist of crushed oats, with boiled oats at night. She should be given little quantities ofken, as much as she will eat. Later on she can be given uncrushed oals. It will do no harn to allow the foal to nibble at its mother's oats if it wants to. Linsecd meal should be added to the mare's feed.

147. Nosebags. - Nosebags, when projerly cleaned and properly filled, and made with air. holes, are very useful articles for the horse to feed trom if it is inconvenient for him to be placed in his stable. A box on a stand, however. is more comforlable and more sanilary. The nosebas must be kept thoroughly cleaned, and must be strapped up higher as the contents hecome less. If possible, a box or other support should be given to the horse to rest his nosebag on. I cannot do better than quate from the Buffalo Horsc IVorld: "For a moment put yourself in the position of a horse forced to feed out of some of our nosebags. His head is encased in a close-fitting, wholly unventilated, foul and heary attachment in the shape of a bag. Though his lips are very flexible and constructed so that his month can perform some of the functions of our hands, the horse cannot reach his food. He is compelled to toss the bag upwards so that the last of his feed may come within reach, and the grains get into his nostrils and cause great annoyance. With his hreathing hindered and his nostrils clogged, he is in tar more pain and distress than a horse that gets a cul from the whip."

148. Causes of Thinness. - When a horse living under ordinary conditions is found to be thin or emaciated, a careful investigation must be marle at once. The following points must be ẩectiaineti.

Does he get his feed? Is he fed regularly?
Is he watered sufficiently and regularly? Does he bolt his food? Do other horses toal his oats? Do his teeth trouble him? (There may be pieces of wood wedgud in between lis molars.) Is his tongue sure? Has he worms? And is his urino all right? Ureat care must be taken that he really gets his feed, and that it is not being systematically stolen by the groom. A horse, if iil reach of another feed, must be racked up on the upper chain until the other horses have finished their onts.

Under-feeding is, I fear, only too cummon in poor districts. The clitef culprits in Canada are the Jewish population. Tho S.P.C.A. have much work before them in this line. Any mall who would under-feed a horse slould be put in prison and staried himself.

149. Slowage of Furage. - Oats should be stored in small bins lintel with zinc, in the loft. These bius must be in dry places. (See Chapter IIII.) IVlien oats are used in large quantities. large bins with wooden floors, ten to firteen feel square, aro made in the $10 \mathrm{ft}$, the oats being shnvelled out when required: but, if possible, they should be metal-lined. Every precaution should be taken to keep rats and mice away. Unthreshed oats should be kept in a stack. thatched with straw. Hay keeps best in the stack, with a good straw-thatched roof.

\section{Watering}

150. Without water a horse will live only a day or two, but lie will live much lunger with. out food. He must be watered at least three times a day, but, as his large intestines are very large, unlike his stomach, he can take in a large supply of water at a time. He should be watered last thing at night, say at 0 p.m., especially in hot weather. He should always be watered before a meal, as the water will be required to assist in the digestion of the grain, etc., besides quenching his thirst. The amount of water required varies very much. In hot weather, with hard work, he may require ffteen gallons a day, whilst in cold weather, when idle, he may only drink a bucketful (four gallons). Eight to ten gallons a day is an average all the year round. The Government allowance on service, where there is a scarcity of water, is ten gallons, but, as a rule, a horse is allowed as much as he wants. A horse will drink as much as from four to six gallons at a time when thirsty. I knew of one horse (15.2 hands) drinking ten gallons at once.

Horses must never be watered for one hour or one hour and a half after feeding grain (two hours after rice). If water is allowed to pour through the stomach en route to the crecum and colon. it will wash the undigested grain into the small intestines, where the grain will lie and ferment and cause colic. Horses, while grazing, 
especially in cool weatler, need only drink twice a clay.

It selctom hurts a hurse to water him when hot or directly afler hot work; cavalry horses are watered in this way, and keep far beller for it. Even ice-coll waler seldom does any harm on such an occasion. It is wrong to take the chill of water unless the liorse is feverish. If a liorse is watered when very hot or lired, he must be walked for ten minutes afterwaris to prevent his internal organs cooling down too suddenty: then he will do far better than if not watered until cool. The horse must never be hurried while watering. One that is used to a bucket often drinks slowly from a trough or stream, so he nuust be allowed plenty of time; flut nuinutes is sufficicint.

151. Reaction is reaijustment of a tisturb. ance, and healthy reaction causes increased functional activity. But if the disturbance is too violent or prolonged it will not become reaifjusted, ena, for example, a chill may result. The greater the functional activity befor the disturbance or shock the more easily will the system be able to readjust itself: hence, the sooner we water a horse after lie returns from work, the better will he be able to stand the shock. But if the horse is very hot or fatigued, as stated above, he must not he allowerl to stand for ten or fifteen minules after being watered. If he is sent straight back into the stable the system will cool down too suddenly, i.e. the blool will be driven from the intestines to the extremities (the legs), and he will become foundered. This is the cause of horses becoming foundered that have been watered on return from work. The groom says that the watering caused the harm; but far from it, the water was necessary to assist the functional activities of the bory. It is the standing still after the watering that loes the harm. As explained farther on, cold water is necessary for a henterl horse.

Ilorses must never be trotted to or from watering, and working horses should be walked for lialf a mile after drinking at the fountain, unless they have irunk only a little. Horses on the marcli shoull, be watered as often as possible. The first time the horse raises his hear from the trough is no sign that he has finished; he is probably getting his hreath. Horses should not be watered with hits in their mouths. When they are ridlen hurehack to water, a watering snaffle should be lisel, which is an ordinary snaffle with a small mouthpiece. Foremen and others in charge of horses shoulil see that lorses are not hurried away before they lave had their fll: a horse cannot take too mucl water.

152. Watering buckuts mist always be clean, and should be scoured nut once a wrek with boiling water. If watering troughs are used they must be high enougl from the gr. and to prevent horses pawing their feet over the edge, and there must be no sharp edges. They should be either painted iron or zinc-lined, and must be well scrubbed out at least once a week. They should be long and wide, eight to ten inches in depth, and the inlet must be sufficiently large. There should be a jlug or tap in the bottom. A horse should be allowed a space of about four feet in width while watering. I fully realise that glanclers and other cliseases may be spread by jublic watering troughs; but while one in a hundred thousand horses may get a disease from a public trough, to a slish them would be to caise one liundred thousand to sufier from. thirst.

If we take such extreme precautions we must never allow horses to get near to one another on the street or pilt a horse into a livery stable, because a glandered horse might spread infection by sneezing. To take such extreme precautions is impossible, and so it would be foolish to abolish the public drinking troughs.

Nevertheless, all public troughs should have a free stream of water running through all the time, and the best plan is to water from the driver's own bucket; and for this purpose all public urinking troughs should have two or three laps for filling privale buckets. The surplus must be thrown down the drain and not into the trough.

153. In 1003 there were 1,945 cases of glanders in the City of London, in 1910 there were 594, and in 1911 about 400 . Yet during these latter years the number of public troughs in use was clouble that in use in 1003 . Half a million horses drank daily at these troughs; the consumption during 1010 was estimated at over $81,000,000$ gallons. An anti-germ individual-cup drinking fountain for horses has been placed on the American market by the II. F. Jenks Company, of Pawtucket, R.I. I can highly recommend the adoption of this cup by city authorities. A new reinforced concrete sanitary drinking fountain is also male by the Sanitary Fountain Company, Kansas City, Mo., U.S.

154. Hat'r. - Good water is not by any means the clearest. Horses as a rule prefer cloudy waler in a ditch to the clear spring water, because the former is softer. As a rule horses prefer soft water to hard water, but the best horse-breeding districts are those on limestone, and the water in these districts is generally fairly hard. Good water must be fresh, pure, tasteless, clean, aerated, fairly clear, colourless, fairly soft,
and odourless.

Bad water very selilom does a horse much harm, because as a rule he will refise water that is harmful. Very bad water can be fltered through a sand bed, or cinders, or charcoal. Hard water undoubtedly rauses a derangement of the horse's intestinal canal ; horses watered much on hard water often have harsh, staring coats, which will rapidly become normal if the water is 
changed to soft water. Horses have been known to become quite ill on hard water. The best way to soften hard water is to add a little lime water (calcium hydrate).

The source of the water supply should always i. vestigated, as the water may come from a nous district or possess a great number of je-producing micro-organisms.

5. The Theory of Watering. - Water is al vaj's required to nourish the system. When wate: has been in the system for a short while it has performed its function and is passed out by the lungs, kidneys, skin, and by the udder in recently-delivered mares, and by other $e x$ cretory organs. On a hot day a hard-working horse passes out three or four times more water through the lungs and skin than through the kidneys.

Water is necessary to keep down the abnormal rise of temperature in the body that is produced by work; hence warm water should not be given to horses. The temperature of the horse is kept down to normal by perspiration; water is necessary to cause perspiration. The coat, when damp with perspiration, becomes cooled down by the moisture evaporating. This cools down the internal temperature of the body. As work produces heat, work withuut increased supply of water will upset tho horse's system. A lieated or over-tired horse can be watered, provided it is not left standing for ffteen minutes or more afterwards. If left standing he is very liable to become foundered. If walked about the horse is far betler for being watered, because he will cool down nucli more rapidly and his system will become normal in a much shorter time. Water quenches the thirst.

Water is a valuable factor in aiding excretion of impurities from the system. This is especially necessary in cases of rheumatism, etc. ; hence horses subject to rheumatism must be given plenty of water and lots of salt to increase the thirst. Water also mechanically aids the in. testines in getting rid of useless residue.

156. The ideal way of watering is to have a continuous flow of water in front of the horse's manger. A horse will never drink more than a few swallows at a time if this is done, and this will never callse any harm. Practice has proved that under this method horses do best. They must, of course, have rock salt before them all the time. Horses that are not used to being watered when hot, and those that aro going out on hard woik, may be given half \& dozen swallows; water must not be given for one or two hours before fast work, as all the space possible is required for the lungs to work in.

It is always best to water a horse after hard work ; it cools him down internally and helps him to recuperate his energy more rapidly. Horses, if not allowed water before them, must be watered regularly. Regularity in watering is as essential as it is in feeding and exercise, and is the secret of good horsekeeping.

157. Water passes down the gullet (cesophagus) into the stomach, which in the horse is extremely small and scarcely absorbs any water at all; it then passes out through tho small intestines, and what is not required passes into the crecum, which holds 6 to 8 gallons. Most of the water that the horse drinks passes into this intestine. Some of it passes still farther into the large colon, which holds 18 to $18 \mathrm{gallons.}$ Only a little is needed at a time by the absorbing intestines, so that most of the water drunk by a horse at a good drink is stored in the cæcum until required. The crecum lies on the right side of the horse.

158. Conditioning Horses.-loung horses require very careful attention when first brought to work. Great care must be taken that they do not lose their flesh and bloom, which, ii once lost through bad feeding, irregular feeding or irregular work, is only regained with much diff. culty. A very steady gradation in the amount of work and in giving hard feed is of the utmost importance. About one-third of an ordinary hari feed ration is sufficient to start a young hor. with. The exercise given him will, of course, be very light for several weeks, depending on his condition and legs. After a few weeks lie may be put on half rations, or even a little more, proper notice being taken of the manner in which the food acts upon him, his dung and urine being watched carefully. Heating food, as beans and peas, is not good for young horses, but is good for old horses that require heat to keep up their condition. An old horse requires much more food proportionately to keep in condition. His teeth must always be taken into consideration.

Blood, power and good looks without condition are of little value to a horse that is required to do strenuous work, e.g. the horse on service or the hunter. By condition we merely mean a body well covered with flesh that is hard, a hard and firm neck, a glossy and silky coat, a bright eye, fresh looks, a good appetite, a good digestion, normal dung and urine, plenty of spirits, no running up light towards the flanks like a greyhound, and capability for doing long and continuous work. (See P. 16, 18, 20, 41.)

It should be remembered that a horse's urine, unlike most animals', is normally cloudy. Condition must not be confounded with fatness, which is distinguished by a certain flabbiness and a distended abdomen. In referring to condition in ordinary horses we do not refer to the high pitch of condition that is so essential in the racehorse. The racehorso is trained to a high nervous state, with not an ounce of weight on him that could be dispensed with (see P. 15b); he is trained to this temporary high state by 
unnatural means, and as a rule it cannot last long. This state is maintained by excessive feeding on lieat-producing food, excessive grooming and hand massaging, and excessive training. A reaction is very liable to set in unless a racehorse is untrained very gradually. Old racchorses are seldoin any good for work.

159. Then, again, the dealer's "condition" is alluther kind; he aims at fatness, not fitness. This neans flabby and fattened muscles ; in fact, the horse's whole system is in a barl, loose cor:dition, and he soon becomes fatigued by a little work. lle is kept idle, so that on being taker. into the ring for a few minutes he prances about and shuws much energy, and the woult-be horseman lhinks lie has a bargain. Next day he takes the horse for a run across country, and after a mile his horse is "done up."

As stated in Chapter III., the dealer in the rilik or show-yard prevents a liorse from shying by keeping its attention turned towards him and his assistants, ly keepilig it always on the "jump," by showing it the whip, and by keeping it on soft feed and other food calculated to keepl it fat.

On account of want of exercise, and through fear of the whip, etc., the horse appears animated. He takes little notice of things he would normally sliy at, and prances about as long as the whip and arms of the assistants around are continually in motion. He associates these movements with previous cuts from the whip, and pays great attention to them through fear. My advice to purchasers of horses is to bewire of the liorse dealer.

160. The only method of obtaining condition is to give the right amount of the best kind of the riglit food, judicionsly cominined with the richt amount of healthy exercise continued over a lons period, which is more easily said than done. Added to this is the great importance of punctuality in feeding and the appreciation of each horse's habits and peculiarities. For this reason it is of the utmost importance that one man should ford a horse all the time.

It is of the litmost importance to ascertain if the lorse is on its feed before taking it ont for exercise. and also that the manger is absolutely clean before each feeding hour. The sooner lorse owners realise that conditioning is not an easy matter the sooner will they be in possession of horses that are able to to the work required of them. It lakes at least six months to get a soft horse into condition for steeplechasing or flat racing; it may take a year. Every few weeks the food, grooming and exercise are increased very gradually. These must be dec reased immediately the slightest sign of too rapid advancement is liscoverel. It requires much time to transform a rally fat horse, and still longer to transform a horse that is much run down through neglect. Asking poor horses or soft horses to do hard work is the surest way to get lameness and disease, and is the surest sign of bad horsemastership.

161. When once condition has been gained, then hard work will do no harm; falls and ninor accidents will probably be withslood by the body which is ready to stand strains and shocks. The tissues of an unconditioned horse will not stand strains, and so we often find that breakdowns are the result of the horse being in bad condition.

When a horse is in a hard state hard work makes his condition better; in fact, without hard work condition will begin to go. For this reason well-conditioned horses, if left idle for a fow days and then given hard work, often fall sick. lymphangitis and azoluria are common ailments from this cause. A horse in good condition should not be given more than a day's rest, and on this day his haru feed must be cut down very considerably. A soft feed should be given the night before the day of rest, which also has the beneficial effect of clearing his system. If such a horse is not required the second day he should be givell at least one hour's good walking exercise. There is nothing like a good walk for keeping up condition.

When a well-conditioned horse has been idle for some days on reduced rations, his work must commence gradually again; sudden work may cause much harm. (Sipe" Azoturia, Sic. 5iz.)

The worst, yet perhays the commonest, form of ignorance displayed in this matter is that of allowing a liorse to be left ill all the week, probably on full rations, and on Saturday and Sunday to give it three or four hours' hard work. One sees this displayed almost every week-no wonder so many good horses are physically injured. This applies to private-owned horses, and especially saddle horses.

162. Conditioning should be cumulative; an hour's walking exercise every lay is not nearly sufficient to keep a horse in good condition. Private-owned horses suffer far more from want of exercise and over-feeding than over-exercise and want of feeding.

Contractors must be carefully watched by owners of horses to see that they supply forage up to the contract standard. Neglect of this precaution is the cause of much waste of money and many horses being improperly fed. The weight must also be ascertained to see that it is up to contract.

I condemn nearly all the stock condition foods on the market; most of those that 1 have had any experience with do little good. They contain in many cases about 80 per cent. oxide of antimony (black antimony), which does a horse more harm than good. For condition powlers, etc., see Section 163.

A small teaspoonful of saltpetre (pot. nit.) once a week in the feed will keep a horse's 
PLATE 19
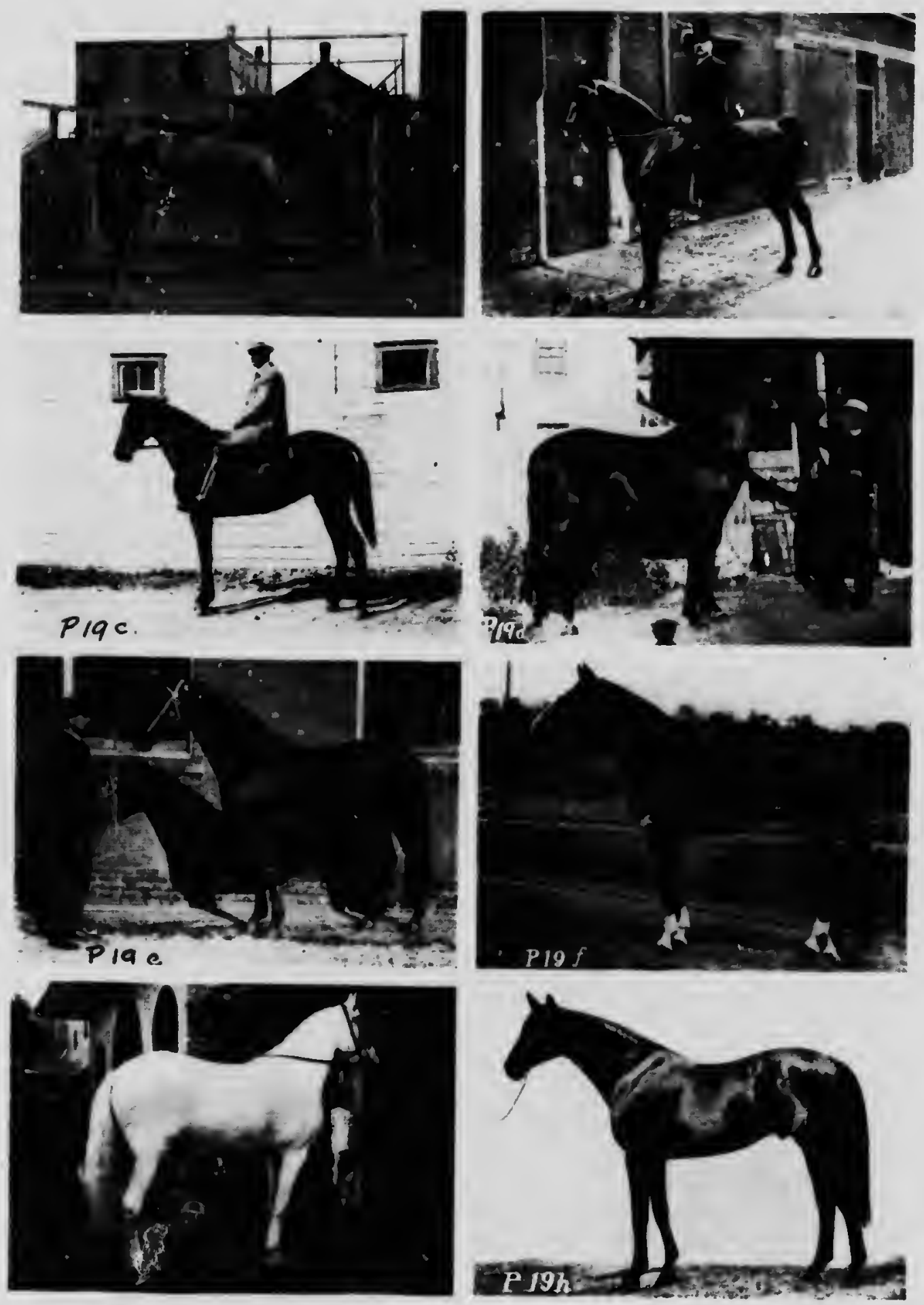

a. Standardfbred Stallion "Cecilian Jay" (43505), owned by Messra. Cose and MeGrepor, Brandon. Man. b. Saddle Hurse, properly of Mr. F. C. Haines. Royal W'ent End Riding School. London. C, Thoroughbred Mare "Joan of Are." owned hy Mr. W. U. Pitfeld, Brandon. d, Standerd.bred Siallion "Lord Bigron," Champion Two-year-old, owned hy Mr. J. Strrey, V'ancouver, B.C. e, "Mhestic." owned by Mr. J. Darrach. Dayton. Ohio. S, Siandard.hred Stallion "Joe Patchen." Sue of "Dan Patch." Courtery of Owner. Mr. W K. Dieterwon. Goothen. N.Y. E, A Rejeh" Arab Charger. Photo:

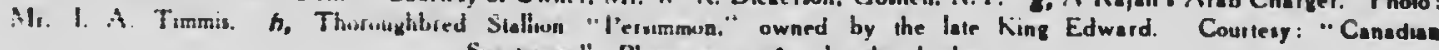
Sportuman." Photos o. c, d, by the Author 
PLATE 211
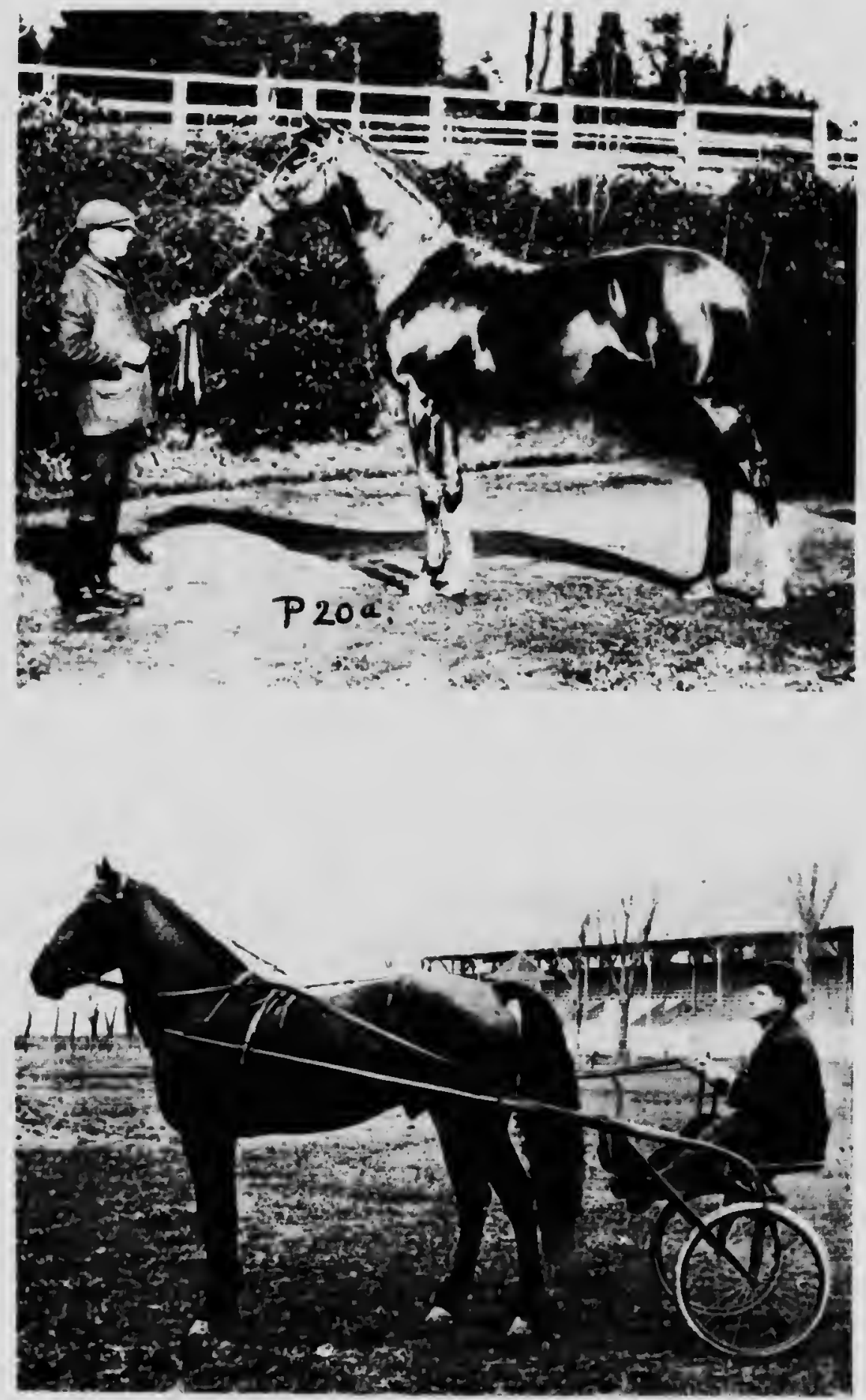

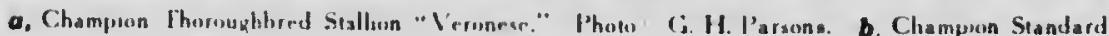
lired Stallun "The Vhoking" Atiles/. Courtesy. Mr B L. Rose, Faulsury, IIl. 
kidneys, and therefore blood, in good order. Overfeeding saltpetre (nitre) will result in serious injury to the heart, etc., of many horses. Any salt of potassium given in large amounts is a poison; loxic doses cause death by gastritis and enteritis and arrest of the circulation. It must not be given in inflammatory conditions of the intestinal tract, kidneys or bladder.

168. Condition Food and Powders.-A good condition food for Saturday night, to be given at the evening meal, is made as follows: Take a bucket of bran, about four ounces of liquorice, and one pound of linseed (ground); pour on enough boiling water to make a pudding, stir well, cover, and feed when cool enough.

Two ounces of linseed oil on the feed every night is excellent for gaining condition and improving the coat. A teacupful of ground linseed will do as well.

A very good condition powder is as follows:

$\begin{array}{lllll}\text { Flowers of sulphur } & \ldots & \mathbf{2} & \mathbf{0 z} . \\ \text { Nitre } \ldots & \ldots & \ldots & \mathbf{1} & \mathbf{0 z} . \\ \text { Gentian root } & \ldots & \ldots & \mathbf{1} & \mathbf{0 z} . \\ \text { Fenugreek } \ldots & \ldots & \ldots & \mathbf{2} & \mathbf{0 z} . \\ \text { Oil of linseed } & \ldots & \ldots & \mathbf{1} & \mathbf{0 z} .\end{array}$

Mix and make into powder; give one tos. spoonful (half an ounce) on damped feed twice a day. Vary dose according to the size of horse. Another good powder is :

$\begin{array}{lllll}\text { Nitre } & \ldots & \ldots & \ldots & \mathbf{z z} . \\ \text { Sulphate of iron } & \ldots & \ldots & \mathbf{2} & \mathbf{0 z} . \\ \text { Gentian root } & \ldots & \ldots & \mathbf{3} & \mathbf{0 z} .\end{array}$

Give two teaspoonfuls at night in feed.

Fowler's solution of arsenic may be given for a week in one drachm (teaspoonful) doses at night ; it should not be given for a Jonger period, as it has a cumulative poisoning effect on the liver. The effects of arsenic poisoning cannot, as a rule, be got out of the system. After a rest of two weeks it may be given again for another week, followed by another two weeks' rest.

16. It must be clearly borne in mind that condition in horses prevents to a very great extent the possibility of galling from ill-fitting saddlery and harness and from bad riding.

Every working horse should be given one whole day's rest once week. The London General Omnibus Company used never to work their horses seven days a week, and there is no doubt that the horses of this company were in better condition than those of many other companies. Il horses have to work on Sunday they must have a day's rest in the week. Every horse-owning firm could arrange this, and it is their duty to do 80 if they study economy and humanity.

It is very essential to attend to the special feeding of horses on their day of rest. They should receive a hot masl, the previous night and be given smaller rations on the holiday. If their usual feed is kept up, on the following day the not uncommon Monday morning ills, as azoturia, lymphangitis, etc., may result. These diseases are a sure sign of neglect or ignorance. Overfeeding in this case is as cruel as underfeeding.

165. Exercise.-Work is that which a horse performs as demanded by man, and may be more than is good for his health. Exercise is that which he performs for the purpose of keeping in good health and for developing his natura] powers. Hence work may be continued until it produces fatigue, but exercise should never bo carried to this extent.

The common fault with grooms is to give too little rather than too much exercise. A horse in good condition requires two hours' good walking exercise a day. Exercise is needed to maintain the balance between bodily waste and bodily repair.

The muscles alone are not affected by exercise, but every organ and portion of the whole body is stimulated in its function, and hence induces a greater blood supply to that part. Secretions and excretions of every kind are increased; poisons are quickly eliminated by increased secretions of the lungs and skin. With fast work a horse may lose five times as much water through its skin and lungs than it does when at rest. This produces health by removing impurities from the system. Hence during hard work and hot weather we must give the horse all the water it will drink, not only to satisfy its thirst, but to keep it in good condition. The same applies to human beings.

Exercise increases the bodily temperature, and, as explained above, cold water is necessary to keep the tomperature down. If hard work is given without water the skin becomes unnatural, hard and dry, but upon water being given soon becomes damp. As long as exercise is continued there is no danger of chill from cold water being given; founder, colic, and other troubles result from hot and tired horses being watered and then left standing, perhaps only for a few minutes. Exercise, as stated before, causes production of heat ; food also causes a production of heat chemically; so that when horses are turned out in cold weather, or when doing slow work in cold westher, they require more food to keep up the internal temperature of their bodies. This food should be of a heating nature, such as beans. (See Sec. 118.)

168. Want of exercise predisposes a horse's tendons, muscles and ligaments to receiving injuries. Lymphangitis, founder and azoturia are generally thie result of irregular exercise and unsuitable feeding. A horse is meant to be at work, and standing idle in the stable is unnatural to him. Exercise places these muscles, etc., in the best state to resist strains, besides being re- 
sponsible for development of new muscle tissue, which is produced partly by new muscle fibres being formed and partly by the enlargement of those already present.

No portion of the muscular system can continue at exercise indefnitely, because the energy it loses while at work is greater than the energy it receives from the bloorl; hence rest is essential. Frell the heart rests butween eacli beat: the period of rest in the heart muscles is about iwice as long as the period of work for each ventricle in turn. Hest is necessary to allow the muscle to regain lost energy; it has also been proved that it eliminates poisons from the system. In fact, fatigue is the result of the formation of poisons in the system.

167. Brathlessness is due to the bloot becoming overloaler with carbon dioxide, the lungs not being able to excrete it puickly enough. The excess of carhon dioxicle is produced by the increased action of the lungs.

Halliburton says that the poison produced in the blood by fatigue is sarco-lactic acid $\left(\mathrm{C}, \mathrm{H}_{4} \mathrm{O}_{3}\right)$. Whatever the poison may be, the best method of removing it is the use of plenty of drinking water. Hence the advantage of watering horses the last thing at night; this applies also to human beings.

Every person should drink a tumbler of cold water before retiring to bed. Nature las made animals feel thirsty when the system requires water. The best method of remoring the poison in the blood proluced by fatigue is to give sorlium salicylate; about half an ounce given in the feed at night will do the horse a great deal more good than giving the usual aloes bal!. When a horse is in bad condition, before being put to work it should be given this salt for four or five days, omitting the dose the day previous to work.

When a horse is fatigued his whole system is fatigued, and therefore his digestive powers will he weakenerl: hence he must be ferl on more casily direstel food and on a lesser quantity than usual.

As in feeding, the essentials in exercising are punctuality and appreciation of the horse's habits and inclividual peculiarities. Great care must be taken that it is ascertained tliat the horse is not of its feerl before it is taken out to exercise.

168. Good food, as oats, stimulates the horse to become excitable to motion; now motion is necessary for the rlevelnpment of the muscles of a young horse, hence the advantage of feeding him at pasture with a little oats every morn. ing. Old horses at rest at pasture do not require oats for this purpose, but may require it if the pasture is very poor. If the horse is unable to be exercised he should have his legs well handrubbed for at least ten minutes to each leg. The leg should also be similarly rubbed if swollen from standing too long or from overwork. The more fresh air the horse gets and the more he is allowed to live as his ancestors did, the healthier will he be. As said above, the horse requires at least two hours' walking exercise a day ; but if he can have three or eien four hours, all the better; this time is better when divided into two periods. Fresh air is essential for good liealth.

The harder work a horse does the more must we try to stimulate the secretions and excretions of poisons; this is most easily and safely done by stimulating the skin secretions, which is best achieved by resorting to much good grooming. The more work a horse does the more grooming he should get; this does not mean that an idle lorse should not be groomed, because grooming is essential to keep him healthy.

169. It is best to bandage a horse's legs while being exercised if the ground is hard. Cottonwool-lined bandages are the best. It has been proved that in order to keep up a horse's speed he must not be allowed to be idle at all; horses that lave been on the race truck or turf year after year liave made some wonderful recorus at ages of flfteen years or more, whilst those that have been irlle for a few years and then raced again have entirely lost their former speed. It is not, how. ever, necessary to keep the horse at fast work all the time. Racehorses are given several hours of slow work every dav, and only one or two sprints a day, and during certain times of the year 110 fast work at all.

170. No good, but much lıarm, will result from trying to hurry a horse at exercise with the false idea that going over more ground will do him more good. On the contrary a walk, and then a little trot, and then more walking, etc., is the best thing. Hurried exercise will make lim thin, tucked up, and perhaps irritable in temper. Exercise should be varied in its form, and different routes should be taken daily. It should be broken up with halts and short grazing moments, when the man must dismount and the girths should be slackened.

Nervous and excitable horses often perspire abnormally; such horses should be carefully ridden by experienced grooms. Everything should be done to prevent this nervous perspiring, as it weakens the horse very much. The example of a well-behaved animal by its side is of great use. The amount a horse perspires while at exercise depends greatly on the weather and humidity of the atmosphere, and horses vary considerably: but generally the sweat of a healthy horse is thin and only slightly oily, and dries quickly, with less liability of a fresh sweat breaking out. That of a soft, unconditioned horse is thick, oily and lathery, which dries only slowly and frequently breaks out again.

171. Modern long-distance rides have shown that a horse lasts longer if cantered instead of trotted, as is usually done. The rate of the 
canter should not exceed eight to nine miles an hour: cantering is the natural gait of the horse. On hard roads, however, cantering throws more work upon the horse's legs than slow trotting.

The following trip of thirty-two miles I made on luard roads with a 16.2 hands thoroughbred horse in good condition in the summer, when there was no mud to soften the surface, and where there was little grass on the sides of the roads to canter upon. My horse had been having eight to ten miles' exercise a day at a steady walk and trot, and fed on ten pounds of oats and twelve pounds of hay a day. My trip away from home for sixteen miles was as follows. I started after lunch.
1.25 to 1.30 walk,
1.30 to 1.40 trot,
1.40 to 1.45 walk,

1.45 to 2.0 troh, finish with a mile canter on

2.0 to 2.7 walk, side of road.

2.7 to 2.18 trot,

2.18 to 2.23 halt, dismounted, fed grass on side of road, walked horse, dismounted, for

2.25 to 2.35 trot, two minutes.

2.35 to 2.40 walk,

2.40 to 2.55 trot (walked down two hills: dismounted on one of these, the other was

2.55 to 3.0 walk, slight).

3.0 to 3.15 trot (mostly),

3.15 to 3.20 walk,

3.20 to 3.25 trot,

3.25 to 3.30 walk.

Arrived at destination, watered, and fed hay. After half an hour fed grain, one gallon of oats with two handfuls of chafl well mixed together.

Started home again 5.30. Arrived home 8.0; slower pace than that of going. Horse in firstclass condition. Next day in like condition, he was walked for one hour. Legs were kept bandaged all the morning. The rate going away from home was about eight miles an hour. which is too fast for an average horse if kept up. Coming home it was six and a half miles an hour.

172. Lending Horses.-Lending horses is all very well in the case of an owner who takes little interest in his horses and who does not care how much they are spoilt; but it is risky unless one is absolutely sure that the horse is being lent to a very competent person who will treat the animal as carefully as the owner wonld. People should know better than to ask their friends for the loan of a horse. It is quite another thing to be offered a horse on loan. Shakespeare tells us that "Loan of loses both itself and friend ; and borrowing dulls the edge of husbandry."
It is not selfish to refuse to lend a horse; on the contrary it shows knowledge of horsemanship and consideration for the horse. The wise horseman would rather hire a horse for his friend than lend one of his own, unless he knew the capabilities of his friend were as good as his own. One ride by a bad rider may cause harm to a horse that will require weeks to undo.

173. Care of Horses on the March.-Under this hearling I include military riding and draught horses on manceuvres or on a campaign, hacks, hunters or carriage horses in civil life, commercial draught horses, farm horses, and every type of horse at work.

There are a lot of men handling horses who should never be allowed to touch them. The Buffalo Horse World says: "They yell at their horses, strike them, swear at them, and other wise abuse them. Gentleness, kindness and quielness are prime requisites in a teamster if he would get most work out of his horses."

Before a horse is asked to make a long march he must be in condition. Cavalry horses on the march walk at the rate of three and a half miles an hour and trot at seven miles an hour, including short halts. The rate of a march, with combined walk and trot, is five miles an hour.

The ordinary walk for a horse is three and a half to four miles an hour; trot, eight miles; canter, nine miles ; gallop, twelve to fifteen, and up to thirty or over on the turf. A distance of twenty to twenty-flve miles per day is a good march for horses day after day, and for this they must be in good condition. Horses must be allowed to go their own rate, and not be continually checked by slower-moving bodies in front. Uniformity of pace, and not a jerky pace, is most essential to prevent tiring of horses.

A pace which is neither too fast nor too slow is essential. Lolling about in the saddle is strictly forbidden, and a sure sign of bad riding and horsemanship. A tired horse, if led for day or part of a day, will recuperate wonderfully.

Before a march or a long ride is taken, special care must be given to ascertain that all saddlery, harness and bridles fit properly, and that horses have no galls or other ailments; also that they are not in any way of their feed. Their shoes must be particularly looked at. An ordinary horse on macadam roads will go 200 to 300 miles on a pair of shoes, but some draught horses will wear out their hind shoes in 150 miles.

Riding horses must be allowed to move on the side of the road whenever possible. Riders and drivers (when on horses) must get of and walk down all hills and up steep hills. They should also walk for a quarter of an hour in every hour, if a long march is being taken, to rest both man and horse. Soft ground should never be overlooked. Halts must be made irequently; a halt every half-hour for five or ten 
minutes is advisable, and one for a quarter of an hour every two liours. A short halt should be made fifteen minutes after starting to tighten up girths and see to the correct fitting of harness and saddlery, etc. At every halt the rider should dismount and loosen his girths, if on a long march. Every opportunity should be taken at all times to allow the horse to drink and graze, never forgetting that the liorse lias a very small stomacli.

174. At every lialt the horse's feet should be examined for loss of or loose slioes, stones in the shoe, etc. Dusty roads should be avoided, and soft roads are always preferable to hard mac. adam roars. If the dist is bad, horses must not be allowed to follow closely behind each other. because, if they do, they will be inhaling a great deal of dust.

Bits, of course, must be removed if horses are given a full drink or when fed grain or hay. If possible, it is best to avoid public troughs, ani to use a clean bucket from a tap. If on active service, horses must always be watered and fed when a chance offers itself, as later there may be a scarcity of forage, grass or water. The horse's stomach being small (one to two gallons), it must be remembered that he should be fed in small quantities, and, as his digestion is continuous (there being no gall bladder to store the bile from the liver), he should be fed as often as possible.

175. On long marches compressed foods may have to be carried, but unless bulky food, as hay or grass, is given as well, horses will never do well on such rations. Horses can be fed grain from a box or more conveniently from a nosebag. Care should be taken to adjust a nosebag properly. At first it must not be too tightly bucklerl "1p, and later, as the horse eats its contents, it must he buckled up higher. A box or log on which to rest the nosebag is very convenient for the horse. Cavalry horses can be coolerl down very quickly while coming home if they are made to move in column of sections (fours), with ten or more feet distance, and ex. tended as much as the width of the road will allow. In crossing a field or common, each section can extend to ten yards interval with much benefit. Cavalry and artillery riters and drivers are usually too severe with their horses in the earlier part of the day, on service or on mancuvres, and by noon their horses are fatigued: a sign of bad horsemanship and lack of common sense.

176. Everything should be done to keep up a horse's spirits on a long trip. I remember, on the trail in Alberta, how I used to whistle or sing while going along alone with my horse. I am sure it used to keep'.p his spirits-because he had not a good ear, possibly. The horse likes company and being spoken to.

When a horse returns from a long trip or from work, as little time as possible should be lost in getting to work on him. In South Africa the Australian horsemen made themselves conspicuous by the way they would attend to their liorses before themselves. Upon arriving home, girths should be loosened, harness removed, and the legs well rubbed down. This increases the circulation in the legs, which is, naturally, weakest at a point farthest from the heart. The legs must be rubbed up, against the coat and in the direction of the flow of blood in the veins; the back must be rubbed against the cout.

On return from work, a horse must be thoroughly groomed. A saddle should never be removed directly, because, after the rider has removed his weight, time must be allowed for the small superficial blood-vessels under the saddle to refill gradually. If this is neglected, these ressels may become ruptured and cause lumps to come up on the back. A great fault in riding a long distance is to ride with stirrups too long, and thereby cause great fatigue to the horse.

A man should not leave his horse, on return from a hard day, to go and refresh himself until lie has properly cared for his horse. The old saying, "What is not inspected is neglected," is worth remembering, and applies very much to a horse at work.

177. Every opportunity should be taken to relieve pack animals of their weight. The pack should be taken of the saddle and the girth loosened whenever possible. The maximum weight for a mule, including the pack saddle, is 160 pounds. No part of the pack must louch the animal, especially over the spine (vertebral column). The weight must be evenly divided on both sides, and not too far forward nor back. It must be entirely taken on the side-bars and arches of the saddle, the former resting on the top portion of the animal's ribs. A mule shows signs of pain very often by twitching his lips and shows latigue by drooping his ears.

It should always be borne in mind that Nature imposes limits on the strength of a horse, which if exceeded will seriously endanger the animal; horses are not machines, and this fact must never be forgotten. Bvery care should always be taken to economise horsefiesh, and only when a crisis arises should the horse be asked to perform abnormal work.

Because a man is a good rider it does not follow that he is a good horseman; successful horsemanship is a rare art, and should at least be studied by every lover of horses. In no case is it so important as in that of a cavalry leader on service, the whole eficiency of his arm depending on his knowledge of horsemanship. The results of the appalling examples of horsemanship during the South African war are well known, when over a third of a million horses 

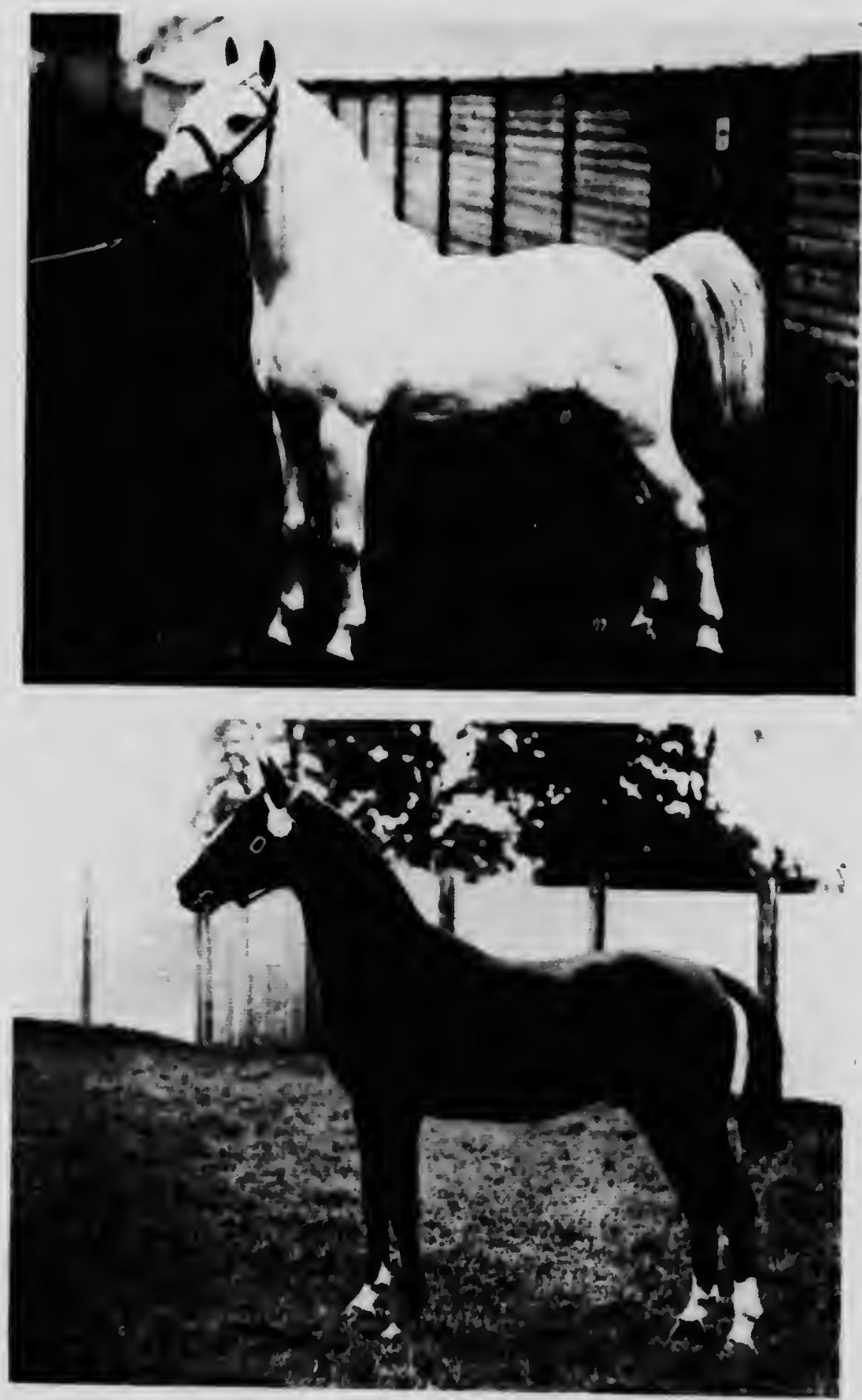

a, Weish Polo Pony "Grey Ligh,", Champion l'oto P'ony of Europe, 1910. B, Champion Polo Pouy Siallion "W'hite II'ings" Photos: C H. Parsons 
PI.AT: 22
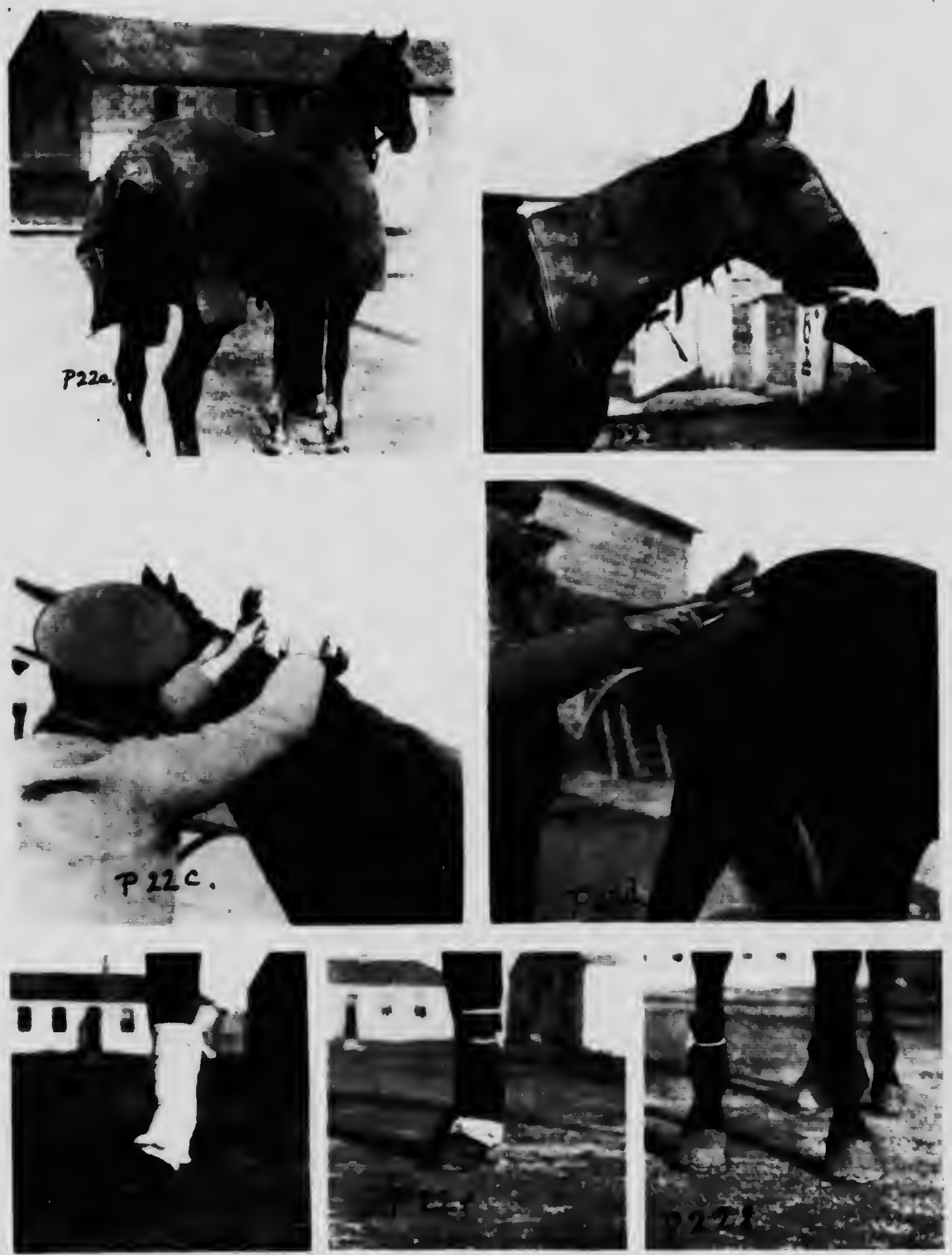

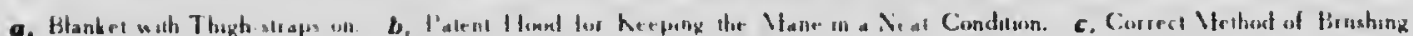

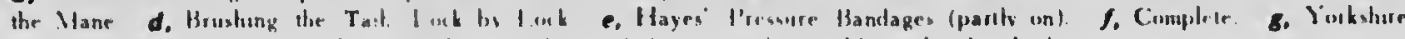

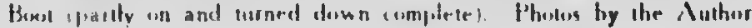


died or were killed. The best way to encourage soldiers to look after their horses well is to give them the same horse all the time, and offer little prizes for the best-kept horse.

Grooms should always be encouraged by being praised for good work and reprimanded for bad, and so on. A feeling of proprietorship must be inculcated in the groom or cavalryman, as thereby he will take great interest in his fourlooted friend. Nothing destroys this most essential spirit more than the feeling that horses can easily be replaced.

178. If not Iresh from the stable, a horse will stand a great amount of exposure to cold: there. fore it is essential that, before he ls to be exposed, he should be gradually acclimatised.

Horses cannot, however, stand heat in the same way. Sunmer heat will very soon make a horse sick, or even cause his sudden death. If horses are in poor condition, or are not given sufficient water, fever will set in, and become worse and worse; at ni.ghts their temperature will drop generally, nearly to normal, and rise again on exposure in the daytime. Hence, the being kept in a cool stable, quiet and well cared lor, will generally cure such cases, with the asslstance of a little medicine. The symptoms are not always easy to diagnose, as the horse's appetite does not, as a rule, show much change. (See "Sunstroke," Sec. 615.)

179. IIorses in Camp. - Wherever possible, horses should be placed in billet (i.e. in a stable) when on service or on a long march; thereby they will get better rest and be fit for more work the next day. If a horse has to be picketed, he must be secured in a way in which he will be less likely to cause harm to himself; next to this his own comfort must be considered. His hind and fore feet should be on the same level. If many horses are picketed together, they should have one hind leg shackled to a heel peg to prevent them trom kicking one another. The shackle must be above the fellock, and on no account below it. If space admits, they should be secured with a strong head-collar and rope to a stout post driven well into the ground, the best form being one with a ring in the top, so that, however much the horse twists around the post, he will not shorten his rope, as he would if tied to a tree.

The head-rope should be just taut when the horse is standing naturally, and a shackle rope should be pegged directly in the rear of the horse, and should be just taut when the horse is standing with his head over the picket peg. A shackle should be of leather, well dubbed, and should be buckled so that the buckle is outside, tight enough only to prevent it from slipping below the fetlock and causing a sore heel. (See P. 31.)

180. The sanitatiofi of a camping ground must always be considered; a gentle slope will facilitate drainage. Manure should be removed at once and taken a long distance away, as it attracts fiies. Chloride of lime or paraifin oll (coal oil) should be sprinkled about to keep nies away. Fly-sheets or nets should be used in hot countries at night or whenever exposed to fies. In windy weather in camp, hay may have to bo fed in hay-nets to prevent it being blown about. Thigh-straps must be placed on all blankets and sheels that are used in camp to prevent wind blowing them up. Sometimes it is necessary to hobble a horse or to knee-halter him, while grazing, if there are no fences around the pasture. The best kinds of hobbles are leather straps with sheepskin lining. rings being attached to which the rope or chain is lastened. Both forelegs, or a foreleg and a hindleg, may be hobbled together. The length of the hobblerope depends on the horse; some horses can move very rapidly with even a short hobble-rope on. Knee-haltering is done by attaching the head at the back of the nose-band of the halter (i.e. the lower gullet-ring) to just above one knee, the length of the rope allowing the horse to reach the ground with its teeth. Knee-haltering is good, and causes less inconvenience to the horse.

The space allowed for each horse in pickets should never be less than five feet in width and twelve feet in length. An interval of four to five yards should be allowed all around the lines. If horses are picketed in two rows, they should stand tail to tail, unless there is a prevailing wind in one direction, in which case they should all stand with their tails to the wind. A gang. way of five yards should be left between the two rows, in which saddlery and forage could be kept.

181. Transport.-A few remarks on transport by rail and sea will be of use. Before sending a horse on a long journey, if hard work is required of him on arrival, he must be hard and fit before he goes on board; he must not be let down in condition. It is essential, however, that horses' bowels are free, and therefore a laxative diet should be given for twenty-four hours previous to going on board. Just before going on, horses should be watered, fed grain and given hay, which will tend to keep them quiet when they get on board. If horses are slung on board with derricks, they must not have been watered for two hours previously, or the large intestine may become ruptured.

Old horses should be led on first, and young ones will then generally follow. If a horse refuses to go on baard or to enter a train car, the best method is to pass a thick rope around his hind legs, behind the stifie, and for three or four men on each side to pull the horse gently forwards. He must not be jerked, so as to cause any fear. Pulling at his head or whipping him will do more harm than good. He should be 


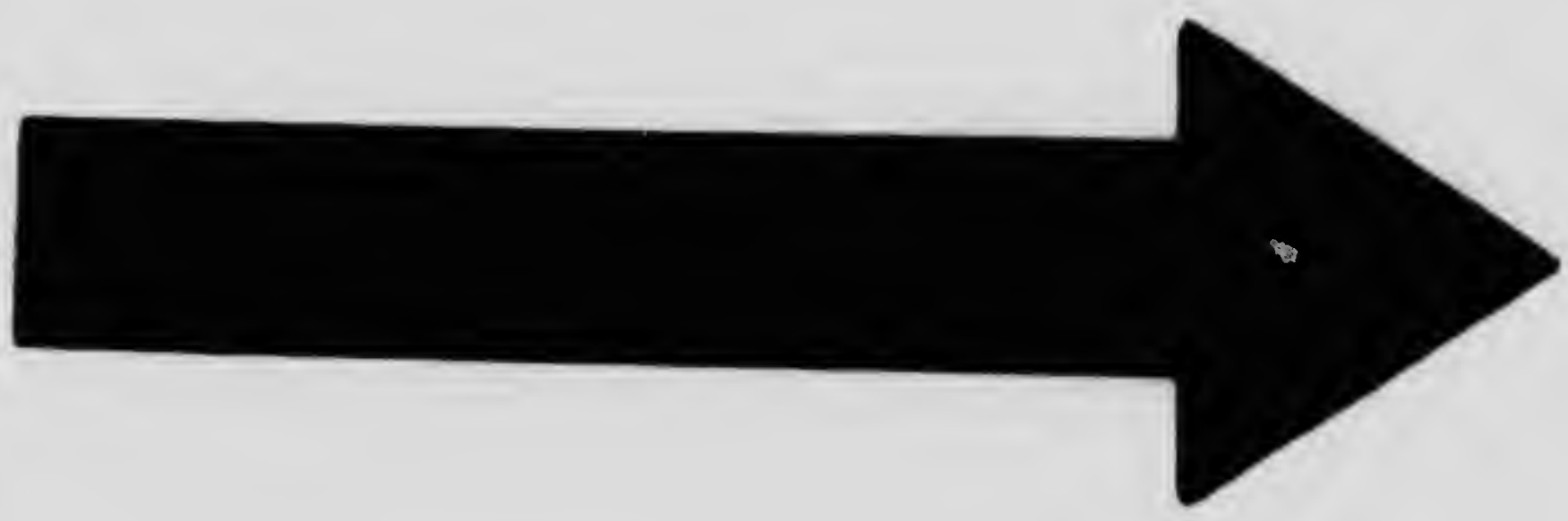



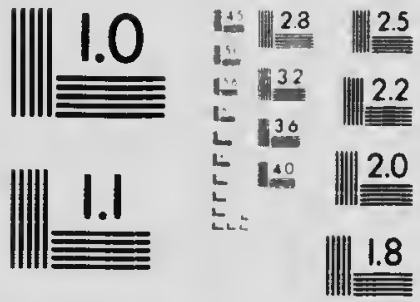

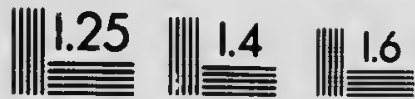

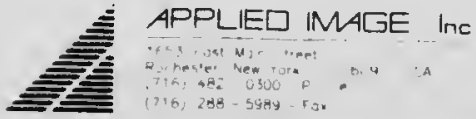


made much of when inside so as to encourage him next time. Backing him in is unnatural, and therefore should not be done. We must try to associate entering a train with pleasant sensations at all costs.

On board ship foothold should be obtained by spreading sand, asles, litter, etc., in the gangways and in the stalls. This should also be done in railway cars. The sight of a bale of hay will encourage many a refuser to change his mind. Some horses may have to be blindfolled before they will go on to a ship or train. Inother method is to pass a thick cord under the tail, and to pull it gently on each side; one man on each side is sufficient, care being taken not to rub the tail.

182. Harness and saddlery will be stored in separate places, except on short journevs of a few hours in the train, when a horse may travel saddled up or with its harness on; but girths must be loosened. It is always better to unsaddle and to put a blanket on the horse. A horse's legs should be bandaged, preferably with cotton-wool inside; and it is advisable to bandage the tail either with a flannel or cotton bandage, or to use a special leather tail-guard sold for the purpose, to prevent the tail becom. ing rubbed. (See P. 24c.)

Stalls and horse-boxes should be kept as clean as possible, and every opportunity taken to exercise horses. Great care must be taken to ensure proper ventilation on a ship or train; sickness on board is usually the result of great heat and bad smells, due to lack of ventilation. Stalls, decks, and horse-cars should be whitewashed before a horse is placed in or on the same.

If weather permits and there is deck space, horses should have an hour's walking exercise every day. When on the railway they should be taken out daily, and if possible walked about for half to one hour. They should be watered on such occasions if it is possible. Feeding will be carried on in the train with nosebags en route, unless halts are long and the horses can be taken out. Nosebags will be filled in the forage cars and put on the horses at a convenient stop. Great precaution should be taken against fire, and therefore no hay or straw will be allowed in the horse-rars as bedding. When mangers are supplied, only a little ilay will be placed in them at a time. The risk of fire on board ship is considerably less than in a car, where it may be impossible to reach it.

Except on very small ships that roll very much, horses as a rule are quite safe in a wide stall (say, $4 \mathrm{ft} .6$ in. in width), so that they can lie down in calm weather (they will seldom to so in rough). In a vessel of, say, 7,000 gross tonnage, in a rough sea, there is absolutely no need to sling a horse unless it is sick. The law should rompei all horses to be allowed at least ift. width, also require a passage along behind each horse, so that the stalls can be properly cleaned out every day. Horses should not be allowed in any part of a ship where there are no port-holes, except on short journeys of one or two days.

The front of each stall should be movable, to allow each horse to be taken out for exercise. Passages should be wide enough to allow for exercising. The partitions between stalls must reach to within one inch of the floor. If there is more space than this, the not uncommon occurrence of a horse getting a leg under the partition, and being unable to get up, will follow. The partitions must reach to a height of $5 \mathrm{ft} .6 \mathrm{in}$. to prevent horses biting at one another, which is a common trick learnt on board ship. The partitions should be made of timber 2 in. by 6 in., with a space of 6 in. between each piece to allow for free ventilation. Straw must be spread thickly on the floor of the stalls. Each stall should be arranged so hat, in the event of the sling being used, an extra partition can be added to make the stall sufficiently narrow.

183. On board ship horses are generally re ceiving at the most only light exercise, and their usual ration varies, according to size and condition of the horse: 3 to $5 \mathrm{lb}$. of oats, 5 to $6 \mathrm{lb}$. of bran, 10 to $12 \mathrm{lb}$. of hay, per day.

Oats should be crushed if possible, and great care taken that every horse is kept free in his movements, any sign of constipation being checked by gruel and mashes, and not by medicine. Carrots or other roots, about one pound a day, should be given, and rock salt as well, or in lieu of part of the oats.

The system of keeping the stomach full while on board ship does not apply to a horse, as normally he cannot vomit. I have only once seen a horse vomit like a human being; then his stomach was ruptured, and he died in ten minutes.

During rough weather men should remain with their horses. On the railway horses are generally placed either in proper horse-cars fitted up or else in long box-cars; in the latter they should be placed as close as possible to one another, with heads untied, and facing away from the other track. Quiet horses will be led in and placed at opposite ends, and the car filled up to the centre. Great care must be taken to see that all doors are properly closed and that the gangway is safe and attached securely before horses are allowed to cross it. The finest horsecars that I have ever seen are those of the Canadian Pacific Railway. P. $89 b$ shows one of the latest types, which holds sixteen horses of moderate size, or twelve large draught horces, the partitions being movable so that they can be placed in any position: mangers and watering-troughs are provided. These cars are rightly called palace horse-cars. 
184. On reaching their destination horses will be gradually brought back to their good condition by judicious feeding and exercise. If, however, the journey has been calm and the horses have received good exercise and a good amount of liard foorl, they will not have lost much in condition: ' ut if they are in bad condition on landing, : ieral days will be required to allow the horses to stretch their legs and to prevent the risk of fever in the feet. Unshod horses that have worn their feet down considerably should not be shod for several days. It will take considerable time to get these horses into condition, and steady gradation must be adopted.

185. Swimming Horses.-A few remarks on swimming may tend to relieve the horse of some mistakes displayed in this art. The horse, naturally, is a very powerful swimmer, and can carry a man in the saddle if its mouth is not interfered with. Horses are often afraid to enter the water alone, and should in this case be coaxed to go in after an old horse, and on no account should it be driven in, which would cause fear. The rider should be able to swim himself, and when in three or four feet of water le should slip off the back. Normally the saddle and bit will not be on the horse, the bridoon-rein alone being used, the rein being knotted to prevent it becoming entangled in the horse's forelegs.

Directly the horse commences to swim the rider will swim or float by the side and hold on to the mane just in front of the withers. With some horses it is possible to swim behind the horse, holding on to the tail. The horse should not be guided by the reins, which must be left alone, and on no account must the rider hold on to any part of the headgear, because he may pull the horse's nostrils under the water and possibly drown him, or at any rate frighten him. He should be guided by splashing water against the neck remote from the side he is required to go towards. If the horse swims well towards its destination the rider should merely float by the side of him.

Horses may be made to cross a river by being led with a rope from a boat, in which case the rope should be tied around the neck by a knot that cannot possibly slip and strangle the horse. Care must be taken not to pull the rope taut and so run the risk of pulling the horse's nose under water. Horses may be driven into the river and kept from going up or down stream by ropes stretched across; horses should stalld on the opposite bank as a guide for those swimming. Another method is the use of the endless rope that is rotated from both banks, the horses being attached at intervals to the rope, and thus gradually led across the water. This method is a rapid one once the rope has been stretched across. It should be remembered that when a horse is in the water he cannot see very far ahead of him, as his eyes are near the surface of the water, so he may not be able to see the opposite bank at all, and he may therefore commence to swim in the easiest direction, which will be down stream.

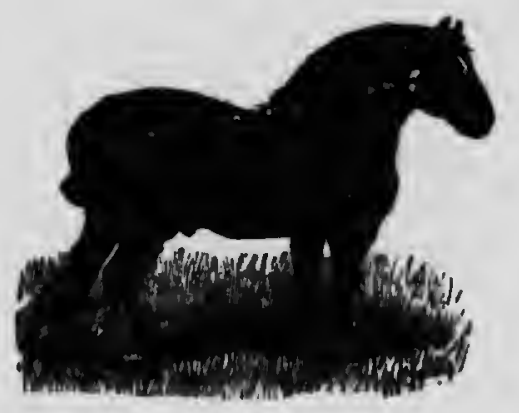




\section{CHAPTER V}

\section{GROOMING AND STABLE MANAGEMENT}

186. The Theory of Grooming the Skin.-The functions of the true skin (the dermis) are: To act as an organ of touch; to rernove poisons from the system; to give off perspiration, and thereby keep the system cool; to secrete oil, which is essential to keep the hair in good condi.io? and to prevent friction on the inner po: i nns of joints; and to form the epidermis, wluch includes the outer skin, hair, hoof, horn, etc.

Perspiration is visible and invisible, the former being what we generally call sweat; the latter is very thin, and contains about 99 per cent. of water. Perspiration is given off by the blood. The free use of water will increase the amount of lood, and thereby increase the perspiration given off, and ennsequently promote good health. When this moisture reaches the surface of the skin it evaporates; the rate of evaporation increases pro rala with the dryness of the air.

187. Heat is required to change a liquid into a gas, and therefore this liquid abstracts heat from its surroundings in order to change into a vapour; hence the skin is cooled down by this evaporation, and the blood in the superficial blood-vessels, just under the skin, becomes cooled, which cools the whole system. Therefore it is clear that the more water given in hot weather the more easily will the horse's system be kept cool. For this reason horses cannot stand damp heat, because, on account of the great. humidity of the atmosphere, evaporation will be very slow ; but in a dry heat the air is dry and evaporation very rapid, the skin normally appearing quite dry. Although the perspiration is invisible, it is going on all the time.

Perspiration is caused, as stated above, by an increased supply of blood, and also by the stimulation of the nerves governing the secretory glands (sudoriferous or sweat glands). It may also be increased by emotion, external heat, muscular exercise, poisons, and nervous affections due to ill-health or fatigue. Cold-sweat is a sign of ill-health, because it is produced when there is not an excessive blood supply in the system through nervous derangements, and upon reaching the surface undue cooling down results from there not being sufficient blood in the superficial blood-vessels to regulate this cooling. We gather, therefore, that with hard work the more water a horse gets the better his system will be. The cleaner the skin of the horse the better will these functions be able to be carried on, hence the necessity for plenty of good grooming. The last-named two functions of the skin, i.e. to secrete oil and to form the epidermis, are stimulated by grooming; in fact, grooming is the most valuable means of keeping a horse in good health and in good condition.

188. Before dealing with grooning let us consider some facts about the horse's coat and hair. The coat has two lalechanical functions-to protect the body from injury and to keep the body warm. The skin is thickest where it is most likely to be injured, i.e. on the limbs and also on the back, and thinnest in between the limbs and inside the joints. Its appendages are hair glands, horn, and hoofs. As stated above, the true skin produces all these appendages as well as the outer skin (epidermis). The skin is divided into the true skin or dermis, and the epidermis or cuticle. Friction on the epidermis causes the dermis mechanically to produce a fluid, and this is what we call a blister, one of Nature's protections against injury.

The epidermis is an epithelial structure which is continually growing outwards, the outer layers are always becoming drier and drier until they flake off in the form of dandruff ; good grooming is most essential to remove this. The epidermis is not vascular (supplied with blood) and is nonsensitive. The dermis is highly supplied with blood and nerves, and its glands are of two kinds. Firstly, there are the sebaceous, which secrete sebum, an oily fluid (two of these glands leading to each hair follicle) which keeps the hair lubricated, supple, and glossy. Good grooming is essential to stimulate the action of these glands. "Scratches" in horses is the result of dirt being allowed to clog up the ducts of the glands, which arrests the flow of sebum and causes an inflammatory condition; hence the need for keeping the horse's heels clean. Secondly, there are the sudoriferous glands, which secrete perspiration. Perspiration contains salts. water, and impurities. The glands are deeply seated in the dermis, and exist all over the horse's coat. They are most numerous at the base of the ears, on the sides of the neck, 

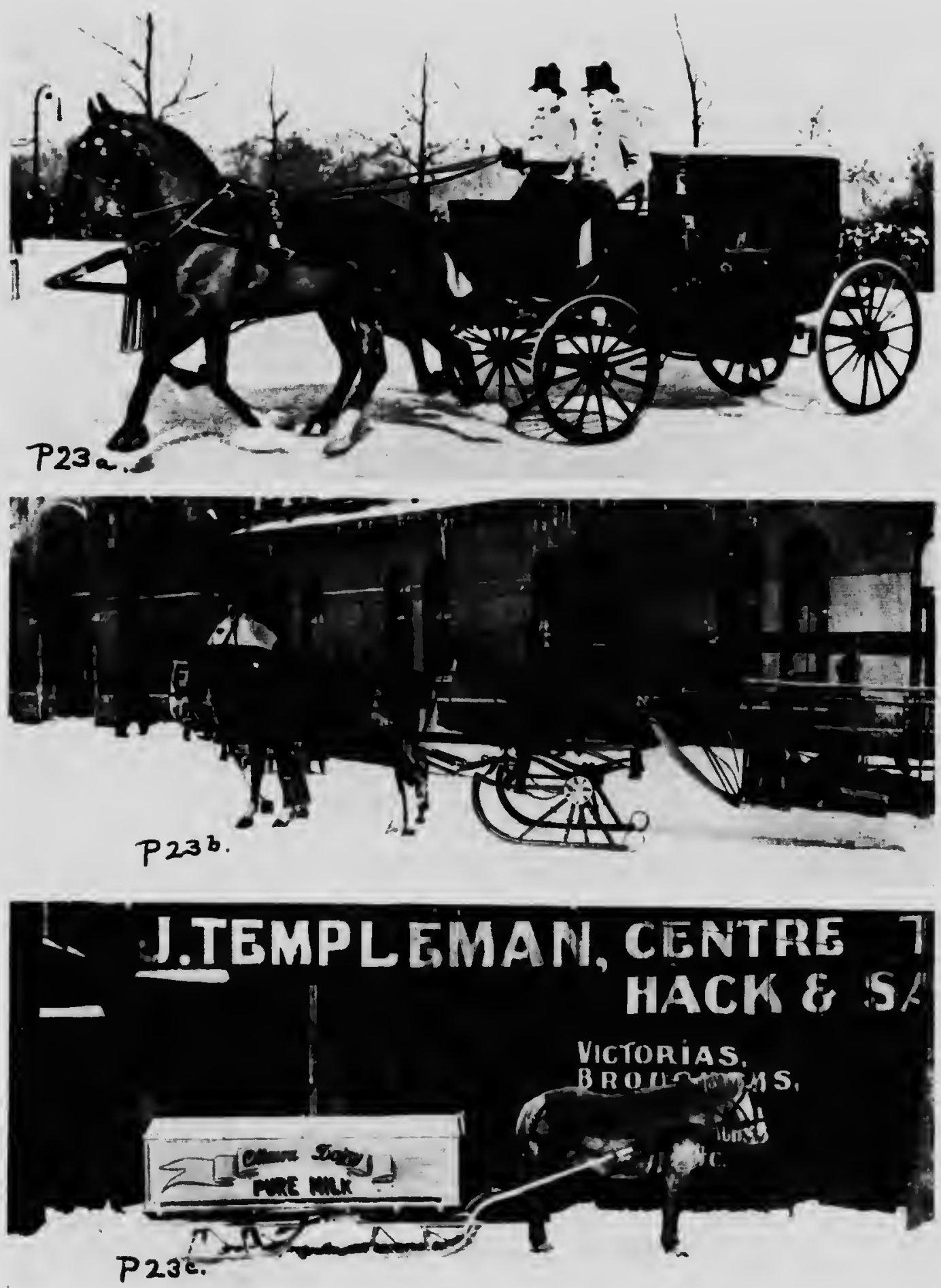

CLOTHING

a. Lomelorh. HM. The King Driting frum Marborough House. Photo: L. N. A. Fleet Strect. b. Woullen Blanket, Ottawa Fire Dept. c, Waterprool Sheet, Lined with Wool, Ottawa Dairy Co. Photos by the Author 

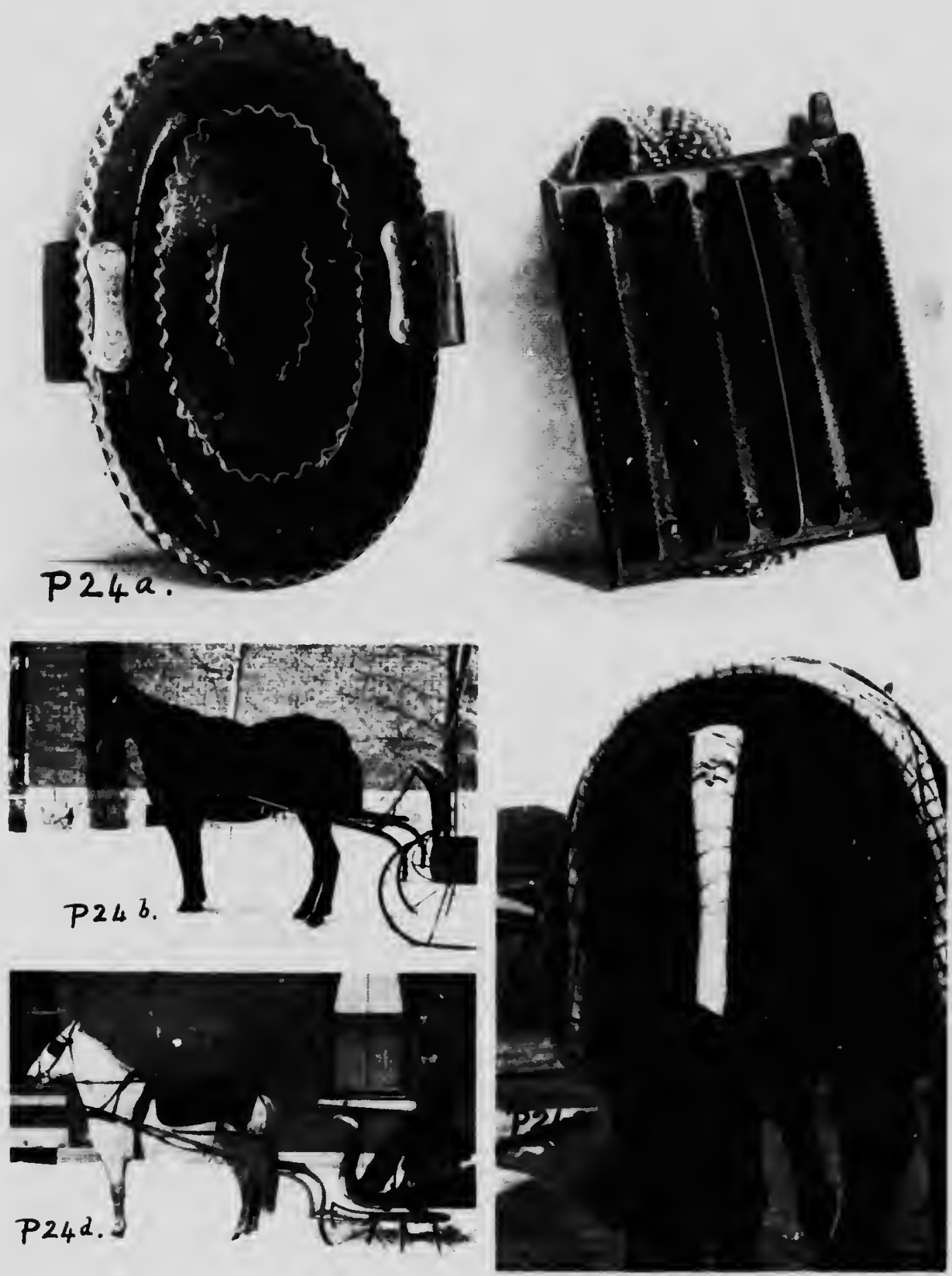

GROONIING AND CLOTHING

a, Oral-shaped Curry Comb and Strazgat Toothed Curry Comb. h, Fur Robe, in use in Winter while Horse is left Standing c. Iaul Bandaged for Travelling. d, Louncloth for Commercial Horses. Courlesy: b. Mr. Landreville, Ottawa. d, Mlessrs. Slinn-Shouldis $\mathrm{C}_{0}$., Ottawd. Photos by the Author 
on the flanks, and on the chest. A horse always perspires at the base of the ears first, irrespective, of course, of the sweating under the saddle, which is produced by the pressure of the saddle and the absence of evaporation.

189. A horse's perspiration should be thin and should wet the coat without in any way standing out in small, globular beads. The presence of such beads indicates over-exertion or ill-health, not uncommon with young horses when first trained. It is very difficult to make a horse perspire by the use of medicine, but comparatively easy by the use of heavy clothing.

180. The Hair.-The hair of the horse is of three kinds: Temporary, all over the body, shed in spring and partially in the autumn; horsehair or permanent hair, mane and tail and fetlocks ; tactile, or feelers, surrounding the muzzle and eyes; these last have a very good nerve supply.

The hair develops as it is required, to keep the horse warm. Grooming tends to keep the coat thinner by removing loose hair.

Each hair, of whatever kind, consists of a follicle or bulb, a root, and a shaft. The hair grows from the follicle by layers of cells, one after the other, the new ones forcing the old ones outwards. Hair has been known to grow over six feet in length. Its length as a rule is limited, but if hair is cut short it will grow again to its previous length. Similarly, if hair is pulled out by the roots, the follicle will grow nother hair, which will take a lew days to nıake its appearance at the surface. The hair shaft is hollow and contains the colouring matter. A hair projects obliquely, and not at right angles to the surface, and also has a small involuntary muscle (erector pili) attached to its follicle, which contracts when the animal is cold or frightened, causing the hair to stand "on end."

191. The black hairs of grey horses gradually become white as the horse gets older; this is due to the black matter, called melanosis, being taken by the blood for some unaccountable reason and deposited in places, such as near the root of the tail. There it forms melanotic tumours, which, if opened, show a black, tarlike fluid; these tumours ere difficult to heal. The skin of most horses is black, which serves as a better protection against the sun, as the colouring matter which is situated on the inside of the epidermis prevents the rays from reaching the dermis. If the rays reach the dermis it will form a blister, as is common with white-skinned horses. Most white horses, fortunately, have black skin.

The "chestnuts" that are seen inside the fore limbs above the knee and inside the hind limbs below the hock are appendages of the true skin. The ergots at the back of the fetlocks are of the same character. These are all supposed to be remains of organs peculiar to the horse's ances. tors. (See Chap. II.)

192. Exfoliztion of Skin and Hair.-The outer surface of the epidermis and ends of the hair respectively are removed by exfoliation, i.e. the outer layers being rubbed off by friction. Grooming and any form of friction tend to do this. Grooming makes the coat fine and short. Exfoliation of hair is shown by the end being tapered. The horse's hoof exfoliates in a like manner unless he is shod, when the excess of horn will have to be removed when the shoes are replaced once a month. Perspiration stimulates exfoliation. Thus we see that good grooming hastens exfoliation and also improves the condition of the coat by increasing secretion of sebum, but does not increase growth of hair, as is commonly thought. The nourishment which the under portion of the epidermis receives is the lymph from the dermal lymph vessels, which escapes through the walls of these vessels. The outer portion of the epidermis has no such nourishment, and therefore dries and exfoliates.

Continued pressure or continued irritation, if not too severe, causes increased supply of blood to the dermis and lymph to the epidermis, and hence increased growth of the latter, which accounts for the thickening of the skin under the saddle or harness and the thickening of the palms of our hands with manual labour. Intermittent pressure causes a still greater growth of the epithelial structure, as we see in the case of a corn. All these growths are pure hypertrophies (over-growths) and not diseased growths.

193. Breaking out into cold-sweats results from the sweat glands being stimulated more than the bodily temperature is raised; a hot stable or too much clothing may cause this. The best cure is to remove the cause and to give friction to the body in the form of hand grooming, or to give exercise.

From the foregoing remarks it will be clear what a beneficial effect grooming has upon a horse's entire system and, therefore, how necessary it is for a horse to have grooming of the right kind to keep in condition and free from chills and other diseases. Neglect of grooming when a horse returns from hard work may result not only in a severe chill, but perhaps in congestion of the lungs and diseases of the liver, etc. The physiological action is as follows: violent exercise causes an increased supply of blood to the muscles and surface of the body; but if a horse's surface is allowed to becomo chilled, as often happens when hunters return home in a cold horse-car, the blood at the surface is driven inwards, and congestion of the lungs or liver may result. If plenty of water is given as soon as possible, this internal congestion may be checked by stimulating the action of the sweat glands, which will again cause more blood to 
flow to the surface. In addition to this, exercise or vigorous rubbing down all over the body should be resorted to at once, thus stimulating the blcod supply to the surface of the body.

184. A point worthy of note to those who live in countries where the winters are cold is that when an organ or muscle has been emptied of its blood through cold, as in a frost-bite, the blood upon returning suddenly may rupture some of the vessels and cause severe inflamma. tion with violent pain, and possibly gangrene (local death); so, to avoid this, the blood must be allowed to return slowly; this is best accomplislied by rubbing the affected part with snow. I have experienced this pain and inflammation niyself, so well know the value of remembering the remedy.

195. To recapitulate, grooming is necessary with horses kept under civilised conditions, for the removal of dirt and dandruff (dead epithelial cells of the epidermis), to keep the coat short, to stimulate the action of the skin glands and oil the hair, to increase the blood supply to the skin, and to stimulate the functions of the whole body.

The lazy groom who has no knowledge of physiology, not being ivatched by his more ignorant master, removes the outer dirt, but does not groom the horse. In no place is grooming carried on better than in first-class racing stables, because without it the horses could not be kept in condition; the extra expense of keeping grooms and strappers counts for little. This last item, however, counts considerably in large commercial stables. Messrs. Tilling, of Peckllam, inform me that their horses get twenty minutes' grooming by machinery every day. I am sorry to say that most commercial horses do not get as much as this. Twenty minutes' grooming by a man who knows how to use the brushes and his weight will do more good than two hours of brushing by a man who does not know. In fact, however long an amateur grooms a horse he will never produce the same effect ; the secret of good grooming is rapidity. It can only be learnt by watching others and by considerable practice. A good groom should groom a horse thoroughly in one hour.

196. Method of Grooming.-In grooming, the whole weight of the body should be used on the brush; I do not believe a man can groom a horse properly unless he perspires himself. Always commence with ench brush or cloth on the near (left) side at the head, and work right down the neck, shoulder, and foreleg, then the trunk, hindquarters and hindlegs. Hold the brush in the left hand if working on the left side, and vice versa. Then do tho off side with the same brush; then start on the near side with the next brush, and so on. If $a$ horse is very dirty and the weather is cold, start on him as soon as he comes inte the slable; rub him all over with a wisp of straw, par- ticularly on the muddy parts, thus removing mud and drying him as well. The fact of rubbing the coat, without even grooming so far as to dry it, will set up increased circulation and prevent chill. The best way to dry a horse is to hand-rub him all over. This is done with the palm and open fingers in the same way as massaging is done. It will not harm a horse to sponge him down when he comes in hot, provided this is done at once, followed by a brisk rubbing down.

Hand-rubbing at any time is of the greatest use, although seldom resorted to on account of laziness. The value gained from it is well worth the time spent. Twenty minutes' hand-rubbing every morning is of the greatest benefit. To get a really good glow on a horse's coat, two men must work, one on each side, and it will take them half an hour. One man working for one hour would not produce the same effect. Horses' feet must be picked out thoroughly in the commissures morning and niglit and after exercise. The feet should be thoroughly washed out with a water-brush and clean water every morning and on returning from work, or at least every morning, as it is necessary to remove all manure or wet straw from the clefts of the frog; such impurities if not removed will dissolve the horn. Clean water will never do any harm, but it should not be allowed to get on to the heels.

197. In grooming a horse, he must never be ill-treated; he should be always gently yet firmly treated, so that he can associate grooming with pleasant things, and thus not object to being groomed, as so many horses do. A horse should never be groomed while he is feeding oats, but he can be given some hay while being groomed. Grooms are too fond of washing the legs in muddy weather. This is not to be roccmmended, as it tends to get rid of the natural oil from the coat. Good hand-rubbing with straw, and then brushing with a dandy-brush, should be sufficient. White legs, of course, require washing more often. If washed, they must be thoroughly dried, especially at the heels, if the hair has been trimmed; dry bran or sawdust is good to assist in drying. Horses that return with wet legs should be rubbed down sufficiently to take the worst off, but experience has shown that if the stable is comfortable and free from floor draughts, cracked heels (scratches) are far less common if horses' heels are not dried, whether they are clipped or not. This holds good even during the Canadian winter, but does not refer to legs that have been washed. If the heels are dried they must be dried properly.

When the saddle is removed, a wet patch is sometimes found underneath. This should be hand-rubbed or wisped against the coat to increase the circulation and prevent cold and the formation of lumps. If a saddle is removed from a horse directly it is brought to the stable, 
vigorous hand-rubbing should always be given. This, of course, is necessary if the horse has been mounled for some time; if it has been mounted for only half an hour, the saddle could be removed in a few minutes after loosening the girths without resorting to hand-rubbing. The dauger of removing the saddle suddenly after the horse lias been ridden for some time is that the emptied blood-vessels under the skin (which have become so emptied owing to the rider's weight) will become filled so rapidly that they are liable to be ruptured, producing small lumps. If a horse is brought in wet from rain or perspiration, the saddle is generally removed immediately, and vigorous hand-rubbing or wisping resorted to until the horse is quite dry. Afler the horse is dry, the dandy-brush (if not already used) should be used on the left and right sides; this should be held and used in the same way as one holds and uses a clothes-brush in brushing a cloak. In brushing the back and hindquarters this brush should be changed to the other hand, i.e. in the right hand, if grooming the left side. Then use the body-brush and curry-comb, the latter being used merely to scrape the dandruff out of the former, and not used on the horse. The body-brush should be stiff and flat, and should be used in a circular or to-and-fro manner, according to circumstances, so as to work out the dandrufi and stimulate the sebaceous glands.

198. The mane and tail should then be cleaned. A groom should bear in mind that the way to brush a horse's mane or tail is totally different from the way we brush our own hair. Except merely to straighten down the hair, the brush should not be used on the outside. Few grooms (outside the army) know how to keep a good mane and tail in proper order; most of them brush out the hairs and do not remove the dandruff. Each time the dar.dy-brush is passed down, several hairs come out, and the tail gets thinner and thinner, as it takes considerable time for new hairs to grow. The tail and mane should be brushed out, lock by lock, at the roots. Commencing at the top of the tail, the roots of tlie hairs are reached by raising the hair in small locks, and thus exposing the roots below. The brush is thus gradually worked down to the end of the tail, travelling across the tail in successive layers. If the tail is neglected and becomes very much matted, it should be well washed with warm water and castile soap, and, whell dry, gently combed out. A well-kept tail does not require a comb to be pulled through it, causing a large number of hairs to go with the comb. A tail should be washed once a week by dipping it right into a bucket of water, and well washing it with castile soap, afterwards well rinsing it.

189. A long, white tail (as in P. 1a, 18b, 48h, 1 ifor) is generally plaited up in muddy weather, but when it gets dirty it can be dipped into water, well soaked, and washed out. Such a tail, especially with a mare, if loosely tied up into a knot at night will prevent it from becoming soiled. It is not advisable to plait a tail at night, as some horses will not lie down with their tails plaited up. A loose knot in the hairs below the dock should not worry the most nervous horse. Tight plaiting left over-night is, of course, most dangerous.

In washing a tail the soap must be well rubbed into the roots to remove the dirt, therefore cheap soap must not be used, as the excess of alkali in such soap will cause irritation to the skin. Likewise, the soap must be well rinsed out. The long hairs of the tail sliould be brushed out daily with a dandy-trush, which should be damped with petroleum (lamp oil) to prevent the hairs being pulled out.

Similarly, the mane is brushed ont lock by lock from the roots and washed by means of the water-brush; with a little practice a mane and tail can be kept in perfect order very easily, and can be washed out without spilling the water over the horse's quarters and neck. This is only learnt by experience.

200. Then the eyes, mouth, nostrils and under-part of dock should be sponged out with cold water. This is most refreshing to a horse, which is often neglected by lazy grooms. The horse misses his sponging as we miss our morning bath. Then the feet should be picked out with a hoof-pick, and washed inside and outside with the water-brush. The grooves between the bars and frog and the cleft of the frog must be thoroughly cleaned; neglect of this operation is often the cause of thrush, eti.

Then the hay wisp is used all over the horse in the same way as a brush is used, the whole weight of the groom being put into his work. Lastly, the rubber is used all over the horse.

Before putting the horse back into his stall, the blanket or rug is put on, and the mane and tail brushed lightly down the outside to make them tidy.

201. In the cavalry the feet are generally washed before anything else, and the hay wisp used only at evening stables. The hay wisp should be slightly damp to collect the dust. Tails and manes-should never be combed out roughly; the comb should only be used very gently to disentangle hairs. A swish tail may be shortened, or a banged tail may be swished, by the use of the comb. For the same reason, as stated before, the brush should not be used roughly on the outside of the tail, unless it is required to make it thinner. In using the comb, it should be held lightly in the fingers and worked downwards slowly, in easy, jerky movements, as if the comb were made of brittle glass, thus avoiding dragging out the hairs. Great care should be taken not to tie a horse up to the pillar reins so that he can rub his tail against the 
manger, or to put a horse that is liable to rub his tail into a loose box (box-stall). Aly sign of this should be carefully watched for, and directly anything is loticed the cause must be immediately removed und the tail attended to. The cure for rubbed tails is dealt with in Secs. 2:6 and 591 .

202. Farm horses with rough coats are often curry-combed with a mild cumb. (Sie P. 2'ia.) The use of this tool saves much labour and removes a great deal of dirt. Generally speakiilg, a curry-comb sliould not be used on the better classes of horses, and in no case should it be used on the joints. Horses' legs and quarters get dirty from lying on damp bedding; if this dirt calnol be removed with a good dandy-brush and hand-rubbing, a weak solution of ammonia should be used, which will immediately dissulve any grease or sticky matter. A white leg or white coat that has become stained, after it has beell treated with hot water and soap or ammonia, should be well rubbed with white clialk and brushed out afterwards.

203. In a well-regulated stable, where horses are properly blanketed in winter and are well groomed, the difference between the winter and the summer coats is not very great. But, as a rule, grooms do little work on the coat in the autumn, so as to allow the couts to grow, and then the horses have to be clipped; this saves a lazy groom a lot of work. Work horses, exposed to the elements day and night, require a certain amount of grooming to promote the circulation of the body, but do 1 ut require the same amount of grooming that is necessary for the over-fed, under-workerl carriage horse.

204. Winter Care of the Horse.-The horse is often sinfully neglected in winter. Because he is doing less work in winter, his owner thinks he requires less care. He is making a great mistake, because a horse requires more care in winter than in summer. With cold and wet, frost and snow, the horse requires a great deal of care, especially to his legs, and good food, grooming and water. Grooming is necessary to promote good health, because he is not perspiring to the same extent as he does in summer. Healthy perspiration promotes good health.

205. In private stables, where often appearance is considered before liumanity, horses are highly groomed in the morning before they go out, so that they will look nice, and only casually rubbed down on return. This is entirely contrary to what liealth demands. A horse should be cleaned before he goes out, but groomed after he returns, when his skin and whole body will be in greater functional activity. Once again physiology has its say. This is generally done with cavalry horses during peace time, when they are exercised for one or two hours before breakfast. having had a small feed of oats an hour before starting. They are brought back, and rubbed down and given hay (and, of course, water), and properly groomed afterwards.

A horse's sheath must be wahed with warm water and castile soap at least once every two weeks. Neglect of this causes disease and dis. comfort to the horse. The penis must be drawn right out and thoroughly cleaned.

206. To Test for Proper Grooming.-Horses should be periodically examined to soe that they are properly groomed. The mane and tail should be examined at the roots of the hairs, and the fingers should be rubbed against the coat to discover the presence of dandruff. The chest, between the forearms, the hocks, the abdomen, the heels, the commissures of the frog, the dock, the sheath, etc., must be carefully examined for presence of dirt. The back, shoulders, quarters, etc., where the saddle and harness rest, must be examined for harness marks. The eyes, ears and nostrils must also be examined.

207. Grooms.-The ideal groom is a man who is naturally fond of horses, not merely fond of them because he can show of with them. He should be willing to give up some of his own time to care for his equine charge, and, above all, never neglect the slightest detail to save him. self trouble. He should not require to be continually watched or told things. Being told once that such and such ought to be done should be sufficient. It is very important to foster the feeling that a horse is the groom's own property. It should be one of his aims never to leave things undone, so that his master can check him for it. He must be observant, exceptionally clean and tidy, cool-tempered, and the opposite to lazy; he should not be a grumbler. Cavalry soldiers and racehorse stablemen are, as a rule, good at their work, but many of them require supervision.

The ideal groom must, of course, be capable of being trusted to feed his horse always as directed, and, should he neglect ever to do so, he should immediately report the matter to his master. A man who is honest to himself and always owns up, without trying to hide anything, is a valuable man among horses.

208. Tools.-The following tools should be kept in every good stable: A good English-made large dandy-brush; a hard, flat body-brush, and curry-comb to clean it with (see P. 24a); a hoof-pick, which must not be too sharp, else there is danger that the groom may pierce the insensitive sole while picking out the feet (the type that folds up is the best, and can be purchased, nickel-plated, for 6d.); a waterbrush, for washing out the feet; a good sponge, which must not be used for soaping the harness, as the soap will get into the horse's eyes; a stable rubber, which can be bought for about 2s. (cheap stable rubbers are no good) ; hay wisps, which can be made up as required by twisting hay 
PI.ATI: 25
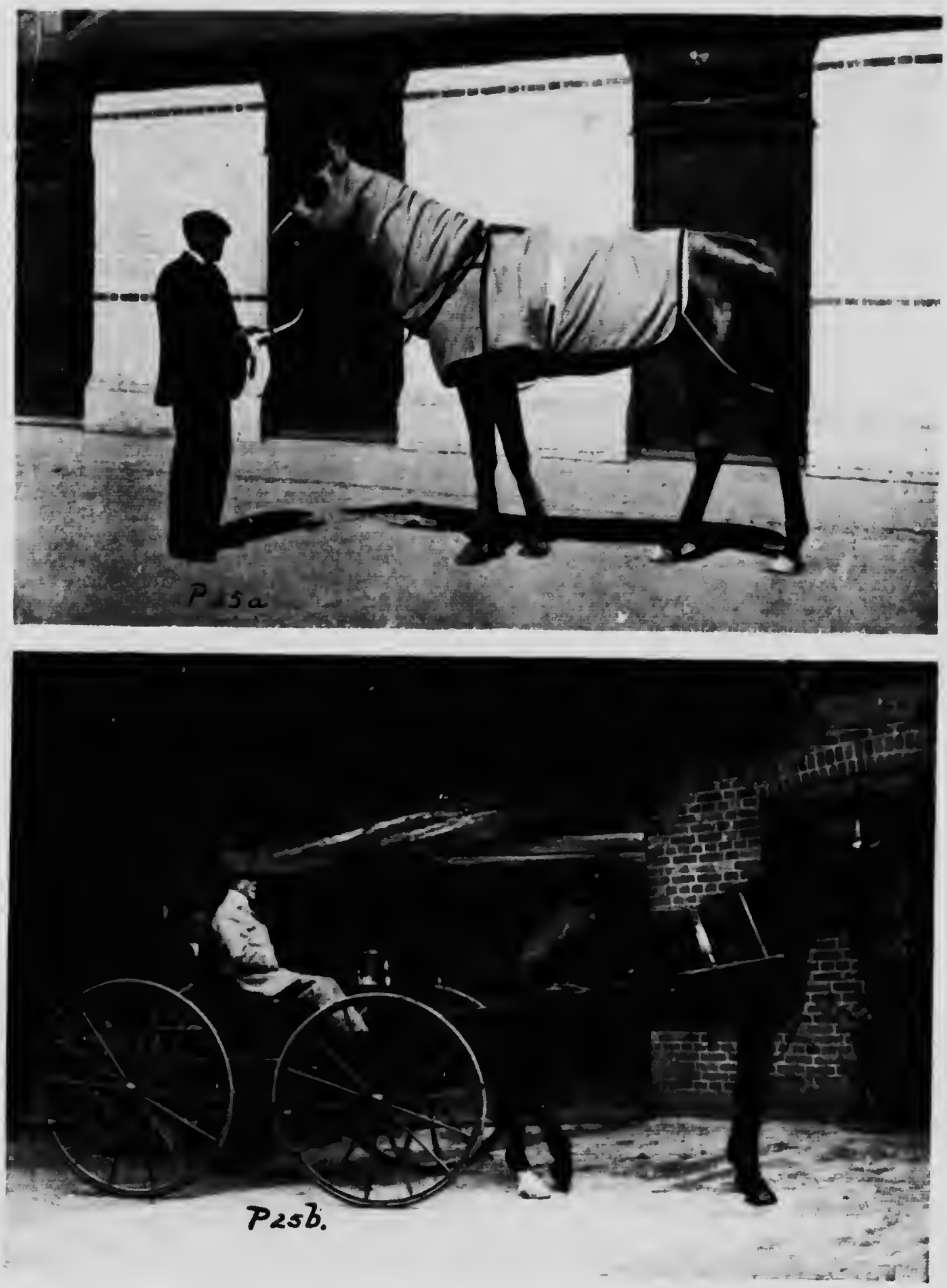

a. "Cicero." the Morning after Winning the Newmarket Stakes. Showing Hood on Head and Neck: also Brushing Boots. Copyright Photo: W. A. Rouch, Sirand, London. b. "Bergamot," Trotting Mare. showing Patent Net used to prevent the Tail getting over the Reins. A Trick that soms. Troublesome Mafes Leain. Courtesy of the Owner, Nlr. Horace Barry. Limpsfield, Surrey 

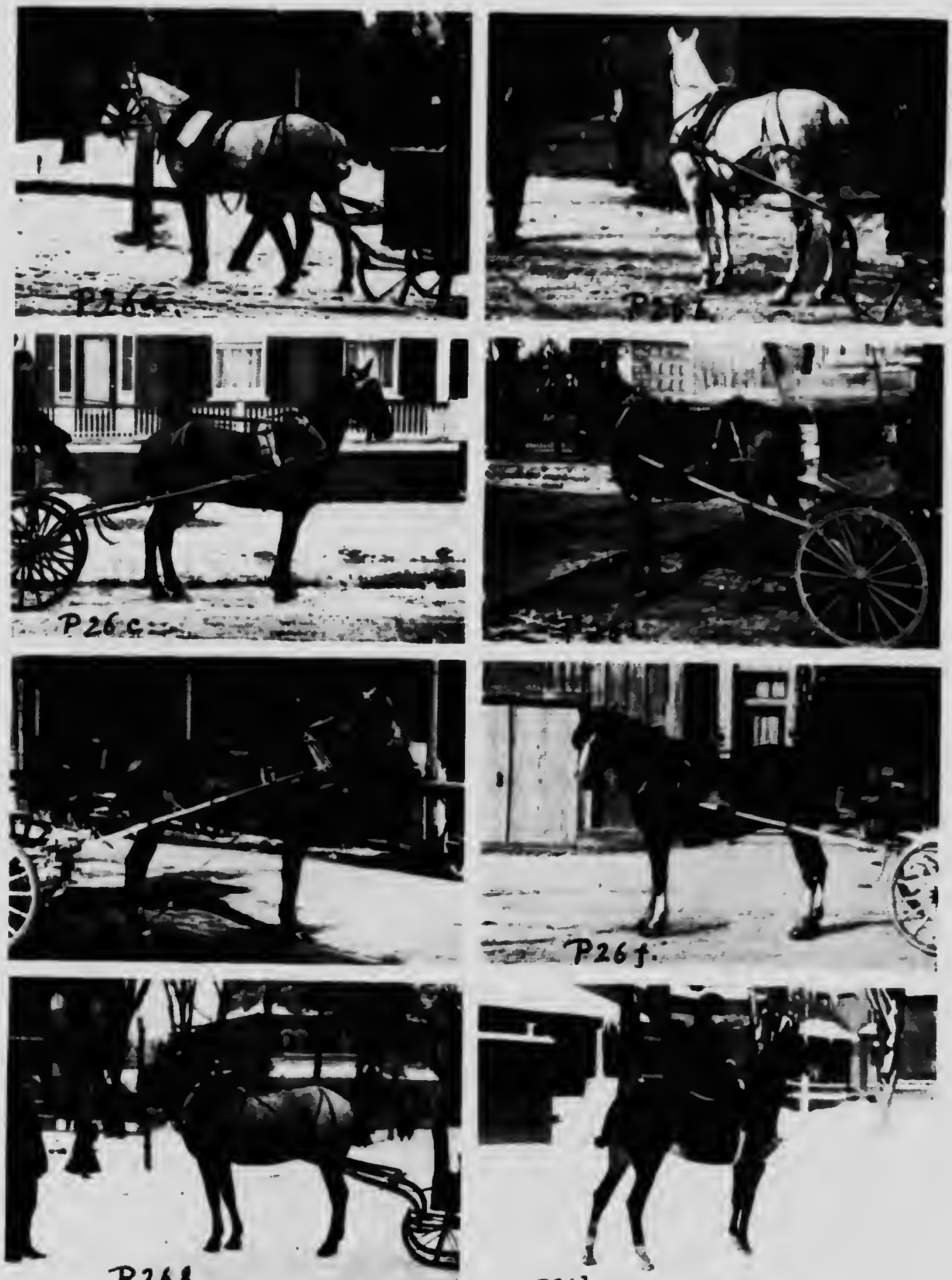

P26h.

TYPES OF PLAITED TAII.S

Courtesy: a, R. Simpson Co. b, Claytun Meat Co. c, Mauthews, d, Parker's Dye Works. e and f. T. Eacon Co.

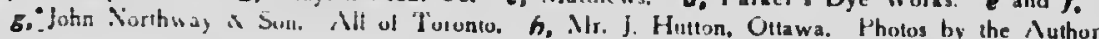


with a rake into a long rope about six feet in length, and then doubling this into two double rows side by side, and working the remainder in and out of these rows, forming a kind of mat measuring about one foot by five inches. A wooden scraper is necessary for scraping the horse down when wel from rain or perspiration ; this consists of a piece of thin wood, measuring aboul eight inches by two inches and a quarter of an inch in thickness, bent into an arc of a circle whose radius is about one foot; a handle is sometimes fastened to this on the inner curve. A mane and tail comb lightly to separate the hairs, etc., and a pair of scissors, for trimming purposes (which must never be used on the eyelashes, muzzle hairs or feelers, or the hair inside the ears), are also needed. If the tail is kept banged (as in $\mathbf{P} .28,29,79,80$ ), tail-squaring shears should be kept, which will cut the hair evenly, a difficult matter with ordinary scissors.

800. Care of Legs. - The legs of the horse require very careful attention, especially if they have been strained in any way or if the horse is not receiving regular and suficient exercise. Such a horse is very liable to suffer from puffed legs above the fetlocks. This pufing (known as filled legs) is owing to the blood becoming stagnant in the extremities of the limbs, due to want of exercise, to exercise not being continued long enough, to over-heating food (as beans and peas), to bad circulation, and to strain or sprain. If a horse stands idle for any length of time after exercise, his legs are liable to become pufted. Therefore a horse requires a couple of hours' walking exercise on the day following a day's hunting or other hard work. Filled legs are reduced or prevented by cotton-wadding pressure bandages and vigorous massaging. (Spe P. 22e, (.) A horse that sufters Irom chronic flled legs should have these bandages on for two hours afler work and during light exercise; and for two hours, following massaging, on ? day when he is not worked. The legs should be well massaged for fitteen minutes against the lay of the cos: (in the direction of the veins), on return from work, before the bandages are put on. Massaging is of no use unless done for about fifteen minutes. On account of the hind extremities being farther away from the heart, they are more liable to become filled. Unless the fllling is bad and of long duration, it will disanpear, or nearly so, upon pxercise being givelı, but may return after standing for some time in the stable.

Filled legs are more liable to become injured, because the existence of such filling is due to poor circulation, and, therefore, want of nutrition to the tendons and ligaments, which will not be able to resist strain so readily.

210. The Coat.-Let us briefy consider the coat. In physics we learn that a shiny body reflects heat better than a dull one, and that a light one reflects heat better than a dark one, and also that good reflectors are bad absorbers and radiators. A shiny white coat will, therelore, refiect cold the most but will radiate heat the least. Therefore a white or light-coloured horse will be able to stand cold better, especially if its coat is well gronmed. Of course, too much grooming in cold weather will remove all the dandrua and oil which tends to keep the horse warm; so that in reality a horse in very cold weather requires very little brushing, but a lot of polishing or massaging with a soft cloth to increase the circulation and to produce a shine on the outside of the coat. In the same way a shiny white coat will reflect heat best and absorb heat least; thus he is cooler in the summer than his black brother. We infer from this that a black horse is unable to stand great heat, and I find that this is the case: Caplain Hayes tells us that his experience proves this also. We always find a black horse's coat extremely hot if exposed to the sun: Nature has, however, made provision for this by giving these animals an extra supply of pigment in the epidermis, whicl prevents the sun's rays from penelrating farther. Besides the above properties the coat possesses that of being an absorber of sweat, and hence prevents over-evaporation and chill.

The rate of growth of the coat varies, being cupendent on the temperature of its surroundings and on the amount of grooming that it gets. I call to mind that in Alberta the horses which we turned out for a whole winter grew coats of hair two to three inches in length. These horses pawed through the snow and ate the grass underneath as well as the snow, and kept fat and healthy without getting any extre feeding. In the severest winters they were fed a little hay.

It is very important that horses should be protected from the direct rays of the sun; heat alone does not do them much harm. (See "Sun. stroke," Sec. 615.)

\section{Clothing}

211. A horse, when at pasture or work, does not require clothing, because sufficient heat is produced by exerc: 2 e, and if the weather is cold Nature provides a thicker coat and extre fat under the skin. Hence a horse should never be worked in a blanket, particularly with a blanket on under the harness. This is a common sight with worn-out horses in the Jewish quarters of some cities, and is no doubt cione to hide the sores. In wet weather a horse may be driven in a waterproof loincloth or in a large waterproof sheet as shown in P. 23c. In this type the reins pass through a hole in the centre, so arranged that the rain does not get through on to the withers. Horses exposed to rain all day, especially in cold westher, are saved much inconvenience by the use of these sheets. I do not recommend their use in mild countries such as 
England, where it is always warm when it rains. The old London 'bus horse would make his daily journey soaked to the skin with rothing but a collar on; but had he worn a sheet of any kind he could not have done his work. Rubber sheets should not be used at any tine for fast work, as they will not allow for ventilation. A waterproof sheet is better if lined with wool, which will absorb the perspiration, but great care musi be taken to dry it thorouglily after use.

When a horse comes into a stable lie requires clothing, partly because lie stands still, and partly because grooming removes the natural oil and dandruff from the coat. Stables should, if possible, be cool enouglı to adinit the use of a blanket; hot stables are very unhealthy. (See Chap. VIII.) Even in summer a light blanket is oftell advisable at night.

212. From the foregoing we learn that a dark, rough blanket is warmer than a white, smooth, shiny one. Apart from the reflecting and radiating properties of the material, the heatconductive properties play an important part. Iron conducts heat about five hundred times as rapidly as wood, and flannels and felts conduct heat far less rapidly than does wood. The material must also possess sweat-absorbing properties. The material which best fulfls these requirements is woul or flannei. For this reason it is not advisable to put a cotton sheet next to the horse with a wool blanket outside. This is also inadvisable for another reason: clothing produces warmth by enclosing air within its various layers; a cotton sheet wuid lie too close to the horse and would not keep a layer of warm air between itself and the horse. The looser the muterial the warmer it will be; it will also allow for better ventilation and therefore will be more healthy. Loosely-woven material becomes less warm than closer-woven material when the horse is exposed to cold wind, on account of it being more porous.

In P. 25a is shown a full suit of clothing, which consists of quarter-sheet, breastcloth, hood, roller, roller cloth and fllet strings (hanging round the thighs). Fillet strings are not generally left on mares while in the stable. The suit may be made of jute or linen. The full suit is generally used on racehorses in winter for walking excrcise or while travelling by train. Extra clothing may be put on underneath, or the whole suit may be murle of warmer material. The hood is attached under the neck and jowl by tanes, which must be loose enough to allow the horse to stretch his neck without breaking tho tapes. Unless the horse is sick, this will not be used at night. Prrsonally, I do not recommend these suits, as they tencl to weaken the horse's power of resistance. WVolien clothing must be kept scrupulously clean and must never be put on to a strange horse, as ringworm and mange are very easily spread in this manner.
Cotton clothing is more easily kept clean by being washed, and does not spread disease so easily. With a very dirty horse a safe plan is to put on a sheet first.

213. Most horses are blanketed witl one blanket, which contains quarter-sheet and breastcloth in one (called in England a rug). Rugs should be made wholly of wool, and, when washed, care should be taken not to allow them to soak in warm water. A separate blanket should be used at night and on Sunday, when horses will lie down, partly so that the day blanket can be kept clean and partly so that the unused blanket can be aired. When horses are at exercise the blankets should be aired and, if possible, exposed to the sun.

A roller is nearly always necessary to keep the blanket in place. (See P. 22a.) This shows thigl straps as used on service blankets, the ruller being part of the blanket; there is also a leary leather breaststrap.

214. Blankets with thigh straps are absolutely necessary for horses in bivoulac to preven. the possibility of the blankets being blown up by the wind. If these straps are not provided, a loose surcingle should be placed far back round the horse's body, or a string can be tied around the thighs, joining the corners of the blanket.

'The roller must be thickly padded on eacli side of the spine to keep it from pressing on to the spine, in the same way that the saddle is kept off the spine.

215. A blanket which is very warm is one made of duck and lined with wool; the duck wears extremely well, whilst the wool keeps the horse warm. Waterproof sheets must on no account be used inside the stable, as they will not allow for ventilation. Light clothing is often used to keep a horse clean, especially white horses. A horse, unless clipped, does not require much clothing in a well-regulated stable, because if it becomes used to much clothing, and is taken outside and left standing, it will catch cold. Some unclipped horses do better without any clothing. A racehorse is generally thickly clothed in the stable, but when he goes out without his clothing he is not kept standing. So, although in a cool stable a horse generally requires a medium blanket in the winter to counteract his inactivity, he must not be blanketed too heavily; if he is, he will have to be heavily blanket $\mathrm{d}$ when left standing outside.

Loincloths (see P. 23a) are very useful and serve as a good protection from loin chills. They look neat and do not cause excessive perspiration. Regarding the excessive use of clothing, an important point is that grooms are very fond of using too much clothing, with the idea uf making the horse's coat shine better. This is very wrong. A coat must be made to shine by manual labour, i.e. good grooming; a gloss that is produced by heated stahles or excessive use 
of clothing does not last, but on exposure to cold rapidly disappears and the coat stands "on end." The amount of clothing required to counteract the loss of coat when a horse is clipped would generally be equivalent to a thick woollen blanket.

216. A tail-guard cunsists of a cloth case or a leather case that fastens in various ways around the tail and is attached at the top to the crupper or blanket. The best and cheapest way to protect a tail from being rubbed on a train journey or to keep it tidy is to use an ordinary threeinch flennel bandage. (See P. 24c.) The bandage will be started about six inches from the root of the dock and wound upwards; two or three short hairs of the tail should be doubled into the folds to prevent the bandage from slipping down. It is then brought right down the tail, and two or three more hairs near the end of the dock are turned in under the folds. In this way there is no danger of the bandage coming off. The bandage must not be put on too tightly. The tail may be protected by plaiting. (See Secs. 243, 244.)

217. Bandages. - Bandages are used for v: rious purposes, but most commonly for applyir pressure to the legs below the knee or hock. This is done $v$, hile exercising, jumping, racing, etc. They may be used as a preventive or as a partial cure for strained tendons. For the former, massaging is far better. Excessive 1:se uf bandages does a great deal of harm. Again, they may be used surgicaily, which use will be dealt with in Chapter IX. Sound legs which are bandaged during exercise are benefited chiefly by the mechanical support rendered, whilst unsound legs are benefited chiefly by the pressure which causes increase of blood to the part, and therefore increased repair of the damage and resistance to further damage. In either case benefit is very marked from the mechanicu: pressure and from the physiological action due to pressure. For this reason bandages must be soft and strong. The softness is required next to the skin and the strength outside. The best method of obtaining this is to wind cotton wadding around the leg thickly, and then to bandape tiglitly outside. By this means the pressure cannot arrest the circulation, as is so easily done with ordinary bandages, and the pressure will be evenly distributed over the legs. To ensure this the best method is as follows ( see $\mathbf{P}$. 22e, $f$ ):

218. Cotton wadding, measuring about 20 inches in wirlth, which can be procured very cheaply, is cut lengthways into strips 10 inches wide. A strip of this is wound round the leg from knee to fetlock, starting from the front and winding outwards and backwards. Then a cotton bandage, 3 inches by 2 yards, is wound loosely over the wadding. Finally, a regular woollen bandage is wound lightly over the whole. It is practically impossible to stop circulation by this method. The cotton bandage may be dispensed with, but it is not so easy to make a good job of it. If the horse is not being exercised, the bandage should extend from just below the knee or hock to just below the fet lock; if he is going to be exercised, it must not extend below the fetlock. For ordinary exercising, a flannel bandage, 9 feet in length and inches wide, is quite suitable. The best kind of bandage I know is the Sandown fleecy wool bandage; one half of this is made of soft woollen material, which is wound around the leg from the knee downward; the other half is made of flannel, and is wound up over the outside of the soft part. This takes the place of the cotton-wadding bandages described above.

Cotton bandages are of little use when used alone, except for surgical purposes. Cotton-wool may be used instead of wadding (batton), but it is more expensive. Medicated cotton-wool is very expensive and is not sufficiently elastic. If the wool irritates the coat at all, whirh is unlikely, a flannel bandage could be put $n$ first.

219. Bandages should not be left on at night, and they do the most good when put on for two or three hours after exercise; if left on too long they weaken the legs. When used on the metacarpal and metatarsal regions, i.e. from knee or hock to fetlock, they support the deepseated suspensory ligament, the flexur pedis perforans, and the back tendon (flexor pedis perforatus), known as the tendon of Achilles. If continued over the fetlock, they support the ligaments of that joint. If bandages are left on over-night they must not be allowed to interfere with the flexion of the knee, fetlock or hock, or the horse cannot lie down comfortably. The arteries of these portions of the limbs a re well protected, so that there is little danger of arresting blood circulation, and there are no muscles below the knee or hock except ver, small accessory ones, which are remains that go to prove the horse's three-digited ancestry. The frequent use of bandages is, as a rule, a great mistake.

The best way to put on any bandage is, firstly, to roll up the bandage with the tapes inside, and to commence a few inches below the top part of the bandage, leaving six inches free, to start rolling round the leg from the front outwards and to the rear, winding it downwards; upon reaching the lower extremity it is rolled upwards ; the free end which was left at the top is turned in under the bandage that is rolied upwards outside. The tape is then tied in a bowknot, with the knot at the side of the leg. On no account must the knot be in front of the leg or at the back. The tape should be about two feet in length, the centre of it being sewn to the end of the bandage.

220. Rolling.-Rolling is a most beneflcial form of exercise for any horse, and still more for one that is idle in the stable. Horses love 
it. Besides giving the horse physical exercise and stimulating the action of the liver, intestines, etc., and stimulating his spirits, it has a most beneficial effect on the horse's coat. Clean sand makes an excellent rolling bath; peat moss or tan bark, as used in riding schools, will also do. Idle horses should be turned loose for at least half an hour a day so that they can exercise themselves by rolling, etc. It is a good plan to allow a horse, when he comes in hot, to have a roll. If a horse, when turned loose in a sand bath, strains his legs at all by jumping about, bandages should be put on. The sand bath should be twenty feet square, the sand being one foot deep. Great care nuust be taken to brush all sand thoroughly from the horse's coat before putting on the harness or saddle; if any sand is left in the coat it will be sure to cause a sore back.

Sand rubbed in lightly to a wet back for a few minutes, and then brushel out again, will dry the coat and remove a great deal of dirt. Sawdust is very useful for drying wet backs.

221. Bedding.-Bedding is necessary in a stable to prevent chill (which would result from lying on a cold stone floor), to add to the horse's comfort, to prevent injuries, for the purpose of absorbing wet, and for neatness. Bedding also affords a soft material for the horse to stand on during the day, which becomes more necessary when the horse is left standing for any length of time in the stable. Ine various forms of bedding are straw, old hay, peat moss, sawdust, shavings anc sand. Leaves, ferns and branches are sometimes used, but are not healthy. Tan bark should never be used, as it destroys the feet. Peat moss will absorb about six times its own weight of water, tan bark nearly as much, and straw between two and three times its own weight. Barley straw will absorb most, wheat straw least. (See "Impurities," Sec. 368.)

222. Bedding must absorb fluid, absorb gases, be free from odour, be soft, be a bad conductor of heat, be cheap, be easily procurable, be free from any properties that harm the horse's feet, and be free from any properties that will harm the coat. It should also be unpalatable to the horse. Ally bedding, as peat moss, tan bark, sicwdust or sand, that will clog in the feet is not the best of bedding. Tan, containing tannic acid, has a particularly bad effect on horses' feet ; therefore a horse on returning from the riding school should have his feet well picked out. Urine has a very bad effect on horses' feet, so any of the above materials the.t will become clogged in the feet are far inferior to straw, etc.

Straw forms by far the best bedding. Wheat straw is the best, because it so less liable to be eaten; it is stiff, and keeps cleaner and lasts longer. Oat straw is liable to he eaten, soon becomes soiled and matted in lumps. Barley straw may cause a skin irritation. Actinomy- cosis is caused by a fungus that is not uncommon on barley straw. The long straw sold in England makes the best bedding; the grain separators in Canada and the United States, unfortunately, break up the straw into such short lengths that it is very dirty and dusty and far less economical. Wheat straw undoubtedly looks the nicest.

223. If peat moss is used, it should contain a large amount of flbre and cork-like lumps, and should not be close like soil. The only advantage of peat moss is its great power of absorbing liquids and gases; therefore it requires to be renewed more frequently than is otherwise thought necessary, because it quickly becumes a saturated mass of harmful chemicals, such as ammonia. A few years ago the British Service used it entirely, but, upon finding that their horses' frogs became damaged, soon discontinued it. The great advantage of it is that it is almost fireproof. It is very convenient on board ship or on the train, as it makes a splendid footing, is not blown about, and takes up less room in stowage. When used, the wet portions must be continually removed and the feet well looked after. Tan bark is worse than peat moss for damaring the feet. Sawdust, wood shavings, and sand are fairly good when they can be procured cheaply in a clean state; but they must be kept clean, which is not an easy matter. They are not suitable for private use, or for horses with flne coats. The shavings should contain no pieces of woou. Sawdust makes a very good bedding if plenty of it is used, and if re. placed frequently. Some large commercial stables use it entirely. The horses shown in P. 29d, $P$, $f$ are bedded entirely on sawdust. Sawdust is valuable in all stables that are not drained.

224. The army horse is allowed eight pounds of wheat straw per day for bedding. The bedding should be taken outside the stable early every morning, and spread on a wooden platform, or put into a wire cage made for the purpose of preventing the bedding from blowing about; this is necussary thoroughly to air the bedding. The manure and the wet portions of the bedding must be thrown away, and not left anywhere near the stable. The manure heap should be cleared away every day, especially during the fly season. A rainproof roof should be provided to protect the bedding from the wet while it is airing. (See P. 89e.) This shows the usual type of bedding roof used in army stables; great economy of bedding results by siring it outside during the daytime. Bedding should never be left in the stable during the day, except on Sundays, when the horses are usually left bedded down. A most foolish practice is that of pushing the bedding to the front of the stall, so that all the harmful gases are breathed by the horse, and affect his eyes, lungs, and general health. 
PLATE 27
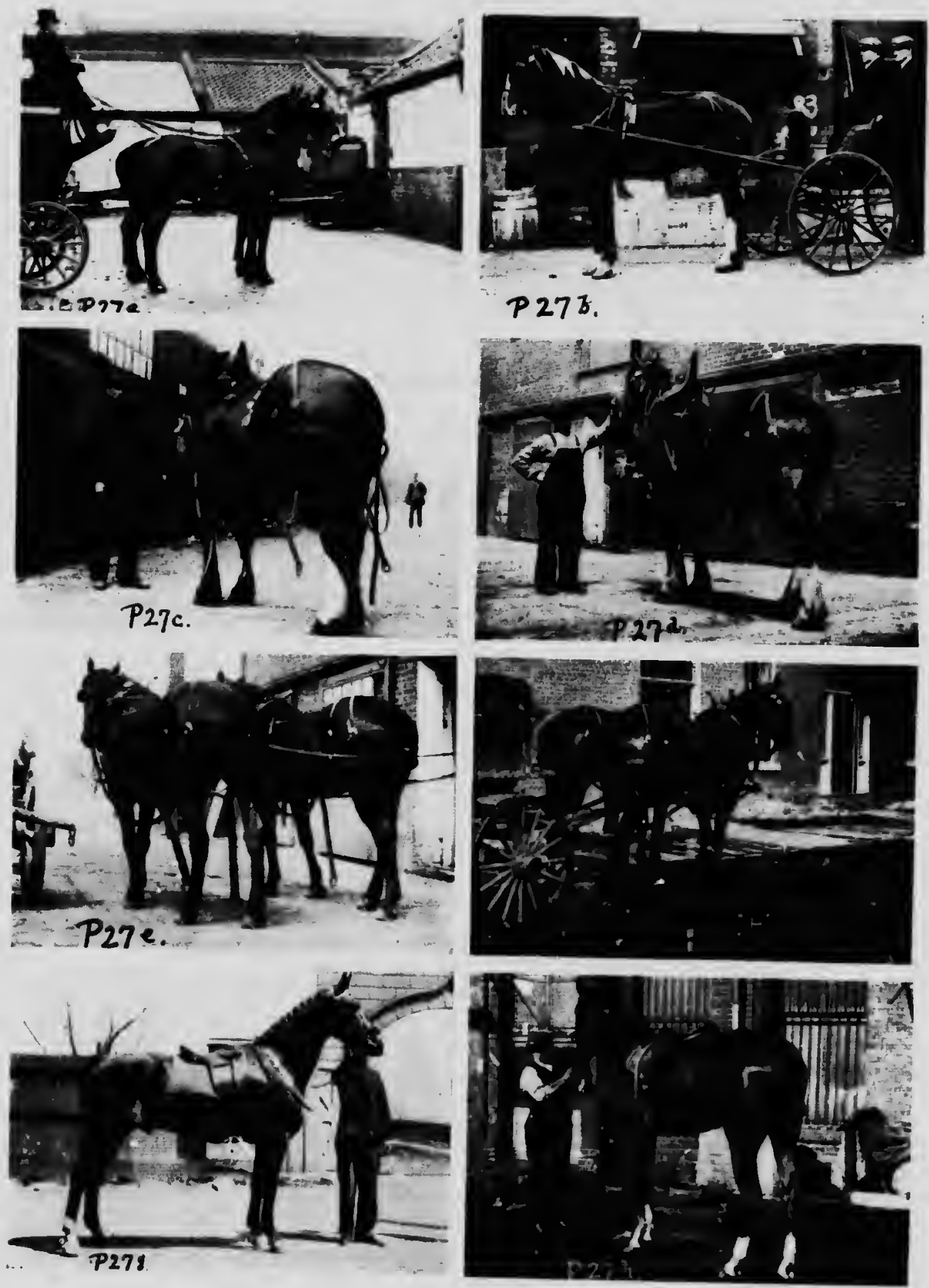

TYPES OF TAIL.PLAITINC

Courtesy: a, Messrs. T. Tilling, London. b, Mr. W. Cross. Toronto. c, d, e, John B. Smith Lumber Co., Toronto g. The Repositery. Toronts. Ho Mr. W. Cross. Photos by the Author (All the Taits are undocked.) 

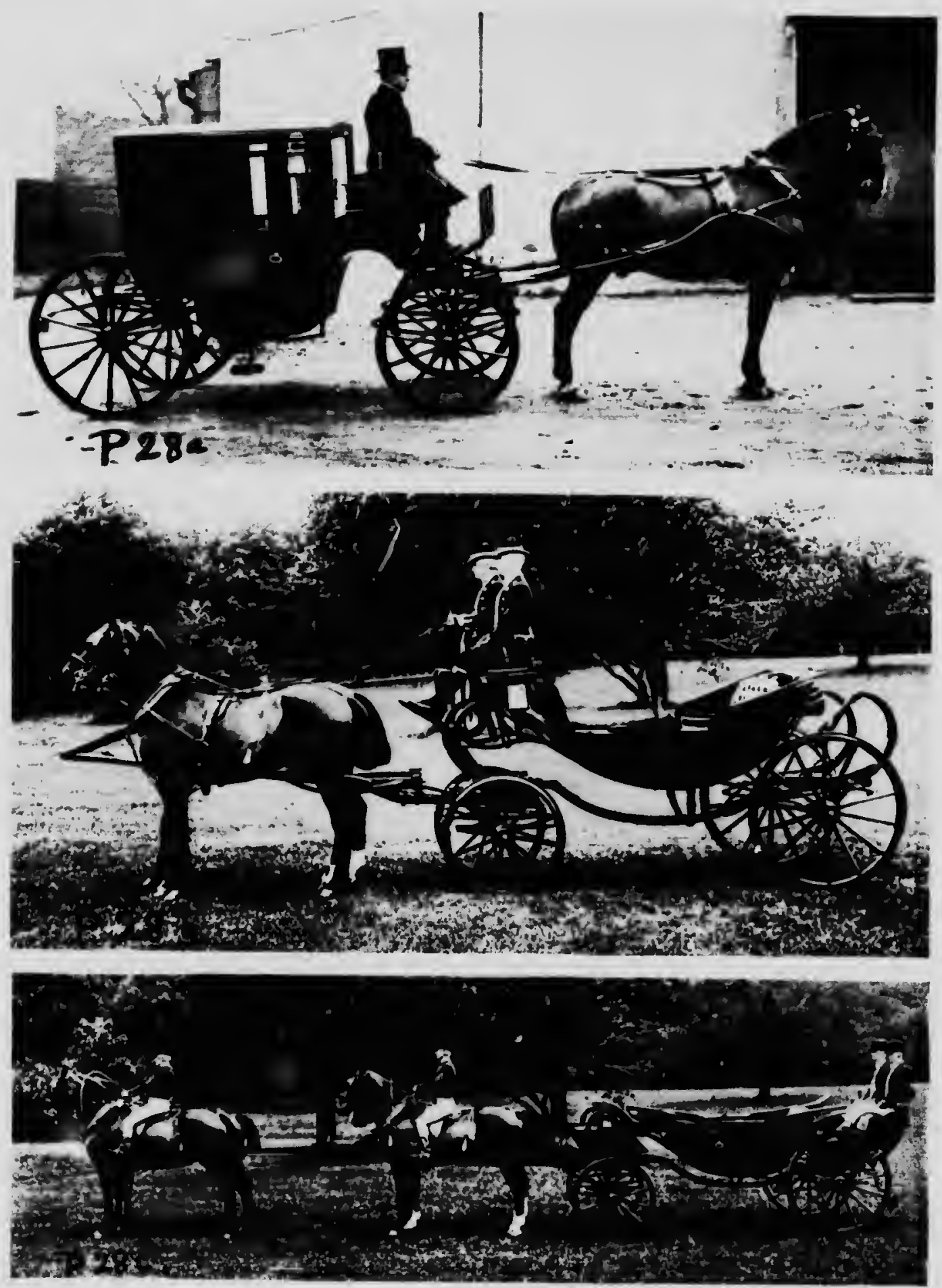

TYPES OF BANGED TAILS IUNDOCKED,

a, Courtesy : Nr, C; Field. Chslehurst, Pholo: Author. b, C, By permission H.R.H. the Duke of Connaught, Ciscernor-fieneral of Canadx. Photos: Pittaway, Ottawa 
When the bedding is down and the groom is about, he should remove all droppings whenever he sees them; these must be taken outside the stable, and not left inside, as is often done by a lazy man.

A heavy draught horse excretes about fifty or more pounds of dung per diem. The weight of dung is approximately double the weight of the dry food eaten, the water drunk making up the extra weight. When a horse has been tied to the pillar reins with its head to the centre of the stable, the manger should be examined to see that there are no droppings in the manger. This is often neglected by grrnms, who will throw the next feed on top $0 . .$. droppings in the manger, and wonder why th horse does not eat its feed.

225. Laying Down the Bedding.-Great care should be taken to make the bed as even as possible. When baled straw is used, the lumps must be carefully shaken loose with the hands, as it cannot be properly done with a fork; on no account must these lumps be left unbroken. In approaching a horse in his stall, with a fork of straw, he must be spoken to, otherwise he may become frightened and kick, and possibly run the fork into his legs. I have seen the quietest of horses do this. If a horse will not move over quickly from one side of the stall to the other, on no account must he be struck with the fork; such an act is contemptible, and will tend to make him fear anyone approaching with a fork. By talking gently to him he will soon get to know his groom, and will do anything for him. (See Chapter III.) I have surprised a great many grooms who had never considered the matter in this light, by being able to do almost anything with a horse which kllew me, whilst the same horse had taken little notice of the rough and harsh methods of the groom; and upon imparting to the groom the secret by which obedience is obtained from such horses, have been able to convince them in a few weeks of the right way to treat a horse. Kindness not only pays, but it saves so much trouble; so that even a lazy type of groom or driver will gain much by calmness. The bedding should be placed well forward, hecause horses generally work it back before lying down. The best way to prevent a horse kicking its bedding too far back is to lay it thinly in the centre and thickly on the sides of the stall, because the horse paws mostly in the centre of the straw. The bedding should be attended to the last thing at night, unless the horse is lying down.

\section{Sanitation in the Stable}

226. The whole stable must be kept scrupulously clean; if it is constructed of sanitary material (see Chapter VIII.), the walls and floor should be washed all over with a 1 per cent. solution of creolin or carbolic once a week. Wooden walls and mangers should be whitewashed at least once a week. The ceiling should be whitewashed with lime every three months. The whitewashing of mangers is very important in livery and sale stables, where strange horses are coming in continually. Metal mangers should be scrubbed out with hot water and castile soap cace a week. Disinfectants which possess an odour, such as carbolic acid or creolin, should not be used in the mangers or watering buckets, etc. A solution of bichloride of mercury (one in five hundred) is a good disinfectant, as it has no odour; but as it is very poisonous, the vessel must be rinsed out with water afterwards. Mercury must not be used on plated metals, as it has a deleterious effect upon them.

Sanitary distempers and washable paints should be washed once a month. Glazed bricks and tiles should be scrubbed once a week. Windows should be cleaned every week inside and outside, to admit plenty of light. Corners must be swept free from cobwebs and dust every week. The floor should be washed out every day, unless it is a wooden floor, which should be kept as dry as possible, or it will rapidly rot. All drains must be opened and flushed out thoroughly with water, and then with a 5 per cent. solution of creolin or other suitable disinfectant, as Jeyes' fluid, lysol, Condy's fluid, etc. If the drain is not working freely it must be immediately reported, as it may require to be cleaned by a sanitary engineer. Neglected drains are often the cause of horses and grooms becoming ill.

Smoking or the carrying of lights, lighted pipes, or throwing matches about in the stable must be strictly forbidden. A lamp must not be placed so that it can be knocked down. Oil lamps are very dangerous in the stable, unless they are the regular stable lantern. Smoking should never be allowed near the stable or near any haystack when there is a wind blowing.

227. Stopping the Feet.-Too much washing will cause softening of the feet; wet roads have not the same effect because the increased circulation during work counteracts the scttening efiect of the moisture. Feet, however, may become too brittle, and require stopping. This is best done by flling the foot over-night with a linseed mash (made with cold water and ground linseed), pressing it well into the foot. It must be thoroughly removed in the morning, and should not be continued for more than two or three nights, or injury may result, due to over-softening. Softening foot in this manner merely to help the blacksmith to pare the wall down must be strictly forbidden. Puddled clay may be used if linseed cannot be procured.

To prevent the feet from balling in the snow, they should be brushed over inside with a thick oil or grease before going out. 
228. Foot Dressing.-The walls of the feet, which are porous and covered witl a porous shell, the periople (see Chapter XVIII.), require to be exposed to the air, hence harm will be done if tlick oil or grease is put on; a very common error made by groonis in order to make the feet look nice. I strongly dcprecate the use of patent hoof dressings. There is no need to blacken the horses' loofs. As a rule, the dressing is put on over the dirt, which causes the feet to become brittle and break, due to the cells becoming clogged up. If a drcssing is insisted on, it should be of an oily naturc; on no account a varnish. A good dressing is made of grate blacking (carbon) and cod liver oil. For brittle feet the following dressing is very good; it toughens the feet considerably:-

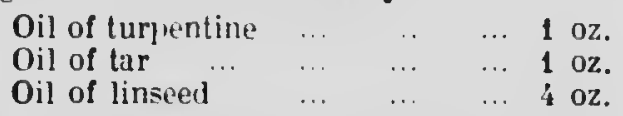

Shake well and apply nicht aud morning.

229. Eramining Shoes.-When a horse returns to its stable his shoes must be carcfully examined. Merely pulling at them or trying to move thcm sideways will not test whether they are loose or not. They should be gently tapped with an iron hammer, their tightness being judged by the sound, in the same way as the wheels of a railway car are tapped to test for cracks. The clenches should be examined to see if they are all right. Any clench that is sticking out must be either bent in or removed to avoid injury to another leg. Any missing nails must be replaced, and a shoe must be examined to ascertain that it has not shifted.

230. Leading into Stable.-A horse should be carefully led into the stable, and not be allowed to rush in, nor be driven in, as he is liable to knock himself against the door posts or to damage the saddle or harness. The groom shovid turn his back to the door and, holding cne bridoon-re': close to the ring in each hand, lead the horse in while walking backwards himsclf. The same is to be done when leading out, but a horse is more liable to hurry in to get his dinner. Some horses objeci to being stared in the face and will not follow the groom when he faces him, so in this case he must turn away from the horse, who will probably follow.

When leading a horse by the halter in stiowing him to anyone, the groom should hold the end of the leading-rope in the left hand and have his richt hand ready to seize the rope near the halter if the horse becomes fractious; the groom will run on the left side. In turning the horse the groom must turn outside the horse; if he allows the horse to swing around outside of him, he is liable to get away: that is to say, when turning he will invariably turn to the right. In deterting lameness this, of course, does not apply.

\section{Clipping}

231. The practice of clipping horses has been much discussed in the past, but I have seldom heard a scicntific explanation of the reasons for clipping or not clipping. On this point I fear some of my horse-loving readers may disagree with me. As in other questions of this kind, I have studied the subject from the horse's point of view before any other.

In nature the horse has a long coat, but he does not exert himself at hard labour while in this coat. If a gymnast was made to go through his performances in a fur coat, what would happen? Would he not die, or at any rate collapse, from excessive fatigue? In the same way it is neither reasonable nor, as we shall see later, liumanc, to ask a horse with a heavy coat to do licary work. In England job-masters have proved this fact for themselves, but the same applics in a lesscr degrce in Canada, where the winters are cold. We provide the horse with a heavy coat whenever he is idle in or out of the stablc, but remove it before we ask him to work. We clip off his permanent heavy coat and provide lim with temporary heavy blankets. Horses doing slow work, as is usual with most draught horses, do not require to be clipped; farm horses seldom require to be clipped. If a liorse with a heavy coat is worked until he is perspiring freely his coat becomes soaked with sweai, evaporation can only take place comparatively slowly, and this only from the ends of the long hairs of the coat; hence sufficient evaporation on the skin is prevented, and the bodily temperature is not reduced, as it should be, to normal. The lungs and the whole system consequently suffer, and the horse is feverish.

Thin horses, when they are clipped in the winter, invariably gain in condition. Nature very soon readjusts matters and counteracts the loss of a coat by producing more internal heat. The fact that the coat is wet and steaming is no proof that evaporation is going on rapidly; on the contrary, because evaporation may be more rapid on a ciipped horse that is showing no signs of persiring, than on a long-coated horse that is perspiring ireely.

232. But-and this is where the cruelty comes in-if a horse is clipped, he must never be left in a stable or outside without his temporary coat. $A$ clipped horse must be blanketed and never left standing if it is at all cold. In Canada harness horses, when left standing, are generally covered up with the fur robes used in the sleigh. For most kinds of weather a heavy blanket is sufficient, and unless the wind is quite calm the blanket should be buckled on to prevent it from blowing up. In very windy weather it must be buckled over the quarters, or it may hlow up nver the horse's head. A common sight, which exposes the ignorance of wealthy horse 
owners, is to see clipped horses standing outside stores or theatres shivering in the cold while their mistresses are enjoying themselves within.

Well-cared-for private horses are as a rule better when clipped, but I think that commercial horses which stand about in their daily rounds are better unclipped, unless they perspire very freely. The length of the coat, the work required, and the amount the horse perspires are factors which decide whether the horse should be clipped or not. The Loncion bus-horse was always better when clipped.

233. The most humane way of clipping horses in a country that has a cold winter is to clip the body only, and to leave the legs from about nine inches above the knees and hocks unclipped. The long hairs on the fetlocks can be taken off. I strongly advocate the frequent use of hand rubbing of the coat in the autumn, thus keeping it short and thin and often avoiding the necessity for clipping. In milder climates, such as in England, light and heavy commercial horses are frequently clipped on the lower part of the body and upper part of the legs, as shown in $P$. $51 b$. This leaves a warm coat on the body, lessens the amount of perspiring, and renders the horse less liable to cracked-heels, etc. All mud must be thoroughly brushed out of the legs upon return from work. It is generally necessary to clip horses in England several times during the winter.

234. Clipping means shortening the hairs of the coat (temporary hairs) by means of shears. The coat may be shortened or thinned, and therefore made cooler, by other means, as singeing, hand rubbing, use of indiarubber, and good grooming. Singeing must be done by an experienced man, and is best done with a gas lamp made for the purpose, as it can be easily regulated. Oil or spirit lamps are dangerous; the oil may be spilt and cause a fire. Singeing should never be done over straw bedding; if done in the stall, the bedding must be removed. Good grooming and a large amount of hand rub. bing will remove a great numbei of the hairs of the coat, and thus lighten it. It may be made still lighter by being rubbed with a piece of indiarubber held firmly in the hand anj drawn in the direction of the coat. Private horses are often singed after they are clipped to improve the look of the coat and to round off the ends of the hairs, which, by closing, strengthens them. Clipping, by squaring off the ends of the hairs, leaves them in a bristly state and causes the coat to be more susceptible to irritation; a coat when first clipped stands up (stares), and does not lie down smoothly. This will allow dirt and cold more readily to gain access to the skin. Horses which suffer from cracked heels (scratches) are better with their fetlocks left unclipped.

Thin-skinned horses, or horses ridden by bad riders, are better left with a patch, the shape of the saddle, on the back unclipped, so as to afford extra protection. Hunters are often not clipped below the hocks and knees; this is advisable in muddy countries, as the mud does less harm to the legs when the coat is left long, and the danger of chill is considerably reduced if the horses are shipped home by train. Hunters are sometimes clipped on the body only.

235. The long hairs inside the ears should never be clipped; they are there for a very good purpose, and their removal may cause deafness or other damage to the ear by allowing cold and foreign objects to gain access. Long hairs projecting beyond the cartilage of the ear may be trimmed off with the scissors. I was sorry to see some of the horses at an international horse show with their ears clipped in this way; it proves gross ignorance. On no account must the eyclashes or the muzzle hairs be clipped. The best method of clipping a horse is to use a machine clipper, worked by hand or by an electric motor, which must have a safety cutout worked by the foot, so that, if anything happens, the machine can be stopped instantly. Hand clippers are useful for finishing off those parts which are difflcult to reach with a machine. If a horse is cold after being clipped, which he will show by the coat staring or even by shivering, he must be blanketed more heavily, and not be kept warm by closing the windows, thus preventing proper ventilation. Private horses are often made sick by stuffy, unventilated stables. After a horse has been clipped, in order to produce the extra internal heat required, more fuel must be supplied by increasing the feed for a week or two.

236. If a horse is clipped too early in the autumn, his coat will not look so nice as if the clipping had been done later, and a second clipping may be necessary. This is necessary with some horses, anyway. It is cruel to wait until the end of November, when the winter coat is fully grown, and then to clip it all off, as the horse will then be without sufficient coat until the spring. But if he is clipped at the end of October, the exact time depending upon the climate, the winter coat will continue to grow afterwards, and furnish him with a moderately short coat all through the winter. Sometimes horses with heavy coats are clipped at the beginning of spring ; this spoils the appearance for a while-that is, until the summer coat comesbut it is often a necessity. When the winter coat is fully grown, "cat hairs," which are long hairs, will make their appearance here and there over the coat.

237. The Forelock.-In Canada and the United Stales the forelock and the mane in between the ears is often clipped off, generally because it gets in the way when an overhead check-rein is used. This unnecessary appendage 
is deal: with in Chapter XIX. The forelock is of great use to the horse in protecting his eyes. (See Chapter XII.) Some draught horses have a very heavy forelock, which partly covers the eyes; this is very detrimental to the liorse. It should be combed out and be nearly long enough to reach the top of the eye. A sadule horse looks far more handsome with a forelock. In the British cavalry about a couple of inches of mane, where the head-stall passes over, is clipped off ; this keeps the mane tidy and prevents it from being doubled under the head-stall and from working out and tickling the horse's ears. This clipping is particularly necessary with some cavalry bridles which have two head-stalls, whilst those in the Life Guards liave three head-stalls.

238. Time to Trim Horses.-A lorse should be trimmed every few months if it is desired that he should look neat and well groomes. It is wonderful what trimming the hair of the fetlocks and around the pasterns, etc., will do towards improving the appearance of som horses.

Tails should be trimmed, if trimmed at all, at the end of the fly season. If a tail is banged short, as in P. 29, it should not be touched after Christmas, so that it will be nearly to the hocks when the flies come; this applies mure to countries where the flies are bad. A docked tail should never be trimmed except at the beginning of winter, but, unfortunately, most owners of such horses do not consider the horse so long as it looks "smart."

239. Banging the Tail. - Banging the tail means squaring the hair off to a desired length below the end of the dock with scissors or shears. (See P. 28, 29, 79, 80.) British cavalry horses' tails are banged so that the end reaches one hand's-breadth above the hocks, but upon going to India the hair is left to grow quite long. (See P. 80.)

To bang a tail, place one hand under the dock near the top, and cause the tail to hang as it would be carried while the horse is in motion, and cut the hair square of at the required length. Sometimes it is cut at a slight angle, so that the tail is slightly shorter next to the thighs. (See P. 80c.) A horse's tail grow's from six inches to one foot in a year, as a general rule. In Canada and the Ur. ted States most of the sadule horses' tails are quite long. (See "U.S. Cavalry Horses." P. 60.)

240. Thinning the Tail.-If a tail is left bushy and heavy it has two disadvantages. Firstly, it keeps the horse much hotter in warm weather: and, secondly, it requires more energy from the horse to move it in striking at a fly. It should be kept neat, and not be combed on the outside; combing breaks the hairs and soon spoils the beauty of a nice tail. P. $14 a, 16 b, 61 b, 67 b, 68 a$ show the tail kept thin at the top, which keeps the horse much cooler, looks neater, and, as it is lighter in weiglıt, the tail will be carried more arched and thus farther away from the body. A tail is thinned gradually by a few hairs being pulled out every day; this will not inconvenience the lorse any more than the daily combing which the average groom loves 10 give the horse. To thin a tail in a day by pulling wut bunches of hair is exceedingly cruel, and should never be allowed.

241. Hogging Manes.-By hogging a horse is meant clipping of the mane close to the crest. Some, who are evident!y grossly ignorant of the horse's requirements, say that this is worse than docking. I hope my readers will know better than this. Nevertheless, I do not approve of the practice by any means. The use of the mane is unknown to most people. The fly muscles (described in Chapter XII.) do not extend to the crest of the neck; therefore a mane is necessary to protect the npper portion of the neck. This he does by shaking his head and switching the mane from side to side. In Canada or India, during the fly season, a mane is of the greatest use to the horse. The mane is also of great service in the prevention of sunstroke. (See Sec. 615.) This is particularly true of the foretop, that part in between the ears. A heavy mane is of no use to a horse ; in fact, it causes excessive perspiration. The ideal mane should be about four inches long, and kept fairly thin so as to keep the horse cool in hot weather. A long mane, if not too heavy, adds considerably to the beauty of some horses. (See P. 2, 18b, 21a.) A hogged mane is generally ugly and gives the horse an unnatural appearance. The absence of a mane is a great disadvantage when an elderly person is mounting a horse. I have found hogged-mane horses in the fly season a positive nuisance. The excuse that a mane takes a long time to clean is an exceedingly lazy one, and not one that one would expect to come from a horseman. I regret to see a number of army horses with their manes hogged; it makes them look exceedingly ugly and gives one the impression of laziness.

Sometimes a mane gets diseased, and the veterinary surgeon orders it to be clipped off ; but, as a matter of fact, this is unnecessary, as various applications can be rubbed into the roots which will cure any disease that I have yet come across.

Field-Marshal Viscount Wolseley said: "I cannot write too strongly against the fashion of hogging manes and cutting tails short. I have seen cavalry regiments and batteries of artillery at home which could not have been sent into the flelds where flies abounded owing to the tails of the horses having been rendered so useless by their silly C.O.'s. I wish all such gentlemen conld be picketed out themselves in a fly country with their hair cut quite close and their hands 

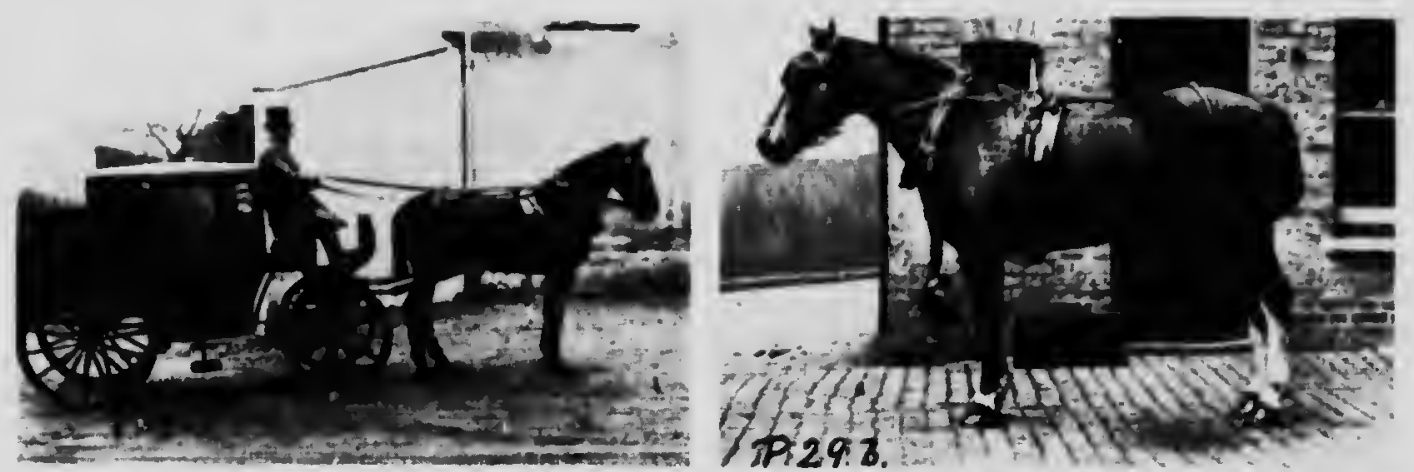

P29.
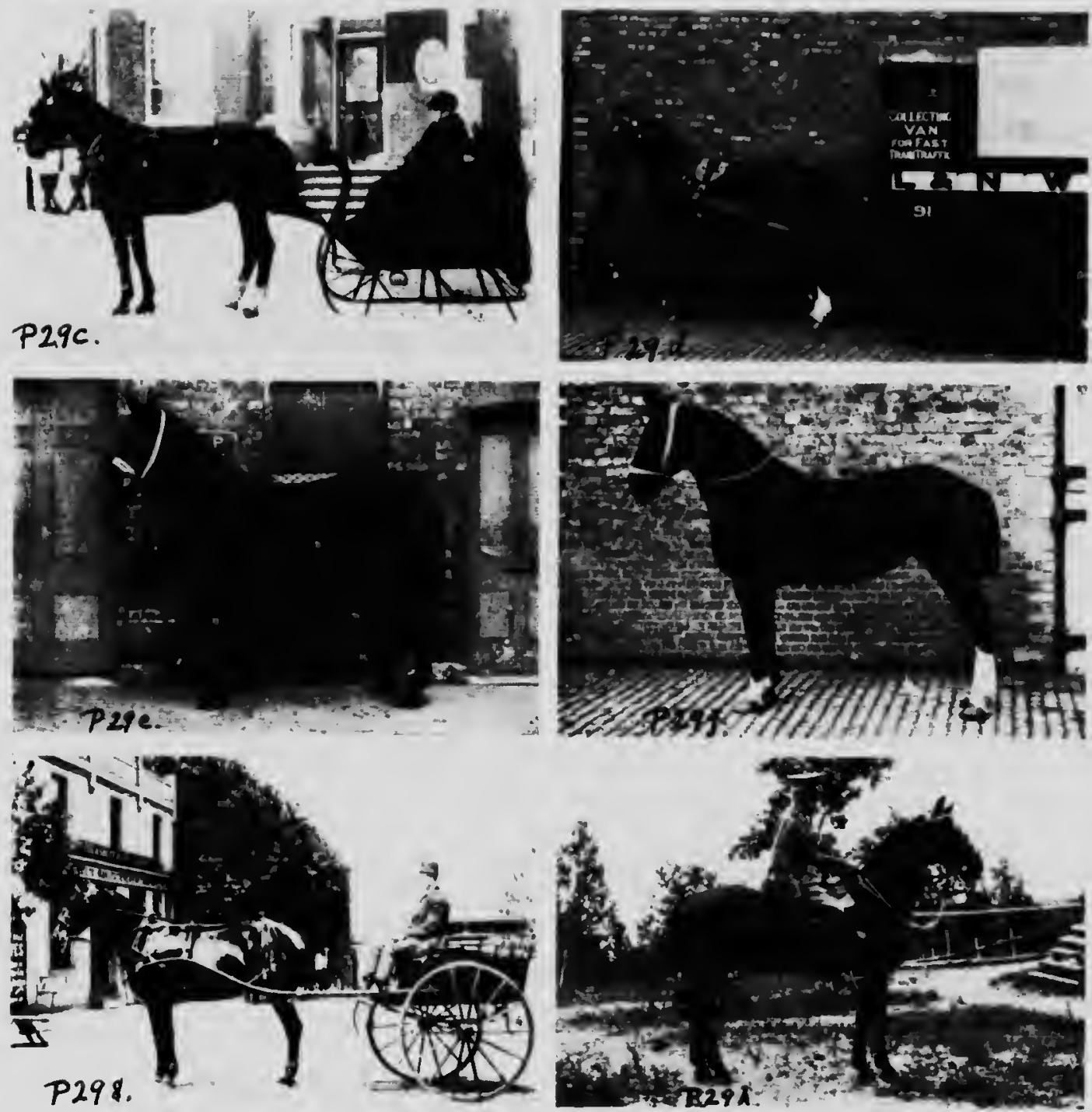

TYPES OF BAXCED TIILS ILNDOCKED,

Courlesy: a, Mr. G. Field, Chislehurst. c, Mr. H. Bristow, Ottawa d, e, f, L. \& N. W. Railway Co, Pholos : Glover, Hammersmith. 6, Mr. E. J. Barclay, Brandon, Man. h, Col. S. Denison, C.M.C. Photos, $a, b, c, 6, h$, by the Aisthor 


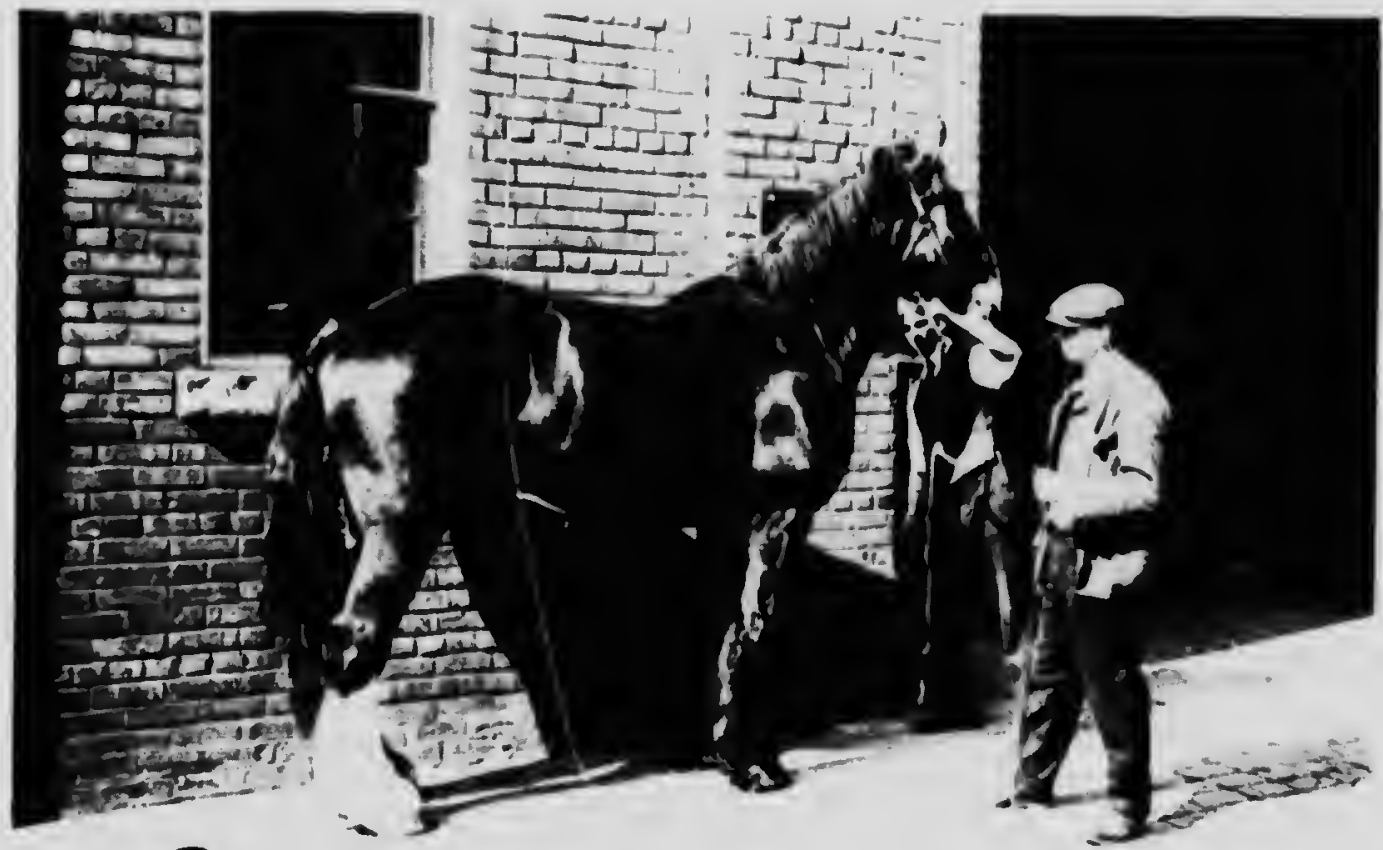

\section{P30a.}

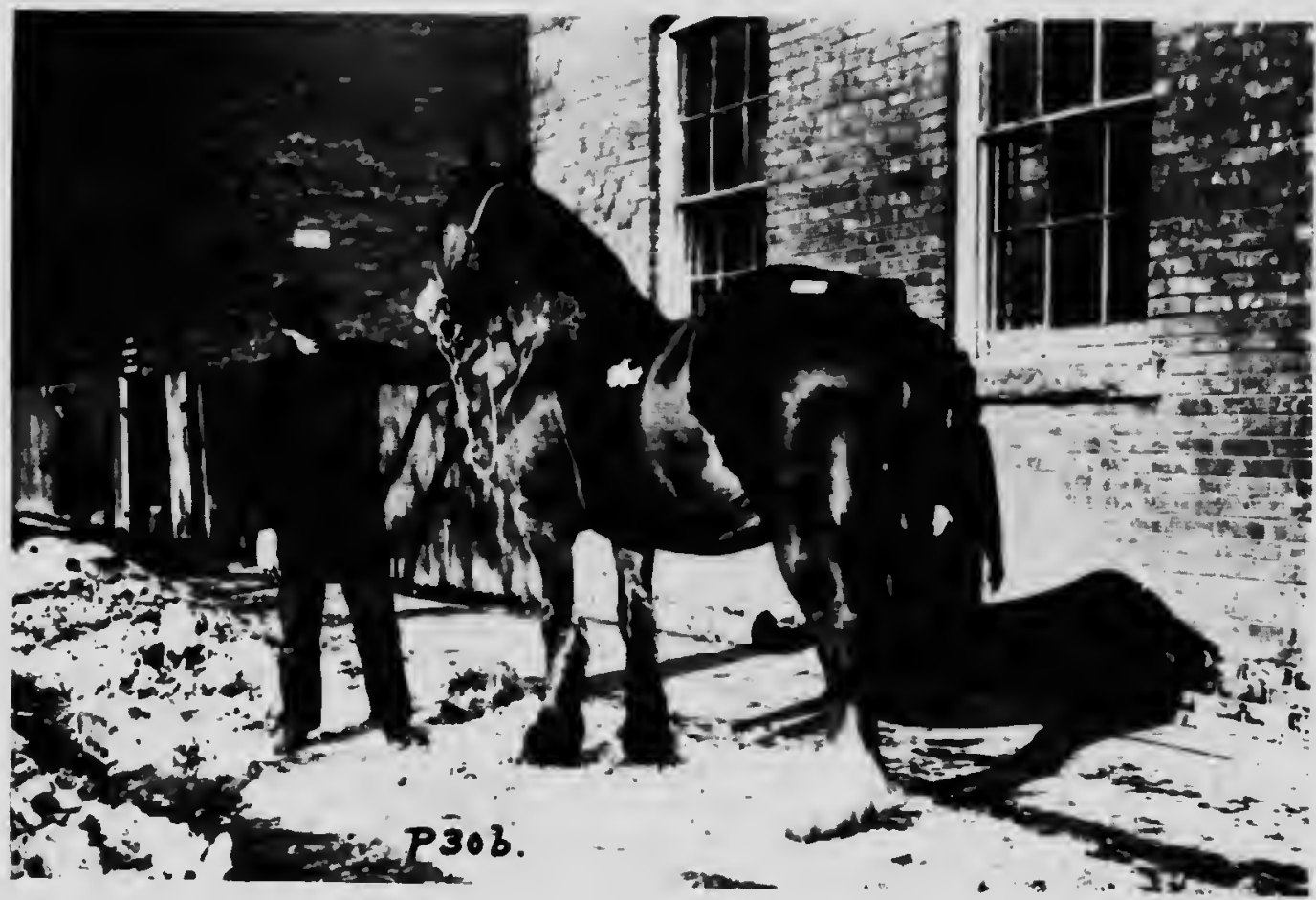

TAIL PLAITING

a. The Tcp I'latied down the Back. b. The Hairs below the Dock Platted and Fastened to the Top of the Tail. kind permission Maher's Horse Exchange. Toronto. Photos by the Author 
tied. Their sufferings then would leach them a lesson."

84. Regrowing Manes.-Manes once hogged can easily be regrown, with a little patience and trouble. It takes about six months for a mane to grow long enough to be plalted or weighted. The best method is to plait it (P. 27g), and then to weight it as well. Another method is to use a hood fastened by elastlc atrings under the horse's neck. (P. 22b.) This hood is of greater use for making untidy manes tidy. The mane must be damped with water before the plalting is done or betore the hood is put on. The latter should be left on for two hours. Civilians, as a rule, prefer the mane to lie on the oft side, but the manes of troop horses are generally made to lie on the near side. The near side is more convenlent for mounting purposes.

848. Plaiting.-Manes that are untidy will be much improved if plaited up and left so for a few days. (See P. 27g, 106.) Plaited manes are quite common in the show-ring.

Plaiting the tail can be done in various ways, with or without coloured ribbons. The lail can be plaited un round the bottom of the dock in various ways (see P. 26, 27); it can be plaited from the top for six or eight inches down the back, as in P. 30a; it can be plaited all down the dock (P. $51 h)$, or it can be plaited, and the plait brought up and plaited into the back of the tail, near the top, as in P. $30 b, 118 \%$. A tail must never be plaited tightly. Plaiting is in many ways better than banging the hair, because, when flies are bad, the horse has a full tail, or, if he is turned out to pasture, he is fully protected from flies. If a tail is kept neat it looks very well plaited up in various forms in dirty woather. I have seen a great many handsome private carriage pairs in Canada and the United States with the tails so plaited. (See P. 37.) Saddle horses should also have their tails plaited up in muddy weather (P. 27h). Fortunately, flies are not generally about in muddy weather. On several occasions I have started out riding or driving with a horse with a very long tail, and on reaching muddy country have stopped for one minute and plaited the tail up. Heavy horses on the farm require a tail of good length, but heavy horses in the city, as a rule, have their tails about level with the hocks; this keeps the tail clean. (See P. 135b.) Dappled greys, so popular in Canada, usually have their tails left quite long, and tied up, of course, in dirty weather. These tails are usually white. (See P. 26a, b, 52.) It is only a matter of a few moments to clean a long white tail, even if it is not tied up in dirty weather ; there is no comparison between clean. ing a tail, however dirty and however long, with cleaning one of the four legs. Besides, a dirty tail will do little harm compared with a dirty leg. which may cause disease.
On thls polnt Stephen H. Terry, in "The Crime of Docklng Hornes," says: "This tying up of the long halrs of the tall has the efiect of keeplng it clean, whilat not depriving the horse of an ornate inatrument for fy destruc. tion and a screen allke valuable for warmth and decency."

Q4. An Important point that I have brought before the public in the Press is the lazy way some people leave horses' talls plaited up overnight. If a tail is tied up quite loosely at the end, no harm will result; but, for the horse's comlort, this should not be allowed, because many horses will not lie down and rest. The practice of using ribbons tied tIghtly around the lall is very dangerous and must never be allowed. A few hours may be sufficient to cause damage in such cases. The common practice of showing of a horse's quarters and hind action by plaiting the tail is a very humane one and should be encouraged, but the above points must not be neglected. Again, damage has often been done by bendling the dock and twisting the hair around near the root of the tail; this is done in a show-yard to show of the horse's hind action. and is quite permissible, as it is only left up for a lew mir.ites. (See P. 118b.) This must not be done at all tightly, or it will cause pain. Cangrene, the result of stasis, has often resulted from plaiting tails 100 tightly. On no account must the end of the dock be clipned, as shown in P. 109 , Fig. 26.

215. Trealment of Mane an.. I Diseases.Neglected manes and tails somt 16 get mane and tail eczema, which is a aisease of the dermis, or true skin. The causes are dirt, continuous washing, irritant soaps, long exposure to rain and cold, bacteria, etc. The usual symptoms are rubbing, hairs becoming matted and talling out, skin becoming thick, hard and inflamed, etc. If the mane and tail are fairly thin - that is, not too thick and bushy-this trouble can easily be cured. A good application is parafin oil (kerosene) one part, water ten parts, thoroughly shaken together, and well rubbed in immediatcly. One application is generally sufficient. Or treat similarly with a 2 per cent. solution of creolin, or rub in powciered iodotorm, which should be powdered finely in a mortar. In bad cases a 5 per cent. solution of silver nitrate is very good. If the disease is caused by neglect or by bacteria, and not from exposure to cold or over-washing, always commence by washing the part thoroughly with warm water and castile soap.

Another good application for itching manes and tails is:
Linseed oil
Sulphur (pon
Oil of tar
... 20 parts.
4 parts.
1 part.

Put these into a bottle and immerse in warm 
water for several hours, shaking at Intervals ; rub well into the part for three days, morning and night. For an itching skln a lew applica. lions of diluted prussic acid (HCN) is very beneficinl.

An excellent remedy for rubbed tails and manes is :

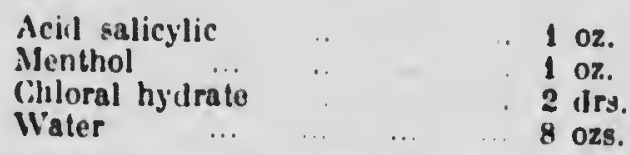

A similar preparation is sold by druggists under the name of "Hedrub." This solution must be rubbed well into the roots for two or three minutes twice a day.

A gooc application for eczema, after thoroughly wasling the part with castile soap, is : Starch and talcum, oz. of each: sugar of learl (lead acetale), 3 oz.; camphor water, 6 oz. Apuly morning and night. Arsenic is used internally for chronic skin diseases, but not for acute attacks. Other external applications for chronic skin diseases are: Salicylic acid, oil of cade, balsam of peru, ammoniated mercury ointment, etc. For mange, wash thoroughly with castile soap and lepid water, and apply morning and night a 5 per cent. solution of carbolic acid. Mange is caused by a minute insect. Antiseptics and cleanliness are the best cures.

Any drug that acts as a purgative, as a diuretic (nitre, pot. chlorate, etc.), or as a diaphoretic (as cliloral liydrate, chloroform, pilucarpine, etc.), wlll lend to curo skin diseases hy drawing away impurities from the blood. Sulphur, which is eliminated through the skin, should be used in chronlc cases, and will asslst in all cases.

246. Causes of Rubbing Tails. - The lall is usually rubhed near the root on the upper surface. Docking is often responsihle for this, the wound causing the tail to itch. Capt. Hayes mentions this in his books.

A tail should always be bandaged if the horse rubs it, because rubbing will make the itching worse. If such a lail is neglected, the hair follicles may become permanently injured, leav. ing a bare patch. A tail guard or bandage should be used on the railway or on board ship to prevent rubbing. When first signs of rubbing are discovered, the horse must be put in a stall where he cannot rub mane or tail. The mane is usually rubbed by the horse getting his mane under the manger. A irequent cause of tail rubbing is either neglect to sponge the under side of the dock, or worms. WVorms can generally be destroyed. (Sec Chapter XI.) 


\section{CHAPTEIR VI}

\section{DRIVING AND HARNESS}

247. On Driving.- The subject of draught is one that affects our servant the horse very greatly, and therefore it is only fair to consider this matter in detail. The subject is not understood to tho extent it slould be, considering that 99 per cent. of the horses in the cities are draught horses. This misunderstanding exists because drivers are apt to allow things to $g 0$ on in the slipsliod way they have been used to in the past. Some books written on the subject are full of theory which could never be put into practice. Mechanics seems to be less understood in this branch than in any other. In considering the load that a horse can draw we must consider three factors: the force and the method of applying this force; the vehicle and the iv zht carried by it; and the track on which the ve. ie is to move. The former refers to the tyr of horse and the type of harness. From the horse's point of view, and from a pecuniary point of view, we must aim at getting the most work out of a horse with the least exertion, i.e. least waste of energy. This is the principle upon which all engines are made, but I am sorry to say upon which horsed vehicles are seldom constructed.

248. We will first consider how a horse draws his load. He throws his weight forward, and then temporarily removes the support under the foremost portion of his body (i.e. his forelegs), and thus allows the weight of his body to be supported by the hindlegs, which will be in compression; the traces of the vehicle will then be in tension. Strictly speaking, then, the weight of his body draws the vehicle forward primarily. As well as this, the muscles of all forelimbs advance the body forward on the limbs, so that the draught power of a horse is much greater than his weight. A horse weighing $1,500 \mathrm{lb}$. can draw up to ten tons on a smooth road for a short distance. We will first consider the best place to attach the traces to. It has been stated that 50 per cent. of the power of draught horses is wasted through want of know. ledge of the theory and practice of draught. I can quite believe it. The load that a horse can pull, i.e. the resistance that he can offer to a load, depends on (1) his own weight. (2) his grip upon the road, i.e. resistance between his feet and the road, (3) his length and height, i.e. the lengths of the levers acting upon the load, (4) the direction of the trace, i.e. the direction of the acting force, and (5) his muscular strength.

P. 32, Fig. 1, shows the forces acting upon the horse. If the trace $A$ is horizonlal, and the vertical weight of the horse on his foreles's is AC, the resultant force, when the horse is in draught, will be $A D$. Now, let us attach the trace as in Fig. $2, A^{\prime} B^{\prime}$; then $A^{\prime} C^{\prime}$ still represents the horse on his forelegs, but the resultant force is $A^{\prime} D^{\prime}$, and with the same lond the horse has an extra force acting upon his collar; hence, theoretically, the horse's traces exert least force upon the collar when they are horizontal. In practice, lowever, there are two lactors that cause a slight modiffcation of this: firstly, by lowering the traces slightly we increase the resistance between the horse and rosd, and, secondly, we diminish the liability of the collar from slipping up the shoulder. This slipping is common if the shoulder slopes very much. Hence the necessity for draught horses' shoulders being as upright as possible. (See P. 29b, 36c, $h, 47 b, 105 c$.) With an almost vertical shoulder wo would have the ideal draught shoulder. The trace should act at right angles to the shoulder to avoid friction on that part, and, when nearly horizontal, causes least friction.

249. Another way of looking at this question is this. A horse is required to draw the load horizontally along a level road, but if we have the trace attached just behind his heels he is partially lifting up the front of the load, and is therefore wasting a great deal of energy. Hence the lower the traces the more energy will be wasted, and the greater will be the weight brought upon the horse's forelegs, and therefcre the quicker will his lorelegs be worn out. Again, the lower the traces the more the collar is drawn down, so that the neck of the collar rests on the horse's neck. This liability increases as the horse's shoulder is more upright. The above points are theoretically correct, and are practicall correct, too. I have taken the trouble of going sinutely into this matter with owners of draught horses who use sleighs with traces attached low down. (See P. 35d.) Messrs. Elias Rogers, the largest coal dealers in Toronto, told me that the above points were absolutely correct; 
that in the winter their horses tire sooner in the forelegs, and that their withers and crests are continually in trouble.

250. We will consider the effect of the resistance between the horse and the road as the traces are lowered. If the traces are very low, as in P. 32, Fig. 2, the resultant force is acting upon the shoulder from a lower point than if the traces were horizontal. Now, if the traces were attached to the ground vertically under the horse, and the weight was hung on the traces, the resultant force would be vertically downwards, which would offer the maximum resistance between the feet and the road. Therefore, the lower the traces the greater the resistance. If th horse wore almost frictionless shoes and moved on an almost frictionless road, it is clear that it vould be necessary to attach traces low in order to obtain sufficient resistance. But this is not the case. A horse with ordinary shoes on, or with spikes or calks on ice, offers g reat resistance betwe $n$ himself and the road, so that we only need to increase this very sligt.tly with heary draughts, and not at all with light. For this reason a draught liorse, in mounting a steep hill, is often backed by its driver to help it pull the load up more easily.

251. From the above facts we gather that for draught horses liarnessed to heavy loads the traces should be attached to the vehicle about six inclies below the horizontal, but with horses attached to light vehicles an almost horizontal trace should be used. The traces should tend to work the collar upvards rather than downwards over the shoulder; hence the importance of a large throat io the collar.

The above points were considered when the horse was moving on a horizontal or nearly horizontal plane. When he moves up a steep hill the conditions are not the same, as we will consider later. The only difflculty to overcome the attachment of the traces seems to be in the case of heavy sleighs. For these vehicles I recommend an attachment as in $P$. $32, F i g .5$, which, although costing a little more, would repay the cost in a few months. In Canada mast vehicles used for heavy merchandise have the wheels removed in the winter, and sleighs fitted on to the axles ( see P. 23b), so in this case the brackets for raising the height of the traces could be bolted on temporarily by a simple arrangement. I do not see why such sleighs should not be built higher off the ground, as the wheeled vehicles are, although the cost would be more and the liability of upsetting greater, but not so great with heavy draught. It would make it easier for lifting coal-sacks and transferring heavy goods to the warehouses and platforms, which are mostly built to fit the wheeled vehicles.

Supposing a horse is drawing a load up a 20 per cent. grade, i.e. one unit rise to every five units of horizontal distance, which is a steep hill.
To draw the load up, the lorse requires increased resistance between his feet and the road, so that he will be considerably assisted by laving the traces attached lower down on the chicle. The steeper the hill the lower should they be attached; of course, the hill itself will cause the traces to assume a lower position behind the horse. This would be impracticable, so we must consider a more reasonable way of helping a horse draw a heavy load uphill. We find that by lowering the traces on the vehicle we increase the resistance of the horse, i.e. the apparent weight of the horse on the road, so the same assistance will be given the horse by increasing the weight on the horse's back. This can be done in two ways: (1) as stated above, by placing the driver on the horse, wlich has a ma:vellous effect upon a horse that has been unable to move a load without this extra weight; (2) by placing the load forward on a twowheeled vehicle, so that some of its weight bears on the shafts.

252. This brings us to the second point in draught: Where should the weight be carried on a two-wheeled vehicle? The two-wheeled vehicle is the ideal one for carrying heavy loads ; firstly, because the load must necessarily be nearer the horse, and, secondly, because the load can be altered in position to assist the horse on varying inclinations of the road. The hansom cab driver will stand up and lean forward, when going up a steep hill, to assist his horse. On a slight incline this should not be done. P. 32 , Fig. 3, shows the load at the back when the horse is going uphill. Let $\mathrm{AC}$ equal the force of the load and $A D$ the lifting effect of the load upon the horse, which he has to overcome. Then, by completing the parallelogram ADEC, BA is the resultant force which the horse has to exert. The direction of this force is such that it tends to raise the horse's feet from the ground, and therefore diminish his power. This power becomes less and less as we increase the load on the back of the cart, until the horse is unable to move at all, and, upon a further increase, the horse is lifted of his legs.

253. Now, supposing the weight is placed forward, as in P. 32, Fig. , then $A^{\prime} D^{\prime}$ is the weight acting vertically downwards upon the horse, $A^{\prime} C^{\prime}$ equals force of load; then $B^{\prime} A^{\prime}$ equals resultant force horse has to overcome, in the direction shuwn. This force is acting in a direction that tends to force the horse's feet into the ground. From this it is clear that, for uphill draught, part of the weight of the luad should be brought on to the shafts, or else the man chould mount the horse ; though in this latter case the total weight will be unnecessarily increased. But it is better for the driver to do this than to ride on the cart, unless he sits well in front. The easiest solution of this problem is for the 
PLATE 31
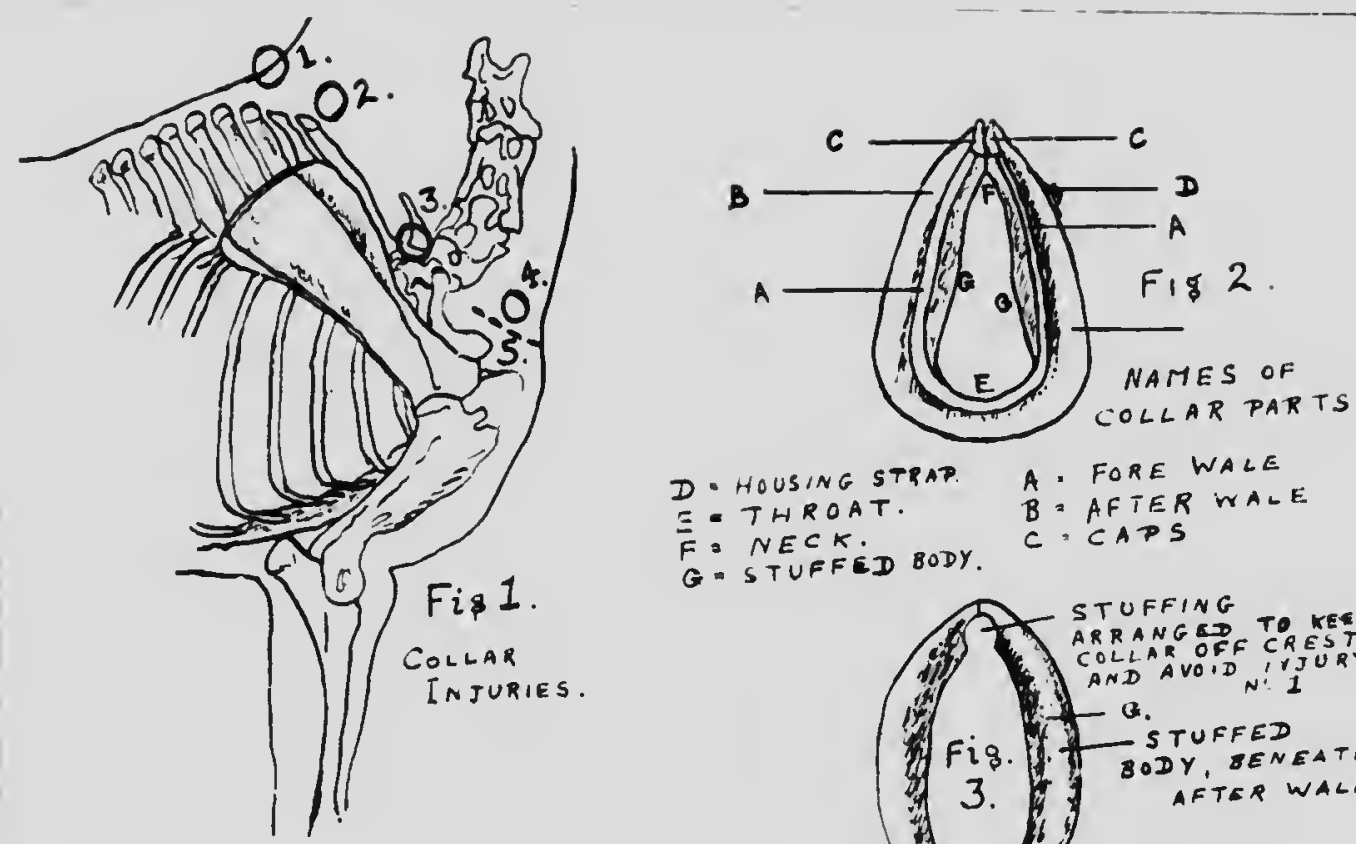

D. HOUSING STRAP.

A FORE wale

E. THROAT.

$\bar{F}:$ NECK.

$B=A F T E R$ WALE

$G$ - STUFFED BODY.
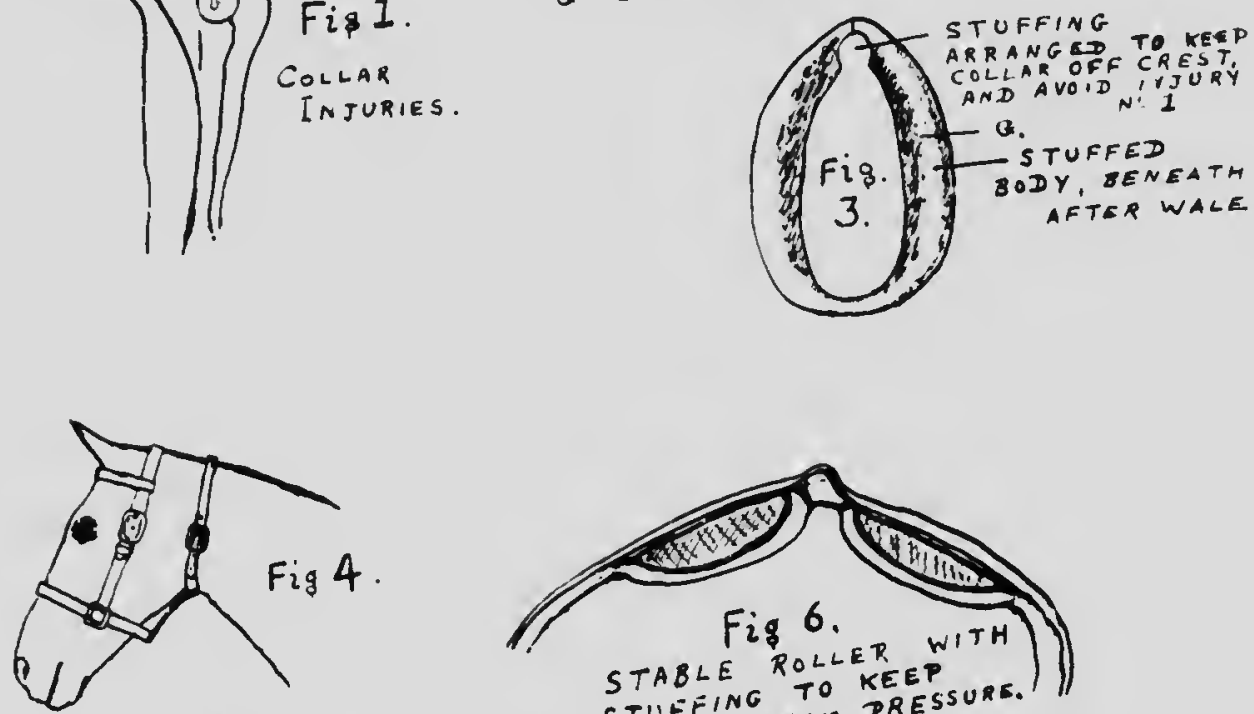

NON-SLIPPING

HEAD COLLARS
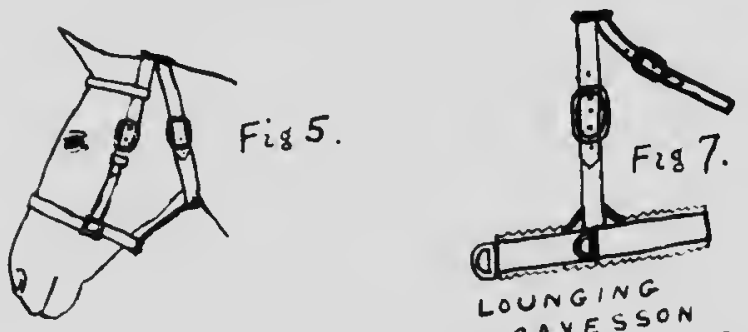

CAVE SSON

(NOSE BAND FELT).

Fig 6 .

STABLE ROLLER WI

STABLENG TO KEEP SPINE FRE
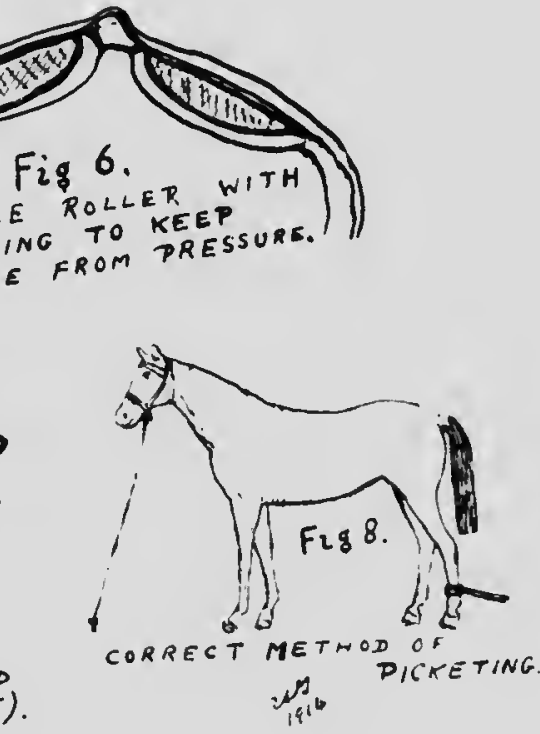

COLLAR DIAGRAMS, ETC.

Fig. I shows Collar Injuries.-No. I Due to Pressure, Remainder Due to Friction: 2, to Tight Collar : 3. to Loose Collar: 4. 10 either Tight o- Loose Collar: 5. 10 Raw Edge of After-wale touching the Skin 
PI. ITE 32

\section{THE THEORY OF DRAUGHT}
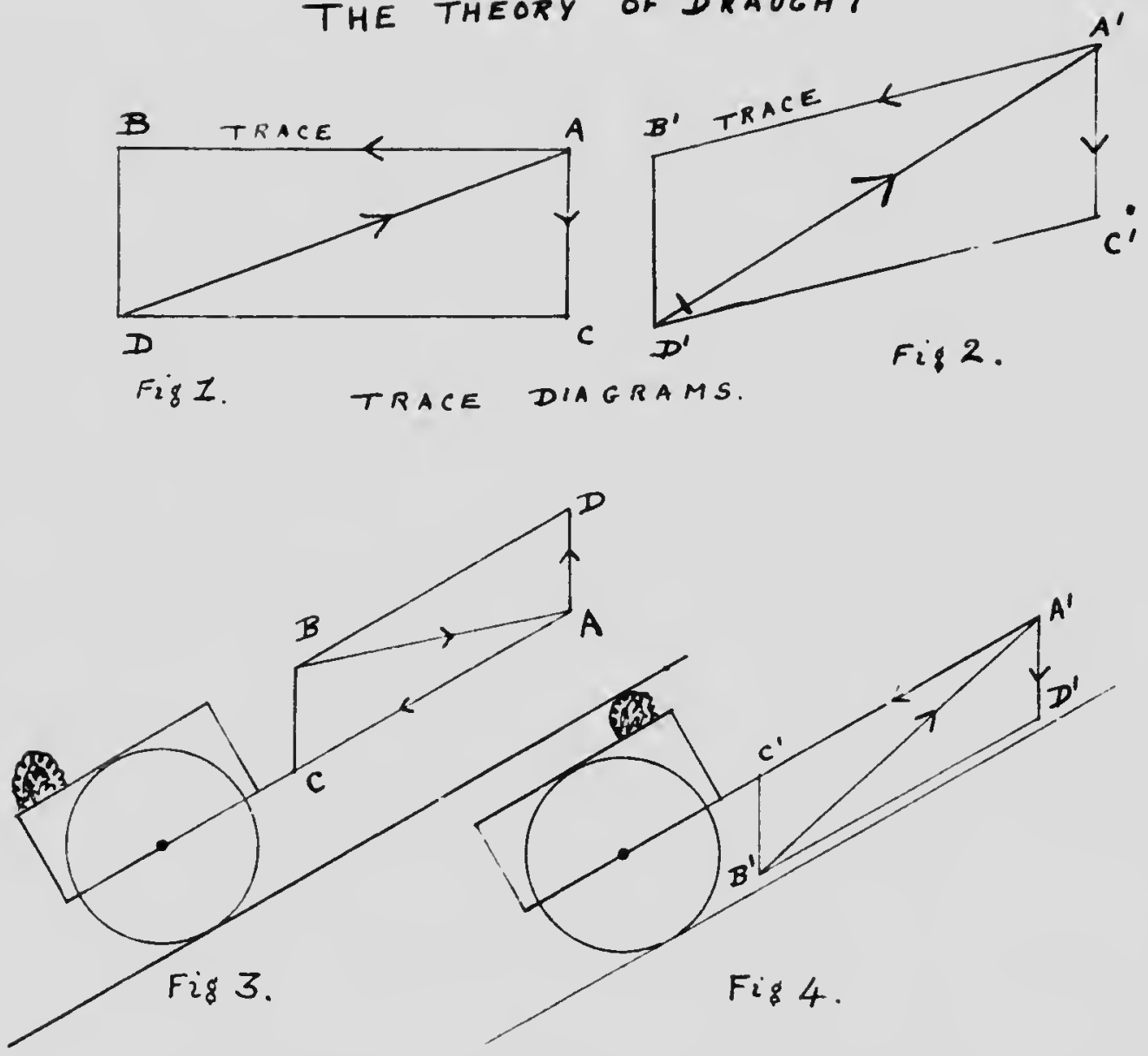

POSITION OF LOAD ON 2 WHEELED VEHICLE.

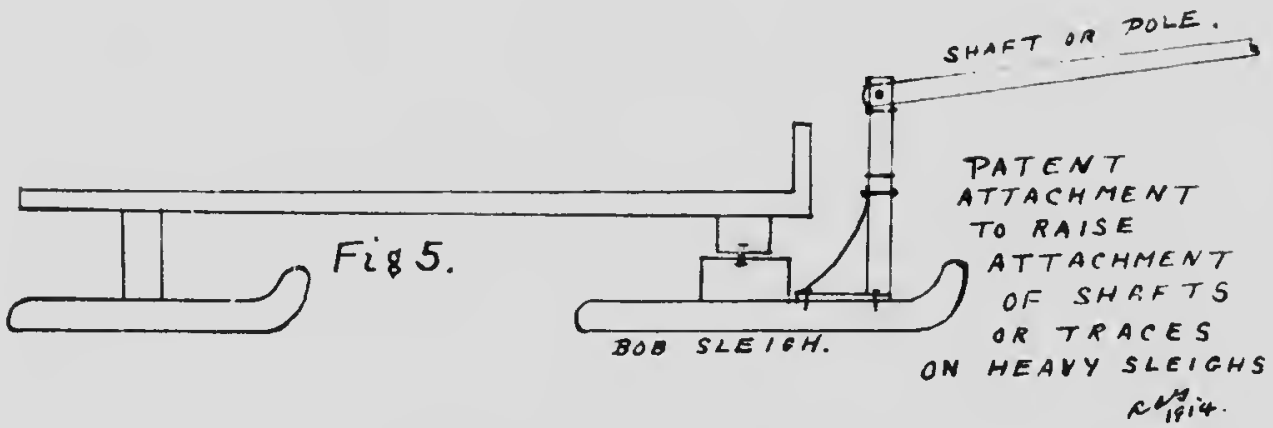

DRAUGHT DIAGRAMS

Showing that the Traces should be Attached High, and when going up Hill (except when very slight! the Weight should be put Forward 

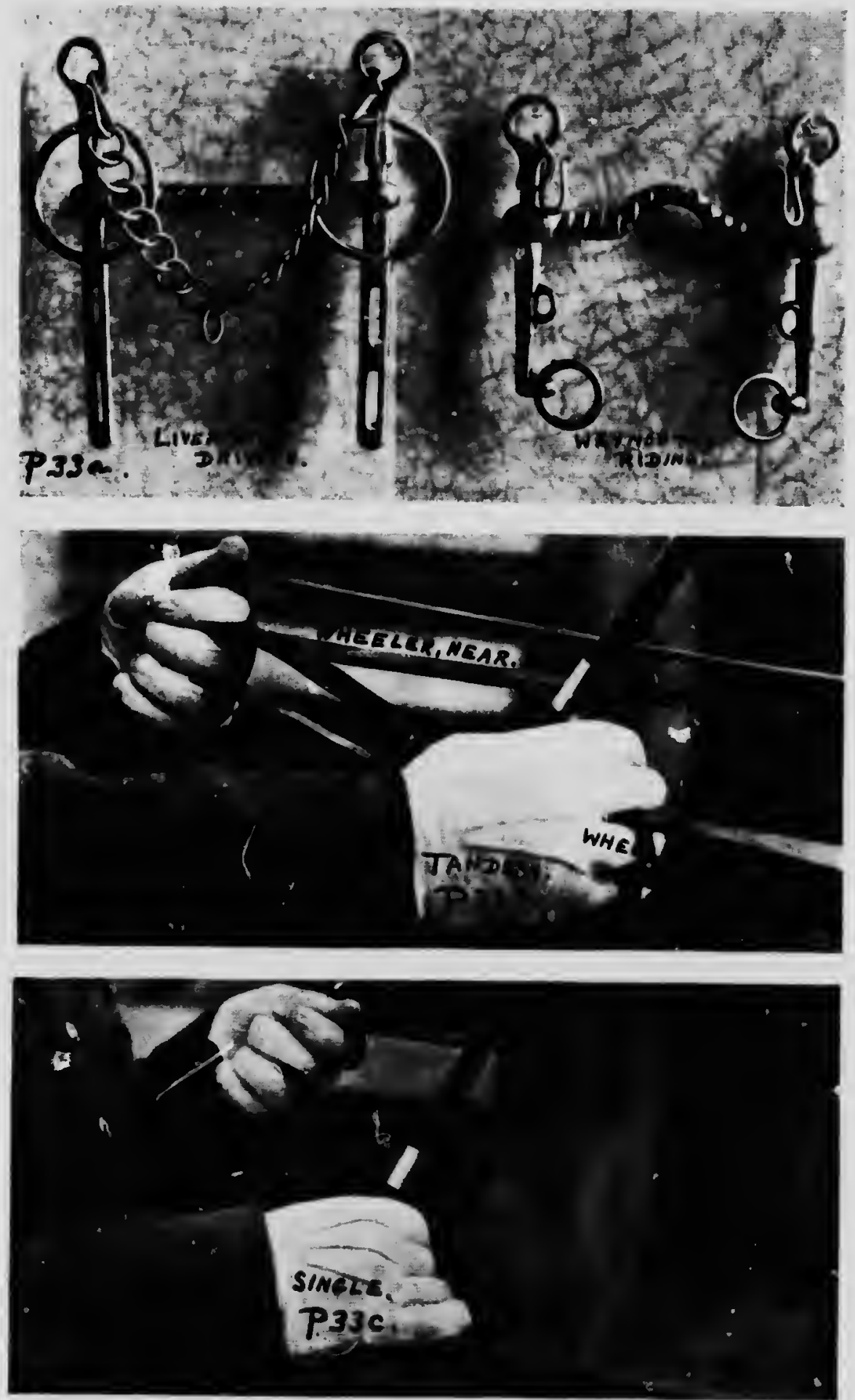

o. Bits Strongly Recommended (Jur Text). b. Correct Method of Holding the Reins when Driving Tandem or Four-inohand. c, When Driving Single or l'air. Photos by the Author 
PL.ITE .34
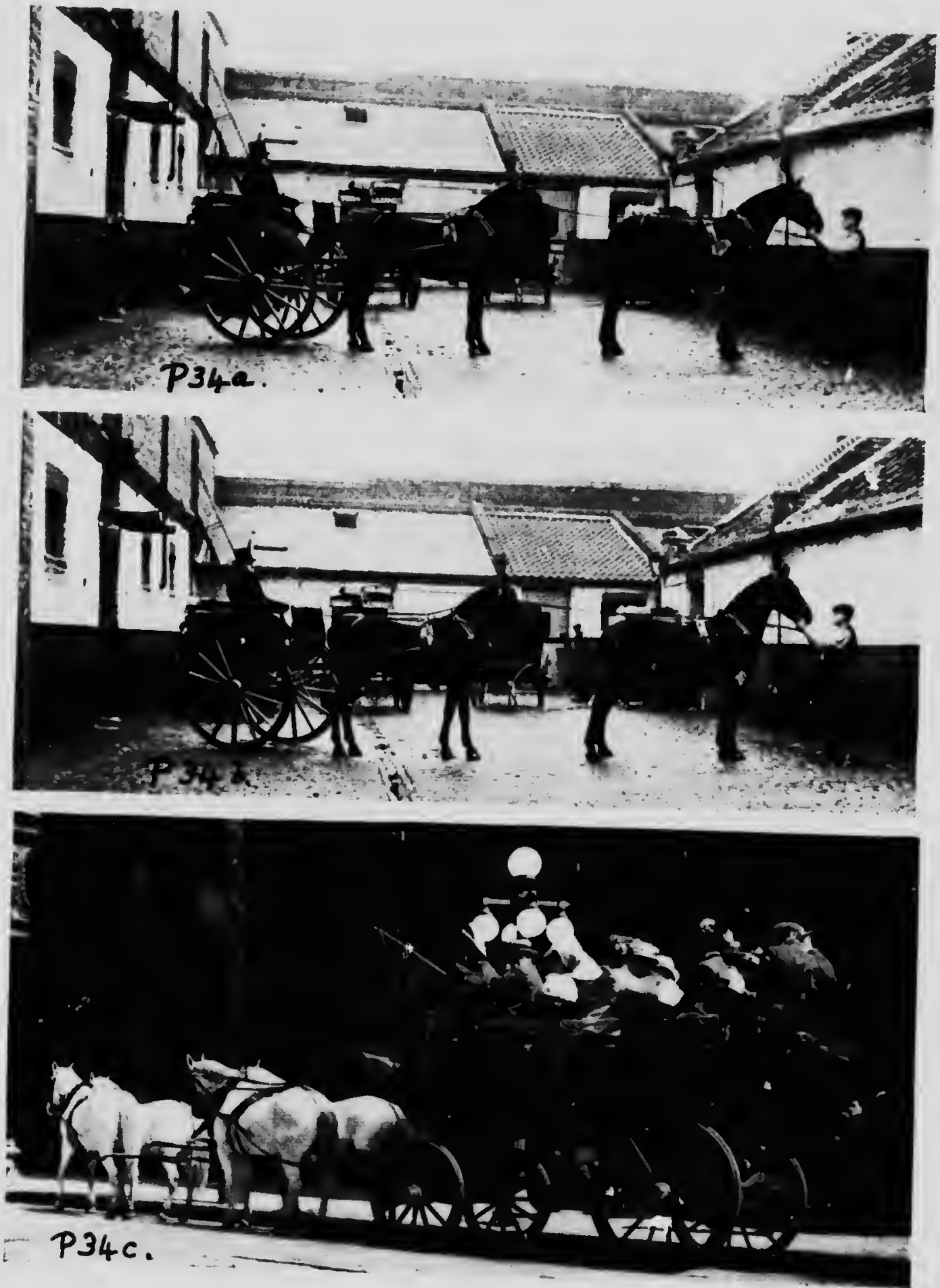

A MODERN TANDENI a. With the Tai's Ieft Natural. b, With the Tauls Plaited.up. Courtesy: Messrs. T. Tilling, London. Photos: Author.
c, Madern Four-in-hand. Courtesy: P. Maher. Toronto. Photin. James, Toronto 
driver to sit right forward upon reaching a steep hill, but the most humane solution is for him to get off and walk and to place the load forward.

For light private two-wheeled carriages or for light two-wheeled carts this alteration of weight is unnecessary, except upon going up very steep hills, when the driver should lean well forward. This cannot be done with fourwheel carriages, 80 in this case the driver would help the horse by mounting him. Experiments to prove this have often been carried out. A cart is loaded until the horse is just unable to draw it up a steep hill, heavy weights of about $300 \mathrm{lb}$. are attached to the saddle of the horse's larness, and the horse proceeds up the hill.

254. The above points do not apply at all $t$ draught along level, up slight inclines, or downhill. In these cases the loud should be placed at the back, tending to raise the horse slightly off the ground, thereby giving his legs less weight to carry and consequently saving fatigue and legstrain. The objection to this is that the horse is liable to get girth galls if the greatest care is not taken. At any rate, when going downhill the driver must sit on the back of the cart if .. 3 two-wheeled. The driver of a light twowhaned vehicle should lean back.

2.55. The poles or tongues of vehicles should either be flxed, as in $\mathbf{P} .47 b, 134 c$, or suspended by a strong spring, so that no weight bears upon the horse's collar. Anyone who has wheeled a two-wheeled hand-barrow, and who has tried the difference between a forward and a back load when going up and down hill, will readily understand how much easier it is to draw a forward load up a hill and to draw a back load down a hill, along level, or up a very slight incline.

256. Whiffe-trees. - The attachment of the traces is of great importance. As a rule, in pairhorse carriages, farm wagons and many other vehicles, especially in England, the traces are attached rigidly on each side. This is quite wrong, and is the cause of many sore shoulders. As explained under the heading of "Collars" (Sec. 273), we seo that as a horse moves at any of its paces the shoulder-blades advance and retract alternately, and not together, so that, with traces fixed independently and rigidly, they become alternately tight and loose, and therefore there is a see-saw-like bearing on the collar. To prevent this the rear end of the traces should be attached to a whiffle-tree (see P. $36 c-f$ ), so that while the horse is in motion the tree is oscillating slightly all the time. This is more important with breast harness. (See P. 36d, e.) The whiffle-trees are used on all American buggies and all heavy vehicles on the American continent; there is no reason why they should not be used on private vehicles, etc. The advan. tage of draught horses boing driven abreast, as in P. 114C, which is a general practice on the American continent, is that the load upon the horses' shoulders is kept constant, whilst in tandem the lead horse does not keop the traces tight all the time and the two horses are not always pulling together. At one moment the lead horse relieves the wheeler of his load, and the reverse happens the next moment. This is most exhausting to the horses. It is most important that the pull exerted upon the horses' sloulders should be constant and steady, and not an uneven one. With the American system the "evener" keeps the traces of both horses al-ways tight, unless one horse drops back very far. A whiffle-tree behind each horse is attached to the ends of the "evener." The pull is kept more oven by using a short, strong spring attachment to the traces (P. 143c). This shows the spring attached to a coal-merchant's harness, which saves the horses' shoulders considerably. On the other hand, this spring must not be such as to allow much elasticity to the traces, or power will be lost. Impetus is necessary to overcome an obstruction on the road, and elasticity in the direction of the movement destroys the full effect of impetus. Thus, when a horse is moving along at a trot, and the wheel meets a stone, if the traces are very springy and the load very light, the stone might decrease the speed of the load so much that by the time the limit of stretch of the traces was reached the load would be stationary, and a terrific jerk would be required to restart it. In fact, in going over a rough road the horse would be continually restarting the load. So that it is of the greatest importance that the traces be non-elastic, except so far as a small powerful spring may be introduced, as described above. This absence of elasticity is of greater importance in the attachment between the load and the wheels or the runners of a sleigh ; for example, ths Ceospring carriage, that allows a backv _.d and forward motion upon the wheels. This type is the worst type of vehicle for a horse to draw. If such a vehicle meets a stone, the impetus of the wheels alone is not sufficient to pass over it, and the impetus of the body of the vehicle is absorbed by the elasticily of the spring. Thus the vehicle will become stationary. Rut with no springs, or springs that allow no forward movement of the body, the impetus of the body will carry the vehicle over the stone and allow it to continue practically at its normal speed. The more rigidly the weight of the vehicle, or the weight in the vehicle, is attached to the wheels or sleigh runners, the more constant will be the speed of the vehicle when going over rough ground, and, therefore, the less will the horse be fatigued. For this reason I do not recommend Cee springe where the horse is considered.

257. We might wonder how it is that a horse, 
when walking, can move so large a load with the muscles of one hindleg, because, normally, when $a$ horse is walking only one hindleg is on the ground at once, and each leg is off the ground $f \cdot r$ the same length of time that it is on the ground. But when a horse is drawing a very heavy vehicle the time that his feet are of the ground is comparatively much shorter ; in fact, most of the time all four legs are drawing the load, each leg being moved rapidly forward to a fresh position whenever the weight of the body is so far forward that it prevents further advance. A horse, when sturting a heavy load, will use both hindlegs and both forelegs together.

258. Poles. - The poles or tongues of vehicles are generally rigid, so that their weiglit is not borne on the holse's neck. With some vehicles, especially wagois, the whole weight of the pole is laken on the collars. (See P. 10'ic.) This should not be allowed, and can easily be avoided by the use of a spring attached to the front of the vehicle bearing the weight of the pole. The other end of the spring is attached sometimes near the front of the pole and sometimes about one-third along the pole. In the latter case a spring must be exceedingly strong, as it will become more easily broken.

259. Loads. - A horse has been known to pull over fifty tons on a level railway, and I have known a draught horse to pull sixteen tons in a level yard. Normally, a liorse should not be expected to pull more than a ton on good country roads, but on city streets he can pull double this with ease. Two horses working together can gentrally pull proportionately larger loads than they can separately, as they help one another. If one ceases to pull for a moment, the load does not stop and have to be restarted, as is likely to happen with a single horse. Provided that all the horses work together, we get proportionately more work out of a span of horses, and the horses will become less fatigued. The only really economical way to harness up two, four, or six or more horses is side by side by means of "eveners." (Sre P. 366.) Thic method is adopted for ploushing and reaping in Canada and the United States. If harnessed in tandem formlation, i.e. one in front of the other, the leading horse is too far away from the load, which means loss of power, and, unlese all the horses are pulling all the time, there will be further loss of power. With "eveners," if one horse drops back a little, lis traces still remain tight.

260. Ocerloading.-A very common form of cruelty daily seen on the streets and country roads is that of overloading horses. Much of this form of brutality, I am glad to say, has been eliminated through the work done by the various S.P.C.A.s, but there is yet much to be done. The motor truck lias relieved and will relieve. many horses of this furm of cruelty; but, as a rule, the type of horse-owner who overloads a horse is the one that is unable to purchase a motor truck, and so he will continue to overload and probably underfeed our equine friend until the law puts him in his right place. A horso that is well cared for and is making good progless with an overload is not such a pitiful sight, but when we see the driver thrashing a worn-out lorse who is doing his utmost, not only should the law, with its trifling fines, intervene, but the penal code should have a say in the matter.

281. Driving.-The amount of ignorance displayed daily in the streets by so-called drivers is positively appalling. The reader should study Chapter III. closely if he is not quite sure that the best way to manage a horse is by kindness. Xenophon, centuries before the Christian era, toli us that horses were laught and managed by gentleness, and not by harshness. Why is it that drivers cannot realise this? The commonest fault of all is the use of the whip, when the horse is doing its best, and jerking the horse's mouth with the reins. Personally, I think that it is far more enjoyable to drive a good horse than it is to drive an automobile; but, unless the driver has any love for the horse, there is no doubt that it does not appeal to him to the extent that it should, and in such cases he had better resort to the motor. It raquires far greater skill to drive a liorse properly than it does to drive a car. It takes the average man but a few months to become a good motor driver, but no man has learnt to becomo a first-class whip in less than five or six years, and even then he is always learning. Not one in a thousand of those who drive horses can be called expert drivers. The man who can cut a good style in the show-ring is not necessarily a good driver; he may have, and probably has, in the first place, bad hands. Besides having good hands, he must have perfect control over his temper, perfect sympathy for the horse, perfect knowledge of the horse's powers and intelligence, knowledge of the manner of accustoming the horse to objects that he is afraid of, the use of
the whip, etc.

A horse must never be turried unless it is absolutely necessary to do so, bevause a few minutes gained may mean a large loss in condition or even bodily harm. He should be walked up hills, especially if a load is heavy or the hill is steep, and walked down, unless the vehicle has brakes. Trotting downhill, witlout brakes on the wheels, does a great deal of harm to the liorse's legs, and is responsible for a great many horses being "over in front." Frequent watering, if the horse is not hurried $\mathrm{fc}$ ten minutes afterwards, will help the horse very much on lonf journeys. In hot weather, city authorities slould supply oatmeal-water for horses. This is done in many cities. It should be remembered that a horse requires to get his 
PlATT: 35
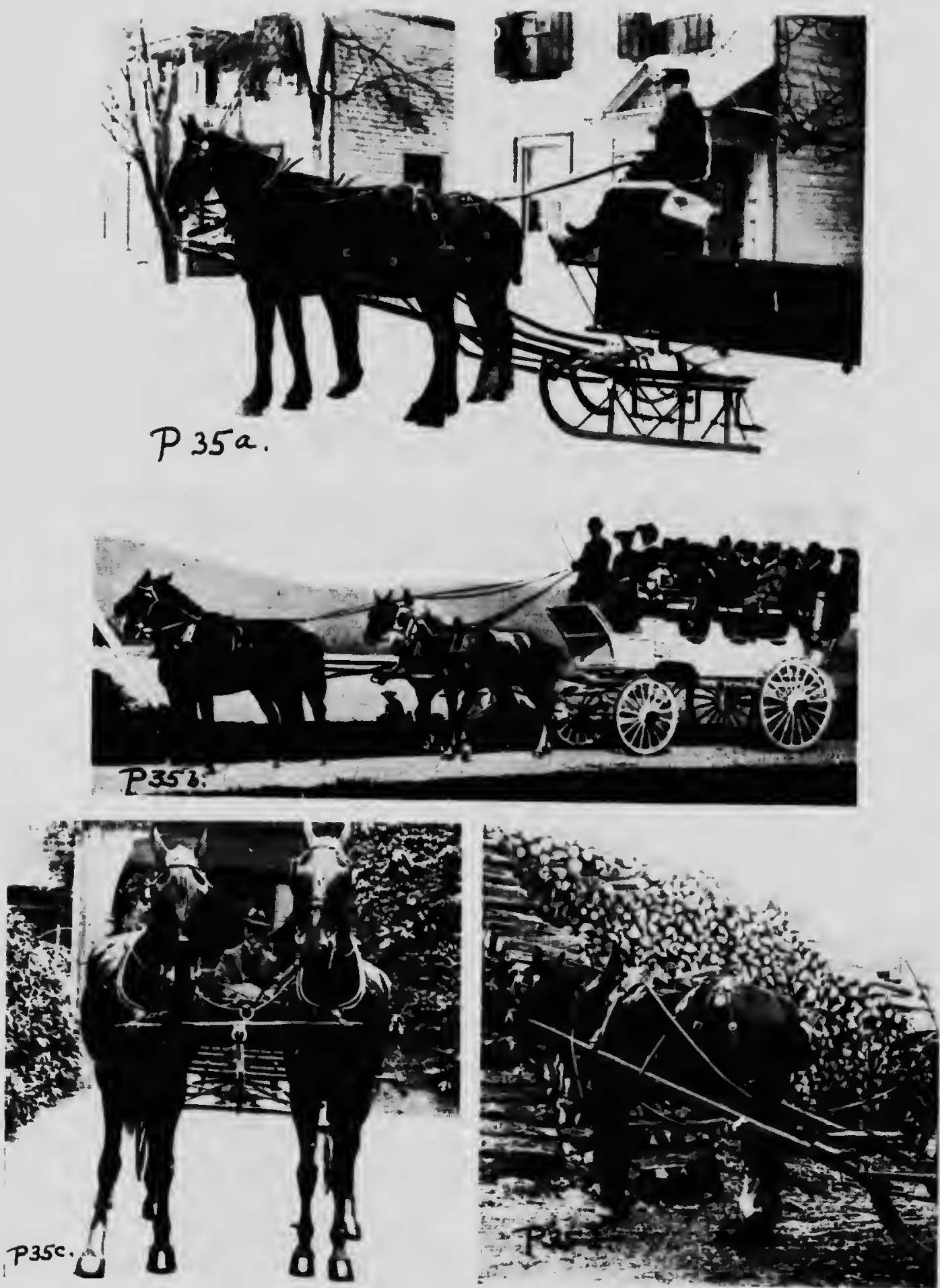

a. Shows the Low Altachment of Traces (sit Texi). Courtesy: Dominion Express Co., Oltawd. Low Allachment of Shat in Winter. Courtesy: Elas Rogers Coal Co., Toronto. Photos: Author. b, Modern Fourrin.hand in British Columbia, c, Rieck yoke Allachment for American Buggy. Courtesy: Mr. H. Barry, Limpsfeld, Surrey 
PI.ATI: 36,

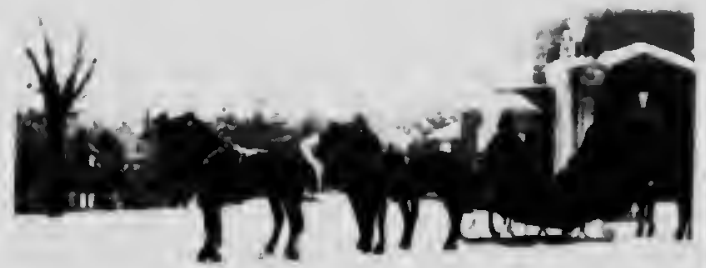

P 36 a.
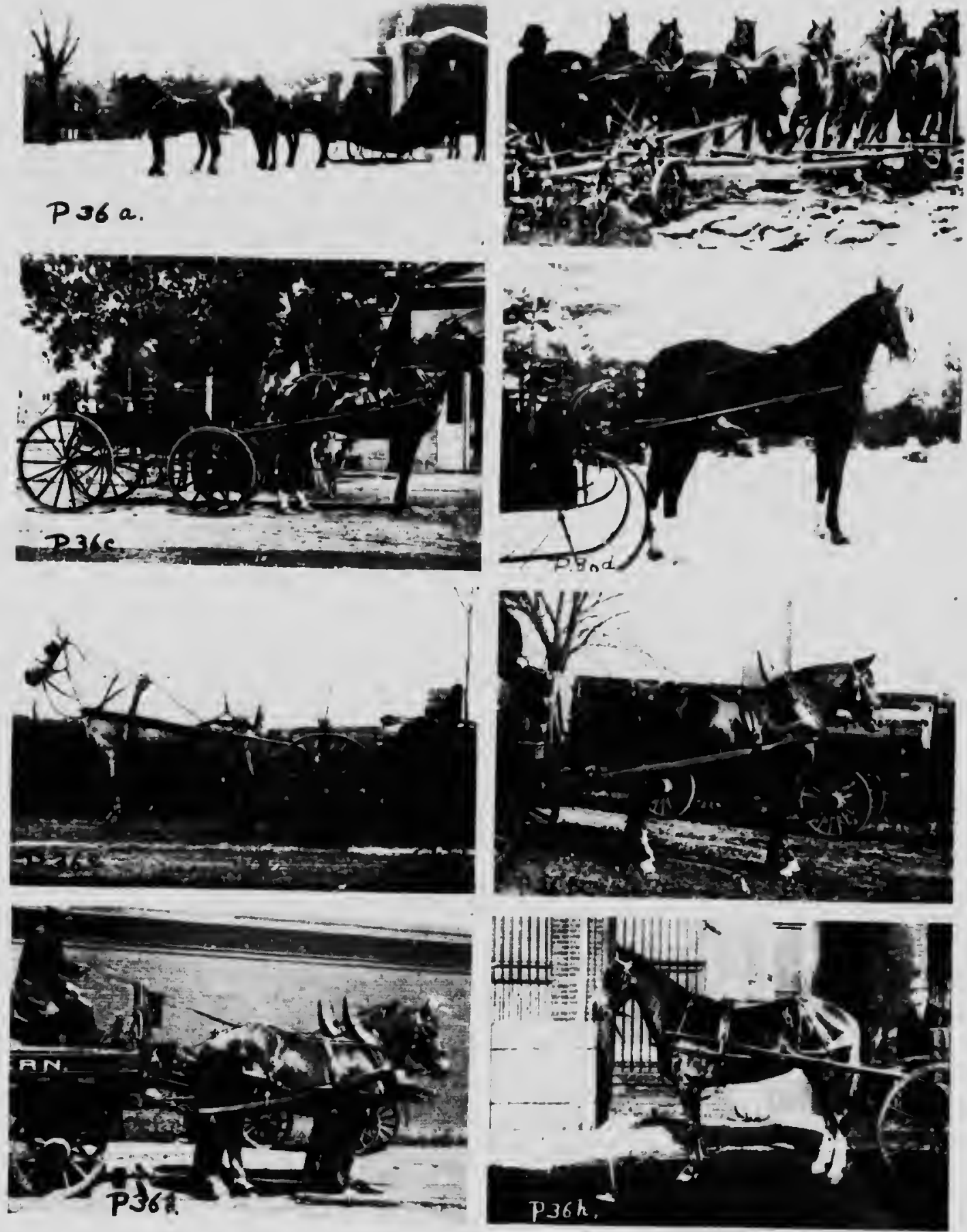

DRIIING AND HARNESSING TO THE VEHICLE

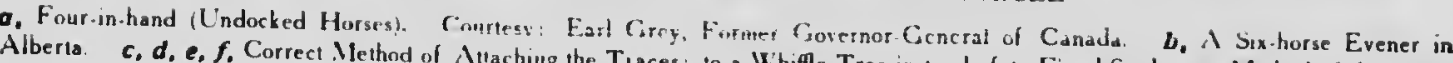
the Breeching to the Neck-ct, Wethod of Nilaching the Tiaces: to a Whifle Tree instead of to Fixed Sinds. $g$, Mlethod of Allaching Guess, Kingston, Ont. f. Dominion Transport Cor Tying Horse to while Standing. Courlesy: c, Mr. Hills. Brandon. Man. e, Mr. Torontos. Canadian Norther
Photos $c$ to $h$ hy the Author 
wind now and then, and therefore he should not be trotted too far without being allowed to walk for a short distance. The driver should watch the horse's breathing, by watching his nostrils or flanks, and rest him when he is seen to be breathing abnormally. The reason that so many horses are so badly treated is that the drivers do not have to purchase the horses themselves, so they do not care how soon they wear them out so long as they can finish their work early. A driver should be continually plecing limself in his horse's place, and realising, if he can, that the animal in front of him is alive and has feeling and is probably doing his best.

262. Very often a horso does not understand what is required of him, and gets thrashed or hit over the head, when it is the fault of the man in the cart. Heavy draught horses should not be trotted; their work is heavy and slow, and trotting shortens their lives and ruins their legs. The time gained does not compensate for the money lost.

If a horse is frightened and moves away from where he is left standing, he should not be shouted at, because this will probably make him more frightened. Of course, if he is not frightened and is shouted at to stop, he will probably obey. If the horse is very susceptible to fear, he must be made to realise that he is not going to be huit; shouting at him will make him think that he is going to be hurt, and he will probably continue to run away. We must calin him, and then show him that he is not going to be hurt. When a horse shies at an object, the opposite rein should be felt slightly stronger than the rein next to the object in order to attract his attention away from it and relieve him of the idea that he is being drawn on to it. (See Chapter III.)

A horse must be blanketed in cold weather when left standing, and rubbed down when brought in ; he must always be watered and cared for before the driver has his meal. The horse should be looked upon as the driver's own property; he should be proud to have charge of it, and take the greaiest interest in keeping it in the best of condition. A horse is much encouraged by being spoken to kindly and quietly now and then; he should never be shouted at. The brutal and useless method of trying to accelerate a horse's speed by jerking the reins should never be allowed. It is the surest and commonest form of ignorance of the correct methods of driving. If the reins cannot be made better use of, they had better be left alone; they are there to guide the horse, to collect him or to stop him, but not to jerk him on. His speed should be accelerated by the voice or by a touch with the whip, which does not mean a thrashing.

283. Whips.-The best kind of whip to use is one with a long lash. (See P. 47.) The kind used in buggies, as in P. 3od, is a good one in the hands of the unskilled. The chief use of the whip is as an indicator, and not as an instrument for punishmont. A horse must be made to be accustomed to being stroked with it; he should only be hit with it when he requires punishment, when the whip must be used on the back or sides, and never underneath, especially between the hindlegs. The whip if used between the hindlegs may cause considerable harm, and, to say the least of it, is a brutal practice. When used to urge a lazy horse on, it should be brought down on to the horse, and drawn away after the lash has touched the horse, and not before, because if it is it may "crack" on the horse's back.

804. Reins.-P. 33c shows the method of holding the reins and whip for driving a single or pair; P. $\mathbf{3 3 b}$ for driving a tandem or lourin-hand. Horses that are well fed and not worked too hard are generally driven "up to the bit "- - that is, with the driver having a gentle feeling on the horse's mouth all the time. This method would not be practicable or at all advisable with commercial horses; such horses last longest if allowed to go along at their own speed, not being interfered with by the reins. But the driver must be careful that the horse does not get into a lazy way of going along. I emphasise the importance of drivers refraining from jerk. ing their horses' mouths; men who do this should have $a$ bar of steel put into their mouths and violently jerked. I have seen a horse's tongue cut almost through by the abuse of the bit. When driving, the traces must be watched ; when they become loose, the brakes must be applied, and, upon reaching the bottom of the hill, the brakes must not be removed until the traces have become tight again. In driving pair or four-in-hand, care must bo taken that all the traces are kept equally tight. A long whip is necessary for this to encourage the leaders to increase their speed. Well-trained leaders will understand a "click" from the driver's mouth.

285. Fints on Tandem and Four-in-Hand Driving.--It is most advantageous to teach the leader to go forward or to increase his speed when the driver chir"ips or clicks with his mouth. The olfest horst, or, rather, the steadiest and most trustworthy, should be placed as the near wheeler. The driver shocld sit high up, so that he is well above the horses, as thereby ho will have greater control over them. The wheelers must always be allowed to start a vehicle; if the lesders are allowed to start first, the traces may break, or, in the case of a tandem, the leeder is very apt to turn round upon finding that the vehicle does not move. The wheelers, ton, must be made to stop the vehicle whon drawing up. Three to four feet should be allowed belween the wheeler's nose and leader's tail; 
wheeler with high action must have four feet ill front of him to avoid stepping on the heels of the leader. (See $P$. 34.) Above all things, the hurses must be started away very steadily, the speed being increased very gradually. If a long-lashed whip is used, the lasl slivuld be kept twistel round the handle, and only untwisted when it is required to be used, which is seldom if the leader is well trained. Onie rein cin bo shortened by pulling it with the right hand through the left hand from behind the left, i.o. between the left hand and the driver's body. In letting one rein out, the right lland is used on it in front of the left hand. The first and second finger of the right hand, or the first finger and thumb of the right hand, will be used to grip the rein that is to be shifted; for this reason the whip must be held well in the palm of the right hand, and not in the fingers, so as to labvo the fingers free. The off-side reins will be held, when necessary, between the second and thirit and third and fourth fingers. "To "ease" the" leader means to tighten his rein in the hand, and therefore to slacken the leader's pace. The leader is always eased when going downhill or along the level, but let out when going uphill. Easing and letting out must be done gradually and .. ot in jerks. If it is desired to tighten the traces of the leader, the wheeler can be easerl or the leader encouraged to go faster.

The wheeler's liead should always follow the leader's tail when making a turn. When making a sharp turn, the wheeler must be held well in hand, the leader being turned almost round before the wheeler is allowed to turn tlie cart. The leader must never be pulled rounil fuddenly with a loose outer rein. The feeling on the outer rein must always be retained. If the leader should start to buck or kick, he must be let out, and not eased (i.e. reined in), so as to tighten his traces. If he were eased, which is so commonly done by nervous drivers, he would become loose in his traces, and would be very liable to get his hind legs over them. The tighter the traces the less liable he is to get his legs over them. As a rule, the larger horse should be bohind, and, in a four-in-hand, on the
near side.

266. Runaways. - The way to stop a runaway horse is not to pull at his mouth or to saw it. but to give him his head for a little distance, and then firmly to draw his mouth in towards his chest, then to lat him have his haad once again and to draw it in again. In this way, if he should have the bit in between his teeth, there will be no trouble in making him drop it. He should be drawn up in the same way as a man pulls in a tug-of-war. He should not be jerkad severely, as this may damage his jaw. This method is far more effective than sawing with the reins, which practice only makes excitrd horses far worsce, becaisee it causes them pain. Paill causes fear, and fear makes a horso go faster. Hence he must not be shouted at. 'The practice of holding on tightly to a runaway's mouth is the best way of keeping him at full speed; the more he is pulled the faster he will go, if he has really made up his mind to 80 , and lie will probably have the bit in between his teeth. I have stopped several runaways within a hundred yards by the former method without doing them any harm, and I have tried the old method with the same horses and given it up as hopeless. I have often seen drivers kicking thoir liorses while sitting on the front of the vehicle. Such usage is most foolish, because the best way to get the maximum of work out of a horse is to treat him as a friend, and not to let him regard his driver as an enemy. A horse will do almost c'erything in his power for a kind master.

267. Horses when left standing, if they will lot stand untied, should be tied securely with a rope from the nose-band, or a halter put on over the bridle, to a post or other rigid object. Great care should be taken, if the rope is looped around a smooth post, that upon the horse lowering his head the loop will not slip down the pole, because, upon the horse raising his head and feeling that his head is tied, he will probably pull hard and break the rope or bridle and get away. A horse objects very much to the feeling that his head is tied lown. Some country houses supply rings, about four feet from the ground, attached to a wall, fence or post, to which delivery horses can be tied up.

268. Notes on the Treatment of Pullers.-A horse pulls from different causas: want of work, excitability, fear, pain and a bad mouth. If he pulls from want of work, the remedy is to give I.1m more work; this extra work should be riven, for preference, on the lunging-rein, and the feed of oats should be decreased. It must be remembered that it takes two to pull, and that the fact that a horse is fresh is no excuse for the driver allowing him to pull. Oood hands, and the best of these, are required to stop pullers from pulling. If from exoitability, the horse requires plenty of good work in competent hands; auch horses go best if driven in harness by the side of a quiet horse; harnees work is always better than saddle work for such horses. If from fear, then the cause of the mischief must bo ramoved; the horse must be accustomed to the object that causes the fear; the voice will do much good, as a rule, to such horses. If from pain, then the mouth must be very sarefully examined; the teeth must be examined for sharp points and for pieces of wood, etc., that may have bocome wedged tightly between them, especially the molars; the bars (gums between the nippers and the molars) hust be examinad; the lips and tongue and the 


\section{PI.ATI: 37}
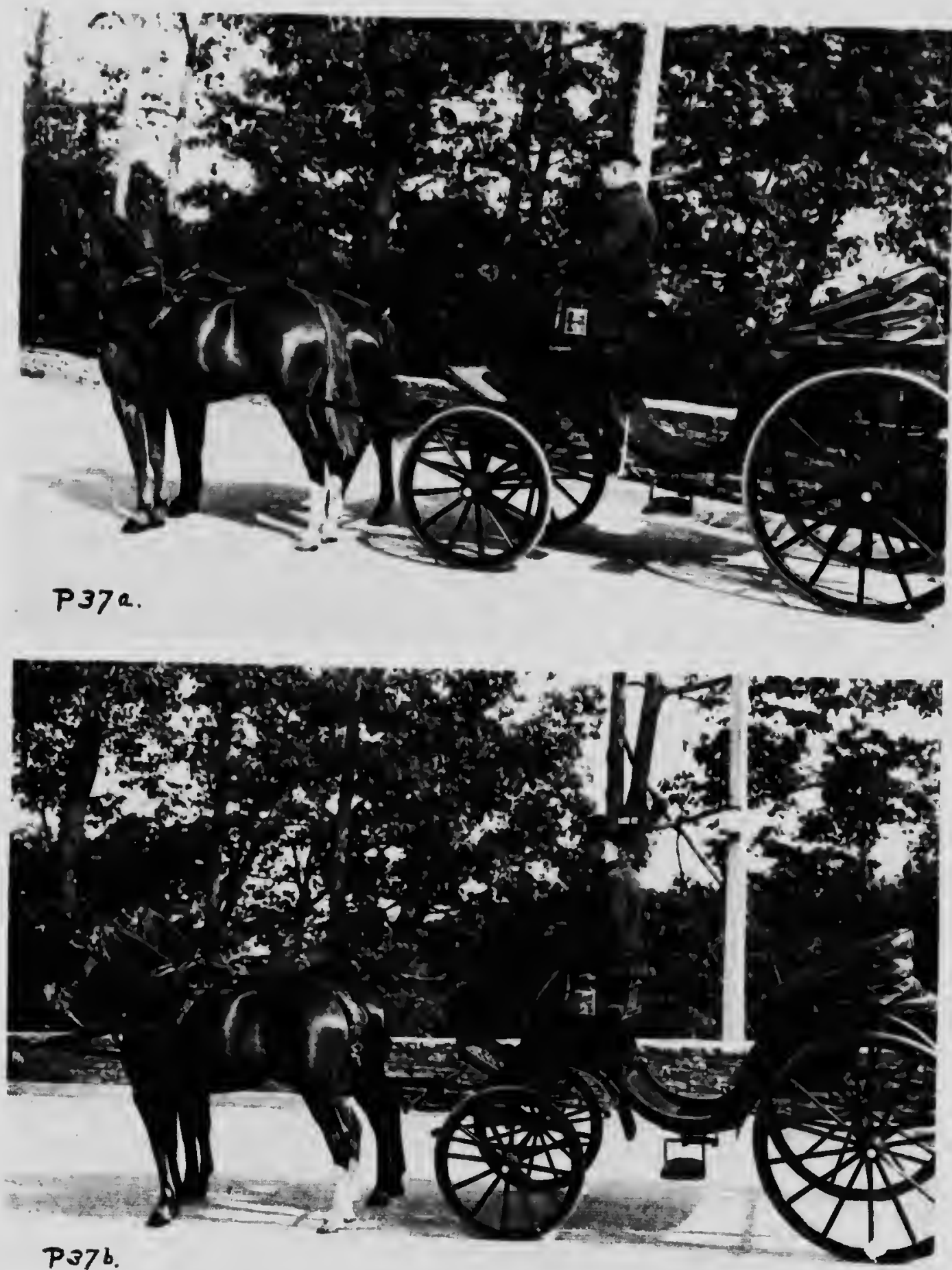

A HANDSONE PAIR OF HIGHSTEPPINC CARRIAGE HORSES

a. With the Tails Dewn b. With the Tails Plaitedafy Conrteay: Major fos. Kifgour, Turunlu. Phous: Ciabraith, 

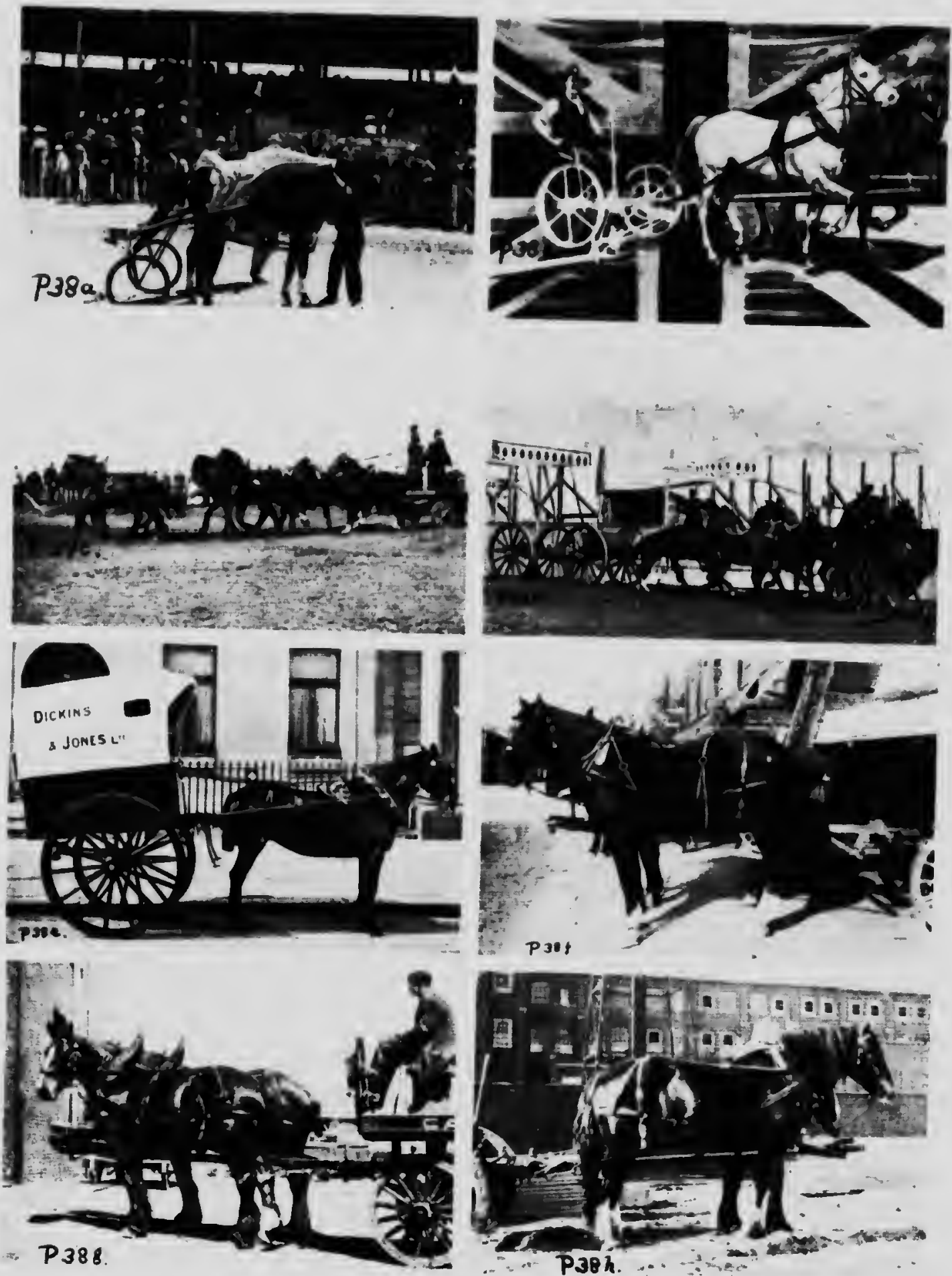

TYPES OF HARNESS

a. "Ruhy R." in Pacing I fobbles. Courtess: Mr. F. .McBean. Oheron. Man. b. Showing Low Draught (sae Text). Courtesy

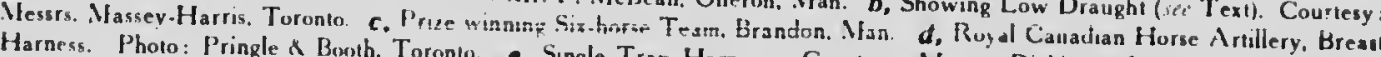
Gaver. Hammersmith. $\&$ Beoth. Toronto. e. Single Trap Harness. Courtesy: Messrs. Dickins \& Jones, London. Photo Co. Courtesy: f, Firstbrook Box Co. 6 , Canadian Northern Transter Co. h, Mr. W'. Crawiford, Toronto. Photos a, c, f, s, ho, by the Author 
PIATI: 30
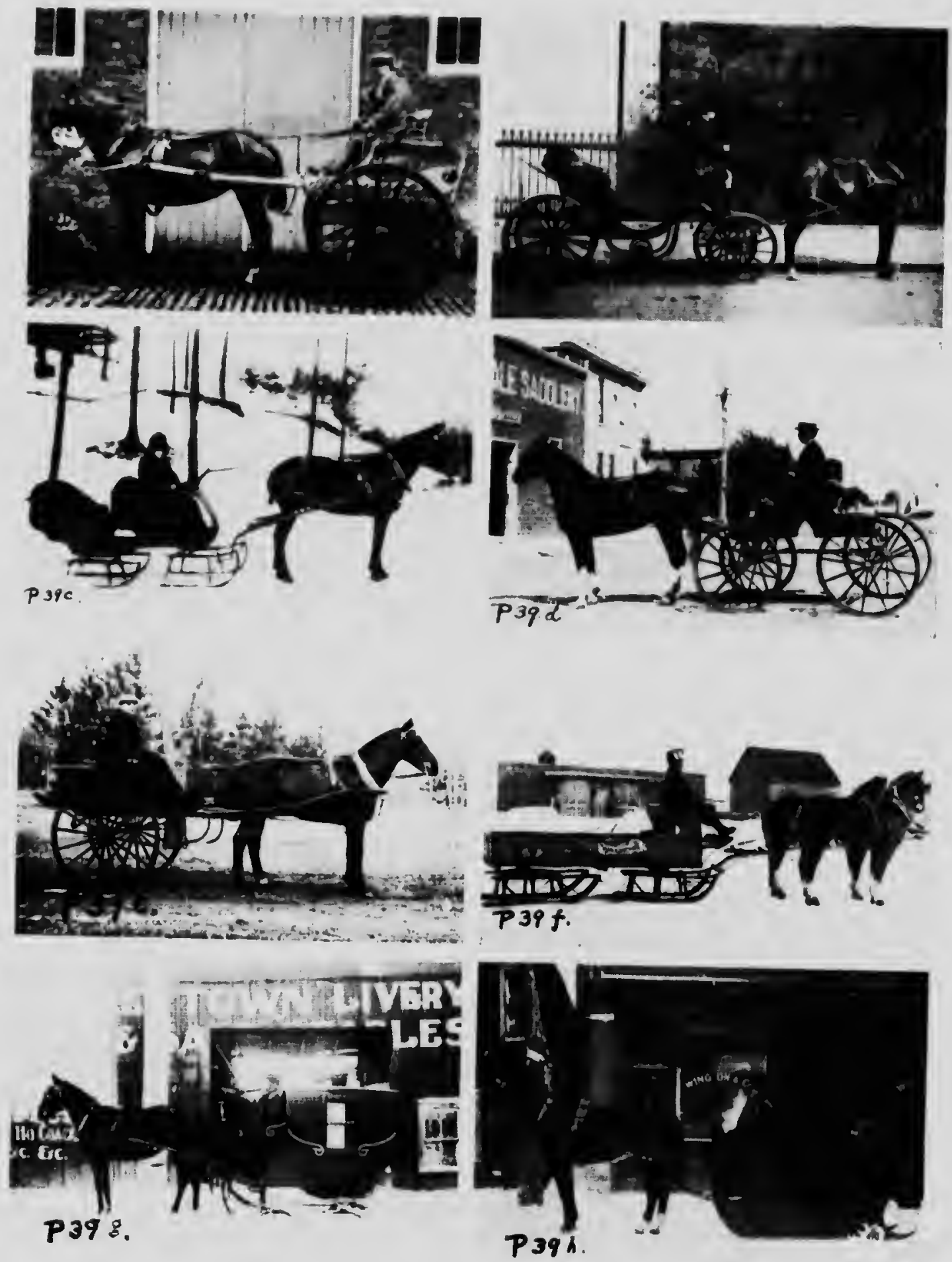

TYPES OF VEHICLES

b. Victoria. cof, Buil.-pieught. d. Three-quarter Lock Buggy. e, Dog.cart. 6, h, Cariole. Courtesy: a, Messrs. W. e, Major Hamilion. R.C.H.A. G, h, Messrs. Jewell \& Hinton. Ottawa. Photo: Glover. c, Mr. W. Wilson. Toronto. 
"I.ATl: 40
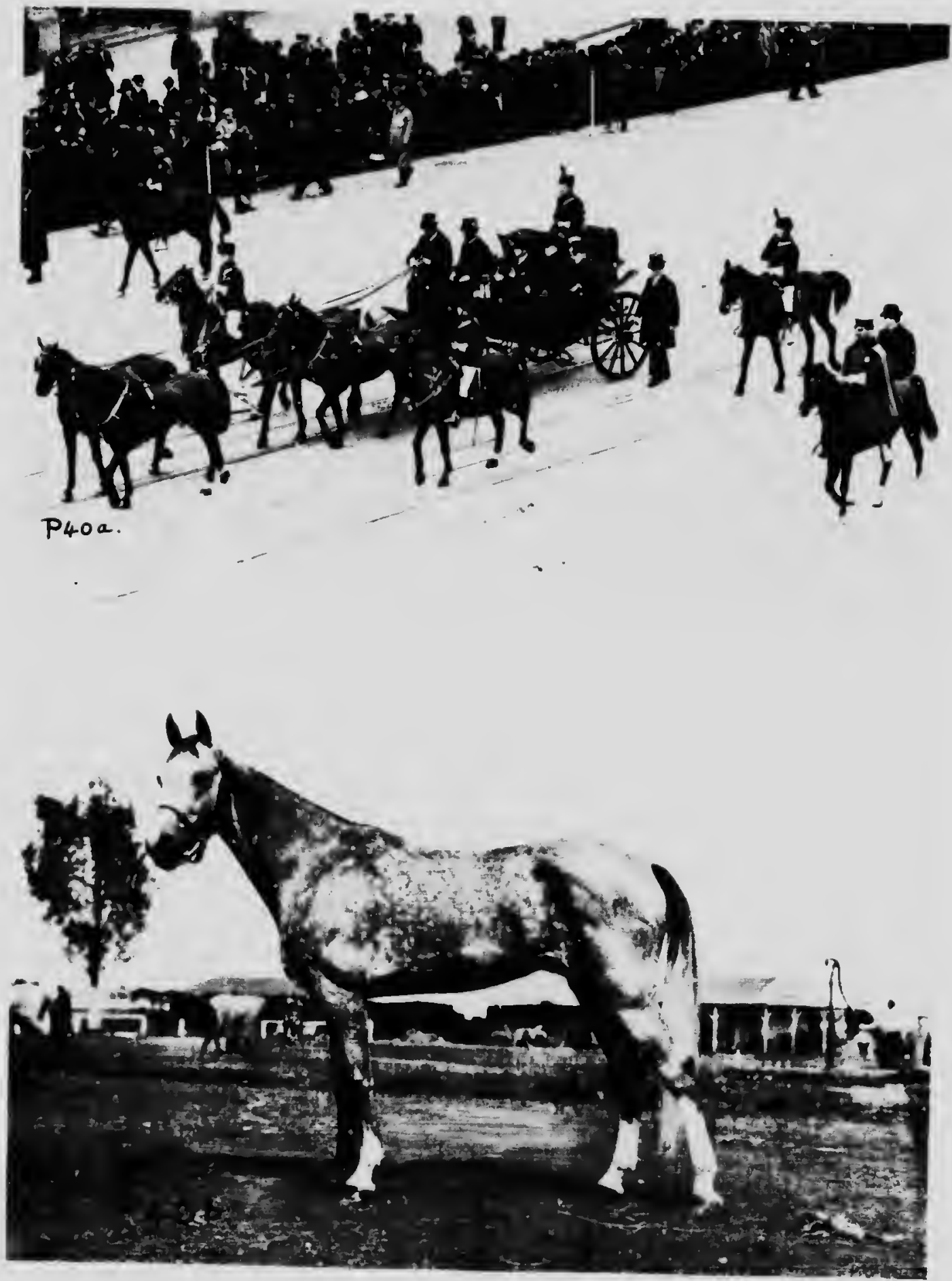

a, The Presidenes Finur in land at The Capuest. Mr. Wilson and Mr. Taft Drusing in State in Washington. D.C. Copyrigt: Photo: International Kens Service. N.Y. b. "The Eel," who broke the I'orld's Ice Record at Ollawa 
examined; the bit must be inspected to ascertain if it fits properly. Any injury must be attended to at once. If the horse pulls through having a bad mouth, it means that he was either badly iuruken or that he has been ridden or driven by bad hands since. In either case severe bits will only make matters worse. It is almost impossible to convince the average groom of this fact. If the driver or rider plays with the horse's mouth by gentle feelings of the reins, and keeps the horse always well collected and not stretched out, as is soen with uncollected horses, tho "orse will not be able to pull. A simple strei snaffle (P. ' $/ 2 a$ ) is the best bit with which to ure inust pullers. Bad hands, of course, will 1:ver cure them, but will probably make them $u$ inse

269. Tying Horses Up.-The methe on the American continent is a very good one. It consists of a weight and strap, that is carried in the vehicle, being used as shown in $\mathrm{P}$. $36 h$. The weight is about $\mathrm{b}$ lb.; at the other end of the strap is a spring hook that snaps on to the bit. Delivery horses that are constantly stopping, and that, by law, must be attached to a weight when left standing, have a long strap permanently attached to the bit that passes back through rings on the harness, and is attached to the weight that stands on the footboard of the vehicle when the latter is in motion. The strup is lowse enough to allow the driver to drop the weight on to the road as he jumps of the vehicle. (See 28e.) Care must be taken that this weight does not drop of while the vehicle is in motion, which would give the horse a violent jerk on the mouth. These weights are used with all kinds of horses, and work most successfully ; the horse soon learns that he is to stand when the weight is snapped on. Riding horses may be made to stand by being tauglit to do so whenever the reins are thrown over their head. Most Western ponics will do this. It is taught by tying a cloth or sack on to the reins, so that, whenever the horse moves forward, he treads on the sack and jerks himself in the moutin. He soon associates the moving forward with the jerks on the bit, and will very soon stand still. He will continue to do this, alter a few lessons, if the reins are put over his head without the use of the sack. It may be necessary to go back to the use of the sack over and over again until the horse thoroughly learns what is required. Great patience is necessary. General Grant once stated, after he had punished a brutal teamster for abus. ing his horses, "If poople only knew how muoh more they could get out of a horse by gentleness than $b y$ harshness, they would save a great deal of trouble both to the horse and to themselves."

270. Teaching the Horse to Allow the Rein to be Placed Under its Tail.-Sometimes we find that horses are apt to try to grapple the reins with their lail. This is generally the result of the driver having bad hands, the horse's mouth being made sore, or of a driver continually jerking the mouth, thus causing the horse to grab the reins to relieve his own mouth. These ignorant drivers cannot conceive that it is their own fault. Of course, at times horses are apt, when swishing at flies, etc., to get their tails over the reins, if the reins are left hanging loosely over the quarters. Horses that are not used to this must be made to become accustomed to it, and then it will not matter at all if they do get their tails over. (See Chapters XII. and XIII.) P. 118a shows a neat litlle device to keep the reins from getting under the tail, which is only necessary in viry rare cases. The best method, and a method that I always adopt with any horse, is to tarch him to pay no attention to the reins boing placed under his tail. This is done by starting off every day with the reins under the tail, and after a little while drawing them out, putting them under again, and continuing to do this until the horse takes no notics at all and will allow them to be gently drawn out when. ever they get under, by the driver merely pulling the reins gently. The horse that is not accustomed to this, upon feeling his tail over the reins, will usually hold his tail down tightly ; the inexperienced driver pulls tightly, causing the horse to increase his grip. Instead of this, the driver should leave the reins quite loose, and the horse will probably release his grip; or the driver may tickle the horse's quarters with the end of the whip, and the horse, taking it to be a fly, will swish his tail round and release the reins. In the worst cases the driver should lean forward and, while speaking to the horse, quietly lift the tail over the reins. But, as stated above, if the horse has been trained to this, as described in Chapter XIII., he will not mind in the least whether the reins are under his tail or not. In this way any horse can be used with perfect safety as a leader in four-in-hand. I have used this method on nervous mares which, it was stated, could not be driven in this way, and in a few hours they have absolutely acceded to my wishes. A horse that has not been trained in this manner, and is sold as a harness horse, is a ewindle upon the public. I wor:ld not employ this method with a horse with a docked toil, as my experience with them has been that they hold their tails down with great force whenever they feel the reins underneath; these horses usually object to having their tails interfered with, whilst the natural horse generally does
not.

271. Types of Harness Horses.-Where light vehicles are used, the lighter breed of horse, as shown in P. 26a, $b, d, 36 h, 30 d$, will outlast the heavier breed. The light breeds of horses, so common in America, seldom break down in their legs, hut with the more cobby types, more common in Enrland, we see the legs go first. For livery work, slower and thicker-set horses, 
as ill P. $36 c, e, 39 c$, are better than the more "breedy" kind. A harness horse should have a fairly upright sloulder (see P. $36 c, h$ ), large and sound feet, fair length in body; sliortness of neck, i.e. of rein, is no fault in a harness horse. A fust trotting horse must have a longer back in order to allow room for his legs while in motion. (See 40b, 41a.) See the various types of harness horses shown in the plates. (Sec Chapter IX.)

272. Types of Vehicles.-I have illustrated various types of wheeled velicles and sleighs, which I think will be of interest to my readers. The common fault of English vehicles is that they are too heavy. American vehicles are much lighter, they last nearly as long (if on good springs), are much cheaper, require lighter horses (which are cheaper to keep), and do not weal out the horses so soon, especially in the forelegs. Heary vehicles should always be provided with good hand-brakes; coaches and heavy lorries with brakes worked by the foot of the driver. Two-wheeled carts should be luaded so that the weight of the shafts is taken of by the load being put far enough back to tend to raise $\mathrm{tl}_{1 \mathrm{t}}$ horse slightly; as described in Sec. 2:17 et seqq., this weight must be shifted forward when ascending steep hills. Two-wheel "dump" carts (P. 118e) must be so constructed that there is no possible chance of the horse's ta'l becoming calight under the front of the cart after the load has been dumped. There is no reason at all why such a danger slould exist if the cart is made properly and fitter to the horse, and not the horse fitted to the cart. See the various types of vehicles in the plates in this chapter. P. $38 a$ shows a popular type of American racing sulky.

\section{Anatomy of the Shoulders}

273. P. 31, Fig. 1, shows the anatomy of the horse's slioulders; it also shows the external parts of the shoulder and the common places where sores are producerl by badly fitting collars and neglect due: 1 , to weight on collar; 2,3 , to collar too tight; 4, to collar too loose; 5 , to afterwale rubbing neck.

Collars.-The ordinary type of leather collar, stuffed with unthreshed rye straw, is the most satisfactory, as it can be stuffed to fit the horse, and it soon adjusts itsplf to the colltures of the horse's shoulders. (See P. 31.) The names of the parts of the collar are: A, forewale; B, afterwale (beneath wlich is the stuffer body); C, caps; $D$, housing strap; $\mathbf{E}$, throat; $F$, neck; G, borly side.

Wc will briefly consider the motion of the shoulder-blade (scapula) as the foreleg is drawn forward by the antea spinatus, the flexor brachii, the extensor pedis, and other nuscles. The upper portion of the scapula moves backwards as the foreleg is drawn forward, this bone moving as if pivoted a little above its centre. When a lorse is standing still, with both legs together, as in P. $36 d$, the collar is resting on two parallel surfaces, but in any ot:.er position the collar is not, but is resting on two planes inclined at an oblique angle to one another, one being nearer the vertical than the other. Thus, as the collar must rest against the anterior border of the shoulder muscles, which cover the anterior edge of the shoulder-blade as wel! as the large levator humeri and other muscles of the neck, it stands to reasun that it has an oscillating motion when the horse is in motion, and therefore the tension on the two traces alternates in intensity. Hence the difficulty in fitting harness and the reason for sore shoulders being so common. It is also clear how careful horse owners and drivers must be to keep the shoulder well groomed and the surface of the collars clean and soft; saddle soap is the best medium for keeping leather collar linings soft. Felt pads and padded cloths, known as sweat-pads, are used a great deal in Western Canada inside the collars; they necessitate a larger collar, but they save the horses very considerably. A very common fault is that of using tight collars. A horse with an upright shoulder is, therefore, the better animal to wear a collar, because it will lie better against the shoulder and not tend to work up, as it will on an oblique shoulder (which is the ideal shoulder for a saddle horse). We found, earlier in the chapter, that the traces should be nearly horizontal, nnd that the collar should be nearly at right angles to the traces; ierice the advisability of upright shouiders. Even with upright shouller-blades, the collar will always rise a little.

274. The best way to avoid sore shoulders and necks from collars is to keep the horse in good condition, because, so long as these muscles re hard and the bones well covered, the dangers of collar sores are slight. Collar injuries, unlike saddle injuries, are caused, nearly always, by friction, so the collar must fit close enough to lie quite flat on both shoulders, and should not see-saw, as it would if stuffed too much in the rentre. If pressed to one side, it should allow the fiat of one finger to pass between it and the shoulder all the way down. All lateral motion must be stopped to avoid collar sores, but the other extreme, of pinching the neck, musi be avoided. The collar must be short enough in length to prevent undue rising upon the horse throwing his weisht on to the collar. The hand and wrist must be able to pass easily between the throat of the collar and the horse's neck, so as to be sure that no pressure exists on the gullet (cesophagus) or the windpipe (trachea). The top of the collar just in front of the withers must admit the fat of the hand hetween it and the neck. When the poles of the wagon bear upon 
PLATE +1
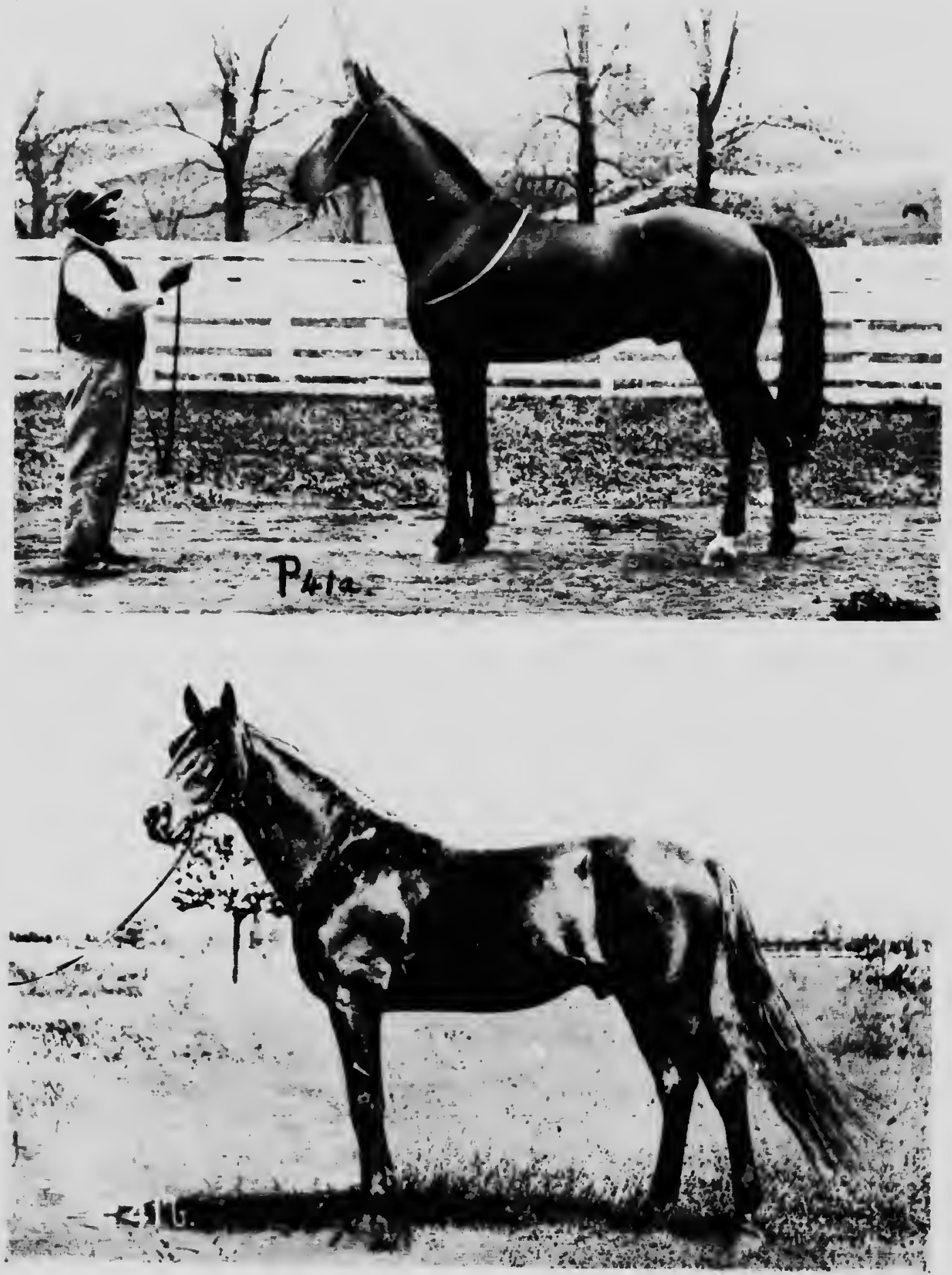

ANERICAN TROTTING HORSES

a. "Peter the Citat," Cunztesy: "Buffato Horsc Worid." b. Champion Standard.bred Trotting Stallion "Ed Winter." Courtesy of the Owner. Mr. M. H. Reardon, Indianapolis, Ind. 
PI.ATI: t2
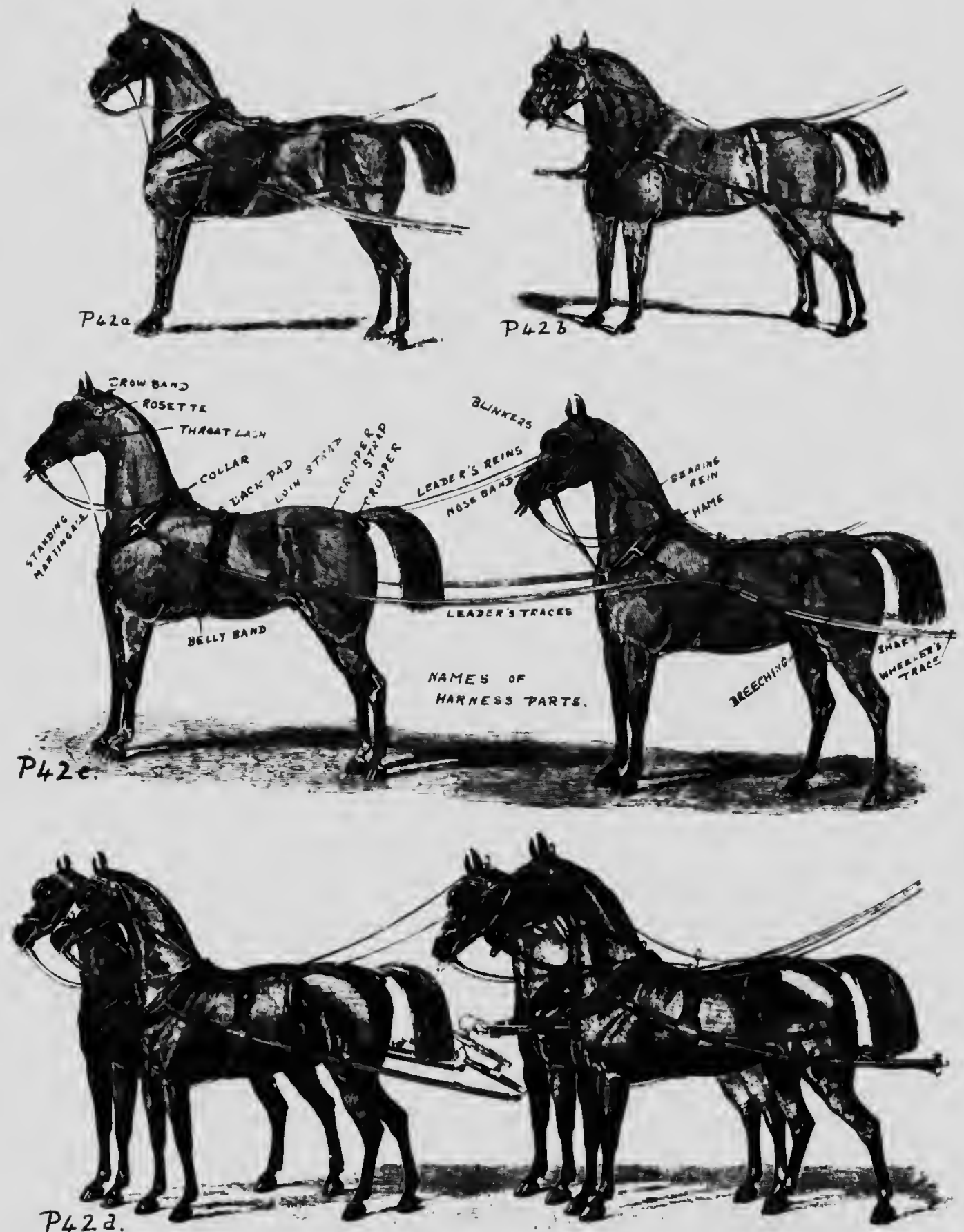

TYPES OF HIRNESS

a. Single, b. Pair c, Tandem d, Fourrin-hand. Courtesy: C. T. Willimont \& Co., Victoria Street. London. c. Shows the Names of the Parts nf the Harnas; 
the horse's collar, the crest of the collar rubs the nock and causes a sore; eventually a hard collar growth is formed. The best method to prevent this is to use pure zinc arch that fits inside the neck of the ccilir and bears on to the crest of the horse's neck. Zinc acts as a stimulant to the part that it touches. The horse's mane should be left fairly long at this part to act as a eushion, so that the collar will not rub. Hogged manes are far more liable to cause sores. The collar must also be pressed hard against the shoulder cn each side to ascertain that the stuffing is sufficient to keep the afterwale from touching the horse. If the stuffing is fiattened, the afterwale may touch the shoulder and cause injury. The larger the body of the collar the better, as it will allow the weight to be distributed over a larger area.

275. New collars are a great source of sore shoulders, and require to be very carefully examined. They must be thoroughly fitted before the horse is made to work in them. It is better to give a horse easy work the first time he wars a new collar. The army regulations recommend wetting the collar by soaking for several hours in water, and working the horse for an hour in the collar, taking the collar off carefully, and allowing it to dry. All the draught-horse collars and most of the light-horse collars on the American continent are not closed at the top permanently, but are kept closed by a housing strap. This is a great advantage in putting the collar on, but they are very liable, unless properly buckled up, to cause some of the hairs to become entangled, and they are more liable to get out of shape. This type must be kept buckled up when not in use.

Hames should really be fitted to every collar after the collar has adapted itself to the shape of the horse. The use of stock hames is absurd, because, if too straight, they will cause the centre of the collar to pinch the horse, and, if too much curved, they will cause the throat or neck to pinch. Metal hames can easily be bent. to fit, and wooden ones either steamed and bent or else cut.

The traces should be fastened to the hames a little more than two-thirds down the collar. Every horse must have its own collar; the borrowing of collars must be strictly forbidden. They should all be marked with the horse's name or number, otherwise they will get mixed up. When a horse becomes thin, the collar must be re-stuffed. The use of small collar-pads is a bad system, as they must cause uneven pressure. If pads are used at all, they must be large enough to cover the whole collar inside.

276. As mentioned before, collar injuries are the result of friction, except those caused on the crest by too much weight bearing on the collar. If this pressure injury is a gall, it is most painful. Much downhill work, and consequent holding back with the crest of the neck, will cause this trouble, unless some such arrangement as the zinc arch (known as a wither pad) is used. A hogging mane under this part of the collar is the worst thing possible, as the collar will drive the stiff short bristles into the crest (the ligamentum nuchæ, composed of yellow, elastic tissue, which is very susceptible to injury). By stuffing the collar so that there is only a little stufing on each side of the crest and over the top of it, this trouble may be overcome. (See P. 31, Fig. 3.) Hence the importance of having poles supported by springs, and the chrins of fixed poles, as in P. $36 \mathrm{~g}$, loose enough so as not to pull down on to the collar when the horse is in motion

Tight collars usualiy cause a friction injury high up on the shoulder, and loose collars an injury low down. The stuffing of the collars must in these cases be altered by a saddler to remedy the trouble. If it is very important to work a horse with a collar sore, a felt pad must be placed inside the collar on the side on which the sore is, the whole length of the collar, and a hole cut in the felt around the sore large enough to prevent the sore being touched however much the collar may move while the horse is in motion ; the edges of the hole must be tapered off.

277. A new form of collar, that extends over the anterior border of the shoulder-blade only, has been invented by the Whipple Horse Collar Company, of Hamilton, Canada. This is claimed to be an improvement on the old-style collar. Theoretically it seems to be a good idea, and I have seen some practical experiments carried out successfully. These experiments were made on level roads. I do not know whether it would be successful for ploughing purposes.

278. Sore Shoulders.-For the method of prevention of sore shoulders and of giving immediate relief, see Secs. 320 to 323 .

The best cure for sore withers, caused by the collar, is the use of the zinc plate, referred to above. If the withers are very bad, the horse should be worked in a breast strap for two weeks, care being taken that the supportiug strap that passes over the neck is kept well away from the sore. The shoulders should be very carefully examined every time the collar is removed. Merely looking at them is not sufficient; they must be felt with the fingers.

For the antiseptic treatment of wounds, see Chapter XVII.

If, while working, a slight lump is noticed, the horse must at once be given a rest for an hour, and the following hardening lotion applied immediately (i.e. previous to the rest):

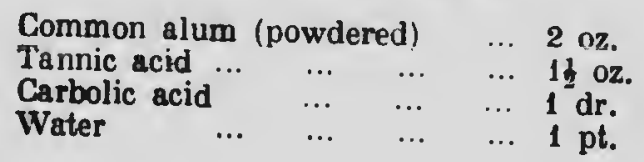


This lotion should be always kept on hand, ready mixed, and should be mopped on to the affocted shoulder. After an hour the horse can be worked. Any abrasion or unevenness on the coller lliat caused the lump must, of course, be removed.

278. Hreast Collars.-P. $30 d, e, h$, shews the breast strap (wrongly termed breast collar) now used in the British artillery and in most light vehicles on the American continent. For light work and galloping artillery there is nothing better than this type, if it is properly fitted. The breast strap has often been abused, generally due to its not having been properly fitted. The strap must not be too high, so as to cut into the gullet. For this reason the top edge is hollowed out in front of the gullet. It must not be too low, or it will interfere with the movement of the upper arm (humerus), which moves forward very considercbly as the foreleg is extended.

The motion of the shoulders causes a strap collar to move to and fro in a see-saw motion; hence it is of ine utmost importance that the material should be kept perfectl $\because$ soft and pliable and that no lumps or uneven stitching be left inside to cause injury. The inside of all collars must be thoroughly soaped with good harnoss soap to keep the leather soft. This does not apply to collars that are not lined with leather.

The traces of breast straps should be attached to whiffle-trees (sec P. 36) to take up the ascillations (see Secs. 256 and 273). The strap musi be broad if it is for heavy draught, but, as explained above, the width is necessarily limited. It should be lined with a seamless piece of leather. These precautions are not so necessary with light buggy harness. I have seldom seen a buggy horse suffer from sores produced by the breast strap. With heavy breast straps the supporting strap may cause crest or wither truubles; a zinc or stiff leather shield should be used to take the weight off the neck. Artillery wheel-horses have metal shields over the crest, above which two siraps pass, one for supporting the breast strap, and the other for supporting the pole. No pole chains are used. Tle strap supporting the pole must be very carefully adjusted. As a rule, pairs of horses are harnessed with ordinary collars, but in the British Service wagon pairs are harnessed with breast harness, the pole chains being fastened to a ring in the breast strap.

For ordinary collars the leather lining, I think, is superior to any other kind, as it is so much more easily kept clean and soft.

880. Harness. - When harnessing a horse, great care must be laken that every buckle is done up properly, that no buckles are twisted, that the horse is securely fastened to the rehicle, and that the traces are of equal length, the harness lying fiat all over. For light vehicles no broeching is necessary (see P. 117e-h), but when any weight is to be kept back, breeching should be used, although it must be remembered that a horse can hold back more with his neck than he can with his hindquarters. The breeching must be horizontal and loose enough to allow the width of one's hand to pass between it and the horse's thigh. It must be about from 10 in. to $1 \mathrm{ft}$. below the root of the dock; if much lower it will hinder the movement of the thighs, whilst when in its correct place it presses, when in use, against the powerful triceps, biceps and adductor magnus muscles of the hind limbs. The hip straps which support the breeching must be loose when the horse is in draught. Two of these are usually necessary. The front one is called the loin strap.

P. $36 \mathrm{~g}$ shows the neck yoke atteched by straps direct to the breeching, so that the horse holds no weight back with his neck, but entirely with his hindquarters. P. 132h shows the neck yoke attached to the back straps, so that the horse holds a load back chiefly with the collar.

281. Crupper.-The crupper strap must be loose enough to allow two fingers to pass between it and the horse's croup. The dockpiece must be kept soft and pliable and must be well padded. It inust fit properly. A draught horse's crupper is best made with a small buckle on one side, so that it can be undone when harnessing the horse, the crupper being passed under the tail and buckled up.

288. The traces must be of equal length, and should be attached at their rear end to a whiffle-tree, as described in Secs. 256 and 273. The traces of horses in a team must be long enough to allow from three to four feet space between the nose of the wheeler and the tail of the leader. The hames must lie evenly in the grooves of the collar and be both at the same level. The wither straps should not be tight, and the free ends of the hame straps of pair horses should point inwards, i.e. towards the opposite horse. The belly band that is attached to the back pad should allow one finger's-breadth between it and the horse's belly; with heavy draught horses this strap is generally left quite loose. The belly band attached to the traces should admit two fingers between it and the belly when the horse is in draught.

883. Harnessing-up.-We often 800 horses harnessed incorrectly into the shafts. Horses are sometimes harnessed too far back, so that when in motion the tail rubs continually against the splinter-bar or the splashboard. Besides irritating the horse, it may spoil the look of the tail. It is the result of carelessness and want of observation. A horse should be hamessed well a way from the splinter-bar or splashboard. In the case of a "dump" cart (P. 118c) this is very injportant, although such a vehicle, when mado by one who has studied the subject, would not 
PI.ATE 43
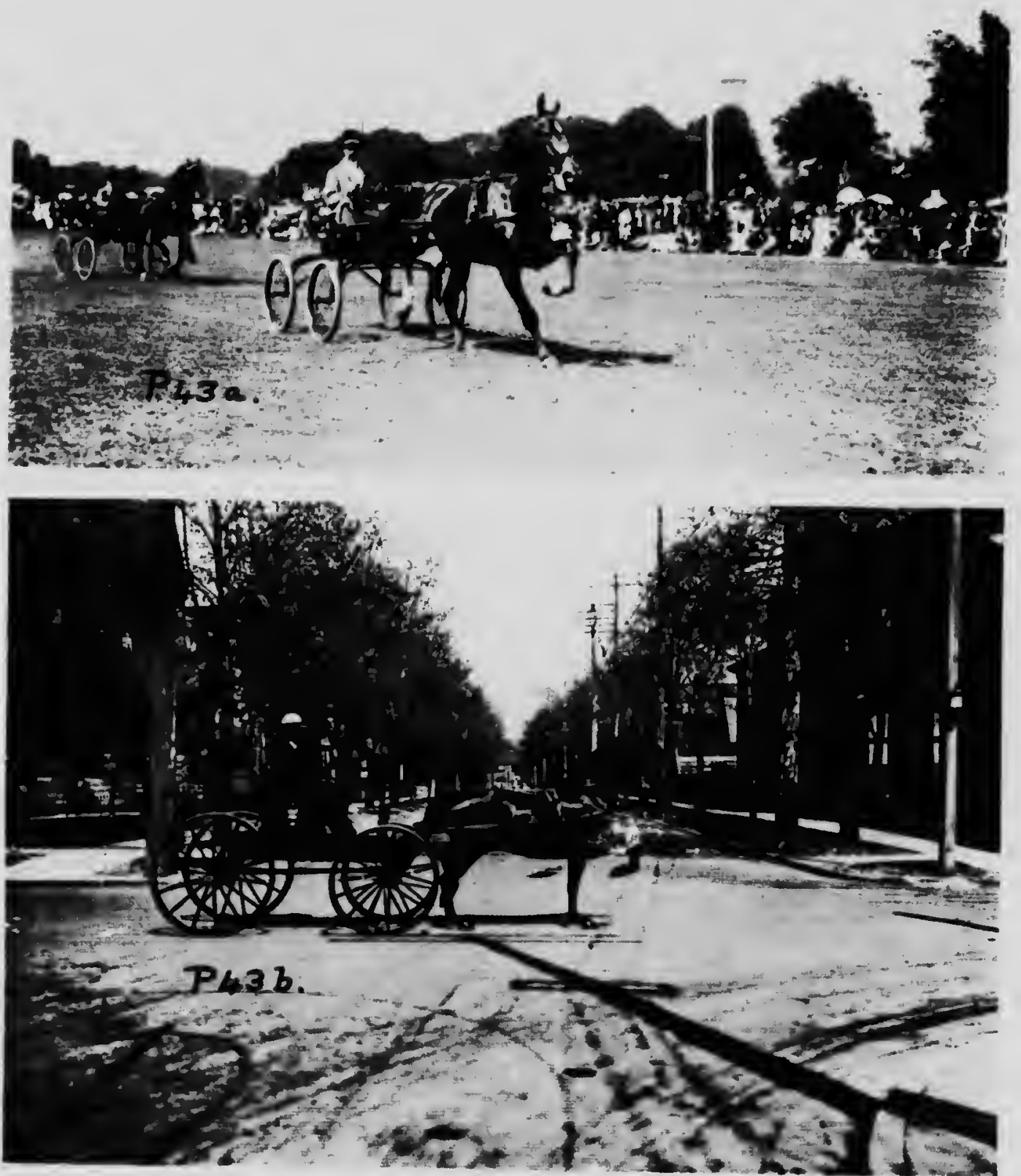

THE HORSE IN ACTION

a. Mr. Walter Winan's "Bonny View." Winner at the Richmond Royal Show. Copyright Photo: W. A. Rouch. b. Champion Standard.bred "Majesice," formerly owned by Mr. J. Darrach. Dayton, Ohio: this Beautilul Horse was bought by a Horse.dealor and Docked, and has since been shown in the Hackney and High.slepping Classes and won Prizes. Photograph by the Author 
PI.ITI: tt
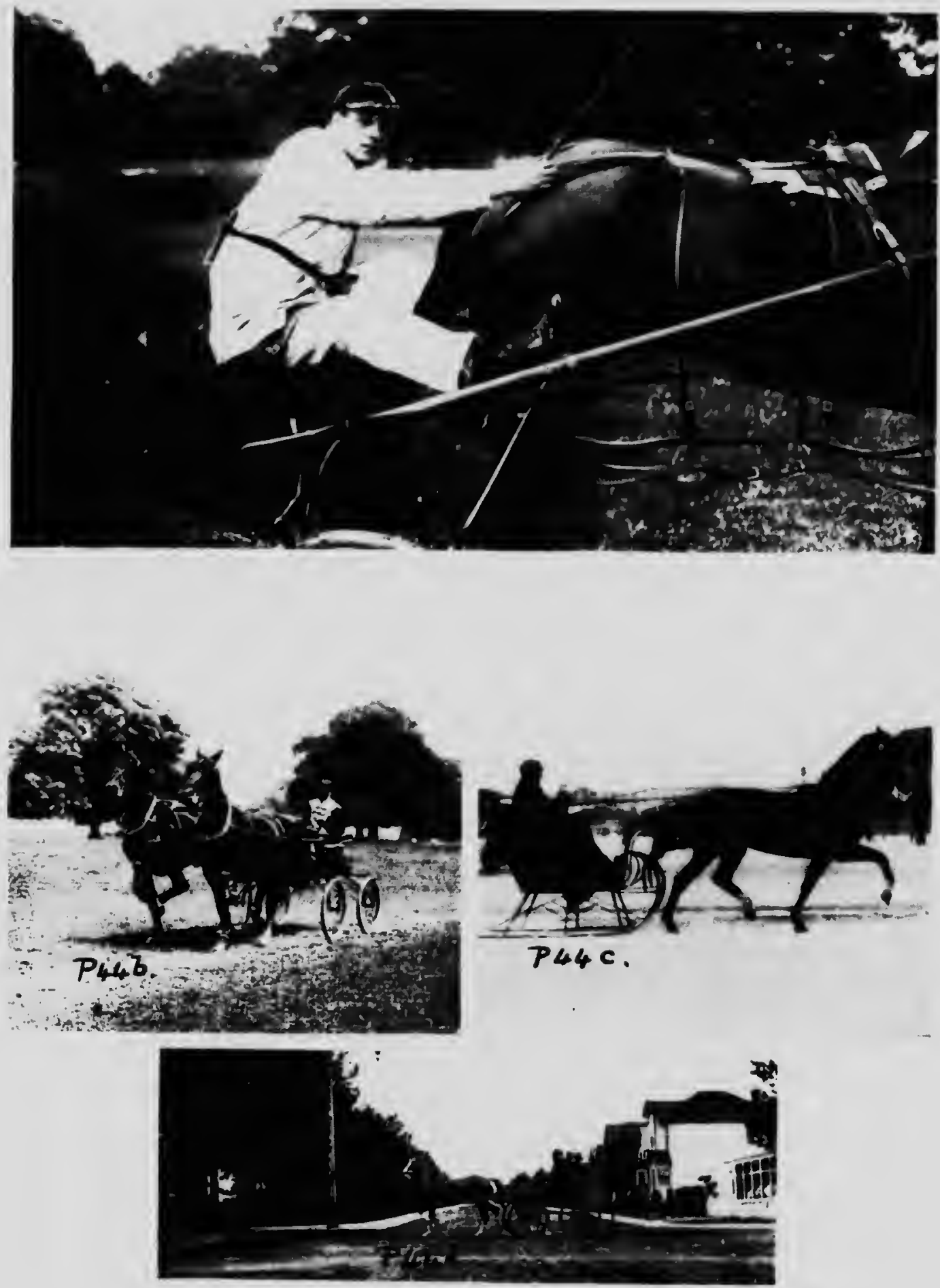

TROTTING HORSES

a. Digger Stanley and hus Pacer. "Cipsy B." Copyright Photo: Topical Press Agency, Fleet Street, London. b, Mr. Walter Winan's "Princell" and "Lake Erie." Copyright Photo: W. A. Rnuch. c, Courtesy: Lieut.Col. Hall. Toronto. d, Courtesy: Mr. W. U. Pitfield. Brandon, Man. Pholos, $c$ and $d$, Author 
PLATE 45
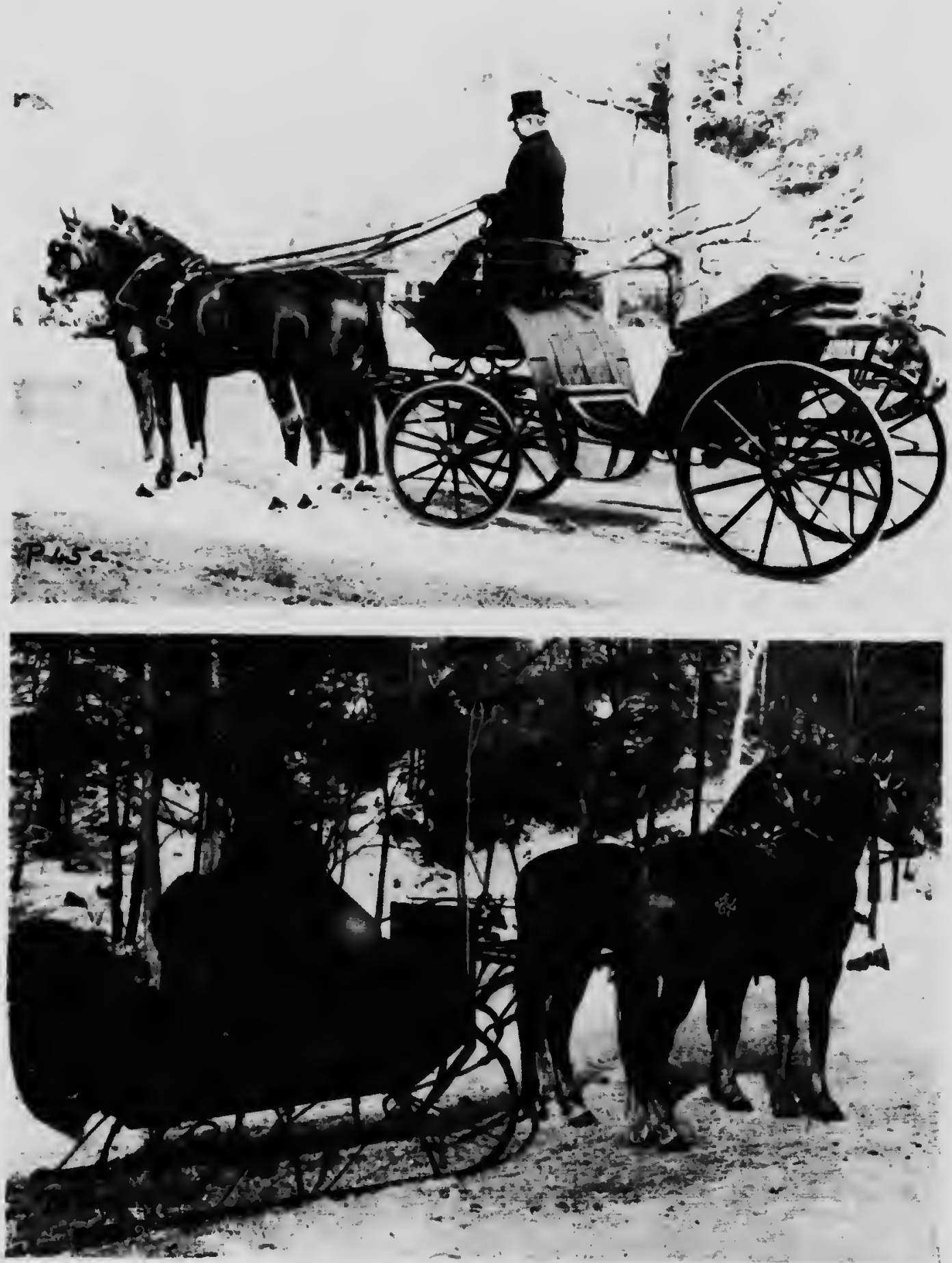

CANADIAN CARRIAGES AND PAIRS

Courtesy: a, Mrs. Massey-Treble. Toronto. b, Mr. Parker, Toronto. Photos: Galbraith, Toronto. 

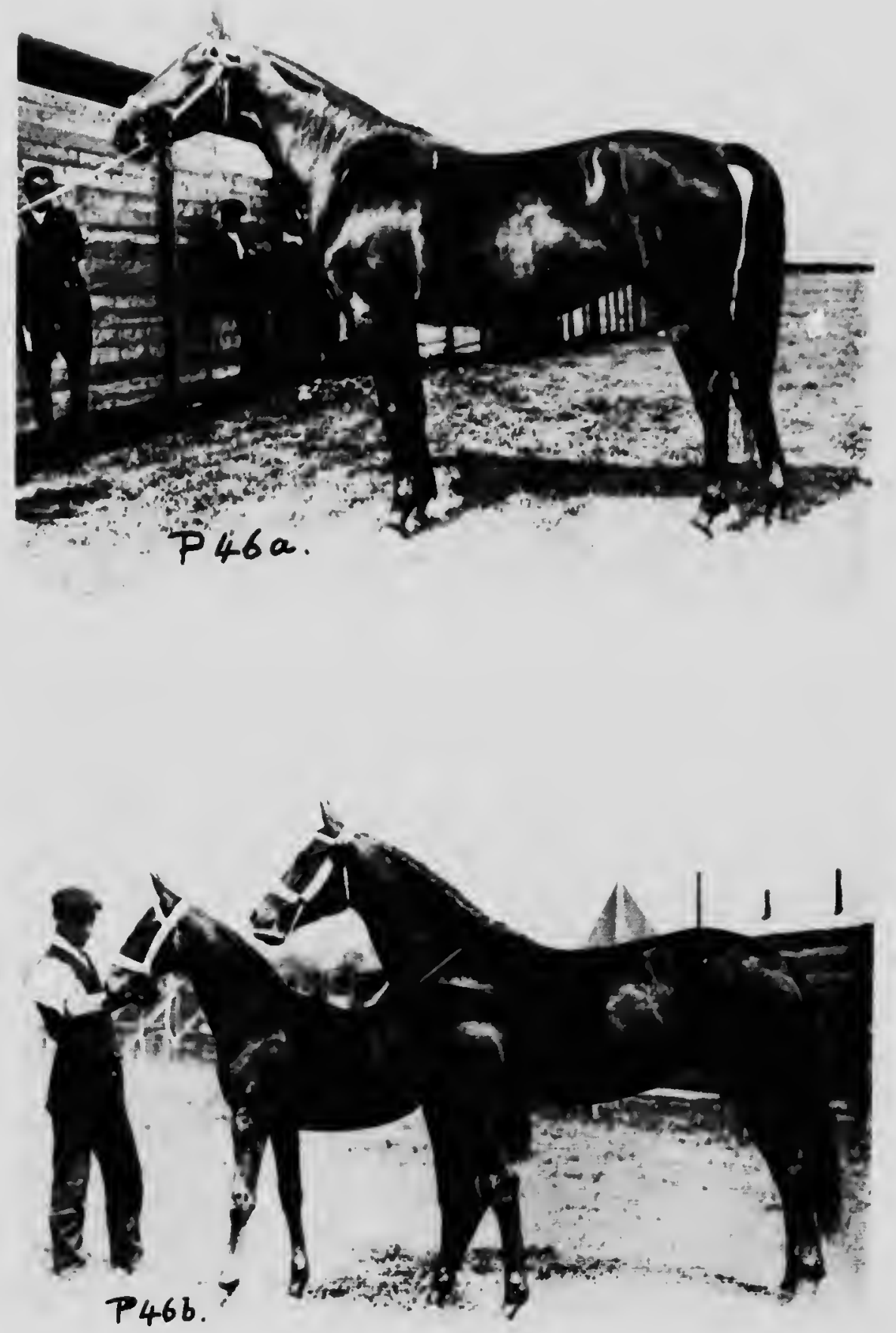

CLEVELAND BAYS

a, "Josephıne," Champion Yorkshire Coaching Mare. Photo: G. H. Parsons. b. "Hawthorn Beauly," Champion Mare and Foal, owned by Mr. Geo. Elders. Copyright Photo: Sport and General 
endanger the horse's tail at all. (Sce Chapler XIII.)

With shafts, the traces and breeching must be arranged so as to keep the points of the shafts ubout opposite the hames.

884. Uarness Injuries.-Apart from collar galls, girth galls, back and croup sores may rosult Irom harness not being properly cared for, the horse being improperly groomed, or the larness fitting badly. Lumps and bad stitching may cause trouble. The girth, it too far forward, may cause a gall. Croup sores are caused from the hip straps being too tight, or from the under surface of the crupper-boss being rough. A sore may result from a badly ftting saddlepad, which must be kept well of the witlers and fit in the same way as a riding-saddle. (See Chapter VII.) Injury will result if there is lateral motion to the saddle-pad.

285. Breast Cloths. - As horses, in cold countries, are liable to perspire freely over the chest, and very liable to chill on standing still, breast cloths are used a great deal, with good result. The breath of the horse, while at work, condenses on the cold shoulders and chest, and very soon covers these parts with moisture, which evaporates and chills the chest so much that pneumonis has often resulted. The use of breast cloths in these cascs will prevent the above trouble. These cloths are padded, and hang from the lower portion of the collar, and are sufficiently large to cover the whole chest.

286. Bridles (see P. 63-72).-Driving bridles are of various types. The headstall, which passes from the bit, over the head, and down to the bit on the other side, should be parallel to and behind the cheek-bone (P. 42c). The nose-bend, if used, should bo the breadth of two fingers behind the cheek-bone; and should admit two fingers between it and the nose. It should be sufficiently rigid to keep it from hanging down over the horse's nose and possibly affecting his breathing.

The throatlash should admit, at least, three Angers between it and the horse's throat, and should really be only tight enough to keep the bridle on the horse. Great ignorance is displayed by grooms buckling up this strap too tightly. Serious injury to the larynx may result.

The brow-band should be long enough so as not to interfere with the horse's ears when laid back, but not so loose as to allow the headstall to slip back. White buckskin brow-bands (P. 132e-h) look very nice, and can be kept soft very easily.

The bit must be placed across the bars of the mouth 80 as to be approximately two inches above the corner looth (incisor) of a mare and one inch sbove the tusk of a horse. So much depends on the shape of the mouth and the dis. position of the horse that no fixed rule can be laid down. A bridoon or snaffle-bit (see P. $72 d$ ) should be placed so as just to touch the corners of the mouth without wrinkling them.

The curb chain should bo twisted up quite flat by a right-liand twist, and should lie flat in the chin groove under the jaw. The end link is hooked up, and then another link, making the curb of such a tightness that it will allow two fingers' breadth to pass between it and the horse's jaw.

All straps, :-1, , are made to do up, if possible, from the near, or left, side of the horse. A horse is always saddled, harnessed and bridled from the near side.

The best way to ensure that the curb chain is properly adjusted is as follows: After it has been wound up with a righthand twist, and the first link hooked on the near side of the bit, let us suppose we find that the fourth link is the correct one to use to tighten the chain suficiently, then the fourth link should be twisted up a half-turn farther and hooked on.

287. Blinkers.-The subject of blinkers, or blinders, has been much discussed, some saying that they are cruel. If they are in good order and fit properly, they can scarcely be called cruel, but one commonly sees them rubbing against the horse's eye or swinging from side to side, striking the eye at every step. Blinkers, if worn, must be kept at least one inch from any part of the horse's eye. Some horses have shades over their eyes to keep the bright light out: these must not be within about one inoh of the eyes. Many horses have had their eyes seriously damaged by blinkers ftting too closely, or by their striking the eye through not being properly fastened to the headstall. Most horses behave better in blinkers, bocause they have always been used to them. If horses were trained without them from the first, there would be only a very fow that would not be better without them. (See P. 30f, g.) The blinker shown on P. $36 d$, as employed for private use, is kept right away from the eye, allowing the horse to have a full front view, being intended merely to prevent the horse seeing the wheels behind. I have driven scores of horses without blinkers that have been used to them, and have never found one that did not go perfectly well after a few days. Like other things concerning horses, the hackneyed argument, "It always has been done," is responsible for most of the blinkers we see to-day.

Horse trainers should teach their young horses to go without them, and allow them to see what is behind them. Many horses are frightened because they cannot see what is coming up from behind. A horse that is frightened, as described in Chepter III., must be able to see the object that causes the fear. Railway companies have wisely abandoned blinkers, because their horses, when unable to 
to the sicle or behind them, are always get ting rill inlo; but now they can see to protect theniselves in the yaris. A horse with blinkers on is greatly handicapped, and, in case of fear from lloise, is a far more dangerous animal. Heavy horses sometimes wear small blinkers which do not hide the side view. Tho only case in which I recommend the use of blinkers is that of the livery horse that is Irivell by people who wase the whip and liands ubout, and conseifuently' frighten the horse. 'I'his becomes very aplarent to anyoue who drives a livery horse without bliukers, holding the whip in the currect manner in the liand; whenever the horse ees the whip move, it expects to bo hit with it. The addition of blinkers in such cases, if the horse is at all nervous, is to be recom. mended. I strongly recommend the disuse of blinker's on uervous horses-at any rate, as an fxperiment-becanse, as stated before, a horse must see the object approaching from behind that is causing him fear.

288. Bits.-The subject of bits is dealt with in Chapter VII., so little need be said here, except that must horses, if trained from the first by a mall that possesses good hands, can bo driven perfectly well or a snafle-bit, or on an easy Liverpool bit, witl large mouthpiece and the reins on the top ring. (Sce P. 33n.) Bad harids and igmorance are responsible for many horses having to be driven in a score of different bits, some of which are extremely cruel. It takes lwo to pull, and a horse that has once learned to pull can be cured of the habit by patient driving with good hands. I remember many instances where coachmen have stated that their horseg culld not be driven except in severe bits, who, upon being shown that such horses could not only go on the simplest of bits, but that they would cease to pull when such bits were used, have "given in" with astonishment.

289. Malters.-A horse, when tied up in a stall in a stable, must be tied up with a good type of halter which must be very strong, because if a horse once gets loose he learns that he can get loose, and will probably try to do so afterwards because he has learned that he is master of the situation. There is considerable rlanger of a horse's getting kicked or over-eating himself it he gets loose at night. In Chapter VIII. other methorls of preventing a horse from getting loose are described.

The plain cow-collar, which consists of a broad strap placed around the neck behind the ears, is very secure, but is liable to spoil the horse's mane. On no account must a horse be tied too short in the stall. He must be able to lie down in any position at perfect ease. I have caught several unprincipled grooms tying their horses up at night to save trouble of prooming them in the morning; such people should be made to sleep standing up. A secure halter must have a lieedstall, noseband, gulletpiece, and s strong throstlash. If this last is done up so that only three fingers' breadth remains letween it and the horse's throat, there is little fear of his being able to slip his halter. Ilaltors, as a rule, buckle up only on the headstall, the throatlash not being able to be shortened. Oriat caro must be taken not to have the throatlash too tight. If a horse does not try to get free al night, it is better not to use a brow-band, which will be more comfortable for the horse. One objection to thls is that the top of the headstall will work hack over the mane and perliaps damage it, whilst the brow. band will keep it just behind the eurs, where a small portion of the mane is usually clipped out. (See Sec. 237.) l. 31 .

A non-slippling halter can be made, as oll

$\Lambda$ horse gets his halter of either by putting his poll under the manger or else getting the slack of the rope over his poll, just behind the headstall, and pulling back, thus slipplng the headstall of his head. Great care should bo taken, in making an improvised halter out of a rope, that the knot is not a slip-knot, because if such is used the horse may be strangled. $A$ good way to make such a halter is to make a loop that will fit quile loosely over the muzzle to a height of about one incli below the zygomatic ridge on the cheek-bone, then to pass the rope over the poll behind the ears, down the other side, and attach it to the loop. Another piece sliould then be tied from each side of the rope that passes over the poll, just behind the eyes, around the jowl, to act as a throatlash.

290. Training Gear.--Some civilian horsebreakers use the most elaborate and absurd appliances tor breaking horses. A liarness horse should be trained at first upon the principles laid down in Cliapter III., with the cavesson and lunging-rein, etc., and later be matle to wear the harness so as to become accustomed to it. Great care should be taken when first putting on the crupper. Horses trained under my ideas as regards crupper and the reins under the tail will not mind their tails being handled at all. (See Sec. 270.) But horses are often trightened and made to grip anything that gets under the tail by being ill-used when the crupper is first put

$I$ consider that the cavesson and rein, and a lunging-whip and a short cutting-whip, besides the ordinary harness and a kicking-strap, are all that is necessary for training a harness or saddle horse. I do not believe in the use of the dumb. jockey, unless the trainer has bad hands. I have tried horses with and without its use, and there is no doubt that a dumb-jockey cannot produce tho same mouth as a pair of light hands. Those which contain elastic or springs are the best apparatus for spoiling a horse's mouth. If a 

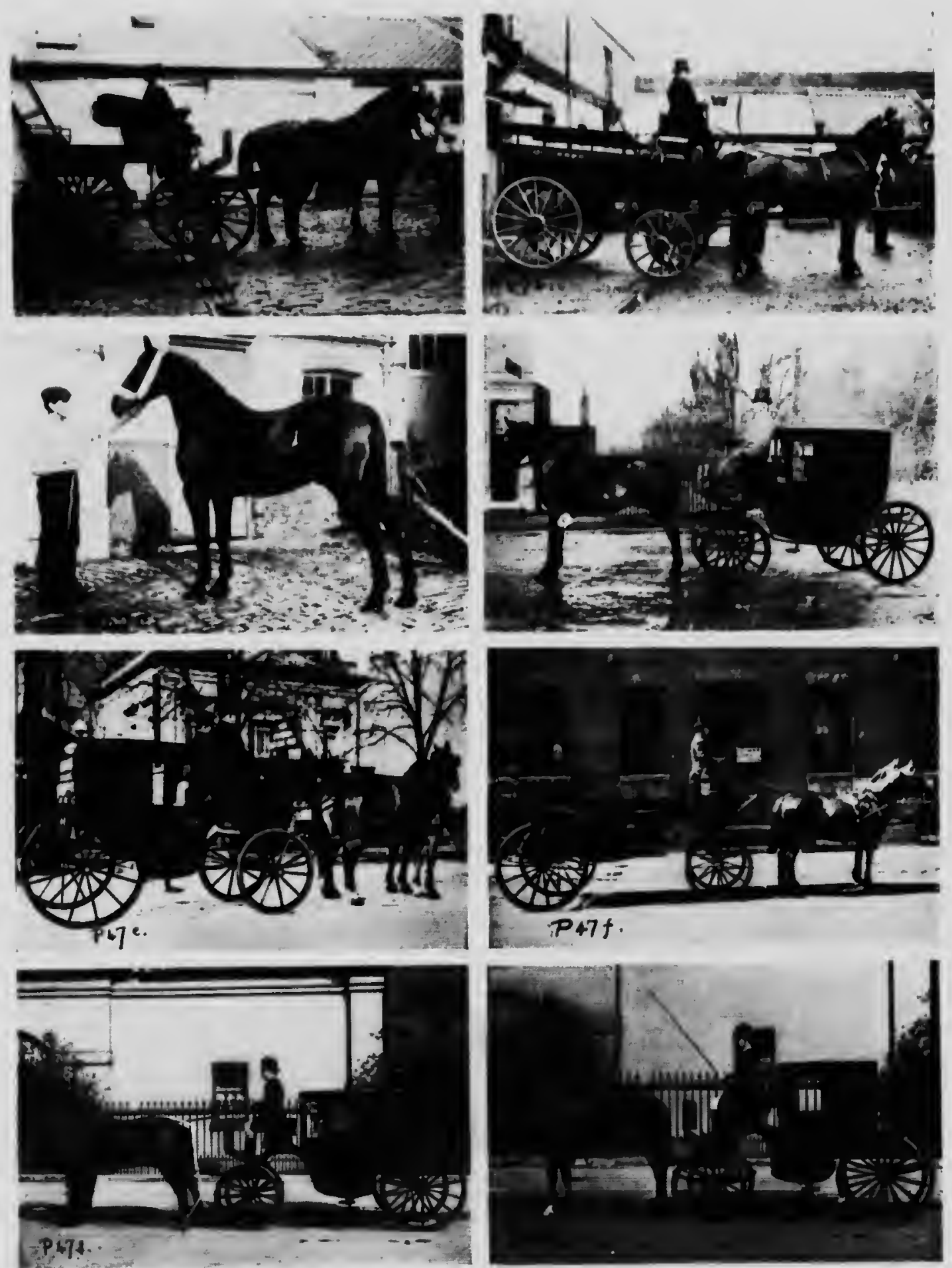

TYPES OF CARRIAGE HORSES

$a, b, c, g$ Cleveland Bays. Courtesy: $a, b, c$, Messrs. T. Tillang. London. d, Mir. G. Field. Chislehurst. e, Sir John Gibsen. Lieut. Covernor of Ontario. f, Vr. Bond. Toronto. G, $h$, Messrs. Wimbush \& Co., Grosvenor Place. London. Photos $a, b, c, d, f$, Author. e, James. Toronto. $8, h$, Glover, Hammersmith 

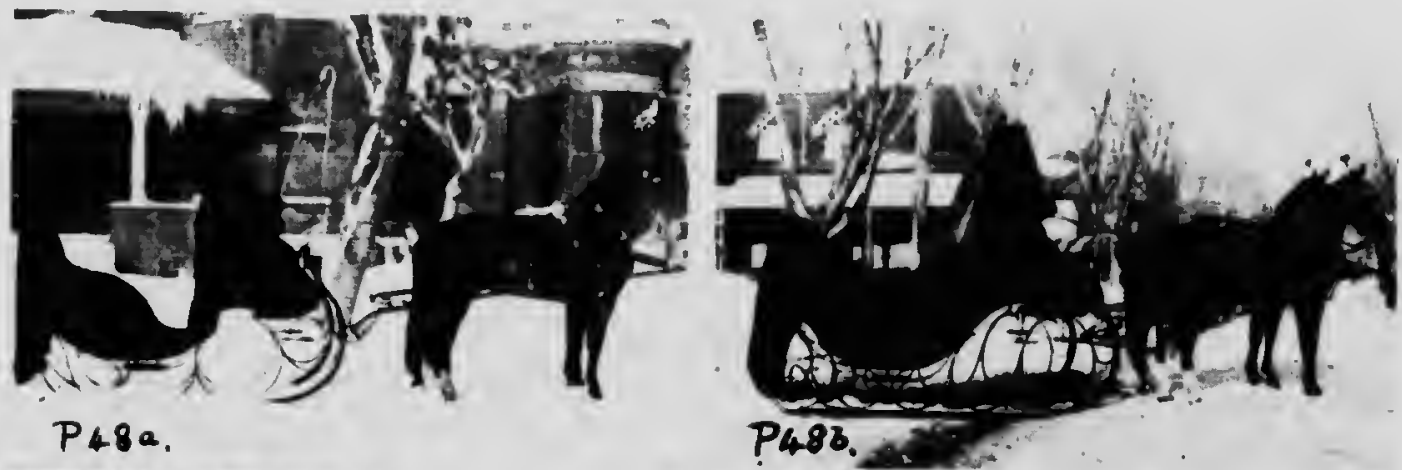

P48a.
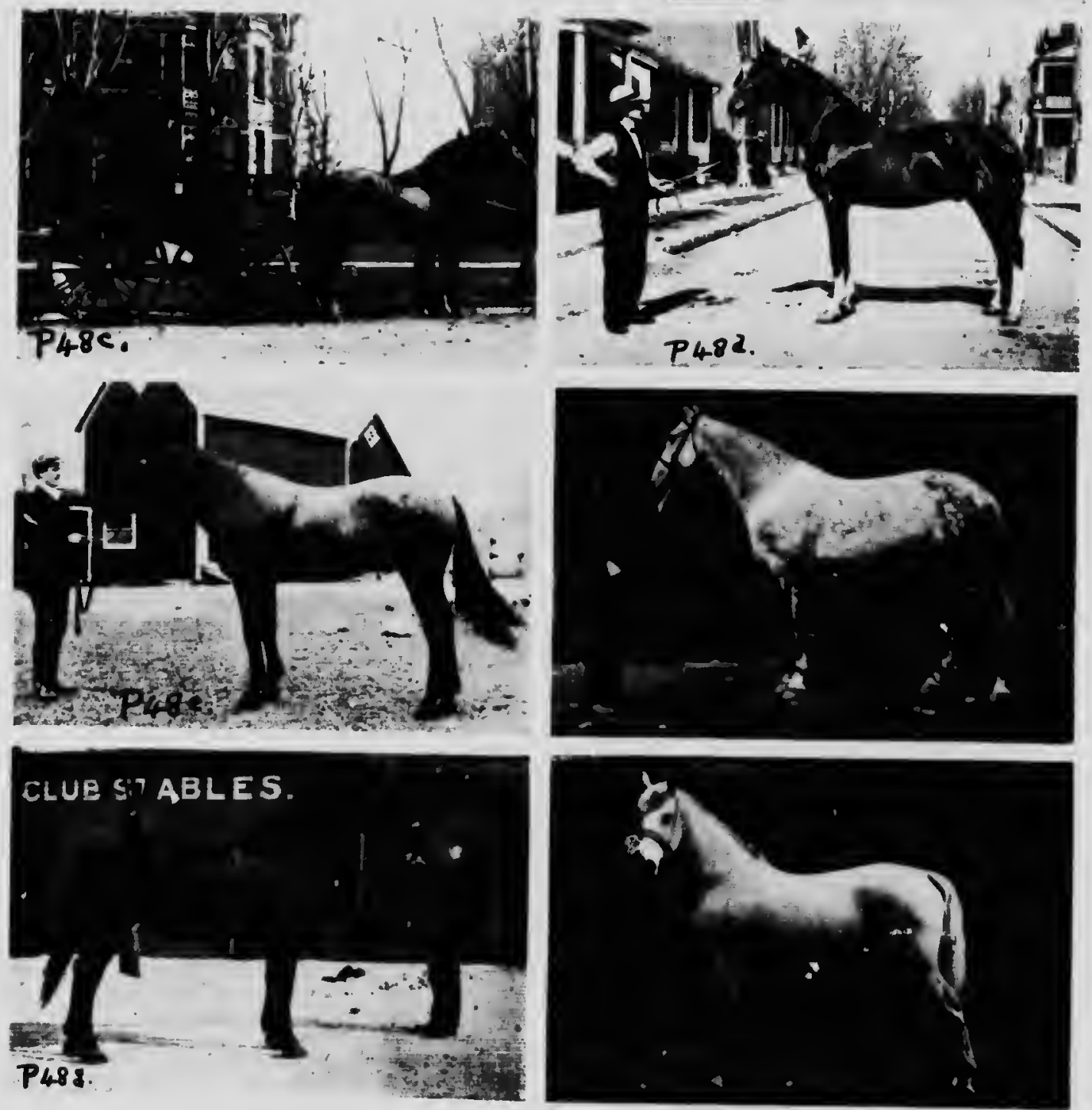

TYPES OF CARRIAGE HORSES: CANADIAN BRED (except h)

Courtesy: O, Mrs. Wilison, Otlawa, b, Hon. S. N. Parent, Ottawa. c. Col. Little, London, Ont. d, Mr. J. Darrach, Toronto. e. Dr. Coxe, Biandon, Man. f. Mr. Roherison, Boissevain, Man. B, Cleveland Bay "Lord Mlinto." Mr. Adam

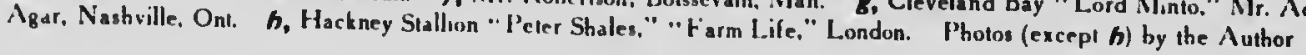


PLATE 49
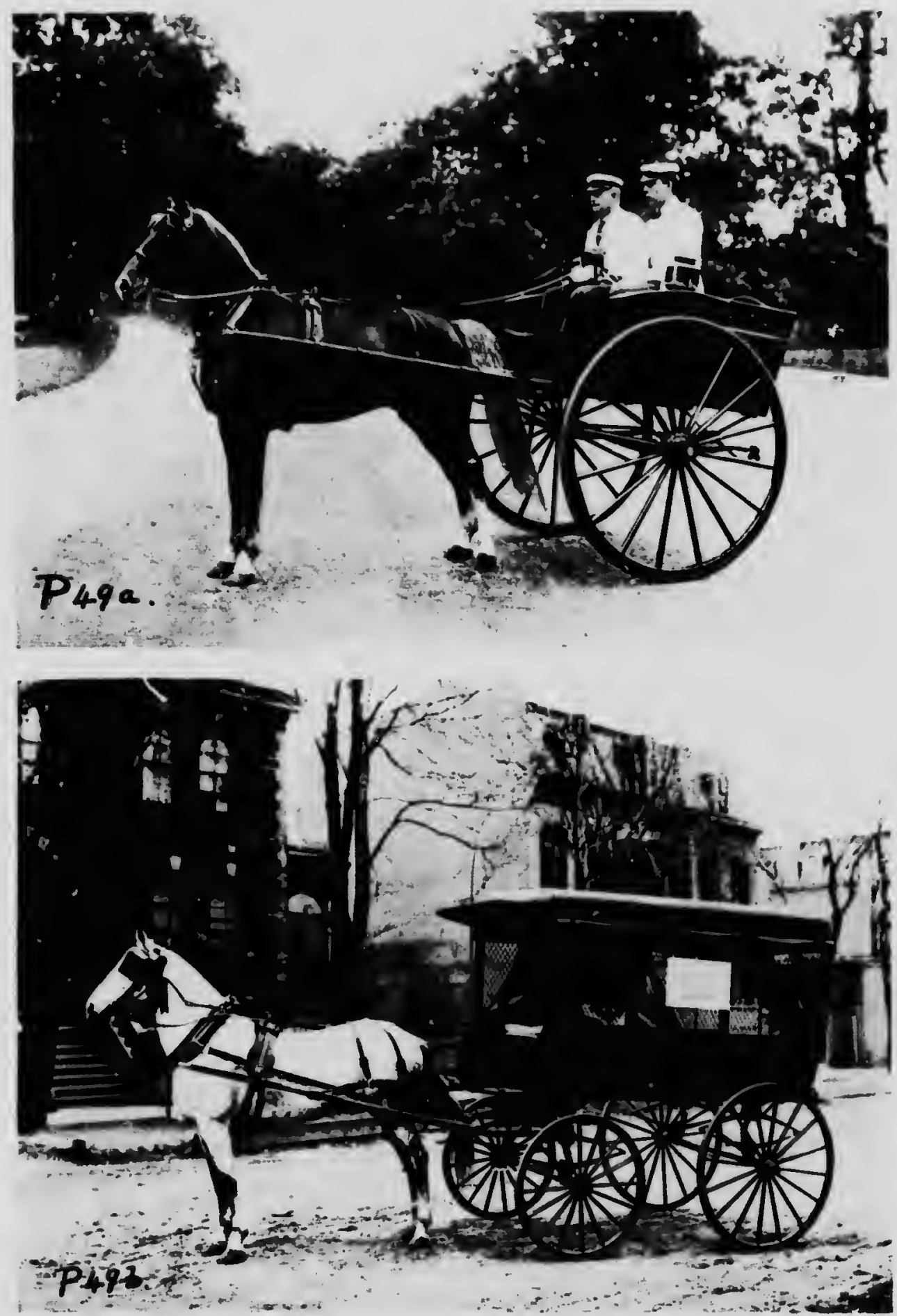

TYPES OF CANADIAN.BRED COMMERCIAL HORSES

a. Hackney Pony. b, Standard.bred Mare. Courtesy: $a$, Mr. J. Holman, Toronto, b, Mesirs. R. Sisnpson Co., Toronto. Photos : Galbraith, Torunts. 


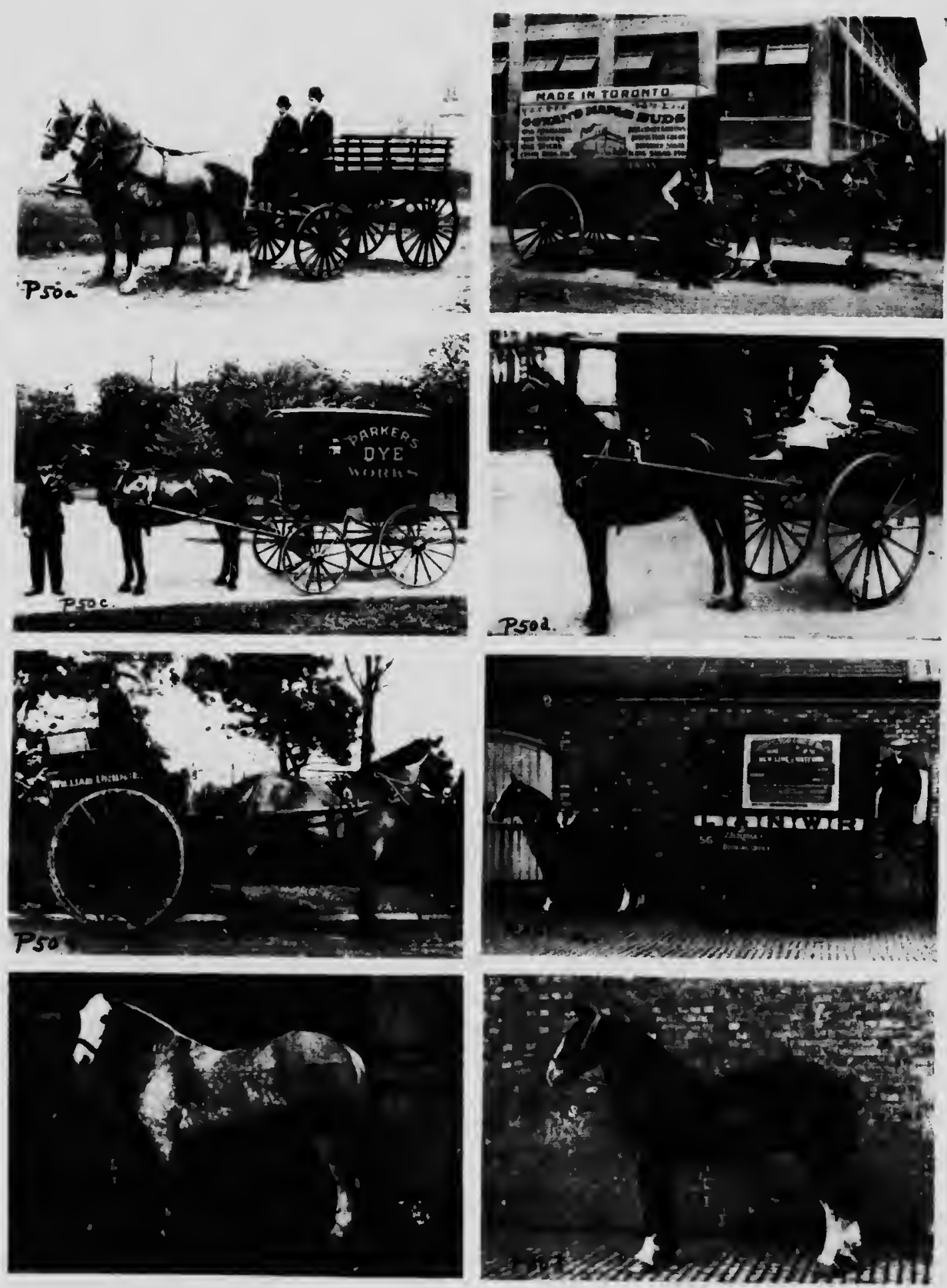

TYPES OF COMINERCINL HORSES

Courresy: a. John Macdonald \& Co. Toronto. b, Cowan Chocolate Co., Toronto. c, Parker's Dye Co.. Toronto

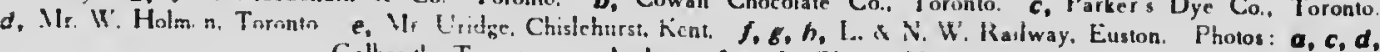
Galbrauth, Trinnto. e, Author. f, s, $h$, Glover, Hammersmith 
(lumb-jockey is used to "place" a horse's head and neck, there must on no account be any lastic or springs in the reins, because such wili teach a liorse to pull and to stretch out his neck and will never make him light in the inouth.

291. The horse, when he has become accuslomed to wearing the harness, should be driven with the ordinary reins, without being attached to a vehicle, for a week or two. He can then be attached to a two-wheeled breaking-cart or uther vehicle that cannot be damaged by a little kicking. It is safer to use a kicking-strap, because if a horse once gets his hind-quarters up he will always remember that he can do so, and at some inopportune moment, through fear or otherwise, he may do it again. Prevention is better than cure, and in this case far more easy. It is not wise to put a young horse into a sleigh before it is used to a wheeled vehicle, because a sleigh runs so differently from a wheeled vehicle, and horses, as a rule, do not take so readily to the former.

When approaching a horse in the stall previous to harnessing, saddling, etc., the hand should not be poked out to him, as it will either frighten him or else teach him to snap at it, and perhaps to become a crib-biter. It is also most foolish to approach a horse in the open, whether in harness or not, with an outstretched hand. This is commonly done, and people wonder why the lorse shies and backs up, or perhaps turns and runs away. The correct way to apnroach a nervous horse is to approach his side; wis head can then be taken hold of after he has become accustomed to the person's presence.

292. Care of Harness (see "Impurities," Sec. 368).-Harness must be kept clean for two reasons : firstly, because, if it is not, the horse will suffer from sores caused by the dirt and the caked dandruff, causing seve,ro irritation; and, secondly, because the harne's will deteriorate. The inside of harness, which is more often neglected than the outside, is the part that requires the most careful attention. It must be cleaned overy day after uso by being rubbed firmly with a wet sponge, and then well soaked over with a good saddle-soap or harness-soap. All hairs, dandruff and dirt must be removed before the soap is applied. Half-liearted measures in cleaning harness, as in grooming liorses, are useless. The outside must also bo cleaned and dressed with suitable dressing. Dressings containing a large amount of methylated spirit, as so many do, ruin the harness. Cloth and felt linings must be dried in the sun and well brushed every day. Blankets and numnahs must be similarly dried and brushed. Perspiration that has become badly caked on can be removed with a weak solution of ammonia. Great care must be taken with insides of collars, saddles, girths and cruppers. After using ammonia, good saddle-soap must be well rubbed in. Steel-work should be greased except when being used for special occasions, when it should be rubbed free of oil, cleaned with bath brick, and burnished. Highly burnished steel can be dipped into water and immediately rubbed dry without causing it to rust. The practice of dipping into water bits that have the reins sewn to them must not be allowed, as this will rot the ends of the reins. Brass- and nickel-work should be cleaned with a metal polish. Nickel bits and stirrup-irons, although commonly used, are not very safe, becauce nickel cannot be forged, but only cast. A casting of such a small size cannot be 80 entirely depended upon to be free from air-blows as forgings can. Harness and saddlery must be hung up on large pegs well above the ground, and, if possible, not in the stable, as the ammonia, etc., rot the leather very rapidly. Grease and saddlo-soap preservo leather from ammonia vapour. Dampness destroys leather, so harness must be hung in a dry place. It is better if covered up with a sheet, to keep dust and poisonous gases from it. Glass-door harness cupboards afford the best protection to harness and saddle. Care must be taken that the mischievous moth is not allowed to get at the paddings in harness. The free use of Keating's powder and oil of cedar will keep the moth away. A saddle must be kept on a saddle-rack that supports the side bars of the saddle only. Harness and saddlery must never be thrown about or dropped. A good hunting saddle may be ruined by being dropped.

203. All saddlery and harness should be given three days' rest at least once a year, during which time it should be "put in oil," i.e. well greased with dubbin, neat's-foot oil, Mars oil, etc. Pigskin leather (seats of hunting saddles, etc.) must not be greased with the above greases; it should only be greased very lightly, or it will stretch and become cockled. Oriffin's saddle-paste is the best preparation I know for pigskin leather. Leather buckets and other articles that should remain stiff must be only lightly greased. The advantage of Griffin's paste is that the leather can be used the following day without soiling the clothes, any superfiuous grease being rubbed of with a duster.

Hot water must never be used on leather ; cold water, a good sponge, and a little energy are all that should be allowed. But if leather has been very badly neglected, it may be as well to rub it with lukewarm water, and immediately to apply saddle-soap or grease. Leather must not be left soaking in water. Soda, or soft soap, which contains a large amount of soda (soda carbonato), must never be used on leather. 


\section{CHAPTER VII}

\section{RIDING AND SADDLES}

294. Anatomy of the Horse's Back.-No part of a horse's harness causes more trouble than the riding-saddle, and most of this trouble is the result of misunderstanding on the part of the saddler or groom, or of bad riding on the part of the rider. The most difficult problem we have to deal with in harness fitting is the prevention of sores from the horse's collar; this trouble, as stated in the previous chapter, is due to friction, as a rule, and not to pressurs. Saddle galls, however, are almost entirely the result of pressure, uneven or continuous. With proper care there is no reason why a saddle should cause a gall.

Due to the gross ignorance displayed in the past by so-called horsemasters, and to the bad riding of cavalrymen, we find that armies have been handicepped in campaigns; and through the bad riding of some hunting men, polo players and others, cruelty of the grossest form has been inflicted v:pon the horse. The question has been asked whether sore backs are not the result of domesticating the horse. The answer is in the negative. This trouble is the result of want of knowledge of the anatomy of the horse's back. If there is any part of the horse that a horseman should understand thoroughly it is the back. We will therefore study the back from the withers to the loins and around the girth or thorax.

295. P. 69, 70 show the bony structure of a horse's back. The horse's body, consisting of thorax, abdomen and pelvis, is enclosed in a musculo-bony frame. The bony part of this frame consists of a horizontal chain of bones called the vertebral column, and circular bones leading from part oi this chain to the breast-bone below, and at ach end the upper portions of the limbe. The body frame is attached by ligaments directly to the hind-limbs, but is only suspended in front to the fore-limbs by muscles on each side (serratus magnus). The vertebral column extends from the head to the tip of the tail. There are 53 to 56 vertebræ in all. Neck (cervical) 7, back (dorsal) 18, loin (lumbar) 6 , croup (sacral) 5, and tail (coccygeal) 15 to 20 .

The vertebræ which we will consider are the 18 dorsal ones. The first eight of these have true ribs (sternal) attached to them, the other ends of these ribs being attached to the breast-bone (sternum) at the base of the thorax. The remain. ing ten have false ribs (asternal) attached to them, the other ends of which are joined together by costal cartilages which are indirectly attached by ligaments to the rear end of the sternum.

286. The first rib is the shortest, the ninth the longest. The curvature gradually increases from the first to the eighteeisih.

The true ribs are wider and flatter; the false are more like a semicircle. The sixth and seventh, which cover the heart, are very wide. The ribs project out almost horizontally for a considerable distance on each side of the spinal column before they bend down over the sides of the thorax and abdomen. It is on this almost horizontal portion, and ncwhere else, that the entire weight of the saddle must be borne. As the horse inspires, muscles draw these ribs forward, being hinged at both top and bottom. As the centre part of each rib is drawn nearer to the head, the diameter of the thorax, i.e. the horse's girth, is increased, in the same way as our chest is expanded by the ribs rising in front when a deep breath is taken. Therefore, a horse should never be girthed too tightly, and the girths must not be too far back, as the expansion is greater as we go farther back. The first rib does not move with the $\mathrm{e}^{+}$pansion of the chest.

297. Having realised what portion of the bony anatomy should support the weight, we must consider which portions must not bear any weight. The loins, situated posterior to the eighteenth rib and anterior to the hip bones (ilium), are not covered by a bone on each side of the vertebral column, but only by muscle. On no account must any weight be borne on these parts. Great care must be taken when a second rider is sitting on a horse, behind a saddle, that he sits on the pelvis, i.e. behind the hips, and not on the loins, bucause, as the kidneys are situated in this region, damage will result. Nor must there be any weight borne by the spinal column itself; neglect of this is the common cause of a great many sore backs. On P. 69 it will be seen that spinous processos project up from the body of each dorsal vertebra; these are usually called spines. The spines increase in length from the first to the fourth or fifth, and then gradually decrease to 

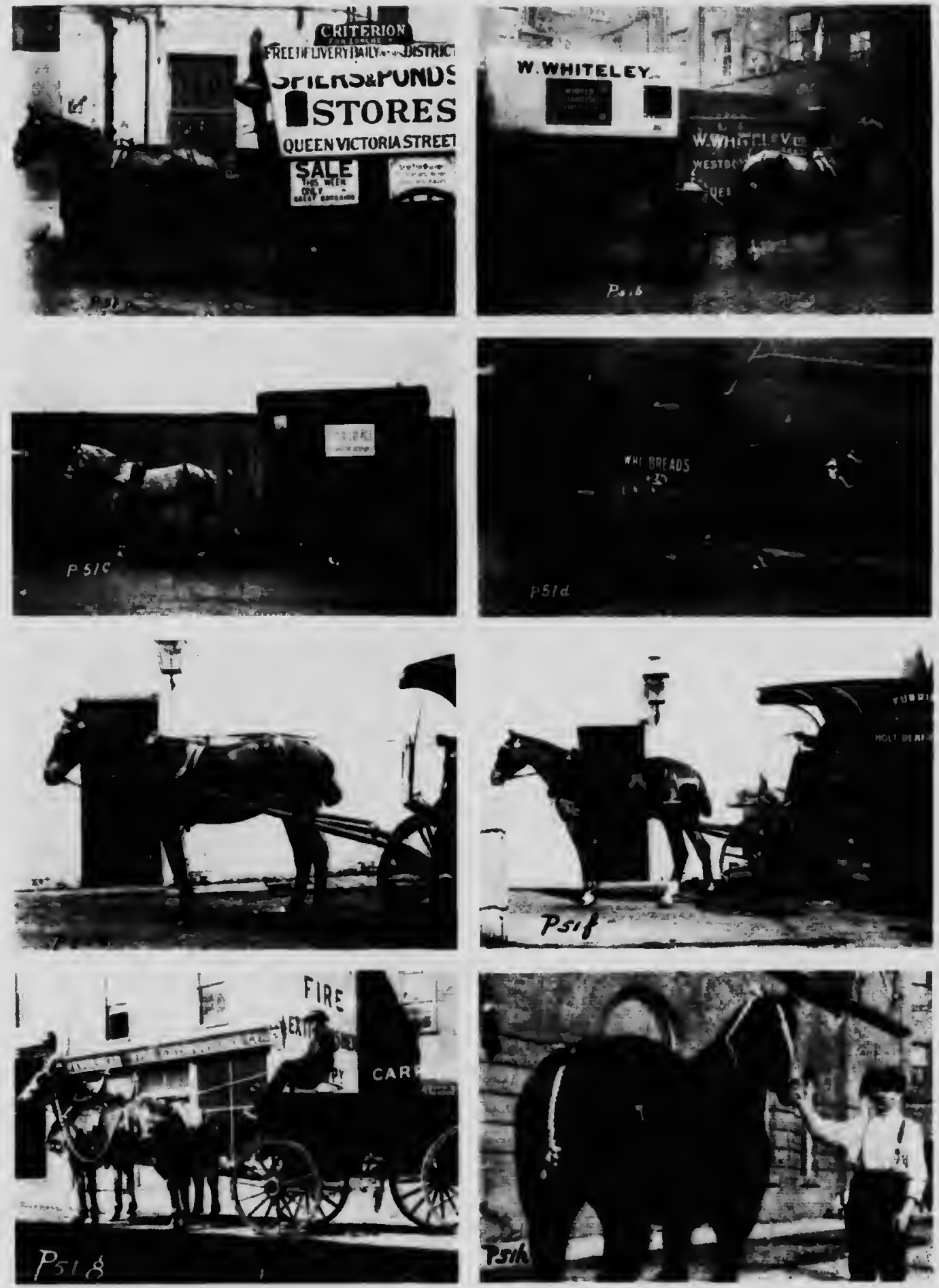

COMMERCIAL VAN HORSES AND SOME TYPES OF TAIL.PLAITING

Courtesy : a, Spiers \& Pond. b, Wm. Whiteley. Lid. c, Juniot Army and Navy Stores. d, Whitbread's Lid..

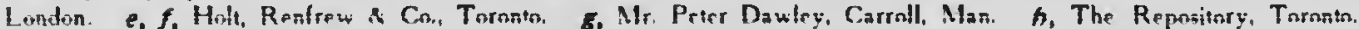
Photos, and $f$, by the Aithor 
PL.ITI: 52
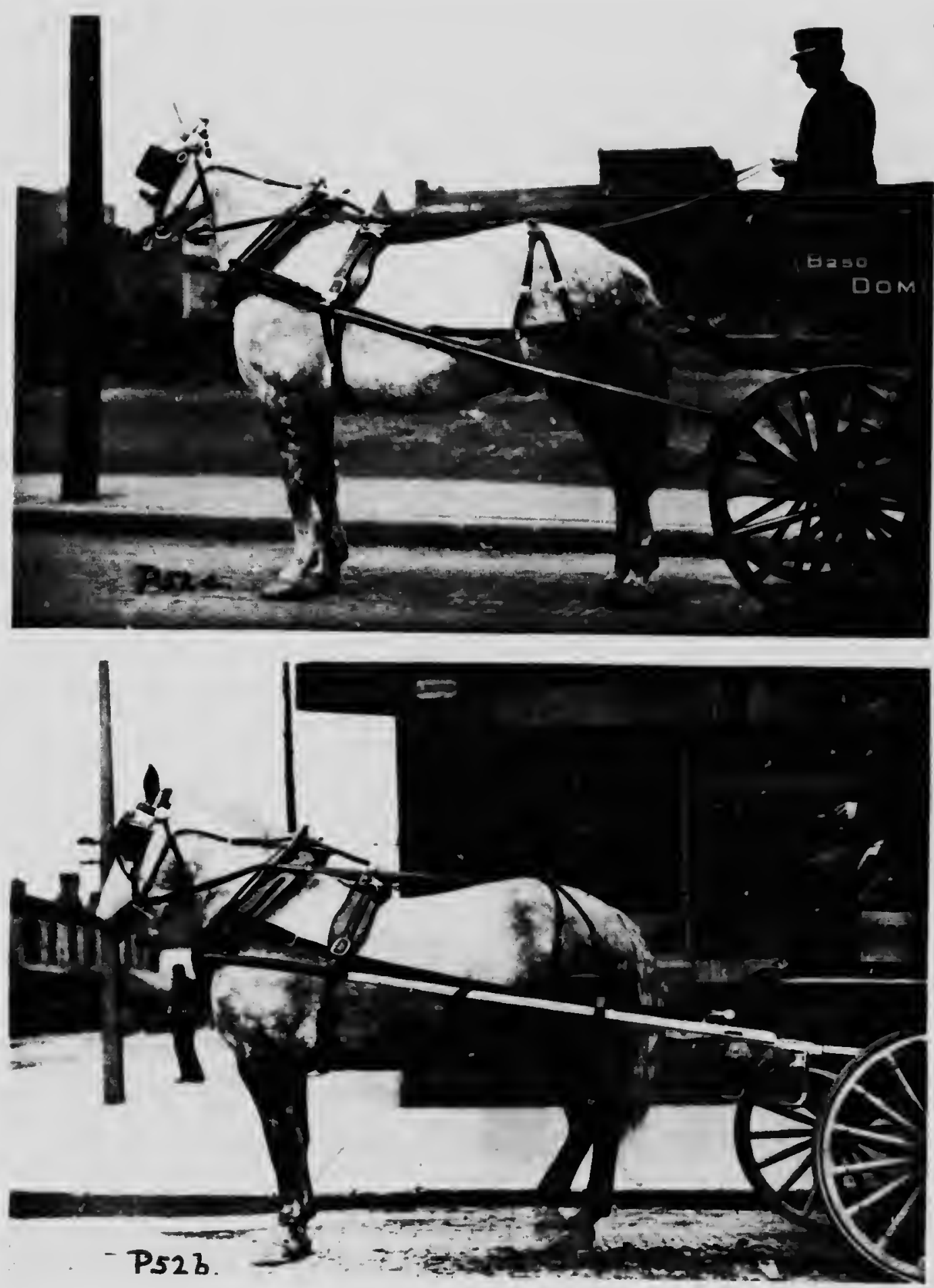

PRIZE. WINNING CANADINN.BRED COMIIERCIAL HORSES

Courtesy: a, Dumunion Express Co., Toronto. b, Firsibronk Box Co.. Toronto. Photos: W. James, Toronto 


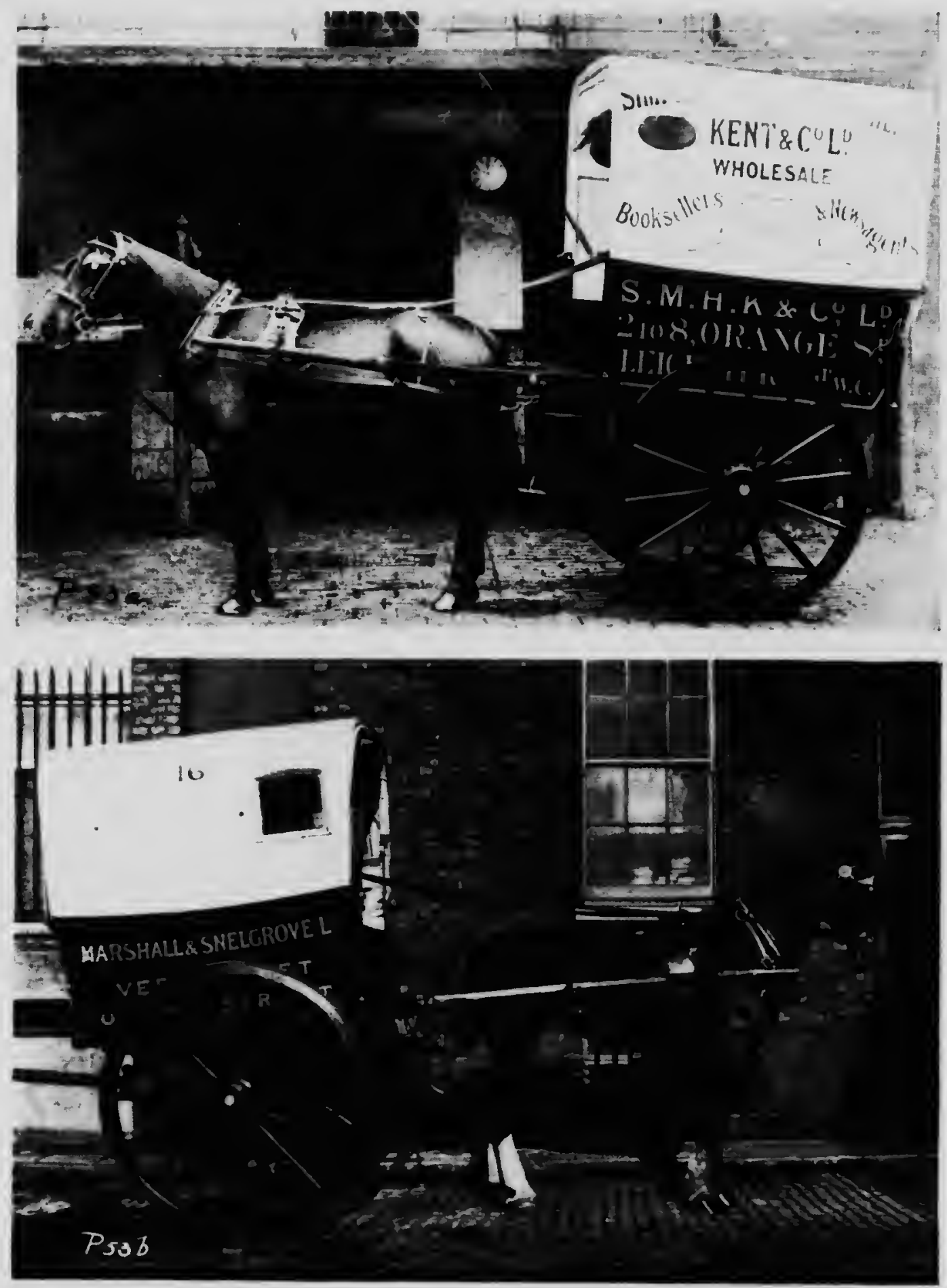

LIGHT COMMERCIAL TRAP HORSES

Courtesy: a, Simpkin. Marshall, Hamilton. Kent \& Co. b, Marshall \& Snelgrove. London. Photos: a, Campbell Cirey. b, Ellis \& W'alery, Baker Streel, London 
PI.ITE it
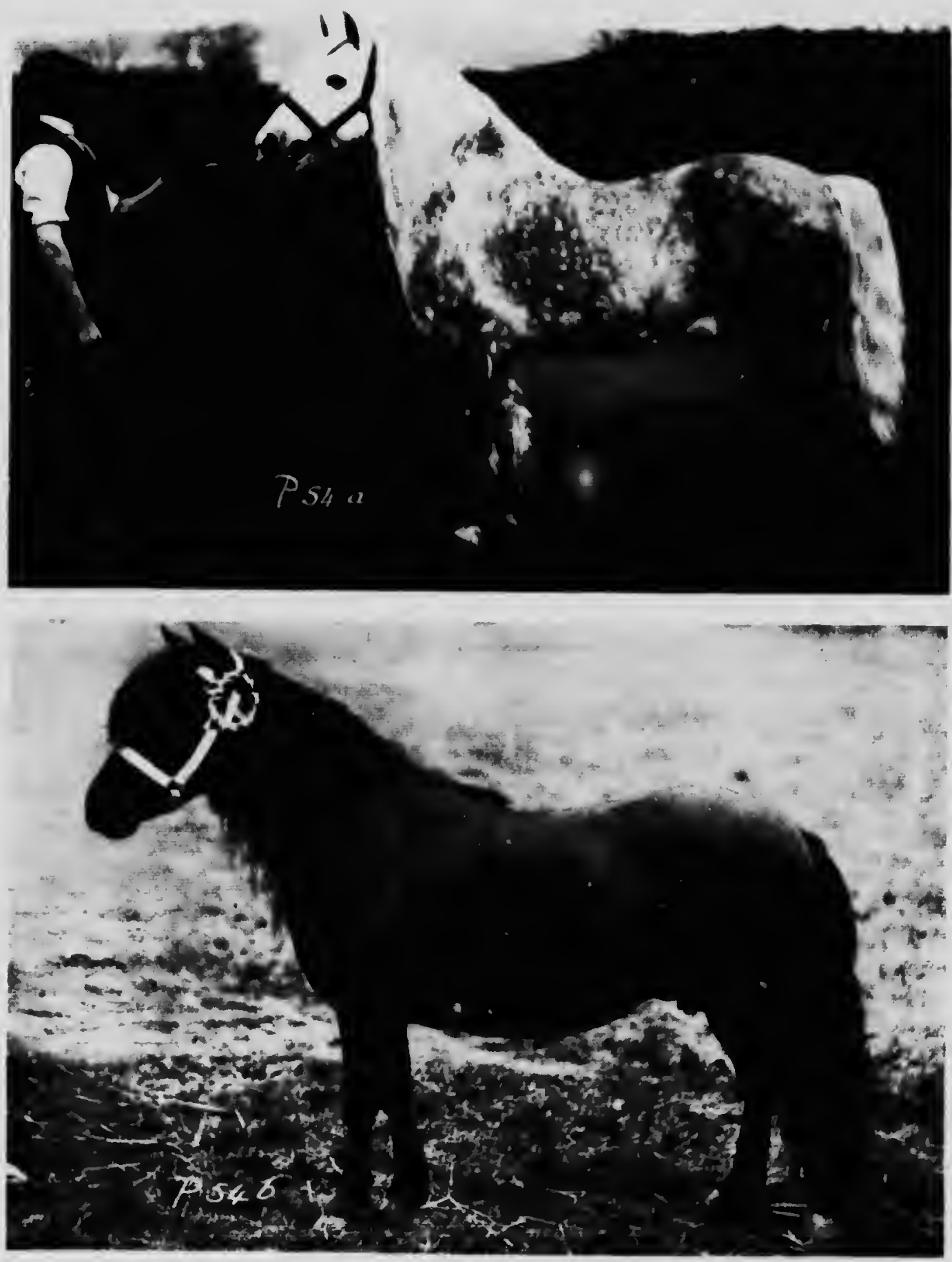

BRITISH ISLE PONIES

a, Highland P'ony Sire "Comariacl." the Property of Lord Middleton. b, Shelland Mare "Thora Lina," Champion at the Royal show. 191?. Photos: G. H. Parsons 
the twelfth, and are of the same length from the thirteenth to the eighteenth. They slope backwards from the first to the thirteenth or fourleenth, the fourteenth or fifteenth is vertical, and slope forward from the fifteenth or sixteenth to the eighteenth.

The twelfth or thirteenth is the smallest and the thickest. Tre bodies of the vertebro increase in size as we pass beck, because there is more movement in the rear part of the back, and therefore a greater curvature is required between each body to allow for this twisting movement. The spinal column consists of an arch with its apex at the fourteenth or fifteenth dorsal vertebra. The arch is trussed by powerful muscles woven in between the spines, scting as ties, and by a powerful muscle under the column (longus colli), as well as by a large number of powerful inelastic and elastic ligaments. This arch or girder is not rigid, as will be clear to anyone who has studied the horse; it can be arched, depressed, or bent to either side at will.

288. The first six or eight of these spines form what is called the withers. On top of the spines there is a white, non-elastic ligament (supra-spinous), but over the withers this ligament is interwoven with the rear end of the yellow elastic ligamentum nuch o that supports the weight of the head. Pressure or friction on any of these spines will cause diseased ligaments and, eventually, diseased bone; but, if over the yellow ligament above the withers, the result will be far more serious. It is for this reason that fistulous withers are so common and so dificult at times to heal.

299. As stated above, the tops of the ribs must be made to bear the weight. The top portion is at a considerable angle in the front ribs, but nesrly horizontal in those at the back, so that the pressure from the front of the saddle will naturally tend to force a saddle downwards and pinch the horse. The pressure is not taken directly by the bones; any pressure or friction is first taken by the periosteum, a thin, highly vascular skin covering the bone. This skin, if damaged, dies, and causes necrosis, i.e. death of the bone below. This shows the importance of keeping all bony prominences free from injury, and shows how much more careful we must be when a horse is in poor condition and has less muscle covering his bones, as, for example, at the end of a campaign. The top portion of the ribs on each side of the spinal column is covered by a powerful muscle (longissimus dorsi), which is again covered by skin and hair. It is this, then, that actually bears the $v$ oight and acto as a cushion between the bones and the saddle.

800. We fonnd above that the front part of the saddle may tend to pinch the first few riba together, and, fortunately, the bottom ends of these ribe are securely attached to the breast- bone, otherwise we should not be able to put a saddle upon a horse without interfering with the action of the heart and lungs. Whilat the amount of muscle covering the bony back makes a better cushion, it is the cause of sore backs, being 80 difflcult to treat surgically. The reason is that when pus (matter) forms under the skin, instead of its breaking out and the wound healing quickly, it burrows down between the layers of muscle, carrying the infection wherever it g0es. In fistulous withers the pus will burrow inside the muscles of the shoulder-blades, and an incision for drainage may have to be made below. Where the pus has burrowed down, setons should be inserted and the holes kept open until they heal from the top. If wounds are allowed to heal from the bottom they will not drain, and blood-poisoning will result. The healing of bad saddle-sores cannot be hurried, because if hurried worse consequences inevitably result. The next point is how far the saddle should extend to the front. We see that it must not extend posterior to the ribs. In Chapter VI. we saw that the shoulder-blade moved to and iro as the horse moved. As this bone moves back, the muscle bulges out. The foremost part of the saddle must not in any way interfere with the play of this bone or the action of the muscles.

801. It is clear that the shape of the back and shoulders will materially affect the position of the weight, the amount of weight that can be carried, and the extent to which the weight will move when the horse is in motion. With nearly all kinds of backs a saddle tends to work forwards, hence a breastplate (now almost abolished) is seldom of any use. On some horses with large girths-i.e. deep and wide over the first few ribs and narrow behind, like a greyhound-the saddle will tend to slip baskwards, and the use of a breastplate is advisable. Although the saddle itself generally tends to work forward, the blanket or numnah, under the saddle, tends to work backwards in the direction of the hair, so that if the numnah or blanket is strapped to the saddle the tendency of the saddle to work forward is greatly diminished.

302. Backs. - The front of the portions of the saddle resting on the ribs must be embedded in the hollow behind the shoulder blade, so as to prevent the possibility of the saddle slipping over these parts. These portions of the saddle must be well padded to prevent injury.

The conformation of the back varies greatly. Short backs are stronger and generally wider in the loin. A back cannot be too short, if it is long enough to fit the saddle. A long back is generally weak and narrow. A horse cannot be too short above his body, but he must have sufficient length underneath. High withers are most liable to injury, as they are thinner and less covered with flesh; they, however, generally, indicate good action in front, which 
means that the horse is a safer saddle horse. These are sometimes found with hollow bscks, and are not suitable for carrying weight. low withers are generally wide, and are very liable to be pinched; they are generally signs of a clumsy action in tront. Rnach backs, the opposito to hollow backs, are strong, but uncomfortable for long riding. Hollow backs, though weak and unsuitable, are very comfortable to ride upon. A wide-backed lorse is the right kind for saddle work of long duration, as the besring surface is large and the lung capacity is large. If too wide, the saddle may tend to work over the withers on to the narrow shoulders. A narrow back is unsuitable to bear weight, and indicates a flat-sided horse, whose stamina is generally deffient.

803. The weight of a horse is carried mostly on the forelegs; the chief function of the hindlegs is to propel the body forwards, as in draught or jumping. About two-thirds of the weight of the saddle and rider is borne on the horse's lorelegs. Now, the weight of the horse on his fore egs is decreased as his head is raised and neck brched. Therelore, the ideal saddle horse should carry his head high and neck arched, so as to save his forelogs. And, again, the rider should not sit forward on the withers, as was formerly done with the old straightlegged seat. The correct sea! on a horse will place the rider's weight almost over the middle of the back. (See P. 58.) The weight is thrown farther back the more sloping the shoulder is, hence the necessity of a sloping shoulder for saddle horses to lighten the veight on the forehand as well as to decrease the liability of the lorse's stumbling. The placing of the head and the correct seat are dealt with in Secs. 321, 330, 347 and 476 , et seq.

304. Pressure.-As slated above, most saddle troubles are caused by pressure, hence great care must be laken to see that the pressure of the rider is distributed evenly over every square inch of the bearing portion of the saddle. Uneven stuffing, uneven folding of the blanket, nails and other foreign substances in the stuffing or numnah (not an uncommon occurrence), wrinkles in the blanket, etc., must never be allowed to exist. The greatest care must be paid to these points when saddling up. Pressure causes death to the bones; it also causes death to all living tissue (gangrene) by arresting the supply of blood to the tissue. Without blood, life in the cells ceases, and gangrene sets in immediately. Directly a cell dies, as explained in Chapter XVII., bacteria commence to devour the dead cell, splitting it up into the various gases and solids of which it is composed.

If one presses his finger against the back of the hand for a few seconds and removes it, the part pressed is devoid of colour; the pressure las driven the blood away. If a finger is tied lightly with a cord for a fow hours, it will die. The same happens if a certain part of the horse's back is unduly pressed upon for a long time; it dies, and is marked aftorwards by white patch, so common on the backs of saddle horses. When a rider mounts a horse, the blood in the subcutaneous blood-vessels is driven out, and these vessels remain empty. If only for an hour or so, no permanent damage is done, but if for many hours damage may result. Hence it is advisable that a rider should never remain in the saddle for more than an hour or two without dismounting, oven if only for a fow minutos. On the other hand, if a saddle is suddenly taken off after the horse has been ridden for some time, the blood will rush back suddenly into these vessels and may rupture them, causing small lumps to appear on the back. This is not uncommon with thoroughbred horses that have thin skins. My advice is to leave the saddle on for fifteen minutes or more after the girths have been loosened. If, lowever, the saddle is removed suddenly, the back must be energetically hand-massaged for at least ten minutes, preferably by a man on each side. This should be done against the direction of the hair. A rider should neve: remain mounted unless it is necessary.

305. Saddling.-In placing a saddle upon a horse's back it should not be dropped on, but be placed on gently from the near side, the girths having been crossed over the seat so as not to swing against the horse as the saddle is lifted over the back. After ascertaining that the pads, numnah or blanket are perfectly smooth on the horse's back, the girths should be done up loosely. They should never be done up tightly at first. After the horse is bridled, and just before he is going to be mounted, the girths should be done up to their proper tightness, but they must be tightened slowly, and never by jerks. Great ignorance is displayed by grooms in girthing up, causing both pain to the horse and waste of energy to themselves. Directly a rider dismounts at the end of a ride he should loosen the girths, leaving the saddle on for, say, fifteen minutes, as alroady advised.

306. If the back is still wet when the saddle is removed, it must be dried, which is best done by hand-rubbing against the coat. If a saddle is taken off in the field to ease the horse's back for a fow moments, the back must be energetically hand-rubbed.

The utmost care must be taken that blankets, saddle-pads, saddle-linings and numnahs are perfectly dry and not cold when placed on the horse's back. If kept in a cold place, they should be warmed first. Damp or cold saddles are uncomfortable to the horse, and cause some mares to kick. They also cause many horses to roach their backs until the saddle has become 
PIATE 55
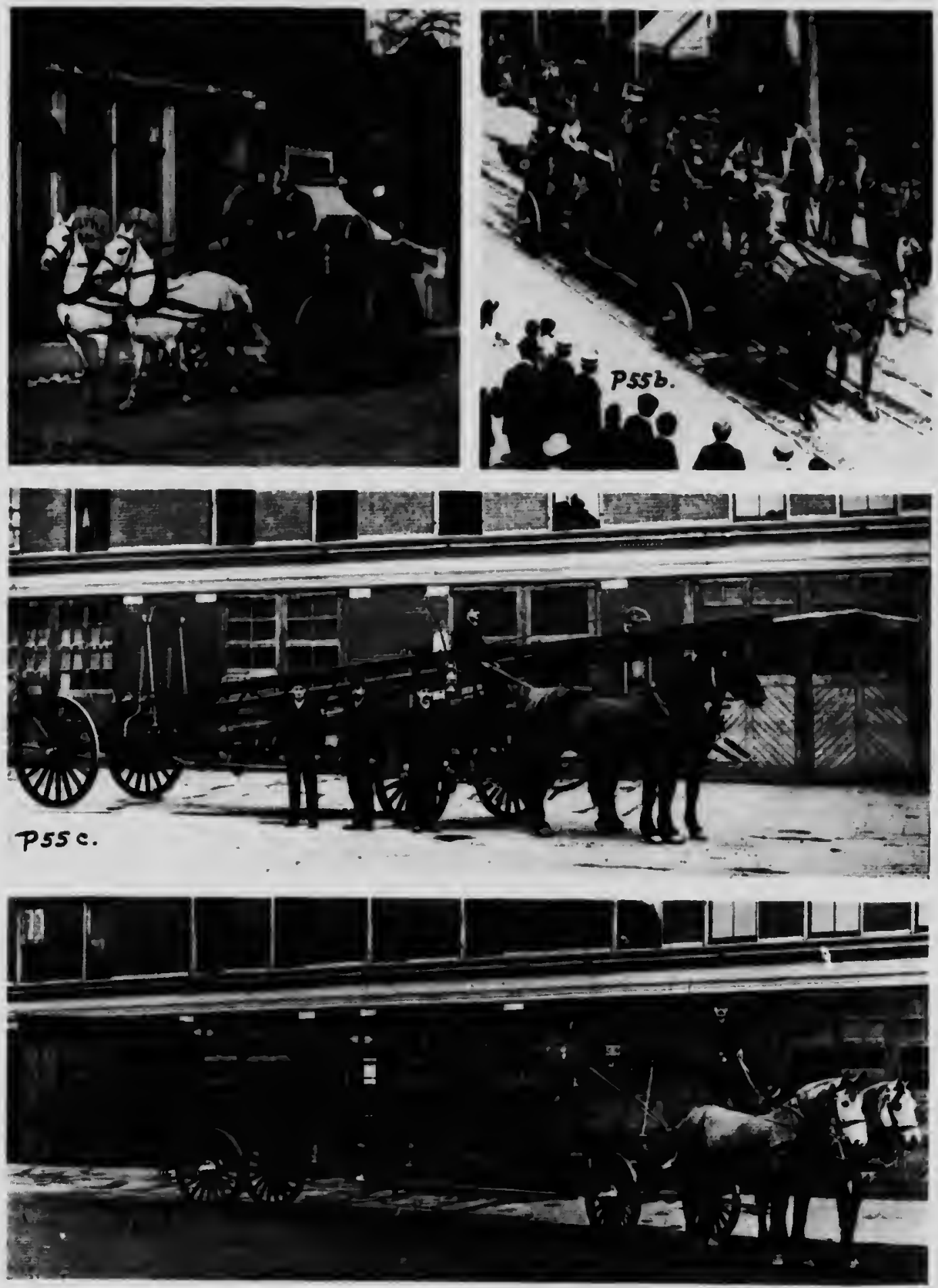

TORONTO FIRE BRIGADE HORSES

Photos: Galbraith, Turuttu 


\section{PI.NII: 56}
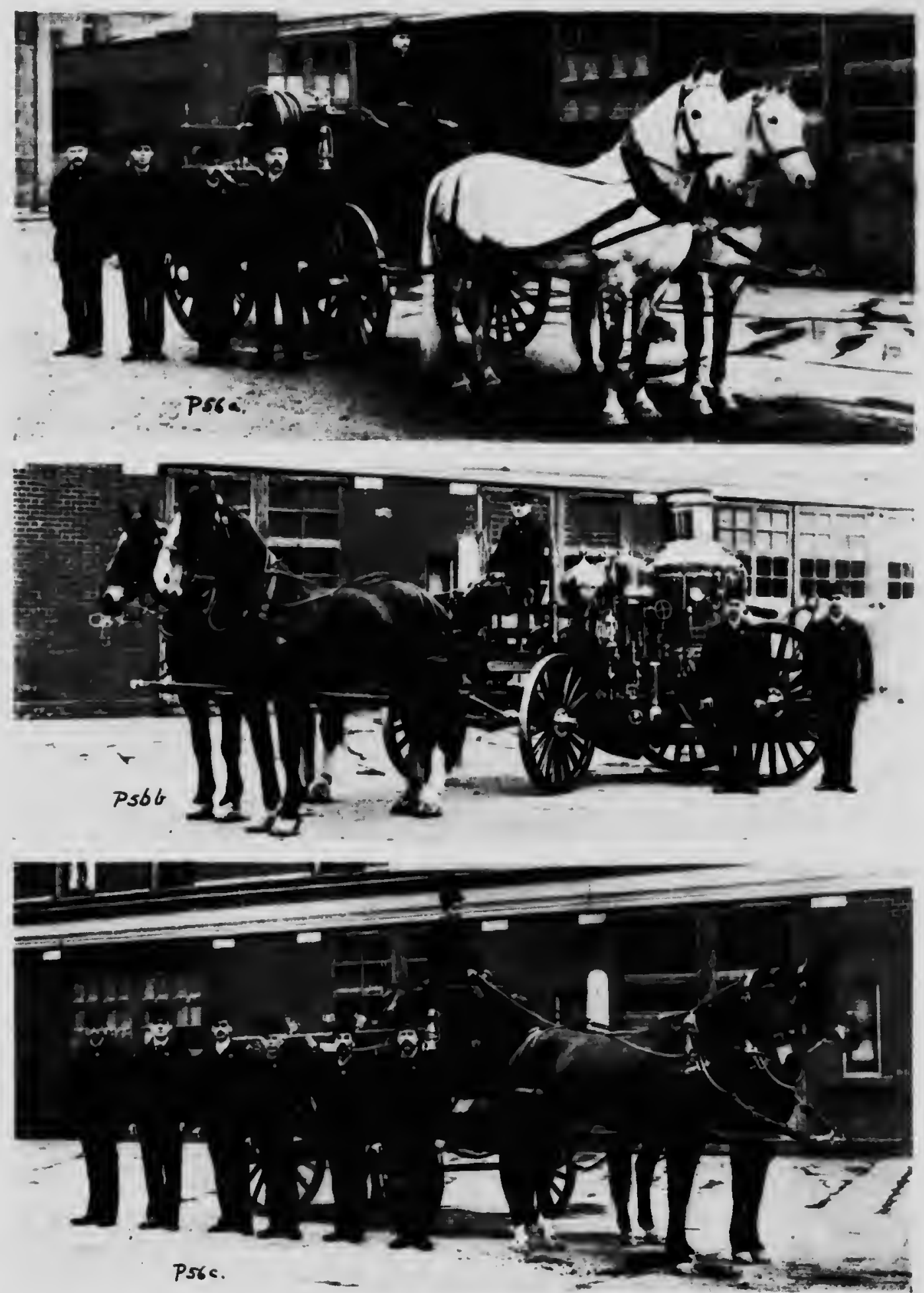

TORUNTU A IiE BRLANDE HORSES

Photos: Calbraith, Toronto, b. Couttesy: Waterhouse Eagtne Co, Brantlord, Ontario 
PI.ATE: 57
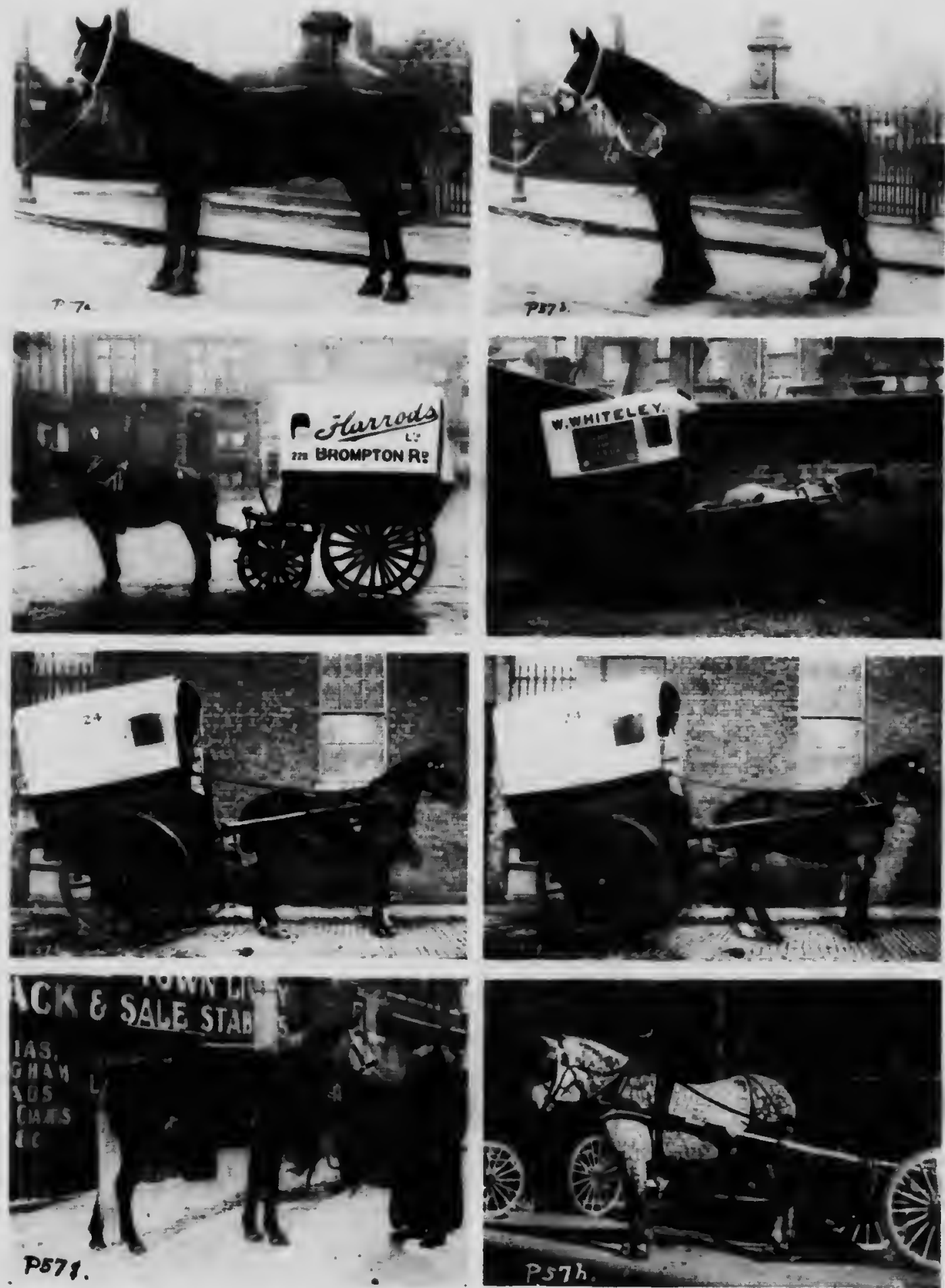

TYPES OF COMIIERCIAL HORSES

a, b, c. Courtesy: Harrod's Lid., London. d, Courtesy: W'm. Whiteley, Lid., London. P, f, Courtesy: Marshall \& Snelgrove. Lid., London. E, Courtesy: Jewcll * Hinton, Ottawa h, Courtesy: The T. Eaton Co., Toronto Photos: g, h, by the Author 


\section{PL.ATE: 58}

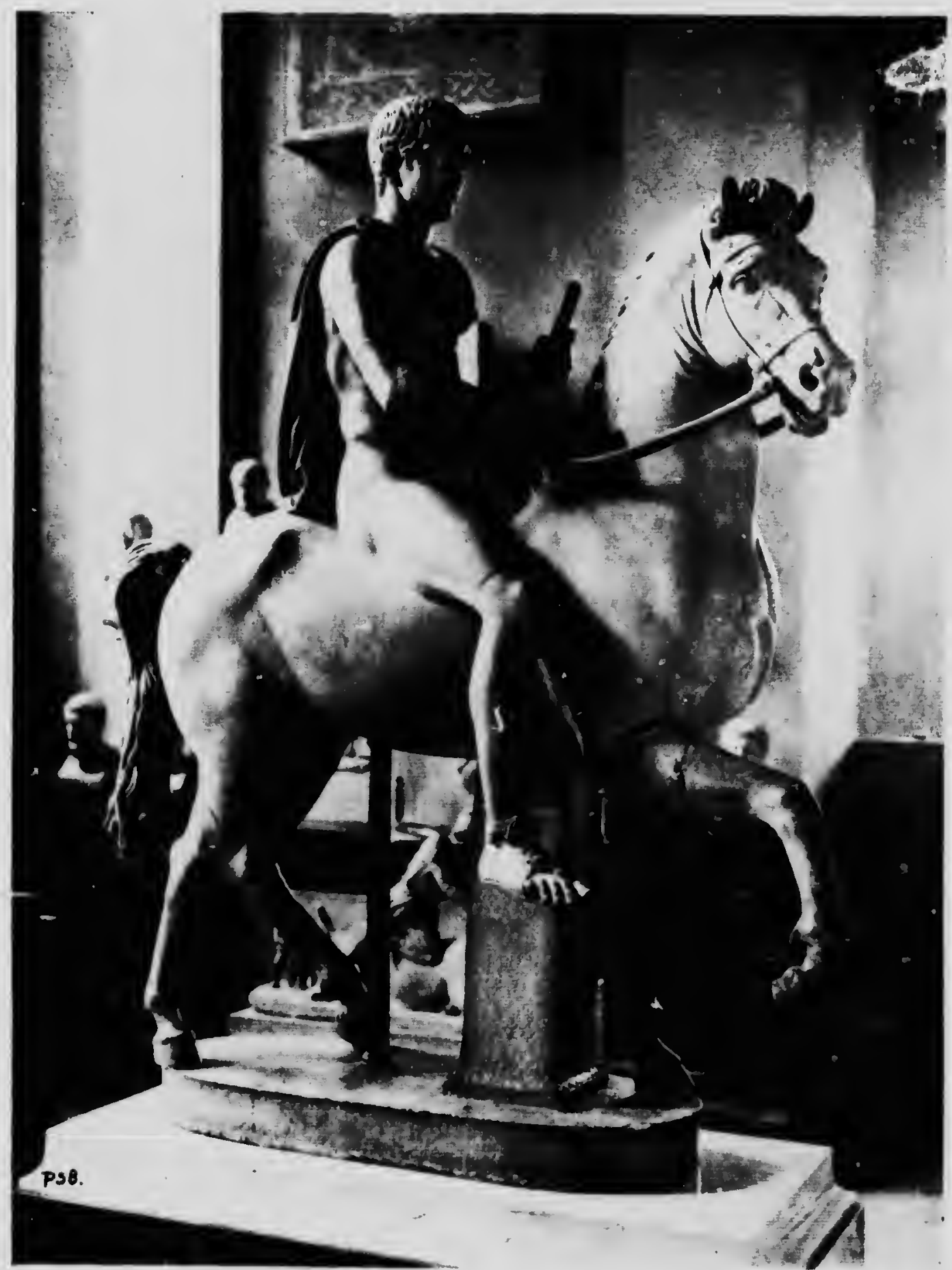

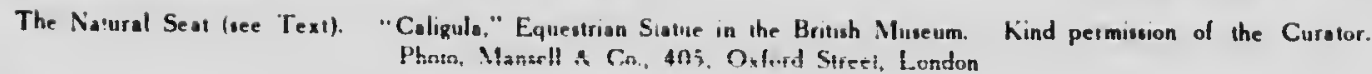


warm. With a freshly clipped horse a damp saddle may do harm to the skin.

Saddle blankets and numnahs should be kept in a warm, dry place, so as to be ready at any moment. When removing a saddle, the instructions laid down in Chapter $V$. on grooming must be carefully adhered to.

807. Saddles.-Having considered the place on which to put the weight, we will next consider the best apparatus to carry a rider on the horse's back. All saddles are, and always have been, built on the same principle. A flat sidebar rests on the ribs on each side of the spine ; these are connected together at the front and rear by arches. The side-bars are usually made of ash wood, and have a twist on their undersurface so as to fit the first ribs, which slant considerably, and the last ribs, which are nearly horizontal. A straight side-bar would rock.

Arches should be made of steel, but some hunting saddles have the rear arch of wood reinforced with steel. The front arch (pommel) must be very strong to prevent spreading, and must be wide enough to prevent pinching, and high enough to clear the withers. If the front arch spreads it will touch the top of the withers. The rear arch is not subjected to spreading, but often breaks down from the weight in the saddle, and comes in contact with the back. Military saddle rear arches are generally strengthened by steel brackets bet."een the arch and the side-bar. With milita jaddles, the use of the numnah and blanket jaithough the former is not used much nowadays) necessitates the side-bars being farther apart and the arches wider and higher in order to keep the cloak, etc., that are carried on the saddle ofi the horse's back.

The real difference between military and hunting saddles is that the high arches cause the seat to be attached higher in front and rear, and, in order to carry out the essential principle of placing the rider as close to the horse as possible, the centre of the seat is lowered, thus giving it a chair-like appearance.

308. The seat is formed by webbing being stretched from arch to arch, and by other webbing being stretched over the first pieces from side-bar to side-bar. The leather seat, pigskin in hunting saddles, is then stretched over the webbing. The rider sits on this, which transfers his weight to the arches and thence to the side-bar. The side-bars and arches are called the saddletree. The shape of the back determines the shape of the tree. Now, although a hunting saddle will fit most horses, provided the front arch is high enough and wide enough, if the stufting in the pannels is adjusted to fit the back, the tree of a military saddle will not necessarily fit even two horses. On account of the extre weight and the difineulty of keeping stuffed pannels in good order on active service, military saddles are made without pannels, numnahs or blankets being used instead. Felt pannels are sometimes used under the side-bars. In military saddles the side-bars must ft each horse, and every military horse should have his own saddle. The wood is roughly shaped to fit the horse's back by the saddletree maker, who ascertains the correctness of the fit by placing a folded blanket on the back and pressing the saddle down for a few minutes on to the blanket. These parts will be shaved off. Again, portions that have been shaved off too much can have small pieces of numnah-felt tacked on. Self-adjusting side-bars have been introduced, and are of great use on active service, as they only require adjusting as the horse loses condition. Under the side-bars of military saddles either felt pannels or numnahs are used with a blanket. The numnah should have a buckle at each end of its middle to buckle to the front and rear arch of the saddle when in position, thus keeping the blanket, if used-which is between the numnah and the saddlo-in proper place. Slipping is impossible with the use of these straps.

309. With hunting saddles it is more practicable to use pannels, stufied with flock or horsehair, which can be restuffed or readjusted as the horse's condition alters or when the saddle is used on a fresh horse. Numnahs are often used under the pannel. The pannel is usually of felt or leather. Leather is easier to keep clean and soft, and does not absorb the sweat, but requires to be kept well soaked or it will get hard. Felt pannels must be dried in the sun after being removed from the horse's back, and brushed clean when dry. Weak ammonia should be used to remove cakes of grease and dandruff. Numnahs and blankets must also bo kept scrupulously free from hairs and grease.

810. Cork and pneumatic pannels are used; the latter answer very well until the air sacs leak, when the saddle is useless. It will be understood that the essential part of a saddle is the tree, and that the seat and flaps are only luxuries and not necessaries. Some Mexican saddles have only a small seat and no faps. A thick blanket laid over the tree would serve the purpose of the seat and fiaps, but would not be so comfortable and would get puckered up.

The bars of the tree must fit the back as the boot fits one's foot. We all know what it is to walk six miles with a lump in the lining of one's boot, so we can imagine what it is for a horse to carry a badly fitted saddle. Besides the undersurface of the side-bars fitting perfectly, the rear and front ends of the side-bars must fit perfectly ; so must the arches.

811. When fitting the + parts or when ascertaining that they do fit, the following important puints must be borne in mind :

The withers must not be pinched or pressed 
upon; the vertebral column, along its whole length, must not be pressed upon; the front parts of the side-bars (burrs) must allow absolute freedom to the movement of the shoulder-blades ; there must be no weight on the loins, and the rear ends of the side-bars (fantails) must not come in contact with the loins; and the sidebars must distribute the weight evenly over the muscles covering the back from the withers to the last rib.

312. Thus, a short back requires a short tree, and a long back is better with a longer tree, provided the tree is not so long that it will rock or move sideways. A wide, thick wither and a wide back require a wide front arch (pommel), whilst broal loins require a wide rear arch (cantle), and vire versa. To cause the least fatigue and risk of injury, every hunter or hack, as well as military horse, should have a saddle chosen for lis back, and fitted or properly stuffed in order to distribute the weight evenly.

The modern military saddle does not carry wallets, but only a light roll in front a. i sometimes a small roll behind. The folly of strapping a heavy pack to the fore and aft of a sadile was conclusively proved during the South African war. In order to keep the light rolls off the back, as well as the arches having to be higher, the side-bars extend more forwards and backwards. As so little is now carried on the military sadrle, I think there should be a new saddle made for military purposes, with a seat more like the hunting seat, in which a man can sit upon his horse in a proper position, whilst the old saddle tends to make the rider us t too straight a leg. The front part of the side-bars could be more like those of a hunting saddle with the necessary D's attached. All that need be carried on a military saddle is the cloak and waterproof sheet on the front arch, and possibly one peg: and, on the rear arch, the nosebag on one side and a second peg on the other. Personal kit should be carried in a haversack. If the saddle were thus modified in shape, one of the greatest troubles caused by our present military saddles would be obviated-that of fitting the burrs and the fantails, particularly the former. We seldom hear of this trouble with a liunting saddle. If these burrs do not fit properly, injury is sure to result; at any rate, the horse is liable to be thrown down by the action of his shoulder blades being interfered with. A huise with a good back (see P. 68a) could not wear a long-tree cavalry saddle.

318. As the hind-limbs of a horse are pivoted to the frame quite widely apart, there is a considerable rolling action to the hind-quarters while the horse is in motion. Long fans or fantalls will tend to cause friction against the loins unless they are kept well above them. With hollow-back horses this is very difficult. Simllarly, it is very dificult to fli burrs to a horse with a thick, low wither or with a hollow back. A roach back is also in danger, as a saddle will rock and the burrs or fans will dig into the horse.

314. Fitting Saddlery. - A saddle must also be fitted and tested for correct fitting when a man is in the saddle.

A careful examination must bo continually made when the rider is in the saddle, and the horse watched for any loss of flesh (muscle) on the back or withers. Absence of wither pressure must be ascertained while the rider is leaning forward in the seat, when the hand should be able to be passed over the withers and down each side between the horse and the numnah, or whatever is next to the horse.

To test for bladebone pressure, the hand must be passed in between the tront part of the side-bar (inside the numnah, blanket, or what ever is next to the horse) and the horse's skin, and, while the rider is leaning forward, the foreleg of the horse must be raised and extended fully to the front by an assistant. If the hand is not pinched at all, then the bladebone is free from pressure. If it is pinched, extra stufing will have to be introduced or another thickness of blanket placed under the side-bars in the rear of the part that pinches, in order to keep that part away from the horse.

815. Both shoulders must be carefully tested as above described. To test for loin-pressure, the rider must lean back, and the flat of one's hand should be able to be passed easily between the fans and the loins.

816. Saddle Blanket.-There is a great tondency to place saddles too far forward. In folding a blanket, great care must bo taken to $8 e 0$ that every layer is absolutely flat and freo from wrinkles. The military saddle blenket messures $5 \mathrm{ft} .5$ in. by $4 \mathrm{ft} .8 \mathrm{in.}$

The best way is to fold it along its length twice, so that when folded it will measure $5 \mathrm{ft} .5$ in. by about $1 \mathrm{ft} .8 \mathrm{in}$. This can then be placed over the horse's back, and the ends brought up nearly to the centre of the back next to the horse, as in P. 70, Fig. 5, thus leaving the thinner portion over the spine, where there must be no pressure. The disadvantage of this method is that the blanket is liable to shift unless the rider has a very good seat. Another method is to fold one end of the strip, made as above, over for about $2 \mathrm{ft}$., and then to turn the other end into the pocket formed by the first ond. This will not slip, but it means that a thick portion lies over the withers and backbone. The blanket should be kept in place by the numnah straps, as described in Sec. 308.

817. The saddle, when on the horse's beck, must lie in the centre (see P. 68a); the exact position can usually be felt by pleclng the saddle little forward and sliding it backwards in the direction of the hair until it seems to embed 
PLATE 59
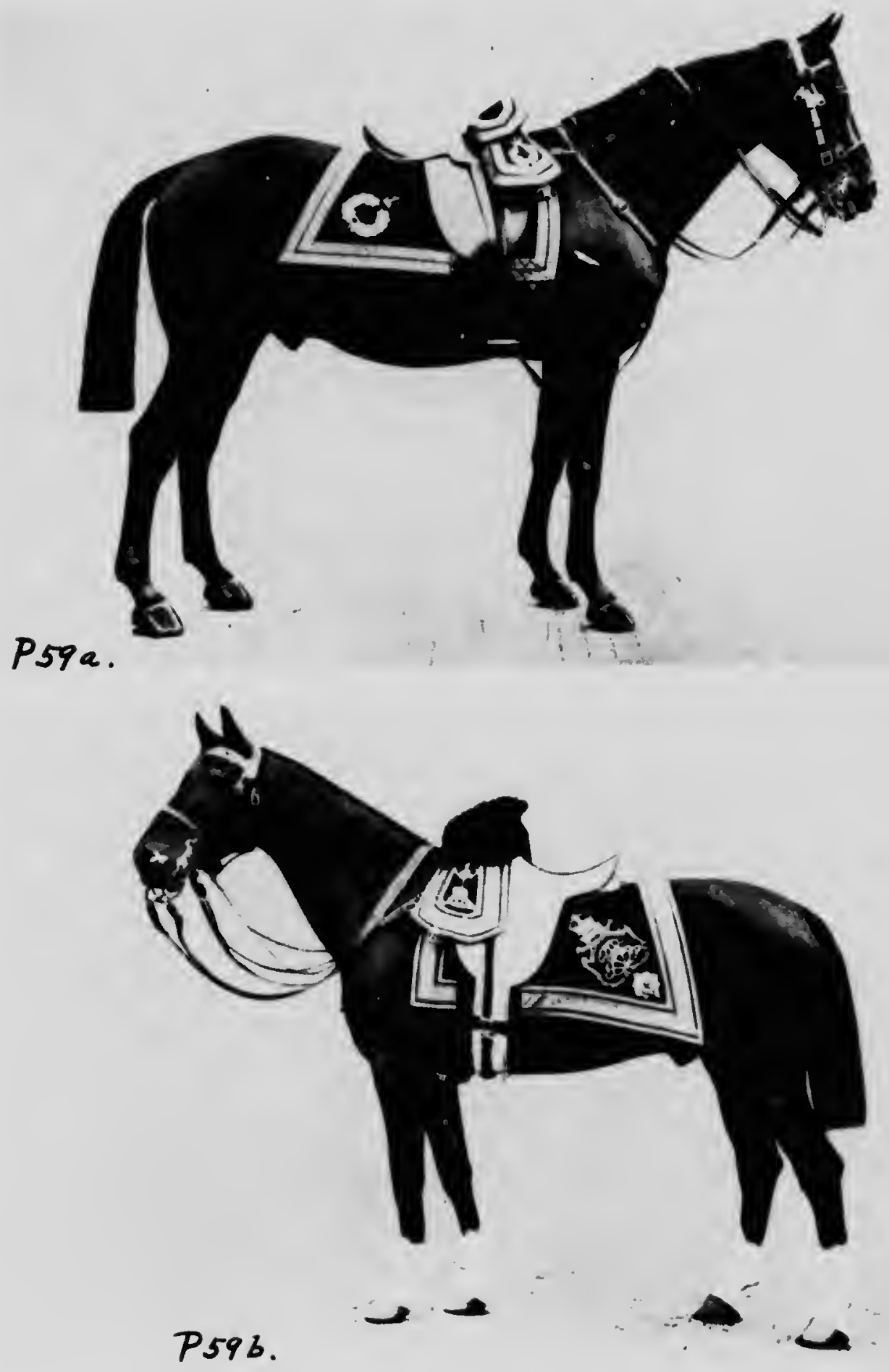

CHARGERS

a, " nildare," Charger of the Late King Edward. b. Charger of an Offeer of the Fitst Lile Guards. Copyright Pholos: W. A. Rouch, Londan 

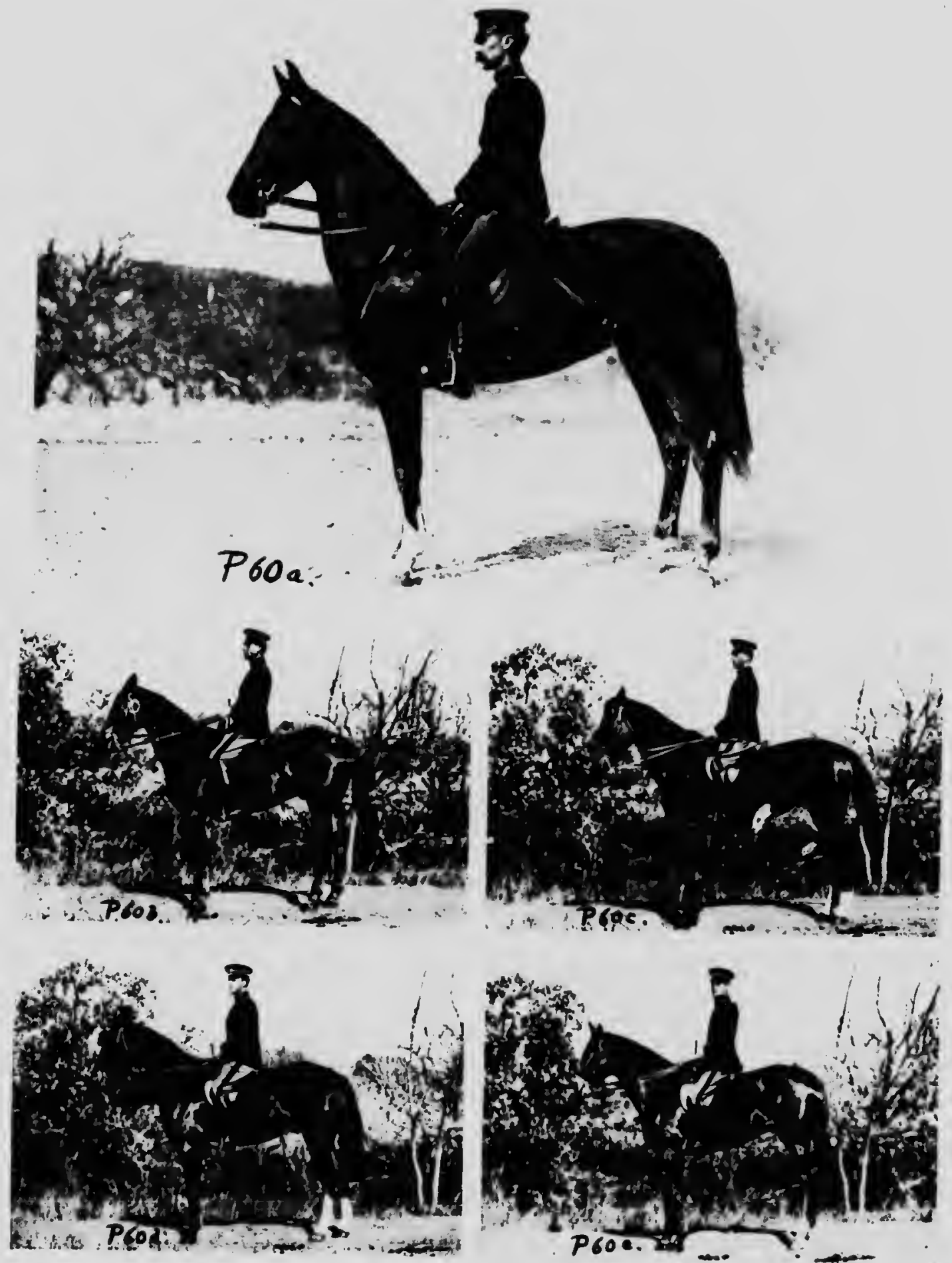

AMERICAN CWNI RY HORSES

a, th Cavalry: Capt. Shori. b, 15th Cavaliy: Capt. Lear, jnr. c, 12,h Cavalry: First Lient. Scott. d, I3th Cavalry First Lieut. Merchant. e, 13ih Cavalry: Capt. Henry. Courtesy: Col Allen. Chiel of the General Staff. Washington, and the Commandant Cavalry School, Fort Riley. Kansas, where these Photos were taten 

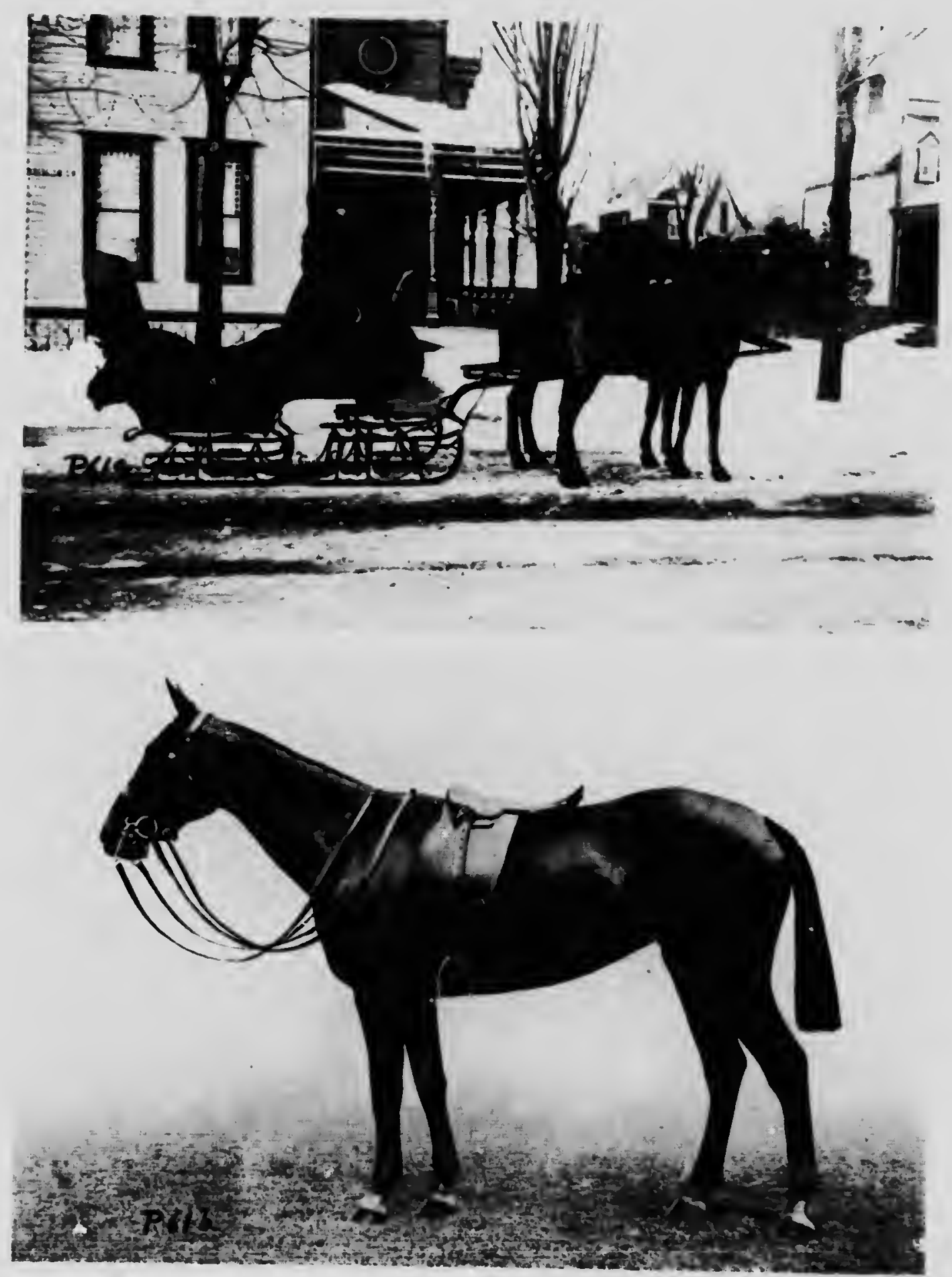

a, An Ottawa Turn-out. Courtesy: (the late) Sir Richard Cartwright. Photo by the Auther. b, Prize.winning Polo Pony "May Star." Copyright Photo: W. A. Rouch 


\section{PI.ATI: 62}
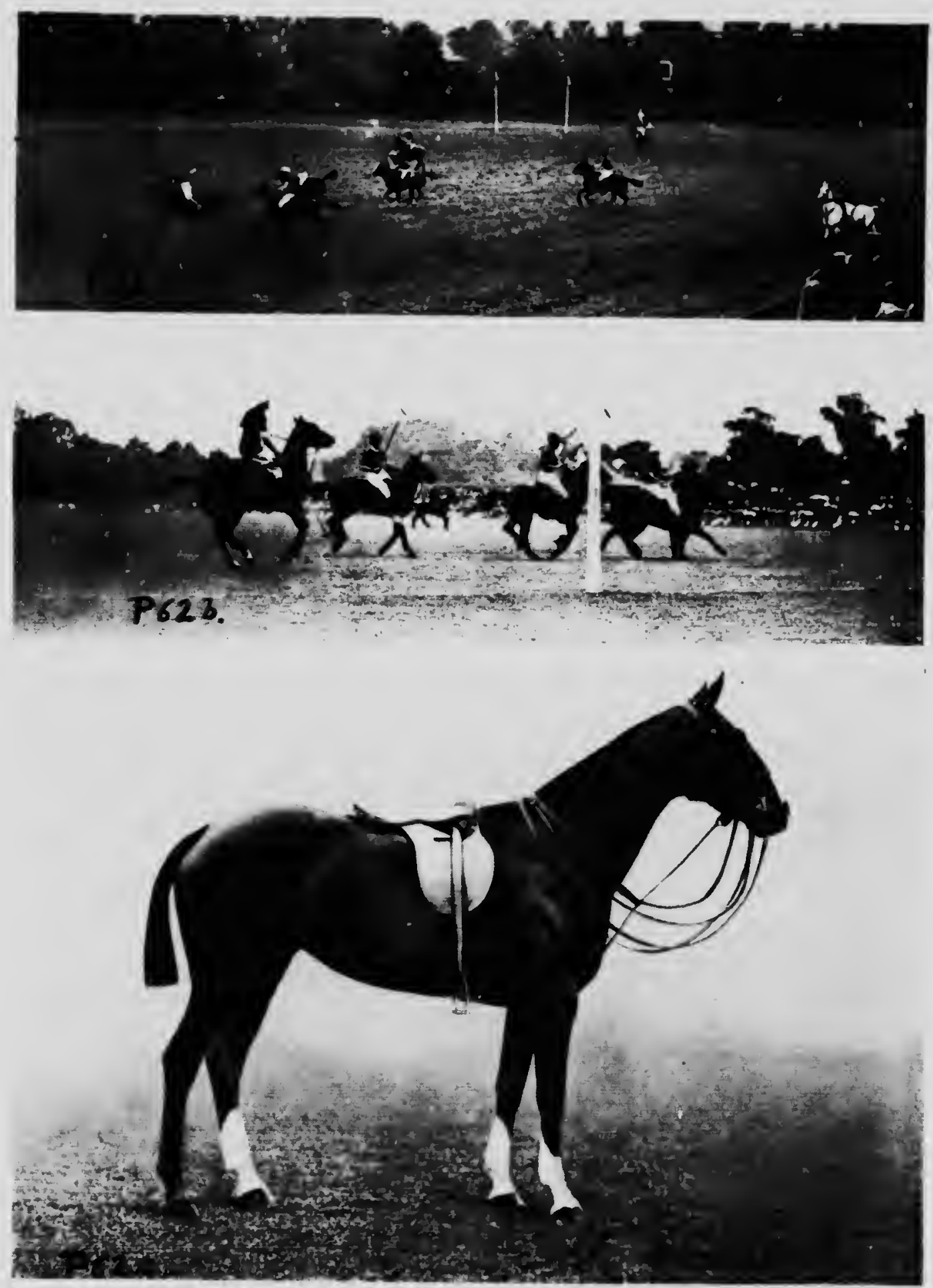

THE MODERN POLO PONY

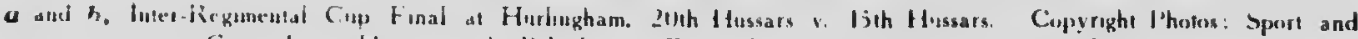
Gencral. c. Heaw weight l'olo l'ony "Energy." Copyraglat I'holo: W. A. Retich 
itself in its right position. Using stirrup leathers of unequal length causes saddles to wear unevenly, the stuffing to wear unevenly, the saddle to rock, and the numnah or blanket to work crooked.

318. Girths. - Girths are made of leather, webbing, cord, raw hide, twisted wool, hemp, etc. The webbing girth is commonly used on hunting saddles, and, if kept soft, is very suitable. But the leather girth, used on military saddles, is better for hard work, is stronger and lasts much longer, and, if kept clean and soft by being well dubbed or greased, will cause very little trouble. It should have slits made in it longitudinally so as to allow for ventilation and to prevent slipping.

A girth should not be attached to only one place on the side-bar, but to each end, and this is done by a $V$-shaped attachment extending from each end and joining the girth nearer the front end, thus causing the girth to have an uneven pull on to the whole length of the sidebar and preventing rocking or dipping in of one end of the saddle.

The side-bar and the two sides of the $V$ attachment form a triangle of which the sidebar is the base. The side of the triangle nearest to the shoulder is thus shorter and more vertical than the posterior side. Thus the apex of the triangle is not below the centre of the sidebar, but about one-third from the front. The girth is prevented from slipping forward on to the play of the shoulder by the shape of the horse's chest, particularly at the under surface of the breast-bone (sternum). Some horses are peculiarly shaped, and an attachment has to be put on to keep the girth back. This is best done by placing a surcingle around the belly over the fans, not tightly, and then joining this to the girth by means of a small strap underneath the horse. The use of the crupper is the best way to keep a hunting saddle from slipping forward, but a crupper tends to rub the tail if used much. A horse that is very badly shaped for saddle work is better driven in harness. A flannel saddlo-cloth strapped on each side to the pannel or sweat-fiap is well suited for use with hunting saddles, but must be well adjusted and kept quito clean.

319. Saddling-up. - The saddle must be placed in the middle of the horse's back, the front a hand's-breadth behind the play of the shoulder, the numnah or blanket being well raised into the arch of the saddle by being forced up with the forearm. The girths must be tightened gradually, and should only be tight enough to keep the saddle in place. The better the seat the rider has, and the more evenly he rides, the looser will he be able to have his girths. With bad, crooked riders the girths need to be tight. The surcingle must lie flat over and not be tighter than the girth.
Breast-plates are very seldom used now, but, if used, must be fitted so that the upper edge of the rosetle is the breadth of three fingers above the sharp breast-bone (anterior end of sternum). It should admit the breadth of the hand between it and the flat of the shoulder and between it and the horse's chest. (For types of saddles, see P. 74 , etc.) Great care must be taken that the girth is well clear of the elbows.

390. Sore Backs: their Prevention and Cure. -Every sore on the horse's back is due to a definite cause, which should be and can be discovered and remedied, thus preventing further ill effects and allowing that which has already been produced to recover itself. Galls are caused either by friction or else by local arrest of the circulation, due to pressure. Grooms, etc., must be encouraged to show the first sign of a sore, and severely punished for hiding anything. The old procedure of punishing a man for causing a sore is the surest way to cause him to be deceitful. A man, if he causes a sore, must, of course, walk his horse and himself, not so much as a punishment, but for the horse's sake.

Bad riding is most certainly responsible for many sores: nevertheless, I maintain that if a saddle fits properly bad riding will not do much harm, as most saddle galls are from pressure and not friction. If a good horseman rides on a badly-fitting saddle, it is quito possible that no harm will result, but it is a risky procedure.

821. A racehorse should have as narrow girths as possible, and his girths should be as far forward as possible, so as not to check his breathing, but they must not interfere with his elbows. If a rider begins to sit uneasily in a saddle or to move about, he had much better dismount for a mile or so. If he goes on until he galls the horse, then he will have to walk. A short walk will soon overcome the tired feel. ing or stifiness that some riders get after being in the saddle for a long time. It is generally the result of having an unnatural and forced seat. By getting off and walking, the rider is easing both horse and himself. Quitting the stirrups on a long march must not be allowed.

The importance of walking one's horse as much as possible, especially downhill and up steep hills, cannot be 100 strongly impressed upon horsemen. Bad-fitting saddles cause many galls; this is due to neglect in fltting the saddle. Bad saddling also causes many galls; this is due to neglect on the part of the groom. Such neglect may consist in allowing straps to get under the saddle or numnah, in numnah or saddle-cloth not being properly strapped to the saddle, in the sweat-fiaps or pannels being turned in at one corner, in the pack (if any) touching the horse, in creases in the saddle-cloth, or in the girth being too loose or surcingle too tight-causing a crease in the girth undernesth.

As pressure causes local death, it is clear that 
the better the condition the hurse is in (the harder his muscles and the better his general health) the better will he be able to resist being galled. For this reason we see so many appalling sores on old, ill-fed horses. Horses in poor condition or in soft condition are liable to be galled very easily. The fantails of the colonial saddle are, unless well ftted, very liable to rub the loins when ridden by a poor horseman. (See P. 74g.)

322. Reme'dy.-In looking for a remedy when a horse has been galled the cause must be sought for and immediately removed. For instanct, if the witliers are being pinched, the stuffing or blanket over that part must be reduced in thickness, or perhaps the saddle raised higher by an extra blanket, etc. If the spine is being rubbed or pressed upon, the numnah must be strapped or forced higher into the arch, or a thicker padding put ulider the side-bars. Injuries from burrs or fans can be eased by folding the blanket shorter or thicker, or by increasing the stuffing and raising these parts farther off the back.

Injuries from the inner edge of the side-bar can be eased by using a wider tree; injuries due to the outer edge of the side-bar pressing into the back can be relieved by padding the inner edge with strips of felt or by increasing the thickness of the blanket, etc.: injuries due to uneven pressure can be cured by readjusting the side-bars or the stuffing in the pannels, or by increasing the thickness of the blanket.

Girth galls are generally due to the girth working forward, and are commonest under tlie breast-bone. The advantage of raw hide or string girths, and leather girths with splits in them, is that they do not tend to shift forward. The girth must be properly adjusted and tight enough to prevent slipping. Some horses blow themselves out, so this must be guarded against by waiting until the horse is tired of holding his breath and expires a long breath, when the girth should be tightened sufficiently. On no account must the girth be done up too tightly. A horse with round, wide ribs and with elbows close to the sides is a difficult horse on which to prevent the girth from working forward. On such a horse the girths must be attached farther back on the saddle, or the use of a surcingle over the rear of the saddle, as explained in Sec. 318, may be resorted to.

323. Cure of Galls. - When an injury is discovered on the horse, the exact spot on the saddlery that causes the same must be ascertained. This is best done by placing a little white powder on the sore, then placing the saddle on the horse in its correct position, and allowing the rider to sit in the saddle. On removing the saddle the spot will be clearly shown by the white mark left on the saddlery. Having discovered the cause, it must be removed. If none of the above remedies will effect a cure, it may be necessary to cut a hole in the numnah round the gall, or remove the stufing over and around the gall, sewing a ring around to keep the pannel at this spot empty. After the gall has haaled, the stufing may be put back or the numnah piece sewn into the hole. It is better to keep old numuahs for this purpose, as any stitches in a numnah will lend to cause a gall if the horse is in bad condition. The best cure for sore backs is rest.

If the sore is not broken, it should be fomented every four hours with cold water, and an astringent applied, such as a strong solution of common salt, or Professor Dick's white lotion, which consists of $1 \mathrm{oz}$. each of lead acetate and zinc sulpliate, in a quart of water. If it is broken, it must be kept thoroughly aseptic with creolin, etc., and bathed every four to six hours with white lotion.

The following gall ointment is most excellent for all kinds of harness and saddle galls, and may be applied morning and night after the wound has been made aseptic:

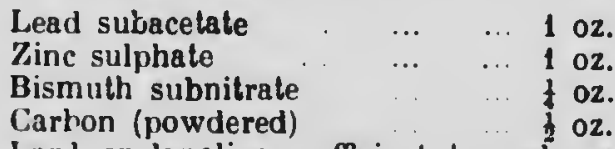

Lard or lanoline, sufficient to make a paste.

Good gall ointments of various kinds are procurable on the market.

324. Seats. - A great deal of nonsense is written and spoken about different seats, some saying that the military varies from the hunting seat, elc. There is only one seat, and that is when the rider is sitting over the centre of gravity in a perfectly balanced position, so that, in whatever position the horse may get, the rider is still in perfect harmony with the horse without using the reins or legs below the knee to maintain his balance. P. 58 shows the seat which is acknowledged by the best modern authorities to be the only correct one. C. course, a certain latitude must be allowed, as the physical formation of two men is not the same. Unfortunately, very few riders can or ever will have a really good seat. A good seat and good balance are rare gifts, and there is one other rare qualification that good horseman must possess, and that is good hands. The latter cannol exist without the former, and if one possess a good seat and good balance one is pretty certain to possess fair hands as well.

325. For hunting, military riding, or any other id of riding except flat racing and broncho-busting, the correct hunting seat is essential if the rider wishes to become an expert at his art. But it is necessary that the rider does not ride with his stirrups too short or too long, for in the former case he will be greatly handicapped in using his weapons in war, and 

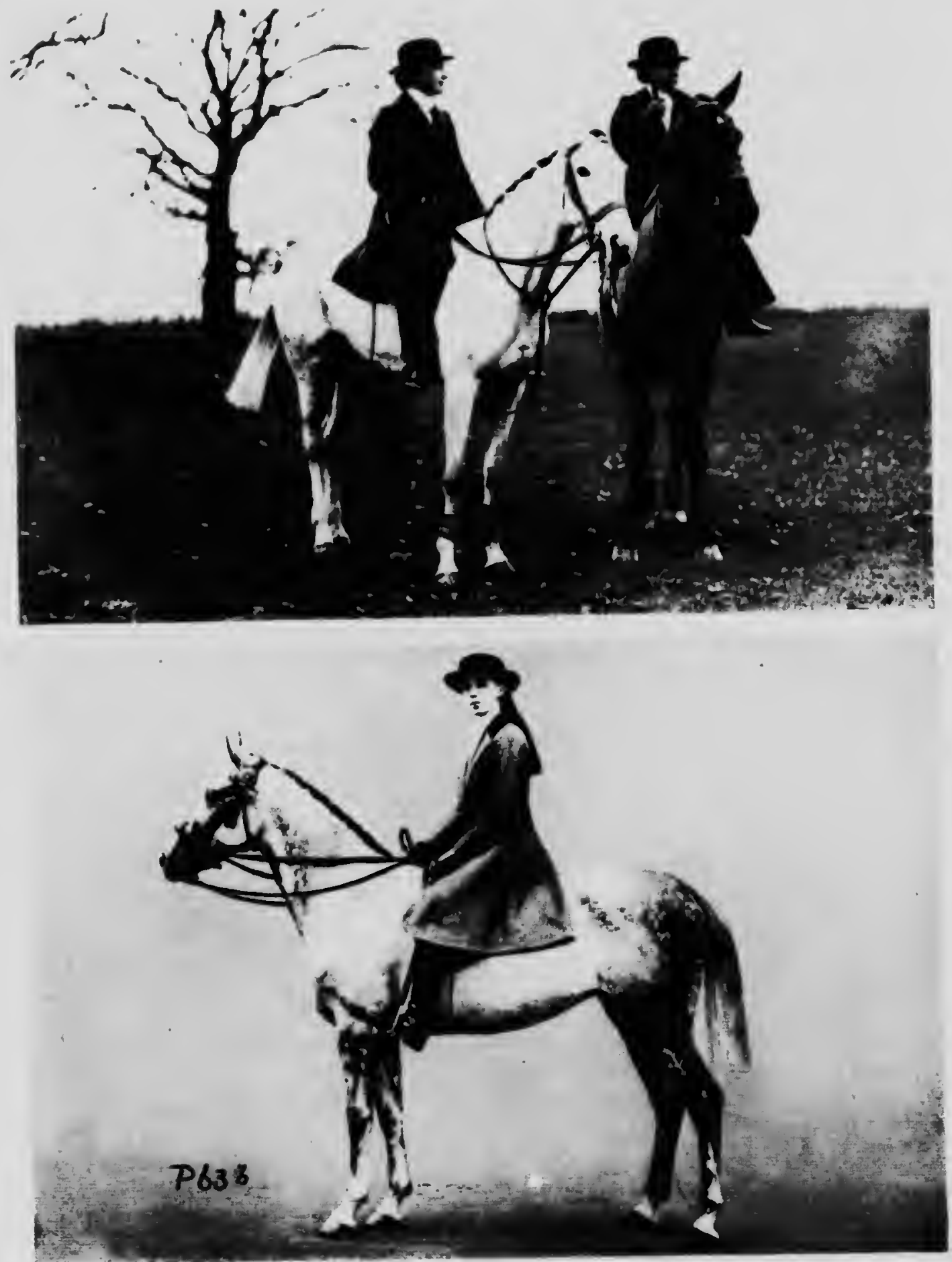

THE LADY ASTRIDE SADDLE

a. Mer: of Lazd Rothachild': Stughounds. Coppright Photo: Sport and General. b, An International Horse Show Champion: Miss Preece on "Silver Grey." Copyright Photo: W. A. Rouch 
PI..TI: 64
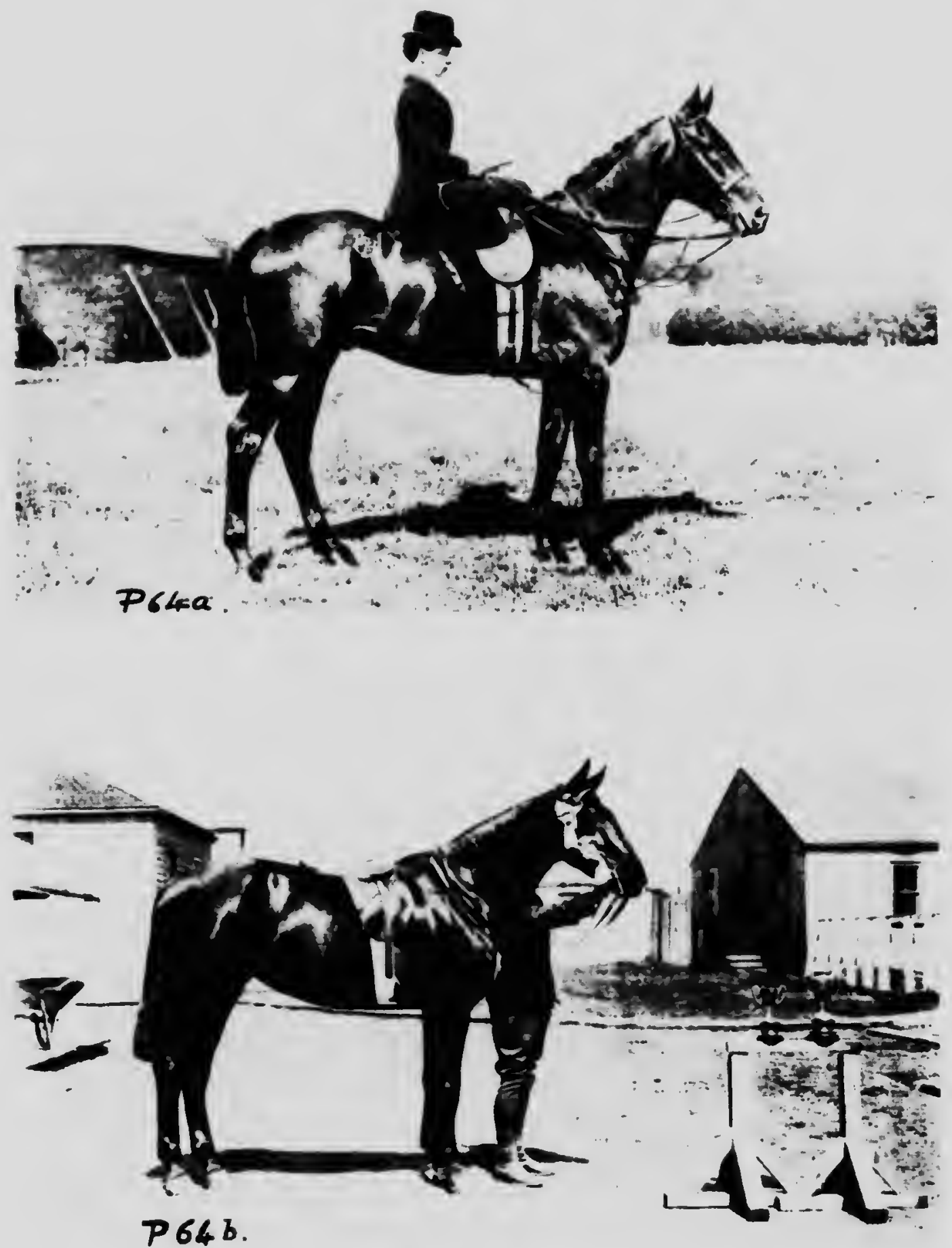

HI NTHES

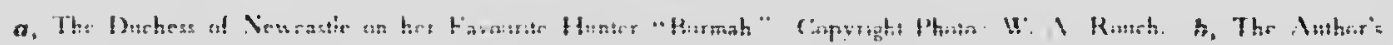
"I ady I cctoria." Photu: Muther 
PI.ATI: 65

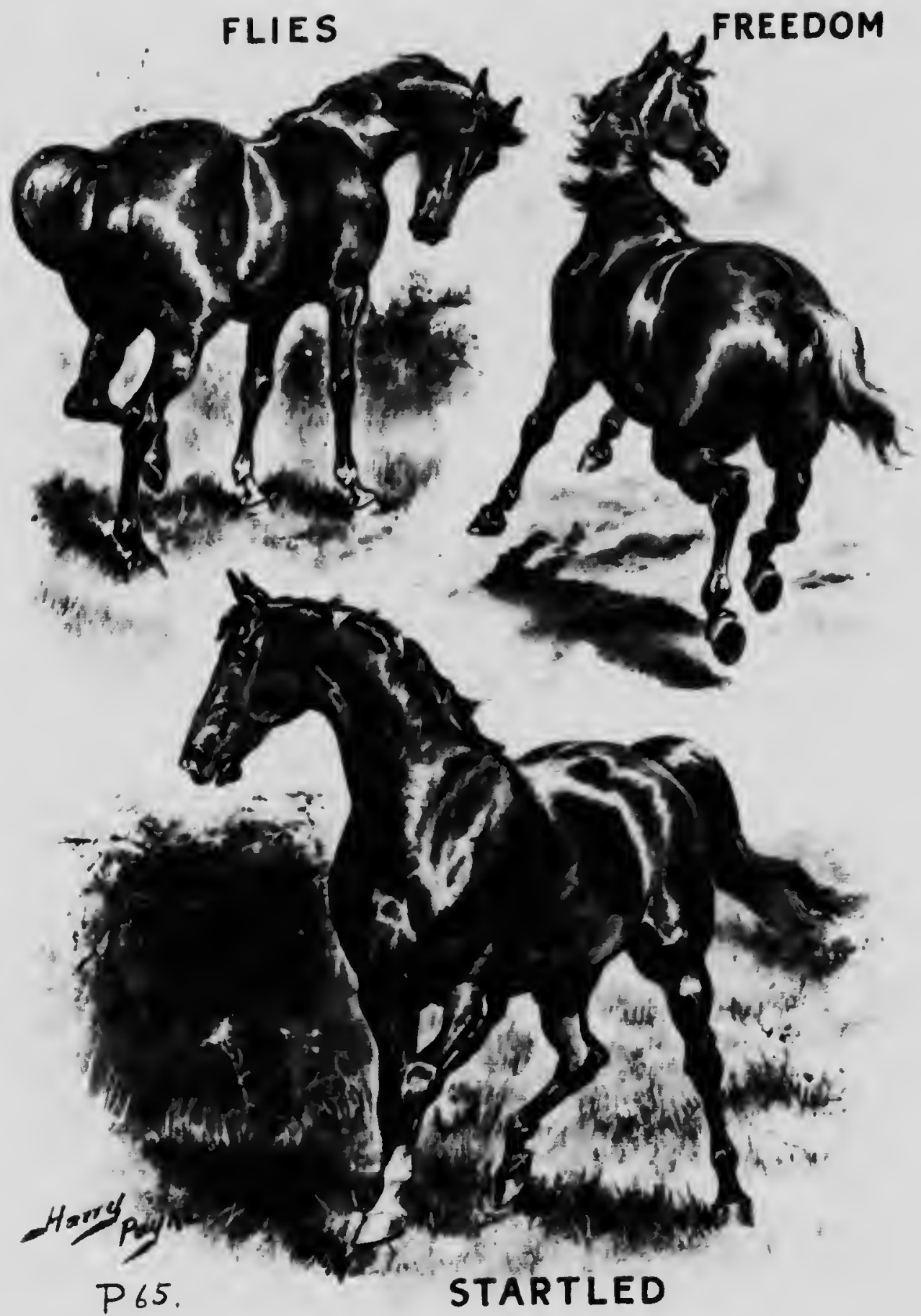

. Flies-Freedom-Startled." Drawn Specially by the Well.known Horse Artist, Mr. Ilarry Payne 
PIII: $x_{0}$
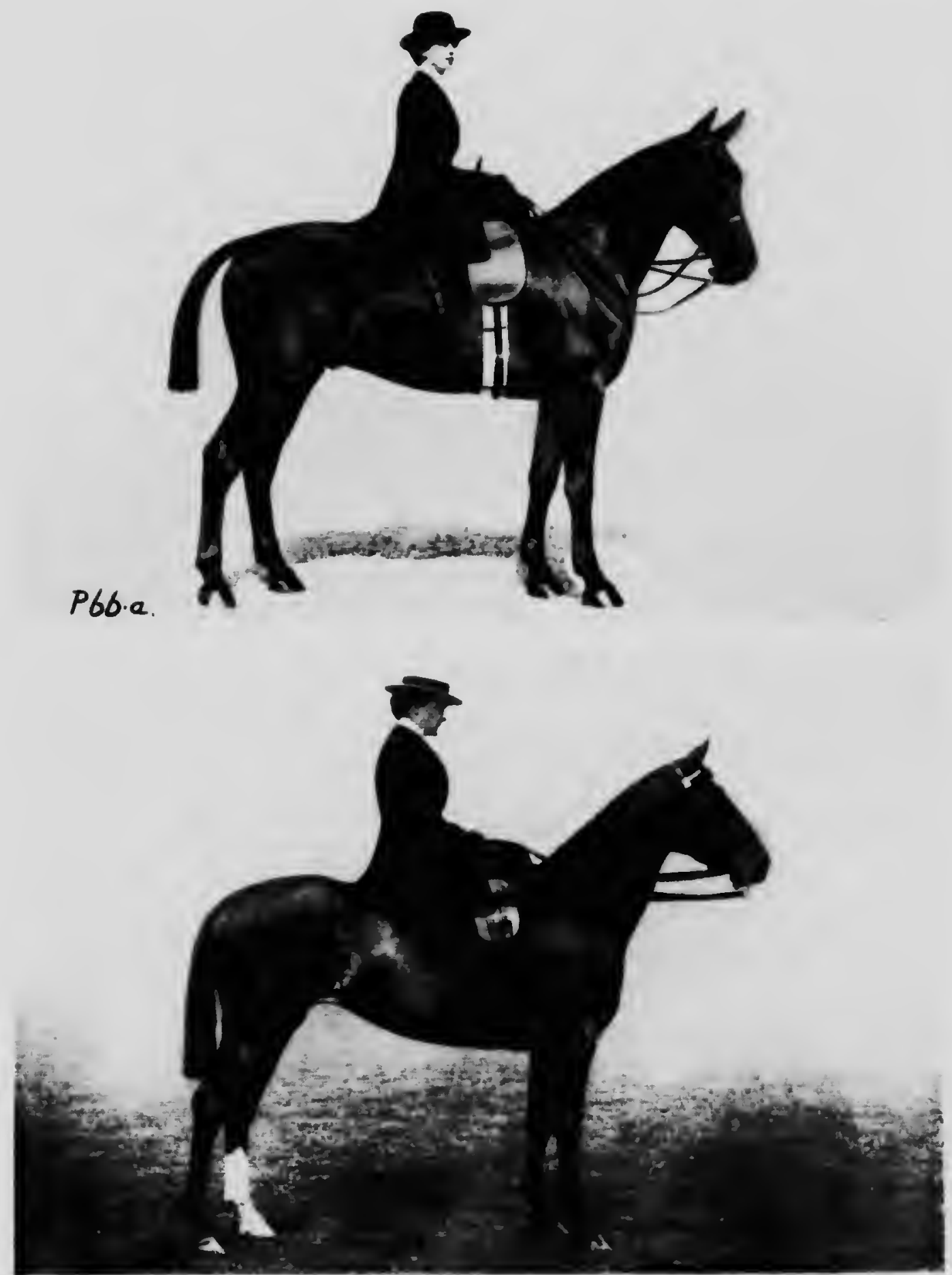

THE SIDE SADDI.E.

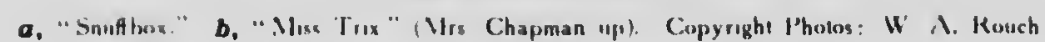


in the latter he will be greatly handicapped in riding across country. For this reason the seat of the military saddle should be made much longer and the arches lower. With a short seal the rider has to lengthen lis leg too much: but the straighter the leg the rounder becomes the inside of the thigh, which should be flat to give the rider the proper position and grip. The grip extends from the top of the leg to the knee, the whole lengtl of the thlgh. The calf is only usell when giving an indication, called by some an "aid," to the horse, or in an emergency, verhaps. The leg must at all times be frec to pivot at the knee to the front or rear, and this is not possible if the rider is holding on by the calf. He should be able to move his leg below the knee almost to any extent without in any way moving any portiou of his body above the knee.

826. If one goes across country bareback, as I often used to for a morning's breeze, one does not sit forward with a straight leg, nor sit with the knees right up on the withers, but assumes, or very soon assumes, a position as in P. 58, becanse this is the only natural and correct seat whether in a saddle or bareback.

The calf should be a little behind the per. pendicular, so that the ball of the foot is approximately below the knee; the legs must not be stuck out like shafts, because in this position the rider can never obtain balance. No weight should be borne on the stirrups; the rider's weight should be transmitted to the seat of the saddle by the thighs and the buttocks, similar to sitting in a chair. The rider must not lean forward, except when in fast motion or when rising in the stirrups, when the science of mechanics tells us that it is necessary to assist a horse. The arms must be kept low, and the horse ridden with a comparatively long reill, especially when going at a jump.

The body itself, when a horse is cantering, remains practically vertical, and when going at a jump it should still remain so. While on top of the jump, and when landing on the other side, the body still remains vertical. Leaning hack as the horse rises at the jump is the surest way to be jerked off. If anything, a man will assist his balance by leaning slightly forward as the horse rises, but he must keep his seat well against the saddle. Leaning forward too much will throw too much weight on the horse's fore hant.

397. A rider must not lean back when landing over a jump. If a horse is going at fast speed, the rider remains ahead of the vertical all the way over the jump; were he to lean back he would reduce the horse's speed considerably when the horse landed, owing to the increased moment of inertia that the horse would have to overcome before he couid regain his former speed. A flat-race jockey adopts a different seat, but such a rider cannot really "ride" his horso except so far as he can control the speed and direction of his mount. He throws his welght forward because thereby, mechanics and practice tell us, the speed of the horse is greatly ill. creased. So the bronchobuster sits in an armchair type of saddle, known as the stock saddle (P. 74h), several inches above his horse, not with the ides of riding the horse, but with the idea of keeping on his back until he stops buck. ing. For this purpose, and for long journeys at the trot or canter, the stock saddle cannot be besten. I have spent some long journeys and some lively moments in s stock saddle, and know what little use a hunting saddle would be in Montana, Alberta, and other ranching countries.

328. I repeat again, that in order to ride a liorse a man must have a sadule that allows his seat to be as close to the horse as possible, and that also enables him to sit on his seat gripping with his thighs and knees only, allowing free motion to the lower part of his legs, and permitting him to sit at the centre of balance. The hunting saddle is the only one that will allow this. (See P. 74e.)

The only way to obtain good balance and a good seat, apart from the natural gift that Nature has bestowed upon us, is to ride without reins and without stirrups for a considerablo time. Perfect balance while jumping will readily bo obtained by boing laught to jump without reins. I have lound with various pupils to whom I have taught riding and jumping, that the progress made by lorbidding the use of reins, once confidence has been gained, until the rider can go over \& fairly stifi jump with hands folded without in any way losing his seat, is far and away more rapid than the old method of allowing the rider to ruin his own hands and spoil his horse's mouth by using reins; and, of course, by the former method hands are improved, balance is rapidly obtained and kept, and the horse's mouth is not only spared, but probsbly improved.

899. After confldence has once been gainedwhich, by the way, is an important point-I make my pupils give up reins and stirrups for. perliaps, as long as two or three months, and ride in a large school or enclosed manege. The reins can be left knotted on the horse's neck, so that in an emergency they can be taken up. By this method I have made many bad jumpers have a moderately good seat within a week, and such people have declared that their change has surprised them immensely. It is only common sense after all.

To allow a beginner or a recruil to jump a horse with reins is downright cruelty besides being very foolish, because it ruins the horse. it is cuss' to discore: horses that haye been ridden in this way by merely taking them once 
over a jump and finding the way they have of throwing uj) their heads as if they were expecting a jeitk on the mouth. This method of riding old liorses that will jump) any kind of jump witl a rider holding on to their nuouths is all right for men whose siats do not allow them to riele otherwise; it is quile rommon to see inen in the lututing field and other places relying on the reins to keep then un the horse's back, but these men are not schouling young lorses. Unfortunately, many riders never inıprove their liands, or their seat, or their general knowledge, because, for some unknown reasoli, they imagine they are perfect in these inatters and have nothing to learn, which is the last thing a good horseman would ever assert. A good horseman expects to learn somilling new every time he mounts a liorse.

If a horse gets jerked in the nouth when going over a jump, lie assoeiales the pain with the jumping and thinks he has done wrong, so the next time lie is asked to jump he refuses. (See Chapter III.) Allowing bill ricters to junip with reins is quite wrong, but allowing them the use of stirrups is nut so bail.

330. Hands. - "Hands" is the power the rirler or driver fossesses, through the medium of his hands, to communicate between himself and his horse.

Good liands are a valuable gift possessed by few. They can be improvel by practice, but, however bad a man's hands may be, if he has good balance he will be far easier upon his horse. A man with good balance and good hands landles his loorse's moutlı as if with silken threads, but not tastic. He has a gentle feeling upon the montis all the while, unless he is riding with a loose rein, and he uses his hands, together with his legs, as indicators to the sensitive animal machine underneath him. A rider with good hands is very soon able to "mouth" a young horse, and, until a horse has been pri serly mouthed (which consists really in sligliist hardening the bars), the horse's head cannot be properly placed. (Ser P. 68, 100.) This placing the lieal of a horse is necessary before the rest of his body can be balanced, and until a horse's body is properly balanced and collected he is not a safe horse, and cannot be trained to any high legree. When a horse is properly mouthed and made obedient, and has had his head and neck properly placed, he will arch lis head as the rider's legs are gently closed upon him, brir $7 g$ his haunches under him and relaxing lo. lower jaw, clamping at the bit. The rider will not make any action with his legs that he is not able to meet with his hands. I'nless a horse will do this, it cannot be called a properly mouthed horse. Mechanical contrivances will never mouth a horse properly; good hands and a good lemper are necessary. Vice versa, it must be remembered that "made" horses never made hands; that is to say, that every young rider should train a number of young lorses in order to improve his hands. The pleasure of riding a properly balanced horse with a gool moutli and that of riding the atcrage liorse one sees in the street cannot be conıpared.

The first-class rider uses lis legs as much as his hands to give indications to his horse. The common use of the leg is to kick the horse in the side or, even worse, to use sharp spurs. (See Secs. 330-7.)

331. A very erroneous idea, commonly held amougst young riders, is that the correct thing to do is to ride with one hand. As a rule, a leginner exposes want of knowledge by trying to ride with one hand. A far better test of good riding is to ride the horse properly with both hands. It is a common thing to see riders trying to train young horses with one liand, and the horse going wherever it likes. Riding with both hands is absolutely necessary for many months of the young horse's training; he can never be schooled $w_{1}$ ch one hand. Above all things, beginners must not sit stifly, but as naturally as possible. The correct seat can only be attained by months of practice; nine months is a fair minimum, as it lakes quite this time for the muscles to conform to their proper shape. The leg must be turned in from the hip joint, so that the inside of the thigh and knee lies fiat against the saddle; turning the toes in does no good unless the thigh is turned in too.

Before a horse is taken out on a ride his feet should be carefully examined to soe whether nails are protruding or the shoe is loose or has shifted. The rider should be careful to avoid riding over pieces of wood, as these often luave nails sticking out of them. A horse that is laught to lie down should not be asked to get up with a rider on his back, as this may strain his legs, especially the hocks.

332. Trealment of Refusers.-A horse that has been in incompetent hands may have acquired some objectionable habits. The principle of treatment in all cases is to associate in the lio's s's mind unpleasant sensations while he is displaying objectionable habits and pleasant ones directly he ceases (Chapler III.). Great patience and firmness are, of course, necessary. In the case of a horse refusing to jump, it is most probable that he has been hurt in one form or another while previously jumping. If he is, therefore, firmly made to jump without receiving any kind of pain or other unpleasant sensations, but given a tit-bit on arriving at the other side, he will soon like jumping. A great fault is allowing the horse too great a distance in front of the jump. Unless the jump is very high, he should be walked up quietly until "iree or four lengths from the obstacle, then quietly cantered up to it, and 

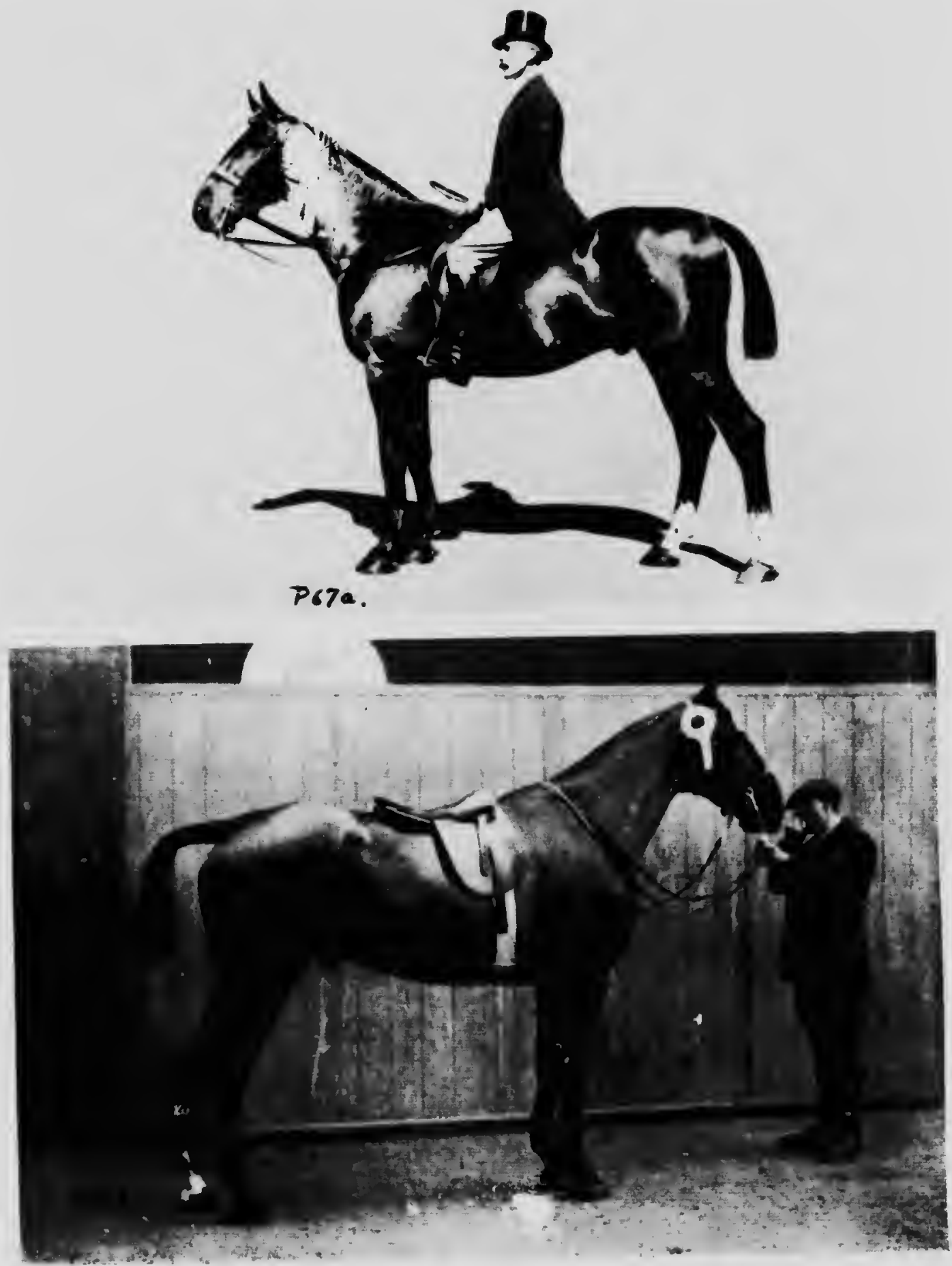

CIDMPION HLNTERS

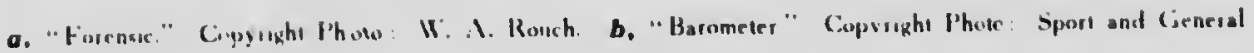


PI.1T1: 68
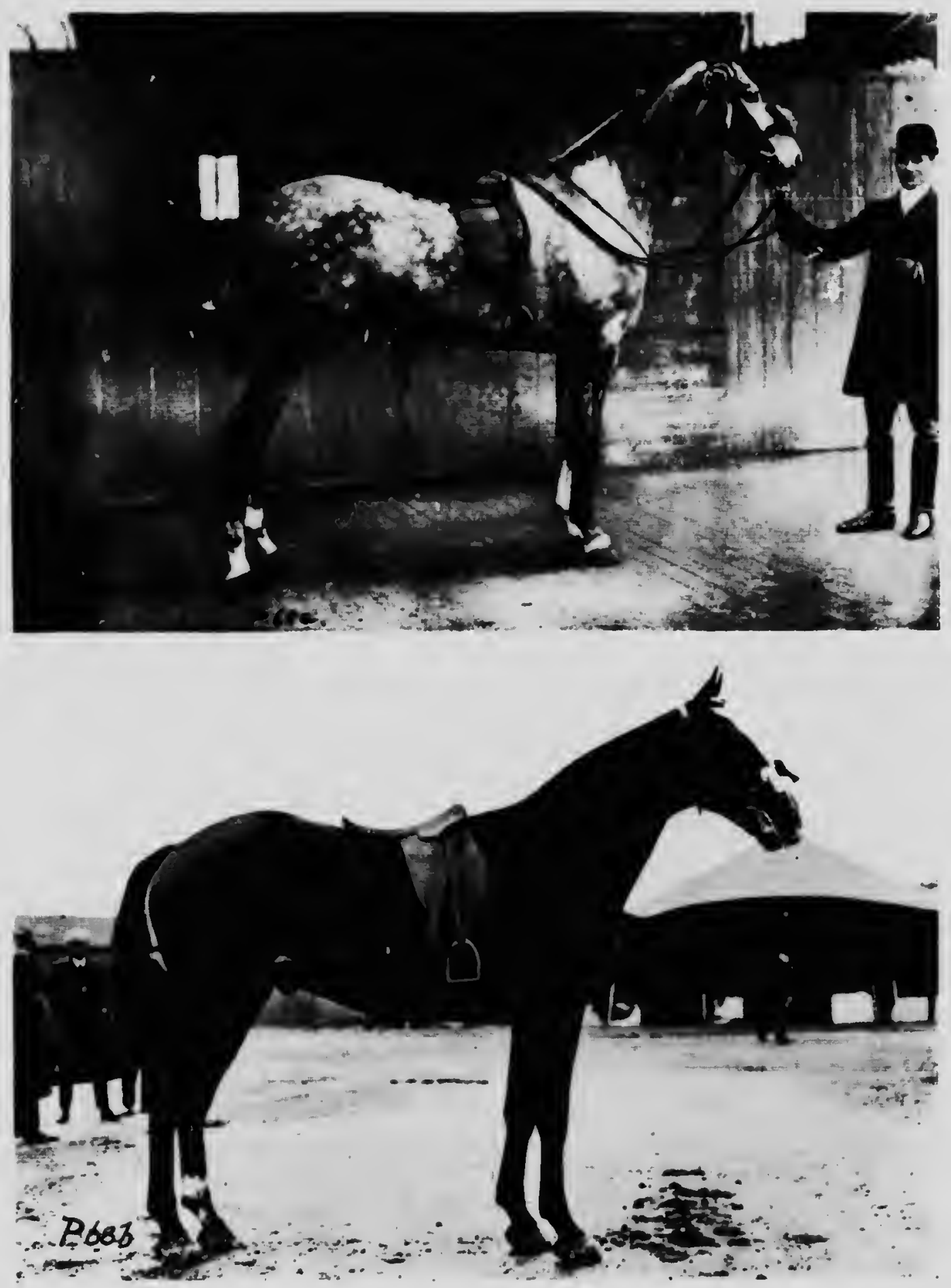

(HIUIION IIITTERS FNCIISH BRED

o. "Wutiarch" b, The Farl if henmare's "Busby," Coppyright Photos: Spott and Cieneral 
PI.ATE 69

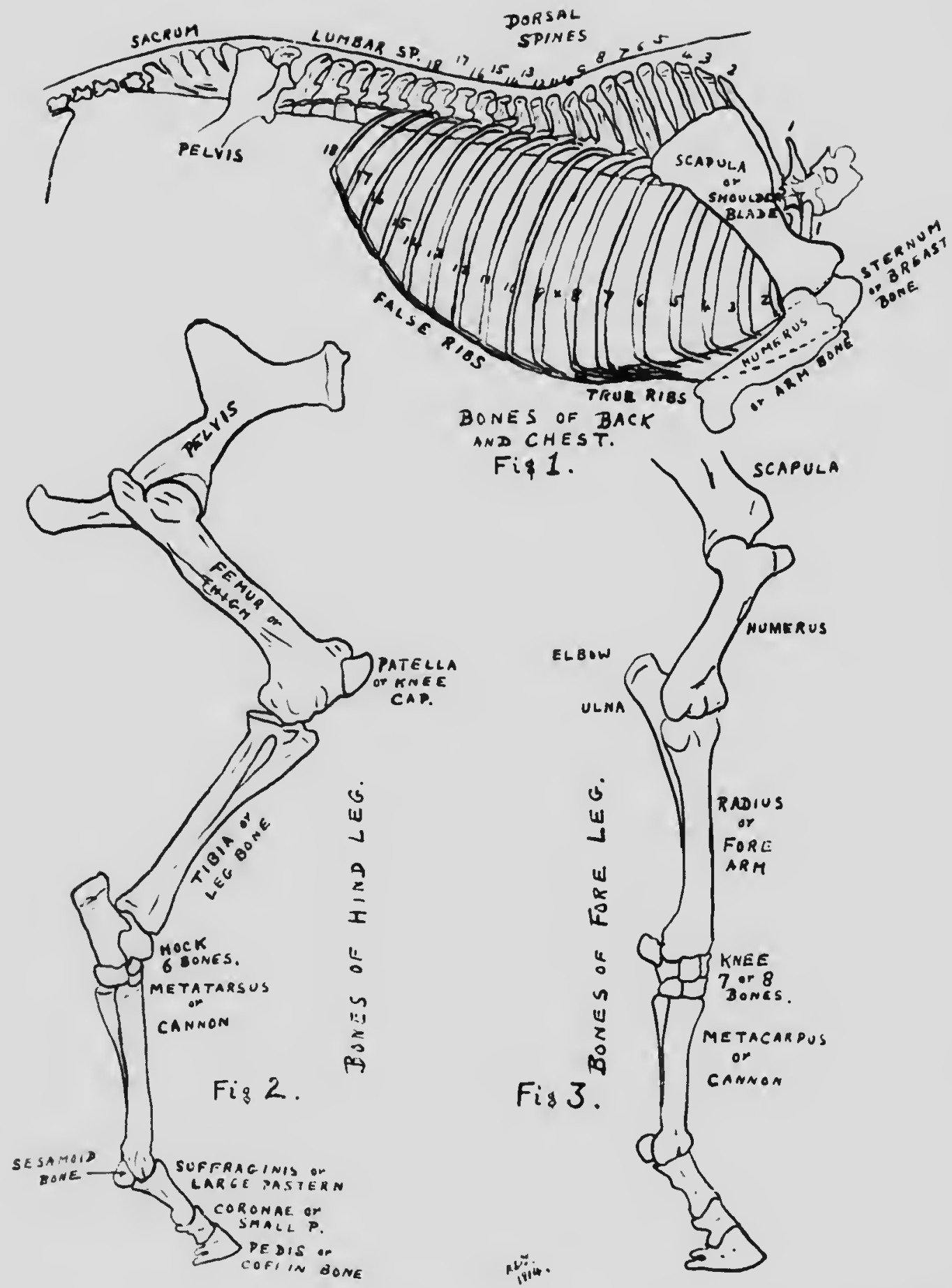

Sketches of the Bones of the Limbs and Back, showing the Part of the Ribs that Bears the Weight of the Saddle, and how this Space is Limited in Front by the Scapula, and Behind by the Loins 
PI.ITI: 70
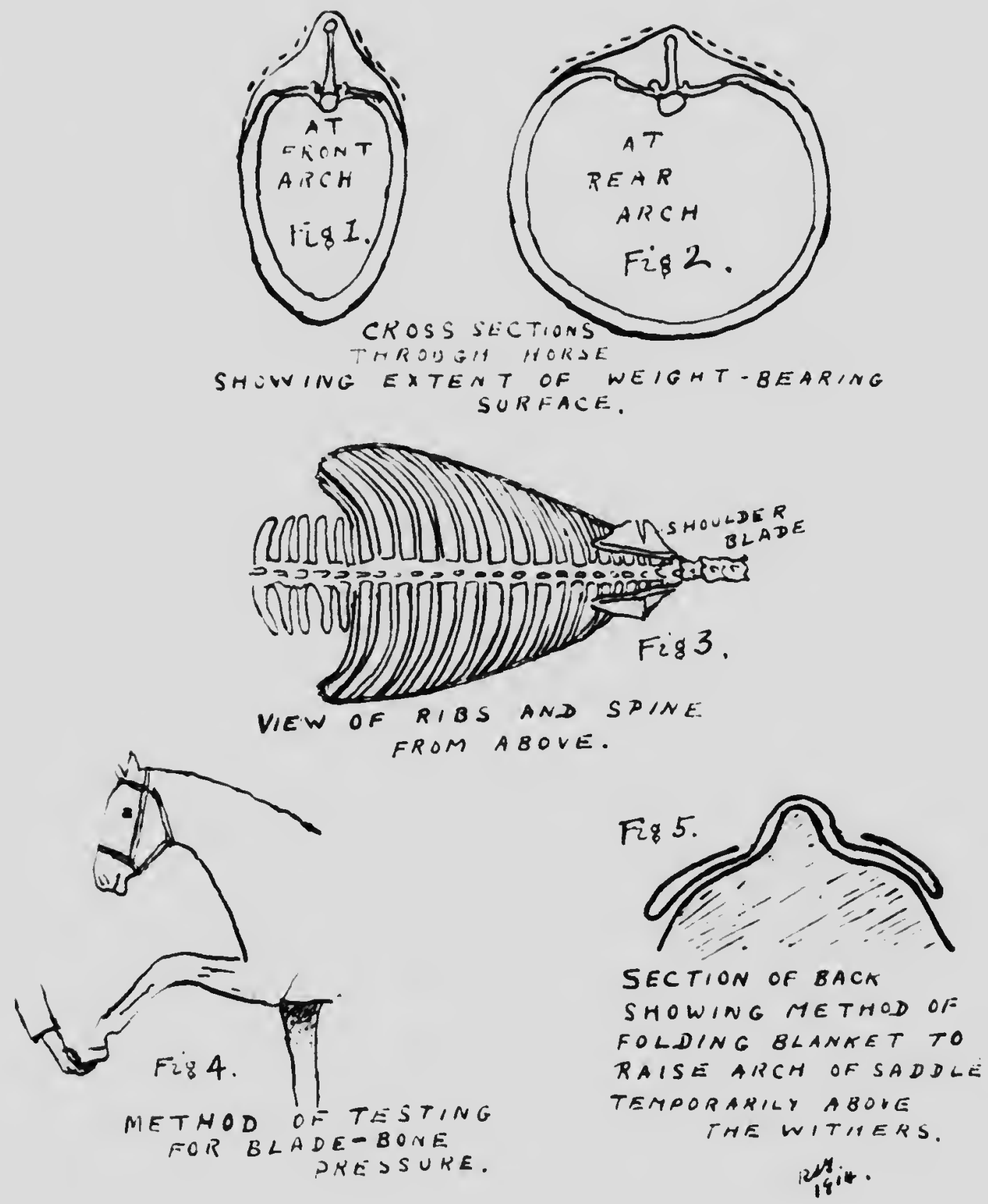

Diagrams showing huw the Surface under the Saddle becomes more Horizontal as 11 pastes Back. necessitating a Twist in the Side-bars of the Saddle-tree 
given his head, so as to allow him plenty of time to take off, the legs being used as required, but on no account should he be whipped or spurred. Such punishment is only necessary when it is quite clear that the horse is deliberately disobeying.

353. When a horse rears up, the rider must immediately give him lis head by letting out the reins. He should try to throw his weight on to the horse's neck, and should be prepared to slip of should the horse come over backwards. The horse should, if possible, be kept moving forwards by, perhaps, being hit over the quarters. On no account must he be hit over the head or neck. I have cured many a bad rearer by laking it on to a sandy beach and slipping of quickly while it was up in the air and gently pulling the reins, thus bringing the horse over backwards. This so frightens the horse, without doing him any injury, that he, as a rule, does not wish to have the experiment repeated.

834. Riders should be very careful when riding over wooden bridges to ascertain that the planking is perfectly safe; many floors of such bridges become so rotten that one is scarcely given a warning before the horse's foot goes through. A one-inch plank is not safe for a horse to walk upon; two-inch planking is the minimum that should be allowed on the bridge, and this should be renewed at least once a year. The safest plen is to have the two-inch bourding covered with a one-inch plank, this latter being replaced when at all worn.

The practice of linking horses, which consists in tying them together side by side by means of the reins-that is, by tying the reins of one horse to the head-gear of the horse next to him-unless done properly, is extremely dangerous. I have known horses to have their jows almost broken by the reins from their bits being tied to the hurse on one side and the reins from the horse on the other side being tied to their nosebands, thus tending to break the jaw, through the horses on both sides pulling at the same time. Clearly the only way to link horses is either to attach the reins from bit to bit-i.e. from the right side of one bit to the left side of the next-or to use the head-ropes attached from nooeband to noseband at the ring at the back (the jowl-ring).

835. The subject of eye fringes is discussed in Chapter XII. P. 104d shows the eye fringe commonly used on bridles. These are eopecially useful for horses with hogged manes.

In the fly season riding is made far more pleasant by using a fly whisk, as shown in P. 104d, as this saves the horse from throwing his head about while endeavouring to reach flies.

When mounting a horse that will not stand still, or one that tries to buck, it is a good plan to take :-id of the headstall with the bridle hand, and hold on to it until one is properly seated in the saddle.

Great ignorance is often displayed by those who lead at the head of a column by their riding at a great speed, with no consideration for those behind them. Such practices are the cause of much distress amongst both horses and riders.

336. Spurs.-A great many of those who ride with sharp spurs should not be allowed to use them at all. If horses are properly trained they would not require sharp spurs-at least, not one in ten thousand would. As a punishment a whip is always far superior to a spur. The whip is more humane, and can be applied in the correct place, which is behind the place where the spur is usually used, and has not the frightening effect that the spur often has. A spur as a means of inflicting punishment, if sharp, is a barbarous instrument, and it is horrible to see young recruits and would-be riders of all types digging their horse's flanks with sharp sfurs when probably the horse does not know what his ignorant rider requires of him. Such men should not be allowed spurs; if they were given a whip they might do more good, or, at any rate, they would do less harm to the horse. I cannot undergtand why riding instructors allow such things to go on. If people must use spurs to show that they ride or belong to the cavalry, the rowels should be filed off or cut out. Most spurs are sharp, and yet not one in a thousand horses requires their use. Some horses get used to being constantly spurred, and take no notice of it, but this is the result of shocking riding. By cutting of the sharp points or taking out the rowels, the rider shows greater knowledge -at any rate, in most cases.

Riding whips (cutting) should not be made of soft leather, but should be stifi, and lined with whalebone, not steel, and, if used as a punishment, must be used well behind the girth, but not under the belly and never over the hesd. The stiff whip can be used as an indicator when required.

887. Personally, I look upon the spur or whip as an indispensable indicator in training or riding a horse after a certain stage has been resched, and only as a means of inflicting punishment in rare cases when the equine pupil is wilfully disobedient. For this reason I always use spurs without rowels. With these spurs one can play on the horse's flank with a touch similar to that of the finger on a piano key. These touches vary according to what is required; the position of the louch varies from far back on the loins to as far forward as the shoulder in rare cases. Were I to use a sharp spur I should expect the horse to give a sudden movement that would be quite beyond the control of my hands; that is to say, by my own ignorance I should place my horse temporarily 
beyond my control, i.t. out of hand. There is nothing gained by using sharp spurs if the same result can be obtained witl blunt ones. This is the case with most old horses, but with young ones the results that could be ubtained with sharp spurs are really not worth anything. If the horse requires punishing, then I use the spur or whip as an instrument of reproof; but directly he is obedient I caress him, and contimue to use the spur or whip as an indicator. The whip is used as an extra indicator on one side or the other while training horses, hence it must be rigitl. This indicator is of the utmost service to ladies using the side saldle, as it takes the place of the right leg.

An objection to the present abuse of this valuable indicator, the spur, was brought home to me a sliort while ago when I overheard an ulservant lady say concerning me, "Oh, look liow he is spurring that poor horse!" As a multer of fact, I was riding a high-spırited horse who objected to pass a street car, and I was passaging lim past. I had no rowels to my spurs.

The word "indicator" as applied to liands and leys is better than the word "aid," because the latter rather implies the application of physical help, which, generally speaking, the hands and legs do not and cannot apply. If one dismounts and by mere force pushes a horse over, then he applies an aid. Our hands and legs would have little effect on a lorse innless it acquiesced in the movements we ask him to perfurm.

338. On Ladies Riding Astride'-Ladies, as a rule, have better hanils than men, and for this reason they often manage horses, loth riding and driving, better than men. Ladies are often handicapped hy riding sirle-saddle. Custom and appearance cause many people strongly to condemn ladies riding astride; they say it is unbecoming, too manly, and so fortli. But in horse natters I think lummanity and common sense should stind ahead of fashion or "what llanl to be clone." It inay be unbecoming to some ladies, especially those who are corpulent, but my puint is, as stated above, that comfort, safety ancl humanity should staml first. Riding astride is not improper any more than cycling, and no laws of cummon propricty or etiquette can be laid down against riding astride for larlies. (Si'fe P. 63.)

Laying aside custom and appearance, we will look into the subject from a practical point of view. There are llıree important points: the comparative ease of properly learuing sidesaddle and astride-sadule riding, the harm to the rider that may result, and the harm to the horse that may result. Of tlie former, there is no loubt that astride-riding is more easily learnel. The number of ladies that ride really well on a side saddle is extremely small. Pro- fessor Savigear, my old instructor, was one of the strongest advocates of abolishing the side saddle, and he has been partly responsible for many ladies taking up riding astride. I had the pleasure of assisting him at Earl's Court in teaching some of his lady pupils to ride astride from the beginniug, amongst whom were many ladies of the nobility, and after comparing the results with those of teacling side saddle there is no doubt which is the easier, with few excep)tions, to become proficient at. Very few ladies sit square to the front, rise square to the front, and rise at the right time. The second point, that of damage to the rider; I have quite enougli proof of a number of ladies who have been seriously, or even permanently, injured in. termally and otherwise by bad side-saddle riding. I do not suggest for one moment that a graceful side-saddle rider will to herself or her horse any harm, far from it; but what I do emphasise is that these graceful riders are so few and far between. (See P. 77b.) It must be remembered that a seat cannot be judged while at rest alone; a bad rider may sit well at the halt.

339. A lady while riding side-saddle is handicapped in that, as a rule, she cannot mount or dismount as easily as a man can. If she is run away with, her life is in far greater danger. If she is a bad rider, she endangers herself every minute by tending to "upset" the liorst. She has no right leg to rely upon as an aid or indicator; at the best she can only have a stiff whip or stick.

Some state that a lady lias not the grip or the flat thigh that a man has, but we must remember that a great numhar of male riders have round thighs, so 1 do not think this plea carries any weight.

340. In the west of Canada and the Unitel States practically all womell ride astride. They would not be of any use if they rode sidesaddle.

My third point, which is more suitel to this book, is the terrible cruelty inflicted upon the horse by bad side-saddle riding. I wonder how many larlies I have ridden behind and watcherl the side uscillations of the saddle on the lorse's back, due to crooked rising, or to rising off the wrong leg of the horse. The lady should rise from the saddle as the horse's near leg comes to the ground; that is, she should sink into the sadule as the of leg comes on the ground. The sights that I have seen in hunting stables and livery stables, due to side saddles, have taught me quite enough to alvocale astride riding for all ladies except the few who are accomplished in the art of side-saddle riding. The number of sore hacks from such bal riding is simply appalling. The question is then brought up: How is a lady to know that she will never become a good side-saddle rider? This can 
PI.ATE 71

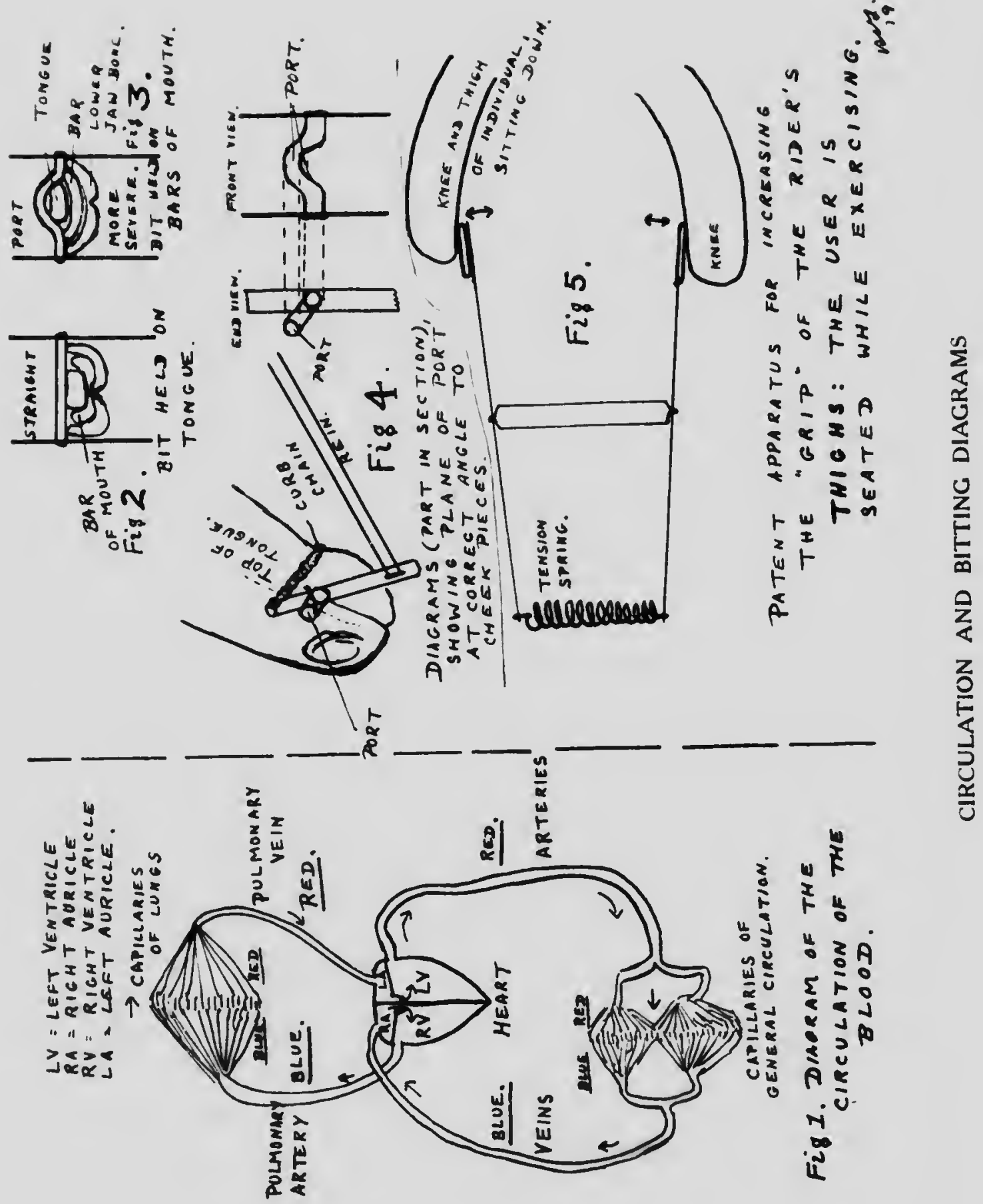


PIATl: i2
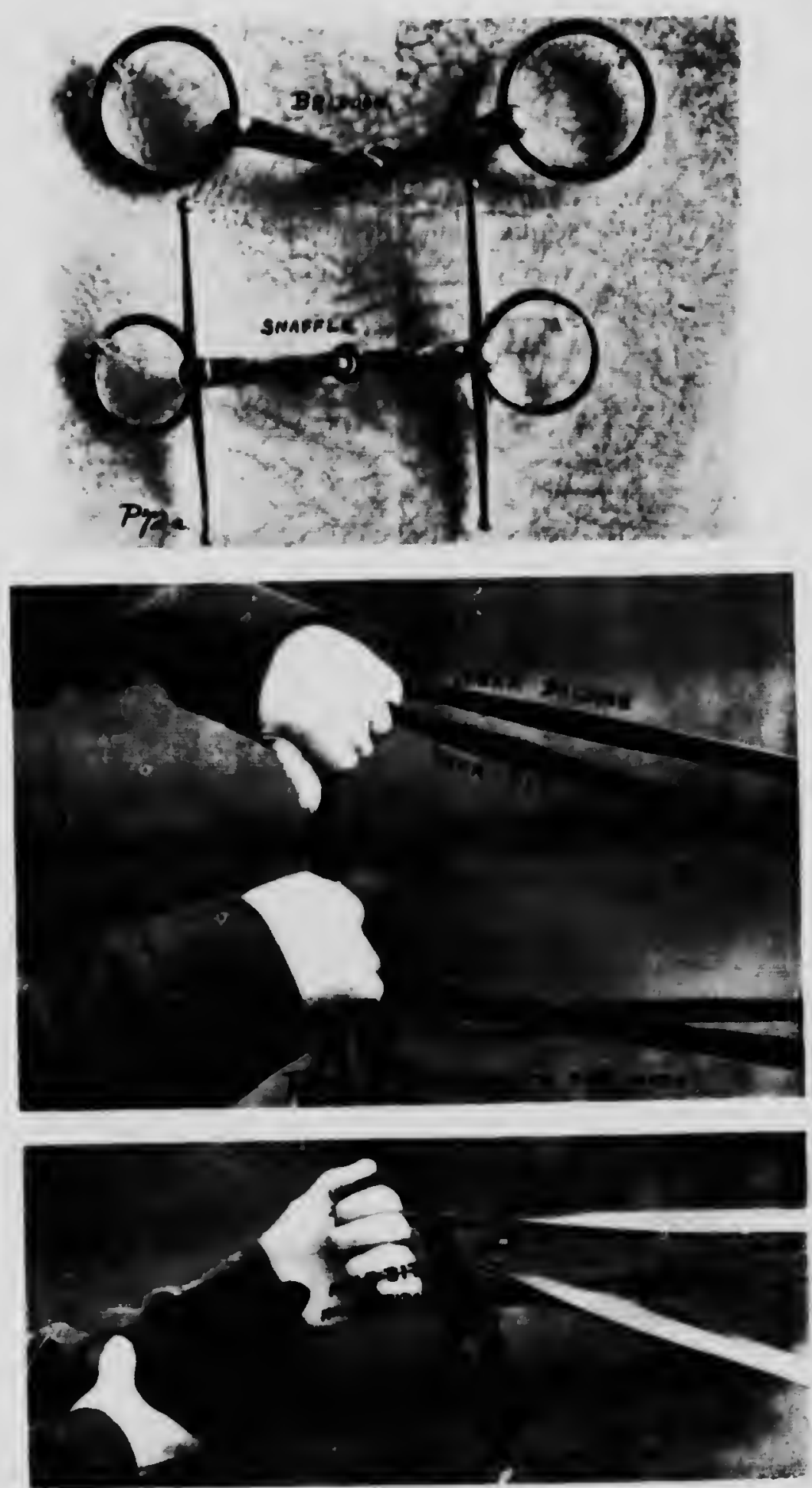

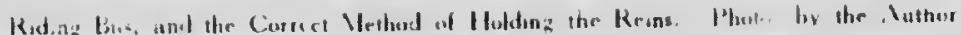



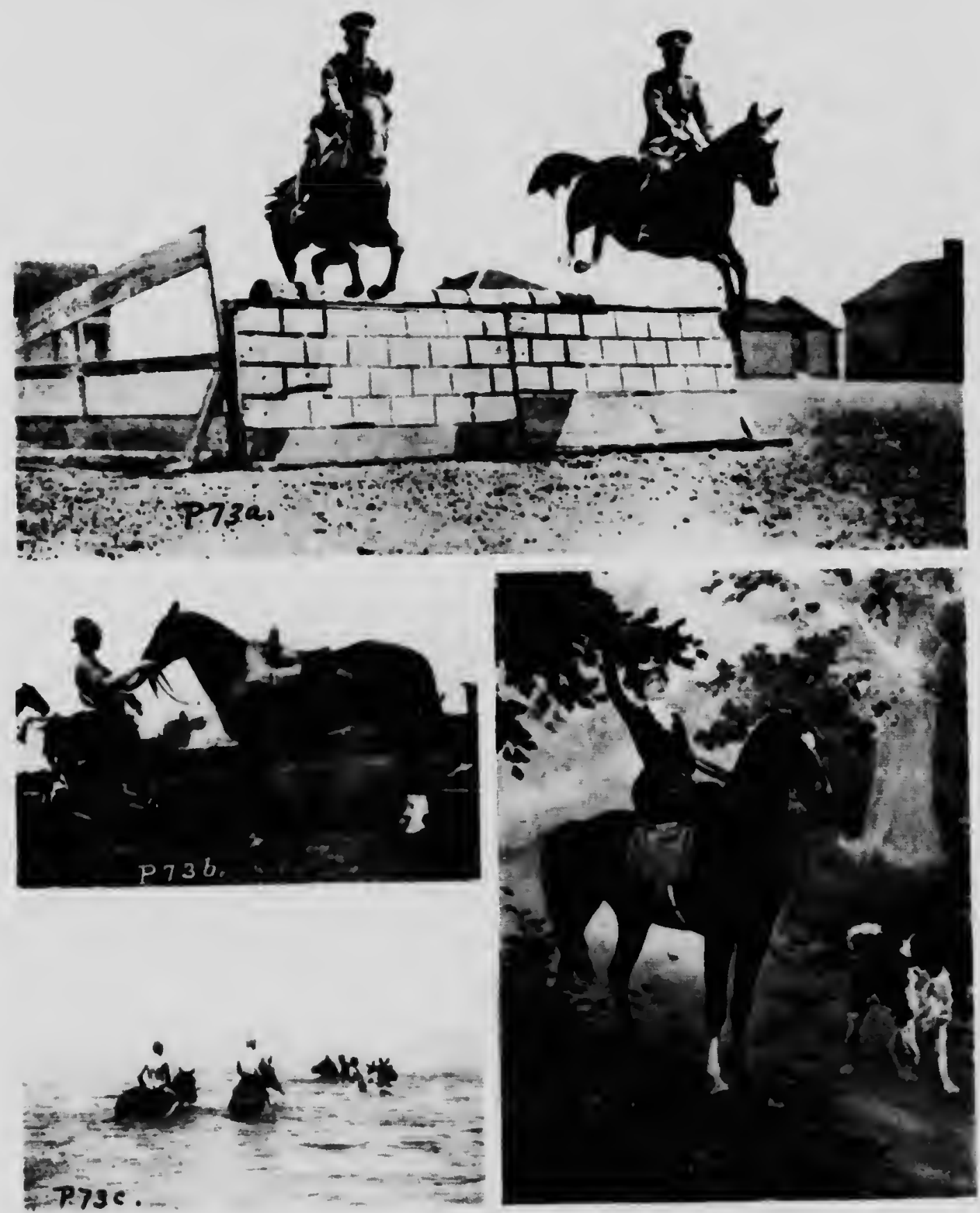

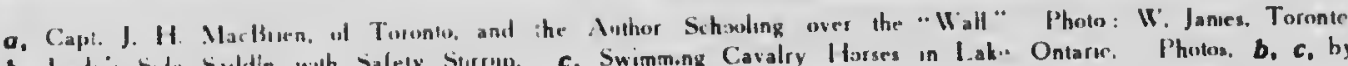

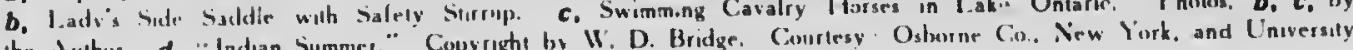
the Anthes. d, "Indan Summer." Copyroght by II. D. Bridge. Sork 
PI.All: it
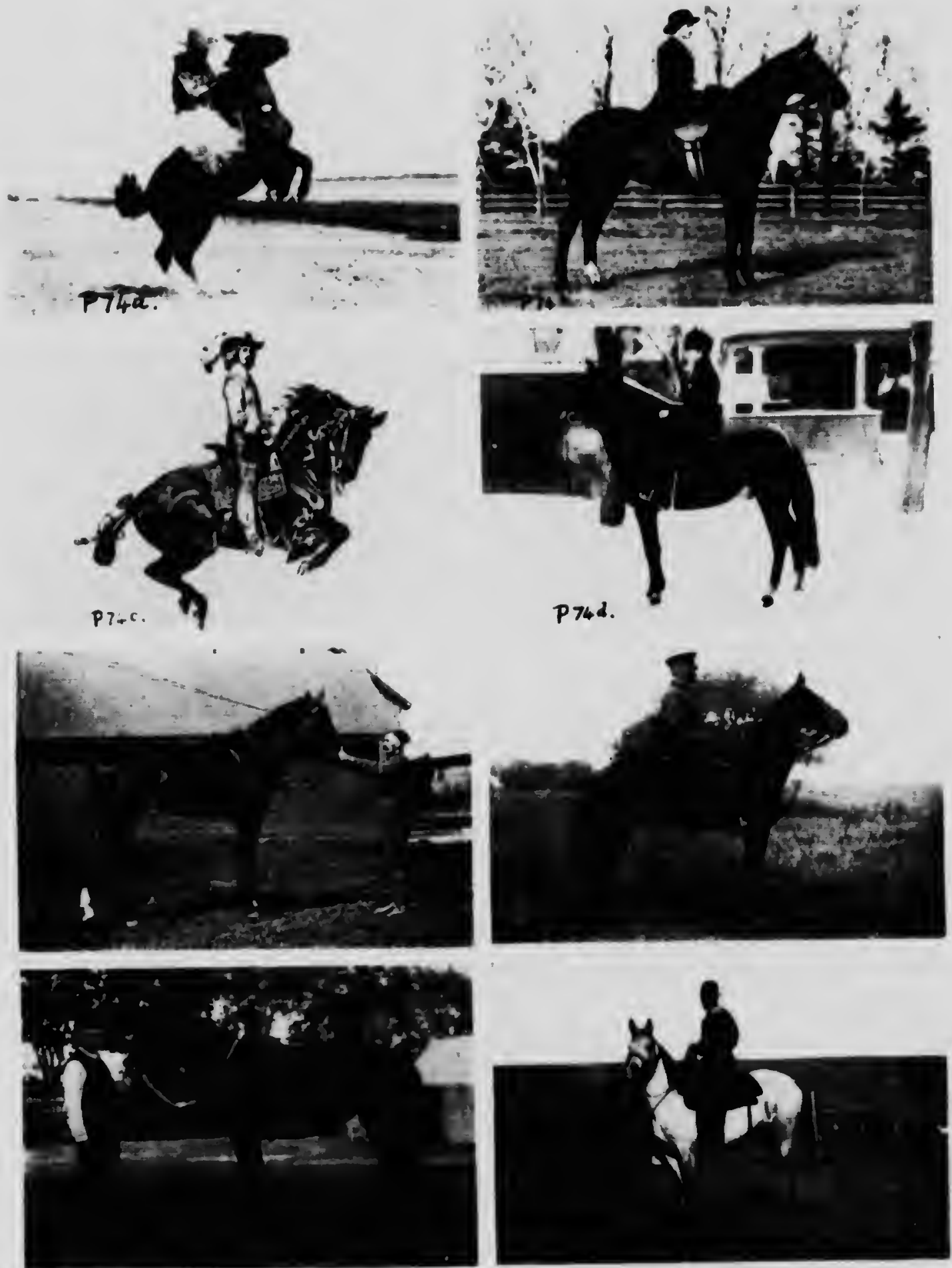

TYPES OF SADDLFS AND SADDLE HORSES

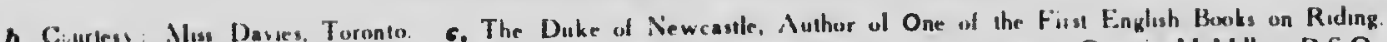

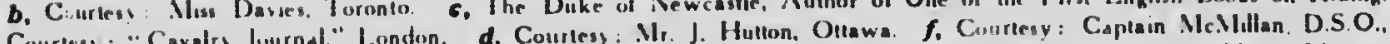

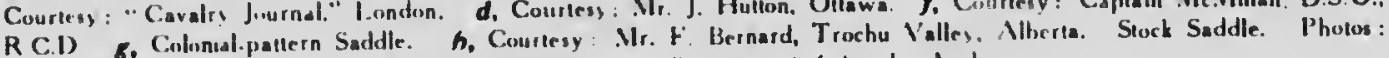

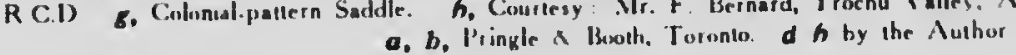


generally be answered by an expert instructor alter a lew weeks.

41. Paces. - The paces of the horse are various, and are generally little understood. The natural pace is the canler, which is a pace of three time. The trot has become getteral with the advancement of the horse's domestication. In the long rides carried on in Europe the horses that cuntered at the slow paces instead of trotting were less fatigued than those that trottel. The ranch horse canters or ambles most of the time; we find the same with the South Africen pony. They never seem to tire, and there is no doubt that it is the easiest pace for the rider. P. 75 shows the tracks made by horse at the walk. The horse raises his legs from the ground in the following order: near hind, near fore, of lind, and of fore. If the walk is a long, striding one, then the liudleg touches the ground a little ahead of the spot from which the foreleg was lifted; in the slow walk the hindfoot is placed behind the forefoot's imprint. In ambling or single-footing, the horse brings the near legs lorward together, and then the off. In trotting (P. $8 b$ ) the diagonally opposite legs are advanced logether, the legs remaining on the ground for a shorter period. In the fast trot the hindleg is brought ahead of the foreleg, and in the slow trot it is placed behind the imprint of the toreleg. In pacing ( $P$. $O a)$ the lateral pairs move together. This is natural with some horses whenover they are in motion, but with others it is not a natural pace, but an acquired one. With these, and also with some natural pacers, hobbles are used while racing (P. 44a). The gait is much laster than trotting.

34. The following are the world's records lor the various pacers:

Pacing.-Dan Patch, 1 mile in $1 \mathrm{~min} .55 \mathrm{sec}$. (P. 8a).

Trotting.-Uhlan, 1 mile in 1 min. 5413 sec., at Lexington, Kentucky, October 9th, 1913.

Trotting on Ice.-The Eel, 1 mile in $2 \mathrm{~min}$. 11) sec., on the Ottawa River, at Ottawa, January, 1009 (P. 40b).

Two-year-old Trotting.-Peter Volo, 1 mile in $2 \mathrm{~min}$. $64 \mathrm{sec}$.

948 . In the canter, which can be made at the same pace as the trot or taster (P. 75), the horse places the leading foreleg on the ground, then the opposite foreleg and leading hindleg together, and then the hindleg diagonally opposite to the leading fore. The true canter is a movement of three time. In P. $55 a$ the near horse is leading with near lore, the off horse with the off foreleg.

In the gallop (P. 75) the motions are quite different. The leading lore is brought to the ground, followed by the diagonally opposite hind, then the other hind, and then tho other fore. A horse while galloping (sometimes called running) cannot bo collected as he can while cantering, but is stretched out; the faster lie goes the farther will he be stretched out. The true gallop is a movement in four time.

With the canter or gallop a horse leads with one or other of the forelegs. A trained horse will never turn on a circle or to one side unless he is leading with the inward leg; untrained horses will not do this as a rule. If a horse is lurned while leading on the wrong leg, ho is very liable to cross his legs and throw himself down: this Irequently happens and often causes accidents, generally due to want of knowledge on the part of the rider. Schooling is most essential for every hunter or military horse. A good rider knows by the feel with which leg the horse is leading; at any rate, a glance at the shoulders in Iront of the saddle will settle the question, because it the horse is leading with his near lore, the of shoulder-blade will move a little torward first, followed by the near shoulder. blade.

244. A horse that canters or gallops with his legs moving in the correct order, but with, let us sup, ose, the of legs leading while turning to the near side, is said to bo cantering united but "false." It his legs are not moving in the correct order, he is cantering "disunited." In order to canter "true" he must, therefore, canter united. "True" is the opposite to "Ialse."

845. Conformation of the Saddle Horse.When judging a saddle horse it is more important that he should go well at the walk, trot and canter than that he should look well when standing. Both conditions are ideal, but difficult to get. A saddle horse must be sure-looled and must not drag his toes, but place each foot fiat on the ground. Of course, the heels really come to the ground first. He should be impetuous, i.e. a free goer at all times, thus keeping up to the bit. A sluggish horse is always behind the hand (or bit), and has not the pluck and reliability that it is most essential a saddle horse should have. He must not be nervous. His conformation must be carefully examined. He must have a long rein, i.e. neck, and a well-set on head. The neck should bo tairly light, shoulders long and oblique, withers prominent and well cuvered with muscle, but not too broad, back and loins short and strong, croup long, pelvis not 100 horizontal. He must bo well ribbed up, i.e. as short as possible between the last rib and the point of the hip (ilium). He must have a long forearm (humerus); hocks well let down, and not too much bent or tied in below the hock.

"Good bone," which means good width between the cannon bones and the back tendons below the knees and hocks, is essential. The tendons should stand out distinctly, cannon bones short, not tied in below the knee, pasterns lairly long and at an angle of $45^{\circ}$ with the vertical, long leet, and heels not contracted. 


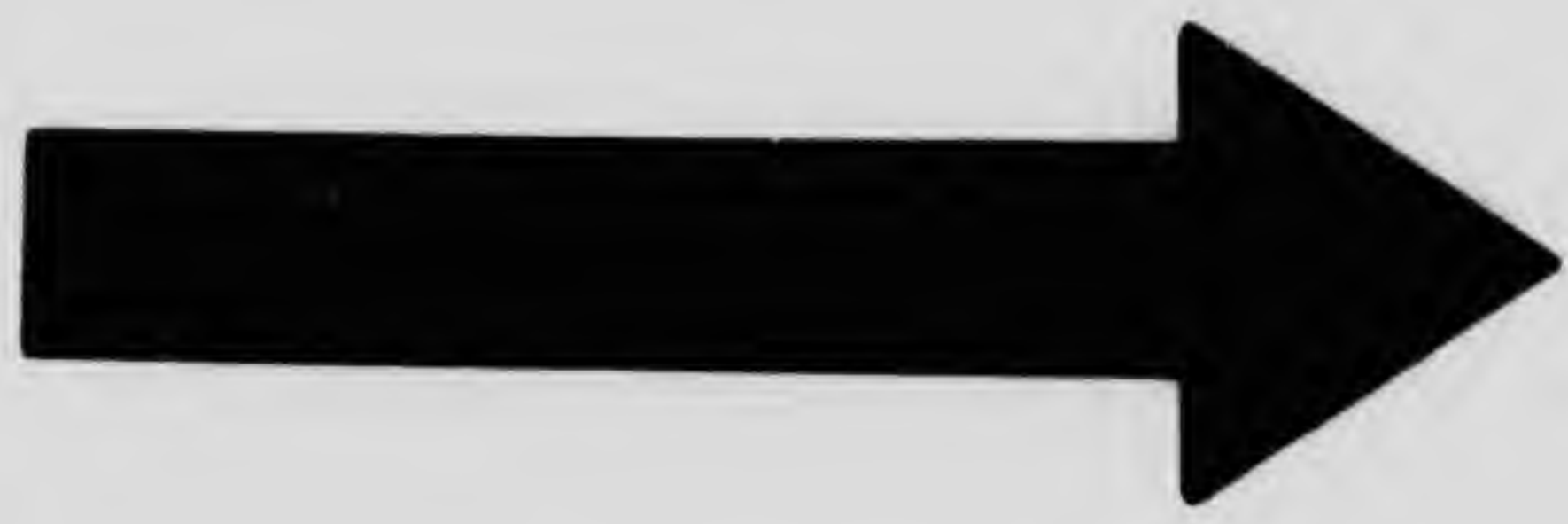




\section{MICROCOPY IESOLUTION IEST CMART}

ANSI and $15 O$ TEST CHART No 2
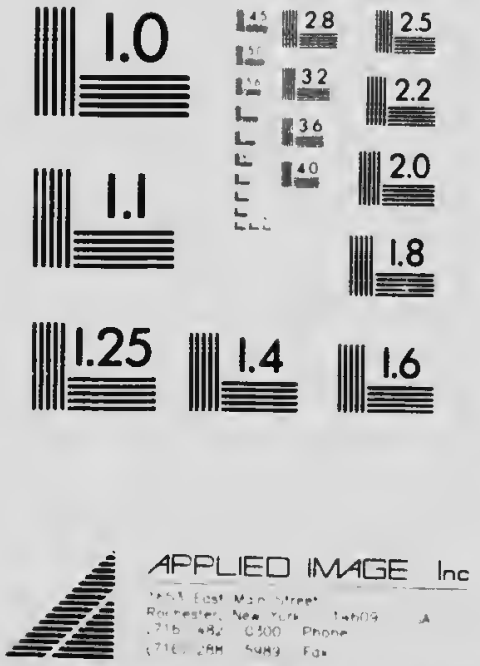
Depth of girth, i.e. distance from witlers to brisket (sternum), is large, nearly equal to distance of brisket above the ground. All joints should be free, especially fetlocks and pasterns.

As well as possessing the above qualifications, a hunter sinould be very strong about the loins and hocks; his gluteal and thigh muscles must be well developed, as these are used in jumping. It is foolish to economise when purchssing a hunter; a cheap hunter is a danger to life. P. 66, 67, 68 show types of good saddle horses.

346. Bits and Bitting.-Bridles and the fitting of bils have been discussed in Chapter VI., Sec. 286 , but I intend here to discuss the uses of bits and the general abuse of the horse's mouth, due to ignorance on the part of certain riders and horsebreakers.

Every horse sliould be schooled and trained in a thick broken bit, with ring attachment to the reirs, usually called a snaffle or bridoon (P. 72a). A snaffle is thicker than a bridoon, and has crosis-pieces attached to it that prevent it being drawn through the horse's mouth. A racing snaffle las no cross-pieces (P. 14c). When a horse during training, i.e. mouthing, etc., has reached a certain stage, his head and nock must be properly placed, and to do this it is really necessary to use a plain curb bit. The functions of the curb bit will be explained later. As horses' mouths vary so much in size and shape, and as their dispositions vary also, the curb bit must be fitted to every individual horse. A snaffle or bridoon will also vary in thickness and length for different horses. Apart from these variations, with very few exceptions, most other types of bits are useless.

Nearly all the varieties of complicated and absurd bits put on the market are worse than useless. They are made by men who know little of the art of bitting, and are sold by harness makers because they make large profits thereby. Grooms and others encourage their use partly because they sometimes receive commissions by recommending them to their would-be horsy masters and partly because they love a display of steel in the harness-room. The horse owner who says, "Come and look at my harness-room," and shows one an elaborate glass case full of marvellous-looking instruments of torture called bits, is exposing his want of knowledge.

347. The best kind of curb bit is the Liverpool bit (P. 33a) for driving, and the Weymouth bit for riding, or modifications of the same. The Portsmouth reversible (P. 74g) is a useful bit for either, especially if in bad hands, as it will not easily hurt the horse. The racing snaffle is the best kind of bit to ride a young horse with. This is broken in the middle. P. 74C shows a method of attaching the reins which gives great leveraga over the horse, but which must make the horse very hard in the mouth, and, being limited in its action, is therefore not to be recommended under any conditions.

If $\mathrm{a}$ horse is laught from the beginning by a good trainer with good hands, the curb bit, except for placing the heed and neck, will probably never be required at all. That is, after the head has been placed and the horse prcnrrly moulhed, the snaftle can be used again. "1/3re is nothing more delightful than riding a l.urse to hounds in a plain racing snaffle. For driving light harness horses a broken bit, which very much resembles a snaffle, is often used (P. $36 h)$; or the month-piece may be unbroken.

848. Many horses are made to pull, and even run away, by bad hands and ignorance of driving and riding. They are driven in severe bits, which make them pull all the more; it takes two to pull, and I have never found a horse yet that did not give in after a few days when he found that he had nothing to pull against. (See Chapter VI., Sec. 268.) It is the playful wut firm feeling that good hands impart to the bars of the horse's mouth or tongue, something like the playful touch an expert chauffeur exerts upon the clutch of a motor-car with his foot, that compels the horse to give way, to cease pulling, to champ the bit and to go in a collected manner. Mechanical bits never have accomplished, and never will accomplish, this. The private coachman, whose hands are often, as Sir Robert Baden-Powell said (in the Cavalry Journal), "mutton-fisted," is a strong advocate of using curb bits and holding on to the horse all the time.

If a horse is going too fast, the fact of pulling with a steady strain upon his mouth will not stop him; his mouth must be played with, not jerked, and if this will not have any effect, through the horse's mouth having been made hard previously, his jaw must be drawn back with determination towards his chest and immo diately released, i.e. the reins let quite loose, followed by his month being again drawn in, and so on. Almost uny runaway horse, as described in Sec. 266, can be stopped in this way.

349. It must be remembered that pain excites a horse to motion, and this is why 80 many runa ways have been caused by the pain inflicted upon the horse by severe bits. Race-track trotting horses are taught to go faster by the feel upon the reins being increased. Pulling on the reins has not much effect upon such horses when it is required to stop them, but it is quite easy to stop these horses by the playful method described above. A horse which apparently cannot be managed without brutal and useless patent bits must be handed over to a competent man for \& few weeks, who will be able very soon to accustom the horse to being ridden or driven in the simplest of bits. I do not believe in rubber-covered mouth-pieces. They teach 
PLATE 75

$$
\begin{aligned}
& D_{10} \\
& 35
\end{aligned}
$$

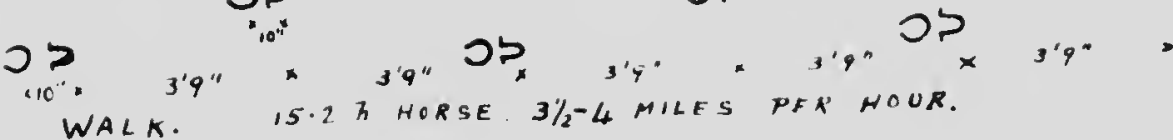

$$
\begin{aligned}
& \text { ○一 ? }
\end{aligned}
$$

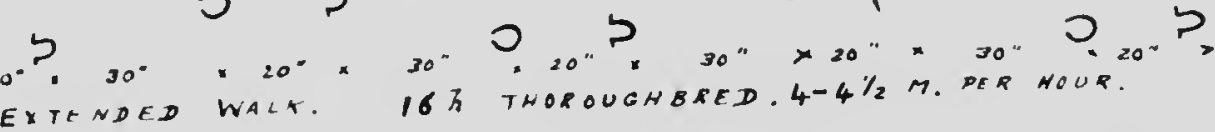

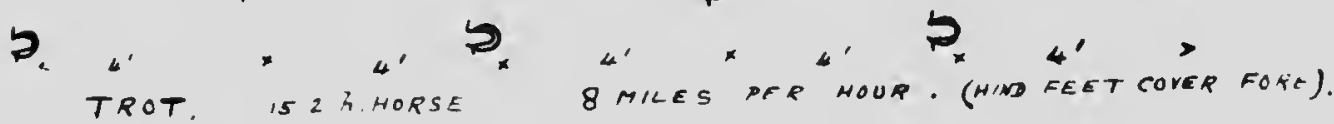

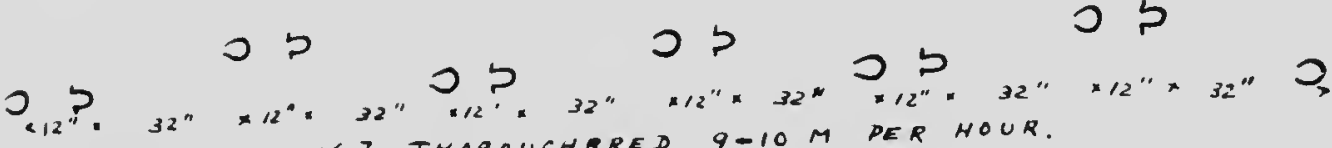

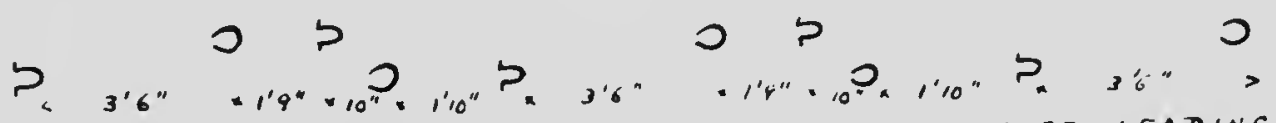

COLlected CANTER. 15.2 T HORSE. YM. PER H. OFF FORE LEADING.

$$
\text { P. }
$$

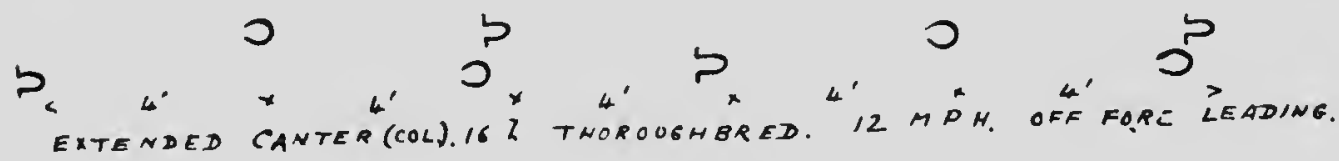

$$
\begin{aligned}
& \text { ○ }
\end{aligned}
$$

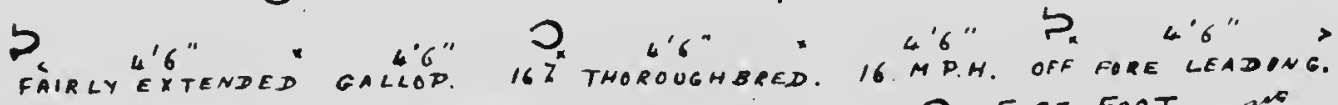

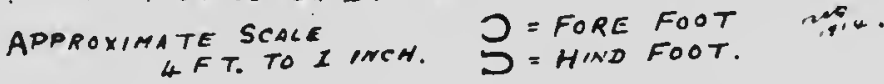

Tracks of Horses Feet at Different Paces. Taken from Tracks made in Clay 
PI.ATI: 76
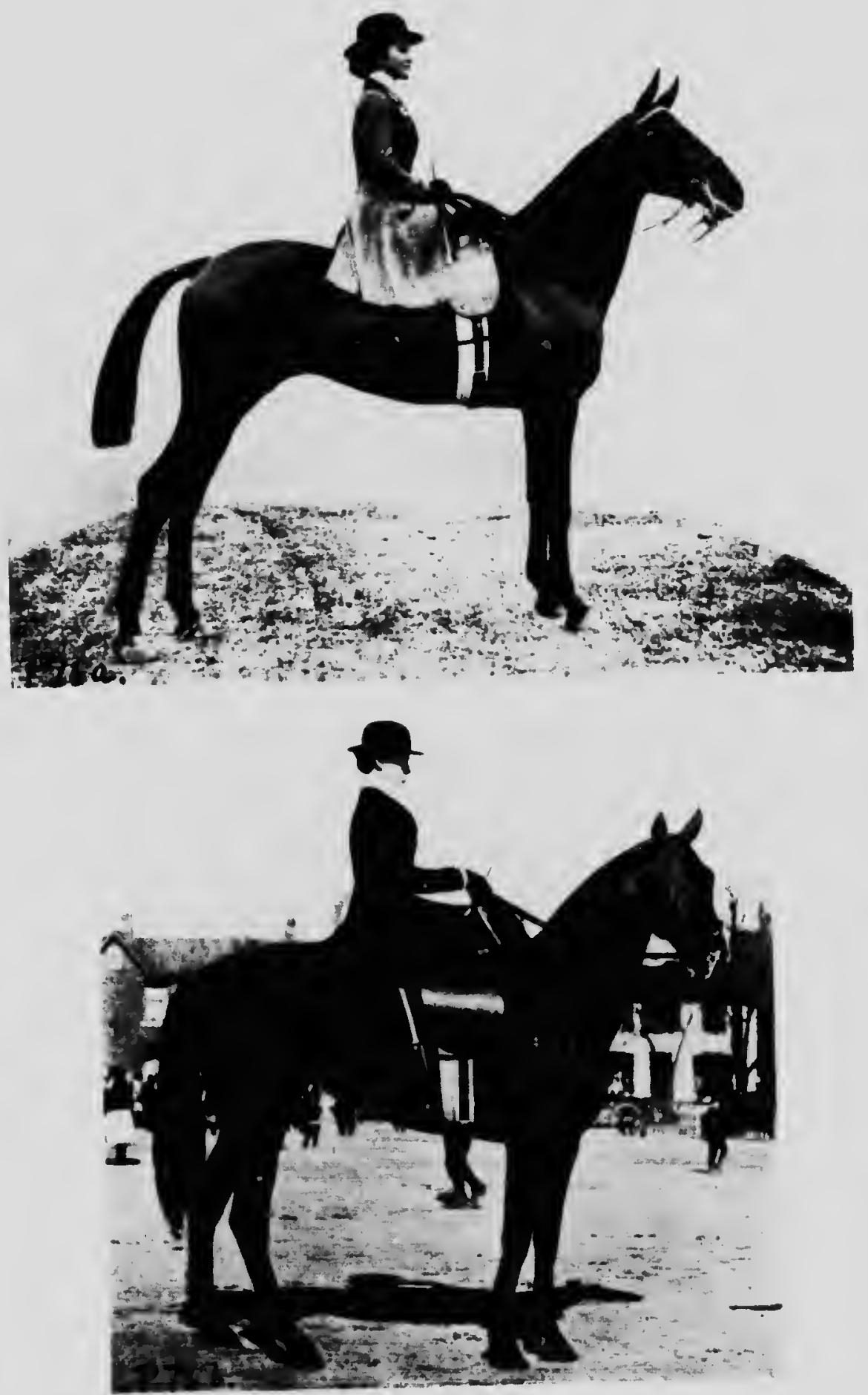

HUNTERS

Couriesy Mr.F. G. Haines, W'est End Riding Scliool, London. b. "Gold Ribbor." Prize Winner Courtesy: "Canadian Sportsman" 
PLATE 77
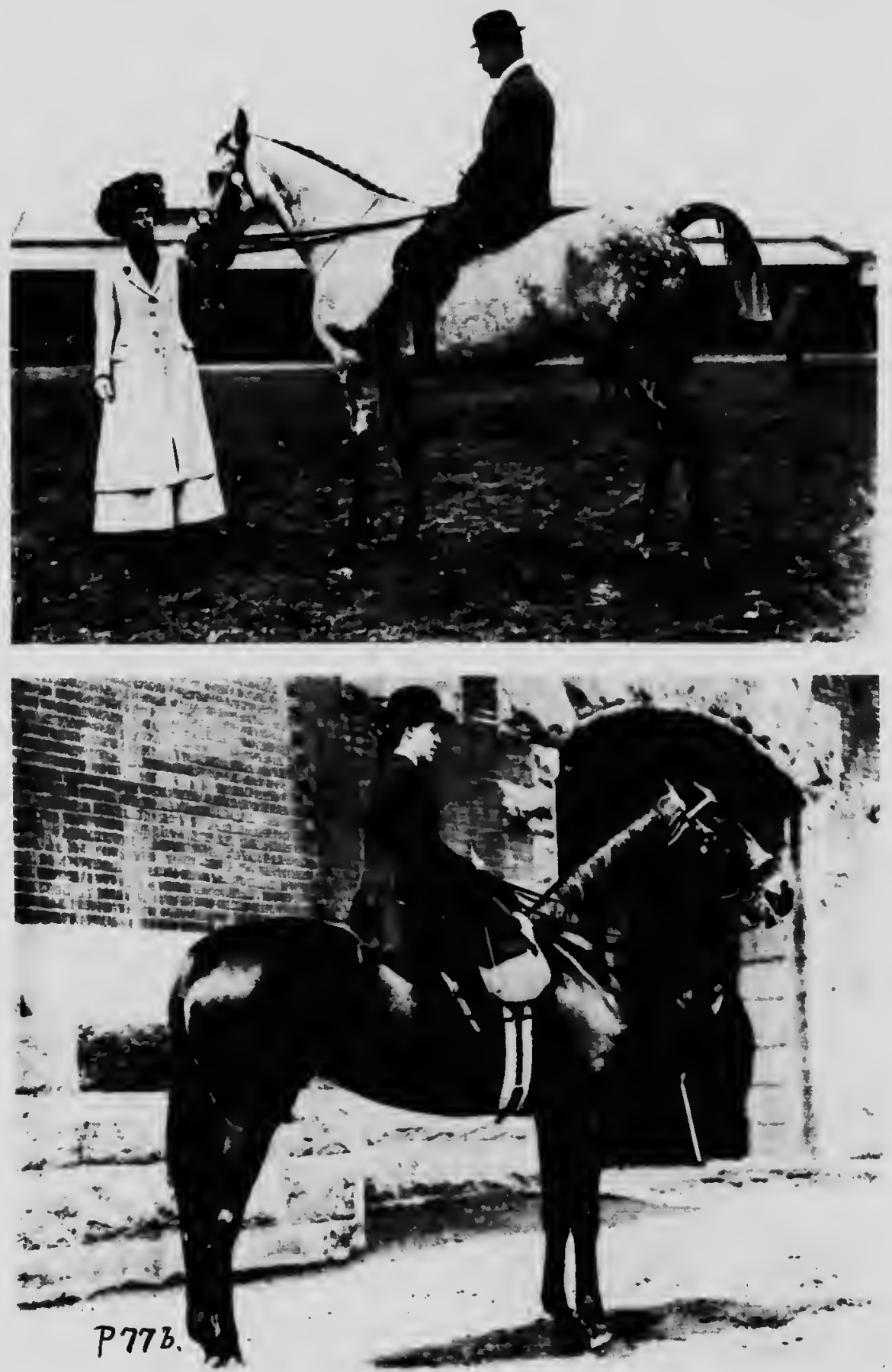

HUNTERS

a. "Grey Mar." owned by Mr. John Ferguson. C.. Antrim. Courtesy; "Weekly Irish Times." b, Courtesy : Major Douglas Young, R.C.D. Photo: W. James, Toronto 
PLATE: 78
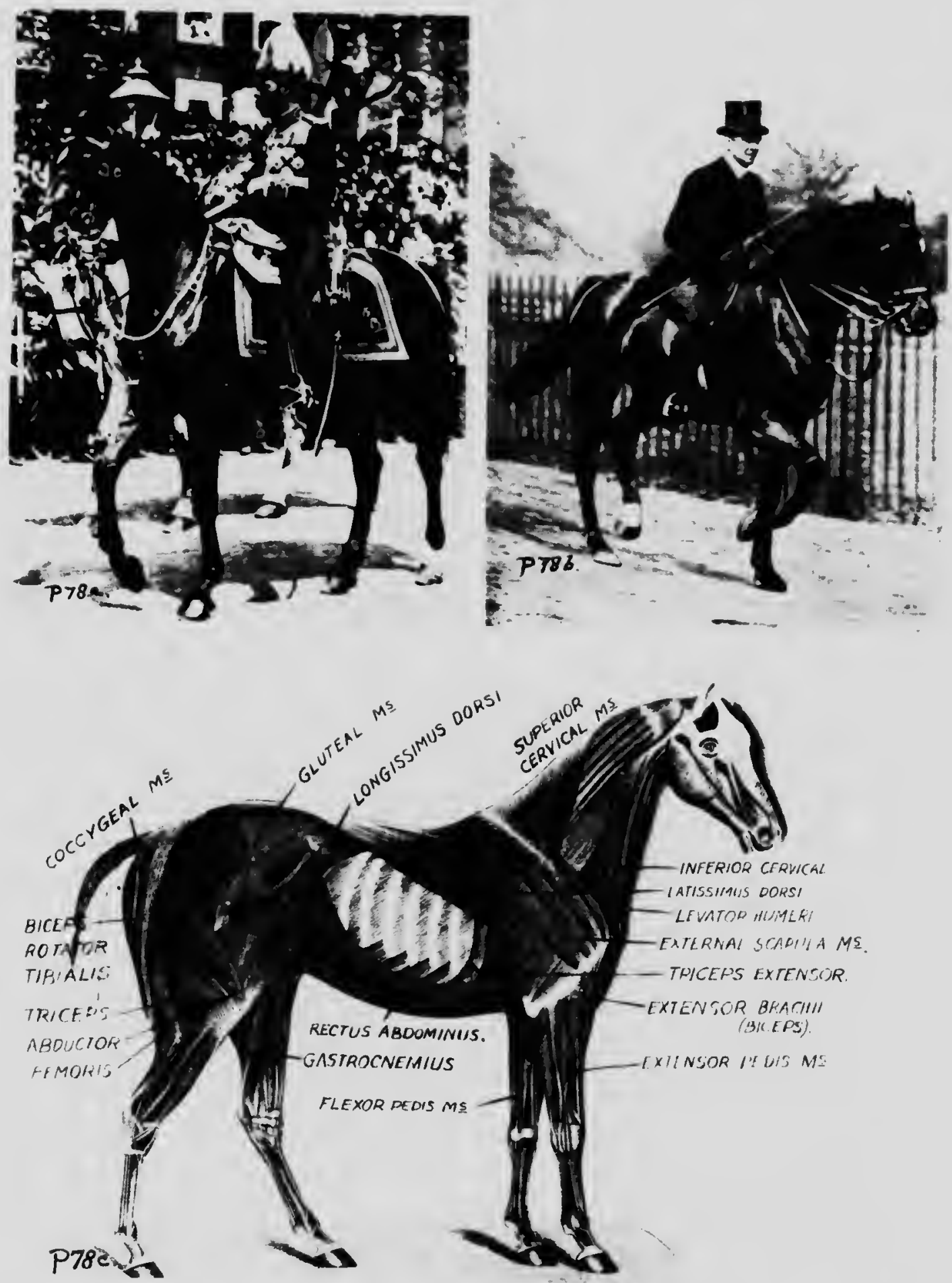

a. H.II. King Ceorge V.un his Favourile Charger. Photo: "Sphere and Tatler." b, The same Horse heing Ruilden

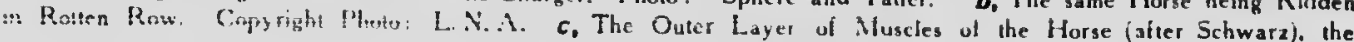
Panniculus Carnosus heing removed 
horses to pull. If a horse has a tender mouth, a thick mouth-piece must be used and an easy hand must be at the other end of the reins.

Jerking a horse's mouth in order to increase lis speed is a sure sign of extremely bad driving.

350. Curb Bits.- The curb bit requires to be fitted accurately to the mouth if the best use is to be derived from it. A curb bit consists of mouth-piece, lateral upper and lower cheekpieces, and curb chain, which is hooked on to both sides. The upper cheek-piece has a ring in its top to which is buckled the headstall, which keeps the bit in the horse's mouth. The chain hooks are also attached to these rings. The lower cheek-piece, i.e. below the mouthpiece, has usually two holes in it in driving bits, and sometimes two in riding bits, for the attachment of the reins. The mouth-piece is either straight or has a port in it which fits over the tongue. (See P. 71.) The surface of the mouthpiece is usually smooth, but may be slightly grooved for horses which have hard mouths. P. 71, Fig. 2, shows how the tongue of a horse usually projects above the side-bars. The sidebars are the ridges (incidental spaces) between the incisor tooth of a mare, or the tusk of a horse, and the first molar. They are covered with mucous membrane, und, unless they are made callous by hard handling, are very sensitive. The degree of sensitiveness of these bars, sometimes called gums, is often designated as "fineness of mouth."

Fineness of mouth is defined as moaning a mouth that is properly trained and responds to the actions of the bridle hand; therefore, the rider cannot be too cautious in the manner in which he uses his bit reins, or too careful that the movements of his hands are the correct indications of his own will, always bearing in mind that fineness of mouth is not produced through laceration of the bars, as the delicate skin that covers them is never so sensitive or tender after abrasion as before.

351. From the diagram it will be clear that the existence of a port and the depth of the port depend on two things: the shape of the mouth and tongue, and the disposition of the horse. Clearly, with a port the bars will take the feel of the reins, without a port (unless the tongue is very small and the bars high) the tongue will take the feel. The tongue is less sensitive than the bars, and therefore a port makes a bit more severe. Some horses go better with the bit on the tongue, some with it on the bars. This can only be ascertained by a careful examination followed by a trial.

The width of the bit must also be correct; if too narrow it will pinch the mouth, and if too wide it will slip from side to side. The width of a jaw can be measured by passing a wooden rule through the mouth and measiring from a quarter of an inch outside the lips on each side when the mouth is closed. This distance is the correct length inside the cheok-pieces. If a bit is too wide, circular leather cheek-pieces can be cut to slip on the mouth-piece inside the cheekpieces of the bit. A horse with a thin skin on his bars or on his tongue will have to be bitted with a thicker mouth-piece to prevent injury and pain.

Besides taking into account the shape of the mouth and the thickness of the skin on the bars, the conformation of the head and neck, fore quarters and back should also be considered.

352. Port.-Tho port is usually made parallel to the cheek-pieces. When it is in this position the lower cheek-piece would have to be moved at right angles to the bars in order to allow the tongue to fit into the port. At the most the lower cheek-piece is drawn to an angle of $45^{\circ}$, and therefore half of the depth of the port will be lost. So that really the correct plane for the port is at least $45^{\circ}$ to the plane of the cheekpieces, as shown in P. 71, Fig. 4 ; the port then forms a small groove for the tongue at all times, but a complete one when the curb is brought into action.

853. Curb Chain.-As explained in Sec. 286. a curb chain must lie flat in the chin groove; it must be broad, so as not to cut into the jaw and cause pain. The curb chain is not meant to cause pain, as is so often supposed. It has quite a different function, as explained below. The object of the curb bit is to subject the head and neck, and therefore the whole body, to the action of the hand. It acts by causing a properly mouthed horse to allow his lower jaw to move toward the rider, thus causing him to arch his neck and to take no hold of the bit.

The longer the lower cheek-pieces and the shorter the upper, the greater will be the power of the bit. The reins for driving are usually not buckled to the lowest hole on the long cheekpiece (P. 33a). The more power such a bit possesses the greater care must be exercised in handling the reins; but, as the mouth-piece should never be thin nor the curb chain narrow, the harm done will be comparatively slight should the horse be accidentally jerked in the mouth. If it is seen that a curb chain causes pain, leather strap should be worn between it and the chin. The length of the upper cheekpiece is limited, because it must be of such a length that the curb chain is just tight when the bit rein is pulled so as to cause the cheek-pieces to be at an angle of $30^{\circ}$ to $45^{\circ}$ from their original position. In this position the curb must be lying fat all along the chin groove, not having slipped up or down. A curb may slip up if the mouthpiece is too high or if the upper cheek-piece is too long. A curb chain will not allow the cheekpieces to form the required angle if it is too short, but if too long it will allow the cheekpieces to be drawn too far over, i.e. too near a 
right angle. Unless this angle is from $30^{\circ}$ to $15^{\circ}$ (preferably the latter) the best results cannot be obtained from the curb.

The curb chain must be several links longer than required, else it will be diffleult to look it on properly; it is always twisted as a righthand screw is turnel (Sec. 286).

It stands to reason that if a curb chain is too short the action of the bit will be too strong. and : ot gradual enough. If, however, it is so long as to allow the cheek-pices to turn nearly at right angles to their original position, the use of the curb is lost, because the rein is pulling against the bars of the mouth in the same way as if they were attacherl to a snaffe bit. The feeling that good hamls las upon the reins is a continuous and playful feeling, but if it is required to stop the horse this feeling is gradual, then stronger, until it ends in a distinct opposition, the whole lasting but for a few seconds, when the horse's mouth is eased again, and the feeling repeaterl. To the casnal observer these motions of the bridle liand would not be discernible.

354. Marlingales. $-A$ horse which is continually throwing up his head or which carries his head too high, so that the bit remains in the corner of the mouth instead of on the bars, may require to be ridden for a while in a standing martingale. This fault is often the result of bad handling, and, therefore, can only be cured by careful handling. The martingale is attached to the back of the noseband, and must be tight enough to catch the horse's nose whenever he throws his head to about a horizontal position or perhaps a little lower, but should never be so tight as to keep his head down; such will ruin the horse and make him far worse when his head is left free. By having it as described above, whenever the horse throws his head up he will catch his nose, which will cause him a slight amount of pain, and he will soon know that he has to keep his head down. Standing martingales are not advisable for hunting, nor for jumping anything but low jumps; even then they must be quite loose.

355. Another type of martingale is the running martingale, which I do not recommend for horses as a rule. When used, leather stops must be placed on the reins, so as to prevent the rings of the martingale from catching on the buckles of the reins, which might throw the horse down.
The objection to the running martingale is that, as the pull is coming from below, it tends to make the horse try to hold his head higher, as he will naturally pull against the reins. When jumping a horse that gets his head very high, a running martingale is generally necessary. They are of great use for horses that are liable to rear, but the martingale should not be used tightly. The best kind of bridle to use with this type of martingale is the double-reined snaffle, so that only one of the reins is attached to the martingale; the other, which is free, is used for riding, except when the martingale is required. $\Lambda$ third type is a fixed one that is attached to the rings of the bit. This is most dangerous, and I do not see how it can do any good, except to throw the liorse on his nose.

856. Cold Bils.-I wish here to emphasise the great cruelty commonly practised in thrusting cold, or even treezing, bits into a horse's mouth. This is common in the Canadian west in winter. Such cruelty should be practised on those who practise it upon their horses. I well recollect a constable of the Royal North-West Mounted Police punishing a cruel lad in this way for having thrust a cold bit into his horse's mouth. He asked the lad to lick a piece of cold steel, which he did, and was greatly surprised when he found the metal firmly stuck to his tongue. The shock was 30 great that he dropped the metal, which tore the skin from his tongue. He learnt a lesson. Bits should be kept at night in the stable, unless the stable is very cold, when they should be kept in the house.

If they are kept in a cold place, they must be warmed by being held for a few minutes in the hand or before a fire, and then put in the horse's mouth. A very cold bit may tear of large pieces of skin from the horse's tongue or lips. This is done by the cold steel suddenly freezing the moisture on the surface of the skin, the ice acting as a cement and securely sticking the skin to the cold metal.

357. The cleaning of harness, etc., was described in Chapter VI., Secs. 292-3. The white buff leather brow-bands, so commonly used on bridles (P. 14c, 77b), must be kept quite soft in order that they will not rub the horse's ears when he moves them. This can easily be accomplished by bending the brow-bands backwards and forwards, after they have been pipeclayed and dried. until they become quite pliable. 

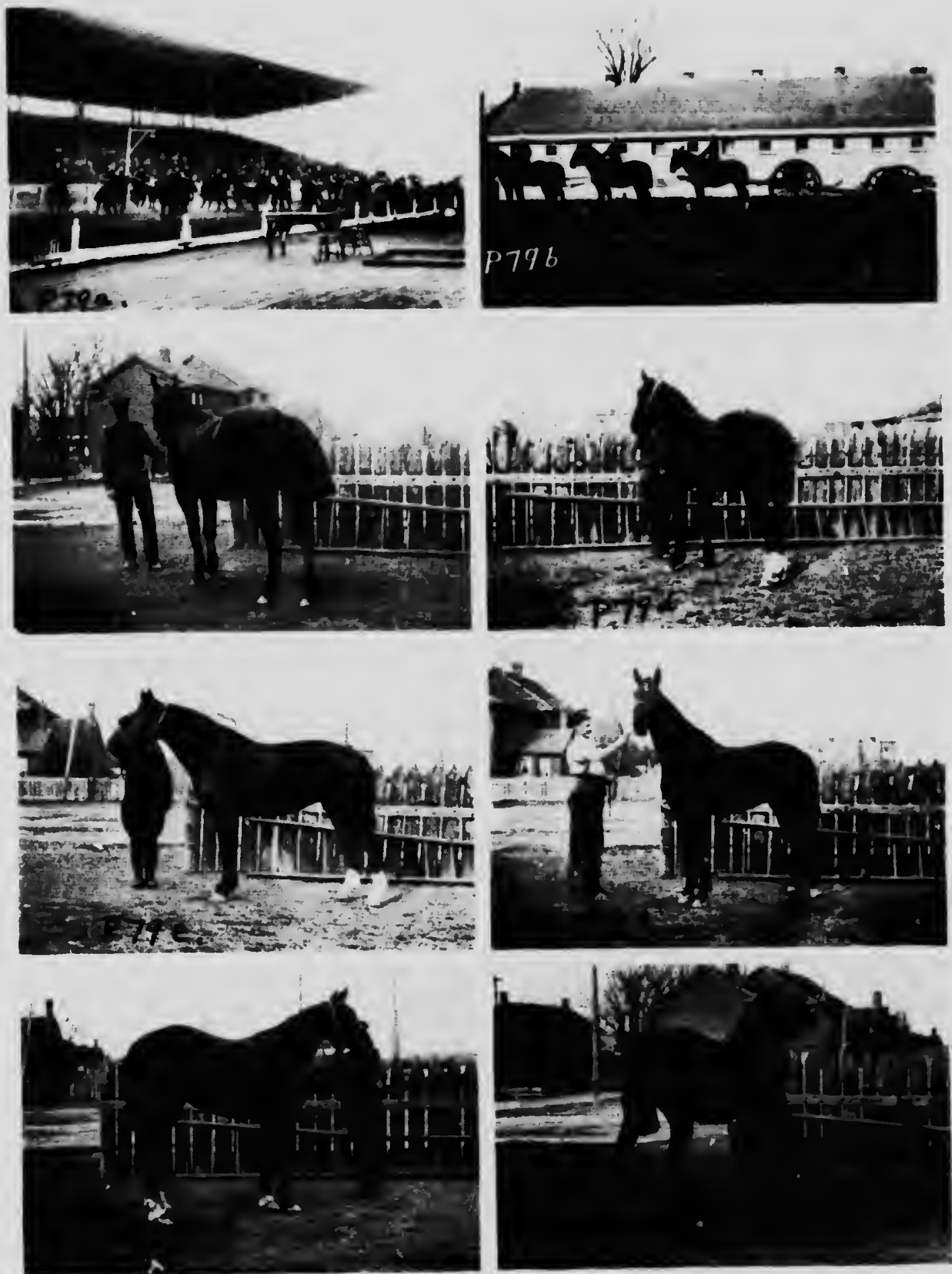

TYPES OF CANADIAN.BRED ARMY HORSES

a, Ruval Canadian Dragoons' Musical Ride, b, Royal Canadian Horse Artillery (Old Dress). Courtesy: Major Lestie. $c$ to h, R.C.H.A. Horses. Photos by the Author 
PI.ATI: 80
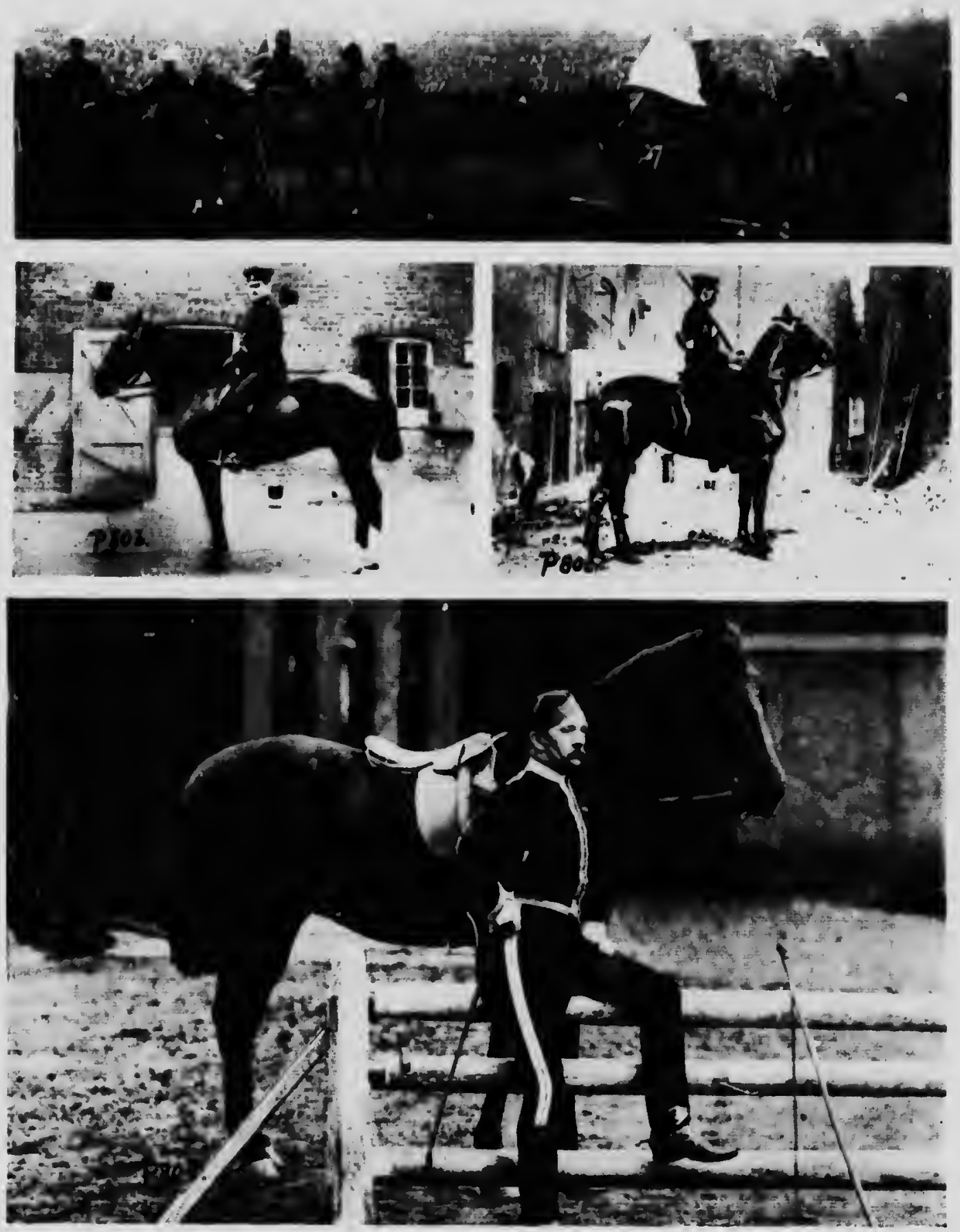

CAVALRY HORSES

a. Treop Horses and Chargers of the Royal Canadian Dragnons. Phn!n: WY Jamrs, Tornnin. b, Trang Harse King s Diagoon Giuards. c, Royal Horse Guards. Photos, Authos. d, Chasger 17th Lancers 


\section{CHAPTER VIII}

\section{STABLE CONSTRUCTION AND THE GIRCULATORY SYSTEM}

858. The Circulalory System.-A knowledge of the use of fresh air is essential before it is possible to realise the necessity for a continued supply of fresh air in the stable.

The food of the living cells of the body is blood. Blood carries two important kinds of food: one, protein, salts, etc., as explained in Chapter IV. ; the other, oxygen. Oxygen is not very soluble in the watery fluid portion of the blood, so Nature has made use of a red substance called hæmoglobin, which has a very great afinity for oxygen, and absorbs a very greal amount of it per unit volume compared with any other liquid. In the horse and other large animals, and in man. Nature has not allowed this hromoglobin to mix freely with the liquid plasma (watery fluid) of the blood, but has confined it to little carriers (like delivery vans) called red blood corpuscles (erythrocytes), which, in the horse, measure 1-5,000th of an inch in diameter. A large drop of blood contains several millions of these circular, bi-concave, plate-like cells. They carry a large quantity of hremoglobin. Their function is, as stated above, to carry oxygen, which they obtain from the lungs, and whenever they reach a place in the body where there is not much oxygen, i.e. where the pressure is small compared with the pressure in the corpuscle, they give up some of their oxygen. By the time they get back to the lungs they have exhausted all, or almost all, of their oxygen, and there they receive a fresh supply, because the pressure of oxygen in themselves is less than that in the lung capillaries.

359. The circulation of the blond consists of a continuous fow that is given an impulse every time the heart beats. The heart is a double pumping station, which is divided into left and right, and each side is again divided into the receiving vessel (auricle) and the pump proper (ventricle). The circuit of the blood is as follows: the left ventricle, which is a very powerful muscular box, forces its contents into the large aorta, then into the other large arteries, and thence into small arteries, until, finally, it reaches the minute capillaries that are situated in every portion of muscle, bone and almost every kind of tissue in the body. Here the blood gives np its oxygen. While full of oxygen, blood is bright red in colour, and is called arterial. After parting with its oxygen it becomes blue, and is called venous. From the capillaries the venous blood passes into small veins, then larger veins, then into the vena cava, and thence into the right auricle of the heart. Before it reaches the heart the lymph vessels empty the nourishment that they have collected from the intestinal walls into it. This is tho other kind of food that the blood carries.

The venous blood passes from the right auricle, down through a strong, three-sided valve, into the right ventricle, which forces it into the pulmonary artery (the only artery in the body that carries venous blood), which carries it to the capillaries of the lungs; in these capillaries the red blood corpuscles pick up their oxygen. The arterial blood then passes into the pulmonary vein, and is poured into the left auricle of the heart. From the left auricle it passes through a very powerful two-sided valve into the left ventricle, whence it is again forced through the body. (See P. 71.)

360. It will, of course, take a number of beats of the heart for a drop of blood to pass around the whole circuit. A heart-beat consists of a complete cardiac cycle, which is the con. traction of the large valves, the contraction of the auricle, and then the contraction of the ventricle; this period, which is called the systole, occupies three-fitths of a heart-beat. Then the auricle and ventricle relex, and cause the heart to refll; this period is called the diastole, and occupies the remaining two-fifths of a heart-beat.

361. Respiratory System.-We must briefly consider how the capillaries of the pulmonary circulation come in contact with the oxygen.

Air contains by weight 21 per cent. (a little over one-fith) oxygen, nearly 79 per cent. nitrogen, and about one-twentieth of 1 per cent. carbon dioxide (carbonic acid gas), and a trace of ammonia gas. It contains other gases that do not concern us here.

Every time an inspiration is taken, air passes into the mouth, through the larynx, windpipe (trachea) and bronchial tubes, to the lungs proper. These consist of numerous branches leading off the bronchial tubes, which subdivide until they become very small tubes that terminate in minite air sacs. The surface thus exposed to the inspired air is very great. In a 
man of average size it is about 625 square feet. In a horse this is many times greater. A common view held is that a lung at each expira. tion emptles itself of air; this is far from being the case.

Every time the lung draws in air, by the clest being expanded and the diaphragm being contracled, the :ittle air sacs become large; ; this expansion of the lungs causes the air sac to expand only une-seventh of its original volume. Now, only one-nftl of the air is oxygen, so pach time an uir sidc becomes explanded it receives only one-tlirty-fleth of its volune of pure oxygern. The venous blool, when it reaches the lungs, besides receiving a fresh supply of oxygen, gives up a quantity of carbon lioxide, which is a waste product from the cells of the boily.

The air in the lungs, as it is expelled by an expiration, takes this carbon dioxide $\left(\mathrm{CO}_{3}\right)$ witl it, so that the uir has a double function: that of taking oxygen to the blood, and that of taking carbon dioxide away from the blood. As the lungs only open and close, approximately, oneseventh of their volume, the air in them must always contain a certain amount of carbon dioxide.

368. It will also be clear how important it is that the air whicl is drawn in is as pure as possible, and that which is blown out is taken away from the nostrils as rapidly as possible. In short, unless fresh air is continually being supplied to the nostrils of a horso, his health must be seriously impaired. Also, the oxygen in a closed stable will rapidly become used up, and the stable will soon become filled with a high percentage of carbon dioxide. Air containing as little as per cent. carbon dioxide is exceedingly bad for horses to breathe. As long as this impure air remains in a closed stable it will remain impure, but when impure air is allowed to escape into the open air Nafure rapidly removes its impurities and transforms it into pure air. This process of changing carbon dioxide back to carbon and oxvgen is carried out by plants, i.e. the vegetable kingdom.

It would, therefore, be possible, if a perfect inflow of pure air and exil of used air were maintained, to keep a horse in a very small enclosed space; but for various obvious reasons, and also because a certain space must be allowed to avoid a draught, the cubic capacity for a horse must be comparatively large. Experiments have shown that the cubic space in a stable for each horse should be 1,500 cubic feet. Thus, if a stable is $12 \mathrm{ft}$. high and about $6 \mathrm{ft}$. wide, it will have to be $21 \mathrm{fl}$ from the front of the stalls to the back of the stable, or the centre of the passage, if there is a double row of horses. The width of $6 \mathrm{ft}$., of course, is the width of the stall. It is quite obvious that there are many stables that have not this required air space.

368. Having got this space for every horse, it is necessary that the air in this space be entirely changed every twenty minutes. The larga volume of air which enters a horse's lungs at every inspiration, and which comes out impure at each expiration, rapldly causes the 1,500 cuhic feet of alr to become contaminated. Cariful experiments have sliown that if there is a largo enough inlet and a large enongh outlet to allow this space to be refilled every lwenty minutes, the horse will obtain all the fresh air that lie could possibly require white standing in tho stable, if he is not suffering from lung disease.

Nature assists us th replace the foul air in a wonderful way. Fonl air, when it comes out of the lungs, is warm. All gases expand when they are heated. Thus, the same weight of a gas when heated occupies a larger space. Thut is, a cubic font of expanded air would weigh less than a cubic foot of cold air. Hence the heated air, being lighter, rises above the heavier cold air. Carbon dioxide (22) normally weighs more than air (14.43), but when heated and mixel witl air it weighs less than pure air; thus the impure air from the horse's lungs rises to the ceiling. If this air cannot continue to rise, but comes in contact with a cold ceiling, it will remain there until it cools down and once more becomes lighter than air, when it will again fall and reach the horse's lungs. Therefore, the air in a closed stable would be breathed over and over again, each time becoming more foul and causing more harm. Thousands of horses in large cities are daily having their health impaired by bad, and in many cases disgracelul, ventilation.

384. On the other hand, if this warm foul air is able to rise up and pass through the ventilator in the roof, it escapes into the outside air. So much for the outlet. The most important question is the irlat of fresh air. This must be nearly as abcindant as the outlet. If it is not, the fresh air will get in under the door and through other places, and cause objectionable draughts. If we close up windows and ventilators we create draughts, as some air will get in some way or other.

If the inlet is at a suitable height above the ground, and is large, there will be very few draughts along the floor. When the foul air loaves the slable through the ventilator, other air must replace it, or else a partial vacuum will be created in the stable; and, as Nature abhors a vacuum, the air has, as we said before, to get in somehow.

365. Windows as the Air Inlet.-The best entrance for the fresh air is through a small window about $8 \mathrm{ft}$. from the ground in front of each horse. The window should be $2 \mathrm{ft}$. square, hinged at the bottom on the inside wall, to open towards the insidu of the stable to an angle of $45^{\circ}$. A little pling should be arranged to fit into the window to keep it right open 

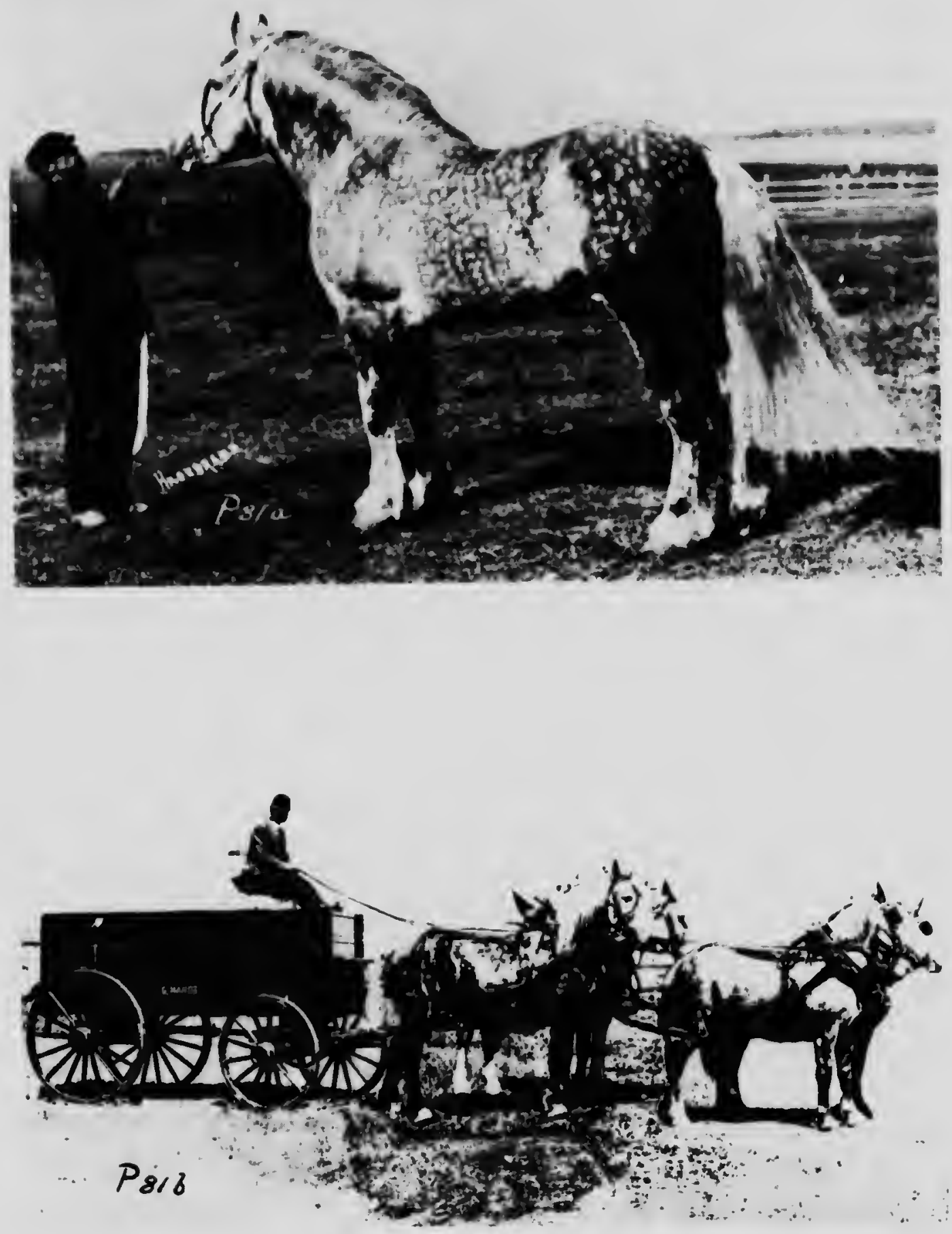

CHANIPION GREY PERCHERONS

a, Phota, Hildebrand, Union Stock Yards, Chicago, Illinois. b, Champion Team, the Property of W. E. \& R. C. U.per, Clezr Water Stark Farm. North Portal. Saste!chewan. Courtesy of the Ownert 


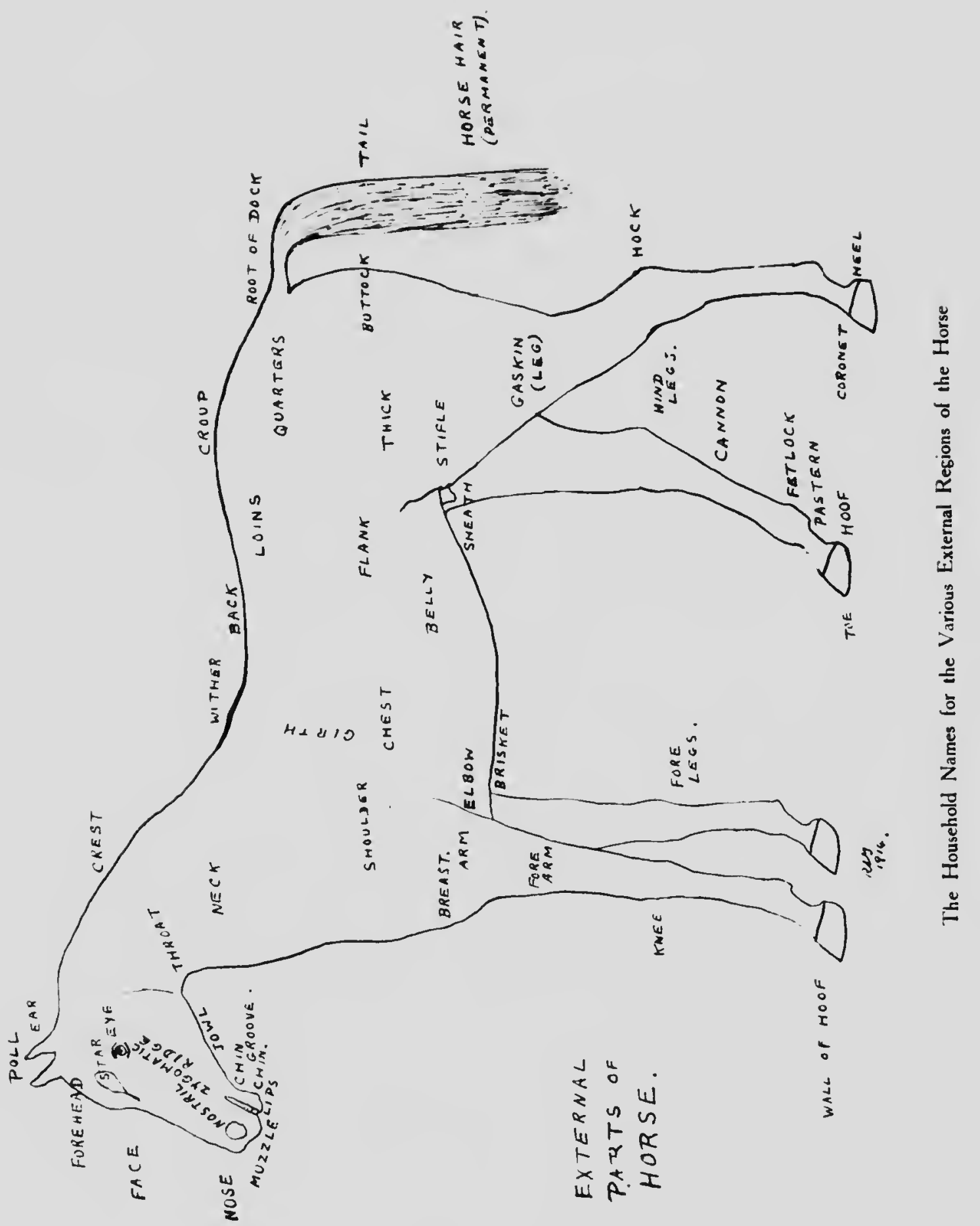


or partially open as required (see P. 84), but it must never be entirely closed, except ill very cold climates. The best way to stop grooms from closing the windows entirely is to have blocks of wood fastened so that it is impossible to close them completely. Grooms have a very bad habit of trying to heat a stable at the expense of fresh air in order to save themselves trouble in grooming. A hot stable makes a horse's coat shine a little better, but a horseman with a little experience will be able to distinguish between a horse that has been groomed properly and one that has lived in hot stables. The glass (which is most conveniently fitted in four panes) must be put in from the outside, so that there will be no danger of its falling on to the horse's head should the putty get dry.

386. A most necessary and cheap addition to a stable is that of fitting fly screens to the windows and doors during the fiy season. They must be put on before the flies make their first appearance. The doors are fitted on to the outside of the door frame with hinges. The windows should either screw on or fasten on to the outside of the frames. These frames must fit very accurately, or flies will get in. Fly strings should be hung inside the stable from the ceiling suffciently high so that a horse cannot reach them if he gets loose. Fly strings are better than papors for catching files.

367. Ventilators.-The outlet, as described above, must bo through ventilators in the roof. The best kind is shown in P. 87, which is of the new louvre-board type. This kind can be used for stables that have no ceilings, or for those with a ceiling and loft above (P. 84), or for those with a living-room above. P. 87 explains as fully as is necessary the detail. The opening at the top, with louvre-boards fastened in to prevent rain and snow from beating in, is the best kind of top to the ventilator. The number and si., of ventilators should be, approximately, as shown. These flgures vary, of course, in proportion to the number of horses and the size of the stable. There must be holes b allow the foul air from the loft or living-room above to pass ont. The bottom of the ventilator shaft should have a trap, as shown, but, to prevent this being entirely closed, holes must be bored through it. If these traps are entirely closed, not only would the ventilation through the windows be poor, but periodic rushes of cold air would descend on to the horse's hoad. When these traps are open, the infiow of cold air tends to rise up and pass well over the horse and fall diffused over a large space. Whatever the style of the stable, it is imperative thet a window be built in front and above every hurse's head. If a stable cannot be constructed to admit of an outward wall being in front of the horses. then a better site should be chosen. Many stables holding a dozen horses heve only one or two windows in them, and the atmosphere is often extremely unhealthy. A stable, if properly fitted with windows, should have such a supply of fresh air that, upon entiring it, there is only a slight smell of horses, and upon leaving it, after standing in it for some minutes, one's clothes should not smell of the stables, except perhaps very slightly. The atmosphere of many stables is very injurious to those who work in them, especially those who groom the horses, because their breathing, while grooming, is naturally more rapid, causing them to breathe so much more foul air.

368. Stable Impurities.-In order to show the bad effect produced by improperly ventilated stables upon the horse and upon harness it will be necessary to discuss briefly the chemical impurities that are produced in a stable.

The lungs give off, as explained above, carbon dioxide and water. Other impurities are given of by the system, which remain chiefly in the coat until they are brushed out by the groom. (See Chapter V.) The urine decomposes into gases ind solid substances. The chief gas is ammona gas $\left(\mathrm{NH}_{2}\right)$; the chief solids are ammonium carbonate, ammonium benzoate, ammonium acetate, and acetic acid.

The dung consists chiefiy of insoluble substances, such as cellulose, which have very little effect on the impurity of the air. It decomposes slightly into ammoniacal substances, lactic acid, and a very small percentage of carbolic acid.

369. Horse Urine.-This is normally cloudy. It is composed of about 90 per cent. water, 5 per cent. mineral salts (salts of $\mathbf{K}$., Ca. Mg. Na.), 5 per cent. organic matter, 3 per cent. of which is urea and 2 per cent. alkaline lactates. Fresh urine contains no ammonia, but, owing to ammonia bacteria, fermentation rapidly takes place, the urea combining with water and forming ammonium carbonate: $\mathrm{CO}\left(\mathrm{NH}_{2}\right)_{2}$ (urea) + $2 \mathrm{H}_{2} \mathrm{O}$ (water) $=\left(\mathrm{NH}_{4}\right)_{2} \mathrm{CO}_{2}$ (ammon. carb.). Urea is present to a certain extent in the blood when the horse is at rest. Exercise changes this partly into hippuric acid.

870. The functional changes in the body produced by work cause urea to be changed into hippuric acid. Hence it will be seen that exercise is necessary to diminish the chance of the horse suffering from rheumatism and gout. These are partly due to an excess of ures in the blood. Urea is decomposed, as stated above, and hippuric acid is decomposed by bacteria (see Chapter XVII.) into various solids, as mentioned above. The ammonium carbonato is again split up into water, ammonia gas and carbonic acid gas: $\left(\mathrm{NH}_{4}\right)_{2} \mathrm{CO}_{2}=\mathrm{H}_{2} \mathrm{O}+2 \mathrm{NH}_{2}+$ $\mathrm{CO}_{2}$.

Ammonia has a very bad effect upon the eyes and lungs of the horse. It destroys all lesther by dissolving the fat that leather contains, thi: leaving the leather at the mercy of damp and 
wet and the action of bacteria. The life of leather is extremely short if it is deprived of its fat, hence the importance of keeping leather well greased.

If leather is luung in a badly ventilated stable it will rapidly deteriorate, however well it is greased. Ammonia also lias a bad effect on polislied and varnished woodwork, suclı as carriages, because it dissulves the varnish. In fact, carriage builders use ammonia to remove varnish from carriages.

As stated above, dung contains comparatively few impurities if kept dry and unmixed with uther fluids. But if mixed with alkaline fluids, as ammonia, it produces certain ferments (Chapter XVII.) which have the power of dissolving albumen and mucin, of which the horse's hoof is chiefly composed; hence the importance of picking out the horse's hoofs two or three times a day and of keeping them dry. It will be clear that the hind feet of mares will be more liable to become affected, which I have found to be the case. Clean alkaline water has a slight action on the horse's hoof. Dung soaked in ammonia is an excellent medium for encouraging the growth of bacteria. (Sec "Tetanus," Secs. 619 and 795.)

371. Light.-Abundant liglit is of the utmost importance, for several reasons. If stables are not well lighted with windows the horse's eyes will become seriously damaged. Many shying horses are made such by boing kept in dark stables, and, upon first coming out into the light, are unable to see properly. If horses live for long in such stables, their eyes will be affected permanently. Liglit is also necessary to assist in keeping the air in the stable pure; light is an enemy to most disease-producing organisms. Dirt, darkness and dampness are the three friends of the disease microbe.

Light, again, is necessary to enable the groom to see dirt and to see that every portion of the stable is kept scrupulously clean. The owner call at once discover any neglected places if there is good light in the stable. While working at night, the stable should be lit with ele-tric incandescent light, which is the best form of artificial light for night work, but this is of little importance compared with daylight. Light assists the groom only, but daylight is necessary to maintain good health. All fittings should be gas-tight stable fittings, and all wires should be laid in gas-tight iron pipes to prevent the ammonia from acting upon the rubber insulation and metal work. Switches should be where they will not be struck by horses that pass near them. The lights should be hung where they will not be knocked by the horses, and should be at least $9 \mathrm{ft}$. from the fioor. In some placrs, where high buildings surround the stables, skyiar'sts (wirdows in the roof) are necessary, but these must not take the place of the other windows $:$ lich are necessary for ventilation. If, however, it is only possible to have skylights, then these must be made to open. The inlet in such cases must come through ventilating shafts on the side of the wall, $6 \mathrm{ft}$. or $7 \mathrm{ft}$. from the ground.

372. Roofs.-Open roofs are cheaper and allow more air space for the horse; but where the extrs expense is not considered, it is far better to have a ceiling above the stable, $12 \mathrm{ft}$. from the ground. The roof can then be built as low as possible above the ceiling, allowing a sufficient slope for drainage off the roof, or it can be built higher to give room for a hayloft or room (P. 84). The advantages of a ceiling are that with it the temperature of the stable is more easily kept consistent. Without a ceiling, the stable becomes hot in summer and cold in winter. A ceiling also keeps the stable much more free from dust. The ideal roof is a ferroconcrete one, because it is fireproof and waterproof, and lasts a long time; but it is very heavy.

The ceiling should always be made of ferroconcrete, and in this case it would be quite safe to have the room above built of wood. Wooden shingles should never be used on a stable, as they are extremely dangerous from a fire point of view. Slates, tiles, or metal shingles should be used. As stated above, ferro-concrete should be used wherever possible as a protection from fire, and in this case the ventilating shaft would be made of sheet metal ; the trap at the bottom should be fireproof also.

373. Walls.-A stable wall should be made of solid brick or concrete, with air space inside (P. 86); this is necessary to keep the stable warm in winter and cool in summer, and to prevent damp from reaching the inside of the stable. There should be a row of ventilating bricks in the outer wall, $1 \mathrm{ft}$. or $2 \mathrm{ft}$. above the ground, and another row beneath the eaves of the roof, thus connecting the outside air with the inside space and keeping it well ventilated. In Canada, where the winters are cold, the total thickness of a stable wall should be $2 \mathrm{ft}$., $1 \mathrm{ft}$. outside the space and 8 in. or $\&$ in. inside, which should keep the stable quite warm in the coldest weatlier. The inside and u!'tside walls are joined at intervals by means of small iron rods.

The inside surface of the stable wall should be of glazed bricks or tiles. Glazed bricks are the best (P. 88). Good smooth cement must be used to "point" the bricks. These walls can then be scrubbed and kept absolutely sanitary. If the walls are not made of glazed bricks, they must be made of ordinary bricks or cement, and should be whitewashed every three months with chloride of lime. As bricks, especially glazed bricks, are expensive, a cheaper kind of wall can be made of concrete. The same air space 

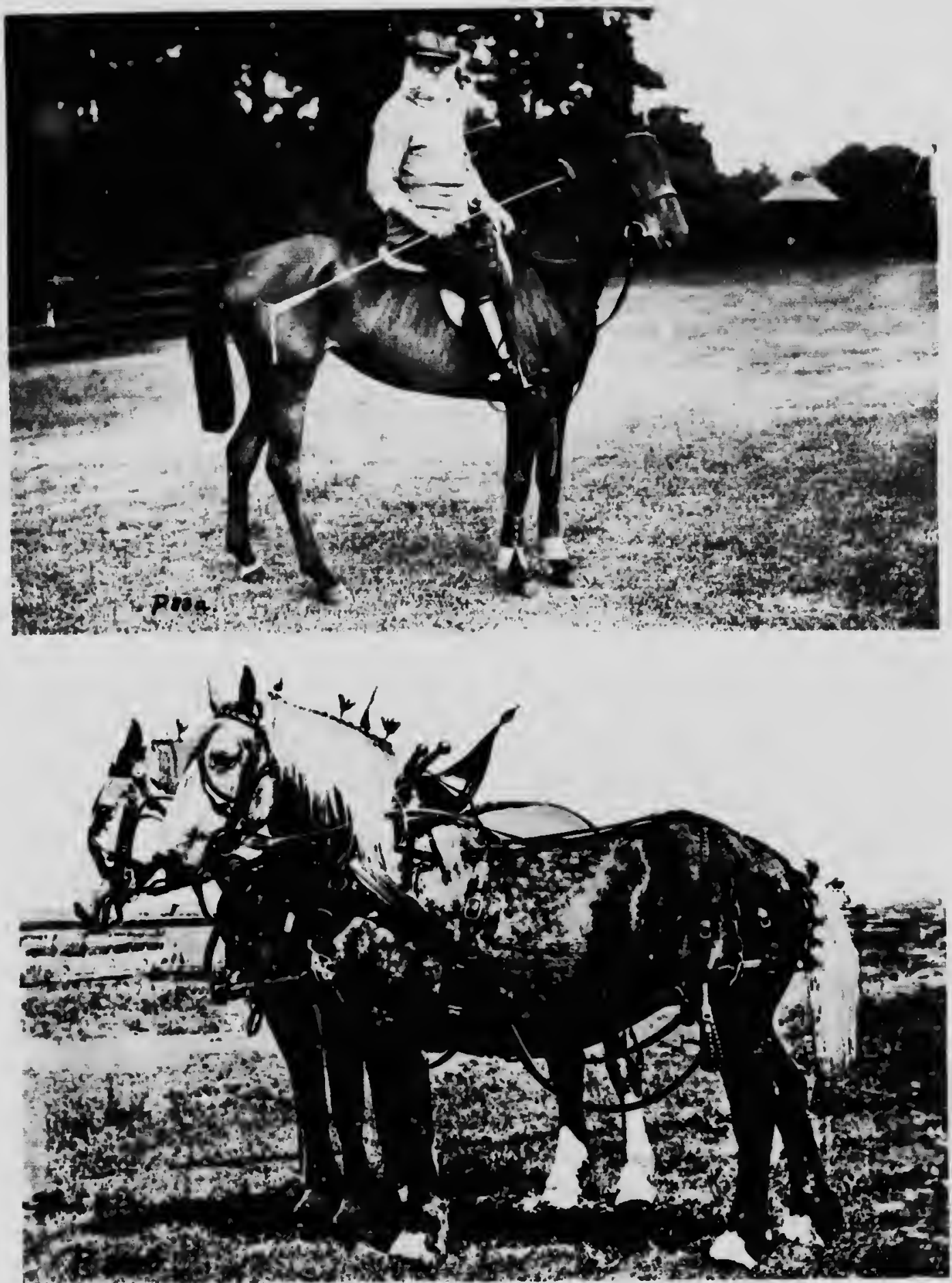

a. Earl Harrington on his Polo Pony at Ranelagh. Copyright Photo: Newspaper Illustrations, London. b. Champion Percheron Pair. "Iennells" and "Abella." Property of Messrs. Upper. North Portal, Sask. 

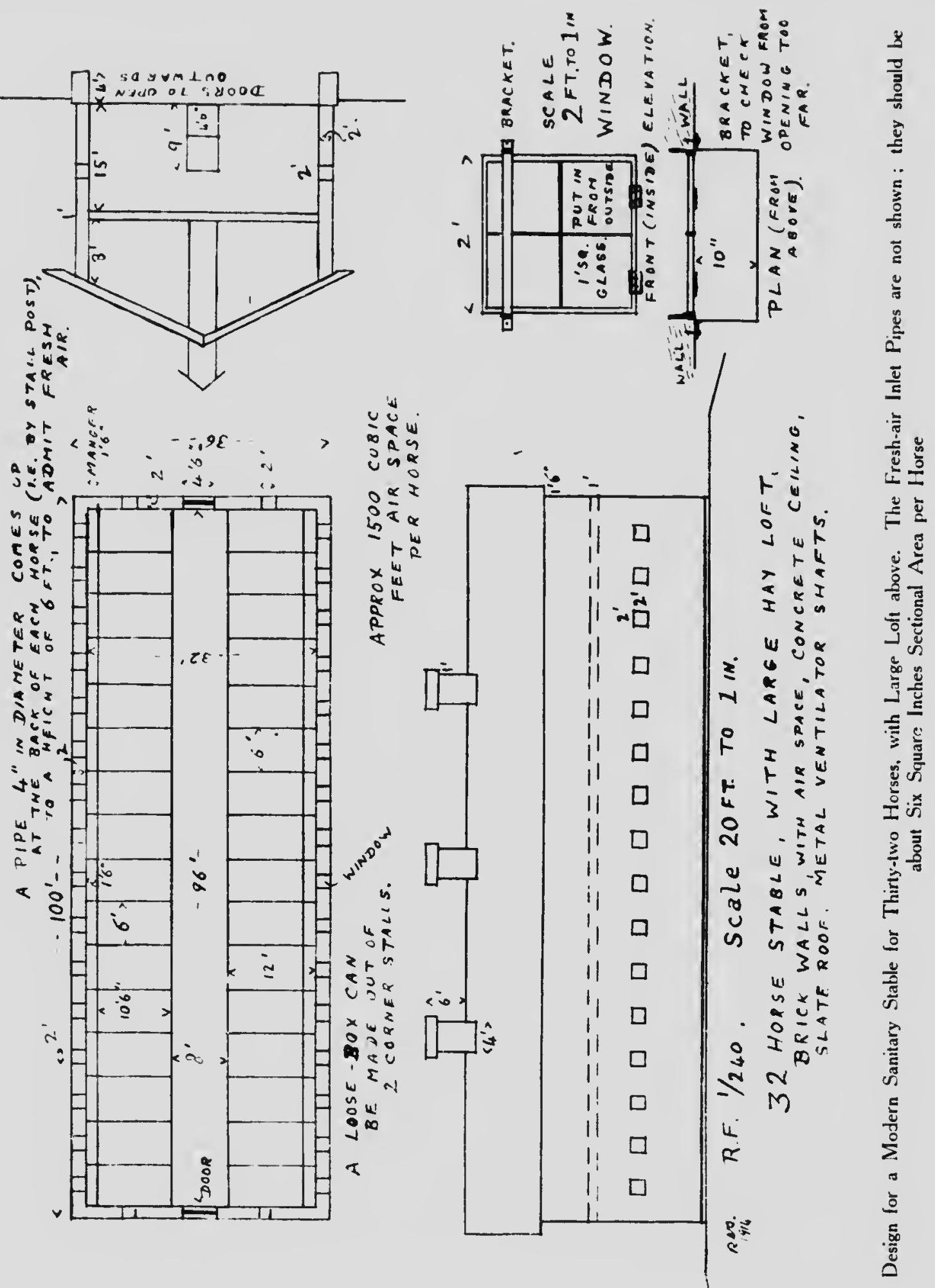
must be left. Concrete is absolutely flreproof, and looks well if lines are made on the outside wall representing blocks of stone. Inside it can bo painted with washable sanitary paint. The best colour for the inside of the walls is white or light cream.

374. Doors and Windows.-In Sec. 365 windows have been discussed. They should be made of metal fireproof frames and casements. If they are arranged as shown il. P. 84 there is no need for any ropes, which are always liable to break; small plugs should be used to regulate the extent to which the window is opened. Doors must be in halves, must be $4 \mathrm{ft}$. 6 in. wide, and should open outwards. Their total height should not be less than $8 \mathrm{ft}$., and the neight of the bottom half not less than $4 \mathrm{ft} .6 \mathrm{in}$. The bottom half should bolt very securely, to prevent a loose horse from getting out when the top half is open. The doors should be made of hard wood, or may be covered on both sides with metal to make them fireproof. The frames should be of metal if it is desired to make the whole stable fireproof. Hard wood is almost as fireproof as thin metal sheeting.

The latches should be such that a loose horse cannot use his muzzle to open the door, but must also be of such a pattern that in case of a fire in the stable they can be opened immediately. In Canada double doors are often used in the winter; in this case the inner door should be put up in the winter and should open inwards. $A$ space of about $\boldsymbol{g}$ in. should be left between the two doors. With good thick doors and properly constructed stables two doors should not be necessary.

On the floor, inside each door, a ridge of concrete an inch high should be made to fit tight against the bottom of the door to prevent cold air and rain beating in under the door.

Sliding doors that are hung on wheels that run on a rail are very convenient where large doors are necessary, such as in coach-houses. They do not sink, as heavy doors on hinges are liable to do ; they are, of course, fastened on to the ouiside of the wall.

375. Coach-houses. - Coach-houses and harness-rooms should be constructed very similarly to stables, except that a fower number of larger windows are better than the smaller stable windows. Strict attention must be paid to ventilation, but the temperature should be kept up to about $60^{\circ} \mathrm{F}$. in winter. Without perfect ventilation the carriages will become mouldy and the varnish will become spoilt; the harness will also suffer considerably. A fireplace, properly constructed, should be placed in the hamessroom, to keep the room dry in damp weather, and also for the purpose of boiling water and cooking food for the horses.

876. Floors.-Floors should be of tiles, or, preferably, small bricks, as shown in P. 87.
These consist of small rectangular $: c k s$, with grooves running in one direction only. If the grooves run in both directions it is more difficult to brush out the dirt.

The slope of the floor of eacl stall must not be more than 1 in. in $3 \mathrm{ft}$. ( 1 in 36 ); therefore, in a stall $6 \mathrm{ft}$. in width the drop in the centre would be 1 in. The slope from front to rear should be 1 in 80 ; therefore, in a stall $10 \mathrm{ft} .6 \mathrm{in}$. in length the drop would be $158 \mathrm{in.} \mathrm{If} \mathrm{the}$ slope is greater it will be uncomfortable for the horse, and if very great it will be injurious. The bricks or tiles must be laid so that the grooves run in the direction of the line shown.

The gangway or passage between two rows of stalls should be level unless surface drainage is used (see Secs. 377-8), and the tiles should be laid so that the grooves run across the passage. The floor should be at least $3 \mathrm{ft}$. thick, and should be at least $1 \mathrm{ft}$. above the outside ground. There should be $2 \mathrm{ft}$. of loose brick and tiles, and 9 in. of good concrete on top, and about 3 in. of tile or brick above the concrete.

The approaches, or ramps, leading up to the stable doors should be made of concrete, well grooved, or wood with slats across them, and should not have a greater slope than 1 in 10 . They should be about $2 \mathrm{ft}$. wider on each side than the door.

If concrete alone is used as a floor, the groove should be as shown in P. 87. Concrete, however, although cheap, does not make a good floor. Horses are very liable to slip, and the concrete wears badly, especially under a fldgety horse. The grooves are also awkward when calkins are used, as is done during the winter in Canada. In the coldest of Canadian winters the best method of keeping the horses warm is to place wooden floors, already fitted together, measuring $6 \mathrm{ft}$. by $12 \mathrm{ft}$., in the stalls. These floors should be made of at least 1-in. boards, separated slightly between each board, and nailed on cross pieces of 2 -in. by 4-in. scantling. These floors should be laken out daily one by one, and the stall underneath washed down. In stables that have wooden floors the horse should not stand on the main flooring, which is generally made of 2-in. planks, but should stand on an upper hard wood floor made by laying 1 -in. planks across the stall. When these become worn they can be replaced, which is considerably cheaper than waiting for the 2-in. floor underneath to wear through, and does away with the danger of the horse's leg breaking through, which I have seen occur several times. When calkins are used a 2 -in. board will wear through in a few weeks. Single flooring in these cases is extremely dangerous.

377. Drainage.-The stall should be crained as shown in P. 87 .

Surface drains are really the best, as they are much more easily kept clean. They should run 
along the back of each stall at least $1 \mathrm{ft}$. in the rear of the purtitions or heel posts. 'These drains should be made of half-pipes (concrete or pottery) messuring about 3 in. internal diameter. In such cases the floor of the stable must slope 1 in 80 from one end to the other, or from the centre to each end, so that the depith of these drains will remain the same. Metal pipes are very easily broken unless they are thick.

In private stables that are carefully looked after, underground drains may be used. I do not like a centre drain in each stall; a drain behind each stall is far better. This Iraiu should be covered with strong iron gratiug, and should lead into a common pipe ruming down under each side of the centre passage. The passage can be made level, and the drain laid deeper as it passes along to allow for the correct slope of 1 in 80 .

If the drains run into a sewer pipe outside, a perfect type of gully-trap must be used to prevent foul gas getting back into the stable. With open drains the pipe should run open for at least $6 \mathrm{ft}$. outside the stable, and then into an ordinary underground drain. This open space acts as a trap to prevent gases from the underground drain getting into the stable.

After the bedding has been taken out to air in the morning, e"ery stall sliould be washed down with a 2 per cent. solution of creolin, or suitable antiseptic, and scrubbed clean with a hard stable-broom. Then a good quantity of 5 per cent. creolin should be poured down the drains if they are underground. The half-pipe open drains must be scrubbed clean as well as the grooves in the floor.

378. If peat moss or sawdust (Sec. 223) is used, drains are sometimes not used at all; but us peat moss is not good for horse's feet when it is soaked with the wet from the floor I cannot recommend this method of stable sanitation. There is no reason at all why upstair stables, if made with ferro-concrete floor (or any kind of foor for that matter), should not be properly drained.

A loose box (box stall) ';ee Sec. 386) should drain in the centre if under . sund drains are used, the floor sloping about 1 in 80 towards the centre. If surface drains are used, the floor should slope 1 in 80 to the back, and slightly towards the centre, similar to an ordinary stall; the partition at the side next to the passage must be raised an incli or two at the bottom to allow for drainage underneath.

379. Damp.-A horse always keeps more healthy in a dry stable; dampness, besides being one of the friends of disease-producing microbes, causes various ailments, such as rheumatism, debility, etc.

In addition to having the walls llamp-proof (Sec. 373) and the floor 3 ft. thick and made as described in Sec. 376, the site of the stable is of great importance. In a drained city the site, of course, does not mattor mo much. Sand is the best soil on which 10 build a stable, and clay is the worst. The stable should be on high ground, if possible. If on low ground the site should be drained.

After the foundations lave been made (see P. 86), and three or four layers of bricks have been completed above ground level, a layer of pitch should be laid over the wholo thickness of the wall as well as over the inner and outer walls. This prevents the damp from rising up the wall. $\Lambda$ stable should be isolated from other buildings where possible; if this is done, more fresh air and light will reach it. If circumstances permit, its longer sides should face the east and west, so that both rows of windows (if there are two rows of liorses) will get a little suin. If facing the worth and south, one row would get all the sun and the other none at all. The practice of building a stable with a coachlouse as a wing on one side, and harness-rooms, etc., as a wing on the other, is not a good plan, as it sluts out light and cuts off the free supply of fresh air.

For purposes of drying bedding every day, a concrete floor, of $1 \mathrm{ft}$. in thickness, rooled to keep rain off, should be made close by. It is not a good practice to lay it under the outside of the windows, as the gases arising from it will re-enter the stable.

880. Sanitation.-Drainage and sanitation are discussed in Secs. 377-8. If glazed brick walls, concrete ceilings, and iron mangers are used, whitewashing will be unnecessary. The partitions, if of wood, must, however, be scrubbed and painted with Hall's sanitary distemper, alabastine, or other suitable washable sanitary paint every six months. The concrete ceilings should also be mopped with an antiseptic solution every three to six months. Walls and ceilings that cannot thus be wushed, such as ordinary brick or plaster, should be whitewashed at least every three months, or painted with sanitary paint every six months.

381. Wooden stables, which are dangerous on account of the risk from fire and are also very insanitary, must be whitewashed all over inside at least every three months. Wooden mangers should be scrubbed out with hot water and soap every month, and brushed over witl whitewash. Creolin, or strong-smelling antiseptics of any kind, must nct be used, nor must water-buckets be used to put these chemicals in, as horses very much object to their odour.

If a diseased horse has boen using the manger, it must be made thoroughly antiseptic by being painted two or three times with chloride of lime.

Buckets and watering-troughs must be kept scrupulously clean, but not have creolin or carbolic put into them. The best antiseptic to use for mangers and buckets, etc., is bichloride of 

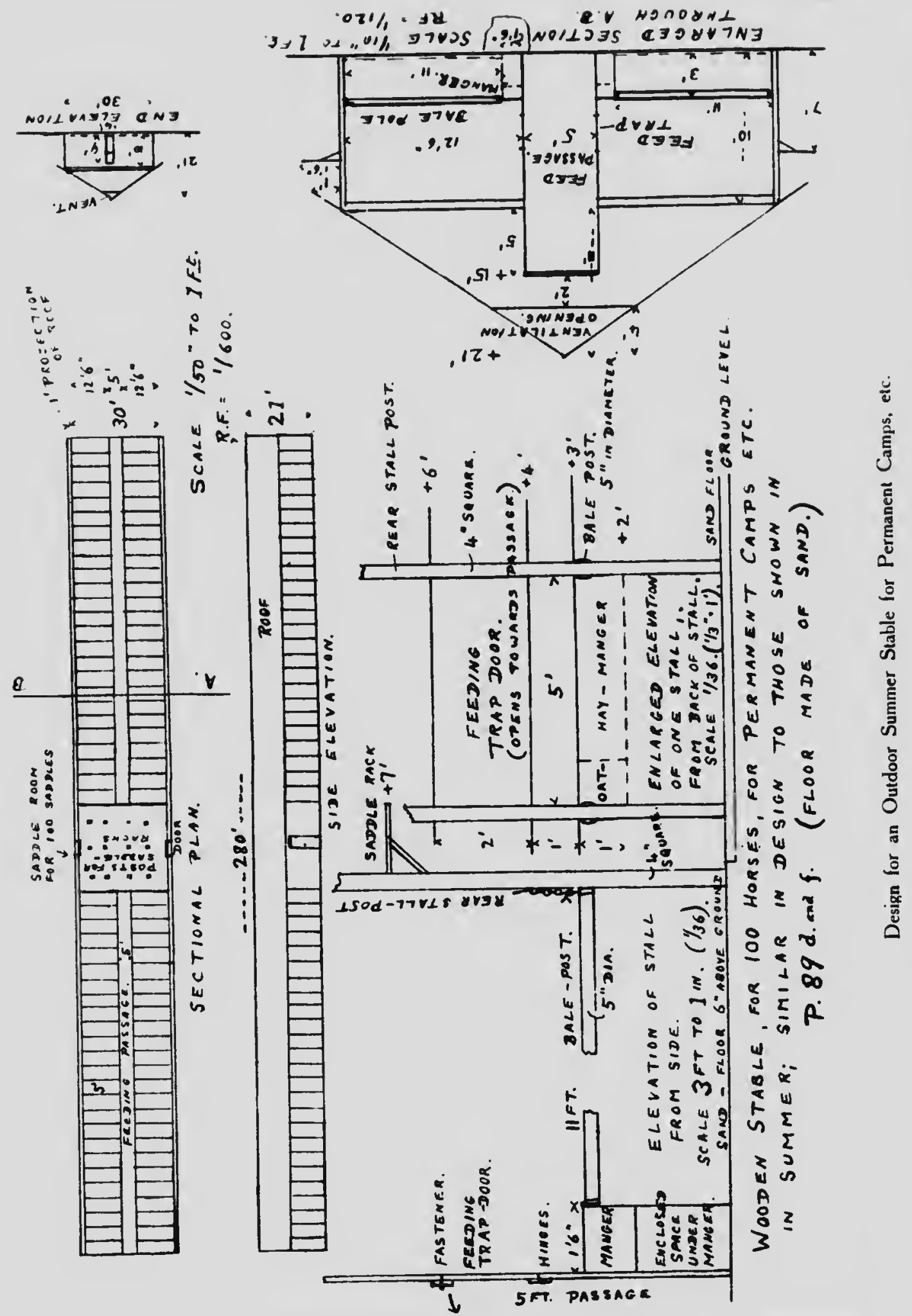
PI.ATE 86

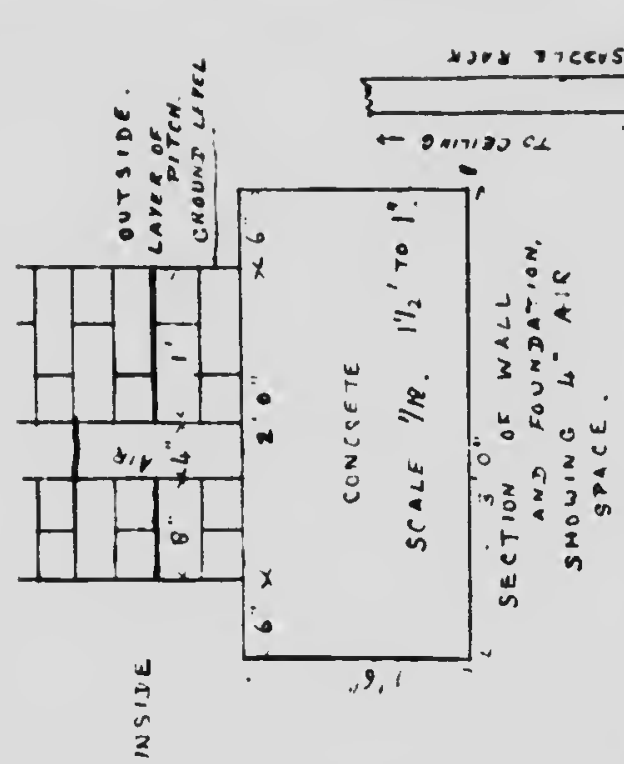


PLATE 87

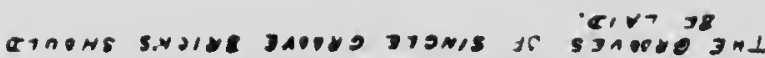

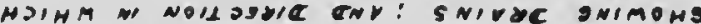

'77VLS C38007J 31SDJNOS y0 NV7L
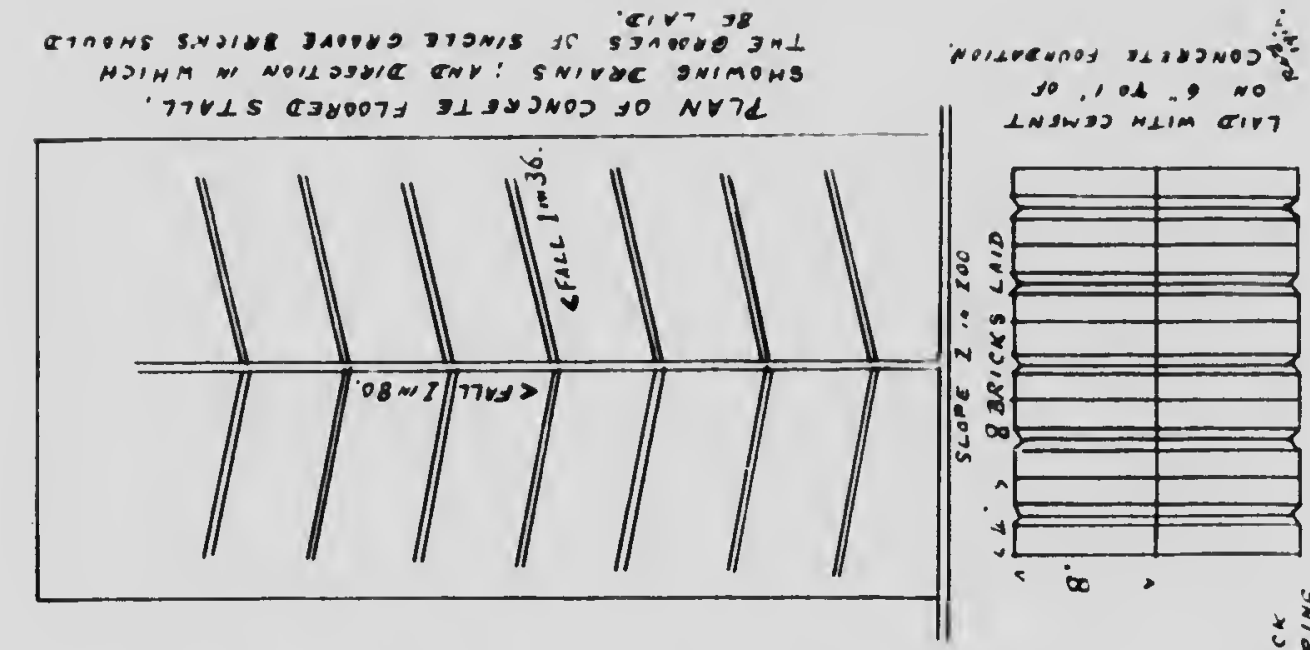

To,

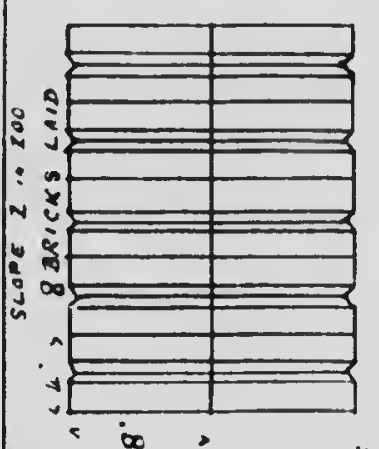

$+2$

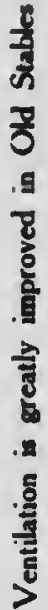

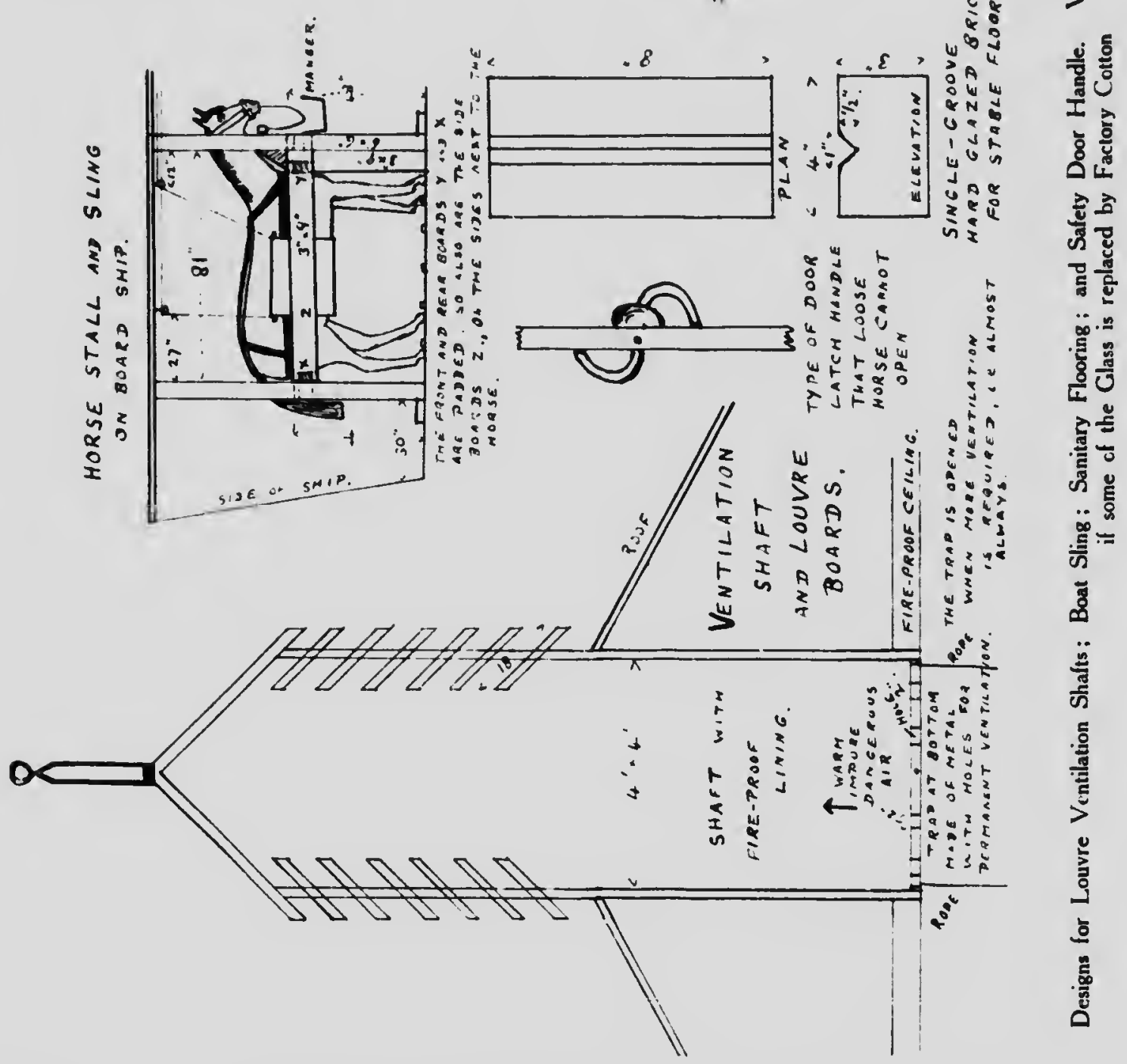


PIATK: $\mathrm{NR}$
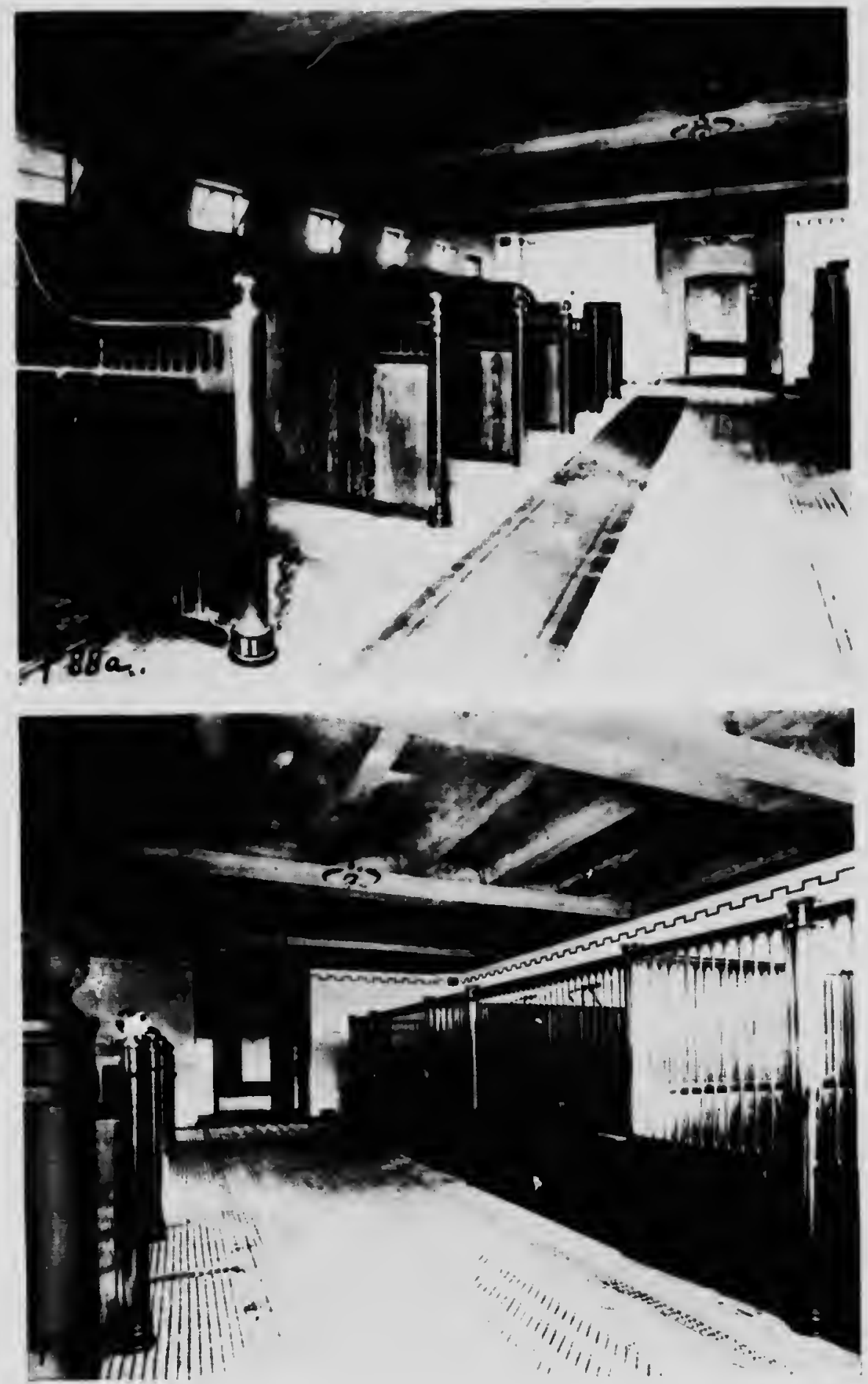

Interior of the Stables of Cros. Sir Henry Peilatt. Toronte, who kindiy sinplied the thotos. a. The S.alls. b. The fosese Boxes or Box stails 
mercury $\left(\mathrm{HgCl}_{3}\right)$, but thorough washing out with clean water aflerwards is imperative, as bichloride of mercury is poisonous. It must not be allowed to come in contact with steel or plated bits, harness, etc., as it will rapidly damage the articles by depositing mercury.

382. Heating.-Horses keep in best health if the stables are not too warm; on the other hand, the stable should not be too cold. If the stable is constructed as laid down in this chapter, it will, even during a Canadian winter, keep warm ellough for horses if they are well blanketed. The heat given of from a horse's body keeps the temperature of the stable from falling too low. The temperature of the stable should be about $50^{\circ}$ to $60^{\circ}$ Fahrenheit. II, however, it is found that in order to keep the stablo properly ventilated the temperature in very cold weather is very low, which might occur when a large stable is unly partly filled, hot-water pipes should be laid under open gratings running along under the centre passage. The stables shown in $P$. 88 are heated by steam pipes, which are controlled automatically, and are therefore never allowed to get too warm.

One great advantage of heating large stables that have few horses in them is that the groom will be less liable to close the window and ventilators to keep up the temperature. A careful horsekeeper would, of course, keep too strict a supervision over the stable economy to allow such practices to exist.

I regret that very many stables in winter in Canada are kept warm, and often hot and stutiy, at the expense of fresh air and consequent good health of the horses. Most of this is the result of faulty stables, combined with the belief that horses can keep well in a loul atmosphere.

388. Precautions against Fire. - I strongly advocate ferro-concrete ceilings, brick walls, and hard wood partitions. If a fire starts, it will not be able to spread far, and may even be confined to one stall. The greatest precautions should be taken in laying electric wires; safety fuses should be connected in every circuit. These fuses should bo either outside or in melal-lined boxes.

Peat moss is, of course, the safest bedding from a fireproof point of view, but, as described in Sec. 223, is not the best bedding.

Smoking must never be allowed in or near any stable, nor in the harness rooms, unless they are detached from the stable. With concrete ceilings, should a fire break out in the loft or in the room above, it cannot spread to the stable below. Upstair stables (so common in cities) should have a sloping "chute" or gangway, made of ferro-concrete, leading to each storey. The gangway should be large enough to allow each storey to be emptied in a fow seconds in case of fre. Wooden gangways are extremely dangerous. Elevators are of little use in case of fire, unless they are very large and fireproof. Even then the shaft is apt to increase the fire by acling as a chimney. The footlng on the gangway is best obtalned by cross-I ies of metal bolted into the fooring.

384. Every stable should have at least one fre extlnguisher hung on the wall. In long stables there should be one at each end. The best kind of extlnguisher is the large brasscylinder type, which has only to be turned upside down to produce a rapid spray of liquld. The spray proceeds from a nozzle attached to the end of a 2 -ft. rubber tube. The contents consist of a strong solution of sodium carbonate and a boltle of strong sulphuric acld; upon the cylinder being inverted, the acid gains accese to the solution, and produces carbonlc acid gas. This type of extingulsher must be kept from freezing, and it is essential that it slould be lested every six months.

385. Improvements 10 old Stables.-Badly constructed stables can be greatly improved by having proper windows made and proper ventilators, drainage and flooring put in. Sanitary mangers can be put in, and many other little items can be fitted or altered to make the stable more up to date without much expense. Ample fresh air, good light, good drainage, and absolute cleanliness are the essentials for keeping a horse in good health. The reason that private horses are so often sick, compared with other horses, is because of the love the coachman has for $\because c a$, unhealthy stables and the want of ext Working horses are often stabled in insa, ry stables, bul, as they get plenty of work and are out of doors during the greater part of the day, their health does not suffer to the same degree.

386. Stalls and Boxes. - Work-horses, as a rule, are kept in stalls. Horses are generally all right in stalls, provided they are $6 \mathrm{lt}$. wide and that the horses get plenty of exercise, but idle horses are much better in box stalls (loose boxes). Sick horses should, if possible, be put into a loose box. All private stables should, therefore, have two or three loose boxes. These are not so necessary in work-horse stables or in cavalry stables, because any horse, upon becoming sick, is put into an infirmary or sick lines. I notice, however, that most large stables in large cities have a couple of box stalls at one end.

One disadvantage of a loose box is that a horse is very liable to rub its tail $-a$ not uncommon habit with idle horses, especially if the grooming of the tail is neglected. (See Secs. 198-9.) A loose box should measure $11 \mathrm{ft}$. square. A stall should measure at least $6 \mathrm{ft}$. wide and $11 \mathrm{ft}$. in length. A ring should be placed about $5 \mathrm{ft}$. Pron the ground, over the manger, for tying up the horse when he is being groomed or if required during part of the day, 
a*, for instance, when he is harnessed up, wail. ilig to go out.

There should be a ring on each heel post 5 it. from the ground, with chains or ropes attached, with syiring liooks on the free end to fisten to the heal, collar or bit when the horso is turned with his tiil towards the manger. 'l'his is known as tying the horso to the pillar chains.

387. Partitlons should be made of haril wood, such as uak or hard maple. which are much more fireproof llian any kind of soft wood. They should be painted with sanitary paint. Partitions are marle alniust fireproof if they are covered on buth sides with sheet iron or zinc, which should be painted, but the objection is that the metal is liable to become warm, and sharp pieces may stick up and cut the liorse.

The heel or bale posts and the top of the partitions should be made of iron. The heel posts should continue right up to the ceiling: then a saddle rack can be altached to them. Sadullery and harness, of course, should not be kty)t in the stable, but in the harness room. Work-horse hariess, which gets hard wear in any case, is generally hung in the stable on the ricks fastenell to the bale posts.

The stall partitions are better as shown in P. 80, withoul openings near the top). But the siles of a loose box next the centre passage shoull be closed for ift. up and open for the top ? $\mathrm{ft}$. This partition, if $\mathbf{B} \mathrm{ft}$. high, is sufficient for any-sized horse, but the partitions in between the stalls should be at least $7 \mathrm{ft}$. near the wall. Low partitions and open-work partitions allow luorses to snap at one another and also contagious diseases to spread. For this last reason, partitions should extend right to the wall, and even be let into the wall. Each stall should be quite separated by the partitions on the ground, so that a fire in the berlding will not spread to the next stall.

388. A goul methoul for preventing horses from getting loose at night, should they slip their head-collars, is to have a rope stretched from heel post to heel post, about $4 \mathrm{ft}$. from the ground. In the stables shown in P. 88 , at night iron rouls are ilrawll out from the insile of each partition right across the centre passage, thus converting each stall into a temporary loose box. The centre passare betwern the heel posts should be at least $10 \mathrm{ft}$. wide in louble stables and $\mathbf{6} \mathrm{ft}$. in single.

Some stables are constructed with only loose boxes, each loose bo: having its own door, in two halves, opening directly out of doors. This is the common practice for racehorse stables. The only disadrantage is that a stable of this construction is difficult to keep warm in the winter, but from a fire and sanitary point of view they are ideal. The door of an inside loose box should be $4 \mathrm{ft}$. wide, and have a very secure furn of bolt that cannot possibly be opened by the horse, but which can be easily opened in case of fire. The most sultable colour for the partitluns in a stable is a light stain colour.

389. Mangers.-The only kind of manger that is really suitatle for a horse is the all-iron paltern, as shown in $\mathbf{P}$. 83 . This klnd coll. sists of a broad iron shelf on a bracket thut has its outer erlge bent down. On the left is an opening that has the oat bowl resting in it. This bowl must bo movable, 80 that it can be easily cleansed. A simple thumbscrew or other arrangement can be attached beneath to keep it from being knocked out by the horse. The bowl sliould be as near the centre of the stall as posslble, when only bale posts are used instead of partitions between the stalls, to prevent the next horse from stealing the oats. The hay rack must be as deep and roomy as possible. Overhead hay racks are not good, as they cause hay seeds to get into the eyes and mane, and oflen cause trouble.

Hay should never be put into the rack with a fork, but with the arms, on account of the danger of the horse rinning his head on to the fork. Iron mangers should be scrubbed out once a week. The oat bowl should be emptied and cleaned out properly before every ineal. Wooden mangers are destroyed quickly by the horse nibbling at the wood, and require to be continually replaced. They require the utmost sanitary attention. (See Sec. 380.) Zinc or sheet iron-lined wooden mangers, unless very care. fully looked after, rapidly become jagged, and are liable to tear the horse's nose, mouth, or even eyes.

Horses which are liable to rub their manes by getting their heads under the manger should have the manger flled in in front with a close iron fencing, so that they cannot get their heads underneath. This fencing should be easily movable, to allow the space behind to be cleaned out daily. The habit of rubbing the mane is generally a sure sign of neglect in grooming. The old method of filling hay racks from the loft above is a lazy one and a dangerous one, and should not be allowed. Some stables are fitted with a continual stream of water in front of each horse : this is most insanitary, as the water runs past all the horses in a row, the horse nearest the tap being the only one that gets fresh water. If running water is used, then a separate supply must be laid for each horse.

Some horses have a most objectionable habit of knocking their knees against the manger in front previous to being fed or while feeding. They often damage their knees by this trick. A wooden partition should be put up underneath the manger, sloping back a little to the floor, which must be covered with sacking or other padding to prevent the horse from damaging his legs. 

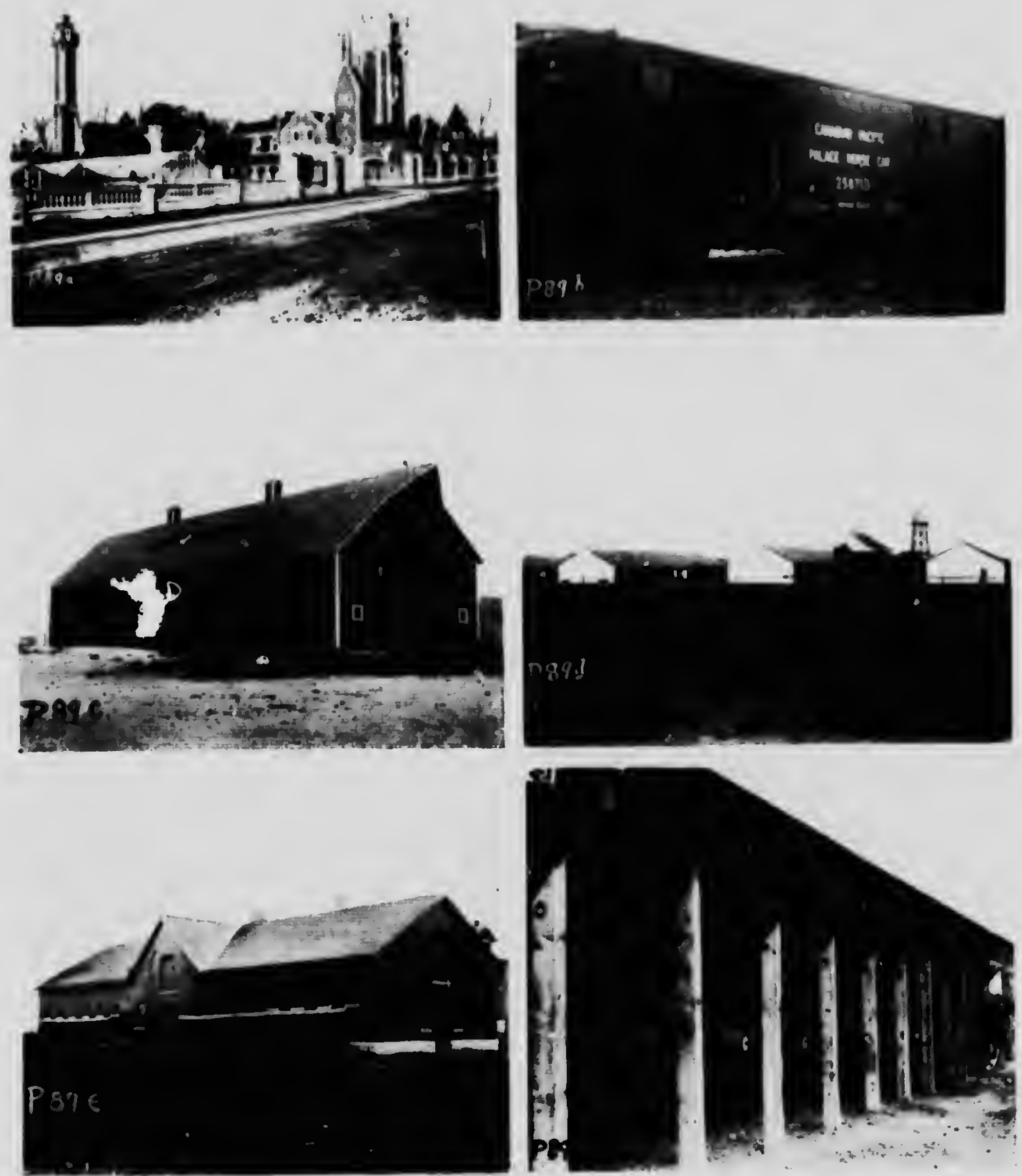

STABLES

a. Exterior of Sir Henry Pellatt: Stables at Toronto. b, Canadian Pacific Railway Palace Horse Car, to hold up to Sixteen Horses: Movable Stalls. A Mlodern Fifty.horse Farm Stable at the Polar Star Ranch, Esterhazy. Saskatchewan. d. Summer Stables for Regilar Cavalry at Pelawawa Camp. Ontario (Exterior). f, Close View of One Side (see Plate 85). E. Military Stables at Rujal Mtilitary Collegr. Kingatos. Ontario. Courtesy: Commandant R.M.C. Photos. a, Galbraith. Toronto. Remainder by the Author 
PI. ITI: 90

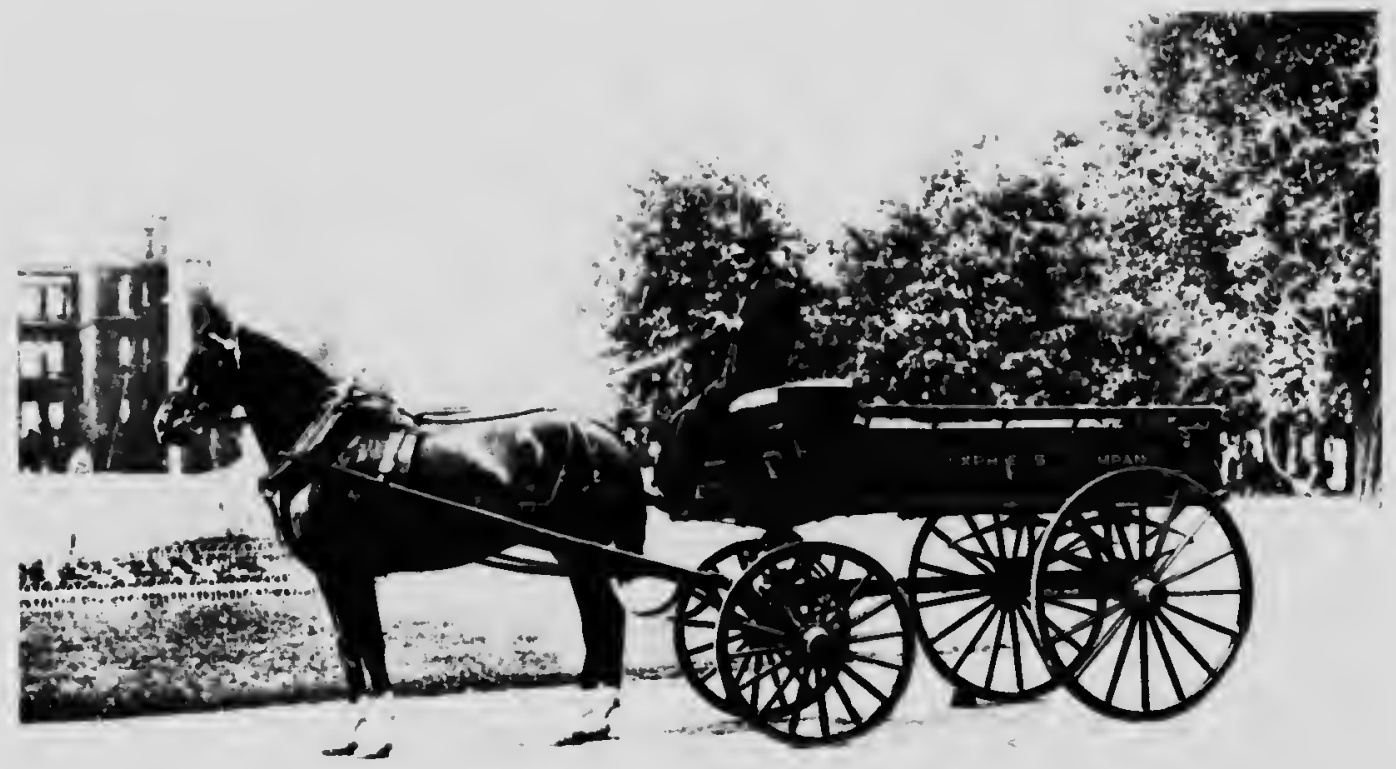

Pqoa.

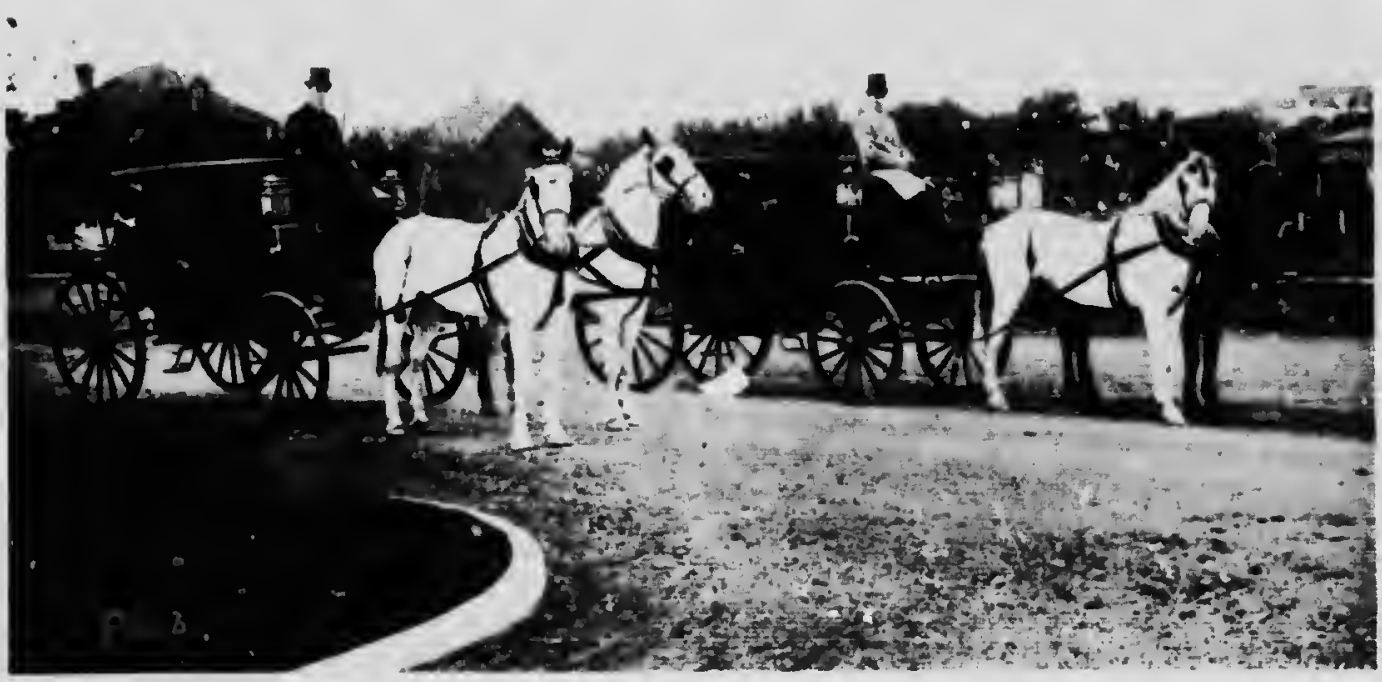

CANIDHANARED HORSES

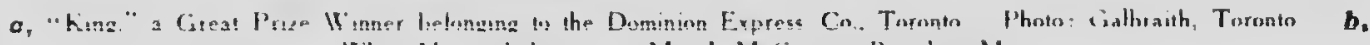
While Horses belengeng to Mr. J. McGiregor, Brandon. Man. 
A similar vartition to this is also necessary to nrevent horses from knocking their heads against the manger after eating hay, etc., lying on the floor at the front of the stall. I remember one lorse stunning ilself by raising its head suddenly and accidentally knocking it against the manger. A horse without a mane is very liable to do himself serious harm. For the above reasons, i.e. rubbing the mane and knucking the head, the addition of a wooden or metal framework or nartition under the manger is highly advisable.

390. Water Troughs.-Water troughs should be of iron, similar to the mangers, and should be emptied and thoroughly scrubbed out every day. Nothing should be dipped into the troughs. Buckets should be filled from a tap, placed at the end of the trough (outside). The trougl should be either filled from a tap or by a stopcock. It should be emptied through a large tap. In countries where the winter is cold, water troughs should be filled just before being required by a hose pipe laid on from the stable and emptied directly after use. Plugs are not very advisable in water troughs, as horses are liable to knock them out.

Public drinking troughs should not be used if other water can be obtained, as there is a certain risk of picking up infertion; but, as described in Chapter IV., the risk of picking up disease in such cases is so slight, as is shown by statistics, that it is almost negligible. There are patent antiseptic horse troughs on the market which consist of a separate bowl for each horse, the bowl being refilled before the next horse drinks from it. I thoroughly recommend their installation by city authorities. (See Sec. 153.)

391. The Loft.- Hay and straw are best kept in a loft, or in a separate forage shed. Oats must be kept in a metal or concrete bin, so that rats cannot get at them. In a ferro-concrete stable a bin can be made in the loft with a trap leading down to an iron bin in the stable below. The trap is fitted with a suitable cut-off. Oats should not be kept in large bulk, for fear of becoming heated and causing fire.

392. Tying up Horses. - The best way to tie a horse up is to use a good, strong, smooth, pliable rope with a heavy wooden log of boxwood. For horses that are liable to eat the rope, raw hide straps should be used, as they will never eat them. This rope or strap can be passed through the opening shown in $P$. 86 , which has a brass ring in it to prevent undue wear; or through a wide staple in wooden mangers.

In modern stables the rope or strap should pass in between two rollers just underneath the front of the manger, and back underneath tlie manger to the wall, where it passes over another roller and down close to the wall. The lastnamed roller is sufficiently far from the wall to allow the log to rise and fall without striking the wall. (See P. 86.) With these arrangements there is also no danger of the horse's legs becoming entangled with the rope, strap, or weight.

393. Chains and iron logs are very noisy, and disturb other horses at night. A horse must be tied up with a rope of such a length that he can lie down on his side stretched right out at night. A most brutal practice exists in some private stables, where the groom does not allow his horses to lie down properly at night. I have been fortunate in discovering cne or two such cases. Every horse-owner should be on the lookout for such matters.

Horses which at night are liable to cast themselves while rolling in the stall, by getting a fore foot over the rope, are better if tied up by a chain or rope from each end of the manger without the use of weights, the chains or ropes being of such a length as to allow the horse to lie down properly.

394. Flings.-It is an excellent plan to have strong rings hung from the ceiling or from small girdles below the ceiling over one stall in the stable, for the purpose of attaching slings, in case a horse breaks his leg or requires to be slung up for any other purpose. P. 87 shows the principle upon which a sling should be made and fitted. It will, of course, be necessary to have a movable wooden partition made to fit close to one side of the horse, because a $6-\mathrm{ft}$. stall would be too wide in which to place a sling properly. The width of the stall can be adjusted to any size by the temporary partition, which should be padded on the one side. Some thick blankets should be hung over the partition on the other side of the horse. Horses are sometirnes put into slings without support on each side, but this does not allow for much comfort.

395. I am indebted to Sir Henry Pellatt, of Toronto, for the photographs reproduced in P. $88,89 a$. The stables are indeed a modern equine palace, and the finest I have yet seen. They are fireproof, being built of stone and brick, with ferm-encerete floors and ceilings. They arc absolutely sanitary, being lined with glazed tiles. Over each horse's head there is a large window which opens inwards; it is hinged at the bottom. The stalls are of full width, and the drains are covered with strong cast-iron gratings. The walls are white in colour, to givo as much light as possible. Each stall is converted into a loose box at night, as previously described, and the stables are automatically kept at any temperature and artificially ventilated.

P. $89 b$ shows the exterior of a modern palace horse car, belonging to the Canadian Pacific Railway. It holds sixteen or fewer horses, or twelve very large draught horses. It has water and feed troughs. It weighs, when empty, $52,000 \mathrm{lb}$., and carries $30,000 \mathrm{lb}$. (15 American tons). The internal dimersions are : length $40 \mathrm{ft}$. 3 in., width $8 \mathrm{ft} .9$ in., height $8 \mathrm{ft}$. $4 \mathrm{in.}$ 


\section{CHAPTER IX}

\section{SURGICAL DISEASES, LAMENESS, TEETH AND CONFORMATION}

396. Lame'ne'ss.-The commonest ailment that the horse suffers from is lameness. Lameness is the outward sign of inward pain. It is very often the result of bad horsenanship, and can, therefore, be put down to pure neglect. Such cases as sprails in the hunting field or a horse slirping on an icy road are, however, nsually examples of accidental lameness. It might be safely said that 90 per cent. of lame horses become lame through causes which are preventable, such as bad shoeing, over-driving, over-loading, over-riding, bad jumping, careless riding or driving (as on slippery pavements in in heary plonglied flelds), abuse with sticks or uther cruel usage, under-feeding, leaving the system in a weak state to resist strains, etc. etc. The horse's balance is easily upset by improper shooing.

Lame horses are seldom found in the possession of the most careful horsemen, who naturally have only the best grooms. Percivall defined lameness as "the manifestation, in the act of progression or while at rest, by one or more of the limbs of pain or weakness, inability or impediment." A horse becomes lame when pain or inability (such as stiffness) causes him, during movement, to diverge from permitting the nornal distribution of weight upon his limbs.

Irregularity of gait is not necessarily lameness. For example, "bridle lameness" consists in the lorse placing one leg about six inches farther forward than the other while trotting, and is due to bad training; this is often difflcult to overcome afterwards. On the other hand, a horse which is lame in both fore or both hindlegs may go apparently sound. Lameness, as a rule, consists in decreased action in the painful limb. Stringhalt, which is a nervous affec. tion due chiefly to an increased involuntary contraction of the peroneus muscle (the tendon of which passes down on the outer side of the hock), is not strictly a lameness, because, as a rule, no pain or inconvenience is felt.

397. The commonest form of lameness is that due to pain, and not to stiffness or other mechanical hindrance; pain is, more often than not, the result of a sprain. A sprain must not be confounded with a strain; the latter is far less serious, and nsually consists of a temporary over-exertion which has been placed on an organ that recovers itself rapidly after this exertion has been removed. A sprain is a certain injury caused to a muscle, ligament or tendon, the result of excessive work enforced upon it by tension or torsion, or the result of an application of work repeated for too long a period; it consists in the stretching of the fibres of the muscle, ligament or tendon, and generally in a breakage of some of these fibres, or the fibres may be broken away from their hold upon the muscle, bone or tendon to which they are attached. Almost all sprains could be cured if rest were as much considered as it should be. Local treat ment is only secondery. Permanent injury is generally the result of trying to keep a lame horse "on his legs."

398. Muscles are of two kinds: red voluntary (striated), and pale involuntary (non-striated), with the exception of those of the heart, which are red and involuntary an striated. Voluntary muscles are those that are generally sprained they consist of bundles of minute fibres laid longitudinally side by side. At the attachment of a muscle these fibres are very securely connected by fibrous tissue to the bone, etc. The end of the muscle that has least motion is called its origin, whilst the other end is called the insertion. The tendon that is attached to a muscle usually has the same name as that of the muscle.

Ligaments are of two kinds: inelastic white fibrous, and yellow elastic. The inelastic ligaments chiefly join bones together and form joints ; they will not stretch. It is, therefore, these that wsually suffer when a severe strain $i$. placed upon a $\operatorname{limb}$, etc. These ligaments are composed of strong white fibres bound tightly together like suspenrion-bridge cables. The elastic ligaments can be stretched considerably without injury. The chief ones in the horse are the inteispinous ligaments in the region of the neck, which allow so much movement in a horse's neck, and the large ligamentum nuchæ, which extenus from the withers to the poll (occipital bone), and supports the great weight of the horse's head. This ligament is particularly weil developed in horses with heavy heads, as Clydes. In the Suffolk Punch and Percheron the heavy appearance of the neck is due to the fbrous crest. (Sec P. 136-131.) The ligamentum nuchæ is also well cueveloped in the horned 
PIATE YI
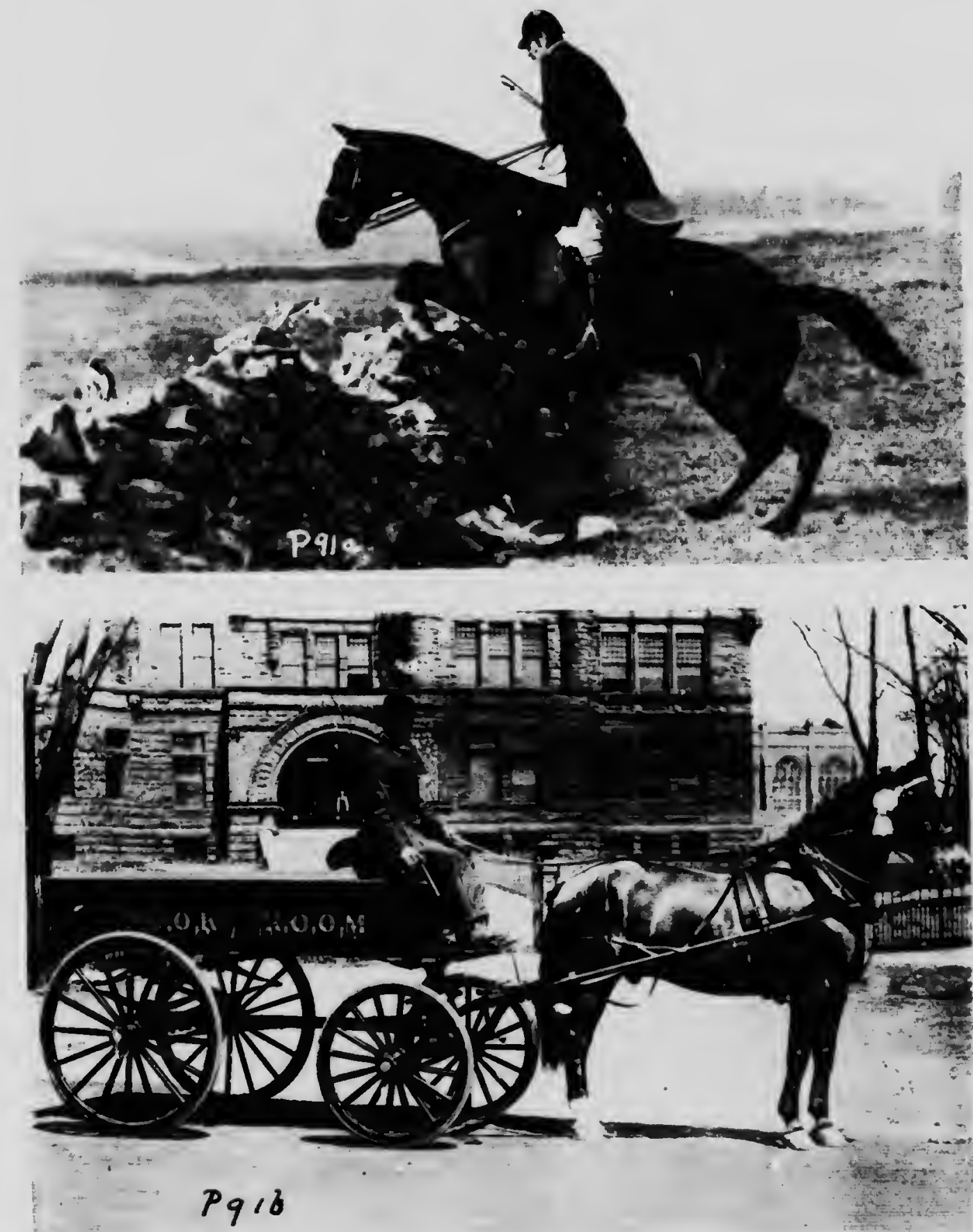

a. Hunting in the North of England. Photo: Topical Press Agency. London. Courtesy: Sperting and Dramatic News. b. Prize -winning Ontario.bred Harness Horse Courtesy: Methodist Book and Publishing House. Toronto 


\section{PIATI: 42}
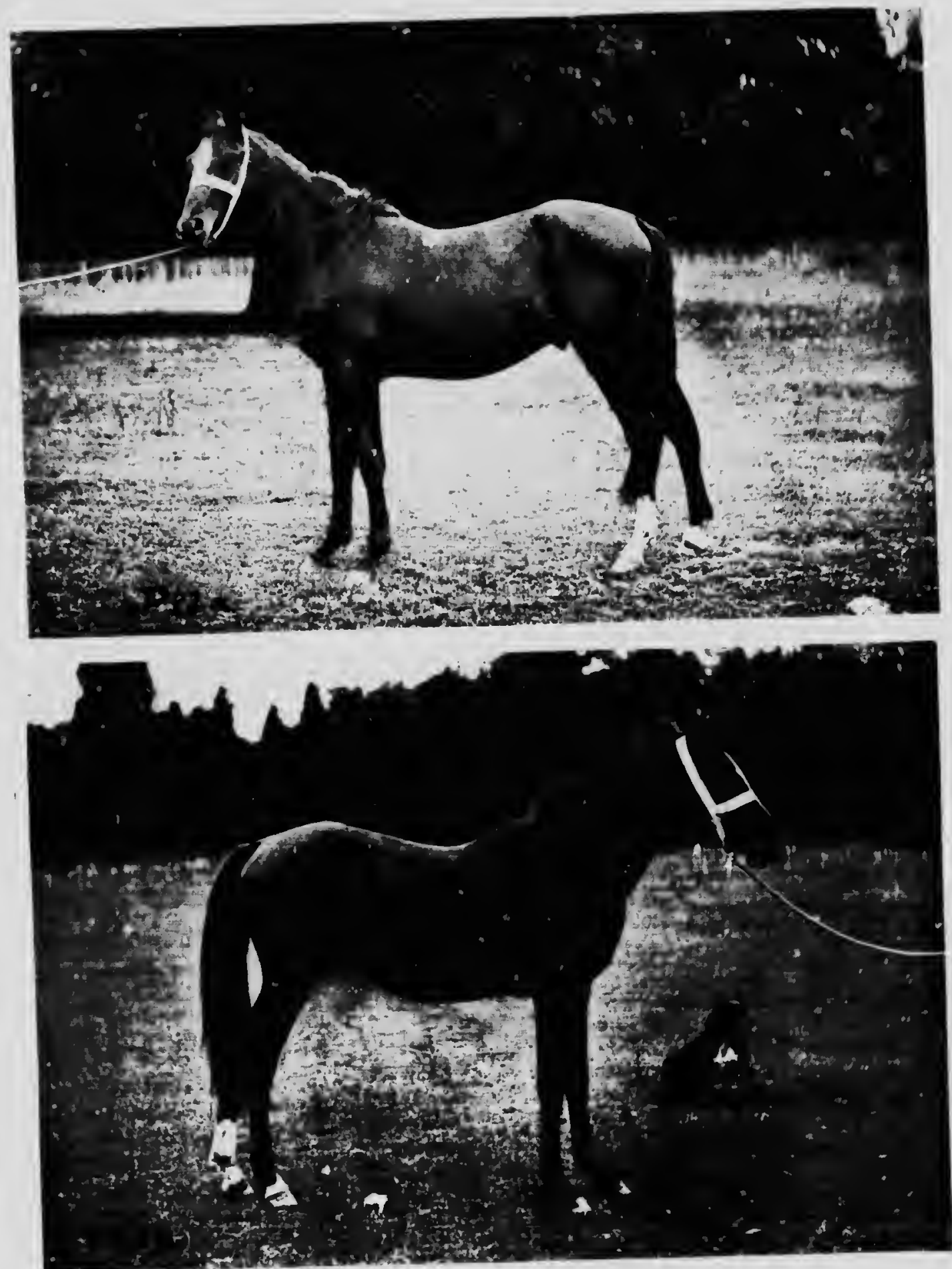

Ares. Savile. Arabs from the Famous English Nrab Farm at Thames Dition, Surrey, Surrey 
stag, whose head is naturally heavy. When a horse wishes to lower his head, the muscles in the under portion of the neck draw the head Jown, the superior muscles rolaxing.

399. The joints of the limbs are securely formed by very powerful ligaments, with the exception of the scapulo-humeral joint between the shoulder-blade and arm, which is kept together chiefly by muscle and by vacuum. These ligaments consist of interosseous ligaments, which are inside the joints, and binding ligaments, which are on the outside. There are also annular ligaments that form loops to keep the tendons in place, and also capsular ligaments that do not hold a joint together, but merely keep the synovia, or joint oil, from running out of the joint. In a broken knee one or more of the capsular ligaments of the carpal joints may have become ruptured or torn, but, as a rule, a bursa of the tendons lias become broken.

Tendons are strong, non-elastic, white, fibrous cords that usually have an activo function; they generally connect the distal end or insertion of a muscle to a bone. A tendon is like the wire of a railway signal, and the bone the signal arm, the signal cabin being the muscle, the electric wire leading to the cabin being the nerve that runs to the muscle.

400. Stmicture of the Bone.-Before passing on to the detection of lameness it will be well to give the reader some idea of the structure of the bony frame. Bone is a bluish-pink, hard, insensitive substance that gives attachment to muscles, acts as pillars of support, encloses cavities and protects vital organs, forms joints and acts as levers.

Diseased bone is highly sensitive; dead bone is yellowish-white in colour. Bone is composed of two substances: animal matter, which is very elastic, and mineral or earthy matter, which is very brittle, but gives hardness and rigidity to the bone. If bone is placed in diluted hydrochloric acid for some minutes the mineral matter becomes dissolved out, leaving an elastic mass of the same shape as the original bone. On the other hand, if bone is burnt in the atmosphere the elastic animal substance will become burnt, leaving a brittle earthy mass the same shape as the bone.

In the embryonic state bone is composed entirely of animal matter. As the animal advances in age the percentage of earthy matter increases until, at very old age, the bones become quite brittle. At birth the foal has a considerable amount of earthy matter in its bones; it is able to stand on its legs without their showing any sign of bending within half an hour of birth. But in the case of the human there is not sufficient earthy matter to enable walking for one to two years. Children's legs become bowed through using them before the bones have sufficient earthy matter in them.
In the adult horse (five to six years of age) the average composition of bone is one-third animal and two-thirds mineral or earthy matter. The liardest bone in the body is the triangularshaped ear bone (petrosal), which has 93 per cent. mineral matter. The ribs are softer than the limbs. A foal one year old has about 55 per cent. animal satter and $\mathbf{4 5}$ per cent. mineral at ten years it would have about 25 per cent. animal and 75 per cent. mineral. When bones are too soft and liable to bend too much, phosphates of lime and iron should be given in the feed.

401. Histology of Bone.-Bone is composed of a hard outside layer of compact tissue and a soft inner portion of cancellated tissue. Normally, this latter is never found at the outside of the bone. The thoroughbred, that has small limbs, has a great deal of compact tissue in its bones, to render them sufficiently strong, whilst the heavy draught horse has a greater amount of cancellated tissue. Compart tissue is composed of minute honeycombs. Inside all long bones, such as those of the linabs, is a loollow space, the medullary canal, which runs throughout most of their length. In this canal we find bone marrow, which is red in early life, but yellow in the adult. Inside the honeycomb of the com. pact tissue there are little spaces called lacunæ and little canals called canalicula which join the little spaces together. The average diameter of these canalicula is $1-7,000$ th of an inch. The lacunæ contain bone-producing cells.

402. Cancellated tissue is composed of thin plates, which contain lacunæ and canaliculæ. In between these plates aro spaces called cancelli, which cuatain bone marrow. The cancellated tissue is chiefly at the extremities of the bunes of the limbs. It gives bulk without increasing weight; the larger the end of a bone the greater will be the area for attachment of muscles and ligaments.

Blood-vesse!s pass in between the various layers of the bone tissue and also amongst the marrow, thus supplying food to the bone cells and tissue. Every bone is surrounded by a thin, very vascular skin (the periosteum), except at the articular ends, which are covered with articular cartilage. The periosteum also has an outer flbrous, thick, noll-sensitive layer. In a joint the two articular cartilages of each of the ends of the bones forming the joints are lubricated by synovia, which, as stated above, is kept in place by the capsular ligament that surrounds the joint. This ligament is lined internally by the synovial membrane that secretes the synovia.

The periosteum is very easily damaged; when ". "s happens, the bone underneath is very liable to die. Thus, when a bone is damaged, rreat care mist be taken to prevent necrosis, nr death, setting in. In the periosteum there is a 
network of arteries and veins that also supply bloor to the outer portions of the bone. The periosteum thus nourislies the bont, protects it, and gives attachment to muscles and ligaments.

Bones are classifled into four classes: long, as the thigh; flat, as the shoulder-blade; short, as those of the knee and hock; and irregular, as the vertebre. Most of the thirty-three bonus of the horse's head are flat bones.

403. As stited above, in feral life the foal's bones are at first entirely cartilaginous; at the sixth or seventh week after conception the cartilacinous bumes berin to form. In the arlult all the bones ale profuerly ossifted.

In speaking of the various sides or surfaces of the various parts of a horse's anatomy the fullowing ternis art useul :

The upper surface is the proximal, superior, or dorsal.

The unller surface is the distal, inferior, or rentrul.

The front surface is the anterior.

The hind surface is the nosterior.

The internal surface is the surface neartst to the median line, which is an imaginary vertical plane drawn through the centre of the horse from head to tail. Thus the internal surface of a foreleg would be that surface nearest to the other leg. The exl-rial surface is that farthest from the median line.

404. Sprains.-The commonest sprains are those of the muscles of the shoulder and hindquarters, the back tendons of the forelegs, the suspensory ligaments of all the legs, and the back ligament of the hock joint (curb). Tendons are more often sprained than muscles. Ligaments and tendons may possibly break, but are more liable to tear, especially small portions of them here and there, so that the whole thickness is not broken across at any one point, but they will not stretch, except under prolonged strain.

When a tissue is sprained, the blood vessels become gorged with blood, and the circulation becoming impeded, there is more or less complete stagnation of blood. There is also, as a rule, blood and other fluid which has escaped from vessels which were ruptured at the time that the fibres were broken. The presence of this blood and other fluid renders the part tense, hot, and painful, by interfering with the circulaticn, or later, by giving rise to adhesions (fibrous bands which will more or less interfere with the movement of the part). In the treatment of sprain, therefore, our first efforts should be directed to checking the accumulation of the fluids and hastening their removal. For this the best treatment that can be appiied is the com. bination of pressure and massage. Pressure must be even and equally distributed. An ordinary bandage hetween the knee and fetleck thos little good, because it only applies pressure to the front of the bone and to the back of the tendon. The method of applying pressure bandages has been described in Chapler V., Secs. 217-9. The inportance of applying pressure bandages and giving much massage must be fully realised to treat sprains with success. However severe the sprain or other injury may be, if even pressure is applied immediately, it will do a great deal of good. Bandages should be taken off every twenty-four hours, and the part vigorously massaged for at least twenty minutes with a suitable lubricant, such as compound liniment of camphor (powdered camphor 5, oil of lavender $\frac{1}{4}$, strong ammonia 10, alcohol 40 , parts by weight). The legs should then be raised, i.e. bent, and straightened alternatnly for at least six times to remove stiffness and to stimulate blood flow, which is essential to encourage rapid healing. Then the pressure bandages must be put on arain. If this is done morning and evening the cule will be more rapid. As the sprain improves, the joints must be passively worked for a longer period without requiring any muscular effort from the liorse.

405. The most valuable cure for mechanical injuries is that described above, i.e. massaging with hand or fingers and passive exercise; the time needed for repair of the injury will be greatly shortened by assisting Nature in her efforts. Purgatives act beneficially by diminishing the congestion in the blood vessels and lymphatics, in that they remove much watery fluid and foreign substances, drawing the blood to the intestines, and therefore away from the congested part. A free supply of good cold water assists greatly by keeping the blood in a pure state and by removing foreign substances from the system. Horses cannot be given too much water. Small doses of nitre, by stimulating the action of the kidneys, which are the filters of the body, cause removal of much foreign matter. Nitre should be given very seldom in cold weather.

Laxative foods, such as green food, carrots, etc., by cooling the system (as they contain very little albumen, which heats the system), and by increasing the action of the bowels and improving the tone of the blood, do much good. Hence if a horse is in gross condition he should be given only a little food for several days.

406. External A pplications.-External applications are sometimes of use. Any chemical or drug that causes stimulation or irritation when applied to a part will increase the blood flow to that part. This is the functional use of massaging. Hence if we wish to remove inflammation from an internal part of a leg or the body, we apply an irr'int to the external part and draw the blood andy from the inflamed part to the surface. Hot-water applications will cause increased blood flow to the surface, but should not he applied for more than a few minutes at a time. The old system of several hours' hot-water 
PLATE. 93
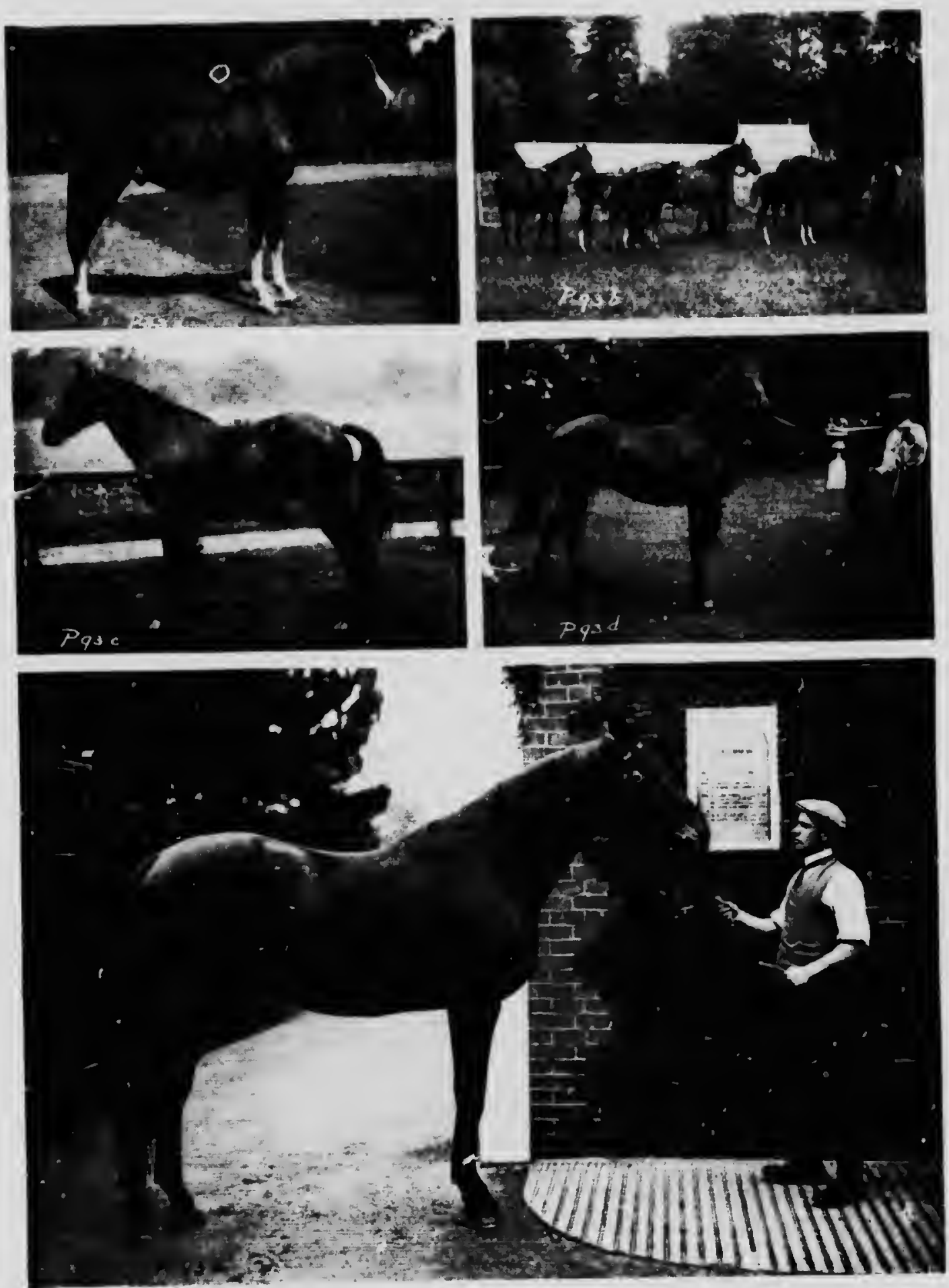

$a, b, c, d$. Types of Arab Horses at the Arab Sud Farm at Thames Diton. Surrey, ihe property of Hon. 'zo. Savile.

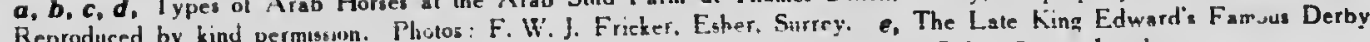

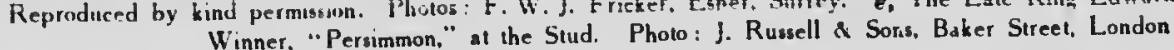



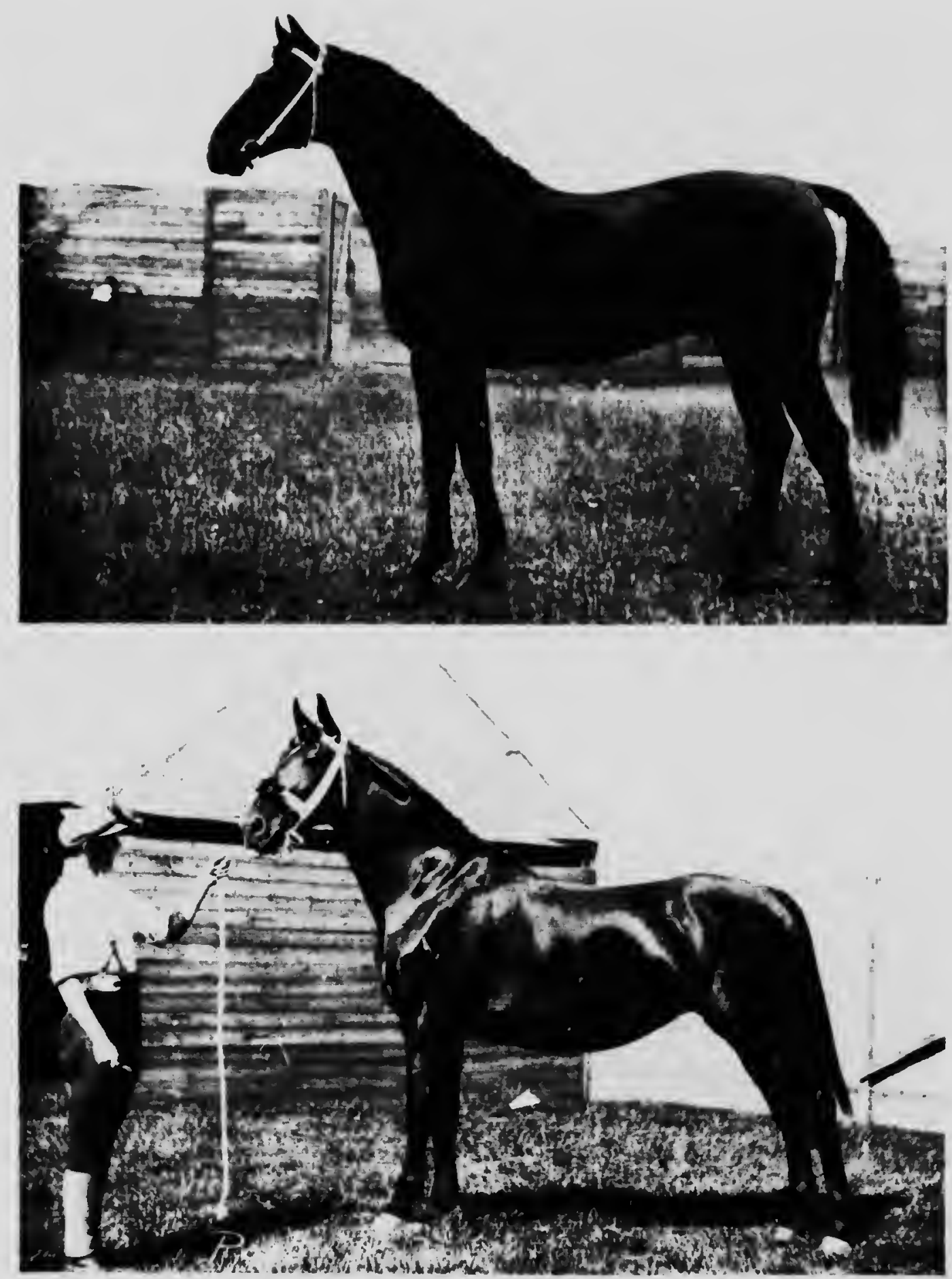

THE ENGLISH COACH HORSE

a, Cleveland Bay Siallion "Rillington Sensation," First, Royal Show, 1913, b, Cleveland Bay Mare "Woodland Briar," Phosos: C. H. Parsons 
fuluentations did little good except to relieve pain by acting as a sertative. On the other hand, it was liable to do considerable harm by softening the tissues, thus increasing the exudation of fuid from the capillaries.

Cold water, ice, or refrigerant lotions, as ammonium chloride, chloroform, ethyl-chloride, ther, anil hydrochloric acid, etc., cause contraction of the tissues and produce pressure that checks the exudations from the capillaries; but in acule inflammation they will check the fow of blood, and as blood is necessary for vital repair, cold water must never be applied until the in. flammation has been removed from the part. Under most favourable conditions the above applications are never so beneficial as proper massage and mechanical pressure, which method is the only satisfactory one for removing inflammation. But if massaging is done, it must be done witl energy for a long period; it is useless unless it is done for fifteen minutes at each application.

407. External Counler-irritanls. - Ether, chloroform, copper sulphate, iron perchloride, tincture of iodine, liniment of belladonna, cantharides, ammonia and water, and alcohol, when evaporation is prevented.

\section{Stimulating Liniments.}

1. Spirits of ammonia. Methylated spirits.

Oil of turpentine.

of each, 1 oz., add water $5 \mathrm{oz}$., mix, and make liniment. If opium, $1 \mathrm{oz} .$, is alded, it is good for sore parts.

2. Camphor. Chloral hydrate.

of each, 1 oz., rub well together in mortar, and the ingredients will form into a liquid.

3. A B C liniment.

Liniment of aconite.

Liniment of belladonna.

Chloroform.

of each, 1 oz., mix well.

4. Camphor, 1 oz.

Alcohol, $4 \mathrm{oz}$.

Liquid ammonia fort., $2 \mathrm{oz}$.

Oi! of linseed, 1 pint.

Mix and make liniment.

5. Compound liniment of camphor (see Sec. 404).

Any of the above counter-irritants ir stimulating liniments must be well applied with good hand rubbing and finger working for twenty minutes.

408. Blistering, Firing, and Massaging.-Blistering on bony exudations is of very little permanent use ; fring is usually more beneflcial. The amount of good gained by either in many cases is slight, but in some it is considerable. In most cases more good could he derived by resorting to thorough daily massaging and using a suitable liniment as a lubricant and aid to stimu- lation. Too great importance cannot be laid on scientific massaging.

From an expert massaging can be learnt by a groom in a few hours suídciently well to enable hinı to be of great value when his horses get sprained or require massaging for other reasons.

Captain Hayes says : "The beneft oblained ill many instances from flring is undoubtedly due to the absence of severe work which it necessitatates." The strongest advocates of fring allow that they only expect 50 per cent. of cases to benent. Severe blisters, as a rule, will do more good, and, generally, massaging still more. This applies to sprained tendons and sprained sus. pensory ligaments and sprained muscles. Other pensory ligaments as curb, bog spavin, thorouglpin, and bone or jack spavin, are usually better cured by blistering. There are a great many patent medicines on the market that practically take the place of fring, and there are likewise a great many which are a swindle.

The success of any treatment usually depends on a long rest of from six weeks to three months, or lor.ger. I have come across scores of horses that have been fired and blistered with scarcely any benefit, and feel confident lliat many of these cases could have been cured at home by scientific massaging.

409. Blistering.-The part must be clipped, but not too closely, then it must be greased with dripping fat or other animal fat around the actual spot to be blistered (and not over it), especially below it to prevent the blister from running down. The blister is then rubbed in for from three to ten minutes. The lorse must have a cradle put on its neck, or be tied up short, to prevent it from biting the part, and other precautions must be taken to prevent the horse licking the part when it commences to smart, as it will in four to six hours. When the action is well marked it must be watched, and when it is considered that sufflient irritation has been caused, i.e. in twelve to twenty-four hours, the part must be gently washed with warm water part must be rubbed gently over the whole.

The grease must be rubbed .. every few days. In any case the part must be washed and well greased thirty-six hours after application, and if the effect is not suffcient the treatment can be repeated in two weeks. It is, however, always best to rub a good blister in for ten minutes, and when sufficient irritation is caused, i.e. when the part becomes very hot and swollen, the leg must be washed and greased as explained above. Strong measures cause less suffering in the end, and do more good than half-hearted ones.

410. Blisters.

1. Strong blister (use with caution).

Oil of croton ... ... ... .. $30 \mathrm{~min}$

Mercury biniodide ... $\ldots . \quad \ldots 2 \mathrm{dr}$.

Oil of turpentine $\quad \ldots \quad \ldots \quad \ldots 2 \mathrm{dr}$.

Parke Davis vesicant, add to make $2 \mathrm{oz}$. 
Rub in lor fifteen to thirty minules. After twenty-four to thirty-six hours wash off aul grease well with antisentic animal fat, $\because . g$. larcl and oil of encalyptus.

2. Mild blister.

Mercury biniodide

Cautharides powder

$1 \mathrm{ilr}$

Lard, to make $2 \mathrm{oz}$.

Rub in as in No. 1.

411. Firing.-The part should be clipped, but not too closely. Local anasthesia should always be resortel to, because firing a horse without using any form of aurestletic is barbarous, and the operation cannot be carried on properly unless the horse is kept quite still. Cocaine is gelerally used. (S'C' Chapler XVI.) When the part is properly anasthetised, the irons must be applied almost at a white heat. Firing is either done with a sharp edge, forming lines close together, kllown as line firing, or with a point, forming a nuinber of small punches close together, known as pin firing. The cross-firing should never be done, because the part enclosed by the crossed lines will have the blook supply cut off. These parts will eventually die and come off. As firing is done to increase the blood supply to the part it would be contradictory to stop the supply to a portion of the part. Before the action of the cocaine has stopped, about ten minutes after the operation, the part must be well greased with an antiseptic grease, such as antiseptic lard. An antiseptic should be used, because the burnt part readily absorbs infection. The part must be greased morning and night. With a local anasthetic there is never any need to use ropes for securing the horse.

It is inadvisable to blister or fire on the inner side of any joint, such as the front of the hocks, or behind the knee, or at the back of the pasterns.

412. Dict.-As stated above, the horse must be dieted when suffering from a severe sprain. On no account must heating foods be given, but green food, mashes, and plenty of water, and a teaspoonful of nitre once $a$ week in the food. If the horse is in 8 well-fed condition, a mild ball of aloes ( $6 \mathrm{dr}$.) should be given. Absolute rest is essential for the cure of all sprains, and the part must be relieved of as much weight as possible; for example, a high heel shoe must be put on for any injury to the back tendons or suspensory lizament. As soon as the horse is able to walk slowly with ease he should be turned out to pasture for six or more weeks. The time the horse is kept in the stable, and the time he is liept at pasture afterwards, depend much on the injury and the length of time that he can be spared. If a horse is valuable, three to six months should be given at pasture for spavins and sprained tendons.

Enlargemen's of a minor nature, such 29 slight curbs, bone spavins, thoroughpin, etc., can often be satisfactorily removed by a mercury and iorline liniment: this treatment does not necessitate the horse being laid up. Enlarged tendons ian be cured also by the following:

\begin{tabular}{|c|c|}
\hline Mercury bichloride ... & $35 \mathrm{gr}$. \\
\hline Potassium iodide & $4 \mathrm{dr}$. \\
\hline $\begin{array}{l}\text { Ionme } \\
\text { Wuter, distilled }\end{array}$ & $10 z$. \\
\hline
\end{tabular}

Ether, to make $8 \mathrm{oz}$.

paint on daily for five days, after clipping the part. Keep the part free from lamp; if it is allowed to get wet the liniment will blister severely. Then wash of and iminerliately grease well. After a week repeat again for five days if necessary.

413. Throwing.-Before many minor cpera. tions, or before a general anasthetic is given to a horse, it is often necessary to throw hinn. The horse must be taken on to a thick bed of hay or straw, so that he will not hurt himself when he falls. He should be taken quite quietly, the hobbles put on him, and then made to fall down get.tly. He must then be secured, someone being at his head to prevent him throwing it about and becoming frightened. The best method of attaching the hobbles is to put on each pastern a shackle with a ring sewn to it; lnese shackles must be very strong, and padded with thick felt. Buckles must be placed on the outside of the legs. A 2 -in. surcingle is passed around the girth and buckled tightly; there must be a ring sewn on each side half-way up. Two long ropes are used, both being put on in the same way. The rope is securely tied to the foreleg hobble and then passed through the surcingle ring down to the hindleg ring, back to the surcingle ring, and is held by an assistant. Another assistant holds the other rope on the other side. When both are ready, a person at the head leads the horse forward a step, and as he raises one foot, both ropes are gently but firmly pulled until the horse drops on to his knees. The ropes then are drawn tight until all the four legs are secure. The rope is twisted around the foot of the hindleg with a double half hitch. The man at the head must hold the head securely all the time the horse is down, and he must make much of the horse after it is down, and avoid causing it fear.

414. Dctection of Lameness.-The horse's attitude in the stable should always be watched. A sound horse stands equally on both fore feet and alternately rests the hind ones. One fore leg may be slightly advanced, but in the sound horse the weight will be equally borne on both. It is better to find out that a horse is lame before starting out to work than when we are away from home. If one suspects lameness, the horse must be taken out on ground that is hard, level, and free from stones. The dishonest horse dealer trots his horse on soft ground.

For the detection of lameness the trot is the best pace : lameness must be acute for a horse to show it at the walk. A horse, like a man, 
PI.ATE ฯ
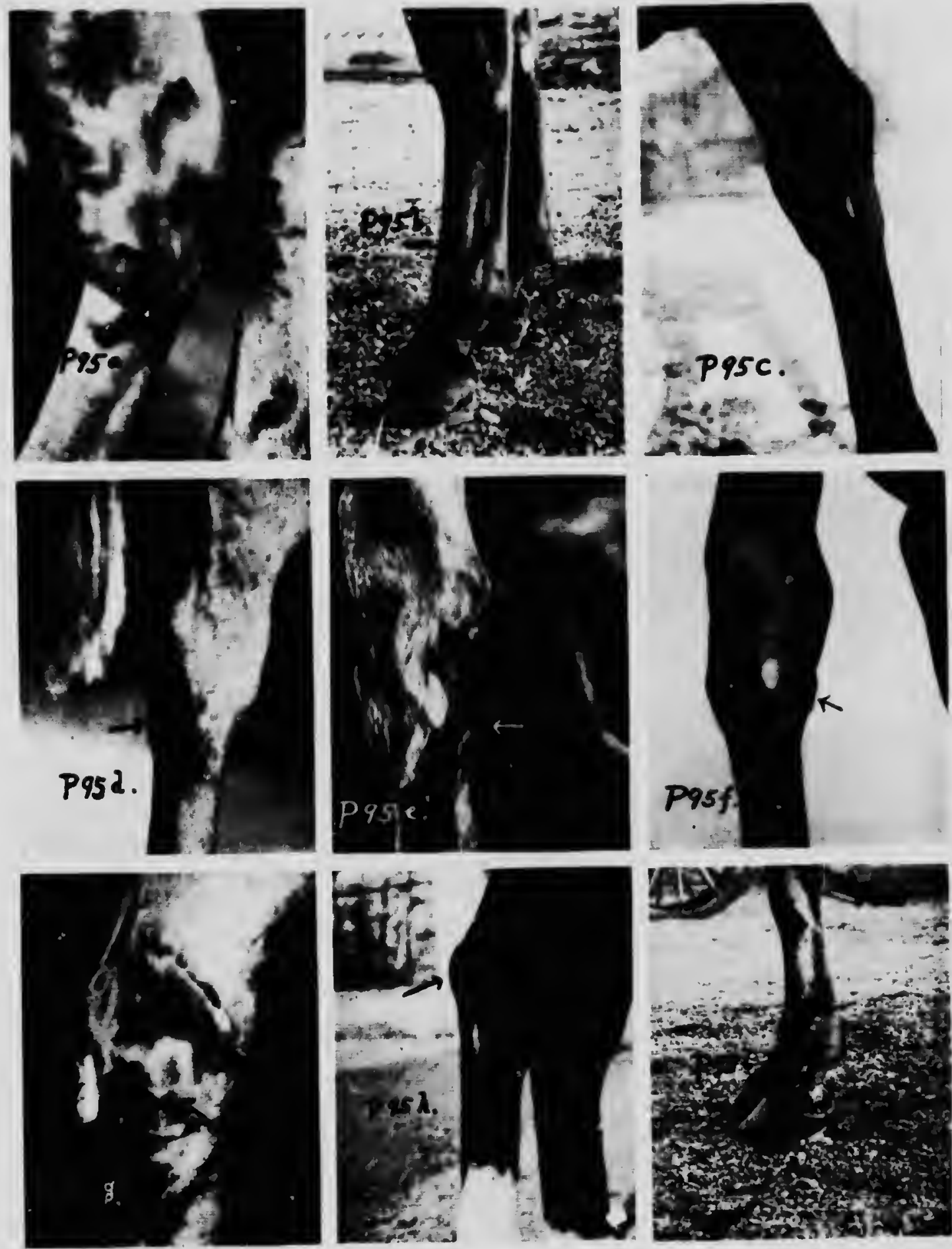

CONFORNATION

a, Curb. bu Clean Ligament a Back of Hock (no Curb). c, Clean Ineide Huck (no Spavinj. d. Eone Sparin or fack e, Bone Spavin. f, Bone Spavin. G, Bog Spavin. h. Capped Hocks. i, Windgalls. Photos by the Author 
I'I ITI: W
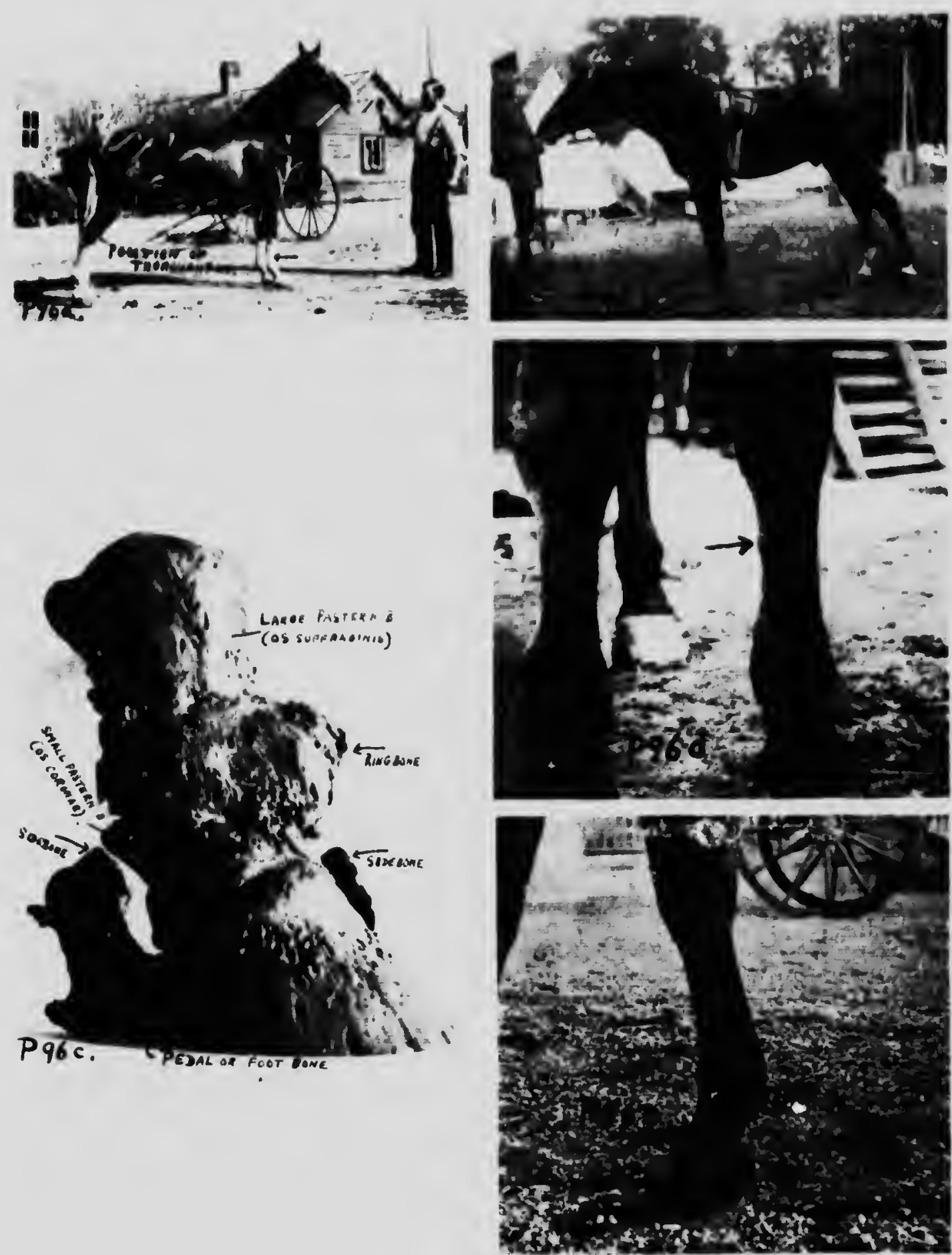

CONFORMATION

a. Giosd Sispensory Ligamem, Fucheg: shuwing ale, the Pusition of a Thoroughpin. Couresy: M. W. U. Pitfeld

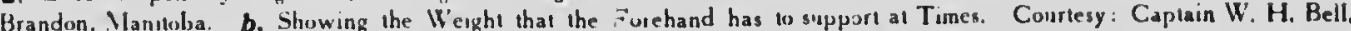
R.C.D. c. A Bad Kingbone, and Two Bad Sitebones. d, Splint. e, No Splint. Photos by the Author 
shows lameness by throwing more weight on the sound limbs than on the injured ones. He also uses his head as a balancing pole, which enables him to shift his weight and thus save the injured limb. Therefore, it he is lame in tront, he will ralse his head when the injured limb comes to the ground, and bring it to its uatural position when the sound one comes to the ground.

If he is lame behind. he will lower his head when the foreleg oppusite to the injured hind one comes to the ground. For instance, if the left hindleg is affected, he will lower his head when the right foreleg comes to the ground.

The examiner must be thirty yaris of, in front of the horse, and on the near side, taklng care that the horse's head is left alone and that it is straight, not bent to either side; it should lisve quite $18 \mathrm{in.} \mathrm{of} \mathrm{rope.} \mathrm{If} \mathrm{the} \mathrm{head} \mathrm{is} \mathrm{held}$ tightly, the horse will not be able to nod it if it is lame. The horse must be trotted lowaris the examiner, who should note whether he dwells more on one leg than on the other, and whether he ralses or depresses his head more than usual. When the horse has been trotted past about thirty yards, he should be turned somewhat sharply $\rightarrow a y$, to the right-about-and the manner in which he turns must be noted and compared with the way he turns left-about. In the second trot past, the examiner should try to detect if there is any difference in the action viewed from the of side from that which was shown from the near side.

Lameness improves with exercise, except in the case of splints, sore shins, corns, laminitis and sprains. Having detected which leg a horse is lame. on, the next thing is to try to find out which part of the leg is affeciod. Disease and injury usually show themselves by heat or swelling, or both. The affected 'pre must be compered with the sound one, both by observation and touch. If one loot is hotter than the other, and there is no heat or swelling elsewhere, the loot which is the hotter is the one affected, and the lameness is probably there. If the back tendon in one leg is more swollen than in the other, and there is no heat or swelling elicowhere, the lameness is probably due to the swelling.

The amount of heat should be detected by using the back of the hand, which is more sensitive than the front. Lameness may often be detected without taking the horse outside; for example, if a horse is continually pointing one foot, it is a sure sign that there is something wrong with that leg, perhaps navicular disease. Holding one leg bent or a peculiar action in moving in the stall may indicate lameness.

Hock lameness becomes more distinct if the horse is turned on a small circle. Some forms of hock lameness are difficult to detect if the horse is trotted in a straight line.
115. The shoes should be ca:elully examined. An uneven wear upon one shoe must be noted. Special shoes are used on horses that are un. sound. For example, a bar shoe is used on a horse suffering from sidebone or ringbone, to take part of the weight of the walls of the foot, and thus decrease the amount of movement between the walls and the bones of the foot; it may aiso be used for corns or foot fever. The insides of shoes are leather-edged, to prevent horses from "brushing." Steel tips and calkins are used in cases o: tendon sprains and hock lameness.

The trog is pared away, and calkius used to place more weight on the toe and to remove it irom the frogs in cases of navicular disease. In navicular disease the horse may go quite sound on soft ground or on sriow, especially after being warmed up.

If it is thought that the lameness is in the foot, the shoe should be remnved, and every nail, as it is drawn out, carefully examined to see if there is any blood or pus on it, which would] mean prick. (For the structure of the foot, s'e Chapter XVIII.)

If the lameness is in the foot, the animal will usually place it on the ground in an abnormal way ; perhaps very carefully, or perhaps he will favour the toe or the heel. The loot must be gently tapped all over to ascertain whether there is any tenderness. The clefts must be cleaned out thoroughly, and a thorough search made for nails and glass. The foot must be examined for heat, splits in the wall or any unevenness, and to see whether the lateral cartilages are "springy" or hard. The pasterns must be examined for ringbone. The loot and parts around must be examined for overreach, treads, cuts, brushing, etc.

If the lameness is not in the foot, but is thought to be in the lower part of the limb, the two back tendons and the suspensory ligament (see P. 101), the fetlock and the front lendon must be carefully examined for heat, puffiness, soreness, swelling, and to ascertain if the back tendons are bowed. (See P. 97g.)

Supposing the lameness is not below the knee or hock, it may be in the ligaments of these joints, in which case there will be hent and tenderness. The hock must be examined for curb. (See P. 95a, b.)

If the lameness is above the knee, it will be in the muscles or joints of the elbow or shoulder. A slip may sprain the internal lateral ligament of the elbow, in which case the horse will turn the point of the elbow outwards to relieve that limb of weight. When passaging towards that side of the 'imb, the horse will drag the limb.

116. I. ite flexor muscles of the shoulder are sprained, whe horse will drag his leg when going forward. If the extansor muscles, he will drag it when backed. These latter (the power- 
ful triceps, extensor brachii, or caput muscles) are very commonly sprained in a slip. IRest and massage are the only cure.

If the lameness is in the shoulder, pain will probably be cvinced when oue presses the muscles. The limb is not nuved nurnally, but swung outwards, and the toe dragged. If the lameness is persistent, the muscles affected will waste (atrophy). (Sce P. $78 c$ and 82.)

If the lameness is above tlue liock, it may be in the stifle joint, hip joint or muscles of the thigl. If th? patella (or kneecap) is out of place, it can be felt, and the horse, in going forward, vil! drag his leg behind lim. A common seat of lameness (known as gonitis) is that of the synovial membrane of the femurpatella joint. This membrane extends about three inches above the anterior surface of the femur under the extensor (crural) muscles of the thigh (the rectus femoris and internal and external rastus muscles). The seat of lameness is di'ticult to get at. If the lameness is in the sti.le, leat nay he detected, and the manner in which the liorse moves his leg will be abnormal.

if the extensor thigl muscles are affected, he will drag lis leg; if the flexor thigh muscles (hose around the region of the buttocks and over the hindquarters), he will drag his leg wh'n backed and show pain when called upon to draw a load. The gluteal muscles are the shief ones used in propelling. (Sec P. 78c.) If the abductor muscles, which draw the leg outwards, or the adductor muscles, which draw the les inward, are affected, the horse will show it if passaged to the one side or the other. (For the treatment of sprains, see Sec. 421 et seqq.)

If the lameness is not due to a sprain of muscles, tenclon or ligament, it is either due to a bony growth or to rleumatism. (See Sec. 583.) If the rheumatism in a joint is bad, the ligaments will become seriously inflamed, and stiffness will probably result. Chronic rheumatism of a muscle may cause atrophy.

417. Surgical Ailments.-Sirain of Suspensory Ligament.-This ligament has its origin in the lower row of knee or hock bones and head of cannon bone (nusteriorly), passes down between splint bones, bifurcates alove the fetlock joint, is attached to the outer surface of sesamoid hones, is then directed downwards and forwards across the outer borders of the pastern bone, and blends with the extensor pedis tendon, forming the broad ligament. (See P. 100, 101.) It is composed of white, fihrous, inelastic tissue. It is the most important ligament in the body, as it bears the greater part of the weight borne by the limb. The more horizontal the pastern is the greater will be the strain on this ligament.

Normally, the ligament can be seen as a distinct ridge, separated from the cannon and the back tendons. (See P. 96a.) This ridge commences just above the fetlock joints, and extends two-thirds of the way up the carnon. It should feel loard and firm, like a bass violin string. When sprained, it will not stand out clearly, and will feel soft. (see P. 97g.) The jistern will be straighter than usual, the knee shaky and perhaps a little "over," fetlocks round and puffy. Heat will be present, and some swelling. The horse will go lame at the trot, and nossibly at the walk, and if very bad, will go on his toe. If the ligament is ruptured known as a breakilowil, the fetlock will nearly reach the gruund.

The suspensory ligaments of the forelegs are generally sprained while the horse is galloping; his flexor muscles having become fatigued, are thereby unable quickly enough to take some of the weight off the suspensory ligament. This weight is greatest when the foreleg is under the body supporting almost the entire weigh?: as the opposite foreleg is being drawn forward. In draught horses the ligameni of the hindleg is generally sprained, a common cuuse being that of allowing a horse to take a heav y load in a twowheeled cart down a steep hill. Horses may sprain any of their suspensory ligaments while getting up from a slippery floor or by walking on icr pavements. (For treatment, see Sec. 421.)

418. Sprain of Fetlock Joint.-Usually due to concussion, hard work, or to a twist. If from concussion, the back tendons will generally not be affected, and there will be a puffed appearance due to listension of synovial bursæ. In a twist the bindung ligaments of a join: vill be injured. The horse may go lame; the chief symptoms are heat and swelling. Fetlock joints "knuckle over," and in ynung horses are due to weakness, and in old horses to sprain of the lateral ligaments of the fetlock joint. (For treatment, see Sec. $\{21$.

419. Sprain of the Back Tendons.-The two back tendons of all four legs are called the perfurans and perforatus. (See P. 101.) The flexor pedis perforans tendon originates in the forclegs on the inner border of the lower ends of the lumerus, and in the hindlegs on the back of the upper end of the tibia, passes behind the knee or hock, down behind the suspensory ligament, is joined by the upper check ligament, and inserts itself at the ilpper border of the back of the pedal bone.

it flexes the ietlock, the pastern and coffin joints, and, in the forcleg, the knee, but in the hind it extends the hock.

The flexor pedis perforatus originates in the foreles at the point of origin of the perforans, and in the hindleg at the lower end of the femur and at the point $n f$ origin of the perforans, extends down behind " " linee or over the point of the hock (called the hindleg), pas and is perforated ie tendon of Achilles in the felluch, aitl is a $\therefore$ i. it the back of the 
small pastern bone. It flexes the fetlock and pastern joint, and, in the foreleg, the knee, but in the hindleg extends the hock.

When sound these tendons feel hard and tense, and are hollow on the side nearest to the opposite leg. If strained they feel large, round, and soft. The perforans is usually sprained just behind the fetlock joint. If the tendons are badly sprained they will assume a bowed appearance. There will be heat, pain, and swelling, and consequent lameness, unless the tendons are sprained very slightly. The perforans is more often sprained, but if badly the infiammation will extend rack to the perforatus.

These ten ons are sprained by working horses when too yc $\| \mathrm{g}$, by hard and severe work on harl roads, by jumping in sticky or hard ground, and iv overloading. Horses that are tied in below the knee and the hock are liable to sprain these tendons. (See P. 97g.) (For treatment, see Sec. 4?1.)

420. Sprain of Check Ligament.-Tlie check licament has its origin at the origin of the suspensory ligament, passes down behind the cannon bone, and joins the perforans tendon half-way down the cannon. It thus forms a direct connection between the cannon and the coffin bone, and assists the suspensory ligament, thus preventing too mucl obliquity of the pastern, and also suprorts the weight of the limb.

The suspensory and check ligaments are brought into severe action when the fetlock joint descends below its normal position, which can be noticed when a foot is placed on the ground at the walk. After the foot is on the ground the flexor muscles normally draw the fetlock up again by partially straightening the leg, and if the ground is sticky the resistance offered to removal of the leg may be great enough to sprain one or other of these ligaments. When a horse is moving normally on level ground, whenever a foot comes to the ground the leg will be straight and the flexor tendons will therefore be assisting the ligaments; but when any sudden irregularity of the yround, or an accident, causes the foot to reach the ground before the tendons are ready, a sprain of the check ligament is likely to occur. Hence this ligament is generally sprained by a sudden shock upon the leg. Again, draught horses, when going up hill, will, unless they have calkins on the heels of their shoes, be very liable to sprain this ligament. The steeper the hill, the longer the toe and the shorter the heel, the farther will the heel have to drop to reach the ground, and the greater will be the sprain brought upon the check ligament.

Symptoms.-The injury is generally at the junction of the check ligament and the perforans tendon. Unless slight there will be lameness, and pain on pressure. There will be heai and swelling. The swelling will probably extend lrom the knee to one-third way down the cannon, close behind the bone. At first, back tendons will not be affected, this being a diagnostic symptom of sprain to check ligament. Later, inflammation will move to these tendons, which may also become bowed. In bad cases the horse rests the toe on the ground. A permanent thickening below the back of the knee or at the junction of the check ligament and perforans tendon may result.

The subject of filled or puffed legs and prevention of same has been discussed in Chapter $V^{r}$., Secs. 200, 217, et seq.

421. Treatment of Sprains of Back Tendons, Ligaments and Fetlock Joints.-The most reliable and permanent treatment for these is removal of the weight by using at once a high-heeled shoe, in case of tendon or suspensory ligament injury. if the latter be ruptured, the fetlock must be kept up in its normal position by a shoe with a long heel, to which a cross-bar is attached, covered with a pad, on which the fetlock will rest.

The injured parts, i.e. if tendon or ligament from the knee to below the fetlock, must have pressure bandages applied immediately, and the pressure bandage and massage treatment, as explained in Chapter V., Secs. 200, 217, et seqq. resorted to entirely. If this system is adopted, far better results will be obtained, in the majority of cases, than from blistering or firing.

422. Curb.-A curb is a sprain of the calcaneo-metatarsal (calcaneo-cuboid) ligament, which binds together the back of the hock joint. It extends from the back of the point of the hock (os calcis), passing over the cuboid bone, to the head of the outer splint bone. The injury, which results in a swelling, is generally four to six inches below the point of the hock, i.e. directly below the cuboid bone. (See P. 69.)

Horses tied in below the hock, and those with sickle hocks, i.e. hocks bent too much (see P. $19 c, 26 b, 74 e)$, are most liable to curbs. A curb is the result of severe work when young, such as jumping, pulling heavy loads, galloping over ploughed fields or sticky ground, etc.

Symptoms. - Generally lameness, pain on pressure. By viewing from both sides a lump will be seen projecting. (See P. 05a.) In slight cases this is not easily noticed. The perforatus tendon of a sound hock will continue in a straight line from the point of the hock nearly to the fetlock; a curb causes this tendon to bulge out. A large head to the outer splint bone must not be confounded with a curb. By looking from the outer side, this large head may look like a curb, but. will not do so when viewed from the inner. The best way to determine whether it is a curb is to run the finger down the tendon; the head of a sr lint bone will not interfere with the passage of $t_{\mathrm{a}} \mathrm{a}$ finger. Horses inherit weaknesses; therefore, curby parents may produce horses liable to become curby.

Treatment.-High-heeled shoe, a good blister, 
and suitable diet are necessary. Keep the lorse in for several weeks, and turn him out to pastıre afterwards for a like period. If very slight, it may be curerl entirely, if taken at once, by the use of the mercury and iodine liniment, described iil Sec. $41:$, without laying the horse up, aml even while giving him steady, slow work.

423. Sprung Hock.-Is one in which the binding ligaments have been severely sprained the back tendous may be affected, too. There will be much swelling, lieat, pain and lameness.

Treatment.- As the horse will not lie down, he nust be put into slings, anil the massage and pressure bandage treatment resorted to. (Secs. 244, 252-4.) When the worst is over, the liorse must be rested, if possible at pasture, for from six to nine weeks.

424. Sprain of the Shoulder.-This nsually consists in sprains of the muscles which keep the legs straight (flexor brachii, etc.), or thuse which keep the leg close to the body (pectorals), and, in rare cases, the capsular ligament, which surrounds the shoulder joint itself.

Cause.-Falls or blows, over-exertion in ploughing or in hunting field, landing over a jump, twists and sudden turns.

Symptoms.-The horse will step snort in front and drag his leg on being backed. Compare both shoulders. If the pectoral muscles are affecteci, the shoulder will bulge out and the foot swing out at each step. If the fexor brachii (biceps) is affected, the foot will be dragged in going forward. Sprains of the capsular ligament may result in a stiff joint; the horse shows pain when the shc"slder is moved passively, and tries to remove weigui from that limb. If these sprained muscles are not attended to immed. atelv, wasting may take place. Shoulder lameness is not common.

Trentment.-Rest, and massage morning and night (Secs. 209, 217-9), passive exercise. These are far better than hypodermic injections and blisters. Afterwards turn the horse out to pasture for several months, and, upon working again, avoid the former cause.

425. Sprcined Back.-The ligaments connecting the vertebra together may be sprained, or the large muscle on top of the back on each side of the spine (longissimus dorsi), or those under the spine that flex the pelvis (psoas muscles) inay be sprainerl.

Cause.-Eflorts to extend or bend the back, struzgling when down or when being thrown, slipping, falling, etc.

Symptoms. - Partial paralysis of hindquarters (if horse has broken his back, but not damaged the spinal cord, he will still be able to move his hindquarters a little and move his tail); heat and pain on pressure, if injury is near the surface.

Treatment.-Put horse in slings. unless he is verv bad, when he is better kept lying down.
Warm water enemas and laxative food several times a day. The sprain must be treated by ellergetic massaging over the part affected. If no symptoms of heat or pain from pressure, the deep-sertad psoas muscles are probably affected. Absolute rest and laxative food are essential.

426. Bone Liseases.-Bone inflammation may result from mechanical injury, such as a blow, concussion, fracture, or from infection or chill, in rheumatic diseases. The treatmont for bone disease is counter-irritation by means of severe blisters or firing; the former is best, as being the more certain. This irritation causes increased blool sunply to the part, and either assists nature in removing the trouble, or else produces more bone and seals the joint togetner, thus preventiug any movement and conseciuent pain. (See P. 98c.) Some cures can be effected by a surgical operation under an anæsthetic.

427. Splint.-Splint is a bony growth on the side of the cannon bone, between it and the front of one of the splint bones. Splints are more common on the inside of the leg, because more weight is borne on this part. (See P. 98d.) A sprain is more common in young horses, especially if worked on hard roads at a fast pace. It is a result of excessive concussion, causing friction, and therefore irritation between the two bones. This is easily caused in early age, when the interosseous ligaments are not strong enough to hold the two bones firmly together. The concussion also sprains these ligaments and sets up inflammation of the periosteum, and eventually of the bone. A splint may not cause lameness if it is well below the knee or hock, in which case it had better be left alone.

Symploms.-Generally lameness, sometimes betore the splint can be ielt, i.e. while it is growing. Probable presence of a small lump. If near the knee or hock great lameness. This will become worse upon exercise. Will not bend kriee normally. There may be more than one on the same leg, and perhaps not on the same side. Lameness at trot will be much greater. A new splint causes greater lameness.

428. Treatment.-If no lameness, leave it alone. If time is unlimited, pressure pads of compressed wadding, bound on with ordinary wadding and bandages over the splint, and massaging the part morning and night will often do much good. If this is no good, or in cases of limited time or very bad splints, a good b? ister repeated two or three times after intervals of two or three weeks is best. Cutting down under local anæsthetics on the splint and severing the periosteum around the splint generally removes the lameness, but must only be attempled by a surgeon ; this is known as periosteotomy. Surgical removal of the splint has been done with success.

Splints must not be confounded with $t$ l e lower head of the splint bone, which generally 

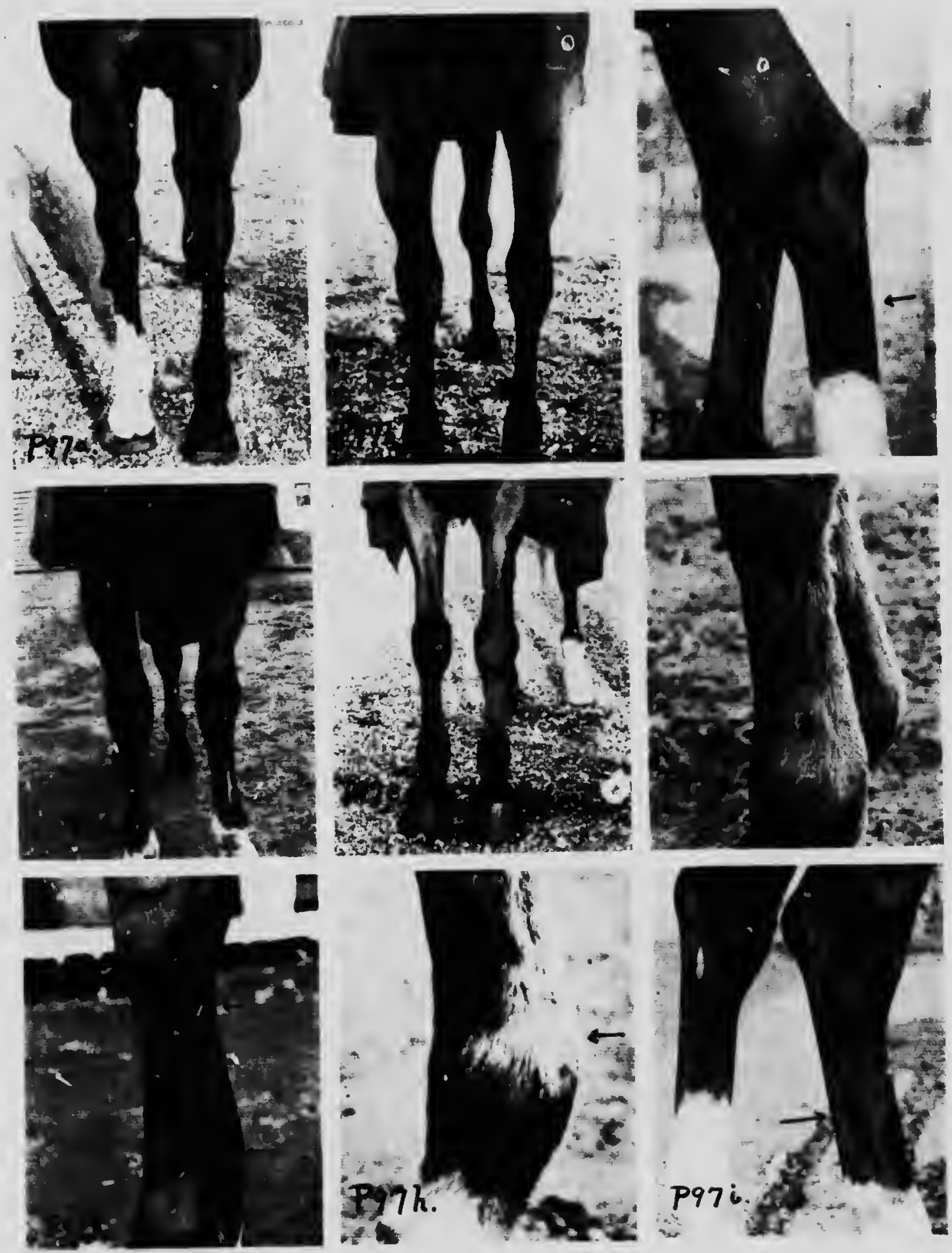

CONFORMATION

Good Straight Hindlegs b, Good W'idth Behind. c, Good "Bone" Behind. d, Crooked Hindlegs. e, Good a. Good Straight Hindegs. i, Ciood Back Tendons Hindleg. I'hotos by the Authur 
P'..1T: 每
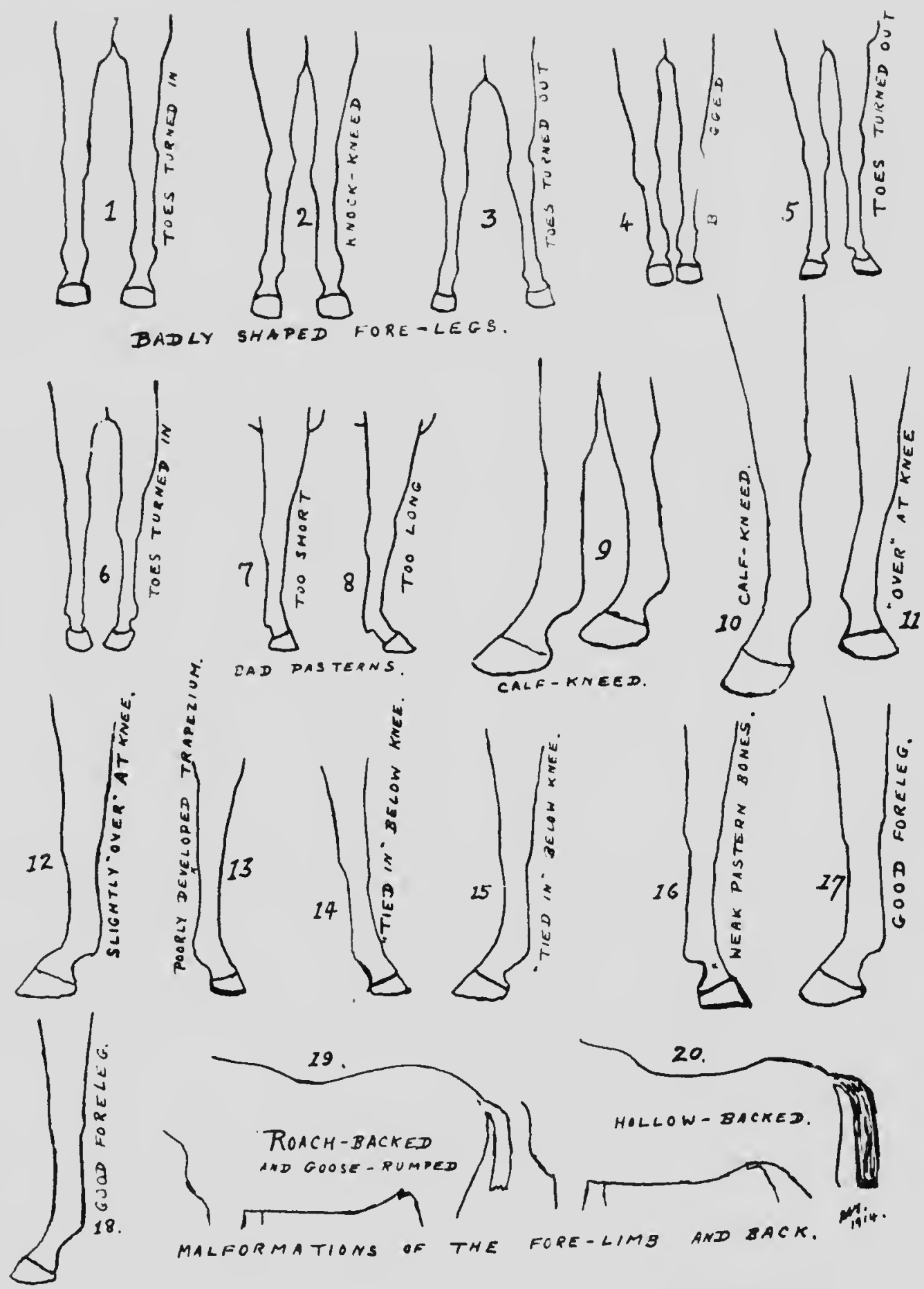

Conformation of the Fores.limbs and Back. Drawn Irom Life and Photographs 
projects out, and can be found by running the finger down the splint bone. Enlargement of this head is not uncommon in France, where it is called a jarde.

489. Bone Spavin.-This is called a jack or spavin. Consists of a bony growth on the lower portion of the inside of the lock. (See P. 95d, $e$, $f$.) It is an inflammation. In the hock there are four joints, the top one, between the tibia and the astragalus, is a pulley joint, and is the true hock joint; the three lower ones allow only a slight movement, which is chiefly a sliding one, when the hock is flexed. The lowest has least, and the lighest most, movement. Hence, as in a splint, the ligher the spavin the more serious it is.

Cause.-Concussion, therefore most common in fast draught horses, hunters, the circus hc es that perform much on their hindlegs; tess common in racehorses and light-driving horses. Young horses more susceptible. Actual concussion, sprain or rupture of the interosseous ligaments which bind the hock bones together is the cause.

Symptoms.-Horse starts out lame in a hindleg and drags his toe, especially going downhill. Lameness disappears or decreases as horse warms up. Will be worse after a hard day's work. A spavined horse will usually wear the shoe of the affected leg thin at the loe. The lameness can often be detected by pushing the horse's hindquarters across the stall. Unless the spavin is very slight or is just forming, a lump can be felt and be seen on the inner lower side of the hock joint just above the straight inner border of the cannon bone. There will generally be heat and pain on pressure. It will be noticed that a spavined horse when turned about to either side will bear most weight on the sound leg.

A good test is to raise the foot of the suspected leg as far as possible, holding the hock well flexed for a minute or two, and upon releasing the leg the lameness will be much increased if there is a spavin. When there are no external symptoms the injury is in between the surfaces of the bones of the hock ; this is known as occult spavin. In bad cases horses often refuse to lie down because of the pain caused when rising.

430. Treatment.-In young horses spavin lameness can generally be cured easily. A highheeled shoe is advisable. We cannot cure a spavin, but we can remove a lameness by means of uniting the lower joint or joints of the hock, thus preventing any movement and, therefore, pain. This union is made by our assisting Nature to throw out a bony growth which unites the bones together. For slow work a horse which has undergone such treatment is not decreased in value. Severe blistering may have the desired effect; but deep pin-firing with an electro-thermocautery needle is the surest method, as the heat reaclies the inside of the enlargement. The true hock joint, the tendons and their sheaths must not in any way be interferred with. Cocaine must be used before firing. Absolute rest is essential while this union is taking place, therefore the horse should be kept in a sling, or the hock put in plaster of paris for from four to six weeks. The horse must be prepared beforehand with purgatives, and given laxative food and diuretics during the treatment. Turn out afterwards to pasture for three months. In young horses, in early stage, cure may be effected before any bony deposit has taken place by rest, massage and pressure bandages, and suitable diet. The seat of spavin is covered by a binding ligament (astragalus metatarsus), and this ligament often becomes seriously inflamed when a spavin is present. A small tendon (cunean), which is an inward branch of the flexor metatarsus tendon, passes over this ligament, and is attached to the small cuneiform bone on the inner border of the lower row of hock bones. This tendon causes pressure on this ligament and therefore much pain. With the use of local anæsthesia this tendon can be cut, and may save much lameness : in some cases it does no good.

431. Ringbone.-This consists in a bony deposit on the pastern bones and varies considerably in position and size. P. $86 c$ shows a large completely formed ringbone. It is usually on the sides and front, and tends to form a semilunar ring. A ringbone on the large pastern generally causes no lameness unless it interferes with the lower end of the suspensory ligament. If it interferes with the joint between the large and small pastern bones, which is the commonest place of occurrence, it will cause much lameness. In this case the deposit will be on the lower head of the large pastern bone or upper head of the small one. It may be on the lower head of the small one and interfere with the coffin joint; this is most serious.

Cause.-More common in the hindfeet, and is due to severe concussion on the toe, sprains or fractures setting up inflammation; and sometimes to rheumatoid arthritis. Ringbone may be caused by a horse going on his toes owing to lameness.

Symptoms.-The deposit car be felt just above the coronet, or higher up on the pastern, unless it is not sufficiently formed. The horse will try to avoid bending his pastern joint more than he has to.

Trealment.-If in the early stage, absorption of the deposit is looked for by giving rest and suitable diet, and by a severe blistering or pinfiring, as in bone spavin. Allowing the deposit to unite the bones, as in the case of spavin, would, of course, greatly decrease the value of the horse; therefore the horse should be turned out to pasture in a few days after blistering or firing, to prevent the joints becoming stif. Neurectomy 
is often resorted to as a last resource. This consists in severing the internal and exterual metatarsal, or matacarpal, nerves just ahove the sesamoid bones at the back of the fellock. (S'c P. 13..

432. Nilebone.-Is an ossified lateral cartilage of the foot. 'The lateral cartilages consist of two flat pieces of translucent liyaline cartilage attached to the wings of the foot bone. Their function is to support and give elasticity to the hets. Sitebone can be internal or external. (vin Pr. 9hc.)

Cause.-On accomnt of the blood supply to these cartilages being noor, lliey readily become diseased if injured. Sidebones are the result of hard work, and occur frequently in the draught horse, especially in the forefeet. Sidebones are hereditary. They may arise from want of frog pressure. (See Chapter XVIII.) High calkins or paring away the frog will cause this ; the soft frog or plantar cushion is consequently not supported by the horny frog, causing great strain on the lateral cartilages. External injuries, such as treads, may a ause sidebones.

Symploms.-Horse goes short and foot dwells on ground longer than in navicular disease. Horse tries to bend his leg and to take the weight on other foot. There will probably be heat and pain on pressure if the finger is pressed above thr curonet in a downward direction. If the cartilage is ossified it will feel hard; a distinct firm ridge will be felt, instead of a soft pliable one.

Trealment.-Obtain frog pressure by lowering heels, and give rest. Reduce the wall of hoof in vicinity of side bone. Hasten ossification by blistering around the part; when this is complete inflammation will decrease. In bad cases neurectomy must be resorted to. (See Sec. 431.)

433. Sore Shins.-Not uncommon in racehorses that do hard work, especially when on hard ground. The disease, which is due to concussion, consists of a swelling in front of the lower third of the cannon. There are heat and pain on pressure; later the swelling becomes more like putty and eventually hard, this being due to bony deposit.

The horse will go short on the affected leg, and will try to bear most weight on the other leg. If on both he will shift his legs about in the stable continually. In slight cases massage, pressure bandages and rest will effect a cure. In worse cases blister.

434. Stiff Joints.-These may often be cured by passive exercise and the breaking down of the tissue that has formed around the joint; and by a free use of massaging with suitable diet. (See Secs. 209, 217-9.)

435. Navicular Disease. - Consists in the navicular bone becoming diseased. This bone bears no weight but acts as a pulley block to the perforans tendon. It is situated in rear of and bulow the foot bone, the perforans passirg behind and under it. (See 1'. 69, 101.) Owing to this, it is subject to compression every time the perforans tendon is put in tension.

Cause.-The trouble is generally in the forefoot, and commonly in trolting horses, especially those which work on city streets. Trolting raceliorses are very subject to it. Caused by concussion, as a rule, but may be the result of injury to the perforans tendon, or direct mechanical injury, or rheumatism.

Symptoms.-There are generally no outward signs on the foot. The surest sign is stepping short and trotting as if sore; pointing the foot while resting, and lying down after hard work. llorse iends to go on his toes. At the walk he is probably not lame. Limeness decreases or disappears as horse warms up. He may go sound on snow or soft sand. Pressure by the finger on the frog nay show pain. Diagnose by negative symptoms.

Treatment.-A cure is impossible, but lameness may be prevented in some cases by paring away the frog and using high lieels, thereby removing frog pressure. I have known this to be successful in several cases. The toe should be kept short. Feed on laxative diet, and encourage horse to lie down as much as possible by giving soft bedding. Place clay in the front of the stall. Work horse on soft ground and turn out to pasture when roads are very hard. Several hours a day standing in cold water will remove much of the inflammation. In bad cases the only relief for lameness is neurectomy. (See Sec. 431.)

436. Quitcor.-This consists of a canal, or several canals, running between the hoof and pedal bone through the sensitive lamina of the foot; it reaches, or tends to reach, the surface at the coronet.

Cause.-Treads, especially from calkins in heavy horses or from loose nails; blows, frost bites, nail pricks, suppurating corns and other mechanical injuries.

Symptoms and Treatment.-A lump forms on the coronet and horse gous lame. If this does not come to a head, it can be hastened by rubbing in a mild blister for a few minutes. Open wound and treat as an ordinary abscess (see Sec. 444), laking great care to remove foreign tissue and matter, and to syringe right to the bottom twice a day, so as to cause it to heal from the bottom only. If the canal goes right through, a seton should be placed in it to insure its being kept open until ready to heal. Inject cocaine before opening. In deep cases put horse under a general anæsthetic, and open canal right through.

437. Enlargements due 10 injury of synovial membrane of a joint and consequent excessive secretion due to a provision of Nature.

Windgalls.-A puffy, flabby enlargement 
around the fetlock; most commonly at the back, behind the bifurcation of the suspensory ligament. (See P. 95i.)

Causc.-Overwork in older horses or weakuess in young. A very common cause is that of suddenly stopping severe work, as in the case of a racehorse. While at speed the synovia flows rupidly around the joint; the horse is suddenly stopped, but the synovia continues to flow for a while, which results in the pressure thereby produced stretching the synovinl membrane and the exciss of synovia causing a swelling. As a rule, tho lameness results, but the pufis are unsightly.

Treatment.-Avoid sudden stoppages and dccrease speed gradually; adopt massage and )ressure bandage treatment. (See Secs. 209, , $7-9$.) The swellings are very liable to rappea:-

438. Bog Spavin.-Consists of a soft, flabby swelling on the inner side of the front of the hock. (See P. $95 \mathrm{~g}$.) It is in front of the true hock joint, and therefore is considerably higher than a bone spavin. It is caused by the distension of the synovial membrane surrounding the hock joint, i.e. that between the tibia and astragalus. The cause is due to workıng when too young, too severe work, or weakness. Unless bog spavin is complicated with sprains of the ligaments of the hock there is not much pain or heat.

Trealment.-Massage, pressure bandages and rest. It often occurs accompanied by a thoroughpin.

439. Thoroughpin.-This is a swelling just in front of the point of the hock, and consists in (listension of the tarsal sheath, which surrounds the perforans tendon (see P. 101), as it passes through the hock. The synovia accumulates in the space between the perforans tendon and the synovial sheath. The swelling can be moved to ani fro from nearly one side of the hock to the other. If unaccompanied by lameness it is not serious. Cause and treatment same as bog sparin. (See P. 96a.)

440. Windgalls sometimes appear along the course of the perforans tendon and re a distension of the bursæ surrounding this :...1don, which ire flled with synovia. These may appear at the back of the hock and may be mistaken for capped hock. Treatment is massage and pressure bandages and rest. Give potassium iodide internally, to $1 \mathrm{dr}$. twice a day, and paint on liniment of iodine for three or four days in aggravated cases of any kind of synovial swelling. This will stimulate absorption. In very bad cases it may be necessary to blister.

441. Enlargements caused by Serous Effusion. -These enlargements or cysts are not uncommon at the point of the hock and elbow, known as capped hock and elbow. They are caused by injuries; as a rule, those of an external mechanical nature. The serum inside, which is the fluid portion of the blood, eventually turns to fibrous tissue if the enlargement is not attended to.
442. Capped Hock (see P. 85/h).-Caused by hicking in the stable or by other blows. Some nervous horses are liable to kick when left in the dark, others kick when they hear mice or rats.

Treatment.-Removal of cause and massage. If very bad, after inflammation has disappeared, the swelling may be opened and kept open with a seton for a while. Antiseptic precautions must be taken. Blistering will assist in bad cases. In long-standing cases the swelling may be removed by a surgical operation. Il seldom causes any defect in action, but is generally unsightly. In synovial capped hock use absorbent liniment of iodine.

443. Capped Elbow.-An enlargenent on back of the elbow joint, point of ulna. Caused as a rule hy the horse lying on hard floor or lying on the heel of the shoe when too long. Allowing too short a rope at night may cause this.

Trealment.-Remove cause by giving plenty of head rope and good bedding, and, if necessary, shortening heels of shoe. Treatment must be commenced directly the first sign is noticed. Treat same way as for capped hock. (Sec. 442.) In some cases, if it is large and loose, it can be removed by a ligature, i.e. by tying aseptic gut around its base, and gradually tightening it day by day until the stasis produced in the circulation causes the part to die and drop off. This is painless, unless the ligature is tied too tightly at first. Treat part then with antiseptics.

444. Wounds.-The antiseptic treatment of wounds is dealt with in detail in Chapter XVII.

Abscess.-An abscess is a collection of pus in a cavity, the result of internal or external injury. In the horse most abscesses are those caused by external injuries. The pus is produced by the tissue becoming damaged and allowing pusproducing organisms (which are present in every part of the animal) to form pus. These organisms (bacteria) have no action on healthy tissue, but directly a tissue becomes damaged they commence to work. If the damaged tissue is exposed to the atmosphere the pus produced is much greater unless antiseptic precautions are at once taken. Even then considerable pus will be formed.

Symploms.-Tenderness, heat and throbbing and later swelling. This swelling tends to "point" in a few days. The part is hard at first and as pus forms becomes soft and fluctuates.

445. Treatment.-If the abscess does not decrease in size, or is already large, it is useless and wrong to try to arrest it. We must try to help it to come to a head by hot fomentations, or applications of antiphlogistine, etc. When it has come to a head it may have to be lanced and drainage allowed in order to free the pus.

The wound must then be kept open for days, and either filled or syringed out once daily with an antiseptic solution until no more pus forms. This will allow the wound to heal up from the 
bottom. If on account of its position the wound will not drain itself perfeclly, drainage must be obtained by making an incision at the lowest part of the wound and kecping a seton in until the wouml appears quite healthy. Woumds that will not heal, but which become harl, can be assisted by placing crystals of comper sulphate in the wound. This irritates the surfaces and causes increased blood supply allil new tissue to be formed. Give horse laxalive fool and diuretics, and in bad cases a purgative.

446. Contusions and Bruises. $-A$ bruise is a contusion on the surface, so the terin contusion inclucles a bruise. It is an injury to the tissue due to a mechanical blow, prolonged pressure, etc., to that part. There is always a rupture of the capillaries, so that there will be blood present round the damaged ti-sue. The tissue may be slightly or severely injured.

Trealment.-Remove cause and effect absorption of the effusion by applying stimulants to the parts or as near to the parts as possible. Give vigorous massaging. If the contusion is deep and the horse is not required, and manual labour is expensive, blistering over the part should be resorted to.

447. Brushing.-Consists in the horse knocking the inside of the fetlock, coronet, or possibly wall of the hoof of one leg with the inmer border or possibly the clenclics of the shoe of the other foot.

Cause.-Outer portion of foot too high causing fetlock to incline inwards, weakness, bad conformation, fatigue, bad shoeing. Horse may brush himself if his legs itch from any disease or presence of parasites while scratching his legs together. A horse that turns his toes out in action is liable to brush.

Symptoms.-The part may be only brushed. A lump or perhaps an open wound may be formed on the inside of the fetlock or coronet, or there may be a cut on the wall. There may be heat and considerable swelling and even an abscess.

Treatment. - Remove cause. Sloe with feather-edged shoe (see P. 139) on the insirle of the foot that does the damage ; and shoe low on the outside of the other foot, keeping the outer wall well pared away. If bruised, foment and treat antiseptically. If there is an abscess or a wound, treat accordingly. Give laxative food. In future use a Yorkshire boot (P. 22g). This is made with a piece of flannel about 8 inches in width, and long enough to go twice around the leg, and doubled over after being secured with a tape as shown. Special leather brushing bouts can be procured on the market.

448. Speedy Cut.-Consists in the horse brushing himself on the inside of the knee or hock. More common in foreleg. The seat of injury is at the bottom part of knee-joint. The causes and symptoms are similar to those of brushing.
Knock-kneed liorses, and those who turn their toes out, are sub. . ct to it. More often caused at the gallop after horse has become tired. Severe blows are liable to cause an abscess, which must be treated. A speedy cut boot should be worn afterwarls, which must come down well over the knees. Give laxative diet, and if an abscess, give purgative. Shoe as for brushing.

449. Over-reach.-Consists of an injury made by the toe of the hindfoot striking the bulb of the heel, the fetlock or the back tendon of the forefoot. Generally done to the leading leg at the canter or gallop, by the hindleg on the same side. Practically never dono at the walk, pace, or amble. The cause is generally due to the torefoot not being removed quickly enough, as when it becomes temporarily stuck in sticky ground. Or it may occur on slippery ground or from weakness or fatigue. A horse that is allowed to go along in a slovenly way may overreach himself.

Symptoms.-Bruise or wound on the part that is struck or rubbed.

Treatment.-Remove cause and make liorse carry himself better by proper schooling uncler competent hands. Heavy shoes, by increasing the action, will generally do good. It may be recessary to use over-reaching boots to cover fetlock, back tendons, or bulb of the heel. These are made of leather or rubber. Treat any wound as for brushing. (Sec. 447.)

450. Broken Knees. - These are the result of a horse being allowed to fall down on to his knees. May be simple, that is not affecting the joint; in which case treat antiseptically. Every precaution must be taken to avoid the damage spreading towards the joints. Therefore hot fomentations, except to clean the wound in the first place and remove all irritating grit (which is absolutely necessary), and poultices are absolutely forbidden, as they tend to soften the part and lessen vitality.

451. Open Joints.-If the knee is so damaged that the synovial membrane of joint proper is cut there will be an "open joint," which is, as a rule, a most serious injury. The cure for open joints, if in the knee, hock or fetlock, is the same.

Symploms.-Synovia will run out (in a closed joint a few synovial sacs may be ruptured, allowing a little synovia to escape), and later there will be heat, swelling and pain; blood and pus will run out. High fever will bo present. If the top synovial sac of the knee is affected it is much less serious than if the middle or lower sac is opened. The lower is the most serious, because this will drain the middle $\operatorname{sac}$ as well. In the hock the most serious is the true hock joint or upper sac.

Trcalment.-Reduce fever in horse and give larative lood. If fever is very slight give mild purgative. The success in treatment depends on keeping the synovial cavity absolutely aseptic 

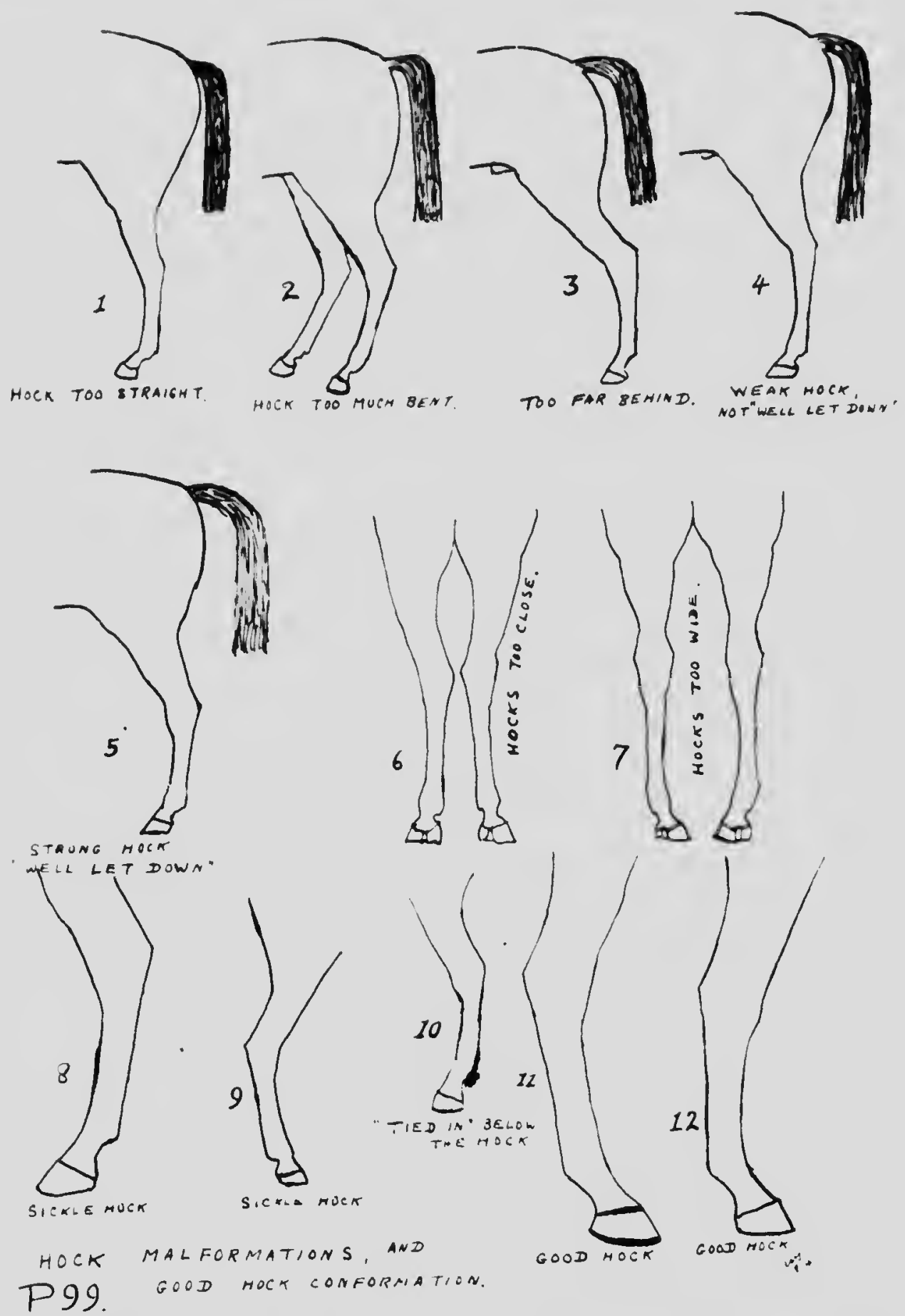

Conformation of the Hock and Hindleg. Drawn from Life and Photographs 
P1.A1t: (N)
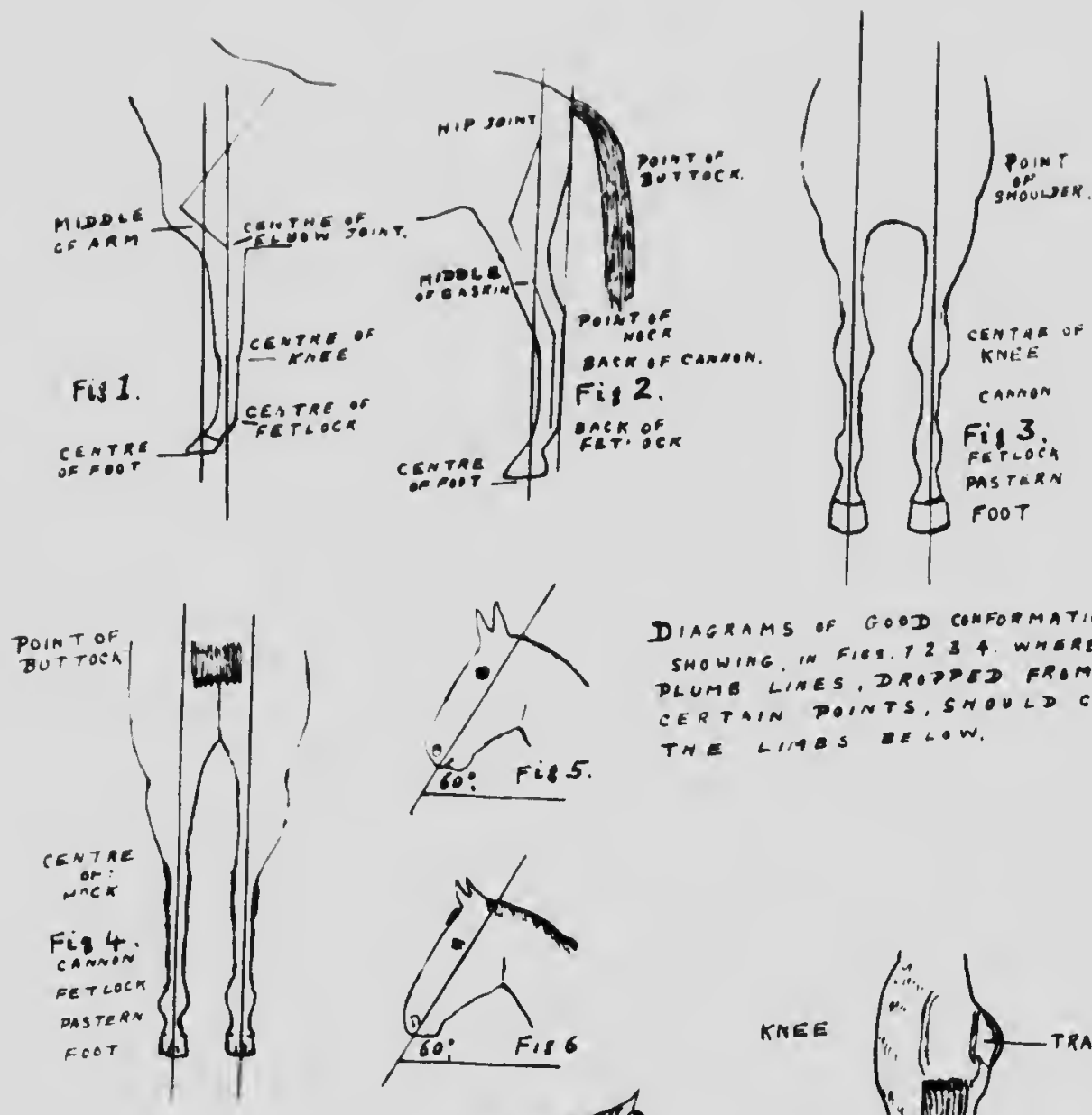

DIAGRAMS OF GOOD CONFORMATION SHOWIMG IN FICS 234 . WMERE SHOWING. IN FICS.TLSTED FROM PLUME LINES, DROADED POINTS SNOULD CUT THE LIMES ELLW.

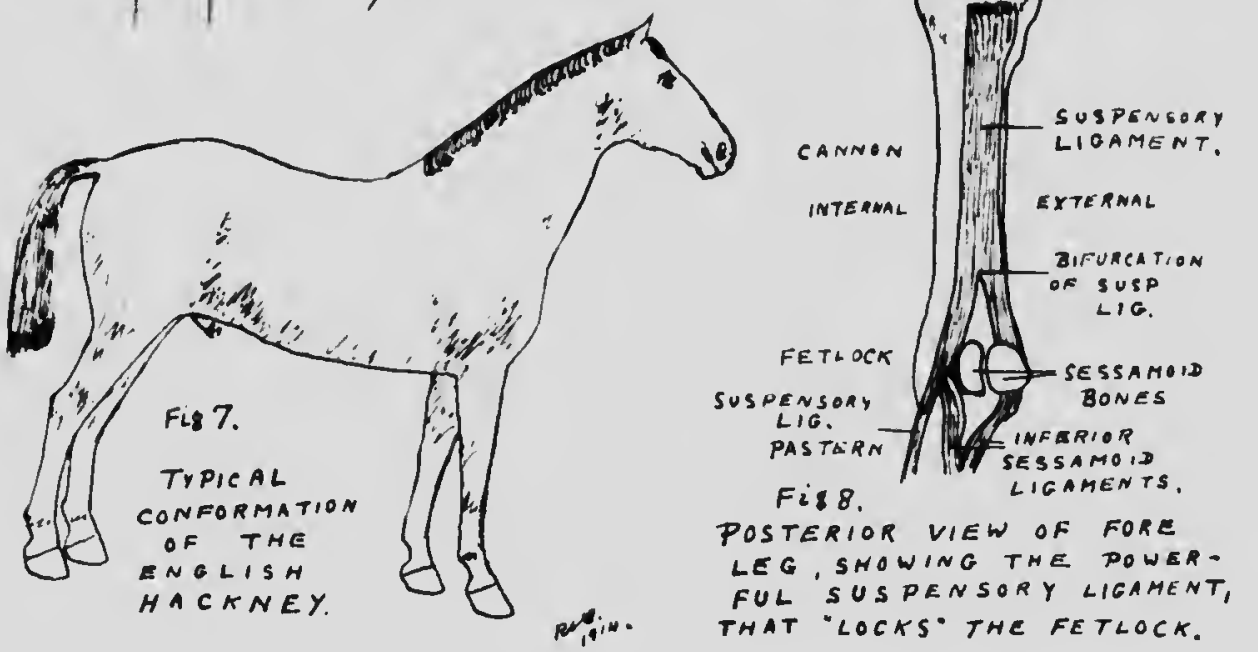

Utagrams of the Coriect Conformation of the Horse 
nud perfectly drained, and in keeping the joint verfectly stutionary by means of splints or plaster of paris cast, with an opening for treating the wound. The wound must be covered between each dressing with antiseptic wadding and sheeting. The horse must bo put into slings, as a rule. When a wound is quite clean tincture of iudine is a very good application; collorlion is good lo arrest bleeding.

The application of a good blister around the part is recommended, as it hastens i'e healing if the wound. A cradle should be int on the horse's neck, to prevent him from biting at the wound. In most cases when the bottom sac of the knee-joint is open, the horse is better destroyed; similarly with the upper of the four sacs in the hock.

452. Galls have been dealt with in Chapter VII., Sec. 323.

Poll Evil.-Is an injury to the poll, which is the part on the top of the head between the ears. Generally commences in inflammation of the bursa that lies between the first cervical vertebra (atles) and the ligamentum nuche (which holds the head up).

Cause.-A blow from a stick or from a low ceiling, as on board ship, or doorway. The overhead check rein oflen causes this. (See Chapter XIX.)

Symptoms.-Swelling, heat, pain in region: if bad, horse carries his head stiffly, and may object to being groomed over the head or to being bridled.

Treatment. - Remove cause. Apply antiphlogistine or other similar agent to bring abscess to a head. Then open abscess and treat. If bad, it will be necessary to oblain drainage from the bottom, in which case a general anasthetic must be given. In mild cases, if discovered early, massage and liniments may cause effusion to be absorbed without any abscess forming. The horse must be given diet and fed from a manger, and not from the ground, nor should he be turned out to pasture, because it is necessary to keep his head up to prevent too much blood flowing to that part. In bad cases the yellow elastic ligamentum nuch $æ$ becomes seriously involved, and an operation under chloroform has to be performed; a portion of the ligament is securely attached at the upper end to the occipital bone of the head and to the second cervical vertebra (axis, or dentata), and if it is severed above the attachment to the axis the horse can still keep his head up almost naturally, but if it is severed between the axis and the withers the horse will be unable to hold its head up except with the upper muscles of the neck, which will soon become tired, and the horse will endeavour to rest its head on any support. Such a horse must be destroyed.

453. Fistulous Withers, or Sinus of the Withers.-Caused by saddle pressure on the top of the withers, pinching at the sides, or collar injuries.

The injury is similar to poll evil and is chiefly in the yellow elastic fibres at the top of the withers, wherc the yellow ligamentum nuchie fbres are interwoven with the white inelastic supraspinous ligament that continues back to the tip of the tail.

The symptoms and treatment are similar to those of poll evil. Great care must be laken to get proper drainage, viserwiso the pus will burruw down in between the shoulder-blade and the muscles and may fi 1 an exit at the bottom of the chest. Great cart must be taken from the first to bring any abscess to a head. This must be opened as soon as possible and kept properly drained and aseptic.

454. Burns.-If the burn is slight and the skin is only reddened the best application is a saturated solution of picric acid. Another good application is carron oil (equal parts of linseed oil and lime-water). If the skin is injured right through, apply zinc oxide ointment. If this callnot be obtained, dust on boracic acid. If nothing else can be obtained, any form of grease must be put on to keep the air away; an antiseptic should be added to the grease, as burnt skin readily admits germs. Baking soda (sod. bicarb.) dusted on will do good. The system suffers from shock if the pain is at all bad, in which case strychnine sulphate should be given hypodermically in the neck, to $1 \mathrm{gr}$. If this cannot be obtained give 4 to 6 oz. whisky. Do not give methylated spirits. If pain is bad, give to $1 \mathrm{oz}$. chloral hydrate in a drench of at least 1 pint of water (a stronger solution will burn the mouth). Put horse on diet.

455. Frost Bites.-Not uncommon in winter in Canada. Horses exposed much to cold winters may have their ears frost bitten at the tips. Tails that have been plaited up tightly with the hair drawn away from the tip of the dock may become frost bitten at the end, therefore it is never advisable to plait a tail up in the coldest of weather, unless plenty of hair is left around the end of the dock.

Usually a frost bite in a horse is discovered after the part has become dead, and in this case any wound that may be a frost bite must be treated antiseptically. If the part is found to be cold and apparently feelingless, the circulation, which has been arrested, must not be allowed to return suddenly by applying friction or warm fomentation, as this will cause inflammation and pain. Cold water, or better, snow, must be rubbed against the part for fifteen minutes or so, until the circulation returns. Horses' feet sometimes become frozen, which may result in thrush, due to walking on a mixture of salt and snow, the salt being put down to prevent street rails becoming clogged with ice.

456. Snalie Bites and Stings.-If a bite is from 
a mon-poisonous snake or is a sting frum an insect, apply at once liquid ammonia (spirits of hartshorii) and treat part afterwards as for a bruise. (Sie Sec. 44t3.)

poisonous snake bites have symptoms of swelling, shock, faintness and perhaps uncunsciousness. Later there may be paralysis, conrulsions and, flually, leath. I hive never had the opportunity of seeing a horse that had been bitteu by a poisumous snake, but the use of stryehnine injected over or near the part in large doses every quarter of an hour has had wonderful effects half a grain being used at a time in very bad cases: in miller cases th grain will be sufficient. After all signs of poison have gone and the twitching effects of strychnine conmenced, its use must be slopped. A careful watch must be kept for hours in order that strychnine may be arain used upon first signs appearing.

457. Lightning and Electric shocks.-Horses that have been rendered unconscious from electric or lightning discharges may recover if assisted, by applying stimulating lininents to the part with vigorous massaging, and by inject ing arian strychnine into the part. Four to $6 \mathrm{oz}$. of whisky slould be given every two hours, and a bottle of stroug animonia should be hedl near the nostrits. 'The legs must be rulbed to promote circulation, anl ufterwards bandaged with flannel.

458. Fractures are of three kinds: simple. when the broken part does not protrude through the skin: compound, when it does: and coinminuled, when the bone is crushed into small pieces.

Simple fractures, as a rule, can be mended, because as there is no external opening there will be less danger of pus-producing organisms gaining access ; in most cases of compound fracture, unless the horse is valuable it is better that he be mercifully destroyed. I have assisted in mending a great number of limb fractures in horses, and the methods laid down in the following sections will be found most successful. I used to drive a heavy horse in Alberta on long trips that two years previous had had its tibia broken, set in plaster of paris and turnel out to pasture for nine months.

459. Physiology of a Fracture.-When a bone breaks, irritation around the fractured ends sets up inflammation; small cells, normally in the bone (osteoblasts, bone-producing), appear on the scene and produce bone that is placed in between the fractured ends inside and outside the fracture. After uniting, the ends are ellcased in a thick mass of bone resembling the lead on a joint on a lead pipe. Next appear bone-devouring cells (osteoclasts). These gradually remove this excessive bone, which may take two or three years, and in many cases its removal is never complete. By giving phosphates (calcium phosphate 1 to 2 drs., or phosphoric acid dilute 1 to
- Urs, once a day, the union will be hastened. If there is nuch fover give as a ftbrifuge, Flen. ing's timcture of aconite 5 to 10 milims (this druy nust be used with caution). Ilest is always necessary, not onty to keep the part motionless, but to allow as much vitnl energy as possible to assist in the repair. Feed on laxative diet, and if in a gross condition give purgative to com. mence with, unless thero is minch fever. If the tracture is compound, and it is intended to attempt to reduce it, very careful antisentic pre. cautions will have to bo taken, which is not an easy matter in a stable.

460. Betore applying the bandages and plaster of paris (plaster of paris bandages are sold in hermeticalty sealed tins), the ends of the bones must be brought together in their normal position. It may ba necessary to give chloroform to tion. It may be nelaxation of the nuscles.

Symploms and Triatment.--Sudden and basl ameness after a fall or accident, pain, fever, deformity and crepitation of part. Fractures of the loug bunes, i.t. the cannon, radius, tibia, can be set in plaster of paris and the horse either kept in slings or turned out to pasture. The former for a few days is nore humane.

Fractures of the pastern bones, especially the small one, due to a horse slipping and suddenly hringing one foot with great furce on to the road, are generally very bad, and, as a rule, the bone breaks into a seore of pieces. The horse will suffer much pain, and is beller destroyed. I have known of this bone being broken into fortyfive pieces by a mere slip and a sudden recovery. If the pain is only slight the pastern must be put into plaster of paris for at least a month.

461. If the coffin bone or navicular bone is brokel the horse had better be destroyed. The symntoms are severe pain and heat. Horse holds the elbow of the affected leg much lower than the other elbow. The knce and fetlock will be bent and the heel raised. These symptoms may occur, however, when the first rib is broken, but there will be no heat in the foot.

Fractures of the upper arm (humerus) or shoulder (scapula) will generally repair them. selves if the horse is turned out to pasture. I have known several instances where horses have broken these bones in a fall, and have kept in good health and free from pain while at pasture the bone quickly muiting. A horse can bear weight day after day oll one loreleg without tiring. because the large muscle (serratus magnus) which suspends the body (1) the inside of the shoulder-blade is interwoven with inelastic fibres. However, in fractures of the thigh bone (femur) the horse must be put into slings for five to six weeks, because one hindleg cannot for five to six weight for any length of time. These upper bones mi: ! handaged as well as possible when the horse is slung to prevent morement. 
462. In fractures of the pelvis (ossa innominata) the horse must be slung for at least three months. In lracture of the jaw (the lower jaw being sometimes fractured owing to cruel use of the bil) the jaw must be bandaged and kept as still as possihle.

In tractures of the ribs, which wi: become apllarent by evidence of poin when the norge is artherl up and should be discoverel when he is "xamined, as he should be after a fall, the best cure is rest. The horse should be lurned out to pasture for a couple of months away from anything that might cause him to gallop ahout. For this reason he must not be turned ont with colts.

Fractured tail bones sometimes occur from falls. The treatment is simple, and consists in applying a leuther guard for at least one month. lie gunrd must be laced up moderately tight, but not so as to arrest circulation.

Broken backs are sometimes caused by tying the horse up short. Placing the horse in slings would tend to separate the broken pieces of vertebre because the slings will cause hin to ruach his back. The point of the hip (external tuberosity of the ilium) and the point of the butlock (tuberosity of ischium) are sometimes fractured in falls; the former may result from the horse being rushed carelessly through a narrow fitteway or door. As a rule, nothing can be done, and if the horse is turned out to pasture for a couple of montlis the part will either unite ur remain permanently loose. This latter is not uncommon and does not affect the horse in its work.

463. Dislocations.-Consist of displacement of a bone, or bones, that form, or help to form, a joint. The symptoms are pain and awkward or lessened gait. The only dislocation which is cenerally successfully treated (and fortunately uther dislocations are uncommon) is that of the patella or small bone at the front of the stifle, corresponding to our kneecap. Chloroform will aften have to be given to get relaxation of the muscles before the bone can be placed back.

Dislocation of Patella.-This generally slips nutwards, i.e. away from the body, and is quito common with foals, who usually grow out of the tendency. which is a sign of weakness. An accident or a sudden wrench may cause the patella to slip out. When it is out, the leg is kept straight and the foot far back. The toe of the foot and sometimes the front of the wall will rust on the ground. The horse will be unable to draw his foot forward.

No time should be lost in treatment. If it is left out the joint may become injured. If it cannot be pushed back, the foot must be drawn forward by an assistant with a rope and the patella pushed into place. If it is difficuit to replace, the horse must be given chloroform to relax the muscles. After replacing the patella, massage the part for twenty minutes morning and night for one month, or it may be blistered, repeating once or twice at intervals of two weeks. A stifle shoe should be applied in cases where the patella slips out repeatedly.

464. Stable Vices.-Kicking.-Thn best way to prevent a horse from kicking in the stable at night is to hang a sack of straw tightly packed from the ceiling, so that when the horse kicks he will kick the sack and cause it to swing against his hindquarters. Chain hobbles on the hindicet may cure in some cases. If a horse kicks irom ill-temper while in the stable, it harness, or in the saddle, a man should stand at his shoulder and strike him a good cut under the girth while his quarters are in the air. He then associates the pain with the kicking; if he is struck afterwards he may kick all the more. (See Chapter III.) The moment he slops he must be caressed and shown that he is doing right by stopping. Horses often kick at a timid person or at rough man, but when halldled by a good horseman give it up altogether. Every attempt should be made by the nder when in the saddle to hold the horse's hearl up; he should close his legs, and speak to the horse directly he feels an allempt to kick. In training a horse to harness, a kicking strap should be used always as a precaution, so that should the horse attempt to raise his hindquarters, he will be checked from the first, and knowing that he cannot do so will probably not attempt it in future. But if, upon flrst trying, he finds he can do it, he will have learned something that he will not easily forget.

465. CaIb BITING.- This is a most objectionable habil. It is a nervous affection, therefore a crib biter should be isolated. He shoild be kept in a stall or loose box, with no manger or other article in it at which he can suck. He should be fed in a manger that is removed directly he has finished, the hay being put on the floor. Crib biting leads to wind sucking and helps to destroy the horse's digestion and keep him generally in the horse'stion. When he sucks he inflates his intestines with air, and is inclined to be subject to colic.

Treatment.-Place a two-inch strap fairly tightly around the neck just behind the throat, so that whenever he tries to wind suck, being unable to swell his throat, he will tind the strap causes pain, and in most cases will cease to try. This must not be tight enough to interfere with his eating or breathing in any way. Idleness is responsible for most crib biting. Horses turned out to pasture usually return cured, but only temporarily, as a rule.

Snapping at one when approaching the horse in its stall is an objectionable habit, and is often caused by the continued practice of giving sugar. The best cure is for the groom to approach the The best cure latter turns round and snaps, the former shozild thrust a hot grilled meat chop into the horse's mouth. The horse 
very much objects, as a rult, to hot grease, and in many cases it will effect it cure.

466. The Honse's TeETh,-The horse's teeth require attending $t$, far mor' often than is generally supposed. Horses get thin and the owners do not suspect that the teeth require attending to, but continue to give paturt medicines which probably do more harm than good. I have seen teeth in horses' mouths that make one wonder how they can eat at all, the condition being merely the result of want of knowledge and often neglect.

I consider it cruel not to secure a veterinary surgeon to examine a horse's teeth once a year. All horses may not require attention every year, but we never know, and it will be money well spent. If the owner knows low to examine the teeth, of course, he should do so. It is the molars and not the incisors (fiont teetl) that require floating with a suitable fle every year or so, depending on the composition of the teeth and on the food. Every horse over eight years of age should have its teeth fioated once a year, or oftener; but horses over five years of age may require this.

467. Floating consists in taking off the sharp) points only, and not in rounding off the edges of the tables. I remember a young vet. who filed a horse's teeth so smooth that the animal died of starvation. Normally the tables of the molar teeth are quite ragged like the grinders in a mill, and unless they are so the horse will not be able to masticate oats, etc. The tables are not in a horizontal plane, but, as shown in P. 103, they incline inwards and upwards. This allow's of a better grinding motion when the horse masticates. The upper teeth are farther apart than the lower. Only points that stick right up above the tables should be taken off with the float. Projections into the gums or tongue, which are sometimes found, must be clipped off with molar nippers or cutters.

Neglected teeth will cause indigestion, because the horse will not be able to masticate his food sufficiently, and consequently there will be a considerable waste of food and money. The symptoms of neglected teeth are irritability and awkward carriage of the hrad, sore tongue and cheeks, ptyalism (slobbering), pulling on the bit, trying to run away, etc. Whenever a horse is off his feed, carries his head to one side, or pulls unnaturally, his teeth must be examinell. There may be a piece of wood jammed in between two teeth and the horse has no means of informing its owner.

468. How to Examine TeEth.--If a speculum is used it is an easy matter to examine the teeth. The hand is then placed into the mouth and each row of molars is examined very carefully in turn: great care being taken to detect any pieces of wood or other foreign substances that may be wedged in between the teeth. Care must be taken to see that the speculum is resting properly on the surface of the incisors, and that it is properly secured and not oponed too far. It is an easy matter, after a little practice, to examine the teeth without the use of a speculum or other instrument to keep the horse's mouth open.

The right hand and arm are inserted into the mouth through the interdental space; the horse's tongue is forced gently with the back of the hand in between the horse's left molar teeth. This prevents him closing his mouth and allows the two rows of molar teeth on the horse's right side (the side on which the person will stand) to be inspected. The other hand is then used to examine the left molars by keeping the tongue between the right. A speculum may frighten a nervous horse.

469. The looth consist of a crown, with a table on ton that is the grinding surface, a neck, fangs, and the roots at the tips of the fangs. The horse has two sets of teeth: temporary, milk, deciduous, fotal or teeth of the first dentition, and permanent, replacing, or teeth of the second dentition.

The front teeth are called incisors or nippers.

The tushes, or tusks, are called canines, and are situated in the interdental space between the incisors and molars, and nearer to the incisors.

The back teeth are called grinders or molars.

The full number in a horse is :

$$
\begin{array}{cr}
\text { Timporary set, Incisors, six on each jaw } & 12 \\
\text { Canines . } & 0 \\
\begin{array}{c}
\text { Molars, three on each } \\
\text { side of each jaw }
\end{array} & 12 \\
\hline & 24 \\
\text { Permanent set, Incisors, six on each jaw } & 12 \\
\text { Canines, one on each } \\
\text { side of each jaw } \\
\text { Molars, six on each side } \\
\text { of each jaw . }
\end{array}
$$

Generally a mare lias no canine teeth, therefore has only 36 . Several mares in Canada have been known to have canine teeth.

470. A tooth is composed of dentine, which is similar in compositior. to bone, and contains 76 per cent. of earthy matter. This is covered on is sides with enamel, which is enfolded from the top in the upper molars; it is very hard, containing 96 per cent. earthy or mineral matter, and is an epithelial growth.

Inside the dentine there is a pulp cavity that extends along a considerable length of the tooth; in the old tooth it is quite short. There are also cilps in the table around which the enamel forms a ridge called the infundibulum. (See P. 102, 103.)

There is a soft yellow material on the sides 
PI.ATE 101

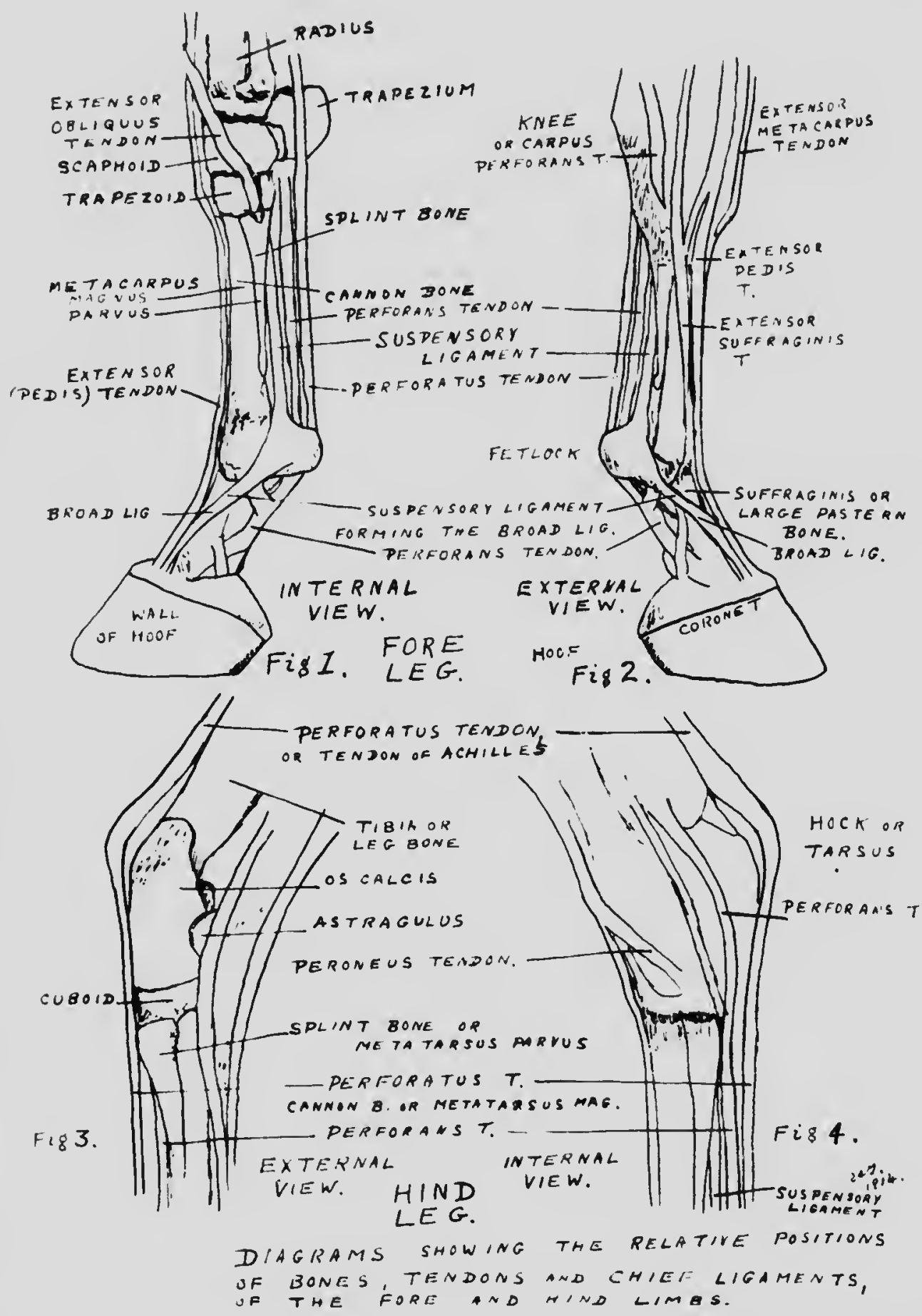

Diagrams of the Relative Posnions of the Suspensory Ligament, Back Tendons (Perforans and Perforatus) and Extensor Teidon of the Fore and Hind Limbs, Viewed from Both Sides 


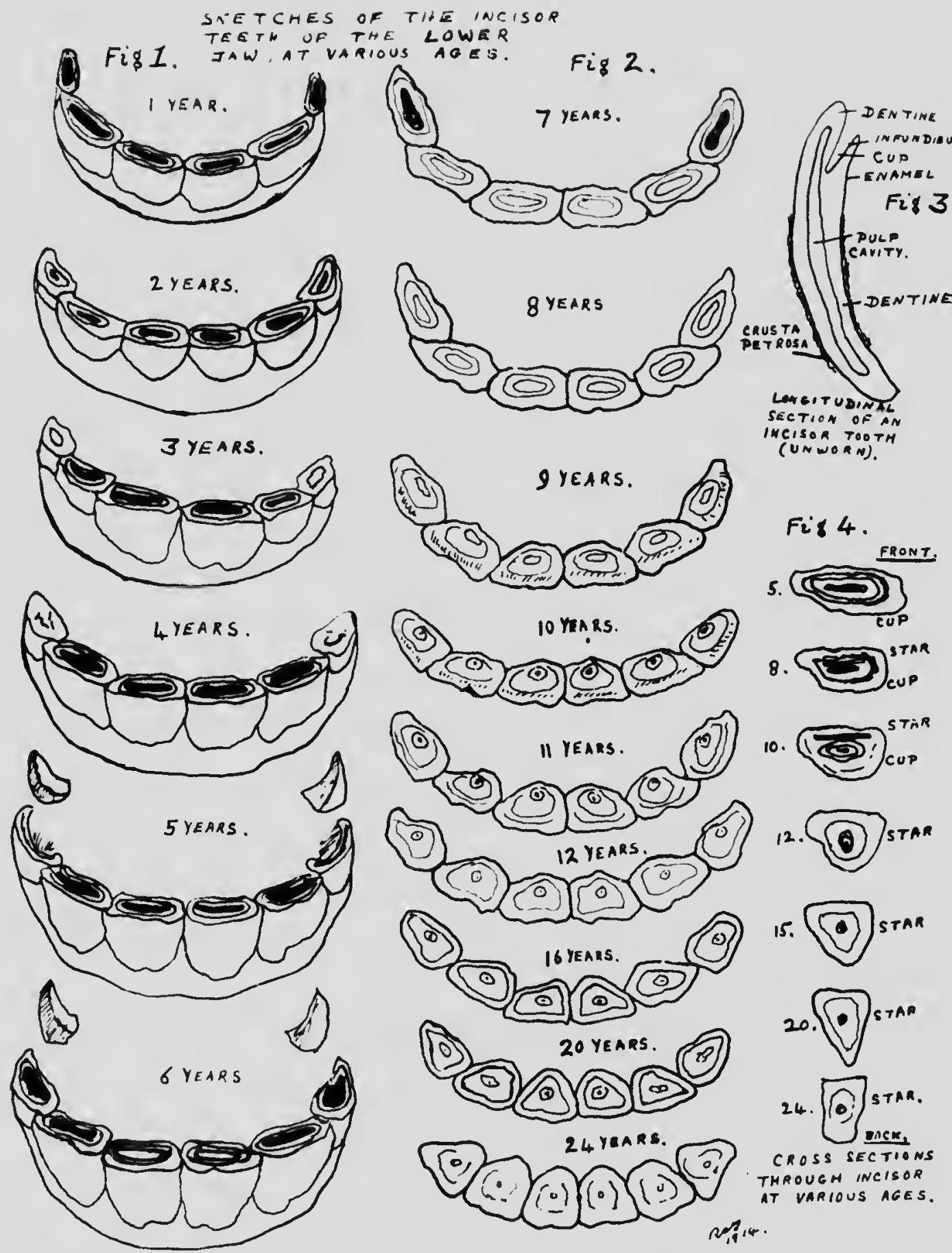

Diagrams of the Incisor Teeth, Showing how the Tatles Change with Age 


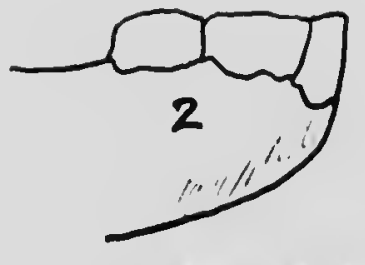

THE ANGLE OF UINCIDENCE OF THE

Fiक 1 .
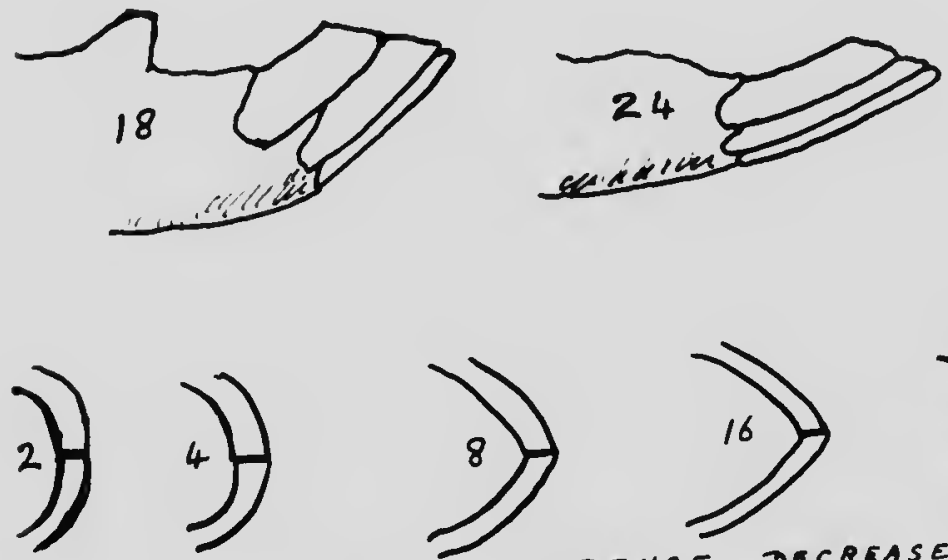

Fig 2. ThE ANGLE of INCIDENCE
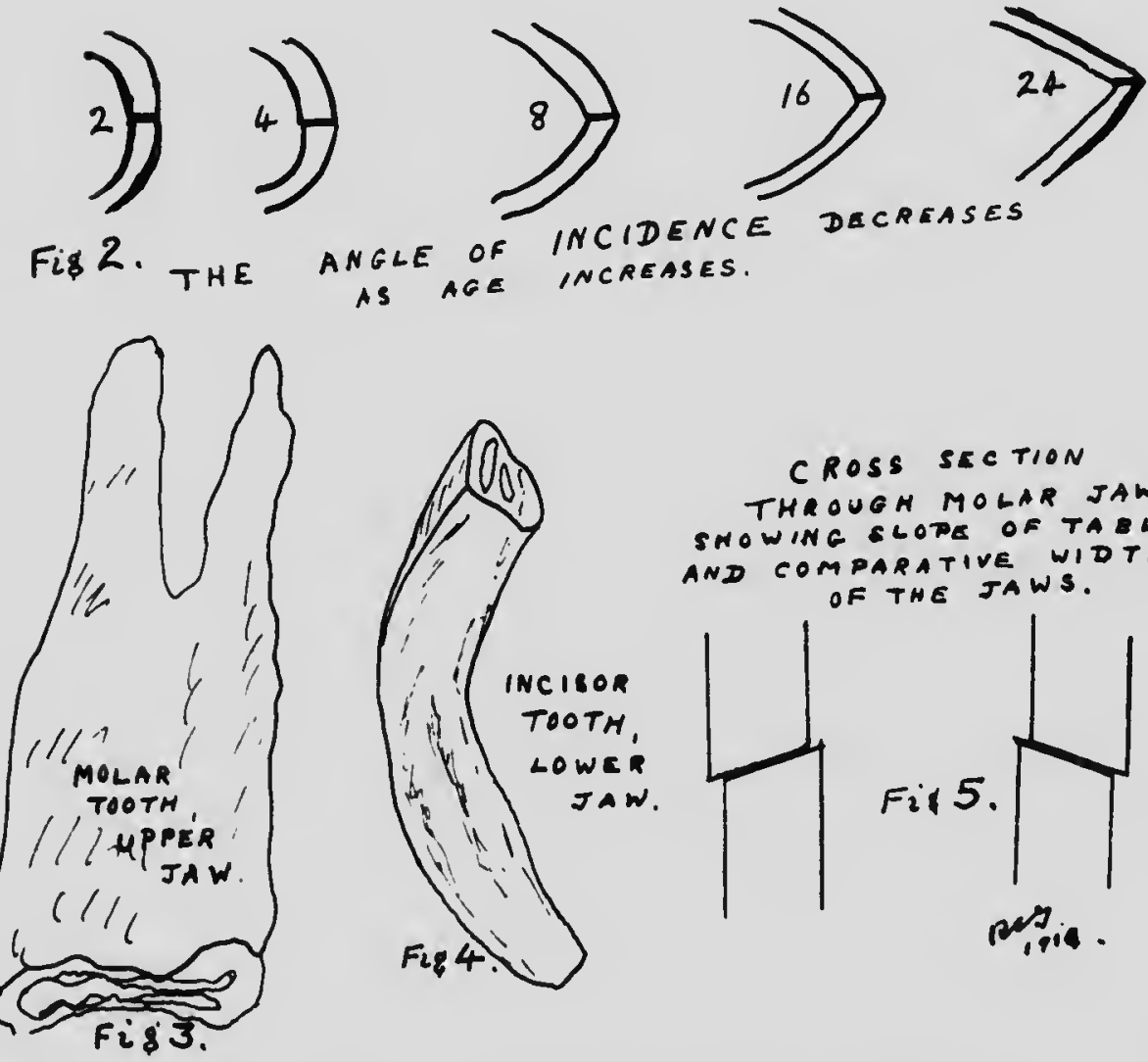

CROSS SECTION

THROUGN MOLAR JAW, SNOWING SLOPE OF TABLIS AND COMPARATIVE WIDTH AND COMPARATIVE WI

Diagrams of the Teeth, silowing the Angle of Incidence. etc. 

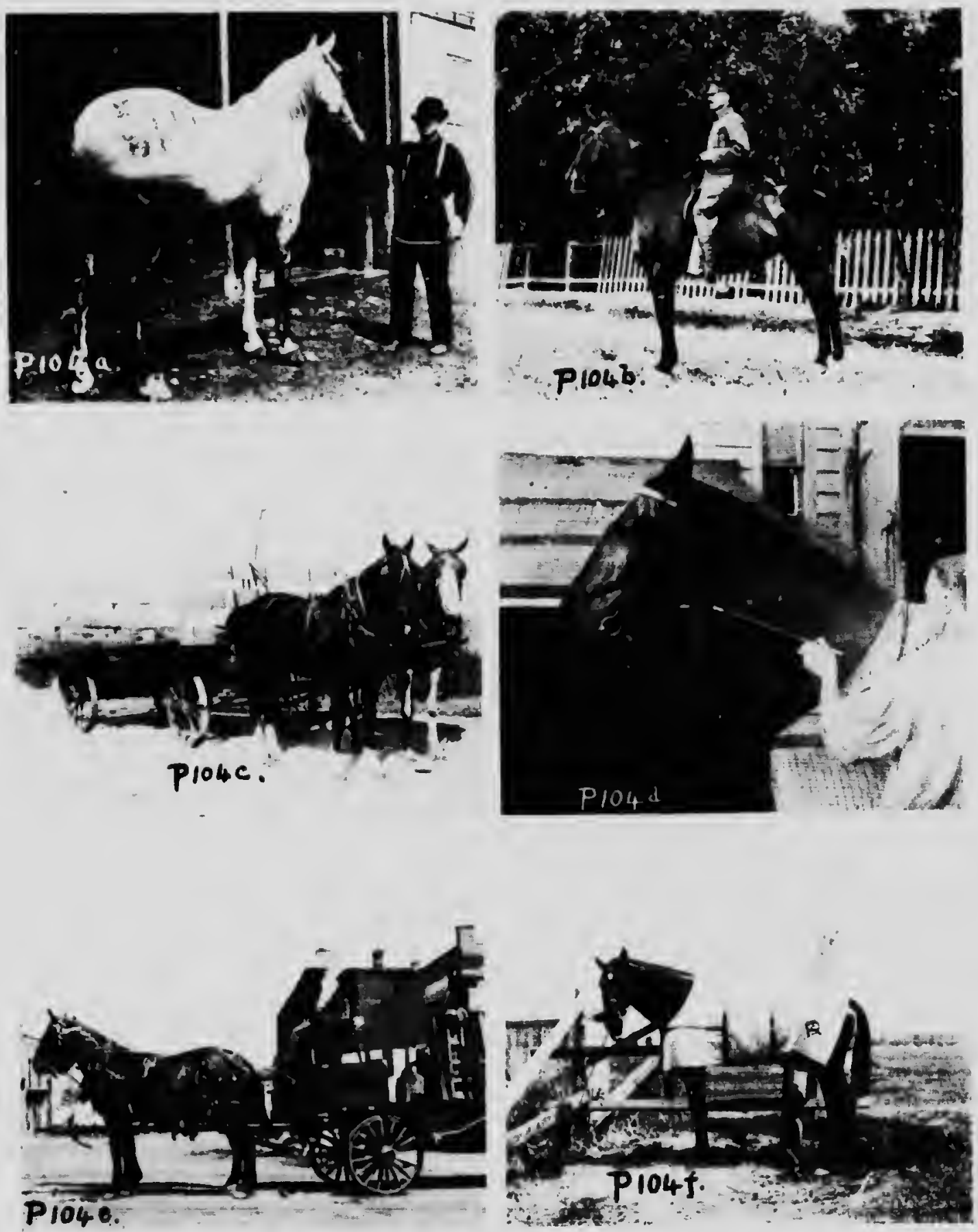

FLIES AND FLY.PROTECTION

$a, b, c$, Show the Horse on the Act of Striking a Fly with it Fly.weapon. $d_{0} A$ Fly. whisk, and an Five-fringe on the

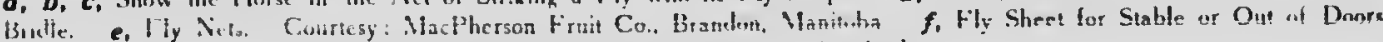
in the Fly Season. Photos by the Author 
of the molar and parts of the incisors called crusta peirosa; this continues to grow after the tooth has formed. It contains about $6 v$ per cent. earthy matter.

Permanent incisors do not have a well-marked neck, as do the milk incisors, are larger and lunger, are not so white, but have a bluisl tint, and are more curved on their outer surface.

The angle formed by the incisors, which can be seen by looking at a mouth sideways with the lips held open, is called the angle of incidence. This angle decreases as the horse gets older.

The cups in the tables of the upper incisors are deeper than in the lower, therefore those in the lower wear away before those in the upper.

The centre incisors are called middte or centre incisors; those next outside are called the intermediate or lateral incisors ; and those outside the corner incisors.

\section{Average Period of Eruption.}

\section{Tooth} Eruption

Shedding

Temp. Mid. Inc. .. Birth to 8 days .. 2 to 2 years Temp. Inter. Inc. $\ldots 4,6$ or 8 weeks $\ldots 3$ to 3 tyears Temp. Cor. inc. .. 7 to 8 months .. 4 to 4 years

The milk incisors are often said to erupt at approximately 8 days, 8 weeks and 8 months respectively.

\section{Tooth}

Perm. Mid. Inc. .

Perm. Inter. Inc. .

Perm. Cor. Inc. .

Eruption

These teeth will be fully grown in six months after eruption, so that at flve years of age a horse should have a full mouth of incisors.

Tooth

Eruption

Canines, Permanent (no temp.) .. 4 to 4 t or 5 years

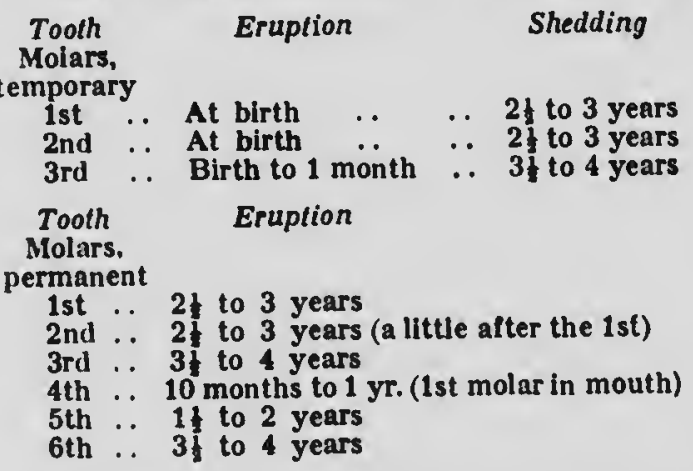

The teeth of the lower jaw generally erupt earlier than those of the upper. Some horses' molars are earlier in eruption than normal, and incisors later. The molars will erupt much earlier if the horse is fed on grain, as a racehorse is, whilst the incisors will erupt much earlier if the horse is at pasture in a sandy district. A thoroughbred horse fed on hard grain, and developed rapidly for racing in the modern "young events," will have many of his molars six months earlier.

472. Table of teeth from birth to five years (an average): At birth or soon after, temp. mid. incisor, 1 st and 2nd temp. molars; at 3 months, temp. mid. incisor, temp. inter. incisor, 1st, 2ud and 3rd temp. molars; at 6 months, temp. mid. incisor, temp. inter. incisor, 1st, 2nd and 3rd temp. molars; at 8 months, all temp. incisors, 1st, 2nd and 3rd temp. molars; at 1 year, all temp. incisors, 1st, 2nd, 3rd temp. molars and 4 th perm. molar; at 2 years, all temp. incisors, 1st, 2nd and 3rd temp. molars, 4th and 5 th perm. molars; at 3 years, perm. mid. incisor, temp. inter. incisor and cor. incisor, 1st and 2nd perm. molars, 3rd temp. molar, 4th and 5 th perm. molars; at 4 years, perm. mid. and inter. incisors, temp. cor. incisors, 1st and 2nd perm. molars, 3rd temp. molar, 4th, 5th and 6 th perm. molars; at 5 years, all perm. incisors, all canines, all perm. molars.

Therefore, at four and a half to five years of age a horse has a full mouth. From this time on we tell his age by examining the cups in the tables of the incisors, by the shape of the tables, by the angle of incidence, and by the length of the teeth.

Molar teeth are matured at nine years of age, and from that time on they commence to grow up from the bottom of the jaw, and the lower edge of the rami of the lower jaw bone (inferior maxilla) becomes thinner.

473. A glance at a longitudinal section of a tooth (see P. 102) shows us that a tooth wears away from mastication, and gradually becomes shorter, causing the shape and nature of a table to vary very much. This takes place in the canines and also in the molars. At first there is no cup in the incisors, then a cup appears, then it goes again. Dishonest dealers make a young horse appear six years of age by filing the incisors and showing the cups. The expert, though, will examine the molars to detect this. Again, old horses are made to appear younger by filing the incisors shorter and making cups, and darkening them with silver nitrate. The expert can tell the difference by the angle of these teeth and by the shape.

TABLE of Incisons.-At 6 years, lower jaw cups in mid. incisors disappear ; at 7 years, lower jaw cups in inter. incisors disappear; at 8 years, lower jaw cups in cor. incisors disappear; at 9 years, the back corner of upper cor. incisors begins to point down below and behind the cor. of the lower cor. incisors ; at 10 years, upper jaw cups in mid. incisors disappear : at 11 years, upper jaw cups in inter. incisors disappear; at 12 years, upper jaw cups in cor. incisors disappear.

After twolve years of age it is diffcult to judge accurately the age of a horse. Successful 
judging of the age of a horse at any age depends on considerable practice. With a good deal of practice it is comparatively easy to judge the approximate age of a horse up to twenty years of age.

Al fifteen years, the table of incisors is triangular and the sharp point on the back edge of the upper cor. incisor is worn away.

At twenty years, the shape of the table is rectangular, being narrow from side to side.

A horse that lias grazed much on sandy soil will have shorter incisors than one that las done little grazing.

AGE of Honses.-The terms "rising" and "off" are used to denote, approximately, how far distant the horse's birthday is. For example: rising six means that the horse is a flve-year-old, but nearly six; six off means that he is a sixyear-old, and nearer six than seven.

474. On Photograpuing Horses. - As one who has photograplied over two thousand horses in the past five years, I think it may be as well to say a fow words on this subject. Photographing horses is far more difficult than it looks, and I do not wonder that many photographers refuse to do this. The photographer has so much to keep his eye on; he must watch the legs, ears and tail at the same time. The first thing he must do is to get the horse standing with all four legs showing from a point directly behind the camera, standing with his legs under him and properly balanced, and not with his legs stretched out, as is so commonly done with hackneys. (See P. 105c.) This latter is an example of the foolishness and ignorance of anatomy displayed by grooms and owners of such horses. It is supposed to look showy, but is unnatural and injurious, causing strains upon the back tendons of the hindlegs and upon the back itself.

When flies are absent, the pholographer's difficulties are considerably lightened. After he has got the horse standing well, he has merely to watch the horse's ears; but, if flies are present, he has to watch the ears and tail. He has to try some means of attracting the horse, so that it will keep its ears forward steadily; he then has to wait for the tail to be still. The worst time of year to take a horse is at the end of the summer, when the flies are hungry and worry horses very mucll. Of course, it is an easy matter for a retoucher to put the ears forward on the photograph, should the horse have them back at the moment the photograph was taken, so this point is not so important as the tail. Many people think that by sitting on the horse or in a vehicle behind and chirruping with the mouth they will cause the horse to prick up his ears; on the contrary, the horse holds them back, listening intently to the signals from the rear. Flapping the reins on the horse's bick will have the same effect of causing the horse to hold his ears back to receive the signals. The man on top or on the vehicle must keep absolutely quiet and still, and mind his own business. An assistant (when the photographer is quite ready) should walk forward with a measure of oats, if necessary, shaking the same. The practice of throwing something up in the air in front of the horse's liead is not a good one, as it will cause him, probably, to prick his ears suddenly and only momentarily. Another good practice is that of leading another horse at some distance in front of the one to be photographed.

475. Conformation of the Horse. - The special good points that should exist in a saddle horse have been described in Sec. 345 .

In considering the external conformation of the horse we have to consider two points: the anatomical conformation or malformation, as the case may be, and the appearance or looks of the horse. Shakespeare says, "Beauty is bought by judgment of the eye."

The former point, of course, is the one which a horseman considers most, but the latter is always considered most by the average buyer. It must be fully realised that a perfect horse is almost unknown, but a good horse must have many good, few indifferent, and no bad points. In judging a horse we consider the various structures purely from the point of view of mechanics. The usefulness of a steel chain depends upon the strength of the weakest link. So in the horse, one bad point will be very much worse than several indifferent points. But in the chain, one very strong link will not weaken the chain, but one very strong structure in the horse may cause considerable weakness. For example, a horse with a heavy, well-made body upon weak legs is far worse than a weak body on weak legs, because in the latter the legs will last longer. Hence two weaknesses often counteract one another.

Then, again, a good point may partially counteract a bad one. For example, a straight pastern may be counteracted to a great extent by a good sloping shoulder. The usefulness of a horse possessing various malformations depends entirely on the work that he is required to do. For example, a horse working on city streets must have good feet, and especially good frogs; a horse with a long, hollow back will not do for saddle work, but is all right for harness work; a weak-hocked horse will not make a hunter, but will last for years in light harness; a wide chest and round barrel are essential for a heavy draught horse, but a narrow, deep chest is essential for speed in the racehorse. Good wind is essential for fast work, but not so essential for slow draught work. It is far eesier to procure a good little horse than a good big horse, and for this reason it is commonly supposed that big horses will always be beaten by the small ones. If both were equally good, the big would win in most cases; good big horses 
are fow and far between. In most large horses the parts do not grow in the right proportions.

Size in bone is no criterion of strength. For instance, a thoroughbred's bones are much smaller than those of a coarse-bred herse or of a pure-bred Clyde, yet they are stronger because they are made of better material. (See P. 16b, 140b.)

A horse must always be examined at the walk and at the trot to ascertain if his action is free and true. The limbs must move freely at every joint, and move forwards and backwards without describing circles. The amount of action in a horse depends entirely upon the work that is required of him.

476. Structural Examination (see P. 95-101). -The head should be small, fairly long, wide between the eyes and in the jowl (to allow for a large brain and large larynx respectively). A good brain is necessary for energy, pluck, endurance and resolution. (See P. 93c, 111c, 138a.) Should taper of towards the muzzle, being wide from the eye to the angle of the lower jaw. The nostrils should be large and prominent. These should appear moist without there being any sign of discharge from them. There should not be many hairs inside the nostrils, which oncumber the free passage of air. The horse breathes entirely through its nostrils in normal health. The line down the front of the face should be straight when viewed from the side. (P. 16b, 63b show good heads. Compare these with P. 20a, 47d.)

The mouth should be small; lips small, thin and firm. (See P. 21a, 63b. Compare these with P. 57d.)

The eyes must be full, clear, large and prominent and mild, with a good brow and fine eyelids. Such an eye indicates a kind, generous disposition and good health. (P. 63b, 66a. Compare these with P. 20e, $f, 30 a$.)

A sunken eye often indicates suspiciousness and perhaps vice. An unduly round eye often indicates short-sightedness and probable shying. Horses which show the white of the eye are often said to be vicious, but, as I know so many horses that show this white which are not vicious, this theory, like so many stablemen's theories, is probably nonsense.

The ears should be small, thin and vi-ij-set on. They should be firm when the hore iz at work, and when pointed forward the tips should be closer together than the bases. Lop ears are not necessarily a bad sign, as they are found in all classes of horses, and are often the result of a nervous affection. (P. $68 b, 113 a$ show good ears; P. 14d, $56 c$ show ears of inferior conformation.)

477. The neck should be light, fairly long (especially for saddle work), and taper so that the chief weight is at the shoulders, thus allowing the end of the neck to be easily controlled, similar to the end of a fishing rod. (P. 68a. Compare these with P. 20d, $f, 37$.) The head must be well set on to the end of the neck; while the neck is held up normally, the head should be at an angle of about $60^{\circ}$ with the ground. (P. 68a, b.) The neck must be well arched, so that the upper edge is longer than the lower; such is called "long in the rein." The crest must foel firm to the grasp.

The withers must be high and well muscled. Fine withers indicate insufficient strength to the shoulders; in such there is a deficiency of muscle.

478. The shoulder (P. 31, 69) consists of the shoulder-blade (scapula), the forearm (humerus) and the point of this shoulder, which is the joint between these bones.

The scapulo should be very long and fairly broad and lie obliquely. The muscle should be well developed. For saddle work, obliquity is essential. For harness work, a fairly upright shoulder does not matter so much. (For saddle, see P. 68a, b. Compare with P. 29b, 47b, 105c.)

The humerus should be fairly short and more upright than the scapula, so as not to bring the elbow joint too far under the body. (P. 67b.)

The chest should be very deep, fairly broad, and well muscled in front. (P. 68b.) P. $117 \mathrm{~h}$ shows want of depth from withers to sternum, The elbow should be well separated on each side from the chest. The forelegs should be straight and broad. A plumb line dropped from the point of the shoulder should pass in front of the leg right down to the foot. (P. 100.) A plumb line dropped from the centre of the elbow joint should pass the centre of the leg right down to the fellock, and touch the ground just posteriorly to the foot. (P. 63b, 68b. Compare with P. $36 c, 47 d, 51 e$.) P. $86 b$ shows clearly the tremendous weight that can be borne by the forelegs of a hoise, and what a tremendous strain must come upon these legs when a horse lands over a jump.

479. The forearm (radius) should be quite long compared with the cannon bone, and be thick and very well supplied with muscle. (P. 63a. Compare with P. 52a, b, 57d.)

The ulna, which is the bone that is attached to the back of the radius at the elbow joint, should be large, strong, and set directly posteriorly to the joint. This allows for ample muscle attachment and full freedom in action. (P. 66a. Compare with P. 36e.)

The knee should be large, broad, deep and prominent. The trapezium bone, whish projects to the rear, should be long; thus the knee should taper of to the rear. (P. 66a. Compare with P. $57 d, f, 60 a, 91 b$.

The cannon should be short and strong ; very short compared with the radius. (P. 21a. Compare with P. $36 e$.)

The tendons must be well set back and feel 
firm, distinct and hard. They must stand out distinctly from the bone, so that the cannon, viewed from the side, has the appearance of being flat from front to rear. This is commonly and erroneously called "flat boned." (P.66a, 67b, 97e, 08, 105c.) P. 74e shows a leg of bad conformation. The cannon, viewed from the side, nust not appear narrow below the knee, called

"tied in," but be nearly as thick as the knee itself. P. $97 \mathrm{~g}$ shows a leg a little "tied" and with tendons too close to the bone.

The pastern should slope at about an angle of $45^{\circ}$ with the ground and be fairly long; should be strong. (P. $16 b, 63 b, 113 b$. Compare with P. $18 a, 53 b, 57 a$.)

The fellock joint should be strong and fairly large. (P. 68b.)

The sesamoid bones at the back of the fetlock should be large. (P. 68b.)

480. The Foot.-The wall of the forefoot in front should slope at an angle of $45^{\circ}$ with the ground. (P. $63 b, 66 b$. Compare with P. 57a, 60d.) A good foot is of the greath importance. It should be sound, fairly large, and of a firm, dense, waxy texture. It should appear healthy. (P. 138b.) Both feet should be similar, i.e. each pair.

The frog should louch the ground at each step and be elastic, and should show wear.

The sole should be concave and feel firm.

The bars must not liave been pared away by the blacksmith.

481. The back should be short, well muscled, and fairly straight. The length of the body underneath the belly should be comperatively long. (P. 67b, 68a, b. Compare with P. 53b, 56c, 98.) These points give strength and freedom in action. If the horse is short underneath, his speed will be limited, and he will bo liable to overreach. Trotting racehorses have longer backs than most horses. (P. 41a.) Old horses have more or less hollow backs, due to the wasting away of the muscles of the back. Hollow backs are weak.

Roach backs are strong, though ugly, and if shoulders and quartes are good the horse will be useful especially for harness work. A roach back is uncomfortable for saddle work, whilst a hollow back is comfortable. P. 47,48 show types of harness-horse backs.

The Barrel-Ribs.-The ribs should be well rounded. A round-barrelled horse will always outlast a flat-ribbed horse when put to the test, and is far more easily kept in good shape at other times.

The ribs should be broad and close together, and continue back close to the pelvis-the point of the hip. (P. 68a, 105a. Compare with 53b, $56 c, 83 a$.)

A horse that is "slack" in the ribs has the last rib approximately more than a hand's breadth from the point of the hip. One that is "liglt " in the ribs has the last rib too short and too flat. Horses that are very slack in the ribs will not stand long-continued work.

A horse that is poor in condition must not be confounded with one that is slack or light in the ribs.

The loins should be broad and well muscled up and short (the latter being the opposite to slackness in the ribs). The muscles of the loins should appear smooth and round. (P. $34 b$ -leader.)

482. The croup, or haunch, should be long and muscular, and should only slope a little towards the tail, the tail being set on high. (P. 67b. Compare with P. $51 b$ for drooping croup, and P. $51 b, 52 a$ for tail set on too low.)

Strength in propulsion (as in draught, jumping or racing) depends almost entirely on length and an ample muscle supply in the croup (the gluteal muscles). A drooping croup, if combined with powerful muscles of the hindquarters, gives great power in jumping for hunters and steeplechasers. (P. 68b.)

The pelvis should be broad; but in a saddle horse, if too broad, it is liable to produce a rolling action behind. It should be deep, and at an obliquity of $30^{\circ}$ to $35^{\circ}$ with the ground to give length to the croup. (P. $67 b$. Compare with P. 113a.)

483. The Tail.-The dock should be naturally (when unmutilated) fairly short. (P. 28.) It should be thick, and, therefore, woll muscled. The hair should be fine and not curly. (P. 16.)

The sheath should be large and well developed. (P. 16a.)

484. The Hindlegs.-There must be great length from the pelvis to the hocks for power and speed ; this is known as being "let down" in the quarters. (P. 63b, 67b. Compare with P. 26a, 29a, 57d.) A horse cannot be let down too far, except, as stated in Sec. 475 , in the case of weak forequarters.

A leg that is bent too far forward is predisposed to curb (P. 19c, 26b,74e), and one that is too straight is predisposed to bog spavin and thoroughpin. (P. 58c, 119h.)

A plumb line dropped from the point of the bullock should pass down the back of the cannon, and, viewed from behind, it should pass down the centre of the entire leg. (P. 64b, 68b. Compare with P. $28 b, 97 a, d$.) A plumb line dropped from the centre of the hip joint should pass across, halfway down the tibia, and through the centre of the foot. (P. 67b, 100.)

The thigh bone (femur) should be long, strong, and lie at about an angle of $80^{\circ}$ with the ground. (P. 67b.)

The tibia should be lnng and let well down into the hock. (P. 63b.)

The muscles of the thigh and tibia should be well developed and continue down close to the hock. The adductor and internal femoral 
muscles inside the thighs should be well developed, and continue down so as to give the gracilis region a plump appearance. (P. 1146.)

The tibia, or gaskin, should slope at an angle of $85^{\circ}$ to $70^{\circ}$ with the ground. (P. 100.)

The patella should be well developed. $15 a, 113 a$.)

485. The hock is one of the most important parts of the horse's anatomy from the point of view of conformation. It should be clean, firm, prominent and large, and without any pufinness or flling-in between the various prominences.

The point of the hock (formed by the process of the os calcis) should be large and strong, and should be separated, as it were, from the leg above. The distance between the point of the hock and the bottom of the front of the hock should be great; suoh a hock is "well let down." (P. 21b, 67b, 68b. Compare with P. 26b, 74e, 80a. See P. 89, 100.)

The hind cannon should be short, the tendons well set back, and there should be good width on top at the base of the hock. The hind cannon bone is larger than the fore.

The hind pastern should be similar to the fore, but this is not of such importance. The hind is not subjected to the same amount of concussion.

The hind foot should be well rounded. The tendency is for the hind feet to be too much pointed. The slope of the frcnt of the wall should be $50^{\circ}$ with the ground. (P. 63b, 68b. Compare with P. 57a, 60d.)

486. Action.-The action must be free, level and straight, i.e. true. A horse that walks well usually trots and canters satisfactorily. The foot should be well raised up and fairly flexed, without being turned more than perhaps a very little in or out. The foot should be placed flat on the ground, the shoe wearing equally all over. In trotting, the hocks must be properly flexed. All action should commence from the top of the limb. In front, from the shoulder, and not merely from the knee; whilst, behind, it should commence from the thigh. (P. 43.)

In the gallop the hindlegs should be brought well under the body and the body carried near to the ground.

High action is of little use except for appearance. Hackney fanciers like it, but it is a fad, and with some people it is carried to such an extreme, by means of very heavy shoes, that it becomes a mere fake. High action destroys speed and destroys the horse's legs and feet.

487. Colour. - Whatever the colour may be, it must be good of its kind, i.e. not light. Particularly should the horse's points (extremities) be dark. Chestnuts, browns, bays, roans, duns, etc., which are lighter in colour at the extremities of the limbs are generally reak in constitution. This is probably due to the circulation in the washy parts being poor. When the colour of a horse is doubtful, the muzzle is the guide; for instance, a black body with a brown muzzle is a brown horse, but with a black muzzle is a black horse.

A grey with a black mane and tail is an irongrey (P. $4 b, 57 h, 63 b)$, but a grey with a dark body and a white mane and tail is a black-grey (P. 57g, 83b). Yellow-coloured horses with light or white manes and tails are called creams. Those with black manes and tails, duns. A chestnut must have a chestnut mane and tail ; if these are black, then the horse is either brown or bay.

A shiny black is called jet-black. Black horses and other colours change considerably between summer and winter. Summer-blacks are dark brown in tho winter.

A horse with a few white hairs scattered about the body is known as a flecked brown, black, chestnut, or whatever his colour may be.

White horses with brown patches are called skewbald. Those with black patches, piebald.

A white horse with small black patches all over its body is called a spotted-grey. The reverse, a black with many white spots, is called a starred horse. A dappled-grey is a white horse with various small ring-like markings on its body, particularly on its hindquarters; they vary considerably in design. (P. 104a, 133, 136d.)

488. Natural Marks.-A star is a round or star-shaped white spot on the forehead from one to three inches in diameter.

A snip is a white strip down the muzzle, in front or at the side.

$A$ race is a narrow white strip down the face. It may extend to the star or it may be separate; it may extend to the snip or be separate.

A blaze is a broad white streak covering the whole face, or part of the face, down to the mouth.

A white stocking is a while leg below the knee or hock. If marked higher up it is known as a high stocking.

A white sock is the leg that has the fetlock and pastern, and a little above the fetlock, white.

There are also white fetlocks, white coronets, white heels, and white hoofs. White hoofs are not, as a rule, so strong as dark ones; they seem to lack vitality.

Natural white hairs in the mane and tail are not uncommon marks. Natural marks must not be confounded with blemishes which are the result of saddle or harness injuries, etc.

Some dun-coloured horses have a blackstriped marking extending down the back from the mane to the tail.

489. Various breeds of horses are shown in the photographs in this book. There is one breed in particular that, I am thankful to say, is becoming more popular, and that is the Arab.

The English thoroughbred is in reality an Arab-at least, it came from the Arab-and more 
than ever its value is being realised by the sportsman of to-day in the hunting fleld, the point-a-polnt race, and in the polo field. As for beauty, style, elegance and smoothness, and perfect conformation, there Is no horse in the world to compare with the Arab. (See P. 2, 4, 5, 18b, $19 g, 02,83 a-d$.$) Napoleon said: "Un bon cheval$
Arabe est le meilleur cheval du monde." To use Major Upton's words In "Newmarket and Arabia": "He is a perfect animal (what more could we want?). There is a balance and harmony throughout his frame not seen In any other horse; the quintessence of all good quali. ties in a compact form."

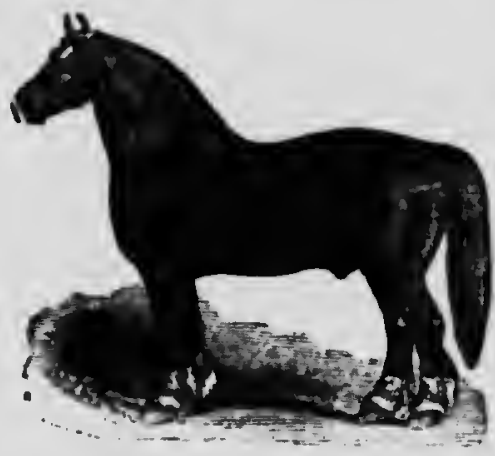




\section{CHAPTER $\mathbf{X}$}

\section{PHARMACOPEIA AND USES OF MEDICINES}

480. Tire Use of MEDicine.-In the treatment of diseases it must always bo remembered that all we can do is to assist Nature to repair the diseased structure, in whatever form the disease may be. We cannot cure the disease, but we can, however, by means of suitable nursing, drugs, and antiseptic precautions, place the patient under the most favourable conditions. In short, what we can do is to fight for Nature against the enemies that are hindering her work.

The abuse of drugs, even in this enlightened age, is very great. The horse is subjected to a great deal of cruelty by owners and grooms administering all kinds of quack and useless medicines because they think their horses are ill. The old story, that if anyone looks up the symptoms of a score of diseases in a book he will come to the conclusion that he has got all these diseases, applies in the case of horses. A well-meaning owner often imagines, on account of his limited knowledge, that his horse has some disease, whereupon he at once goes to his shelf of ancient drugs, many of which are useless, and in some cases harmful, and administers a dose.

481. As in all medicinal science, faith is half the battle. This does not apply to the horse in the same way that it does to man; but, generally, if the owner has faith in his treatment, the horse has a better chance of recovering.

It is always wise when in doubt to call in a professional. "A little learning is a dangerous thing," and many a horse lias died, or has been hindered in recovery, by inexperienced people meddling with drugs. It is not necessary to be continually giving drugs. The flnest cure is Nature's fresh air, plenty of good exercise, and healthy surroundings. The commonest of harmful drugs that are given to the horse are nitre, spirits of nitre, opium and black antimony. Nitre is a salt of potassium, and all potassium salts have a bad effect on the heart if their use is continued. Opium is used in all patent medicines for colic; but this drug should never bo used except in one case of colic, i.e. when there is diarrhœa. Antimony forms the largest proportion of many stock medicines; it is a useless drug, and in many cases does much harm.

492. The belief in old-fashioned recipes is also most amazing. Books printed over half a century ago are kept on the shelf and are referred to whenever medicine is required. I strongly advise that such books be burnt, because, if they lie about, people are sure to take hold of them and read them. A recipe in print is held by some as almost sacred, however old it may be.

Owners of horses should keep a strict watch over their grooms to see that drugs are not given whenever the latter think fit. Cruelty is not limited to the abuse of drugs, for it is practised in the use of the knife; some old-fashioned surgical practices are continued to-day, and in many cases gross cruelty is perpetrated, such as blowing powdered chalk into the eye to rid it of a piece of chafi, and other even more foolish notions. Then, again, a common practice is to soak a horse's coat with coal oil or creolin when it is suffering from mange. Others cover a horse with coal oil to keep flies off, and in many cases seriously impair the horse's health by stopping up the pores of the skin with a mineral oil.

493. Methods of Intaoducina Druas.

1. Intravenous consists in injecting a solution of the drug into a vein, generally the jugular (see P. 137), by means of a hypodermic syringe. The disadvantages are that it is difficult to make the point of incision aseptic, that a slight over-dose would reach the heart, and the danger of injecting a bublle of air.

2. Subculaneous consists in injecting a solution with a hypodermic syringe under the skin, usually on the neck. Certain drugs, as barium chloride, which cause irritation to the tissue under the skin, must not be introduced in this manner.

3. Intratracheal consists in injecting the solution into the trachea or windpipe by inserting a needle in between two of the cartilage rings. This is the best way of introducing eserine and other drugs that are required to act in a hurry. Chloral hydrate must not be introduced in this manner, as it may cause pnoumonia.

4. Inhalation.-Volatile drugs, as ammonia, ether, chloroform, amyl nitrite, eucalyptus, etc., are introduced in this way for diseases of the respiratory tract.

5. Oral.-This is the usual way of introducing drugs, either as a drench, or in a gelatine capsule, 
or in the form of a powder. The action, how. ever, is slow.

6. Reclal injection, i.e. per rectum, used when llie patient is in convulsions or a coma, also in tetanus and for local elfects, as for the cure of worms in the large intestine.

7. Inunction consists in mixing the drugs up with vehicle to form an ointment or liniment which is rubbed through the skin. The vehicle must be either an animal or vegetable fat: mineral fats are only absorbed very slightly, if at all, by the skin.

Wool fat, lanoline, lard, and oleic acid are absorbed rapidly through the skin, and should always be used for making ointments; petrolatum and vaseline are not.

494. Notes oN THE L'SE of DHLGs.-Absorption occurs through wounds and abscesses very rapidly, therefore great care must be taken in applying drugs to these cases. I remember a liorse that died after its coat had been soaked all over with kerosene oil, and another that almost died from having its coat soaked all over with 5 per cent. solution of creolin, in each case with the idea of curing mange. The symptams are identical with those of taking the poison by the mouth. Iodoform is a dangerous drug if used over large surfaces, especially wounds.

An animal can do without food for several days provided large quantities of normal saline solution $(.85$ per cent. solution of salt, $\mathrm{NaCl}$, in distilled water) is injected per rectum. An empty stomach absorbs more rapidly tlian a full one, although it is not so vascular, i.e. its blood vessels are llut so well filled with blood. In cases of puncturing from bloating, drugs may be introduced through the opening, i.s. through the cannula before it is withdrawn.

495. In whichever way a drug is adminis. tered it eventually reaches the blood; if given per oram it reaches the intestincs and the blood by passing, by means of osmosis, through the cells of the intestines and of the walls of the blood vessels. From the blood it reaches the liver, and certain cumulative poisons such as salts of mercury, arsenic, antimony, silver, tin, bismuth, asd lead, remain in the liver, and if repeated continualty, cause a slow death, hence the danger of playing with these metallic salts.

496. Administering Drugs.

Balling.-The most convenient way of giving a horse medicine is to give it in the form of a ball or a capsule.

A ball is composed of the drug in powder or syrup form, mixed with a vehicle to make it of the right consistency. (Sce "Purgatives," Sec. 5t4.) A capsule consists of a hard gelatine cup. shaped box, with a lid that slips on; it holds nearly an ounce of most drugs. Any form of drug can be put into it, but warm drugs must not be left in many minutes, because they will melt the gelatine.
To give a ball, take a good twi gentle hold of the tongue with the left hand, and draw it out of the mouth a little way, holding i: between the right molars so that the honse cannot close his mouth. With the right-land fingers take hold of the ball or capsule parallel to the fingers, between thumb, first, and fourth fingers, squeezing the hand so as to mak" it of as smell a compase as possible. Turn the skeve up and insert the liand rapidly riglit to the back of the tongue, and throw the ball over the tongue into the formen crecum, whlch is directiy in front of the pharynx. At the same time lat go the tongue, and the horse will withdraw the tongue and cause the ball to slip down his throat. If the tongue is held for too long a period, the horse may be able to cousis tlit? ball up again. There are mucous glands around the base of the tongue that make the ball slip easily into the pharynx and down the gullet. The horse inust not be frimhtened, but taken quite quietly. The weight af a ball must not exceed $1 \mathrm{oz}$. ; the size not Eater than 3 in. in length and $1 \mathrm{in}$. in diameter. It is a good plan to put a glove, with the tagers cut off, on the right hand, to prevent the nolurs from scratching it.

497. Drenching.-In curum a drench the horse's head must not be tied up, as there is always a danger of the horse choking. However, unlike the cow, sheep and pig, a horse can completely close the back of its mouth if it wishes; the other animals named cannot. And thus many cases have occurred where liquids have been poured directly into the lungs of the unfortunate animal who has refused to swallow the drench.

The horse must be handled quietly so that he may associate pleasant sensations with the process, and a tit-bit should be given afterwards. One can easily hold the jaw up with one hand and pour a little of the drench from a soda. water bottle or drenching horn over the bars of the mouth in front of the molar teeth, though an assistant to hold the horse's head up may be necessary. If the head is held up at all by a rope, the rope must pass over a pulley in the ceiling, so that it can be let loose directly there is any sign of choking. The drench must always be diluted with a pint or more of water. After each mouthful is poured into the mouth the throat should not be rubbed, which is a dan. gerous habit, but the horse should be made to swallow by pressing one's thumb gently but firmly up against the hyoid bone, in between the rami of the lower jawbone, which can be felt as a little lump about half-way down the jaw. The dangers of harming a horse from drenching a re very slight compared with those in the case of a cow. I remember one cow which died before its head was let down. The ignorant vet. had tied its head up securely, and poured a bottle of liquid into its mouth. The cow refused to swallow, 
and, being unable conipletely to close the ptiaryngeal opening (the isthmus of the fauces) uith its solt palate (volum pendulum palati), the liquid ran directly into the lungs.

488. Uypodermic Injections.-A little patcl of hair should be clipped of, one or two inches across, proferably half-way up the nerli. The lieedle is screwed of or slipped of the sylinge, and made aseptic. It is then quickly pressed through the skin with the rlght hand, the skil being held up away from the under-tissue with the left hand, and then the syringe, previously filled, is slipped on to the needle, and the whole cuntents squirted gently in. This must not be done rapidly. The syringe and ueedle are then withdrawn together. Care must be laken that the liquid does not escape; for this reason it is always better, after inserting the needie, to make suro that the inside of the needle is wot clogged up by passing the small wire througl it which is provided for the purpose. In flling the syringe, care must be takell that the plunger is slightly greased to ensure its being air-tight. The plunger should be pressed down very slightly until one or two drops of liquid come out, thus ensuring that there are no air bubbles left in the syringe. This is most important in making injections into the veins.

If the liquid remains like a blister under the skin, it can be assisted in its absorption by being gently rubbed with the fingers. If injected into the windpipe, the needle must be inserted between two of the cartilage rings, and pressed right through. If into the jugular vein, the greatest care must be taken to avoid a bubble of air getting into the blood, which would pass to the heart, and might cause death. The jugular vein is discovered by pressing the thumb into the jugular groove (see P. 137, 138a) and causing the pressure of blood slightly to distend the vein. The needle is inserted into the distended portion of the vein.

499. Rectal.-Enemas are given per rectum. As most of the fuid in the horse's alimentary canal is absorbed in the floating colon, any drug placed in a liquid state into this intestine will be absorbed into the system. The back portion of the floating colon is only about two feet from the anus; the floating colon is about ten feet in length. Before anything is pumped in, the horse must be backraked by greasing the hand and arm and passing it into the rectum and removing all its contents. It wonld be useless to try to fll the colon with an enema unless it were empty.

The enema must not be colder than $100^{\circ} \mathrm{F}$. The best method of injecting is with an enema pumn, which has a six-loot rubber tube and a wouaen nozzle attached to it. The nozzle is greased, and, with the hand, passed right into the floating colon, without any force being used. The enema is then pumped in slowly, the tail being depressed with the hand for about fifteen minutes to allow the drugs to be absorbed into the system.

If an enema is given merely to decrease infammation or to act as a purgative, as in colic cases, it is not so important to pass the nozzle so far in. A large bucketful (four gallons) is about the right aniount to use for a single injection.

\$00. Inunction.-Ointments or liniments for this purpose must be put on tairly thickly, and rubbed in until the skin is quile dry.

501. Use of Trocar and Cannula.-Whenever tympanites becomes bad (i.e. the horse becomes badly blosted in the abdomen), a trocar and can. nula must be used to save life. These must be separated and sterilised, if there is time, or dipped into an antiseptic. The trocar is inserted into the cannula, and the two together are pressed rapidly through the hide until the head of the caunula is right home. In the case of abdominal tympanites, the place of puncture is at a polnt equidistant from the last rib, the point of the lip, and the transverse process on the side of the lumbar vertebre. The trocar is then rapidly withdra" " from the cannula, when the gas will escape with a rush. When all the gas is out, and the animal seems to be recover ing, it will be necessary to remove the instruments. The trocar must be placed back into the cannula, and the whole rapidly drawn out. An antiseptic must be placed over the spot.

Drugs are often administered through the cannula, especially when the digestive powers of the stomach are affecled or when a constriction in the small intestines is suspected.

502. Passing the Catheter.-In a mare it is an easy matter to pass the catheter. The hand and arm are cleansed and slightly oiled, and inserted into the vagina; with the flrst finger the opening into the bladder (meatus urinarius) can be felt about half-way towards the neck of the womb, on the floor of the vagina. The finger is inserted, and the catheter, which must be greased, is passed in under the hand and finger into the bladder.

Passing the catheler in a horse is a dangerous operation unless understood, as it is easy to injure the animal. The yard must first be withdrawn right out, and the catheter greased. This must be slowly and gently passed up the passage in the centre (urethra). When the end of it has got as far as where the urethra passes under the tail just midway between the points of the buttocks (ischial bones), it must be assisted in passing round the sharp bend with the fingers of the other hand. Tlie end can be felt, and must be pressed slightly to help it along, great care being taken no: to use any force with the other hand.

Catheters must be kept scrupulously ciesn, always immersed for three minutes in an anti- 
septic before use, and rinsed with cold water after use. They should be kept greased, otherwise they will become stiff, and are liable to break in two when inside and perhaps cause serious trouble. They must never be inserted unless they are absolutely flexible. A wire should be used to keep the inside free of foreign matter before use. They must never be allowed to become frozen.

503. Poullices.-Every poultice that is put on must be antiseptic. One pound of linseed should be taken, and enough boiling water added to make a mash; sufficient carbolic or creolin must be acdued to the water to make a 3 per cent. solution. The poultice must be well mixed with a stick. In modern medicine, poultices are seldom used; their chief use is to bring an abscess to a head and to draw a poison out of it prick in the feet, or to soften the feet. A poultice made without an antiseptic is a dangero's thing to put on an open wound, because it acts as an incubator to the germs of disease, thus probably causing more harm than good.

A poultice must never be left on over night; if, therefore, the horse is not attended to for any length of time, as during the night, hot cottonwool should be used in the place of a poultice. This remains hot for a longer period, and never gets cold and damp as a poultice does. A cold, damp poultice, for this reasul1, oftell counteracts the good that the hot poultice has done. The hot wool should be put on so that the hand can just be borne against it, and plenty of flannel bandages placed outside to keep in the heat. Pillow feathers make the best insulator against the conduction of heat.

504. Mustard.-This must be mixed with cold water only, and on 110 account must it be mixed with warm water or vinegar, as they destroy more than half the life of the mustard. To dilute the action, flour should be added. Mustard should be mixed with the fingers or a spoon in a large basin until it is of a fairly thick consistency. This is plastered on the part with a spatula or blunt knife fairly thickly. The time that it remains on depends entirely upon the thickness of the skin and the disposition of the animal. In some cases half an hour will cause sufficient irritation to render it advisable to remove the mustarl; in others it may be left on until its action ceases-say, iwelve to twenty-four hours-when it may be necessary to repeat the plaster. In pneumonia and pleurisy, as a rule, mustard is put on all over the area of the lungs. Ordinary newspaper should be put on outside the mustard, and a blanket over the paper. As a rule, mustard should not be rubbed in.

505. Condensed Pilarmacopoisa. - Realising fully that a veterinary surgeon can treat all the cases he has in a year's practice with drugs from a few dozen bottles. in the pharmacoporia which follows, I have listed the drugs that are most necessary in treating diseases of the horse. Many are not listed for obvious reasons; then, again, there are many which sume practitioners would not use themselres - but, as one drug is often handy whil $r$ is not, it is advisable to give doses .... ses of them. One practitioner prefers one diug and another prefers something different. Chauging about from one drug to another is not good therapeutics, except in those difficult cases in which one drug having proved of no avail, another must be tried.

It is neither possible nor wise to lay down any liard and fust rule for the treatment of diseases, as each practitioner has his own method, guided by broad rules and a sound knowledge of the acticn of drugs.

506. Dosage.-Approximately, if a dose for a man is 1, that for a horse, of, say, 15.2 hands in height, is 60 .

Doses for young horses:

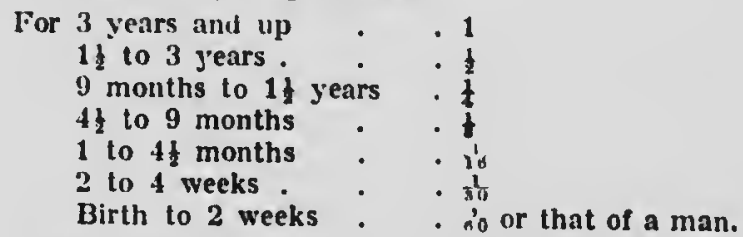

These doses, of course, must vary according to the size and condition of the patient.

At first all drugs must be given in small doses until the horse is used to the drug; then they can be enlarged. A thoroughbred or standard-bred horse of high quality requires a smaller dose, as his nerves aro better developed. Farm horses take much larger does, even if they are small animals.

All fluid measures are imperial. (See Sec.517.)

A tablespoonful is approximately $\frac{1}{2}$ oz. water.

$A$ teaspoonful is approximately $1 \mathrm{dr}$. (See Sec. 520.)

Solutions. - The strength of a solution is generally stated as a percentage, e.g. 5 per cent. sol. carbolic acid in water equals 5 units by weight of carbolic in every hundred units by weight of the solution.

507. Pharmacopocia.

The action, doses, names and formulx of drugs :

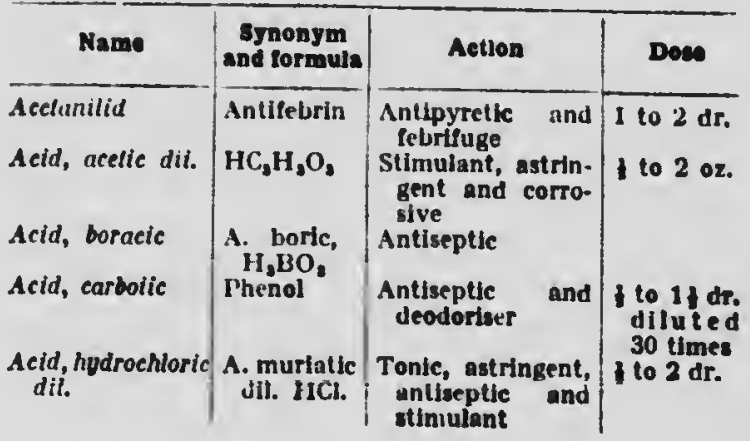




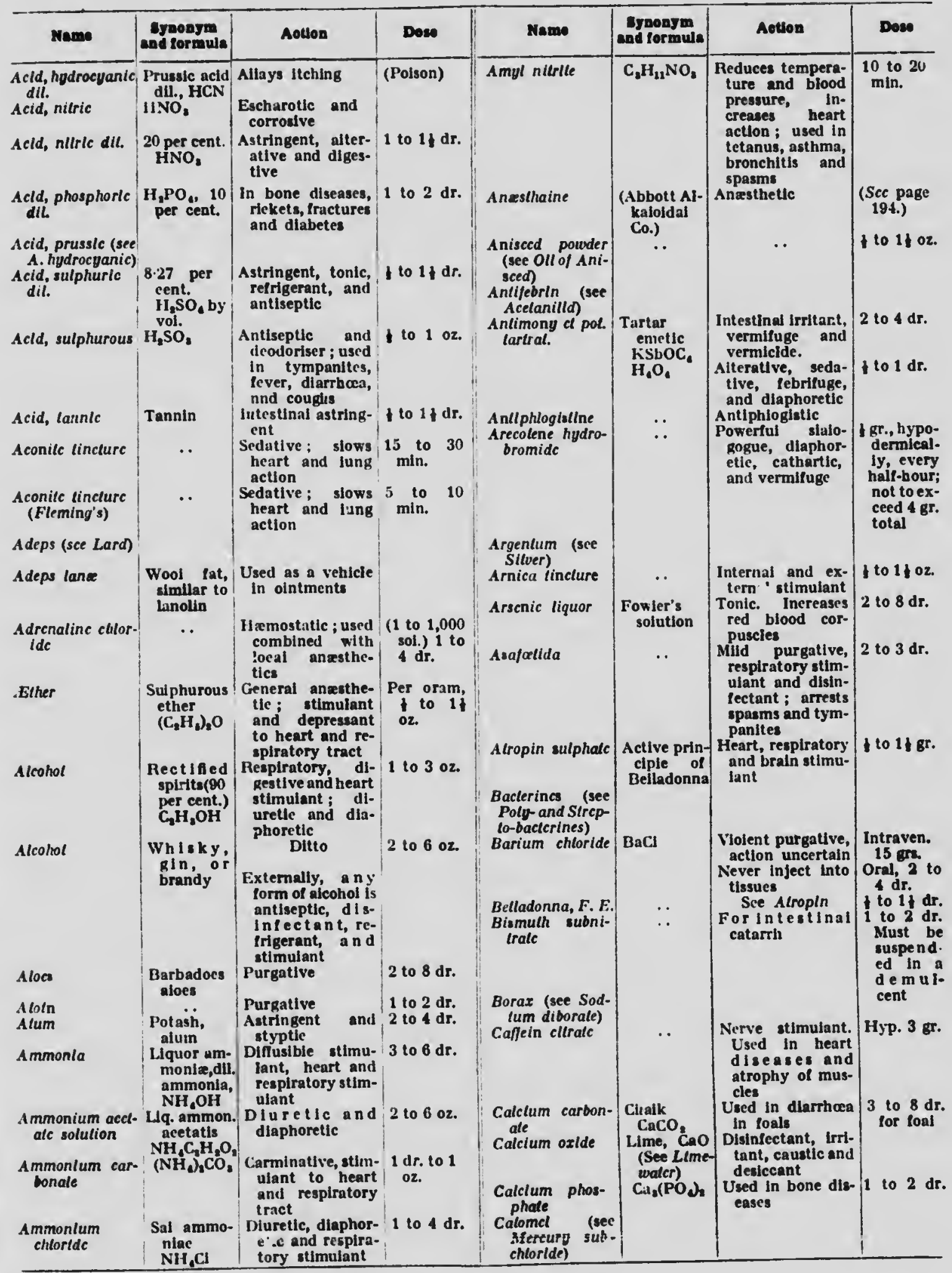




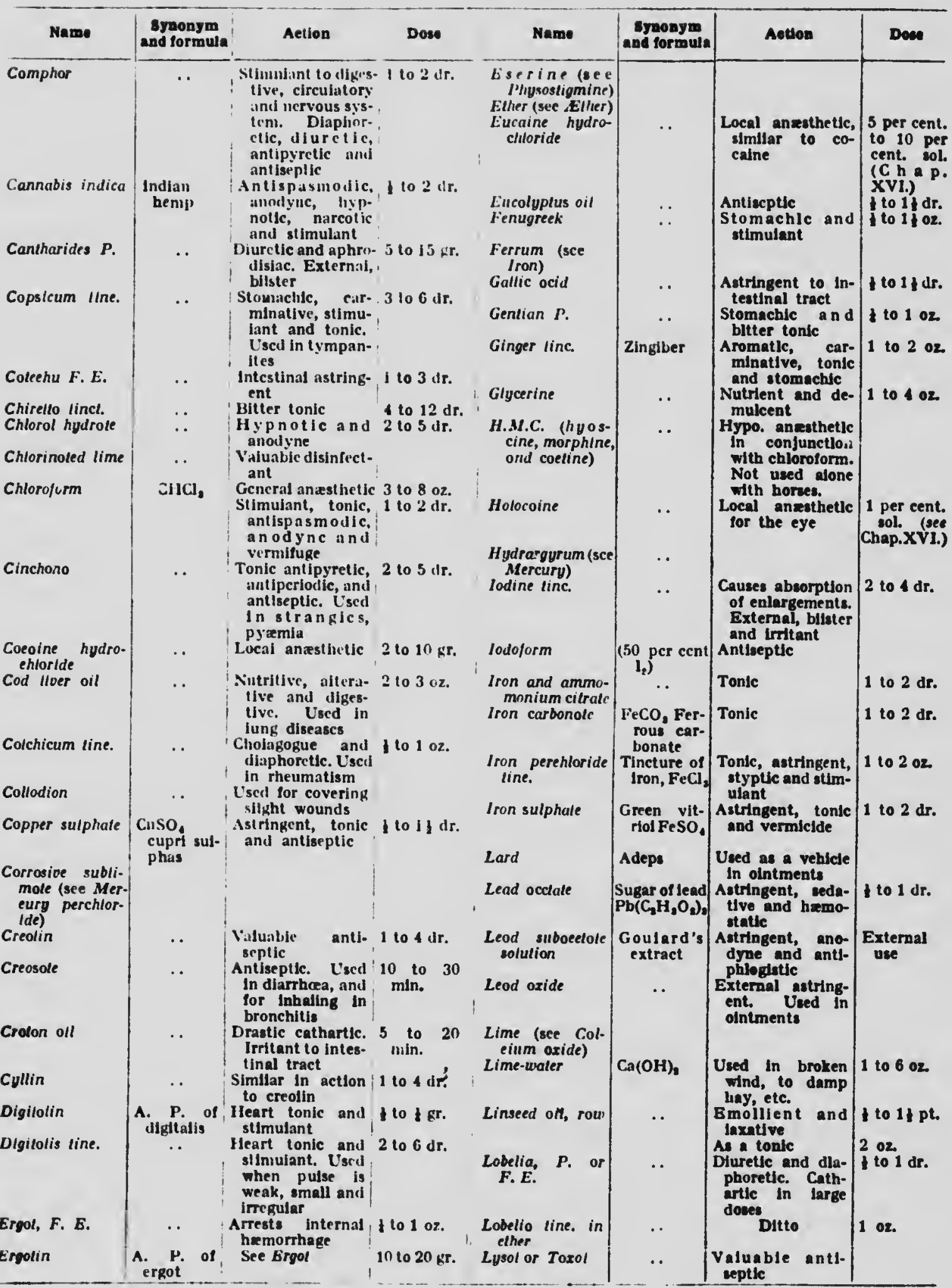




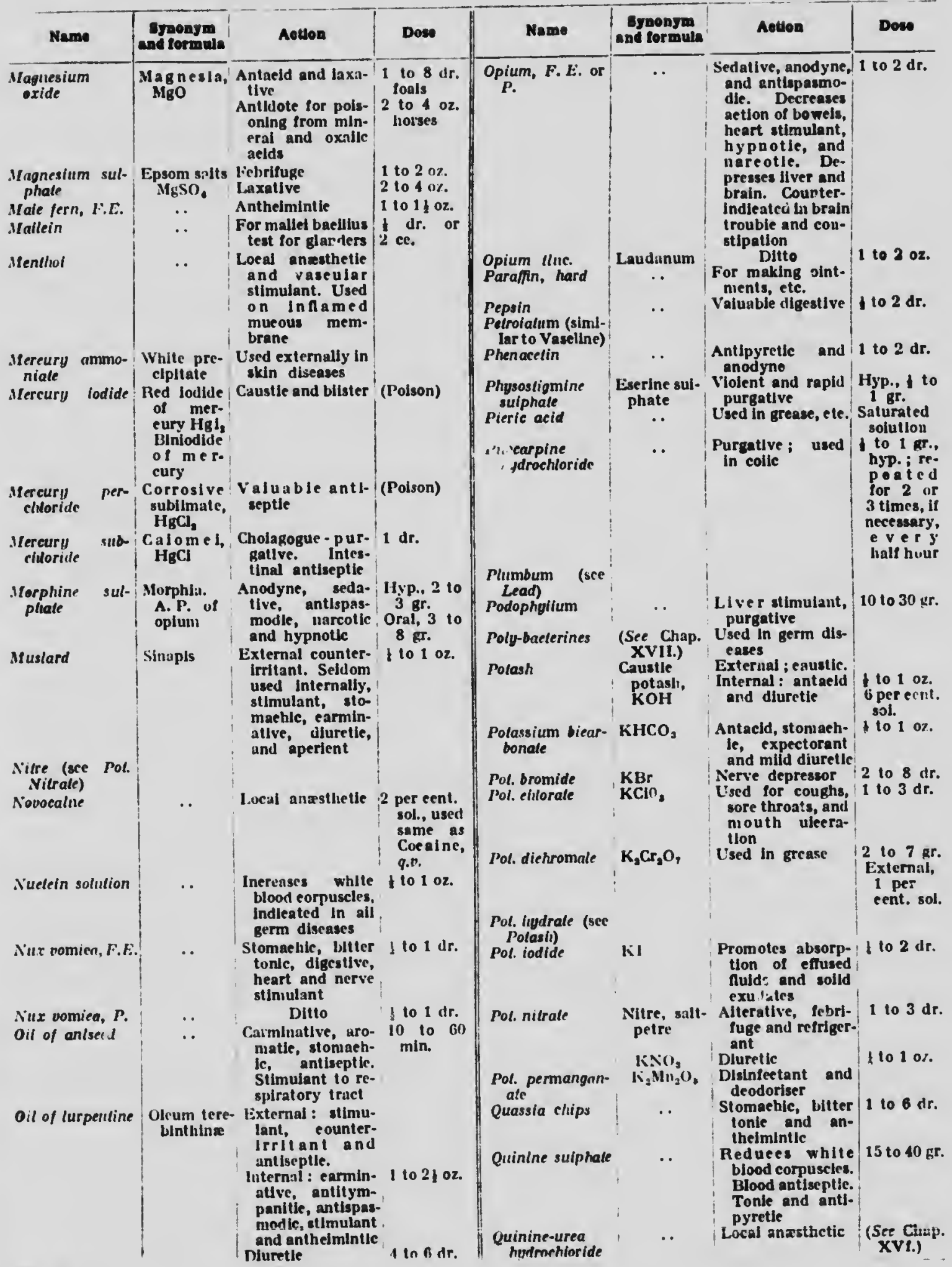




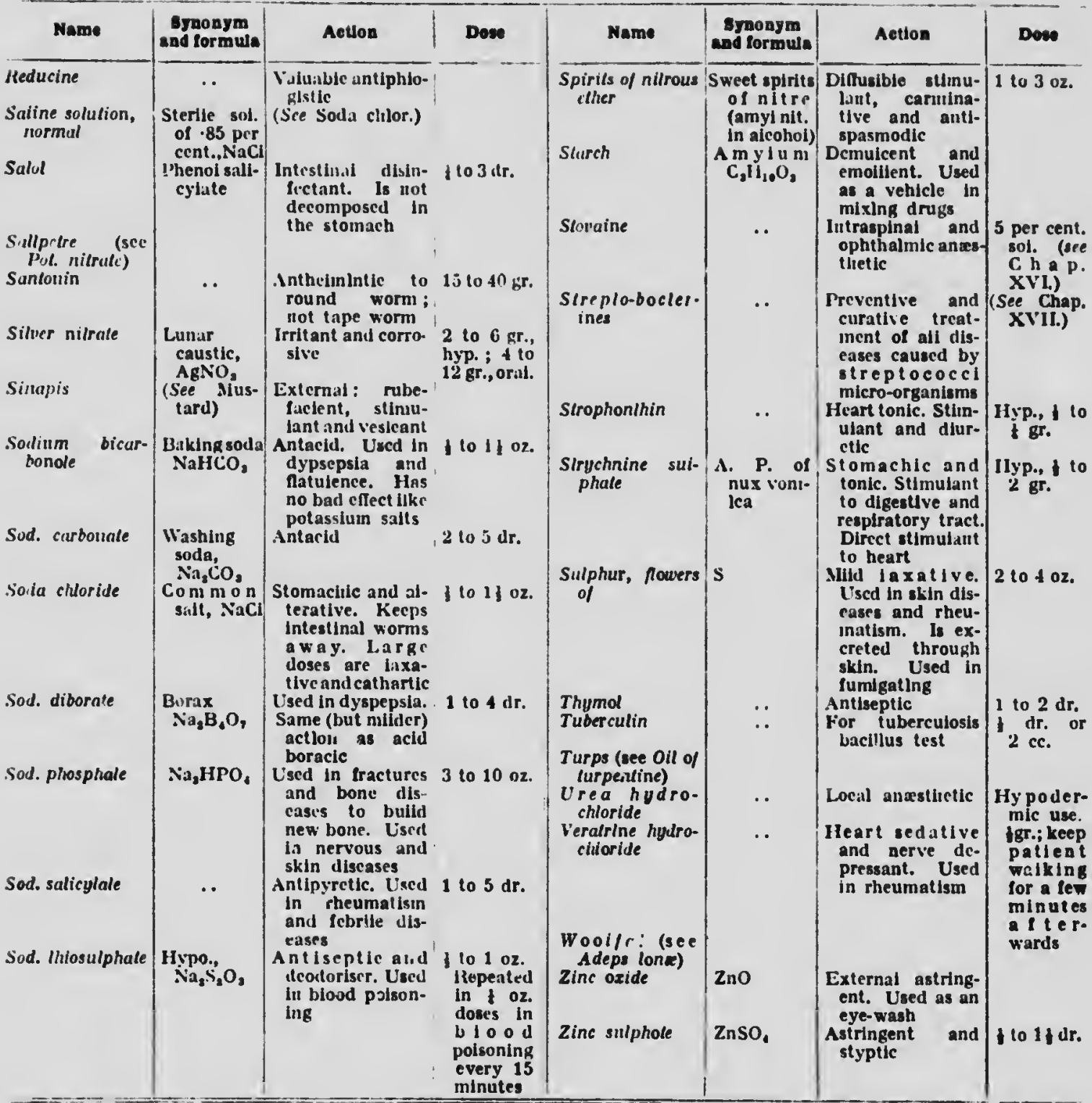

508. Sirength of Drugs. - The most suitable form in which to keep nost drugs is that of the fluid extract or in tablets.

For hypodermic use they should be kept in tablets; then there is no risk of giving the wrong dose, as there will be no weighing out to be done.

The dose of the fluid extract is the same as that of the powder, if there is one.

The dose of the tincture, which is an alcoholic solution of the fluid extract, is eight times that of the fluid extraci (F.E.).

509. Useful Compounds to be kept in Stock.

1. Amsonis, dllute llquld.

Llquor ammonia fortls (-880) , 1 part.

Wiler . . . . 2 parts.
2. Ball: Aloes. (See Secs. 514-6.)

Barbadoes aloes $\quad 6$ dr.

Calomel $\quad 1$ dr.

Ginger, $\mathbf{P} . \quad \cdot \quad \cdot 2 \mathrm{dr}$

Petrolatum . . . t dr.

Glycerinc, sufficier.t to make homogeneous mass.

Grind the solids tairly fine In mortar, and then add the petrolatum and glycerine. Roll in tisaue paper.

3. BALL: AJoln.

Aloln . . . . . . $2 t d r$

Glnger P. . . . . . $\mathrm{dr}_{\mathrm{d}}$

Calomel . . . . 1 dr.

Mix and put Into hard gelatise capsule. 
4. Buster. Mercury and cantharides. (See Sec. 410.)

5. Busten. Mercury and cro!on oll. (See Sec. 410.)

6. Buster. Red Mercury. (See Sce. 410.)

7. Carron oll.

Raw llnseed oll . $\quad$ - $\quad$ - $\quad$. 1 part.

Shake well before uslng.

8. CONDITION POWDER.

Flowers of sulphur . . . . 2 parts.

Nitre.

Fenugreek . . . . . . 1 part.

Gentlan . . . . 1 part.

Iron carbonate . . . . . 1 part.

Anlseed, $P$. .1 part.

MlX well into a powder, and give 1 oz. twice a day in the teed.

๑. Dick's rotion. (See Lotlon, Whlte.)

10. EleCtuaky (for coughs).

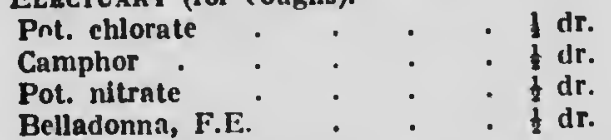

Belladonna, F.E.

Treacle, about $1 \mathrm{lb}$.

Dissolve the camphor in methylated alcolol ; and the belladonna In boilling water. Place on the tongue with a spatula.

11. Lime-waten. Saturated solutlon of llme in dlstilled water.

12. LiNimENT OF AMMONIA.

Ammonta fort. $\left(\mathrm{NH}_{4} \mathrm{OH}\right) \quad . \quad 25$ parts.

Almond oil . . . . 25 parts.

Ollve oil . $\quad . \quad$. 50 parts.

Shake weil.

13. LINIMENT OF AMMONIA, COMPOUND.

Ammonla dll. . . . . 1 part.

Alcohol, meth. - $\quad$ - $\quad$. 1 part.

Oll of turps. $\quad$. $\quad$. $\quad$. 1 part.

Water, to make 5 parts by volume.

14. Liniment OF ANMoNia AND OIL.

Camphor . . . $1 \mathrm{oz}$.

Alcohol, meth. : . . . 4 oz.

Llq. animonie fort. - . $\quad$ oz.

Oil of llnseed . . . . 1 plnt.

15. LINIMENT OF CAMPHOR, COMPOUND.

Camphor . . . 1 part.

Ammonla fort. . . . $\quad 2$ parts.

Alcohol, meth. : : : 6 parts.

Dissolve the camphor in the alcohol, and then add the ammonla.

16. LINIMENT OF OPIUM.

Tinc. oplum . . . . 1 part

Liniment of soap . . . 1 part.

Leave for a few days, and fitter through fiter-paper,

If a clear linlment is required.

17. LINIMENT OF SOAP.

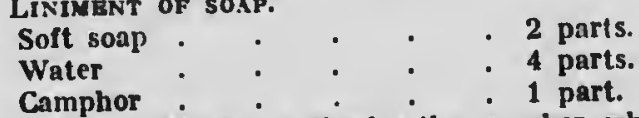

Camphor suficient to dissolve the camphor, which

Alcohol, suficient to dissolve the camphor, which
must be dissolved before adding the soap and water.
18. LINIMENT OF IODINE.

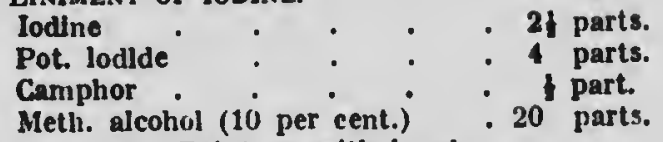

Paint on with urush.

19. Linimzast, strong, for spralns, curb, etc.

Mercury perchloride . . . $35 \mathrm{gr}$.

Pot. lodide . . . . $4 \mathrm{dr}$.

Iodlne . . . . 102

Water, dlstilled : $\quad . \quad$. $10 z$.

Ether, to make $8 \mathrm{oz}$.

dry.

20. Liniment, to case paln.

Cliloral hydrate : $\quad$ : $\quad$. 1 part.
Camphor

Rub well together in mortar untll they become llquld.

Rub well Into part for 10 mlnutes.

21. LOTON FOR EYE.

Zlne sulphate . . . $3 \mathrm{gr}$.

Oplum tine. . . . . $4 \mathrm{dr}$.

Water : $\quad$. 1 plnt.

22. Lotron, พHITE (Dick's).

Lead acetate . . . 1 part.

Yine sulphate . . . . 1 part.

Water . . . 40 parts.

(If 4 parts oil eucalyptus are added, it is good to keep flies off.)

Always shake well before use.

23. OINTMENT OF AMMONIATED MERCLRY (whlte preelpltate olntment).

Petrolatum . . . 31 parts.

Hard parafin . . . . $1 \pm$ parts.

Ammonlated mercury . . . 1 part.

Melt the two greases in a tin, stlr until cold. Rub In the nercury with a spatula on a plate.

Good for grease and ringwornı; is scarcely absorbed by the skin.

24. OrNTMENT, Bonacic.

Boracic acid . . . . 1 part.

Lard . . . . . 9 parts.

Heat, and stir untll cold.

25. Ointment of eucalyptus.

Hydrated wool fat . . . 5 parts.

Petrolatum . . . $2 \frac{1}{2}$ parts.

Oil of eucalyptus . . . $\frac{1}{2}$ part.

Mix on glass plate with spatula. Good for sores;

Is a disinfectant.

26. OtNTMENT OF IOdine.

Iodine . . . . 1 part.

Pot. lodlde : $\quad$ - $\quad$ - 1 part.

Glycerine . . . . . 3 parts.

Lard . . . 20 parts.

Rub the first three ingredients together In a mortar, and then gradually rub in the lard.

27. OINTMENT OF IODOFORM, for slow-heallng wounds.

Iodoform

$. \quad . \quad .20 \mathrm{gr}$

Oil eucalyptus . . . . $30 \mathrm{~min}$

Acid carbolic . . . . $20 \mathrm{~min}$.

Lard 
28. OIL OF MiNTHOL

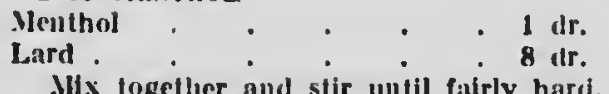

94. Ointuent on zixc.

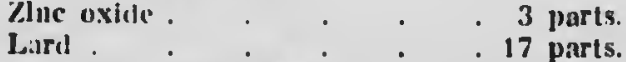

Melt togelier and stir untii set.

3\%. TONIC rowdes.

Iron suipinile . . . . 1 part.

Nux vomica, 1'. . . . 1 pacrt.

Sodal hilcarbonite . . . 1 parl.

Mix together weli. Give 1 dr. (teaspounful) tlirce limes a day on the food. for a week.

31. Toxic powni:m.

Nux vounic:il, $P$.

Iron sulphate

vilte.

Gentian P.

1 parts.

4 parts.

1 part.

1 parts.

Mix weil. Give 2 dr. twice a daly in the f(ed.

3:2. Tosic powdin.

'Turtur emelie . . . . 1 part.

lron suiphisle . . . . 1 part.

Anisced T. . . . . 12 parts.

Gentian l'. . . . . $1 \frac{1}{1}$ parts. neek.

Vlix weil. Civis \& $0 \%$, in foed once al day for a

510. Incompatibility of lirugs.-In the past serious accidents have occurred through certain Irugs being mixeil together that are not compatible. In some cases nothing very serious happens, but certain drugs when mixed together explode, whilst others, though harmless them. selves, become poisonous when mixed together.

The following list is one of common ilrugs that must not be mixed together :

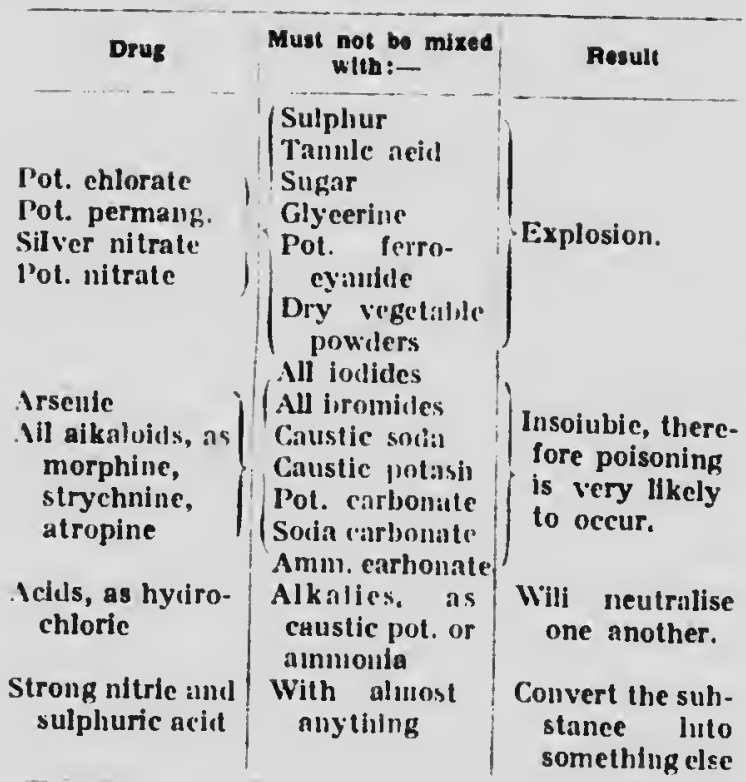

511. Antidotes to Poisons.-When a horse is poisoned, action must be taken immediately. If possible, it must be ascertained what kind of poisoning the horse is suffering from. The poison must be expelled as soon as possible from the system by purgatives, diuretics and diaphoretics. It is not possible to make a horse vomit, so emetics (as apomorphine) must not be used. The poison must also, if possible, be chemically changed to an insoluble or inert substance. The inflammation (high temperalure) must be subdued by sedatives and antiphlogistics. The internal irritation must be eased by demulcents. Stimulants must be given to counteract narcotic and hypnotic effects. Tonics and careful dieting must be resorted to to restore the lone of the system.

The following antidotes are recommended for the more common forms of poisoning. The antidote is always given in a dose far larger than the normal dose for that drug. In very bad cases five to six times the normal dose can be given with sufety.

512. Poisons and lheir Antidotes.

\begin{tabular}{l|l} 
Polson & \multicolumn{1}{c}{ Antidole } \\
Acid, canbolic & $\begin{array}{l}\text { Turps, soda sulphate, eastor oii, } \\
\text { strong tea, and coffee. } \\
\text { Water (except for sulphuric), } \\
\text { chalk, soap, magnesia, fol- } \\
\text { lowed by deniulcents, seda- } \\
\text { tives, and tonics. }\end{array}$
\end{tabular}

ACID, Nitric AxD Vagnesiun or ealelum earbon-

OXALIC ates, folloxed by demulcents, sedatives, and tonies.

Acovite

Alkaloivos

External and internal stimulants.

Animal carbon (chareoal), caffeln citrate (hyp.), ether, and diflusible stimulants.

AHMoNiA

A.TIIVony

Anvica

Ansenic

Atrorin

BELLADONNA

Atropin

Cantilarides

Carbonic acid

(CARBON DIOXIDE)

Cillorine oas or

CHOHINATED LIME

Cillororoky

Vinegar, oils and demulcents.

Tannlc acid, oil purgatives, and sedatives.

Opium (inorphine).

Iron earbonate, Iron sesquioxide $\left(\mathrm{Fe}_{2} \mathrm{O}_{2}\right)$, lime-water, vegetable tonies; raw cggs and gruel every hour.

(Sce "Belladonna.")

Opium and caflelı (iıyp.).

Opium ; do not give oils.

l'resh air, oxygen, coid effusions, and diffuslble stimulants.

White of egg, mllk, flour, ammonia, magnesin. Not acids.

Dilute hydroryanic act, amyl nitrite, strychnine, artiffcial respiratlon, and electricity.

Coppen salts

Soap, metallic Iron, oil purgatives, stnmonia, demuleents ; raw eggs and gruel every 1 holir. 


\begin{tabular}{l|l} 
Polses & Antidete \\
\hline Cinoton ous & Opium, astringents, mucllagin-
\end{tabular}

CROTON OLL

CYANIDES AND prussic AcID

Diontals

IEMLOCK

IODINE

LE.ID SALTS

MERCUAY SALTS

Motapline on MorpHIa

Nux vomica on StRYCININE

Opiual or MonPIINE

Phospizonus

PII Ysostiomine on Estatne

Pilocaripine

Pressic acid

Strychnine

SULPHURETTED HYDHOOEN (IIYDROCEN SULPIIDE) $\left(\mathrm{H}_{2} \mathrm{~S}\right)$

jomacco on NicoTIYE

IFW

\%inc salts

\section{ous fulds.}

Chlorine gas Inhalations, ammonia, chalk, magnedin, oxides of Iron, cold ablutions.

Tannin, stimulants, aconite (hyp.).

Oil purgatives, diffusible stimuiants, tannin, atropin (hyp.).

Starch and demuicents.

Magneslum and sodium suiphates, pot. lodide; followed by linseed oil, milk, and oplum.

Eggs, starch, milk, albumen, wheat lour in large quantity, iron suiphide, magnestum suiphate, fresh preparation of iron sesquioxide.

(See "Oplum.")

Pot. bromide, chloroform, anodynes and sedatives. Give chioral hydrate, 4 to $8 \mathrm{oz}$. (normal dose, 1 oz.).

Animal charcoal, pot. permanganate ; exercise is most nccessary, counter-irritants, ainnonia Inhalations, oil purgatives, atropin, caflein, and eserine (hyp.).

Turps, gallic actd.

Atropin (hyp.), chloral hydrate, stimulants.

Atropin (hyp.).

(See "Cyanldes.")

(See "Nux vomica.")

Fresh air, cold cffusions, diffusi. hie stimulants.

Tamic acid, strong tea, purgatives, strychnine; stimulants Interial and external.

Purgatives, mucilaginous drinks and sedatlves.

Milk, white of egg, tannic acid, nni warm water.

513. List of Apparatus lept in a Veterinary Pharmacy.-One 2-dr., one 4-0z., and one 1-pt. glass graduated measures. The cylindrical form is the best. The most accurate are those marked outside by hand; those marked inside are moulded, and are cheap and inaccurate and cannot always be kept clean. Clinical thermometer with magnifying scale, to register in thirty seconds. Pestle and mortar of glass, about 12 in. in diameter, for grinding up drugs into fine powder. A spatula, and sheet of glass about is in. square, on which ointments, etc., can be mixed. Watch. Bandages, needles and thread (silk). A hypodermic syringe and noedles. Set of scales. Oral syringe. An enems pump and tube, a catheter, trocar and cannula. Labels to label all bottles, packages and tins very carefully. (See Sec. 529.)

514. Uses of Purgatives.-To romove accumulation of foods, lessen fermentations, and to remove toxins from the skin; to divert blood from the brain in brain diseases by increasing blood in the intestines; to remove fluids from the system as in dropsy.

Purgation is produced in three ways: by increasing peristaltic action of bowels, i.e. muscular contraction; by increasing intestinal secretions; by decreasing absorption of fluid.

In the first method we can cause purgation by the use of drugs that act on the brain, i.e. on the nervous centre. For instance, any drug that stimulates the vagi nerve centro increases peristalsis, or a stimulant to the solar plexus decreases peristalsis. An example of the first is eserine, or croton oil ; of the second, aloes, rhubarb; and of the third, Epsom salts (magnesium sulphate).

515. Purgatives are counter-indicater, i.e. must not be used, in the following cases:-

\section{Lung diseascs,}

Gastritis and enteritis,

Influenza and high fever,

Advanced pregnancy,

Inversion of rectum or uterus.

A horse has 550 square feet of intestinal mucous membrane on which drugs can act, or through which absorption takes place; therefore great harm can be done by the abuse of drugs.

There are five kinds of purgatives:-

1. Laxatives liquefy secretions and stimulate peristaltic action, as raw linseed oil, sulphur, green grass and roots.

2. Simple Purgatives increase secretions and produce semi-liquid evacuation, as aloes, calomel, linseed oil in large doses, cascara, and rhubarb.

3. Drastic Purgatives violently increase peristaltic action and secretions, as croton oil, jalap, barium chloride, and eserine.

4. Hydragogue Purgatives prevent absorption of fluids, as Epsom salts and all laxative salts.

5. Cholagogue Purgatives stimulate liver (and must be followed by a simple or hydragogue purgative, to clear small intestines), as calomel, podophyllin, and sodium salicylate.

516. Notes on Purgatives.-Action is increased if given on empty stomach. Horse must be prepared on soft food for at least one day previous to a strong purgative being given, except in cases of colic, when this is impossible. An enema should be given to assist in emptying the large back bowel. 
llorses are seldom given purgative salts. If a ball does not act in twenty-four lours, a pint of raw linsecd oil must be given, and, if necessary, repeated in five hours. Large doses of aloes produce nausea and colic; for this reason aloes is always combined witl a stomachic or stimu. lant, as ginger or nux vomica, to prevent griping.

Much cold water must not be given until the action of the purgative has partly gone off : water should be made tepid. Horses must not be worked until the action has passed off. Aloes must not be repeated for at least thirty-six hours. Linseed oil is safe ill pregnancy, diarrhœa, and dysentery. Carron oil is useful in cases of foals with diarrlıe. Afterwards horses must be fed on easily-digested foouls, such as mashes, until action is passed, and then be fed carefully for a lew days.

For Balls, Aloes, and Aloin, see Sec. 509.

A suitable purgative for a few-months'old fual which is constipated is rhubarb (rhei), $t$ oz to $1 \mathrm{oz}$.

517. Liquid Measunes. IMPFinal Meastere. 60 minims (m) $=1$ fluil drachin (13) (A. (lr.). 8 fluld drachms $=1$ fluld ounce (f弓) (f. 02.).

20 fuld ounces $=1$ pint (O.) (pt.).

8 plnts $=1$ galloul (C.) (gal.).

518. Standand Weiguts. At $62^{2}$ Fahr, anl barometer at 30 inches.

1 fluil ounce weiglis 1 ounce Avoirtupols

gallon $=437$ grains

ounces $=10 \mathrm{lb}$

1 pint weighs 20 ounces $=13 \mathrm{li}$.

1 euble foot of water weighs 621111 .

1 cuble inch weighs $252 \mathrm{gr}$.

1 ounce cquals nearly 2 cubic Inclics.

519. Wine Mrastir.. American llquld mensure.

8 fluid irachns $=1$ fluld ounce.

60 minlnis $=1$ fluill drachn.

16 fuill ounces $=1$ pint.

8 pints $=1$ gallon (128 ounces).

1 whe gallon of ellstilled water weighs approxlinately 8 ib.

1 fluld ounce whe me-sure weiglis $454.6 \mathrm{gr}$.

The winc ounce is larger cian the Imperlal ounce, lut the whe pint is sualler than the Imperlal pint.

520. Housfiloto Lrevid Me.Astines.

1 tumblerful $=8$ to 10 fild ounces.

1 tcacupful $=j$ to 8 fluld ources.

1 wineglassful = 2 fuid ounces.

1 tablespoonful $=5$ ounce, or 4 fluld draclums.

1 dessertspoonful $=1$ oz. or 2 fuld drachms.

1 teaspoonfui $=1$ fuld drachm.

1 drop of water $=1$ minim (approximatciy).

521. Solid Weiguts. Apothecarics' Welght.
20 grains
3 scrupies
$=1$ scrup : (3).
60 grains (gr.)
$=1$ draclin. (3)
8 drachms.) $=1$ irachm.

2 ounces or 480 grains $=1$ ounce $(\xi)$

12 ounces or 5,760 grains = puund (lb.).

All dlspensing is done, and formulæ are made up, with this welght.
589. TroY Weicht.
480 grailis

12 ounces, or 5,760 gralns $=1$ pouncl.

528. AvoIndupoIs WEIOKT.
16 draclims
437t gralis
16 ounces or 7,000 gralns
$25 \mathrm{lb}$. (Canada)
28 lb. (England)
4 quarters $\left\{\begin{array}{l}100 \mathrm{lb} . \\ 112 \mathrm{lb} .\end{array}\right.$
$20 \mathrm{cwt} .\left\{\begin{array}{l}2,000 \mathrm{lb} . \\ 2,240 \mathrm{lb} .\end{array}\right\}$
-1 ounce.
$\Rightarrow 1$ ounce.
$=1 \mathrm{lb}$.
$=1$ quarter.
$=1$ quarter.
$=\left\{\begin{array}{c}1 \text { hundredwelght } \\ \text { (cwt) }\end{array}\right.$
$=1$ ton.

All drugs are bought and sold lyy thls weight.

The grain of all welghts is the same.

480 mlulms of water weigh $1 \mathrm{oz}$. avolrdupols = 439 gr., therefore $1 \mathrm{mlnl}$ is of water weighs a little less than 1 grain.

524. Grain Measune (or Dry Me.ssure).
2 pints $=1$ quart.
4 quarts $=1$ gallon.
2 gallons $=1$ peck.
4 pecks $=1$ bushel ( 8 galions).
4 bushels $=1$ sack.
8 bushels $=1$ quartcr.
5 quarters $=1$ loacl.
2 loads $=1$ last.

525. H.ay and Straw Weights.

1 truss of old hay $=56 \mathrm{ib}$.

1 truss of new hay $=60 \mathrm{lb}$. (untii Sept. 1st).

1 truss of straw $=36 \mathrm{lb}$.

1 load $=36$ trusscs.

1 load of old hay $=2,016 \mathrm{lb}$.

1 load of new liay $=2,160 \mathrm{lb}$.

1 load of straw $=1,296 \mathrm{lb}$.

526. Thi Metric SysteN.

\section{Liquid}

1 cubic ccutlmetre of water, at $0^{\circ}$ Centigrade and baronieter at 760 millimetres, welghs 1 gramme.

1000 cublc centlnietres (cc.) $=1$ litre.

1 litre = approxiniately 35 fuld ounces Inperial $=13$ Imperial pints. Height

1 gramme (gıu.) $=\mathbf{1 5 . 4 3 2}$ grains (gr.).

1 nou grammes

100 $=11$ kilogram (approx. $2 \nmid 1 \mathrm{~b}$.

00 avoir.).

10

: $\quad=1$ decagram.

1. $\quad=1$ gram (15.432 gr.)

01 $\quad=1$ decigram.

(101 " = 1 centlgran.

$=1$ milligram ( ${ }_{6}^{\prime}$ th $\left.g r_{0}\right)$. Linear

1 metrc is 00000 th part of the circumference of the carth.

1000 metres $=1$ kllometre (approx.

$100 "=1$ hectometre.

10 " = 1 decametre.

1 metre $=39.3708$ inches (approx. 1' 1 'ords),

1 . 1 = 1 decimetre.

01 " $=1$ centimetre (approx. if inch).

$.001, "=1$ millimetre (approx. 
527. Enouan Livkan.

$\begin{array}{ll}12 \text { Inches (") } & =1 \text { foot ('). } \\ 3 \text { feet } & =1 \text { yard. } \\ 220 \text { yards } & =1 \text { furiong. } \\ 8 \text { furlongs or } 1,760 \text { yards } & =1 \text { mile. } \\ 4 \text { inches } & =\left\{\begin{array}{c}1 \text { hand (used in } \\ \text { meas uring } \\ \text { horses). }\end{array}\right.\end{array}$

528. Comparison betwelin Englisil and Metric Weichts and Measuhes

1 Imperial flutd onnce weighs 437 gralns $=$ 1 oz. avolriupois.

1 gramme weighs $15 \cdot 432$ grains (ce. : cuble centimetre).

1 Imperlal fluld ounce weighs 28.35 grammes $=$ 1 ounce avoirdupols.

1 fuld ounce $=28.417$ cc. (Note-thls is at $62^{\circ} \mathrm{F}$.; $1 \mathrm{gm}$. $=1$ cc. at $32^{\circ} \mathrm{F}$.)

The apothecaries' pound and ounce and the troy pound and ounce arc the same, but are differcitiy divided.

1 ounce apoth. weighs $31 \cdot 10$ gran. $=480$ grains.

$1 \mathrm{lb}$. avolrdupois weighs 453.6 gram.

$1 \mathrm{cwt}$. weighs 50.8 kilogram.

1 ton weighs 1016 kllogranı.

1 grain weighs 0648 gram.

1 litre $=1000 \mathrm{cc}$, or 1 cublc decilitre $=$ 175.9 pints $=35.2$ fuid ounces.

1 cuble centinetre $=.061$ cublc inch.

1 cubic Inch $=16.387 \mathrm{cc}$.

1 yard $\quad=.9144$ metre.

1 mile $\quad=1.609$ kllometres.

1 gallon $\quad=4.546$ lltres.

$1 \mathrm{plnt} \quad \Rightarrow 568.3 \mathrm{cc}$.

$1 \mathrm{mlnim} \quad=.059 \mathrm{cc}$.

1 cc. $\quad=16.9$ minins.

529. Drugs.-List of the most important drugs that should be kept in the veterinary pharmacy (see Sec. 513):

Acid boracic

Acid carbolle

Aconite tinc.

Alcohol

Aloes balls (Sec. 509, 2)

Ammonla

Arecolene

Belladoma, F. E.

Calomel

Cannabis Indica

Chloral hydrate

Chlorolorm

Cocalne

Creolln

Eserine

Ether

Gentian

Ginger tinc.

Iodine tinc.

Iron perchloride tinc.

Iron sulphate

\section{Glossary and Therapeutical Classifica- TION OF DRUos.}

Abscess : a collection of pus in a cavity formed by the disintegration of tissucs.

Ansonaents. (See "Desiccauts.")

Acnio: pungent, producing an Irritation.

Active pninciple: the part of a drug or herb that is responsible for the chicf actlon of that drug or herb; morphine is the active princtple of oplum.

Acure: short and relatlvely severe; not chronlc.

ADnesion: the abnormal joinlng of parts together.

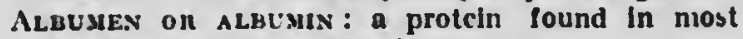
animal and vegetable tissics.

Altenatives: drugs that gradually change and correct the niorbld condition of organs, e.g. aloes, ammonium carbonate, sllver nitrate, arsenic, pot. bromlde, dil. hydrocilorle, ammonium chioride, pot. chloras., soda chloridc, colchlcum, lead loulde, pot. lodide, magnesium sulphatc, nercury lodide, mercury subchloride, mercury perchloride, soda phosiphatc.

Avesthetics : drugs that cause insensiblity to pain and unconsciousness, alleviate spasms and pain, and relax museles, e.g. general-cther, aniyl iltritc, chloroform, nitrons oxide; local-cther, cthyl chloride, cocalne, eucaine, holocalne, lce, menthol, novocalne, stovaine, urea liydrocbloride.

AvcnyLosis: abnornial inmiobility of a joint.

ANoDYNes: drugs that dimlnish and allay paln, c.g. aconitc, carbollc acld, digitalis, ethyl chloride, oplum, lead subacetate.

Axtactos: drugs that reduce activity and make blood and secretlons more fluid (useful in fever, rhcunıatism, etc.): anmonia, ammoniun carbonatc, chalk, lime-water, pot. blcarbonate, pot. carbonate, soda bicarbonate, soda carbonate.

A.vtalkalines: drugs that increase activity, e.g. dil. hydrochloric and nltric acids.

ANTEMetics : drugs that arrest vomlting, c.g. belladoma, linic-water, chloral hydrate, chloroform, magnesla.

Antinelaintics : drugs that destroy, expel, or prerent the rcturn of wornis, c.g. aloes, asafoctida, copper sulphate, Iron snlphate, mercury subchioride, quassia, santonln, soda chloride, thynol. (See "Taniafuges.")

Antidotes. (See Sec. 512.)

ANriliruics : drugs that prevent the formation of sediment and calculi in the urinc, c.g. acetic and liydrochloric acids, magnesia, pot. carbonate, soda blcarbonate, soda phosphate.

Avtiparasitics: drugs that lestroy animal and vegetable parasites. (Sce "Anthelmintics" and "Insccticides.")

Axtipeniodics : drugs that arrest intermittent diseases, e.g. arsenic, cincliona, quinine, soda chloride.

Axtiphlogistics : drugs that contract inflammation (see "Sedatives"), e.g. aloes, antiphlogistine, mermiry subchloride, reducine.

Astipyratics : drugs that reduce fever, e.g. acetanilld, dil. vegetable and mineral acids, aconlte. 
autlpyrin, ammonlum ncetate, canj])ıor, dlgitalis, mercury subcliloride, magneslum sulphate, pllocurplnc, pot. nltrate, quilnine sulphate, socla blcarbonate, soda carbouate.

Axtmizumatics: irngs lliat relleve rlicumatisul. e.g. scrla likearlomiate. smili carhouate, soda sitlleylate.

A.vtist:PTics. (Sie Secs. 798-8111.)

A.rtisf.asmodics : Irugs that prevent or allay muscular spasins, e.g. anmonla, bellndonnn, asafre tldi, bronildes, camplior, cainnabls Indlea, pliysostignilne, jpirlts ellier ultrate, turpss, zlnic sullihate.

Antrtrapanitics: drugs that reduce or prevent tynıpanites, e.g. mumoula, anumonlun cnrbonite, carbon, turps, asafoctlda.

I.l'. : actlve princlpic.

Irenients: irugs that cause gentle purging. (Siee "Laixallves.")

Ipinodisiacs : Arugs that exeite the vencreal nppetIte, c.R. Lelladonna, camlihor, camiahis lindlca, Iron perchlortde, phospliorus, hlood and nerve tonl.s.

Inoxatics: irugs that counteract griplug from acrill drugs. (See "Stlmulants-Stomachic.")

InтEny: a vessel througli whlch blood passes from the heart to the body.

Inticulan: pertalnlng to a jolnt.

AsEPTIC: free from septic materlal.

Aspuyxia: silfocatlou, deflelency of oxygen lil thic blooul.

istnivgexts: drugs that retract tlssues, coagulate lylood, and check secretions, e.g. mineral-aluin, borax, dllute inlneral actels, and metallle salts; vegetuble - acid acetlc. acid tannle, acjd carbollc, catechu, cinchoun, ergot, opluni, turps.

Irnorir : a wastlug of a part.

ic'sccltation: the act of listening for sounds withln the body, chiefly of the lungs, licart, nnd womls.

fi.cildes (pilural, bacill]): a rod-sliapeil nileroorganisin.

13 sстелicm (plural, bacteria): vegetahle mleroorgaulsn.

l3.ıns of Motrin: that part of the gums between the incisors and the molars of the horse.

liLE: gall, a greenish-yellow substance secreted loy the llver.

13.P.: Britlslı Pharmncopnin.

13Resurno: the act of a horse brushing olle leg agalust another while in motion.

C.alctul plural of calculus: an abrormal concretion within the nuinal hoty. nsually composed of mineral salts.

C.scer: a malignant tumour. clicfy of epithclial cells.

CanNela : a tuhe for insertion lnto the hody.

Capillany: a ninute vessel that ennuects an arteriole to a verule.

C.Aput : the head or licad-llke structure.

CARIES: the molecular decay or death of a bone.

C.sRmivatives: drugs that relieve flatulence ind assuage pain. (See "Stimulants-Stomachic.")

C.sptilage: gristle, a white clastle or luclastlc substance.
Catiantics: (Irugs that Increase peristaltic actlon. (See "Laxatlves," " Drastles," " Cholagogues," "Hydragogues.")

CAturtea: a tuhe for discharging nulds from a cavity ln the bolly, usually that of tlie blalder.

Cicstics: irugs that iestroy tlssue, e.g. stroug arlds, sllver nltrate, creosute, copper sulphate, Iron perchlorlde, inercury percliloride, lodlıe, putasli, zlnc sulphnte.

Choldgogurs: Irngs that stlinulate the secretlon $r$ blle from the llver, and cause purgings. e.g. alc _s, niercury perchloride, inercury subchloride, podophyllin, soda sallcylate.

Cinnonic: long-contlnued; not ncute.

CLystik: an enema; $n$ injection linto the reclun.

Concave: presentlng a depressed or hollow surface.

Conoris: $n$ rounded enilnence at the articular end of a bone.

Congistion: alnormal accumulation of blood in $n$ plart.

Coxtagron: the communlcation of dlsease by inedlate or lmmedlate contact, or by eflluvla.

Contacious: propagated by contagion.

Coviex : liaving a roumded and somewhat elevated surface.

Convexity : a convex prominence on a bone.

Convulsion : a vlolent involuntary contraction of a voluntary muscle.

Connosives. (See "Cnustles.")

Cotrloid cavity : a cup-shnped cavlty.

CovNtkn-IRritants: drugs that Irrtate and stinullate the skln, and thus relleve internal pain and Inflanmation. (See "Veslcants," " Rubefacients," " Pustulants," " Derivntives.")

Cnest : the top of the horse's neck, where the maile grows.

Deciduous : teilporary.

DEcoction: a medlcine or llquill prepared by bollhng.

Defecation: the dlscharge of fxces from the bowels.

DEnUlCEvTs : drugs that soothe, soften and protect mucous mcinhrane, e.g. glycerine, gum, oll.

DEodorisens : drugs thint ahsorl or decompose fotid cllluvla. (See "Antlseptlcs," "Dlsinfectants.")

Denivatives : drugs that stlnulate certain parts of the body to rellese others. (See "Counter-Irritants," "Stlmulants-Extcrnal.")

DEsicc.ants: (Irugs that iry up discharge from wounds and alscesses, c.g. alum, bismuth suhultrate, Lorax, chalk, chlorlde of llme, llinewater, catechu, carlion, Fuller's earth, Frenclı (halk, mercury perchlorlde, magnesla, lead sul)acetate, alcoliol, zlne sulphate.

Dretengests: drugs that cleanse sluggish wounds, etc., e.g. horax, caustic potash, soap solution.

Diagnosis: the art of dlstlogulshlng one disease froin another.

Diaphonerics : drugs that increase the exhalation of the skln, e.g. ether, spirlts ether nitrate, ammonluni salts, antifebrin, nrilca, belladonna, camphor, mercury subchloride, pilocarplne, pot. nitrate, alcohol, sulphur, turps, veratrine, frlctlon, warm clothlng, hot appllcations.

Dinpuysis : the shaft of a long bone. 
Holistion: the process of coluserting food Into unterlals fit to be assinuliated.

Discetrents: cirugs that alsorb tumours uud Nuld In the body, c.g. acctic actd, anmonlum chlorile, camphor, fodline, jot. lorllde, sota cliloride.

lisilixi, : the act of -rying the lower parts of the forclegs turned out while trolting.

lus.sFECTANTs : Iruks thut destroy inlero-orgiulsms or toxlns. (See "Antiseptles.")

Diuniorics: drugs that stimulate the secrollon of urlne from the kldneys. I'sell to reduce fever and to remove polsons and fild from the body. c.g. ether, spirits ether ultrate, ajoes, ammonlun chioride, belladouna, cantharides, dlgitulis, nercury subchlurlde, magneslum sulpliate, potus. slum salts, sodlum salts, turpentine.

1)icistics: drugs lliat produce rapld and plentlul purging, c.g. aloes, crolon oll, mercury subchloride, podopliyilir veratrine, arecolene, pilocarplne, physostigmine (eserine).

URENCH: a llquid medlcine or compoumd that is adnililstered by the inoutil.

FcBouscs: drugs that contract the uterus (wombused at gnrturttiou), e.g. digitalis, ergot, purga lives, quiluine.

l:Frluvia (plural of eillusium): III-smelihg exhalations.

Iipfusion: the escape of fuld linto a part or tlssue.

Electuany (see Sec. 509, No. 10) : a powdered drug made Into a paste with syrup, etc.

liliminatives: drugs that ellnilnate matter from the system by Increasing the secretlons. (See "Catharties," "Dlaphoretles," "Dluretics," " Emetles," " Expectorants," " Gaiactagogues," "Slaiagogues.")

Fivanyo: the fatus in lts enriler stage of development.

F.мBRYoNic: pertaluing 10 , or in the condition of belng, an enbryo.

I:vistics: druge that enipty the stominch througli the mouth (never used In horses), e.g. apomorphine, tartar enetic, copper suipliate, mercury subchloride, podophyilln.

livoluests : substances whlch soothe sensitive surfaces and prevent irritation, e.g. Jard, borax, fats, glycerine, Ianolin, olis, poultices, vaseline.

ENPYEMA : accuinulation of pus in a borly cavily, especlally the chest.

Fintusion : an olly or resinous substance divilded and held in suspension through the agency of a mucilaginous substance.

EvemA : clyster or Injection; the injection of a liquid Into the rectum.

livzootic: occurring endemically among animals.

Limpirses (plural of eplphysis): the ends of a long bone that are separated from the main shaft lit carly life by cartllage.

Firitielial: pertalining to, or composed of, epitheIlum.

Epitheliuy : the covering of the skin and mucous membranes, composed of cells.

Epizootic : any disease which occurs as an epideuic, rapldiy spreading and becoming widely diflused.

Enytunocytes : the red blood corpuscles.
Escinnotics: drugs that produce a scab or sitfast when applled to II ing lissuc. (See "Caustles.")

lixnllanasts: drugs that exalt the spirits and thus Increase tlie functlonal activity of the whole hocly, stimuiating heart, hervous system, etc. (See " stimuiants-Dinusibic.")

I:xostosis: a bolly growth projecting from the surface of a bone or touth.

lixpi:ctorants: drugs that Increase the secretlons of the bronchlal tract (used in sore throats, irritable couglis, etc.), e.k. sther, aninionia, ammonilum chioride, aniseed, camplior, encalyptus, pot. chiorate, turpentine.

FAcrt: a small, smoolli surface on a bone.

F.E. : nuld extract, atandardised solution of a drug. In whilch, as a rule, 1 dr. of the F.E. contains $1 \mathrm{gr}$. of the artlve principic.

l'eosiruoes: irugs that counteract fever. (See "Antupyreucs," "Laxallves.")

FECUNDATION: Impregnation or fertilisation.

FERRO-CONCRLTE: conctete relnforced with lron rods.

lietid: offenslve in smeli.

FEVEn: a disease marked loy an fincrease of bodlly teuiperature.

Fissurz: a cieft or groove.

Fresil: muscie.

liarvs: the unborn In the womb, after the embryonlc stage.

[Ронимем : a hole or perforation, especially in a bone.

Frssa: a pit, depression, or hollow.

1'.10G: the triangular pad situated in the posteriormedial portion of the horse's foot. (See P. 139.)

GAlsctAooours : glands that increase the secretlon of milk from the nianimary giands. Jaborandi is a sllght galactagogue. Albuminoid and fatty foods i crease the supply of milk. General good health is of the first importance.

GANGRENE : mortifleallon or non-molecular death of a part.

GleNi id cavity : a plt or socket.

H.f.MAtinics: drugs that Increase the number of red blood corpuscics, e.g. Iron salts, nianganese clloxlde.

Hewostatics : drugs that arrest hremorrhage (givel In Internal hemorrhage), e.g. enrbolle acid, dll. sulphuric acid, tannic acid, gallle acld, adrenalin cluloride, line-wnter, catccliu, ergot, iron perchloride, turpentine.

IiE.an (of a bone): that portlon whlch articulates wlll another bone.

IIfavis : the protruslou of a loop of an organ through an abnormal openlng.

Iliates: a gap or fissure; the vulva.

lironacoours: drug that produce a very liquid evacuation, e.g. aloes, croton oll, Jalap.

IIYGIE.NE: the sclence of health and of Its preservatlon.

11) : : hypoilermic.

Hrponiamic (Injection): an injection uniler the skln.

HypertRopIY : an overgrowth of an organ or Ussue.

ifYPNotics: arugs that produce siecp, e.g. pot. bromille, cannabls indlei. chiloral hydrate, oplum or inorpline, chloroforn. 
Injopstuc: :elf-originated; nelller sympatletic uor trananatice.

Imst:vi: : protected ugalust a disense.

INce B.ston: the periol leetween the finplanting of It disease and lis munlfestation.

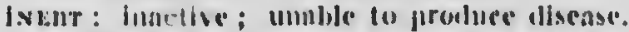

infretion: the communleation of alisease lig thluvis or eonture, meliate or lmmellate.

INFLamatios: the colidilion Into whleli lissucs cuter as a reaction la irritation.

Infesion: the extraction of the actlye principle of a suinstance by the agency of a liquid without netlially bulling.

Inoculatinn: the Insertion of a virns Intu tissile in orcler to prouluee a ellsease.

Insecticives: Irugs that klli lnsects, \& g. curloolic acicl, tanule acjd, sulpluturous achi, arsenfe, calluphor, ellloroform, ereoiln, Iron perclilorlde. Iodoform, lodlne, mercury ammoniate, mercury per. chloricle, napithol, petrojeum, turpentine.

INTEnDENTal, sPACE: the space ont the gums between the Inelsors and the inolars of the horse's moutl.

IrRitasts: drugs that stlmulate, Irritate, and cause inflammutlou of the part. (Siee "Stinmulants," "Hubefucleuts." "Virslcants.")

Kanrokivesss: the elhnuges and division of the nuelens prlor to binnry fission in the dlvlding il a rell.

L.AMs.s. (of a foot): the pinte-jike projertlons of horn that foin the horny will to the senslive wail in a horse's loot.

Laxatrves: Irugs that prodince gentie purging. c.g. grecn lookls, alocs, magnesia, magueslunı sulplate, mashes, Ilnseel oll, podopilyllin, roots, suiphur.

I.ESION : a liurt, wound, or local degeneration.

LEc cocyte: a whlte blood corpuscle, lymph corpuseie, pus corpuscic, or any colouriess amabola ceil-mass.

Macenatios: the softenlng of a soid by soaking.

Malionant: virulent, and tending to go from bahl to worse.

Meatus : a passage or opening.

Mevbrana nictitans: nletitating meinbraue, the "thlra" eyelld of a horse, that part wisich is exposed when the cyelld is inverted during $\mathrm{cx}$ amination for fever.

VICro-organisms: nilnute vegetable and amlmal organisus.

Micnoscore: an Instrument whilei miagnifies nilnute objects for visual lispectlou.

Mictunate: to pass urinc.

Monbib : liscased.

Mtecrlaoe: a gummiy or lextrinous substance used as a vehicie in plıarmacy and as a demuicent in therapy.

Nocous membnaxe: al epithellal membrane that lines the canals anil cavitles whleh conmunleale whth the external air.

Mucus: the viscid watery secretlon of the mucous glanils.

Nescle: an organ which. by contraction, produces the movements of an aninial organism; flesh.

Mypaiatics : drugs that dilate the pupll of the cye, e.g. belladonna or atropin, cocaine, caffein.
Nyosurces: druga that coutract the pupli of the eye

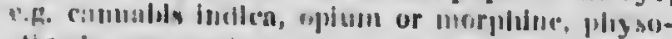
stiguilue or serrince

Xisecorstes: druges that problete stupor and slerp.

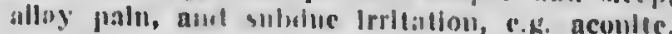

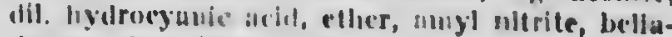

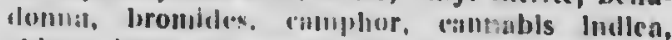
dhloral livirate, chlorulurm, digitalis, ophim or morplifine.

Naenisa: sleknens of the stumacll,

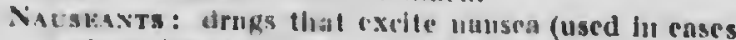
of excltenent), r.g. uroulte, ill. Iyelrochlorle aclil, hloes, poclopliyllin.

Nichosis: the molecular or nom-molecular denth of al lisstice (Relicrally refers 10 a bonte).

Niriulerose : the excision of a part ni a nerse.

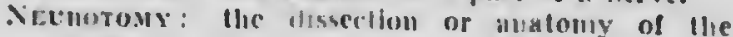
inerses.

Nitrustres: drugs that absist in mildting mp the tssues of the bocly, e.g. Ill,umln, hlycerine, wil, millk, mait, white of rag, eggs.

Qidaria : sweillug alue to the effusion of watery fludel into the connectise tissue.

Rinnarous: jertaining lo, or affected l,y, ademal.

Uestnex: the perloul of lulug in scason; tite crlsls of venereal excltement.

Onoavic: pertulning to :II organ; pertuining to substances derived fron living organlsuns.

Osmoase: the passage of a nuld through " mennbranc.

Ossmficatiov: comversion inla, or formatlon of, lowe.

Ossifice tissue: one llial has become bone.

1?: pewier, pulvis.

I'ARAFFE OIL: coil (iil.

PARAsitmanes: drugs that lestroy parasltes. (Sce "Awatiolninties," ." Insecticides.")

Pantunuevts. (Siee "IEcbolics.")

l'Antiutros: the act or process of giving birth to llie yeung.

PAssaoive A monse: the act of causing a lorse to muve in a lnteral dircetion by crossing Its legs.

Pathogenic: discase-producing.

Pathologv: the scichee of disease.

Privic cavity: that portion of the body, situateil posteriorly to the abilomen, whlch contains the bladder and rectum, and vagina in the mare, and tlirough which the foetus passes at hirth.

I'Eprics. (See "Stimulants-8toniaehle.")

Pencussion: the act of striking a part to aid in liagnosing.

Period of incubation. (See "Incubation.")

PEnIOrLe: the eplthellal covering whlch surrouncis the wall of the hoof, aul whleh should never be louched by the farrier's rasp.

Periostrum : the tough, fibrous membrane that surrounds the bone, exeept where there Is artieulallon.

Penistalsis : tlie worm-like motions by whlleh the alimentary canal moves its contents.

Peritoneum: the serous membrane that lines the abdominal walls.

Phnoocytes : cells that destroy harmful germs by enveioping and absorbing them. 
l'unucytoss : the destruetion of micro.(nganlsulls by phagorytes.

l'n Insucy: the 11 of preparlug and componnding meellefines; an apulhecory's shop.

litision.oris: the science of the functlous of lising orgins ant their ports.

l'zantan ci'smon: the cushion situated ditectly above the horiyy fron of the liorse.

l'uchisposi:s: possessing a fendency to a dlsuse.

l'Rocess: a slcuder, projectling polnt.

lononosis: a forecust us lo life probalole result of all uttuck "f llscasc.

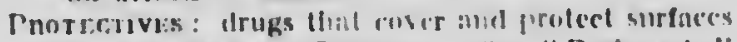
from Irritatlug luflucuers, (See "Desiccants." "Licolllents.") l'scll as dlustluk powders on vounds, etc.: c.k. collotion, French clatk, fulicr's carth, gclatlu, lycopodium, plaster uf paris ( $\left.\mathrm{CuSO}_{4}\right)$.

I'syculozory: the selence of the mind.

I'TOMaise: any ulkaloblal ur lisic product of the putrefaclion of anlmal or veketable matter.

Piril: the opening at the centre of the iris for the transiuisslon of Hght.

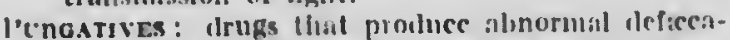
tlon. (See "Iaxalives." "Cholagogues," "Ily dragogutes," "Drastie's.")

lentifist : cousisting of, or contalulng, pus.

Pes: a liquill composel of llquor puris, leucorytes, und pus-produclug gerins: llie productlon of pus-produclng geruis.

lestulants: Irugs that canse pustules of pus to lie formed on the skill, llus drawing pus away from internal parts, c.g. numoula, silver ultrnte, croton oll, mercury, anil cantlıarlies bllslers.

Petnefaction: Ilie ilecomposillon of vegetolule or anlunal malter, cffected chiefy by llie igeney of milcro-orgiunlsms.

Qr.anteniwa a ronse: light grooming, such as is lone before a loorse ls exerclsed.

ItwuFy : to dlverge, or traverse, In branches.

linuts (plural, ranii): a branch, as of the lower faw. or of a vela, nerve, artery, cle.

REFLEX ACtioN: any involuntiry action prolueed by a stlumbis that is conveyed to the nervous system mid reflected to the periphery.

Rifnicenasis: Irugs that cool part3, diminlsh circulation, nllay paln, and quench the lhirst, c.p. acetle acld, dil. lijilrochlorle acid, ether, ammonlum chloride. water. clılornform, pot. chlorate, pot. ullrate, alcohol, soda elilorlde.

Regciugitstion: the eastling up of whinl or food through the gullet ( $\alpha$ sophiagus).

IResulvists: Irugs that dissolve and disperece tissue. (See "Diseutlents.")

Restonatives. (See "Tonics.")

libee: a eresl or elevated borler.

Higon: chlll or "slilvers."

ReBlicicients: drugs that redden sklu ly thcir irritant action, e.g. acetle acid, carbolic acit. aımınonia, caulphor, chloroform, croton oil. mercury perchloride, lodine, alcohol, turpentinle.

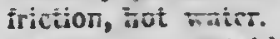

SApnopnytes: vegetalsle organisms that live on dend vegetable matter.
Sensudentan memnnanr: the inucous membrone that llnes the nose.

Sicnerion: the function or process of separatling virious substances from the blood.

Snotives: irugs that diminlali the actlon of the Viscular mid nervutis system, and allay mucons nicmlirane Irritation. i'sed liı palnful abdomlual aftectlons, sposms, coughs, to clicek secretlons of mueous memliritue, and in vomitlug. (See "Anoriyues," "Antemelies," "Antiphlogistles," " Limolileuts." "Mi.frlgerants.") Stomachicscetmilit, carbolle acill, dil. liyilrocyanle acld, bellalonua, bismuth suluiltrate, uagnesis, oplum. surla blenrbonate, Mda corlomate; Nervouscamplior, phenacetin. pot. Iromlale, pot. nltrate, yluc suphate: Vascular-dil. hydrocyanle acli, aconile, anyl nitrlte, camuabis lidica, colelicum, digltalis, ergot, pot. ultrale.

Si:mix: the fecumbintlug secretlon produced by life testes aud ejected in coltlon.

Srot's : pertainln to, or rescubling. scrum ; producing or contalulug scrum.

SRMRATID: linving a saw.llke vige or borler.

Srencu: the cienr, liquld purtlon of blood; also used to denote the clesir portlon of any anlmal Duld scpirated from its uiore solld clemeits.

Srins: a strlp of sllk or llien drawil tlirough a wound (1) heep a passage or seton open; the passage so formed.

Sivingonues: drugs that linerense the secritlon of the saliva, e.g. dlil. liydrochlorle acld, arecolenc, mercury subchilorlile, finger, puclopliglilu, pot. lodicle.

Solvtios: a llepuid contaluing dissolved matter. A saturated snlution is onc of a substince In water of such a strength that if more of that substance lie acluled it will not dissolve.

Specific: producel by a slugle kinil of milcro-organism: a remedy speclally Inclleated for a particular alsense.

Srectzum : an listrument used to linid the mouth of a horse open whille it is belng examblued, generally used lin dentistry

Spensatozoon (plural, spernatozoa): the mollle gencrative nilcro-organism of llie semen whlch liupregnates the fomale oviun.

Srivf: a slender thorn-like process of bone; tl:c vertelsal column.

Sponanic: not epldemle; occuring here and there. Srasis: a stoppage of the now of blood ln a part.

Strarle: nut fertile, aseptle, barrell.

Strmulants: drugs that lincreise the sensibllity of the nervous and muscular systems, secretions of mucolls membranes, and the functions of thie whole hody. Used in loss of appetlte, delollity. paralysis, collc. (See also "Aplirodislacs," "Ecloolics," "Liuctles," "Nauscants.") Diffusible Stimulasits.-Exhilarant and vascular-cther, splrlts cther nltrate, alcoliol, ammonla, caffelı, camuabls livlica, caniphor, chloroform, turpentlice: Nervous-ether, arnlea, belladouna, cannabls lindlea, :l!toral hudra!e, ergot, strychnine. Irictlon, electrlcity; Stomachic-clilute hydrocyanle acid. spirits cller nitrate, ellier, anmonla, unlscel, 
arnica, asafotida, chiretta, gentlan, sola chlorlde, finger; External Stimulants-(see " RubeIncients," "Pustulants," "Caustics," " Werlva. Uves," "Discutlents," "Traumaties").

Sromacnics : Irugs that linprove appetite and assist dlgestion. (See "Sthnulauts -Stomıaclile",)

irmappise: thoronglı groonlug, such as a horse should get after he returns from work.

Siryitics: Irugs that arrest hacmorrliage and contract mucous memirane, etc.. e.g. acctic scid, rarbolic acill, taunlc actll, gonllle acis, alum, collodion, copper sulphate, ergot, Iron perchlorille. lead suhacetate, zlue sulphate, callery, cold applications. (Sec ulso "llamostatles.")

Sibcutaneots: simated or oceurring bencath the skin.

Siluonifics: Irogs that increise the secretion of the sucloriferuts or sweat glands. (Sie" " Diapllonretics.")

Si:Lci's : a groove, trencli, or furrow:

Sieplewants: Irugs that caluse the formallom of pus (sce " Pustulants"), e.g. nmmmnlu, eroton oil, cautcry, sclons.

Suprenation: the formation of pus.

Srmpatmetic: perlalnlug to, caused by, or cxhiuiting sympathy; the sinipathelic nerve swstem, which lnchudes all the nerves except those of (')anial or spinal arlgiu, whlch supply the in. voluntary muscles.

Table of Molar : the grimliug surface of the molar inoth of a horse.

'rexuafiges: drugs that ant on tapeworms, c.g. male ferm, turpenthie.

'luenapectucal: juctaluing to the art of licallug ; rurative.

THERAl'El'tics : llie scilolce aud art of heiling.

lintanpy: the treilment of disease; therajeuties.

Tissure: an aggregation of cells, fibres, and barious cell-products, forming il structural elcment.

lovics: Irugs that improve the quality of hiloed and give tone to Hic nervous, vascinlar, and viigestive systems. Ised in debility, ferer, in dlgestlon, anxemia, epilepsy. Blood tonicsarsenle, Iron, inlmal, and vegetillye vils, fresl air; Nervous tonies-arsenle, silver nitrate. ralfelı, cinchona, copper salts, Iron salls, digitalis, phosplorns. quinlne, mux vonica, or strychulue; Stomachic tonics-stomatchic stimu- lants, vegetable liltlers, nincral and vegetable aclels, pepsin.

Toxicolooy: the seience of puisners.

loxis : nny polsonous allumulit produced liy bacterlal action.

'J Ralmatic: pertalning to an lnjury.

l'ratmatics: drugs tli:it are applied to wounds, such as nutiseptics, astringents, cuustics, emollents, protectlves, deslcrants.

rrocan: a shirp listruncut used with a camuula for plerclng a cavily wall.

lnochanten: a liurge bony process, sucls as that below the neck of the femu:

'JnocmLeA : a pllley-shaped promlnence on a hone, such as that on the astragalus.

'feBi:ncLe: a Hodlule on a bone; a nuass of small rounded nodules produced by the tuberculosis bacillus.

'l' nerosity: a broal cmlnence sltuated on a bone.

F'volu: n neoplasn ; u mass of ncw tissue that has Ho pliysiological use.

lyupasites: dlstension of the abdomen due to the juresence of gas.

ILCI:R : an open sore other than a wound.

Iiletura: nembranous canal that leads from the blatder to the surface.

liminate: to vold or dlscharge urluc.

Vagisa: the canal trom the slit of the vulva in the neck of the uteris, or womb.

Vasculat: pertalning lo ur full of vessels; well supplled with blonol.

Venicte: a sulistance used li making oiutunents, linluents, emulsions, clc.. such ns lart, viosclluc, oil, ete. It is Itself inert and ls used to produce the correct consistency.

Viax: a sessel which couveys the hlood towards the lieart.

Vinvesol: : a drug that destroys intestina! wornis. (See "Anthelnintles.")

VI:MMIFti:: a Irug thit expels Intestinal worms. (See "Anthelninties.")

Vissu:ters: drugs that produce bllsters or vesleles "f scrum when applicel to the skln, e.g. acetic aldid, ammonla, cantharliles, croton oil, mercury thlisters, turpentior, stemu.

Vunt.lint: excedelingly noxions.

Vi wa: life external piart of the organs of generation if Ilue fomale (nialre). 


\section{CHAPTER XI}

\section{GH:IERAL DISEASES : ORGANIC, FUNCTIONAL AND CONTAGIOUS *}

531. In this chapter we consider the comnionest diseases of the horse, with the general causes, chief symptoms, and the best method of treatment. I neither go into detail nor make mention of uncommon diseases. The practice of experimenting with a horse is a dangerous one, and therefore it is always advisable to call in professional aid when anything serious is suspected. It is a common practice amongst grooms and others to "fll " a horse with patent druzs that in most cases do more harm than good. 'The fewer drugs kept in the stable the better. It is impossible to lay down hard and fast rules for the treatment of any one disease, as different practitioners use different methods, and the horse and its surroundings vary so much as to necessitate i variation in the details of treatment.

The methculs of treatment are those that liave mel with the most success in the past few years, but as new ideas and new drugs are being brought forward every day, it is impossible to be absolutely up to date in everything. The progress made in the manufacture of vaccines has changed very considerably the treatment of many infectious diseases.

532. Temperature.- This is taken at the anus by moistening the thermometer and inserting it well in. A good thermometer registers in thirty seconds; it is safer, however, to leave it in for one minute. Care must be taken to shake the nercury down to about $96^{\circ}$ before using the thermometer; this may be done by holding it firmly in the hand and shaking it as if trying to remove a drop of gum from the bulb. Always wash the thermometer with an antiseptic before putting it back in the case. The normal temperature is $100^{\circ} \mathrm{F}$., or $38^{\circ} \mathrm{C}$.; in the human being it is $98.4^{\circ} \mathrm{F}$., or $37^{\circ} \mathrm{C}$.

The temperature of a mare may be one-lialf to one degree Fahrenheit ligher. Young horses as a rule register a higher temperature than old ones. The tempe:ature is generally higher in the evening and lower in the morning. During work, during digestion, and while in a warm atmosphere the temperature is higher. Cold vater or a cold atniosphere lowers the temperature (see \$ecs. 150-1).

- For Surglcal Discasce, ece Chapter IX. ; for Discases of the Fool, ace Chapler XVill.
533. The Pulse.-The beats of the heart are generally taken by pressing the first finger on the submaxillary artery (glosso-facial), which passes under the lower edge of the lower jaw bone, just in front of the expanded portion at the angle of this bone. (See P. 137.) The artery must be lightly pressed just inside the hollow between the rami of the lower jaw. At this point three vessels pass under the bone, submaxillary artery in front, submaxillary vein, and Steno's duct from the parotid gland behind. The flrst finger must be used in feeling the pulse. Normal pulse is thirty-five to forty-five beats a minute. A wiry pulse is one in which the artery is hard and small, like a small wire. Normally, the pulse should be iairly full and quite steady in its action.

Thi Heart Sounds.-The cardiac sounds are taken by lolding the ear against the chest just lelind the elbow, with the leg held forward. A stethoscope should be used, as it is difficult to hear the heart sounds distinctly with the naked ear. The true sound is thus: Lubb-dupp-Lubbdupp. The first is a long, booming sound, due to contraction of the ventricle and, simultaneously, the vibrations of the auriculo-ventricular valves. The second is a short sound, due to the sudden closing of the large semi-lunar valves of the arteries above the auricles (aortic and pulmonary arteries).

534. Respiralion.-A horse breathes normally when at rest at the rate of twelve to fifteen respirations per minute. This is counted by watching the horse's flanks.

The murmur of the lungs is noticed by holding the ear, or, preferably, a stethoscope, against the side of the horse's chest. The inspiration is louder than the expiration. In some cases the expiration can scarcely be heard. In horses that are very fat it is difficult to hear the respiratory murmur. In rare cases this murmur is undetectable for no apparent reason. The murmur is produced by the friction of the air entering the alveoli. The normal murmur is a soft, moist purring sound, without any jerks or harshness. It sounds like the noise made by the air coming out from a pair of hand bellows when gently blown. Near to the trachea at the entrance to the lung can be heard the additional noise of the 
bronchi. The numrmur censes before the end of each expiration: therefore, ticl inspiration does not directly follow the expiration, but eacll expiration immedialely follows the inspiration.

535. Crine.-Normilly the urine of the horse is cloudy, unlike that of other animals.

The Membrana Niclilans.-This is a piece of cartilage, covered by mucous membrane, that is situnted insile the ryelict of the horse. The 'ye is protected from tarticles of solid matt.r lig meaus of this nembriuc, which renuoves such liarticles. The eye is also protecterl by the eyelids, which sweep the cormen. Tuars also fush the surface of the cormea, which is covered with at liyer of mucous membranc. Normally this niembrane is pale pink: in anamin it is white, illil in fever it becomes (ongested, i.e. rod. The femporature, therefore, can be approximated by "xamining this monulatue. This is done by tressing the first two joints of the first finger of the right haind on to the top lid of the horse's left eye, and, with the thumb and first finger, the two lids are drawn apart, thus, as it were, turıing the upper lid inside out, when it can be "xamined. The colour of a healthy liorse"s membrane slowuld be studied.

536. Trarhrolom!.-Whenever the breathine is very difficult, due to swellings in the throat, resulting from injuries, etc., aul the disease kHown is jurpura hemorrliaten, or when a liorse roars badly, traclientomy should be por. formed. In many cases it is llecessary to save life. The trichootomy tube is made aseptic by being sterilised in boiling water for five minutus. Cocrine is injected under the skin over the pait of the windpipe that is going to be cut, which should be approximately on a level with the withers. A line is cut with a sterile knife down the middle line on the frout of the neck for about one and a half inches. The knife is then passed throngl botween two cartilage lings, nud cut up half-way through one ring and clown hulfway through the other, taking au elliptical piece out of each, makiug a liole a little larger than the tube. The pieces are removel, the liole is made free from tissur, and the two portions of the tube inserted and fistencil socurely towether. The whote operation tukis but il few seconds. but great care must be taken not to cul througl a riug of cartilage, untess the luhe is very large. The relief given to a half-suffocated horse is extraortimini.

If a cartilayinous ring is cut rie-ht through, it is liable to contract on healiug, and thus lissiol the size of the linnen of the tractien. 'Tle' tube must be cleanerl twice daily. A 10 per cent. solution of common salt is very excellent for soflening the discliarge, etc., on the tube.

The following is a list of Diseases of the Alimentary Canal from Moulh to Rerlum.

537. Stomatitis.-This is a catirrl anul ulceration of the mucous membrane of the mouth.

Cause.-Rough food; use of undiluted, irritating nedicines, such as turpentine, cliloral lydrate; damp and mouldy hay, silage (if too nulich fermented).

Symploms.-Redness of mucous membrane: salivation is excessive; saliva is ropish, hangs from mouth: mouth smells fetid; if bad, the liorse is off feed; if ulcerated, pustules of pus will be present.

Trratment.-Remove cause, give soft food, give lavitive. Wash out mouth with diluted antisep:ic sulution. Snear potassium chlorate, dissolved in molasses, on tecth.

538. Glossitis is inflammation of the tougue. The tongue will be swollen and teuder; other symptonis sume as stomatitis. Treatment saine as stomulitis. If very sore, laxative must be givell per rectum. Keep tongue in moutl by means of a ponch, ete.

539. Pryilisi, or SlobBering.

C'ulst.-Foreign bodiss in the mouth, such as picees of woul werlged between the nolar teeth: clover and other summer herbs: drugs, such as mercury. Injuries to lower jaw from larsh use of severe bits.

Symploms.-Excessive flow of salive. Diges. tion nay be affected. If foreign bodies are wedgel in teeth, horse may hold head on one side.

Treatment. - Examiue mouth and teeth thoroughly, and remole cause. Wash out mouth with cold water and alun : change food; give tonic.

540. Panorits is inflammation of parotid fland-numps. This frequently occurs with - trancrles.

Cenuss.-Tight bearing- or cleck-rein. External iujury, fermented food, contagion.

Symploms. - Enlargement below ears on both silles of the jaw, hard and hot, painful on t)resilure. Mastication may be interferel with. Later, gland becomes soft and fuctuating. Hair easily rubbed off. later, swelling points.

Treatment.-Fomentations with poultices, to aid in pointing. Opell swolling, when rendy, ind treat wommd antiseptically. Give soft feed, febrifuges and tonics. Aflerwards rub on ioline ointmont to redice swelling, and give potassium indide intermally.

541. Pili, or IMRnilen APPETITF.

Cause.-Stomach out of order, lying idle in wirm stuble. Common in foals.

symptoms.-llorse eats its own dung. Foals nibble their mothe's's tail.

Trialment.-Prevent cause. Give purgative and grood food.

542. Pilaningitis, or Inrlamaition of l'DAHYNX-SORE TIInOAT.

Couse.-Contagion, exposure tn cold and dampness, impure air (badly ventilated stables;, 
chemicel irritants, smoke, bad food, damage while trying to give a ball.

Symptoms.-Ptyalism may be present, pain if throat is pressed, dull and sick-looking, sometimes fever. Respiration generally increased. As horse swallows water it may be discharged out of nostrils; will play with water, and not drink much. Constipation or diarrlicea may follow. Carries nose extended. May take in food, chew it a little, and throw it out. Mucous membrane of noso reddeneli. Discharge from llose, at first watery and clear, later thick and yellow. Dry congh, becomes loose about third day, caused by extension of inflammation to the larynx. Respiration varies witl fever. Pulse generally up. Temperature up, except in mild cases. Recovery generally in six to ten days. septicamia or pnemmonia nay follow : abscess may form in thront.

Treatment.-l'ure air, iry and woll-ventilated box stall. Body well clothed, legs bandaged. Give nourishing, tempting, and easily digested foods. Isolate. Mild diffusible stimulants and febrifuges, if horse can swallow; otherwise, give hypodernically. Give electuary. Put pot. clllorate on back of tongue. Give inhalations of steam and oil of eucalyplus. Pilocarpine is very dangerous in this disease. Poultice throat in laytime, hot cotton batton at night. Attend to bowels. Open abscess exterually. Tracheotomy may be necessary. Examine lung3.

543. Disfases of CEopilagus or Gullet.Dilatation and constriction of the gullet are not common. Generally caused by nervous affection, irritants or injuries. The symptoms are choking and uneasy eating.

Treatment.-Sloppy food. If constricted, a probang should be passed each day down the gullet, a larger size being used each day. If iliated, the swelliugs can be seen externally. Exlernal pressure may do good. Treatment, as is rule, is unsatisfactory.

Rupture or Laceration.-Tliese are fairly common.

Cause.-Improvised probang, as whipstock, and abuse of probang.

Symptoms.-Dull and listless. Respiration increased. Probable external swelling. Pain oll pressure. Breath becomes fetid later.

Treatment.-Generally of 10 avail. Put animal out of misery. In some cases give chloroform, and open from outside and sew up gullet. In paralysis of gullel, give strychnine or nux vomica, and stimulating liniments on neck. In spasms, horso holds neck arched as if trying to vomit. Give chloral hydrate, apply opiate liniment. In inflammation of sulict there is pain on feeding, and heat will br yresent. Apply anodyne, liniment, and give rashes and soft food.

ga. Catarail of Stomicit.

Cause.-Feoding on cosrse or unsuitable food, especially when teething.
Symz:oms.-Ofi feed, diarrhces, or constipation. If ulceraled and extensive, horse may try to vomit, and may bring up mucus covered with blood.

Treatment.-Remove cause, attend to bowels, give stomachic. Give linseed oil and good, easily. digested food. If ulcerated, do rot give purgative, but give bismuth subnitrate or lead acetale. If much blood is coming up into mouth, there is hremorrhage of the stomach. Give tincture of irun, lialf an ounce, in water as a drench.

545. Gastritis, or Inflimiation of Stomacit.

Cause.-Irritants or poisons in stomach, as copper, arsenic and mercury; feeding from yew trees, etc.

Symptoms.-Great pain, almost continuous, sweating, pulse slow, loss of appetite, dullness. Eyes stare, great thirst, red mucous membrane, anxious expression. Temperature up, discharge of frothy saliva.

Treatment.-Give repeated stimulants and mucilaginous drauglis to stimulate nervous system. Backrake and give warm cnema. Give antidotes for poisons. (Sep Secs. 511-2.) Give anodyne. Drugs given by the mouth will not be digested. Give raw linseed oil to soothe stomach. If from yew poisoning, do not give oplum.

546. Rupture of Stomacil.

Cause.-Too large feed. Tympanites (bloal. ing), straining, acute attack of colic.

Symptoms.-Pulse feeble and very rapid, perhaps 120. Legs cold; cold sweat. Temperature up to $106^{\circ}$. May sit on haunches. Difficult respiration, stiff gait. On giving turpentine, pain gets worse. May vomit.

Trealment.-No hope; death in six to eight hours. Horse falls suddenly. If only one coat of wall of stomach ruptured, may live several rlays.

547. ACUTE INDIGEstion (Engorged Stomach).

Cause. - Overlonding stomach with coarse, indigestible food. Not masticating food. Hard cereals, such as Indian corn (maize). Big feed after a ?ong fast. Cliange in diet. Getting at oal bin.

Symptoms.-Generally sudden. Uneasy, off feed, lies down and gets up again. Oets worse and worse. Respiration difficult, eructations (belching); later throws himself about and unwilling to move; partial loss of control of limbs. May hide head in manger. Pulse quickens, according to severity. May snort later, may have sleepy staggers. Distress greater in evening.

Trcatment.-Giva boiled food only in small quantilies. Remove cause. Neutralise gases formed. Give ether and chloral hydrate. Arecolene $1 \mathrm{gr}$. , to clear bowels. If much tympany, isse stomach tube, and give liquid animonia $10 z$., iron sulphate $1 \mathrm{oz}$., waler 2 pints, as a drench. Hot-water enema every lwo hours. Nux vomica F.E. 1 dr.

In Foals.-Coused by mare being kept from 
foal too long, mare tired or liot when foal sucks. loal overfeeding, mare in bad lealth.

Symptoms.-Diarrhoa, faces are fetid. May be spells of yain. Idoss of appetite. May grind teeth. May be painful evacuations.

Treatme'nt.-linseed oil $207 .$. clıloral hydrate dr., turps oz., for two- or tliree-weeks-old foal; double this for six-weeks-old foal. Later rive anmonum acetate, spirits cther nitrate ancl -pirits of cannhor in milk and water. Do nut rive gruel. A foal has a dose equal in size to that of a large dog. A foal's stomach is very (lelicate; it is better to give too little, and to repeat the dose. If mucl weakness, give a wine"lilss of port wine or whisky, in water. Hot iimentitions over abdomell, followed by friction. Wien he starts to suck again, give foal very litlle, and milk the mare by hand. Always inilk a little before foal sucks. Change mare's food, and give her diureties.

548. Chronic Indigestion.

Cause.-Bad feeding, irregular meals, overfeeding, and not sufficient exercise; crib biting", bad teeth, bolting food, wornss, mouldy or 111 suitable food.

Symptoms.-Slow pulse', temperature may be I'p or down. Capricious appetite, sometimes eructations. Thirst, bowels irregular. Feces hard, fetid, and covered witlı mucus. If stomach is acid, horse will lick wall. Elevates head and lurns up upper lip.

Trealment.-Give light, easily digested food i: small quantities five limes a day. Examine tweth; give aloes ball after two or three days lleparation on bran mashes. If digestion is woak, give dilute hydrochloric acid $1 \mathrm{dr}$., and pejosin. Afterwards give tonics, particularly nux lomica.

549. Diaranci.-Diarrhasa is an increased amount or an increased fluility of the faces, due to accelerated peristaltic action, excessive secre. tions of glards, or prevention of absorption by blood-ressels.

Cause.-Nervousuns, irritants, worms, rough food, bad water, irregular or bad feeding, suddeu change of food, polatoes, new liay or oats. llorses with flat sides are more liable to this than round-bellied horses.

fiymptoms.-Excessive ind liquid evacuations. At first, no constitutional disturbance. Iater, may be colicky pains: pulse may be weak and ripil, and breathing quickened; thirst. Later, loss of appetite. If due to worms, the diarrhoea will be persistent, cast unthrifty, irregular appetite, worms in taces.

Treatment.-Keep warm and comfortable, and give linserd tea and warm gruel. Give no colll water. If much pain, five opium, camphor and spirits ether nitrate. If horse is not weak, a pint of linseed oil will often stop the diarrhoea. Do not check it at first, unless result of too much medicine. When the pain is more easy, give astringents, such us tannic acid, lead acetate, copper sulpliate, calechu, chalk, etc.: one pint port wine is very goorl. If much continued pain, upply liot fomentations over abdomen for two or tluree hours. If much strain, give enema witl 2 dr. oplum in it. If due to over-purgation from lllelicines, give at once:

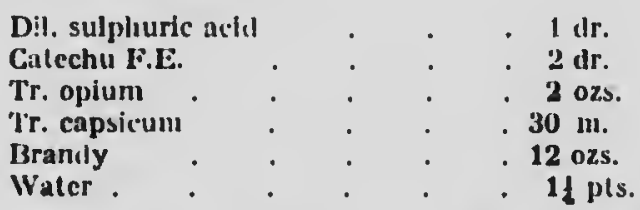

Give as a drenclı; later, follow with intestinal antiseptic, as salol, creolin. If due to feeding polatoes, give an ustringent. llest comfortably, and givo light food, such as starch and flour gruel. Small does of tincture of iron or gentian, or nux volnica and raw eggs. Flour and water is often sufficient to stop excessive purging.

550. ENTERITIs. - Inflammation of mucous membrane lining the intestines, usually large colon; generally fatul.

Cause.-Woak and washy animals are predisposed. Drastic purgatives, as croton oil. Feeding on frozen turnip tops, coarse straw, mouldy hay. Bad teeth. Eating sticks, sand, weeds; stagnant water; exposure to cold whell heated, tired or weak. Bran and cold water: extra focd before hard work. Feeding when hot or tired. May follow colic, diarrhca or constipa. tion.

Symptoms.-Dullness, pawing with alternate forelegs, looking round at sides; pulse quick, temperature up, nol fuctuating as in colic. Pain continues, but less violent than colic. Evinces pain if side is pressed, unlike colic, later, lies on back or sits on haunches; paws with foreleg contilually; wants to lie down, but appears to Le afraid to. Abdomen tense, cold sweat, peculiar sighing. In last stage pulse is small and wiry; eye bloodshot, cornea glassy; finally, quiet, due to partial unconsciousness ; extremities cold, mouth cold ; may fall suddenly at this stage. During attack any faces passed are generally hard. May try to urinate oflen; urine scanty and lighl-coloured. If diarrhoea, there is less liope.

Treatment.-Give opium (to lessen peristalsis) $1 \mathrm{dr}$. and camplior $1 \mathrm{dr}$. This will also soothe pain. Repeat in half-dose overy two liours. Backrake, and fll back bowel with warm water every two or throe hours. Apply blankets soaked in boiling water over abdomen every ten minutes. Keep warm and comfortable. Give Fleming s tincture aconite, 10 to 15 minims, every two lours, and 10-15 gr. calomel every three hours. If much pain, give morphine $3 \mathrm{gr}$. hypodermically. If very weak, give pt. port wine. If horse wishes to eat, give handful 
cruslied oats and bran. Feed very carefully after recovery, and give vegetable tonics.

551. Colics.-Commonest disease horse is heir to.

Spasmodic Colic.-Cause.-Change of food : feeding roots; sudden change in surrounding temperature; severe purgatives, if not given with a carminative; pea straw: raw potatoes ; wate:ing directly after fecting oats and other grain.

Symptoms.-Pain cones on snddeuly, lorse turns head to side, whisks tail, kicks at abdomen, throws himself about. Then quiet for a while. Then pain again. Pulse up to 60 or 80 during attack, normal during intervals. Horse tries to urinate. A good flow between attacks is a sign of improvement. Ears and legs generally normal. Generally eats between attacks. Passe's hard freces. Diarrhoea is a bad sign.

552. Dirterence Between Colic and ExtrilTis.- It is very important that no mistake be made between the two.

$$
\text { Colie. }
$$

Eye bright and clear ; llmbs and cars generally normal.

Paroxysnis of paln alterunte with frecdom fron paln.

Iressure on ahdnmen pleases horse. Pulse nearly uormal, excejt luring paroxysins.

I Iorse lakes no troulble to protect abdoinew.

\section{Enterilis.}

Eye alull and bloodshal : llinbs and ears cold.

Piali continuous, whleh may get a little casy at ilnies.

Pressure on abdnmen causes pain. Higlı pulse, hard and wiry: Is constant.

lides down and rlses very earefully.

553. Treatment for Spasmodic Colic.-Give carminative. Often gets well of own accord. If pain bad, give 1 oz. clsloral hydrate in $1 \mathrm{pt}$. water, or a capsule. Give ether, brandy or whisky. Do not give drastic purgatives, but a laxative to clear tract. Backrake, and give enema. Pass catheter in case bladder is very full. If acidity of stomach, shown by horse licking wall, etc., give soda bicarbonate $10 \%$. If no acidity, ammonium carbonate $\mathbf{1} \mathbf{0 z}$. Do not give turpentine or strong purgative unless there is no inflammation. Warm clothing. Allow horse to roll ou soft bed in a roomy box. If very severe, put hot-water blankets on abclomen. Do not give is recolene.

554. Flitelent Colic.

Cais".-Fermented foods: sudden change of food: not masticating the foorl; bad teeth; bad digestion; inferior food, as sour or mouldy hay or oats: wincl sucking. Is more serious than spasmorlic.

Symproms.-Unensiness, pawing, looking at side. Tlurows himself down and rolls. Pulse un, abdomen becomes larger and larger, due to tympanites. Great pain, cold sweats, show: great anguish. Ears and legs may be cold. Abdomen sounds resonant, like a drum. No eructations through mouth, but gas passed per rectum. Lies down more carefully, and pain is more constant than in spasmodic colic. Escape of gas per rectum is good sign.

Treatment. - Act immediately. If bloated badly, must not be allowed to throw himself about. Oive turpentine $1 \mathrm{oz}$. in capsule to arrest formation of gas. Give cannabis indica. Give chloral hydrate 1 oz. If no acidity of stomach, give 1 oz. ammonium carbonate; if acidity, givo soda bicarbonate. Pass catheter if bladder is full. Backrake, and give warm water enema every half-hour. If badly bloated, use trocar (see Sec. 501) at once. If pulse very fast, give aconite; if only slightly bloated, give eserine gr., or arecolene $\mathrm{gr}$. If pulse is feeble, give strychnine $-1 \mathrm{gr}$. Keep animal quiet in roomy box stall, with good thick bedding. Afterwards, feed sparingly for days. If tympany is very bad, give the following: iron sulphate $1 \mathrm{oz}$., liquid ammonia 1 oz., water 2 pts.

555. Constipation, or Impaction Colic.

Cause.-Overfeeding, not exercising enough. Paralysis of intestinal tract, indigestion, unsuitable food.

Symptoms.-Uneasiness, looks to side, lies down and gets up. Pain, but not so severe as in other colics, seldom throws himself about. Straining to evacuate. Anxious expression. Pulse aud temperature up. Any freces passed will be hard, or may be very loose.

Treatment.-Remove cause. Give hypodermic at once of arecolene $\frac{1}{2 r}$. and strychnine $\frac{1}{2 r}$.; repeat arecolene in half an hour up to $4 \mathrm{gr}$., total until action. Give moderate exercise. Give $1 \mathrm{oz}$. chloral hydrate in capsule (great care must be taken not to allow the chloral to touch the horse's mouth, as it burns severely). Give aloes ball, also cannabis indica. If no action in a few hours, give linseed oil $\frac{1}{2} \mathrm{pt}$. every half-hour. Pass catheter. Give nux vomica tr. $t$ oz. in water every two or three hours to increase action of bowels. Watch for any bad effects on nerves from the strychnine in the nux vomica, which will be slown by twitching. This must not be confounded with trembling of the inuscles of the shoulders produced by eserine. If pulso very weak, give aconite. Never give opium or morphine in any form of colic except diarrhœa. If much tympany, see Sec. 554.

556. Colic Dur to IVoras.

Symproms. - Generally in young horses. Pains recurrent and not severe.

Cause.-Generally chronic indigestion, unthrifty appearance, very anemic. If obstruction, lain will be acute and death quickly follow. May be worms in the faces.

Treatment for Worms.-BoTs: The common bot is the larva of the gadfly (gastrophilus equi). During autumn and winter expulsion is difficult. 
as the bot has its head deeply buried in the inner ront of the horse's stomach.

Prepare horse for one week on iron sulphate 1 dr. in feed, morning and night. On day previous give bran mashes, and at night no hay. Early in the morning give the following drench:

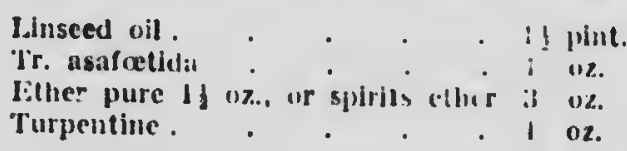

Give mashes for the remainder of the day, and on the second day watch the fieces for worms. After three days continue with the iron, and in ten days repeat the above course.

As a preventive against bots during the autumn and late sumner lorses should be kept away from pasture. The horse must be examined on the forelegs, etc., for the minute lellow ege that the bot fly lays. If any of these are seell, the leg must be well rubbed every day with paraffin oil 1 part and sweet oil 2 parts. Put this also on the legs and around the mouth, as the bot fiy will not settle where this has been put on.

557. TAPEWORus (TENIA). - Withhold all food for twenty-four to thirty-six hours in order to starie the worm, and give turpentine $\mathrm{oz}$., male fern 102 ., linseed oil $1 \mathrm{pt}$.

Rovnd Worms (Ascaris MEgalockphlala) aro like an earth-worm in shape, a re yellowish-white, stiff, and elastic, six inches to one fuot in length. and are generally found in the snall intestines. III slight cases 110 discomfort is felt. In bad cases morbid appetite, diarrhoea, and perhaps
colic.

Give tartar emetic and iron sulphate, of each $\$ d r .$, in food three times a day for a week, and five sma!ler feeds of bran and hay. Then prepare for and give drench in Sec. $\mathbf{5 5 6}$.

Piv Worms (THaean Worms, Oxyeris CuhV(1..) live in the large intestiue, therefore treatment througl: the mouth will have very little wffect. Are $1 \frac{1}{2}$ to $13 \mathrm{in}$. in length. Tail thin and whip-like. They do little harm: may cans. irritation about the dock and cause horse to rub tait. Yellow eggs may be seen near the tail.

Give, per rectum, warm water enema of 1 per cent. tobacco or quassia infusion, or turpentine $6 \mathrm{oz}$. and linseed oil $\frac{1}{2}$ gal. Rub a little am. moniated mercury ointment insirle the anus.

Stronguldis ARMiti's (Palisade Woru).-. This worm is founil in almost any part of the horse. Commonly lives in the large intestine. Varies from 1 to $2 \mathrm{in}$. in lensth, and is 1, in. 11 diameter, reddish-grey in colour, and straight and stif. In the adult state it lies in the colon or cecuns. It enters the horse as an embryo) in in. in size, gains arlmission under the mucous membrane and forms a cyst. It is sometimes found in the liver, testicles, and cven brain, where it gains its admission turough the arteries. These embryos form into an immature worm the size of a small hazel nut. After a period they pass through the arteries into the intestines and form into mature worms; some pass out and some remain and lay eggs. The symptoms produced by the mature worms are probably nil, unless the worms are very numerous, when there will be colic without any apparent reason, the horse crouching down and getting his hindlegs under him, showing that the pain is far back. The danger of the inlmature worm being present in the arteries is that rupture of the walls may result, and probable deuth due to internal hemorrhage. Enteric apoplexy may result from the intestinal arteries becoming blocked. This is generally fatal. Periodic attacks of colic may be produced by this worm; an attack may be fatal. The treatment for the palisade worm when situated in the intestines is the same as for round worms.

558. The manure of holses suffering from worms must always be thoroughly burnt and never spread in the flelds, or the eggs will be eaten by other horses. The figs of worms hatch only in damp places, so horses should be pastured in dry places where there is no suspected worm infection. Always give horses, at pasture and in the stable, a plentiful supply of rock salt. Suspected pastures should be treated in November with lime and salt: they can be used again in four months for feed. It is always advisable to treat horses that have been out to pasture for worms. In the place of asafcetida, mentioned above, 1 oz. of carbon disulphide $\left(\mathrm{CS}_{2}\right)$ can be given with good result.

\section{Diceases of Liver, Spleen and Peritoneum}

559. Jaundice (ICTEnus or lollows) is the commonest of liver diseases.

Cause.-Inactivity of the liver, or obstruction in the biliary duct, which lears from the liver to the small intestine (dnodenum). As the horse has no Eall bladder, the bile passes directly into the intestine as it is secreted by the liver. The cause may be anything that induces inflammation of intestines, such as feeding on frozen clover, rich feeding and no exercise. It may result from influenza, strangles, or other debilitating disease. 'The lile duct may be stuffed up with stones (calculi).

rymptoms.--Mucous membrane of eye and gunts is yellow. Urine high colour, coat dry anil staring. General dullness, loss of appetite, constipation, as a rule, and droppings hard and bad orlour, because there is no bile in intestines.

Treatment.-First ascertain if bile duct is stopped or liver is inactive. This may be done hy Harley's test, which consists in pulting some of the nrine into a glass and adling loaf sugar, then adding very slowly $1 \mathrm{dr}$. concentrated sulphuric acill. If there is a scarlet or purple-red 
colour at line of contact, jaundice is due to obstruction in the duct; if a brown colour, it is due to inactivity of liver.

In cases of inactivity of liver, give calomel I dr., followed by all aloes ball, and feed on pasily digastive soft foods.

If due to obstruction in duct, do not give calomel, but give ball of aloes and nux vomica, and feed rationally. (Many ready-mado balls contain calomel.)

560. HLPATITIS, OF INELAMMATION OF LIVER.

Cause.-Often follows jaundice. Feeding on orgolised grasses, fermented malt. Generally fatal if whole liver is involved.

Symptoms.-Dull and languid. Coat staring, dry, and dusty in appearance. Ilorse looks to his right side, pulse quick and weak, appetite gone, thirst increased, rapid breathing, faces devoid of colour ancl hard. Urine scanty and tinged in colour. Horso rolls moderately and gets up again. May bo lamo in forelegs. Dropsy of hindlegs and belly may follow.

Treatment.-Careful feeding; scalded bran; also roots and grain fodder. Give cathartic and nerve stimulants (strychnine); if pulse is quick, give aconite. Apply counter-irritants over region of liver. On slight recovery, give pot. iodide internally. (Liver is at back of diaphragm, more on right side.)

561. Rupture of LIVER. - May result from a fall or collision, or from a diseased liver. Difficult to diagnose. Horse looks to his right side, pulse irregular and rapidly decreasing. Heal down, internal hæmorrhage. Mouth cold and clammy, legs and body later become cold. Cold sweats. Mucous membrane blanched. If very slight, treatment may be of use.

Treatment.-Perfect quietude. Dieting ; in. ternal styptics, as iron. Mineral acid tonics as liydrochloric acid.

Gall stones are unknowu in liorses; liorse has $n$ no gall bladder.

582. Spurwitis is inflammation of the spleen, which is situated behind the diapliragm on the left side of abdomen, on left of stomach. Splenitis is uncommon, and often fatal.

Symptoms.-Like colic, but less alarming in appearance. Quiet and weak pulse, dullness, ears droop, head down, respiration increased, abdomen tucked up. More coma in summer.

Trealmenl.-Give morphine. Counter-irritants over spleen. Givo cannabis indica and aconite. Very careful diet.

563. Peritonitis. - Inflammation of peritoreum, which surrounds practically all the viscera in the abdomen and pelvis.

Cause.-Follows other inflammation in abdomen, as metritis, enteritis, gastritis, etc. Punctured wounds. Badly-conducted operations, allowing infection to reach periloneum.

Symptoms.-Horse turns head towards flank, does not roll. Great pain, mouth hot, respiration increased, pulse 60 to 80 . Eye a little reddened. Temperature high, wiry pulse. No peristaltic action, i.e. absence of internal murmur. Usually constipation, faces slimy. Abdomeu very Lender. lielaxed anus.

Treatment.-Give tincture opium $2 \mathrm{oz}$., and spirits ether nit. 2 oz. Backrake, and warm enema. Hot water application over abdomen, and give linseed oil $1 \mathrm{pt}$.

564. Ascites, or DROPSY, is a non-inflammatory transudation into the abdcmen. Is uncommon.

Cause.-Often follows diseases of heart, kidneys and liver, peritonitis and tuberculosis.

Symptoms.-Coat staring and dry. Dull and languid. Hidebound; Iorse is sluggish, pulse quick and weak, abdomen extended, dull sound on lapping (not like colic). Appetite generally good, bowels irregular.

Treatment.-Diet, give diuretics, also pot. iodido $1 \mathrm{dr}$. twice a clay, also pilocarpine $1 \mathrm{gr}$. every two hours. If bad, use trocar. All fluid must not be drawn off at once; therefore, do not puncture too low down. If convulsions present, stop flow of fluid. Death often occurs froni asphyxia by pressure on diaphragm, and therefore on lungs.

Dropsy of Womb (Uterine Dropsy).-Due to abnormal presence of fluid in uterus, resulting from perverted secretion. Examine by inserting greased hand into vagina. The womb will fcel like a cushion. Do not mistake for pregnancy, when the footus will feel hard.

Treatment.-Open neck of uterus and allow fluid to escape. Same treatment as above.

565. ACUTE NePHIITIS, or INFLAMMATION OF KIDNEY.

Cause.-Chills, sudden checking of sweating. abuse of diuretics, as nitre; overdose of turpen. tine, cantharides, croton oil, etc. Over-ripe grasses, mouldy or inferior food, too severe external blistering with cantharides, turpentine, croton oil. Over-exertion, blows and falls. In conjunction with anthrax, foot and mouth disease, glanders and tuberculosis.

Symploms.-Bladder empty, temperature up, pulse quick and generally weak, mouth and nostrils hot, pain and uneasiness. Points nose at kidneys (just behind saddle on top of back). Rolls gently, may moan, frequent attempts to urinale; urine may be suspended, any passed is dribbly and thick, due to uriniferous tube casts and fibrin. Heat around kidneys if hand is passed in rectum. Constipation, flanks sunken, abdomen tucked up, often straddling gait, patches of perspiration on shoulders and flanks. Later, perspiration may smell of urine; this is uræmic poisoning.

Treatment.-Examine per rectum. Massage all over kidneys and keep body very warm. Hot applications to region. Induce perspiration by all means possible. Freshly fayed sheepskin, 
Heslı side down, put ou for eight luurs; not longer, or lıairs of coat will come ont. Oil jurgatives, not aloes. llot water enema. 'linc. Heonitc. Anorlyncs (nıorpliime). Sorl. liyposulplite is gool. Ciarcfill diet for several weeks.

\section{ChHonic. Nepiritis.}

Causp.-More coinnion in old, Litrd-worked and debilitited lıorses. Fxposure lo colll, abuse of urugs, bad food.

Symptoms.-Mucl millor than atule forn. Uriue scanty, ligh colour. No acute juin, stiffness in regions, jasses off ou cxercise, nıa: stretcl out hindlegs. Falls of in condition, legs may swell while standing. Dull and sluggish, lulse slightly up, appetite uncertaiu.

Treatmem.-Remove cause, feerl (ull rasily digested fook. (iive plenty of good willer nuil fresl air and gentle r.xercise.

566. Cistitis, or INFLAMIIITIUN OF BLIDDEH. -Uncommou.

Caust:-May follow parturition, lixperurt: to cold and damp, irritant medicines, abuse of diuretics, such as nitre.

Symptoms.-l'ulse up, fever, paiu, noutl, lot, constipation, generally straddling gatit. Frequent urinatiug, wluicl is a sure sigu. Horsc maj roll very gently, often stanns feet. Exami. nation per rcetum revials lieat around bladder, probably paiu an pressure. "lie bladder is situated umier the leclum, on the floor of the: pelvic cavity.

Treatment.-Give febrifuges, inject opiun 1 ilr. aul tepid water into blader through catheter. Clothe warnly, especially over loins. W'arm. water enema every hill-lsonr; kcep quiet, give linseed tea.

567. Cataruil uf Hi.nduer.

Cause.-Chill, calcull.

Symptoms. - Urine thick and slimy, no symptomis of any other lisease.

Trealment.-Flush out bladder witl \& ner ent. solution buracic acid. Give pot. chlorate 1 dr. twice a lay. A fair-sized horse will hold over half a gallon iu bladder; loold fluid $i$ u for several seconds, and then let out.

568. Dysuris, or Rerention of URine.

Cause.-Obstructions ill urethra (the lube that passes from the bladder to the end of the penis). Danage to penis, paralysis of bladder, contraction of ucck of bladder. May follow colic.

Symptoms. - Pain and uneasiupss, which increases. Violent afternpts to uriuate. Groans; may lie down and get up. Rectal examination reveals full bladder.

Treatment.-Pass catlieter and iusert liand, and press all urine out of liladder. Warm-ivater enemas. Give nux vomica 1 dr., belladonna F.F. 1 ilr. In mare, rub belladonı, F.E. around neck of bladder, which is felt un the bottom of the vagina about six inches inside the vulva.
569. InCONTINENCE OF Linive (Dribbling).

Cause.-Gicnerally nervous disease, probably of brain. Mny follow stringhalt, which is a nervous disease. Influcriza, weakness, feeding on much sugar, diabetes.

:ymploms.-Dribbliug of urine continually.

Irratment. - liemove calse, give mild purgalive, goon food and stryclinine (nux vomica li.l. is dr. morning and niglit) for four or five liays. Iodine crystals given in the form of bolus uften produce good results.

570. Di.nertes Meu.itus.-Very uncommon in lıor:is. (ienterally unfavourable.

("inst"-. May be due to too rich, starcliy feeding. I'robalsly from liver disease.

symmomin.-Debility, clepression, weakness, IIItlirifty coat, grent thirst, appetite much increasel, urine las sickly smell and contains sugar. Test for sugar:

Frminlation Test.-Take a test tube of uriue, illl yeast, invert. Carbon dioxide gas will forni iil tolj if sugar is present.

Trommier's Test.-Take two inclues of urine in test tube, add about oue-eightl of its volume soda hydrate solution, then add, drop hy drop, I per cent. solution copper sulpliate. Sliake. If -licir is prescnt, cuprous hydrate will be disiolvel. Acld until this remains precipitated at the bottom of the tcst tube. On boiling, top part "I solution gocs yellow ; boil inore, and it turus red (cuprous oxide). If too much copper sulphate lins been adiled, the solution will turn black, aud experiment must be commenced again.

Treatment.-Reduce starchy foods, give dilute hydrocliloric and salicylic acid and preparations if iron.

571. Dinbetes Insipidus, or Polyuras.

Cause.-Bad slable management, dusty or livaterl oats. May follow infuenza or brain Ilisenses.

Symptoms. - Weakness, digestion impaired. culic pains, excessive urinating, excessive thirst (drinking 17 to 18 gallons of water per day). lemperature normal or low. No sugar in urine. lirine is alkaline and plentifu!, coat harsh and slaring, much debility, mouth clammy, sour smell, pulse quick.

Treatment.-Good food. Do not allow much water; mix clay in water. Give mild purgative and learl acelate. Give lugol's solution (iodine, pot. iorlicle, and water) 2 ilr. tivice a day. If stomach is acid, slıown by regurgitation, give clıalk.

572. Azoturia.-Called hamoglobinuria, but it is now thouglit that it has nothing to do with the blooil.

Cause.-Illeness and stimulating diet. Bad hygiene and want of fresl air predispose horse lo an atlick. Heavy horses suffer most and die more easily from it. More common during raw cold winter days. Stancling for a day or two 


\section{XI] ORGANIC, FUNCTIONAL AND}

on heavy feed and then given hard work predispose to an attack.

Symploms.-Horse goes well at first, then becomes dull; later, goes slow, and gets stifl over hindquarters; will drag hindlegs, and may then paw with the forefeet. May be stiff in forelegs (caput muscles). Later, staggers, sweats urofusely, and shows great pain, may tremble und fall down. Muscles over hindquarters are very hard, pain on pressure generally. Breathing difficult, signs of great nervousness; may moan. Urine is colour of tar, due to the colouring matler in the muscles escaping into the blood and thence into the kidneys; may be in forequarter only, but very rare. Temperature may go up to $104^{\circ}$; pulse always affected, which is quick, jerky and hard. Mucous membrane reddened; if very bad, may be dirty yellow. legs and ears cold. Coma is generally acule. May recover almost instantaneously. May recur. May leave partial paralysis.

Treatment.-Keep quiet in big box-stall with plenty of bedding. Apply hot water over hard muscles. Do not put into sling. Pass catheter every four hours. Give purgative at once, arecolone $1 \mathrm{gr}$. hypodermic. Massage gently with stimulating liniment over hard part. Give plenty of water and pot. bromide. Keep bowels loose aflerwards. Give adrenaline, if pulse is not full and quick. Give anodynes and stimulants. After acute stage give nux vomica F.E. 1 dr., tinc. iron 1 oz., soda carbonate $1 \mathrm{oz}$., morning and night. for two or three days, and massage affected muscles. If paralysis of muscles, give electric trealment.

\section{Diseases of Heart}

573. Penicanditis, or inflammation of pericardial sac, which encloses heart, is uncommon.

Cause.-Chill, external injury, blood poisoning, swallowing nails, etc. May follow pleurisy, rheumatism, influenza, tuberculosis, lung abscess, etc.

Symptoms.-Palpitation of heart. Difficult breathing, respiration quick: may be mistaken for pleurisy. Eyes unnaturally bright. Mouth hot, ears and legs alternately hot and cold, pulse generally small and weak: often a pulse in the jugular veins, due to valve of heart not closing uroperly. Bowels and appetite irregular.

Trealment.-Absolute rest, no excitement or fright. Cold water irrigation for half an hour over region of heart (outside sixth and seventh ribs). Followed by mustard plaster. Give oral laxative to keep bowels free. Small and re perted doses tinc. aconite $5 \mathrm{~min}$. Give opiates if pain bad. Give pot. hicarbonate $2 \mathrm{dr}$. every two hours until relief. Pot. iodide helps to absorb effusion. Never give digitalis if valves of heart ire not working well. Feed very carofully afterwards, and continue giving pot. iodide until symptoms of iodism appear.
574. Hypeatrophy Or HzARt.-A hypertrophy is not in itself a diseased condition, but merely a part that has increased in size due to increased work of that part, and, therefore, increased nourishment.

Cause.-Excessive exercise, as in racehorses. Valvular defects. May result from tuberculosis or chronic nephritis.

Symploms.-Great weakness, pulse strong and liard, or weak and quick. Pulse in jugular veins; may be fainting fits. Throbs of heart shake the whole body. If compelled to move, almost suffocates. Respiration quick. If only slight, as in many racehorses, there will be no se rious symploms.

Treatment.-If very slight, give horse slow work. If bad, of little use. Give pot. iodide 2 dr. twice a day, and diffusible stimulants.

575. Dilatations of Heart. - May follow hypertrophy. Size of heart cavities is increased, and walls are thinner.

Symptoms and Treatment.-Similar to hypertrophy. Horse may sometimes continue at slow work.

576. Rupture of IIEart.-May be the result of any sudden exertion, or follow any heart trouble. Death follows instantaneously.

Cranosis, or blue disease (very uncommon), is due to the non-closure at birth of opening in lieart (foramen ovale), which normally becomes closed. Medicinal trealment is of no use. In fotal life the foramen ovale is the communication between right and left auricles. Normally, this closes at birth, leaving the fossa ovalis.

\section{Blood Veasels}

577. ANeurism of ARtery, or Dilatation of WALL OF ARTERY.

Cause.-Exertion, fall, blow, weakness.

Symptoms.-Faintness, staggering, difficult breathing. May fall down, and get up, after fifteen minutes, apparently all right.

Treatnient.-Give lead acelate $1 \mathrm{dr}$., pot. iolivle $2 \mathrm{dr}$., twice a lay. If possible, operate under anzsthetic; ligature artery, and dissect out the aneurism.

578. Thrombosis, or Clot in ARtery.

Cause.-Aneurism, breaking up of a diseased vessel, heart disease. The block caused by the clot (thrombus) is generally in femoral artery, near the front border of the pelvis (where the artery gives off the profunda femoris and prepubian arteries).

Symploms.-Sudden and severe lameness, but not hardened muscles, as in azoturia. Limb deathly cold. May be sweat patches, due to severe pain. May suddenly rocover. Perhaps only places toe on ground while pain lasts. Trembling, quick breathing, may fall down. Examination per rectum may assist in diagnosing case. 
Triatment.-Apply lut wister to purt imnic. ituately; then vigorous musistge will liniments. live Fleming's tinct. uconite $\$ 0$ nin., and ano"jolle to relieve pain. If reververing, rest and lienl woll, antl give luinio-

\section{Blood Diseases}

579. Il.t:MIolumll.1, ur absence of clutting power in the blomel (elotiug is caused by tibrui, furmanl lụ netion of seleril ferntento ill tlio blevel'.

canse'-llerulitary tedulency.

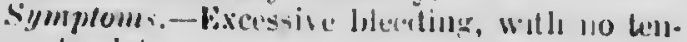
leney to elot.

Trenlment. - Iron perchloride internally. Arrest blont-flow medhanically.

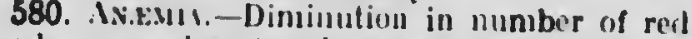
blood corpuscles (erythrucyhes), and "lso in anumunt of fibrinogen.

Calis: - Ilamorrhago, diarrhea, diabrtes, yoneral ill-health, stariation, bad foul, bail luggioue and contagion.

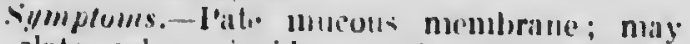
be slate colour indide mstrits (Schneiderian utembrane). Mouth cout, tongue soft, debility. slariar coat. Depravel appetito, julse feeble, jerk! and irregulitr, sulltil slock causes palpitutiuns. Generally lintebund, easily fatignel, digestion weat. lints collc eisily, swelling of legs common.

Treatment.- Gicul slabling, fresh air nut groul food : gruel. switched eggs, nilk, stont. I fair-sizel foal will take a gallon of milk twice " rlay. Give foals livpopliospliates, and maturel luorses iron sulphate, gentian aul quinine. If stomach is acirl, give sorli bicarbonate. If much constipated, give only very milul purgative strong purkatives are dangerums. Groom well, and give arsenic for two or three wecks.

581. LEtC.EMIA, or increasel number of white-bloorl corpuscles (limerocyter).

Cause.-Unknown; probably ilue to diswase of spleen or lymphatics.

Symptoms.-Fractically same as ancmial. Staggering, vertigo. Rapid breathing, if exerted : pale mucous mombrane, but not slate-colourer Schneiderian. Pulse viry quick, small all irregular, depraved appetite. Microscopic examination of blook is surest way of diagnos. ing case.

Treatment.-Generally useless. Good stabling and food. Give iron, yninine. The latter reduces number of white corpuscles in blowd.

582. Diseases of LYMPHatics. - Lymphan. gitis, weel, Monday morning ill, or water farcy.

Causp.-Feeding work-liorses on normal feei during a day's rest. Iye gruss, new hay.

Symptoms.-Swelling in one or botli hind. legs. Shivering, carly lameness; later, fever and fast breathing. Pulse fast, full and strong. up to 9 ; temperature up to $105^{\circ}$. Constipation usual, ulucous menibrane reddened, urine scanty, gencrally thirst. If from new liay, there will be diarrhoo.

Trialment.- Hot fomentatious to legs. Give arecolene $\$$ gr. every half-liour until passaye. live stimulants if mucl shivering. Diuretics. Aconite if temperature very higlı. Uso pressure lundages on leg below swelling. Treat care. fully, and give occasional purgatives afterwarls. Many repetitions of this lisease may canse ulepliantiasis, when there will be considerable new tissue formed in the limbs. The best treat. nieut is pot. lodide 1 dr., three tines a day.

583. ACUTE RHEUMATISM.

Cause.-Cold, damp, drauglits (not fresh air). lapjid cooling when swealing. Hereditary predispusition.

Symiptoms,-Generally in single groups of inuscles, as hip or slioulder. Allack comes on sudilenly, groat stiffness, muscles may be swollon unil pailuful; joints crack on movement. Affectel muscles may quiver. May be swellings (oedema) uniler skin. Temperature varies, not ginerally highl. Pulse up if much pain. In bad rases, sweating. May disappear in a fow days, or last for wecks, or may suddenly move to anotlier set of muscles. In horse, generally in shoulders or loins (lumbago). If in shoulder, the horse will go belter down hill (if lame in foul, he gues worse (lown hill). On being backed, he will drag his foot. Dificulty in turning: great diffculty in rising; may not be able to rist:

Treatment.-Good stabling and food; no Irauglits. Hot fomentations over part, then apply limiment of turpentine, camphor and belladonna. Give veratrine gr. lyypodermically. once a day : later, increase to one or two grains. Always give gentle exercise after its use, otherwise do not use it. Give soda salicylate in t-0z. loses once a day, mill purgatives and nitre. If constipated, give $\mathrm{gr}$. arecolene hypodermically.

584. Muscular Degeneantion.-May follow rheumatism, or any injury that has caused a muscle to remain idle for some weeks. May follow azoturia. Common in shoulder (caput) muscles after a sprain.

Symptoms,-Generally atrophy (wasting) of muscles.

Trealment.-Caffein citrale $3 \mathrm{gr}$. hypodermically. Careful diet, tonics, and massage and electricity.

\section{AnticulaR RHzUMatis.M.}

Causc.-Generally infection, or same as acule rheumatism.

Symptoms.-Great fever, up to $100^{\circ}$. Swell. ing of joints, sudden lameness, joint is hot and painful and tense. Horse generally stands conlinuously; he groans from pain if he tries to rise. Pulse, 70 to 80 . If acute, rapid wasting (emaciation). If continued for long, atrophy of surrounding muscles. May change to another 
joint. Cenerally chronic, but may go quite ouduenly.

Treatment.-hood stabling and laxative food, 110 draughts. (iive soula salicylate in large, repealed (loses, "ijl to b oz. a day. Give nitre and antifebrin in sinall noses. Local, loot fonienta. llons and antiphlogistiue or refluciue. Massage and electricity. In all case's il nay he nulvisalle to blister the joint.

\section{Diceaces of Eye}

\section{Opittilalmia.}

Cause.-llay seeds, cliafl and other foreign substances; injuries.

Symptoms.-Eye partially closed, swelling. flow of lears, eje retracted. Conjunctiva red. dened. Cornea opaque; white, if severe. If lue to injurits, opacity commences at seat of iijury. May be red spots on conjunctiva.

Treatment.-Examine eye very carefully will inagnifying glass for foreign hody. C'se cocaine, and remove any body. Bathe eve with warm water and milk, if much influmnation, or will warm solution of boracic acid, 10 per cent. If ulcer is present, touch witl silver nitrate solution, 1 per cent., in distilled water. Give mild purgative. If fever, give aconite.

White or blue spots (called albugo and nebula respectively) are somelimes present on the cornea of an eye. They are not an unsoundness unless they affect tho sight. Trentment is good food and hygiens. Touch with silver nitrate.

587. Periodic Opitialmia.

Cause.-Constitutional disturbance. Injuries. Bad stable management. Hereditary. Eatting rank grass in marshy pastures. Exposure to snowstorms or to sun's rays. More conımon during period of dentition (two to five years).

Symproms. - Allack comes on suddenly, generally during night. Eye retracted a little: is very sensitive to light. Pupil contracted. Cornea opaque at first round outer edge. Whole eyo becomes inflamed, iris becomes yellowisls. Eyes may be affected alternately. After each allack, sight gets worse and pupil more contracted. Eye sensitive to touch. Horse may become blind after repeated attacks.

Trealment.-Good food and hygiene, change of climate. Purgative during acuto altack. Foment as for acule ophthalmia. Put a little belladonna in eye; after attack, give iron sulphate, nux vomica and a little nitre.

888. Amaunosis, or Glass Evz.

Cause.-Paralysis of optic nerve (second cranial nerve). May follow periodic ophthalInia.

Symptoms.-Complete loss of vision, large pupil, round and motionless. Eyelids generally open. Eye is glassy in appearance.

Test.-Put horse in the dark, and bring a llght close to eye; there will be no contraction of pupil.

Treatment.-Keep horse in the dark, and give stryclinine and electrical treatments. Recovery duubtful.

\section{Disenses of Skin}

889. IInebolind is the lerm given to a horse's cont when it is firnı und immovable, as thougl cummed on to his boty inslead of being loose. It shows bad health, and is generally the result of boul stable managemenl, bail feeding audl lack of exercise. The cure is goud stable inanagement, grooning, feediug and uxercise.

580. Non-Parasitic Diseases of SKIN.-It the outer skin (epidermis) is alone affected, the disease is called erythema; but as the causes, symptoms and trentment ure so similar, erythema and eczema (which is a disease of the underskin) will be trealed togetlier.

Ecrsin is inflammation of the true skin, underskin or dermis.

Cause.-Pressure, cliafing, etc., from saddle or harness. More general in the young and fineskinned horses, especially at change of coat in spriug and autumn. Irritant oinlments and liniinents. Extremes of heal and cold. Exposure to wet. Bad cises due to dirt, bad feeding, bad constitution and certain fungi. Dirty woollen clothing, want of grooming, constitutional disturbance, causing a clieck in the perspiratory glands.

Symptoms. - Ninniber of small nodules size of small pea. The hairs on these become erecl and, later, knotted. Scabs form, which drop of and leave bare spots. Itching; scritching makes it worse.

Treatment.-Soften the scabs with glycerine. Then wash thoroughly with tepid water, a little creolin and castile soap (not soft soap). Dry thoroughly, and bathe with Dick's white lotion. If change seems slow, bathe with oil of tar or 5 per cent. solution of dilute hydrocyanic acid. Change food, and shelter from heat, cold or sun. Give ball, and then soda hyposulphite. If very bad, give Fowler's solution of arsenic and sulpliur. Groom well, and take great care of horse.

591. Mane and Tall Eczema.

Cause.-Dirt, contintous washing with cheap irritating soap. Long exposure to rain or cold. Often a sign of neglect when horse first shows signs.

Symptoms.-Rubbing of mane or tail, hairs become malled, and later drop off. Skin is thick, hard and inflamed.

Treatment.-As for eczema. Do not allow horses to rub, as rubbing causes most of the trouble. If above, external applications are no good; use 6 per cent. solution of cilver nitrate. Never necessary to clip the hair of unless it has been neglected for weeks. 


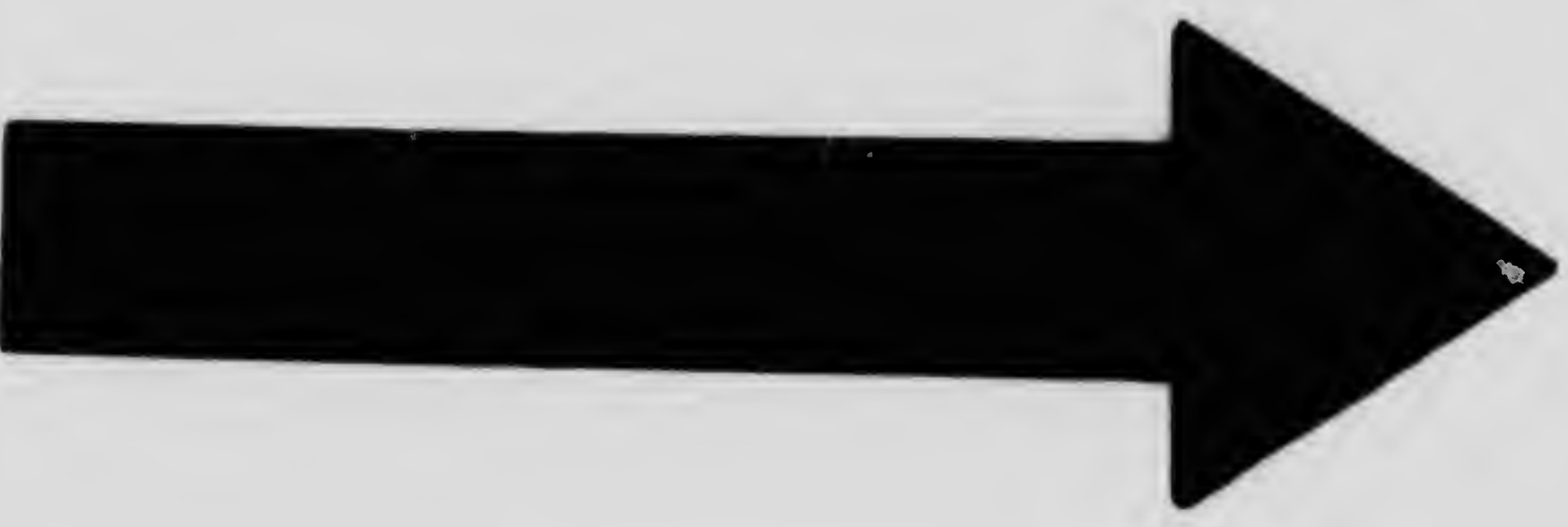


MICROCOPY RESOLUTION TEST CHART

AN5I and ISO TEST CHART NO 2
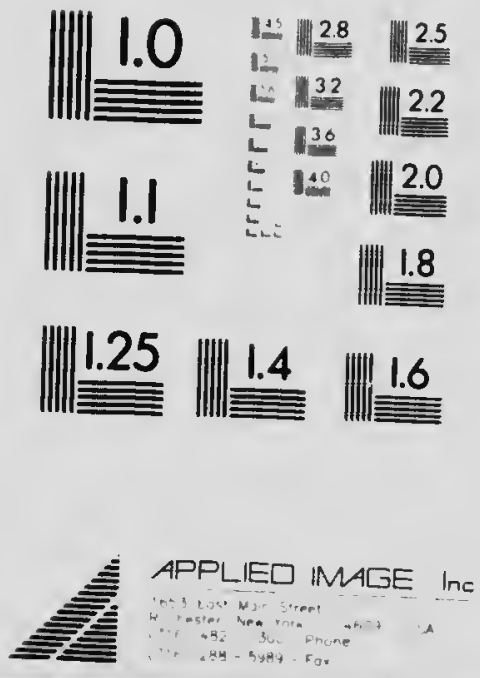
592. Grease (Cracked Heels) or Scratches.On back of pasterns and bulbs of heels. Grease is a term used for badly cracked heels.

Mallenders.-Behind the knee joints.

Sallenders.-In front of lock joints.

All these are forms of eczema. The latter two are more comnioll in heavy draught liorses.

Cause.-Dirt, dust, grit, long exposure to damp, cold and snow. Wet legs in stable with draught along floor. Constitutional disturbance.

Symploms.-Skin red and thickened, little blisters (vesicles of serum) form, burst, and leave cracks. Hairs fall out; later, diseharoe of offensive fluid.

Trealment.-. Absolute cleanliness. Wash well and ary thoroughty, without causing any irritation. If very bad, use carbolic poultice overnight. Trail externally with saturated solution of picric acid three times a day. Give internally as for ordinary eczema.

My experience has been that trimming liorses' heels has not made them any more susceptible to cracked heels, and that it is better not to rub the heels when the horse returns from work with wet heels, but marely to brusl off all the dirt, and to allow fresh air to gain access to the pores. The natural ?leat of the body is sufficinit to dry that part. If the part becomes used to being artiflcially dried, and is neglected for once, trouble may result.

Other applications are:

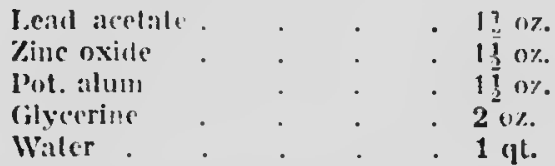

Sliake well, and rub in after thoroughly washing the part and drying it well. Keep legs out of dirt and away from draughts, and keep horse well exercised and on laxative foors.

A good application for bad grease, ifter cleaning and drying the part, is zinc chloride 1 dr., and water $6 \mathrm{oz}$. Well rub in morning and niglit for alsout two days. The following treat. ment will often cure sc rutcles when others have finled. After washing and thoroughly drying. apply a dressing of thernofuge, cover witli absorbent cotton wool and bandage. Next day, wash off, dry thorouglily, and paint with liniment iotine i oz.., alcolol 8 oz. Paint on twire a day. Freel hor: on pasily digesterl. liwht foorl, and not tuo much. Redicine will do in the place of thermofuct: excellent results have beer attained from the use of reducine.

593. Mud Fever is eczema of legs and abdr. men, due to neglect or continued washing. Horses should be brushed clean when they return, and not waslied, as is so common witl some grooms who are too lazy to use the brush. Picric acid, or the treatments in last section. nust be used for this disease.
594. Warts are abnormal growths of the outer skin (epidermis), often caused by ill health and neglect. They can be removed by the knife, ligature, firing-iron, with use of cocaine or caustics.

The best caustics are nitric acid, silver nitrate and caustic potash. Change the food.

\section{Parasitic Diseases of the Skin}

595. Mange.

Cause.- $\Lambda$ small multi-legged insect, something like a beetle, measuring 1-100th to 1-50th of an inch in diameter. Can be transmitter between horses, dogs and human beings.

Symploms. - Itching. The animal shows pleasure when the parts are scratched. The jarts later become thick, hard, wrinkled, devoid of hair, and perhaps covered with sores. Crusts form. The disease takes several weeks to establish itself properly. The only way to be quite sure of the presence uf the insect is to examine the crusts with a very strong magnifying glass, when the movements of the insects will be seen.

Trealment.-Clip the part, burn all the hair clipped off. Thoroughly wash with castile soap and dry. The insects must then be destroyed. In doing this it is very easy to kill tho horse as well, hecause, if the whole coat is covered with a dru; strong enough to kill the mange insect, it will also kill the horse. Therefore, only onethird of the horse should be covered at one time. Care must be taken that the parts are well overlapped, as the insect moves slowly, and that the horse is not allowed to lie down until the whole body is treated, nor must he wear the affected clothes. Clean clothes and fresh bedding must be used. The horse must be isolated from other horses. All tools, harness, etc., must he dis. infected. The old bedding must be burnt, and the old clothing either burnt or baked for several hours. The stall must be washed down with antiseptic solutions, such as whitewash, formaldehyde, etc. The best application for the coat is :

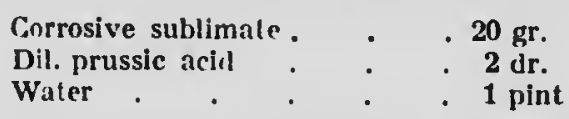

Soak coat well, covering one-third of the coat at one time. This is poison. Another good one is:

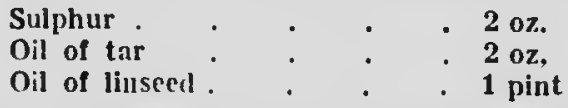

Heat for an hour in hot water, and thoroughly shake together. Rub well in.

596. Ringwora. - Due to a fungus, or vegetable micro-organism (tinea tonsurans). Is contagious. Can be conmunicated between man, horse and cattle, and very easily between horses, A saddle or blanket will remain infectious for months if not properly disinfecter. 
Symptoms.-The disease spreads in circular patches, leaving bald places wherever the skill is attaeked. There is generally no inflammation it horses and no itehing. When the patel reaclıes a certain size (one or two inches), the fungus dies, and the liair returus. 'There is a form of eczema known as non-eontagious ringworm, in whieh the rings grow larger', and thele is itching present.

Trealmenl.-Isolate horse. If cout is very long, clip round the patches, and wash thoroughly with cr.stile soap and warm water and dry. Apply, twice a day, biniodide mereury ointment (1 to 30 liard), or iodine $10 \mathrm{gr}$., turpelitine 1 oz., or 5 per cent. solution creolin. 'Thoroughly disinfect all harness, saddlery, tools, clothing, burn bedding, and wash down stalls, etc.

597. LICr are sometimes found on neglected horses. The insect is about 16 th of an inch in length. It does not attack man. There is a great itching on the parts affected, chiefly at roots of tail and mane, shows the hair standing $11 p$, and little casts of skin.

Treatment.-Clip the part, and apply 5 per cent. creolin, tobacco or carbolic.

598. 'Ticks.-Horses get these while grazing in certain places. They should not be pulled off, but made to drop off by putting a little kerosene oil (coal oil) or turpentine on to then.

Mites.-The host of this insect is the chicken, pigeon, and other birds, so they will not live more than two or three days on a horse. They cause great itching.

Treatment.-Remove cause, and apply 5 per eent. creolin, tobacco or earbolic.

\section{Diseases of Respiratory Tract}

599. Laryngitis, or Sore Thro.tT. - The causes, symptoms and treatment of this are practically the same as those for pharyngitis; these are both forms of sore throat. Laryngitis is very much more serious. There will be nucli difficulty in drawing in the breath. It may be sifficiently bad to necessitate tracheotumy being: performed. (Sec. 536.)

600. Cougil or Col.d. etc.

Causr.-Chills, negleet, bad health, contagion,

Symploms.-Congh, running at the nose, fever, dullness, coat unthrifty, off fe'el. Water may run back out of nostril as the liorse swallows. Sore throat.

Treatment.-Bran mashes and linseed and careful stable management. Plenty of fresh air and good clothing. Give lots of eold water and a little nitre. Give inhalations of steam from bucket of boiling water, with $6 \mathrm{oz}$. turpentine a dilerl. Do not int heail in bag, as hurse lnust get as much fresh air as possible. Give electuary on tongue of:

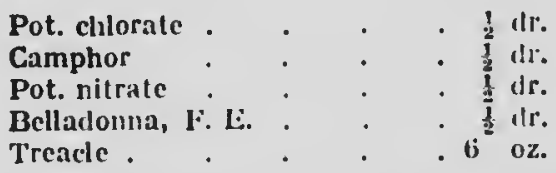

Dissolve the camplior in a little methylated spirits and the belladonna in a little boiling water. Put a little on tongue every two hours with a spatula.

In elironic, irritable coughs, give morning and night:

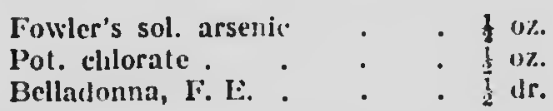

in the feed.

601. Nasal Gleet is a chronic and fetid discliarge from the nostrils.

Cause.-Injury to the bolly sinuses in the head. Bad teeth. Cold in the head. More common in old horses.

Symptoms.-Discharge from the nostril or nostrils, which is chronic and fetid (bad smelling).

Trealment.-If a sinus of the head is filled with pus, which will be apparent by there being no other causes present, the affected sinus will have to be opened by a professional, and treated antiseptically. If the cause is a bad tooth, it must be removed. Syringe out the nostrils every six lours with a solution of alum and pot. chlorate. Change feed. Give horse tonic, and treat very carefully for some weeks.

602. Acute Asth.M (rare in horses).

Cause.-Nervous derangement. May follow pleurisy, pneumonia. Foul air. Faulty feeding, as on dusty hay.

Symptoms.-Very difflcult breathing, respirations not hurried, expiration is very slow and difficult; may be slight uasal discharge.

Treatment.-Careful feeding, sanitation and ventilation. Give morpline $3 \mathrm{gr}$., and chloral hydrate $1 \mathrm{gr}$. Chloral hydrate may be given in a pint of water per rectum, the tube being inserted well in, and the tail depressed for ten minutes. Give caffein citrate, $3 \mathrm{gr}$, hypodermically. Tincture lobelia $1 \mathrm{oz}$. is good. Food should be damped. Do not give too much water at a time.

603. Roaring, or WIIISTLING, is an affection of the larynx.

Cause.-Due to paralysis or partial paralysis of the recurrent-laryngeal branch of the tenth eranial, or pneumogastric nerve. On accuunt of the left nerve being given off at the base of the lung, and winding a round several vessels (whilst the right is given off at the first rib), it becomes more readily injured, thus affecting the left side of the iurynx, allowing the cartilage of the 
epiglottis ' obstruct the opening of the glottis, causing a "roar" on inspiration. Injuries, tumours or swolleu lymphatic glaurls nuly damage this nerve.

Symptoms. - Noise in throat as loorse inspires, due to the glottis being occluded. To test for roaring, the horse must be galloperl and inlled mp filirly sudden, and, if a loaler, the noise will be liearil as the horse inspires.

Treatment.-Good food, slow resereise, and careful stable management. Gice strychinire and pot. iodide for three dilys, cease for a week, and then repeit. In very bad eases, tracheotomy. nuist be performed bri a suluten.

604. BROKEX WIND, ENPIYSEMI OF THE

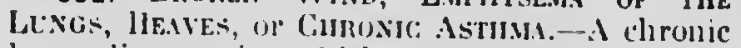
lung disfilse, in which expiration is always longer than inspiration, and the abdominal wall is brought into play to issist in expulsion of the air. There is legeneration of the air cells of the lungs.

Cause.-Bad horsemastership, hard work ou a full stomach, on accuunt of the stomach pressing agaiust base of lungs. Ilard work when in bad condition. Fast cuntinual work, such as racing. The tissues of the air sacs of the lung: break down and cause much difficulty in breatl. ing. May follow any lung (iisease that has been neglected.

Symploms. -.May come on suddenly. Difficult bresthing, especially after work, and worse after a meal. Wheezy, distressed expiration of air, accompanied with considerible dilatation of nostrils. Double contraction of the abdoninal muscles after each inspiration. A weak, sup)pressed cough, as if the lungs were not stroner enough to force any air out. General health is nearly always affected. Often passage of gas per rectum in long-standing cases. May occur in horses foll years of ilse.

Treatment.-Cannot be cured, but can be eased. Give green feed innl mashes and very carefill diet. Always wet hit with lime-water; give plenty of linseed oil and tea. Water frequently in small quantities. Give Fowler's sol. arsenic, $1 \mathrm{oz}$. per day on alternate weeks. Give plenty of fresh air. Good hygiene. Give easy, slow work, and tike gleat care of patient. Change of climate is generitly only hope; horses taken from Ontario to Ilberta, 3,000 ft. above sea, are generally practically cured in twelve inonths. Make np the following powder:

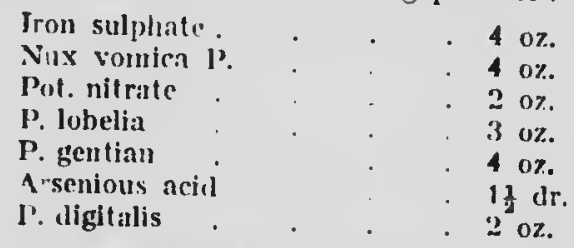

Mix well, and give 1 oz. on damp feed twice a
605. BRONCIIITIS, or INFLammation OF TIIE Broxcin, which lead from the trachea (windpipe) to the liungs proper.

Camsr.-Chill, damp; may follow laryngitis or otlur disease.

$\therefore y m p t o m s$. - Ilurried breathing, not painful, tenperature ligh, pulse quick, nucous membrane of nostrils and eyelids dark red, horse lull. Dry and painful cough, which becontes moist and loose, with probable nasal discharge in thres or four days. A gurgling sound can be heard if the ear is pressed against the side, just behind the sloulder.

Treatmint.-Fresh air, comfortable box-stall, good clothing, legs bandaged. Mashes and linseed tea. Give digitalis and a little nitre. Give bill of ammonium carbonate, camphor, bellaIonna, I'.E., of each $1 \mathrm{dr}$. Later, give strychnine as a tonic. Give inhalations of eucalyptus and boiling water.

606. Concestion of Lungs.-The functional blood-vessels of the lings berome engorged with blood.

('mise--Over-exutuon, clill after hard, fast work, bad ventilation. Bad condition predisjuses a horse to the disense. An over-riduen horse in the hunting fleld may suddenly get it, or may get it after he roturns to the stable.

symjtoms. - Horse berins to blow. Later, he uses every effort to breathe. Forelegs stretched, nostrils wide, head stretched out, breathing repid. Signs of great distress, eyes blondshot. Flanks heaving, eitrs and legs cold, mucous membrane in nostrils and eyes purple colour, due to blood not being oxidised properly. Pulse full, bounding and irregular; may be bieeding it nose; may become insensible. Extremities cold.

Treatment.-Give fresh air, turn lorse towards wind, clothe well, place all four legs in liurm water, and apply hot water or mustaril all over thorax to draw blood away from lungs. If pulse very fast, give nconite. Afterwards give tonics and nashes, and a litle nitre for several lays.

607. Pneunonia is inflammation of the vesicles of the lings, calused directly br. a vegetable micro-organism, a streptococcus.

Cause.-May follow other diseases of the lungs, as congestion. Chill ; and same as would ciluse congestion.

Tranmitic Pneunonia is dile to medicines, ctc., getting into the lungs.

Catarkial, Broncimal or Lobular PneuMONI.A.-Bronchioles become clogged witl pus and mucus. As a rule, in small lobes; may "xtend over large area.

Croupols or LOBAR, produced directly by the streptococcus pneumonix, is acute and febrile; inflammation of one or more lobes of the lungs, together with consoliciation.

Sporadic Pneumonia, said to be non-con- 
lagious. Due to cold, exposure, etc., isolated cases.

Contagious Pneunonia often appears in an enzootic form, i.e. localised in one stable or district. An epizootic form is sometimes ushered in by pink-eyc.

Symptoms.-Dullness, shivering fits gener. ally. High temperature, quick pulse, respirations very fast, up to 50 . No pain, unless complicated with pleurisy. 3reathing mostly abdominal. Nostrils distended, eyes bloodshot. Full and strong cough, which later becomes small. Mucous membrane of eyes and nostrils corlgested. On sounding the iung, if in the engorgement stage, there will be a well-marked, thickened sound, which will disappear when the second or solidifled stage is reached, when the sound will be atsent in the affected part. If pleurisy present, there is a crackling sound, like the rubbing together of several hairs between the fingers. There may be dropsical swellings on chest, forelegs, abdomen, sheath and lindlegs. The congested or engorged stage of the lungs may last only ten hours, or may, later, beconie solid from accumulation of blood, and exudate. The fourth stage is the grey stage, wlien the exudate is absorbed. May appear and disappear in six or fourteen days, if favourable. Depends on extent and area affected. Tapping will reveal a duller sound than usual if the case is bad. Urine generally scanty and high-coloured. Horse generally stands up all the while with forclegs stretched out.

Treatment.-An abundance of fresh air is of the first importance; a horse will never recover from pneumonia if kept in many of the stables that horses live in. Place in box-stall with door opening to the south; top half of door sliould be open day and night. Screens should be placed outside to prevent direct draughts blowing on to the horse. Allow horse to lie down if he wishes. Warm clothing, stable kept at $60^{\circ} \mathrm{F}$. by artificial means, and not by excluding fresh air. No draughts. Take chill off water, and give plenty of it. Keep quiet, give friction to legs for ten minutes on each leg twice a day, and bandage with thick flannel. Do not bleed or give purgatives. Keep bowels loose with enemas of soap and warm water. Feed carrots and turnips (chopped), linseed tea and mashes. If pulse quick, give Fleming's tinc. aconite $10 \mathrm{~min}$. twice a day. Give the following

\begin{tabular}{|c|c|}
\hline Strychnine & \\
\hline Alcohol & \\
\hline Acetanilin & ${ }^{\circ}$ \\
\hline Water . & . \\
\hline
\end{tabular}

three times a day.

Make up a large quantity to save trouble. Dissolve acetanilin in alcohol and strychnine in hot water. Give bacterines. (See Sec. 507.) Give turpentine $1 \mathrm{oz}$. in capsule twice a day. Cerse this when urine smells of turpentine. Mustard should be put over both sides of chest, and covered with paper, and then with thick blankets; do this with botll sides, even if only one lung is affected. (See Sec. 504.) If pulse improves after a few days, give ammonium carbonate $1 \mathrm{dr}$., spirits nitre 1 oz., belladonna F.E. $1 \mathrm{dr}$., three times a day. If horse seems hungry, give handful of crushed oats and bran. When patient is convalescent, feed very carefully on tempting and easily digested foods, and give tinc. chiretta $4 \mathrm{dr}$. and quinine sulphate $30 \mathrm{gr}$. as tonic in feed twice a day.

608. Pleurisy. - Inflammation of the pleura, which surrounds the lung: and lines the inside of the thoracic cavity.

Cause.-Same as pneumonia; seldom alone, but generally in conjunction with pneumonia.

Symptoms.-Shivering fits may appear first. In early stage crackling sound can be lieard if ear is placed against the horse's side behind the shoulder, due to the friction against the pleural sac. High fever, pain ratler like colic at first. Great disinclination to move at all. Affected side tender to pressure. Abdominal breathing, horse tries not to move ribs at all. Generally short, dry, painful, suppressed cough. Often grunts on expiriug and when made to move. After the worst is over, the crackling sound goes, temperature drops, and pain decreases. If there has been any effusion of serous fluid, the breathing becones quick, and auscultation will reveal a sound resembling dropping water, and the lower part of the chest, on being tapped with the fingers, will sound dull and full of fluid. The disease runs through four different stages.

Trealment.-Same as pneumonia. Givo also opium P. $\frac{1}{2}$ dr., cannabis indica F.E. $\frac{1}{d} \mathrm{dr}$., in a ball. After worst pain is over, give digitalis $P$. $20 \mathrm{gi.}$, pot. nitrate $\frac{1}{2} \mathrm{dr}$., and cantharides $\mathbf{P} .2 \mathrm{gr}$., in feed twice a day for a week.

609. Tuberculosis of Lungs. - Generally called consumption. Extremely rare in horses.

Cause. - Contagion; a vegetable microorganism (tuberculosis bacillus). Neglect. Follows pneumonia and other lung diseases.

Symploms.-Cougl, varied appetite, rapid wasting away.

Tuberculosis of bowels, spleen, liver, lymph glands and of the bones and almost any gland of the body exists, but is extremely rare, in the horse. The only sure way of diagnosing the existence of tuberculosis is the tuberculin test, discovered by Professor Koch, who also first isolated the $T$. bacillus, in 1882.

610. Tuberculin Test. - Keep horse quiet. Take temperature every three hours for twelve hours. Inject, at the end of the twelve hours, $2 \mathrm{cc}$. tuberculin in front of shoulder under skin, not into the muscle. Commence taking temperature again six hours after injection, and continue every three hours for twelve hours; $2^{\circ} \mathbf{F}$. rise 
perature as for tubcreulin test. (See Sec. 610.) Inject 2 cc. mallcin sol. into side of neck under skin, not into muscle. Aftcrwards take temperatilre cvery three hours for thirty-six hours, and watch the swelling on tlie ncek. If horse has glanders, temperature will rise $2^{\circ}$ to $4^{\circ} \mathrm{F}$., maxinuum in fiftcen hours, which will continue for ten to fifteen more hours. The swelling at the point of lyypodermic injection will become very large, seldom less than 5 in. in diametcr; it increases in size up to twenty-four to thirty-six lours, or even longer. If horse has not glanders, the swclling will seldom get larger than 3 in. in diameter, and will be practically gone in twentyfour hours, and temperature will not be affected. The period of incubation for glanders is one to six, or more, weeks.

If the horsc has glanders it must be destroyed and all tools and clothing destroyed or made thoroughly aseptic. Other horses that have been in contact must be isolated and tested. Report to local authorities. Permanent immunity from glanders cannot up to the present be acquired, either by a previous attack or by introduction of antitoxins, etc. Mallein will in no way niake a horse immune from glanders. A horse may have chronic glanders for years without having an acule attack.

614. Staggers, Epilepsy or Megrims.-Sunstrnke is really a form of staggers.

Cause.-Tight collars, which interfere with circulation, tight check-reins, exposure to great heat, sun, etc. Overworking in hot weather. Another form is caused by cngorged stomach.

Symptoms.-Sudden. Horse staggers and throws head about. Quickened breathing. Pcrhaps convulsions and loss of consciousness.

Treatment.-Remove cause. If from collar, drive with breast collar. Remove all headgear, and apply ice packs to top of head, or cold water irrigation. Keep very quict, and feed and exercise carefully for days. Keep bowels open to prevent recurrence. If stomach is engorged, treat with arecolene. Give caffein citrate $\mathbf{3} \mathrm{gr}$. hypodermically.

615. SuNSTROKE is a sudden state of unconsciousness.

Cause.-Nearly always brought on by continued exposure to great lieat, or to the sun, while at work. Seldom occurs when at rest, unless horse is tied out in the open with no shade and no mane to protect his poll. The unconsciousness is produced by the shock or the fatigue causing temporary failure of the heart. Insufficient water predisposes the horse to the disease; so does bad ventilation, exposure to sun rays while in the stable or picketed, insufficient cooling food, as green food, and too much corn or heating food, as peas, beans, etc.

Symptoms.-Horse starts of all right, then becomes distressed, and begins to falter, to totter, and eventually falls down insensible. He may be quiet, wlich is hopeful, or he may throw himself about in convulsions, being unable to raise his hindquarters, which will be paralysed. This paralysis is a distinct symptom of sunstroke. Tlic horse is unconscious, which distinguishes the disease from azoturia. Respiration quick and shallow, pulse quick and weak, temperature high. May be sweat on skin. Muscles may quiver. Eyes stare, but cannot see. Fatal cases in six hours. Congestion and inflammation of the lungs may follow when apparently convalescent.

Treatment.-Avoid any predisposing causes as a preventive. Never take a loorse out in lot wcather if there is any sign of unnatural breatl-. ing or ill-health. Sun-bonnets are of little use unless they shade eyes and forelead. Give plenty of salt and water. In a threatened case, give an oil purgative, and plienacctin $1 \mathrm{dr}$. every four hours. Give plenty of green food and water, and no oats, bcans, peas and maize.

Treatment of horse that has fallen.-Apply cold water from a hose over head, spine, body and legs. Pack ice between the ears and over forehead and down crest of neck. Give no medicines if horse is unconscious. Horse may recover in an hour or less. Treat afterwards as for tlireatened case. On recovering consciousness, give $1 \mathrm{pt}$. Whisky in $1 \mathrm{qt}$. water or $4 \mathrm{oz}$. a romatic spirits of ammonia. Keep horse quiet.

616. Nagana, or Tsetse Fly Disease.-Very uncommon on American continent, but common in Africa.

Cause.-Directly, by a protozoa, trypanosoma Brucii, which is carried in the stomach and salivary glands of the tsetse fly.

Symploms.-High temperature, $104^{\circ}$ to $106^{\circ}$. Anæmic, due to red corpuscles being destroyed by the protozoon. Later, swelling of head, legs and urino-genital organs. Course, about thirty days.

Treatment.-The best treatment known is pot. iodide and carbolic internally, followed by arsenic, cinchona, and careful dieting and diuretics.

617. Lampas, or Swollen hard Palate. health.

Cause.-Indigestion, cutting of teeth, bad

Symptoms.-Swelling on hard palate on roof of mouth. Off feed. Difficulty in eating.

Trealment.-Do not burn or cut the swelling ; such is useless and cruel. Give cooling dict, diuretics and gentle exercise.

618. Merunosis.-Caused by a micro-organism. Is practically entirely confined to grey horses. Tumours, containing a tarry substance, appear on the tail or near it, and perhaps on the sheath and crest of the neck. The hairs on these parts eventually drop out. These tumours appear when the horse is turning white, at about pight to ten years of age. The tar-like material 
seems to the composin of the colunring matter frum tha dark grey hairs.

Melanusis is conmun in ludis, and I lave seen several cases in Englind, yet in Cilnadil, where dappled-grey horses are so very jupulat, lhe discase is not common. Ilonoval of these tumours liy the knife llsilally dons little good.

619. Tetaxlis, ur Locksaw.

Cause.-Direclly, by a bicterium, tetanus hacillus, which gairs acerss to ant (b) nen, ne?lected wound, where it rominins in the damaged lissue, and there produces a poison (toxin) that readily spreads throughont the uervous system, tiausing tetinic spasm of the voluntary nuscies. lin the lunnan subject there ar' several states, but in the horse only one, called trismus. (Sir Chapter XVIl.) These garms are present in the eartl, especially in clay and any hishly organic soil. llorse-dung causes then to become more virulent; hence, if they gain access to a stable. they become more dangerous. Thiz bacillus and lhe anthrux bacillus are the only two yet discovereal that will remain for any length of time off their host without lyine. The tctanus bacillus is anaerobic, i.e. cannot tlirive in the presence of oxygen. Indirect causes are cuts, wounils, broken kneses that hive been neglected from the first. In some countries (as parts of Spain and France) the tretams bacilli are so numerous in the soil that any wound, especially a puncture, is a sonirce of great danger.

Symptoms. - Similiar to poisoning from strychnine. Conses on gradually. Contraction of muscles of expression. Later, the rest of head, neck, back and tail. Nick ewed, eyes drawn back. Horse stands with outstretched limbs, looks nervous and terrifled. Breathing quick, flanks tucked up. Recovery seldom occurs unti! after second or third weck.

Trealment.-Treat any wound with keenest intiseptic care, cutting out all unhealthy tissue. If much toxin has got into the blood, case may be fatal. Put in dark box-stall, keep absolutely (juiet and away from any excitement. Dust wound with antitetanic powder and inject antitetanic serum, as follows:

620 . Inject hypodermically at once 2,000 to 3,000 ampules (units) of fresl antitetanic serum, and repeat in twenty-four hours. The dose will probably make the horse feel sick for a few hours. I liave used this upon horses that have been badly wounded witlı rusty nails, as a pre. caution against tetanus, with splendid results. In one case a horse had had a rusty nail in its foot for twelve days, and on removal black pus came out suddenly. Two injections, as above, were given with an interval of twenty-four hours, and the horse was worked, in seven days, absolutely sound. Of course, there was no proof that he was going to have tetanns, but there was a great chance. Give aloes ball and calomel and laxative food. Give cannabis indica $12 \mathrm{dr}$., chloral liydrate oz., and pot. iodide o dr., in capsule, every four liours. If the serum cannot be obtained, inject uniler the skiı 2 per cent. Solıtion carvolic acid, oz. every two hours. Do excito or try to drencli. Give clrugs in ball ol gelatine capsule.

621. Paralysis. - For paralyzis, whicl beconles apparent by loss of control of certain inuseles and no hardness, as in azoturia, the best treatment, but whicl may be of no use, are locil stimulants, or oven blisters, to the parts, and electricity and massage. The bowels must be kipt open, and horse carefully fod and attenler to. Give nux vomica F.E. 1 dr. in feed morning and niglit.

622. Stringiialt.

Cause. $-\Lambda$ brain affection, generally, but may bo due to pressure on the nerve that leads to the atfected muscle. It affects one or both hindluess.

Simmptums.-Raising the leg, or legs, very lickl, even when at the walk.

Trealment.-Good feeding and electricity may do good. As a rule, an operation is necessary, that of removing part of the tendon of the peroneus nuscle, which causes the abnormal action of the hindlegs. Give stryclinine.

623. Cenebro-spinal Meningitis is inflammation of the meningeal covering of the brail and spinal cord. Its method of transmission from horse to horse is undoubtedly through a microorganism, i.e. througl the horse eating and drinking infected food and water.

Symptoms.-Its course is gencrally acute and fatal. It is not uncommon in Western Canada in hot weatler. Attack may come on suddenly or slowly. Unconsciousness, partial paralysis of the hindquarters, probable pain on pressure along spine. Head very hot. Horse walks about with head low, as in a sleep, not knowing where he is going. Will try to hide hoad in dark corner. If given a bucket of water, may suffocate himself by immersing head in the water, owing to its being unable to swallow; this may be first symptom noticed. May walk into a stream and drown himself. I romember a large Clydesdale in Manitoba drowning herself in this way.

Treatment.-Sling lorse, if he lies down; otherwise let him walk about, if he cannot hurt himself. Put ice bags to spine. Give purgative and diuretics. Give strychnine $\frac{1}{2} \mathrm{gr}$. and cannabis indica F.E. $\frac{1}{2}$ dr. every four hours.

624. Anthinax, or Cattle Plague (8ometimes called Horse Plague).- Very rare in horses. Generally a most fatal disease; due to the presence of the anthrax bacillus in the blood, causing imperfect oxidation of the blood, which becomes thick and dark. Is very infectious. The anthrax bacillus, like that of tetanus, will live in a passive or spore state for any length of time away from its hast; thus a field in which an 
infected animal lus died and been opened may carry tho disease to a subject ten years or more afterwards.

Syinptoms. - Temperature up to $107^{\circ}$. Ilorse almost suddenly loses appetite, and becomes dull and weak. Pulse quick and weak, mucous membrane red. Respirition yuick, nostrils dilated, abdominal brcathing. later, lorse almost suffocates from want of oxygen. There may be colic pains, dark nasal discliarge, or swelling under lower jaw. Call be distinguished from lung disease by auscultation.

Treatment. - 'Tlie horse hat better be lestroyed, as it will die anyway. Report to local authorities at once. Under legal supervision, for experimental purposes, the following treatment lias been tried: Laxatives and stimulants. Soda salicylate, soda hyposulphite and carbolic acid, internally; also injection of anthrax vaccine "Pasteur." Good water and soft food.

625. Blood Poisoning: Sfpticemia, Pyaluia and SAPREMIA.-There are three kinds of blood poisoning: (1) Where the poison or toxin is made outside the blood vessels and passed into the blood, as in tetanus, called sapræmia; (2) where the germ is in the blood, and produces a poison or toxin while circulating in the blood, as in anthrax, called septicamia; (3) where pusproducing bacteria are in the blood, and may locate at any place in tle body and form multiple abscesses, called pyæmia (pus-blood).

Sympiorns.-Generally results from a bad wound or abscess. High temperature, grcat depression and debility; swellings.

Trealment.-Attend to hygienic conditions, clean any wound, and make as aseptic as possible. Give nutritious diet, pure air, stimulants, as whisky. Give iron sulphate $\frac{1}{2} \mathrm{dr}$., quinine sulphate $20 \mathrm{gr}$. Give nitre and lots of cold water to clear blood. I have seen very advanced cases cured by giving $1 \mathrm{dr}$. soda hyposulphite every twenty minutes by the moutl. Afterwards give tonics.

626. Nivr, ILl in Fonls (called Omphalophlebitis, or Joint IIl).-Caused sometimes by admission of a micro-organism through the navel before it his healed up after birth.

Cause.-Being born in dirty stables, instead of out-of-doors in pasture tliat has not had navelill foals in.

Siymploms.-Dullness, fever, lameness, solt swelling over joint, or joints, which becomes hot and painful. Later these joints suppurate.

Treatment.-Very difficult to get good results. $I$ have secn scores of foals in the West of Canada given various treatments. Under the same treatment some recover, whilst others die. Keep up strength by use of stimulants. Give fresh polybacterines. (See Sec. 507.) Very careful hygiene. Isolate animal, bathe part, give the mare pot. iodide. Keep the navel ausolutely aseptic and covered with bandage, which must be renewed every twolve hours. Nuclein solution has cured some cases.

is a further precaution, allow all mares to foul in clean pasture, and keep foal out of doors for several months; und, as this period will be in the fly season, it is absolutely necessary tlrit brood miares should lave long tails.

\section{Diseases of Cenital Organs}

627. Dounine, or Maliuie du Coït (sometimes called llorse syphilis).-Ciutsed by an animal micro-organisin, trypanosoma equiperdum mastigophora.

Symploms.-Sheatl swells; swalling will extend along belly to breastbone, and will become cool and doughy. Penis becomes swollen later, and probably clironic protrusion. Loins become tender, painful urination. Knuckling of fetlocks, appetite good, but good food does no good. Joints crack, temperature a little up.

In mares there will be a discharge from vulva that will mat the tail, awkward gait, white spots on vulva. Mortality up to 70 per cent.

Trealmienl.-Arsenic 1 gr., mercury iodide $1 \mathrm{gr}$., and pot. iodide $3 \mathrm{dr}$., every four hours. keep all venereal excitement away. Good hygiene and cartul feeding. Wash organs with 1 to 1,000 mercury percliloritle.

628. METRITIS, or INFLAMHATION of WoMB.

Cause. - Follows parturition. Infection ; general blood poisoning, neglect and dirty stabling.

Symiploms. - High temperatille $\left(105^{\circ}\right.$ or higher). Loss of appetite, shivering and sweating, great distress, rapid breathing, straddling gait.

Trcalment.-Give mild purgative, aconite, belladonna, camphor, opium, and chloroforn. Inject into womb every twelve hollrs a warm antiseptic solution ( 1 in 1,000 mercury perchloride), followed in five minutes by a thorough flushing out with normal saline solution ( 85 per cent. sodu chloride in water). Hot fomentations to loins. Keep very comfortable, quiet, feed on linseed mashes and linseed tea, and keep awny from sexual excitement.

\section{Notes on Parturition}

629. Period of Uteno-Gestition for MARE (Duration of Pregnancy).-335 to 345 days (11 to 11 months). A foal may live if born after ten months from day of conception.

The duration is generally less in weakly, poorly fed mares and in old mares. The day of conception (fecundation) canmot be definitely decided, because even if the mare has only been put to the stallion once, the male seed (spermatozoon) may not impregnate the female ovum for several days afterwards. Spermatozoa have been known to live in the womb for eight divs. 
A mare put to a thuroughbred stallion is geverally longer priguat than oule jut to a common-bred.

630. TABle of Estreis for Man:

Uuration, 4 to 7 days.

Return if not impregnated, 2 to 3 weeks.

Ileturn after parturition, 7 to 10 lays.

Several hours before parturition the muscles over the (juarters (gluteal) will siuk, lue to the relaxation of the large sacro-sciatic ligarnents, which thus allow the easy passage of the fortus through the pelvic cavity. After the foal is born, if the after-birth (placenta) lias not come away cleau, it nust be carefully removed with the laud, which must lo thoroughly aseptic. The wounb must theu be fuslued out with 1 per cent. (reoliu. This latter precaution should be tisken in iny case.

The navel of the foal sliould be well clearised

will a similar solution directly after birth.
Foals should bu weaned when it to 8 months old.

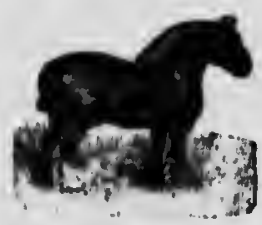


PIATI: 105
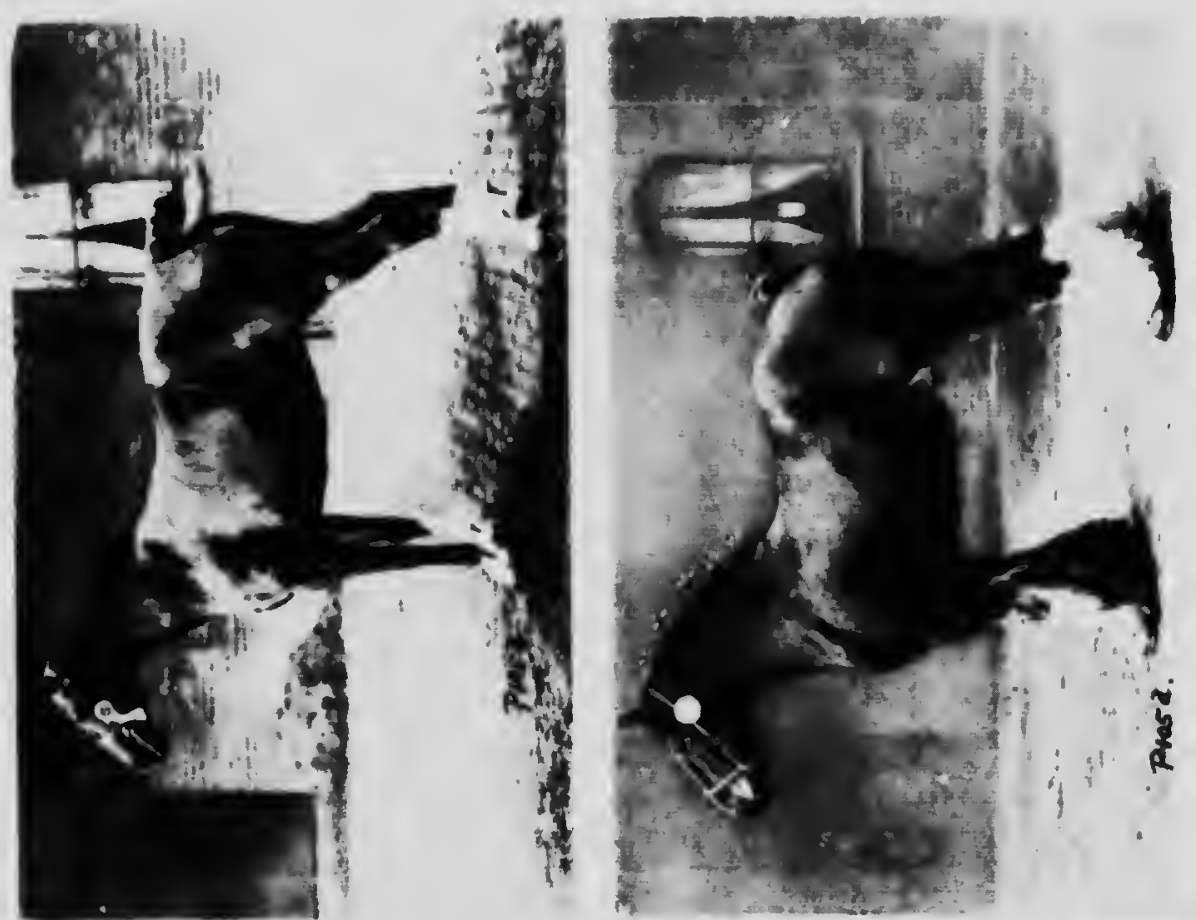

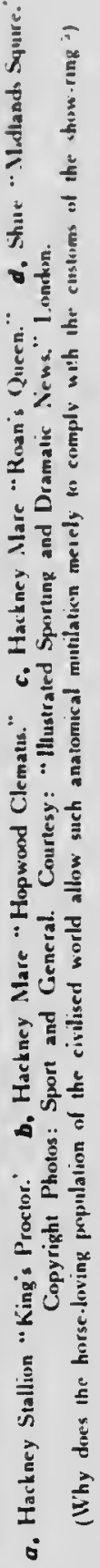
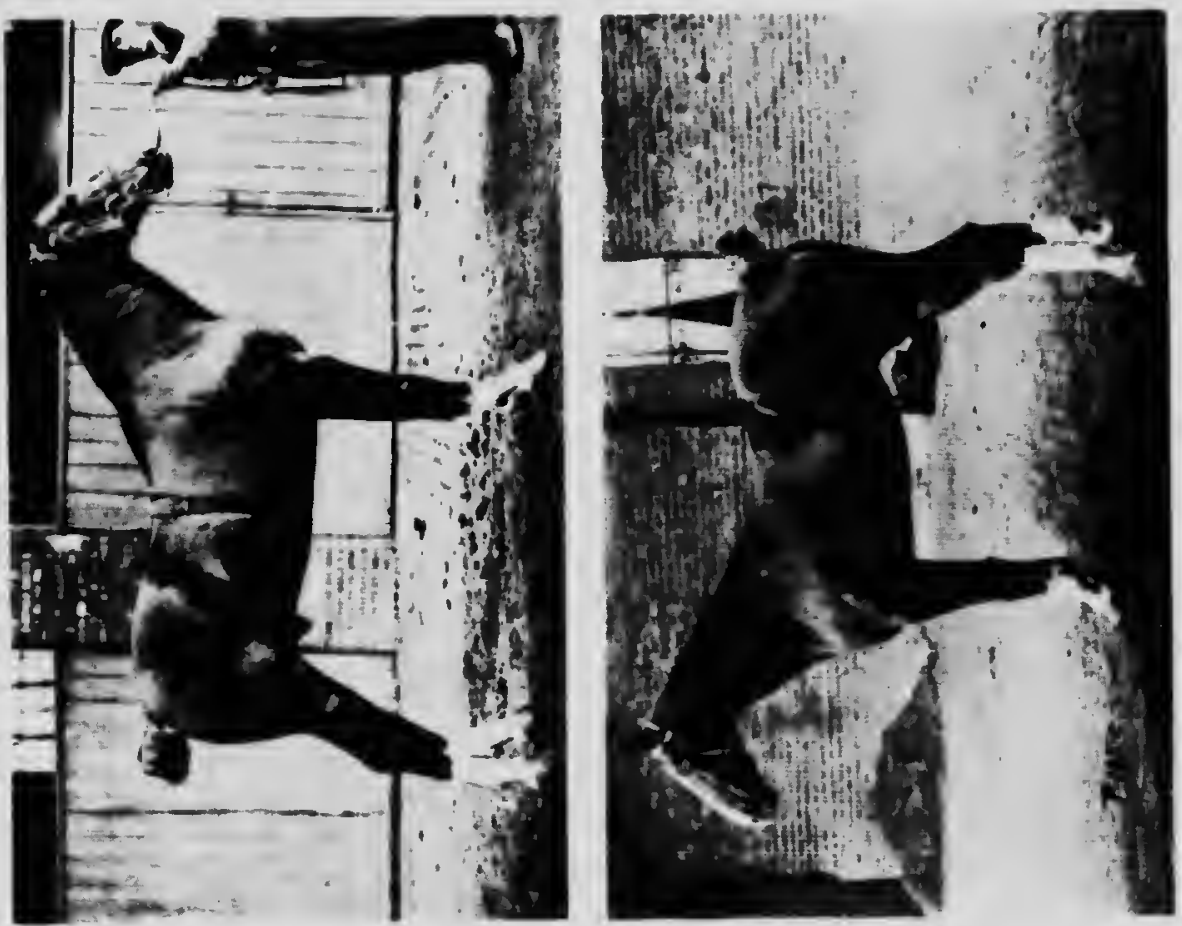


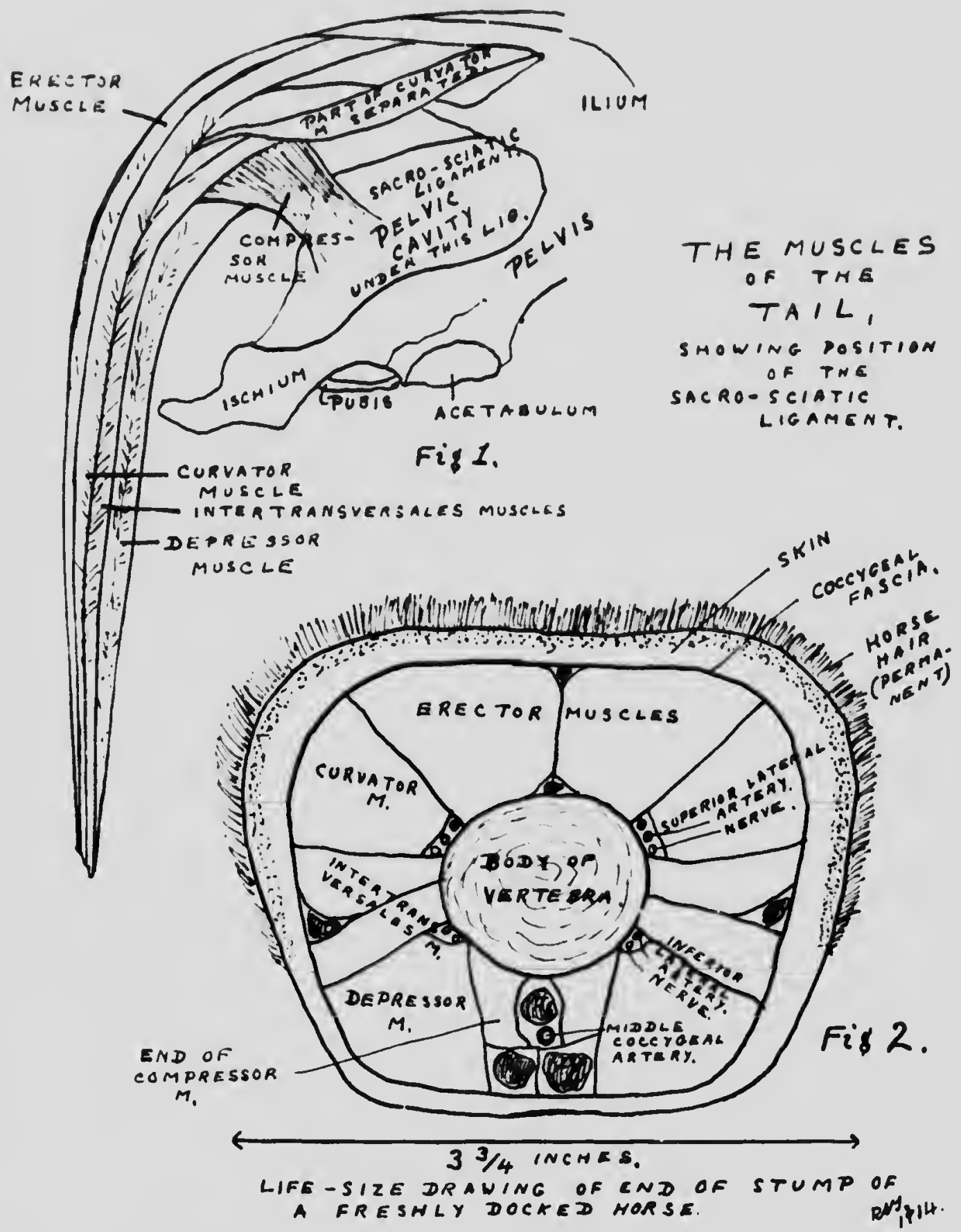

The Anatomy of the Tail. Fig. 2 is Drawn to Scale 


\section{CHAPTER XII}

\section{ANATOMY AND USE OF THE HORSE'S TAIL}

891. THE tall consiats of a continustion of the spinal column. It sonsists of vertebre, muscles, ligaments, blood vessels, nerves, fascia, skin and hair. There are fifteen to twenty coccygeal vertebrw, which decrease in size until the last two or three are quite small, round, and resemble somewhat a spindle. The first four or five are very similar to the sacral vertebre. They contain a body, superior or spinous processes, called spines, and a transverse process projecting from each side of the body. The muscles, which lie along the outside of these vertebra on all sides, are eight in number. There are four pairs, and a bundle of muscles on both sides that reach from one transverse process to the next, called inter-transvorsales cauds, which help to keep the bones together or, singly, to assı. in curving the tail.

639. The eight muscles are: two above (erecfor coccygis), that raise the tail, or, acting singly, help to draw it to one side; one at each side (curvator coccygis), that carry it to the side; two underneath (depressor coccygis), that depress the tail, or, acting singly, help to draw it to one side; and two situated underneath, outside the depressors, i.e. on the inferior outward portion of the tail (the compressor coccygis), which compress the tail over the perineum, or, acting singly, help to draw it to one side. These are used when the horse compresses his tail with force.

The erector coccyges have their origin on the last three sacral spines, and their insertion on the first two or three coccygeal spines and the dorsal (upper) surface of all the coccygeal vertobre.

The curvator coocyges have their origin on the sides of the sacral spines and the transverse processes of the sacral and coccygeal vertebro.

The depressor enccyges have their origin on the ventral (under) surface of the posterior parts of the sacrum, and their insertion on the ventral surface of the transverse processes and of the bodies of the coccygeal vertebre.

The compressor coccyges have their origin on the large sacro-sciatic ligament inside the pelvic cavity, and their insertion on the ventral surface of the first four cocczigeal vertebre.

The tail also contains the superior and inferior coccygeal ligaments, which run along the dorsal and ventral surfaces of the tail respectively, and the intercoccygeal ligaments, which join the bodies of the vertebres together. These latter are thick and elastic, to allow the tail to bend into fairly sharp curves.

638. There are three arteries that supply blood to the tail: the two lateral coccygeal arteries, which are a continuation of the lateral sacial artery (these divide into two, the superior branch passing down between the erector coccy. gis and the transversalis, and the inferior branch between the transversalis and the depressor coccygis (P. 106), each supplying twigs to the muscles and skin), and the middle coccygeal artery, which either arises from the lsteral coccygeal or from the right or left lateral sacral (I hive seen it arise more often from the lateral coccygeal), and is not paired; it pesses down the inferior surface of the tail between the two depressor muscles.

654. There are five pairs of coccygeal nerves, five dorsal and five ventral. These unite, forming two trunks on either side, which pass down the thil. The superior trunk accompanies the superior lateral artery, and the inferior trunk accompanies the inferior lateral coccygeal artery. These four trunks extend to the tip of the tail, and give of th:e muscular and cutaneous nerves.

635. The Panniculus Camosus.-The panniculus carnosus, or fy muscle, is a muscular layer, varying greatly in thickness, from a very thin, pale muscle over the face to a thick, dark muscle of two inches in thickness over the breast, which extends over most of the body, neck and head, under the skin. It is very closely attached to the skin, and only attached in a very few places to bones, the most important attachment being on the inner surface of the arm bone (humerus).

It is divided into facial (heaci), cervical (neck), thoracic (chest) and abdominal (belly).

The facial portion extends over the sides of the jaws, the submaxillary space (between the lower jaws), and reaches to the mouth.

The cervical originates in a thick muscle at the anterior end of the breastbone, and extends over the sides of the neck and becomes ambedded in the levator humeri muscle, which runs up the side of the neck. The panniculus camosus does 
not extend to the crest of the neck where the mane will reach.

The thoracic and abdominal portion (known as the cutaneus maximum) extends over the whole chest and abdomen, over the forearm above the knees, and back to the points of the hips. It does not extend posterior to this, that is, over the lindquarters, nor around tho linea alba or median line under the belly.

Its action is to twitch the skin and drive away offending flies, mosquitoes, etc. A few minutes' study on a hot day in the fly season will give anyone a good idea of the use of this muscle. So it will be seen that the hindquarters of the horse are unprotected from flies, a tail of sufficient leng th to reach to the hips being necessary to protect these parts. The mane also is intended to protect the upper portion of the neck. I discuss this subject fully in Chapter XIII.

There is also a thick, triangular piece of fascia directly over the tail where the horse is unable to reach. This fascia cannot be penetrated by the proboscis of a fly. An undocked tail, with only two or three inches on the end, will resch very near to the hips, but a docked tail will not. A tail of sufficient length to reach to the hocks is necessary, though, to reach the belly and in between the thighs. This is dealt with in Chapter XiII.

The skin at the end of the tail is very thick, being over a quarter of an inch in many cases, and it is from this alone that the long tail hairs grow. Therefors, a docked horse will never have a long tail. I hule come across one or two very rare exceptions with horses only slightly docked. The hairs on top of the tail are short and finer. of course, a longer tail than described above is better for the horse, as he will be able to keep the flies from settling on his flanks, back and abdomen, and be able, probably, to kill those that do settle, instead of merely driving them away with his fly muscle.

\section{Flies.}

636. Flies are a very active means of spread. ing infectious diseases; they are filthy, dirtspreading insects, and cause no end of worry in a score of ways during their short life.

Reference to any book on insects will furnisl a good idea of the flies that attack the horse; they are chicfly of a blood-sucking type, and are mostly large. Steven H. Terry, in his "Crime of Docking Horses," illustrates the commonest types that attack the horse. Some of these flies have been known to drive docked horses mad, as they insert their lancets right into the horse's hide wnere the tail will not reach, and there suck blood until they are flled.

637. Below is a list of some of the flies that worry the liorse:
Tabanus equi, $\mathrm{T}$. bovinus, $\mathrm{T}$. autumnalis, $\mathrm{T}$. bromius, $T$. morio, $T$. rusticus, $T$. fulvus and $T$. albipes. These are called bref ies.

Hippobosca equina.

Simulia reptans an. S. maculatum.

Hæmatopota pluvialis (clegg fly), so called because it lives un blood.

Chrysops cæcutiens (blinding fly).

Stomoxys calcitrans, S. ferox. S. irritans and S. serrata.

Hydrotoea meteorica (storm fly).

Glossina morsitans (tsetse fly), that causes nagana. (See Sec. 616.)

Musca domestica (common fly), M. bovina (ox fly), M. vaccina (cow fly) and $M$. carnifex (fly executioner).

Calliphora vomitoria (blue flesh fly).

Sarcophaga carnaria (grey carnivorous, or flesh-eating fly), S. magnifica.

Lucilia casar, L. sericata (causes maggots), L. macillaria.

Hypoderma equi (subcutaneous bot maggot).

Gastrophilus equi (bot, gad or breeze fly, or horse bee), G. hæmorrlioidalis, G. pecorum, G. nasalis and $\mathbf{G}$. duodenalis.

658. The common bot is the larva of a gad fly (gastrophilus equi). This fly lays its eggs $0^{*}$ the horse's forelegs, etc., in the auturnn, and in two or three weeks these eggs hatch and form small worms that cause irritation; the horse licks the part, and the worm gains access to the mouth, and then to the stomach, where it attaches itself to the mucous membrane of the stomach by means of its little hooks. In nine or ten months, i.e. the following summer, it quits its hold and is expelled. It then lives in the ground, is changed into a chrysalis, and after a month becomes a gad fly. The female fly becomes impregnated, and lays eggs on the horse as described above.

The bot fly, or gad fly, has a long quadratal lancet that pierces the horse's skin, and then a large sucker that enters in between the four lancets and sucks up the horse's blood.

639. Mosquitoes.-The common mosquitoes are of the genera anopheles, culex, stegomia, simulium, etc. Some of these attack the horse and some do not.

All these flies and mosquitoes belong to the arthropoda phylum or form, and to the insecta subphylum in the animal kingdom.

Medical science has proved that a great many cispases, as malaria, Texas fever (in cattle), yellow fever, etc., are spread by flies; therefore, the more flies that are killed the better. If a horse can kill a fly, or even drive away a bot fly before it can lay its eggs, it has done a good turn; a docked horse has very little chance of driving it away from its hindlegs.

640. The Spread of Disease by Flies.-Having considered the worry and pain caused to the horse by the insect world, we will consider 
briefly how these pests spread disease. A great amount of disease is carried on the feet of flies; this is not to be wondered at when one realises how flies delight to visit filthy places, and immediately afterwards to settle on one's food.

Dr. MacMurchy, in the Toronlo World, rightly says that "few people reslise what a seriulus duty it is to prevent the existence of flies and to destroy utterly the one or two "winter flies' found in so many houses in the winter months. All garbage must be placed in fly-proof receptacles, and all manure must be removed entirely every two or three days. It takes but eight days for a fly's egg to hatch, and these are deposited by the million."

The winter flies must be got rid of by leaving in every room and stable one or two sticky flyreels hanging from the ceiling ; all corners must be swept out in the winter to remove any flies that may be hidden in such places.

It is acknowledged now that infantile paralysis (anterior poliomyelitis) is spread by the stable fly (stomoxys). This fly bites an infected person, and thus conveys the germ to the next person that it bites.

It seems so foolish for people to leave a few flies about the house all the winter. It is most objectionable to have to sit in such houses. I have found a very large number of such houses, those that usually are kept in a very hot and unhealthy condition.

The anopheles is the cause of the spread of malarial fever. The mosquito bites an infected human being or animal, and the malaria parasite, which is a protozoon, or one-celled animal (these are known as the hæmamoba mastigophora protozaa), enters the stomach of the mosquito. In this stomach, and nowhere else, a male (microgamete) and a female (megagamete) unite and reproduce. Here they actually fuse together and bury themselves as one mass, like an egg, in the epithelial cuating of the stomach. After a while this egg or ovum divides into a number of little spores, which each, in time, break up into a number of tiny elongated rods. These rods make their way into the salivary glands of the mosquito. When the mosquito, which itself is sick with malarial fever, bites an animal or human being, in order to prevent the blood frum coagulating as it passes up into its mouth (and thus choking it), it injects some of its saliva into its victim before commencing to suck. In this way some of the rod-like organisms in this saliva gain access to the victim. In their new host they grow into the hrmamcebs, eventually giving the host malarial fever.

Fortunately for us, everyone so bitten does not contract malaria, because in most cases the white blood corpuscles (leucocytes) in the blood of the new host devour the invaders.

611. Other Uses of the Tail.-The horse, when at pasture, stands with his back to the rain or the cold wind, because he thus protects himself by mesns of his tail. A docked liorse cannot protect his bladder and other vulnerable parts when 80 exposed to cold and damp. He also uses his tail, as we do our hands, to scratch those parts that he cannot otherwise reach. It is surprising how many people with considerable experience are not aware of the fact that the long tail is of use to the horse in making quick turns and in retaining his balance in polo and many military sports, and also in sword fighting. I suppose ignorance of this fact can be put down to the want of minute observation and lack of horse-sense. I have described in detail the use of the tail for brood mares at pasture in Chapter XIII. I was glad to see Farm Life point out the importance of leaving brood mares their tails, and advise owners of docked horses not to turn them out to pasture during the fly season. The other uses of the tail are fully described in the same chapter.

642. Fly Ncts.-The excuse that the fly net is all that is necessary for a docked horse is a poor one, and no observar $t$ horse lover could possibly believe it. Horse nets are common articles used on well-cared-for, long-tailed horses in Canada, the United States, India, etc., in the fly season. I do not mean to assert that fly nets are of no use on docked horses, but what I mean is that a net in no way takes the place of a tail, particularly as it dnes not reach in between the thighs, where there is no fly muscle and where the skin is particularly delicate.

A net on an undocked horse adds decided comfort to the animal. (P. 10ie.) It allows him to use his tail posteriorly and relieves him of having to switch it around to either side, which means that the horse can go along more at ease, and will not be describing various flgures with its tail when the flies and mosquitoes are abundant. White cotton sheets are often used on farm and heavy draught horses in British Columbia and the great North-West of Canada.

643. The subject of hogging manes is mentioned in Section 241. The mane is a valuable weapon of defence against flies, because the fly muscle joes not extend to the top of the neck. With the mane the horse has merely to shake his neck from side to side, and the mane will brush away any offending insects; especially is this necessary at the end of the season, whell flies and mosquitocs cling on very securely. A mane four or flve inches in length is all that is required. It should be kept thin; a thin mane is much cooier. (P. 80a.) The panniculus car. nosus, or fly muscle, extends almost to a mane of this length. The forelock eerves as a great protection to the eyes, and for this reason should not be cut ofi. The forelock is a berutiful addition to most horses. (P. 80.) Eye fringes are useful appendages on the bridle for horses that have no forelocks. (P. 104d.) Tliese also protect the 
eyes from the strong sun. They are made of leather or string; the latter keeps softer. If leatlier is used, it nust bo kept quite soft by continually being well greased. An eye fringe can be either sewn on to the bridle, or hooked or binttoned on, or it may be, as in P. 104d, a separate brow-band.

644. Fly W'hisks.-P. 10:id shows a loorsehair fly whisk whicl is often carried by a rider in the fly season in a country where the flies are bad. They save horse and rider cunsiderably. They can be purchased for a small sun, either black or white, or une can be made fronı tho hair of a cleid horse's tail.

645. Hly Papers. - These should be of the sticky, reel variety, which are far superior to the poison papers or to the sticky papers. A large number of reels should be liung in every stable. 'The most suitable type consists of about one yard of sticky paper, an inch in widtl, that is liung up to the ceiling and unrolled from its reel. Fly screens should be used on every window and door. (See Sec. 366.)

\section{Nicking Tails}

646. The vulgar expression "nicking" refers to the dividing of the depressor, and perhaps compressor, muscles of the tail, which, of course, should be done under an anæsthetic. Nicking was originally performed, and is to-day chiefly lone, for one reason, fashion-to make the liorse carry its tail higher. Most of the horses th.t are nicked to-day are the docked or hat-pegged variety (P. 105), in which case the underside of the tail is cut across in several places, and the tail tied up, or even over the back, for perhaps a week. The inhuman type of man that practises this is, fortunately, not common. Hackney admirers have a singular desire for such specimens of liorses as are shown in P. 105, 1126, 113. The operation, when done merely for fashion, of course, is illegal. Horse shows are responsible for a great many of these tails. I cannot understand how the law allows such loorses to win prizes, or even to enter the ring.

This form of nicking might truly be called cruel; a local anæesthetic is seldom used. But it nuust be remembered that after the operation is over, the horse has not lost one of its members, as it has when it loses its tail. I mean that it is none the worse, so that the nicking operation can scarcely be compared with that of docking. I have often been surprised to see that writers, not nocessarily autloorities, have declared that nicking is more cruel than docking. They evidently merely consider the operation. Even so, to have two or three cuts made in one's finger, or to have the finger chopped right off, and the stump seared "ith a red-hot iron, could scarcely be compared with wo another. The chief point is the loss of the tail il. the operation of docking. A tail to a horse in the fly season is a great deal more important than anger $\omega, 1$ man. Somo say that nearly all the long, flowing tails we in the show ring have been nicked. This is quite wrong; as a matter of fact, I find that extremely few have been.

647. The operation for nicking a long-tailed horse, as described below, is nothing like as painful as that for producing the "hat peg" in P. 113. Only those long tails that are carried tightly on the quarters are nicked, and these are uncommon with well-bred horses. If docking becamo extinct, nicking would be decreased by from 80 to 90 per cent.

\section{Dividing the Depressor Muscles}

648. I object to the term nicking. As stated above, this operation is performed sometimes on horses that carry their tails down tightly, generally due to coarse breeding. If the operation is done only for this it is illegal, although it may be done without any pain, providing a local anastletic is used. There is, however, one occasion on which the operation can be performed perfectly legally, and that is when a horse grabs hold of the reins, and then endangers those driving behind as well as itself.

Nicking in this case is performed, not for fashion, but to cetter the horse, lessen the liability of its being docked afterwards, and, in fact, make it perfectly safe to drive under all conditions. I have described in Chapter VI., Sec. 270 , the correct way of training a horse to harness so that it will not object to the reins being held under its tail while going along. This subject is also dealt with in detail in Chapter XIII. Fear or nervousness causes 90 per cent. of those who grab the reins to do so. There are, however, a very few who will maliciously grab the reins if they can; these should bo nicked, as described below, for their own good. Ticklish mares sometimes have this habit.

My friend, Professor Fowler, one of the leading authorities on comparative anatomy on the North American continent, says: "A sure way of making horses safe that have acquired a bad hubit of grabbing hold of the reins is the performance of a slight operation on the depressc $r$ muscles of the tail. This is not cruel: it is done for the horse's good, and not for any sil's fashion. It is soon over, and afterwards the horse is the better for it."

649. The operation is performed thus: A draclim of 5 per cent. cocaine hydrochloride (see Chapter XVI.) is injected on each side of the tail near the root of the dock. In fifteen minutes the tail is raised, and one or two transverse cuts made across each of the depressor muscles on each side of the median line close to the root of the dock. There will be no feeling in the tail. Tlie open wounds are then plugged up lightly with wet antiseptic cotton-wool, and the tail wrapped in oil sheeting to keep the wool from 


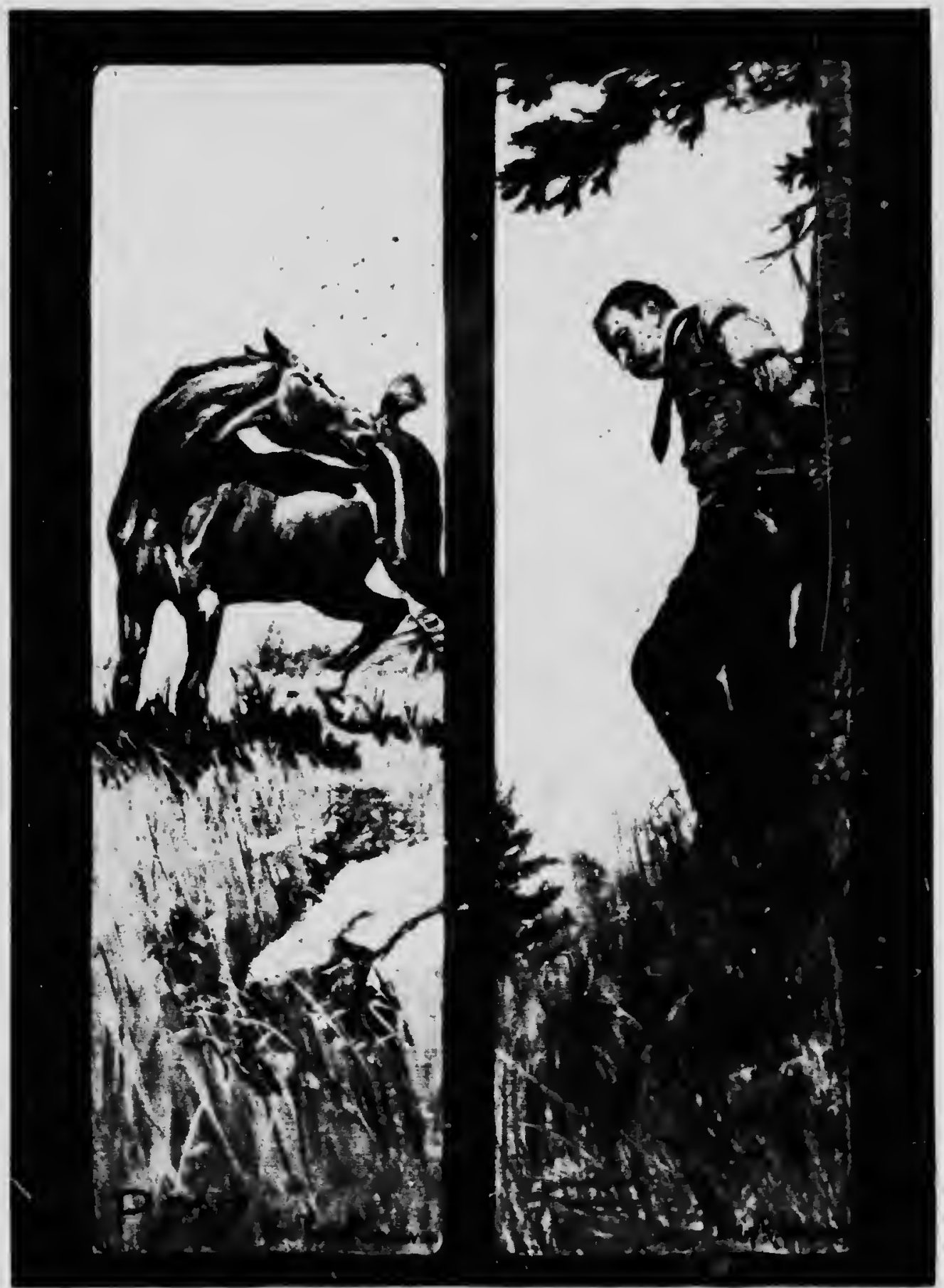

"How would he like it?" A Picture Parable by Philip R. Goodwin. Through courtesy of "The Craphic." Copyright: London Electrotype Agency. Fleet Street 
J'. ITE IOS

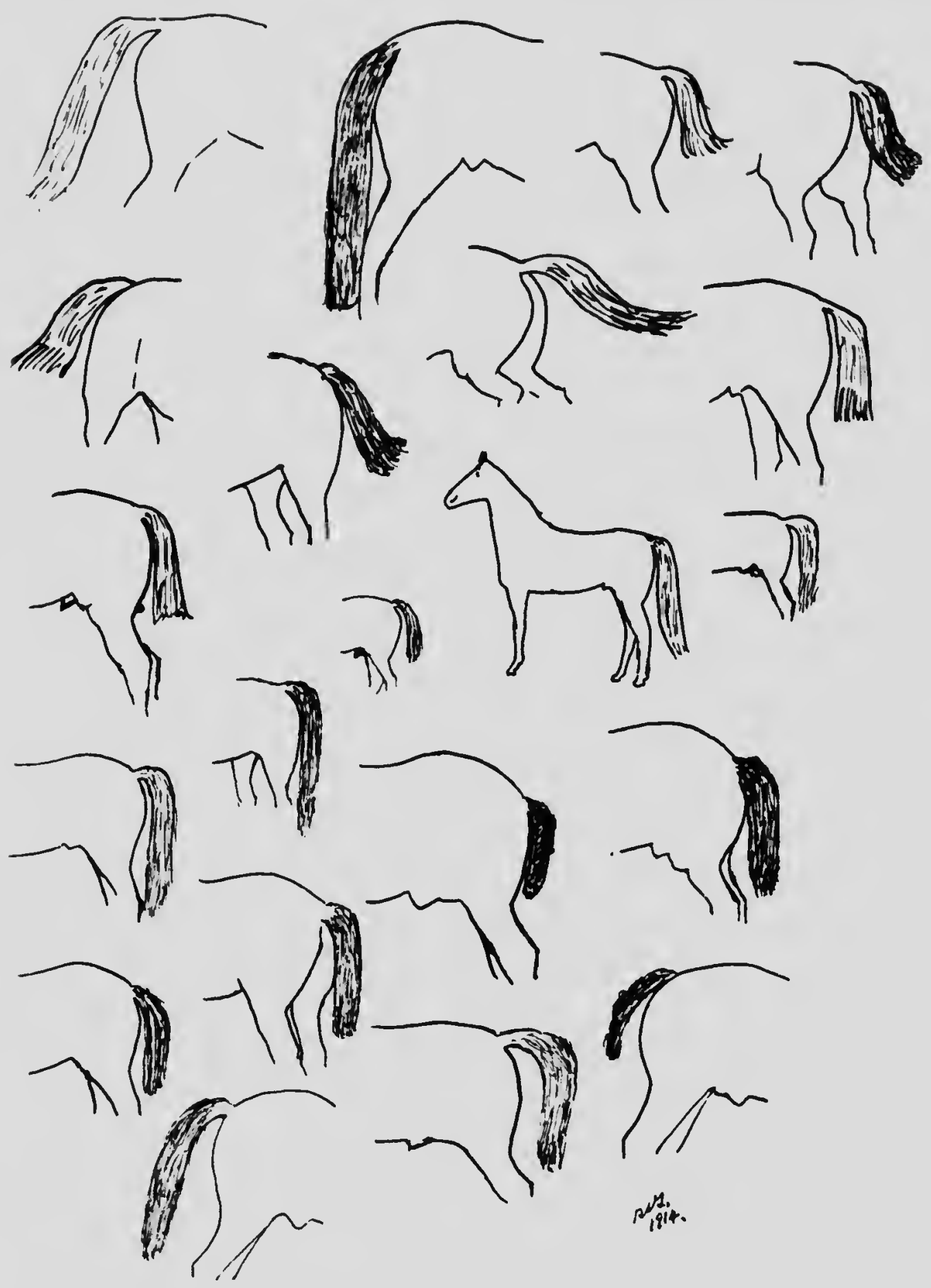

Some Sketches from Iife of the Beauty of the Undocked Tail 
PLATE 109
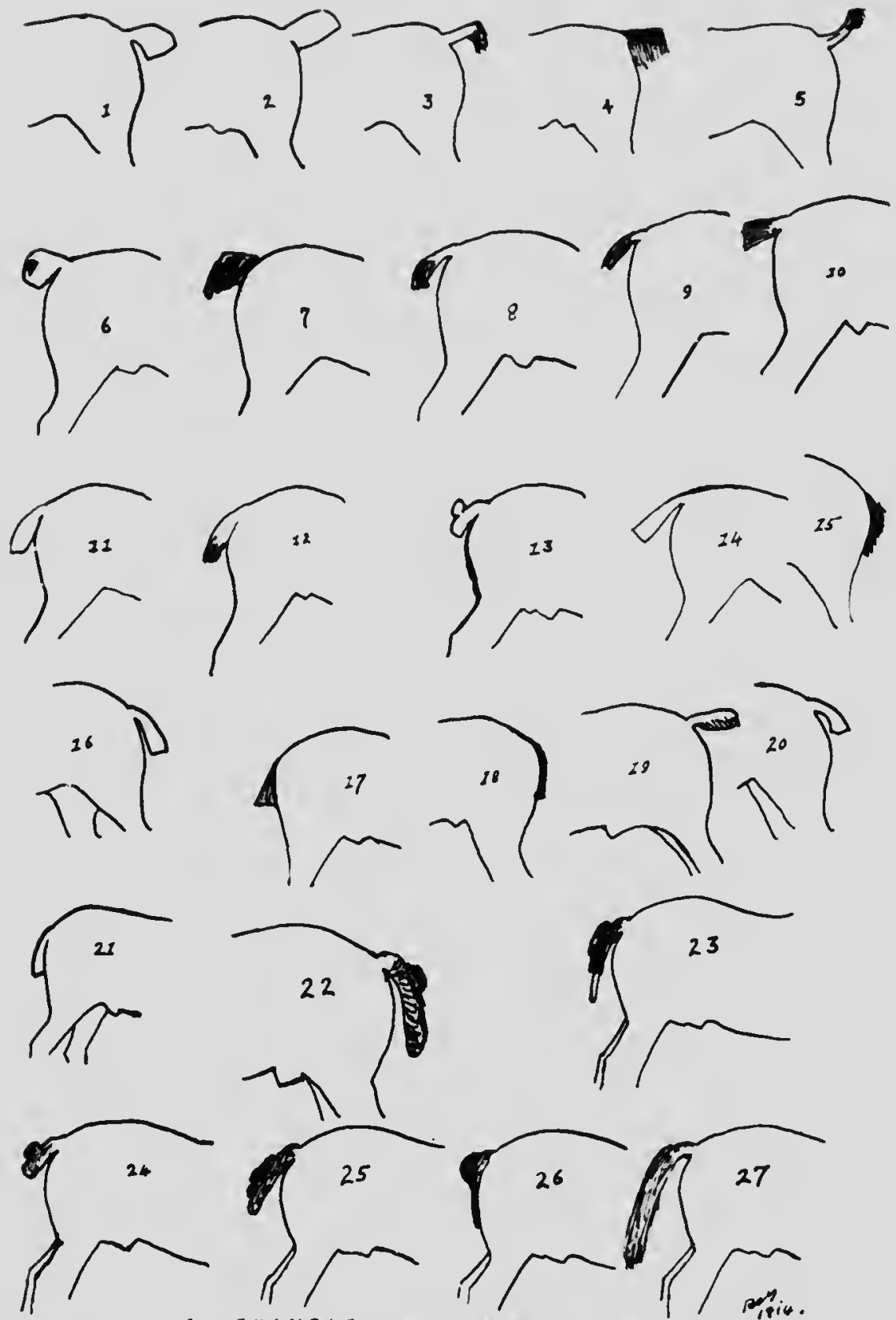

1 2 21 ind $24, E X A M L E S$ of

$22.25,26,27, H U M A N G$ MET HODS THE TAIL (WITHOUT MUTILATION), 23 SHOWS THE DANGEAOUS

PRACTICE JF CLIPPINE THE GNS OF THE DOCK FREE OF HAIP: THIS MUST NEVEA OE ALOWED (SEG TEXT).

The Art of the Docking Advocates. Sketches from Life of Docked Tails; and Suggestions for Flaiting and Trimming the Shire Horse's Tail 
PI. IT1: 110
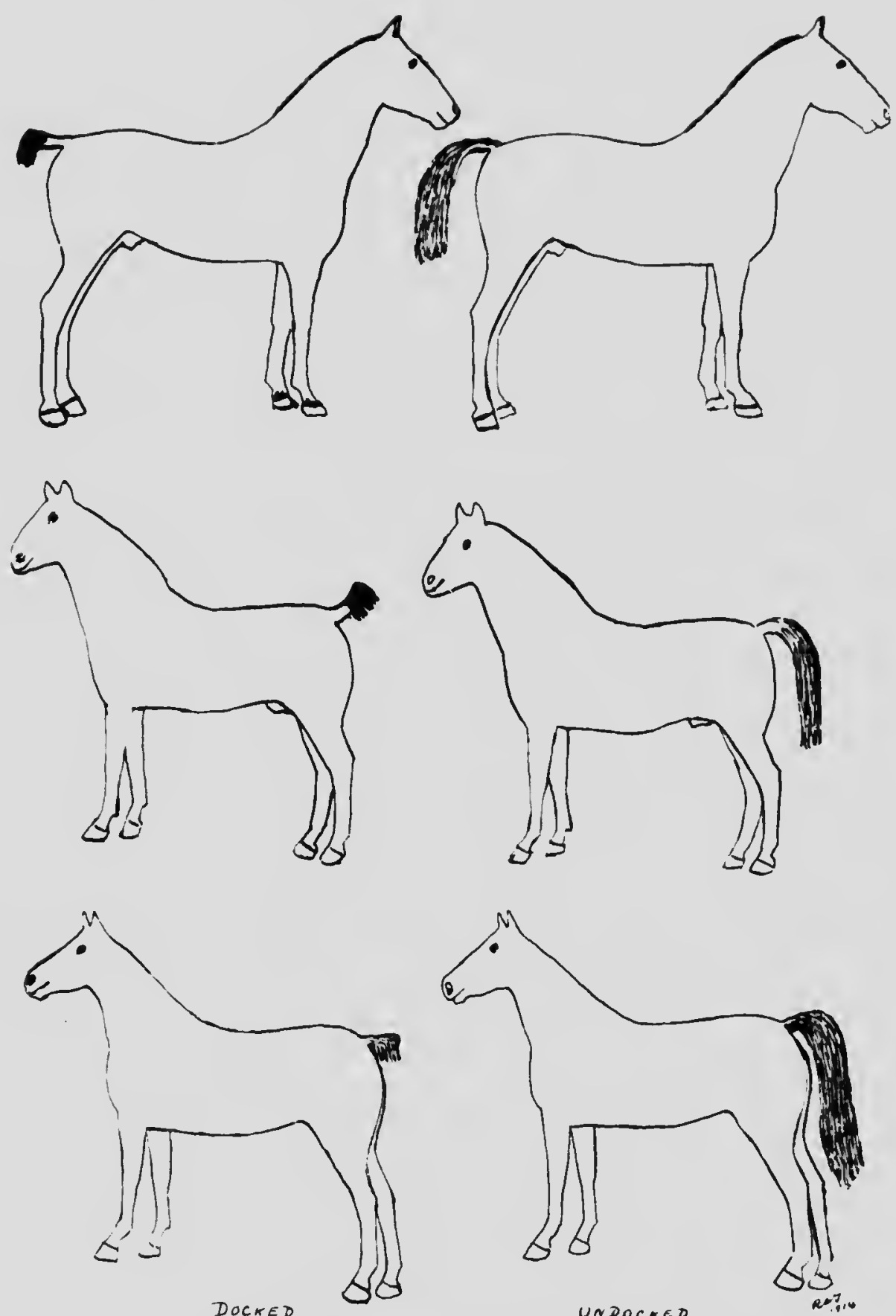

THREE FAMOUS HACKNEYS. TS THEY ARE (TAMEESS), AND

AS THEY SHUULD OE (BALANCED OND OEAUTIEUL).

Skctches of Three Famous Hackncys, as They are, and as Nature intended They should be 
becoming dry. In two or three days the wound is again dressed, and in a couple of weeks will be quite healed up, leaving a portion of the muscles divided. The degree to which the muscles should be divided will depend on the extent to which the tail is held down by the horse wlien he takes hold of the reins. There is no need to tie up the tail to a pulley or tie it over the back, as is commonly done even to-day by some thoughtless persons who perform illegal operations for horse-show exhibitors.

\section{Straightening " Kinked" Tails}

650. A very important point concerning the above operation is the straightening of a kinked or crooked tail, or one that is carried to one side or other. By the above simple operation tails that have kinks in them can be made absolutely straight, or a tail that is carried to one side can bo made to hang perfectly straight. If the kink is small, a slight nick is made on the concave side of the kink, i.e. on the side towards which the lail is bent; if the tail is carried on one side, the nick is made on the same side near the root of the dock. The wounds aro gently plugged and the tail is bound and treated similarly to the treatment after nicking, as described above. After the operation the horse is none the worse, and, in fact, is far better, as it is less liable to have its tail docked. This is similar to a human being having the squint removed from the eye, and can scarcely be called an operation performed for fashion.

In the place of cocaine, the ether spray can be used for operations for kinks in the tail, as they are so near to the surface. (See Chapter XVI.) 


\section{CIIAPTER XIII}

\section{THI: CRIME OF DOCKING HORSES' TAILS}

651. We hive in a civilised country that boasts of its modern civilisation, yet allows the reprehensible practice of mutilating the horse to exist. There would, to-day, scarcely be any necessity to write against this custom, which was introduced centuries ago by barbarians who linew no bett'r, liad the various hackney and heavy drauglit-horse societies chone what it was in their power to to a few years ago, namely, to forbid locked horses from entering the show ring, as diul the llunters Improvement Society. Thanks to this society, the docked liunter is to-day, in every country, practically extinct.

Field-Marshal H.1R.1I. the Duke of Connaught, Governor-General of Canada, speaking in Ottawa on this subject, stated: "I think the docking of horses is a relic of barbarism. It is a slame to deprive the horse of the tail God has given it." No doubt these remarks are laughed at by upholders of docking, but it should be remembered that they come from a horseman of no little knowledge, which cannot always be alleged of the persoll who sanctions docking.

652. We will consider the practice systematically in the following order: The use of the tail ; the operation; the reason for and excuses jut forwarl, namely, cleanliness, strengthening the hindquarters, safety, appearance, neatness, show and fashion.

653. The lise of the Tail.-This has been described fully in Chapter XII., but, to recapitulate briefly, its chief use is as a weapon of defence against fies. Tlıe panniculus carnosus muscle extends all over the horse's body except the hindquarters, which part is supposed by Nature to be protected by the tail. In between the thighs and the portions of the belly between the stifle $j$.ints there is no fly muscle, and the tail is also supposed to reach here. A tail should be long enough to reach nearly to the point of the hip. If the hair is left quite long, this will, of course, Irive tiies away that have got their lancets in deeply, as is not uncommon at the end of the fly season.

Just over the root of the tail, where the horse cannot reach, there is a thick fascia that a fly cannot penetrate. It will, therefore, be seen that it is not necessary to leave a horse's tail quite long. When a horse is turned out to pasture he requires a tail a little below the hock for comfort, lunt if it is a little shorter he win be able to ricl himself of most flies that the fly muscle will not reach. Any observant person must have noticed how peacefully a long-tailed liorse grazes at pasture, compared with a horse with the liair banged near the end of the dock which kicks at the flies tluat get on the belly between the thighs. Such a horse, of course, will soon have a longer tail, as the hair grows from a natural dock fairly fast.

llere we come to a most important point which I have impressed upon farmers, through the columns of various papers, over and over again. Dr. Rutherford, formerly Veterinary Director-General of Canada, brought out this point very strongly while talking to me on the subject a short time ago. The point is that if a mare is to be used for breeding purposes it should, so modern veterinary science tells us, be turned out to pasture not only after the foal has been born, but before, as foals born out-of-doors in fine weatlier, or even in the snow in Alberta, are always better for it, and are not so likely to levelop that often fatal disease, navel ill, so common in some listricts.

Now, if a mother is locked, is it humane to turn her out, sceing that the fly season commences very soon after the time for foalingApril, May or June? of course, the practitioner of docking thinks little about this, and if he were to he wonld say, "They are all right; the fies won't kill them." In expressing himself he really shows want of true sympathy for the lorse. If, however-and here is the point-the mare, or any other horse which is to be turned out to pasture, has not been docked, but has merely had its tail banged (the hair squared off), as in $P$. 79 , or even as short as in $P$. 29, the hair will soon grow again. It will be a few months before the hair will reach the hocks, and then there will be sufficient protection to reach where the fly muscles will not. If, of course, the horse is going to be used for breeding altogether, the tail can be allowed to grow as long as possible.

Horse owners have a culpable habit of allowing their grooms to trim their horses' tails in the spring, i.e. just before the fly season commences, instead of in the autumn, after the flies have 
gone. In Canada it would have to be late in the autumn. Then, again, if a horse's tail is merely banged short, when he is sold as worn out, as he often is, the new owner, who will not take, perhaps, the same care of him, can let the hair grow to its full extent; but if the horse has been docked, it has to remain a victim of fly torture during the rest of its unhappy days. If, again, it were not docked, the owner could pension it off in a nice pasture to spend the rest of its life ill peace.

Those who employ docking invariably trim their horses' stumps to an absurd degree in the spring, thus depriving them of every little bit of fly protection that wise Nature has provided, in spite of the vet.'s knife. Why don't these overzealous people leave the hair on the stump until after the fly season? Then, if they wished, they could trim to their hearts' desire during the winter months.

654. A horse in harness does not require a tail below the hocks, because if it is very long. as in P. 10e, it will not be of any more use than if it were as in $P .36 d$. In fact, if very long, and the horse is harnessed in close to a two-wheeled cart, as in P. $29 \mathrm{~g}$, he would not be able to use it so easily as if it were trimmed out or combed out to reach to the hocks.

Any observant horseman, of course, knows well the real use of the tail, and it must irritate such a man to sit behind a bobtail horse when the flies are about and to see the wretched animal trying all day in vain to rid itself of flies. The incessant wagging of a docked tail is, I think, most painful to watch.

655. Other uses of the tail are described in Chapter XII., and are as a means of protection from cold, as a rudder in turning, as an appendage for scratching parts that itch and cannot be reached by tle mouth, etc.

People too commonly argue that a private horse is kept in a well-cared-for stable away from flies, but they misstate the facts. I have never found such a stable yet. Besides, why cannot these horses enjoy pasture in the summer? And why are they generally sold when too old to work, and perhaps for ten years exposed to flies? The general complaint in livery stables at the end of the fly season, especially in Canada, is that the docked horses are the poorest in condition.

656. Mr. Terry, in "The Crime of Docking Horses," referring to illustrations of flies, says : "They show the sort of enemy against which the horse has to contend. Mr. Austin, of the Natural History Museum, London, has written, and the departinent has published, a most sumptuously illustrated and learned work on British bloodsucking flies. No one who has turned over these pages will ever consent to any horse of his being docked, for the awful nature of these flies and their weapons will not soon be forgotten."
657. A lover of a horse for the horse's sake aloni will surely lay aside thoughts of fashion before deciding to involve his noble friend in such an operation and such a loss merely for a trifing difference in appearance from his or her point of view.

Queen Alexandra set an example for other ladies to follow as regards docked horses, when she refused to accept a pair of docked horses presented to her by some ladies of Ottawa. It was discovered afterwards that these horses had been docked by a man in Ottawa without the consent of the donors. I had the pleasure of investigating this case. Nothing gave me greater pleasure than when I heard that ho had to buy another pair at his own expense and ship tliem to England. King George also refused to accept a pair of bobtailed horses sent to him as a present from Australia.

658. A natural tail need not, and should not, be left thick and bushy, because it only tends to make the horse hot and gives extra weight for him to switch around at the fites. A tail should be kept neat and fairly thin at the top, as this will tend to keep the horse cooler. (P. 16b.) Some docked horses have a bunch of untidy hair hanging from the stump that keeps them hot, and in many cases the hair is so much in the way that it is insanitary. Undocked tails will never get bushy like this even if left alone.

No one can call a bobtail shire or Clyde neat or smart; in the summer it is very cruel to plait the hair up, and when it is not plaited it is extremely untidy, whilst a natural tail cannot be called untidy. Three summers ago I saw a carload of Percherons imported from Belgium which were almost tailless. The horse dealer who had bought them told me that he had diffculty in selling them, as farmers could not plough in the autumn, when the flies were so bad, because the horses would be kicking at files all the time. The exporter in Belgium only considered his own pocket when he shipped such horses to Canada, but I do rot think he realised the profits he had hoped for.

659. The polo pony is now allowed its tail. Besides the usual reasons for leaving it long, it is of great use for making quick turns. (P. 62.) The want of knowledge on this point is often explained by the bad horsemanship one so of ten sees in the polo fleld. The old argument that the tail gets in the way of the stick has, I think, become exploded. Even if it were so, it would not justify permanent mutilation, as both sides would stand the same chance.

660. The Operation.-Unfortunately, there are some who, after seeing a horse docked, say that the animal does not mind it ; they expose thei: want of horse knowledge and entire lack of observation.

Horses do not cry out like dogs, unless they 
are in intense tear or lett alone by other horses. I have seen horses in grave accidents have large gashes torn in them, and yet to the ordinary individual they have probably shown little signs of pain, but to tle trained eye there was quite a different story. The horse's eye should bo vatclied when the raw end of the stump of a tail is seared and seared again with a red-hot iron. The operation, in brief, usually consists in taking up the hair above the joint of incision and clipping of a ring of hair around the joint. The docking instrument is then placed around the joint, nuidway between two vertebrex, and the dock chopped off. The stump is grasped and seared over with resin and a red-hot iron until all bleeding is arrested. This sometimes takes as long as twenty seconds.

A horse does not feel so much the severing of the tail, because it is done very quickly if done properly; but, here again, how often is it dono properly? In many cases the tail is chopped off with an axe or with a large knife. The horse does, however, suffer pain from the hot iron. Sume show intense pain, otlers not so much. It is an extraordinary thing that horses seldom kick or flght in self-rlefence when being so mutilated. I think this is due partly to their utter surprise at finding their tail ruthlessly taken away from them, and partly to their probably being in such fear that they remain more or less motionless.

People who say that horses are nowadays docked humanely are mistaken. In the first place, they may refer to one in a thousand cases, but certainly no more; and, secondly, even if the majority of the operations were properly performed, this would not affect the practices that I have seen in the remote parts of cities.

In all likelihood these people do not know, nor do they care, whether sucl? things are done humanely or otherwise, but what they look for is an excuse that will make the - appear to others less indifferent than they are. The average man that docks a horse seems to care little what method he uses or how much pain the horse suffers. He considers his own pleasure before anything else, though in some cases it may be granted that the evil is wrought for want of thought. It takes several weeks, and sometimes months. for the end of the dock to heal up properly. The wound gradually heals, and the roasted portion dies and drops off. A tail that has once been docked, however slightly, will not grow hair at the tip, but an undocked tail will always have hairs growing from the actual end.

If the tail is not properly seared over, the hæmorrhage may recommence, and the red-hot iron will have to be used again. An English farmer orce told me that he sent his horses out to plough after having docked them ; and sometimes the bleeding would commence again, whereupon he had to have them brought in, and the red-hot iron used again.

P. 108 is a drawing that I have made trom an actual stump that had been previously seared over with a red-hot iron. This horse was docked merely because it was going to be exhibiled al a show.

Some advocale using chloroform for docking, but I do not think that this will in any way relieve the horse of much pain, because, firatly, a horse struggles against the chloroform, and, secondly, the after-pain from the burn is in no way lessened.

The bleeding is sometimes arrested by tying a cord tightly around the tail above the point of incision, but the portion below the string will eventually die and drop off. The tight string causes pain.

661. The Afler-Effects of Docking.--There is always a danger that trouble may follow the operation. Hundreds of cases of lockjaw (tetanns) have resulted in the past from this needless oneration. Gangrene has also been 8 very common sequel. When either of these sets in, as a last hope the stump is redocked, so that in some cases the horse has practically no tail at all, but somewhat resembles a Manx cat. As for fly defence, it has none. P. $120 d$ shows a pony that was docked by a vet.; gangrene set in, and, to save its life, it was redocked. The number of kickers that have been produced by this brutal faslion is inconceivable. Scores of horses have been made to fear burning coals, red-hot irons, the smell of roasting meat, hot oil, steam engines, sight of fire, etc., owing to the intense fear they experienced at the time that they were docked.

A Percheron horse in Kent was docked when it changed hands because its new owner thought that it wculd look smart. The vet. made a hopeless muddle of the operation, and the poor horse got blood poisuning, and remained in a critical condition for several weeks. At the end of this time it was redocked, and now it has to wear a false tail to be shown in the show ring. I have heard of several horses bleeding to death after the operation. If I attempted to give details of a number of horses that have been ruined in various ways by being docked, I should fill a large volume. I remember a very fine hunter, some few years ago, being so much weakened in the back by the operation that for ever afterwards it was of no use for jumping. It took a long time to convince its shortsighted owner of the cause of the horse's failure.

Those who wish to read up this subject in detail should procure from the R.S.P.C.A., 105 Jermyn Street, London, "The Wanton Mutilation of Animals," by the late Dr. Fleming, C.B., Li.D., F.R.C.V.S., etc. (is. 6d.). He was formerly the chief veterinarian of the British Army, and the author of at least a dozen 

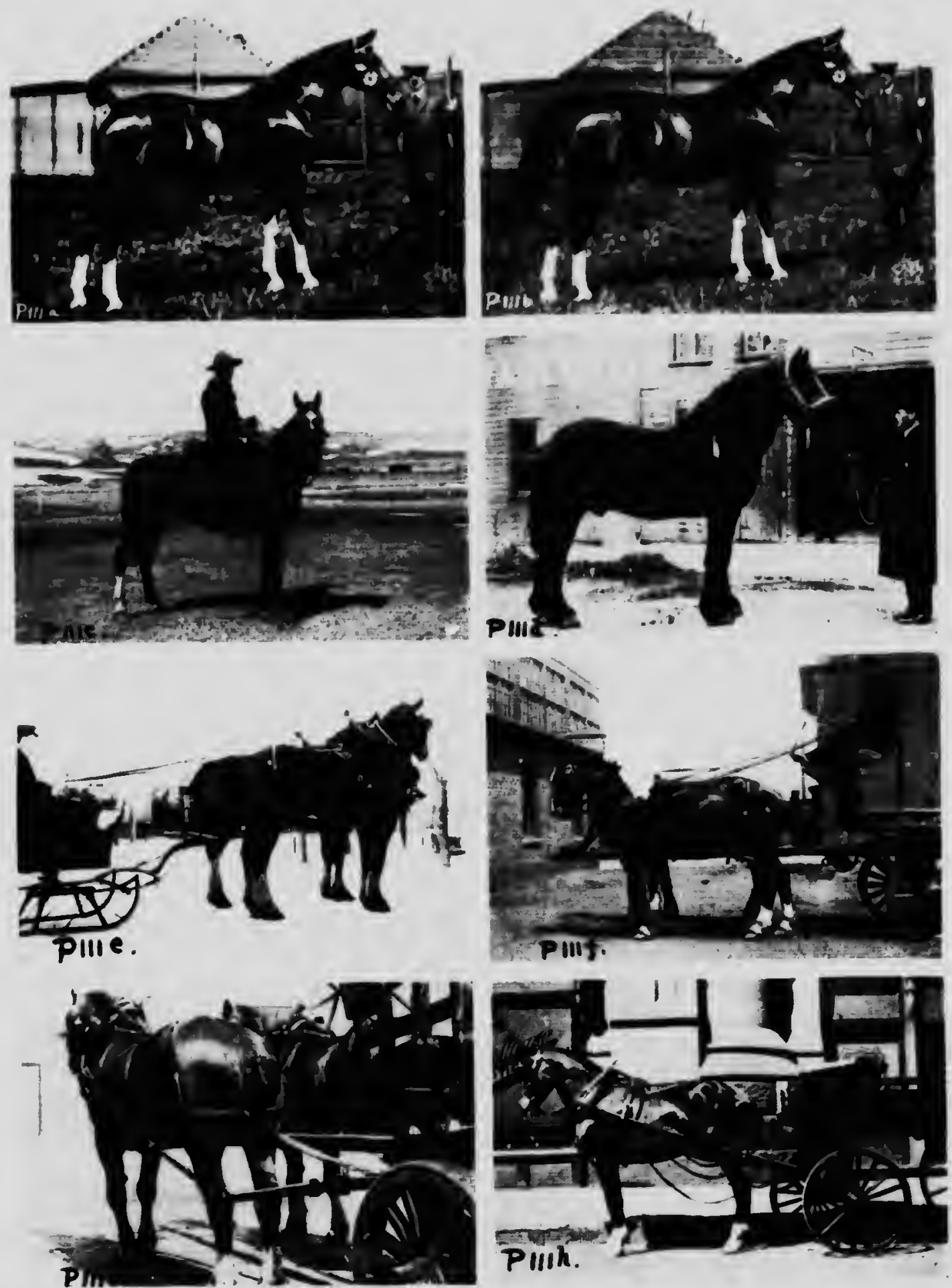

\section{UNDOCKED versus DOCKED}

a. "Hawster Kosina" as She as, and $b$, as She was meant to be. I'hoto: C. If Parsuns. c. Registered Hackncy Stalion in Alberta being ridden (rom Ranch to Rench (Undocted). Courtesy: Mr. Wynne. d, $A$ Prize-winning Per. cheron. Courtesy : Mr. Lewis. e, $f, s, h$, Examples of Undocked Tails Plaited up. which shows of the Quarters just as much as Docking would. Courtesy: e, Mr. Wm. Wilson, Brandon, Manitoba. f. of Mesurs. John Inglis Co., Toronto. Photos, $c$ to $h$, by the Author 


\section{1'1.111: 112}
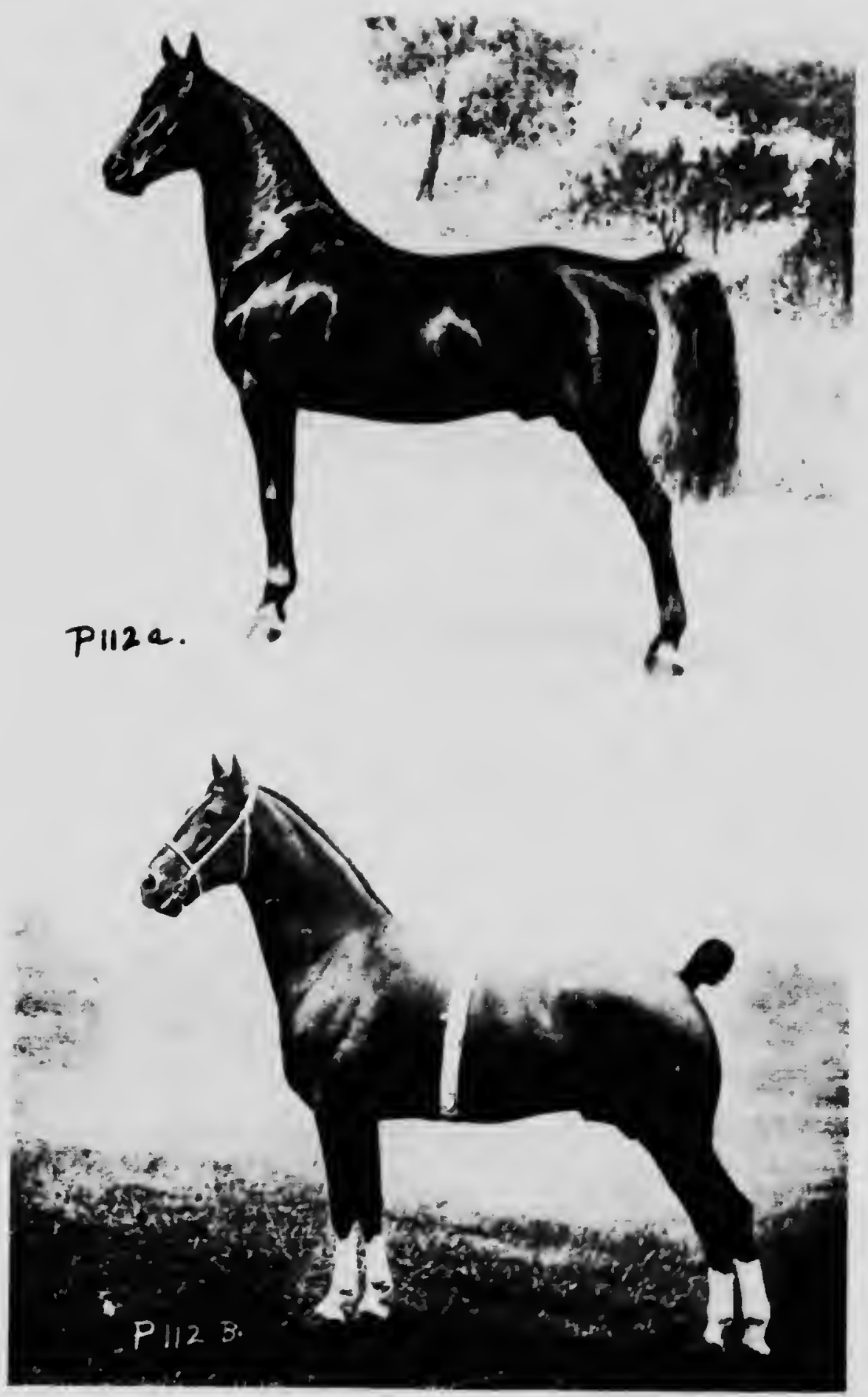

THE BENLT: OF THE: MATURML HORSE

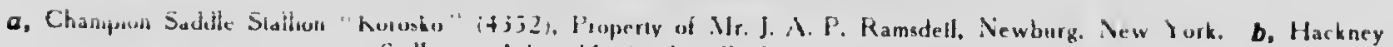
Stallon. "Armurable. Cinchion." Photo: (j. H. P'arsuns 
standard works on the horee. Ho explains the Corrible torture the horee had to go through to satisfy objectionable farhions and looiish super. stitions.

Cood Queen Vicloria rewarded Dr. Fleming for his etlorts against the docking craze. I do not know what her Majesty would have thought of some of the six-inch "hatpegs" we see in the modern hackney ring, hores bred and owned by people who doubtless deem them. selves animated by sincere regard for the animals' wellare.

602. The following paragraphs are Laken from Dr. Fleming's book: "Hartzmann asserts that during the last century the English cavalry were several times rendered almost useless from the losses among the horses, caused by the attack of flies from which they could not protect themselves. In 1756 the files caused 80 much trouble among the British dock-tailed horses at Minden that the battle was nearly lost. Beringer adds: "Yet such is the cruelty and absurdity of our notions and customs in cropping the ears of horses, docking and nicking their taiis.' Percivall, the volerinary surgeon of repute, asserts: "The unfortunate creature is subjected anew to torture, so that there is reason to believe that many horsen are docked thrice. It would ill become me as vefessional man to decry the operation.

Bloomfield alludes to it:

- In thy behalf the crest waved boughs avall More than the short-cllpped remnant of a tall, A moving mockery, a useless name,

A living proof of cruelty and sbame.

Shame to the man, whatever form he bore,

Who took from thee what man can ne'er restore, Thy weapon of defence, thy chiefest good,

When swarming Ales, contending, suck thy blood.'

"Sidney remarks: 'No carriage horse, nor pack horse of any kind, can be ranked first class without a noble tail."

Fleming continues: "But the danger of reins getting under the tails of saddle horses cannot surely be offered as an excuse. Are our equestrians less accomplished and less courageous than the tens of thousands of horsemen whose horses' tails almost reach the ground and who almost live in the saddle? Docking is a mania."

668. Jara Linard reminds us that the custom of docking has descended to us as a relic of barbarism, having originated in an era far less intelligent and human than the present century. She continues: "In those days the Scripture, If an eye offend thee pluck it out,' was taken litterally: and, if a tail got in the way, tn cut it of seemed only right. There was no ple for the pocr animal that was trying to ease its suffering mouth from the jerks of an ignorant driver."

684. Cruelty of Docking.-I remember a doctor in a Cenadian city who lancied that a nice little horse of his would look smarter if dooked. He did the operation himself. The method adopted need not bo explained; surice It to say the hore was utterly ruined, and would not even a'suw this man to enter the stable. It i.ad to be sold, and has ever since been driven in a grocer's cart.

In India a colonel in the British cavalry, many years ago, had a number of the troop horres docked. Some of these stood in pools of blood afterwards, and some almost died. Dow not this scem almost incredible?

A clergyman, some ten yoers ago, was discovered trying to dock his own horse with a pair of scissors. The horse's moans were heard, and the perpetrator got several months' imprison. ment.

The above are typical oxamples of the many hundreds of cases that I have come across; to quote more of them would certainly revolt the reader.

665. Excuses for Docking.--The usual excuses put forward are: that the docked tail is cleaner: that it strengthens the hindquarters; that with a long tail it is dangerous to drive: it always has becu done, and that it looks smart.

The Cleanliness Excuse.-The foolish piea has been made that in muddy weather a horse with a long tail might switch mud on to the rider or on to someone else. A sportsman would give three answers to this: (1) If afraid of a little dirt, do not ride; (2) plait the tail, as is now commoniy done: (3) bang the hair short.

I am fully aware that many coachmen and grooms make the excuse that they have not time to clean long tails in muddy weather. If long tails are not even plaited or banged, however dirty they may get, it takes but a little while to clean them properly compared with the time taken to clean one of the horse's four legs. My advice to those who employ such grooms is to dismiss them immediately. A lazy man is no good in a stable. Such an excuse only throws a useful light on the maker of it.

668. The subject of plaiting and banging has boen discussed in Chapter V. P. 26, 27 show types of plaiting: P. 28, 29 show types of banged tails.

A tail that is well cared for is, of course, more easily kept clean inside, i.e. at the roots of the hairs; it should be kept fairly thin, and not left thick and bushy. (See Secs. 240, 658.) Examples of well-groomed tails are seen in $\mathbf{P}$. $16,59,63,64$.

Docked horses seldom look neat, and the stump-tailed hackney does not belie its woo begone aspect. The laste of those who drive behind some of these is admired by few people. To dock a shire horse's tail to keep it clean and then to leave four white legs to grow twelve inches of hair on them, is an inexpressibly 
ludicrous practice. The latter is responsible for all kinds of disense, but it is the fashion. How. ever dirty a tail may get, it is very rare that wo hear of ally real trouble. In reality, horses that suffer fron itchy tails are generally well caredfor, highly-fed ones, the disease being caused by constitutional disturbance, and not outward neglect.

667. Excuse that it Strengthens the Hindquarlers.-The abcve excuse is worse than none. The velerinary profession, anlatomists and physiologists alike, has declared the utter foolishnes, of sucl in excuse. People who are not over-observant think this is the case even to-day, because a horse that is docked shows off its hams (buttocks) more and has the appearance of being more cobby nbout the hindquarters. When I mentioned this matter to Dr. Rutherford, he laughed and said, "Why, you don't believe it, do you?"

I read a book the other day in which the writer still accepted this excuse. He declared that a draught-horse foal, if rlocked when young, would grow stronger in the hindquarters. I only ask those who have studied the anatomy and physiology of the horse to consider this. I thought that Fleming and other leading veterinaries had settled this years ago. The amount of nourishment required to supply the end of a natural tail is minute compared to the large amount required by the hindquarters, which are supplied by different arteries. The large artery that feeds these arteries is one of the largest in the body, so I do not think it would be taxerl to this extent. I suspect those espousing such views confound a totally different physiological function, that, namely. in which one kidney grows larger when the other has beer removed. This happens because the olle has to do the work of both, whilst in the case of tho tail there is plenty of nour.ument to supply the tail sind hindquarters; besides, if one went without, it would be the tail, and not the quarters, because the former is farther from the heart. Might I ask people with such extraordinary views how it is that the best standard-breds have better quarters than most hackneys (P. 19, 112a), and why Suffolk Punches and the undocked Percherons (P. 112a, 126b, 140a) have generally better quarters than the docked Clydes and shires? Besides, all the beet Clydes and shires in Canada, witl a few exceptions, have been docked whell at the age of three or four years.

The farmer in the States or Canada does not believe in making his horse hideous to comply with a barbarous practice, nor of depriving them and torturing them; but in every city we find a fow horse-dealers who buy these horses and dock them. There has been, however, a great change in the cities of Canada dilring the past few years. The average man who buys these horses is not humane enough to refuse to acquire them, partly because it is fashionable to exhibit them in the horse sliow.

668. The Safely Excuse in Driving.-The excuse that a long-tailed horse is dangerou? to drive, for fear the tail may get over the reins, is as superstitious as the excuse that it is dangerous to walk underneath a ladder lest it may fall on the wayfarer. All things are possible. People who use the excuse have a limited knowledge of what a properly-trained horse is, and of the methods of training a horse properly. The rein excuse explodes when we visit the United States, Canada, India, Russia, Arabia, and other countries.

By statistics I find that there are $100,000,000$ horses in the world ; $25,000,000$ of these are in the United States and Canada; of these about OO per cent. are undocked; and 90 per cent. of these are used in harness work. This means that there are over $22,000,000$ undocked harness horses in the States and Canada.

I ask the English coach-driver, who still says that he must have his horses docked: Are you a worse driver than your American cousin, or are you too slow in changing to more humane and modern customs? I think the latter.

The docked hackney is now driven in the American buggy; hence, away must go the old dog-cart excuse. The dump, tip, or tumble cart (P. 118e) scarcely exists on the American continent, yet heavy draught hirses, used for show purposes, are docked. The dump cart excuse cannot be used.

669. There are Four Imporlant Points:

1. My own experience has been that horses (lriven in English vehicles are less liable to get their tails over the reins; yet most American horses, as stateu above, are undocked.

2. California has the largest number of coaches and four in the world, yet ducked horses are forbidden in this State, and the penalty is two years' penal servitude.

3. Docking is not the way to make a tail safe ; but the tail of a horse that has learned the habit, through bad driving, of endeavouring to grab the reins can be made quite safe by resorting to the simple operation of dividing the under muscles of the tail, ar cplained in Chapter XII.

4. To fit the boot to the foot seems more humane than to fit the foot to the boot. So that if there are any kinds of vehicles that are not safe-which is not the trutll-it would be better, and the only legal metlod to adopt, to alter the vehicle lyy raising the dashboard, or to have some other arrangement attached to the harness.

Undocked horses are a dozen times more common in England now than they were six years ago; do we hear of more rein trouble? Do we ever hear of such trouble in the United States? Not as often as wo used to with docked 
PI.A'TE: 113
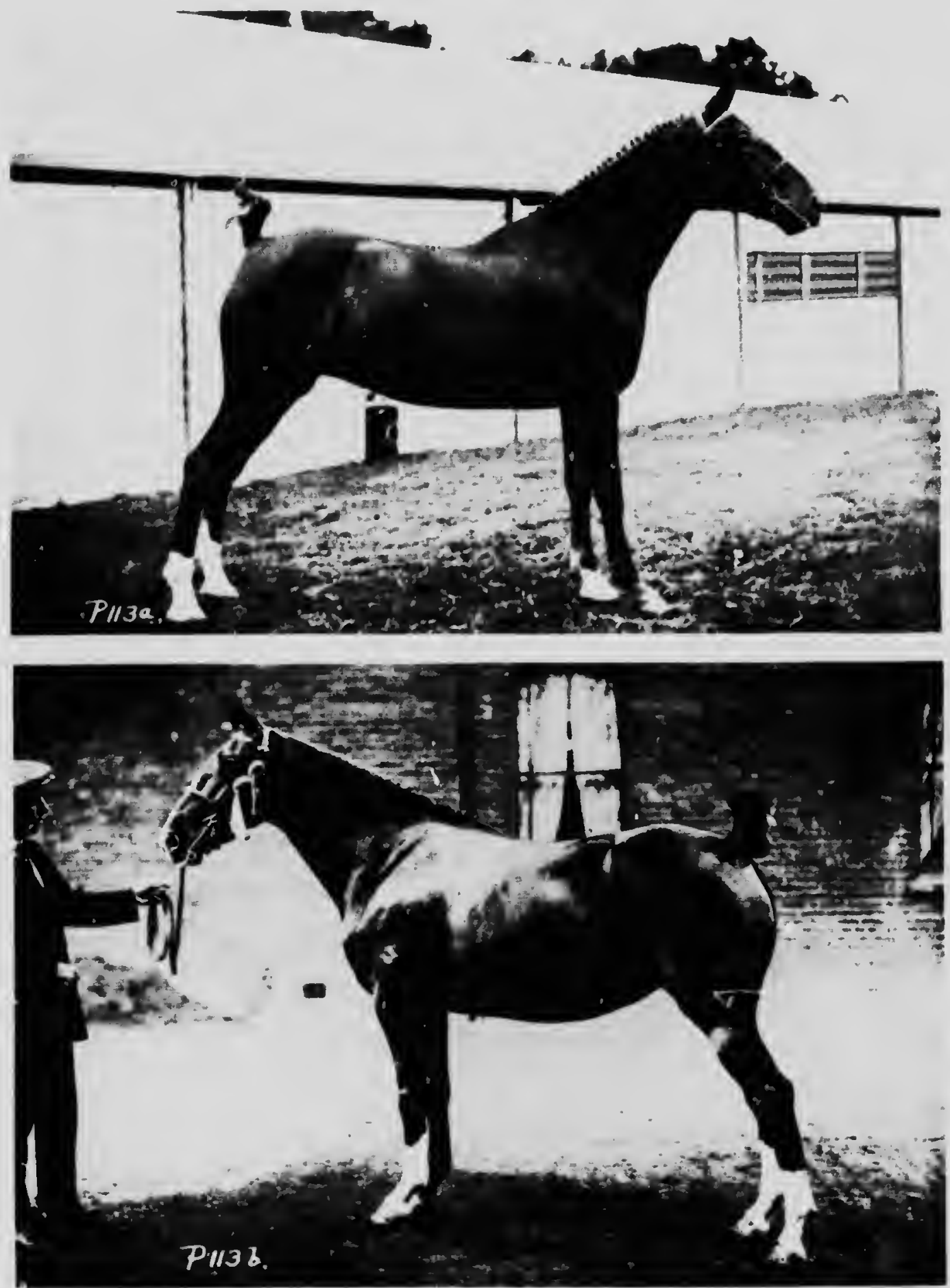

SHOW RING HACKNEYS

a, "Beckingharu Lady Crace." b, "Lady Beckingham." Copyright Photos: Spout and Cieneral.

Fine horses disfigured and made victims of Av-torture for life: the result of an ignorant fashion introduced centuries ago by batbarians, and still kept in evidence by a tew people. It is inconceivable why the law allows it to exist 

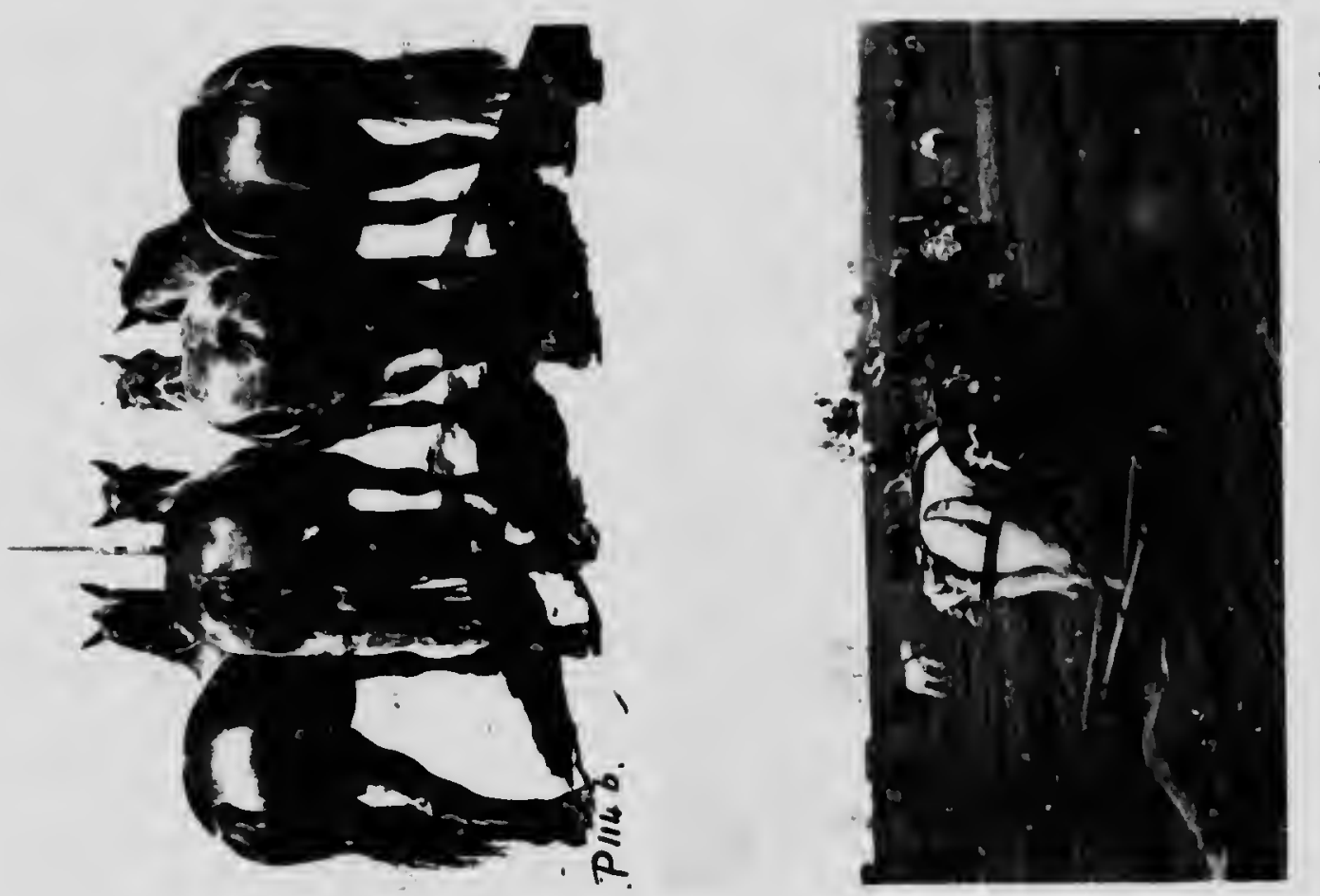

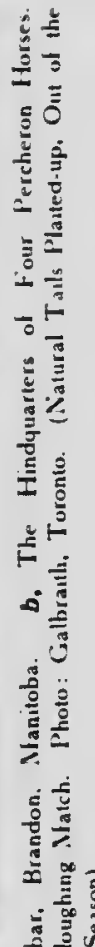

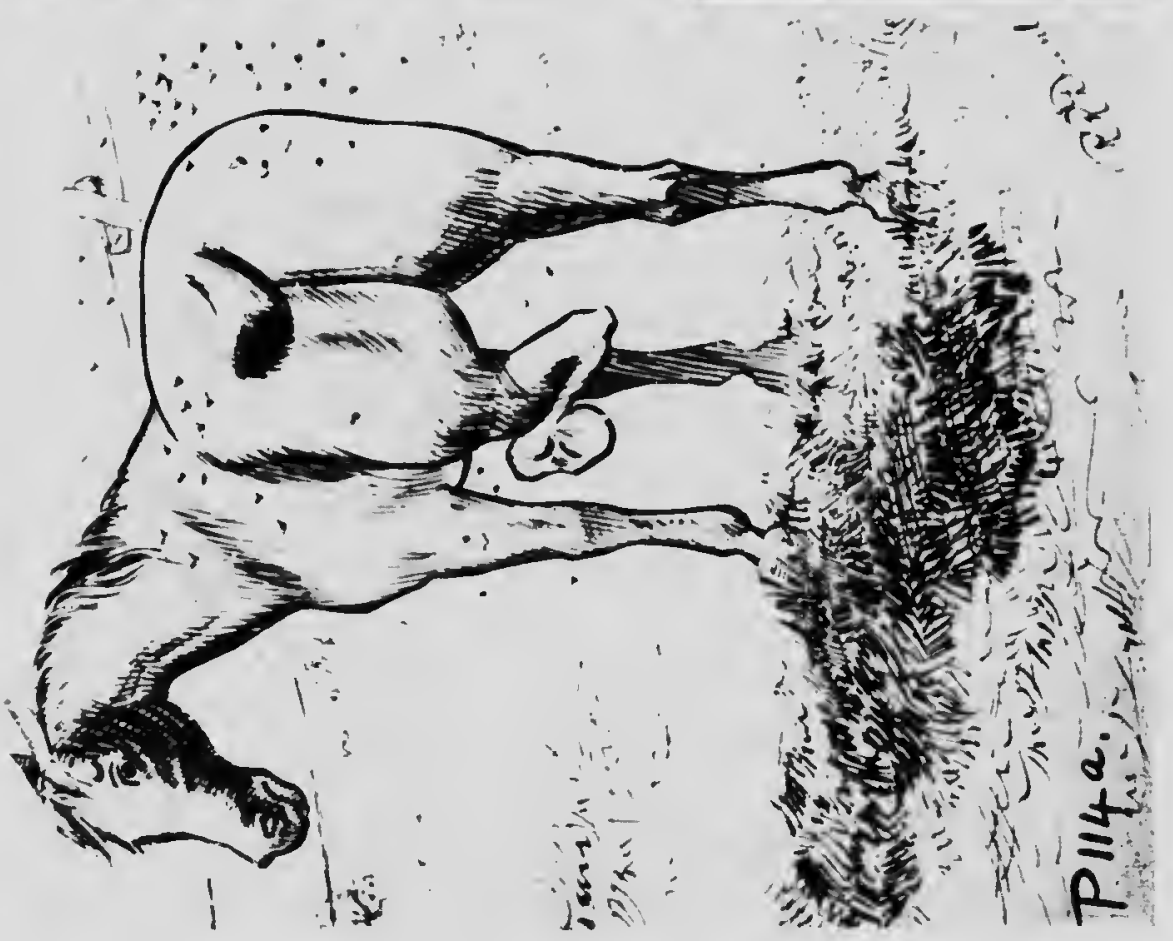

言茫

蒡

吾

I.

告

跣产

:

$\Xi 0$

है

जे

每

旅

.

$<$ ن 
horses in England. Mast of the rein trouble that we hear of in England is produced and wantonly exaggerated by advocates of docking.

670. Are we inferior horsemen to the Russians, Americans, or South Americans, who use almust entirely long-tailed horses? The Russians are supposed to be the finest horsemen in the world.

I guarantee to drive any of these so-called unsafo horses as a leader in tandem or four-inhand with its tail untouched after a couple of days' practice, provided that the horse in question will go in this position. I have aescribed fully in Chapter VI., Sec. 270, the method I adopt to make any horse safe as regards reins. I remind the reader that, if he trains his own horses to drive, and sells them as being properly trained without making sure that they have no objection to reins getting under their tails, he will be, firstly, selling horses improperly trained, and, secondly, culpably negligent.

Besides adopting the method described in Sec. 2\%, the following appliances, etc., can be used to inake horses that grab the reins absolutely :- fe. It is one's duty to resort to such mean neglect of which is inexcusable. A tail left quis long, as in P. $14 b$, is far safer for driving purposes than one that is squared off, as in P. $29 \mathrm{~g}$. P. $25 b$ shows a method adopted to make a mare that continually grabbed the reins quite safe. It is the invention of Mr. Horace Barry, of Limpsfield, Surrey, and consists merely of a fly or insect net. Mr. Barry writes: "In my mind there is nothing so graceful as a natural tail. As to its danger, it is comparatively small, in my experience. To make it quite safe with a bad lıorse I have adopted a safeguard which I saw in India, and which is, I believe, Australian. It consists merely of a net. If a horse is properly broken I do not see why he should mind the reins under the tail any more than the crupper. Mine do not, and every now and then I purposely put the reins under my horse's tail (in the stable yard before starting, and in other places) to get them accustomed to the foeling. I do not find any more difficu?:y with mares than with horses."

671. I. $118 a$ shows a simple attachment that is scarcely noticeable (in the photograph it has been painted in white). There is a strap on each side passing to the breeching-supporting strap at one end and tn a small strap placed loosely around the tail at the other. This strap must not be tight round the tail. The horse can move its tail as much as it likes, but it cannot grab the reins.

Another method is that of plaiting a small ring into the hairs of the tail near the splinter bar, and attaching a loose tape from the ring to the bar. In summer, of course, this would prevent the horse from using its tail to drive away flies. Great care must be taken not to unharness the horse from the vehicle without first untying the tape.
Another method is to have two small rings fastened to the harness over the croup, through which the reins pass; reins are thus kept from slipping down the sides of the quarters.

A patent device, known as Harsh's hip strap, consists of a small stud that is strapped on to the harness over the croup that prevents the reins from slipping down the side when they are left loose, or when the horse is driven with a loose rein, thus preventing the horse from getting his tail over the reins when he switches around at a fly. An arrangement such as this is useful for some tandem ieaders.

672. If, howevi the tail does get over, the horse, if properly irained, as described above, should take little notice of it, and it is generally quite easy to draw the reins out again, or one can lean forward and lift the tail back over the reins.

I have seldom seen accidents with undoc'd tails, but I have seen scores with docked tails. In fact, whenever a docked horse gets his tail over the reins, it is almost impossible to free them. It usually kicks violently, probably reinembering the operation performed on its tail.

P. $119 a$ shows the long-tailed horse used in four-in-hands in British Columbia, which is similar to those used all through the west of North America. These drivers never seem to have any trouble, and if asked such a question they would laugh.

I have noticed a few cases in Canada where ho. es had their tails plaited loosely to the ends of the breeching. This was done because they had acquired, through being jerked in the mouth, the habit of trying to grab the reins. This, of course, would not be done in the fly season; other methods would be adopted.

673. Some farmers use the weak excuse that a long tail is liable to become caught in the dump cart. (P. 118e.) This is supposed to occur after dumping the load, when the box of the cart is brought back to its normal position. If there is any real danger, then the law should compel an alteration in the construction of these carts; but as they are used without any trouble in many countries and in many parts of England, I think that, ger..-ally speaking, the excuse is employed by advocates of docking. At any rate, a net or screen could be placed on the front of the cart, just behind the horse, which would make it absolutely safe.

674. The London Coaching Club has not displayed its knowledge of horsemanship in some of its excuses concerning their "leaders." If they cannot manage with long-tailed horses, how is it that caach-drivers can in the West? Are drivers in London inferior?

675. Smariness.-As regards this excuse, it is only a matter of opinion: "Beauty is in the eye of the beholder." One thing should be remembered by all supportors of docking, 
whether they think docked horses look smart or not, and that is that humanity and justice stand ahead of mere looks. A glance through the photographs in this book will convince ore that there is not all that difference as regards smartness. Personally, I think smartness lies on the other side. Nature's own design, in 99 per cent. of cases, cannot be imitated or improved upon.

The average person does not admire a docked horse. Many people wlo do admire them think that docking means trimming the lair.

676. When Nature designed the horse she gave to various breeds tails of different lengths. For instance, the cobby type (P. 29g) has a shorter lock, whilst the longer-legged, lighterbuilt horse has a longer one. A carefully-bred horse of any breed has nearly always a comparatively short dock; it is the coarse-bred horse that has the very long dock. Hence it is all the more absurd to dock well-bred hackneys, Clydes, shires, etc. People should realise how ridiculous they are apt to look perched upon or sitting belind a horse with a hat-peg tail. (P. 113.)

\section{"Oh wad some Power the giftie gie us}

To see oursels as others see us !"

677. Nealness. - The excuse that docked liorses are neater is again a matter of opinion, and in no way justifies the existence of the practice. As a matter of fact, there is no doubt that a well-kept tail is neater than the average docked tail we see. The only way to make a docked tail look really neat is to trim it continually, but this will deprive the horse of all fy defence, whilst the natural tail looks neat whether left long or banged to various lengths.

It is quite clear that tha practice of docking exists in order to satisfy a certain fashion or whim. This whim is encouragerl by unprincipl, I people, who are found even amongst horse dealers and horse-show followers.

I think the clearest point that proves that docking is a mere fashion is that hackneys and show heavy llaught liorses, and in some countries cobs, are the three types commonly docked. Hunters, saddle horses, carriage horses and the ordinary grade farm horses are not. We find harness horses in both grollps; therefore the rein excuse can be eliminated. In reality the hackney is generally driven in an American buggy, a vehicle which is used with most long-tailed horses in the United States. Then, again, mast of the heavy draught horse: are never driven at all, but are used for breeding purposes, so how can the rein excuse, or any other excuse, be nsed? I ask a horse-loving nation why it allows these horses to be docked?

Realising, therefore, that docking is merely the result of a fashion, we will consider the chief culprits.

678. There are three classes who encourage it:
1. Ladies and gentlemon who own private turn-outs. These people mostly know little or nothing of the practice. They mean well. I do not attacl much blame to these people because they drive behind docked horses, but I certainly blame the dealer that sold these horses.

2. Poor peuple, who will do anything to make a little money. Such people we see standing around sale stables. I do not blame them so much. They perform cruel operations, not with the idea of disfiguring a horse, but in order to mal.s a living.

3. The horse-show man or woman, or horse dealer. To this type of person, who encourages docking for no tangible reason, I attach nearly all the blame. They know exactly what the practice means, and, further, they do everything in their power to encourage it, whilst it is in their power to prevent it. They know it is illegal, because they try to hide it.

679. The horse show could be the means of inculcating kind treatn snt to horses instead of encouraging mutilation and other forms of cruelty as it does to-day. Gross cruelty is practised by ignorant horse-breakers in preparing horses for jumping, etc. The Hunters Inıprove ment Society lias done enormous good by taking the stand it did a few years ago, when it roquested that all horses shown in their shows should be undocked. This spread all over the world. p.ince Christian was president of this society at the time, and it was in great measure due to llis Royal Highness that the motion was introduced.

People who encourage this practice have been criticised freely, but not a whit too severely. The Toronto Evening Telegram said: "Docking is mainly due to thoughtless people."

The Toronto Daily Star said: "Docking is largely due to horse show followers with no knowledge of, or respect for, a horse."

These are the opinions of two leading newspapers out of ai least a score that I have read on this one poini. The breeder would cease to dock his horses if he knew that the purchaser would not buy them; therefore, by refusing to buy them we he!p the cause of humanity.

680. These adherents of docking will do almost anything to gain their end. I have known of instances where men have damaged purposely the lail of a horse in order to have it docked. In truth there is not one in many thousand that gets its tail damaged accidentally, necessitating amputation. Some people like their horses to look different from the commercial horses on the sureet, but surely the difference need not be made by mutilation. A private tirn-out is dis. tlnguished by its appointments, by its harness, livery, carriage, etc., being well cared for.

Some people drive quite commonplace horses, but because their tails are docked, imagine their turn-outs are fine ones. Not only do they expose 


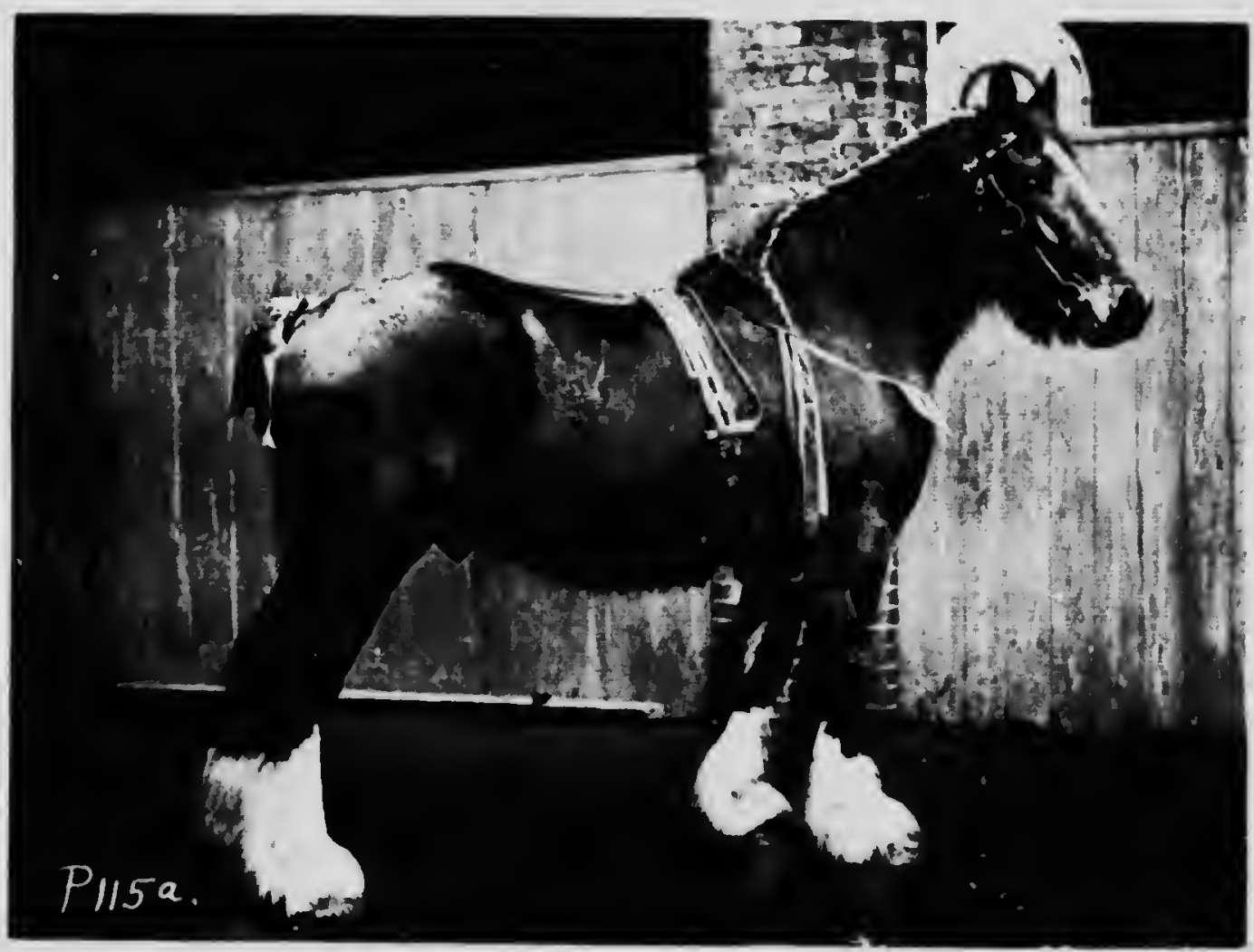

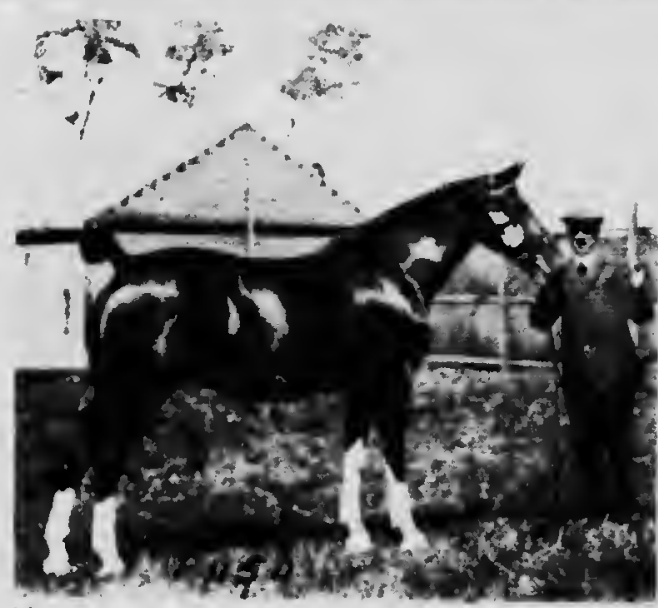

CRLEL. IND INARTISTIC

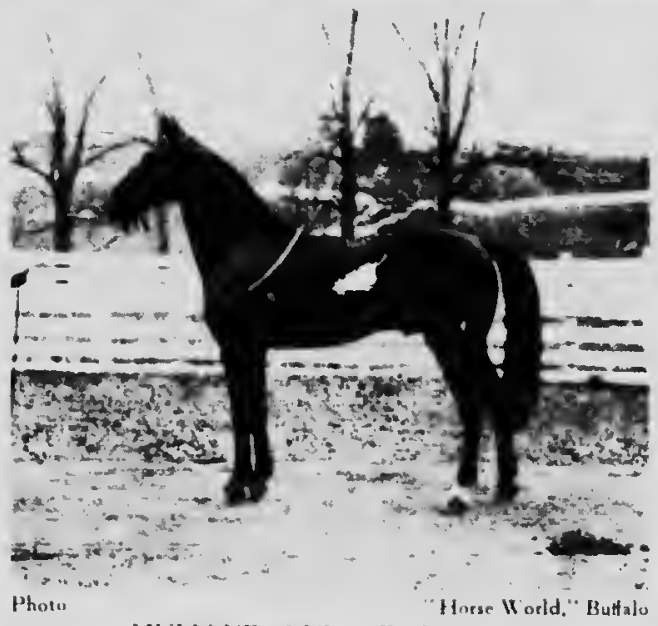

HUNINE IND BEILTIFUL

$a$, Shire Stallien "Rickford Coming hing," Cupyright Photo: Sport and Cieneral. b, Reproduction of a Post Card that was Sold all over Canada and the States

It is regrettable that certain horse societies do not follow the humane example of hinntr and polo pony societies, instead of being responsihle for hundieds of horses being dorked every year in order in stand a gend chance of winning prizes. See P. $43 h$ 

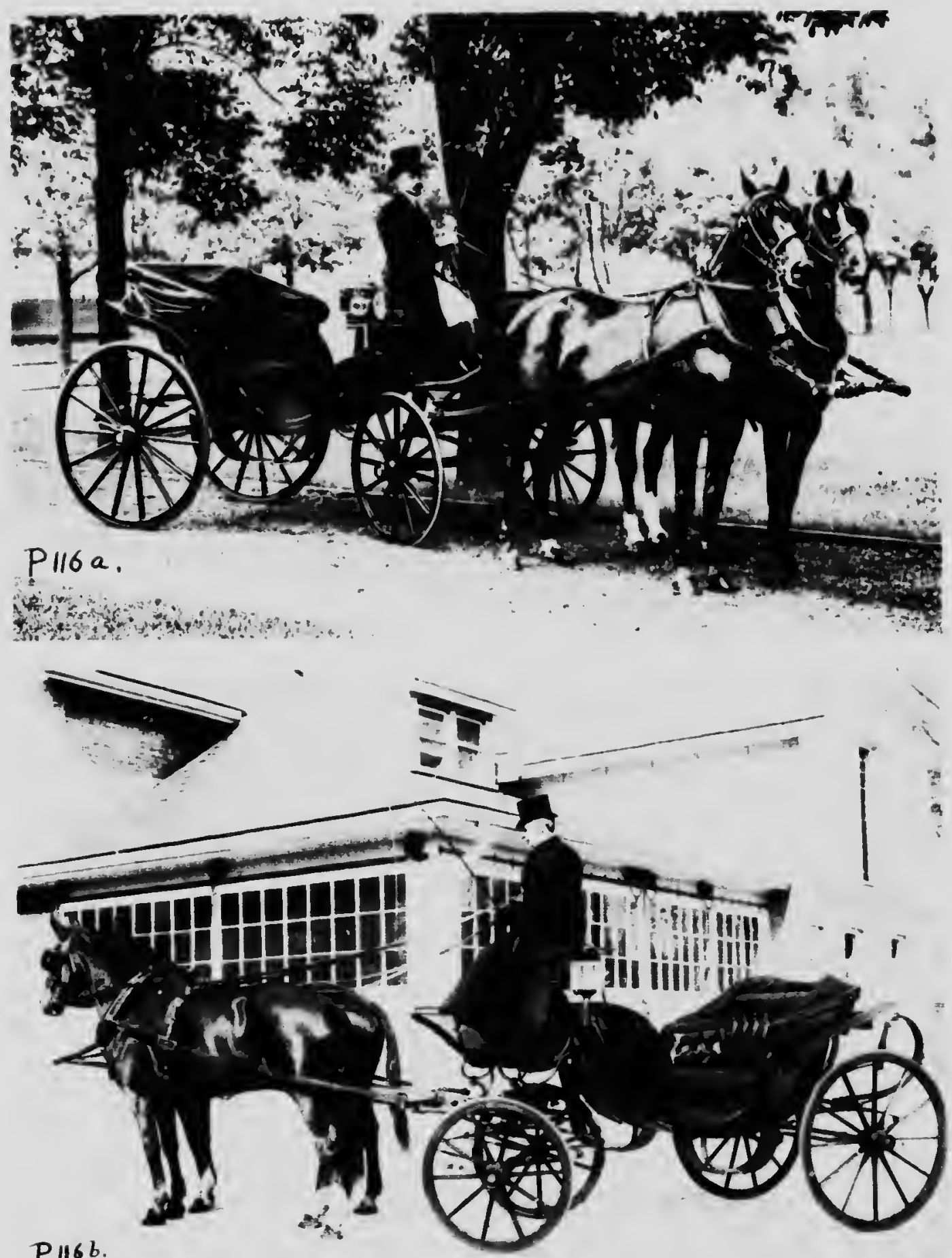

THE BEAUTY OF THE LONG.TAILED HORSE

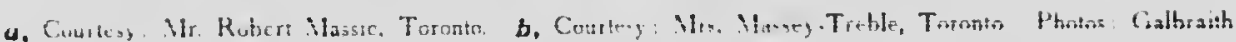


their own want of knowledge, but make the whole practice ridiculous.

681. The Hackney.-The hacknoy is really a most besutiful animal if left as Nacure designed him. (P. 48h, 49a.) Hackney dockers forget the following points:

1. The liackney lias naturally a comparatively short dock, and therefore trimming or plaiting is all that is necessary for those who like a short tail.

2. He seldom has a kink in his tail or carries it crooked.

3. He always carries it better arched than most breeds ; in fact, ho is very similar in many respects to the Arab, which is never docked. (P. 18h, 21a.)

682. I have seen several pairs of horses belonging to private owners in Canada of late, with one horse docked and the other (a new one) witt. a long tail which had been plaited up cr banged short. This shows to the observant horseman that the owner at least understands the horse's requirements, and that he places humanity bofore fashion or appearance. An obstinate coachman, of course, says that he could not possibly drive an odd pair.

Some people dock a horse and then leave the hair to grow long. What sense is there in this? It is often insanitary and irritating to the horse, because he is unable to keep the loose hairs away from his quarters. It certainly is not neat. P. 105, 113 illustrate the tails of some show hackneys. Such are hideous; yet, if the hair is trimmed right off, the horse has no fly protection at all over his hindquarters.

683. Scores of horses, especially heavy draught hurses, are docked simply because they are going to be put in a show, and the fashion ordains that certain breeds, unless docked. stand little chance of winning a prize. I received the following encouraging words from a friend in the veterinary profession in Western Canada a short while ago: "You must have done much good for the horse here, because docking, which was fairly common while you were practising with us, is now extinct ; at least, I am thankful to say we are doing none of it."

Grooms and certain fanatics seem to love to see the horse's buttocks (the gracilis region especially) shown off. These people seem to have no control over their enthusiasm. What the young lad in the stable is to learn from such practices passes comprehension.

Great care should be taken, in harnessing horses into a vehicle, not to harness too far back, as is so commonly done in England, allowing in many cases the tail to rub against the front of the vehicle.

684. Prevention.-Now wo will consider the various ways of stopping this barbarous practice: by the law, by setting the fashion against it, and by means of the horse show.
The quickest and easiest way, I think, is to forbid the appearance of docked horses, except those that have been docked before a certain date, in the show ring. If this were done, dock. ing would rapidly become extinct.

Another way is to adopt the method used in California, where all horses that wore docked before a certain dalo are registered in records. Any horse that is docked must therefore have a certificate, and when the owner cannot produce this, it is prima facie evidence that the horse, as it is not registered, has been docked since the passing of the law (see Chapter XV.). This has its disadvantages, as it entails considerable trouble.

The second way, that of selting the fushion against the practice, is what has happened in England and other countries with hunters, saddle hurses, and the better class of carriage horses, and also polo ponies. This method, however, is slow, and, of course, there are many fanatics who do not change their opinions. These the law should get at.

685. Now, if horse shows forbade docked horses frois entering the ring-as, practically speaking, thra Hunters Improvement Society did some six years ago-all horses would be as the hunter is now-a horse, and not a "fake," as the hackney is. Fine horses do not require to be mutilated in order that they should win prizes. Such a custom might exist amongst barbarians, but one would hardly expect it to exist openly in a civilised country, yet it not only prevails but is encouraged.

The type of person, as a rule, that shows in these bobtail classas does not rank amongst good liorsemen, and in many cases they are not very desirable. I was glad to see these classes poorly patronised at a recent horse show in Toronto, and the people less interested in them. Horse show authorities have it in their power to stop this craze in a few months. The Hackney Horse Society and the Shire Horse Society should realise the gross cruelty which they are responsible for, instead of meeting well-informed criticism with such inconsequent replies as "The subject has been ventilated before."

Even if horse shows forbade docked horses from entering the ring, there would still have to be close police and S.P.C.A. inspection, because, as I have already hinted, there are people who still think that an undocked horse should not be allowed to live.

Some years ago the Royal Agricultural Society passed a resolution condemning this practice, but at the following meoting a small section of the members, possessed $O_{i}$ great influence, used this influence in getting the motion voled down. Among them was a man who was supposed to be a lover of horses, yot his action Led to the defeat of one of the most humar.o motions ever proposed in a civilised countis. 
Hence this person was more or less answerable for thousands of horses being docked.

686. If people refuse to buy, or drive, or ride docked horses, dealers will cease to dock them. Sucli harmful fashions teach cruel idas to the young and have a hardening effect which goes far to ruin naturally good dispositions.

Docking advocates used to say that hunters must be docked, etc., but now they have to change their tune, and urge that hackney's must be rlocked.

687. The veterinary profession, I am sorry to say, is not improved by the existence of such cruel fashions. Of course, there are scores of veterinary surgeons who now refuse to dock horses (see (hapter XIV.), but there are others who are not wealthy and who are afraid of losing their practice if they refuse. The veterinary profession is a most noble one, and I am thankful to say that there are many in it who do not countenance the custom of dorking and, indeed, do all that lies in their power to assist in thr restriction of the practice.

If the veterinary colleges, however, were more struct in granting certificates, there would be fewer of tire type of man who does no credit to his profession. A great number of vets. have openly denounced docking in the Canadian and Initel States Press, and many have declared that they have abandoned it for ev'r. The Ottawa papers said a few years ago, "The capital is proud to boast of the fact that three of its leariing veterinary surgeons have openty declared in the Press thit they will not perform the unnecessary operatiou of docking horses any more."

In many parts of the States a good tail alds twenty dollars to the value of a horse. I have known of several Americaus who have offered $\$ 500$ extra for a good English lackney with a tail.

For a long while the dockel horse in France was known as the Finglish horse; so the bobtail horse today is known as the Finglishman's horse in many parts of the United States and Canacla.

688. Dr. Fleming sairl that norse shows might be largely instrumental in abolishing docking by refusing to admit ciocked horses, or, at any rate, not awarding them prizes.

Shortly before his death this great surgeon, while chief veterinary of the British Army, said in a public speech: "Thus, you see, there is not cnly the pain at the time, and for a long time afterwards, but the operation deprives the animal of its most important defence against insects."

The Press in Canada and the United States has done a great deal of good in denouncing this cruelty. In England, I am sorry to say, the Press is much slower in taking the matter up. I hope, however, that when it does take it up it will do so thoroughly. But it must not be supposed that every British newspaper is silent on the subject. Wo shall presently see that powerful protests have emanated from this source, and who can doubt but that more shall follow?

689. Our Royal Family has set a sufficient example to those who wish to be up to date. Queen Victoria and King Edward both denounced the practice, and used their influence against it. Queen Alexandra, as stated above, refused to accept a pair of docked horses, and so, too, as we have seen, did King George.

Dr. Rutherford, V.D.G., of the Dominion of Camada, said to nie: "The nujority of horses look mucl better undocked, and the practice is, after all, only a fashion or fad which can be abolished without injury to anyone. Not only is the operation painful, but the subsequent annoyance and irritation to which docked horses are subjected in the summer-time from flies, etc. especially when at pasture, is in itself a sufficient argument against the practice." This was published by his request all over Canada and in other countries.

Mr. Basil Tozer, in the Daily Graphic, in June, 1912, at the conclusion of an interesting article on the International Horse Show, said: "In spite of all that has been said and written by Walter Winans and by other men whose ouninns command attentiou against the ridiculous fashion of amputating horses' tails and then singeing the stumps until they look like hat pegs, alvocates of the so-callcd docking are to be seen daily at Olympia. Half a dozen wellknown sportsmen, in a box close to the royal box on Tuesday night, wore discussing this very point, and the opinion they all expressed was that animals with their tails chopped off, as are the tails of Kitty, Why Not, Pat, and a dozen others, ought, ipso facto, to be disqualified."

A leading article in the Daily Graphic said : "Not unil the horse-owning public insists on purchasing undocked animals will the practice be stopped. The subsequent torture endured by docked horses in the fly season should be sufflcient to stop it. Why the stumpy tail should be thought smart it is difficult to realise. It is sincerely to be hoped that other societies will follow the splendi example of the Hunters Improvement Society."

The Cavalry Journal stated: "So persistent is mutilation that some have to make a mental endeavour to prefer whole tails like that on the King's horse to the stunted, useless, indecent, inartistic things like that on the German Emperor's horse. The adjective 'smart' is akin to the German schmerz, i.e. pain Smart may certainly be used of docked horses likely to suffer fly persecution in stable and paddock for twenty years following the initial pain. Think of twenty years of pin-pricks. It is the rein danger 


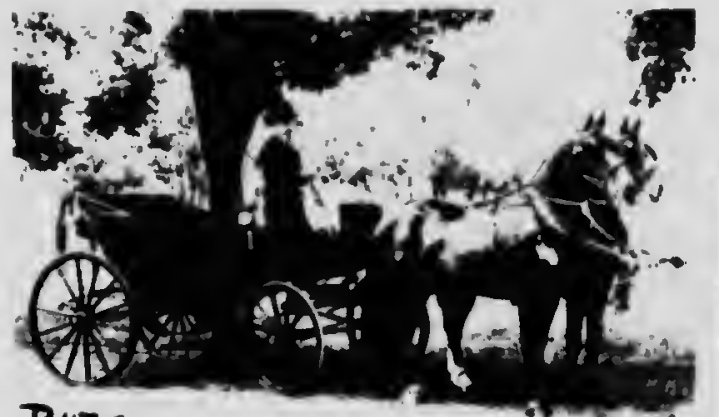
P 117 a.
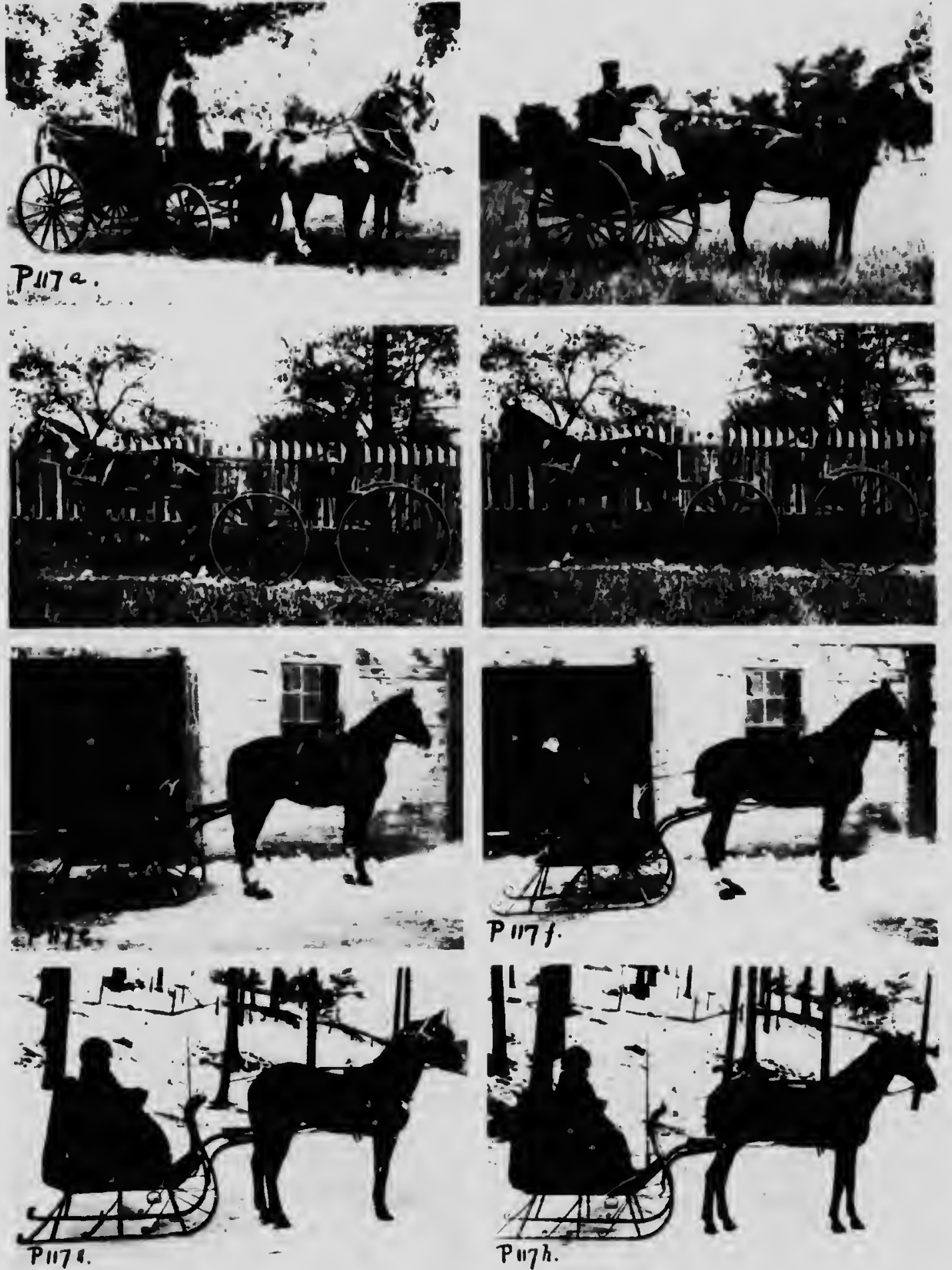

Uniocked Horses: Tais Long. Mated, of Banged. Coutlejy: a. Mr. R Massie, Toronio. b, Major Rrnnett. Kingston, Ontario. e, f, Mr. P. Cardinal, Ottawa. $c_{0} d, g, h$, Mr. W. Wilson, Toronto. Photos: a, Galbraith, Toronto: Remainder by the Author 
II. NTI: II
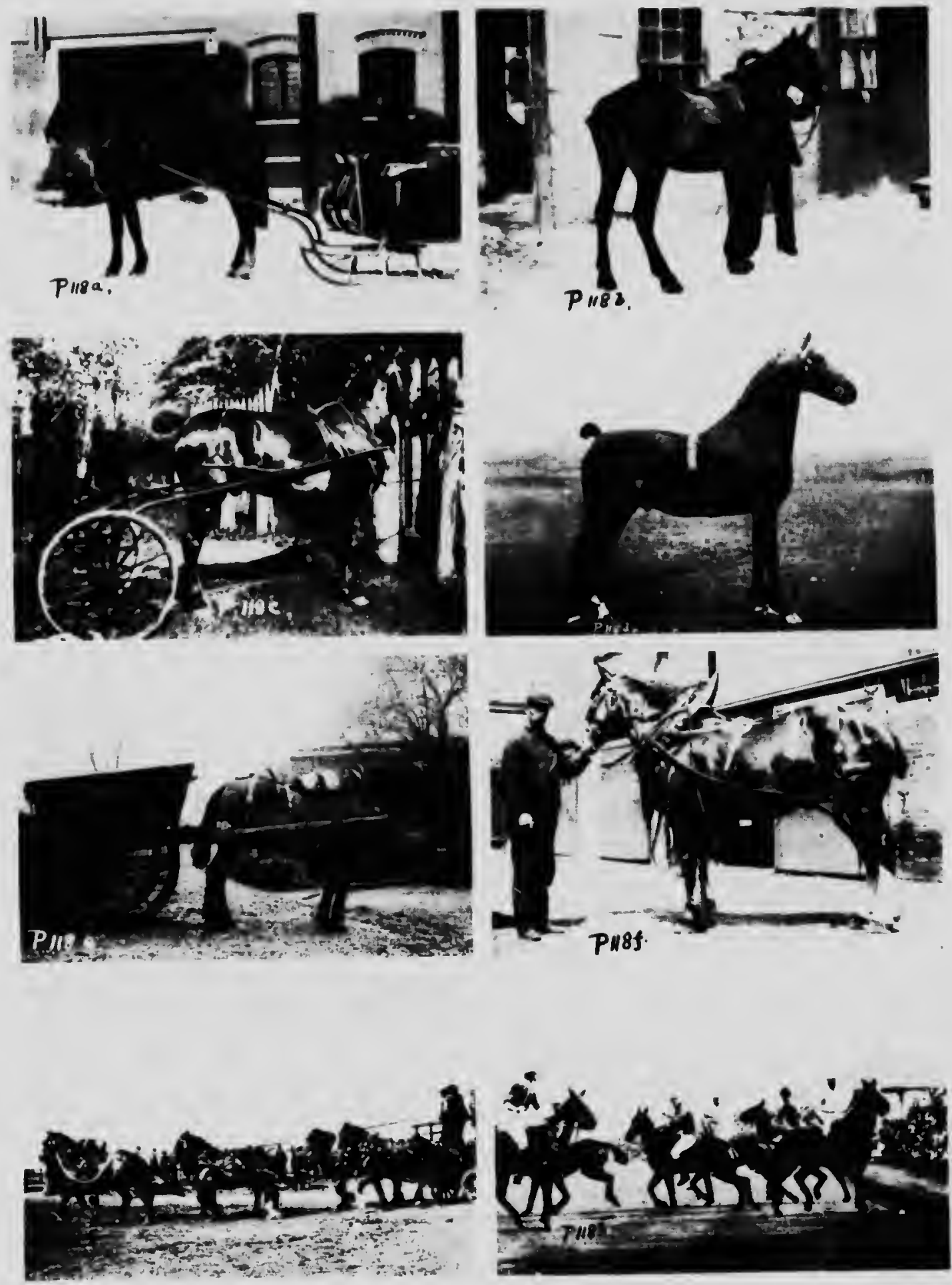

\section{DOChING}

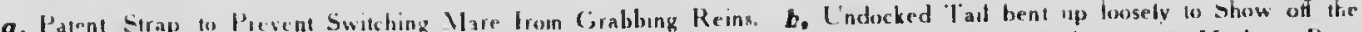

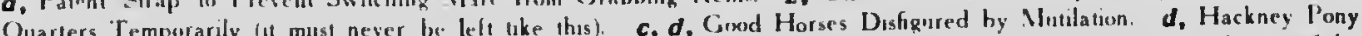
'. Talke W'ildfire.' The Tip (Cast (see Text) and a Suffolk Punch. f, Quarters of an Undocked Horse shown off by 1'lathng

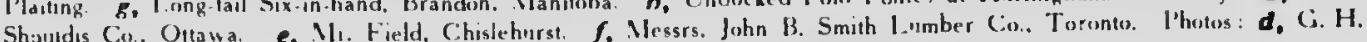

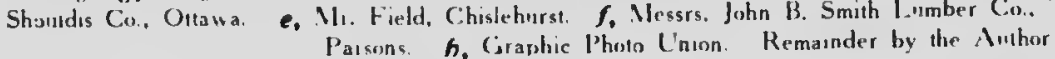


excuse that is robbing the horse of his first aid, of his first line of defence against winged vermin, coll wind, and rain. And let us not forget that the horse-dealer achiever selling you your optical illusion (strong hindquarters) at an enhanced nrice for a damaged article."

690. I received the following remarks from the head of one of the largest horse-owning firms in Canada: "Docking horses of any description has always been discouraged by me. It is, I am sorry to say, rather prevalent amongst importers of heavy draught stock, who think that it adds massiveness to the appenrance."

I liave received scores of letters from horsemen of note, and some of these will be quoter in the next chapter. As an example of one, Lord Leigh, a well-known horseman, writes: "I fully sympathise with your views as to the docking of horses' tails."

The Toronto Sunday World says, at the conclusion of a lengthy article: "With such illustrations before one it should not be necessary to use any further arguments in favour of nondocking to the people of Canada. But as long as horse shows consider docked horses eligible to compete, so long will the practice continue, unless forbidden by law, as is done in many of the States."

A noled horseman writes me: "If people could realise how absurd they look perched belind a horse with a bob-tail, it would have far more effect than reminding them of the cruelty. We must remember the type of man that encourages this practice."

691. People who dock horses should be severely punished. Most of them, I find, are great cowards, and cowards dislike physical punishment. Small fines, such as magistrates are too prone to impose, will never meet the case.

Our Dumb Animals (Boston) says: "From numerous articles published in the Press it is evident that the bob-tailed horse is rapidly growing unfashionable in Canada. The Duke's longtailed four-in-hand is, of course, admired by everyone. Trimming the hair is all that is necessary for those who like a short tail."

The Rider and Driver (New York) says: "They are no longer tails, but hat-pegs. This refers chiefly to the English hackneys."

The Troller and Pacer (New York) says: "The custom of docking horses has no justification whatever, except a senseless and snobbish deference to the decree of fashion."

692. The Folly of Docking.-Telling is the power of ridicule, and one hopes for forcible support from this quarter. I recoliect a man in Western Canada, unconscious of his own misdoings, having a horse docked and driven in tandem. Fie thought he would be up to date and attract attention; he was not admired, but it was not until several people told him what a fool he was that he realised his mistake. "When in Rome do as Rome does," applies also to other countries. Many people prefer docked horses becauso they liave been used to seeing them; but they would be just as happy if the practice became extinct. Anyone who has lived for lons in the Unlted States or Canada and has noticed the lovely types of undocked horses in all kinds of vehlcles must confess how much more handsome they are compared with the poor creatures that suffer from the caprice of Fashion.

I cannot conceive why some docking advocates absolutely refise to own natural horses, and even despise those who work for a good cause. Because a poor man imagines he is a king or a teapot he is confined in an asylum; but the man who uses every effort to encourage the wanton mutilation of an animal is allowed his freedom in a civilised country. No wonder the American papers called such people "Anglomaniacs."

A Christian should be satisfed with trimming the hair. In China, the lowe of superstition, by which, in the past, the inhabitants have been doninated, they now see their folly, and are giving up two of their degrading custrms, foot binding and opium smoking. These, however, only affected the people who practised them, and not dumb animals. When the Chinese realised their folly, strict repressive laws were passed; when we realise ours, we allow the practice to continue. Some years ago a noted Chinaman visiled England, and on his retum home said: "The ladies wear long tails that are useless and insanitary, and yet they deprive their horses of the tail that is of the greatest necessity."

The sight of a horse constantly switching its docked stump in the fly season and turning its body into all shapes while endeavouring to reach fies is a cruel spectacle.

698. Dr. T. C. Evans, D.V.Sc., of the Dominion Experimental Farm, Ottawa, writes me: "Docking is an inexcusable piece of barbarism, except when the tail is diseased, either by a pathological growth or by necrosis. The latter has been caused through grooms and horse dealers tying up the tail tightly and leaving it so for several days; the after-effects are most distressing."

A docked hackney cannot be turned out to enjoy pasture in the summer, and just for this little difference in eppearance it has to be taken in the day, fed, watered, sheeted, and kept in a stable. I came across a man who told me his former occupation was that of assisting in redocking hackneys in singland for the horse shows.

Imitation hackneys are not at all uncommon, and the following is an example of what the modern hackney is responsible for. I heard a man ask another if he was going to show his horse, that had high action and a long tail, in 
the coming sliow. The reply came that he did not know in whllch class to shnw $1 t$, whereupon he was told: "Cut its tail ofl and enter it in the hackney class."

Advocates of docking will dock a liorse in any country; one has only to see the tailless hackney in fly-stricken comtries to verify this. English and Scottisl horse show's are respunsible for the terrible fly torture in Comala and other hot summer countries, the docked Clyde mare being one of the worst examples of ignorance, foolistiness, and cruelty.

A pair of freshly-docked horses was seen in Ottawa about eight years ago on the streets with the wounds dripping with blool. The matter was taken up and the case prosecuted. A police inspector came into the offlce of the Toronto S.P.C.A. and said that he had just seen a horse docked, the hot iron applied intermittently for twenty-eight miuntes. This case was also prosecuted.

I noticel a sien of modern times in the ladies' Field a few months ago. An advertisement read : "Mare Mona, very smart, bay, undocked, Is hands, 6 years, quiet to ride or drive, etc."

A well-known London firm of jobmasters, when they send horses out on hire, request that the hairs of the tails be neither trimnied nor pulled.

694. Will such cruelty be left unpuinished?

The following examples of mitribution overtaking persons who were guilty of cruelty to horses may be altributed by some to the long arm of coincidence, yet I feel they afford an answer in the negative to the above question.

A farmer in Western Canada was boasting one day of having docked a number of his Clydes for a coming show; that night his wife suddenly died.

A horse dealer who formerly docked a number of horses lost his leg as a result of a kick from one of his victims.

A veterinary surgeon was badly mauled by a horse whom he had mulilated; the never re. covered.

A foreman of a stable had a number of his horses docked secretly; three necks afterwards his little boy chopped one of his feet off with an axe.

The proprietors of "Relucine" say: "A man who docks a horse commits a crime. Every person who has a horse docked is an accessory to the crime. Every person who uses a docked horse is an accessory after the crimt, and by his or her influence stimulates or encourages the commission of the crime."

695. Since writing the foregoing sections a Bill has been introduced by Sir John Rolleston into the House of Commons to forbid the dock. ing of horses, and supported by a large number of the leading horsemen in London. Mr. Walter Winans, the celebrated American millionaire lioreman, has done an immense amount of guod in supporting this Bill by demonstrations In public witl his beautiful long-Lailed horses. He lias also had clinemalograph pholographs axhibited all over London and the provlnces, of the operation of docking, and also films showing the beauty of a natural tail and the method of training horses to become accustomed to gotting the reins under the tail. I recuived a lotter from him in which he slated that the only opposition he got were rulle letters of abuse froin men who believed in docking. This shows the sort of men who advocate the continuance of this barbarous practice.

680. By request of the edilors of sonie fifty of the leading newspupers in the United Kinglom, Canada, and the United Slates, I have prepared articles on the subject of docking. The following section is a summary of the points bronght forward in this chapter, and is very similar to the articles just referred to. It is reproduced here by kind permission of the etitor of the Canadian Citizen (Ottaws).

The number of letters I have received from the Royal Family, nouble horsemen, political personages, and others on both sides of the Atlantic is sufficient evidence of the influential opinion against the mutilation of the horse.

\section{Summary}

697. Why does a civilised people allow docking? Anyone who has had much experience, and who has studied the horse closely, must have realised how brutal and foolish is the fashlon of locking. In support of a Bill now belore the Britisl Parliament, it is only right and fair to our friend the horse that if ie: joints sirould be brought out, points that absolutely prove that locking is never necessary (except in one in a inillion cases, due to accident), and that its present existence is llue to only one thing, the show ring, and llotably the English hackney, Shire and Clydesdale show ring. The chief use of the tail is not as generally known as it ought to be. There is a fly muscle extending all over the neck (except at the crest, where the mane reaches), thoracic region, forearm, the loins and abdominal region. This muscle (the panniculus carnosus) does not extend over tha hindquarters posterior to the hips or between the thigus. It is used whenever the horse wishes to twitch the skin to rid itself of flies. If a horse is docked, it can never have any defence from the fly over the parts mentioned above. If the hair has only been banged off, as is common with some harness horses and military horses, the lail will still reach over the quarters.

It is barbarous to turn a docked horse out to pasture when the flies are active. The tail that has been banged, even very short, will soon grow again; a docked tail never will. This is why the veterinary prolession, with which I was 

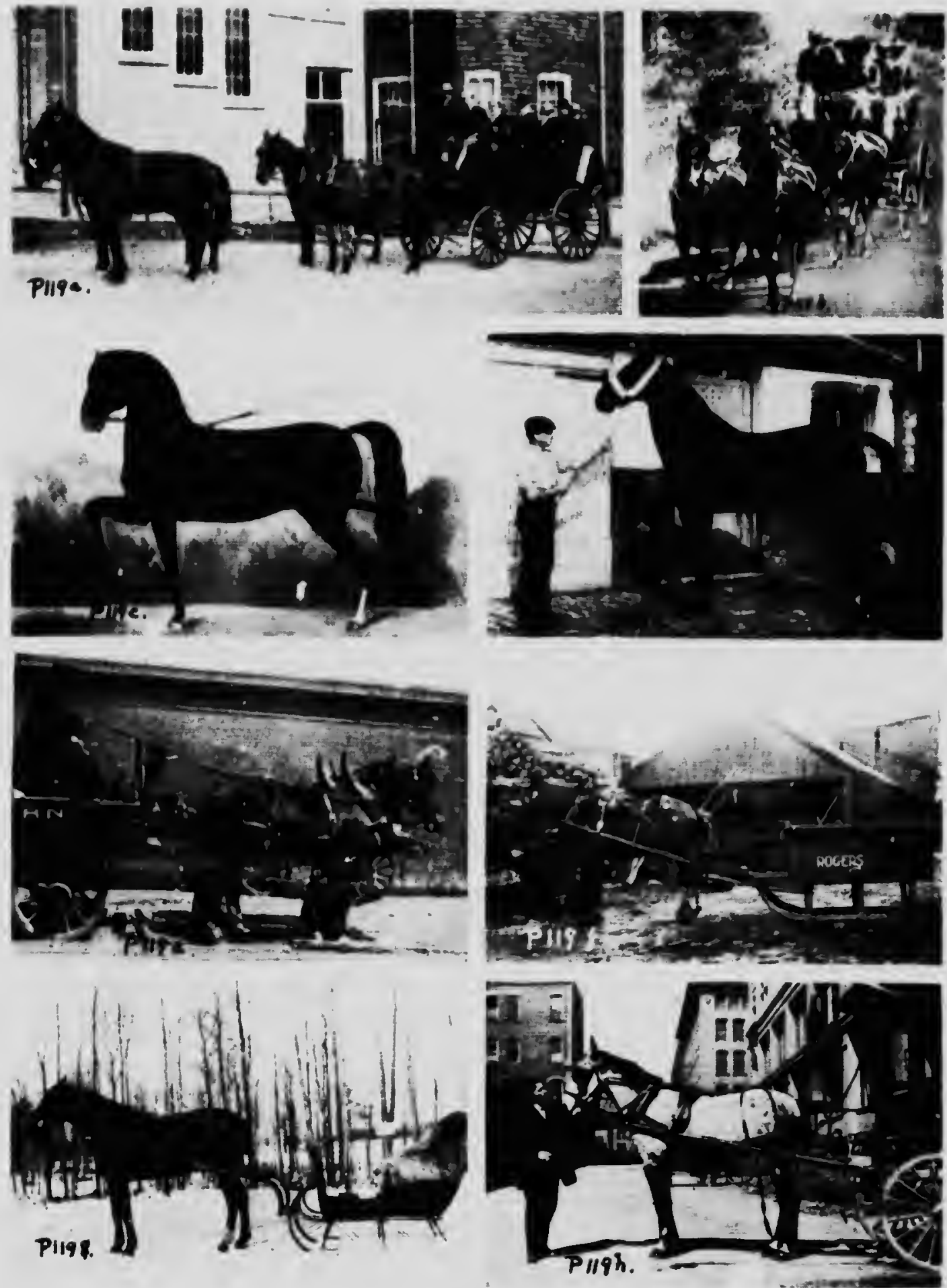

DOCKINC;

$a, b$, Long taled four-in.hands. Couriesy: a, San Francisco S.P.C.A. b, Canadian Pacific Rallway Co. (Banff. B.C.) c. d. The W'ell-carried Tail. Courlesy: c, Electric Transter Co.. Ollawa. d, Mlesirs. Themas Tilling. Lid.. London. e. The Long Tail in the Hly Season. Courtesy: Canadian Northern Tiansler Co. Toronto. f, $8, h$, Evamples of Natural Tauls Plaited up. Couriess: f. Elias Rogers Coal Co. Turonto. g. Mfr. W. W'ilson. Toronto. h, R. Simpson Co., Toronto. Photes, $c$ to $h$, by the Nisthon 

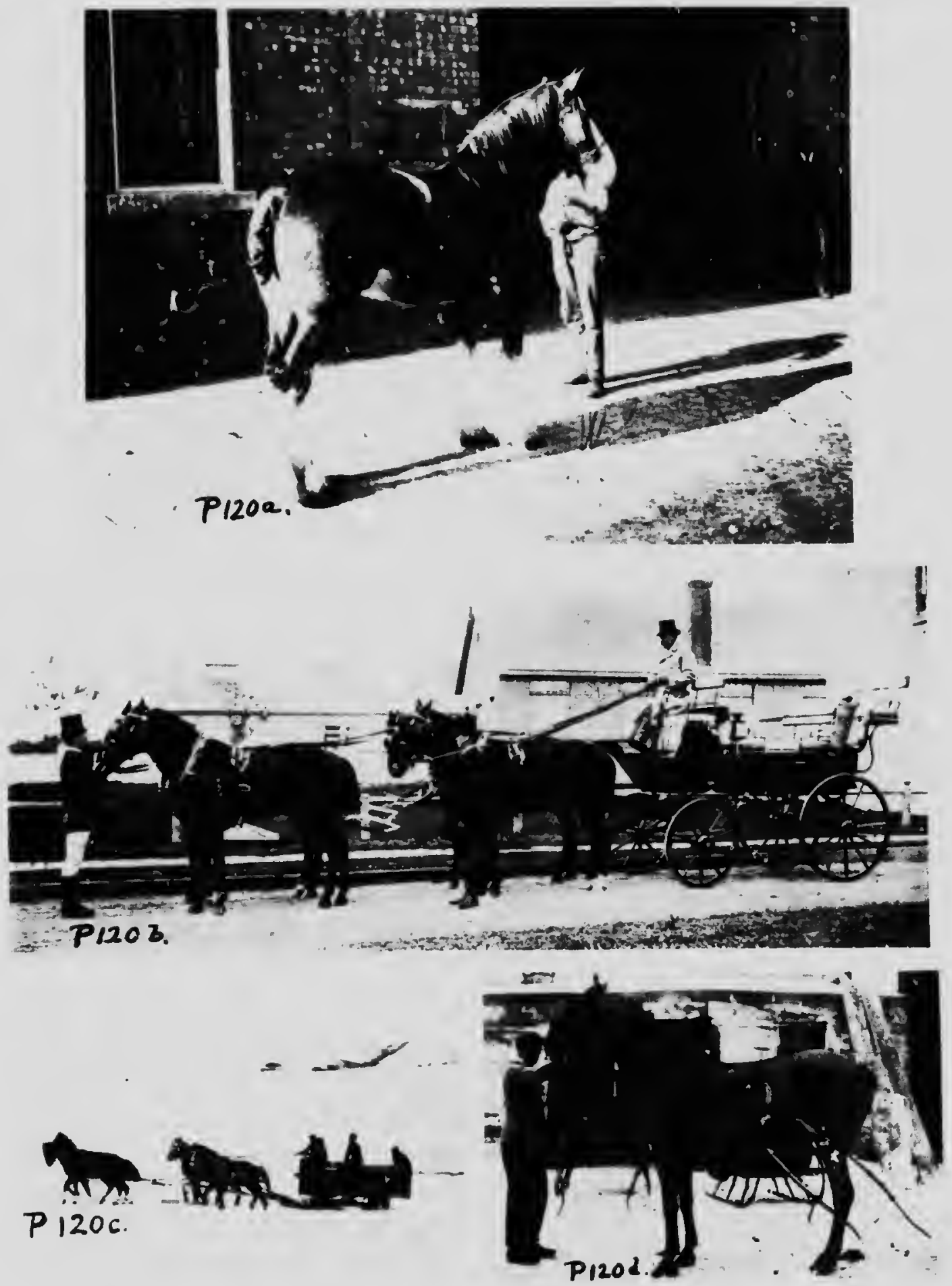

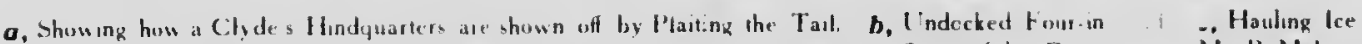

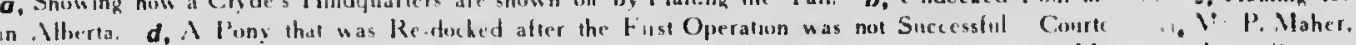

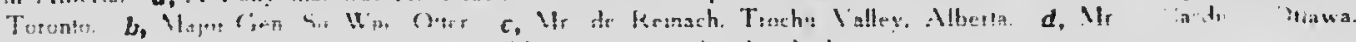
I'husers, $a, c, d$, by the Aushor 
connected for several years, has advised breeders of bruod mares to spare them their tails, as so many foals have been killed by their mothers kicking them, when trying to drive away flies, while the foal is sucking.

Docking is supported by a fow untenable excuses that can scarcely convince even those by whom they are advanced. They are used to support the real reason, smartness, or a curious ambition to see the horse's hams fully shown off. Plaiting or banging the hair does this without resorting to anatomical mutilation. The excuses whicl are beived by the inexperienced are: clean!inass, strength io hindquarters, and danger $\mathrm{i}$, driving. The fi st may be brushed aside unt silatingly. Any groom who would use it shol. ho dismissed. A lazy man cannot be a good i rsemaster. The second is an impossibility. It would not be used by anyone who has had any veterinary experience. Docking really shows of the hindquarters well, and gives the false idea that they are strengthened. It is a "fake." Plaiting and banging will have the dosired effect. The third excuse also explodes, because I find that there are $23,000,000$ undocked harness horses in the North American continent, and several thousand fours-in-hand with long tails. The trouble lies here: there are a fow horses that grab hold of the reins with their tails, the habit being generally due to jerking the reins or to bad hands. Such horses, however, can soon be made quite accustomed to being driven with a tail over the reins, and will allow the driver to draw the reins out and put the tail under again whenever he likes without making any objection. For instance, each day, as the horse sets out, and while going along, the rein is placed under the tail and again drawn gently out (without any force), and in a few days, with the worst cases, the horse will take no notice. It is the docked horse that holds its stump down with such force. A horse that is not trained to avoid this habit is, in my opinion, a swindle. I have driven the worst of undocked switching mares as "leaders" in tandem without any trouble after a few hours' schooling as above. The man who docks horses hes a great burden of veritable lorture resting upon his consclence. I used to see scores of draught horses in the fly-pestered West taken to the veterinary, a few weeks before a show, to be docked because they were going to be exhibited. These men are also responsible for several hundred Percheron horses of matured age being docked in Chicago about six yoars ago. Yet all these stud horses are never employed in harness, so the rein excuse cannot be used. Farmers in Canada and the States, as a rule, will not dock their forls, because no man who wished to plough or reap in peace would think of using docked horses in the fly season. It is the wealthy horse-show exlibitor that has his horses docked. The third prize at Toronto in the ligh-steppers' clase in 1913 went to a long-tailed horse, so it shows that all hackney judges are not beyond redemption. The English show is again respcnsible for such cases as this: an American judge, who figures in the English show ring, bought a famous trotting horse for several thousand dollars, had it docked, nicked and heavily shod, and has since won a number of prizes in the hackney classes. Is not this "faking"? One veterinary I know docked over forty horses for this purpose. The International Horse Show has to be credited to a great extent with the modern hunter and polo pony with their beautiful long tails, but I regret to say that it is answerable for a great many horses boing docked in order to compete in Hackney, Shire and Clydesdale classes. Docking is absolutely unnecessary, and could be dispensed with for ever. No docked horses, except for breeding purposes, are allowed to enter California. 'Two years' penal servitude is the punishment for breaking the law. When shall we follow suit and set an example to the rest of the world, or "go one better" by forbidding it by law for ever?

698. Colonel Seely stated in Parliament, in June, 1913, that as fow docked horses as possible were purchased for the army, and that an order had been issued that after three years from that date no docked horses would be purchased by the military authorities.

Mr. Harris, in the Toronto Humane Pleader, says: "The army has thus set a fashion in humanity. We are glad to know that for yeers no docked horses have been bought for the Canadian Regular cavalry." 


\section{CHAPTER XIV}

\section{OPINIONS OF EMINENT MEN, BOOKS AND THE PRESS ON DOCKING}

699. Captain Hayes, F.R.C.Y.S., says: "All Russian harness horses have long tails, and we hear of no trouble."

Justice Hawkins (Lord Brampton) said: "Docking is a painful operation; I hold a strong opinion against allowing fashion, or the whim of all individual or individuals, to afford justification for sucl painful mutilation."

Mr. P. C. Laverton-Har is, Managing Director of the Toronto S.P.C.A., says: "If the horse, why not the man? The absence of a tail makes the horse look ugly and out of proportion. The Almighty gave the horse the tail for protection from flies. It is an outrage."

J. Lee Osborn, the well-known horseman, says: "The tiling io aim for is to make the possession of a docked horse discreditable and unfashionable."

Mr. Walter Winans says: "When I went to England I found that horses got into trouble by getting their tails over the reins. The reason I discovered was the English custu.. of docking horses."

At a meeting of the City Council of Westminster, not long since, a resolution was moverl to abolish this unbecoming custom.

Mr. Harry Payne, the celebrated horse artist (P. 65), has done a graat deal c' good by his illustrations of the horse as Nature designed it. He has on several occasions denounced this fashion.

Dr. A. E. James, the leading veterinarian in Ottawa, openly declared in the Ottawa Press that lie would not dock any more horses. He says "that horses look smarter docked is only a matter of opinion, and that, as far as safety is concerned, an undocked horse is just as safe as, if not safer than, a dorked one."

Shakespeare, on the beauty of the tail:

" He sees his love, and nothing else he sees,

For nothing eise with his proud sight agrees.

Look, when a painter would surpass the iife,

In limuing out a well-proportion'd steed,

H!s art with nature's workmanship at strife,

As if the dead the living should exceed;

So did this horse cxcel a common one,

In shepe, in conrage, colour, pace and bone.

Round-hoof'd, short-jointed, fetlocks shag and long,
Broad brcast, fuil cye, small hcad, and nostrils wide, High crest, short ears, straight legs and passing strong,

Thin mane, thick tail, broad buttock, tender hide : Look, what a horse should have, he did not lack, Save a proud rider on so proud a back.

Sometimes he scuds lar off, and there he stares; Anon he starts at stirring of a leather:

To bid the wind a base he now prepares,

And whe'r he run, or fly, they know not whether; For through his mane and tail the high wind sings, Fannlng the hairs, who wave llke feather'd wings."

700. Hayes, in "Points of the Horse," says: "It is a relic of barbarism. The idea that it improves a horse's appearance is an absurdity, hecause mutilation, especially of a very appa! ent kind, cannot be an aid to beauty."

General Heath, Director of Remounts, War Office, says: "I am entirely in sympathy with your endeavcur to put an end to this barbarous practice."

Profissor Beery, the high school riding expert of Ohio, says: "I am radically opposed to the inhuman, cruel prictice of docking horses."

Professor McGillivray, the famous Australian horse trainer, says: "Never fancy you can improve oll Nature and dock your horses, thinking they are better with only a stump instead of a tail."

Francis H. Rowley, President of the American Humane Education Society, says: "I was the flrst person in this country to secure a conviction for docking horses. I cannot imagine anyone calling himself humane who would countenance for a moment such an operation."

H.R.H. Prince Christian said in the Times: "How would you like to see the winner of the Epsom Derby pass the pust with a bobtail?"

Professor Pritchisd, President of the Central Veterinary Medical Association and of the Reyal Veterinary College, said: "I look upon the practice es a gross act of cruelty, and, as the attention of the profession all over the country has been drawn to the question, I wish to enter into it completely. The excuses used by advocates of the practice have no foundation at all,"

701. Dadd, in his book, accounts for the 
practice as the result of want of knowledge and cruelty.

The Lord Bishop of Toronto writes to me: "I am glad you are waging war against the practice. I regard it as a barbarity unworthy of an enlightened, not to say Christian, civilisation."

Sir Henry Pellatt writes: "I have always felt very strungly against this barbarous practice, one that is enti "cly unjustified by the results."

Ruskin said: "Without perfect sympsthy with the animals around us, no gentleman's education, no Christian education, could be of any possible use."

Sidiley Trist, editor of the Animal Guardian, has written some splendid articles against this practice.

The American Field says: "The man who tortures animals is a dangerous member of society; he is a degenerate, who would commit just such crimes upon the human race were it not for his fear of punishment."

The late George T. Angell said: "I trust that no person present this evening will ever be guilty of such a crime against the horse and against humanity."

At the entrance to the railroad bridge at Cologne an equestrian statue of the Kaiser was erected; the horse has a short tail. Several Aluerican societies sent a petition to the Kaistr requesting that the horse be made as Nature designed it, urging upon His Majesty the bad effect upon the future generation that would be produced by such a conspicuous object.

Not many years ago the late Duke of West minster, at a meeting of the Royal Agricultural Society, moved that the practice be discontinued. He was supported by Prince Christian, Sir Nigel Kingscote, and many other noted horsemen; but, in deference to tive fashion then prevailing in England, the great society, whose object is to improve our domes!ic animals, decided against the Duke's humane and sensible proposal, and endorsed the continuance of a custom as useless as it is cruel.

Mr. Watts, R.A., in the Times, said: "There is degraded want of taste; the harmonious balance of the beautiful horse, the somewhat heavy head, must be balanced by a full tail. Setting aside the disgusting cruelty, this want of taste which can preier to see the noble animal changed by the destruction of the fine appendage into a thing that resembles the stump of a worn-out broom; and this is found amongst the classes that boast of education and refinement."

Sir Howard Vincent, in the House of Commons, said: "The system of docking causes enormous suffering to the animals, through their being unable to protect themselves against the pest of flies, and it was responsible for a great share of the mortality among the horses in South Africa."

The Sporting Editor of the Toronto Sunday
World writes: "The rruelty of docking and its unnecessary character completely smother any advantages gained by the practice, if there are any."

The Rev. J. G. Wood, in Horse and Man, says: "The result comes from the rivalry of grooms and coachmen. Mr. Brown's coachman sees that Lord Kennaquhair's horses have their tails docked, so nothing will serve him but to dock his own still shorter."

702. "Aims and Objects of the Toronto Humane Society" says : "The praclice is a cruelty that lasts through life. The victims can never afterwards brush away tormenting insects."

Terry, in "The Crime of Docking Horses," says: "Who that saw the modern hackney compared with a fine thoroughbred, and with an unbiased mind, would hesitate for a second in saying that the long-tailed horse was a beautiful object, whilst the docked horse was a monstrosity and, in fact, disgusting?"

Professor Alfred Savigear, in "Horsemanship and Hors. Training," says: "Docking is cruel and brutal, which all who appreciate the horse and understand him would be glad to see abolished by law."

W. Smith, in "Uses ald Abuses of Domestic Animals," says: "The operation is absolutely unnecessary. The President of the Veterinary College, who has condemned the practice, demands considerable atiention."

Hayes, in "Veterinary Notes for Horse Owners," says: "Men who dock their horses merit the contempt of all horse lovers. Apart from the stud question, a , cked mare, especially when ridden by a lady in a hunting fleld, is a disgusting and indecent sight which should not be tolerated in any decent country."

Basil Tozer, in "The Hurse in History," says : "We need not look into the streets to be convinced that we have not degenerated from our ancestors, although His Majesty has endeavoured to prohibit the practice by forbidding docked horses in his army."

E. S. Hamilton, M.R.C.V.S., in "The Stable Manual," says: "A most dangerous and barbarous disfigurement that still exists in parts of the country."

703. 'The Daily Graphic says: "One of the sights of the City is the ... Lord Mayor's four-in-hand, driven undocked and without bearing-reins."

The Toronto Sunday World says: "Tha usual arguments, even to the most minor degree, cannot be advanced in favour of docking, which is a cruel fad advanced merely to save labour and to give the animal a peacocky appearance."

The Ottawa Free Press says : "The practice is a relic of barbarism."

The Chicago Record Herald says: "A dorked horse is delenceless against flies Fie should 
lave a law similar to that in California, which imposes two yeurs' penal servitude as a punish. inent."

The Ollawa Cilizen says: "It is a shane to deprive the dumb animal of what Nature has given it for a purpose."

The Toronto Globe says: "Tlie contrast between horses with long silky tails and those of the hat-peg variety was most strikingly exemplifled by some beautiful photographs."

The Toronto Daily Star says: "Docking is due to horso-show maniacs, with no knowledge of or respect for the horse."

The Field says: "The barbarous praclice of docking the tail. . . . It is not generally realised that the real use of the tail is as a defence against flies. The New World is far in advance of England in this matter."

The Daily Express says: "The practice is strungly coudemned by nearly all horse owners in Canada and the States."

The Toronto News says: "Prosecute those who are responsible for such practices."

The Toronto Evening Telegram says: "The practice is mainly due to maniacs."

The Daily Graphic says: "Horses with such hideous tails resemble hat-pegs more than anything else ; they should be disqualified in horse sliows."

The Ottawa Evening Journal says: "Such practices can only be classed amongst the work of barbarians."

The Otlawa Evening Citizen says: "There is absolutely no reason for the docking of horses' tails. People think, of course, that a short tail makes the horse look like a show horse. Hence the show authorities should look upon the matter more seriously."

Farm Life says: "The British nation boasts of its kind treatment of horses, yet it allows such an abominable fashion as the docking of horses to continue."

The Dally Graphic says: "Not until the horse-owning public insists on purchasing undocked animals will the practice be stopped."

The Troller and Pacer (N.Y.) says: "We have always taken a strong ground against the fashion, and never have allowed a picture of a docked horse to appear in our paper."

The Ottawa Pree Press gays: "Those who prefer a short tail can, by banging the hair, satisfy their desiros without resorting to torture."

The Now York Evening Post says: "The horse struggles, and the tail is off. Then the iron, at a white heat, is applied. . . . After the horse has been mangled the is allowed to rise-an entirely different creature. What crimes will a civilised nation allow?"

The Times says: "The practice is a most barbarous one, and we cannot conceive how experienced horsemen can approve of it."
I noticed a recent book on photography where it advised lovers of Nature, when photographing horses, to represent the horse as Nature made it, and not to photograph bobtails.

The Winnipeg Free Press says: "Here it is frequently done because we used to do it in England; and in this country, where moenuitoes and flies are so agonising, it is horribl think what the animals must suffer. It is conded fronı an era far less enlightened than tiu present one."

The Toronto Sunday World says: "The practice is not only a senseless one, but cruel in the extreme. It does not enhance the beauty of the horse, but rather does it detract from it."

The Toronto W'orld says: "Pretty well everybody nowadays agrees that docking is un. necessary, barbarous and cruel, and yet it goes on."

704. The Chicago Record Iterald had the following verses by S. E. Kiser :

The horse and the dog had teased a man, and fastened hlm to a fence.

Sall the liorse to the dog. "For the life of me, I don't see a bit of seuse

"In letting hIm nave the thumbs that grow at the sides of hls hanits, do you ?"

And the dog looked solemn and shook hls head and salt, "I'm a goat if I do."

The poor man groaned and trled to get loose, and sactly begged them stay.

"You'll rob me of things for whieh I have use by cuttling my thumbs away:

"You will spoil my looks, you will cause me paln. Ah, why would you treat me so ?

"As $I$ am, God made me, and He knows hest. Ol, inasters, pray let me go I"

The dog laughed out and the horse replied, "Oh, the eutting won't hurt you, you see.

" We'll have a hot iron to elap right on, as you dld in the docking of me.

"God gave you your thumb and all, but still the Creator, you know, may fall

" To do the artistle things as He dld in furnishing ne with a tall."

So they bound the man and cut of his thumbs, and were deaf to his pltiful cries,

And they searcit the stumps, and they vlewed their work througl happy and dazzled eyes.

"How trin he appears," tlie horse exclaimed, " sinee his awkward thumbs are eone,

"For the llfe of me I eannot sce why the Lord ever put them on I"

"Still lt seems to me," the dog replled, "that there ls somethlng else to do;

" His ears look rather long to me, and how do they look to you ?"

The man eried out, "Oh, spare uy ears, God fashloned them as you see,

"Anil ll you apply you. knlfe to them you will surely disfigure ine." 

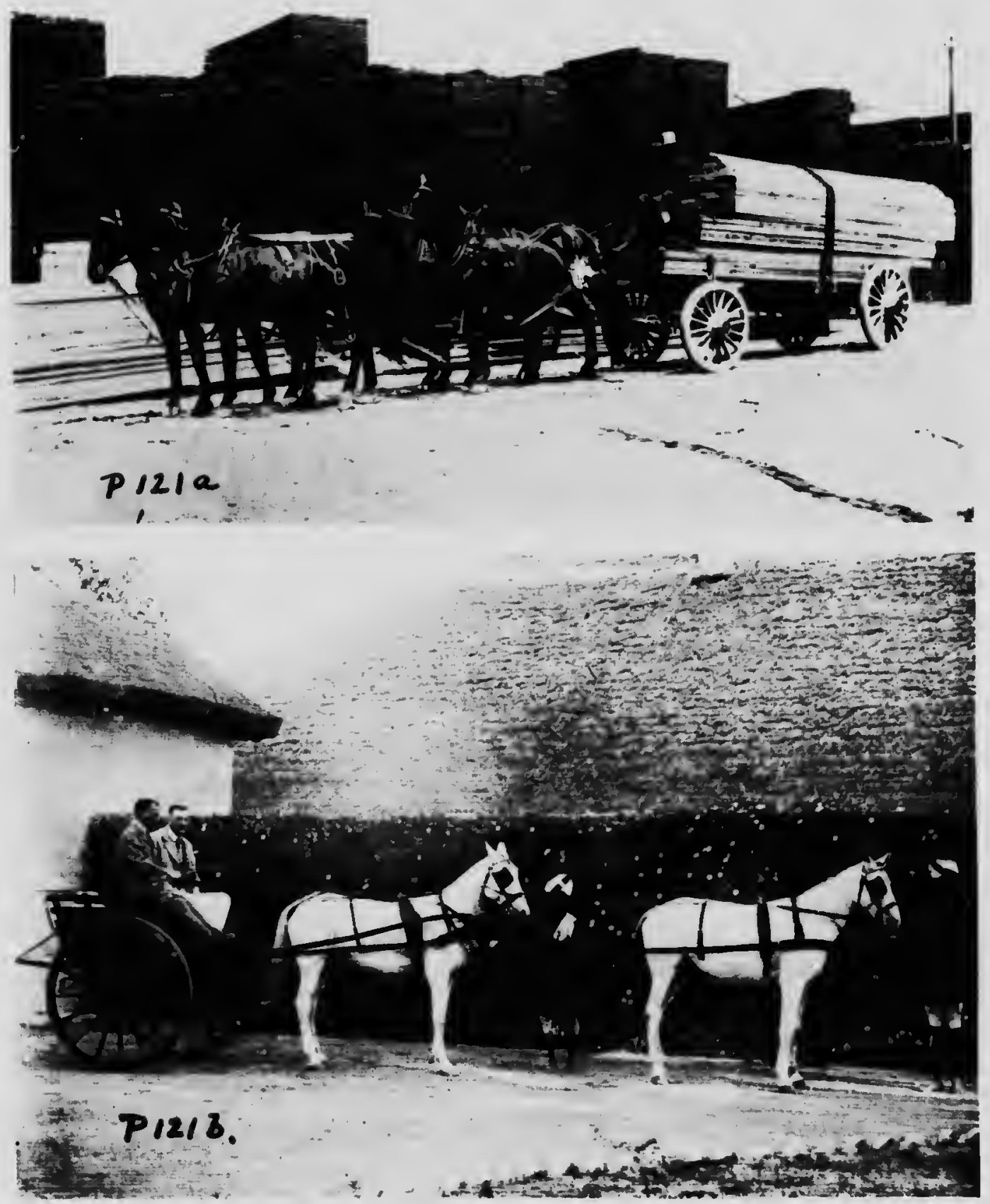

"THE REIN EXCUSE"

a, One of the Many Four-in.hands in Caliornia. Courlesy: San Francisco. S.P.C.A. b, Tandem ol Ponies in India. The Pioperily of Capt. A. W. Timmis 
PI.ATI: 122
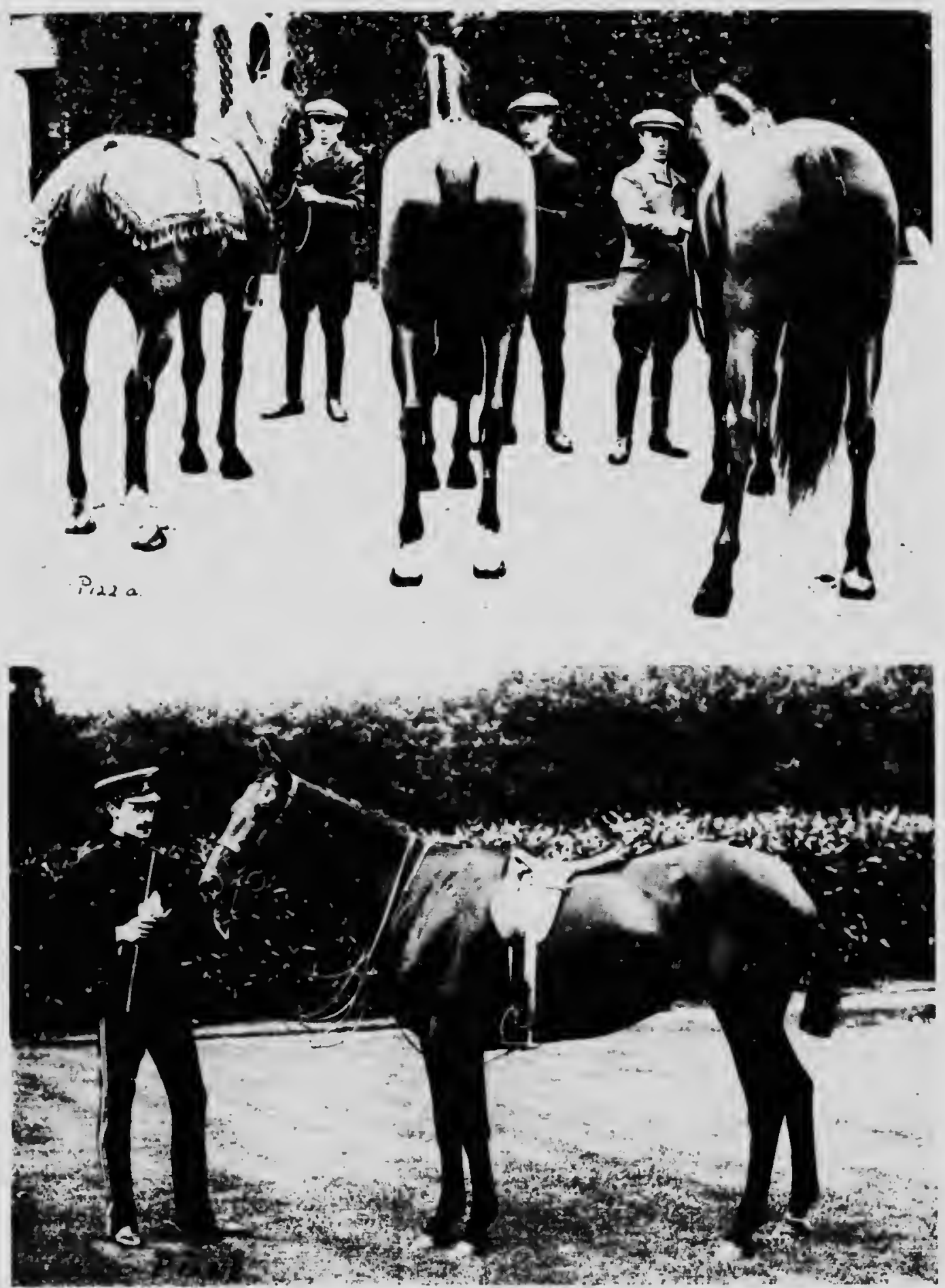

TAILS

a, Mir. Waiter Winan, Horses, showing the Dorked Tail, the Banged Tail, and the Long or Swish Tail. Photo: L. N. A. London. b, Major Brooke's Prize-winning Jumper "Betty." Photo: Cale and Poiden, Aldershot 
"But you don't disfigure me, you know," the dog derisively said,

"Why, yeu bound me fast and trimmed my ears down close to the top of my head."

So they let him moan and they let him groan while they chopped his ears away,

And they praised his looks when they let him up, and proud, Indeed, were they.

The New York Herald says: "One of the fastest trotters ever converted into a high stepper is Dr. Pitsen. Judge Moore paid 89,000 for this grand-looking horse, and he is now to be seen nearly every day in Central Park, docked, nicked and in heavy harness, with heavy shoes on his feet."

Dr. A. G. Hopkins writes to Captain Hayes: "During a winter stay in Chicago standardbred horses with fast records are procured, docked and their tails set up, and when they get great growtl of foot and heavy shoes, the Anglomaniac buys them and shows them in the highstepping classes."

The Ottawa Evening Cilizen says: "The capital is proud to boast of having at least three veterinary surgeons who have refused to perform the needless and cruel operation."

General Smith, D.S.O., in the Veterinary Journal, says: "Fashion and appearance take the place of utility."

The New York Commercial Advertiser says:

"There sit their coachmen, looking down from their boxes on the lacerated stumps at tho one end of their horses, while the other end is jerked up in the air."

The Detroit Evening News says: "One of the worst of all the fashion manias is the docking of horses, now practised in deflance of the law. It is the relic of the days when bull-baiting and dog-fighting were national sports."

The Rider and Driver (N.Y.) says: "It is no exaggeration to say that some of the tails were to all intents cut clean off, for not more than four or five inches of the stumps were left, and these scraggy stumps were made to look mor. absurd by being shaved ard heavily singed." This refers to the International Horse Show.

Our Dumb Animals says: "It is clear that the owner of such animals does not care one straw for the suffering of dumb animals."

Farm Life (London) says: "It is surprising what little attention the protest made by Prince Christian against the practice has received in the Press. This is much to be regretted, because it is only by wide condemnation of this barbarous practice that the public will be sufficiently aroused."

The Animals' Friend says: "Let all horse owners refuse to purchase animals that have been 80 mutilated."

The Daily Graphic, in referring to a prosecution by the Royal Society for the Prevention of Cruelty to Animals, London, says: "The practice is most cruel, and robs the animal of its protection against flies."

705. Many of the Canadian and United States papers have had large headings against this practice, such as: "Duke deplores the docking of horses"; "The docking of horses is childish, and the law should be amended"; "Practice of docking horses severely condemned"; "A relic of barbarism."

The Hampshire Chronicle said: "The sale of these fine, undocked horses resulted in most of them being disposed of. ... This shows that undocked horses for hunting command top prices."

The Sporting and Dramatic News (London) says: "In the winter, when the long tail is not required for fly protection, it can be plaited up to keep it clean. The horse will then not be deprived of his most essential waspon."

The Toronto Daily Star says: "As long as show horses are docked, horses will be tortured, docked, and then nicked. The operation is, how: ever, nothing compared with the loss of the tail."

Our Dumb Animals (Boston) says: "From numerous articles published in the Press, it is evident that the practice is rapidly growing unfashionable. The Governor-General of the Dominion is opposed to it. His long-tail fourin-hand is much admired by everyone. The Veterinary Director-General and three of the leading surgeons of Ottawa have declared themselves against the practice. It is certain that the hat-peg is passing, and that even now it is not countenanced by owners of fine horses and those who take pride and pleasure in them and have the sense to understand their needs."

The New York Bil and Spur says: "It should be noted that under a new law it will be impossible to sell foals of this year in England if they are docked."

The Times says: "Docking is much less common than formerly. The courts, indeed, have held that it constitutes cruelty. It is admitted that the practice often results in the spoiling of a good horse. Mr. Walter Winans showed, a short while ago, that a normal horse was a guarantee of greater safety for rider and driver."

708. The Reducine Company, of Dublin and New York City, in a most excellent book, just issued, on the modern care of horses, says : "We do not believe in docking horses; we believe that God knew how to make a horse. We believe that the tail is necessary, not only as a protection against flies, mosquitoes, etc., but to add to its beauty.

"The dealer can take a bad-tailed horse, and by docking and other cruel practices make the horse appear of good breoding. We wish wo could carry every person who reads these lines with us to Central Park, New York, and show 
them most of the expensive vehicles. Ladies riding in most of them, behind long-tailed horses, they are those of wealth, position, brains and refinement. This we could show in other cities. The late Mrs. Eddy's turn-out was noted for the good taste and elegance of every detail of its appointments. The horses wore no checks, open bridles and long tails. She left an influence uver more lives than any Americall woman since Harriet Stowe. Mrs. Eddy was one of thousands of real women of brains and wealth who will not lend their influence to the senseless and cruel practice of locking horses. You will see many flashy turn-ouls drawn by docked horses. The wen in these are not of the classes that make the world betler; they do not turn the wheels of industry: they are not called great in any useful, honourable vocation. The women in these types of vehicles are only thoughtless; they do not mean to be cruel. We know they are very kindhearted to their poodles anc pugs, also to the co-respondents. If a horse's posterior was a thing of beauty and a joy for ever, the excuse might bo offered that a continuous and unobstructed view was a pleasure and an inspiration to people who ride behind docked horses. Don't get an idea that you must have a mutilated horse to make you appear fashionable. It is going out of fashion, as it should. Walter Winans, the Russian-born American millionaire, whose home is in England, and who is an allround horseman, and one of the largest and most successful exhibitors at international shows, has done nuch to stamp out this cruel practice. He is a personal friend of every European sovereign, and is a man of many accomplishments. His opinions are entitled to the highest considera. tion." 


\section{CHAPTER XV}

\section{HUMANE EDUCATION-THE LAW}

707. "No civilisation is complete that does not include within its sphere of charity and mercy the dumb and defenceless of God's creatures."Queen Victoria.

Of all cruelty, cruel fashions are the easiest to banish, because they are set generally by educated people, or at any rate by people who should know botler; cruelty committed by the acknowledged upholders of brutal customs is of course more difficult to abolish.

I cannot emphasise too strongly the necessity for humane education of children; for the prevention of, rather than punishment for, cruelty ; the establishment of animal hospitals, ambulances, and humane inspectors who know their work, and strict prohibition of any mutilated animal from being shown in the show ring or any other form of animal show. The Duke of Connaught, at a meeting of the Ottawa S.P.C.A., expressed his feelings thus forcibly : "I hope my presence here will irdicate the deep interest 1 have in the work oi the Ottawa Humane Society. Surely the objects of this organisation are such as all of you must feel a personal interest in. I hope all who are here will do all they can to advance these objects."

708. Less than a quarter of a century ago the humane societies of the world were less than ten. To-day they amount to many thousends. By teaching kindness to animals these societies are forming the basis for the reception of religious instruction and are leading the way to a higher civilisation.

Bishop Ninde rightly said: "Merciful treatment of animals should be taught from every pulpit and in our Sunday schools as a most imperative Christian duty."

In the heart of Canada and the States, societies are springing up in the larger towns. For many years there was no check on the cruelty that one saw, but now there is a great difference. There should be greater encouragement from the officials of these various cities and towns. In the North-West great strides have been made during the past few years; they have to deal in particular with improper clipping, blanketing, frozen bits, cverloading, and, up farther north, cruelty to the husky dog.

700. When the great Lord Erskine, in 1811, appealed for compassion for the humbler crea- tures of God, on the floor of the British House of Lords, he was met with nothing but contumely and insult. When Richard Martin caused the first Act for the protection of animals to be passed by the British Parliament in 1822 , he was openly an object of derision, and only a glorious minority sympathised with his views. When Henry Bergh first walked the streets of New York City in 1860 as the apostle of mercy for those who had received no mercy, he was the co'stant object of caricature in the Press, and $\mathbf{w}$. 3ubjected even to personal insult. All this was not to be wondered at. The world had been through long ages of heedless brutalities wherein the wanton spirit of the savage in man had been allowed free play without repression.

The Animal Guardian said: "Humane reform involving an alteration of the law can only be carried by votes. To influence votes you must educate the electors. There are three classes of people who need to be missioned-the bishops and clergy, the magistrates, and the local labour leaders."

710. I have always been horrified at the cruelty that is allowed to exist in FrenchCanadian parts of Quebec. In many cases the magistrates are totally incapable of dealing with cruelty. Gross cruelty can be seen any day in these parts of Canada. The worse type of man is the coalhesver and the lumberman.

Great good has been done of late by owners of large hotels, etc., lending their buildings for humane purposes. For example, the Chateau Frontenac, belonging to the Canadian Pacific Railway, at Quebec, loaned part of their hotel to the Quebec S.P.C.A. The Toronto Horse Show authorities regularly allow the Toronto Humane Society to run a tea room during the horse show in aid of this society.

I have come across several instances where those who have ill-treated horses have been made examples of in their neighbourhood. For instance, the Quebec Humane Society employed as an inspector an old middle-weight champion. When he first commenced he sot an example to the reat of the city by inducing a cruel man to aght. The latter, not knowing who the inspector was, thought he had an easy task; but it ended in his being put into hospital for four months with a broken nose and jaw. 
Another example I well remember is that of a young fellow, who had learut boxing, jumping up into a coal cart, and throwing the man back. wards on to the hard pavrment, and so disfiguring him that for mauy yenrs afterwards there was very little cruelty secn in this neighbourhood. This particular man had cut out the eye of lis horse with the lash of the whip.

The Toronto Open-Air Horse Parade Assoriation passed a law that they would not ullow any horses with docked tails to win prizes.

711. The necessity for reform in legislation is empliasised by many articles that have appeared in various papers on both sides of the Atlantic. The New York Times a few montlis ago devoted a whole column to the tricks of horse "doping." It described in detail the cruel methods adopted by horse dealers to hide lameness and other defects by dope and by other forms of gross cruelty, such as laming the other foreleg in order to make the horse appear sound on both. A Bill was introduced at Albany, New York, to protect buyers from frauds of hoise dealers, and to save worn-out horses from torture.

I think one of the worst things which the British nation allows to exist is the decrepit horse traffic. Thanks to the hard work of the R.S.P.C.A. and other societies, this offensive practice lias been greatly checked; but therc is still much to bo donc. I refer the reader to Sidney Trist's excellent book "The Under Dog," in which is described in detail this abominable trafilc.

712. I was glad to sec the English Press take up strongly the subject of doctoring horses at the International Horse Show. The Daily Graphic had some excellent articles on the cruel practices of grooms at Olympia. Great credit is dive to the R.S.P.C.A. for their work in showing up these practitioners.

We must, however, be thankful that the brutal "sport" of bull-fighting has been banished from the British Empire. The following extract from an article by my twin brother in the Animal Guardian will suffice to show what awful cruelty is allowed to go on in Spain. The article runs: "I can vonch for this. A horse which had liad its belly ripped open by the bull's horns, and a portion of its entrails protruding, was kicked and beaten until it hobbled out of the arena. The entrails were then pushed back, a piece of cotton-waste stuffed into the wound, and a few crude stitches put in to hold the wound together. It was then sent back limping into the arena to be again used as a target for the next aitack from the bull. I maintain that there is no 'sport' in the world where such wanton cruelty is perpetrated as to the horses in the Spanish bull-fights, and yet in other respects the snaniard seems to he a true sportsman."

718. The following article from the Canadian Press will bear repetition: "Always bearing in nind that in everything prevention is better than curc, and that the chipf object of a lumano organisation is prevention of rather than prosecution for cruelty, we should realise fully how important it is for us to see that the young generation is taught very strictly the principles of kindness to other people and animals. Most people, when they sec an act of cruelty, say, 'Why don't they punish lim?' They little realisc low mich better it would be to educate those who have to work with horses to the right way of treating animals. II such people were taught to treat animals kindly, the law would serve to remind them not to neglect what they knew."

An authority on horsc matters writes: "Let fashion raise he voice that dogs' ears be trimmed to points or horses' tails be converted into hat-pegs, and fashion followers are willing to acccde. It matters not that a Queen Victoria or a King Edward or a Queen Alexandra or a King George and his consort frown upon such mutilation, with its unavoidable suffering. Through such mutilation the smart ones are discourtcous to our King and smile at indecency, but what care they for that?"

Speaking of fashions, I rectived the following lines from the well-known horse artist, Mr. llarry Payne: "It would almost seem that the cutling fever has spread to the human species just now, as the present fashion is for all the men to cut and scrape every hair from their face, especially the moustache, the onc time much-prized appendage every youth hoped to grow. They lct their hair grow long on the forehead, so as to allow its being brushed right back, ending in a fringe at the back of the neck, greased, plastered and glued down. They cultivate a stoop, draw in their chests, round their shoulders, wear the trousers several inches too short, adopt a vacuous look, and then they call themselves 'nuts.' A proud record for the manhood of the country to attain."

714. The American papers have done mucl good by publishing comic pictures against cruel fashions. P. 125e shows one of R. F. Outcault's Buster Brown picturcs, in which the inscription says, "No, dear heart, we will never be civilised until we have quit slaughtering animals and birds by the wholesale to adorn ourselves; when we throw away the check-rein and quit docking our horses' tails."

I never so fully realised the brutality of the docking fashion until I saw the number of mutilated dranght horses in the fly-pestered North-West, toiling all day in the plough or reaper, absolutely unprotected from the fly, merely because fashion demands that these animals, if they are to win prizes at the show, must not be as Nature designed them. It is quite time the legislature of this country passed a similar law to that of California. 

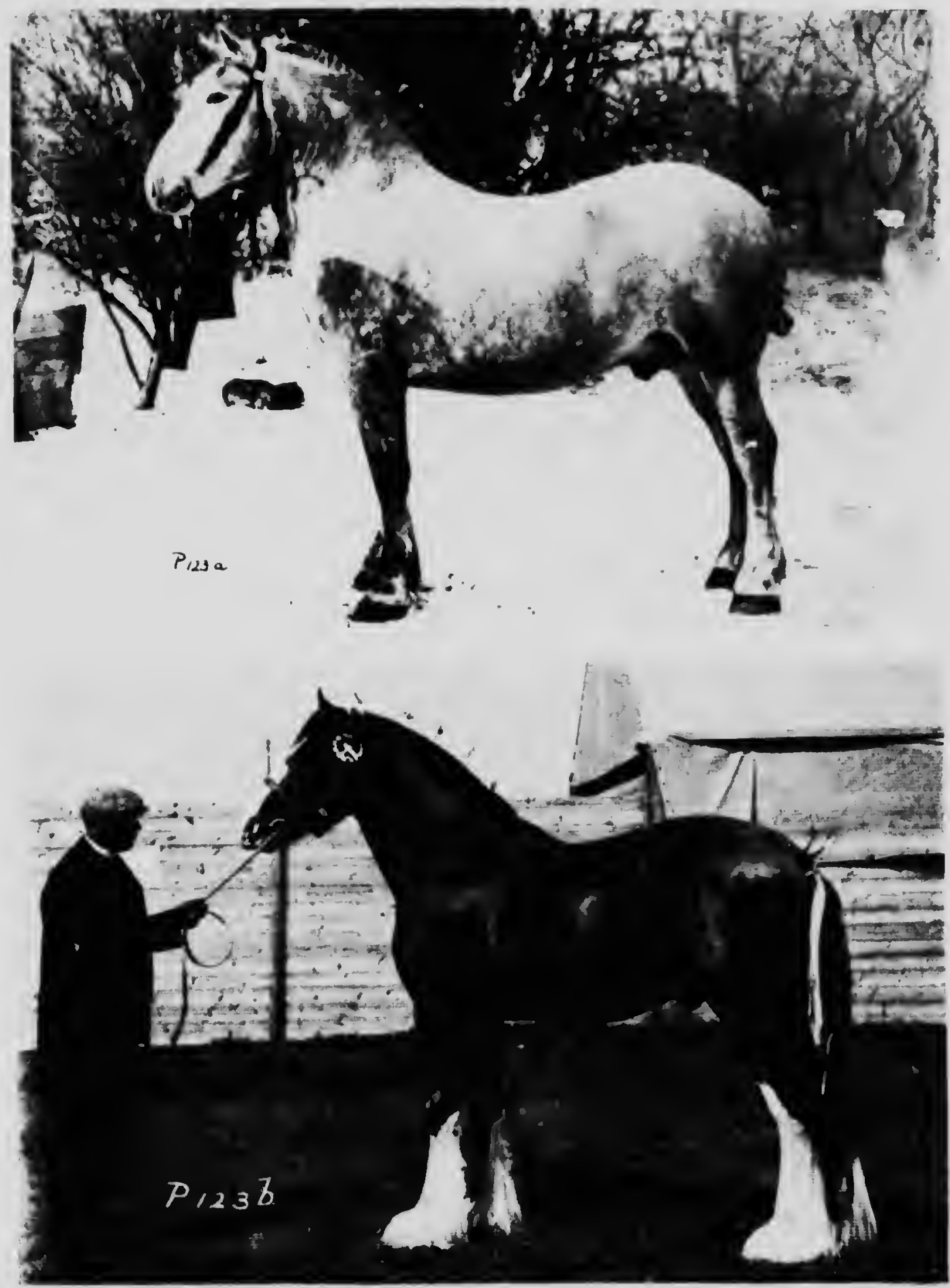

CHANIPION HEAVY DRAUGHT HORSES

a, Percheron Stallion "Frank J." Conrtesy of the Uwners, Messrs. Upper, North Portal, Sask. b, Clydesdale Stallion "Bonnie Buchlyvie," Champion, Royal and other Shows. Photo: C. H. Parsons 
['1.11T: 12t
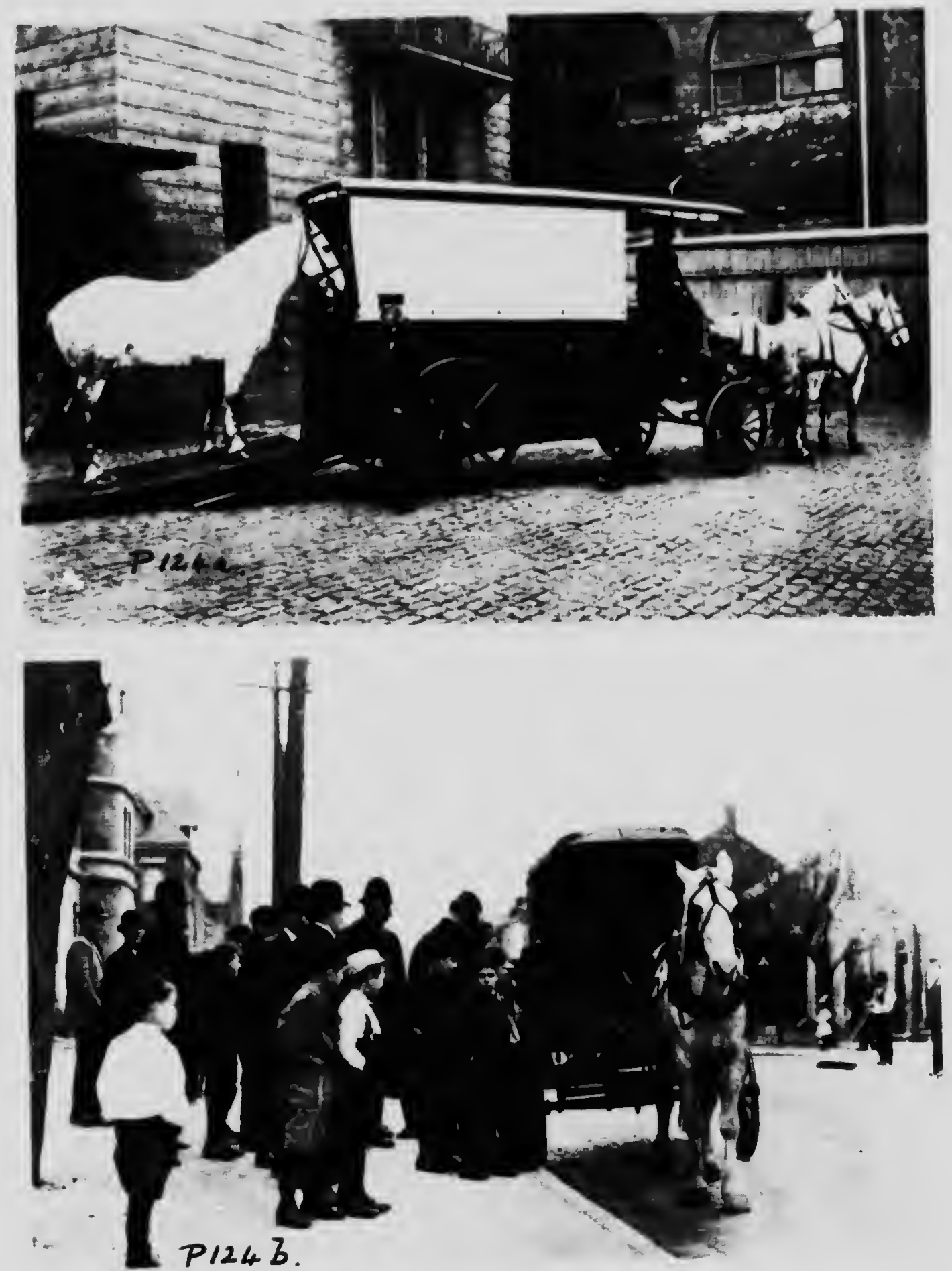

FOR THF DUNB DEFFNCELLSS

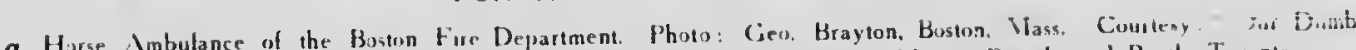
Animals." b, Toronto Ci,y Poluce Working with the Humane Society. Photo: Pringle and Bouth. Turonto 
715. The penal code of Californis re docking horses reads:

"The people of the State of California reprosented in senate and Assembly do enact as follows: It shall be unlaw/ul for any person to dock the tail of any horse or to procure the samie to be done, or to bring Into the State any docked horse, or to drive, work, $118 e$, race, or Jeal in any docked horse that lias not been registered in the State.

"Within thirty days after the pasage of thls Act every owner or user of any docked horse shall rogister it by fling in the office of the County Clerk; a certificate shall contain the name of the owner, together with his address, and a full description of the colour, age, size and the use made of such docked horse. The County Clerk shall number the certificates consecutively and record the names in a register. Ho shall receive a fee of $50 \mathrm{c}$. for doing the same, whereupon he shall issue the said person a certiflcate containing the facts recited in this section, which upon demand shall be exhibited to any Peace Ofilcer, and the same shall be conclusive evidence of a compliance with the provisions of this code.

"The driving, working, keeping, racing, or using of any unregistered docked horse after sixty days from the passage of this Act shall be deemed prima facie evidence of the fact that the party using such horse docked the tail of sueh horse.

"Any person violating the provisions of this Act shall be deemed guilty of a misdemeanour, provided, however, that the provisions of this Act shall not be applied to persons owning any docked pure-bred stallion or mare imported from foreign countries for breeding or exhibition purposes, as provided by Act of Congress, and to docked native-bred animals brought in for the same purpose, and provided, further, that the description of each such animal so brought into the State, together with the date of importation and name and address of the importer, be fled with the County Clerk of the connty where such animal is kept within thirty days of the importation."

The penalty for committing an offence against the above Act is up to two years' penal servitude.

716. In Montreal a fine of $\$ 20$ is imposed upon the perpotrator of this breach of the law.

The Massachusetts S.P.C.A. award the lollowing sums: A hundred dollars for evidence to convict any perpetrabr within a certain radius of Massachusetts, and 225 for evidence to convict anyone in the city itself of a violation of law by causing any horse to be mutilated for life by docking. At present the English law could prosecute for the practice, because it is an offence to mutilate any animal for the purpose of conforming to custom or fashion, but it does not specify this pariciular practice. Many of the other States of the Union have similar laws to that of California, and they seo that these laws sre strictly enforced.

717. King Georgo $V$. accepted the honorary first vice-presidency of the flrst Amerlcan International II umane Couference, held iu Washington some fow years ago. President Taft wus $\therefore$.: honorary prosident, and opelled the meeting by an address. Dr. W. O. Stlliman is presldent of thls association.

718. The Protection of Animals Act, 10t1, has some excellent sections. It has a wider control than former Acts, and sllows for more severe punishment. It gives the court power to destroy an animal or to deprive the owner of future ownership. It has some important additions in respect of the control of knackers, slaughterhouses and pounds. It forbids the use of dogs for draught in England. It causes all those who set traps for hares or rabbits to inspect the same every day between sunrise and sunset. It gives far greater power to constables. The court can direct the employer of the offender to produce the said man at the hearing of the case.

The following Bills will shortly be introducerl in the British House: the Anmsthetics Bill (see Chapter XVI.), and a Bill to prohibit tlie docking of horses. (See Sec. 605, Chapter XIII.)

719. Mr. P. C. Laverton-Harris, of the Toronto Humane Society, has prepared amendments to the present British penal code. Some of the important points Lought out in this amendment I introduced to the Minister of Justice at Ottawa, and it is to be hoped that before very long the penal code wlll be greatly improved.

The amendments provide that no one may deprive an animal of necessary and proper food or water for more than eight successive hours; that no one may kill any animal in the sight of any other animal awaiting slaughter; that no one may permit any animal to be carried in such a position or manner as to cause it any unnecesary suffering; that no one may perform any operation that is not necessary through disease or accident; that everyone must provide proper, aficient and sanitary stabling for any animal that he or she possesses or is in charge of ; that no one be permitted to use a captive bird lor the purpose of a target or for any kind of frap; that it bo unlawful for any person, in the presence of any pupil, to practise vivisection or exhibit any animal that has been vivisected; it makes it lawlul for any constable, peace oncer or humane society inspector to break into any stable or building in whioh it is suspected that cruelty exists ; that any constable, etc., may order to be removed from work any animal lound to be suffering; that it be unlawful for anyone to sell or deal with any grain or seed that has been rendered poisonous except for bons fide use in agricuiture; that it be unlawful for anyone to place any poison on the land or in a building 
where a domestic animal would be able to reach the same.

720. The Rev. M. J. Savage said: "If I were a man of means and had a hor'e I liked, I would turn him out to pasture in his old age (if he had a natural tail), or put him in the hands of someone who I knew would treat him kindly, or put him to a painless end myself. I would not turn him over to end his days in suffering, cruelty and neglect."

I have often contrasted horses turned away from a comfortable home to live a miserable life with hawkers or rag-and-bone men with a 27-year-old horse belonging to Sir Henry Pellatt, of Toronto, which is pensioned off for life. This particular horse was the one ridden by King George when in Canada in $\mathbf{1 0 0 0 .}$

"Deo dante dedi" can be well applied here. Brother Carthusians will join with me.

\section{1.}

The quality of mercy is not strain'd, It droppeth as the gentle rain from heaven Upon the place beneath: it is twice biess'd, It blesseth him that gives, and him that takes: 'Tis mightlest in the nightiest; it becomes The throned mollarch better than his crown.

SIIAKESPEARE.

The cost of unkindness was very aptly recorded in the New York Record Herald: "There is a wonderful system of government that directs the affairs of human beings. If you do a good act, a good act will be done you. If you deal out an injustice, you will be afflicted with like punishment. None can afiord to be unkind, for unkindness always returns, and in a greater measure." (See Sec. 694, Chapter XIII.)

722.

A man of kindness to his beast is kind, But brutal actions show a brutal mind. Remember, He Who made thee, inade the brute, Who gave thee speech and reason, formed him nute. He can't complain, but God's all-seeing eyes Behold thy cruelty and hear hls cries; He was designed thy servant, not thy drudge; Renember, his Creator is thy Judge.

The above lines were exhibited in a number of the cab-stands in London, and, there is no doubt, did a great deal of good.

I love the hoss from hoof to head :

From head to hoof, and tail to mane.

I love the hoss, as I have said,

From head to hoof and back again.

I love my God the first of all,

Then Him that perished on the Cross,

And next my wife, and then I fall

Down on my knees and love my hoss.

Janies Whitcomb Riley in " Our Dumb Animals."

723. "Now, I say that with eruelty and oppression, it is everybody's business to interfere when they see it."-" Black Beauty."

Knowledge alone does not make men better, but kindness does. Knowledge confers power, and kindness prevents its evil application, 80 both must be inculcated.

A well-known preacher a short while ago said that the greatest gift was the gift of understanding others; the gift of sympathy for others.

By kind permission of Dr. Francis H. Rowley, I am able to reproduce the original version of the "Horse's Prayer," published by the Massachusetts S.P.C.A., and posted up by law in all the livery and Governmunt stables in that State:

724. "To thee, my master, I offer my prayer; feed me, water and care for me, and, when the day's work is done, provide me with shelter, a clean, dry bed, and a stall wide enough for me to lie down in comfort. Always be kind to me, talk to me, your voice often means as much to me as the reins. Pet me sometimes, that I may serve you the more gladiy and learn to love you. Do not jerk the reins nor whip me when going up hill. Never strike, beat or kick me when I do not understand what you want, but give me a chance to understand you. Watch me, and if I fail to do your bidding see if something is not wrong with my harness or feet.

"Do not check me, so that I cannot have the free use of my neck and head. If you insist that I wear blinkers, so that I cannot see behind me, as it was intended I should, I pray you be careful that they stand well out from my eyes. Do not overload me or hitch me where water will drip on me. Keep me well shod, examine my teeth when I do not eat; I may have an ulcerated tooth. Do not tie my head in an unnatural position, or take away my best defence against flies and mosquitoes by cutting of my tail. I cannot tell you when I am thirsty, so give me clean cold water often. Save me by all means in your power from that fatal disease, glanders. I cannot tell you in words when I am sick, so watch me that by signs you may know my condition. Give me all possible shelter from the hot sun, and put a blanket on me, not when I am working, but when I am standing in the cold. Never put a frosty bit in my mouth; first warm it by holding it in your hands. I try to ccrry you and your burdens without a murmur, and wait patiently for you long hours of the day or night. Without the power to choose my shoes or path, I sometimes fall on the hard pavements, which I have often prayed might not be of wood, but of such a nature as to give me a safe and sure footing. Remember, I must be ready at any moment to lose my life in your service.

"And, finally, 0 my master, when my useful strength is gone, do not turn me out to starve or freeze, or sell me to some cruel owner to be slowly starved to death; but do thou, my master. take my life in the kindest way, and your Qod 
will reward you here and hereafter. You will not consider me irreverent if I ask this in the name of Him Who was born in a stable.-Amen."

725. The following words are those of General Sir F. Fitzwygram: "Animal suffering and a future in prospect for animals must always, I think, be present to those who make veterinary science their life's study, as I have done. It is impossible for the man of average sensibility to witness their sufferings, to witness the brutal treatment which they too often meet with from ignorant and cruel man, without sorrow, withsut endeavouring to alleviate their agony, and to ameliorate their hard fate. It is justly said to be the type of highest Christian virtue to do good to those who cannot repay and who cannot thank you; then there can be no higher virtue than the alleviation of animal pain and suffering."

I know of $n n$ greater satisfaction than that of relieving a suffering animal or of curing a sick one, and of no greater satisfaction than that of punishing, for the animal's sake, the perpetrator of any cruelty practised on the defenceless creature.

The horse's life is without doubt the most unhappy one of all animals. He is the victim of tndless labour and fatigue, of endless and merciless cruelty, and the older he gets, instead of hlE trials becoming easier, they become harder. The rich man, who for the sake of fashion transforms him into something ridiculous to look upon, has little love for him. He sells him when his usefulness begins to falter. The poor man buys him, and with him he tries to earn his daily bread. Is it not easier for rich people to save this awful suffering amongst poor people's horses? Is it not their Christian duty to do this? Thank God, when the motor becomes more common, it will diminish the number of miserable-iooking horses that we see daily on the streets. I cannot close this chapter without appealing to wealthy people to give what they feel they can to sncieties for the prevention of cruelty to animals. Their kindness assuredly shall not go unrewarded.

726. Ruskin said: "Can any man account for all that happens to a cab horse? Has he ever looked at the fate of ore of those beasts as he is dying? Has he measured the work it has done and the reward it has got? Has he ever put his hands on the bloody sores through which his bones are piercing, and so look to Heaven with an entire understanding of Heaven's ways about the horse? Yet the fate of the horse is no dream, no revelation among the myrtle trees by night. The dust it lies upon and the dogs that eat it are facts. And yonder happy person who owned the horse until its knees were broken over the hurdles, who sold it to \& cab owner as soon as it was blemished; yonder happy person, with an immortal soul, with peace and wealth on earth, shall this happy person have no stripes?"

\section{Ne OnLIVISCAMUR}

Only a horse that lies dead In the street Prone on the pave, 'mld the hurrying feet; Only a horse that through sunshlne and rain Toiled for his master and dld not complain. Rough is hls coat with each rib showing through, Scant though hls food, he was faithful and true. Beaten, abused, bearil.g burdens of pain, Only a horse and he could not complain. Who thall dare say such as these have no soul, Nothlng before them, no far away goal ; No need for toil and no balm for their pain, Though they are silent and never complaln?

727. Ars LONaA, Vita brevis Among the noblest in the landThough he may rate hlmself the least, That man I honour : d revere Who without favour, without fear, In the great city dares to stand The friend of every friendless beast. LONGFELLOW. 


\section{CHAPTER XVI}

\section{ON ANESTHETICS AND ANESTHESIA-HUMANE DESTRUGTION}

798. The Nervous System.-The living body is controlled by a wonderful mechanism known as the nerrous system. This system is divided into two distinct branches: the voluntary branch, and the involuntary branch or reflex branch. The latter is responsible for the vital organs continuing in their functional activity day after day.

The whole of this wonderful system is controlled by "minor offices" called local centres, these being situated in the spinal cord. There is a local centre for every one of the viscera and organs in the pelvis, abdomen, thorax, neck, face, etc. The whole of the blood supply is controlled by local centres which contract and dilate the minute blood capillaries, and thus regulate the flow of blood. All these local centres are controlled by one large centre, the " head office," which is called the brain. The brain keeps perfect harmony between the local centres; this function is known as co-ordination.

By means of co-ordination, blood is distributed as required over the whole body, and certain organs are not allowed to take too much blood, thereby leaving other organs bloodless. But for this main central control the minor organs might demand all the blood and leave none for the brain or other important organs, and consequently cause death to the animal.

After a meal more blood is required in the stomach and intestines, and the blood supply of the muscles and brain is therefore reduced; hence hard muscular or mental work shou!d not be allowed while heavy digestion is going on. Horsemen must remember this, otherwise the best value will not be obtained from the food, but serious trouble may result. Indigestion is the common sequence of neglect of the above fact.

The control of all internal viscera or other organs, such as the blood-vessels, etc., is carried on by the involuntary system, which is known as reflex action. Every nerve passing from a portion of an organ to the spinal cord has another nerve passing back along the side of it. That passing to the cord is the sensory nerve, as it carries sensation, and that passing back is the motor nerve, as it causes motion.

A reflex action takes place in this manner: a stimulus is given to the receiving surface, that is communicated to the sensory nerve; this passes it to the local centre in the spinal cord, the cord sends back a message along the motor nerve, that conveys a stimulus to the active part to which it is attached, which is called a muscle flbre. Hence, a sensation felt by the part causes a stimulus to be given to the muscle of that part: this is a reflex action. The blood supply is controlled entirely by reflex action.

The voluntary system is also controlled to a certain extent by reflex action. The voluntary system controls all the red, or striated, muscles (except the heart muscles), and is generally at the entire command of the individual.

729. The brain and spinal cord, which form the nervous column, are composed of inner grey matter and outer white; the grey is the more important part. From the brain and spinal cord, all the way to the tail, numerous nerves, sensory and motor, branch off ; the motor nerves, strictly speaking, go out, and the sensory come in.

Nerves are always seen in bundles of minute nerve flbres, each flbre being a nerve. The bundles (like telephone cables) vary very much in size. Sensory and motor nerves are mixed up in the same bundle.

There are twelve pairs of cranial nerves leading from the under surface of the brain: three sensory, slx motor, and three mixed.

730. The first (olfactory) controls the sense of smell; the second, third, fourth and sixth control the sense of sight-the third, fourth and sixth being motor nerves. The flfth (trifacial) is a very large mixed nerve, and controls most of the face, mouth and teeth.

The seventh (facial) is a large motor nerve, and controls the face, ears and part of the teeth. The eighth (auditory) controls the sense of hearing. The ninth (mixed) controls the tongue and pharynx. The tenth (mixed) controls the larynx and neck. The eleventh (motor) passes to muscles in the neck; and the twelfth (motor) controls the muscles of the tongue.

781. Leading from the spinal cord, there are eight double pairs of nerves in the neck (cervica) region); the sixth, seventh and eighth, together with some of the dorsal nerves, form the brachial plexus, that sends of the nerves of the fore 


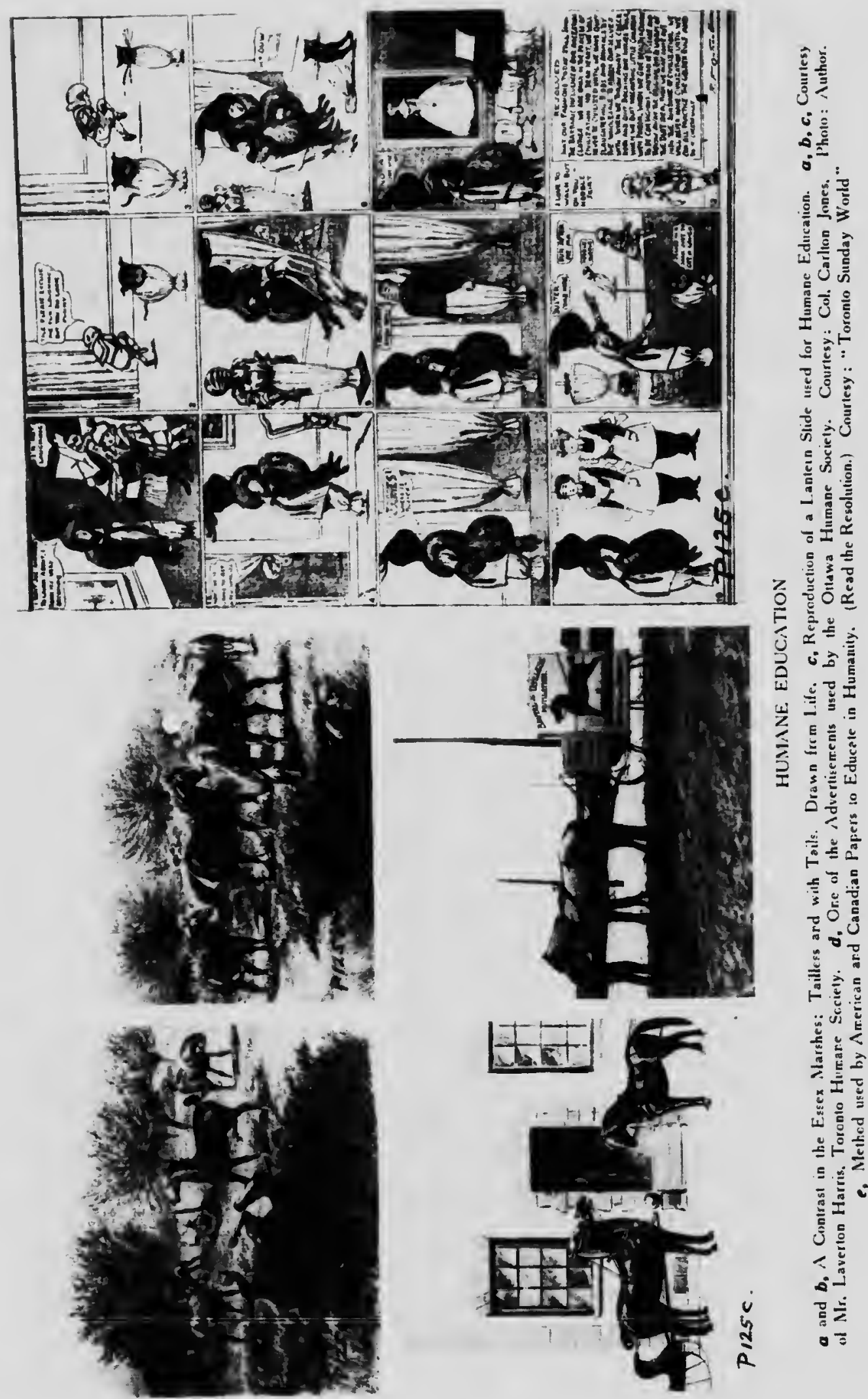



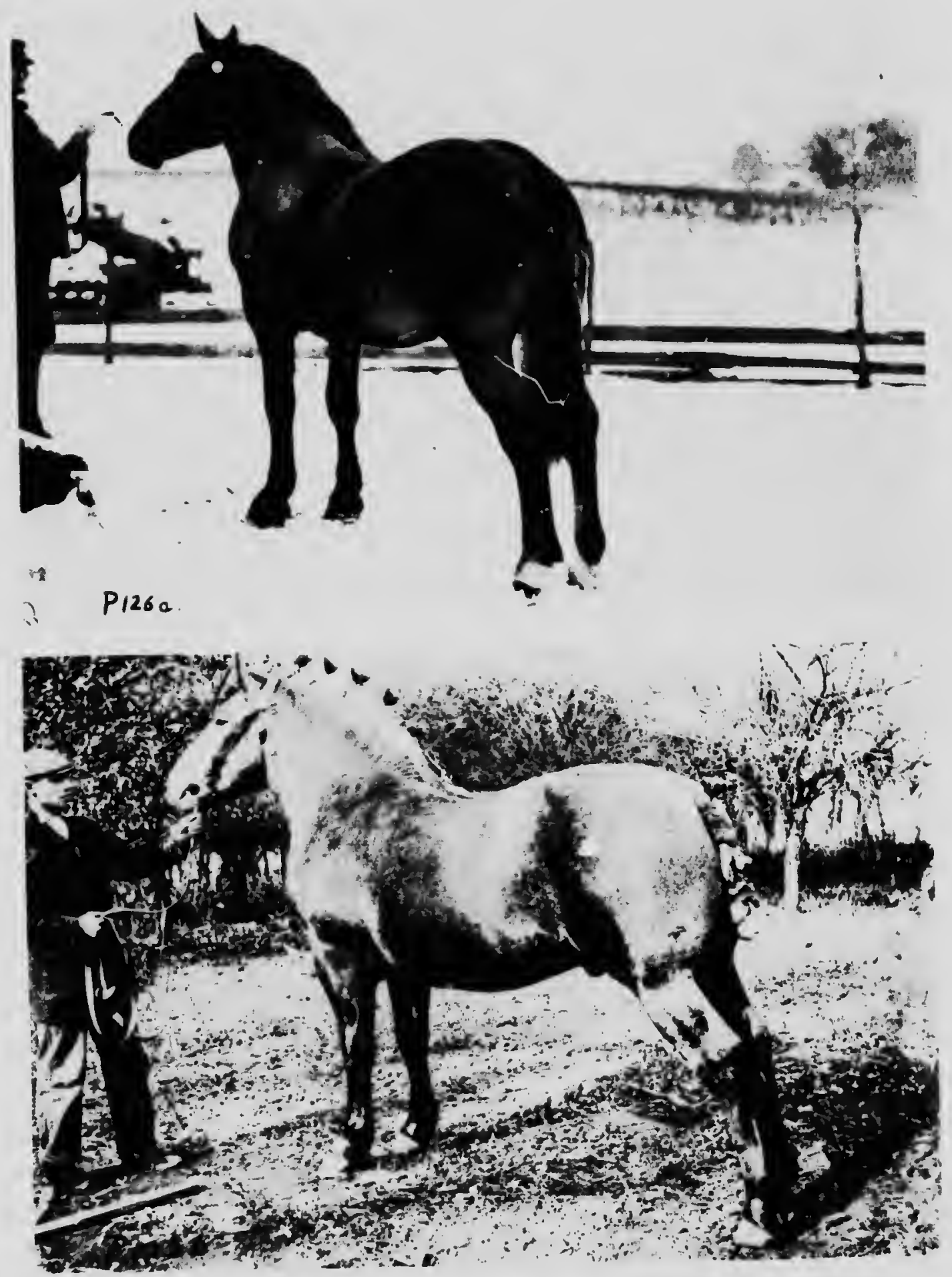

CHIMPION ROIN PERCHERONS ILNUUCKED,

a. Photo: R. F. Hildehrand. Chicagc. b. Two-vear.old "Narg is," Property of Nessrs. Upper. North P'ortal. Sask 
limbs, which we will consider from the point of view of local aneothesia later in the chapter. In the thorax there are seventeen double pairs of dorsal nerves, the flrat and second forming pert of the brachial plexus. Farther back, towards the lail, there are in the abdomen six double pairs of lumber nerves, the fourth, fifth and sixth helping to form the lumbar-sacral plexus, which sends of the nerves to the hind limbs. Farther back there are five double pairs of sacral nerves, situated in the pelvic cavity, the first, second and third helping to form the lumbar-sacrel plexus. Lastly, there are six or seven double pairs of coccygeal nerves that supply tha muscles of the tail.

78. P. 137 and $138 a$ show the nerves given off by the brachial plexus and lumbar-sacral plexus, and the places where the cocaine, etc., would be injected as a local anesthetic.

As well as the large number of motor nerves which branch into the hundreds of smaller nerves, all of which have their own names and special functions (for instance, the fifth cranial nerve branches into nineteen main nerves, each of which subdivides and re-subdivides many scores of times), there is the sympathetic system, that assists in controlling the involuntary functions of the bocij, and is in immediate contact with the molor system, briefly described above.

The sympathetic system consists of a double chain of ganglion bodies extending from the head to the tail, outside and bolow the vertebral column. There are five main groups in the sympathetic system: the cophalic ganglia, in the head; the corvical ganglia, in the neck; the doreal, or thoracic, ganglia, in the thorax or chest, which forms the great splanchnic ganglion, solar ganglion and the solar plexus, that gives of nerve brenches to most of the abdominal viscera; the lumbar, or abdominal, ganglia; and, lastly, the sacral, or pelvic, ganglia.

This chain of ganglia ends just below the first coccygeal vertebra.

The resder will gather from the above some idea of the extraordinarily complex nervous mechanism the horse or human being possesses. In the horse the motor nerves in the spinal cord are better developed, whilst in the human being the brain is better developed. It is easy to realise how soon the nervous system can be upset and how diffcult it often is to repair nervous disorders or breakdowns.

783. Brief Description of the Nervous Tissue. -The nerve tissue is divided into a contral nervous system (brain and spinal cord), smaller centres or ganglia, nerves, and nerve endings (special senses). In the embryo the nervous systom is formed from the epiblast (or ectoderm).

Fach individual nerve consists of a dendrite, that carries an impulse to the cell body of the nerve, the cell body (or ganglion cell), and the neuraxis, that carries the impulse from the cell body to a muscle, blood-vessel, gland, etc. The whole is called a neurone.

Those that cause muscular contraction are called motor, and those that convey sensation are called sensory. The coll body contains, amongst other things, minute chromatophile granules, which, under such conditions as diseases of the nervous system, poisoning, and excessive fatigue, disappear altogether.

78. Thus a nerve fibre may consist of a number of neuraxes, or dendrites, or both. The cell bodies are situated in the brain, apinal cord, or the sympathetic ganglia (e.8., solar plexus, situated pusteriorly to the liver in the horse).

The nerve flbres are made up of little fibrils and neuroplasm, which is the matrix, surrounded by a skin (axolemma). It is often surrounded again by a medullary sheath and an outer sheath of Schwann (or neurilemma), and outside this is Henle's sheath, which is always present. The medullary sheath is absent at certain intervals along the nerves, leaving a dip in the surface, called the node of Randier; it is at these nodes that nerve branches originate. A nerve trunk (which we see if we dissect an animal, and which rather resembles white cord) consists of several bundles of nerve fibres, each bundle being called a funiculus. Bach funiculus consists of a number of nerve flbres in their respective sheaths. The end of the nerve varies; some end like a brush, others in a node.

\section{Brief History of Ansesthetics}

785. The ancient writers were aware that certain herbs had the effect of producing insensibility to pain. Pliny, Gaien, Dioscorides and Isodorus all mentioned that certain roots and herbs had the power of paralysing sensation and motion.

In the reign of Henry VIII. a doctor used a herb, probably mandragora, to cause insensibility to pain. It was also krown that the vapours of certain drugs, as well as the use of drugs administered orally, had this effect. The discovery of oxygen by Joseph Priestley (1774) caused the importance of the inhalation of gases to be brought to light.

Sir Humphry Davy, in 1790, flrst discovered the anssthetic properties of laughing gas (nitrous oxide, $\mathrm{N}_{2} \mathrm{O}$ ).

Faraday, in 1818, also made some experiments with sulphuric ether. Progress was very slow. In 1831, Samuel Guthrie, an American-and in the same year, Soubeiran and Sir James Young Simpson (Edinburgh)-independently procured by distillation a substance from chloride of lime and alcohol. This preparation was submitted to Dumas, who called it chloroform $\left(\mathrm{CHCl}_{2}\right)$, on account of its similarity in composition to formic acid.

Jacob Bell and M. Flourens also experimented 
independently with chloroform. The surgeon, however, is more indebted to Sir J. Y. Simpson for his valuable research work towards introducing the general use of anæsthetics.

For many years chloroform was not generally used, because, as in things of to-day, people who could not mind their own business and peopie who knew nothing of anatomy or physiology experimented, often with fatal results, upon people and animals, thus discouraging the use of this humane discovery, instead of encouraging it.

736. The Use of Anzsthetics.-It is surprising to find what a number of painful operations are performed upon dumb animals without the use of anasthetics-not even local. It is still more surprising to find that many veterinary surgeons in different countries do not know how to administer anæsthetics properly. I have often heard medical men bring this point up. Consequently, partly due to want of knowledge and practice, and partly due to pecuniary considerations, many veterinarians prefer to torture dumb animals, instead of performing humane and more scientific operations. Men who perform vivisection on dumb animals without anesthetics really merit punishment.

Anwsthetics, apart from preventing pain, are of the greatest use in all bone-setting and many other operations, in that they cause relaxation of all voluntary muscles. The out-of-date vet., to save himself a few pence, would keep a horse in agony for half an hour, and then probably make a mess of the operation. Had he spent a small sum on chloroform, he could readily have charged extra, because the operation would have been more skilfully performed, and he would, therefore, have deserved a higher fee. The dangers of after-effects also would have been minimised.

737. Dr. T. C. Evans, of the Biological Department at Ottawa, reminded me the other day that "the time is past when a veterinarian restrained his patient with ropes and operated promiscuously while the massive bone and muscle writhed beneath the cutting edge of the knife." Only when under an anæsthetic will all the voluntary and some of the involuntary muscles be in a state of relaxation, and only then will the animal remain motionless and allow an uninterrupted, scientific operation to be performed.

\section{Anesthesia and Choice of Anæsthetics}

738. There are four stages in anæsthesia:

1st. Stimulation, when the animal becomes excited, which is increased if the anæesthetic is used too strongly at flrst, and is much greater with chloroform than with ether.

2nd. Sedation, or hypnotic stage, complete calmness, but not insensibility to pain; the eye- ball responds to a touch of the finger. While in this second stage, complete calmness must be observed, especially with dogs, or the patient may become excitable (dog howls), and the first stage will again be reached. With chloroform, any attempt to operate while in this siage (2nd) may be fatal by causing reflex action on the heart. With ether, this danger is not supposed to exist. The simple operation of extracting a tooth has been known to kill a man, the dentist having pulled while the patient was only in the hypnotic stage, under chloroform. His heart must have been weak.

3rd. Anæesthesia proper, in which there is complete relaxation of all voluntary and some involuntary muscles, complete insensibility to any pain, and complete loss of consciousness.

4th. Paralysis and probable death; this stage, of course, must never be reached.

739. The commonest total-anæsthetics used are chlorofort 1 , ether, and nitrous oxide, or laughing gas. The last is not used with horses or dogs, and is used chiefly for human dentistry, its action lasting only a few seconds. Chloroform and ether are used separately, together, or combined with alcohol, the latter being known as the A.C.E. mixture (ove part alcohol, two chloroform, and three ether), which is used with children and dogs. It is doubtful whether the alcohol has any real effect other than diluting the mixture.

In liuman medicine, chloroform is seldom given ; the death-rate with it is 1 in 2,500 , whilst with ether it is only 1 in 12,000 .

740. Chloroform has a very depressing effect on the heart, whilst ether has not. In the horse, however, the heart is not often weak, and, unless it is, chloroform is used. Ether causes violent struggling to commence with, which may do considerable harm. On the other hand, ether should not be given in lung or kidney diseases; ether-pneumonia and uræmia respectively may follow. Ether may kill an advanced consumptive. Chloroform has not the same nauseating effect that ether has, and for this reason I strongly recommend it for horses, because a horse cannot vomit normally. (I have seen a horse vomit fifteen minutes before death.) Again, in hot climates ether cannot be used, as it boils at $98^{\circ} \mathrm{F}$. (blood heat of human beings equals $98^{\circ}$, that of a horse about $100^{\circ}$ ).

741. In confinement, just previous to parturition, there is far less danger of heart failure from an anæsthetic, as the heart is always enlarged at this time and can stand a great shock.

With horses, chloroform is often given, and when the patient is completely under its influence the anæsthetic is changed to ether. Chloroform must always be given very freely diluted with air. If the chloroform is given too strong, suffocation will take place; this is almost impossible with ether. Whichever is used, the 
patient must be very gradually brought under it influence. The patient should pass slowly into a peaceful sleep without any struggling.

748. Anasthetising a Horse.-The anmsthetic should be given on an empty stomach. The heart should always be examined for signs of weakness ; if it is found at all weak, ether should be used, otherwise use chloroform.

The proper way to administer it is to lay the horse on an operating table or cast it in the usual way with ropes. It is often given to the horse while standing, tbe horse being brought into a sleepy state, and left to fall on to a very soft bed of straw provided for the purpose. There is a certain danger of the fall causing too great a shock on the heart, although I have never seen this result. The nostrils, lips, and the parts round the mouth must be previously greased with an animal fat, such as lard, to prevent any of the chloroform from getting on to the skin and burning it.

743. There are several methods of administering the drug. I think the best way, which is the simplest, is to make a cotton bag or to take the leg of an old pair of cotton overalls, tie the end up loosely with a bow knot, cut one small hole half-way down the bag thus formed, and place a plug of cotton batton in the bottom over the part that has been drawn in with the bow knot. The object of the bow knot is that the cotton batton can be removed immediately if required. A piece of cord is then tied on, making the whole into a nosebsg, the cord slipping over the horse's head.

Some recommend giving a horse morphine and other similar drugs twenty minutes before administering the chloroform. Experience, how. ever, has proved the inadvisability of this. It only causes more trouble while the patient is recovering. It is a good practice to give two to four drachms of chloroform by the mouth as a drench in a pint of water twenty minutes before administering. This causes the horse to go under with far less chloroform, thus lessening the danger of heart failure.

744. Other apparatus are on the market. A bucket-shaped nosebag is often used, which has a side trap to admit air, a tin tray at the bottom to hold the sponge or cotton batton, and a wire frame to prevent the horse's lips from touching the sponge. A proper anesthetising muzzle, with tubes and taps leading to it by which the amount of chloroform and air can be regulated, is on the market. Messrs. Krone and Sessamon, of London, have one of this type.

In giving chloroform to a borse on the operating table, one nostril is generally partly closed with the hand, whilst the sponge is held a few inches from the other nostril. On no account must the one nostril be plugged up. A sudden inhalation may draw the plug in and cause suffocation. Always put a pair of blinkers on the horse, if he is not on the table, to protect his eyes from dust and other injury. Tan-bark will do a lot of harm and cause much pain if it gets into the eye.

745. In using the nosebag or the home-made cotton bag, the horse, if he is to be anmsthetised standing, is taken quite quietly and held by a line or rope on either side by an assistant. The bag is then put on and drawn up so that there is very little space between the face and the top of the bag.

The anæsthetist then drops on chloroform, drop by drop, through the trap of the nosebag or the cotton bag itself, great care being taken that all air holes are fully open to allow the horse to breathe naturally without drawing in the sides of the bag at each inhalation. In ten to fifteen minutes the horse should begin to sway; the moment he begins to sway badly the chloroform-dropping must be discontinued, and the horse allowed to fall down. When he is down, his haad must be stretched out so as to give freedom to the throat, and the bag temporarily removed to allow plenty of fresh air, and then put on again, and anesthetising continued.

746. If he can be thrown previously, then the best method is to use the hand and sponge, as are used on the operating table; one nostril must not be plugged up, but the hand held over it. On no account must the anæsthetising be hurried.

Four to ten ounces for an average-sized horse will be required to put him under. If chloro. form has been used orally, considerably less will be required. The horse will soon get into the second, or hypnotic, stage. He may appear to be in the third, but by gently raising the eyelid, if necessary, and touching the eyeball, it will twitch, showing that he is still in the second stage.

When there is no reflex action of the eyeball, the horse is properly anesthetised. It is now the duty of the ancasthetist to give sufficient chloroform to keep him under, and no more. He is to attend to nothing else. He will have one assistant if the horse is not on the table.

747. Any uneven or stertorous breathing is a bad sign, and the nosebag and sponge must be at once removed. Great care must be taken, when the horse falls down, that the bag is kept open, so as to allow plenty of fresh air, or else removed altogether. Breathing through the mouth is a very sure sign that there is not sufficient air. It must be remembered that, normally, the horse cannot breathe through his mouth.

A hurried start in giving the chloroform will often retard progress instead of expediting it.

When the horse is down, the method of lay. ing a handkerchief over one nostril and pouring on chloroform drop by drop must not be allowed. 
Besides burning the nostrils, some of the liquid is very liable to get inside them.

The sponge or batton must not be within three inches of the lips or nostrils. The head nust be kept a little raised, with the nostrils a little below the level of the head. The pulse must be continually felt at the submaxillary artery. Weakening of the lieart must be watched for. Great care must be taken that no dirt gets into the lower eye. The blinkers must be properly filted: special ones for this purpose can be had.

If the horse is on a table, he must be kept there securely fastened while he is coming round. If he is loose in a field or loose box, etc., he should be left quite free to recover slowly.

748. The fore arm and shoulder muscles may quiver as the horse is recovering from the effects of the anasthetic. To test if he is recovering properly, draw back the eyelid, and the pupil will contract on exposure to light. The horse must be given water to drink if he wishes it, but food must be withheld for two or thre hours afterwards. Then he must be fed on warm mashes for the rest of the day. If there is retention of urine, the catheter must be passed.

748. When death takes place, it is due to asphyxia, the heart ceasing to beat after the lungs have ceased to work; hence the patient can often be saved if the cliloroform is removed immediately, and artificial respiration resorted to for perhaps several hours.

Spirits of ammonia or anyl nitrite should be given at the nostrils as an inhalant. One to two grains of strychnine should be injected into the jugular vein. (P. 137.) Normally, of course, such a dose would probably kill the horse. Give also one gallon normal saline solution as an enema. (Normal saline equals one drachm common salt to one pint of water, approximately.)

If the horse is not given sufficient air, shown by laboured breathing or breathing through the mouth, more air must at once be given, and the chloroform and bag removed. On no account, let me repeat, must the anasthetising be hurried. The operator must cease to work whenever the anæsthotic has to be removed or more air has to be suddenly given, in case conscioueness should partly return. The heart shock in such cases might be fatal if the operater continued. This, of course, would not occur with an experienced anæsthetist.

750. Use of Morphine Prior to Chloroform. -Some surgoons prefer to use morphine or morphine compounds hypodermically before administering chloroform. Personally, I think there is very little gained; although a horse may go under moro quietly when morphine has been used, he takes longer to come round. It is claimed that morphine lessens the danger of bronchial troubles following anæsthesia.

Four to eight grains of morphine should be injected hypodermically half on hour before the chloroforming is commenced. The hore will be drowsy and will not generally fight the cliloroform so much, although I liave known casus where the fight was increased.

Morphine is givell hypodermically to dogs, about one-sixth of a grain, previous to anasthetising, to prevent vomiting.

A mixture of hyoscine, morphine and cactine, called H.M.C. mixture, is made by the $\mathbf{A b b o t t}$ Alkaloidal Company of Chicago, and is sold in small tablets in two sizes, containing 11 graill morphine hydrobromide and $2 \frac{1}{2}$ grains respoctively. It is better to use this than morphine alone as a preparation for chloroform. For a large draught horse the larger tablet is used, one an hour before and another half an hour before giving the chloroform. Ansesthesia is prolonged and the danger of bronchial pneumonia greatly diminished. H.M.C. can also be used as a local anresthetic to allay excitement or to correct the ill-effects of other drugs. It is used with good effect on dogs.

751. Anzsthetising Dogs.-Dogs are not often given chloroform by itself. It is far safer to use morphine or, preferably, H.M.C. A solution is made of the latter by using a tablet containing $\$$ grain (for $15 \mathrm{lb}$. dog), and injected under the skin; in half an hour a similar injection is given, which for a short minor operation will be sufficient by itself. If, however, a profound anesthesia (sleep) is required, it is safer to administer ether, and not to use cliloroform at all. A dog while under morphine may whine, due to delirium, but it will be insensible to pain.

With dogs the morphine has a quietening effect while coming out of the anrsthesis, and vomiting will be unlikely. The objestion to ether in dogs is its nauseating effect. It must not be used in lung or kidney diseases.

752. The Animal Anasthetics Act.-It is to be sincerely hoped that this Bill will successfully pass the llouse, as it is one that fills a gap that horsemen have for years tried to flll, and it is also heartily supported by the veterinary profession. It forbids horses, two years of age and over, from being castrated without a total anæsthetic. It forbids neurectomy (removal of a nerve), enucleation of the eyeballs, trephining, radical operation for quittor, line firing, operation for stripping the sole, radical operation for poll evil, and for fistulous withers without a total anæesthetic.

It omits to provide for ovariotomy without anæsthetics, but I believe this omission is being provided for. It also omits pin-firing, which is often as painful as line firing.

\section{Local Anacethetics}

753. Again I repeat how shameful it is that local anwesthetics are seldom used by vets. How 
IAP.

corve

the

own

logs,

sthe-

tine,

bbott

Id in

grain

spec-

hine

or a

, one

efore

inged

eatly

local

$t$ the

good

often

safer

. $A$

ng a

and

ur a

short

If,

is re-

d not

under out it

ening

, and

on to

must

is to

ccoss-

fills a

o fill.

rinary

of age

lotal

val of

ining,

opera

on for

out a

ithout

being ich is

s that

How
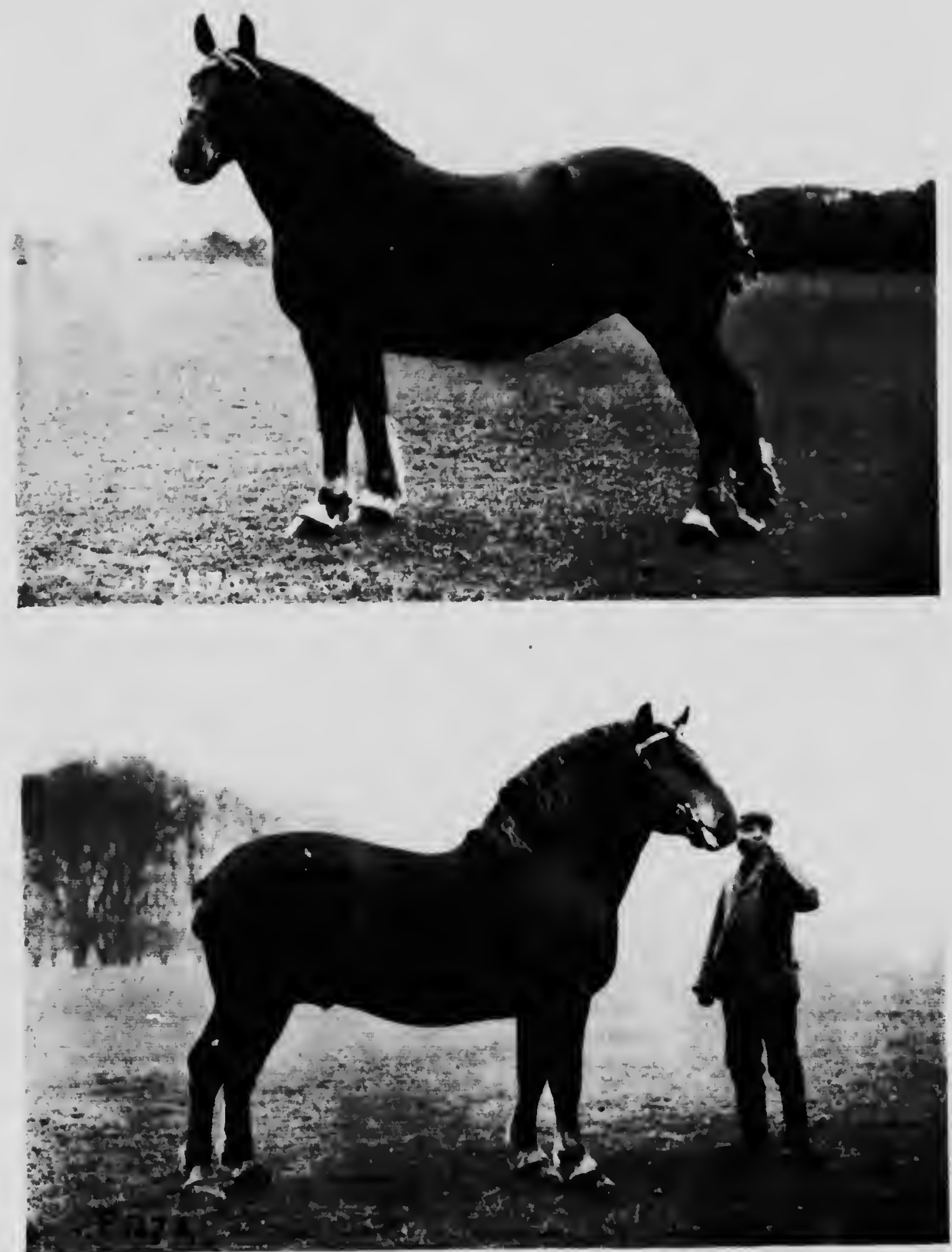

Two Famous Sufolt Punches, the Properiy of Mr. Kenneth M. Clark. Sudbourne Hall, Orinrd. Suffolk. a, "Sudbourne Lasse." Winner of many Firsts and Champion. B, "Sudbourne Redcup." Three-year Old Champion. Pholos kindly Lent by Mr. R. Gilling. Estate Manager. (Note the natural tails of these Suffolk horses.) 
PI.ATE: 128
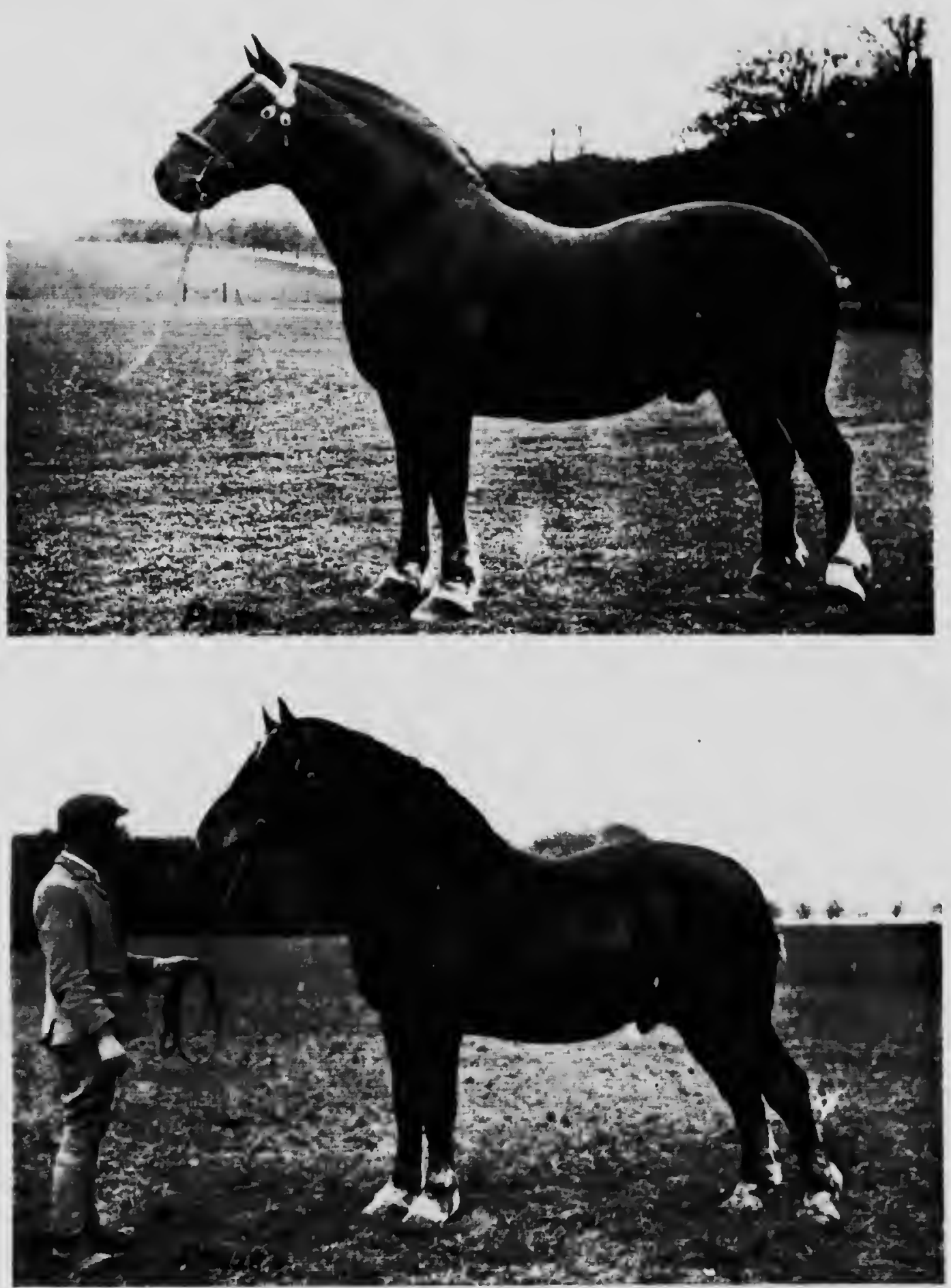

Two Famous Suffolk Stallions from the Sudbourne Hall Estate, Orlord, Suftolk (Mr Kenneth M. Clark). a, "Sudbourne L.ord," Champion. b. "Sudbourne Beaumonde," Champion 
often have I seen neurectomy, quittor and operations for seton, removal of tumours, etc., castration, straightening of crooked tails (see Sec. 650), etc., performed without the use of aven a local anesthetic! It is a cowardly practice and foolish to dispense with such aid, because there is no need to rope a horse down as if he were a ravaging lion. With local ansesthetics nearly all of the above operations can bo performed without the use of a single rope and without the horse feeling pain.

754. The methods of producing local anasthesia are: (1) freezing the part; (2) injecting a drug that temporarily kills the nerve; (3) by local application of fuids, or by rubbing these in : and ( 4 ) by electricity.

For the first method, an ether spray and etliyl chloride are used.

For the second, cocaine, eucaine, quinine and urea hydrochloride, slovaine, and anæsthaine are used.

For the third, any of the above solutions are poured on to the part-for instance, into the eye.

For the fourth, a series of electrical impulses are produced upon the part.

765. Local Anxsthesia by Freezing.-It a very slight local ankesthesia is required, ethyl chloride is merely poured on to the part drop by drop, but for deeper effects the ether spray must be used. The principle is this: an apparatus that produces a very fine spray of ether (similar to the bottle barbers use to spray the face) is used. When a liquid is forced through the air in a fine spray it will evaporate (turn into vapour). When a liquid is transformed into vapour, heat is required to cause this transformation. Thus, if a liquid in contact with another body is changed into a vapour, the heat that it requires for this is taken from the body with which it is in contact. For example, one's hand, if wetted and held in the wind, becomes cold, due to the evaporation of the water taking heat from the hand.

This reduction in heat is very great, as it requires 536 times as much heat to change one volume of water at $212^{\circ} \mathrm{F}$. into steam at the same temperature as it does to raise that volume of water, say, from $211^{\circ}$ to $212^{\circ}$. The figure 538 is called the latent heat of steam or water vapour.

Very volatile liquids, as ether, by evaporating at a very low temperature-about $84^{\circ} \mathrm{F}$. (less than blood heat)-produce a very much greater reduction in temperature. If ether is sprayed on to a part of the body, in a lew minutes that part becomes frozen and insensitive to pain. of course, the freezing is quite local.

756. Method of Using Ether Spray.-For veterinary use the methyl ether is generally used, as it is much cheaper than the ethyl ether. The part is clipped free of hair. If only a cut is to be made in the skin, as in inserting a seton needle, the part is sprayed in the direc- tion of the needle until the tissues become quite hard and the skin appears a peculiar blue colour. The incision is then made with the seton scissors, and the spray brought upon the incision for a minute. The needle is inserted, and the sprey again played over the skin ahead of the point of the needle. The seton thread is greased with an antiseptic, so that when it is drawn through it will cause no pain.

Other small cuts are made in the same way. In removing a tumour that is on the surface, the same procedure is resorted to, the spray being kept well round and over the part to be cut and well into ach incision as it is made. the knife being only inserted a little way, withdrawn, and the spray injected, and so on. No part must be cut unless it is quite hard, show. ing that there is no feeling. It requires con. siderable skill to operate successfully in this way, and if done properly there will be no pain felt. In large tumours more than one spray will be necessary to keep the part insensitive.

757. For firing the same is done. Large patches six inches square have been fired by deep line firing without the horse having his legs tied ut all and without his feeling any pain. In using the spray for firing, only the skin is frozen, i.e. the anresthetising must not be done too deeply, as the cooling effect on the iron will bo too great. The local ansosthetic also prevents the after-pain considerably, which, by the way, is the most painful part of firing.

For applying caustics and escliarotics, the ether spray sliould be used as above, thus remov. ing all pain.

758. For nerving, the ether spray is of the greatest use. The operation of culting a norve (e.g. the common operation of radial neurectomy) in the horse is an extremely painful one, yet how often is a local anæsthetic used? The incision is made, as above explained, right over the nerve. There will be no bleeding, because everything will be froz $2 n$. The spray is kept on until the tissues around the nerve are quite hard. The nerve is then exposed, and made free from connective tissue underneath; the spray is then kept on until the nerve becomes almost like metal. The nerve is cut-an inch should bo taken out-and the wound dressed in the usual manner. Sewing up is not advisable.

Ether spray is also used to detect lameness. For example, a certain joint, as the knee, is suspected of lameness ; it is made insensible, and if the lameness disappears it is clear that it was the knee that caused the trouble.

Internal operations, such as removal of an obstruction in the cacum, or the passage of the fœtus through the side of the womb when normal delivery through the pelvis is impossible, have been carried out with success with the aid of the ether spray when used very carefully, so that no part was cut unless hardened. 
Elline suray shoula be used before a trocar and canmula ure inserted, provided there is tiune.

759. Inasthesia by Local Injections. - The second methoul, that of injecting cocaine, ete., is used wheneser the operation is near the surface. "lie principle is that of numbing the nerve before it sets to the pinrt-that is, on the sute towaris the brain or spinal corl. For this reasul a certain knuwleme of neurulugy anatomy of the nerve's) is repuired. P. 1:17 and $13 \times \mathrm{k}$ slow the positions wlore injections are mate for comnon local operations.

In neuretonty of the rollial nerve, for in. stance, the injection is made, ten to fiften minutes before the uperation, oser the radial nerve on botli sides of the lex, futur to six inclies above the point of incision.

In operations for straightening the tail the

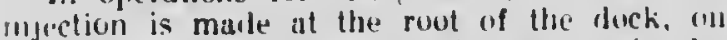
hoth sides, ten to fifteen minutes previously. lersomally, I think the ether spray is better, as it jrevents the necessity for inserting a newlle: therefore, there is less liability of missing the nerve, and it is easy to discover when the pirt is frozen.

Freshly made colutions of cocaine hyilro. chlorile mist be userl; old solutions are of no use. A 5 per cent. solution is generally used, 1 iraclim of it for each injection: 10 per cent. cocaine should also be rubbel over the place to be cut. In operating on the side of the borly, the injections should be male on the spinal cord side in two or three places. For continued lucal anæsthesia the duses must be repeated: larger doses must not be given at first. The action lasts from twenty to thirty ininutes.

760. The best way is to procure cocaine hydrocliloride in 5-grain tablets; one of these added to nearly 1: irachm of water would make a 5 per cent. solution. Two tablets added to the same amount of water would mnke a 10 per cent. solution, for external application. For llogs, always use a 5 per cent. solution. Over-ioses of cocaine problice a toxic effect. If serioms, strychnine must be given.

761. Anxsthaine (Abbott Alkaloidal Company) is a valuable local anesthetic, which is soll in 1 oz. bottles. It has not the toxic effect of cocaine, and produces lucal iffects much more (puickly: in two to four minutes if applied externally as a snray, and in fuur to six minutes if injected hypodermically. A solution of anres. thaine is equivalent in strength to a is per cent. solution of cocainle.

Quinine and urea hydrochloride is also a new local anæsthetic of great value. One grain of it is equivalent to one grain of cocaine; it is used in 5 per cent. solutions. It has no toxic effects. Over-doses produce no harm, excent to induce prolonged antesthesia. The anresthesia lasts much longer, sometimes several hours or even days.

Barker's solution of eucaine is also a valuable lucal anasthetic, which has less toxic Aect than cocaine. Its strength is cinivalent to per cant. solntion cocalne. Holocaire und acoute are local ancesthetics: they are also antisepti. Stovain und novocaiss ure used in 1 to 2 per cent. valutions insteat of cocaine.

In giving cocuine to doga, great care must be exercisid. (me-tenth of a grail III b per cent. solution is stafficient for liypodermuc use on $n$ snall dog. P.F. a small fox-terrier. This should be rejutateil if ther is no sign of curebral nervous c.xcitument.

762. The third method of anresthetsing, by exteriual applications of the flude mentioner above, is also uset. but generally un conjunction with lyjwolermic injections over the part to be cut.

'This can be rimertad to in order to relieve pain from a bruise or a painful part. The drug is rubbed in gently to hasten its absorption by the skin. This metluol is used for opumations on the eye, such as removal of hay semed, cinder, citaract, etc.

$\checkmark 1$ per cent, solution of cocaine, mass about (n)e-twentieth of a grain, i.e. 5 minums of the solution, is dropped into the rye by means of $n$ ilropper or clean fountain-nen tiller. The surface of the eye and a little beneath will be insensitive when the punil is much dilated, i.e. two or three times its normal diameter.

763. The fourth method, that of applying electric impulses at a very high rate of speed, is also practised in modern surgery considerably. The Leduc apparatus produces a hundred electric impulses to the second. The effect on the limb is almost instantineous loss of feeling.

764. Degree of Sensibility. - The sensibility to pain in animals is less than that in humau leings, it being greatest in the horse and dog. Next to them probably comes the guinea-pig. The sensibility to pain in the cow, sheep and pig is considerably less than that in a well-bred liorse or dog. The better the breeding the Ereater the sensibility to pain.

\section{Humane Deatruction}

765. The destruction of a suffering horse is very often a matter of considerable difficulty, not through want of means, but through want of the knowledge of the method of doing it. If one knows how a horse can be destroyed painlessly by means of an ordinary penknife, he may be able on many occasions to put a suffering horse out of its misery.

The most humane and the quickest and cleanest way is that of shooting through the brain. The layman who has not a thorough knowledge of the anatomy of the skull should shoot throurl the forehead into the lateral ventricles of the brain. P. $138 a$ shows the exact position for the bullet to enter. Lines drawn 
crussway from encll ear to the opposits pye will intersect une inuther oner the forelsad. The bullet should rnter at this point of intersction, aul be directed slightly uj,wards, and uti no accou., downwards. Weath is instankaneous. but there may be uervous twitching after death.

A loullet ful in behint the ear, through the fomrth ventricle of the lirain, cairses absolute cessation of nervous twitching, lut this should not be attempted by the anateur. It must be fulle bornt in mind that the lonse's brail is between the base of the ears, and not between the eyes.

The R.S.P.C.A. (Jermyn Street, Lundon) has invented a hunane horse-killer, which consists of a loug handle with a kind of revolver attacletl to one end, the whole somewhat resembling a pickaxe. The liandle is held so that one elld of the "pick" is against the forehead, i.e. where the bullet is to enter. The cartridge is fired by releasing a spring in the handle.

766. The knife can be used to pith the horse or to sever the posterior aorta. Pitling causes instantuneous death. It consists of completely dividing the spinal cord between the first and second cervical vertebra (atlas and axis); but this sliould not be attempted by anyone who has not studied the anatomy of these two bones when joined together, as it is very easy to insert the knife and not to be able to find the cord. I do not recommend this method to the layman. An exjuct will insert knife, cut the nerve, and withdraw the knife in one rapid stroke, the horse dying immediately. A steel dissecting knife, with a double edge, is the correct instrument to use for this operation.

I have only pithed a horse once, when the animal died immediately my knife was in. I did this as the only means available to put it out of its misery. I think there are far betler methods.

The postcrior aorta is the large artery that supplies the entire hindquarters and hind-limbs : it runs along underneath the backbone on the left side, passing under the left kidney. The hand and arm should be greased and inserted up to the elbow in the rectum; by placing the hand against the roof of the rectum the throbbing in the artery can be easily telt, and at a place approximately between the points of the hips the artery should be cut right across. No pain is felt, and the animal rapidly dies as if falling to sleep. The hand must be rapidly withdrawn to avoid escape of blood. The artery must not be confused with the vena cava, which runs along on the other side of the backbone, and which has no throb in it. This carries the venous b!ood back to the heart. I mention this as a means when no others are available, as horses are so oflen left suffering because no one will put them out oi their misery.
767. Prussic acid (hydrocyanic) is sometimes used to destroy horses. I strongly ileprecale its use, as I know of so many hopeless failures. Unless the acid is absolutely fresh, it is of little llse, as it rapinlly decoumusers. The only kind that I can recommend is that bouglit in hermetically sealert tubes, when it will be Iresh. Once opened, the whole should be used, or the remainder thrown away. It is sold in $20 z$. sealed bottles, contuining 2 per cent. (B.P.); once the bottle is opened. it must not be kept. It should be squirted into the mouth by means of a syringe or bullb. It would be safer to use 4 oz., i.e. two bottles, because the normal dose of prussic acid for the horse is to $1 \mathrm{dr}$. A 4 per cent. solution (Scheele's) is also on the market, half of this amount being required.

Prussic acid is commonly used with dogs; 1 oz. should be poured into the dog's mouth, whicl must be held open with the jaws upwards. Death is instantaneous.

Chloroform can be used. When the animal is completely anæsthetised, the air is cut of, and the animal asphyxiated.

768. Strychnine is also used. A hypodermic injection of 10 grains strychnine suiphate made into the jugular vein (P. 137) will cause instantaneous death, but violent reflex struggling will follow after the horse is really dead. The jugular vein lies in the jugular groove on the side of the neck. By pressing the finger into the groove the blood pressure in the vein causes the vein to swell up above the finger towards the head; the hypodermic needle is injected into the swollen part. Either side of the neck will do.

Electrocution is used for $\log s$ and cals and other small animals, and is a very humane method of destroving such animals painlessly and instantameously. Mr. Harris, of the Toronto S.P.C.A., lias had installed two of the latest types, one for cats, and a larger one for dogs.

The apparatus consists of a large cupboard with double sides. top and bottom, and a damp bed, on which the animal is laid. A metal collar is placed around the animal's neck. The animal is placed inside, and a wire hooked to the collar. The door is closed, and a current of high voltage, is turned on, which makes the animal insensitive and probably kills it. The current is then increased in pressure (voltage), to 1,150 , to make sure that life is extinct. After a minute the door is opened, and the animal taken out.

I do not approve of the lethal chamber, so popular a few years ago. It consists of a box, in which the animal is placed, and, after he is insicie, chloroform vapour is introduced, thus asphyxiating the animal. I conclude by reminding the reader that there is no more humane method of destroying the horse than shooting it. I lavie never seen a case tail. 


\section{CHAPTER XVII}

\section{BACTERIOLOGY, ANTISEPTICS AND THE THEORY OF DISEASE}

769. Theory and Prevention of Disease.-Disease (literally, without ease) is defined as "an abnormal condition of a vital tissue." A diseased condition, however, must not be confounded with an abnormal condition of an organ composed of healthy tissue, such as a corn, which is merely a hypertrophy, due to irritation, or an enlarged muscle, which is due to excessive nourishment being supplied to the part, a result of increased exercise to the part. The tissue itself, and not only the organ, must be actually abnormal, otherwise there is no disease. Disease is caused in two ways: firstly, by a microorganism, in which case the disease is said to be contagious or infectious ; and, secondly, by other means than such organisms.

770. IVe will consider the second condition first, as it does not concern us so much in this chapter. Diseases produced by non-contagion are those produced by a breakdown in tissue, due to excessive strains, by a breakdown in the nerves supplying the parts, by arrest of blood supply to the part, and by abuse of habits, such as use of liquor, smoking, etc. Diseases produced in this way are paralysis, heart disease, diabetes, liver disease, various nervous diseases, etc.

The prevention of such diseases is clearly the removal of the cause, health" living, plenty of good exercise to all parts of the body, absence of worry, faith in one's own health. The cure is healthy exercise, fresh air, moderate habits, careful dieting, absence of worry, and faith in one's own health. I deal with the prevention of human disease at the end of this chapter.

771. Conlagious Diseases.-Diseases produc?d by contagion are those that are receiving the greatest consideration to-day. We will consider how such are produced, how they are spread, how they are prevented, and how they can be cured.

Micro-organisms are of two kinds, animal and vegetable. The former are called protozoa (one cell), the latter, bacteria, yeasts, and moulds
or fungi.

The surface of the earth and everything on it, as well as the atmosphere, is covered or filled with millions of vegetable micro-organisms. In fact it would be impossible for life to continue without these germs. These vegetables are in reality our best friends, and it is only by accident that a small percentage (not more than 2 per cent.) do us any harm.

Bacteria and yeasts carry out one of the most important functions that exists in the world. All putrefaction and decay are due to bacteris. Bacteria destroy dead bodies, and transform important chemical elements like nitrogen and carbon from unavailable combinations into substancos that can be utilized and changed into higher forms of plant life. Bacteria modify the composition of the soil and the character of crops, and are, therefore, of the greatest use to farmers. bacteria impart the flavours and the aromas to butter, cheese, milk, etc.; bacteria are responsible for the tanning of hides, retting of fax, and the curing of tobacco.

Vinegar, which is acetic acid, is formed by bacteria. The chemical equation is as follows: $\mathrm{C}_{2} \mathrm{H}_{5}(\mathrm{OH})$ (alcohol) $+\mathrm{O}_{2}$ (oxygen) $=\mathrm{HC}, \mathrm{H}, \mathrm{O}$, (acetic acid) $+\mathrm{H}_{2} \mathrm{O}$ (water).

Lactic acid bacteria eat and digest the acid and make cheese.

Formerly, ammonia was made by the action of bacteria on urine, forming ammonium carbonate.

Iron is liberated as iron hydrate in some bogs by bacteria.

The acidity of peptone, an agent in the digestive system, is due to bacteria.

Gelatine is produced partly by the action of bacteria.

The preservation of many foods is due to bacteria.

772. Fermentation is due to yeast cells, which break up the structures that they attack in order to obtain nourishment for themselves, and in doing this they cause important chemical changes to take place. For instance, yeast cells are present on the outside of all grapes, and when grapes are put into a vat for the purpose of making wine, the yeast cells cause fermentation; if these cells were not present, fermentation would not take place. The yeasts convert all starches into sugar by combining a molecule of starch with a molecule of water and forming $\mathrm{H}_{2} \mathrm{O}=\mathrm{C}_{4} \mathrm{H}_{12} \mathrm{O}_{4}$. 
PI. ITE 129
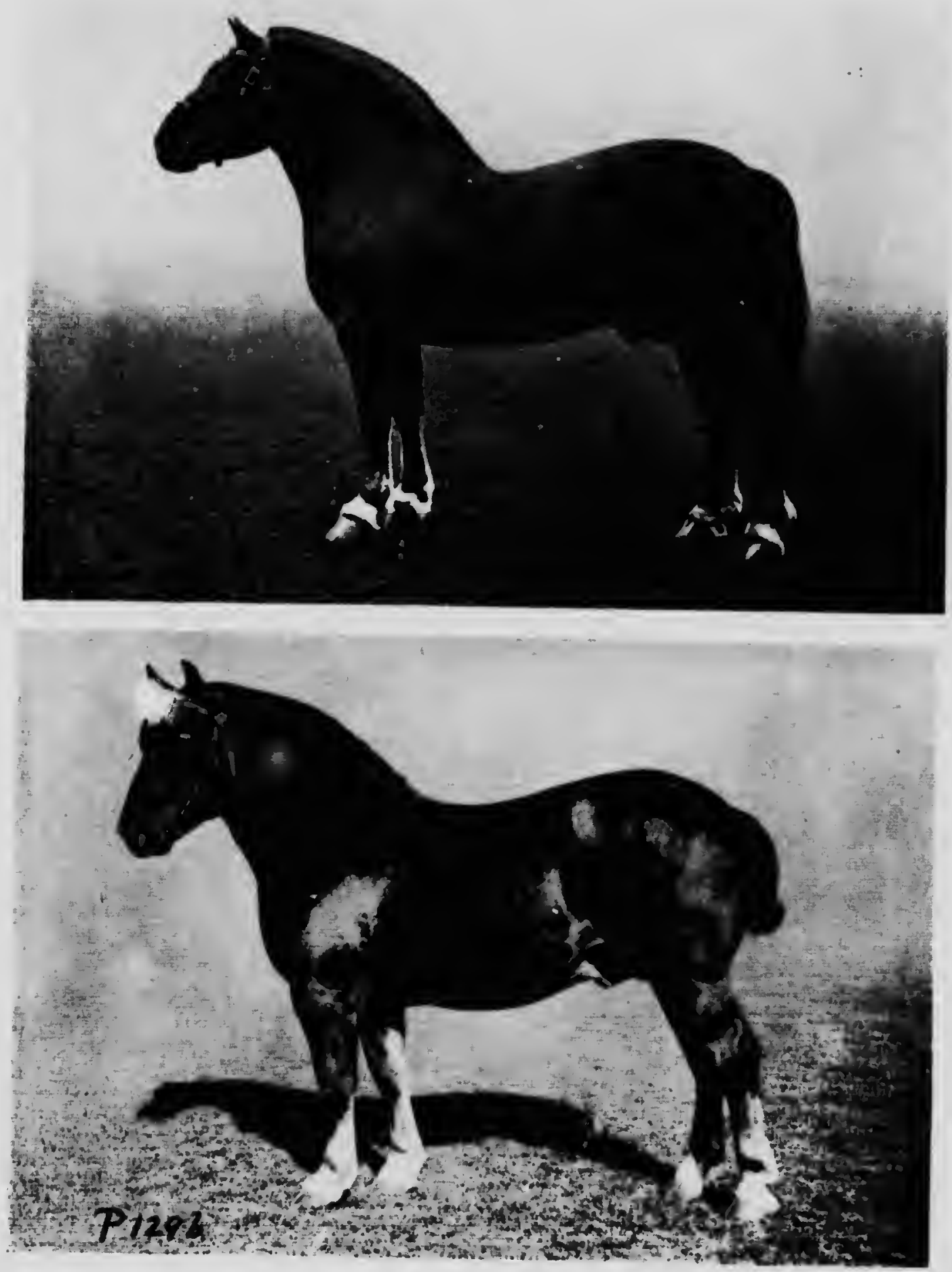

TWO BEAUTIFUL CHAMPION SUFFOLK PUNCH STALLIONS

o, "Saturn." b, "Sudbourne Arabi," Copyrighe Photes; W. A. Routch. Londasn. TTail of the latter is plaitedup and quite nalural.) 
PIATI: 130
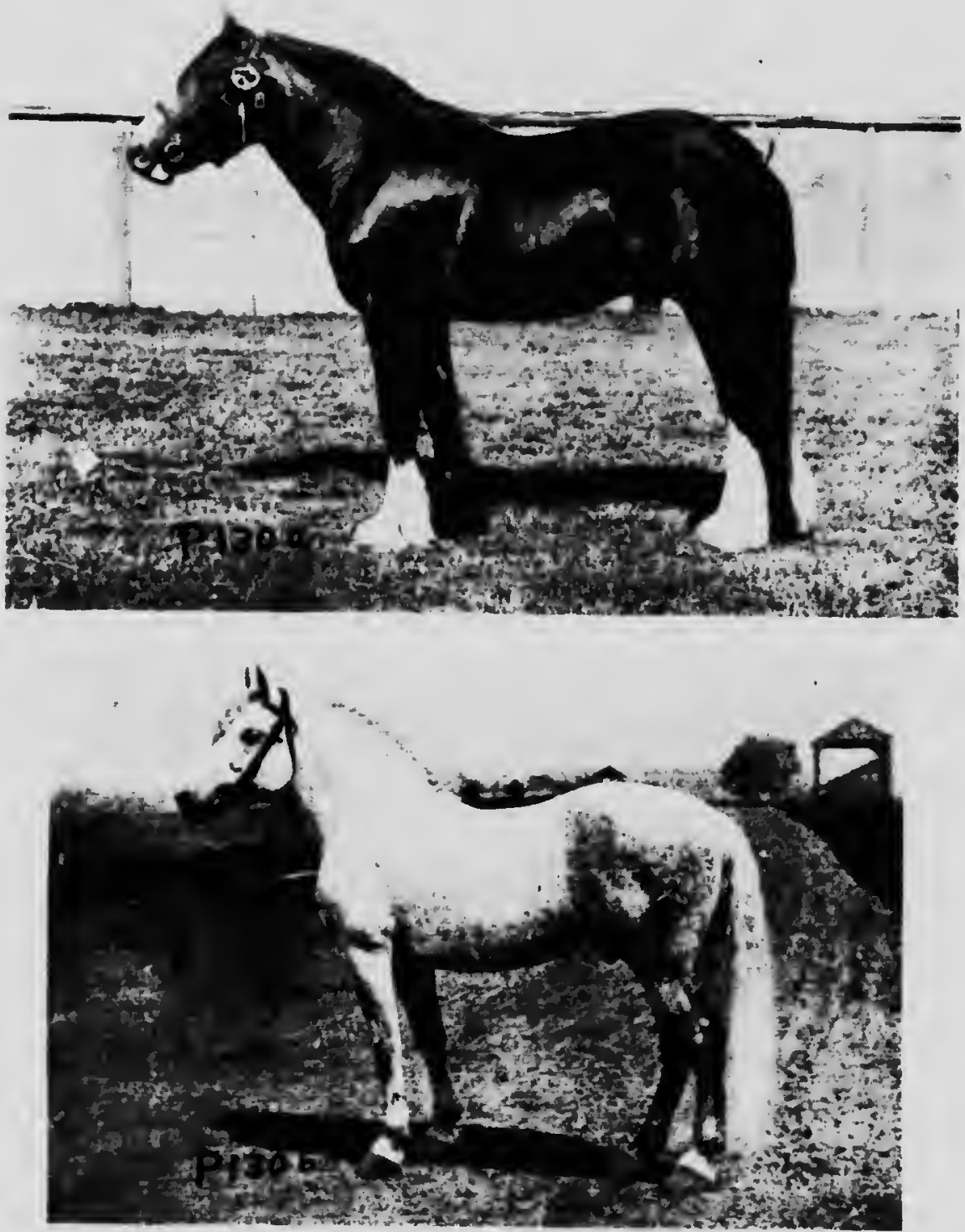

a. Twosearcold Champun Clydesdale Stallon "Roval Ciuest." Owned by Mlessrs. $\lambda$ and W: Mlontromery. Couritesy: "Canadian Farm." b, Champon P'ercherou Stallion " Ther," American Bred. From the "Standard Cyclopardia of Modern Agriculure" 
Yeast cells are a little larger than most bacteria.

Moulds and fungi decompose dead matter underground and inside trees, where bacteria, efc., cannot gain access. Mushrooms are a form of fungi. The fermentations of sauerkraut and those of bread, etc., are due to yeasts.

Vegetable micro-organisms are not alone in helping along daily life, because protozoa carry out their portion of work; they eat up bacteria after the bacteria have done their work. Protozos are found in all waters and in grass, hay, etc., and in any infusion of grass, hay. herbs, plants, etc. The chalk cliffs of Dover, England, are composed of millions of fossilised protozoa, showing that these cliffs were once inundated. It will be understood from the above remarks what an important part micro-organisms play in the routine of daily life independently of that of producing disease.

773. A very short while ago it was considered that bacteria were necessary for the actual existence of life, but it has of late been proved in the Pasteur laboratories that chickens can live, and live abnormally well, in an atmosphere absolutely free from micro-organisms, and on food also free from any microbe. Whether invertebrates can live without bacteria is doubtful. Grass-eating animals (herbivora), which devour a great deal of cellulose, require bacteria (bacilli colli) in their stomach to assist in digesting the cellulose.

But even if all animals, vertebrates and invertebrates, could live without microbes, plants could not, and the lowest forms of life could not, so that our food supply would soon become exhausted.

774. Protoplasm is the substance of which all cfll life is composed. When any animal or vegetable dies, it is split up by bacteria, etc., into its original elements. Plants have a power, in the presence of sunlight, by means of the chlorophyll (the green colouring matter in plants) that all plants contain, of building up protoplasm again from the elements that they collect from the air. In this way the elements are used over and over again to form animal life.

An animal dies, and is decomposed by bacteria, who eat some of the elements and liberate the rest. They themselves may be eaten by protozod. Plants gather some of the elements and reform protoplasm. Animals (e.g. cattle) eat the plants, we oat the cattle, and thus obtain protoplasm. Again, fish eat protozod, we eat the fish, and thus obtain more protoplasm. We also require starch and fat besides protoplasm; these substances we get from plants. plants have the power to produce starch and fat from the elements. By plants are meant all grasses, herbs, cereals, etc.

775. The micro-organisms that live on dead material, as described above, are called saprophytes.

Those that live on living matter, such as worms, mistletoe, certain ivies, etc., are called parasites ; they do not necessarily kill, but live on the living matter in order to exist.

There are others, called infective agents, which have not yet learned to live without doing liarm to living tissue; these cause disease. Vegetable infective agents attack animal tissue mostly, whilst animal infective agents (harmful protozoa) attack animal and vegetable tissue.

It is difficult to differentiate between living and dead material, because when an animal dies there is at the moment of death only a very small portion of his body really dead-for example, all his muscles, if healthy, remain alive until decomposed by bacteria, whilst iron, sugar, etc., are dead materials. The best definition of dead and living material, 1 think, is the following: living material can construct more material, e.g. more protoplasm and more fat can be former from the elements by protoplasm and fat rt ptively; dead material cannot construct.

776. This construction is carried out by agents, know as ferments (enzymes), that are always present; these ferments do not themselves become used up. Thus, bacterium attacks a piece of muscle; by means of the ferment it breaks up the elements and digests those that it requires, and liberates the rest into the atmosphere in the form of gases. The process is the same whether it lives on dead or living material.

All infective agents, i.e. all micro-organisms that produce disease, whether vegetable or animal, are called pathogenic (disease-producing), whilst those that do not produce disease are called non-pathogenic.

Pathogenic micro-organisms, or microbes, have not yet been discovered that will produce disease in every form of life; in fact, most pathogenic microbes produce disease ir only one or two varieties of hosts. For instance, those that produce disease in mammals, as a rule, do not in cold-blooded animals, and vice versa. Some are restricted to sheep, some to dogs, whilst some are restricted to a certain kind of tissue, e.g. the liver. The typhoid banteria when swallowed by a man produce disfase, or may do so, but if swallowed by a horse or ox have no effect, as a rule. Thus, e.g. an organism that is pathogenic to some animals or to human teings is non-pathogenic to others and plants. There are other factors in the patient that affect the pathogenicity of a microbe, as age, hunger and thirst, fatigue, exposure to extremes of heat or cold, unsuitable diet, general health, nervousness, condition of blood, the habits of life, etc. Then, again, the pathogeniclty of a microbe depends upon its virulence and upon the nimber that gain access to the body. 
777. We will now briefly consider the various forms ef micro-organisms :

Animal, called protozuil.

Vegetable: bacteria, yeast and moulds or fungi.

Bacteria are divided into: (a) bacilli, or rod-shaped (as those of tuberculosis, antlirax, tetanus); (b) cocci, little spheres, which are of different forms, diplococci (as in pneumonia), tetracocci, sarcinæ, staphylococci (as in abscesses) and streptococci (as in abscesses); and (c) spirilla, or spirals (as in syphilis).

Bacteria, etc., are able to reproduce asexually, i.e. without different sexes having to unite, very quickly by merely increasing in size, and then dividing into two. The rod-shaped bacillus of tuberculosis divides into two rods in half an hour under favourable conditions; thus, if we start with one bacillus, and place it on a suitable medium, as broth, in one hour there would be four bacilli, and in 32 hours there would be approximately $\quad 10,000,000,000,000,000,000,000,000$ bacilli, providing that each microbe formed into two at the end of half an hour; but, fortunately, such an occurrence would be most improbable. Some bacteria multiply in five minutes.

778. The study of bacteria is generally looked upon as an easy task. Many imagine that all one has to do is to take a high-power microscope and place some infected matter under it, and ther. to view at leisure the thousands of microbes wriggling about under the lens. Such is not the case, and far from it. The difficulties that beset the bacteriologist are countless, and it las truly been stated that there is no science with greater difflculties to overcome.

Briefly, bacteria, etc., are studied in the following way: an infected substance is taken and diluted considerabiy with freshly sterilised distilled $u$ ater (all vessels used must be previously sterilised); then variocs anilıne stains are used upon this infected solution, thereby staining different bacteria different colours. After years of study it has been discoveren that various bacteria "take" various stains, and thus, by repeated staining and unstaining, we can eventually produce a certain stain in cne form of bacteria (the form that we suspect is present in the solntion) that will stand out distinct from all others. In this way we can ascertain not only if that particular form is present, but can study it after we have found it. The presence of some bacteria is detected by the actions they have on different sugars.

Again, we might have a certain matter that was suspected of containing bacteria. What we have to do then is to cultivate the growth, i.e. produce a culture. We take the suspected matter and put it into a suitable medium, such as broth, blood serum, agar, gelatine, potato, milk, starch, jelly, ete, and keep the hole free from atmospheric impurities at a certain temperature for a day or so. At the end of this time we shall find that large colonies, many visible to the naked eye, have been formed, and we are then able to study these colonies either as a whole or by making dilute solutions of them.

If we place a dilute solution of the original matter into a thick sulution of gelatine, for instance, and form a culture, we shall find that each individual bacterium, etc., lias formed its own gigantic culture, without being able to move on accoint of the stifiness of the medium. Thus we can take these cultures separately and examine each one, by diluting it several hundred times and then staining it, and find what particular bacteria each culture consists of. The reason of the dilution to such an extent is that, unless the solution is diluted to a required amount, it will be impossible to see anything through the microscope that will furnish us with the information required.

779. Methods of Admission into the System. -Pathogenic microbes enter the system in various ways-through the respiratory tract, the alimentary canal (from mouth to anus), the genital organs, the mucous membrane of the eye, the navel (umbilicus), abrased skin, and any form of wound or bruise.

The virulence and even the pathogenicity of a microbe often depend on the manner in which it enters the system; thus the bacterium of Asiatic cholera is far more dangerous if eaten than if injected under the skin, whilst, on the other hand, the typhoid bacillus can be fed to a rabbit without doing any harm, but if injected under the skin is nearly always fatal. It must be remembered that anything in the stomach or intestines is as much outsite of the system as if held in the hand, because it must be absorbed through the intestinal walls before it is in the syste .; thus many of the harmful germs that we eat never gain access to the system. As stated above, the health of the animal governs so much the likeliness of any eaten bacteria doing any harm.

780. How Pathogenic Microbes Produce Disease.-We now come to the important question of how these various pathogenic animal and vegetable microbes produce disease. There are several ways in which disease is produced.

Briefly they are as follows: (a) by forming chemical poisons (toxins) and emptying this into the blood; (b) by moving in the blood and forming poisons ; (c) by destruying cells of the tissue without producing free toxin in the blood: (d) by destroying the blood corpuscles.

Protozoa (animal microbes) produce diseases mostly by entering the blood and destroying the red corpuscles. Snch diseases as malarial fever (see Sec. 640), sleeping sickness, Texas fever in cattle, maladie du coit in horses, surra in shetp, etc., are examples of those produced by protozoa. 
These microbes are la.ger than bacteria, and are in some cases larger than the red blood corpuscles, which, in the horse, measure less than so's in. in diameter.

Bacteria, as stated above, produce disease by forming a poison known as a toxin. If the toxin is produced outside the system and injected into the blood, as in lockjaw (tetanus), it is called an extra-cellular toxin; if produced inside, as in anthrax, it is called an intra-cellular toxin. There are two varieties of bacteria forming the intra-cellular toxin: those like anthrax, which spread over the whole blood system; and those like tuberculosis, which locate in certain glands and remain there.

781. Bacteria vary in size, but the average size of a bacillus is Trod in. in length and ริ much smaller they are than red blood corpuscles. The reader might reasonably ask how animal micro-organisms are distinguished from vegetable. As a matter of fact this is a difficult question to answer, because in some forms of socalled vegetable microbes there is more motion and more animal signs than there are in many forms of animal microbes. For instance, the spirillum bacterium, that is supposed to produce syphilis, looks just like the little worm-like animal (equiperdum trypanosoma mastigophora) that produces maladie du coit in horses, wrongly ralled horse syphilis for this reason. Yet the former is a vegetable and the latter an animal. Again the rod-shaped bacillus (vegetable) that produces typhoid has numerous little wriggling legs (flagella), and yet many of the trypanosomes and other protozos are far less like animals to look at under a high-power microscope with, say, 2,000 diameters magnification.

The real difference between vegetable and animal microbes seems to be that the vegetable microbe digests its food externally, thus liberating at once all the useless elements and assimilating only those that it can make use of ; while the animal microbe, like all animals, digests its food internally, and afterwards assimilates the useful elements and excretes the useless ones.

782. Pathogenic animal microbes are also distinguished from bacteria, yeasts, and fungi in that they generally live in two distinct hoststhe one in which they produce the disease (e.g. the horse, in the disease known as nagana, common in South Africa); and the other in which they generally breed (a fly or mosquito, e.E. the tsetse fly). The peculiarity of these flies is that they alone are able to reproduce in their stomach these protozoa, and after a certain period, when they bite an animal, they inject into that animal some of the virulent protozos. So that most protozos, unless in company with one particular kind of $f y$, are unabio to produce disease. Hence it will be seen that the way to get rid of these diseases is to destroy the disease-producing fy or mosquito. This is what is being done now in many parts of the world, e.g. Malts, South Africa, and South America. (See Sec. 840.)

783. Some non-pathogenic bacteria (saprophytes) produce certain poisons called ptomaines, and it is possible for a sufflcient quantity of these to be produced in the intestinal tract to cause harm to the animal or person. However, most so-called ptomaine poisoning is now put down to pathogenic bacteria and not to the production of ptomaine poisons. The toxins produced by pathogenic bacteria are of a most poisonous nature. Here is a comparison with other poisons :

$$
\begin{gathered}
\text { Fatal dose for adult man, strychnine . grain } \\
\text { colora venom } \\
\text { tetanus toxin } \\
\text { (lockjaw). }
\end{gathered}
$$

One of the peculiarities of toxins is that they have the power of producing antitoxins when injected into suitable animal bodies. This discovery was one of great importance in the prevention of disease.

784. Some of the commonest diseases produced by bacteria are the following: tuberculosis, tetanus, anthrax, influenza, glanders, pyæmia, septicæmia, diphtheria, typhoid, pneumonia, syphilis, gonorrhoe, etc.

Although in some of the following diseases the presence of certain bacteria has been sus pected, up to the present time the specific cause has not been isolated: scarlet fever, mumps, smallpox, measles, whooping cough, yellow fever, spotted fever, foot-and-mouth disease, and chicken-pox.

785. How Microbes Enter the Internal System.-In Sec. 779 an idea is given of the various ways in which bacteria enter the system. It is possible, but very exceptional, for bacteria to enter through hair follicles and sweat glands; but if the animal is healthy, the tissues under the skin will prevent this invasion; resistance is also increased by the antiseptic properties of lymph.

Generally speaking, bacteria reach the walls of the intestines, i.e. the mucons membrane, by gaining entrance with the food eaten by the animal. When there, they must actually get into the circulation by entering in between the cells of the tissue : the healthy state of the tissue affects this considerably. They can also get in by passing in with globules of fat that pass through little openings that receive these globules. Non-fatty r: aterial enters the circulation hy a diffusive process known as osmosis, which is very similar to the way water passes through the porous parts of a fiter. Thus, fat is a decided assistance to the admission of microbes, and, therefore, septic milk (milk con- 
taining poisonous microbes) is far more dangerous than septic water, as milk contains minute globules of fat.

Microbes may reach the air sacs of the lungs. Here they have very little diffculty in passing into the circulation by the lung capillaries. In the same way they may pass through any mucous membrane, which may be reached by way of the genital organs, the navel, the eye, etc. Skin, as long as it is healthy, will not admit the passage of bacteria, but directly it becomes cut, bruised or burned the reverse is the case.

From the above remarks the reader may wonder how it is that every animal and person lias not always some disease, there being no doubt that we are in constant contact with millions of pathogenic organisms almost every day of our life.

786. How the System Fights Against Microbes that Produce Viscase.-Firstly, many portions of the body prevent the entrance of microbes. Unbrokell or undamaged skin is an impossible barrier. Lymph is an antiseptic. The sub. cutaneous tissues prevent admission, partly mechanically, by forming fresh tissue. Mucus, which is present on the mucous membrane of the respiratory tract, etc., is an antiseptic. The mucus, by continually moving, prevents a permallent lodgment. Perspiration is a slight antiseptic: the conjunctiva of the eye is protected by irrigation; the lachrymal secretion (tears) is slightly antiseptic, eyelashes and eyebrows and hairs in the nostrils also assist. The tiny hairlike cilia in the nasal passages and windpipe are continually waving towards the nose and mouth respectively, the cilia in the womb are continually waving towards the exit; saliva is slightly antiseptic (altlough a healthy human mouth may have as many as fifty kinds of bacteria in it at the same time). Air, as it enters the lungs, is filtered from bacteria by the cilia and wet mucous membrane of the nasal passages; hence the necessity for always breathing through the nose.

Bacteria which pass through these traps are probably caught before they reach the minute air sacs of the lungs. The gastric juices in the stomach are antiseptic. Nervousness affects the supply of these juices very considerably, and thus nervous people often pick up diseases through neriousness. Bile is slightly antiseptic. Tle juices in the intestines, however, are very slightly, if at all, antiseptic; in fact, the number of bacteria in the intestines increases from the stomach to the end of the large intestine (colon). If the tissue is quite healthy, the presence of these microbes does no harm; thus pus-producing streptococci and other germs are always present in large numbers, and typhoid bacilli may be present in large numbers withoul ever affecting the system.
The case of a cook in Now York City having been in the best of heslth, but having had typhoid bacilli inside her in large quantities for two years, is one instance of suoh possibilities. This womar, on account of her being unclean in her habits, caused about 200 cases of typhoid fever and twenty deaths before anyone suspected that she was the cause.

Thus it must be clearly understood what an important part good health plays in the prevention of germ disease.

787. After the germ has reached the system, i.e. the blood circulation, it meets with two most important enemies: the one, the white blood corpuscle; the other, chemical poisons (poisons that either kill the microbe or else chemically destroy the toxin produced by the microbe). White blood corpuscles (leucocytes) are, strictly speaking, the scavengers of the body, and are, therefore, called phagocytes. Their chiof function is to devour foreign bodies, such as bateria. Then, again, the system contains certain antitoxin poisons that destroy certain bacteria, or destroy toxins produced by bacteris. Thus one animal would possess one antitoxin and another would possess another, and, therefore, one animal might be immune or safe from contagion to one disease, whilst another animal might contract it.

788. Immunity from Disease.-Immunity can be natural or acquired. As stated above, certain animals and certain races are naturally immune against certain diseases; thus vertebrates are generally immune against invertebrate diseases, and cold-blooded animals immune against warmblooded animal diseases. Individuals also possess striking immunity from certain diseases.

Acquired immunity is of two kinds: active and passive. Active immunity is due to direct participation of the microbe concerned; for example, the inoculation, by means of vaccination, of the microbe of cowpox, which produces a mild form of smallpox.

Passive immunity, on the other hand, necessitates no active generation of the disease in question, but consists in introducing chemicals (antitoxins) into the system that make that system immune against that particular disease. For example, diphtheria is prevented by the introduction of diphtheria antitoxin; lockjaw, by the introduction of antitetanic toxin. Passive immunity, however, is not so permanent as active immunity, and in most cases disappears rapidly.

789. Active immunity may be produced in the following ways :

1. By introducing living bacteria of full virulence in a small quantity, which is gradually increased. The disease is thus produced in a mild form, which apparently produces antitoxins and makes the subject immune afterwards. 
PI.ATE: 131
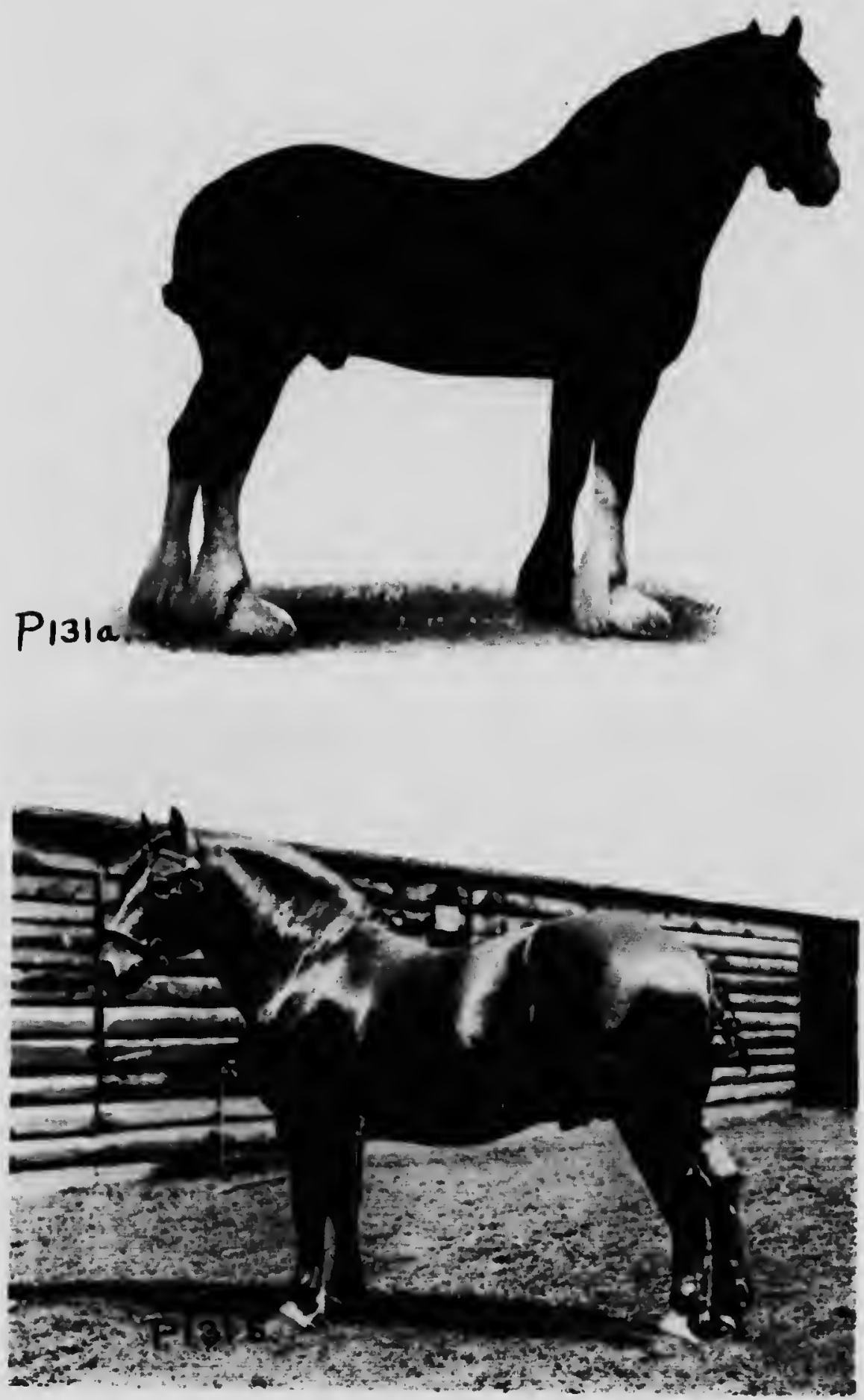

a. "Baron O'Buchlyvie," Champion Clydesdale of the World. Photo: A. Brown. Lanark. Scotland. b, Champion Suffolk Punch Stallion .. Easton Duke," owned by the Marquis of Graham. Copyright Photo: Sport and Ceneral 

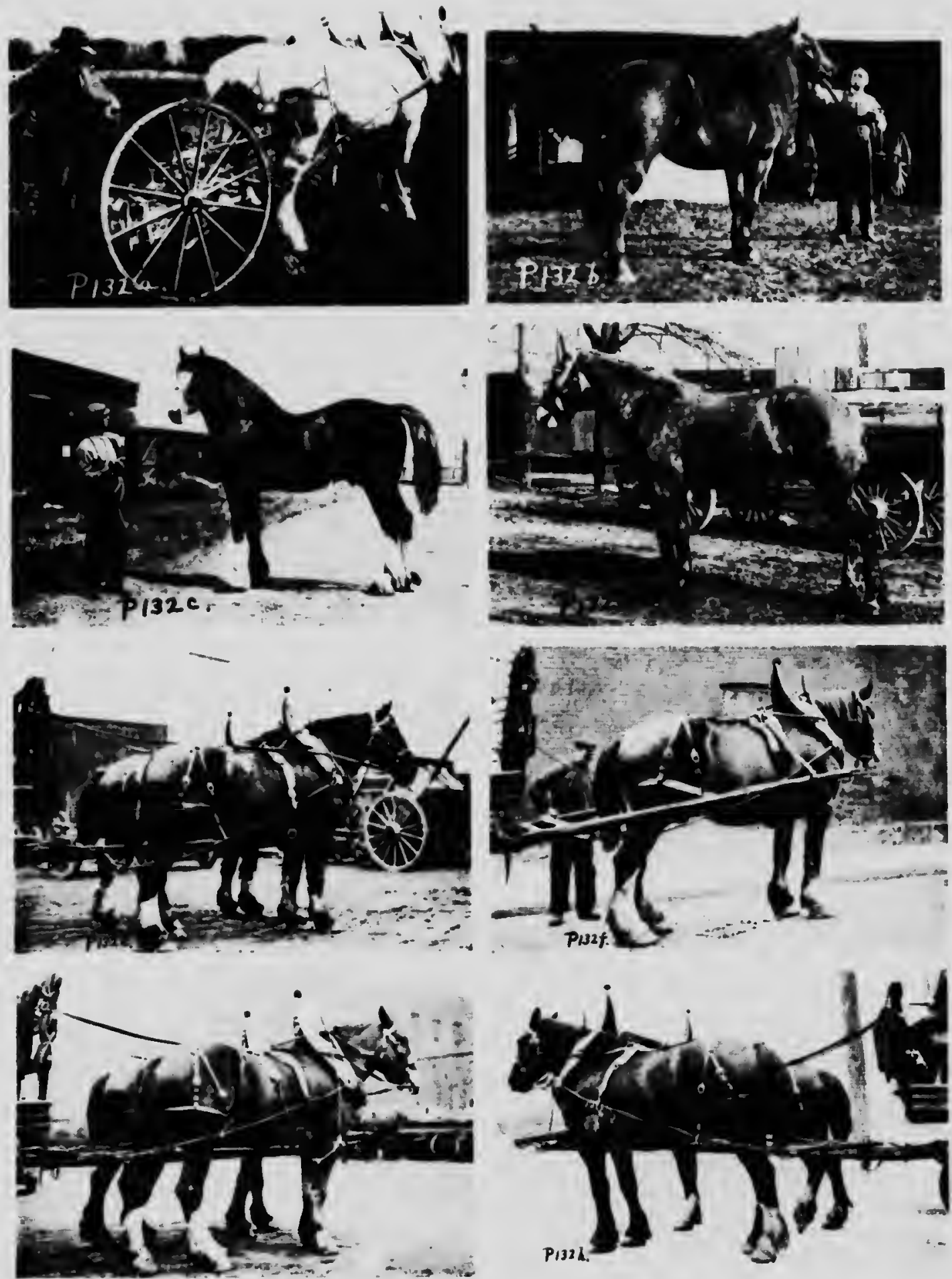

TYPES OF HEAVY DRAUGHT HORSES

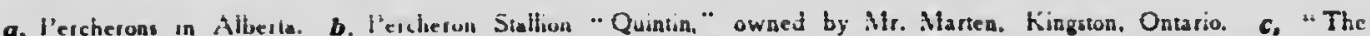
Bruce," Champion. Winnipeg Show. Courtesy: "Canedien Farm." d, Courtesy: Dominion Transport Co., Toronio (Cana. daen Pactife Railway). Photos. b, d, by the Authur. to h, Courtesy: Col. W'm. Hendrie, Hamilion (Grand Trunk Ralway Co.). Photos: W. James. Toronto. 
2. By introducing living bacteria that have been made much less virulent.

Passive immunity may be introduced in the following ways :

1. By introducing dead bacteria into the system. This has been done in immunising people against typhoid, cholera and plague. The chemicals contained in the dead microbes are evidently the cause of immunity.

2. By introducing bacterial chemicals secreted by bacteria while living, as in the case of diphtheria antiloxin.

3. By introducing chemicals produced by dead bacteria.

4. By introducing bacteria or bacterial chemicals (vaccines) that have nothing to do with the production of the disease, as is done in immunising animals against anthrax.

790. Baclerial Vaccines. - A bacterial vaccine is a liquid suspension of the killed culture of bacteria or germs. These vaccines are prepared in a bacteriological laboratory by growing, in a suitable medium, the bacterial organism associated with the particular disease. These cultures are then killed at their minimum thermal death point, after which the vaccine is slandardised according to dosage, and a very small amount of preservative added to ensure sterilisation of the product. Finally, the vaccine is tested upon healthy guinea pigs. If these remain well after injection, the vaccine is considered safe for use.

The scientist Metchnikoff discovered that when a germ entered the animal it caused a local irritation that attracted large numbers of white blood corpuscles to the part. These cells are able to pass through the walls of the blood vessels. They are antagonistic to the invading germ, and, providing the germs are not too numerous, will completely destroy them.

Professor Wright showed that the serum of blood contained a substance which, in the presence of a germ, reacted upon the white corpuscle, making it more active. This action is known as "opsonin" (Greek for "prepare for"). He also demonstrated the value of the opsonic index in determining the state of active im. munity. He showed that when an emulsion of killed bacteria was injected into the blood of an animal suffering from the analogous disease, the white corpuscles became very active and were able to destroy three or four times as many germs as they could previous to the nnimal receiving the vaccine.

Dr. T. C. Evans, B.V.S., of the Experimental Laboratories at Ottawa, tells me of an instance of a little girl who owned a small pony. The pony contracted glanders and was destroyed. The child developed a chronic infection which resisted all medical treatment. A pure culture of glanders was isolated from an ulcer in the 21 child's leg, and a bacterine was made from it. After a few injections with it the case made complete recovery. Glanders is usually fatal in the human being.

The time is at hand when modern sanitation and modern business will unite to sweep diseases away and assist the laboratory-worker to bring successful results from his hard labours in the preparation of these bacterial vaccines.

791. Of late a great number of new vaccines have been made for the prevention and cure of infectious diseases. One has been used for several years for anthrax and black-leg.

Dr. Evans has successfully made a vaccine against that common disease strangles. Splendid reports have been received regarding the im. munisation and therapeutical treatment with this vaccine. This vaccine has also been used with great success in influenza. I have had occasion to see the results of its use. Evans has treated several cases of severe quittor in the horse by preparing an autogenous vaccine from the germs isolated in the actual case.

There are many conditions where a vaccine can be used in the scientific treatment of infected wounds of the horse: for example, indolent abscesses, infected nail pricks, fistulous withers, poll evil, scratches, etc., and all wounds that are slow in healing through bocterial infection. Much useless pain from operations could thus be avoided by the timely and judicious use of bacterines.

The Japanese scientist Hideyo Noguschi has made some wonderful discoveries in quite recent times. It was he who discovered the real cause of tartar on the teeth, called gingivitis, or, more properly, pyorrhoea alveolaris ; it is a minute microbe. He also isolated the germ of infantile paralysis and is preparing a vaccine against it. (See Sec. 640.) He also showed that the negri bodies are the real cause of rabies.

Noguschi also isolated the germs that cause locomolor ataxia (tabes dorsalis) and relapsing or intermittent fever. Both of these are caused by a minute bacterium, a spirillum.

792. It will thus be seen that in reality a pathogenic microbe has quite a number of battles to fight before it can settle down quietly in its host.

Let us consider, for example, the journey of a typhoid bacillus. The microbe gets into a piece of food that is ready to be eaten through the cook not being scrupulously clean. It passes into the mouth and manages to escape all its enemies, as mucus, saliva, etc., then passes into the stomach; but, on account of its being em. bedded in some hard substance, it escapes the hydrochloric acid in the stomach and also any other of its enemies. It reaches the intestines, where it has to fight against the mucous membrane of the walls, and, after a great struggle, gains access betwoen two cells in a piece of tiosue 
that is not in perfect liealth, and eventually gets into the blood. Here it meets even more formidable enemies, because it has to face a great number of very large white blood corpuscles many times bigger than the microbe itself. We will suppose that when it reaches this stage it has been multiplied to several thousand bacilli, surficient to attack the white blood corpuscles. It hoppens that the system is in bad hralth, and that its white blood corpuscles are few in number and are not in a fit state to fight; also that there are ver; few antitoxins in the blood and, generally speaking, through the ill-health of the animal or jerson, these microbes win thicir battle, i.e. typhoid fever is contracted. It is interesting to know how these white corpuscles are often bealen. They lestroy germs by eating trem, but when germs are very plentiful they often over-eat themselves to sucli an extent that, as it were, they drop some of these germs, being unable to hold them, and thus allow them to continue their destructive existence.

703. Other Means of Destroying Disease Microbes.-Having considered the means Nature aclopts to resist disense-producing animal and vegetable organisms, we will consider what other means there are of fighting these microbes. It has been found that they can be killed by various means, such as intense cold, heat, fresh air, sunlight, pure water, and various chemicals, and also by starvation. Anything that will destroy pathogenic germ life is known as a germicide, antiseptic, or disinfectant.

794. The manner in which antiseptic agents destroy germs varies considerably; for instance, distilled water will destroy bacteria by causing them to swell and burst; a solution of common salt in water, stronger than a normal saline solution (which is .45 per cent.), will do the opposite; it will cause them to lose their water (that is in the protoplasm), and thus cause them to shrivel up. Sunlight causes most germs to shrivel up, and oxygen destroys many of them. Most antiseptic chemicals have a chemical action with them which causes death. Microbes are starved by being removed from their host; fortunately most bacteria, when entirely removed from their host, can only live a few hours, and, if in fresh air or sumliglit, perhaps only half an hour.

But it must be remembered that in this case they must be removel from their host, because a scarlet fever microbe can undoubledly live for many weeks on a piece of the skin of the patient, and the tuberculosis bncillus can live for weeks on the sputum of a patient. Hence the grave danger of consumptives spitting anywhere except into antiseptic cuspidors, etc.

785. There are, however, two species of bacteria that do not die when removed from their host: those of lockjaw (tetanus) and anthrax. These are both bacilli. They have a little spore altached to one end that possesses the power of making the rest of the bacillus virulent whenever it comes in contact with animal tissue (such as an open wound). Thus a tetanus microbe may lie in a dormant state for years and years, and yet, on coming in conlact with the open wound caused when a horse falls and cuts its knees, it becomes virulent and produces the toxin. This production of poison is not instantaneous, because, if the horse is taken home and the wound thoroughly syringed out with an antiseptic, the langers of lockjaw are slight. It is a marvellous thing that dust procured from the tombs of Exypt which liad not been opened for two thousand years contained anthrax and tetanus bacilli that produced, after suitable cultivation, theso diseases in animals.

786. Certain pathogenic microbes, as stated before, are found in various quantities almost everywhere where there is animal life. Those of typhoid, pneumonia, and diphtheria are the commonest. But these harmful microbes are only found in large quantities on, in, or near an infected animal or person, i.e. on the articles handled by the patient, or the excreta, in the sputum, etc., and not on things that have not come in contact with an infected person or animal. Thus, if we want to collect some tuberculosis germs, we do not collect air from a room or the dust from the street, because our chances of collecting any would be small; but we would go to the sputum of a patient. Again, for diphtheria we collect it from the throat of a diphtheria patient. Air in a room, if very foul, will contain a great number of bacteria attached to the particles of dust, and so dust on a street pavement will contain consumptive germs if consumptives have been spitting into the street. But under strict hygienic conditions the number of pathogenic bacteria in the atmosphere would io us no harm. The percentage of harmful bacteria in the air varies very considerably. Tbe percentage of all kinds of bacteria also varies; this depends to a great extent on the number of particles of dust in the air. Thus there are more bacteria in the city air than the country, and very few in mountain air, whilst the air in mid-ocean and on high mountains is free from germs.

797. There are thousands of bacteria in every grain of soil ; uncultivated sandy soil contains over 60,000 bacteria per grain, whilst highly manured soils may contain 100,000 , and sewagecontaminated soils as many as $7,000,000$ per grain. The majority of these bacteria are nonpathogenic, and without them agricultural cultivation could not exist. Water, again, may contain several thousand bacteria per cubic centimetre. Pure spring water, after standing in a flask at a certain temperature, may contain several thousand bacteria per cubic centimetre, but nay be absolutely harmless to drink. The 
only water that is dangerous to drink is that! which contains freshly added typhoid and other petnogenic germs due to pollution from sewage, etc. 'Tlie presence of thousends of bacteria per cubic centinietre, which is generally accepted as prool of dangerous water. is no prool at all, because it furnishes no e....ence whatsoever of the presence of pathogenic rerms. In fact, typhoid, cuolera, and other disease microbes live for only a very short while in water, and for this reason a large volume of water-e.g. a large river-purifles itself in its conrse of perhaps a hundred miles. Harmful water must contain colli germs or typhoid germs, as a rule.

Most of the diseases in plants are due to bacteria. The commonest are: Pear blight, wilt disease (in jumpkins, cucumbers, etc.), brown rot (in tomatoes, potatoes, etc.), black rot (in cabbage), basal stem rot (in potatoes), and yellow disease of hyacinth. 111 the foregoing are produced by bacilli.

798. In the following section is a list nf antiseptics and disinfectants. Disinfectants can be used either in the blood to destroy bacteria in it, as quinine, turpe:! tines, as salol; or in the stomach and mouth, as alcohol, ether, etc.; ur externally. This last method is one adopted in aseptic surgery and in the general prevention of the spread of contagions diseases, and is the one that concerns us most here.

The term "antiseptic" really refers to those agents that prevent the growth of micro-organisms, but it is frequently used in the same sense as the term disinfectant. The term "disinfectant" refers to those agents that actually destroy microbes. It is clear, therefore, that only the more powerful of antiseptics are really disinfectants, i.e. a disinfectant must also be an antiseptic, but an antiseptic is not necessarily a disinfectant.

If an infected substance is acted upon by a true antiseptic, the microbes are prevented from growing, and in time will die (with the exception of anthrax and tetanus bacilli). The period during which they will live depends on their surroundings : therefore, if they are exposed to healtiy surroundings, they may only live a few hours.

\section{Antiseptics}

799. (Those marked (D) are disinfectants as well. Those disinfectants specially recommended as being quite safe and reliable under most conditions are printed in capital letters.)

Practically all disease-producing microbes are destroyed if boiled in water at atmospheric pressure (bar. 30 in.) tor three minutes. This process, known as sterilisation, is the surest method of making instruments and vessels aseptic, because it is difficult to be sure that

\begin{tabular}{l} 
Antiseplic \\
\hline Acld acetic \\
Acld boracic \\
ACID CARBOLIC \\
pure (D) (see Sec. 801) \\
Acld chromic (D) \\
Acld cresylic (D) \\
Acld hydrochlorle dil. \\
Acld nitric (D) \\
Acld salicylic (D) \\
Acld sulphuric (D) \\
Acld suiphurous (D) \\
Acld tannic (D) \\
Ether (D)
\end{tabular}

Alcohol (D)

Calomel (sce Mercury subchloride)

Charcoal or carbon (wood or animal) (D)

Chinosol

Chloral hydrate

Chlorinated lime (D)

Chlorine gas (D)

Chlorofon:1

Copper suphate (o)

Corrodive sublimate (see Mercury per. chloride)

CREOLIN (D)

Cresol (D)

Creosote (D)

CYLLIN (D) (con. tained in Jeyes' nuld)

Earth (soll) (D)

Ether (see Ether)

Eucalyptus oll (o)

Formalln (D)

Freezlng

Fresh air (D)

Glycerine

Hydrogen peroxide (D)

Hydroquinlue

Ichthyol (v)

lodine

Iodoform (D)

Irnn st:!n!tiate (o) Iron, tincture of Izal (D)
Strength and form used

Pure.

As a dusting powder or in sat. solution.

3 to 5 per cent. sol. will destroy any mlerobe.

Used Internally.

Used Internally.

Used Internally.

Used Internally, and also In surgical soaps.

60 per cent. Is equal to 3 per cent. carbolic acid, pure.

Used In filters, etc.

1 per cent. for wounds.

Used Internaly.

Valuable disinfectant for closets, etc.

For disinfecting rooms.

Used Internally.

Used in water puriflcation.

3 to 5 per cent. solution.

3 to 5 per cent.

3 to 5 per cent.

1 to 2 per cent.; 15 times as powerful as pure carbolic In lts action on bacteria.

Used In luhaiation and in wound dressing.

Valuable In agricuitural work.

Is not a means of disinfecting.

Oxygen destroys most bacteria.

1 to 10 water; for open jolnts and abscesses.

Used externally in ringworm, etc.

Valuable as a dusting powder for wounds.

1 to 3 per cent. 


\begin{tabular}{l} 
Antiseplic \\
\hline Jeyes' (see Cyliin) \\
Lead subacetute (sugnr \\
of leadi) \\
LYSOL or Toxul (D) \\
Menthol . \\
MERCURY PER- \\
CHLORIDE (corro-
\end{tabular}
sive sublimate) (D)

Mercury subchloride (calonel)

Naphthaline

Petroleum

Phenacetin

Potassiun bichromate

(D)

Pot. chlorate

Pot. nitrate

Pot, pernianganate (D)

Quinine (D)

Salol (plienol sailcyiate) (D)

Sanitas puwiler or oll (D)

Sodilum rilioride (coinmon salt) (D)

Sod. bicarbonate (baking soda)

Sod. hyposulphite (ilypo) (D)

Sorl. salicylate

Sorifum suiphite (D)

Sugar

Sun light (D)

Tannolorm

Toxol (see Lysol)

Thymoi (D)

Turpentine (D)

Vinegar (see Acid
acetlc)
Zinc chloricie (D)

Zinc oxide

Zinc sulphate (D)

Strength and form used

Csed ill lutions.

1 per ccit. for surgical use. Very suitable for surgical use.

2 to 5 per cent. Ior instruments, drains, etc.

lised in ointments.

Very valuable for all external purnoses. 1 to 500 is very strong. 1 to 1,000 tor wounds. Is polson.

L'sed Interualiy, and In thrush.

For closets, urinals, clc.

Used for skin pirasites.

Valuable disinfectant when in a solution the colour of claret.

L'sei internally.

Intestinal antiseptic, is not llgested in the stomach.

Sick room or cioset disintectant.

Good antiseptic for gargling, etc.

Is sanie strength as boracic acid.

C'sed intermally in blood polsoning, etc.

C'sed Internaliy.

Used Internaliy.

Very quick and powerful destroyer of unost germs.

Valuable for fintenal use to prevent artion of ferments.

Lsed in lotions; 1 to 10 water.

L'sed iu olntments.

Ised in intions.

every little crevice is reached by an antiseptic agent, as creolin, carbolic acid, etc. Cotton wool is a filter to microbes, so that if a bottle which is free from microbes is loosely plugged

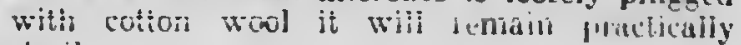
sterile.
800. As oil is a protective agent to bacteria, carbolised oil should never be used.

The most suitable liquils to be used for disinfecting purposes and for dressing wounds are: the coal tar (creolin, cresol, Jeyes' fluid, izal, lysol), mercury perchloride, and carbolic acid. Carbolic acid by itself is not suitable for surrical work, as it has an anti-healing action on the raw tissue.

The most suitable powiters for surgical purposes are: salol, boracic acid, iodoform. Salol is, of course, a reliable disinfectant, but it is expensive. For disinfecting purposes in closets, stables, etc., chlorinated lime, Jeyes' powder (cyllin), potassium permanganate, and Sanitas powder are the best. Jeyes' powder is the safest disinfecting powder on the market that 1 have had anything to to with, because its base is lime, which is itself an antiseptic. Cyllin has no action upon the lime, whilst the lime has a very high capacity for absorbing ammonium sulphide -(NH.),S-and other bad gases. The disinfecting power of cyllin powder is several times greater than that of carbolic powder, and all the carbolic in most carbolic powders is not available on account of the base retaining some of the acid itsell.

801. Commercial Carbolic Acid.-1 do not recommend this as a reliable disinfectant, because it generally contains over 80 per cent. of tar acids that are only very slightly soluble in water. Some forms of commercial carbolic acid are only soluble in 500 times their own volume, i.e. a saturated solution would be one in $\$ 00$. This as a disinfectant wriuld be of little commercial value. Ordinary creolin (commercial) is soluble in 50 to 100 times its own volume of water; thus we can produce a 1 to 2 per cent. solution, which is sufficiently strong for ordinary surgical purposes and, as a rule, for general disiufecting. But there are times when we require stronger disinfectants for rapid use, such as when disinfecting diseased tissue or septic utensils. The method generally adopted is the production of stronger solutions by forming saponiferous or soapy emulsions. Lysol and cyllin are two very excellent forms of emulsified coal tars.

Pure cyllin is fifteen times as powerful as pure carbolic acid and is very much more soluble than creolin. Strong solutions, however are not necessary, 1 to 2 per cent. being generally sufficient.

lysol is soluble in almost any quantity of water. Very strong solutions can therelore be made. Five per cent. is all that is required for cleansing septic utensils, instruments, elc. : 1 per cent. for surgery. It is particularly suitable for surgical use in parturition, because it is a soap as well as a disinfectant. It also dissolves crease and mucus very readily, and therefore rapidly comes in contact with all microbes. 

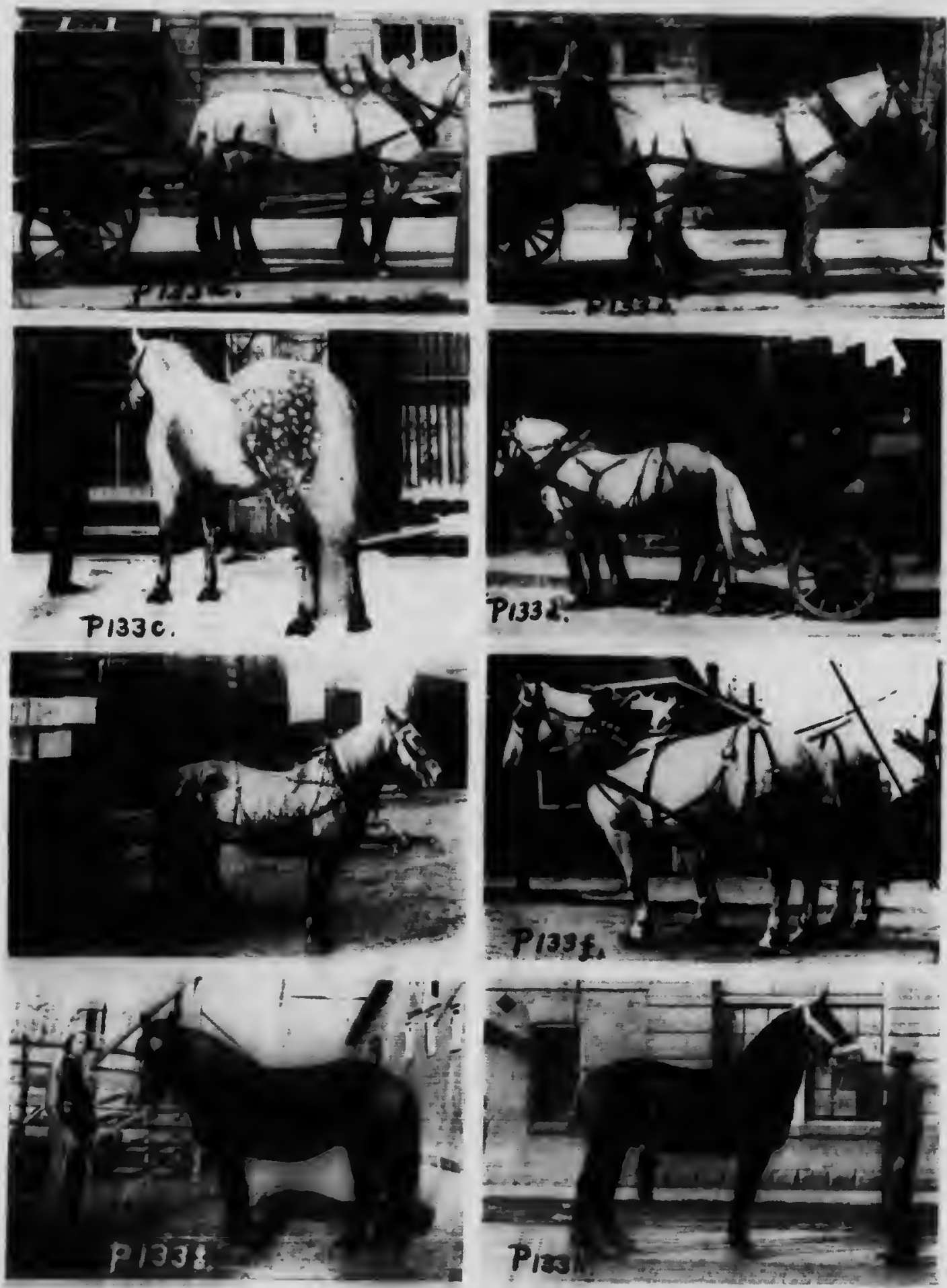

I'ERCHERON-BRED HORSES

a, b. Shedden Forwarding Co. Toronto (C.T.R.). c, 1,900 lb. Percheron. Courlesy: "Polly of the Circus "Co. d, Beautiful Pair of Percherons of the R. Simpion Co. Toronto. e, Courtesy: Firstbruok Box Co., Toronto. fo. Brundon Brewing Co., Brandon, Man. Eo Imported Belgian Percheron. Courtesy: St. Ann Ranch Trading Co., Trochu Valley. Nha. ho Belgian l'ercherun. Courlesy: The Repository. Toronto. Photos hy the Author 
PI.191: 1.34
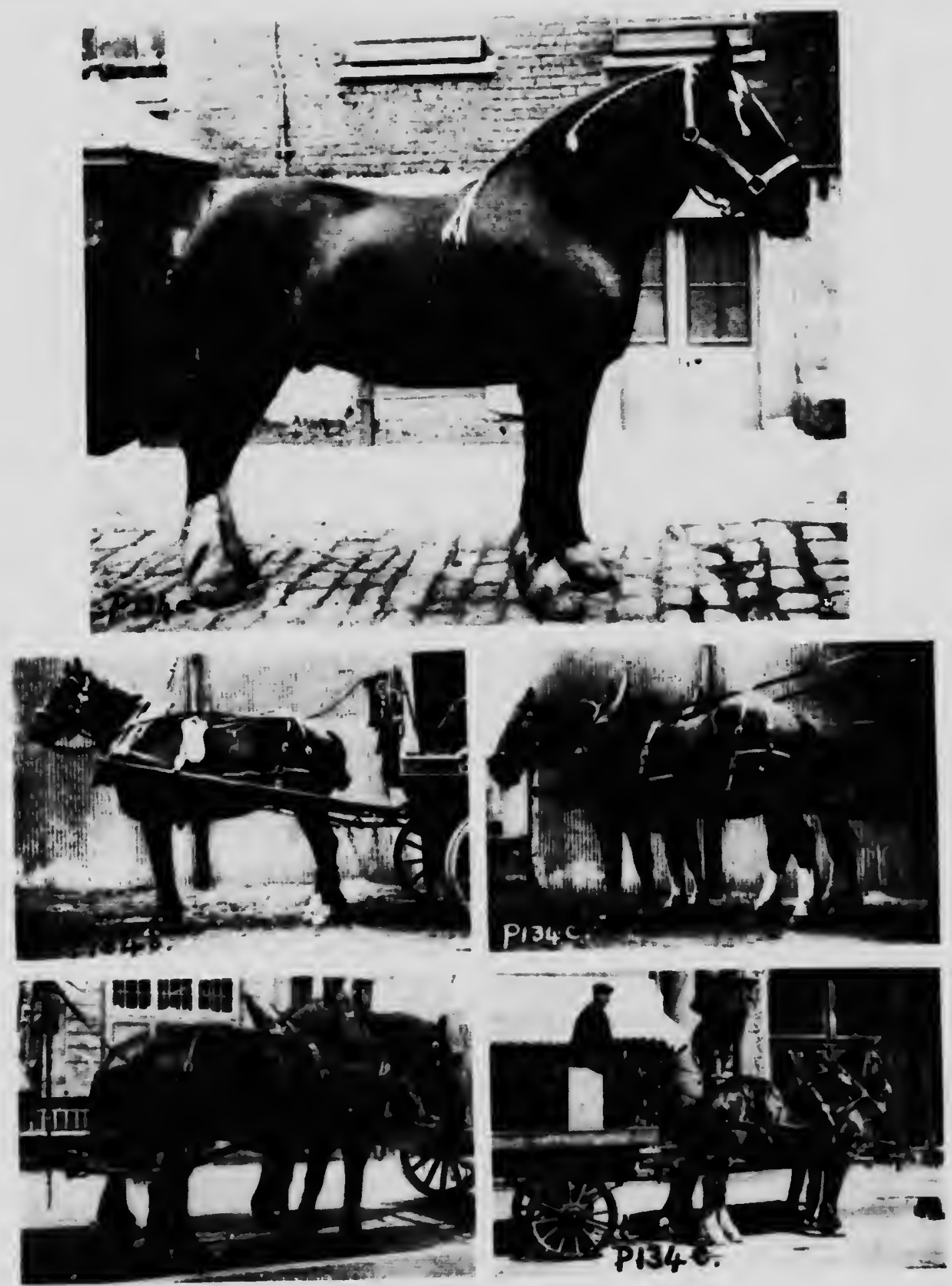

TYPES OF HEAYY DRAUGHT HORSES

a, Prue winnang Shure. Courtesy; VI, N. J. Hulmes. b, c, Canadian Northern Transler Ca.. Torouto. d, Shedden Forwardeng Cor., Tirono, e, De ineen Transpors Co., Toronto. Photos. b to e, by the Author 


\section{The Aseptic Treatment of Wounds and Aceptic Surgery}

802. From the foregoing remarks on the cause and prevention of disease it will be clear to the most unscientific mind that successful surgery is impossible, except by occasional good luck, unless aseptir methods are resorted to.

When Lord ': first suggested the idea of using certain d to fight germs in surgical operations he " ridiculed, and, in fact, it was not until h, d shown to many eminent medical men tha. operations which had previously been imposible could be performed if the use of these drugs were resorted to that any allention was paid to his teaching. However, directly this fact became widely known, surgery was revolutionised. In short, Lister showed to the world that by the use of solutions such as carbolic, coal tars, etc., surgery could be practised withoul any risk of death from blood pcisoning.

At this time the exact reasons were unknown, although it had been suggested for over two centuries that disease-producing organisms did exist. Later, however, Louis Pasteur, who has been rightly called the true founder of bacteriology, brought before the world the results of his wonderful bacteriological researches. Lord Lister himself, in 1802, acknowledged to Pasteur. "Truly there does not exist in the entire world any individual to whom the medical sciences owe more than they do to you. Thanks to you, surgery has undergone a complete revolution, which has deprived it of its terrors and has extended almost withont limit its efficacious power" (Jordan's "Bacteriology").

There is room for a great deal of improvement in this direction in the manner in which many operations are performed upon animals. Great risks are run daily, yet if an owner loses a valuable horse he is assured by the operator that it could not have been helped; whilst in reality the horse would probably not have died if aseptic surgery had been resorted to. It is a case of "where ignorance is bliss."

Modern schools, however, are teaching the latest methods of aseptic surgery, and we look forward to the time when the old-school methods will become obsolete.

808. Wounds. - There are four types of wonnds: cut, tear, puncture, and bruise.

Cut wounds are those which have a clean, sharp edge, the blood-vessels being cut straight, and not jagged; these wounds heal very quickly if the two surfaces are brought near together. The old idea, however, that two clean-cut surfaces, when brought logether, would unite spontaneously is incorrect.

Torn wounds, which are made by hooks and blunt instruments, do not heal so quickly, although they generally bleed less. The exposed surfaces are stretched, and portions of them have to be removed or fall of before the wound heals.

Punctured wounds are generally deep and small, and are therefore dangerous because infection enters deeply into the system. A nail prick from careless shoeing is the most common form of punctured wounds.

Bruised wounds are the commonest and most serious that we meet with in horses. They are difficult to heal. Such examples are bruises from falls, broken knees, harness and saddle galls, treads, quittor, brushing, over-reach, etc. In a bruise the skin may or may not be broken; but it must be remembered that germs can enter through bruised tissue, although not as easily as through an open wound.

801. Method of Healing.-Wounds heal by each surface throwing out material, called granulations, which gradually fll up the wound; this material is not the same as fiesh, but is a temporary substitute. On the top of this a sitfast (scab) forms. After the wound has healed up the granulated material gradually shrinks up, drawing the original edges of the wound logether, and the sitfast comes off. Eventually the granulations are entirely absorbed (in most cases), and the flesh becomes as it was before the wound was made. As a rule, however, a permanent mark is left on the skin, and the coat of a horse does no! 'row normally over the place where the wound was. White hairs usually grow on these places. The benefit of the sitfast is that it acts as a preventive against the admission of germs ; hence it is wrong to pick it off, and specially to do this witl unclean fingers, as is so commonly done.

\section{Aceptic Treatment of Wounds}

805. In treating wounds it must be clearly understood that all we have to do is to assist Nature to heal. We have to remove all foreign substances present and prevent the admission of further foreign substances which would hinder Nature's work. The treatment of wounds is quite simple if this principle is understood. As long as live microbes are present in the tissues of a wound it will not heal.

First, we must arrest the bleeding, which is done by styptics, pressure, cold applications, cautery, ligature, or by actually closing the artery or vein with artery forceps. Bleeding will not stop of its own accord unless the blood is permilled to clot: the chemical changes that go on before the blood clots are very complicated. Broadly speaking, the fluid portion of the blood (plasma) consists of serum and fbrinogen. When tissue is exposed to the atmosphere, very com. plex chemicals are produced which, when they come in contact with this fibrinogen in the blood, produce flbrin, which is clot. This production of clot takes about two minutes. If it look 
a mucli shorter time to form, the dangers of internal blood clotting would be very great. Thus it will be seen that time must be allowed ior bleeding to cease by clotting.

Before arresting the bleeding we must remove all dirt trom near the blood-vessels so as to be sure that no foreign mutter will be enclosed in them. A good flow of bloor will always clean the ressels, so when there is a good flow of blood there is less danger of infection. In stopping the blool flow it is useless and dangerous to plug the wound up with cloths, because we only increase the temperature of the part and encourage continued bleeding. If we cannot aprly pressure to the artery on the heart side of the wouml. We must cut down on to it and take hold of it with forceps. In small, deep punc. tures, if there is much bleerling, after the wound has beell thoroughly syringed ont with antiseptics, antiseptic double cyanide compressed gauze should be rammed tightly into the wound ; this will not allow bleeding to continue. Stuffing a wound with cotton wool and rags will not, as a rule, stop bleeding.

If the artery can be reached it is cither tied with aseptic silk or closed with artery furceps, which are kept on for a few minutes to allow the blood inside to clot, and then carefully removed. If, huwever, the bleeding is slight, as is the case in many fiesh (muscle) wounds, no attention need be paid to it until the whole wound has beel: thoroughly cleaned.

Cleaniug a wound consists in removing by knife, or a stream of liquid, all visible foreign malter, cutting off ragged bits that tend to do harm, and then making it aseptic by free syringeirrigation $w$ ith a suitable antiseptic, which must not be too strong. (Spe Sec. 700.) Tlien, if bleeding continues, the surface can be syringed over with an astringent, such as a 10 per cent. solution of tincture of iron (1 tincture to 10 water.

806. Although the wound may be absolutely clean at this period, it must not be closed up, but left open, as the formation of pus is sure to continue; for this reason the wound must be only covereil sufficiently to keep dirt from getting in, and nust be tressed night aul morning. Rest must be obtained to assist in healing.

A most important point is that of securing proper drainage, which consists in having a free downwarl exit from the lowest portion of the wound. If the bottom of the wound does not drain of its own accori, a hole must be made as an outlel and a suture (strip) of aseptic linen must be passed through the hole to keep it:e passage open. If perfect drainage is not obtained, pus will lie in the buttom of the wound and caus: blond poisoning. Healthy wounds always heal from the back, or bottom. but if neglected, or the mouth of the wound is allowed to close too soon, pus may become enclosad, and the wound will have to be reopened. The wound must never be allowed to heal except from the bottom or lack, so that it gradually closes together until the edges unite. Pus is produced by pus-producing bacteria (streptococci and stapliylococci), which are always present in the air, except where the air is absolutely pure. They produce pus by forming ferments that dissolve albumen and mucin, etc. After dissolving these materials they decompose them into less complicated materials and eventually into their original elements-nitrogen, carbon, hyurogen, oxygen, sulnhur, etc.

807. In very large wounds, or those in which the skin is bidly torn, stitches of surgical silk are used to draw the edges together; but the wound must never be closed entirely ; an opening at the bottom for drainage must always be kept, and one at the top communicating with it. into which the antiseptic solution can be forced. It is often necessary to leave a drainage-tube in the wound.

In syringing out a wound, considerable torce should be used in order to reach any microbes that might be embedded in the tissue. In most cases stitches are unnecessary, and the wound will heal up of its own accord as long as we syringe it out night and morning with an antiseptic solution and then with an astringent. In liliman practice, of course, it is so much more easy to make wounds aseptic, to have aseptic surroundings, and therefore to keep wounds closed, but with horses it is always risky. Much the best results are always obtained by leaving the wounds open, except where large muscles are widely separated.

808. When a horse has been wounded for some little time and the wound hus been exposed to infection, there is the possibility of tetanus (lockjaw) germs having gained admission to the wound. If they have only been in a few hours they can be destroyed by the use of antiseptics before they have produced the tetanic poison. But if they have been in the wound for several lours or even days, their poison may have already gol into the system. In such cases it is a very wise procedure to give the horse at once an injection in the neck of 3,000 ampules of fresh anti-tetanic serum, and to repeat this in twentyfour liours. I have never known of a horse contracting lockjaw when the serum has been injected before any outward signs of lockjaw have alpeared. (Ser Sec. 620.)

809. Srwing Hounds.-If stitching is resorted to, specially curved surgical needleswhich have been sterilised and soaked for five minutes in an antiseptic solution other than corrosive sublimate-and sterilised silk are used. In horse wounds the best method is to put a single stitch tlirough both edges at least half an inch from the edge, and to draw the edges of the wound nen:ly together, and then to tie the ends 
of the thread with double reef knot, then to make another similar stitch two or three inches, as the case may be, from the first. As few stitches as possible should be used. This method is far superior to that of sewing continuous threads as a tailor does in mending a tear in a garment.

810. Bandaging Wounds.-It is generally highly inadvisable to put bandages nver wounds. In some cases this is necessary, but drainagetubes must be put in, or else the bandages or dressing must be removed every twelve hours and the wound thoroughly syringeri out and rebandaged. If a wound must be covered to keep dirt ont, a light sheet dipped in antiseptic solution should be put over it, then a waterproof sheet over that.

If it is required to prevent a wound from healing too quickly for various reasons, as for the purpose of maintaining internal irainage, wet antiseptic cotton-wool pads sinould bo applied to the wound and covered with air-tight sheets. Sometimes it is necessary to dust a wound with a powder such as boracic acid or iodoform; this will keep fies of and also prevent foreign matter from lodging in the wound.

811. Antiseptic Precautions in Operaling.All instruments that are not already cleaned must be scrubbed with retherial antiseptic soap (the ether dissolves any grease). Then they must be sterilised immediately before the operation for five minutes in boiling water. The opcrator must woar a clean, white, long overall cuat, and have his shirt and other coat sleeves turned up inside this coat. A table or tray that is absolutely clean must be used to rest the instruments on. A glass slieet that has been scrubbed and disinfected is best for this. The operator's hands (especially nails) must be thoroughly scrubbed in hot water and atherial antiseptic soap for several minutes with a hard nail-brush. A cleun basin of 5 per cent. solution of creolin, lysol, toxol, or Jeyes' fluid, must be ready, with plenty of aseptic collon wool for mopping purposes. The instruments, syringes, needles, etc., must be ready and lying on a towel that has already been sterilised and soaked in an antiseptic. The animal is given an aniesthetic or local anasthetic by an assistant, or by the operator, who should venr gloves. The part to be cut, and for a space of several inches around it, is shaved, and scrubbed for three to five minutes in the same way as were the operator's hands.

Sponges should not be used, as it is im. possible to keep them clean, but aseptic cotton tufts should be used which should be destroyed afterwards.

Corrosive sublimate (mercury inrchloride) must not be used to disinfect m.tal, as it will corrode it.

812. The operator must take the greatest care that his hands touch nothing that has not been made antiseptic; he should have an assistant who has similarly prepared his hands and who takes the same precautions as he does, while inother assistant should attend to the chloroform, etc. If the horse is under chloroform there is no need to hurry, as all voluntary muscles will be relaxed, and by taking one's time a very scientific operation is more likely to be performed. Most bad and hurried operations that end in blood poisoning are the result of the operator not using chloroform, a question of being penuy wise and pound foolish, or, perhaps, igrorance of the method of administering chloroform.

While the operation is being performed, whatever it may be, it must be borno in mind that an exit must be allowed from the wound through which pus, etc., can drain after the animal is in its normal position.

After some operations-which do not consist in removal of internal abscesses, etc., and where no pus-producing microbes gain entrance, due to most careful precautions-it will be safe to close the wound up altogether, keeping aseptic dressings on the outside of the opening for several weeks until the hole has healed over.

After any operation the temperature of the horse must be watched for days, because a sudden rise in temperature will reveal blood poisoning, whereupon the wound will have to be opened and attended to, and suitable internal remedies given at once. (See Sec. 625.)

\section{Some Notes onthe Prevention \\ of Human Disense}

813. I feel that a few hints on the prevention of human disease will not be out of place in this chapler. Anyone who has studied higher medical and veterinary science must realise what appalling ignorance is daily displayed in the knowledge of the spread of disease. If only a few fundamental principles were observed by every individual, the worst diseases that exist to-day would soon become practically nonexistent.

Consumption (tuberculosis of the lungs) is easily spread by consumptives expectorating on the streets and floors. Consumptive people often seem to be the worst offenders in this objectionable and dangerous habit, because habit it merely is. They should expectorate into vessels flled with antiseptic solutions and nowhere else. If they spit on the floor or street, the microbes settle on pieces of dust, elc., and when the moisture surrounding them dries up, the septic particles of dust may enter the lungs of a person who is predisposed to the disease. Such infection might have no effect on most people, but sooner or later a predisposed person may become infected.

Consumptives should also cough into hand- 
kerchiefs that have been previously soaked in antiseptic; by using their hands as shields when coughing they ale liable to transnit the mic robes to others when shaking hands, as these others may apply their fingers directly to their mouths. In the same way consumptives, by not laking precautions, can leave virulent sjutum on door handles, car rails, etc. If these little precautions were ouly taken, the dangers of contracting disease by handling articles and then licking one"s tingers would be very small : and probably those who were predisposed, or who were not in good enough health to fight the diseast germ, would escape getting sufficient into their system to do them harm.

814. I do not think that consumption is inherited as a rule, i.e. that the new-born babe of consumptive purents is born with the germ in its system. I do not see how the tuberculosis bacilli that are in the lungs of the mother, and not generally in the blood, can possibly get intu the foetus. If, however, the mother had tuber. culosis of the womb, the microbes might pass through the cells with the nourishment. Chil. dren are, however, born with syphilis in their system.

In most cases there is no dombt lhat the liew. borm babe is free fron the tuberculosis germis, but it is predisposed to them by having a weak chest, throat, etc., and therefore will very rapilly. contract the disease. Now this babe trom birth is exposed to millions of the germs in the house, in the bed, and on the articles that it plays with, and even in its mother's milk. So no wonder the poor child gets consumption afterwaris. Had it been taken from its nother at birth, and had its weak parts (lungs, etc.) been developerl later by the modern methods of physical culture, there is no reason at all why it should not be as healthy as any other.

If people who are predisposed to disease anl who are in bad health would really try to develop their weak organs by morleru physical culture, they wonld be able to fight disease. I do not mean weight-liftiug or liurning somersaults, or anything like that, bul the gymnastics which develop every organ of the houly.

The fresh-air cure for consumption is almost useless in many cases unless tlie patient is first taught how to use his lungs. Deep breathing is the secret of healthy lungs and general goor health. While exercise is beilıg taken, deeper and slower breathing must be practised, and not last, short breathing. This can easily be acquired. Everybody should devote ten ninutes to breathing deep, slow breaths in through the nose and out through the mouth every morning and night.

The Medical Times, a short time ago, demonstrated the importance of inhaling through the nose for half a dozen times at intervals of half a minute. A full inhalation should be taken, and the nostril kept closed with the fingers for fifteen seconds to force the oxygen into the air sacs of the lungs. The article further explained that this must be done immediately before retiring to bed, doing nothing more before lying down; by this means the habit continues. The window, of course, must be open.

Other exercises should also be done to develop the chest, such as raising oneself from the floor by the arms, as in Swedish drill, twenty times every morning.

815. In order to destroy any bacteria in the air sacs of the lungs, the lungs must be opened right up by deep breathing. Horse-back exercise, if one keeps his shoulders back and does not stoop like a jockey, is the most healthy exercise in the world. Not only is it the finest medicine for the liver and bowels, but it exerts a wonderfill effect on the whole system.

A few pounds or dollars spent on horses will save many more oll doctors bills. Next to riding comes motor driving, providing the speed is temperate.

People with weak chests, especially broad shoulders and shallow chests, should not go into spor! that tends to cramp the chest, such as much cricket, billiards, etc.; the latter, of course, is also less healthy, as it is indoors.

Everyone should sleep with his window open at night, however cold it may be outside. If one is brought up used to this no harm will result, and it is one of the secrets of good health. Architects should be far more particular in the way they design windows and ventilators, and the law should make it compulsory that storm windows (as used in cold countries in the winter) should be made so that at least one large pane will slide open.

816. Worry has a great deal to do with disease; some people imagine they have got all kinds of diseases. II they participated in healthy exercise and had more faith in their own health in many cases they would be far more happy and keep well. Taking patent medicines continually is a dangerous habit; many of them. indeel, are worthless, even if they do no harm. In many cases bad illnesses of long standing are cured by belief that a certain doctor or drug is going to do gool.

Homoeopathy has cured thousands of sick people; yet what else than faith has cured these? The drugs used in homoopathic treat ment could not do any physiological good; their strength sometimes is only one-thousandth of that of a normal dose.

Greatest antiseptic precautions should be taken in handling the clothes and bedclothes of diseased patients. A free use of antiseptics must be practised in a patient's bedroom. Sputum of consumptives and the excrets and urine of typhoid patients must be put into vessels containing 5 per cent. creolin, or carbolic, otc. 

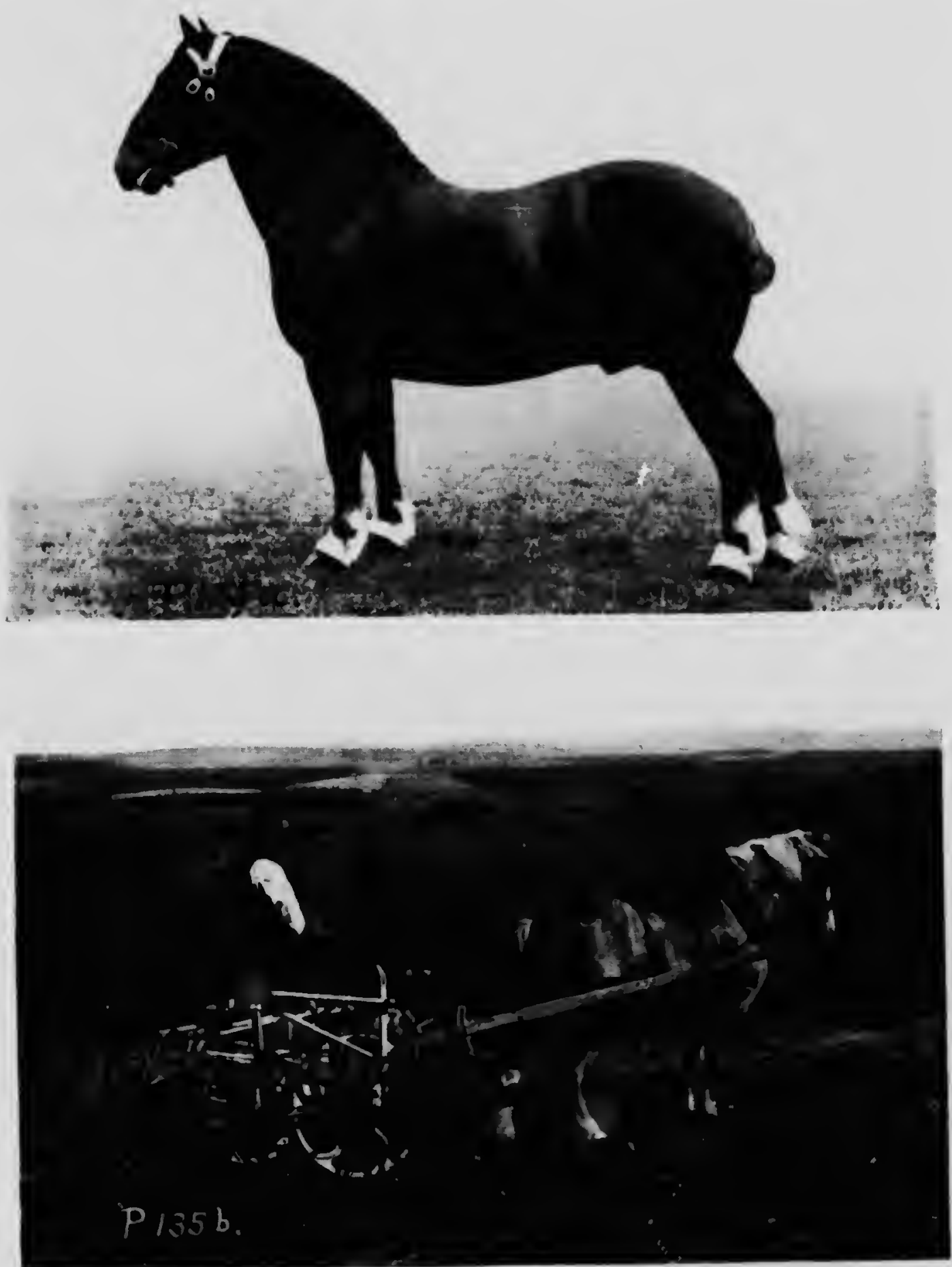

a. Champion Sufolt Sullion "Sudbourne Peter," 3955. Winner of Five Championships. Courteny of the Owner, Mr. kienneth M. Clart, Sudbourne Hall, Orford, Sufolt. Photo: Sport and General. b, Farmirg in Scotland. Photo: Chas. Reid. Wishaw. N.B. 
PI.AIL: 1.36
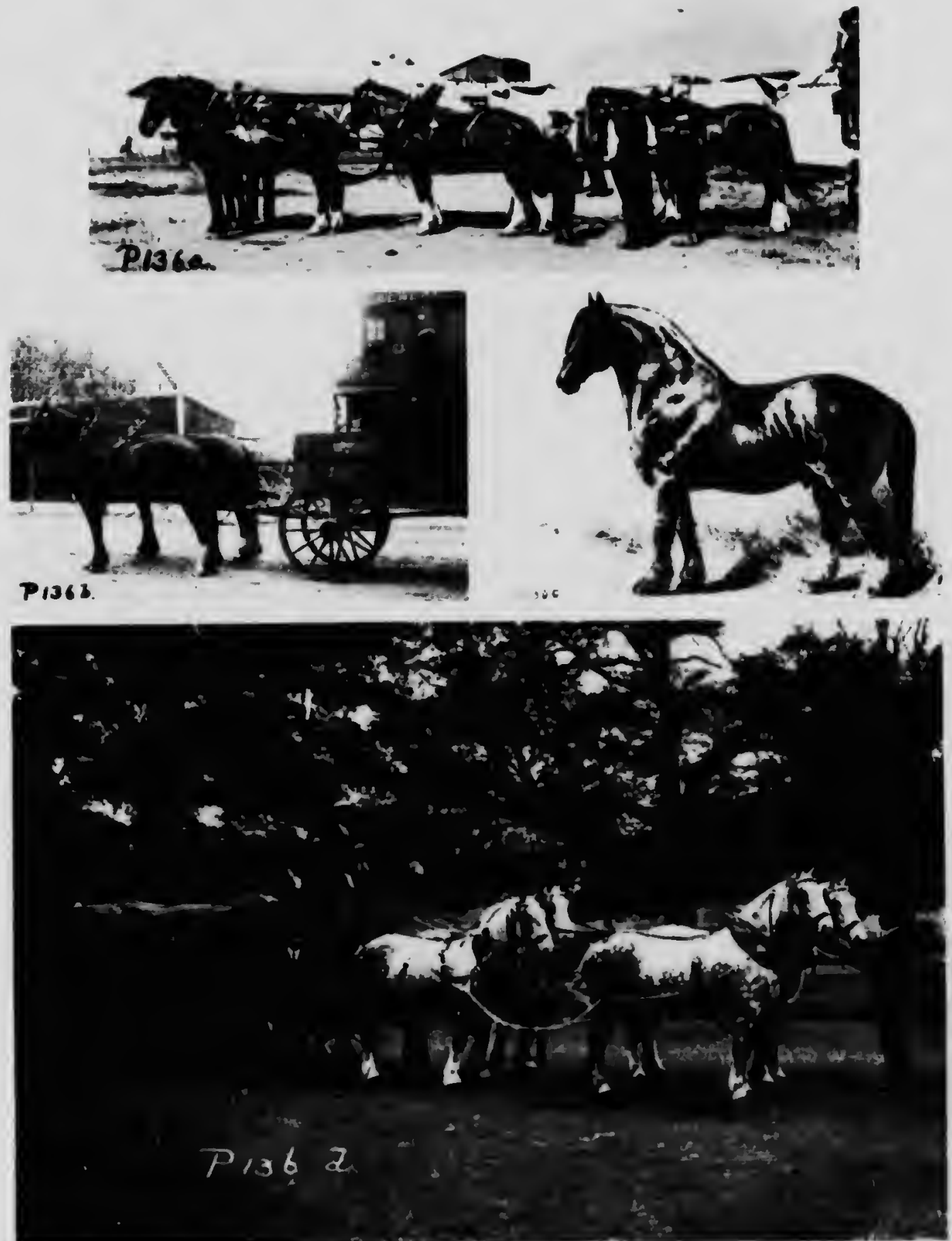

SONF. HINE TYPLS OF LNDOCKEI IDRNI:HIT IHORSES

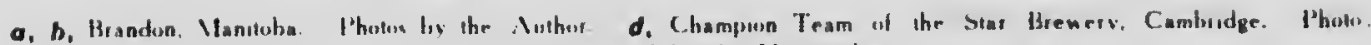
Vladdisesun and llinde. Iluntıngdion 
I do not believe in laking much medicine: often medicine is better left alone. When one is really sick it is better to send for the doctorprovided he is one in whom the patient has faith. If he loses faith in his doctor he had botter $g 0$ to another at once.

I have been more than surprised at the information I have received from many sanatoria relating to the insanitary precautions taken by the nurses, doctors, and attendants in these places. Several people who have been to sanatoria have told me of instances that I could hardly believe. Highly undesirable conditions exist in many cases, such as patients who are only slightly consumptive, or who are suspects, having to use the same drinking utensils as bad cases, and having to sit next to them at meals, or to sleep) in the same room, etc.

817. Disease germs are not, as some suppose, found hanging about everywhere, waiting to attack human beings and animals. As stated in the early part of this chapter, their existence is a mistake, and they only occur in dangerous quantities where they have been left by infected patients. It is a deplorable fact that lower types of human beings, as well as many educated people, do not take any precaution to guard against other persons contracting their diseases. Their carelessness is most indiscreet. It is always advisable to be clean in one's habits, to take ordinary precautions against coming in contact with disease. Certain precautions can elways be observed. It is dangerous to rub one's hands over dirty seats in public waiting-rooms, etc. and then to lick one's fingers. It is not wise to lick stamps or envelopes that have been left Iring about in public places, especially as gum is a good medium for the growth of bacteria. The gum used on stamps should be antiseptic.

Speaking-tubes are most insanitary, especially es it is generally necessery to blow into the tube at one end. Public telephones are fairly safe as long as the speaker does not put his mouth into the mouthpiece, which, by the way, telephone companies ask you to do. If a consumptive has been blowing small particles of sputum into the mouthpiece and afterwards one speaks as directed, "close to the mouthpiece," one stands a good chance of breathing in a good many germs.

The German physician, Dr. Friedman, has Intoly discovered a serum, produced from the turtle, which he claims to be cure for tuberculosis. Its chiel use is supposed to be in cases of surgical and not pulmonary tuberculosis.

818. Most diseases are contracted from what we eat, and not from what we breathe. Diseased people, by dirty habits, leave infected matter about, and this may reach our lood. The baker may handle bread with dirty hands. If the bulcher does this, however, there is less danger, as the meat is made safe later by cooking.

Dry breath, even from a consumptive, is 2 B generally harmless. But consumption may be caught by coming in contact with the drops of moisture that fly from the mouth of the consumptive while speaking or coughing. We do not pick up a disease, as a rule, by walking through an infected hospital, especially if we breathe through the nose, but we are far more likely to do so by handling the beds and door. knobs and licking our hands afterwards, or by getting our clothes infected while in contact with infected clothes. Of course, in dirty towns where there is a great deal of dust flying about as compared with a modern hospital ward, there is great danger of breathing in germs of disease. For this reason doctors and nurses who attend plague districts in China, etc., always wear anti. septic shields, which are absolutely germ-proof, over the mouth and nose.

819. Dirty water should not be drunk, and food should under no circumstances be left ex. posed to fies, which are graat propagators of disease. Fly screens should be used everywhere, especially in the kitchen, dining-room, and closet. (See Chapter XII.) One's hands should always be washed before a meal and before attending to lood, as when cooking. Money should never be held in the mouth, and the practice of licking the finger while counting dirty bank notes is dangerous. Finger sponges, as used by bank clerks, should be soaked in a solution of corrosive sublimate $(1$ to 1,000$)$, be. cause if they are soaked in ordinary water the sponges soon become hives of germs.

As most tuberculosis in man is not that contracted through the lungs, but through what we eat, and in great part through milk, all milk should, by law, be sterilised. Consumptioni.e. tuberculosis of the lungs-is seldom contracted from cow's milk, but most surgical tuberculosis is. The number of cows that have consumption is enormous, the reason being that the cow is an abnormal animal which has developed into a milk-producing machine, and nearly all its vitality is used up in working this machine, and therefore it cannot easily reslst disease germs.

Milk is a very good bacterial incubator. It should never be left uncovered and exposed to the air. Milk that has been boiled will become contaminated with bacteria more quickly than that which has not, because the friendly germs have been also destroyed.

820. Dog fanciers are very careless in the way they allow their pets to lick them on the face and to dip their noses inte water-jugs from which they will drink themselves. This is extremely dangerous, because a dog will dip its nose into any filth that it may come in contact with. A horse, on the contrary, will not.

Cats are very liable to tuberculosis, so strange cats should not be kissed or allowed to lick one's hands. 
821. Syphilis is nost certainly inherited; I mean that bitu's are born with the syphilis bac. teria in their system. For this reason parents suffering front tle disedse should, by law, be prohibiled from lawing children. (ansumptives prohitilet fom have chilifen either, but, if they do,

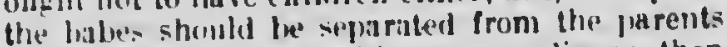
and lirusht up in liealthy surroumdiugs: then there will be less likelihood of the weak-chested chilil devloping consumption.

Dr. Naplleys, in his "Ihysical life of Womin." expresses himself very strongly on this puint when he says. "When there exists any contagious disease, refusals are, of coirtie, valiol and often a disty to the umboru." les, indeed, a di:ty to the unburt).

822. Drink is, of course', the curse of lo-day. Driuking is a llsolse. To ask the real drumkard to stop drinking would be as foolish as to tell a corsimplive that he hadul got the disease. The only cure for such casts is to resort to medicinal cure: many valuable cures are now known to the medical profession.

Deplorable family misuries result from this curse. Aleohol to the trmperite person is inost valuable wilien an emergency demands it. whilst alcohol to the irunkard is worse than uspless. I do not believe in teptotalism, because at limes I think one beneflts by a slight stimulant: for instance, anremic prople beneft from wine. Anyone who has a strong will of his own can lake such things in moderation: it is the weak-willed indivijual who caunot control his desires. The offsprings of drunkards are often insane.

823. Excessice Smaking Causes the System ta be Unahle to Fight Distasr. - Excessive use of lobacco also does much harnı. Lungs are put in a good state to receive tuberculosis; the heart is weakened and often diseased; the larynx is often chronically inflamed.

Inhaling tobacco smoke is a poisonous habit and 8 dangerous oue. Moderation in everything ancl absence of mental worry will tend to produce goorl health.

More exercise and an abundance of fresh air. and less stuffy thealres, ten-rooms, and unvenlilited offices, will produce healthier people.

824. Schools of physical culture should be organised all over the country, and a few years of military training is an excrilent thing to make young men physically fit. Discipline will not do auyone any harm.

If more money were spent on teaching a nation plysical work, discipline, honour, etc. lijere would be less mouey required for the police, police-courts, lunatic asylums, prisons, ete., and a nation's young would grow up honest and herithy.

825. The importance of washing one's fingers after handling anything that might be infectious caunot be over-estintated. Dr. Helen MacMurchy wrote solle very interesting words in the Toronw Funday IIorld a short time ago on this subject. She said: "Alcoliol is not the only enemy we may put into our mouths to steal away our brains and strength. Keep your hands clean, and you will avoid many infections. The hand that writes these things carried the typhoid bacillus to the writer's month fifteen years ago. The hand that holds the newspaper in which these words are printed may do the same thing. Children are infected by each other's saliva. They put their fingers to their mouths and noses, and then they kiss each other. Pencils, books, pens and toys are exchanged and carried in the hands after being put in or to the mouth. Disease is thus directly transmilted. Do you ever luru the leaves with a moistened finger? Do you not use these fingers for handling dirty articles?

"The two classes of people who sliould be most particilar about the care of their hands aro those who cook and those who attend the sick. Do everything you can for the sick, and do not be afraid to do anything for the sick, but do not inhale the direct bresth of the sick, and always wash your hands after attending the sick. Even touching the bedclothes of an infectious patient means that your hands require to be washed. There are ten sources of infection on every human being; two thumbs and cight fingers. From hand to mouth, this is the main infection route."

It is commonly acknowledged now that most disenses are carried by the fingers to the mouth, and only exceptionally by the breath. A close study of bacteriology, and even of the notes at the beginning of this chapter, will convince the reader how easy it is for germs to be transmitted by the fingers from handles, street-car rails, monev, dirty books, shaking hands with consumplives, etc., to the mouth, and how comparalively diffleslt it is, by breathing, for the germ to enter the lungs and cause harm.

Cancer, according to Dr. Fibiger, of Copenhacen, is dile to a microhe. This microbe is supposed to be transmitted externally by improper washing of the face and hands, and by eatine raw foods that have not been properly cleansed. Metchnikon says: "Hereditary cancer is a myth: if cancer finds several victims in the same family, it is because their hygiene is equally bad." 


\section{CIIAPTER XVIII}

\section{ON SHOEING AND CARE OF THE FEET}

898. TuE Structunt of THE Foot.-The horse's foot consists of the hoof and its contents. These contents are the coffin or pedal bone, the navicular bone, the small pastern bone and the lower end of the large pastern bone, the ligaments of the joints, the syllovial membrane and synovia, the lower ends of the perforans and perforatus Lendons, blood-vessels, nerves, lateral cartilages, sensitive lamina, sensitive sole, plantar cushion, coronary substance, and the perioplic ring.

Thus the hoof is the horny box enclosing the soft structure and the bones. It consists of wall, bars, frog and sole. (P. 138, 139.) The wall is divided into loe, quarters and heel. The bars are formed by the walls turuing in at the heels; these bars do not meet by about in. at the front of the frog.

827. Wall. - The outside of the wall is covered with an epithelial skin (periople) which grows downwards from the perioplic ring. This is Nature's prolection to the hoof: it prevents the hoof from drying up and becoming brittle. Hence the common fault of farriers rasping the outside of the hoof is absolutely wrong, and should never be allowed, even at the toes. The hoof grows downwards from the coronary band, and takes eleven to thirteen months at the toe and six months at the heel to grow from top to bottom. The hoof does not grow from the selusitive wall. The wall is thickest at the toe, where the wear is greatest, and thinnest at the heel, to allow of greater elasticity. The thick too is also necessary, as it is used in propulsion, the toe being the last part of the foot to leave the ground. The elasticity of the heel is also increased by the presence of more moisture in the horn.

The wall is composed of ininute flbres that extend downwards anil forwards (hence a quarter crack, or toe crack, extends downwards and forwards). Each fibre starts at the coronary band, and, if this band is cut or destroyed, the hoof will not grow down again below this part. Nature, however, produces a kind of horny substance as a substitute. In quittor operations (Sec. 436) the greatest care must therefore be laken not to damage the coronary band. The outer part of the wall is drier and harder than the inner, due to exposure to air. This is neces- sary to resist wear, hence this part should never be rasped.

If the hoot is partly removed, Nature sends out a secretion temporarily to protect the sensitive structure until the hoof has grown down again. A nail cannot, of course, be driven into this temporary structure. As the inner wall of the foot is more vertical and bears more weight, there is greater thickness of hoof at this part than on the outside of the foot.

The sensitive laminæe are attached to the walls of the pedal bone, and are very freely supplied with blood and nerves. Hence grast pain results from foot injuries, and blood poisoning is more liable to occur in the horse's foot than in any other part of his body, excer' his lower jaw. The function of these sensitive lamina is to join the pedal bone to the hoof, and thus they bear most of the weight on the leg ; they also nourish the horny hoof. The growth of the hoof is increased by applying stimulants (as cantharides blister) to the corunary band, or coronet, just above the hoof.

828. Sole. - The horny sole is similar in structure to the wall, but grows downwards from the sensitive sole, which is attaclied to the perlal bone. It is slightly arched. The horny sole lakes six months to grow. In health it should be firm, and not spongy. The sole must never be pared away ; only jagged pieces should be removed by the farrier. Under the weight of the body the sole becomes slightly flatter.

829. The Bars.-These divide the sole from the frog. Between them and the frog, on each side of the frog, is a groove or commissure, that leaves room for the expansion of the frog when it is placed on the ground. The bars grow down from the sensitive sole. They must never be pared away; they should be kept lower than the sole. Contracted heels are very rare with good bars. Their function is to support the wall at the heels and to prevent contracted heels. They increase the bearing surface of the wall and allow for expansion of the heels at each step.

880. The Frog. - This is a wedge-shaped portion of hoof situated between the bars. It grows downwards and forwards from the sensitive frog. It takes two months to grow down. 
Its function is to bear weight, to prevent slipping, to prevent shocks by acting as a cushion, and to expanil the litels wherever the foot is brought to the ground; therefore it should always be on the gruund (except in navicular (tisease). Un its under surfuce is a grovove called the cleft, which runs along the nertian line of the foot: this groove shonld be shallow and rounded. Its pirpose is to incrense the mobility of the frog and to decrease the liability of slip. ping. At its base (back) are two bulbs, callerl the bulbs of the heel.

The frog is mich softer and nore like a cushion than the hoof walls and sole. It con. tains water and some oil, and its flbres are wavy, causing it to be more elastic. If a horse stands on a dry floor for ling, the frog becomes too hard. A liorse in motion normally brings his heels to the ground first. but in ravicular disease he nuay brillg the toe down first. The frog must never be cul, cinly jaggerl pieces being trimmet off.

The heels spreat every time the frug comes to the ground; hence high calkins, which keep the frog off the grounil, tend to cause contracted heels and diseased feet. The frog should touch the ground every time the foot is brought to the cround. The grooves on eacli side of the frog allow for its expansion.

831. The sensitive frog is situated immediately above the frog and below the plantar cushion; it is situated between the retrossal processes of the pedal bone, and is similar in shape to the under-surface of the frog; the frog srows from it.

The plantar cushion, or frog-pad, is situated hetween the lateral cartilages and above the sensitive frog, ant is composed of a network of fibrous bants, having the interstices flled with clastic tissue. The plantar cushion prevents jar or concussion, and also plays an important part in the action of the foot. The frog below it must, therefore, touch the ground.

838. Lateral Cartilages. - On each side of the pedal bone, i.e. on each wing, or basilar process, of the pedal bone, is attached a plate of cartilage. These are situated just inside the wall of the hoof. They support the heels and give elasticity, allowing the heels to expand whenever the plantar cushion expands. They are not very vascular, and they therefore very easily become diseased, producing quittor, and they may even become ossified, producing sidebone. (See Sec. 432.)

They are joined together by inelastic fibres that pass through the planlar cushion, thus preventing the heels from spreading too much. The lateral cartilages form an elastic wall to the posterior part of the foot and give attachment to the sensitive laminze.

As the foot expands, the lateral cartilages prevent any disturbance between the sensitive and insensitive lamiure. They also, while in motion, assist the circulation in the veins situated within their structure.

839. Mechanism of the Fool. - When tho loorse's foot is brouglit down the heol normally touches the ground first, and therefore great concussion is brought upon the heel, which is not transmitted through the limb. This concussion is overcome by the elasticity in the fetlock and pastern joints; the compression and lateral expansion of the sole, and therefore the descent of the pedal bone; the compression and lateral expansion of the frog. sensitive frog and plantar cushion, and, finally, the expansion of the heels, dire to the expansion of the plantar cushion.

The expansion of the frog widens the bars and the expansion of the plantar cushion widen the lateral cartilages, i.e. increases the width between them.

Apart from the perfect shock-absorbing and nur-slipping meclianism of the frog when it touches the ground, the foot cannot keep healthy and remain uncorrtracted at the heels unless this expransion takes place freely. Hence the great importance of not allowing any horse to have its frus interferell with, us is so outrageously and conmonly the case with many farriers.

This expansion of the foot allows it to "give," instead of offering resistance as anything solid woull. This "give" is sufficient to prevent fracture. A har sloe in no way affords the requireal pressure on a horse's frog. The only justifable orcasion when a high-heeled shoe should be used is to relieve pain in navicular disease by relieving frog pressure, and for the purpose of temporarily removing the strain of the back tendons, or suspensory ligaments, afler a sprain.

\section{Principles of Shozing}

Rasping.-The primary essential of good shoeing in all cases is that the outside of the wall be not rasped. As explained in Sec. 827, if the periople on the outside of the foot is rasped, the hoof becomes hard and brittle. If merely the edge of the toe is laken off, called "dumping." then the bearing surface on the ground is made smaller, and the ends of the fibres are exposed, as Nature requires they should not be. Farriers rasp the foot to save trouble; they fit the foot to the shoe instead of the shoe to the foot.

835. Paring.-Great care mist be taken to make both the feet of the same length when paring the foot, as is usually done when the horse is re-shod, or at any rate once month. Every time a foot is re-shod the walls will have grown to a certain extent since the foot was laot shod; this extra growth, but no more, has to be rasped or pared away. This is done by paring the under-surface of the wall only with the farrier's knife, and then making the surface quite lovel with the rasp. On no account must any part except the under surface of the wall and any 
Pl. 1T: 1.37

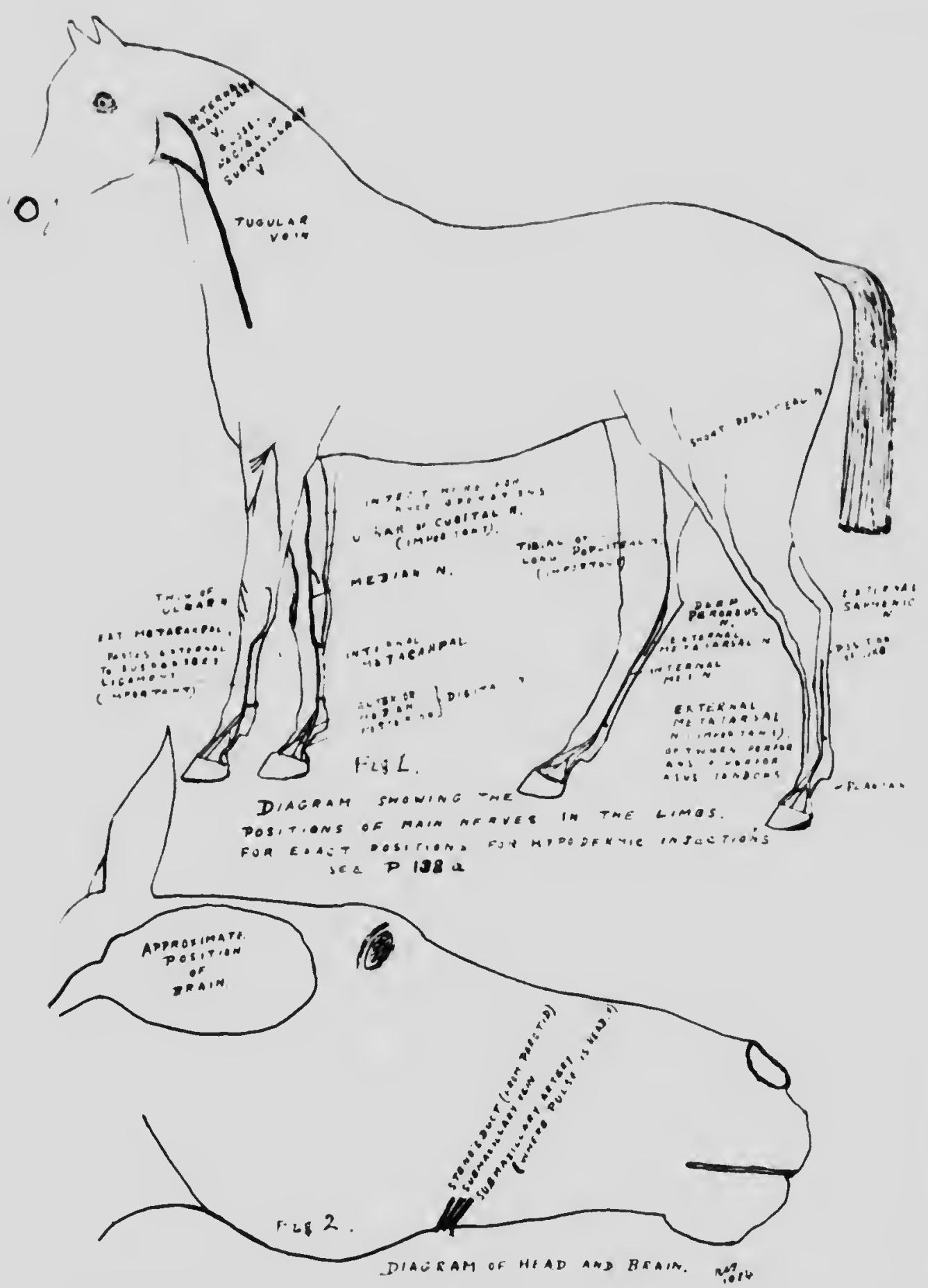

Diagrams showing the Nerves of the Limbs. Position of the Jugular V'ein. Submaxillary Artery and Brain 


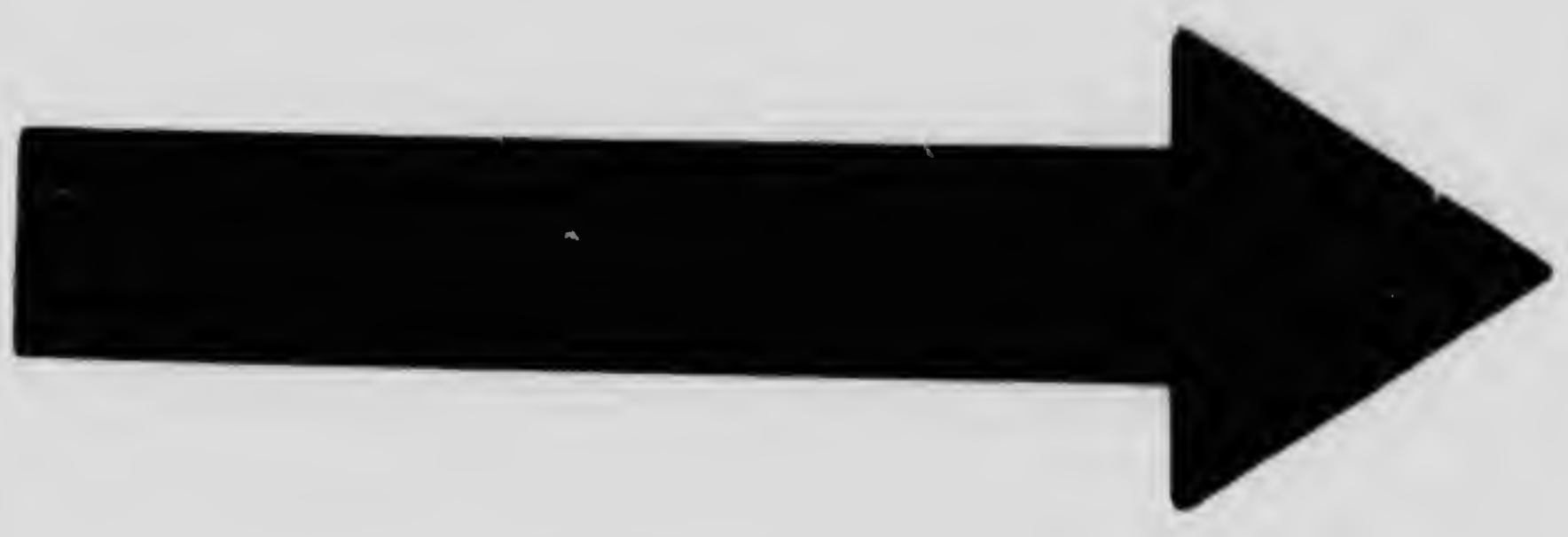




\section{MICROCOPY RESOLUTION TEST CHART}

ANSI and 150 TEST CHART No 2
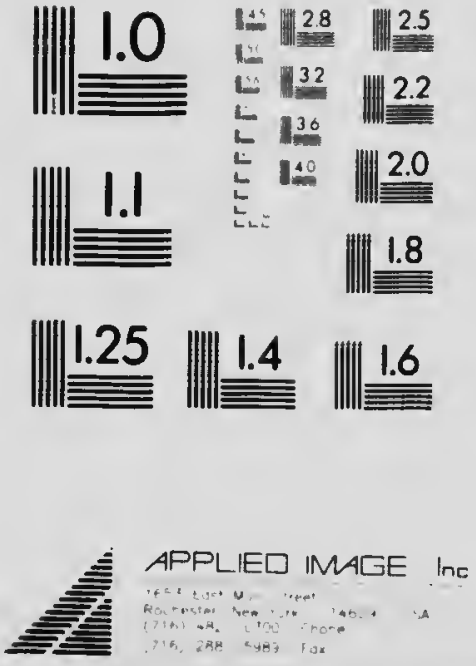


\section{PLATI: 138}
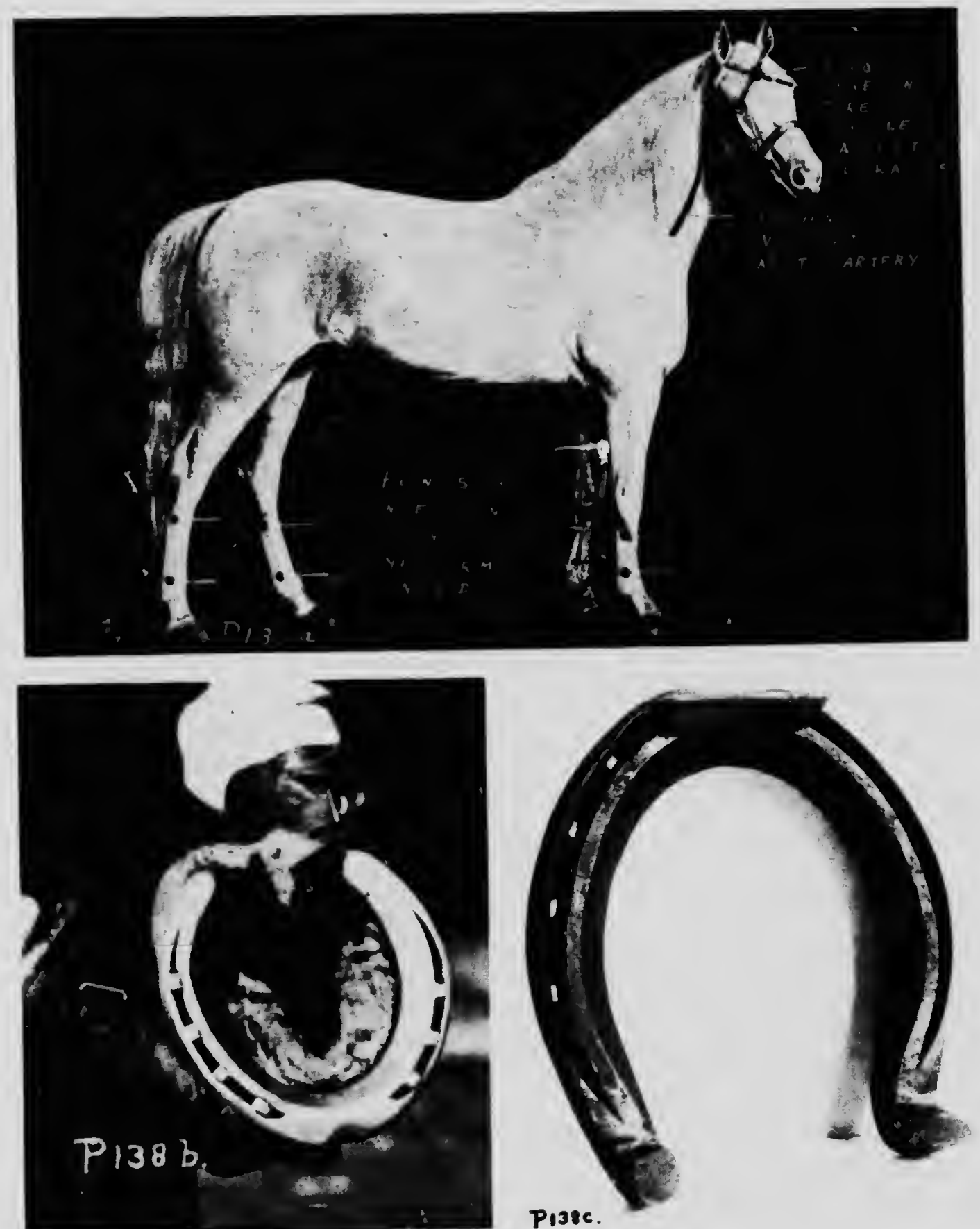

a, Stuwing the "Points" for Hypodermic Injections (see P. 137). Courtesy: "Our Dumb Namals," Boston, Mlass. a. Strowing the "Points" Hef althy Foot, with Shoe on. c. The Type of Shoe used in Winter in Canade. The Blunt Calts is on the laside. Phoios, $b, c$, by the Author 
jagged pieces of the frog, bars or sole be touched. If a clip is used on the shoe (Sec. 846), only sufficient of the wall should be cut out to fit it.

When the foot is placed on a plane it must lie absolutely flat and even, with every portion of it touching the plane. The walls must be pared and rasped underneath so that when the foot is on the ground the angle of the wall is $45^{\circ}$ in the fore feet and $50^{\circ}$ in the hind feet, i.e. at the toe of the foot. To prevent the wall from chipping at the bottom, a rasp must be run round the outer edge, just to remove the sharp edge and no more, before the shoe is put on.

836. The Conformation of the Foot.-Small feet do not stand hard work, especially with farm horses; on the other hand, if they are too large they will probably be coarse and deficient in toughness and strength. Healthy feet will always be in pairs, i.e. both fore and both hind alike. It is, therefore, generally easy to discover a contracted heel by comparing it with the opposite foot. The existence of odd feet is nearly always a sign of disease.

The practice of leaving the heels too high is quite wrong and most injurious, as it tends to reduce frog pressure and increase concussion on the limbs. On the other hand, if the toes are left too long, there is a tendency to cause extra strain on the back tendons of the foot. (P. 139.) This shows approximate angle of the toe and height of the heel, heels too high, and heels too low. As feet vary as much as, or more than, other parts of the horse, it is impossible to specify any one type of foot, and most foolish to attempt to make all horses' feet of the same shape.

887. Expansion of the Heel.-As explained above, the foot expands slightly every time the frog is brought to the ground; hence the necessity for not having nails near the heels of the foot. The top surface of a shoe at the heel always becomes worn a little and appears bright if the foot is healthy and the frog in contact with the ground. This worn portion on the shoe is due to the expansion and contraction of the heels at each step.

898. Shoeing.-Horses should either be reshod, or have their shoes rcmoved and feet trimmed and shoes put on again, once a month. In Canada in winter, when horses wear spikes or calkins to prevent slipping (P. 138c), the shoes get very little wear, and very often the owners neglect to send their horses to ine forge every month. Light shoes will wear away in two or three weeks on very hard macadam roads if the horse is doing much work.

In shoeing a horse it must always be well treated, and thus made to associate shoeing with pleasant things. If this is done he will not object to being shod, and the work of the farrier will be made very much more easy. (See Chapter III.)

889. Shape of the Foot.-The fundamental principle is that the upper surface of the shoe should be quite flat, and not "seated," i.e. with a bevel on the inner edge. (P. 139.) The whole of the surface should bear against the under surface of the wall of the hoof. The width of the shoe (known as the web) should, therefore, be exactly the width of the weight. bearing wall, so as not to touch the sole and not to leave any of the wall unsupported. This width is approximately in. for most horses. The practice of seating shoes should never be allowed. The thickness of a shoe (i.e. the weight of a shoe) should be sufficient to last about five weeks-that is, for one week longer than the period for using the shoe-and, therefore, this will vary with the work and roads.

For fast work the shoe should be as thin as possible, whilst for slow work, with heavy horses, extra weight will not matter so much. Heavy shoes on horses only tend to tire them sooner, as the horse lifts unnecessary weight every time he raises a leg. The practice of shoeing with heavy shoes is carried on with hackneys in order to make them lift their feet higher than is natural. The high stepping of standard-breds is, as a rule, natural, es I do not remember ever seeing one of these with heavy shoes. (P. 43.) The practice of heavy shoeing merely to give a showy effect is cruel and contrary to good horsemanship.

840. A shoe should be made of the best wrought iron. Most shoes nowadays are made by machinery, and merely fitted by the farrier. But every farrier should practise continually in the making of shoes by hand, as it is an art that soon dies with lack of practice. For light racing shoes steel is used in order to get sufficient strength into a small amount of material.

The weight of an ordinary riding shoe should be between $9 \mathrm{oz}$. and $16 \mathrm{oz}$, but those of carriage horses should be a little heavier-up to $24 \mathrm{oz}$. in heavier types. Very heavy draught horses sometimes have shoes up to $7 \mathrm{lb}$. in weight; on the other hand, light ponies and horses for special work have shoes of $6 \mathrm{oz}$., or even less.

The under surface of the shoe should be flat and on a level plane, except when it is "fullered." The fuller consists of a groove running round the under surface of the web a little nearer the outside than the inside. (P. 138c.) Fullering is done in order to diminish the risk of slipping, as the bearing surface on the ground consists of two narrow webs instead of one broad one, as is the case when there is no fuller. The length of the shoe should be the exact length of the wall; if longer, it is apt to be torn off, and, if shorter, the ends are liable to press into the foot and produce corns. For this reason it is safer to make them longer than shorter. If the heels of the fore feet are too long, they may cause capped elbows. 
841. Filling the Shoe.-After the foot has been prepared as clescribed in Sec. 83't ct seqq., the type of shoe most suitable is chosen, and heated to a bright red heat. It is then placed close to the under surface of the foot to ascertain approximately how its shape requires to be altered to fit the foot. It is bent as nearly as possible to the shape of the foot on the anvil, and again tried. This is repeated until it seems to fit well. The heels of the shoe are now cut off to the right length. The contraction that takes place when the iron cools niust, of course, be allowed for. Each time the hot shoe is compared with the foot it should not be held against the foot, or it will burn the foot too much; but after the slioe lias heen made to fit well, and the nail holes made, it is heated to a dull red heat, and held for a few seconds only against the foot, thus momentarily burning the uneven portions of the foot away, making the fit more perfect. This also has the beneficial effect of making the contact surface waterproof. Continued burning must never be allowed, as it dimages the structure of the foot.

After this final fitting, of course, the shoe must not be altered in shape in any way. On no account must the red-hot shoe be used to burn down the wall, as is not uncommonly done by lazy farriers. The inside of the foot may be permanently damaged thereby; at any rate, the hoof will be damaged.

842. Nails.-Only sufficient nails should be used to hold the shoe in place. This number, of course, will depend on the size and weight of the shoe, the kind of work, the action of the horse, the toughness of the wall, the accurate fitting of the shoe, and whether the wall has been rasped and the clenches interfered with, as is so frequently the case. Nails must never be near the heels nor at the toes.

Five nails (three on the outside and two on the inside) are sufficient for the fore-shoes, and six (three on each side) for the hind-shoes. Heavy draught horses usually have seven (one more on each sicle) on the fore-shoes and eight on the hind-shoes. It is far better to use few nails, and to examine the nails and shoes carefully every day, than to fill the foot with nails. The fewer nails ased the better will be the condition of the foot. Nails must be of the toughest iron procurable, and should stand being bent in a vice backwards and forwards four or five times without breaking. Most nails are now machine made, and are very good ones too; consequently, making nails by hand is very little practised.

The holes in the shoe should be made fairly small, and the isail should fit exactly into each hole. Nails slould, therefore, be fitted to each hole before the shoe is put in place. If the nails are loose in the shoe, however tightly they may be clenched, there will be certain movement between the shoe and fout.
849. I strongly recommend Alfred W. Kniglit's (of 4 Upper St. Martin's Lane, London) patent safety loorse nails. From experience, I find the chief advantages they possess over the ordiuary fiat nail are: that the shank of the nail is curved in cross section, i.e. concave on the side towards the centre of the loot and convex on the outside; that with these nails there is no necessity to bend the nails lengthways, as is often done with fiat nails; that the clenches, having ribs on each side, are extremely strong; that there is never any necessity to make a notch under the clench, and the nails need not be clenched so tightly; and that the dangers of nail pressure are very greatly lessened. The nails are slightly more expensive, but the slight difference is easily outweighed by the saving in nails and the lessened chance of losing shoes, and they are far more humane.

The R.S.P.C.A. says about these nails, "There is no necessity for curving or . znding longways. The inward bending pressure from the fiat nail, that often causes lameness, is avoided, and the horse works with more comfor and freedom."

844. The nail holes in the shoe must not be too near the toe, because the heads will woar off too quickly, nor must they be too near the heels, as explained in Sec. 837. (P. 138b, c.) The nail holes must be a little nearer the outside than the inside of the web.

The fit of the nail is made more secure if the holes are countersunk with a rectangular counter-sinker on the ground surface of the shoe. In fullered shoes the holes should be countersunk just a little, and the heads of the nails, as a rule, are buried deeper into the web, the fullering allowing for this. There is not much object in leaving the heads of the nails projecting below the shoe, as they so rapidly wear off.

If rose-headed nails (P. 139) are used, they project, of course, farther out and, while they last, act as a protection against slipping. The ordinary countersunk-headed nail is the best. It should be fitted practically flush with the lower surface of the shoe in a fullered shoo, and only project about one-eighth of an inch with a nonfullered shoe.

Fullering is often objected to because it lessens the wearing surface of the shoe, and it also causes the nail heads to fit less securely on account of there being only two sides of the head, instead of four, in contact with the shoe. The fore-shoes of saddle horses are usually fullered.

845. Before punching the holes in the shoe, any weak part in the hoof should be noticed, because nails must only be driven in where the wall is perfectly sound. The nails must bo driven in with the bevel side of the point (P. 139) inside, i.e. towards the centre of the foot. This prevents the nail from being driven into the foot and causing a "prick," The centre 
nail should be held at about right angles to the under surface of the foot while it is being driven in, the toe nail with its head away from the centre of the sole, and the heel nail with its head towards the frog. This will cause them to come out in line. They must be so held that their points will come through the wall about one inch above the bottom of the wall. This can be done after a little practice; but if it is found that a nail comes a quarter of an inch too high or two low, it should be left, because if another hole is made close to the original it may give way.

When each nail is driven through, it should be driven right home. The claw of the hammer is then used to twist the point of the nail over, and the point is twisted of by turning it in a rotary movement. Care must be taken that at least one-eighth of an inch is left sticking through the wall to form a sufficiently strong clench to hold the nail in.

After all the nails are thus driven in tightly and clenched, they are again hammered in to make sure they have not become loose. The head of the pincers or other tool is held against the head of each nail while the clench is hammered down tight on to the wall. The practice of rasping a groove under the clench should be forbidden, as it tends to weaken the hold of the nail; but if the clench, after it has been securely hammered down, projects too much, causirig it to catch in anything, it should be lightly touched with the rasp, but on no account heavily so as to weaken it. The rasp should not be drawn round the edge of the wall to make the foot look "neat," as is often done, because, however neat this may appear to some, it becomes covered up directly the foot gets dusty or dirty. The outside of the wall must never be touched with the rasp.

Shoes will practically never be lost if the above simple rules are strictly adhered to.

846. Clips (P. 139). - These consist of a vortion of the front of the web of the shoe being forced up by the farrier, while the shoe is being made, to afford a firmer holding between the shoe and foot. The wall is pared out to fit the clip, which must be as small as possible in order to avoid the necessity for paring away much of the hoof, and also to avoid lessening the bearing surface of the hoof tou much. A clip, if used, is generally made at the toe for fore-shoes and one on each side of the toe for hind-shoes. They are used more in artillery and heavy draught horses, and are not necessary in saddle and carriage horses.

847. Removing Shoes.-Before any attempt is made to draw a shoe off the foot, the head of each nail must be sharply tapped home, and every clench must be cut off with the buffer. The shoe should then be drawn a little out with the pincers. first drawing at the toe, and next at the two heels. The shoe should then be hammered on again, when each nail head will protrude sufficiently for it to be withdrawn carefully with the pincers. The practice of wrenching of shoes is dangerous, and seldom saves time, but very often causes a great deal more trouble in the end.

848. Calkins.-These consist of projections on the wearing surface of the shoe on both heels. They are generally used on heavy draught horses to prevent slipping. (P. 132e.) I object to their use, unless made very short, because they tend to keep the frog off the ground. They also tend to raise the heels too high. For this reason they should be made of steel let into the iron shoe, because then they can be short and wide, and will not wear at all rapidly. The use of calkins in winter is described in Sec. 852.

849. Tips. - These are shoes of half the ordinary length, or not more than half, which cover only the toe and fore part of the quarters of the hoof, leaving the heels and rear part of the quarters bare. They should be tapered of towards the rear so as to afford a level surface against the ground from toe to heel. With their use the dangers of contracted heels, diseased frogs, slipping, etc., are greatly reduced, and the only objection to their use is that, until a horse is used to wearing them, hard roads and stones will damage the unprotected parts. For unpaved and stoneless trails, as we see in Alberta, for example, they should be used in preference to whole shoes. Heels and frogs rapidly become stronger and better fitted to resist hard work if tips are used, but of course, at first, care must be taken not to go over stony or hard roads. Two nails are generally sufflcient on each side, i.e. four in all.

850. Bar shoes have a small bar passing from heel to heel under the frog, and are only used to relieve some other portion of the foot from pressure, as in corns, etc. They do not, however, in any way compensate for want of proper frog pressure. Continual use of these will cause contracted heels. When used, great care must be taken that the nails are not near the heels. (Secs. 833, 837.)

Rocking shoes, as the name implies, are made with thick quarters and thin toes and heels, i.e. with a rocking wearing surface, but level upper surface. They are used to relieve the foot in laminitis, etc.

851. Feathering. - Feather - edged or "Knoclied-up" Shoes (P. 139).-Feathering consists in narrowing the web on the inside of the shoe. This is done to prevent "brushing," or "speedy cutting," etc. Many horses that do not "brush" at all are shod in this manner as a precaution. The hind feet, as a rule, are the only ones that are shod with feathered shoes.

Concave.-A shoe is said to be concave when its inner border is bevelled, so that the top of 
the web is broader than the bottom, or wearing surface. (P. 138b.) A hunter's shoes are often slightly bevelled, as it helps the horse to draw the foot out of the sticky ground and lessens the ehance of the shoe being pulled off. Concave shoes should be used on the fore feet of all horses that "forge," otherwise concaving only makes the wearing surface smaller.

852. Roughing or Sharpening for Winter Wear.-This consists in either screwing in screws to ordinary shoes or in making special shoes. In England, where one day is frosty and another wet during the winter months, shoes are punched and drilled ready to receive little roughs, or sharp-headed screws. The best form of screw for this purpose is one that is made of good steel and has its centre harder than its outside, allowing it to wear more on the outside than the centre, thus keeping the point always sharp. A make, the "Neverslip," which claims the above properties, is on the market.

In Canada, directly the winter-which, as a rule, lasts from three to four months, or longer -threatens, most horses are shod with winter shoes. P. $138 \mathrm{c}$ shows a typical saddle-horse shoe for winter purposes; this will also do for light harness horses. It has a sharp calkin on the outer heel and toe and a blunt calkin on the inner heel, making the bearing on the ground level; the calkins should be of steel, let in, so that they need not be too long.

A certain amount of frog pressure is main. tained on account of the horse treading on snow most of the while; but the web, which gets prectically no wear, can be made thinner, so as to bring the frog as near to the ground as possible. These shoes must be removed every month, the foot dressed, and the shoe refitted. As a rule, shoes will last two or three months in the snow, and, therefore, can be refitted several times. For heavy horses three larger calkins can be used. I have ridden for several winters almost daily along the snow- and icecovered asphalt pavements on young horses, and have never had a horse slip down when wearing the type of shoe shown in P. $138 \mathrm{c}$.

Ice-race show generally consist of wedgeshaped calkins at the toe and both heels, fitted either transversely or longitudinally at the heels. The American or Canadian ice-shoe has generally one broad wedge at the toe and one transverse wedge (i.e. across the web) at each heel.

853. Pavements.-From the point of view of wear of a horse's legs, the softer or the more muddy the roads are the better; but for draught horses, the harder and the more level the roads are the easier is the draught. For this reason saddle horses are best kept on the grassy sides of country roads, and the roads themselves should be macadamised. Macadam roads, of course, would not wear sufficiently well in a city, and it is the city pavement that meets with so many objections. On hills, smooth pavements are not at all suitable for horses; cobbles make the best pavement.

On level or nearly level streets two kinds of pavement are used: tarred wood blocks or Limmer asphalt. In London the former is largely used, whilst in Toronto and most Canadian and United States cities the latter finds favour. Wood is easier for the horse's feet, but is not so lasting, is not so easily kept clean, and is more slippery after a little rain.

Limmer asphalt is very hard for the feet in winter, but is softer in very hot weather. In frosty weather it is extremely slippery until sufficient snow has fallen to give it a footing. On the whole, I believe wood is the better for horses, as it is so much softer; but for level running and for motor traction, the asphalt is the better. Both wood and asphalt are easily repaired where small patches have become worn.

The practice of allowing oil to drip from motor engines on to the pavement is very dangerous, and has in the past caused scores of horses to slip. This practice should be prohibited by law. Many cities in the States have by-laws compelling all motors to carry dripping-pans under the engine to collect grease and oil, and thus eliminate the danger that the horse is subjected to. The crown grade on streets should be lowered, and the free distribution of sand in slippery weather should be generally enforced.

854. Common Paults in Shoeing.-Besides those already dealt with, as rasping the outside of the wall, rasping a notch for the clenchers, rasping the clench, and paring the frog or sole, etc. there is the common fault of lowering the wall too much, so as to cause the inner edge of the web to press against the edge of the sole. The wall should be left a little below the sole.

Dumping, as explained in Sec. 834, consists in making the shoe a little smaller than the foot and rasping the wall to fit the shoe-a moot contemptible and injurious practice. American farriers generally use seven or eight nails, even for light horses; these are often necessary on account of the manner in which they rasp the walls and reduce their holding power.

Excessive burning is another common fault, which is done to save trouble and with the intention of getting a good fit. The opposite, as a matter of fact, is the result, because the excessive heat causes the horn to become so brittle that it is unable to bear weight. Slight burning for a very few seconds, as explained in Sec. 841, will, however, do no harm and will make the ends of the fibres waterproof. Excessive burning also makes the foot harder for the farrier next time he shoes the horse; brittle horn is hard to cut.

855. Pricks. - Pricks consist of injuries to the highly vascular, sensitive lamina from nails 
PLATE 139

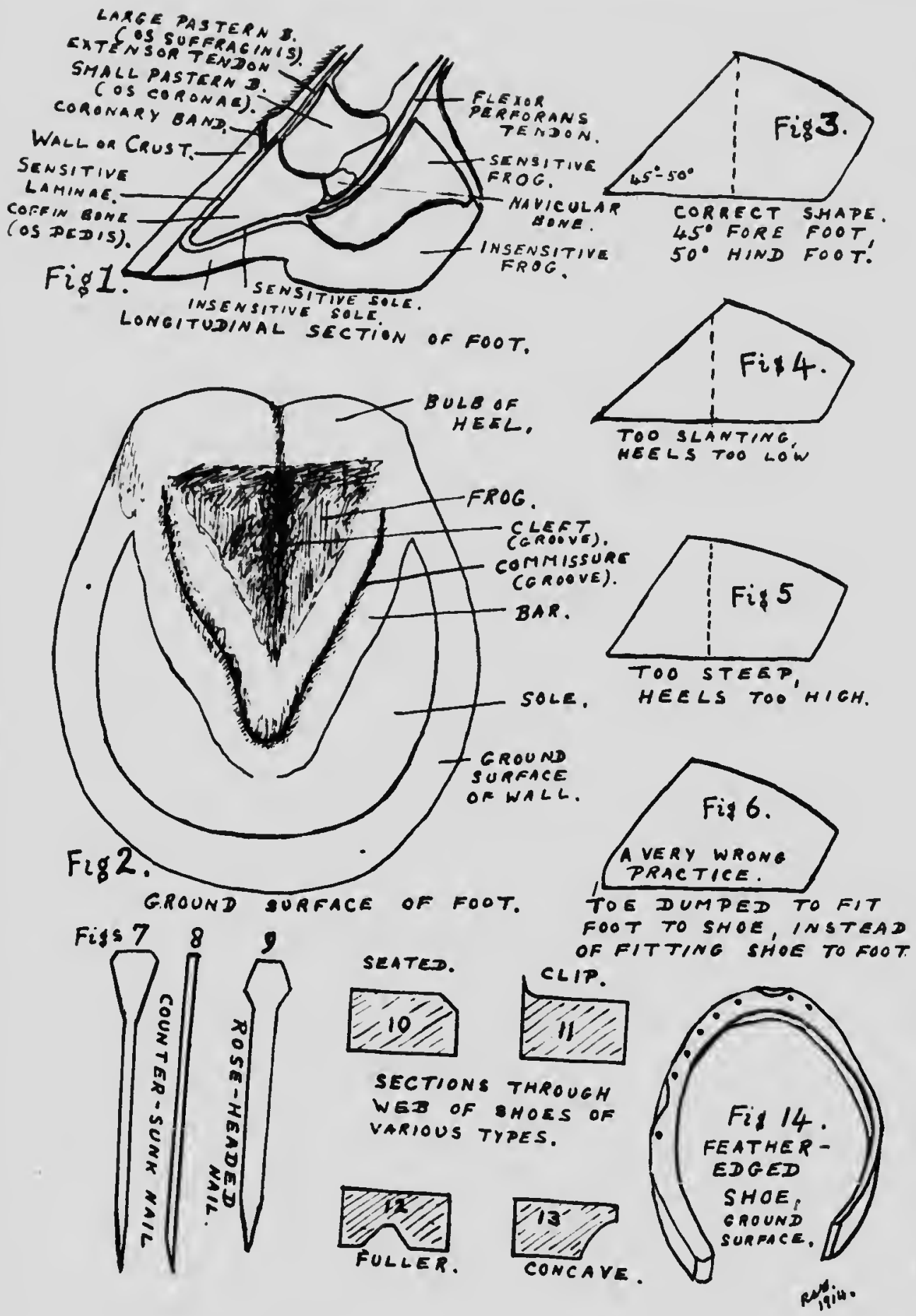

Diagrams of the Foot, Shoes and Nails 
PI.ATI: $1+0$
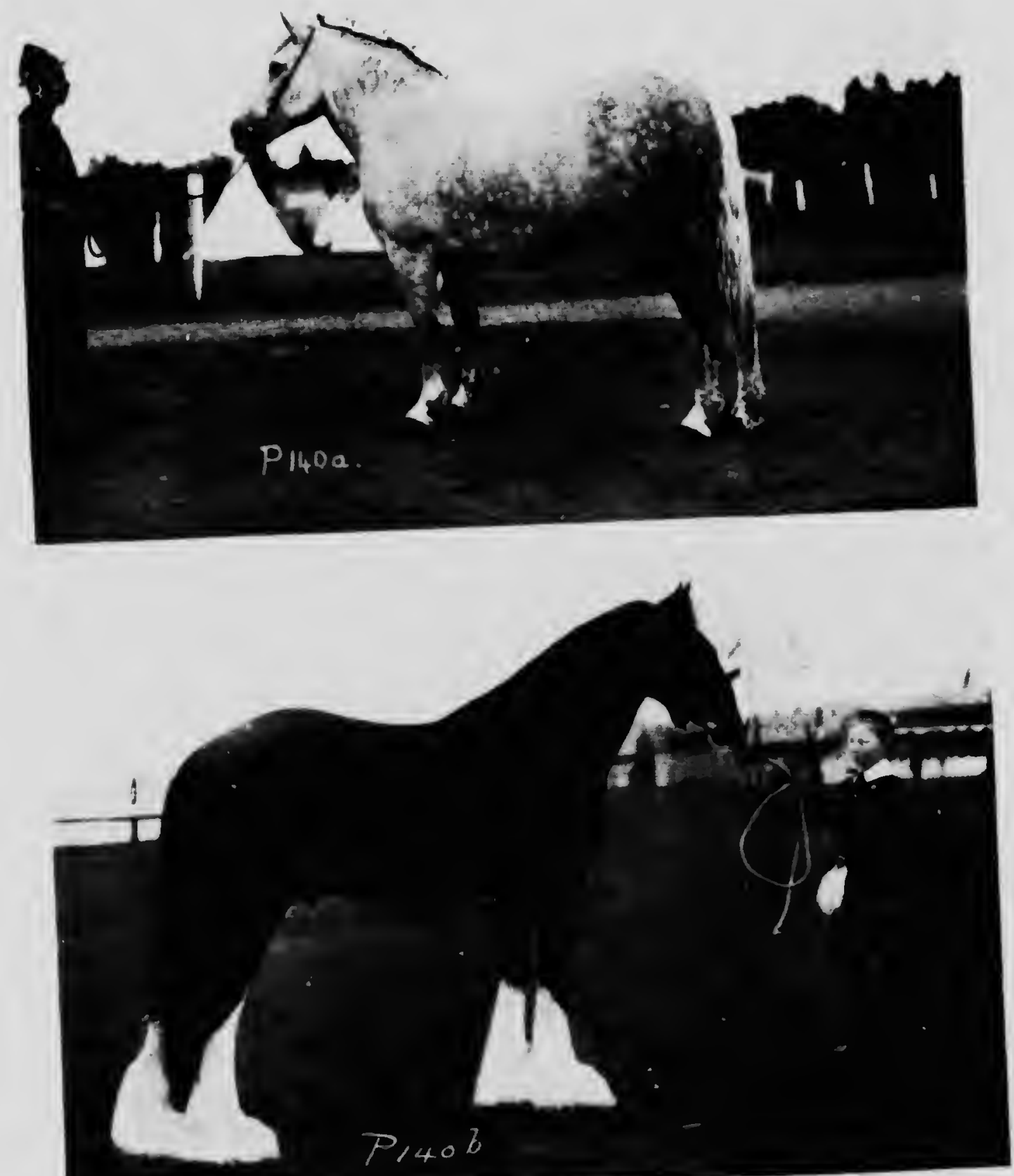

TWO CHAMPION HORSES

a, "Marjorie." Cirey Percheron the Property of Messrs. W. E. \& R. C. Upper, Nont
Clydesdale. "The Dunure." Photo: G. H. Parsons 
being driven too far inwards, i.e. towards the centre of the foot. If the instructions laid down in Sec. $8: 4$ are carried out, there is little danger of pricking a horse. Some walls are very thin, and special care must be taken. A study of P. 139 will show that the thickness of horn is never very great, necessitating every nail being driven in with much care. Many a horse lias been totally ruined by being pricked. When a horse is pricked he will generally fincls; the nail must be at once withurawn. There will be a little blood on the end of the nail. The horn must be pared away until the seat of the injury is reached, and a drop or two of pure carbolic acid, or 50 per cent. solution, must be syringed, by means of a hypodermic needle, right into the bottom of the wound. A tuft of aseptic cottonwool can be plugger in t? keep dirt from getting in. The wound must be re-dressed every four hours. Blood poisoning, lockjaw, etc., may very easily follow a neglected prick.

856. If the nail has been in a few hours, or the district is one in which lockjaw itetanus) is common, the horse should be treated at once with anti-tetanus serum, and again the following day. (See Sec. 620.) Whenever a nail is drawn out of a fool, either one that has been driven in the wrong place by the farrier or one that has been picked up accidentally by the horse, and it is seen that the nail has been in a considerable distance, the foot must be pared away to the sensitive part. A probe must then be used to reach the bottom of the hole, or a hypodermic needle may be used for this. When the hole is found, the carbolic must be injected as described above. This must be done with force right to the bottom of the hole. This will aruterise the surface of the wound and destroy all septic matter. The horse will give a jump as the carbolic touches the bottom of the wound, which is a sure test that the needle is in the right place. The depth that the needle is to be inserted must be compared with the length of the nail that was drawn out. Many cases of tetanus have resulted from farriers cutting a bit of the sole or frog away and plugging the hole up with tar, thus closing in all germs.

If the nail has been in long enough to allow the foot to swell, after treating as above, it will be necessary to apply a hot antiseptic poultice at once, and to repeat it in a couple of hours, in order to draw out the poison. Upon the first signs of swelling about the fetlock, the antitetanus serum must be used, and repeated the following day, as described above.

Presses or Binds.-These are caused by the nail being driven in very nesr to the sensitive wall, but not actually into it. The result is a bruise of the sensitive laminæ. The horse will show it either by a flinch or else by going lame after shoeing. The nails must be withdrawn one by one to ascertain wi.ich is causing the trouble. If there is no blood on the nail points, it is clear that there is not a prick. On removal of the nail that presses, the trouble will generally right itself of its own accord; if very bad. the horse should not be worked for a few days. As the farrier withdraws the nail that causes the trouble, the horse will generally flinch slightly, so it is easy, as a rule, to discover which nail it is.

857. Forge Tools. - The anvil, which is familiar to everyone, is the most important tool for fitting or making shoes.

The fire tongs are used to hold the shoe in the fire, and have long handles; the shoe tongs are used to loold the shoe at the anvil while it is being shaped.

The turning hammer, weight about $\& \mathrm{lb}$., has one flat and one convex face, and is used on the auvil. The sledge hammer, weight $9 \mathrm{lb}$., is used by an assistant, the striker, to weld metal and to cut or mould the bar in making shoes.

The concave tool, or swedge, and other shap. ing tools are held in place by the farrier while the striker hammers the bar of iron into the mould.

The fuller is a blunt chisel, with a wooden handle, resembling a hammer, that is hammered into the web by the striker as the farrier draws it around the web.

The pritchel, or counter-sinker, is used to punch the holes for the heads to fit in accurately. The stamp is used to punch the holes right through the web. The pritchel and punch must be the exact shape of the nails used to ensure accurately fitting nails.

858. Shoeing Tools.-The shoeing hammer $f_{1}$ is a small head and bent claws, and is used for driving and clenching nails.

The buffer is made of steel, about 51 in. long, lias a point at one end to punch out broken nails, and a chisel at the other for cutting off clenches. Pincers are used for drawing nails, and also as a buffer held against the heads while the clenches are hammered down tight.

The drawing knife has a curved blade, and is used to pare the wall and to remove ragged bits of horn. It must be of best steel and kept very sharp. The rasp has one half on one side file cut and the remainder coarse cut. It should be 16 in. long and of the best steel.

859. Faulty Feet.-Flat foet are large, have very sloping walls in front, low heels, and flat and generally thin soles.

Narrow feet are the opposite: small, have upright walls and high heels. Flat feet are preferable to narrow feet, as they generally have large frogs, whilst narrow feet generally have very small frogs. Natural flat feet must not be confounded with feet that have been incorrectly pared by the farrier, as described in Secs. 835 and $8 \mathrm{u} 4$. 


\section{Diseases of the Hoof}

860. Disease of the internal bony struclure of the foot lave been lealt with in Chapter 1X. We will here consider the external diseases of the foot and diseases of the sensitive lamina.

Forginfi, or Clickino.

Cnuse.-A horse generally strikes the inner erfe of the grounil surface of the web of the forefoot with the toe of the hindfoot on the same side, as this foot is raisel from the ground, while trotting. This is often due to the walls not being properly pared down or to careless driving or ridling.

Trealmenl.- Hasp the top of the lind-shoes and shorten them. Slioe the forefoot with concave shoes. Drive or ride horse carefully and in a collected manner. Pare the walls properly, i.e. shorten the toes if they have grown too long.

861. Stumbling.

Cause.-Horse catches toe of shoe on ground as he turns the toe forwards to place foot on ground. Often due to careless driving or riding.

Trealment.- Shorten toe of shoe and make it much thinner than rest of web. Drive or ride horse carefully and in a collected manner.

862. Contracted Heels.

Cause.-Result of thrush (Sec. 871); going on toe, as is done in navicular disease and certain forms of lameness ; maliormation, and generally want of frog pressure, due to erroneous shoeing and the abominable practice of paring away the frog.

Symptoms.-The frog is quite narrow, and not wirl and healthy looking, as in P. $138 b$; the heel are quite close together.

Trealment.-If there is thrush, treat accordingly. Obtain trog pressure at all costs. Allow full expansion of the heels.

863. Conss.-A corn in a horse is very different from that in a human being. In the former it is the result of a bruise to the sensitive laminz: in the latter it is the result of intermittent pressure on a part of the foot. A corn is a hypertrophy or an abnormal growth of tissue that is not diseased.

Cause.-Horses with weak heels and flat soles are more suhject to corns: bad shoeing; fast work on hard roads; stepping on sharp stones, small pebbles, etc.; small stones working into the heels of the shoe when they are "sprung"; paring away the bars; heel = of shoe too short larce calkins; paring away too much of the walls at the heels.

Sympioms.-Horse may not always he lame from a corn. The lameness gets worse as horse works. A few days' rest may temporarily remove the lameness. Horse may point the affected foot when standing, or stand sery uneasily, if both forefeet or hindfeet are affected. They rarely occur in hindfeet. The corn usually ncrurs on the intermal portion of the sole near the heel, owing to there being greater weight on the inside and owing to the inner wall being more upright.

Trealmeni.-Remove shoe, and pare enough of the horn out to get access to the corn. If there is any suppuration, the wound must be treated as for pricks. (S'e Secs. 855-8.) If odour is bad, probably pedal bone is diseased, so any diseaserl bone will have to be removed under chloroform. If the wound is troublesome, anasthetise foot with cocaine, and insert red-hol iron to burn the diseased parts. Watch lor signs of quittor. (Sec. 436.) After wound has healed, or if there is no suppuration, shoe with threequarter shoe, so that there is no web under the heel near the corn, and put bar across trog to keep weight of seat of corn. If there is a corn on both sides, shoe with a tip, and extend a bar from the loe across the frog.

864. SANDCRACK.-This is a fissure in the crust or wall that runs in the direction of the fibres.

Cause.-Generally due to weakness in loot or conslitutional listurbance. More common in flat feet. May be the result of rasping the walls.

Symptoms.-There may or may not be lamoness. A fissure or groove, perhaps very slight at first, appears in the wall running downwards and slightly forwards; may be at the top or may not reach up to the coronet.

Treatment.-If there is lameness, poultice with antiseptic poultice (Sec. 503) for a few days. Thoroughly syringe out the fissure. If it does not extend to coronet, rasp a deep nick, about $t$ in. long, horizontally above the fissure, remove shoe, and pare out a semicircular groove on ground surface of wall to take weight of the fibres, which extend from the fissure to the shoe; then replace shoe. If the fissure is at the top of the foot and extends to the coronet, rasp or burn with wedge-shaped iron a $V$ large enough to enclose the fissure inside the $\mathbf{V}$. The tops of the $\mathbf{V}$ must reach the coronet. The foot must be anæsthetised with cocaine. (Sec. 759 , et seq.) If the fissure extends the full length of the wall, little holes must be made on each side, aboul 1 in. from fissure, and iron staples hammered in to hold the wall together. Ground surface of wall pared as ahove. If fissure reaches coronel, horse must not work until the horn lias grown at least one inch below coronet, when a horizontal nick must be made to prevent the crack from running up. Wherever the fissure is, the growth of horn musi be stimulated by blistering coronet with a good cantharides blister.

865. Splt Hoof.-Split hoofs may be due to concussion or external injuries. As a rule, the split starts at the bottom, and extends only for a short way up. It may be horizontal; in this case use clenches. Treat split hoof as described for sandcrack. (Sec. 864.)

886. False QuARTER.-This is a diepression 
extending in the direction of the fibres from the coronet. It may appear at any place, and is due to Injury to tho coronet, as quittor, tread, or other external Injury.

Trcatment.-Blister the coronet; tlils is the only hope. Take precautions, as for sandcrack, to prevent the hoof from splitting at the weak. ened spot. Give the horse easy work.

867. SeEdY TOE is similar to false quarter, except that the depression is inside instead of outside the wall. The cavity is flled witl a soft, cheesy, crumbly material.

Causp.-Result of laminitis or perhaps same as false quarter. Continued strain, continual standing.

Symptoms.-The end of the depression will be seen when the shoe is removed. There will be lameness, and if the portion outside the tissue is tapped it will sound hollow.

Treatment.-If due to laminitis, treatment for this alone would be useless; therefore, treat for laminitis. Pare away all the loose horn until all signs of the original crack are removen. The foot must be first anasthetised with cocaine; then make the wound thoroughly aseptic with turpentine, and not with water solutions. Next apply the following dressing over the pared-out part to keep moisture away:
Oil of turpentine.

Oil of tar

Fish oll

1 ounce

1 ounce

4 ounces
Shake well, and apply it night and morning. This is an excellent dressing for brittle feet.

888. INFLAMMATION OF CORONET.-Very uncommon in horses, fairly common in asses. The cause is probably due to constitutional disturbance, to a nervous disorder, or to external injury.

Symptoms.-The hoof becomes like the bark of a tree, and splits, pieces breaking off.

Treatment.-Dress the foot with coal tar and fish oil. Pare away all affected horn. Attend to horse's diet. Rest the horse on soft bedding.

869. BRITTLE FEET are generally constitutional. Some horses, however healthy, have brittle feet. Working and standing on hard, dry ground tend to make feet brittle. Most patent dressings are injurious, and may cause feet to become brittle.

Treatment.-Obtain frog pressure, and rub in daily dressing as for seedy toe. (Sec. 867.) Stand on clay floor in stable and work on soft ground. Small washers can be used under the nail clenches to prevent the clenches chipping the wall.

870. TREads consist of injuries to the foot due to the shoe of one of the other feet treading on it. The term is generally applied to a wound on the coronet.

Treatment.-Syringe out wound, and treat aseptically. Apply a little lodoform and tannic acid. If healing is slow, apply weak cantharides (1 to 20 lard) blister round the tread, on coronet. 871. Thnusu.

Cause.-Want of proper use of the foot; dirt; neglect. Always a sign of bad stable management or bad shoeing, as improper paring, contraction, high-heeled shoe. If from neglect, It is due probably to manure, combined with ammonis, clogging in the grooves in the foot. Horse not using frog in navicular disease. Symptoms.-Bad smelling secretion comes from the cleft or commissures of the frog. This secretion originates from the plantar cushion.

Treatment,-Remove with paring knifo all rotten horn. Clean foot thoroughly, the clefts right to the bottom, and syringe out with strong antiseptic, or, better still, apply calomel well rubbed in. Plaster tar and tow over this to keep it in. Shoe properly, and keep stables clean and dry. Obtain frog pressure. Kerp clefts plugged up with calomel for several days and covered with tar. Calomel is rather expensive, but is by far the best drug to use. A mixture of iodoform and eucalyptus oil ( 1 in 8 oil) is a good dressing if calumel cannot be obtained.

872. Canker is really a diseased condition of the sensitive sole and plantar cushion, and has the appearance of a bad chronic condition of thrush. It comes on slowly and does not show much sign of pain. The disease is probably due to micro-organisms.

Treatment. - Remove the shoe, anmsthetise the foot with cocaine, and remove all diseased portion of the horn with a knife. Syringe the whole of the exposed sensitive and horny parts with a 25 per cent. solution of carbolic acid for five minutes, then allow to dry for fifteen minutes, and apply calomel. This must be blown right into the sensitive structure. Cover with aseptic cottonwool and suitable bandages. Repeat the carbolic (10 per cent. only) and calomel every twenty-four hours. Keep stable floor scrupulously clean, attend to diet, and give mild purgative, and rest horse on soft bed. Obtain good frog pressure afterwards, and keep feet thoroughly washed morning and night.

873. ACUTE LaMINITIS, or FoundeR, or Fever in the Feet.-For pumice, see "Chronic Laminitis," Sec. 874. The acute form is acute inflammation of the sensitive laminæ of the foot.

Cause.-Defective feet and hereditary tendency predispose horses to the disease. More common in forefeet. Concussion. Exposure at a slow pace for many hours on hot roads. Rasping the walls, paring frog and sole. Excitement, indigestion, overwork, continual standing. Overfeeding, with insufficient exercise. Flat feet are a predisposing cause.

Symptoms.-Very sudden. Horse goes lame and seems incapable of moving. Generally in left and right foot together. Great heat in the 
feet. Horse bears most wright on his heels. Great paill. Temperature high, Pulse quick, full, and hard. IRespiration increased, like confestion of lumgs, for which it is oftell mistaken. Horse unwilling to move.

Treatment.-Give a pint of linseed vil, and warm water and soap enema. On no account give a strong purgative. Apply pressure bandages below the knee or hock. Ilimove shoes carefully, and pare walls to allow as much weiglit as possible on the frog; do not touch frog. Give gentle exercise a few times a day, if horse will move: otherwise, leave him alolle. Fecil on laxative diet, grass, ctc., and make horse lie town, if he will.

When not lying down, sland him in cold water, and on no account poullice foot or stanil in hot water, as this will draw more blood to the already inflaned tissues. Pass catheter, as horse may withhold urine. If colicky pains, give cannabis indica F.E. I Ir.

Broad web shoes, with leather or rubber pads next to the foot, should be used for a few weeks. and the web should be thin at toe and heels to form a rocker-shaped shoe, which will ease the horse.

Prevention.-Exercise herses on boarl ship or on a long train journey, and sling them occasiunally, if they will not lie down, to relieve weight on feet. After much standing, as on banrd ship, put horse into lonse box for a week. $A$ few miles' walking after two or three weeks on board ship may bring on laminitis.

Laminitis is not uncommon after parturition. After a foal is born, if the after-birth (placenta) does not come away clean from the mare in three or four hours, it must be removed very carefully with the hand, the hand and arm being made thoroughly aseptic with lysol solution and in serted right into the womb (uterus). The womb must then be syringed out with corrosive sublimate (1 to 2,000$)$, followed immerliately by a thorough flushing with normal saliue solution. This changes the poisonous mercury perchloride (corrosive sublimak) into mercury subchloride (calontel), which will do 110 harm, but will act as a stight laxative. Laminitis is very tiable to occur again. On no account must a strong solution of the mercury be used in this case.

874. Ciltononic Laminitis.

Cause. - Due to reported attacks of acute laminitis (founder). whelt the union between the sensitive lamina and the horny wall becomes partially destroyed, If this is very bad the toe of the pedal bone (os pedis) may touch the sole, a condition which is known as pumice.

Symptoms.-Horse is lame and tries to bear all weight on the heels and keeps feet as much as possible to the front (the opposite to navicular disease). When moving, horse will take short steps. The slope of the wall at the toe is concave instead of straight. The wall of the toe near the ground will be thick; sole, flat; horn, brittle and weak; frog, healthy and large, due to increasel work on it. Work increases the lameness (opposite to navicular disease). There will generally be the regular rings of horn projectirig around the outside of the wall. Dishonest horse dealers rasp these rings away.

Treatment.--Obtain frog pressure. Lower wall at heels to bring more weight on to the heels. Use rubber or leather between shoe and foot. Shoe must not touch sole. Heels of shoe must be thinner and broader. Blister coronet with mild cantharides ointment ( 1 to 24 lard); feed on laxative food, and give gentle work on soft ground, on no account on harrl. Give good soft bedding, and, if heal in feet after work, stand for two hours in cold water. 


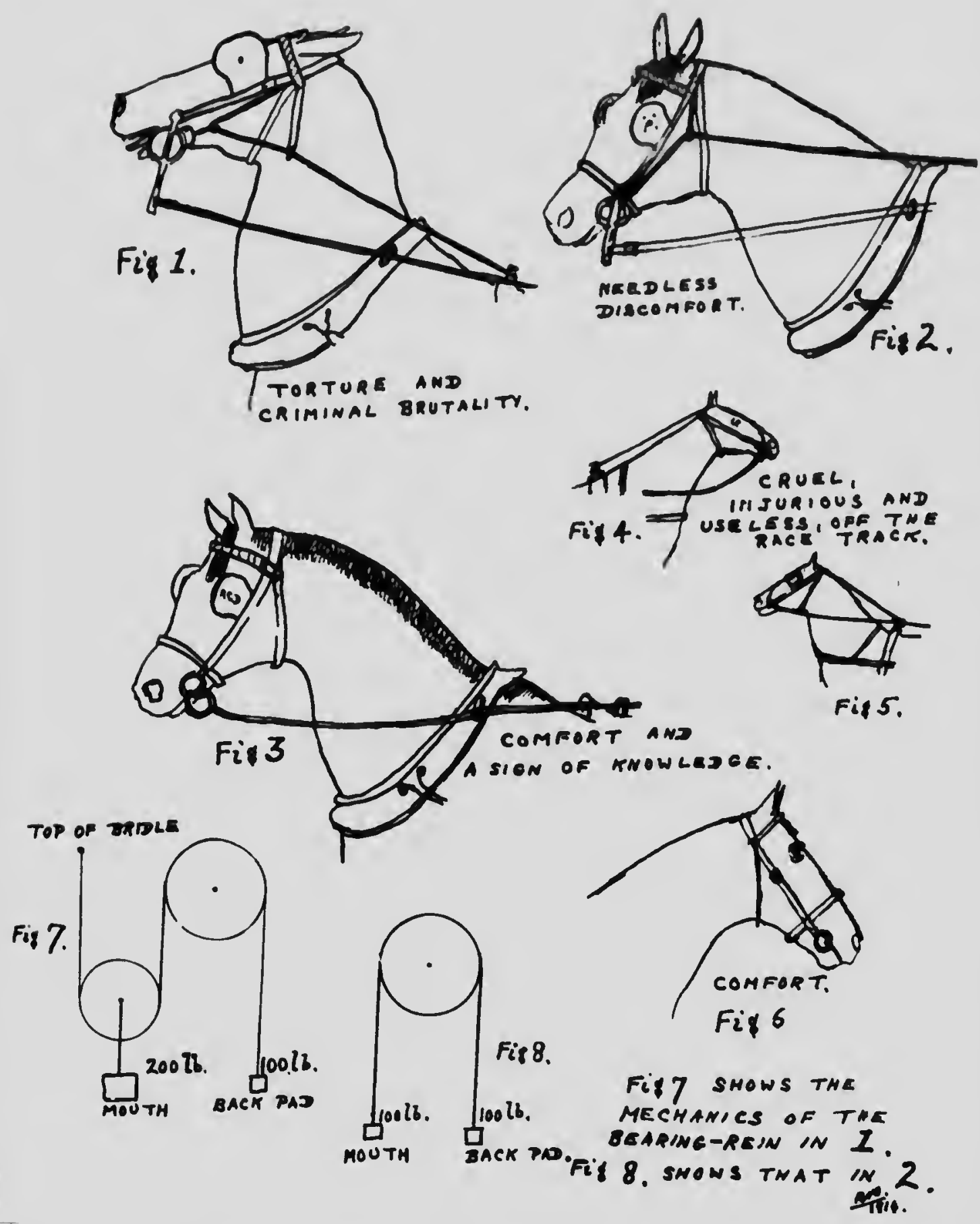

Sketches showing the Brutality and Foolishness of the Tight Bearing-rein, and the Mechanics of the Bearing-rein 
PI.ATI: 142
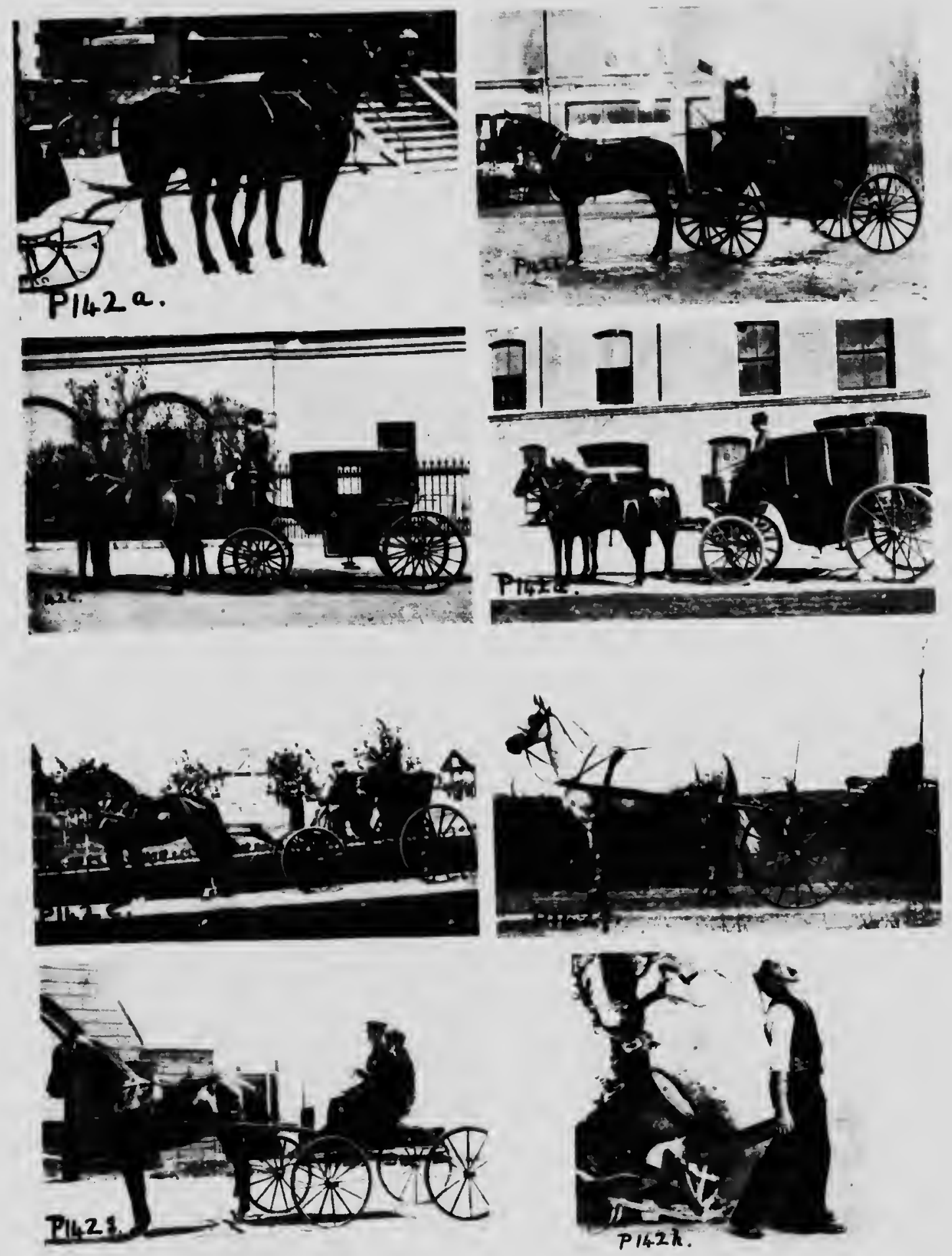

BEARING; REINS

a. Single Action. c, Double Acrion. d, Overhead Cbeck-rein f, Side Check-rein. b, s. The Free Neck Courtesy: a, Mr. C. Bryson, Ottawa. b, Mr. G. Field, Chislehurst, Kent. c. Messrs. Wimbush and Co., London Corguson. Brandon. f, Mr. Gucss, Kingston, Ont 6. Col. Hall. d, Mr. W. I. Elder, Brandon, Man. e, Mr. Wm Ferguson, Brancion. f, Mr. Gucs, Kingson,
Toronto. h, The Toronto Humane Soc. (Mr. R. Craven). Photos, $a, b, d$ to $g$, by the Author. c, Glover 


\section{CHAPTER XIX}

\section{THE USE AND ABUSE OF BEARING-REINS}

875. Тнв American overhead check-rein (P. $141,142 e$ ) is, I consider, a brutal and injurious appliance, and is most certainly in opposition to the correct driving of a properly mouthed horse.

It causes the horse to point his nose, to become ewe-necked, and to hold the bit in the corners of the mouth instead of against the bars; in fact, it ruins the horse's mouth in every way. It is absolutely impossible with its use to mouth a horse; consequently, it is not surprising to find that most buggy horses have no "mouths." Apart from this, the overhead check-rein causes various diseases. (See Sec. 883.)

It was introduced into England, but, in the few instances that were discovered, the users were prosecuted, because the R.S.P.C.A. regarded its use as cruel.

876. The check was invented for the trotter and pacer on the race track, and used with the idea of supporting the horse's forehand while in motion, similar to the way that a flat-race jockey hol's on to his horse's mouth, and also to prevent a horse's head being drawn towards its chest when the driver stops it from "breaking." I have officiated on some of the large race tracks on the American continent, and I have always noticed that the overhead check is removed from the back pad immediately the race is over. It is not used for show or fashion, and the horse is not left standing for hours with his head checked up, as private carriage horses often are.

If, from the commencement of a horse's training, the driver supports its forehand with the reins, and not the overhead check, there is no doubt that the race-check could be dispensed with in many cases. This has been tried by many large racehorse owners in America with very successful results. To tie one part of an animal to another surely cannot have the same effect as that of tying the animal to an outward point, the driver's hands.

877. The side bearing-rein is the only kind that should bo permitted off the race track. (P. 143d.) I am glad to say that even this is rapidly taking the place of the overhead checkrein on the race track. When the side rein is used for ardinary driving it must be used quite loosely (P. $49 b)$, so that the horse may, when going up hill, lower his liead so that the pol: of his head is as low as his withers. When the driver is always sitting behind the horse, as in private carriages, there is, as a rule, no reason at all for using the bearing-rein. On the race track it has been found that several horses have almost suffocated themselves by getting their heads down while in motion; the sheck-rein in these cases has allowed freer use of the horse's lungs and larynx. So in cases like these the rein should be used.

But with ordinary driving horses the driver supports the horse's forehand, if necessary, from his seat. Bad di vers think it horsemanlike to drive with a tight bearing-rein. As a matter of fact, a poor driver is considerably helped with the check-rein, and therefore it would be to his credit to drive without it, because difficult horses may cause an indifferent driver considerable trouble if this mechanical assistance is not used. Most advocates of bearing-reins are poor drivers and have bad "hands"; if they had good hands they would understand the harm bearing-reins generally do.

But with delivery horses, as in P. $49 b$, where the harse is left standing unattended, a loose check-rein is often advisable to prevent the horse from getting his head down and eating grass or snow, and possibly treading on the reins and causing further trouble. The loose checkrein (which must not be the overhead check) will allow the horse full freedom in lowering his head when pulling up hill, but will stop him from getting his head down and getting into trouble.

878. Thousands of horse-power of energy are ijst daily by the use of bearing-reins of various kinds. The London Anti-Bearing-Rein Association has done a great deal of good in stamping out the tight bearing-rein on carriage horses. These are only put on for show and to help the mutton-fisted coachmen. The society has also been the cause of many large horseowning firms in England giving up the use of the bearing-rein or hame-rein. The London omnibus and cab companies never used these appiiances, because they wished to get as much as possible out of their horses, and they well knew that a bearing-rein would hinder them. of course, there are horses that require them loosely for the first day or two of their training, 
and also those that lave become so accustomad to them that at first they will go badly without them.

879. The excuse made by some that the bearing-rein prevents stumbling is marte for this reason: while the neck is held up, the levator humeri muscle-which passes from the top of the head and neck to tlie arm (humerus) above the elbow-causes the arm, or fureleg, to be drawn more forward; this would, therefore, lessen the liability of that leg catching on the ground and causing a stumble. Now, in the case of a horse that carries his head very low, a bearing-rein, to keep his head up a little, may prevent stumbling; that is, provided the horse has been so badly mouthed and placerl that his driver is unable to make him hold his head up by means of the reins. Now, supposing the horse does stumble, as he often does with a tight bearing-rein on-showing that its use is not worth much-the animal cannot recover limself, because he has no lever to bring into immediate action to throw his body up again. If his neck is free, and he stumbles, down goes his heid and up goes his body, a simple law of mechanics brought into play instinctively.

This is too often shown by a checked-up horse invariably breaking his bearing-rein when he stumbles; if he does not break it, he generally falls and remains on the ground a helpless mass. At any rate, he gives himself a painful jerk in the mouth, and the fool of a driver checks him up higher next time. I acknowledge that the levator muscle does draw the leg more forward at every step, if the head is held $u p$, but surely common sense will tell us that the same muscle will thus prevent the leg from completing its full stroke backwards, i.e. underneath the horse. And if a horse, while stepping with long strides, has his forelegs suddenly checked as they reach the back end of their strokes, a tendency either to hinder the animal or even cause him to fall will result.

880. In training a lorse, the better the skill of the trainer the less will he require to use mechanical means to "place the horse correctly." Stumbling is generally the result of the horse not being properly balanced, and this is generally the fault of the trainer. One of the first objects to be aimed at in training a young horse is to place his head. Good hands will do this without useless aids.

Compare the graceful necks in $\mathrm{P} .34 a, b$, $53,142 \mathrm{~g}$ with the necks in P. 14t, 143, otc. The use of the bearing-rein will always tend to harden a horse's mouth. The ignorance of many drivers who use these articles is shown by the way they jerk the horse in the mouth every time they wish to accelerate his speed. How would they like to receive a jerk in the mouth every few minutes, syen when they were doing their best?
881. The hame-rein is used on draught horses (P. 143a), and consists of a short rein similar to that used on a saddle horse. More horse-power is lost by the abuse of this rein than of any other. Its use is similar to the use of the louse side boaring-roin as explained in Sec. 877-that is, to prevent the horse from getting his head down and eating the crop, while reaping, or the grass, etc., when left standing. This is very necessary in the case of the horse in a reaper that is noxt to the uncut oats, to prevent him from nibbling at these all the time. But in most cases the drivers do not use common sense, and, because they have these reins, think they must be used tightly, as in P. $143 b$, thus hindering the horse very greatly and causing much loss of energy, and therefore loss of money from the owner's point of view. These heavy horses must be allowed, while drawing a load up a hill, to lower their heads almost to the ground, otherwise not only are they less able to make progress, but they will be very liable to do serious harm to their backs through having to pull the load without being able to put their weight in the place that mechanics demands it should be. The foolishness of these reins when used tightly cannot be understood by owners of horses, or they would never allow their use. The only way to be sure that they are not used tightly is to forbid their use altogether, except in the rare case of the outside horse in reaping, for example.

In Scotland the hame-rein is practically unknown. P. $143 b$ should be carefully studied by the reader; it is quite clear that the hamerein should never be used unless very loosely, and even then unhooked altogether when ascending a steep hill. If the horse's neck is free, he can pull a greater load, he can pull it faster, he will not fatigue himself, and he will not cause himself physical harm. Is not this economy? Apart from all this is the question of cruelty; but, unfortunately, certain people consider this point last.

882. In Russia, where trotting horses are so popular, the overhead check-rein is not generally userl; and the Russians are the finest horsemen in the world. Why are these reins used so much on the American race track? Neither mechanical contrivances nor fashionable torture can restore lost spirit to a horse ; no remedy exists but careful treatment and proper encouragement. There are few, unfortunately for the horse, that are able to exercise the necessary remedies.

Professors Fleming, Pritchard, Axe, Walley, McCall, Mayer, McGill and others have written condemning any check- or bearing-rein unless very loosely worn (and then their use is unnecessary with most horses). Professor J. A. McBride has written largely on the evil effects tight checks of any kind have on the circulation of the blood. 
883. Discases Caused by Chcck-Rcins.-The diseases caused by tight bearing- and overhead check-reins are so numerous that a volume could be flled in dealing with them. The more common ones are: parotitis, pharyngitis, laryngitis, various diseases of the cesophagus and trachea, diseases of the tongue, teeth and lips, injuries to the gums, roaring, poll evil, fistulous withers, sores under the tail, disorders of the brain, cerebro-spinal meningitis, etc. Over a thousand veterinary surgeons have signed a protest that the tight bearing-rein is painful, useless and cunducive to disease. A book published on this subject in London, containing the names of solve six hundred members of the Royal College of Veterinary Surgeons who denounce the use of the rein except loosely in rare cases, is well worth reading. It contains full particulars of diseases and evils which arise from the use of the bearing-rein, diseases which have been discovered in great measure by years of experience in the post-mortem house and dissecting-room, as well as through connection with a horse insurance company.

884. Thanks to the London Anti-BearingRein Association, the bearing-rein has been discontinued by all the London railway, tramcar, omnibus, cab and brewery companies, and by H.M. mails and parcels post. The hame- or bearirig-rein has been discontinued by 21 London borough councils, 88 county and borough councils of England, and about 120 urban councils.

885. The Mechanics of the Bearing-Rein.In Chapter VII. the abuse of the bit has been discussed, and a few words on the mechanics of the bearing-rein will be suitable here. Fig. 3, P. 141, shows the horse in comfort, with a free neck and reins pulling in a direction as nearly at right angles to the bars of the mouth as possible. Note the arched neck; a horse cannot be driven correctly unless his head is prope:ly placed and neck arched so that the lower jaw will respond to the touch on the reins. Discomfort is opposed to all correct mouthing, horsemanship, humanity and common sense. Many owners of carriages know no better; the coachman is to blame because, in most cases, he says the horses cannot be driven without these reins. With the simple single-pulley bearingrein, as in Fig. 2, P. 141, the force at the back pad is equal to that on the horse's mouth. Let anyone try to unhook the strap at the back pad, anci he will realise the amount of pain the horse suffers from the force of the strap on his mouth. If the horse stumbles, several hundred pounds are momentarily transmitted to the bars of the horse's mouth. The bearing-rein often breaks, and many of these reins will support a steady load of nearly half a ton, so the reader can imagine the pain that the horse has to bear. Fig. 1, P. 141, shaws the modern hearing-rein of the double-pulley ijne. As shown in the diagram (Fig. 7) on the same plate, the force at the bars of the mouth will always be double that at the back pad, neglecting friction, which in this case would increase the force. The pull on the top of the head will be equal to that on this back pad. These two forces will act together on the horse's sensitive mouth. This type of bearing-rein, however loosely worn, should be forbidden by law, because, if the horse stumbles, he receives exaclly double the jerk on his mouth that he would receive were the simple bearing. rein used.

886. Briefly, the use of the bearing-rein should not be allowed except to prevent horses left unattended from getting their heads down and walking on the reins, or to prevent horses in the harvest field from lowering their heads and nibbling at the crop. In these cases it must be only tight enough to prevent the horse from getting his head right down. A moderately tight bearing-rein is therefore never of any use except, perhaps, in the early part of a horse's training, to assist in placing the horse's hoad. The extent to which this is used depends on the ability of the trainer. It is always more to the credit of a driver to drive a horse without a bearing-rein at all; the more troublesome the horse the greater will be the credit due to the driver. Drivers should remember this. Tight bearing-reins, hame-reins, and overhead checkreins are never necessary, with the passible exception of a fairly tight overhead check-rein on the race track on horses that are liable to get their heads down and suffocate themselves when at full speed.

887. Opinions of Others on Bearing-Reins.Dr. Fleming, F.R.C.V.S., C.B., LL.D., etc., late chief veterinarian of the British Army, gave the following reasons why a tight or moderately tight bearing-rein should not be used:

"1. It is an unnecessary expense to purchase it.

" 2. It adds to weight of harness and time required to clean it.

" 3 . It spoils the appearance of the horse, and largely detracts from his free and graceful movements. (See Plates.)

"4. It wearies the head and neck of the horse by the constraint and unnatural position in which they are fixed.

"5. The long, continual pressure on the jaw tends to give the animal a hard mouth, and therefore renders it less obedient to the driver's rein.

"6. It does not prevent stumbling; on the contrary, it predisposes the horse to fall, and with much moro severity than if it were not used.

"7. In hot weather or during extreme exertion it may directly or indirectly produce an attack of apoplexy, probably terminating in death.

"8. In heavy draught, in addition to the 
torture it occasions, it causes a large proportion of the horse's power to be lost, from the animal being unable to get its head and neck down, and thus to throw more of its weight into the collar.

9. The powerful muscles that pull forward the shoulders and, indirectly, the fore-limbs, and which are attached to the head and neck, are by it placed in the least favourable position for exercising their function, so that the lorse's action, as well as its speed and strengtl, are. impaired by this mechanical disadiantage.

"10. It causes pain and distress in breathing.

"11. It tends to distort the upper part of the windpipe and cause roaring.

"12. It frets the temper of nervous and excitable horses, and shortens the lives of all."

888. The late Professor Axe, of the Royal College of Veterinary Surgeons, said: "It is respunsible for poll evil, abscesses, sprung knees, paralysis, and disorders of the brain and muscles."

Wm. Pritchard, President of the Royal College, says: "An act of great cruelty is daily perpetrated, and often by good people who know not what they are loing."

Senator Stanford, a well-known American horseman, some years ago abolished the use of the overhead check-rein on his racehorses.

Jolin Splan, in "Life with the Trotters," says: "A great many people think that a trotting horse should be driven with an over-check. I used to have this opinion, but know now it is a serious mistake. I have seen one or two horses choked to death with their use."

Professor Norton Smith, the noted horse trainer, said: "The overdraw check should be prohibited by law."

Dr. McEachran, F.R.C.V.S., says: "Never cause pain and discomfort by bearing-reins ; the overhead clueck is a disgrace to civilisation."

H. W. Herbert, in "Hints to Horsekeepers," says: "The check-rein or bearing-rein is a mistake in harness invention: it holds the head in an unnatural, ungraceful and uncomfortable position; it gives the mouth a callous cliaracter, and entirely destroys all chance of fine driving."

Sir Arthur Helps said: "Whenever I see a horse suffering from a tight check-rein I know the owner is unobservant, ignorant or cruel."

Charles Sheard, M.D., M.R.C.S., says: "I can testify to the cruel barbarity imposed upon horses by the over-check. It should be condemned by law."

J. Algernon Temple, M.D., says : "The overcheck-rein is both injurious and barbarous, and ought to be prohibited by law."

Wm. Mole, M.R.C.V.S., says: "If horsemen could see and understand the effect of its insidi. ous work on the respiratory organs and glands of the neck, they would cuase lo use them."

Dr. Rutherford, formerly Veterinary Director-
General of Canada, writes: "Except on a few vicious and otherwise uncontrollable horses, and on some which, through bad training, have become habituated to it, I consider it not only useless but cruel."

Dr. James, of Ottawa, writes : "I consider it, when applied tightly, as it usually is, to be most cruel, causing interference with the proper action of the urgans of respiration and locomotion."

Dr. Harris, of Ottawa, says: "They are productive of disease, and greatly hinder horses from employing their full strength."

A Glasgow man was heard to say: "We dinna use them. You winna get half their power with them crimped up so."

The Daily Graphic said: "One of the sights of the City is to see the absence of bearing-reins on the beautiful, long-tailed four-in-hand of the Lord Mayor."

889. New lork Life says: "To the kindhearted amongst horse owners, and those with independence or standing enough to do as they please, a little enlightenment on the subject would do much good. How soon the small fry would follow suit if a score of prominent people would condemn its use!"

The Lancet says: "We are glad to find that this needless and mischievous piece of harness is being discarded by the best drivers. Whether on grounds of policy or of humanity, a system which has conclusively been shown to be injurious, and to produce an ungainly, exhausting and unsafe carriage of the head, is likely to be given up."

The Toronto Mail says: "The Toronto Humane Society is to be congratulated in the effort it has made to abolish this senseless and cruel piece of harness."

The Duchess of Portland, the well-known horsewoman, says: "For some time I have thought the evil consequent upon the abuse of this rein only required to be pointed out to owners of horses to induce them to dispense with them altogether."

E. F. Flower, in "Bits and Bearing-Reins," says: "A liorse in harness without a bearing. rein has free command of its limbs under the direction and control of its driver. If the driver has good hands, the horse yields a prompt and ready obedience, and a most perfect sympathy exists between him and his master. A slip or stumble is not likely to occur, and, should it happen, recovery is easy."

890. Land and Water says: "We do not mean to say that coachmen should be flogged the way they flog their horses, but we do say that if their masters took the trouble to see that they obeyed their orders with regard to the bearingrein, horses would be far less fretted and would last a great deal longer."

The Spectator says: "A large number of solf- 

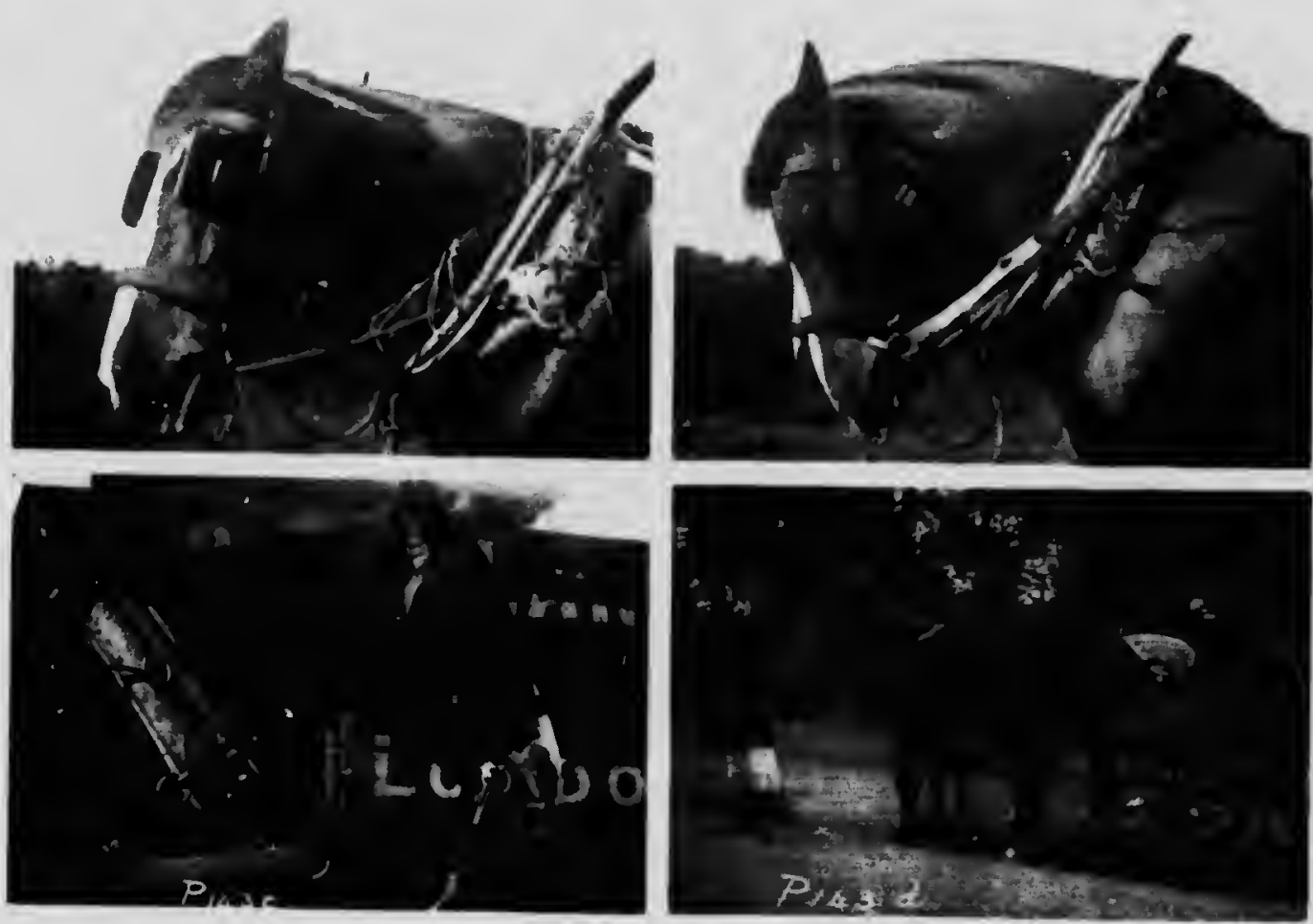

The Bearing Rein uearies our necks - Frets our Tempers Causes Discuse. Do relieve us of it.

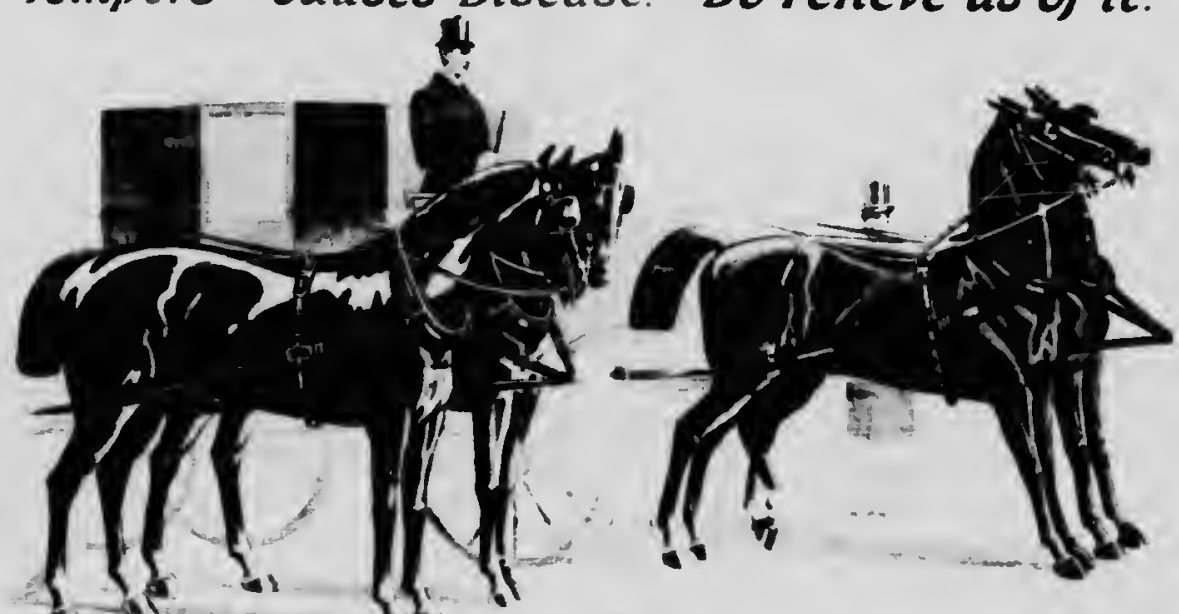

$P / 43$

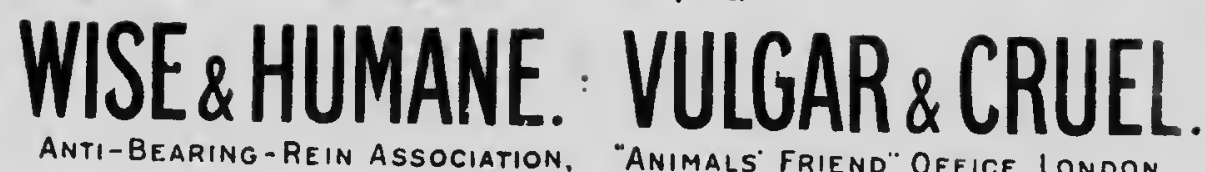

anti-Bearing-Rein association, "Animals" friend" Office. LONdon

BEARING.REINS

a, Hame Rein Loose. b, Hame Rein Tight. c, No Hame Rein, no Blinkers, and a Patent Spring in the Trace :o Absorb Shock. d. "Rest for the Coachman, but not for his Horses." Photos by Mr. C. J. Davies, Lindfield, Sussex. e. One of the Many Excellent Posters of the Anti-Bearing-Rein Association, London 
PLATI: Itt
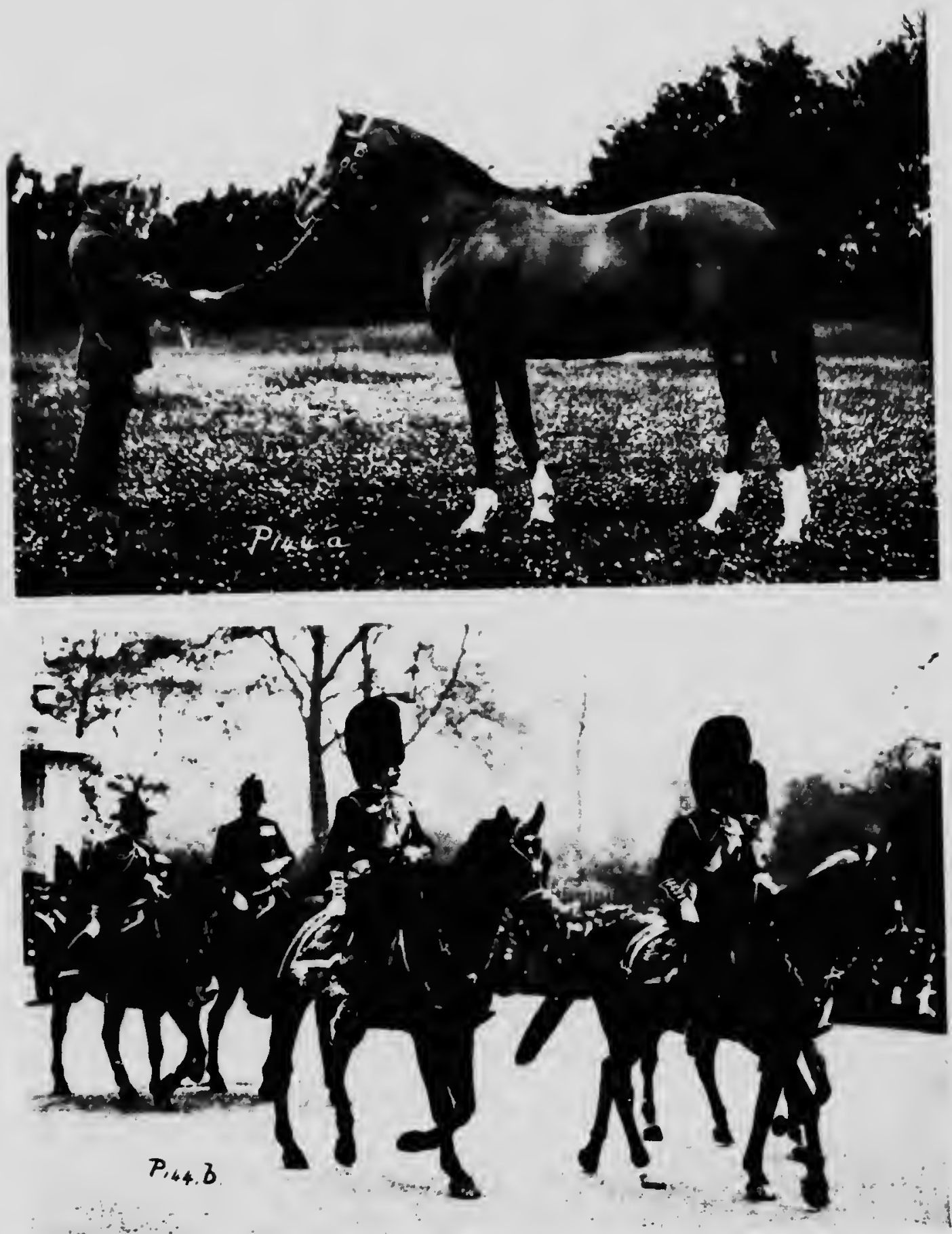

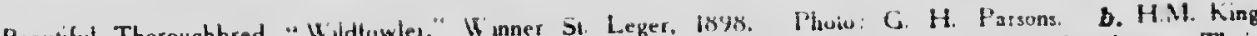
a. The Beautufut Theroughbred "Wilduwlet. George V. and H.R.H. the Duke of Connanght. Inspect the Household Troops 
made rich men, having no knowledge of horses, allow their horses to rest completely in the hands of their coachmen and grooms who use this unnecessary appendage to the detriment and discomfort of the animals."

An American paper says: "There was a long line of carriages in front of the building, and many of the horses were suffering most intensely from tight bearing-reins, while their owners were weeping over the woes of the animals of the poor inside the building."

The Evening Standard says: "Not only are such fashions cruel, but their adoption spoils good horses and indicates that the coachman knows little of his business."

The Times says: "Many are the evils of this bearing-rein, especially when coupled with one or other of the atrocious bits now in use."

891. Lord Portsmouth says: "I never allow bearing-reins in my establishment, nor did my father before me; I am sure they are useless and cruel."

The late Baroness Burdett-Coutts said: "Their use shows a want of information and knowledge of a horse."

The Duke of Westminster said: "I would venture to appeal to owners to give express directions to their coachmen to loosen these bearing-reins."

Lord Leigh, the well-known horseman, writes: "London horses are much to be pitied; the use of the bearing-rein is stupid and cruel."
John Wesley, who read Homer's "Iliad " and "Odyssey" on horseback, stated that the reason his horse never stumbled was because he left the reins hanging loose on the neck.

Sir Francis Head says: "The bearing-rein is an unnecessary, inexcusable and barbarous piece of cruelty. No horse can be properly mouthed or driven unless the rein is extremely loose."

The following is reproduced by kind permission of Mr. J. A. Livingston, proprietor of the Canadian Sportsman, Grimsby, Ontario.

"The most nobie animal in God's creation, The pride and boast of every nation;

From birth to youth, when kindiy reared, He's petted, ioved, by all endeared.

With few exceptions, if truth be told, He's often worth his weight in gold.

From youth to age he'il do his part With ail his might, or break his heart. He's fought our batties, won our race, When kindiy urged will go the pace.

The friend of King, of Prince, or Tsar, But does not like a motor-car.

With champing steel and restiess paw, He waits outside his iordship's door; Eager to start with dashing speed, The cruel whip he does not need.

When kindness greets his ilstening ear, He'il safeiy take you far and near.

With mournful pride and pluming crest, He takes us to our final rest."

EQuUs Est. 


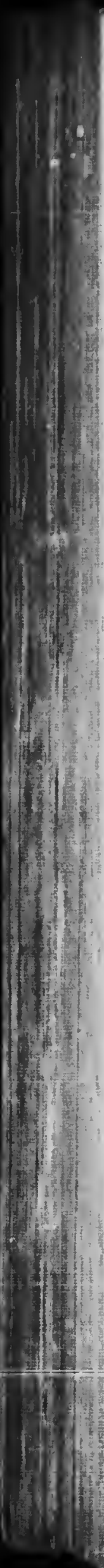




\section{INDEX}

[Numbers with 8. preceding them refer to pholos or drawtings in the plates. Other numbers refer to sections, nol pages.]

\section{$\mathbf{A}$}

Abeott Alkaloidal Co., 750, 76 Abscess, 444 el seq. Abuse of drugs, 531 Achilles, 10

Aeids, 507

Acknowledgments, 5

Across country, 84

Action, $486, \mathrm{P} .43,44$

ireedom of, 84

- of drugs, 507

Acts for profection of anlmals, 718

Aflection, 41, 53

Alrican horses, 25

Are of horse, 471

Alds, $85,86,330$ et seq.

Alr, composition of, 361

space required, 362

Atbumen, 370

Aleohol, action of, 37

Alexander the Great, 11, 28

Alexandra, Qucen, 657

Alfalfa, 137

Alfred the Great, 18

Alimentary canal, 105

Amaurosis, 588

Amble, 341

Ambulance, horse, P. $124 a$

Ameriean breeds, 23

- llquid measure, 519

Antemia, 580

An resthesia, stages of, 738

Anasthetics Act, 752

- cholce of, 738 et seq.

- history ol, 735

_ tocal, 753 et seq.

_- use of, $736 \mathrm{et}$ seq.

An sesthetising, $742 \mathrm{et} \mathrm{seq}$.

- dogs, 751

Anatomy of back and lorehand, 294 el seg.

_ of tall, 631 el seq.

Ancestors of the horse, 32

Aneurism, 577

Angell, Geo. T., 701

Animai Guardian, 709, 712

Anterfor, 403

Anthrax, 624, 795

Antl-bearing-rein Assoclatlon, 884

Antidotes to polsons, 511, 512

Antiphlogistine, 445

Antiseptic drinking troughs, 153 , 390

Antiseptics, 798-80

Antl-tetanic serum, 620

Anothecaries' welght, 521

A pparatus in pharmacy, $\mathbf{5 1 3}$

Appetite, 138

depraved, 541

Approaching a horse, 201

Arab, character of, 28
Arab horses, 21, 22, P. 2, 3, 4, 5, 8, 10 , $11,18,19,92,93$

mares, 26

- origin of, 15

Arabia, earty, 16, 17

Arm, 478

Arresting bleeding, 805

Arteries of tall, 633

Articular rheumatisin, 585

Ascites, 564

Aseptle surgery, 802, 811

Associations, $46,68 \mathrm{el}$ seg.

Assyrians, 9

Asthma, 602

Astride riding, 338 , P. 63

Author's Introduction, $1 \mathrm{el}$ seq.

Avolrdupols weight, 523

Azoturia, 572

BACK, 481

anatomy of, $294 \mathrm{et} s e q$.

conformation of, 302

sprain of, 425

tendons, 419

Backs, sore, 320 el seq.

Bacteria. (See also Microbes)

action of 77

admiesion of, 779,785

stze $0 t, 781$

study of, $778 \mathrm{el}$ seq.

Bacteriology, $769 \mathrm{el}$ seg.

Balting, 496

Balls, 509

Bandages, 217-9, 404, 405

use ol, 219, 404, 405, P. 22e,

Bandacing wounds, 810

Banged talts, P. 28, 29, 79, 87

Banging the tall, 238

Barb, African, 25

Bartey, 115

Baron O'Buchisvle, P. 131a

Bar shoes, 859

Bars of the loot, 829

Barrel, 481

Batton, 253

Baulking, 73

Beans, 118

Bearing-reins, 875 el seq., P. 141-3

- meehanlcs of, 885

$\longrightarrow$ opintons on, $887 \mathrm{el} \mathrm{seq}$. use of, 886

Bedding, 221 el seq. down, 225

Bedouln Arab, 26

Beery, 81, 700

Bend Or, P. 15a

Beringer, 17, 662

Bll agatnst docklng, 695

Bishops, 701, 708
Bites, 455-6

Blls, 286-8, 346-7, P. 33a, 72a

curb, 350 el seq.

Bitting, 70, 89

_, theory ot, 350 et seq

Black Beauty; 723

Btadder diseases, 566 el seq.

Blanketing in the open, 214

Blanikets, 212-4

Bleeding, 805

Blinders, 287

Blinkers, 75, 287

Bilstering, 408-9

Busters, 410

Htood, 358 el seq.

- eirculation, P. 71

_ polsoning, 625,808

- vessets, diseases of, 577

Bloomflet, 662

Boadieea, 15

Bolting food, 145

Bone di.cases, 426 et seq.

- histology of, 401 et seg.

Bonnic Buchityvie, P. $123 b$

Bot $\mathrm{Ay}, 638$

Box-stalis, 385

Brain, 37, 729

Bran, 121

Breast etoths, 285

B eollars, 279

Breath, 818

Breathing, 786

Bridle tameness, 390

Bridles, 286

Bridling, 70, 89

Brittle teet, 869

Broken wind, 604

Bronchlits, 605

Browbands, 280

Brulses, 446

Brushes, use of, 195-7

Brushing, 447

mines and tatl, 201,7P. 22

Buceplıatus, 11

Buik In lood, 141

Butl fighting, 712

Bullet ptaces, P. 138a

Burns, 454

Bushel, the, 113

\section{c}

Cesar, Julius, 14

Casaresco, 41

Callfornia penal code, 715

Callgula, P.58

Calkins, 848

Camp, horses In, 179

Camphor liniment, 404

Canadian breeds, 25 
[Numbers wilh P. preceding them reler to photos or drawings in the plotes. Other numbers refer fo seetlons, not pages.]

Conodion Cilizen, 690

Cancer, 825

Canker, 872

Cannon, 470

Cannula, 301

Canter, 341 ef seg.

Cappadocian, 26

Captive ani.iais, 899

Carbolic, 81)1

Cardiac cycle, 460

Care of horse on march, 173

- of saddilery and harness, $202-3$

- while driving, 261-2

Caressing, 67

Carron oil, 454, 309

Carrots, 122

Catheter, passing of, $5 / 2$

Cats, 820

Cavolry Journal, 689

Cavesson, 1'. 31

Cellings, 372

Ceil, animal, 104

Celts, 17

Cerebro-spinal-menlngitis, 623

Chaff, 111

Character, acquired, it

Chargers, P. 59

Check ligament, sprain of, 420

Check-reIns, 875, P. 141-2

Chestnuts, 191

Chemical composition of animal body, 104

Chemicals, 507

Chicago papers, 703-4

Chinese, 692

- horses, 28

Chloroform, 739, 767

- recovery from, 747-9

Chop, 126, 142

Christian duty, 725, Chap. XIV.

Chrince, 2, 700-1

Circulatory system, 358, P. 71

Circus horse, 89, 91

Clcaning grain, 126

- wounds, 805-6

Cleanliness, 825

Cleveland Bays, P. 46, 47, 94

Clicking, 860

Climate, suitablilty of, 31

Clipping horses, 231 et seg. time for, 236

- poodles, 903

Clips on shors, 846

Clothlng, 211

Clover, 136

Clydesdales, P. 123, 130.2, 140

Coach driving, 265

Coaches, 21

Coach-houses, 375

Coaching, 674

Coat, horse's, 188, 210

signs, 57

Cocalne, 759

Cold, 600

- blts, 350

Colic and enteritis, 352

-, consilpation, 555

- due to worms, 556 et seq.

- tiatulent, 554

-

Colics, 551

Collar Injuries, 270

Collars, 273-5

-, breast, 279

Colour, 487

Combs, curry, P. 24 a

Conipany, 103

Composition of anlmal body, 104
Composition of vegetable food, 107

Conipounde, 008

Concelt, is

Concrete, 376

Conditlon, 158 el seq.

, bad, 148

- powders and foods, 163, 301

Couformation, 475 et seg., I', 05-101

- of back, 302

of foot, 830,859

of saddle horse, 345

Congestion of lungs, 606

Conjunctivitis, 586

Connaught, Duke of, 651, 707, P. 14a

Consumption. (See Tuberculosis)

Contaglous discrases, 771, Chap. IX.

Contracted heels, 802

Contusions, 446

Cooking food, 106

Copylng others, 54

Corn, Indian, 114

Corns, 863

Coronet, Inflammation of, 808

Cough, 600

Courageousness, 54

Cowards, 59

Cracked heels, 592

Creolln, 799-800

Crib-blting, 465

Crime of dockIng, 651 \& seg.

Crooked tails, stralghtening, 650

Cropping ears, 22, 802

Cruelty, 2, 3, 18, 21, 97

Crue of horse-dealers, 98

Croup, 482

Crupper, 281

Cups of tecth, table of, 473

Curb, 422

- chain, 286, 353

Curry combs, P. 24 a

Cyanosis, 576

Cyllin, 799-800

Cystitis, 566

\section{D}

DAMP, 379

Dan Putch, P. 9a

Dark stables, 75

Darley Arabian, 21

Deslers, 98

Deatli Irom an aesthetlcs, 739, 749

Decropit horse tramc, 711

Dermis, 188

Dest ruction, humane, 765

Detroit papars, 704

Diabetes insipidus, 691

- mellitus, 570

Diarrhoea, 549

Dictlonary of terms, 530

Diet when sprained, 412

Digestive organs, 103

- process, 104

Discipline, 82.

Discase, 103

$\longrightarrow$, production of, 780,817 spread of, hy flies, 640 theory of, 769 et seg.

Diseases caused by bacteria, 784

- of hoot, 860 et seq.

of niane and tall, 245

of skin, 245

- organic or general, 537

Disinfeetants, 798

Disloeations, 678

Dismounted training, 85
Dlsobedlence, 38, 62

Disposition, 8

Distal, 403

Distemper, 612

1Meuria, 668

Doclitty, 54

Dock, 483

Di, length of, P. 29

Docking, 651 ef seq.

- after-efiets, 728

- and nieking, 648 ef 160

- Bill in House, 095

- exeuses, 665 el seg.

- , foliy of, 092

horses, 22, Chap. XIII., P. 105. 123

- Important points agalnst, 600

operation, 660

- opinions, Chap. XIV.

- prevention of, 684

- reasons for, 652

_ummary of, 607

_. will such be punished 9694

Doctoring horses, 711-?

Dog. The under, 711

Dogs, 820

-, an esthetletns, 751

Dongoia, 25

Doors, 374

Doping horses, 711-2

Dorsal, 403

Dosage, 506

Doses, 506-8

Drainage, $377-8$

Drains, 226

Draught, theory of, 247, P. 32

Drenching, 497

Dressing wounds, 805 el seq.

Drink, 823

Drinking fountalns, 152-3

Driving, 261 et seq., 877, 878

exeuses for docking, 668-73

reins, $P .33$

Dropsy, 564

Drugs, 507

- abuse of, 531

-, administering, 498

- important, to be kept, 329

- Ineompatibility of, 510

- methods of Introducing, 498

- notes on use of, 494-5

- strength of, 508

Dry measure 113, 52

Drying a horke, 196, 220

Duke of Connaught, 651, 707, P. $14 \mathrm{a}$

Dumb-jockey, 290-1

Dump cart, 272, 283

Dumping feet, 834

Dung, 108, 369

-, welght of, per dlem, 224

Dust in hay, 133

Duty, Christian, 725, Chap. XIV.

\section{$\mathbf{3}$}

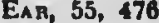

Ears, hair in, 235

Eczema, 245, 590-1

Education, humane, 707 a seq.

- of ehildren, 707-8

Edward, King, 689

Eel. The, P.40b

Egyptian horses, 25

Eibow, capped, 443

Electric shocis, 457 
INumbers with P. preceding them refer to photos of drawings th the plates. Other numbers refer to wettons, not pages.)

Eiectrocution, 768

Electuary, 500

Limphysema, 601

Enemas, 400

Enclishi breeds, 23

Entertic, 550, 532

Entralning horves, 181

Epldermis, 180

Epllepsy, 614

Ergot, 116

Ergot, 191

Eriklne, Lord, 708

Eruption of tecth, 471

Erythrocytes, 781

Elf:cr, 730

- spray, 755 el seg.

Etymology, 33

Eucalyptus oll, 445

Evane, T. C., 693, 737, 790-1

Evener, 256

Examination for lamences, 414 el seq.

of horse, structural, 470

Exerclae, 58, 160, 165, 369

- bandages for, 169

- hurrytng at, 170

Exfollation of skin and hals, 193

External applicatlons, 456

Extace, 403

Extingulsher, Are, 383

Extracts, fluid, 307

Eye, 56, 476

- discases, 580 el seg. fringes, 397, P. 104

Feces, 369

Faith, 491

False cantering, 344

quarter, 860

Farcy, 613

Farm L1/e, 703

Fashions, 713

Faligue, 168

Faults in shocing, 85

Fear, 75 el seq.

prevention of, 78,86 signs of 77

Feathering, 851

Feed, proportions of, $14 t$

Feeding, 121 el seq., 728

- after clipping, 23

_- after foailing, 146

- on board ship, 183

- on the march, 174, 175

-

-, princlples of, 142-4, 160

-

Feet, brtttle, 869

- Paulty, 859

- tever in, 873

- stopping the, 227

Fermentation, 772

Fetlock, 479

aprain, 418

Fever, mud, 593

Flefd, 703

Figures, weights, and measures, 529

Filled legs, 209

Filis, 40, 41

Fineneas of mouth, 350

Finfand horses, 30

Fire brigades, P. 55, 56

extinguishers, 38

precautions, 182, 226, 383

20
Firing, 408, 411, 757 Firt continent to produce horse,

Fistulous wlthers, 300, 453

Fitzwysram, Gen, Sir F., 725

Feming, Dr., 601-2, 688, 887

Femish horses, 30

Fies, 636-8, 656

destruction of, 610

Floailing teeth, 407

Floors, 376

Fluid exiracts, 507

Fiy nets, 612, P. 10 papers, 645 screens, 360 sheets, P. 104

whisks, 397, 614, P. 104

Foaling fecding after, 140

Foctal ilfe, 403

Food, bulk in, 141

, composition of, 1110

- digestiblilty of, 108

- functions of, 107

cuitability of, 108

Foot, care of, 200, 370

- dressing. 228

- mechanisin of, 833

shape of, 480, 836,839,859, P. 139

- structure of, 826

Forage, stowage of 149

Forearm, 479

Forelock, 237, 043

Forgind, 860)

Formulie of drugs and chemicals, 507

Found :ions, 379

Fountains, Jrinking, 152, 153

Four-in-hand driving, 265

Fours-In-hand, P. 34-36, 38, 40, 120

Fowler, Prol., 648

Fracture of foot bones, 481

- of leg bones, 46i)-1

- of peivis, 162

of ribs, 402 of tali, 462 phystology of, 459

Fract ures, 458 el seq.

Freedom of action, 84

French Canadians, $7 t 0$

- horses, 30

Frog of the foot, 480,830

Frost bites, 194, 455

Frozen bils, 356

Fuliering, 840

\section{G}

GAl s.08, 341 el seq.

Galls, care of, 323

Gaskin, 484

Gastrtis, 545

Gauls, 9

Geat for training, 290.1

Genital organs, discascs of, 627 et seg.

Geology of horse, 32

George, King, 657, 689, P. 23, 78

German horses, 29

Germicides, 798-9

Gifts, $710,720,725$

Girthing up, 318, 322

Girths, 318, 322

Glanders, 613

Glands of skin, 188

Giass cye, 58.

Glossary of terms, 530

Gloswtis, 538
Giycoron, $10 t$

Geaction In training, 83

Grain menoure, 521

Grant, Generai, 269

Graplice, 689, 703-4

Grasees, 135

Grusing. 120

Grease, 107, 502

Greeks, 9, 14

Green lood, 128

Greylight, P. 21 .

Groom, tinie 10,205

Grooming, 186 ef seq., 195

$\rightarrow$ examining for good, 206 goorl, 168

Groums, 2197

Gruel, 125

Grunt, 56

Gulfet, dlacascs of, $5+3$

H

IfAotTs, 61, 00

Hackncy, the, 681, 603, P. 48, 105. 112,113

unmutilated, 704, P. 48

Hemapiobinuria, 572

IIemophllla. 570

Hemorrhage, 805

Hair, 190

Halliburton, 167

Halters, 289

Halls, 173

Hame rein, 880

Hames, 275

Hands, 328, 330, 318

Haricy's Test, 550

Harness, care of, 292-3

- fitting of, 281 horses, 271, P. 34-40

Injurics, 28t rooms, 375

Harneasing up, 70, 283, 280

Harris, 698, 699, 710

Hartzman, 662

Haunch, 482

Hay, 131 el seq. and straw welghts, 525

, composition of, 132

- examination of, 13.

- saviug of, 133

Hayes, Caplain, 408, 699-700

Hayes' bandages, P. 22c, ?

Head, 476

- placing of, 330, 347, 476

Healing wounds, 804

Heaith, 103

Hearing, 39

Heart, 358 el seq

- beats, 533

- diseases of, 573 el seg.

Heat, aclion of, on coat, 210

Heating, 382

Heaves, 604

Heels, 187

- contracted, 92

-, expansion of, 853

Hepatilis, 560

Herodotus, 9

Hildebound, 589

Find fool, 485

Hund-legs, $484-5$

Hints on drifing, $261 \mathrm{el}$ seq.

Histology of animal ecll, 104

History, 8 el seq.

- of an wisthetics, 735

Hock, 485 


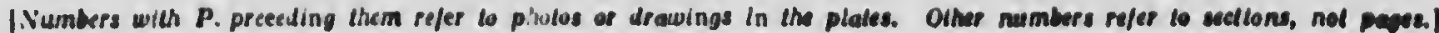

Hock, cappetl, 142

- strung, 4:3

Iogkilnk mancs, 241, 643

Homer, 8

Ilomaropithy, 8tì

Hinod lor malle, P. 22b

llool. (See lioot)

- illicases of, 860

- spilt, 805

- st ructure ol, $820 \mathrm{ll} \mathrm{seq.}$

Horso at liberty, ?2

L car, palace, P. 89b

- native of forist, 22 paraules, 711

shows, 670-8n, 685, 702 "syphiliss" 62.7

llorse's prayer, 7:1

welkli, distribution of, 303

Jlorseback cxercise, 815

Itorsemastersilip, 177

Hospltal for horses, flrat, 12

llouseliold nicisures, 5211

llumane idestruction, 765, 813 el scq.

_- plender, 698

- trinling. 81

Huntcrs, ?.66-68,76,77

Hygiene, 220

IIjpodermic injections, 493, 408, P 137,138

\section{l}

ICFIAND horscs, 30

IcenI, 15

Ieterue 559

Ignoralice, our, 65

Imaqination, 42, 58

Iminunity, 788-9

Imperial measure, 517

Improviments 10 old slables, 385

Impuritles, 368

Incompatibility of Irugs, 310

Indian horses, 28

Indications, 85-6, 303 ef seo., 337

Indigestion, acutc, 347

- ch ronle, 548

Inferior suriace, 403

Infucnza, 611

Inhalation, 493

Injuries, rcporting, 102

Instinct, 52

Intelligence, 40-1

Intelli,

International horse show, 697

Intestinis, Inflammation of, 530 ef seq.

- of horse, 515

Int ratracheal Injections, 493

Int rilvenous injectlons, 493

Inunctlon, 493,500

Italian horses, 29

12al, 799.800

\section{$J$}

JAMES, Dr., 699,888

Jaundice, 5509

Jealous, 53

Jeves' nuld, 799

Jockcy, dumb, 290-1

Joc Patchen, P. 19 I

Jolnt III, $6 \pm 6$

Johtnts, 399

- open, 4j1 folnts, stin, tit1

Jugular veln, l'. 137

Jumpink, Jad el scq., P. 7Ja, 01a

$\mathbf{K}$

lilcxive, an, thif

Klilines, dlswares of, 565, 570-1

lilldiare, P. ill.t

Kinduses, 722

Kilun, the, $657,689,713,717$, P. 23a, 78 .

linketl Lills, st r.lightening, 650

Kince, liy

Knees, liroken, 4:m

Kulghit's sloge nilliv, 8 t3

lioclidunt Arall, 2to

\section{L}

1.Ames ritling, 338-40

L.nHeness, $396 \mathrm{cl}$ sep. 414 el seq.

- and exerclac, 114 and shoelnk, 115 Ictection of 114 et ane

Laminitis, acute. 873

- chronle, 874

L.impas, 617

Lateral carttages, 832

Leatling. 84

- Into stabic, 230

Learning, rate ol, J

Legs, care of, 209

L., use ol, JJ't el seq.

Lending horses, 172

l.cssons, lengtb of, 84

l.ethul clianiber, 768

l.eucenul:1, 381

Ley hay, 131

Liberty, at, 92

Libyans, 8

Lder, 597

Leking onc's fincers, 825

ligaments of till. 6j?

i.lgamentum nuche, 298, 432

LIght, 371

- action ol, on coat, 210

I. Lghiluing, 457

Lime-water, 309

L. luard, Sird, 663

Linear mensurc, 527

Liniment, mercury-lodide, 112

l.Iniments, 407,519

Linsecil, 119

- mash, 120

- tia, 120

Lister, Lori, 802

Llver, Illscascs of, 559 et seq.

Loads, 259

Local an westhesla 753

Loekjaw, 619

Loft, the, 391

Loinciollis, 215, P. 234

Loins, 481

Lonflellow, 727

Lonse-l, ox's, 385

Lord Brysoll, 1', 19d

Lotions, 5019

Lounging, 82-3

Love, 41, 53, 722

Lucerne, 137

Lung dliscascs, 604 el seq.

Lunurmur, $5: 34$

Lungs, the, $358 \mathrm{cl}$ seq.

Littifythaftis, 582

Lysol, 799-800
$M$

Macedonians, 0

Malze, 114

Mlujesile, P.43i

Malinlle un coil, 627

Malnrlit, (b) (1)

Malformations, P. 77.0

Maliein test, 813

Matlenders, 592

Mune and tnll cezema, 30 :

- -, brualing. P. 22e

- cire of, 1980

Ilscrases 215

licioll, P. 220

_, re-krowink, 212

Nanc 3 , 211, P. Bil

- looksing, 613

t rimming. 643

Mange, 245, 505

Muruer, 380

Mingers, cleaning, 140

Murch, care of horse, on returm, 170

-, catre on, 173

Mare, cestrum of, 630

Marriage, 821

Nirtinguice, 35t-5

Mash, bran, $12 !$

M, linsced, 120

Massacliusetts S.P.C.A., 716

Missงage, 193, 2110, 217-0, 104, 403

Mcliwell, 90

Mc Glili fiy, 81, 700

Me:ils, lingth of, 14t

Mirat, 108

Measure, dry, 113

Measures, 317 el seg.

- Aulil, 506

Mechanics of bearing-rcin, 885

- of draught, $247 \mathrm{el}$ seq.

Mechanism of foot, 833

Mcilicine on board sliph 183

Midicines, 507

- use of 490

Melinosls, 191, 618

Megrins, 614

Ilembrana nictitans, 535

Memory, 50, 51

Meningitis, 623

Mercury, 700-800

Merey, 721

Mlctchnlkoft, 790

Metric system, 520

Metritis, 628

Mlcrobes. (Sce also Bacteria)

- - admission of, 779, 785, 792

, lcstruction of 793 et 309 - where they are found, 796-?

Nilcro-organisms, 777

Iilitary horacs, P. 70, 80

- trilning, 824

Nilk, 819

Mind, 40

Mites, 508

Molisses, 124

Montreal S.P.C.A., 716

Mosquitoes, 639

Motion, excitablitty to, 43

Mountcbank, the, 91

slounted warrior, 1

Mout 1,476

- Aneness of, 350

- lecth in the, 472

Mouthing, 326

Mlud fever, 593

Muics, 177

Mitristur of lungs, 534

Muscle, 166, 398 


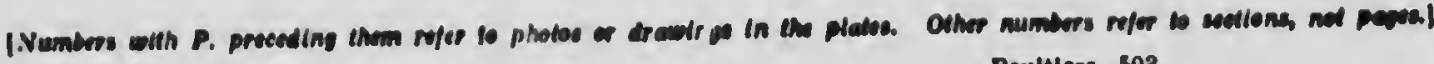

Nuscle, hidtolons of, 398

Muscles of tail, 632

Muceular degeneration, $\mathbf{1 M}$

Musie, 88

Mustard, 303

Murzie of horee, 39

Murzles, 805 el seq.

\section{N}

NaOAXa, 616, 78?

Nall holes, 844-5

Nalis, shoeing, 837, 842-3, P. 130

Nasal ulsenses, 601

Navel ill, 620

Navicuiar diseane, 435

Neck, 477

Necrouts, 290

Netah, 30

Nephritls, acute, 565

- chronle, 563

Nerve tlusuc, histology of, 733 at seg.

Nerves, P. 137, 130

Nerves, tail, 633

Nerving, 758

Nervous syotem, 728 et $\mathrm{kg}$

Nets, $n y, 6 t^{2}$

Neurcctomy, 738

Newcastie, Duke of, 20

Newmarket, 20

New York pilpers, 703-5

Nicklng, 610

- and docklng, 646 el 24.

Nictltatine membrane, 535

Nitre (saltpetre), 18?

Noguschi, $79 t$

Norman horses, 18

Normans, 18

Norwegian liorses, 30

Nosebags, 145

Noseband, 280

Nost rils, 476

Numnahs, 3n8-9

\section{o}

Oatmeal, 125

Oats, 109

$$
\text { crushed, } 112
$$

vicfects in, 110

measuring, 113

Obedience, 60 el seq.

Observation, horse's power of, 47

Obstinaey, 54

Esophagus, diseasea of, 343

Estrum of mare, 630

Ointments, 509

Oid horses, 720

- receipts, 492

stables, 385

Omphallt1s, 626

Open foints, 451

Operating, aseptic, 811

Operation of docking, 660

Ophthalmia, 586-7

Opinions on bearing-reins, 887 et 3 eq.

On docking, Chap. XIY.

Ottawa papers, 703

Our Dumb Animals, 691, 704-5, 722

Outward slgns, 55-7

Over-eating, 139

Overlogdine. $2 \mathrm{fO}$

Overreach, 4.49
Paces of the horw, 341, P. 75

Pacing, 341

- horves, P. On, ste, 48

Pack onimals, 177

Palnt, 336

Palace horee car, 395, D. 290

Pannets, 300-10

Panniculus arnosue, 035

Papers, ny, 345

Paralyals, 621

Parasites, 775

Parauttie :' In disececes, 895

Paring the foot, 835

Parotitis, 540

Partitions, stall, 387-8

Parturtion, 020

Pastern, 179

Pasteur, 773, 802

Pasture, 130

Patelia, 184

Dinlocation of, 405

Patent medkiner, 49

Pathogenic nilerobes, 776

Pavements, 853

Payne, Harry, 699, 713

Peas, 118

Peat moss, 223

Peliall's, Sir Henry, stable, 305, P. 2

Pelvls, 482

Penal Code, 713

penis, washing of, 205

Percherons P. 81, 83, 123, 126

Percivall, 396, 662

Jerforans and perforatus teadons, 419

Period of presnancy, 620

Periosteuni, 299, 01

Feritonitis, 363

Perslan horees, 28

Persimmon, P. 101, 930

Permiration, 180-8

peter Shales, P. 40h

Pharmacopoia, 507

notes on, 505

Pharyn pitis 542

Photograpbing horses, 474

Physiotonical action of friction, 438

action of purgatives, 514

Plca, 541

PicketInk, 170

Pletro, 92

Pink eyc, 611

Pithing, 766

Plague, horse, 624

PluitIng, 243-4, 455

points to be remembered, 244

Platis, P. 26, 27, 30, 51, 117

Piuns of stables, P. 84-7

Plantar cushion, 831

II:aster of paris, 460

Plicasure, 47

Plcurlsy, 608

Pliny, 15

Plutarch, 11

Pneumonla, 607

Polsoned wounds, 808

Polsoning, blood, 625, 808

Polsons and their antidotes, 511-2, 783

- In the system, 167-8

Poles, 255, 258

Poll Evil, 452

Polo ponies 659, P. 21, 61, 62

Polyurea, 571

,rt. the, 352

osition of welght of horse, 303

Postcrior, 403

Potatoes, 122
Poultlees, 503

Prayer, the horse's 724

Precaution: acalnat Are, Jto

Prexnancy, 620

Pr nikes, shoe, 856

Prensure bandages, 404 at ap.

- saddle, 304

$\longrightarrow$ teut for, 314

Prevention of dockint. 024

Pricts microbic

Pritchurd, Prol., 700

Pritchird, Prot. 170

Protection of Animals Act, 718

Proteln, 104

Protoplasm, 774

Proximal 403

Prusule neld, 707

Psycholocy, 37 el seq.

Ptyallerts, 539

Pufled lexs, 208

Pullerw, 260, 348

Pulae, 533

Punilce, 874

Punisioment, 71, 336-7

- and fear, 73-4

Purgatlves, 514 ef $3 e 9$

Py emia, 625

\section{Q}

OUACK mediclnes, 491

Uuarter, false, 866

Quittor, 430

n

RAcr. clothing, P. 25

Heclne, eariy, 20

$\longrightarrow$ iirst, 9, 15, 17, 18

A:irey, 81

H.C.D. horses, P.79, 80

R.(i.H.A. hories, P. 79

Reactions, 64 ef seq.

Rearing, 333

Recelpts, old, 492

Record paces, $\mathbf{9 4}$

Reetal injections, 190

Reducine, 694, 706

Reflex action, 728

Befractory, 50

Refusers, treatment of, 332

Relis, eheck or bearing, 875 ate method of holdlng, 264, P. 33, 72

- under tall, 270

- - use of, 262, 329

Removing saddle, ¿76

- shoes, 847

Respiration, 534

Resplratlons per minute, $\mathbf{5 3 4}$

Resplratory system, 361 et seq.

Rest, traet,

- when spralned, 412

Rheumatism, 370, 583-5

HIbs, 296, 481

Rlee, 123

Rider and Drlver, 691

Rides, long distance, 171

Ridlng, 326 et seq., 336 et seq., 346, 816

- astride, 338 et seq astride, 338 et seq with two hands, 331

Ringbone, 431

Ringtorm, 536 
[Numbers with $P$. preeding them refer to photos or drawings in the plates. Other numbers refer to sections, not pages.]

Roan Barberry, 19

Roaring, 603

Robe on horse, P. 24b

Rock salt, 126

Rolleston, Sir John, 695

Roliers, 214

Rolling, 220

Romans, 16

Roofs, 372

Roughing shocs, 852

Rowley, 700, 723

Kubbed talls, 246

Ruby R., P. 38a

Rugs, 212-4

Runaways, 266, 349

Kunning water, 389

Rupture of heart, 576

- of liver, 561

- of stomach, 546

Kuskin, 726

Russian horsemanshlp, 882

Rutherlord, 689

Rye, 116

\section{s}

SADnLE flting, 297 el seg., 314

- galis, 294, 320-1, 323

- horse, 345

- position of, 317

removing, $t 76$

Saddiery, care of, 292-3

Saddies, P. 74

$\longrightarrow$, first, 16

_... storing of, 306

_., structures of, 307

Saddiling, 304-6, 3 t9

Sailne solution, normal, 628

Salienders, 592

Salt, 126

Saitpetre (nitre), 162

Sandcrack, 864

Sunfoln, 137

Sanitary paint, 380

Sanitas, 799-800

Sanitation, 226, 55j el seq.

- In camp, 180

_ - on board ship and train, 182

Sapropliytes, 775

Savigea Prof. Alired, 702

Schooing, 84

Scratches, 197, 592

Screens, fly, 366

Scytblans, 11

Sea, horses at, 181 et seq.

Seating, 839

Seats, 324 el seq.

Seedy toe, 867

Senses, 38

Sensibility, degrees of, 76

Septic amia, 625, 808

Serous sweilings, 441

Serum, anti-tetanie, 620

Sesamoid bones, 479

Sewing wounds, 809

Sexual intercourse, 821

Shakespeare, 699, 721

Sharpening shoes, 852

Sheath, 483

- washing, 205

Sheets, $2 t 1$

Shins, sore, 433

Ship, horses on hoard, 181 e! seq.

Shires, P. 105, 115, 134, 136

Shocks, 457

Shoe fitting, 841
Shoe material, 840

putting on, 845

Shoeing fauits, 854

- pricks, 855-6

- principies of, 834 el $\mathrm{seq}$.

lime for, 838

- tools, 857-8

Shocs, P. 138

- and lameness, 415

-

,-- before riding, 331

- first, 12,17

__- Ior winter, 852, P. 138

$\longrightarrow$, wear of, 173

Shooting a borse, 765

Shortage of war borses, 19

Shoulder, 273, 478

- sprain, 424

Shouiders, sore, 268

Shouting, 48

Showing a horse, 230

Shytng, 66, 262

Side bone, 432

Side-saddie riding, 338-41

Siduey, 662

Six-in-hand, P. 38c, 136 a

Skin, 188

- alseases, 245, 589, 595

thlekness of, 74

Skuthorp, Prof., 81

Silngs, 394

Slobbering, 539

Sneliing, 39

Smith, Captain, 689

Smoking, 823

- in stables, 226, 383

Snake bites, 456

Snapping, 465

Soclability, 53

Soll, $379,-07$

Sole of lioof, 828

Sore backs, 320 el seq.

- shoulders, 437

- shins, 433

- tiuroat, 597

Spanish Armada horses, 20

horses, 18, 19, 25, 29

Spavin, bog, 438

- bone, $420-30$

Spearmint, P. 15b

Speedy cut, 448

Spleen, diseases of, 562

Splenitis, 562

Splint, 427-8

Sporting and Dramatic News, 705

Sprains, 397, 404, 417

- treatment for, 421

Spread of disease by flies, $646^{\circ}$

Sprung-hoek, 423

Spurs, first, 14

- use of, $336-7$

Stable logs and ehains, $392-3$

— plans, F. 84-87

- vices, 464

Stabies, P. 88, 89

Stage coaches, 21

Staggers, 6 t4

Stains, removal of, 202

Stall, In the, 101

Stalls, $385,387-8$

Standard welghts, $518 \mathrm{el}$ seg.

Stephen, L., P. $14 \mathrm{~b}$

Stimulants, external, 407

Stings, 456

Stomach, diseases of, 544 et seq

Stomatitis, 537

Stopping the feet, 227

Stowage of forage, 149
Straightening crooked talls, 650

Strains, 397

Strangies, 612

Straw, 222

Streets, 853

Strength of drugs, 50 \&

Stringhalt, 622

Structural examination of bosse, 476

Strychnine, 456, 768, 783

Stumbling, 862, 879

Subcutaneous inlection, 493

Submaxiliary artery, P. 137

Suflolk Punches, P. 127-129, 131, 132 135

Sugar, 124

- tests, 570

Summary of docking, 697

Sunstroke, 615

Superior surface, 403

Superlority, 58

Surgery, iscplic, 802 el seq., 811

Surglcal diseasts, 117 et seq.

Suspensory ligament sprains, 417

Sutures, 806

Swedishi horses, 30

Swimning horses, 185, P. 73c

Sympathetie system, 732

Synonyms of drugs, 507

Synovial eniargements, 437

\section{$\mathbf{T}$}

TABLEs of teeth, 471.2

Tacitus, 15

Tactlie lialrs, 235

Tall, bangling the, 239

--, eare of, t98-9

- Uiseases, 245

- cczema, 591

- - guard, 216

- plaiting the, 243

- signs, 57

-_, straightening the, 650,759

_-, the, 483 el seq., 631

_-, thinning the, 240,658

_- tralning horse to aliow reins under

-

_. value of, 687

Tails, rubbed, 246

"Talking" horses, 86

Tandem driving. 265

Tartary horses, 24

Tasting, 39

Tea, Inseed, 120

Teasing, 90

Teeth, examining, 468

- -, noating, 467

- neglected, symptoms of, 467

- number of 469

- perlod of eruption, 47

- , the, 466 et seq.

Temperature, 382,532

Tendons, 479

-, back, 418

Terry, 702

Test for bladebone and loin pressure. $314-5$

-_, Hariey's, 558

- - mallein, 613

- sugar, 570

- Trommer's, 570

- tuberculin, 610

Tetanus, $619,795,808$

Theory of bilting, 350

Therapeutical ciassiffeation of drugs. 530 
[Numbers with $P$. preceding them refer io phoios or drawings in the piaies. Oiher nurabers refer to seetions, noi pages.]

Thermometer, 532

Thlgh, 484

The straps, 213-14

Thinness, 148

Thinning the tail, 240,658

Thoroughbred, the, 25, P. 8, 12-17, 19 , 20

Thoroughpin, 439

Throat, sore, 590

Throat-lash, 286

Thrombosis, 578

Throwing a horse, 413

Thrush, 871

Thucyulides, 12

Ticks, 598

Tiles, 376

Times, The, 701, 705, 894

Tinctures, 507

Tips of shocs, 849

Tobacco, 823

Tongues. (See Poles)

Tonics, 509

Toois, grooming, 208 shoeing, 857-8

Tooth, the, $169-70$

Toronto, Bishop of, 701

- Humane Soclety, P. 99

papers, 703-5

Tozer, Basil, 689, 702

Traces, 248, 256, 282

Tracheotomy, 536

Train, horses on, 181

Trainer, character of, 80

Training, advanced, 93-4

- gear, 290-1 horse to allow rein under tali,

_. principles ot, 79 et seg., 336, 346

Transport, 181

Treads, 870

Treatment of sprains, 421

Trees, whinle, 256

Trembling, 57

Trieks, 94

Trimming, 234-5

Trist, Sidney, 701, 711

Trocar, 501

Trot, 341 et seq.

Trottcr and pacer, 691

Trotting horses, P. 9, 14, 18-20, 40, 112

Troucs, drinking, 152, 390

Troy weight, 522

True cantering, 344

Tsetse fly disease, 616

Tuberculin, 610

Tuberculin, 610 609, 794, 813-4, 819

Turkish horses, 29

Turkoman horses, 29
Turning, 343

Tumips, 122

Tying horses up, 84, 267-9, 392-3

Types of harmess horses, 271, P. 34-49

of vehicles, 272 , P. $34-57$

\section{$\mathbf{U}$}

UNDER Dog, The, 711

Underfeeding, 148

Undocked horses, statistics of, 668

United, cantering, 344

Unsaddling, 304-6

Urea, $369-70$

hydrochioride, 761

Urine, $369-70,535$

U.S. Cavalry, P. 60

Use of bearing-reln, 886

of spurs, 336-7

of tail, 597, 635, 653-5

Uses of medicine, 490 et seg.

Utero-gestation, 629

\section{$\mathbf{v}$}

VACCINES, 790-1

Vehicle for drugs, 493

Vehlcles, types of, 272, P. 34-57

Ventllators, 362 et seq., 367

Ventral surface, 403

Vertebra, 295, 297

Veterinary pharmacy, drugs and ap. paratus in a, 513, 529 profession, 687

Vices, 464

Viciousness, 45

Victoria, Queen, 661, 689, 707

Virgil, 8,13

Voice, 48,86

\section{$\mathbf{w}$}

WALK, 341 et seq.

Walking exercise, 161-2

Wail of hoot, 827

Walis, 373

War, care of horses In, 177

Warts, 594

Washing mane and tail, 198-9

one's Angers, 825

Water, 154

Wassage of, 157

- running, 156, 389

- troughs, 152, 390

Watering, 150 et seq.
Watering, physiological principles of, 151,155 et seq.

- utensils, 152

Waterprool sheets, 211

Weaning loal, 630

Weed s, 135

Weight for tying up, 269 , P. $36 \mathrm{~h}$

Weights and measures, 748 ef seq.

Wheat, 117

IVhime trees, 256

Whipple collar, 277

Whips, 263

Whisks, ny, 397

Whistling, 603

Whitewashing, 380

Wicked horses, 49

Winans, Walter, 695, 699

Wind, broken, 604

Windgalls, 437, 440

Windows, 365,374

Wine measure, 519

Winnipeg papers, 703

Winter, care of horses in, 204

dies, destruction of, $6 \div 0$

lloors, 370

- shoes. 852

withers, 248

Wolsey, 19

Womb, inflammation of, 628

Wool ciothing, 212

1.ork, 165,370 after leeding, 142-4

World, Toronto, 690

Worid's specd records, $3+2$

Worms, 556 el seq.

prevention of, 556-8

Wounds, 444 el seq., 803 el seq.

bandaging, 810

_ cleaning, 805 el seq. seving, 809

Wright, 790

\section{$\mathbf{x}$}

XeNophos, $10,12,14$

\section{$\mathbf{Y}$}

YeASTS, 772

Yorks' (re boot, 447, P. 228

$\mathbf{z}$

Zoolooy of the horse, 34 
Pristed ay

Cassell o Consayy, limited, la Belle Sacraje,

Lo:pox, E.C.

F50.115 


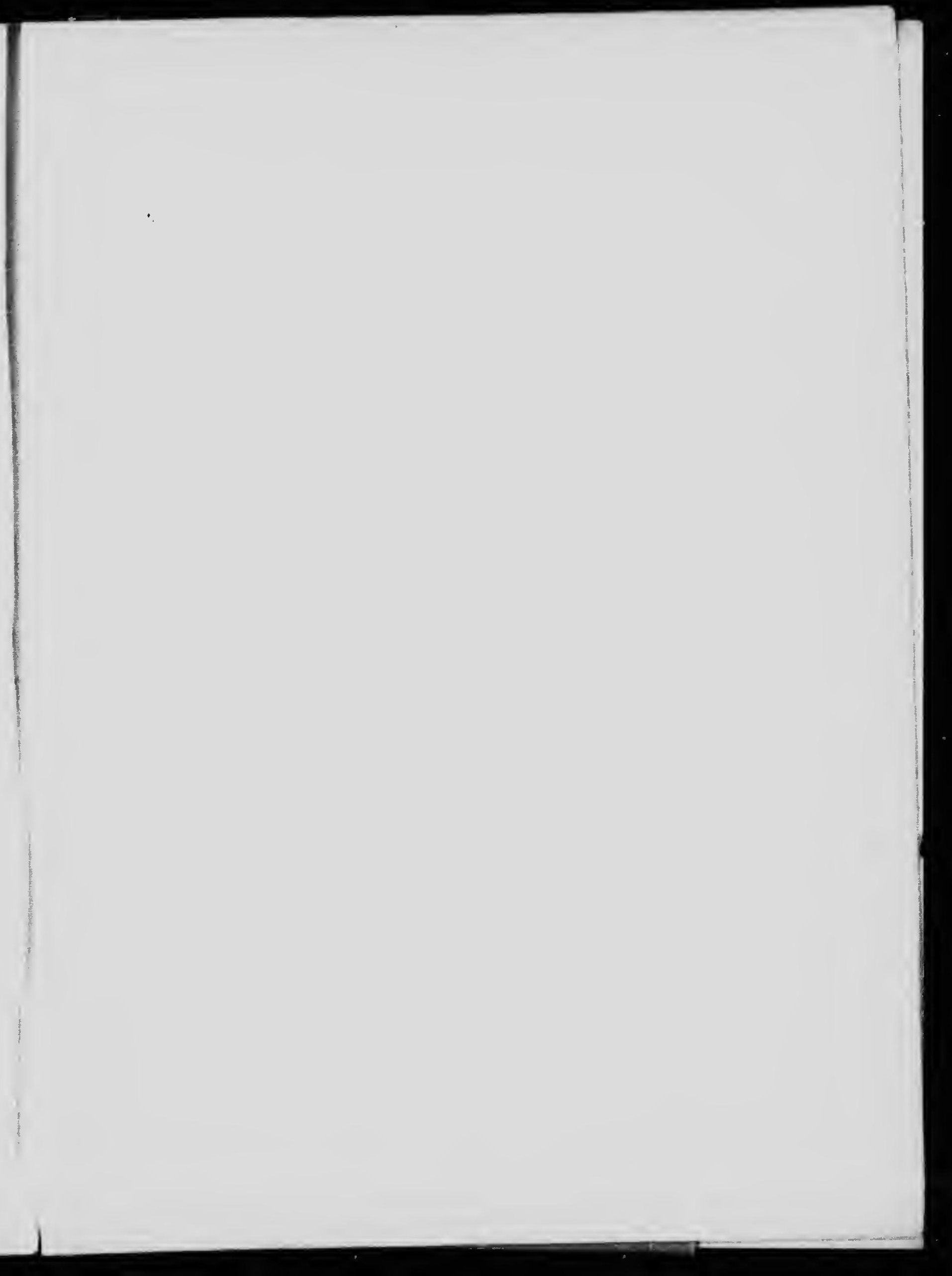




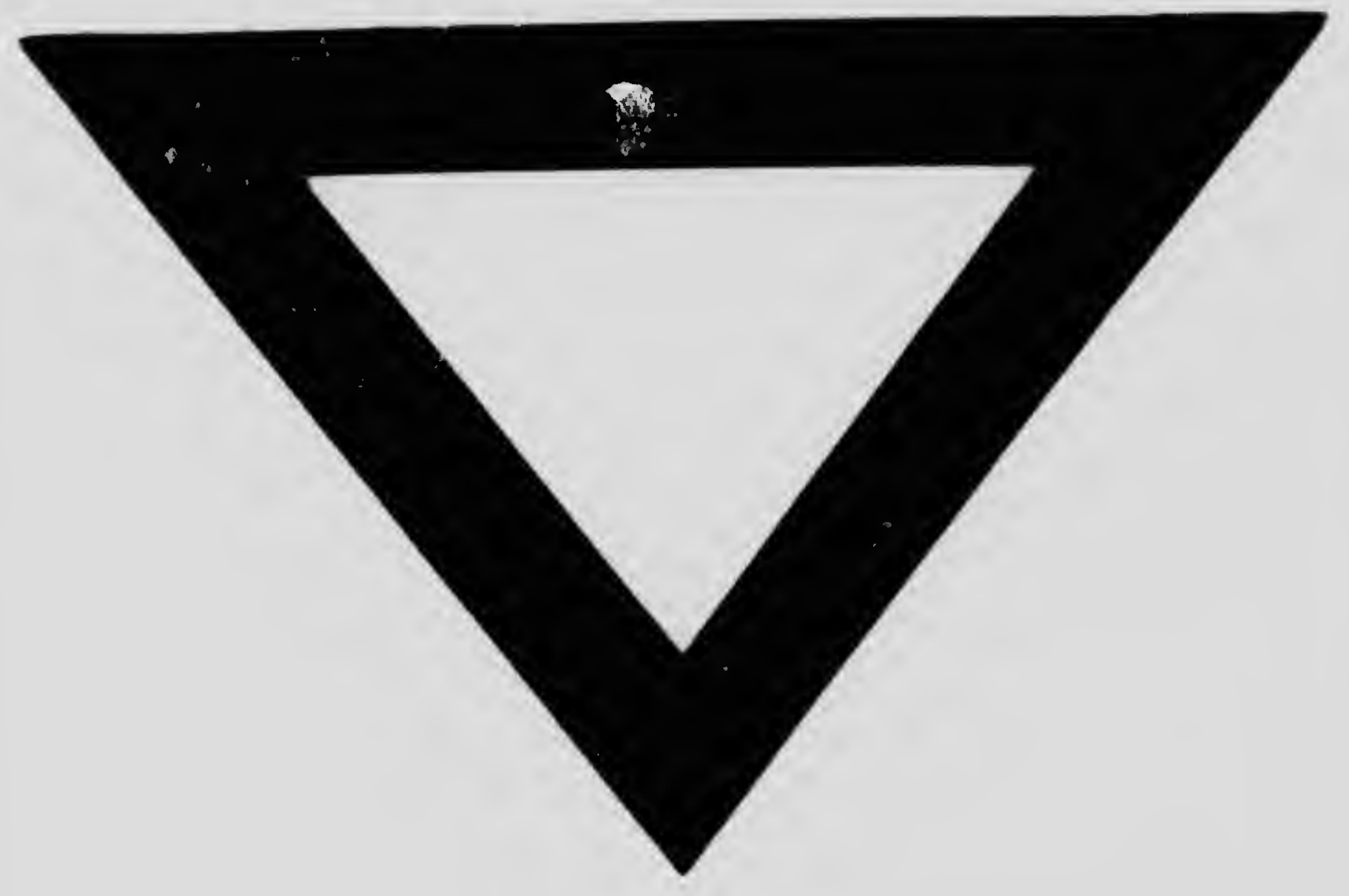

